UNIVERSIDAD DE SALAMANCA

FACULTAD DE DERECHO

DEPARTAMENTO DE DERECHO ADMINISTRATIVO, FINANCIERO Y PROCESAL

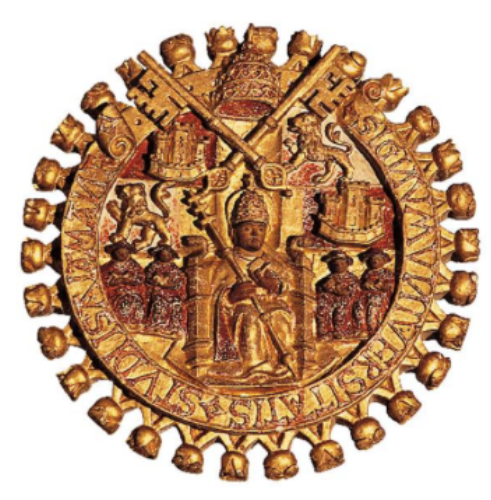

EL ACCESO Y USO DEL AGUA EN CUANTO DERECHO FUNDAMENTAL

TESIS DOCTORAL

PROGRAMA DE DOCTORADO: "EL MEDIO AMBIENTE NATURAL Y HUMANO EN LAS CIENCIAS SOCIALES"

DOCTORANDA: LILIAN STARLING DE FREITAS

DIRECTORES: MARÍA ÁNGELES GONZÁLEZ BUSTOS DIONISIO FERNÁNDEZ DE GATTA SÁNCHEZ

SALAMANCA, 2015 
UNIVERSIDAD DE SALAMANCA

FACULTAD DE DERECHO

DEPARTAMENTO DE DERECHO ADMINISTRATIVO, FINANCIERO Y PROCESAL

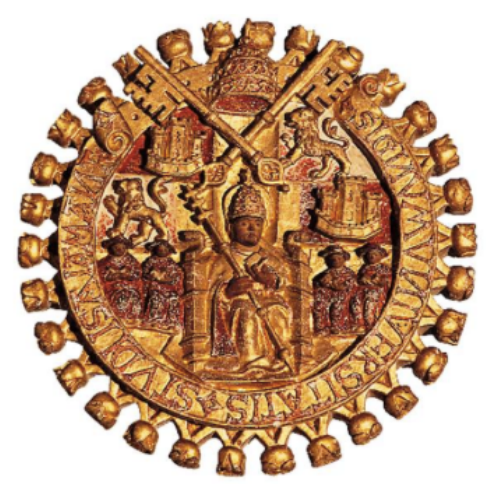

\section{EL ACCESO Y USO DEL AGUA EN CUANTO DERECHO FUNDAMENTAL}

Tesis doctoral presentada por la D. ${ }^{a}$ Lilian Starling de Freitas para obtener el grado de Doctora en Derecho por la Universidad de Salamanca, dirigida por la Dra. María Ángeles González Bustos, Profesora Titular de Derecho Administrativo de la Universidad de Salamanca, habiendo obtenido la Suficiencia Investigadora en el marco académico del Programa de Doctorado "El Medio Ambiente Natural y Humano en las Ciencias Sociales".

La Directora de la Tesis

Fdo. Dra. María Ángeles González Bustos

El Director de la Tesis

Fdo. Dionisio Fernández de Gatta Sánchez

La Doctoranda

Fdo. Lilian Starling de Freitas 
A mis padres Luiz y Márcia y a mi marido Fábio por el apoyo incondicional y por hacer mi sueño realidad. 
Mis más sinceros agradecimientos a los profesores doctores María Ángeles González Bustos y Dionisio Fernández de Gatta Sánchez por la orientación, paciencia y constante estímulo. A los profesores Rubens Valtercides Alves y Rafael Sastre Ibarreche, cada cual a su modo, me dedicaron un poco de su tiempo y me motivaron a luchar para la realización de este trabajo. Manifiesto aquí mi gratitud a mi socia Michelle, que por un año se encargó de todo el trabajo de nuestro bufete, y que además donó su tiempo y apoyo para que yo pudiera emprender este trabajo. Agradezco también a todos mis amigos y familiares que a través de una palabra o de un gesto, o con la simple presencia me apoyaron y creyeron en mí. Mis respetuosos agradecimientos por la participación de los miembros del Tribunal de Tesis. A mi marido Fábio, por todo. Principalmente por su amor, su compañerismo, su ejemplo de vida y de determinación, que a diario revigoran mis ganas de luchar por un mundo mejor. Por fin, agradezco a mis padres que desde siempre contribuyeron en la formación de mi carácter, y por el amor y apoyo incondicionales. 
Índice

Introducción.

\section{Capítulo 1. Estado y Derechos}

1.1. Estado social y democrático de Derecho y dignidad de la persona humana como fundamento de la Constitución Española de 1978................................25

1.2. Estado democrático de Derecho y la dignidad de la persona humana como fundamento de la Constitución Brasileña de 1988.................................. 37

1.3. Estado democrático de Derecho: algunas consideraciones.......................38

1.4. El Ciudadano como sujeto de deberes..................................41

1.5. Dignidad de la persona humana.......................................45

1.6. Concepto y características de los derechos fundamentales. Historia y funciones...49

1.6.1. Derechos fundamentales como incorporación legislativa interna de los derechos humanos. Consideraciones sobre algunas de sus características: universalidad; indivisibilidad; irrevocabilidad y complementariedad; e interdependencia.............55

1.7. Norma de derecho fundamental y enunciado normativo de derecho

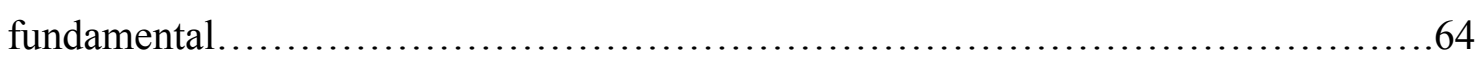

1.8. Derecho interno y Derecho Internacional................................... 76

\section{Capítulo 2. Sobre el medio ambiente y su concepto}

2.1. Sobre el medio ambiente y su concepto................................... 81

2.2. Breve síntesis histórica de la relación hombre-medio ambiente..................85

2.3. El surgimiento de la cuestión ambiental en Brasil. La Constitución Federal de 1988 y el nuevo tratamiento de la cuestión ambiental ............................... 88

2.4. El medio ambiente: Áreas Legalmente Protegidas, Urbanismo y Medio

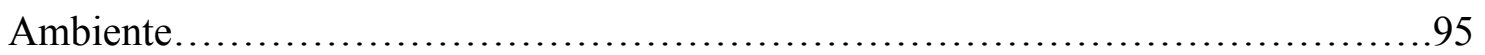

2.5. El origen de la preocupación sobre la preservación ambiental...................105

2.6. El Derecho Ambiental y su relevancia en la actualidad. Características............108

\section{Capítulo 3. El agua y los principios ambientales}

3.1. Agua y su importancia............................................... 116

3.2. El agua como bien jurídico fundamental................................ 127 
3.3. Antropocentrismo y ecocentrismo: cosmovisión y bien jurídico protegido.

3.4. Importancia de los principios para la ciencia: Aspectos relevantes de su surgimiento y evolución

3.5. Los principios como normas jurídicas: Estructura normativa y diferencias entre reglas y principios 148

3.6. Principios y reglas según Ronald Dworkin 153

3.7. Principios y reglas según Robert Alexy 155

3.8. Principios y reglas según José Joaquim Gomes Canotilho 163

3.9. Principios jurídicos aplicables al agua. Consideraciones iniciales. 165

3.10. Principios que instruyen el Derecho Ambiental además del Derecho de Agua

3.10.1 Principio del derecho al desarrollo sostenible. El derecho al medio ambiente ecológicamente equilibrado: un derecho fundamental. ... 186

3.10.2. Principio de prevención-precaución

3.10.2.1. El principio de precaución: Características e incertidumbre del daño ambiental. .204

3.10.2.2. La imposibilidad de tipificación del riesgo, peligro y amenaza ambientales. Gestión de los riesgos ambientales. 211

3.10.2.3. Costes de las medidas de prevención y su aplicación inmediata.... 214

3.10.2.4. La inversión de la carga de la prueba. Instrumentos de efectividad y la relación con los demás ramas del Derecho. Críticas a la efectiva aplicación del principio de precaución. .215

3.10.2.5. El principio de prevención propiamente dicho. 226

3.10.3. El principio de prohibición de retroceso. 228

\section{Capítulo 4 - El agua en el derecho brasileño}

4.1. Las características del federalismo brasileño y las Constituciones 235

4.2. El histórico de la protección hídrica. Agua como bien jurídico en Brasil.... 240

4.3. La tutela del agua en Brasil a partir de 1988: dispositivos explícitos y dispositivos implícitos en la Constitución brasileña de 1988.

4.4. El Sistema Nacional de Gestión de Recursos Hídricos - SINGREH. La evolución histórica de la gestión de recursos hídricos en Brasil.............................252

4.4.1. La interfaz con el saneamiento ambiental.............................256 
4.4.2. Las políticas ambientales brasileñas.

4.4.3. La gestión contemporánea de las aguas.

4.4.4. Las competencias del SINGREH. El Sistema Nacional de Informaciones en

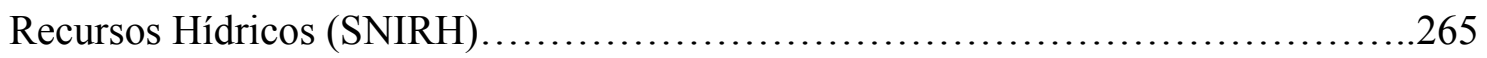

4.5. El Consejo Nacional de Recursos Hídricos (CNRH) .........................270

4.5.1. La Agencia Nacional de Aguas (ANA).................................270

4.6. Los Consejos de Recursos Hídricos Estaduales y del Distrito Federal..............271

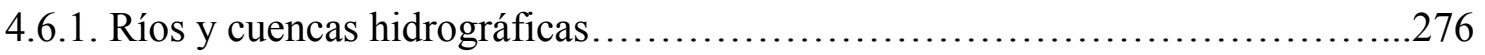

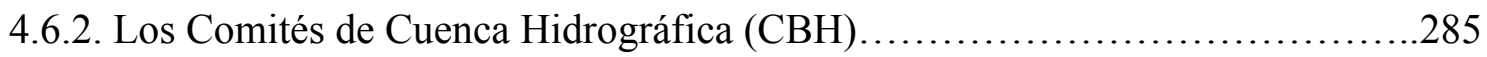

4.6.3. Las aguas subterráneas.............................................289

4.6.4. Los miembros de los Comités de Cuenca..................................291

4.6.5. Las Agencias de Agua o de Cuenca Hidrográfica.............................292

4.7. La representatividad de la sociedad en el SINGREH. El histórico de la representación de la sociedad en el Derecho Romano.............................296

4.7.1. La noción jurídica de pueblo. El pueblo, el Estado y el Derecho. ...............298

4.8. La evolución de la representación de la sociedad en la gestión de aguas en Brasil. Las definiciones y clasificaciones de Sociedades Civiles. La

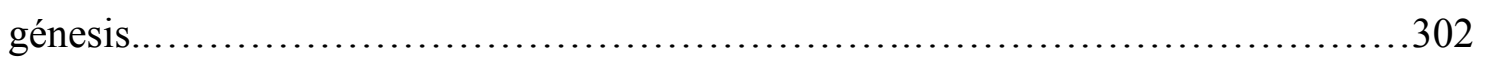

4.8.1. La representación de la sociedad civil en el Sistema de Recursos Hídricos......310 4.8.2. La representación de la sociedad civil en el Consejo Nacional de Recursos Hídricos.

4.8.3. La representación de la sociedad civil en los Consejos Estaduales de Recursos Hídricos. .314

4.8.4. La representación de la sociedad civil en los Comités (federales) de Cuencas

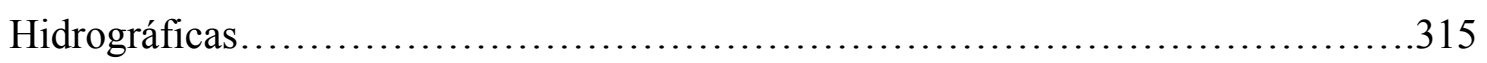

4.9. Las necesidades de regulación y los problemas encontrados.....................324

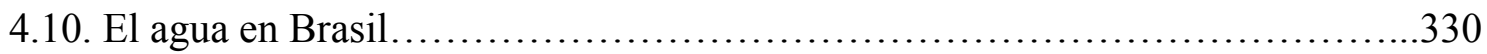

\section{Capítulo 5 - El agua en el derecho español}

5.1. El medio ambiente en la Constitución Española de 1978. Su consideración como principio rector en materia económica y social. La inclusión del agua................340

5.1.1. Concepto de medio ambiente en un sentido estricto..........................342

5.1.2. Concepto de medio ambiente en un sentido amplio........................345 
5.2. Acceso a la justicia. .354

5.2.1. Solapamiento del contenido del derecho al medio ambiente con el contenido de

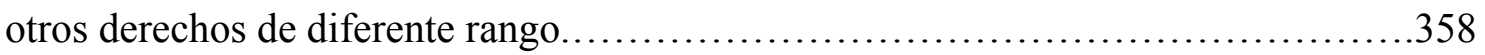

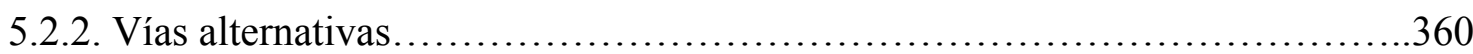

5.2.3. Relaciones de vecindad y reparación del daño causado.........................362

5.2.4. La vía administrativa y contencioso-administrativa.........................363

5.2.5. Acción popular y acción pública............................................ 371

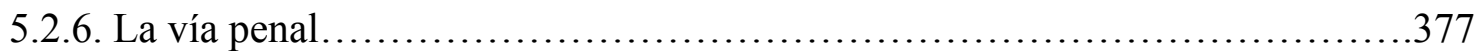

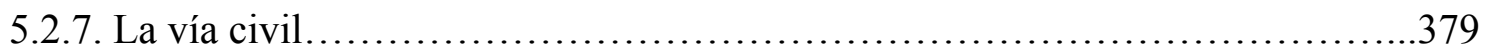

5.2.7.1. La responsabilidad civil por daño ambiental............................. 380

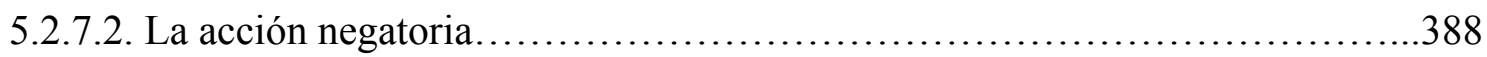

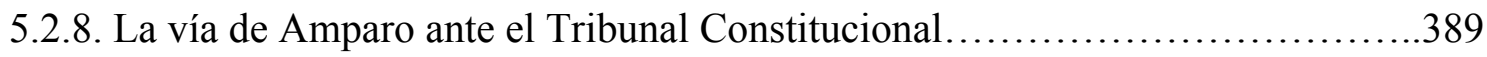

5.2.9. Cuestiones de inconstitucionalidad..........................................

5.3. El papel de la Administración en la defensa del medio ambiente..................395

5.4. Distribución territorial de competencias en materia de medio ambiente (Estados, Comunidades Autónomas y Administraciones Locales).

5.5. Distribución territorial de competencias en materia de aguas (Estados, Comunidades Autónomas y Administraciones Locales)..........................408

5.5.1. Principios generales de la Administración Pública del Agua...................413

5.5.2. Funciones del Estado en relación con el Dominio Público Hidráulico...........414

5.5.3. Régimen jurídico básico aplicable a las Comunidades Autónomas..............414

5.5.4. Marco competencial en materia de aguas.................................415

5.5.5. La distribución de otras competencias.................................4420

5.5.6. Competencias asumidas en los Estatutos de Autonomía.......................421

5.5.7. Concurrencia de competencias..................................... 422

5.6. El sistema normativo y administrativo de protección, acceso y gestión del agua en España: Texto Refundido de la Ley de Aguas de 2001 y sus normas de desarrollo. Administración Hidráulica. Uso del agua por los particulares.......................423

5.6.1. El principio del Estado Social y su relación con el derecho al agua..............434

5.6.2. España: legislación histórica y actual....................................436

5.6.3. La gestión del agua en España. Marco regulador y agentes implicados.........442

5.6.3.1. Dominio público hidráulico......................................447

5.6.3.2. Administración de los recursos hídricos..............................452 
5.6.3.3. Planificación hidrológica. Marco normativo 464

5.6.3.4. Utilización del dominio público hidráulico 468

5.6.3.5. Protección del dominio público hidráulico. 473

Capítulo 6 - Sostenibilidad y agua en el derecho internacional y en el derecho de la Unión Europea. Convenciones y Tratados

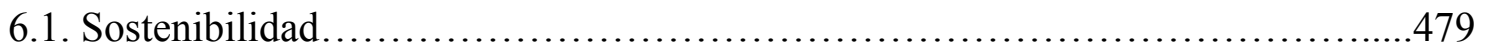

6.1.2. Riesgos ambientales................................................481

6.1.3. Desarrollo Sostenible ................................................483

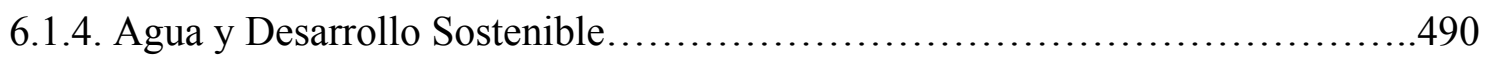

6.2. El agua en el Derecho Internacional...................................510

6.3. Fuentes de Derecho Internacional Público................................514

6.4. Convenciones de Viena de 1969 y 1985 sobre Derecho de los Tratados entre Estados, entre Estados y Organizaciones Internacionales, o entre Organizaciones Internacionales entre sí...................................................... 521

6.5. La teoría monista en España.............................................522

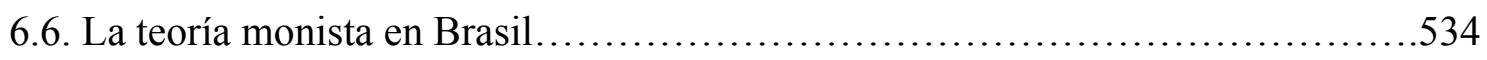

6.7. La protección internacional del agua. Eventos y foros sobre el agua...............537

6.8. Década del Agua.....................................................542

6.9. La vida y la dignidad de la persona humana en una dimensión ecológica.........544

6.10. Tratados Internacionales y Tratados Europeos..............................549

6.11. Los Tratados Europeos y el agua..........................................550

6.11.1. El Tratado de la Comunidad Económica del Carbón y Acero.................553

6.11.2. Tratado de Roma - El Tratado Constitutivo de la Comunidad Económica Europea - CEE ....................................................557

6.11.3. La afirmación del medio ambiente en el Acta Única Europea - AUE..........575

6.11.4. El Tratado de Maastricht o Tratado de la Unión Europea - TUE y la gestión de

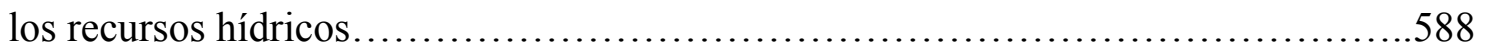

6.11.5. El Tratado de Ámsterdam.................................................598

6.11.6. El Tratado de Niza y la gestión de los recursos hídricos...................607

6.11.7. El Tratado de Lisboa y el desarrollo sostenible...........................620 
6.12. Especial referencia al Séptimo Programa Ambiental: el Programa General de Medio Ambiente de la Unión hasta 2020 - 'Vivir bien, respetando los límites de nuestro planeta' .648

Capítulo 7- Instrumentos de protección del agua: énfasis en el Derecho Administrativo Sancionador y en el Derecho Penal

7.1. Medio ambiente como bien jurídico: contribuciones para la legitimación de la intervención penal.

7.1.1. Sobre el objeto o contenido material del bien jurídico

7.2. Responsabilidad Administrativa - aspectos represivos y preventivos 674

7.3. Responsabilidad civil y administrativa sobre el agua.

7.4. Tutela administrativa del agua 680

7.5. Derecho Administrativo y su carácter sancionador. 686

7.6. Intersecciones entre Derecho Administrativo y Derecho Penal. 688

7.7. Derecho Administrativo Sancionador. .693

7.7.1. Principios esenciales. .696

7.7.2. Ilícito administrativo .698

7.7.3. Sanción Administrativa.... 700

7.7.4. Proceso administrativo. .702

7.7.5. Accesoriedad en materia ambiental. 703

7.8. Análisis comparativo entre el Derecho Penal y el Derecho Administrativo Sancionador: Aspectos semejantes. Observancia del principio de la razonabilidad y de proporcionalidad.

7.8.1. Carácter punitivo en la búsqueda por la protección de los intereses tutelados. Observancia del principio de la intervención mínima. Tipicidad del ilícito disciplinar. Aspectos discrepantes .712

7.8.2. Forma procesal para aplicación de sanción. Autoridad competente. .714

7.8.3. Gravedad. Manera de positivación: ¿en código o no?. Legitimidad para legislar.

7.9. Ilícito penal y administrativo. ¿Derecho de Intervención como alternativa viable? Posicionamiento crítico .717

7.10. Responsabilidad penal ambiental: evolución legislativa y dogmática. 719

7.11. Tutela penal del agua. 726 
CONCLUSIONES.

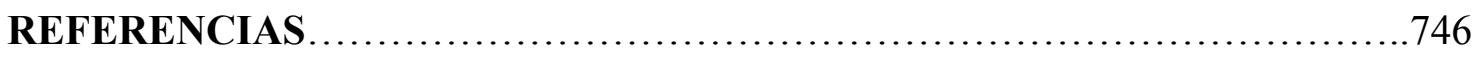




\section{LISTA DE ABREVIATURAS Y SIGLAS}

\begin{tabular}{|c|c|c|}
\hline$\S$ & - & Parágrafo \\
\hline ABAS & - & Associação Brasileira de Águas Subterrâneas \\
\hline ABES & - & Associação de Engenharia Sanitária e Ambiental \\
\hline ABGE & - & Associação Brasileira de Geologia de Engenharia \\
\hline ABID & - & Associação Brasileira de Irrigação e Drenagem \\
\hline ABRH & - & Associação Brasileira de Recursos Hídricos \\
\hline AEMA & - & Agencia Europea de Medio Ambiente \\
\hline ANA & - & Agência Nacional de Água \\
\hline Art. / Arts. & - & Articulo / Artículos \\
\hline AUE & - & Acta Única Europea \\
\hline BAT & - & Mejores Técnicas Disponibles \\
\hline $\mathrm{BNH}$ & - & Banco Nacional da Habitação \\
\hline BOE & - & Boletín Oficial del Estado \\
\hline Bol. & - & Boletín \\
\hline $\mathrm{CBH}$ & - & Comitê de Bacia Hidrográfica \\
\hline CCAA & - & Comunidades Autónomas \\
\hline $\mathrm{CC} / 2002$ & - & Código Civil brasileiro de 2002 \\
\hline $\mathrm{CDC}$ & - & Comissão de Defesa do Consumidor \\
\hline CDI & - & Comissão de Direito Internacional \\
\hline $\mathrm{CE} / 78$ & - & Constitución Española de 1978 \\
\hline $\mathrm{CE}$ & - & Comunidad Europea \\
\hline CEE & - & Comunidad Económica Europea \\
\hline CEEA & - & Comunidad Económica de Energía Atómica \\
\hline CECA & - & Comunidad Europea de Carbón y Acero \\
\hline CERH & - & Conselho Estadual de Recursos Hídricos \\
\hline CESB & - & Companhia Estadual de Saneamento Básico \\
\hline CETESB & - & Companhia Ambiental do Estado de São Paulo \\
\hline $\mathrm{CF} / 88$ & - & Constituição da República Federativa do Brasil de 1988 \\
\hline CME & - & Comissão de Minas e Energia \\
\hline CNAEE & - & Conselho Nacional de Águas e Energia Elétrica \\
\hline CNRH & - & Conselho Nacional de Recursos Hídricos - Brasil \\
\hline
\end{tabular}




\begin{tabular}{|c|c|c|}
\hline CNUMAD & - & $\begin{array}{l}\text { Conferencia de las Naciones Unidas sobre Medio Ambiente y } \\
\text { Desarrollo }\end{array}$ \\
\hline $\mathrm{COM}$ & - & Comisión de las Comunidades Europeas \\
\hline CONAMA & - & Conselho Nacional do Meio Ambiente - Brasil \\
\hline CONAMA & - & Congreso Nacional del Medio Ambiente - España \\
\hline CONSEMA & - & Conselho Estadual do Meio Ambiente \\
\hline CREA & - & Conselho Regional de Engenharia, Arquitetura e Agronomia \\
\hline CTASP & - & Comissão de Trabalho, de Administração e Serviço Público \\
\hline DAEE & - & Departamento de Águas e Energia Elétrica \\
\hline DF & - & Distrito Federal \\
\hline DMA & - & Directiva Marco sobre Aguas - 2000/60/CE \\
\hline DNAEE & - & Departamento Nacional de Águas e Energia Elétrica \\
\hline DNOCS & - & Departamento Nacional de Obras contra as Secas \\
\hline DNPM & - & Departamento Nacional da Produção Mineral \\
\hline DO & - & Diario Oficial \\
\hline DOCE & - & Diario Oficial de las Comunidades Europeas \\
\hline DOU & - & Diário Oficial da União \\
\hline EAE & - & Evaluación Ambiental Estratégica \\
\hline $\mathrm{ECO} / 92$ & - & $\begin{array}{l}\text { Conferencia sobre Medio Ambiente y Desarrollo celebrada en Río de } \\
\text { Janeiro, en } 1992\end{array}$ \\
\hline EDS & - & Estrategia de la Unión Europea para el desarrollo sostenible \\
\hline EIA & - & Estudo de Impacto Ambiental - Brasil \\
\hline EIA & - & Evaluación de Impacto Ambiental - España \\
\hline EMAS & - & Sistema Comunitario de Gestión y Auditoría Medioambiental \\
\hline EPIA & - & Estudio Previo de Impacto Ambiental \\
\hline ERA & - & Estación de Generación de Aguas \\
\hline EURATOM & - & Comunidad Europea de Energía Atómica \\
\hline FEDER & - & Fondo Europeo de Desarrollo Regional \\
\hline FEOGA & - & Fondo Europeo de Orientación y Garantía Agrícolas \\
\hline FGTS & - & Fundo de Garantia por Tempo de Serviço \\
\hline IBAMA & - & $\begin{array}{l}\text { Instituto Brasileiro do Meio Ambiente e dos Recursos Naturais } \\
\text { Renováveis }\end{array}$ \\
\hline IBGE & - & Instituto Brasileiro de Geografia e Estatística \\
\hline
\end{tabular}




\begin{tabular}{|c|c|c|}
\hline ICWE & - & International Conference on Water and the Environment \\
\hline ILA & - & International Law Association \\
\hline IPPC & - & Prevención y Control Integrados de la Contaminación \\
\hline LAg & - & Ley de Aguas 1985 \\
\hline MAPA & - & Ministerio de Agricultura, Pesca y Alimentación \\
\hline MARM & - & Ministerio del Medio Ambiente, Medio Rural y Marino \\
\hline MMA & - & Ministério do Meio Ambiente - Brasil \\
\hline MS & - & Ministério de Saúde \\
\hline n. ${ }^{o}$ & - & Número \\
\hline NBT & - & Normas Técnicas da Associação Brasileira de Normas Técnicas - ABNT \\
\hline & - & Organização Mundial da Saúde \\
\hline OMS & - & Organização Não-Governamental \\
\hline ONG & & \\
\hline ONU & - & Organização das Nações Unidas \\
\hline Op. Cit. & - & Obra Citada \\
\hline OS & - & Organização Social \\
\hline OSCIP & - & Organização da Sociedade Civil de Interesse Público \\
\hline p. / pp. & - & página / páginas \\
\hline PAA & - & Programa de Acción Ambiental \\
\hline PACE & - & Comunicación sobre la Política de Aguas de la Comunidad Europea \\
\hline PESC & - & Política Exterior y de Seguridad Común \\
\hline PHN & - & Plan Hidrológico Nacional \\
\hline PHC & - & Plan Hidrológico de Cuenca \\
\hline PL & - & Projeto de Lei \\
\hline PLANASA & - & Plano Nacional de Saneamento \\
\hline PND & - & Plano Nacional de Desenvolvimento \\
\hline PNMA & - & Política Nacional do Meio Ambiente \\
\hline PNB & - & Producto Nacional Bruto \\
\hline PNR & - & Plano Nacional de Regadíos \\
\hline PNRH & - & Plano Nacional de Recursos Hídricos \\
\hline PNRH & - & Política Nacional de Recursos Hídricos \\
\hline PNUD & - & Programa de las Naciones Unidas para el Desarrollo \\
\hline PNUMA & - & Programa das Nações Unidas para o Meio Ambiente \\
\hline
\end{tabular}




\begin{tabular}{|c|c|c|}
\hline $\mathrm{RD}$ & - & Real Decreto \\
\hline RDPH & - & Reglamento del Dominio Público Hidráulico \\
\hline SABESP & - & Companhia de Saneamento Básico do Estado de São Paulo \\
\hline SANEGRAN & - & Projeto de Saneamento para a Grande São Paulo \\
\hline SBG & - & Sociedade Brasileira de Geologia \\
\hline SEGRHI & - & Sistema Estadual de Gerenciamento de Recursos Hídricos \\
\hline SEMA & - & Secretaria Especial do Meio Ambiente \\
\hline SINGREH & - & Sistema Nacional de Gerenciamento dos Recursos Hídricos \\
\hline SISNAMA & - & Sistema Nacional do Meio Ambiente \\
\hline SMA & - & Secretaria do Meio Ambiente \\
\hline SNIRH & - & Sistema Nacional de Informações em Recursos Hídricos \\
\hline SRH & - & Secretaria de Recursos Hídricos \\
\hline SRHU & - & Secretaria de Recursos Hídricos e Ambiente Urbano \\
\hline ss. & - & siguientes \\
\hline STF & - & Supremo Tribunal Federal \\
\hline STJ & - & Superior Tribunal de Justiça \\
\hline STC & - & Sentencia del Tribunal Constitucional \\
\hline STJCE & - & Sentencia del Tribunal de Justicia de la Comunidad Europea \\
\hline SUDENE & - & Superintendência do Desenvolvimento do Nordeste \\
\hline $\mathrm{TC}$ & - & Tribunal Constitucional \\
\hline TCE & - & Tratado de Maastricht, de 1992 \\
\hline TCECA & - & Tratado de la Comunidad del Carbón y del Acero \\
\hline TCEE & - & Tratado por el que se establece la Comunidad Económica Europea \\
\hline TJCE & - & Tribunal de Justicia de la Comunidad Europea \\
\hline TRLAg & - & Texto Refundido de la Ley de Aguas \\
\hline TUE & - & Tratado de Maastricht de 1992, por el que se establece la Unión Europea \\
\hline UE & - & Unión Europea \\
\hline UNCCUR & - & $\begin{array}{l}\text { Conferencia de las Naciones Unidas sobre la conservación y utilización } \\
\text { de los recursos }\end{array}$ \\
\hline
\end{tabular}




\section{LISTA DE IMAGENES}

\section{Cuadros}

1- Generaciones (dimensiones) de los Derechos Fundamentales......................59

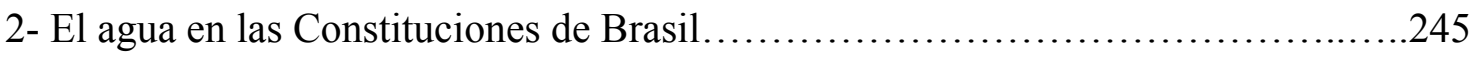

3- Consejos Estaduales de Recursos Hídricos y su legislación.......................271

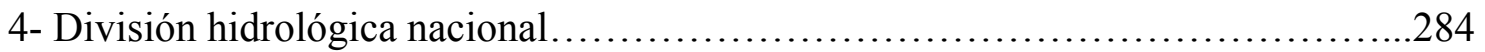

5- Comités de Cuencas Hidrográficas - Ríos Federales...........................288

6- Comités de Cuencas Hidrográficas - Ríos Estaduales y Distritales......................288

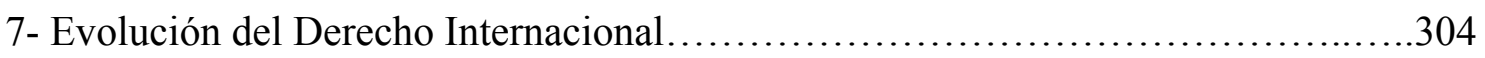

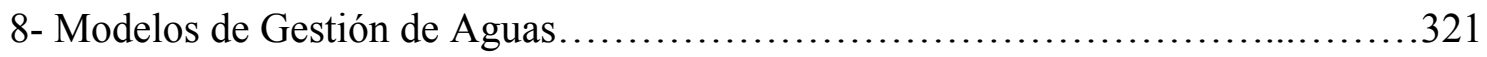

9- Distribución de competencias que establece la Constitución Española en las materias más significativas con el Dominio Público Hidráulico............................421

10- Competencias en los Estatutos de Autonomía................................422

11- Competencias y Administraciones que más frecuentemente concurren en el Dominio Público Hidráulico..................................................4423

\section{Figuras}

1- Procesos de planeamiento de los Recursos Hídricos...........................266

2- Desarrollo de capacidades: niveles, actividades, rendimientos y metas.............268

3- Representación de las Regiones Hidrográficas.................................278

4- Ejemplo de subdivisión de la Cuenca Hidrográfica..............................2279

5- Codificación de Cuencas Hidrográficas de Sudamérica (nivel 1).................280

6- Codificación de Cuencas Hidrográficas de Sudamérica (nivel 2)................281

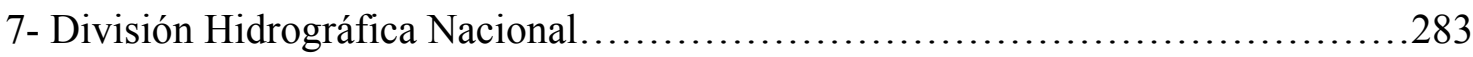

8- Mapa de la escasez de agua por motivos naturales y económicos................496 


\section{Introducción}

El Derecho es un producto humano, con función instrumental de regulación de las conductas sociales, de modo a permitir la tranquilidad y la seguridad de las relaciones entre los seres humanos en sociedad. Al disciplinar y buscar pacificar las relaciones humanas, el Derecho ofrece a la sociedad la seguridad para la persecución de sus objetivos comunes, entre ellos la preservación de la especie y del grupo social.

Toda la vida del Derecho - de su génesis al alcance de sus objetivos y finalidades - gira en torno al ser humano. No existe pues, derecho que no afecte, aun que indirectamente, en última análisis, el ser humano. De esta manera, es el hombre el único sujeto de derechos posible, el único que puede ser investido de y, efectivamente, ejercer, de modo autónomo e independiente, derechos. También, es ello el único que crea reglas para defender a sí mismo y sus semejantes de actos practicados por sus pares - sean estos considerados de forma individual o colectiva, cuando organizados en asociaciones de las más diversas, de la familia al Estado. Las reglas creadas para disciplinar la vida en sociedad, para conferir o imponer derechos y obligaciones individuales o colectivas, reciben el nombre de reglas jurídicas.

La relación del ser humano con sus pares en sociedad crea una serie de situaciones, de hechos, de relaciones, que, cuando entran en el campo de incidencia de la regla jurídica, se tornan hechos o relaciones jurídicas.

Relaciones jurídicas, bien como las respectivas reglas que así las transforman, son, modernamente, aquellas de interés o disciplinadas por el derecho dictado por el Estado, lo que constituye el origen de la juridicidad. De ahí la distinción entre interés jurídico de los otros tipos de interés, siendo aquél el que tiene valor, en el sentido más amplio, para los otros individuos que componen la colectividad, y que, por tanto, debe ser objeto de atención y de disciplina estatal a través del Derecho.

Ya régimen jurídico aquí, debe ser entendido como el conjunto de reglas e imposiciones jurídicas que rigen determinada relación o situación.

A principio, tenemos de recordarnos que los Estados, en cuanto miembros de la sociedad internacional, no son seres autónomos, dotados de voluntad propia. Son personas artificiales, cuyos actos y voluntades surgen de estrechos comandos legalmente definidos, tanto en sus respectivas constituciones, cuanto en otros componentes de sus ordenamientos jurídicos. Y estos comandos normativos, estos 
valores expresos en normas jurídicas deben, o deberían, guardar relación siempre estrecha con los valores de la sociedad la cual corresponden. La acción de un Estado, tanto en la sociedad interior, cuanto internacionalmente, se deriva estrictamente de comandos legales, incluso porque es esta la fuente de su existencia.

De este modo, el Estado debe ser visto como una persona jurídica, con límites de actuación, objetivos y poderes estricta y legalmente establecidos. Aun que un Estado adopte acciones de hostilidad, violencia o agresión en la sociedad internacional, total y legalmente apoyado por su ordenamiento interior, con el apoyo incondicional de los valores de su sociedad, aun así, su conducta no puede prescindir de un orden jurídico internacional.

Como en cualquier sociedad, en la internacional el simple hecho de estarse inserido en ella ya demanda la existencia de reglas, principios, valores, sin los cuales, por más fuerte y autosuficiente que sea el Estado, la viabilidad de su permanencia en este grupo estaría siempre en la inminencia de riesgo fatal. Así, independientemente de cual sea la visión que se adopte en relación a la sociedad internacional, su existencia depende íntimamente de la existencia del derecho internacional.

Así, el derecho internacional es el responsable, de hecho, por proporcionar un orden sustancial en la sociedad internacional. Tanto que, actualmente, determinadas áreas de las relaciones internacionales se tornaron muy específicas, sea por evolución técnica, sea por relevancia de sus respectivos temas para la supervivencia y seguridad de los Estados y sus sociedades, desarrollando estructuras y mecanismos jurídicos específicos, dentro del derecho internacional.

En este sentido, el presente trabajo visa el estudio del régimen jurídico del agua dulce, más específicamente su acceso y uso analizado aquí a la luz de las normas, principios, reglas y procesos de toma de decisiones que confrontan, y de la relación de estos con el derecho fundamental y principalmente con la dignidad de la persona humana, tanto en el ámbito del derecho internacional público cuanto, también de la perspectiva de su reflejo en el orden jurídico de la Unión Europea, España y Brasil.

Hay los que creen que existe suficiente agua dulce en el mundo para las presentes y futuras generaciones, existiendo, sin embargo, una distribución absolutamente irregular, vez que algunas regiones del planeta son extremadamente áridas mientras otras son altamente irrigadas. 
La mayoría de los ambientalistas y científicos que poseen una visión tradicional asocian la creciente escasez hídrica y la dificultad de su acceso per cápita apenas al aumento poblacional de la Tierra. No obstante, culpar la población mundial misma por los sufrimientos los cuales pasa es, sin duda, un actitud magnífica, pues libra los verdaderos culpados y alivia la consciencia del sentido común, pues el aumento poblacional es mayor a medida que aumenta el nivel de pobreza, exactamente estas son las poblaciones que más sujetas están a una severa escasez de agua, saneamiento y cualesquier condiciones mínimas de subsistencia.

Seguramente el aumento poblacional aumenta el estrés hidrológico de algunas regiones del planeta, o las condiciones de escasez de otras; sin embargo, no es él el principal factor de la critica situación en que se encuentran las reservas de agua dulce del mundo. Estas son atacadas principalmente por dos grandes problemas: modelos predatorios de producción y de consumo, y mala gestión.

La principal causa de escasez de agua dulce, mundialmente, es su alto consumo por los medios de producción, sea directamente a través de su apropiación como insumo, sea indirectamente a través de su contaminación por las más diversas fuentes de contaminación derivada de los procesos productivos humanos.

El aumento de la población aumenta directamente sólo la más pequeña parte del consumo de agua dulce, una vez que solo aproximadamente un décimo de la cantidad de agua disponible es utilizada para consumo humano. Y eso en las regiones con disponibilidad hídrica.

Ya de manera indirecta, el aumento de la población afecta la cantidad de agua dulce disponible para consumo humano a través de la deficiencia de las estructuras e instalaciones públicas de saneamiento y de urbanización. Además, eso suele ocurrir más en países pobres o en vía de desarrollo, por ser exactamente en estos países que poseen una situación económica más delicada que se verifican los mayores crecimientos de las tasas de urbanización y migración interior, en su mayoría por cuestiones económicas.

También, la ocupación desenfrenada y la falta de respeto a las legislaciones locales de uso y ocupación del suelo, o hasta mismo su inexistencia, causan la impermeabilización del suelo, lo que afecta directamente el ciclo hidrológico, vez que el agua de la lluvia que se precipita sobre las áreas urbanas, literalmente se pierde en cantidad, por la falta de sistemas para su captación y reinserción en aquello proceso natural, y en calidad puesto que en la mayoría de las veces ella es conducida 
directamente para los sistemas de eliminación de aguas residuales, donde se mescla a los más diferentes tipos de sustancias toxicas y perjudiciales a la salud, para finalmente volvieren sin ningún tratamiento a los ríos, lagos, manantiales o mares.

A pesar de todos reconocieren ampliamente la importancia del agua para el mantenimiento de todas las formas de vida, para el equilibrio de los procesos naturales que mantienen la sostenibilidad de la vida en la Tierra, y para la salud humana, la calidad de las reservas de agua dulce vienen deteriorándose cada vez más, exclusivamente debido a la acción humana y sus procesos contaminantes y no sostenibles de producción y consumo, lo que afecta la capacidad de renovación de los procesos naturales, esencialmente, el ciclo hidrológico, haciendo con que la escasez del agua pase a ocurrir en regiones donde antes su disponibilidad era abundante o suficiente.

Importante destacar que tanto especialistas como investigadores en recursos hídricos concluyeron que el consumo de agua dulce es directamente proporcional a la renta del individuo, de modo que, a la medida que la riqueza aumenta, el individuo, la sociedad, el país, consumen más agua dulce, sin embargo, son esos países, con mayor renta per cápita por individuo los que más condiciones económicas tienen para hacer inversiones en gestión hídrica, desalación del agua, reúso, educación y concienciación ambiental, investigación sobre el tema, entre otros.

Así, sea en el actual escenario de degradación y de crisis, sea en el futuro escenario de crisis y exclusión, la posibilidad de conflictos y de situaciones que violen frontalmente las condiciones de supervivencia y de dignidad de los seres humanos es una realidad. Ahora nos queda analizar de qué modo el agua dulce tiene sido tutelada por el derecho internacional público, y claro, por el derecho de la Unión Europea, España y Brasil, y de qué manera esta tutela sirve para buscar la prevención de ocurrencia de conflictos o para garantir la efectividad de la existencia humana con su debida dignidad.

Además, en razón de su vital importancia a la vida de los seres humanos, cuál es la relación del derecho al agua con respecto a otros derechos que no pueden ejercerse sin aquél, tal como: el derecho a la vida, derecho a la dignidad humana, derecho a la salud física y mental, derecho a la alimentación, derecho a una vivienda digna y adecuada, derecho al desarrollo, derecho al medio ambiente adecuado, derecho a la paz, derecho al saneamiento. 
¿Está el derecho al agua, implícito en el derecho a la vida?

¿Por qué la mayoría de los Estados no consideran el acceso y uso del agua como un derecho fundamental por el simple hecho de lo mismo no está previsto en su Constitución?

¿Qué es más importante la previsión legislativa o la necesidad vital?

El capítulo 1, trata de desarrollar los conceptos de Estado Social y Democrático de Derecho, estableciendo la dignidad de la persona humana y su protección por el Derecho como uno de los fundamentos de las Constituciones Española y Brasileña.

Para tanto, abarcaremos la evolución lenta y gradual del Estado hasta alcanzar los días actuales, y por otro lado, la identificación de la importancia de la persona en el contexto político, van a ser de gran importancia para la línea de investigación científica adoptada a lo largo del trabajo.

Merece destaque el abordaje sobre la historia, concepto, características y funciones de los derechos fundamentales, hasta mismo porque ellos no se constituyen como un producto listo y acabado desde su presentación original. En realidad, los derechos fundamentales aún están en desarrollo y merecen mejor consolidación en la hermenéutica jurídica e inserción en las legislaciones. En este aspecto, análisis y confrontación entre derecho humanos y derechos fundamentales son confeccionadas a lo largo del capítulo.

El medio ambiente y su protección por el Derecho Ambiental será desarrollado a partir del capítulo 2 .

Para los fines que se pretende alcanzar, tornase necesario revisitar conceptos que, aparentemente están desarrollados por la doctrina, pero dada la busca de la integración permanente entre las ciencias jurídicas española y brasileña que se pretende realizar, es importante traer a la consideración. Esta necesidad tornase aun más presente en virtud del establecimiento del fenómeno de la globalización y del reconocimiento de una sociedad que convive con riesgos advenidos, notablemente, de los procesos industriales y de la gran utilización de los recursos naturales. Por esto, crece la importancia del Derecho promover la protección y preservación de áreas de interés ambiental. En este contexto, dada las dimensiones continentales de Brasil, sumada a su enorme diversidad de fauna y flora, varias áreas diversas entre sí reciben protección jurídica, lo que permite el Derecho Ambiental brasileño servir de referencia para otros países. 
En este capítulo, las relaciones establecidas entre globalización, sociedad de riesgo y medio ambiente son cuidadosamente descritas.

En la secuencia, los principios jurídicos ambientales serán revisados en el capítulo 3, antes, sin embargo, algunos importantes posicionamientos teóricos acerca de los principios y reglas son traídos con la preocupación de distinguir el concepto y papel de cada uno, y con eso evitar errores en la comprensión e importancia. Para impulsar la contribución que pretende prestar el trabajo en este campo, autores no españoles o brasileños fueron utilizados para establecer las distinciones y provocaciones que el tema permite.

Sigue el capítulo revisando cada uno de los principios de Derecho Ambiental, y por supuesto inherentes al agua y su protección jurídica.

Junto a los principios son presentadas características y situaciones específicas en el campo de su aplicación, además, de dificultades y criticas.

Con el manifiesto intuito adoptado durante el trabajo de trocar conocimientos y experiencias entre España y Brasil con respecto al Derecho Ambiental y específicamente el tratamiento jurídico dado al agua, el capítulo 4 investiga el histórico, las características y la protección ocurridas en Brasil.

Hecho esto, el capítulo aborda el sistema administrativo de gestión de recursos hídricos, y presenta al lector el lado político y técnico de sus órganos, la relevancia de la participación de la sociedad civil en la formulación de la política hídrica y composición en los órganos públicos es presenta como importante instrumento democrático.

Ya el capítulo 5, relata el tratamiento dado por el Derecho Español al agua.

Inicialmente, se aborda la previsión constitucional dada al medio ambiente, para enseguida ser desarrollado el concepto jurídico de medio ambiente en varios sentidos.

Con el objetivo de constatar la garantía al medio ambiente, son abordados temas relativos al acceso a la justicia ambiental a través del Derecho español, oportunidad en que algunas vías administrativas y jurisdiccionales son objeto de análisis, al lado del papel y competencias que poseen algunos Tribunales, aun que no sea el objetivo del trabajo agotar la materia.

El trabajo sigue con indicación de los principios generales de la administración del agua, funciones del Estado con relación al tema y exposición del régimen jurídico y 
distribución de competencias en materia de medio ambiente y aguas aplicables al Estado, Comunidades Autónomas y Administraciones Locales.

Termina el capítulo con la presentación del modelo de gestión del agua en España, estableciéndose el marco regulador, indicación de los agentes implicados y cuestiones en torno del dominio público hidráulico.

Estando el tema 'agua' al orden del día de diversas agendas globales, se justifica la intervención de órganos de referencia mundial a regularla a través de la celebración de tratados y otros documentos internacionales. Dada la importancia natural del tema, el capítulo 6 ingresa en esta análisis.

Respecto al Derecho Internacional se destaca, Conferencias y Tratados sobre el agua, la gran preocupación con el desarrollo sostenible y riesgos vividos por la humanidad. En este aspecto, ingresa el trabajo en la investigación envolviendo la crisis hídrica, corroborada por la falta, escasez y restricción sobre el acceso y uso del agua.

En virtud del alto crecimiento demográfico y largo uso industrial del agua por un lado, y por otro lado los grandes cambios climáticos ocurridos en el planeta en el último siglo, el tratamiento político y jurídico del agua ganó importancia internacional, lo que llevó a la discusión y elaboración de diversos documentos internacionales.

Se establece un conflicto difícil de armonizarse, consistente en la disminución de la oferta del recurso natural 'agua', y por otro lado la solidez del derecho humano al agua en cuanto materialización de la dignidad de la persona humana.

Tratándose de un bien fundamental para la humanidad, y ocupando posición de destaque en el ámbito internacional, entre otros órganos la Organización de las Naciones Unidas y la Unión Europea, discutieron y siguen discutiendo el papel del agua y del desarrollo sostenible en conferencias, convenciones y en diversas ocasiones, subscribiendo Tratados, Declaraciones, Directivas y Programas. Por esta razón los principales documentos internacionales serán objeto de reportaje, y consideraciones serán formuladas en el ámbito del derecho interior.

Por fin, habiendo el Estado llamado para sí el papel de decir el Derecho, y por así decir proteger el agua y recursos naturales, el capítulo 7 se refiere a las formas más severas de intervención del Estado para promover la protección del medio ambiente, que son dadas por el Derecho Administrativo Sancionador y por el Derecho Penal.

Reconocida el agua como bien jurídico fundamental, por esto se constituye como objeto de protección por el Derecho. 
Dada la importancia de este bien para la vida en sociedad, se suma ahora el Derecho Penal para promover su protección a partir de la creación de normas incriminadoras, con el propósito preventivo, esto es, de inhibir conductas lesivas al medio ambiente, y específicamente al agua.

Por esta razón, cuestiones en torno de la legitimidad del Derecho Penal para promover la tutela del medio ambiente y precisamente del agua son puestas a discusión, y el debate crece aún más de importancia a medida que, ordinariamente, el Derecho Administrativo ya ocupaba el importante papel de fiscalización sobre las potenciales fuentes de peligro o de lesión al medio ambiente. En este aspecto, son traídas al trabajo el abordaje acerca de la responsabilidad administrativa sancionadora y su embate con la responsabilidad penal sobre el agua.

Después de la caracterización del sentido a ser atribuido al Derecho Administrativo Sancionador son presentadas análisis comparativas entre este y el Derecho Penal, estableciéndose puntos de semejanza y divergencia teniendo por consideración la protección del agua. 


\section{Capítulo 1 - Estado y Derecho}

\subsection{Estado social $y$ democrático de Derecho y dignidad de la persona humana como fundamento de la Constitución Española de 1978}

La expresión 'Estado social y democrático de Derecho' aparece en el Título Preliminar, en el artículo 1.1, de la Constitución española de 1978. Aquí, es necesario desentrañar el sentido general de la fórmula, contemplada en su totalidad y en sus tres componentes. Se trata de una terminología ampliamente consagrada que apunta a una concepción sintética del Estado, producto de la unión de los principios propios del Estado liberal y del Estado social. La imagen resultante del Estado, como toda síntesis, supone una superación de sus componentes básicas aisladamente consideradas, lo que permite añadir la tercera característica de la fórmula constitucional: la democracia. La importancia respectiva que se atribuya a cada una de las tres componentes examinadas dependerá en forma notable de la concreta visión política de que se parta. Cuando se habla en Estado social y democrático de Derecho, uniéndolos, lo que se pretende es superar los modelos de Estado liberal y Estado social ${ }^{1}$.

En la origen, como es sabido, el Estado de Derecho era un concepto típicamente liberal; de ahí hablarse en Estado Liberal de Derecho, cuyas características básicas fueron: a) sumisión al imperio de la ley que era la nota primaria de su concepto, siendo la ley considerada como acto emanado formalmente del Poder Legislativo, compuesto de representantes del pueblo, pero del pueblo-ciudadano; b) división de poderes, que separe de forma independiente y armónica los poderes Legislativo, Ejecutivo y Judicial, como técnica que asegure la producción de las leyes al primero y la independencia e imparcialidad del último delante de los demás y de las presiones de los poderosos particulares; c) enunciado y garantía de los derechos individuales ${ }^{2}$. Esas exigencias siguen siendo postulados básicos del Estado de Derecho, que configura una gran conquista de la civilización liberal.

\footnotetext{
${ }^{1}$ Conforme Santiago Mir Puig. El Derecho Penal en el Estado Social y Democrático de Derecho. Editora Ariel Derecho, Barcelona-España: 1994, p.31.

${ }^{2}$ Conforme Elías Díaz, Estado de Derecho y Sociedad Democrática, Editorial Cuadernos para el Diálogo, Madrid-España: 1973, pp. 29 y ss.
} 
La concepción liberal del Estado de Derecho había servido de apoyo a los derechos del hombre, convirtiendo los súbditos en ciudadanos libres, conforme nota Verdú ${ }^{3}$, la cual, todavía, se torna insuficiente, por lo que la expresión Estado de Derecho había evolucionado, enriqueciéndose con nuevo contenido.

Sin embargo, hubo concepciones deformadoras del concepto de Estado de Derecho, pues es perceptible que su significado depende de la propia idea que tiene el Derecho. Por eso, razón cabe a Carl Schmitt cuando señala que la expresión "Estado de Derecho" puede tener tantos significados distintos como la propia palabra "Derecho" y designar tantas organizaciones cuanto a las que se aplica la palabra "Estado". Así, añade, hay un Estado de Derecho feudal, otro estamental, otro burgués, otro nacional, otro social, además de otros conforme con el Derecho natural, con el Derecho racional y con el Derecho histórico ${ }^{4}$. De eso deriva la ambigüedad de la expresión Estado de Derecho, sin más calificativos que lo indique contenido material. En tal caso, la tendencia es adoptarse la concepción formal del Estado de Derecho a la manera de Forsthoff $^{5}$, o de un Estado de Justicia, tomada la justicia como un concepto absoluto, abstracto, idealista, espiritualista, que, en verdad, encuentra su matriz en el concepto hegeliano de Estado Ético, que fundamentó la concepción de Estado fascista: "totalitario e dictatorial en que los derechos y libertades humanas se quedan prácticamente anuladas y totalmente sometidas al arbitrio de un poder político omnipotente e incontrolado, en el cual toda participación popular es sistemáticamente negada en beneficio de la minoría (en realidad, de la elite) que controla el poder político y económico" ". Desde luego, es importante decir, que el Estado de Justicia, en la formulación indicada, nada tiene que ver con el Estado sometido al Poder Judicial, que es un elemento importante del Estado de Derecho. Estado sometido al juez es Estado

\footnotetext{
${ }^{3}$ Conforme Pablo Lucas Verdú, La Lucha por el Estado de Derecho, Bolonia, Publicaciones del Real Colegio de España, 1975, p. 94.

${ }^{4}$ Conforme Carl Schmitt, Legalidad y Legitimidad, trad. esp. José Díaz García, Ed. Aguilar, MadridEspaña: 1971, p. 23.

${ }^{5}$ Conforme Ernst Forsthoff, Stato di Diritto in Trasformazione, Ed. Giuffrè, Milán-Italia: 1973, p. 6, donde, respondiendo a las criticas, reafirma que sigue a sostener que el Estado de Derecho debe ser entendido en el sentido formal.

${ }^{6}$ Conforme Elías Díaz, Estado de Derecho y Sociedad Democrática, Editorial Cuadernos para el Diálogo, Madrid-España: 1973, pp. 57 y ss., amplia discusión sobre el Estado Ético. El texto citado se encuentra en la p. 77. Con excepción de -“en realidad, de la elite"- que es nuestro.
} 
cuyos actos legislativos, ejecutivos, administrativos y también judiciales se quedan sujetos al control jurisdiccional con respeto a la legitimidad constitucional y legal. Es también una abstracción confundir Estado de Derecho con una visión iusnaturalista de Estado.

Por otro lado, si se concibe el Derecho apenas como un conjunto de normas establecidas por el Legislativo, el estado de Derecho pasa a ser Estado de Legalidad, o Estado legislativo ${ }^{7}$, lo que constituye una reducción deformante. Si el principio de legalidad es un elemento importante del concepto de Estado de Derecho, en el no se realiza completamente.

La concepción jurídica de Kelsen también ha contribuido para deformar el concepto de Estado de Derecho. Para él, Estado y Derecho son conceptos idénticos. En la medida en que él confunde Estado y orden jurídica, ya que desde su punto de vista, todo Estado tiene que ser Estado de Derecho ${ }^{8}$. Por eso, dedica significativo desprecio a ese concepto. Como en su concepción, solo es Derecho el derecho positivo, como norma pura, desvinculada de cualquier contenido, se llega, sin dificultad, a una idea formalista del Estado de Derecho o Estado Formal de Derecho, que sirve también a intereses dictatoriales. Pues, si el Derecho se acaba confundiendo con mero enunciado formal de ley, destituida de cualquier contenido, sin compromiso con la realidad política, social, económica, ideológica, o sea (lo que, en el fondo, esconde una ideología reaccionaria), todo Estado acaba siendo Estado de Derecho, aunque sea dictatorial. Esa doctrina convierte el Estado de Derecho en mero Estado Legal. En verdad, destruye cualquier idea de Estado de Derecho.

Afirma Santiago Mir Puig que: "Del Estado liberal adopta, sin duda, la idea de Estado de Derecho, es decir, de Estado gobernado por el Derecho emanado de la voluntad general, expresada por los representantes del pueblo, en el cual radica la soberanía nacional (artículo $1^{\circ}, 2$, de la Constitución), en contraposición al Estado absoluto, en el Derecho se halla en manos de uno o varios hombres. Así, se expresa en

\footnotetext{
${ }^{7}$ Conforme Carl Schmitt, op. cit., 1971, p. 4: "Por "Estado Legislativo" se entiende aquí un determinado tipo de comunidad política, cuya peculiaridad consiste en que ve la expresión suprema y decisiva de la voluntad común en la proclamación de una especie cualificada de normas que pretende ser Derecho".

${ }^{8}$ Conforme Antonio Enrique Pérez Luño, Estado de Derecho y Derecho Fundamental. Los Derechos Humanos - Significación, Estatuto Jurídico y Sistema, coord. por Antonio Enrique Pérez Luño. Publicaciones de la Universidad de Sevilla, Sevilla-España: 1979, p.165.
} 
el artículo $9^{\circ}, 1$, de la Constitución que $<<\operatorname{los}$ ciudadanos y los poderes públicos están sujetos a la Constitución y al resto del ordenamiento jurídico $>>$. Este modelo de Estado aporta a la trilogía acogida en el artículo $1^{\circ}, 1$, de la Constitución la exigencia de que el ejercicio de los poderes públicos respete determinadas garantías formales, ciertos límites que aseguren la salvaguardia de las esferas de libertad formalmente reconocidas a los ciudadanos. El Estado liberal responde a la preocupación de defender a la sociedad del Estado, lo que pretende conseguir mediante la técnica formal de la división de poderes y el principio de legalidad"9.

El individualismo y el abastecimiento o neutralismo del Estado liberal provocaron inmensas injusticias, y los movimientos sociales del siglo XIX y especialmente del pasado siglo XX, desvelando la insuficiencia de las libertades burguesas, permitieron que se tuviera consciencia de la necesidad de justicia social. Pero el Estado de Derecho que ya no podía justificarse como liberal, necesitó, para enfrentar la marea social, despojarse de su neutralidad, integrar, en su seno, la sociedad, sin renunciar al primado del Derecho. El Estado de Derecho, en la actualidad, dejó de ser formal, neutro e individualista, para transformarse en Estado material de Derecho, mientras adopta una dogmática y pretende realizar la justicia social ${ }^{10}$. Se transforma en Estado Social de Derecho, donde el calificativo social se refiere a la corrección del individualismo clásico liberal por la afirmación de los llamados derechos sociales y realización de objetivos de justicia social ${ }^{11}$. En el propósito de compatibilizar, se caracteriza, en un mismo sistema, apunta Elías Díaz, dos elementos: el capitalismo, como forma de producción, y la consecución del bienestar general, sirviendo de base al neocapitalismo típico del Welfare State ${ }^{12}$.

Además, conforme el autor Santiago Mir Puig: "El Estado social, en cambio, supone el intento de derrumbar las barreras que en el Estado liberal separaban a Estado y sociedad. Si el principio que regía la función del Estado liberal era la limitación de la acción del Estado, el Estado social se erige a continuación en motor activo de la vida social. Si el Estado liberal pretendía reducirse a asegurar las garantías jurídicas y, por tanto, meramente formales, el Estado social se considera llamado a modificar las

\footnotetext{
${ }^{9}$ MIR PUIG, Santiago. Op. cit., 1994, pp. 31-32.

${ }^{10}$ Conforme Pablo Lucas Verdú, op. cit., 1975, p.94.

${ }^{11}$ Conforme Elías Díaz, op. cit., 1973, p. 96; Pablo Lucas Verdú, op. cit., 1975, pp.95 y ss..

${ }^{12}$ Conforme Elías Díaz, op. cit., 1973, p. 106.
} 
efectivas relaciones sociales. Del Estado-árbitro imparcial, del Estado-guardián preocupado ante todo por no interferir en el juego social, se pasa progresivamente al Estado intervencionista que deviene Welfare State",13.

Los regímenes constitucionales occidentales prometen, explícita o implícitamente, realizar el Estado Social de Derecho, cuando definen un capítulo de derechos económicos y sociales. Expresas son las Constituciones de España (art. 1.1, CE) y de la República Federal de Alemania (art. 28. 1, de la Constitución alemana), definiendo los respectivos Estados como sociales y democráticos de Derecho.

Pero aún es insuficiente la concepción de Estado Social de Derecho, aunque, como Estado Material de Derecho, revele un tipo de Estado que tiende a crear una situación de bienestar general que garanta el desarrollo de la persona humana. Su ambigüedad, todavía, es manifiesta. Primero, porque la palabra social está sujeta a varias interpretaciones ${ }^{14}$. Todas las ideologías, con su propia visión de social y de Derecho, pueden acoger una concepción de Estado Social de Derecho. Bien observa Paulo Bonavides: "[...] el Estado social se compadece con regímenes políticos antagónicos, como sean la democracia, el fascismo y el nacional-socialismo"15. En segundo lugar, lo importante no es el social, calificando el Estado, en lugar de calificar el Derecho. Tal vez hasta por eso se pueda dar razón a Forsthoff cuando exprime la idea de que Estado de Derecho y Estado Social no se pueden fundir en el plano constitucional $^{16}$. El propio Elías Díaz, que reconoce la importancia histórica del Estado Social de Derecho, no deja de recordar la sospecha cuanto a saber si y hasta que punto el neocapitalismo del Estado Social de Derecho en realidad no estaría encubriendo una forma mucho más matizada y sutil de dictadura del gran capital, eso es, algo que en el fondo podría denominarse, y se tiene denominado, neofascismo ${ }^{17}$. Él no descarta esta posibilidad, admitiendo que, el gran capital encontró fácil entrada en las nuevas estructuras demoliberales, llegando así a constituirse como pieza clave y central del Welfare State. Aunque institucionalizado no llamado Estado Social de Derecho,

\footnotetext{
${ }^{13}$ MIR PUIG, Santiago. Op. cit., 1994, p. 32.

${ }^{14}$ Conforme Ernst Forsthoff, op. cit., 1973, p. 53.

${ }^{15}$ Conforme Paulo Bonavides, Do Estado Liberal ao Estado Social. Ed. Saraiva, São Paulo-Brasil: 1961, pp. 205-206.

${ }^{16}$ Conforme Ernst Forsthoff, op. cit., 1973, p. 70.

${ }^{17}$ Conforme Elías Díaz, op. cit., 1973, pp. 121 y 123.
} 
permanece siempre bajo este - representada por sus grupos políticos y económicos más reaccionarios y violentos - esa tendencia y propensión del capitalismo al control económico monopolista y a la utilización de métodos políticos de carácter totalitario y dictatorial, visando a evitar, sobre todo, cualquier eventualidad realmente socialista ${ }^{18}$.

Por todo eso, la expresión Estado Social de Derecho ${ }^{19}$ se manifiesta cargada de sospecha, aunque se torne más precisa cuando se la adjunta la palabra democrático como hicieron las Constituciones de España y Alemania para llamarlo de Estado Social y Democrático de Derecho. Pero, ahí, manteniendo el calificativo social relacionado al Estado, encajase aquella tendencia neocapitalista y la petrificación del Welfare State, con el contenido arriba mencionado, delimitadora de cualquier paso adelante en el sentido socialista. Tal vez, para caracterizar un Estado no socialista preocupado, no obstante, con la realización de los derechos fundamentales de carácter social, con el que se definiría una concepción jurídica más progresista y abierta, y luego, en lugar de Estado Social de Derecho, diríamos Estado de Derecho Social.

Las consideraciones supra muestran que el Estado de Derecho, sea como Estado Liberal de Derecho, sea como Estado Social de Derecho, ni siempre caracteriza Estado Democrático. Este se basa en el principio de soberanía popular que "impone la participación efectiva y operante del pueblo en la cosa pública, participación que no se agote, como vamos a ver, en la simple formación de las instituciones representativas, que constituyen una etapa de la evolución del Estado Democrático, pero no su pleno desarrollo"20. Busca, así, a realizar el principio democrático como garantía general de

\footnotetext{
${ }^{18}$ Conforme Elías Díaz, op. cit., 1973, pp. 122 y 123.
}

19 Sobre el Estado social de Derecho, Manuel García-Pelayo, Las transformaciones del Estado contemporáneo. $2^{\mathrm{a}}$ ed., Alianza Editorial, Madrid-España: 1985, pp. 16-18, afirma que la idea se debe al tratadista alemán de Teoría del Estado, Hermann Heller, quien entre los años veinte y treinta del siglo pasado, lo propugna, como alternativa socialdemócrata entre la anarquía económica y la dictadura fascista, sosteniendo además, que no se trata de renunciar al Estado de Derecho, sino de dar a éste un contenido económico y social, de realizar en el marco del Estado de Derecho un nuevo orden laboral y de distribución de bienes. Lo que inicialmente forma parte del ideario de los partidos socialdemócratas pasa progresivamente a extenderse a los partidos democratacristianos, conservadores o liberales, de manera más o menos intensa, es cierto, según los momentos, lugares e ideologías políticas de los gobernantes. Esa generalización lleva el autor a sostener que el Estado social significa históricamente el intento de adaptación liberal - burgués a las condiciones de la civilización industrial y posindustrial.

${ }^{20}$ Conforme Emilio Crosa, Lo Stato Democratico, Ed. UTET, Turín-Italia: 1946, p. 25. Además, conforme explica Santiago Mir Puig, Op. cit., 1994, p. 33: "Históricamente, el Estado liberal y el social se 
los derechos fundamentales de la persona humana. En ese sentido, en realidad, se contrapone al Estado Liberal, pues, como recuerda Paulo Bonavides, "la idea esencial del liberalismo no es la presencia del elemento popular en la formación de la voluntad estatal, ni tampoco la teoría igualitaria de que todos tienen igual derecho a esa participación o que la libertad es formalmente ese derecho"21.

El Estado de derecho, como arriba recordamos, es una creación del liberalismo. Por eso, en la doctrina clásica, radica en la concepción del Derecho natural, inmutable, y universal, de ahí, se deduce que la ley, que realiza el principio de legalidad esencia del concepto de Estado de Derecho, es concebida como norma jurídica general y abstracta. La generalidad de la ley constituía la fundación del Estado de Derecho. En ella se asentaría lo justo conforme la razón. De ella y solo de ella difluiría la igualdad. "Siendo regla general, la ley es regla para todos" ${ }^{\prime 22}$. Carl Schmitt bajo la Constitución de Weimar, resucita la proposición de la generalidad de las leyes, después de haber sido abandonado bajo la influencia de Laband, surgiendo, en su lugar, la división de las leyes en formales y materiales ${ }^{23}$. Esa restauración tiene sentido ideológico preciso, pues,

hallan en la relación dialéctica de tesis y antítesis. La sustitución paulatina del Estado liberal por el intervencionista representó una progresiva relajación y un distanciamiento de las garantías liberales, que acaban viéndose como $<<$ prejuicios burgueses $>>$ puramente formales, frente a los cuales no tiene por qué retroceder la acción del Estado. Se llega así a los totalitarismos de izquierdas o de derechas que van sembrando el panorama político de entre las dos guerras mundiales. Pero ello no significa que el Estado liberal y el Estado social no puedan converger en una síntesis. El Estado intervencionista no implica necesariamente una concepción autoritaria. Lo único esencial al mismo es la asunción de una función de incidencia activa en las relaciones sociales efectivas, y esta función puede ponerse al servicio no sólo de una minoría o de un discutible todo social, sino también del progreso efectivo de cada uno de los ciudadanos. Siendo así, no resultará contradictorio con ese Estado social el imponerle los límites propios del Estado de Derecho, igualmente al servicio del ciudadano, los cuales podrán impedir que se desarrolle la tendencia del Estado social a un intervencionismo autoritario, que dejaría de servir a los intereses también $<<$ reales $>>$ - del particular".

${ }^{21}$ Conforme Paulo Bonavides, Do Estado Liberal ao Estado Social, Imprensa Universitária, FortalezaBrasil: 1958, p. 16.

${ }^{22}$ Conforme Manoel Gonçalves Ferreira Filho, Estado de Direito e Constituição, Editora Saraiva, São Paulo-Brasil: 1988, p. 21.

${ }^{23}$ Conforme Franz Leopold Neumann, Estado Democrático e Estado Autoritário, trad. de Luiz Corção, Zahar Editores, Rio de Janeiro-Brasil: 1969, pp. 60-61, apud José Afonso da Silva. A advocacia pública e o Estado Democrático de Direito. Disponible en: < http://bibliotecadigital.fgv.br/ojs/index.php/rda/article/viewFile/46346/45117>. 
como recuerda Franz Neumann, la teoría de que el Estado solo puede gobernar por medio de leyes generales se aplica a un sistema económico de libre competencia ${ }^{24}$, y el “renacimiento, bajo la Constitución de Weimar, de la noción de generalidad de las leyes y de su aplicación indiscriminada a las libertades personales, políticas y económicas, fue así utilizado como un dispositivo para restringir el poder del Parlamento que ya no más representaba exclusivamente los intereses de los grandes terratenientes, de los capitalista, del ejercito y de la burocracia. Y luego, el derecho general, dentro de la esfera económica, era utilizado para conservar el sistema de propiedad existente y para protegerlo contra intervención siempre que esta fuera juzgada incompatible con los intereses de los grupos arriba citados" 25 .

Con frecuencia, se analiza la doctrina de la "voluntad general" de Rousseau para fundamentar la afirmativa de que la igualdad solo puede ser alcanzada mediante normas generales, recordando que él discutía el derecho general con referencia a una sociedad en que sólo había pequeñas propiedades o propiedades comunes ${ }^{26}$. De hecho, la "propiedad particular, que es sagrada y inviolable, según Rousseau, solo es propiedad hasta donde permanece como un derecho individual y discriminado. "Si se considera común a todos los ciudadanos, quedará sujeta a la 'voluntad general' y podrá ser infringida o negada. Así el soberano no tiene el derecho de tocar en la propiedad de otro o de diversos ciudadanos, aunque legítimamente pueda tomar la propiedad de todos"27.

En conclusión, en la concepción clásica, la igualdad del Estado de Derecho, está basada en la generalidad de las leyes, o sea, en un elemento puramente formal y abstracto. No tiene base material que se realice en la vida concreta. El intento de superar eso, fue con la construcción del Estado Social de Derecho, que, no obstante, no fue capaz de asegurar la justicia social ni la autentica participación democrática del pueblo

\footnotetext{
${ }^{24}$ Conforme Franz Leopold Neumann, op. cit., trad. de Luiz Corção, 1969, p. 61, apud José Afonso da Silva. A advocacia pública e o Estado Democrático de Direito. Disponible en: < http://bibliotecadigital.fgv.br/ojs/index.php/rda/article/viewFile/46346/45117>.

${ }^{25}$ Conforme Franz Leopold Neumann, op. cit., trad. de Luiz Corção, 1969, p. 63, apud José Afonso da Silva. A advocacia pública e o Estado Democrático de Direito. Disponible en: < http://bibliotecadigital.fgv.br/ojs/index.php/rda/article/viewFile/46346/45117>.

${ }^{26}$ Idem, p. 61, apud José Afonso da Silva. A advocacia pública e o Estado Democrático de Direito. Disponible en: $<$ http://bibliotecadigital.fgv.br/ojs/index.php/rda/article/viewFile/46346/45117>.

${ }^{27}$ Idem, p. 62, apud José Afonso da Silva. A advocacia pública e o Estado Democrático de Direito. Disponible en: < http://bibliotecadigital.fgv.br/ojs/index.php/rda/article/viewFile/46346/45117>.
} 
en el proceso político, de donde la concepción más reciente de Estado Democrático de Derecho, como Estado de justa legitimidad (o Estado de Justicia material), fundante de una sociedad democrática cual sea la que instaure un proceso de efectiva incorporación de todo el pueblo en los mecanismos de control de decisiones, y de su real participación en los rendimientos de producción ${ }^{28}$.

La configuración del Estado Democrático de Derecho no significa apenas unir formalmente los conceptos de Estado Democrático y Estado de Derecho. Consiste, en realidad, en la creación de un nuevo concepto, que lleva en cuestión los conceptos de los elementos componentes, pero los supera en la medida en que incorpora un componente revolucionario de transformación del status quo. De ahí, la extrema importancia del artículo 1.1 de la Constitución Española de 1978, cuando afirma que España constituye en un Estado social y democrático de Derecho, no como mera promesa de organizar tal Estado, pues, la Constitución ahí, ya lo está proclamando y fundando.

La Constitución española emplea adecuadamente, apoyada por la doctrina, que el "social y democrático" califica el Estado, lo que irradia los valores sociales y de la democracia sobre todos los elementos constitutivos del Estado y, pues, también sobre el orden jurídica. El Derecho, así, imantado por esos valores, se enriquece del sentir popular y tendrá que ajustarse al interés colectivo ${ }^{29}$.

\footnotetext{
${ }^{28}$ Conforme Elías Díaz, op. cit., 1973, pp. 139 y 141.

${ }^{29}$ Según, Manuel García Pelayo, El Estado Social y democrático de Derecho en la Constitución Española, en Manuel García-Pelayo, Las transformaciones del Estado contemporáneo, Madrid: Alianza Editorial, pp. 92-104: “(...) la originalidad y significación de la fórmula "Estado social y democrático de Derecho” (...) radica en la integración de los tres términos en una totalidad conceptual que define a un tipo de Estado relativamente complejo constituido por la unidad de tres componentes vinculados entre sí (...). El hecho de que se trate de una totalidad significa que: Cada uno de los términos, sin perjuicio de su propia autonomía, está vinculado con los demás mediante relaciones de coordinación que, de un lado, establecen limitaciones a su desarrollo y, de otro, amplían sus posibilidades de realización, lo que en sus términos más generales significa lo siguiente: (i) El componente social no podrá desarrollarse ni autoritaria ni arbitrariamente, sino por métodos democráticos y sometido a la disciplina del Derecho. Pero, a su vez, el principio democrático es la garantía de que los intereses sociales sean atendidos por la legislación y las políticas gubernamentales en proporción a su menor o mayor presencia en la sociedad. Su vinculación al Estado de Derecho asegura, por su parte, la realización ordenada de los valores sociales y garantiza su respeto frente a posibles actos arbitrarios de los poderes públicos; (ii) El componente democrático encuentra sus límites en la estructura normativa del Estado de Derecho, a la vez que es generalmente
} 
Importante resaltar que la Constitución española acoge a los principios democráticos, consagrando como derecho fundamental la igualdad ante la ley y rechazando cualquier discriminación por razón de nacimiento, raza, sexo, religión, opinión o cualquier otra condición o circunstancia personal o social (art. 14, CE), también, convierte la participación política en derecho fundamental (art. 23, CE).

La democracia que el Estado Democrático de Derecho realiza hay de ser un proceso de convivencia social en una sociedad libre y justa, en que el poder emana del pueblo, que debe ser ejercido en provecho del pueblo, directamente o por representantes elegidos; participativa porque envuelve la participación crecente del pueblo en el proceso decisorio y el la formación de los actos del gobierno; pluralista, porque respeta la pluralidad de ideas, culturas y etnias y presupone así, un diálogo entre opiniones y pensamientos divergentes y la posibilidad de convivencia de formas de organización y diferentes intereses de la sociedad; tiene de ser un proceso de liberación de la persona humana de las formas de opresión que no depende apenas del reconocimiento formal de determinados derechos individuales, políticos y sociales, pero especialmente de la vigencia de condiciones económicas susceptibles de favorecer su pleno ejercicio.

Explica Mir Puig que: “(...) la fórmula $<<$ Estado social y democrático de Derecho $>>$ supone no sólo la tentativa de someter la actuación del Estado social - a la que no se quiere renunciar - a los límites formales del Estado de Derecho, sino también su orientación material hacia la democracia real. Se pretende, por esta vía, acoger una modalidad de Estado social - al servicio de todos los ciudadanos. En cuanto social y democrático, tal Estado deberá crear condiciones sociales reales que favorezcan la vida del individuo, pero para garantizar el control por el mismo ciudadano de tales condiciones deberá ser, además, un Estado democrático de Derecho. El carácter democrático de ese Estado aparece vinculado, pues, a la síntesis del Estado social y del Derecho, y expresa tanto la necesidad de libertad $<<$ real $>>$ - oponiéndose a que el

considerado como una parte integrante y esencial de éste. Su contenido se amplía a la dimensión social, que pone, a su vez, los límites al decisionismo democrático, ya que debe respetar los valores sociales constitucionalmente protegidos; (iii) El formalismo del Estado de Derecho no podrá extenderse hasta bloquear los valores sociales y democráticos, a la vez que la orientación hacia estos valores contribuye a que el Estado de Derecho no degenere hasta convertirse en un simple Estado legal compatible conformas autoritarias o con cualquier especie de contenido material”. Disponible en: $<$ http://www.uned.es/dptoderecho-politico/IV._Manuel_Garcia_Pelayo.pdf>. Acceso en 27-07-2015. 
$<<$ Estado social $>>$ dirija sólo su intervención en beneficio de ciertos grupos - como $<<$ formal $>>$ - cerrando el paso a la posibilidad de un $<<$ Estado de Derecho $>>$ no controlado por todo el pueblo - para los ciudadanos"

Por lo tanto, la Constitución española, abre la perspectiva de realización social profunda por la práctica de los derechos sociales que ella inscribe y por el ejercicio de los instrumentos que ofrece a la ciudadanía y que posibilita concretizar las exigencias de un Estado de justicia social, fundado en la dignidad de la persona humana ${ }^{31}$.

${ }^{30}$ MIR PUIG, Santiago. Op. cit., 1994, pp. 33-34. Sobre el tema, Manuel García-Pelayo, El Estado Social y democrático de Derecho en la Constitución Española, en Manuel García-Pelayo, Las transformaciones del Estado contemporáneo, Madrid: Alianza Editorial, pp. 92-104 afirma que: "La jurisprudencia del Tribunal Constitucional ha tenido reiteradamente en cuenta el carácter vinculante de la fórmula Estado social y democrático de Derecho y ha puesto de manifiesto su importancia como punto de referencia interpretativo. En este sentido ha manifestado que dicho tipo de Estado supone respecto al Estado liberal de Derecho que los derechos fundamentales no tienen un alcance meramente negativo y que han de ser garantizados por prestaciones sociales o de otra índole a cargo del Estado (voto particular a la STC 86/82); que tiene entre otras significaciones la de legitimar medios de defensa a los intereses y grupos de población socialmente dependientes y que si el Estado social no excluye los conflictos socioeconómicos, sí puede y debe proporcionar los adecuados cauces institucionales para resolverlos (STC 11/1981). (...) Ha interpretado que el carácter social y democrático del Estado impide que en nombre del principio de igualdad se prive al trabajador de las conquistas sociales conseguidas (STC 81/82) (...)”. Disponible en: < http://www.uned.es/dpto-derecho-politico/IV._Manuel_Garcia_Pelayo.pdf>. Acceso en: 22-07-2015.

${ }^{31}$ Según, Manuel García Pelayo, El Estado Social y democrático de Derecho en la Constitución Española, en Manuel García-Pelayo, Las transformaciones del Estado contemporáneo, Madrid: Alianza Editorial, pp. 92-104: "No es imposible un Estado autoritario que desarrolle una política socialmente orientada y que por ello pudiera ser designado como social, pero (...) la misma dignidad de los ciudadanos hace que el principio social sea complementado con el democrático, que ofrezca la posibilidad de que las demandas sociales al Estado sean planteadas por los ciudadanos mismos y satisfechas como un derecho y no como un acto de benevolencia. La articulación del Estado de Derecho y del Estado social se planteó (...) para hacer compatibles las necesarias transformaciones sociales con las libertades fundamentales y con las garantías que para la seguridad jurídica ofrece el Estado de Derecho (...)". Disponible en: $<$ http://www.uned.es/dpto-derecho-politico/IV._Manuel_Garcia_Pelayo.pdf $>$. Acceso en 27-07-2015. Conforme Pablo Lucas Verdú, Estimativa y politica constitucionales, Madrid, UCM, Facultad de Derecho, Sección de Publicaciones, 1984, pp. 100-118, in Fernando Batista Jiménez, La dignidad de la persona en la Constitución española: naturaleza jurídica y funciones. "La dignidad de la persona humana, contenida en el artículo 10.1, CE, constituye un valor constitucional. En efecto, a su juicio, desde el punto de vista conceptual, los valores constitucionales se diferencian de los derechos —aunque se relacionan con ellos - en atención a tres razones, a saber: 1) porque les sirven de fundamento, 2) 
porque inspiran su perfeccionamiento, y, 3) porque ayudan a su interpretación. Desde su óptica personal, aun cuando no se señale así en el artículo 1.1 — citado en líneas precedentes-, la dignidad de la persona ha de ser considerada como valor constitucional, en atención a las siguientes consideraciones: En primer lugar, en razón de que al redactar la norma de apertura, el constituyente no pretendió fijar un número determinado de valores constitucionales, sino solamente decretar aquellos que sirvieran como lineamiento general reflejo de la cultura política, dentro de la cual se inscribe el ordenamiento constitucional español; En segundo término, habida cuenta que el preámbulo de la propia carta fundamental, al señalar que la nación española — en uso de su soberanía - debe "promover el progreso de la cultura y de la economía para asegurar a todos una digna calidad de vida", se refiere a las personas, "pues el párrafo se refiere a todos, y la digna calidad de vida se promueve partiendo, implícitamente, de que todo ciudadano es digno acreedor de la misma"; y, por último, en virtud de que los valores libertad, justicia, igualdad y pluralismo político, se propugnan partiendo de la base de que se trata de postulados axiológicos en favor de personas dignas, lo que quiere decir que "en la medida que la dignidad humana es valiosa, los valores, ex artículo 1.1, redundan en su beneficio, y los cuatro valores de este precepto son propugnados porque sirven para la protección y perfeccionamiento de la dignidad humana". Así, la dignidad de la persona es un valor constitucional porque cuenta con la nota axiológica característica de la superioridad... la dignidad humana no es - así- un resultado del Estado social y democrático de derecho, sino un presupuesto del mismo... el hombre no es digno porque su convivencia se configure con arreglo a dicho Estado de derecho, sino justamente al contrario: el Estado social y democrático de derecho es digno en la medida en que cuadra con la dignidad humana”. Disponible $<$ http://www.juridicas.unam.mx/publica/rev/cconst/cont/14/ard/ard1.htm\#N*>. Acceso en: 27-07-2015. María Merino Norverto, Sinopsis artículo 10 de la Constitución española, afirma que: "Por lo que se refiere a la cláusula interpretativa, de los derechos fundamentales y de las libertades que la Constitución reconoce, conforme a la Declaración Universal de Derechos Humanos y los tratados y acuerdos ratificados por España, establecida en el apartado segundo del artículo 10, supone la apertura al Derecho Internacional de los Derechos Humanos. De este modo, tanto la Declaración como los tratados se convierten en parámetro interpretativo de todos los derechos y libertades contenidos en el Título I de nuestra Constitución, con independencia de cuál sea su ubicación en la sistemática del mencionado Título y por tanto de su sistema de garantías. Sin embargo, hasta el momento, nuestro Tribunal Constitucional no ha interpretado derechos contenidos en el Capítulo III de la Constitución a la luz de ningún Tratado Internacional, aunque podemos señalar, a modo de ejemplo, la STC 199/1996, de 3 de diciembre (fundamentos jurídicos 2 y 3 ) en la que parece admitirse únicamente de manera implícita la labor exegética del Convenio de Roma en la interpretación del artículo 45 de la Constitución. Resulta necesario aclarar que, a través del artículo 10.2 de la Constitución, no se otorga rango constitucional a los derechos y libertades proclamados en los Tratados Internacionales en cuanto no estén también recogidos en nuestra Constitución. Ha sido el Tribunal Constitucional el que ha delimitado el valor de esta estipulación. Así, La STC 36/1991, de 14 de febrero declaró que «esta norma se limita a establecer una conexión entre nuestro propio sistema de derechos fundamentales y libertades, de un lado, y los Convenios y Tratados internacionales sobre las mismas materias en los que sea parte España, de otro. No da rango 


\subsection{Estado democrático de Derecho y la dignidad de la persona humana como fundamento de la Constitución Brasileña de 1988}

El Título I de la actual Constitución brasileña viene nombrado como "Principios Fundamentales" y se compone de cuatro artículos. Esos principios son los fundamentos para la Constitución. Establecen el contenido, las directrices y las finalidades las cuales el legislador (constitucional o infraconstitucional) debe seguir, no pudiendo ir más allá, so pena de transgresión, y no puede quedar corto, so pena de omisión.

En el caput de su art. $1^{\circ}$, la Constitución afirma nuestra República como un Estado Democrático de Derecho fundado - al que importa destacar en el presente estudio - en la dignidad de la persona humana (inciso III). Tal fundamento, así como los demás constantes del citado artículo primero, está dirigido a la consecución de objetivos también fundamentales (artículo $3^{\circ}$ ), entre los cuales: "construir una sociedad libre, justa y solidaria" (inciso I); "asegurar el desarrollo nacional" (inciso II); “erradicar la

constitucional a los derechos y libertades internacionalmente proclamados en cuanto no estén también consagrados por nuestra propia Constitución, pero obliga a interpretar los correspondientes preceptos de ésta de acuerdo con el contenido de dichos Tratados o Convenios, de modo que en la práctica este contenido se convierte en cierto modo en el contenido constitucionalmente declarado de los derechos y libertades que enuncia el capítulo segundo del título I de nuestra Constitución (F.J. 5). Así, en palabras del Tribunal Constitucional "aunque los textos y acuerdos internacionales del artículo 10.2 constituyen una fuente interpretativa que contribuye a la mejor identificación del contenido de los derechos cuya tutela se pide a este Tribunal Constitucional, la interpretación a que alude el citado artículo 10.2 del texto constitucional no los convierte en canon autónomo de validez de las normas y actos de los poderes públicos desde la perspectiva de los derechos fundamentales, es decir, no los convierte en canon autónomo de constitucionalidad". "Si así fuera, sobraría la proclamación constitucional de tales derechos, bastando con que el constituyente hubiera efectuado una remisión a las Declaraciones internacionales de Derechos Humanos o, en general, a los tratados que suscriba el Estado español sobre derechos fundamentales y libertades públicas". SSTC 64/1991, de 22 de marzo (fundamento jurídico 4), 372/1993, de 13 de diciembre, (fundamento jurídico 7), 41/2002, de 25 de febrero (fundamento jurídico 2) y STC 236/2007 de 7 noviembre F.J 5. Hay que advertir que los tratados citados en este artículo 10.2 han de estar publicados oficialmente en España para su consideración como parte del ordenamiento jurídico interno y su utilización a efectos interpretativos, tal y como se establece en el artículo 96.1 de nuestra Constitución". Disponible en: http://www.congreso.es/consti/constitucion/indice/sinopsis/sinopsis.jsp?art=10\&tipo=2>. Acceso en: 2707-2015. 
pobreza y la marginalización y reducir las desigualdades sociales y regionales" (inciso III) y "promover el bien de todos, sin prejuicio de origen, raza, sexo, color, edad y cualesquier otras formas de discriminación" (inciso IV). Aun en aquel Título I, demostrando haber absorbido e introducido los influjos recibidos de los organismos internacionales de derechos humanos, Brasil se compromete con las demás naciones a dar prevalencia a los derechos humanos (art. $4^{\circ}$, inciso II).

Los principios fundamentales de la dignidad de la persona humana y del Estado Democrático de Derecho, de importante relevancia en el presente estudio, constituyen directrices estructurales y axiológicas que no solo determinaran la inscripción de los varios derechos fundamentales en la Constitución de la República, sino que siguen siendo valores que guían todo el trabajo hermenéutico del legislador, del administrador público, del juzgador y de todos los ciudadanos en sus relaciones privadas ${ }^{32}$.

\subsection{Estado democrático de Derecho: algunas consideraciones}

En ese ítem no se buscará agotar toda la extensión que el "concepto clave"33 de Estado Democrático de Derecho tiene para la Constitución brasileña. El presente estudio no se dirige o comporta tarea demasiadamente extensa y merecedora de trabajo específico. La preocupación está en mostrar lo que caracteriza un régimen político de esos moldes, su relación con los derechos fundamentales y, principalmente, el papel de cada institución y instituto, así como de los ciudadanos en general, en la construcción de un Estado con aquel perfil.

\footnotetext{
${ }^{32}$ Ingo Wolfgang Sarlet, Algunas notas acerca de la relación entre principio de la dignidad de la persona humana y los derechos fundamentales en la orden constitucional brasileña, in George Salomão Leite(Org.), Dos princípios constitucionais: consideração em torno das normas principiológicas da Constituição, Editora Malheiros, São Paulo-Brasil: 2003, p. 223, al analizar como la positivización de la dignidad de la persona humana, como principio constitucional fundamental, se relaciona con los derechos fundamentales, bien destaca la "función instrumental integradora" y la "función hermenéutica" de aquel principio no solo para esos derechos, sino que para todo el ordenamiento jurídico.

${ }^{33}$ Sobre la extensión del Estado Democrático de Derecho y sobre ser el un "concepto clave" para la Constitución Portuguesa, v. José Joaquim Gomes Canotilho y Vital Moreira. Constituição da República Portuguesa anotada. Editora Revista dos Tribunais, São Paulo-Brasil: 2007, v. I, p. 204, item III.
} 
Para eso es necesario partir de la visión de que Brasil es una República y, con eso, fijarse que el poder, en su acepción más larga, adviene del pueblo y no de la fuerza militar, de líneas hereditarias o por elección divina. En nuestra República, conforme preceptúa el párrafo único del art. $1^{\circ}$ de la Constitución, "todo el poder emana del pueblo, que ejerce por medio de sus representantes elegidos directamente, en los términos de esa Constitución". Luego, hay una soberanía popular que se hace presente a través de los procedimientos por ella elegidos para ser representada ${ }^{34}$.

En esa perspectiva de soberanía popular en el ápice del poder, la determinación de que Brasil sea un Estado Democrático de Derecho asegura que la nación guiada no por hombres, sino que por leyes (estado de Derecho) soberanamente elegidos por el pueblo, lo que lo confiere el atributo "democrático".

En la etapa actual de la ciencia del derecho constitucional, la fórmula elegida por nuestro constituyente se muestra el ideal, pues, además de exceder tanto al concepto de Estado de Derecho cuanto al de Estado Democrático, extrae de ambas fórmulas lo que representan de mejor. Hubo en la historia humana Estados de derecho profundamente violadores de las más elementares garantías humanas; así como también hubo Estados Democráticos (en el sentido clásico de gobierno representativo, en el cual la mayoría decide los destinos) que, por no poseyeren límites legales para la actuación de sus líderes, estos se tornaban autoritarios, por cuanto entendían que en nombre del pueblo, del público o del estatal podrían violar la vida y los intereses privados, particulares o individuales, como por ejemplo muchos Estados comunistas ${ }^{35}$.

En ese contexto, en un Estado Democrático de Derecho no hay un gobierno de los hombres (mismo estando en mayoría) o de cualquier ley, sino que de supremacía de las leyes tenidas por la población como las más relevantes para su pacifica convivencia en búsqueda de la felicidad. Esas leyes, soberanamente elegidas y limitadoras de la

\footnotetext{
${ }^{34}$ Para un análisis de la soberanía popular como uno de los puntos más relevantes de un régimen republicano, y el reflejo de eso para el sistema constitucional, v. José Joaquim Gomes Canotilho. Direito Constitucional e Teoria da Constituição. $5^{\mathrm{a}}$ edição, Editora Almedina, Coimbra-Portugal: 2002, pp. 224228.

${ }^{35}$ Jorge Miranda expone una crítica al retroceso, en materia de derecho fundamental, ocurrido en el interior de los regímenes soviéticos, fascista y autoritario, no obstante fuesen de "derecho", y, aun, en muchos otros regímenes actuales, de diferentes tendencias, de Asia y de África. Manual de direito constitucional: Constituição. $3^{\text {a }}$ ed. Revista e actualizada. Editora Coimbra, Coimbra-Portugal: 2000, t. IV, pp. 27-30.
} 
actuación o del poder del hombre, mismo en eventual o momentánea mayoría, son las leyes puestas a nivel constitucional $\mathrm{y}$, especialmente, los derechos fundamentales consagrados en ese nivel jerárquico.

El Estado Democrático de Derecho es la fórmula empleada a fin de haber una perfecta interacción entre dos "principios sustantivos - el de la soberanía del pueblo y el de los derechos fundamentales - es la mediatización de los principios adjetivos de la constitucionalidad y de la legalidad, en una postura extrema de irrestricto dominio de la mayoría, el principio democrático podría resultar en violación del contenido esencial de derechos fundamentales; así como, llevado a los últimos corolarios, el principio de la libertad podría rechazar cualquier decisión política sobre su modelación; el equilibrio se obtiene a través del esfuerzo de conjugación, constantemente renovado y actualizado, de principios, valores e intereses bien como a través de una compleja articulación de órganos políticos y jurisdiccionales, con conocidas gradaciones"36.

\footnotetext{
${ }^{36}$ MIRANDA, Jorge. Manual cit., t. IV, p. 211. En ese mismo sentido, a favor de la vinculación efectiva e irrestricta del legislador a las normas de derechos fundamentales positivadas como una manera de prevenir que cualquier mayorías parlamentarias nos violen, v. Martin Borowski, la estructura de los derechos fundamentales, traducción de Carlos Bernal Pulido, Bogotá: Universidad Externado de Colombia, Serie de Teoría Jurídica y Filosofía del derecho no . 25, 2003, pp. 36-37 y 85. Comentando el sistema italiano, que también tiene tanto la concepción "democrática" como la "de derecho", Luigi Ferrajoli, Diritto e ragione: Teoria del garantismo penale, $3^{\mathrm{a}}$ ed., Bari: Laterza, 1996, item 57 A) 2, pp. 898-901, en traducción libre: "Es superfluo recordar que el estado moderno nació históricamente como estado de derecho, antes de nacer como estado democrático; como monarquía constitucional y no como democracia representativa. Con más precisión, nació como estado de derecho limitado por prohibiciones (o deberes negativos de no hacer) y todavía atado a obligaciones (o deberes positivos de hacer). (...) pero también axiológicamente, y no solo cronológicamente, la limitación legal del poder soberano precede a su fundamentación democrático-representativa. La primera regla, de todo pacto constitucional sobre convivencia civil no es el hecho de que, sobre todo si debe decidir por mayoría, sino que no si puede decidir sobre todo (o no decidir), ni mismo por la mayoría. Ninguna mayoría puede decidir la supresión (o no decidir la protección) de una minoría o de un único ciudadano. Bajo ese aspecto el estado de derecho, entendido como sistema de límites sustanciales impuestos legalmente a los poderes públicos para la garantía de los derechos fundamentales, si contrapone al estado absoluto, sea el autocrático o democrático. También la democracia política más perfecta, representativa o directa, es de hecho un régimen absoluto y totalitario si el poder del pueblo es en ella ilimitado. Sus reglas son, sin duda, las mejores para determinar quien puede decidir y como debe decidir, pero no son suficientes para legitimar cualquier decisión o no decisión. Ni por unanimidad un pueblo puede decidir (o consentir con que se decida) que un hombre muera o sea privado sin culpa de su libertad, que piense o escriba o no piense o no
} 


\subsection{El Ciudadano como sujeto de deberes}

El Estado Democrático de Derecho también representa, como fórmula política, una superación de la dialéctica entre Estado Liberal y Estado Social, pues, tiene como compromiso la "armonización de intereses que se sitúan en tres esferas fundamentales: la 'esfera pública', ocupada por el Estado; la 'esfera privada', en que se sitúa el individuo, y un segmento intermediario, la 'esfera colectiva', en que se tiene los intereses de individuos en cuanto miembros de determinados grupos, formados para la consecución de objetivos económicos, políticos, culturales u otros" ${ }^{37}$. Existe, pues, una convicción que está se generalizando en la doctrina constitucional brasileña, merced de los derechos fundamentales sociales y liberales incorporados en la Carta Constitucional, que Brasil es, en esencia, un Estado Democrático y Social de Derecho ${ }^{38}$.

En ese perfil juspolítico, la participación popular para la garantía de una fórmula política no puede limitarse a la elección de lo que debe o no ser asegurado (derechos), esperando con eso que el contenido y finalidad de la norma se auto-realicen o sean efectuados por ente (público o privado) diverso del ciudadano, por cuanto este último lo es, de una sola vez, el determinador y el titular. Inscribir en la ley los aspectos de la vida cotidiano que el individuo quiere ver protegidos y efectuados no limita su misión constitucional de ciudadano. La ciudadanía, otro fundamento de todo el ordenamiento brasileño (art. $1^{\circ}$, inciso II, CF/88), exige que cada integrante (público o privado) de la nación brasileña asuma los deberes y responsabilidades por las elecciones

escriba de una cierta manera, que no se reúna o no se asocie con otros, que se case o que no se case con determinada persona o que se quede con ella indisolublemente relacionado, que tenga o no tenga hijos, que haga o que no haga determinado trabajo, u otras cosas semejantes. La garantía de esos derechos vitales es la condición indispensable de la convivencia pacífica. Por eso su lesión por parte del Estado justifica no simplemente la crítica o el disenso, como para las cuestiones no vitales sobre las cosas vale la regla de la mayoría, pero la resistencia a la opresión, hasta la guerra civil. 'sobre cuestiones de resistencia', se dice, 'no se deja establecer la minoría'”.

${ }^{37}$ GUERRA FILHO, Willis Santiago. Processo constitucional e direitos fundamentais, $4^{\mathrm{a}}$ ed., Editora RCS, São Paulo-Brasil: 2005, p.24.

${ }^{38}$ SCARLET, Ingo Wolfgang. A eficácia dos direitos fundamentais. $7^{\mathrm{a}}$ edição. Editora Livraria do Advogado, Porto Alegre-Brasil: 2007, pp. 69-74, con mucha referencia bibliográfica nacional y extranjera. 
hechas democráticamente y, entre esas responsabilidades, está la promoción, realización y respeto de aquellas elecciones.

El nomen juris del Capítulo I del Título II de la Constitución de la República de Brasil recuerda a todos que en los dispositivos inseridos en ello hay: "derechos y deberes individuales y colectivos". Los deberes, naturalmente, resultan de los derechos “en la medida en que cada titular de derechos individuales tiene el deber de reconocer y respetar igual derecho del otro, así como el deber de comportarse, en las relaciones inter-humanas, con postura democrática, comprendiendo que la dignidad de la persona humana del próximo debe ser exaltada como a su propia"39. Si el Estado Democrático de Derecho es una garantía a los ciudadanos, son estos, en sus actuaciones (públicas o privadas), los grandes responsables por su efectuación en cada aspecto de su contenido político-estructural. Los derechos fundamentales, para que sean efectuados, dependen de la actuación cotidiana de los agentes privados (individuales o colectivos) y de los agentes públicos (individuales o institucionales).

Hay, en Brasil, una costumbre de se transferir responsabilidades por la efectuación de los dispositivos constitucionales. Eso ocurre, con frecuencia, por los agentes privados (individuales o colectivos) que, desconsiderando su importante actuación privada en la realización de los ideales constitucionales, entienden que todas las elecciones por ellos hechas en el texto legal o deben ser efectuadas por el Estado, o su no realización es culpa de la falta o de la ineficiencia de leyes. Actuando en esa "tercerización" al "otro" de "sus" responsabilidades, los ciudadanos niegan - no viendo o pretendiendo no ver - un medio relevante para la realización de los designios legales (constitucionales e infraconstitucionales), cual sea, su actuación cotidiana. La actuación de los individuos, en el ejercicio diario de la ciudadanía, es una de las formas más importantes de transformar los preceptos constitucionales de "law in the books" para una "law in action", para una "living constitution",40.

${ }^{39}$ SILVA, José Afonso da. Curso de direito constitucional positivo. $29^{\mathrm{a}}$ ed. Revisada e atualizada até a Emenda Constitucional no. 53, de 19-12-2006, Editara Malheiros, São Paulo-Brasil: 2007, p. 196.

${ }^{40}$ CANOTILHO, José Joaquim Gomes no apenas destaca la iniciativa de los ciudadanos como importante para tornar los preceptos constitucionales una realidad práctica, sino que la coloca al lado de los procesos judiciales, de los procedimientos electorales y legislativos. Esos tres últimos, al lado de la actuación administrativa, son comúnmente tenidos como los medios más, si no los únicos, indicados por los agentes privados brasileños como los responsables para la realización de los derechos y deberes que deberían competir a todos. Op. cit., 2003, pp. 1162-1163. Willis Santiago Guerra Filho, asevera que la constitución 
Analizándose la "fórmula política" del Estado Democrático de Derecho frente a los derechos fundamentales ${ }^{41}$, no se puede dejar de percibir un profundo nexo de “interdependencia genética y funcional” entre ambos, pues los derechos fundamentales reconocidos en el texto constitucional imponen una gama de valores básicos que deben ser respetados y efectuados ${ }^{42}$. Determinados en la constitución, condicionan no apenas toda la aplicación y la interpretación de los varios dispositivos inseridos en ella, sino que se tornan normas conformadoras de toda la legislación infraconstitucional. Son mejores especificaciones, un mejor detallado, de lo que se debe entender como Estado Democrático de Derecho y, por medio de sus efectuaciones, realizan este principio fundamental.

Cuando un Estado Democrático de Derecho inscribe, en nivel constitucional, un conjunto de derechos fundamentales, de diferentes naturalezas (liberales, sociales, colectivos, etc.), está dejando claro no solo su perfil juspolítico, sino que imponiendo valores esenciales a toda y cualquier acción (pública o privada) bajo su auspicio ${ }^{43}$.

De eso se puede extraer dos consecuencias relevantes para el presente estudio: la primera, que los derechos fundamentales no si pueden agregar apenas una visión individualista, como si fuesen el antípoda del colectivo o del social; la segunda, que aquellos derechos esenciales no tienen en el ciudadano apenas uno de sus destinatarios, sino que también su más relevante promotor y garante. En síntesis, los derechos fundamentales no son óbices individualistas a la consecución estatal del bien común y

\footnotetext{
“se presenta como un 'programa de acción' a ser compartido por todo integrante de la comunidad política, y por eso, responsable a un solo tiempo por su movilidad y estabilidad". Op. cit., 2005, p.17.

${ }^{41}$ Más adelante hablaremos sobre el contenido de los derechos fundamentales y su diferencia para muchos doctrinadores, con los derechos humanos.

${ }^{42}$ No obstante E. Perez Luño, Antonio trate referida interdependencia entre derechos fundamentales y Estado de Derecho, utiliza argumentos de todo aplicables al Estado Democrático de Derecho, en la medida en que se explicitó ser este programa político continente del cual aquel (Estado de Derecho) es contenido, especialmente en el aspecto referido por el constitucionalista español. Los derechos fundamentales. $3^{\text {a }}$ ed., Editorial Tecnos, Madrid-España: 1998, pp. 19-21.

${ }^{43}$ Por esa razón, observada la significativa gama de derechos fundamentales de segunda generación (derechos sociales) en la Constitución, es que se viene firmando que Brasil es, materialmente, un Estado Democrático y Social de Derecho. Sobre el hecho del Estado ser más liberal o social dependiendo del perfil de los derechos fundamentales por el asegurados en nivel constitucional, vide Antonio E. Perez Luño, Op. cit., 1998, pp.19-20.
} 
no son efectuados exclusivamente por actos del Estado, necesitando también de la actuación de cada ciudadano en sus relaciones privadas.

No obstante expuesto arriba sirva para todos los derechos fundamentales, se puede dirigirlo hacía los derechos fundamentales destinados a la tutela ambiental, entre el cual se encuentra el acceso al agua.

Los valores supremos representados por los derechos fundamentales son el mínimo elementar y esencial para el desarrollo humano de sus ciudadanos. Como ocurre en la Constitución brasileña, forman un amago irreductible del Estado Democrático de Derecho y, en el ámbito formal, se constituyen en clausulas pétreas no suprimibles ni mismo por fuerza de emenda constitucional ${ }^{44}$. Esto significa decir que, independientemente de eventual y circunstancial mayoría legislativa, no si puede retirar o de cualquier forma vaciar, en la esfera legislativa, todo contenido de aquellos derechos.

De esa manera, para que no haya una negación de vigencia y validad fáctica de los derechos fundamentales, cabe a una nación, fundada en la propuesta juspolítica de un Estado Democrático de Derecho, no apenas garantir su mantenimiento normativo, sino que cuidarlos a través del mantenimiento y promoción de su contenido esencial. Cabe, por lo tanto, no solo mantener la norma constitucional inalterable por supresión, pero buscando tornarla una verdad al ciudadano, dándola mayor efecto.

Por lo tanto, no basta no suprimirla del ordenamiento o no proceder a la reglamentación que la niegue eficacia, es necesario más que eso, es imprescindible que si emprenda todos los esfuerzos para dar a ella la mayor extensión práctica posible.

En la medida que Brasil se firmó en el escenario mundial como un Estado Democrático de Derecho, en armonía con los más tradicionales derechos humanos consagrados internacionalmente, tanto que los introdujo en su sistema constitucional, cabrá a el so pena de sanciones y represalias internacionales (políticas, económicas y jurídicas), no apenas mantener los derechos fundamentales de la Constitución, sino que regularlos tornando su contenido tanto más extenso y efectivo cuanto sea posible.

Ese tal vez sea el paradojo más perverso de los Estados Democráticos de Derecho en naciones de economía emergente o de modernidad tardía. Son los países

\footnotetext{
${ }^{44}$ Preceptúa el art. $60, \S 4^{\circ}$, inciso IV, de la $\mathrm{CF} / 88$ : "A Constituição poderá ser emendada mediante proposta: (...) $\S 4^{\circ}$ Não será objeto de deliberação a proposta de emenda tendente a abolir: (...) IV - Os direitos e garantias individuais".
} 
cuya población más precisa de la efectuación de los derechos fundamentales, son los que más dependen de aparatos públicos para efectuarlos y, al mismo tiempo, son los más desproveídos de recursos (políticos, económicos, educacionales, sociales, etc.) para tornarlos realidad.

La determinación juspolítica de Brasil ser un Estado Democrático (y Social) de Derecho, por lo tanto, no es una meta, pero un punto de partida. Es un objetivo y un principio fundamental de todo el ordenamiento. No está realizada porque haya sido inscripta, sino porque es un programa de acción abierto y continuo. Como principio que es, orienta e informa el sistema en la búsqueda de objetivos representados por los derechos fundamentales, producto aun inacabado de los deseos de la humanidad para su realización plena y pacífica.

\subsection{Dignidad de la persona humana}

En el principio fundamental del Estado Democrático de Derecho, lo que merece destaque es su importancia política y estructural a determinar que el ciudadano es fuente y destino de los derechos fundamentales y, también a definir los procesos y los procedimientos (legislativos, electorales, procesuales y administrativos) para que el ciudadano ejerza su representación y participación en la elección de aquellos derechos. De la dignidad de la persona humana lo que emerge de manera más relevante es el direccionamiento que ella establece, es el componente teleológico y axiológico que ella impone al ordenamiento y que viene representado por el propósito en se reconocer, promover y tutelar el respeto del ser humano en todos sus aspectos.

Siendo el Estado Democrático de Derecho un programa político de acción de Brasil, la dignidad de la persona humana lo da un criterio, un límite y una finalidad. Por mayor eficientismo, utilitarismo o funcionalismo que si quiera emprender en las acciones (públicas o privadas), si ellas no respetaren el ciudadano en su integralidad carecerán de legitimidad y resultarán inconstitucionales por violación directa de la "dignidad de la persona humana". Así, por más que si quiera, como programa de acción sociopolítica, erradicar el hambre, no si puede querer atingir tal desiderata decretando la muerte, expulsión de personas o prohibiendo que personas tengan hijos. 
La "dignidad de la persona humana" es la representación constitucional brasileña del primer precepto de la Declaración Universal de los Derechos del Hombre de 1948: "Todos los hombres nacen libres e iguales en dignidad y derechos. Son dotados de razón y consciencia y deben actuar unos para con los otros con espíritu de fraternidad". Ese hecho muestra bien la proximidad entre la Carta Política brasileña y los Tratados Internacionales de Derechos Humanos en la desiderata de colocar el ser humano como valor principal del Estado brasileño ${ }^{45}$.

Su topología legal lo confiere jerarquía de principio fundamental no apenas en la Constitución, sino que de todo el ordenamiento jurídico y de las acciones (públicas o privadas) reguladas y implementadas bajo los auspicios de aquel diploma juspolítico ${ }^{46}$. Como el se afirma en nivel nacional, ser la persona humana el principio y el fin de la sociedad, del Estado y del Derecho. La dignidad de la persona humana eleva el hombre a la posición de finalidad ultima de los programas de acción (pública y privada), y no como medio para la consecución de algo 47 .

Esa su jerarquía constitucional y los fines humanos que propone la colocan como un "principio de valor que está a la base del estatuto jurídico de los individuos y confiere unidad de sentido al conjunto de los preceptos relativos a los derechos fundamentales" $" 48$. Se pone, por lo tanto, a la base axiológica de todos los derechos fundamentales, pues sería un disparate imaginarse un derecho fundamental que no

${ }^{45}$ En ese sentido, vide Flávia Piovesan, Direitos Humanos e princípio da dignidade humana, in George Salomão Leite(org.), Dos princípios constitucionais: considerações em torno das normas principiológicas da Constituição, Editora Malheiros, São Paulo-Brasil: 2003, p. 188. También Ana Paula de Barcellos, $A$ eficácia jurídica dos princípios constitucionais: o princípio da dignidade da pessoa humana. Editora Renovar, Rio de Janeiro-Brasil: 2002, pp. 108-109.

${ }^{46}$ Para Flávia Piovesan, Op. cit., 2003, p. 192, “o valor da dignidade da pessoa humana impõe-se como núcleo básico e informador de todo o ordenamento jurídico, como critério e parâmetro de valoração a orientar a interpretação e compreensão do sistema constitucional".

${ }^{47}$ En ese sentido, vide André Ramos Tavares. Curso de direito constitucional. $5^{\mathrm{a}}$ ed., Editora Saraiva, São Paulo-Brasil: 2007, pp. 508-511; y Luiz Virgílio Dalla-Rosa, O direito como garantia: pressupostos de uma teoria constitucional. Editora América, Rio de Janeiro-Brasil: 2003, p. 71, afirma que el Derecho, mismo como experiencia jurídica, y antes mismo de la consecuencia científica, tiene en la persona humana su valor primero y último.

${ }^{48}$ ANDRADE, José Carlos Vieira de. Os direitos fundamentais na Constituição Portuguesa de 1976. $3^{\mathrm{a}}$ ed., reimpressão da edição de 2004. Editora Almedina, Coimbra-Portugal: 2006, pp.101-102. En el mismo sentido, vide André Ramos Tavares, op. cit., 2007, pp. 517-519. 
tuviera como causa y finalidad la calidad completa del ser humano en algún punto de su dignidad. Ese principio fundamental, por lo tanto, tiene necesaria y profunda interrelación con los derechos fundamentales, habiendo apenas variación en el grado de esa vinculación. Es un "superprincipio" que compendia la "unidad material de la Constitución" y, sea en el plano nacional o internacional, "unifica y centraliza todo el sistema normativo, asumiendo especial prioridad"49.

Ingo Wolfgang Sarlet, en el intento de definir lo que se debe entender por dignidad de la persona humana, delimitando tanto cuanto posible y recomendable su contenido material, la entiende: "la calidad intrínseca y distintiva de cada ser humano que lo hace merecedor del mismo respeto y consideración por parte del Estado y de la comunidad, implicando, en ese sentido, un complejo de derechos y deberes fundamentales que aseguren a la persona tanto contra todo y cualquier acto de cuño degradante y deshumano, como vengan a garantirlo las condiciones existenciales mínimas para una vida saludable, además de propiciar y promover su participación activa y corresponsable en los destinos de la propia existencia y de la vida en comunión con los demás seres humano"

Por todo lo expendido, el principio de la dignidad de la persona humana se pone frente a los derechos fundamentales del ciudadano no apenas como valor básico e informador, pero como "principio supremo" a conferir al catalogo de aquellos derechos una conexión sistemática y apta a eliminar eventuales lagunas y a indicar una finalidad común.

Al verificarse que la dignidad de la persona humana, en diferentes grados de vinculación, se relaciona y orienta el conjunto de derechos humanos, entre los cuales están los sociales y los colectivos, se revela el equivoco en analizarla como algo destinado apenas al individuo y cuya tutela dificulte o obstaculice los intereses de la sociedad $^{51}$. La construcción de ese equivoco se debe al encuentro de algunos puntos de

${ }^{49}$ Las palabras son de Flávia Piovesan, op. cit., 2003, pp. 193-196, con fundamento en los juristas Paulo Bonavides y Konrad Hesse, respectivamente.

${ }^{50}$ SARLET, Ingo Wolfgang. Algumas notas em torno da relação entre o princípio da dignidade da pessoa humana e os direitos fundamentais na ordem constitucional brasileira. In: LEITE, George Salomão (org.). dos princípios constitucionais: considerações em torno das normas principiológicas da Constituição. Editora Malheiros, São Paulo-Brasil: 2003, pp. 213-214.

${ }^{51}$ En el sentido del texto y direccionando sus comentarios para el sistema alemán, Konrad Hesse, Editora Sergio Antonio Fabris Editor, Porto Alegre-Brasil: 1998, pp. 244-245. José Carlos Vieira de Andrade. 
la ideología nazifascista - en la cual el interés público o social se sobreponía hasta mismo a la vida de los ciudadanos que se lo opusiera - con otros de la ideología comunista - en el aspecto de que el hombre solo existe en función de la comunidad, para la cual pierde su individualidad y tiene deslegitimado cualquier derecho contrario a los respectivos intereses públicos/estatales. Lo que ambas ideologías tienen en común es la visión de público, estatal o comunitario como enemigo o antípoda del individual o, en sentido inverso, de que el interés privado, particular o individual sea un obstáculo a la consecución del bien común. En la sociedad actual, tal postura se muestra anacrónica e impropia, pues lo que se debe buscar es la compatibilización de los intereses (públicos, privados y colectivos), en una comunión para la realización del ser humano, integrante y destinatario último y siempre presente en esas esferas de intereses.

La dignidad de la persona humana, en un modelo político de Estado Democrático (y Social) de Derecho como el brasileño, transciende la visión que es atribuida en un Estado Liberal y se suma a lo que se podía esperar en un Estado Social. La dignidad de la persona humana, como principio fundamental, es puesta para beneficio de todos, pues solamente con ese direccionamiento la orden jurídica decidirá “por" y "para" el hombre, no "obstarlo", marginalizándolo o desconsiderándolo. Sin embargo, es garantida y ejercida, en regla, por el individuo - o grupo de individuos delante de omisiones o acciones ilegales, sean ellas públicas o privadas. Finalmente, no debe ser confundido su ejercicio, en regla individual y delante de omisiones o acciones ilegales (públicas o privadas), con su destinación y beneficio a todo el universo humano.

En esa visión de ser algo puesto y desarrollado para el bien común, así como ocurre con el Estado Democrático (y Social) de Derecho, y demás derechos y garantías individuales del ser humano, la dignidad de la persona humana tiene vedada la posibilidad de ser suprimida del texto constitucional (art. 60, $\S 4^{\circ}$, inciso IV, CF/88).

Vale destacar, todavía, que, por las líneas doctrinarias aceptas en el presente trabajo, del contenido esencial relativo y del ámbito de protección amplio de la norma, como todo y cualquier principio fundamental, también la dignidad de la persona humana no es principio absoluto y admite restricciones, desde que justificadas de modo

Op. cit., 2006 , pp. 97-98, coloca la dignidad de la persona humana como un principio de valor que da unidad y sentido a los derechos fundamentales. Ana Paula de BARCELLOS. Op. cit., 2002, pp. 110-111, afirma que la dignidad de la persona humana siempre será respetada en cuanto los derechos fundamentales sean realizados. 
iusfundamental, o sea, con base en otras normas fundamentales que se muestren aplicables para el caso concreto en determinada condición fática y jurídica.

Sin embargo, incluso con esta advertencia cuanto a la posibilidad de su restricción, ella no deja de ser referencia cultural, axiológica y normativa en relación a cualquier duda o incertidumbre cuanto a la aplicación o interpretación de los derechos fundamentales relacionados al medio ambiente.

La dignidad de la persona humana va a ser siempre una referencia axiológicanormativa para el desarrollo de los estudios ambientales, porque este derecho fundamental tiene mayor significación para el ser humano exactamente en el instante en que este está puesto en situación de peligro, una vez que todo reposa sobre el equilibrio de las relaciones.

\subsection{Concepto y características de los derechos fundamentales. Historia y} funciones

"Crear y mantener los presupuestos elementares de una vida en la libertad y na dignidad humana, esto es lo que los derechos fundamentales anhelan, según Hesse, uno de los clásicos del derecho púbico alemán contemporáneo." 52

Las prerrogativas que integran los llamados derechos humanos pueden ser vistas de tres formas distintas.

La primera de ellas identifica los derechos humanos como valores intrínsecos al hombre, poco importando si son reconocidos por el Estado o no de esta forma. Esta concepción denominada de iusfilosófica o metafísica fue distintiva en el período feudal y podía ser identificada en las ideas de los autores iusnaturalistas del siglo XVII.

En contrapartida, la concepción positivista entiende que los derechos son fundamentales, porque así les cualifica y les reconoce el orden jurídico vigente. De esta forma, el status de fundamental sería dado por el propio ordenamiento jurídico y no por el hecho de expresaren valores inherentes a la calidad de hombre.

\footnotetext{
${ }^{52}$ Konrad Hesse, "Grundrechte", in staatslexikon, v. 2, apud BONAVIDES, Paulo, Curso de direito constitucional. $18^{\mathrm{a}}$ ed. São Paulo: Editora Malheiros, 2006, p. 560.
} 
"Sin esta positivación jurídica, los derechos del hombre son esperanzas, aspiraciones, ideas, impulsos, o, por veces, mera retórica política, pero no derechos protegidos bajo la forma de normas (reglas y principios) de derecho constitucional." 53

La tercera concepción llamada de materialista-histórica surgió en el siglo XIX, cuyo principal pensador fue Karl Marx. Para esta corriente teórica, los derechos fundamentales serían reflejo de las luchas sociales de la época, que llevaron a la ascensión la burguesía e impulsaron la derrota del Antiguo Régimen.

A pesar de esas fundamentaciones teóricas identificaren los derechos fundamentales de forma distinta, estos deben ser entendidos como un conjunto de derechos y garantías importantes y especiales, una vez que son responsables por la manutención de la vida del hombre como ser humano. Así, los derechos humanos aseguran la dignidad, la libertad y la igualdad de los hombres.

La fundamentación de estos derechos puede ser vista en dos diferentes aspectos, uno formal y otro material.

El fundamento formal de los derechos fundamentales se encuentra consustanciado en las normas constitucionales, que tienen por objeto estos derechos especiales. La enmienda de estas normas constitucionales está sometida a un proceso más riguroso y dificultoso, cuando comparado al procedimiento de creación y reforma de las demás normas existentes en nuestro ordenamiento jurídico.

La Constitución además de determinar un procedimiento más rígido para las enmiendas constitucionales establece en su artículo 60 , párrafo $3^{\circ}$, límites materiales al poder de reforma constitucional, o sea, trata de algunos temas que no pueden ser abolidos o modificados en su aspecto conceptual. Las materias de que trata dicho dispositivo se califican como derechos fundamentales, ya que discurren sobre el federalismo; el voto directo, secreto, universal y periódico; la separación de Poderes y los derechos y garantías individuales. A pesar de la lista no abarcar la totalidad de los derechos fundamentales consagrados en la Carta Magna, hay otras garantías constitucionales creadas con el objetivo de asegurar el ejercicio y el gozo de estos derechos, así como protegerlos de una amenaza o de una lesión. Así, se encuentran el habeas corpus, el habeas data, la acción popular, el mandato de seguridad (recurso de amparo), el mandato de interdicto (recurso de interdicto).

${ }^{53}$ CANOTILHO, José Joaquim Gomes, Direito constitucional e teoria da constituição. 3. ed. Coimbra Portugal, 1999, p. 353. 
El fundamento material de los derechos fundamentales está en el contenido identificador de las estructuras básicas del Estado y de la sociedad. Y es por intermedio de esta noción que la relación de derechos fundamentales puede ser ampliada, dando origen al principio de la no-tipicidad de estos derechos.

Así, se puede decir que los derechos fundamentales como cimientos del Estado y de la sociedad, están incorporados o no en normas constitucionales.

Para José Afonso da Silva los derechos fundamentales son históricos, inalienables, imprescriptibles e irrenunciables. La historicidad es característica intrínseca a todos los derechos, sean ellos fundamentales o no, ya que traducen las "relaciones sociales materiales en cada momento histórico." ${ }^{4}$ Los derechos fundamentales son inalienables, e sea, son intransferibles e innegociables, una vez que no presentan contenido económico-patrimonial.

"El ejercicio de buena parte de los derechos fundamentales ocurre sólo en el hecho de existieren reconocidos en el orden jurídico. En relación a ellos no se verifican requisitos que importen en su prescripción", 55 por ello son imprescriptibles.

En relación a la última característica mencionada por el autor, los derechos fundamentales no permiten que sus titulares renuncien a ellos.

Carl Schmitt entiende que los derechos fundamentales, desde el punto de vista formal, son aquellos nombrados $\mathrm{y}$ especificados por el propio instrumento constitucional y que recibieron de este mayor garantía y seguridad, pudiendo ser inmutables o alterados solamente por enmienda a la Constitución.

Los derechos que integran la lista de los derechos fundamentales surgieron en los instrumentos normativos en momentos históricos diferentes, como expresión de un "proceso cumulativo y cualitativo." ${ }^{, 56}$ Por esta razón, la doctrina verificó la existencia de cuatro generaciones de derechos fundamentales.

En la Antigüedad, había una clara y notoria distinción entre los hombres que administraban el Estado y aquellos a quienes debían incondicionada obediencia, cualificándose como sus súbditos o esclavos. Estos últimos no eran considerados "hombres" sino cosas, pasibles de ser propiedad de los hombres.

\footnotetext{
${ }^{54}$ SILVA, José Afonso da, Curso de direito constitucional cit., p. 176.

${ }^{55}$ SILVA, José Afonso da, Curso de direito cit., p. 181.

${ }^{56}$ Conforme Paulo Bonavides. Curso de direito constitucional. $18^{\mathrm{a}}$ ed. São Paulo: Editora Malheiros, 2006, p. 563.
} 
Aristóteles, al defender la condición natural del esclavo, decía que "el que por una ley natural no se pertenece a sí mismo, sino que, no obstante ser hombre, pertenece a otro, es naturalmente esclavo ${ }^{57,}$

Sin embargo, es posible identificar en el pensamiento sofístico y en el pensamiento estoico ideas que se relacionan con la igualdad natural y la humanidad. Por naturaleza, son todos iguales, sean ellos bárbaros o helenos, declaró el sofista Antifón.

En el pensamiento estoico el principio de la igualdad asume un lugar prominente: la igualdad radica en el hecho de todos los hombres se encontraren bajo un nomos (ley) unitario que les convierte en ciudadanos del gran Estado universal ${ }^{58}$.

La noción de igualdad difundida en este período histórico se restringía a un plan filosófico, individual y cosmológico, que no consiguió efectuarse en el ámbito jurídico.

La Edad Media fue marcada por la sustitución de la voluntad divina y la vinculación del derecho positivo a las normas jurídicas naturales, fundadas en la naturaleza de los hombres. Estas concepciones contribuyeron para el surgimiento de la noción de derechos naturales del individuo y de derechos humanos universales.

Es importante destacar, la importancia de las cartas de franquicias medievales establecidas entre los reyes y los vasallos, que consistían en el reconocimiento de los derechos de los reyes y de los derechos de libertad de la aristocracia feudal. A pesar de los derechos consagrados en los documentos no beneficiaren todos los ciudadanos, contribuyeron para la noción de los derechos del hombre. Así, los derechos corporativos se transformaron en derechos de todos, cuando el concepto de hombre libre pasó a alcanzar no sólo algunos estratos sociales, sino todos.

El surgimiento de las minorías religiosas, la defensa de la libertad religiosa y la prohibición del Estado imponer una religión oficial son hechos atribuidos por G. Jellinek como punto de origen de los propios derechos fundamentales. En contrapartida, José Joaquim Gomes Canotilho entiende que las ideas difundidas están más relacionadas a la tolerancia religiosa que con el derecho del hombre a la libertad de religión y creencia ${ }^{59}$.

\footnotetext{
${ }^{57}$ CANOTILHO, José Joaquim Gomes, Direito constitucional e teoria cit.,p. 357.

${ }^{58}$ CANOTILHO, José Joaquim Gomes. Direito constitucional e teoria cit., p. 357.

${ }^{59}$ CANOTILHO, José Joaquim Gomes. Direito constitucional e teoria cit., p. 358.
} 
La falta de libertad política de la burguesía, su marginalización delante de una nobleza centralizadora y detentora de privilegios; la defensa de la autonomía privada, consustanciada en derechos de defensa del ciudadano en relación al Estado forman un contexto favorable para el surgimiento del primer conjunto sistemático de derechos fundamentales en los siglos XVII y XVIII.

Los derechos de la primera generación o derechos de la libertad tienen por titular el individuo, son oponibles al Estado, se traducen como facultad o atributos de la persona y ostentan una subjetividad que es su aspecto más característico; en fin, son derechos de resistencia o de oposición ante el Estado ${ }^{60}$.

Si hasta el siglo XVIII el foco era el fortalecimiento del Estado, a partir del siglo XIX, el foco pasa a ser el apoderamiento de la sociedad, como protagonista de sus actos y, por consecuencia, segmento sobre el cual el Estado debe ser el garantizador no sólo de la aplicación de las leyes, sino la expresión.

De esta forma, se percibe el aspecto individualista de los primeros derechos fundamentales sistematizados por el hombre.

Las aspiraciones humanas fueron expresión de sus respectivos contextos históricos, en mayor o menor grado de aplicación o eficacia. Así, en el siglo XX el capitalismo mercantil, caracterizado por acumulación de riquezas; la necesidad de seguridad en las relaciones comerciales; la lucha de las clases trabajadoras y las teorías socialistas dan origen a los derechos sociales, culturales, económicos y colectivos. Estos derechos de la segunda generación exigen que el Estado ofrezca mecanismos hábiles que permitan su uso y gozo por sus titulares.

"Independientemente de la adhesión a los postulados marxistas, la radicación de la idea de la necesidad de garantir el hombre en el plan económico, social y cultural, de forma a alcanzar un fundamento existencial-material, humanamente digno, pasó a hacer parte del patrimonio de la humanidad." 61

El término de la segunda Guerra Mundial y la diferencia en el desarrollo de las naciones generaran un contexto histórico-social propicio al surgimiento de nuevos derechos fundamentales al hombre.

\footnotetext{
${ }^{60}$ BONAVIDES, Paulo. Curso de direito cit., pp. 563 y 564.

${ }^{61}$ CANOTILHO, José Joaquim Gomes. Direito constitucional e teoria cit., p. 361.
} 
Se consolidan así, al final do siglo XX, los derechos de la tercera generación, que "no se destinan concretamente a la protección de los intereses de un individuo, de un grupo o de un determinado Estado." 62

Se incorporan a los derechos fundamentales el derecho a la paz, el derecho al medio ambiente, el derecho al desarrollo, el derecho de propiedad sobre el patrimonio común de la humanidad y el derecho de comunicación.

La globalización política intenta universalizar los derechos fundamentales en el ámbito institucional, y, para ello, con relación a los derechos de la cuarta generación están el derecho a la democracia, el derecho a la información y el derecho al pluralismo, como espectro de consecuencia de esta globalización.

"Los derechos da la cuarta generación no solamente culminan la objetividad de los derechos de las dos generaciones antecedentes como absorben - aunque sin removerla - la subjetividad de los derechos individuales, a saber, los derechos de la primera generación." 63

Estas generaciones de derechos fundamentales se complementan, por lo tanto, no habiendo superación o exclusión de los derechos consustanciados en cada una de las fases mencionadas.

Los derechos fundamentales cumplen la función de derechos de defensa de los ciudadanos bajo una perspectiva doble: (1) constituyen, en un plan jurídico-objetivo, normas de competencia negativa para los poderes públicos, prohibiendo fundamentalmente las injerencias de estos en la esfera jurídica individual; (2) implican, en un plan jurídico-subjetivo, el poder de ejercer positivamente derechos fundamentales (libertad positiva) y de exigir omisiones de los poderes públicos, de forma a evitar agresiones lesivas por parte de los mismos (libertad negativa) ${ }^{64}$.

Además de los derechos fundamentales asumieren la función de derechos de defensa de los ciudadanos, presentan también la función de prestación social, en la medida en que exigen del Estado, por medio del poder Ejecutivo, Legislativo o Judicial la realización efectiva de condiciones que garanticen la efectividad de estos derechos reconocidos constitucionalmente.

\footnotetext{
${ }^{62}$ BONAVIDES, Paulo. Curso de direito cit., p. 569.

${ }^{63}$ BONAVIDES, Paulo. Curso de direito cit., p. 572.

${ }^{64}$ CANOTILHO, José Joaquim Gomes, Direito constitucional e teoria cit., p. 383.
} 
La garantía constitucional del ejercicio y gozo de los derechos fundamentales genera para el Poder Público el deber de evitar la lesión o la amenaza de terceros a estos derechos. Por ello se entiende que hay una tercera función, que es la de protección ante terceros.

Por fin, la doctrina apunta una función básica y primaria de los derechos fundamentales: la de exigir que el Estado trate sus ciudadanos sin cualquier discriminación.

Es incluso con una acentuación-radicalización de la función antidiscriminatoria de los derechos fundamentales que algunos grupos minoritarios defienden la efectuación plena de la igualdad de derechos en una sociedad multicultural e híper inclusiva $^{65}$.

1.6.1. Derechos fundamentales como incorporación legislativa interna de los derechos humanos. Consideraciones sobre algunas de sus características: universalidad; indivisibilidad; irrevocabilidad y complementariedad; $\mathrm{e}$ interdependencia.

Un aspecto preliminar a ser enfrentado se relaciona con las elecciones terminológicas emprendidas en el transcurso del trabajo. Así, aceptando la distinción ya clásica y cada vez más común en la doctrina, que diferencia derechos humanos de derechos fundamentales.

Aunque que no haya una separación definida entre los contenidos y conceptos de los derechos humanos y de los derechos fundamentales, una aceptación doctrinaria viene generalizándose, la de que los derechos fundamentales son la positivación nacional de los derechos humanos reconocidos internacionalmente. Esa incorporación en los ordenamientos nacionales no provocan cualquier alteración en la origen, objeto, finalidad, eficacia, extensión o fuerza ética de los derechos humanos ${ }^{66}$.

\footnotetext{
${ }^{65}$ CANOTILHO, José Joaquim Gomes, Direito constitucional e teoria cit., pp. 385 e 386.

${ }^{66}$ En ese sentido, vide Ingo Wolfgang Sarlet. A eficácia dos direitos fundamentais. $7^{\mathrm{a}}$ ed. Verificada, ampliada e atualizada. Editora Livraria do Advogado. Porto Alegre-Brasil: 2007, pp. 35-36; Willis Santiago Guerra Filho, Op. Cit., 2005, pp. 42-43, de modo especial, en nota 77; Dimitri Dimoulisy Leonardo Martins. Teoria geral dos direitos fundamentais. Editora Revista dos Tribunais, São Paulo-
} 
Brasil: 2007, p. 40, con pequeños destaques, Antonio E. Perez Luño. Los derechos fundamentales. $3^{\mathrm{a}}$ ed., Editora Tecnos, Madrid-España: 1988, pp. 43-51; Luis María Díez-Picazo. Sistema de derechos fundamentales. $2^{\mathrm{a}}$ ed., Editorial Aranzadi, Navarra-España: 2005, pp. 159-160. Para un significativo estudio terminológico, no obstante la autora acepte las expresiones, para las finalidades de su trabajo, como sinónimas, vide José Adércio Leite Sampaio. Direitos fundamentais: retórica e historicidade. Editora Del Rey, Belo Horizonte-Brasil: 2004, pp. 7-22. También en estudio terminológico especifico, concluyendo que se trata de sinónimos, vide André de Carvalho Ramos. Teoria geral dos direitos humanos na ordem internacional. Editora Renovar, Rio de Janeiro-Brasil: 2005, pp. 17-29. Fábio Konder Comparato. A afirmação histórica dos direitos humanos. $2^{\mathrm{a}}$ ed. Revista e ampliada, Editora Saraiva, São Paulo-Brasil: 2001, pp. 56-57, entiende que los derechos fundamentales son derechos humanos positivados, sea en nivel nacional o internacional. José Joaquim Gomes Canotilho. Op. cit., 2003, p. 393, así distingue derechos del hombre y derechos fundamentales: “As expressões 'direitos do homem' e 'direitos fundamentais' são frequentemente utilizadas como sinônimas. Segundo sua origem e significado poderíamos distingui-las da seguinte maneira: 'direitos do homem' são direitos válidos para todos os povos e em todos os tempos (dimensão jusnaturalista-universalista); 'direitos fundamentais' são os direitos do homem, jurídico-institucionalmente garantidos e limitados espacio-temporalmente. Os direitos do homem arrancariam da própria natureza humana e daí o seu carácter inviolável, intemporal e universal; os direitos fundamentais seriam os direitos objetivamente vigentes numa ordem jurídica concreta”. Después de destacar algunas debilidades en la posición Carl Schmitt - para quien los derechos fundamentales son los derechos humanos positivados constitucionalmente - Robert Alexy. Tres escritos sobre los derechos fundamentales y la teoría de los principios, traducción y presentación de Carlos Bernal Pulido, Universidad Externado de Colombia, Bogotá-Colombia: 2003, pp. 24-26, afirma ser aconsejable que los derechos fundamentales sean materialmente conceptuados como los derechos alzados a derechos positivos con el propósito y la intención de dar una dimensión positiva a los derechos humanos, por consiguiente, completa el constitucionalista alemán, "los derechos fundamentales 'deben representar' derechos humanos transformados en derecho constitucional positivo". Martin Borowski, Op. cit., 2003, pp. 30-33, por su vez, acepta que derechos humanos son derechos morales que valen por su fundamentalidad y corrección material, no por su fuerza vinculante de judicialidad. Para ese autor, derechos fundamentales internacionales o supranacionales son aquellos derechos humanos positivados en convenciones y tratados y, por lo tanto, con fuerza vinculante. Ya los derechos fundamentales nacionales son los derechos individuales que adquieren una dimensión positiva en las constituciones nacionales de los Estados democráticos constitucionales y que en general representan una intención de transformar derechos humanos en derechos positivos. (...) estos derechos tienen la máxima jerarquía en el sistema jurídico nacional y son judicialmente exigibles. Para el presente estudio, se acepta que los derechos humanos y los derechos fundamentales difieren por el tipo de ordenamiento en que son positivados, son derechos humanos cuando puestos en textos internacionales y, de otro modo, serán denominados en este trabajo derechos fundamentales cuando inserido en el ordenamiento nacional, en nivel constitucional. Importante resaltar que el Positivismo Jurídico considera que derechos fundamentales son aquellos considerados como básicos en la norma positiva (norma puesta), o sea, en la Constitución. Eso no impide 
Los derechos fundamentales, por lo tanto, constituyen la esencia de lo que un individuo debe tener respetado para tener su plena dignidad, tal cual los derechos humanos históricamente formados, reconocidos y garantizados en nivel internacional. $\mathrm{Su}$ única diferencia está en el ámbito en que se insieren, pues, al ingresaren en el ordenamiento legal de un país los derechos humanos pasan a ser denominados “derechos fundamentales", especialmente si son positivados en nivel constitucional ${ }^{67}$. El cambio sufrido es solo cuanto a la denominación doctrinaria, el derecho tutelado no tiene alterado su fundamento ético, su fuerza histórica o su finalidad de asegurar, integralmente y por una interacción conjunta, la dignidad humana de todo y cualquier ciudadano. Claro que la efectividad de esos derechos serán tanto mayor cuanto estén o no inseridos en la Constitución, por eso una parcela de la doctrina entiende que van a ser fundamentales sólo los derechos que tuvieren un ese nivel legislativo ${ }^{68}$.

Los derechos fundamentales traen para el ordenamiento patrio las características ya consagradas de los derechos humanos, cuales sean: la universalidad, la indivisibilidad, la interdependencia y la interrelación ${ }^{69}$. Luego, se aplican a todos los

que se reconozca la existencia de derechos implícitos, delante de lo que dispone, por ejemplo, el art. $5^{\circ}, \S$ $2^{\circ}$, de la $\mathrm{CF} / 88$.

${ }^{67}$ MIRANDA, Jorge. Op. cit., t. IV, 2000, pp. 52-56, después de afirmar que delante del actual desarrollo de la doctrina constitucional y del constitucionalismo, acepto por un número siempre creciente de países, se justifica que la expresión "derechos fundamentales" presente mejor técnica una vez que tales derechos están siendo inseridos en las constituciones, el texto juspolítico fundamental de una nación. Robert Alexy, Teoría cit., 1997, pp. 66-73, después de analizar la "relación de precisión" y la "relación de fundamentación" como criterio identificador de fundamentalidad de la norma, adopta el criterio formal para determinar cuando una norma es o no es de derecho fundamental, alargándolo, por fuerza de derivación o delegación de las normas iusfundamentales originarias, a "normas adscriptas" de derechos fundamentales.

${ }^{68}$ Los autores ya citados y que siguen la diferenciación derechos humanos $\rightarrow$ ámbito internacional y, por otro lado, derechos fundamentales $\rightarrow$ ámbito nacional, resaltando los que prefieren considerar fundamentales sólo aquellos constitucionalmente inseridos, vez que creen en una conceptuación material de esos derechos, por ejemplo, el constitucionalista portugués Jorge Miranda (Conforme nota anterior). En Brasil podemos citar, de manera ejemplificativa, Dimitri Dimoulis y Leonardo Martins, Op. cit., 2007, p. 53, y André Ramos Tavares, Op. cit., 2007, pp. 433-437, para quienes no se puede limitar los derechos fundamentales sólo al catálogo constitucional.

${ }^{69}$ Las características puestas en destaque y que van a ser pormenorizadas vienen inscritas tanto en la Resolución 32/130 (1968) de las Naciones Unidas, cuanto en el $\S 5^{\circ}$, de la Conferencia Mundial de Derechos Humanos de Viena de 1993. Disponible en: < 
ciudadanos del Estado que los incorporó, en plenas condiciones de igualdad, de modo complementar $^{70}$ e interactivo, no habiendo conflicto en sus incidencias, pero un necesario e imprescindible sopesar para que tengan la más amplia y exhaustivo alcance en cada situación concreta. Como consecuencia de esa positivación material y formal como derechos fundamentales, son irrevocables, inalienables e imprescriptibles ${ }^{71}$.

La característica de la universalidad, tal cual los propios derechos humanos, sufrió una transformación. De una universalidad abstracta y filosófica, concebida e inscrita en la Revolución Francesa de $1789^{72}$, después del adviento de la Declaración Universal de los Derechos Humanos de 1948 es vista hoy como una universalidad positivada y tratada de manera jurídica. Esta nueva perspectiva, conducida para dentro de los sistemas nacionales, hace con que los derechos fundamentales tengan mayor grado de explicitación y exigibilidad delante del Estado y sus ciudadanos. Ellos no solo tienen como destinatarios todo y cualquier ciudadano, sin cualquier distinción de color, raza, religiosidad, lengua, origen, nivel social o económico, formación cultural o intelectual, como pasan a ser jurídicamente exigibles por cualquier individuo capaz de actuar y ejercer aquellos derechos. La universalidad se relaciona directamente a la amplitud de titularidad conferida a los derechos fundamentales, en la medida en que garanten, en regla y a principio, que todos sean titulares de todo y cualquier derecho fundamental ${ }^{73}$.

Esa nueva acepción de universalidad, ya incorporada a los derechos positivados por los países en sus ordenamientos, vino a aumentar aun más la eficacia de los llamados derechos fundamentales de primera generación, clásicamente divididos en derechos civiles y políticos. Eso porque, esos derechos, por se caracterizaren más por el derecho a la abstención del Estado de intervenir en la esfera de libertades del ciudadano, muchas veces perdían o tenían reducida su eficacia práctica por no se crearen

http://www.ohchr.org/Documents/Events/OHCHR20/VDPA_booklet_Spanish.pdf $>$. Acceso en: 18-072015.

${ }^{70}$ La complementariedad, así como la irrevocabilidad, son aspectos desarrollados por Fábio Konder Comparato, Op. cit., 2001, pp. 63-65.

${ }^{71}$ Esas últimas, algunas características de los derechos fundamentales apuntadas por José Afonso da Silva, Op. cit., 2007, pp. 180-182.

${ }^{72}$ En términos muy amplios a todos los ciudadanos, no solo franceses como del mundo, ya se posicionaba el preámbulo de la Declaración de los Derechos del Hombre y del Ciudadano de 1789.

${ }^{73}$ En ese sentido, vide Jorge Miranda, op. cit., 2000, t. IV, pp. 215-218. 
condiciones o no se delimitaren espacios claros de libre actuación del ciudadano, o de restricción a la acción del Estado o de los agentes privados. Así, esa nueva universalidad, ahora ya ampliada por los llamados derechos fundamentales de segunda (derechos de igualdad) y de tercera generación (derechos de fraternidad), vino conferir más positivación y exigibilidad aquellos derechos de libertad (derechos de primera generación), haciéndolos alcanzar un "grado más alto de juridicidad, materialidad, positividad y eficacia. Es universalidad que no excluye los derechos de libertad, sino que primero los fortalece con las expectativas y los propósitos de mejor realizarlos mediante la efectiva adopción de los derechos de igualdad y de fraternidad"74.

El cuadro 1 presenta de forma clara las generaciones (dimendiones) de los Derechos Fundamentales:

\begin{tabular}{|l|l|l|l|}
\hline \multicolumn{2}{|l|}{ Cuadro:1 - GENERACIONES (DIMENSIONES) DE LOS DERECHOS FUNDAMENTALES } \\
\hline & $\mathbf{1}^{\boldsymbol{a}}$ generación & $\mathbf{2}^{\boldsymbol{a}}$ generación & $\mathbf{3}^{\boldsymbol{a}}$ generación \\
\hline Titularidad & Individuo & Grupos sociales & Difusa \\
\hline Naturaleza & Negativos & Positivos & Supraindividuales \\
\hline $\begin{array}{l}\text { Contexto } \\
\text { histórico }\end{array}$ & Revoluciones liberales & Revolución industrial e Revolución Rusa & Revolución Tecnocientífica \\
\hline Ejemplos & $\begin{array}{l}\text { Vida, libertad, } \\
\text { propiedad, igualdad } \\
\text { frente la ley } \\
\text { Valor- } \\
\text { objetivo }\end{array}$ & $\begin{array}{l}\text { Salud, educación, vivienda, recreación, } \\
\text { asistencia a los desamparados, garantías } \\
\text { de trabajo }\end{array}$ & $\begin{array}{l}\text { Medio ambiente, comunicación } \\
\text { sociancianza, adolescente, } \\
\text { anciano }\end{array}$ \\
\hline \hline
\end{tabular}

A partir de la Conferencia de Derechos Humanos de Teherán, en 1968, la tesis de la indivisibilidad de los derechos humanos pasó a ser defendida.

Se reconoció en la Conferencia de Teherán que la plena realización de derechos civiles y políticos seria imposible sin el goce efectivo de los derechos sociales, proclamándose la profunda interconexión existente entre esos derechos. La Proclamación de Teherán sobre Derechos Humanos adoptada por el plenario de la Primera Conferencia Mundial de Derechos Humanos en 13 de mayo de 1968 ponderó aun en su párrafo trece que como los derechos humanos y las libertades fundamentales son indivisibles, la realización de los derechos civiles y políticos sin el goce de los derechos sociales se torna imposible. La consecución de un progreso duradero en la implantación de los derechos humanos depende de sólidas y eficaces políticas nacionales e internacionales de desarrollo económico y social. A partir de ahí, las

\footnotetext{
${ }^{74}$ BONAVIDES, Paulo. Curso de direito constitucional. $21^{\circ}$ ed., Editora Malheiros, São Paulo-Brasil: 2007, pp. 573-574.
} 
Naciones Unidas tiene aprobado diversas resoluciones reafirmando la tesis de interrelación de los derechos humanos, como la Resolución 32/130 de 1977: La plena realización de los derechos civiles y políticos sin el goce de los derechos económicos, sociales y culturales es imposible: la consecución de un progreso duradero en la implementación de los derechos humanos depende de políticas nacionales e internacionales de desarrollo económico y social, de buenas y efícaces, como reconocidas por la Proclamación de Teherán de 1968, endosada por las resoluciones 39/145 de 1984 y 41/117 de 1986 de la Asamblea General de las Naciones Unidas.

Con la multiplicación de diversos tratados de derechos humanos y con el aumento de resoluciones de organismos internacionales sobre tal tema, se realizó en 1993 la Segunda Conferencia Mundial de Derechos Humanos en Viena, en un intento de coordinar los instrumentos internacionales que pasaron a coexistir. Esa Conferencia adoptó la Declaración y Programa de Viena de 25 de junio de 1993, la cual también trató de ponderar la universalidad y la interrelación de todas las categorías de derechos humanos, así, como previó el deber de los Estados de promoverlos y de protegerlos, independientemente de sus sistemas políticos, económicos y culturales, llevándose en cuestión, todavía, sus peculiaridades.

Con efecto, aunque haya categorías de derechos humanos que exigen obligaciones positivas del Estado como los derechos de segunda y de tercera generación, y otras a ejemplo de los derechos de primera generación, que, contrariamente, exigen obligaciones negativas por parte del Estado, es cierto que todas las diferentes categorías son interdependientes, y que los derechos sociales y de solidaridad constituyen presuposiciones esenciales para el goce efectivo de todas las libertades clásicas. El propio derecho a la vida, comprendido como el derecho más elementar de la persona humana, es extremamente comprometido cuando de la negación de aquellos derechos.

En ese sentido, sostiene Antônio Augusto Cançado Trindade ${ }^{75}$ que nada impediría epistemológicamente que en el futuro, algunos de los derechos sociales y de solidaridad, como el derecho al desarrollo, viniesen a integrar el núcleo de derechos inderogables, a la luz de la concepción de la indivisibilidad de los derechos humanos. Además, resalta el autor que entre los derechos humanos no puede haber antinomia,

${ }^{75}$ TRINDADE, Antônio Augusto Cançado. A proteção internacional dos direitos humanos. Editora Saraiva, São Paulo-Brasil: 1992, p. 57. 
contrariamente el entendimiento de Bobbio $^{76}$, sino que complementariedad. Así, es necesario registrar que los "nuevos" derechos no sustituyen los demás, sino que los complementan, ampliando y enriqueciendo el núcleo de los derechos humanos.

Esto revela que las categorías propuestas de derechos humanos presentan una relación orgánica entre si, y que, luego, la emancipación de la persona humana debe ser buscada a través de la implementación más eficaz y uniforme no solo de las libertades clásicas, sino que de los derechos sociales, económicos y de solidaridad como un todo único e indisoluble, aunque infelizmente eso todavía sea negado y descuidado por muchos Estados, lo que torna los derechos humanos, muchas veces, un mero ideal de los pueblos, aun lejos de ser concretizado, poseyendo una función, quizá, solo retórica en los documentos que los disciplinan.

Los derechos fundamentales, por se trataren de conquistas de la humanidad a expensas de muchas injusticias, sufrimientos y vidas, una vez regulados pasan a ser conquistas irreversibles del ser humano ${ }^{77}$, prohibiéndose su supresión o limitación. Con eso, se garante no solo la permanencia del derecho formalmente en el texto legal (prohibición del retroceso formal), sino que, también, se garante que su contenido siempre tenga una tendencia de expansión, haciendo con que los nuevos campos de la vida humana ya alcanzados por aquel derecho fundamental no puedan más ser privados de ello (prohibición del retroceso material) y, aun, nuevas áreas de la vida puedan venir a ser por ello reguladas y conformadas.

Esos dos aspectos de la irrevocabilidad son complementares e interdependientes, pues la restricción formal de revocación de los derechos fundamentales garante la aplicación de su contenido material siempre de manera más amplia. Por otra perspectiva, la restricción de revocación material del contenido de los derechos fundamentales torna efectiva su positivación en el ordenamiento, en la medida en que el derecho deja el mundo normativo y pasa a tener efectiva y práctica incidencia en beneficio de todos los ciudadanos. La irrevocabilidad formal es condición previa para efectividad de su contenido.

\footnotetext{
${ }^{76}$ Afirma Norberto Bobbio, A Era dos Direitos. Editora Campus, Rio de Janeiro-Brasil: 1992, p. 21, que sí son antinómicos en el sentido de que el desarrollo de ellos no puede proceder paralelamente, pues la realización de unos impide la realización integral de otros.

${ }^{77}$ COMPARATO, Fábio Konder . Op. cit., 2001, pp. 63-65.
} 
En el sistema constitucional brasileño, la irrevocabilidad formal está garantida, al menos para los derechos y garantías fundamentales del individuo, por la restricción a que tales normas no sean susceptibles de deliberación (supresión o reducción), mismo por emenda constitucional (art. 60, $\S 4^{\circ}$, inciso IV, CF/88). La irrevocabilidad material, a su vez, debe ser una conquista diaria no solo por obra de los Poderes Públicos (Legislativo, Ejecutivo y Judicial), sino que, también, por la actuación de los agentes privados; muchos de los cuales, en un mundo de capitalismo globalizado y de grandes conglomerados económicos, tienen más capacidad lesiva o garantista que muchos países de economía emergente o debilitada ${ }^{78}$.

Todavía, la irrevocabilidad, con sus debidas imposibilidades de retroceso formal o material, no puede ser confundida o llevada al extremo de no permitir restricciones al ejercicio de aquellos derechos fundamentales en situaciones fácticas en las cuales con ellos se choquen otros derechos de igual estatura ${ }^{79}$. Para eso, es esencial que se tenga en mente que todo derecho fundamental no es absoluto y que todos comportan restricciones, desde que esas sean proporcionales y justificadas con base en argumentos constitucionales consistentes y coherentes delante de las condiciones fácticas del caso concreto.

En la medida en que los derechos fundamentales fueron concebidos para asegurar al ser humano un grupo de intereses y necesidades que son esenciales a ellos, todos tienen la misma génesis axiológica y destinación funcional, cual sea, atender, en diversos grados y vinculaciones, a la persona humana en la integralidad de su dignidad.

Su percepción y reconocimiento en el curso de la historia de la humanidad hacen con que varias veces se recorra al termino "generaciones" de derechos fundamentales, a fin de caracterizar con mayor nitidez el criterio de la historicidad de esos derechos. Sin embargo, la palabra "generación" no autoriza imaginarlos como una sucesión de derechos, en la cual los posteriores abarcan, revocan o superan los anteriores. También esa constante ampliación no se limita a una sumatoria de los derechos, pero consiste en verdadera conjugación e interpenetración mutua entre los

\footnotetext{
${ }^{78}$ Sobre el deber de cada ciudadano en garantir los derechos fundamentales en su ejercicio diario de ciudadano, sea en su actuación pública o privada, vide ítem anterior "el ciudadano como sujeto de deberes".

${ }^{79}$ Sobre la restricción a derechos fundamentales poder ser hecha solamente por otra norma de igual estatura, vide Robert Alexy, op. cit., 1997, pp. 272-276.
} 
nuevos, los antiguos y los que todavía están por venir ${ }^{80}$. En ese punto es que se debe comprender las características de la complementariedad y de la interdependencia.

Con los sucesivos acrecimos al catálogo siempre expansible de los derechos fundamentales, los derechos posteriores suplen espacios dejados por los anteriores, transformándolos y ampliando sus ámbitos de incidencia, sea por consecuencia automática del mejoramiento doctrinario propiciador del surgimiento de nuevas series de derechos esenciales al hombre sea por la dependencia que los nuevos preceptos fundamentales tienen de los anteriores, por presuponerlos existentes y efectuados en la realidad de la vida.

Así, ejemplificando, el moderno derecho fundamental a la información, derecho de la cuarta generación ${ }^{81}$, presupone y es incrementado por el derecho fundamental a la educación (art. $6^{\circ}$, caput c/c art. 205, CF/88), integrante de la denominada segunda generación ${ }^{82}$. La educación es presuposición para el acceso a la información y el derecho a la información será tanto más efectivo cuanto mayor el nivel educacional de su titular. En sentido inverso, el derecho a la educación, cuando alcanzado históricamente a la categoría de derecho fundamental (siglos XIX e inicio del siglo XX), no era integrado, en su contenido material, por la cantidad de informaciones asequibles, por ejemplo, por medios informáticos. Luego, ese derecho a la educación tuvo su contenido tan ampliado por fuerza de la informática cuanto la cantidad de informaciones, en ella contenida, exige cada vez más personas con mayores niveles educacionales. Ambos los derechos, solamente cuando actuantes de forma complementar se aseguran mutuamente y se efectúan de la manera más amplia posible. Solamente se interrelacionando garanten al individuo la efectiva inclusión en la actual sociedad globalizada.

Las conquistas posibilitadas por nuevas series de derechos fundamentales reconocidos e incorporados al catálogo ya existente vienen a agregar atributos a los derechos preexistentes y son por estos incrementadas.

\footnotetext{
${ }^{80}$ En el sentido del texto, vide Jorge Miranda, Manual cit., t. IV, pp. 24-25.

${ }^{81}$ BONAVIDES, Paulo. Op. cit., 2009, pp. 570-572.

${ }^{82}$ SAMPAIO, José Adércio Leite. Op. cit., 2004, pp. 261-263.
} 
Cuando se aplica lo anteriormente expuesto a los derechos de defensa (derechos de primera generación ${ }^{83}$ ), se verifica como mayor beneficio por ellos recibidos de los denominados derechos sociales a percepción de que para su realización no basta solo una abstención de interferencias estatales en la esfera de libertad del individuo, pero, en determinadas hipótesis, deberá haber una actuación del Estado (Legislativo, Ejecutivo y Judicial) para garantizar su efectividad. Para asegurar plenamente aquellos derechos no basta al Estado abstenerse, pero, muchas veces, deberá actuar en el sentido de crear condiciones (operacionales, legales u organizacionales) al efectivo y completo ejercicio de aquellas libertades. Ese actuar tanto puede ser en el sentido de crear procedimientos u organizaciones de fruición del derecho, cuanto en el sentido de trazar restricciones claras y legítimas a la actuación de los agentes privados y públicos o, aun, concebir instrumentos jurídicos eficaces para reverter eventuales violaciones (públicas o privadas) de aquellos espacios legales de libertad.

\subsection{Norma de derecho fundamental y enunciado normativo de derecho fundamental}

El presente trabajo no comporta una discusión de las razones y diferentes consecuencias entre las varias teorías que, en el ámbito de la teoría general del derecho, se proponen a explicar el concepto de "norma" y, por consecuencia, de "norma fundamental” ${ }^{\prime 4}$. Así, en este punto, existe un determinado campo de consenso de la doctrina ${ }^{85}$, por lo cual se afirma que hay una diferencia entre "norma" y "enunciado

\footnotetext{
${ }^{83}$ En ese sentido, vide: José Adércio Leite Sampaio, Direitos cit., p. 260; Paulo Bonavides, Curso cit., pp. 562-564; y André Ramos Tavares, Curso cit., pp. 427-428, observando que este último prefiere la expresión “dimensión” en sustitución a ya clásica "generación” (op. cit., pp. 426-427).

${ }^{84}$ Sobre el enunciado de las varias líneas teóricas explicativas del concepto de norma, vide Robert Alexy, Teoría cit., pp. 48-50; Idem, El concepto y la validez del derecho, 2a ed., Gedisa Editorial, BarcelonaEspaña: 1997, cap. 2 y 3; y Martin Borowski, La estructura cit., pp. 26-27.

${ }^{85}$ En este momento del trabajo, intencionalmente utilizaremos líneas argumentativas de Robert Alexy y Friedrich Müller. Es sabido que las teorías de esos dos autores en diversos puntos son inconciliables y, que lo mismo ocurre, en la propia visión que tienen de la estructura del derecho y de la norma; sin embargo, apenas al punto que importa en esta parte del trabajo, las teorías se acercan. De esa misma opinión es Virgílio Afonso da Silva, Princípios e regras: mitos e equívocos acerca de uma distinção,
} 
normativo" ("texto normativo"). Ese modelo consensual es el "modelo semántico", para el cual el concepto de norma parte de la idea de que hay una diferencia entre "norma" y "enunciado normativo" 86 . Siendo la norma el significado del enunciado normativo y, por lo tanto, está más allá de la literalidad de las expresiones elegidas e inseridas por el legislador en el texto ${ }^{87}$, es el "producto de la interpretación de ese enunciado" ${ }^{\text {" }}$.

A partir del texto se comprenden y se extraen significados actuales $y$ apropiados al caso concreto sometidos al análisis y, de igual manera, con las normas superiores pueden conformarse normas inferiores que dan la mayor organización y efectividad posibles al significado inserido en los enunciados superiores. Así, no obstante el texto permanezca lo mismo, la interpretación permite que de ello se extraigan varios significados, hasta mismo porque cualquier texto puede ser escrito de diferentes maneras, que dejen uno u otro punto de su significado con mayor o menor realce.

La doctrina entiende que un criterio seguro para la conceptuación de norma son las "modalidades deónticas básicas" del mandado, de la prohibición y de la permisión. Expresiones como "puede", "prohibido" y "deben", cuando puestas en enunciados normativos o que están implícitos en su redacción, forman "enunciados deónticos", modalidades del "deber ser" inseridos en el dispositivo normativo. "No todo enunciado

Revista Latino-Americana de Estudos Constitucionais, Belo Horizonte, n. 1, jan./jun., 2003, ítem 3, específicamente nota 36. Para aquellos autores existe una distinción entre "norma" y "enunciado normativo" ("texto normativo" o "disposición normativa"): la norma es el significado que se extrae del texto. Para una excelente análisis en paralelo entre las dos teorías, en el punto tratado en el texto, vide Robert Alexy, Teoría cit., pp.73-80.

${ }^{86}$ Sobre el modelo semántico, vide Martin Borowski, La estructura cit., p. 27, con buena citación bibliográfica, y Robert Alexy, Teoría cit., pp. 50-55.

${ }^{87}$ Eros Roberto Grau, Ensaio e discurso sobre a interpretação e aplicação do direito, $2^{\mathrm{a}}$ ed., Ed. Malheiros, São Paulo-Brasil: 2003, pp. 71-83, con muchas referencias de la doctrina alemana, especialmente de Friedrich Müller, afirma que la "norma" es diversa de "texto normativo" y que este es apenas una fracción de aquella, que fue absorbido por el lenguaje jurídico. Para aquel autor (op. cit., p. 73) la "norma congrega todos os elementos que compõem o âmbito normativo (= elementos e situações do mundo da vida sobre os quais recai determinada norma)". Más adelante (op. cit., p.79), afirma ahora, con base en Canotilho: “'Texto' y 'norma' não se identificam: o ‘texto' é o 'sinal linguístico'; a 'norma' é o que se 'revela, designa'”.

${ }^{88}$ Virgílio Afonso da Silva, Princípios e regras cit., p. 616. 
normativo es un enunciado deóntico, pero todo enunciado normativo puede ser transformado en un enunciado deóntico" ${ }^{, 89}$.

El "enunciado normativo" es el texto, el conjunto lingüístico con lo cual se forma el dispositivo legal. La "norma" es el significado de un enunciado normativo y, como tal, puede ser un concepto anterior a ese enunciado, ya que el texto elegido por el legislador tiene como objetivo satisfacer el significado que él tiene la intención de imprimir y, por tanto, preexiste al texto de ley ${ }^{90}$.

Al salir del campo de la teoría general de la norma e ingresar en el campo de la "norma fundamental", entre los criterios indicados por la doctrina para verificar si una norma es o no una norma fundamental, lo más conveniente, para los efectos del tema del presente trabajo, es el criterio formal, complementado por el criterio material ${ }^{91}$.

${ }^{89}$ Robert Alexy, Teoría cit., p. 54.

${ }^{90}$ Según Robert Alexy, Teoría cit., pp. 50-55, como la norma es anterior al enunciado no se puede buscar en ello un criterio para su conceptuación.

${ }^{91}$ Según J. J. Gomes Canotilho, Direito Constitucional op. cit., pp. 406-407: “ (...) a distinção entre direitos fundamentais em sentido formal e material e direitos fundamentais em sentido meramente formal. No âmbito dos direitos fundamentais, a distinção reconduz-se ao seguinte: há direitos fundamentais consagrados na constituição que só pelo facto de beneficiarem da positivação constitucional merecem a classificação de constitucionais (e fundamentais), mas o seu conteúdo não se pode considerar materialmente fundamental; outros, pelo contrário, além de revestirem a forma constitucional, devem considerar-se materiais quanto à sua natureza intrínseca (direitos formal e materialmente constitucionais). A base da distinção deve procurar-se, segundo uma persistente tradição doutrinal, na $<<$ subjetividade pessoal $>>$, no $<<$ radical subjetivo $>>$ caracterizador dos direitos fundamentais materiais. Direitos fundamentais materiais seriam, nesta perspectiva, os direitos subjetivamente conformadores de um espaço de liberdade de decisão e de autorrealização, servindo simultaneamente para assegurar ou garantir a defesa desta subjetividade pessoal. No plano jurídico-constitucional, trata-se de uma distinção dificilmente compatível com o regime geral dos direitos fundamentais positivamente consagrado. Por um lado, e não obstante a dicotomia entre direitos, liberdades e garantias e direitos económicos, sociais e culturais, a Constituição qualificou ambas as categorias de direitos como direitos fundamentais (cfr. Título I). Em segundo lugar, e como resulta da própria sistematização dos direitos, liberdades e garantias, em direitos, liberdades e garantias pessoais, direitos, liberdades e garantias de participação política e direitos, liberdades e garantias dos trabalhadores, a base antropológica dos direitos fundamentais não é apenas o $<<$ homem individual $>>$, mas também o homem inserido em relações sociopolíticas e socioeconómicas e em grupos de vária natureza, com funções sociais diferenciadas”. Además, afirma el autor, pp. 403-404: “Os direitos consagrados e reconhecidos pela constituição designam-se, por vezes, direitos fundamentais formalmente constitucionais, porque eles são enunciados e protegidos por normas com valor constitucional formal (normas que têm a forma constitucional). A Constituição admite (cfr. art. 
El criterio formal está basado en la "forma de positivación" hecha por el constituyente (legislador fundamental) en la Constitución. Así, todos los "enunciados normativos" inseridos en el capítulo de derechos y garantías fundamentales (Título I, Capítulo Cuarto de la Constitución española y arts. $5^{\circ}$ a 17 de la Constitución brasileña) son "enunciados normativos de derechos y garantías fundamentales" o, hablando con más sencillez, "disposiciones de derechos fundamentales". Por este mismo criterio, las "normas de derecho fundamental" son "las normas directamente expresas por esos enunciados".

Siendo esa norma el significado prestado por el intérprete al enunciado normativo de derecho fundamental, y como el contenido lingüístico no es la única ni precisa fuente de información para la formación del significado contenido en ese dispositivo, se deben emprender las más apropiadas formas y métodos de interpretación para que se pueda comprender el mejor y más amplio espacio normativo de aquel tipo de enunciado.

Es necesario emprender una interpretación genético-sistémica y outra de carácter doctrinario-comparativo para comprender como se extrae de disposiciones normativas de las Constituciones toda la extensión humanitaria, ambiental y doctrinaria que la comunidad internacional ha prestado y sigue prestando.

En España, el Título I de la Constitución española se denomina "De los derechos y deberes fundamentales" y, dentro de este Título, el capítulo segundo, se denomina "derechos y libertades" y está estructurado en dos secciones diversas: la sección $1^{\mathrm{a}}$ se denomina como "de los derechos fundamentales y las libertades públicas", donde aparecen recogidos derechos y libertades de la persona física ${ }^{92}$, derechos y

$16^{\circ}$ ), porém, outros direitos fundamentais constantes das leis e das regras aplicáveis de direito internacional. Em virtude de as normas que os reconhecem e protegem não terem a forma constitucional, estes direitos são chamados direitos materialmente fundamentais. Por outro lado, trata-se de uma $<<$ norma de fattispecie aberta $>>$, de forma a abranger, para além das positivações concretas, todas as possibilidades de $<<$ direitos $>>$ que se propõem no horizonte da ação humana. Daí que os autores se refiram também aqui ao princípio da não identificação ou da cláusula aberta. Problema é o de saber como distinguir, dentre os direitos sem assento constitucional, aqueles com dignidade suficiente para serem considerados fundamentais. A orientação tendencial de princípio é a de considerar como direitos extraconstitucionais materialmente fundamentais os direitos equiparáveis pelo seu objecto e importância aos diversos tipos de direitos formalmente fundamentais".

${ }^{92}$ Como el derecho a la vida, libertad personal, intimidad, libertad de residencia y circulación, entre otros. 
libertades de la intelectual y moral ${ }^{93}$, y derechos colectivos y cívico-políticos ${ }^{94}$, además de derechos centrales en el Estado de derecho como la tutela judicial efectiva (art. 24), el principio de legalidad penal (art.25), y el derecho a la educación o derechos de contenido social ${ }^{95}$; la sección $2^{\mathrm{a}}$ se denomina "de los derechos y deberes del ciudadano" y recoge desde derechos clásicos como el derecho de propiedad y libertad de empresa, hasta derecho de contenido diferente como el derecho a la objeción de conciencia, al matrimonio, de fundación o al trabajo. Así, se observa que la Constitución española no ha seguido un método de clasificación material en la enumeración de los derechos fundamentales, sino que los ha clasificado de acuerdo con sus garantías constitucionales, como se nota en el artículo 53, Capítulo IV de la CE.

Ya en el capítulo tercero, se encuentran "los principios rectores de la política social y económica" entre los cuales están derechos como la protección a la salud, a una vivienda digna o a un medio ambiente adecuado. Estos últimos, diferentemente de los primeros, necesitan de la intervención del legislador para que sean alegados ante la jurisdicción ordinaria (art. 53.3 de la $\mathrm{CE}^{96}$ ). Es exactamente esta particularidad del capítulo tercero que ha llevado a la mayoría de la doctrina a considerar el capítulo segundo en su totalidad, como la carta de derechos fundamentales de la Constitución española ${ }^{97}$.

\footnotetext{
${ }^{93}$ Como la libertad ideológica y religiosa, de expresión, de información, entre otros.

${ }^{94}$ Como el derecho al sufragio, a la asociación, de reunión, de petición de manifestaciones, entre otros.

${ }^{95}$ Como el derecho a la educación, sindicación y huelga.

96 “Artículo 53
}

1. Los derechos y libertades reconocidos en el Capítulo segundo del presente Título vinculan a todos los poderes públicos. Sólo por ley, que en todo caso deberá respetar su contenido esencial, podrá regularse el ejercicio de tales derechos y libertades, que se tutelarán de acuerdo con lo previsto en el artículo 161, 1, a).

2. Cualquier ciudadano podrá recabar la tutela de las libertades y derechos reconocidos en el artículo 14 y la Sección primera del Capítulo segundo ante los Tribunales ordinarios por un procedimiento basado en los principios de preferencia y sumariedad y, en su caso, a través del recurso de amparo ante el Tribunal Constitucional. Este último recurso será aplicable a la objeción de conciencia reconocida en el artículo 30. 3. El reconocimiento, el respeto y la protección de los principios reconocidos en el Capítulo tercero informarán la legislación positiva, la práctica judicial y la actuación de los poderes públicos. Sólo podrán ser alegados ante la Jurisdicción ordinaria de acuerdo con lo que dispongan las leyes que los desarrollen". ${ }^{97}$ Conforme Augusto Aguilar Calahorro, El sistema constitucional de España. Además, añade el autor que: "La fundamentalidad de los derechos del segundo capítulo se evidencia en que además de adquirir 
En primer lugar, al analizar el artículo 45 de CE, necesario se hace una interpretación para desentrañar el concepto jurídico indeterminado de la expresión "medio ambiente" contenida en ello. Para tanto, debemos apoyarnos en la STC $102 / 1995^{98}$, la cual señala que el constituyente parte de una concepción amplia del medio ambiente, que incluye además de los recursos naturales, los elementos artificiales que rodean a la vida humana (F.J. $4^{\circ}$ ). También entiende el Tribunal que el término

las garantías propias de las disposiciones constitucionales (supremacía), adquieren una eficacia y garantías reforzadas (art. 53.1 y 2): vinculan a todos los poderes públicos, su regulación se reserva a la ley, en la que se garantiza su contenido esencial por lo que son indisponibles para el legislador, tienen eficacia directa y se les proporciona una tutela particular por el Tribunal Constitucional (TC). Estas garantías se refuerzan aun más para los derechos dispuestos en la sección primera mediante el procedimiento de amparo ante el Tribunal Constitucional, la reserva de ley orgánica y un procedimiento de revisión constitucional agravado (art. 168.1)”. Disponible en: $<$ http://www.ugr.es/ redce/REDCE15/articulos/01AAguilar.htm>. Acceso en: 10-08-2015. En sentido contrario, Ana Garriga Domínguezy Susana Álvarez González, Notas sobre el derecho a un disfrutar de un medio ambiente adecuado, Álvaro Sánchez Bravo (editor), Políticas públicas ambientales, ArCiBel Editores, Sevilla-España: 2008, pp. 61-62: "Por el contrario sostiene parte de la doctrina su condición de derecho fundamental. Su defensa resulta problemática habida cuenta la falta de acuerdo doctrinal tanto sobre el concepto de derechos humanos como acerca del concepto de medio ambiente. Sí resulta más unánime la opinión de que este derecho, de reconocerse, constituiría una respuesta jurídica ante los peligros de la sociedad tecnológica, que se produce cuando el hombre ha adquirido conciencia de la existencia de unos parámetros físicos y biológicos que han permitido su aparición y desarrollo como especie y que pueden alterarse por causas antropogénicas, 'poniendo en riesgo, directa o indirectamente, la vida, especialmente la humana'. Al respecto, resulta especialmente relevante la postura defendida por el Pérez Luño que entiende que la dimensión axiológica y finalista del medio ambiente encuentra su expresión adecuada en el concepto de calidad de vida, vinculada a la idea de dignidad humana; noción que 'refleja una réplica a la idea puramente cuantitativa del bienestar y postula un desarrollo cualitativo y equilibrado, en armonía con la naturaleza; y que sustituye al consumismo por la satisfacción de las necesidades humanas básicas de acuerdo con el principio de solidaridad'. En ese sentido, sostiene el citado autor la posibilidad de calificar como derecho fundamental a la calidad de vida o 'a disfrutar de un medio ambiente adecuado para el desarrollo de la persona'.

${ }^{98}$ Define la citada expresión constitucional en los siguientes términos: "En la Constitución, el medio ambiente es, en pocas palabras, el entorno vital del hombre en un régimen de armonía, que aúna lo útil y lo grato. En una descomposición factorial analítica comprende una serie de elementos o agentes geológicos, climáticos, químicos, biológicos y sociales que rodean a los seres vivos y actúan sobre ellos para bien o para mal, condicionando su existencia, su identidad, su desarrollo y más de una vez su extinción, desaparición o consumición".

Disponible en: < https://www.boe.es/buscar/doc.php?id=BOE-T-1995-18444>. Acceso en: 10-08-2015. 
"medio ambiente" del artículo 45 debe ser interpretado de forma mucho más amplia que el contenido en el artículo 149.1.23 de la Constitución ${ }^{99}$. En este sentido, la STC $306 / 2000$ viene a confirmar que el término "medio ambiente" debe ser interpretado de manera más amplia en el artículo 45 que en el 149.

Por un lado, el artículo 45 figura en el Capítulo Tercero - De los principios rectores de la política social y económica - Sección $2^{\mathrm{a}}$ de los derechos y deberes de los ciudadanos, que compone el Título I, relativo a los derechos y deberes fundamentales. Haciendo con que su reconocimiento, respeto y protección deberán informar la legislación positiva, la práctica judicial y la actuación de los poderes públicos conforme determina el artículo 54 de la Constitución española. En este sentido, la STC $126 / 2002^{100}$ afirma que no cabe ampararse en la falta de competencia para no actuar, una vez que todas las Administraciones deben adecuar sus políticas a este objetivo. Según esta Sentencia la protección del medio ambiente es un deber finalista que se proyecta sobre cualquier decisión de naturaleza pública, llevándonos a la adopción del principio in dubio pro naturaleza.

Del artículo 45 se puede comprender que todos los individuos tienen derecho a desarrollarse en un medio ambiente adecuado, que debe ser protegido por las vías que establezca el legislador. Al considerar el medio ambiente un derecho de tercera

\footnotetext{
99 “Artículo 149:
}

1. El Estado tiene competencia exclusiva sobre las siguientes materias: (...)

23. a Legislación básica sobre protección del medio ambiente, sin perjuicio de las facultades de las Comunidades Autónomas de establecer normas adicionales de protección. La legislación básica sobre montes, aprovechamientos forestales y vías pecuarias".

100

Disponible

en:

$<$ http://www.tribunalconstitucional.es/es/jurisprudencia/Paginas/Sentencia.aspx?cod=14130>. Acceso en: 10-08-2015. En este sentido, Raúl Canosa Usera, El derecho a la integridad personal, Editorial Lex Nova, Valladolid-España: 2006, p.131 afirma: "Como ocurre con el derecho a la protección de la salud, en otros casos y también en el resultado por la STC 119/2001, la conexión entre derechos fundamentales protegibles en amparo y derecho a la protección de la salud o derecho a disfrutar del medio ambiente, permite que entren en amparo eventuales lesiones de derechos no mencionadas en el artículo 53.2 de la CE. En los casos apuntados se trata incluso de derechos reducidos por el artículo 53.3 de la CE a una posición casi subalterna. Obvio es decir que no todo el contenido posible del derecho a la salud puede potencialmente ser protegido en vía de amparo, solapándose con el derecho a la integridad - sólo, en opinión del Tribunal Constitucional, los riesgos más graves - ni todo el contenido imaginable del derecho al medio ambiente puede acomodarse tampoco". 
generación, para su plena realización, necesario se hace una actuación específica de los poderes públicos. Acercándose a la tesis de que el medio ambiente a que se refiere el artículo 45 de la $\mathrm{CE}$ es un derecho subjetivo perfecto de que son titulares todos los españoles y cuyo contenido viene determinado en gran parte por el desarrollo legislativo existente en cada momento, está la jurisprudencia de la STC 32/1983, de 28 de abril.

En este sentido, Jesús Jordano Fraga afirma que: "El derecho a un medio ambiente adecuado es un verdadero derecho subjetivo. Ellos se deduce, en primer término, del sentido propio de las palabras empleadas por el artículo $45 \mathrm{CE}$ y de la interpretación de este precepto realizada por la jurisprudencia del Tribunal Supremo. En segundo lugar, en virtud del artículo $10 \mathrm{CE}$, la consideración del derecho consagrado por el artículo 45 como verdadero derecho subjetivo, se impone a la luz de los Principios primero de las Declaraciones de Estocolmo y de Río. Dichas Declaraciones constituyen una interpretación generalmente aceptada de la noción de derecho del hombre que figura dentro de la Carta de las Naciones Unidas y en tal sentido es indudable que son elementos interpretativos integrantes del bloque señalado por el artículo 10, 2 CE"101.

Buscando perfeccionar la defensa que todos los individuos pueden ejercitar visando la protección del medio ambiente, además de la información pública y de la acción popular, la legislación medioambiental ha desarrollado las técnicas de participación pública, siendo esencial la aprobación de la Ley $27 / 2006^{102}$, de 18 de julio, que viene a regular los derechos de acceso a la información, de participación pública y de acceso a la justicia en materia de medio ambiente, lo que nos lleva a creer que el artículo 45 reconoce en derecho subjetivo real y perfecto.

Otra cuestión importante es la tendencia que la jurisprudencia ${ }^{103}$ ha adoptado de vincular el derecho al medio ambiente con el derecho a la intimidad, haciendo con

\footnotetext{
${ }^{101}$ JORDANO FRAGA, Jesús. La Protección cit., p. 540.

${ }^{102}$ Disponible en: < https://www.boe.es/buscar/doc.php?id=BOE-A-2006-13010>. Acceso en: 10-082015.

${ }^{103}$ En este sentido, Ana Garriga Domínguez y Susana Álvarez González, Notas cit., p. 76 afirman que: "Más reciente ha sido la invocación en amparo de violación de determinados derechos fundamentales entre ellos, derecho a la vida, a la salud, intimidad e inviolabilidad del domicilio ("La importancia del derecho al medio ambiente ha sido puesta de relieve también por el Tribunal Europeo de Derechos Humanos que ha declarado que, en determinados casos de especial gravedad, los daños ambientales pueden llegar a vulnerar el derecho de una persona a su vida personal y familiar" - Fundamento jurídico
} 
que los derechos medioambientales tengan las vías más enérgicas de protección que el ordenamiento español reconoce ${ }^{104}$.

Además, Ana Garriga Domínguez y Susana Álvarez González: “Apuesta por lo tanto por la defensa de un criterio material e integrador del sistema de derechos fundamentales de la Constitución española en el que la calidad de vida tenga cabida, pues se trataría de un derecho humano positivizado en un texto constitucional, 'aunque sea diversa la cantidad de instrumentos jurídicos previstos para reforzar su tutela'. Entendido en estos términos, su significación, en una interpretación sistemática del texto constitucional, 'aparece como una norma finalista en cuanto impone una determinada orientación a todo el ordenamiento jurídico'. En este sentido, quizás pueda afirmarse incluso un marcado carácter instrumental del derecho recogido en el artículo 45 de la Constitución, relacionado de forma más o menos directa con otros derechos fundamentales, entre los cuales pueden señalarse el derecho a la vida y a la integridad física".

Añade las autoras que: "Sin embargo, cabe concluir con Pérez Luño, que este derecho a un medio ambiente adecuado o a la calidad de vida a través de una adecuada protección del medio ambiente no puede concebirse en la actualidad sino como una meta o como una aspiración, cuyo logro dependerá de grandes transformaciones culturales y socioeconómicas, que requieren una participación activa de los poderes públicos. A esta participación hace referencia precisamente el artículo 45, apartado segundo, de la Constitución. En la actualidad, resulta especialmente reseñable en este punto la mención sobre esta necesidad de llevar a cabo este tipo de transformaciones contenida en el Tratado de Lisboa por el que se modifican el Tratado de la Unión Europea y el Tratado constitutivo de la Comunidad Europea, firmado en Lisboa el 13 de diciembre de 2007. Sobre este particular puede citarse la obligación, contenida en el artículo $10 \mathrm{~A}$, punto segundo, apartado f, de ejercitar políticas comunes y acciones con

tercero, STC 199/1996, de 3 de diciembre) - como consecuencia de contaminación medioambiental grave que pueden afectar al bienestar de la persona; invocación influenciada, sin lugar a dudas, por la jurisprudencia del Tribunal Europeo de Derechos Humanos".

${ }^{104}$ En este sentido, la Sentencia del Tribunal Europeo de Derechos Humanos (STEDH) - caso López Ostra contra el Reino de España - abre el camino a una larga serie de resoluciones españolas e internacionales que concluirán que el disfrute de un medio ambiente adecuado tiene innegables repercusiones en el derecho a la intimidad y a la integridad física y moral. Disponible en: < http://hudoc.echr.coe.int/eng?i=001-57905\#\{"itemid":["001-57905"]\}>. Acceso en: 10-08-2015. 
el fin de, entre otros, 'contribuir a elaborar medidas internacionales de protección y mejora de la calidad del medio ambiente y de la gestión sostenible de los recursos naturales mundiales, para lograr el desarrollo sostenible ",105.

En conclusión, las autoras afirman que: "Quizás sea éste el primer paso para un reconocimiento efectivo y protección sólida de un derecho fundamental al medio ambiente o de un derecho a la calidad de vida, que confirme y corrobore la doctrina constitucional de que la Constitución no consagra derechos meramente teóricos o ilusorios sino reales y efectivos, cuya protección es necesario asegurar no sólo frente a las injerencias tradicionales sino también frente a los riesgos que pueden surgir de una sociedad tecnológicamente avanzada" ${ }^{\text {"106. }}$.

Además, para quien el derecho ambiental es un verdadero derecho fundamental ${ }^{107}$, añade Jesús Jordano Fraga: "El derecho a un medio ambiente adecuado es un derecho fundamental que goza de protección refleja a través del recurso de amparo. Aunque en nuestro ordenamiento no sea posible la invocación directa de amparo, este derecho es susceptible de lo que podríamos denominar una protección refleja a través del recurso de amparo dirigido a la tutela de otros derechos. Este sería el caso del derecho a la vida (art. $15 \mathrm{CE}$ ), el derecho a la intimidad (art. $18 \mathrm{CE}$ ), el derecho a la participación (art. $23 \mathrm{CE}$ ), el derecho a la tutela efectiva de los derechos e intereses legítimos (art. $24 \mathrm{CE}$ ) y el derecho a la educación (art. $27 \mathrm{CE})^{\text {"108. }}$.

A su vez, en Brasil, la orden constitucional positiva no ha dado al medio ambiente ecológicamente equilibrado, notablemente, status de derecho fundamental. En dos aspectos, analizando el dispositivo constitucional pertinente, se observa una aparente disminución, por su propia localización en la Constitución brasileña, o sea, el artículo $225^{109}$ está en el Título VIII, relativo a Ordem Social - en el Capítulo VI - Do

\footnotetext{
${ }^{105}$ Conforme Ana Garriga Domínguez y Susana Álvarez González, Notas cit., p. 63.

${ }^{106}$ Conforme Ana Garriga Domínguez y Susana Álvarez González, Notas cit., p. 79.

107 JORDANO FRAGA, Jesús. El derecho a disfrutar de un medio ambiente adecuado: elementos para su articulación expansiva. Disponible en:
}

$<$ https://idus.us.es/xmlui/bitstream/handle/11441/17294/file_1.pdf?sequence=1>. Acceso en: 10-08-2015. Para una mayor comprensión sobre el recurso de amparo, vide: < http://www.tribunalconstitucional.es/es/tribunal/competencias/Paginas/COMPT_04_RA.aspx>.

108 JORDANO FRAGA, Jesús. La Protección cit., pp. 541-542.

${ }^{109}$ Capítulo VI - Do Meio Ambiente

“Art. 225. Todos têm direito ao meio ambiente ecologicamente equilibrado, bem de uso comum do povo 
Meio Ambiente -, que, por tanto, está lejos de los proclamados "Direitos e Garantias Fundamentais" ubicado en el Título II, que ostenta el rol de derechos fundamentales (arts. $5^{\circ}$ a $\left.17 \mathrm{CF} / 88\right)$.

Además de la distancia de doscientos veinte artículos entre los derechos fundamentales y el derecho al medio ambiente ecológicamente equilibrado, aun acrece la peculiaridad literal que el art. 225 no califica "el derecho al medio ambiente

e essencial à sadia qualidade de vida, impondo-se ao Poder Público e à coletividade o dever de defendê-lo e preservá- lo para as presentes e futuras gerações.

$\S 1^{\circ}$ Para assegurar a efetividade desse direito, incumbe ao Poder Público:

I - preservar e restaurar os processos ecológicos essenciais e prover o manejo ecológico das espécies e ecossistemas;

II - preservar a diversidade e a integridade do patrimônio genético do País e fiscalizar as entidades dedicadas à pesquisa e manipulação de material genético;

III - definir, em todas as unidades da Federação, espaços territoriais e seus componentes a serem especialmente protegidos, sendo a alteração e a supressão permitidas somente através de lei, vedada qualquer utilização que comprometa a integridade dos atributos que justifiquem sua proteção;

IV - exigir, na forma da lei, para instalação de obra ou atividade potencialmente causadora de significativa degradação do meio ambiente, estudo prévio de impacto ambiental, a que se dará publicidade;

V - controlar a produção, a comercialização e o emprego de técnicas, métodos e substâncias que comportem risco para a vida, a qualidade de vida e o meio ambiente;

VI - promover a educação ambiental em todos os níveis de ensino e a conscientização pública para a preservação do meio ambiente;

VII - proteger a fauna e a flora, vedadas, na forma da lei, as práticas que coloquem em risco sua função ecológica, provoquem a extinção de espécies ou submetam os animais a crueldade.

$\S 2^{\circ}$ Aquele que explorar recursos minerais fica obrigado a recuperar o meio ambiente degradado, de acordo com solução técnica exigida pelo órgão público competente, na forma da lei.

$\S 3^{\circ}$ As condutas e atividades consideradas lesivas ao meio ambiente sujeitarão os infratores, pessoas físicas ou jurídicas, a sanções penais e administrativas, independentemente da obrigação de reparar os danos causados.

$\S 4^{\circ}$ A Floresta Amazônica brasileira, a Mata Atlântica, a Serra do Mar, o Pantanal Mato-Grossense e a Zona Costeira são patrimônio nacional, e sua utilização far-se-á, na forma da lei, dentro de condições que assegurem a preservação do meio ambiente, inclusive quanto ao uso dos recursos naturais.

$\S 5^{\circ}$ São indisponíveis as terras devolutas ou arrecadadas pelos Estados, por ações discriminatórias, necessárias à proteção dos ecossistemas naturais.

$\S 6^{\circ}$ As usinas que operem com reator nuclear deverão ter sua localização definida em lei federal, sem o que não poderão ser instaladas". Disponible en: < http://www.planalto.gov.br/ccivil_03/Constituicao/ConstituicaoCompilado.htm>. Acceso en: 05-08-2015. 
ecológicamente equilibrado" como derecho fundamental, sino como "bien de uso común del pueblo y esencial a una mejor calidad de vida" cuya fruición es "derecho de todos". Ya el inciso III del artículo $129^{110}$ de la Constitución brasileña determina como una de las funciones institucionales del Ministerio Publico (Fiscalía) la protección del medio ambiente y de otros intereses difusos y colectivos.

Sin embargo, el derecho a un medio ambiente ecológicamente equilibrado debe ser considerado un derecho fundamental ${ }^{111}$, sea por el concepto mismo de derecho fundamental, sea por fuerza de otros ordenamientos jurídicos que así lo consideran.

Como ya hemos visto, los derechos fundamentales tienen como objeto de protección valores e intereses en la esfera de la dignidad humana, con esto, surge la convicción de que una caracterización ontológica de los derechos fundamentales siempre da importancia a un criterio material en desfavor de criterios formales y mismo topográficos ${ }^{112}$. Un análisis positiva del ordenamiento jurídico brasileño, y en especial de la Constitución, conduce a que se prestigie el criterio material como caracterizador de un derecho fundamental ${ }^{113}$.

${ }^{110}$ Art. 129. São funções institucionais do Ministério Público:

I - promover, privativamente, a ação penal pública, na forma da lei;

II - zelar pelo efetivo respeito dos Poderes Públicos e dos serviços de relevância pública aos direitos assegurados nesta Constituição, promovendo as medidas necessárias a sua garantia;

III - promover o inquérito civil e a ação civil pública, para a proteção do patrimônio público e social, do meio ambiente e de outros interesses difusos e coletivos; (...). Disponible en: < http://www.planalto.gov.br/ccivil_03/Constituicao/ConstituicaoCompilado.htm>. Acceso en: 05-08-2015. ${ }^{111}$ Dos referencias normativas son obligatorias: la Declaración Universal de Derechos Humanos de 1948, que en el artículo 25 proclama: "Toda persona tiene derecho a un nivel de vida adecuado que le asegure, así como a su familia, la salud y el bienestar, y en especial la alimentación (...)”. Y el Principio I de la Declaración de Estocolmo de 1972 que determina: "El hombre tiene el derecho fundamental a la libertad, la igualdad y el disfrute de condiciones de vida adecuadas en un medio de calidad tal que le permita llevar una vida digna y gozar de bienestar y, tiene la solemne obligación de proteger y mejorar el medio para las generaciones presentes y futuras". Disponibles en: <http://www.un.org/es/documents/udhr/ $>$ y $<\mathrm{http}$ //www.unep.org/Documents.Multilingual/Default.asp?DocumentID=97>. Ambos con acceso en: 05-08-2015.

${ }^{112}$ En sentido contrario, Robert Alexy, Teoría cit., p. 65: "Más conveniente que la fundamentación del concepto de norma de derecho fundamental sobre criterios materiales y/o estructurales es su vinculación con un criterio formal, que apunte a la forma de la positivación".

${ }^{113}$ Vale resaltar que la propia Constitución brasileña garante este método en su artículo $5^{\circ}, \S 2^{\circ}$ cuando determina: "Os direitos e garantias expressos nesta Constituição não excluem outros decorrentes do 
En Brasil, suponer que la lista de derechos fundamentales se limita al rol del artículo $5^{\circ}$, sería hacer una interpretación derogatoria del propio texto constitucional, lo que sería prohibido por la metodología jurídica ${ }^{114}$.

Así, independientemente de status constitucional o ubicación en catálogo propio, los derechos fundamentales a dignidad de la persona humana, tal como "el derecho a un medio ambiente ecológicamente equilibrado" debe ser entendido como un derecho fundamental. La propia concepción contemporánea de dignidad de la persona humana abarca necesariamente el reclamo de calidad de vida, que no se quedó en el olvido de la Constitución brasileña.

\subsection{Derecho interno y Derecho Internacional}

Derecho y sociedad tienen una relación tan intrínseca y simultanea, que puede ser resumida en un antiguo proverbio latino, Ubi societas, ibi ius ${ }^{115}$. El Derecho es un

regime e dos princípios por ela adotados, ou dos tratados internacionais em que a República Federativa do Brasil seja parte". En este sentido, Tiago Fensterseifer, A dimensão ecológica da dignidade humana: as projeções normativas do direito (e dever) fundamental ao ambiente no Estado Socioambiental de Direito, afirma que: “A Constituição brasileira de 1988 (art. 225 e art. 5’ $\S 2^{\circ}$ ) atribuiu ao direito ao ambiente status de direito fundamental (formal e materialmente), consagrando a proteção ambiental como um dos objetivos ou tarefas mais importantes do Estado de Direito brasileiro, bem como direito subjetivo do indivíduo e da coletividade. O direito ao ambiente caracteriza-se como direito fundamental de terceira dimensão, tendo como fundamento axiológico o princípio constitucional da solidariedade e a natureza de um direito transindividual e mesmo universal". Disponible en: $<\mathrm{http}$ ://www.unisc.br/portal/upload/com_arquivo/dissertacao__a_dimensao_ecologica_da_dignidade_hu mana_as_projecoes_normativas_do_direito_(e_dever)_fundamental_ao_ambiente_no_estado_socioam biental_de_direito..pdf>.Acceso en: 05-08-2015.

${ }^{114}$ Importante aquí comentar que el propio art. $5^{\circ}$ de la $\mathrm{CF} / 88$ que trata de los derechos y garantías fundamentales, en su inciso LXXIII determina: "Qualquer cidadão é parte legítima para propor ação popular que vise a anular ato lesivo ao patrimônio público ou de entidade de que o Estado participe, à moralidade administrativa, ao meio ambiente e ao patrimônio histórico e cultural, ficando o autor, salvo comprovada má-fé, isento de custas judiciais e do ônus da sucumbência”. O sea, podemos afirmar que la protección del medio ambiente es sí un derecho fundamental.

${ }^{115}$ Donde hay sociedad hay derecho. Aforismo romano al que suele seguir Ubi ius, ibi societas (donde hay derecho, hay sociedad), para significar la conexión intrínseca entre ambos fenómenos. 
instrumento de regulación de conductas sociales, producto de la voluntad humana, tanto de la voluntad autónoma cuanto de aquella organizada y institucionalizada socialmente.

Las conductas del ser humano se tornan relevantes para el interés del restante de la colectividad, exactamente debido al trato y la relación entre ellos. Sea para el mantenimiento de la paz, del orden, de la seguridad buscada por los individuos, o sea por su propia vida en particular - consciente o inconsciente - cuando se juntan y se organizan en sociedad.

Cada individuo tiene sus valores particulares, e independientemente de eso, son en los valores colectivos, que surgen directamente de los objetivos que llevaron a la formación de la sociedad en que se insiere - o en la consideración de aquel colectivo de individuos como tal -, que reside el vector orientador de la regulación de conductas deseables e indeseables, de conductas prohibidas, permitidas u obligatorias, o sea, de estimulo y ordenación de conductas que van a contribuir para la realización de los objetivos comunes y desestimulo y repudio de aquellas que pueden dañar la realización de estas metas por la sociedad.

La sociedad, sea ella formada por personas, organizadas bajo un único conjunto de normas jurídicas, dentro de un mismo espacio geográfico - por lo tanto, la sociedad dentro de un Estado soberano ${ }^{116}$ - sea compuesta por el grupo de Estados soberanos, también conocida como Sociedad Internacional ${ }^{117}$, en ambos los casos, la sociedad no puede prescindir de reglas que la organicen y organicen a la vida de sus

\footnotetext{
${ }^{116}$ La sociedad conformada dentro de la esfera de acción del poder de un Estado soberano, en los limites de su territorio, se da el nombre de sociedad nacional o sociedad interna, y al Derecho que la rige de derecho interno. Las relaciones jurídicas provenientes del contacto entre miembros de dos o más sociedades internas, ligados así, a distintas ordenes jurídicas soberanas, son disciplinadas por las reglas de Derecho Internacional Privado, que se constituye básicamente de reglas para la solución de los conflictos de normas que surgieron de aquella intersección.

${ }^{117} \mathrm{La}$ sociedad formada por la colectividad de Estados soberanos y, más recientemente, por organizaciones internacionales y por el propio ser humano - como sujeto de derechos y deberes frente estas mismas entidades -, se da el nombre de sociedad internacional, y al Derecho que la rige de derecho internacional público. Público porque rige intereses y conductas de Estados soberanos y de sus creaciones, las organizaciones internacionales, diferenciándose del Privado que regula intereses y conductas de individuos sujetos al conflicto entre normas de su estatuto jurídico y del local donde se encuentran, así como, de las de su estatuto jurídico nacional con las de otros ordenamientos nacionales.
} 
integrantes, tampoco puede el Derecho prescindir de la sociedad, puesto que tiene su génesis y legitimación en el poder que de ella es generado ${ }^{118}$.

El derecho internacional público es definido por Podestá Costa como siendo aquel: "constituido por el conjunto de normas que rigen las relaciones entre los Estados y también las de estos con determinadas entidades que, sin ser Estados, tienen personalidad internacional" ${ }^{119}$, además, enseña que la denominación derecho internacional fue introducida por el inglés Jeremy Bentham ${ }^{120}$ en 1780 , con la finalidad de distinguir el Derecho de las relaciones entre Estados soberanos del Derecho interno nacional. Antes de eso, otros autores utilizaban los términos "Derecho de gentes", que provenía del “ius gentium" romano ${ }^{121}$, lo que Bentham consideraba un término

${ }^{118}$ No por otra razón que Pontes de Miranda, Tratado de direito internacional privado, Livraria José Olímpio Editora, Rio de Janeiro-Brasil: 1935, t. I, p. 6, afirma que toda regla jurídica, sea escrita, o sea no escrita, supone poder que, inconsciente -, subconsciente - o conscientemente, la hizo o la dictó.

${ }^{119}$ PODESTÁ COSTA, L. A. Manual de derecho internacional publico. Librería Editora El Ateneo, Buenos Aires-Argentina: 1943, p.11.

${ }^{120}$ Bentham cunó la expresión international law en su obra An introduction to the principles of moral and legislation. La expresión aparece en la obra en oposición a la national law y a la municipal law. Las criticas que se hacen a la expresión international law en realidad, se deben, a un equivoco de traducción. Es que en inglés, nation tiene el mismo significado de State, lo que no fue debidamente observado en las traducciones para el francés, y de este para las demás lenguas latinas. Así, aquellos que la critican, diciendo tratarse, en realidad, de derecho interestatal, en realidad, no conocen la esencia del objeto de la crítica, una vez que es exactamente a eso que la expresión se refiere. De todas maneras, ella se encuentra absolutamente consagrada. In PODESTÁ COSTA, L. A., op. cit., 1943, p. 11. Más informaciones sobre su obra An introduction to the principles of moral and legislation disponibles en: $<$ http://socserv.mcmaster.ca/econ/ugcm/3113/bentham/morals.pdf>. Acceso en: 29-07-2015.

${ }^{121}$ En ese sentido, Paulo Dourado de Gusmão, Introdução ao Estudo do Direito, $10^{\mathrm{a}}$ ed., Editora Forense, Rio de Janeiro-Brasil: 1984, p. 187, afirma que “A expressão 'Direito internacional' foi usada pela primeira vez por Bentham, em An introduction to the principles of moral and legislation. Anteriormente, denominava-se 'direito das gentes', expressão usada no século XVI, por Francisco de Vitória”. De acuerdo con Celso Albuquerque Melo, Curso de direito internacional público, $13^{\mathrm{a}}$ ed., Editora Renovar, Rio de Janeiro-Brasil: 2001, v. I, pp. 68-69, Samuel Pufendorf, en el siglo XVII, fue el primero a utilizar la expresión ius gentium para designar el derecho natural de los elementorum jurisprudentiae universalis. Isidoro de Sevilla también ha mencionado la expresión en sus Etimologías. Francisco de Vitória se refería a una expresión un poco más elaborada, ius inter gentes, sustituyendo, en la definición de Gayo, en las Institutas, la palabra homines por gentes, poniendo así la palabra en su expresión moderna, no refiriéndose apenas a los hombres, sino también a sus colectividades organizadas. 
inapropiado, una vez que aquel derecho romano no se refería a normas que regían relaciones entre Estados.

A que pesen los argumentos a favor y una cierta tendencia de considerar correcto entender Derecho de gentes como expresión idéntica a Derecho internacional, este no es nuestro entendimiento, una vez que compartimos del entendimiento de Guido Soares ${ }^{122}$, que el derecho internacional es el conjunto de reglas, normas y principios, tanto de origen convencional cuanto de origen consuetudinaria, que rigen las relaciones de Estados, organizaciones intergubernamentales, de entes despersonalizados y, también, del ser humano.

Aunque la realidad del mundo actual y las evidencias apunten para la consolidación de una de las corrientes (monista y dualista) del Derecho Internacional, una cuestión que surge es la que trata de la relación entre derecho interno y derecho internacional público: si estas dos esferas del mundo jurídico se comunican, se relacionan, o no. O sea, la dicotomía entre monismo y dualismo.

La primera reconoce la vigencia de las normas internacionales en el orden interno, como tales, o sea, la primera establece que el derecho interno y el derecho internacional son dos sistemas u ordenamientos jurídicos de idéntica naturaleza jurídica, porque sus funciones y destinatarios son los mismos. En efecto ambos sistemas jurídicos tienen como fuente un acuerdo o consenso de voluntades; la segunda, en cambio, solo reconoce, en el ámbito interno, la vigencia de la norma jurídica propia, aquella que es proveniente del ejercicio del poder soberano del Estado, a través del proceso legislativo constitucionalmente establecido para sus órganos legisferante, o sea, entiende que el Derecho Internacional Público y el Derecho Interno Estatal son dos sistemas $\mathrm{u}$ ordenamientos jurídicos de naturaleza jurídica diferente porque tienen fuentes y destinatarios distintos.

\footnotetext{
${ }^{122}$ Guido Fernando Silva Soares, Curso de direito internacional público, Ed. Atlas, São Paulo-Brasil: 2002, p. 21 y Hildebrando ACCIOLY, Manual de direito internacional público, 12 ed., Ed. Saraiva, Rio de Janeiro-Brasil: 1996, p. 1, ambos definen derecho internacional público como siendo "o conjunto de regras e princípios destinados a reger os direitos e deveres internacionais tanto dos Estados, de certos organismos interestatais, quanto dos indivíduos". En sentido contrario, Francisco Rezek, Direito internacional público: curso elementar, $8^{\mathrm{a}}$ ed., Ed. Saraiva, São Paulo-Brasil: 2000, p. 3, afirma que el derecho internacional público se constituye en el: "sistema jurídico autônomo onde se ordenam as relações entre Estados Soberanos", y es la expresión sinónima de Derecho de gentes.
} 
El enfoque de este trabajo no es el análisis de la discusión entre monistas y dualistas, así que, analizaremos solo lo que de esta discusión se aprovecha para el objetivo aquí propuesto: saber la posición de España y Brasil sobre el tema.

España, así como Brasil, es partidaria de la teoría monista, al menos en el sentido latu del concepto. Es decir, reconoce vigencia a las normas internacionales, a los tratados, como tales, en su ordenamiento jurídico interno ${ }^{123}$.

\footnotetext{
${ }^{123}$ Aunque, como bien advirtió Pedro Bohomoletz de Abreu Dallari: "a regra brasileira de regência da matéria de recepção e integração dos tratados internacionais na ordem jurídica interna não detém os atributos de clareza, precisão, harmonia e exaustão". Constituição e tratados internacionais. Ed. Saraiva, São Paulo-Brasil: 2003, p. 86.
} 


\section{Capítulo 2 - Sobre el medio ambiente y su concepto}

\subsection{Sobre el medio ambiente y su concepto}

Para los griegos, la naturaleza era la medida de todas las cosas. Lo que no era bueno para el medio ambiente no podría ser bueno para el hombre. A partir de este principio, eran formuladas leyes y reglas de convivencia, volcadas, principalmente, para el bien de la sociedad.

Mucha cosa cambió en esta trayectoria. Los valores colectivos poco a poco fueron cediendo lugar a los intereses individuales y, la naturaleza dejó de ser criterio para el desarrollo de la humanidad, lo que resultó en sucesivas agresiones ambientales, generando efectos perversos para toda la población del planeta. Frente a esta realidad, con la finalidad de cohibir la degradación ambiental, crean y ejecutan leyes al largo de la historia.

La palabra ambiente, del latín ambiens, entis, significa lo que nos rodea, que envuelve. La gran mayoría de los estudiosos está de acuerdo que la expresión medio ambiente no sería la más correcta, debido a la redundancia existente, una vez que medio es lo que rodea, circunda, o sea, el ambiente. Aunque haya redundancia, ella tiene la función de dar mayor énfasis al asunto.

El medio ambiente es lo que nos rodea, es el conjunto de bienes naturales y culturales necesarios para la calidad de vida ecológica y existencial de la persona humana. Tal expresión abarca desde el suelo, las aguas, el aire, la flora, a fauna, las bellezas naturales y artificiales, el ser humano al patrimonio histórico, artístico, turístico, paisajístico, monumental, arqueológico, entre otros.

La clasificación del medio ambiente puede ser vista bajo cuatro ángulos diferentes, todos previstos en la Constitución Brasileña, a saber, el ambiente natural (artículo 225, § $1^{\circ}$, I y VII), ambiente artificial (artículos $5^{\circ}$, XXIII, 222, 182 y 21, XX), ambiente cultural (artículo 216) y ambiente del trabajo (artículo 200, VII).

El ambiente natural puede ser entendido como la naturaleza vista de una forma general, como el aire, el agua, el suelo, la flora y la fauna, o sea, el ecosistema. Este ambiente engloba el espacio que no fue alterado por el hombre. El ambiente artificial es el área formada por la producción humana, es el medio ambiente construido (urbano y rural), el cultural y el del trabajo. 
El ambiente cultural es formado por los bienes de naturaleza material y inmaterial, tomados individualmente o en conjunto, abordando diversas formas de manifestación cultural, no sólo de producción científica, pero también de creación. Además, integra el medio ambiente cultural el patrimonio histórico, artístico, arqueológico, paisajístico y turístico. Son competentes para proteger los bienes patrimoniales la Unión, Estados, Distrito Federal y Municipios. Un instrumento muy utilizado en la protección y manutención del patrimonio cultural es la figura jurídica del Tombamento (declaración de Monumento Histórico-Artístico).

El ambiente del trabajo es el local donde se desarrollan las actividades laborales del hombre. Es importante destacar que tal ambiente debe ser un lugar sano, conforme las leyes de salud, higiene y seguridad.

Con el aumento de la degradación de la naturaleza, para atender un grito de socorro del medio ambiente, surge el Derecho Ambiental. En Brasil, fue con la llegada de la Constitución Federal de 1988 que esa disciplina ganó el status de ciencia autónoma.

El Derecho Ambiental es la rama del derecho que se ocupa del estudio del medio ambiente y sus relaciones e interacciones con la sociedad. El hombre no es más visto como algo externo a la naturaleza, como un ser distinto del medio en que vive, como entendía la visión antropocéntrica. Su rol es luchar por la preservación de la naturaleza, con la finalidad de buscar siempre mantener el equilibrio ecológico.

Tal disciplina jurídica no siempre tuvo esa denominación, antes era conocido por la mayoría de los autores y estudiosos como Derecho Ecológico, entre ellos Sérgio Ferraz y Diogo de Figueiredo Moreira Neto. Para este el derecho ecológico sería una de las ramas componentes del derecho ambiental, ya según aquel sería el derecho urbanístico.

Michel Despax prefiere la denominación Derecho del Ambiente, ya que el concepto de ambiente es más amplio que el de naturaleza, incluyendo, además de los elementos que el hombre encontró sobre la tierra, de todo lo que él mismo construyó o remodeló. $^{124}$

${ }^{124}$ DESPAX, Michel. Droit de 1'Environnement. Paris: Librairies Téchniques, 1980 apud Paulo Affonso Leme Machado. Direito ambiental brasileiro. $14^{\mathrm{a}}$ ed. rev., atual. e ampl. São Paulo: Malheiros, 2006, p. 50. 
El sujeto del Derecho Ambiental es la propia naturaleza, el hombre también es protegido, pero por la vía indirecta. Acerca de la finalidad de este derecho no hay un consenso entre los doctrinadores, entendiendo algunos tratar del proprio hombre, que necesita de un medio ambiente sano para vivir. Para un segundo grupo, su finalidad es la naturaleza, en la que se inserta el ser humano como objetivo último del medio ambiente.

El Derecho Ambiental es un derecho que lida con la anticipación, teniendo como objetivo prevenir el daño que por ventura venga a suceder. En este aspecto se difiere de las otras ramas del derecho, pero es una característica necesaria, considerando que determinados impactos ambientales pueden tener consecuencias irreversibles, como por ejemplo, la extinción de animales. De esta forma, la simple amenaza de daño ya es suficiente para la determinación de medidas restrictivas o paralizadoras o la aplicación de la sanción.

El objeto de protección del Derecho Ambiental es el bien ambiental, que está identificado en el texto constitucional brasileño, cuando dispone que todos tienen derecho a un medio ambiente ecológicamente equilibrado, que es un bien de uso común general y esencial a la sana calidad de vida. De esta forma, el bien ambiental es el entorno ecológicamente equilibrado, que es un bien inmaterial, teniendo en cuenta que también un derecho del hombre. Fue alzado a la categoría de bien público, razón la cual posee régimen de derecho público. El foco de protección del Derecho Ambiental es bastante amplio, abarcando desde la protección jurídica de las condiciones necesarias para la existencia de vida en el planeta hasta los seres vivos, que son los destinatarios de esta tutela.

Todas las disciplinas jurídicas existentes mantienen relaciones entre sí, no existen de forma aislada. El Derecho Ambiental presenta una gran interdisciplinaridad debido al hecho de varios temas del derecho ambiental ya haber sido abordados en otras ciencias jurídicas, por ser un derecho sistemático y por sacar de disciplinas tradicionales sus fundamentos, principios e instrumentos. El Derecho Ambiental articula la legislación, doctrina y jurisprudencia relativas al medio ambiente, como forma de evitar el aislamiento de los temas ambientales. Además, no ignora lo que cada tema tiene de específico, sino que busca unir las materias con los instrumentos jurídicos existentes de prevención, reparación e información. 
Por otro lado, el Derecho Constitucional guarda íntima relación con el Derecho Ambiental, una vez que de la Constitución Federal es que son extraídos todos los principios del Derecho Ambiental, es en ella que está presente la base de institutos administrativos, como los instrumentos destinados a la tutela ambiental, por ejemplo.

El Derecho Ambiental trae los instrumentos jurídicos disponibles para la protección del patrimonio cultural y, de la misma forma, el Derecho Administrativo ${ }^{125}$ fornece los parámetros de diversos institutos utilizados por el derecho ambiental, como es el caso del "tombamento" (declaración de Monumento Histórico-Artístico). Por otro lado, el Derecho Procesal es necesario para la efectividad del Derecho Ambiental, por fornecer los mecanismos y los caminos a seguir para la tutela de este derecho.

El Derecho Internacional se hace presente principalmente por el hecho de la crisis ambiental no ser algo local, sino de proporciones que envuelven todo el planeta. La relación entre esas dos disciplinas es de extrema importancia en la búsqueda de soluciones globales para los crecientes problemas ambientales, como la firma de tratados internacionales sobre el asunto.

Cuestión pacífica entre los estudiosos del tema, es la necesidad de aplicación tanto de las normas urbanísticas como de las ambientales para alcanzar efectivamente la elevación de la calidad de vida en los centros urbanos. El Derecho Urbanístico se ocupa con las cuestiones relativas a la ocupación, organización y parcelación del suelo, en la estructuración de las ciudades, siempre con la preocupación de actuar en conformidad a las exigencias ambientales.

\footnotetext{
${ }^{125}$ Respecto a las transformaciones que del Derecho Administrativo por influencia del Derecho Ambiental Manuela Mora Ruiz, Tendencias del Derecho Administrativo. "El Derecho Administrativo Ambiental: Transformaciones en el Derecho Administrativo General". Derecho y conocimiento, vol. 1 , W. Hoffman-Riem, "La reforma del Derecho administrativo", DA, 234 (abril-junio), 1993, pp. 523-532 afirma que: "[...] el Derecho Administrativo Ambiental se está convirtiendo en la avanzadilla del Derecho Administra- tivo General en cuanto a los cambios que se están operando en nuestra sociedad y que, fundamen- talmente, se relacionan con una tendencia generalizada a la reducción de cuotas de presencia de lo público en el desempeño de funciones que, hasta ahora, venían siendo atendidas, casi con exclusi- vidad, por la Administración" (p. 528). Disponible en: < http://rabida.uhu.es/dspace/bitstream/handle/10272/1568/b1205773.pdf?sequence=1>. Acceso en: 17-112015.
} 
El Derecho Tributario se relaciona con el derecho ambiental ayudando en la prevención del daño ambiental o actuando en la punición por medio del aumento de los tributos, imposición de multas a los que no respetan la legislación ambiental, entre otros. La disciplina tributaria estimula conductas favorables al medio ambiente con incentivo a la reforestación por medio de la exención o minoración de impuestos.

El Derecho Ambiental tiene preocupaciones comunes con el derecho público del trabajo y de la seguridad social, cuando busca condiciones salubres de trabajo, evitando la peligrosidad y gravedad en el ambiente laboral. De la misma forma, el Derecho Económico posee como uno de los principios de la actividad económica la preservación del medio ambiente y se manifiesta principalmente en la concesión de licencias ambientales para la ejecución de determinadas actividades.

Además, el Derecho Ambiental trajo innúmeros cambios al Derecho Civil, principalmente en lo que se relaciona a la propiedad privada, que debe existir en consonancia con su función social. La responsabilidad civil, en lo que se refiere a los daños ambientales tiene carácter objetivo, o sea, existirá independientemente de comprobación de dolo o culpa.

\subsection{Breve síntesis histórica de la relación hombre-medio ambiente}

El hombre posee una relación, de veras, problemática con el medio ambiente natural, porque desde su aparición sobre la Tierra intenta transformar todo lo que le rodea conforme sus designios. La jornada del hombre sobre la Tierra siempre fue marcada por intervenciones sobre la naturaleza, sea durante el paleolítico, en el que ellos cazaban y cosechaban frutos, sea construyendo herramientas, o aprendiendo a vivir en grupos nómades.

Uno de los hitos de la intervención humana sobre el medio ambiente fue en el exacto momento en que se dio su fijación a determinado local, porque esto llevó a la "revolución neolítca" con la invención de la agricultura y la domesticación animal. El segundo hito, y uno de los responsables directos por el actual cuadro de crisis

\footnotetext{
${ }^{1}$ BOURG, Dominique; SCHLEGEL, Jean-Louis. Anteciparse a los riesgos: el principio de precaución. Barcelona: Ariel, 2004, p.97; MOTA, Myriam Becho; BRAICK, Patrícia Ramos. História: das cavernas ao Terceiro Milênio. São Paulo: Moderna, 1997, pp. 5-7.
} 
ambiental $^{2}$ que enfrentamos fue la revolución industrial del siglo XVIII. Desde entonces, el hombre pasa a absorver del medio ambiente los recursos naturales necesarios para sus actividades y a devolver en cambio, contaminación y desechos en escala superior a sus condiciones naturales de asimilación. Por fin, se llega a un tercer ciclo, denominado por algunos de revolución tecnológica o sociedad tecnológica ${ }^{3}$, marcada por la era de los ordenadores, de la biotecnología, entre otras peculiaridades.

La revolución neolítica que ocurrió hace aproximadamente unos 10 mil años se caracterizó por la fijación del hombre a la tierra, dejando de ser nómade. Tal hecho lo permitió interferir directamente en su entorno: la característica fundamental de ese período puede ser atribuida a las transformaciones aceleradas en las relaciones entre el hombre y el ambiente. La práctica de la agricultura y la domesticación de los animales, permitió a las sociedades primitivas el control de la producción de alimentos, el sedentarismo, y, consecuentemente, el aumento de la población. Esas modificaciones son conocidas como revolución neolítica o revolución agrícola, y marcaron el progresivo aumento del dominio del hombre sobre la naturaleza ${ }^{4}$.

A la medida que el hombre se fijó en determinado local, estableciendo raíces físicas y psíquicas con la región en la que ejercía sus actividades, el medio ambiente sufría sistemáticamente, ya que era modificado para atender a las necesidades humanas. La primera gran interferencia humana fue propiciada por la agricultura, haciendo del ambiente natural un medio para alcanzarse los fines de su actividad. Tal período fue el primer paso para el problema demográfico de la humanidad, ya que aquí se inicia la formación de tribus bajo la forma de clanes (organización social), viviendo en aldeas construidas por los hombres con los recursos naturales como la madera y el barro. Se estima que la población de todo el planeta se situaba probablemente entre los dos y los quince millones de personas (seguramente mucho más próximo a primera que a la segunda cifra) $)^{5}$. No obstante, podemos considerarlo como el inicio de la apropiación del

\footnotetext{
${ }^{2}$ Crise esta advinda da modernidade simples (sociedade industrial), logo mais abordada neste capítulo no item 3.1, intitulado "A modernidade simples (sociedade industrial)".

${ }^{3}$ GALLO, Silvio. Ética e cidadania: caminhos da filosofia. Campinas: Papirus, 1997, p. 105.

${ }^{4}$ MOTA, Myriam Becho; BRAICK, Patrícia Ramos. História: cit., pp. 5-6.

${ }^{5}$ BOURG, Dominique; SCHLEGEL, Jean-Louis. Anteciparse a los riesgos: el principio de precaución.

Barcelona: Ariel, 2004, p. 96-97.
} 
medio ambiente, entendida tal expresión como un hito de la cosificación de la naturaleza.

La Revolución Industrial que tiene inicio en el siglo XVIII, extendiéndose por todo el siglo XIX, significó el principal hito de la degradación ambiental, porque a partir de este momento se inicia el enlace más terrible que podría suceder para el medio ambiente: la "boda" entre el capitalismo y el industrialismo. También ocurre aquí, la segunda explosión demográfica ${ }^{6}$, agrupando personas en ciudades, bajo la forma social de clases (burguesía y proletariado), de forma jamás vista, como afirma David Goldblatt: "El aspecto fundamental de las ciudades industriales del siglo XIX fue su crecimiento demográfico explosivo, aglomerando las personas a una densidad y en números absolutos casi únicos en toda la historia"7. El impacto sobre el medio ambiente fue devastador, imponiendo a la naturaleza modificaciones de significativo impacto, como la extracción indiscriminada de recursos ambientales y la absorción de los residuos (contaminación) de la actividad productiva del hombre. El conforto humano es dispensable y a veces, fútil, mientras los recursos ambientales (en sentido más amplio, el medio ambiente natural) son indispensables, y limitados. En este aspecto Édis Milaré afirma: "Todo deriva de un fenómeno habitual, segundo el cual los hombres, para satisfacción de sus nuevas y múltiples necesidades, que son ilimitadas, disputan los bienes de la naturaleza, por definición limitados", consumía más de 18 millones de toneladas de carbón por año, al mismo tiempo que 200 toneladas de hollín por día dañificaban los edificios y aumentaban la incidencia de enfermedades respiratorias" 9 .

La percepción de la posibilidad de escasez de los recursos naturales llegó tarde a la conciencia de las sociedades humanas. Consecuencia del mito creado en torno del progreso científico, tasado como infalible, el que hinca sus raíces en el pensamiento renacentista (hito del antropocentrismo), pasando por el Iluminismo. Se pensaba que los

\footnotetext{
${ }^{6}$ BOURG, Dominique; SCHLEGEL, Jean-Louis. Anteciparse a los riesgos: cit., p. 97: "Fue la segunda explosión demográfica, y este elemento explica, por una razón puramente cuantitativa, el impacto masivo de las actividades humanas sobre la Tierra".

${ }^{7}$ GOLDBLATT, David. Teoria social e ambiente. Lisboa: Piaget, 1996, p. 96.

${ }^{8}$ MILARÉ, Édis. Direito do Ambiente: doutrina, prática, jurisprudência, glosário. $3^{\mathrm{a}}$ ed. São Paulo: RT, 2004, p. 47.

${ }^{9}$ GOLDBLATT, David. Teoria social e cit., p. 96.
} 
recursos naturales eran inagotables, tanto es así que los mayores íconos de la filosofía moderna, René Descartes y Francis Bacon, predicaban la razón a cualquier precio. Este último llegó a proponer que la naturaleza era una esclava a servicio del ser humano, debiendo este colocar aquella en una cama de fuerza, sacando todos sus recursos. En ese aspecto asevera Leonardo Boff haber olvidado nuestra unión con la Tierra fue el equívoco del racionalismo en todas sus formas de expresión. Lo que generó la ruptura con la madre. Dio origen al antropocentrismo, en la ilusión de que, por el hecho de pensar la Tierra, nos podríamos colocar sobre ella para dominarla y para disponer de ella por capricho. ${ }^{10}$

Delante de una aplicación irresponsable del conocimiento científico, embaído por un sistema económico capitalista voraz, perceptible es la situación de crisis que vive el medio ambiente.

El último período el que denominamos de sociedad tecnológica guarda similitudes con la época denominada postmoderna por algunos, sociedad del riesgo por otros, y puede ser resumida en el desenlace final de la modernidad, marcada por algunas peculiaridades como: la globalización, la biotecnología, la era de la información, entre otros.

\subsection{El surgimiento de la cuestión ambiental en Brasil. La Constitución} Federal de 1988 y el nuevo tratamiento de la cuestión ambiental

No existe un consenso entre los autores acerca de la fecha del surgimiento del Derecho Ambiental. Según algunos estudiosos, como Ann Helen Wainer ${ }^{126}$, él ya existía desde la época del descubrimiento de Brasil, considerando que Portugal poseía una legislación ambiental fuertemente evolucionada. Es importante recordar que el derecho ambiental existente hoy es resultado de un proceso histórico influenciado por la

\footnotetext{
10 BOFF, Leonardo. Planeta Terra, Ecologia e Ética. In: ARRUDA, Marcos; BOFF, Leonardo. Globalização: desafios socioeconômicos, éticos e educativos. $2^{\mathrm{a}}$ ed. Petrópolis: Vozes, 2001, p.108.

${ }^{126}$ WAINER, Ann Helen. Legislação ambiental brasileira: evolução histórica do direito ambiental. Revista forense, v. 88, n. 318, p. 19-26, abr./jun. 1992 y también en la Revista de informação legislativa, v. 30, n. 118, p. 191-206, abr./jun. 1993.
} 
herencia cultural de los indios, de convivencia pacífica con la naturaleza y por la visión colonialista del explorador portugués.

Brasil recibió una herencia de la colonización que se fundamenta en el mal aprovechamiento de las tierras, lo que generó grandes latifundios improductivos, la exploración inconsciente de los recursos naturales, como la degradación de las florestas en la búsqueda del famoso "pau-brasil" (palo-brasil). Como bien observa Guilherme José Purvin de Figueiredo, la historia económica de Brasil siempre caminó en dirección opuesta al Principio de la Función Social de la Propiedad. ${ }^{127}$

En la fecha de 12 de diciembre de 1605, bajo el reinado de D. Felipe II, es aprobado el Regimiento del Pau-Brasil, que es considerado la primera ley de protección forestal y traía reglas para la exploración del "pau-brasil", como la concesión de licencias especiales para su corte y penalidades severas para los infractores.

La agricultura comienza a surgir en Brasil, fruto de un proceso lento que trajo consigo enorme degradación ambiental. El cultivo era precario y la única forma utilizada para reaprovechar la tierra consistía en la técnica de tala y quema, dejando en poco tiempo el suelo agotado, sin capacidad de producir otra vez.

En el año de 1798, Manuel Ferreira da Câmara Bittencourt e Sá juntamente con Alexandre Rodrigues Ferreira e José Bonifácio de Andrada e Silva son llamados por la Corte para elaborar una legislación que ejerciese un riguroso control en el uso de las aguas y selvas de las regiones mineras.

Según Vladimir Passos de Freitas, la primera ley de intervención en la propiedad privada fue editada el 9 de septiembre de 1826, y traía dos casos en que podría suceder la desapropiación, a saber, por necesidad pública, que sería examinada por el juez y por utilidad pública, que sería analizada por los legisladores ${ }^{128}$. En 1830 fue publicado el Código Criminal, que previa penalidades para los que practicasen la tala ilegal de maderas en sus artículos 178 y 257. Ya en el año de 1886, con la Ley n. ${ }^{\circ}$ 3.311 el delito de incendio fue previsto en la legislación patria.

La Ley n. ${ }^{\circ} 601$ de 18 de septiembre de 1850, tenía como objetivo regularizar la propiedad establecida en la actividad agraria, suprimiendo los grandes latifundios improductivos. Para que los agricultores pudiesen recibir títulos de dominio, deberían

\footnotetext{
${ }^{127}$ FIGUEIREDO, Guilherme José Purvin de. op cit, p. 14.

${ }^{128}$ FREITAS, Vladimir Passos de. A Constituição Federal e a efetividade das normas ambientais. São Paulo: RT, 2000, p. 58.
} 
hacer prueba de la cultura efectiva realizada en el área y mostrar que la utilizaba como vivienda. Como prueba de la existencia de cultivo, no eran aceptas la tala de bosques, tampoco la técnica de tala y quema. De acuerdo con la referida ley, cabía a los delegados la función de asegurar la conservación de las selvas nacionales dentro de sus distritos, competiéndoles instaurar investigación policial y encaminarla al juez.

La Constitución brasileña del año de 1824, en su art. 179 aseguró el derecho a la propiedad privada, solamente haciendo referencia a la desapropiación en razón del bien público. La Constitución de 1891 trajo la misma orientación de la constitución anterior, pero sustituyó el término bien público por necesidad o utilidad pública.

En la década de 1930 fueron editados el Código Forestal, el Código de Aguas, este vigora hasta hoy y el estatuto referente al "Tombamento" (Declaración de Monumento Histórico-Artístico - Decreto-Ley 25/37). Sin embargo es importante esclarecer que en esa fecha no había una noción de protección jurídica del medio ambiente o la implementación de una disciplina que objetivase su estudio.

La Constitución de 1934, trajo la norma de que el derecho de propiedad no podría ser ejercido en desconformidad con el interés social o colectivo, en la forma de la ley (art. 113, XVII). Según Paulino Jacques, esa fue la consolidación del principio de la Función Social de la Propiedad. ${ }^{129}$ En 1934, también fue instituido el Código de Aguas. La Carta Constitucional de 1937, siguió la misma tendencia de la de 1934, atribuyendo a la propiedad función social, sin embargo transfirió la tarea de la fijación de sus contornos para la ley ordinaria.

El año de 1946 trajo una Constitución que relacionaba la propiedad privada al bienestar social, en su art. 147. Según Maria Sylvia Zanella di Pietro, el art. 141, § 16 de esa Constitución sirvió de inspiración para la creación del instituto jurídico denominado desapropiación por interés social. ${ }^{130}$

Al final de la década de los 60 , hubo un aumento considerable de la población y del consumo, lo que contribuyó para el cambio de la visión ambiental, mostrando que los bienes ambientales eran escasos y que el desarrollo económico y el medio ambiente deberían caminar juntos. Hubo la institución de la Ley n. ${ }^{\circ}$ 4.771/65 que instituyó el

\footnotetext{
${ }^{129}$ JACQUES, Paulino. Curso de direito constitucional. 8. ed. Rio de Janeiro: Forense, 1977, p. 36.

${ }^{130}$ DI PIETRO, Maria Sylvia Zanella. Direito administrativo. São Paulo: Atlas, 1990, p. 147.
} 
segundo Código Forestal Brasileño, y que fue revocado por la actual Ley n. ${ }^{\circ} 12.651$, de 25 de mayo de $2012^{131}$.

Ya con la Ley n. ${ }^{\circ} 4.771 / 65$ se instituyó el control de deforestación, que debe ser ejercido por el Estado. A partir de entonces, quien fuese realizar deforestación, primero tendría que conseguir una autorización concedida por un órgano ambiental del gobierno, denominado Instituto Estadual de Florestas (IEF). En la misma legislación, fue instituido el concepto de reserva legal en las propiedades rurales y el gobierno pasó a ejercer la función de gestor, proveyendo mecanismos de control ambiental.

La Constitución de 1967 trajo la expresión función social de la propiedad (art. 157, III) y delineó los contornos de la desapropiación territorial rural, que podría suceder, mediante indemnización por títulos de la deuda pública que serían rescatados con corrección monetaria. Las características de referido diploma, fueron mantenidas por la Constitución de 1969, la Enmienda Constitucional n ${ }^{0}$ 1/69.

El inicio de tal preocupación tiene como hito la Conferencia Internacional del Medio Ambiente realizada en Estocolmo en 1972, oportunidad en la que fue elaborada una Carta definiendo los principios y objetivos de protección ambiental. Esta fue la primera vez, en que el tema ambiental fue tratado de forma global, trayendo la protección del medio ambiente como una tarea de todos los países y mostrando la necesidad de una acción en conjunto.

En 1975, Diogo de Figueiredo Moreira Neto, en su obra "Introdução ao direito ecológico e ao direito urbanístico", conceptuaba el Derecho Ecológico. De acuerdo con él, sería un conjunto de técnicas, reglas e instrumentos jurídicos sistematizados e informados por principios apropiados, que tengan como fin la disciplina del comportamiento relacionado al medio ambiente. ${ }^{132}$

La ley 6.938/81 conocida como la Ley de la Política Nacional del Medio Ambiente fue el hito inicial, el primer diploma legal brasileiro a tratar el medio

\footnotetext{
${ }^{131}$ Ley n. ${ }^{\circ}$ 12.651, de 25 de mayo de 2012 que dispõe sobre a proteção da vegetação nativa; altera as Leis n 6.938 , de 31 de agosto de 1981, 9.393, de 19 de dezembro de 1996, e 11.428, de 22 de dezembro de 2006; revoga as Leis $\mathrm{n}^{\text {os }} 4.771$, de 15 de setembro de 1965, e 7.754, de 14 de abril de 1989, e a Medida Provisória $\mathrm{n}^{\mathrm{o}}$ 2.166-67, de 24 de agosto de 2001; e dá outras providências. Disponible en: $<$ http://www.planalto.gov.br/ccivil_03/_ato2011-2014/2012/lei/112651.htm>. Acceso en: 25-05-2015. ${ }^{132}$ MOREIRA NETO, Diogo de Figueiredo. Introdução ao direito ecológico e ao direito urbanístico. Rio de Janeiro - São Paulo: Forense, 1975, p. 24.
} 
ambiente como un derecho propio y autónomo, acabó por crear el Sistema Nacional del Medio Ambiente (Sisnama). Antes de ella, la protección del medio ambiente era hecha de forma indirecta, o sea, ocurría sólo cuando se prestaba tutela a otros derechos, como la propiedad, por ejemplo. Con la Constitución Federal Brasileña de 1988 el derecho ambiental fue elevado a la categoría de ciencia autónoma y pasó a ser un derecho constitucionalmente protegido, teniendo un capítulo entero en la Constitución.

En 1981, el Estado de Minas Gerais, siguiendo la legislación ambiental brasileña, reglamenta el Licenciamiento Ambiental que consiste en un procedimiento administrativo, a través del cual el órgano ambiental otorga el permiso o autoriza la implantación de emprendimientos de agricultura, pecuaria o forestales. La licencia es un derecho del productor rural.

Con la Conferencia de Estocolmo hubo el inicio de un proceso de estructuración de la administración ambiental en todos los países. En Brasil, los reflejos de esa acción culminaron en la edición de leyes de gran importancia, como la ya citada Ley de la Política Nacional del Medio Ambiente (6.938/81), la Ley de la Acción Civil Pública (7.347/85) y con la creación, por la Ley 7.735/89, del Instituto Brasileño del Medio Ambiente y de los Recursos Naturales Renovables (IBAMA). La Ley de la Acción Civil Pública es considerada por algunos autores como el momento de la autonomía plena del derecho ambiental brasileño, trayendo un instrumento procesal adecuado para buscar la protección de los bienes ambientales y, aun, formando la nueva jurisprudencia ambiental.

La Conferencia de las Naciones Unidas sobre Medio Ambiente y Desarrollo tuvo lugar en Rio de Janeiro en 1992 y fue uno de los hitos para el derecho ambiental brasileño, llamando la atención para la búsqueda de soluciones para el problema de la degradación ambiental. En esa oportunidad, fueron creadas la Agenda 21, la Declaración de Rio de Janeiro y la elaboración de la Convención sobre Cambios Climáticos. La Agenda 21 es un instrumento de planeamiento de políticas públicas para el medio ambiente, que viabiliza la participación popular y por medio de la Agenda 21 local, permite que las personas opinen sobre las cambios que quieren para su región.

En el año de 2002 fue promulgado el actual Código Civil brasileño (Ley n. ${ }^{\circ}$ 10.406/02), que determina que el derecho de propiedad debe ser ejercido de acuerdo con sus finalidades económicas y sociales, pero también en consonancia con la protección ambiental. 
La legislación ambiental de un País, Estado o Municipio es un poderoso instrumento de ciudadanía. No sólo porque informa los derechos y deberes de cada uno en relación al medio ambiente, pero también porque, a través del conocimiento de esas leyes, es posible cuestionarlas, proponer cambios e incluso participar de la elaboración de una nueva legislación ambiental.

A partir del momento en que los problemas ambientales tomaron una proporción considerable y la degradación de los recursos naturales pasa a amenazar no sólo individuos, sino también la calidad de vida y la propia existencia humana, se tornó imprescindible la interferencia jurídica para tutelar la preservación ambiental.

En Brasil, la tutela ambiental se inició con leyes esparcidas y puntuales, con la creación de la Ley 6.938/81 recibió un enfoque más amplio y sistémico, pero solamente con la Constitución Federal de 1988, fue elevada a la garantía fundamental.

Por medio de la Constitución Federal, el medio ambiente fue elevado a la categoría de derecho fundamental de la persona humana, garantido constitucionalmente para las presentes y futuras generaciones. Ese enfoque de protección para las generaciones futuras amplió mucho el alcance del derecho al medio ambiente que, ahora, debe ser compatible con el desarrollo económico a punto de ese ser limitado para la preservación futura de recursos naturales.

Una de las innovaciones de la Carta fue crear el deber constitucional del Poder Público de preservar el medio ambiente, transformando su actuación, que deja de ser discrecional, pasando a una acción vinculada, como resalta el autor Édis Milaré. ${ }^{133}$

El deber de preservarlo, sin embargo, no es una atribución exclusiva de órganos públicos una vez que nuestra Constitución extendió esta función a la

\footnotetext{
${ }^{133}$ MILARÉ, Édis. Direito do Ambiente. $9^{\mathrm{a}}$ ed. rev. atual e ampl. São Paulo: Editora Revista dos Tribunais, 2014, p. 175, en sus palabras: "[...] cria-se para o Poder Público um dever constitucional, geral e positivo, representado por verdadeiras obrigações de fazer, isto é, de zelar pela defesa (defender) e preservação (preservar) do meio ambiente. Não mais, tem o Poder Público uma mera faculdade na matéria, mas está atado por verdadeiro dever. Quanto à possibilidade de ação positiva de defesa e preservação, sua atuação transforma-se de discricionária em vinculada. [...]. Não cabe, pois à Administração deixar de proteger e preservar o meio ambiente a pretexto de que tal não se encontra entre suas prioridades públicas. Repita-se, a matéria não mais se insere no campo da discricionariedade administrativa. O Poder Público, a partir da Constituição de 1988, não atua porque quer, mas sim porque assim lhe é determinado pelo legislador maior".
} 
colectividad, o sea, la cuestión ambiental deberá ser pensada por toda la sociedad. En este se incluye también el deber de fiscalización.

La Carta Magna definió el medio ambiente como bien de uso común general, esto es, bien colectivo, bien de todos, por lo tanto es "un bien que no está en la disponibilidad particular de nadie" ${ }^{, 134}$.

La definición constitucional de que "Todos tienen derecho al medio ambiente ecológicamente equilibrado [...]"135 revela que se trata de un derecho social del hombre, de un derecho indisponible, difuso, que huye de la titularidad exclusiva de individuos determinados y se "esparce difusamente sobre toda la colectividad y cada uno de sus miembros" $" 136$.

Ya en el capítulo I del Título VII 'Da Ordem Econômica e Financeira', la orden económica brasileña 'fundada en la valoración del trabajo humano y en la libre iniciativa' ${ }^{137}$, tiene entre sus principios, la 'defensa del medio ambiente ${ }^{138}$. El sentido y el alcance de ese principio, y de su inclusión como límite a la libre iniciativa, son demasiadamente complejos y amplios, cabiendo aquí resaltar que, en los términos de la Constitución Brasileña, están, según Édis Milaré, “disconformes- y, por lo tanto, no pueden prevalecer- las actividades provenientes de la iniciativa privada (de la pública también $)^{139}$ que violen la protección del medio ambiente. O sea, la propiedad privada, base de la orden económica constitucional, deja de cumplir su función social elementar para su garantía constitucional - cuando va contra el medio ambiente"140.

\footnotetext{
${ }^{134}$ SILVA, José Afonso da, Direito Ambiental Constitucional. São Paulo: Malheiros, 1994, p.31.

${ }^{135}$ Art. 225 de la Constituição Federal de 1988.

${ }^{136}$ MILARÉ, Édis. Direito do cit., pp. 172-173. Respecto al derecho de propiedad, y su función económica y social, vide también art. 1.228, § $1^{\mathrm{o}}$, del Código Civil Brasileño de 2002.

${ }^{137}$ Art. 170, caput, de la CF/88.

${ }^{138}$ Art. 170, VI, de la CF/88.

${ }^{139}$ Aquí con base en el art. 225 de la CF/88.

${ }^{140}$ MILARÉ, Édis. Direito do cit., 2001, p. 233.
} 


\subsection{El medio ambiente: áreas legalmente protegidas, urbanismo y medio}

ambiente

Los seres humanos constituyen la única especie de seres vivos inteligentes que actualmente habita el planeta. A pesar de este importante diferencial, que les confiere cierto poder de dominación sobre lo que les rodea, se sabe que ellos no viven solos, estando envueltos por diversas estructuras y formas variadas de vida, a cuyo conjunto harmónico se atribuye la denominación de medio ambiente.

El medio ambiente, aunque pueda ser fácilmente percibido y caracterizado por el sentido común, es un término cuya definición científica encuentra dificultades, debido a su amplitud y exhaustividad. El medio ambiente puede ser diferentemente conceptuado en las varias ciencias que lo estudian, es un término de carácter interdisciplinar $\mathrm{y}$, muchas veces, transdisciplinario, una vez que abarca aspectos trabajados en variados campos de estudio.

La dificultad de conceptuación del medio ambiente es corroborada por su alto dinamismo. La variedad de transformaciones sufridas, provocadas o naturales, conduce a constantes modificaciones en las formas de abordaje y al permanente surgimiento de nuevos conceptos, lo que termina por dificultar la consolidación de una definición de medio ambiente.

Algunos autores, como José Rubens Morato Leite, Édis Milaré y Paulo Affonso Leme Machado, indican, incluso, la existencia de una impropiedad gramatical en la denominación de medio ambiente, uba vez que medio y ambiente son sinónimos en Lengua Portuguesa, indicando, de forma simplificada, el local y las estructuras que rodean a alguien, abrigándole y proveyéndole condiciones de vida o de desarrollo de alguna actividad.

Aunque sea cuestionado en la doctrina, el término medio ambiente tuvo su uso consolidado en el Derecho Positivo Brasileño, siendo adoptado, en especial, por la Carta Magna. A pesar de su amplio uso, la Constitución Federal no se ocupó de su definición, tal vez en virtud de la amplitud y dinamismo del tema, conforme ya tratado.

En el texto de otra ley específicamente ambiental, la de número 6.938/1981, hubo, sin embargo, la preocupación en definir medio ambiente, una vez que este era una de los primeros abordajes ambientales del país y era necesario definir el objeto sobre el que incidirían sus previsiones. Así, este tema fue conceptuado bajo el punto de vista de 
los abordajes legales hechos, esto es, se definió medio ambiente solamente en relación a los fines objetivados por esta ley. Esto es lo que se puede percibir de la lectura de su art. $3^{\mathrm{o} 141}$

Se nota que, aunque sea un concepto legal, construido únicamente para la óptica jurídica, también es caracterizado por la amplitud descrita anteriormente. Esto porque, son definidos como elementos del medio ambiente todas las formas de vida existentes y todo lo que las abrigue, posibilite su existencia y oriente su desarrollo.

Todos estos elementos y seres presentes en el medio ambiente constituyen los llamados recursos ambientales, que efectivamente forman el objeto de trabajo del Derecho Ambiental, sobre el que inciden las previsiones formuladas y positivadas. Este grupo de elementos fue, igualmente, definido por la Ley 6.938/1981, de la siguiente forma: Art $3^{\circ}$. Para los fines previstos en esta Ley, se entiende por: V - recursos ambientales, la atmosfera, las aguas interiores, superficiales y subterráneas, los estuarios, el mar territorial, el suelo, el subsuelo y los elementos de la biosfera.

En términos jurídicos, el medio ambiente puede ser entendido, de forma genérica, como un conjunto formado por recursos naturales, esto es, aquellos existentes y disponibles originariamente en la naturaleza, abarcando tanto los seres vivos como los sustratos inorgánicos, tales como el suelo y el aire, y por los demás elementos de la biosfera, que podrían ser traducidos como los elementos artificiales y culturales, tales como construcciones y obras artísticas.

Este grupo que forma el medio ambiente se les nombra recursos ambientales, que abarca los elementos naturales, los artificiales y los culturales, todos pasibles de tutela jurídica igualitaria, a pesar de, en muchos textos legales, ser dado mayor destaque a los recursos naturales.

De esta forma, el medio ambiente, para el abordaje jurídico, debe ser comprendido no como o simples conjunto de recursos disponibles en la naturaleza, pero también como el grupo de elementos oriundos de la transformación y creación humana, tales como las varias riquezas culturales de los agrupamientos humanos y las antiguas construcciones declaradas Monumento Histórico-Artístico. En las palabras de Édis Milaré, el medio ambiente es resultante de las interacciones recíprocas del ser humano y

\footnotetext{
${ }^{141}$ Art $3^{\circ}$. Para os fins previstos nesta Lei, entende-se por: I - meio ambiente, o conjunto de condições, leis, influências e interações de ordem física, química e biológica, que permite, abriga e rege a vida em todas as suas formas;
} 
del mundo natural. Sin embargo, este entendimiento no es suficientemente difundido a punto de dar fundamento y cuerpo a formulaciones doctrinarias innovadoras. No obstante, ya se anuncia, a través de políticas ambientales modernas, la tendencia de incorporarse estos aspectos también en el ordenamiento jurídico ${ }^{142}$.

Pero el medio ambiente no se limita al conjunto equilibrado de los recursos ambientales simplemente. Hay que considerarse el elemento antrópico, primeramente porque él es el responsable por la creación de los elementos artificiales y culturales, que también componen el ambiente. En segundo lugar, porque el medio ambiente se caracteriza, en mayor parte, por la relación - harmónica o no - establecida entre sus componentes, entre los que se incluye el ser humano. Por fin, en virtud de que el estudio, trabajo y la preservación del medio ambiente solamente encuentran sentido en la existencia humana e, igualmente, sólo se hacen posibles por medio de acciones humanas, o sea, el abordaje científico del medio ambiente y las intervenciones en él son hechas por los hombres, a fin de atender sus propios intereses, sean ellos en el sentido destructivo (producir algo) o preservativo (preservar para disfrutar y vivir). De todos modos, gran parte de lo que se hace en el medio que rodea el hombre visa atenderlo, tiene naturaleza antropológica, aunque hoy ya se haya incorporado ideales éticos que llevaron al abandono de la idea egoísta de que los recursos ambientales existen visando atender, exclusivamente, la especie humana.

En este sentido, Paulo Freire Vieira ${ }^{143}$ enseña que el medio ambiente no sirve para designar un objeto específico, pero, de hecho, una relación de interdependencia. Tal interdependencia es verificada de manera incontestable por la relación hombrenaturaleza, puesto que no hay posibilidad de separar el hombre de la naturaleza, por el simple hecho de la imposibilidad de existencia material, esto es, el hombre depende de la naturaleza para sobrevivir.

Este relacionamiento cercano entre hombre y ambiente, evidenciando una total dependencia del primer en relación al segundo referente a su propia existencia, hizo surgir una conciencia y valores éticos direccionados a la preservación del ambiente. Estos pasaron a fundamentar conductas volcadas tanto a la represión de la degradación

\footnotetext{
${ }^{142}$ MILARÉ, E. Direito do Ambiente: doutrina, prática, jurisprudência, glossário. $2^{\mathrm{a}}$ ed. São Paulo: Revista dos Tribunais, 2001, p. 422.

${ }^{143}$ Apud LEITE, J. R. M. Dano ambiental: do individual ao coletivo, extrapatrimonial. São Paulo: Revista dos Tribunais, 2000, p. 73
} 
ambiental, como a la prevención de acciones pasibles de la generaren, todo en función de preservar los recursos ambientales para la sociedad actual y, sobretodo, para las próximas generaciones. Esta preocupación con la vida de las sociedades futuras pasó a configurar los llamados intereses o políticas intergeneracionales.

La preservación del ambiente surgió, así, como un reflejo del instinto de supervivencia humano, al notar la intensa relación existente entre hombre y naturaleza y la fragilidad de la vida humana delante de la destrucción ambiental. José Rubens Morato Leite aclara este entendimiento: "Cualquier que sea el concepto que se adopte, el medio ambiente abarca, sin duda, el hombre y la naturaleza, con todos sus elementos. De esta forma, si ocurre un daño al medio ambiente, este se extiende a la colectividad humana, considerando tratarse de un bien difuso interdependiente."

Se concluye, así, que del establecimiento de una conceptuación más amplia de medio ambiente, englobando como elemento principal el hombre, surgió la preocupación con su preservación y la manutención de su calidad.

La Constitución Federal, en su art. 225, $\S 1^{\circ}$, III establece la tarea del Poder Público de definir, en todos los Estados, espacios territoriales y sus componentes que deben ser especialmente protegidos, pudiendo ser suprimidos o alterados sólo por medio de ley, siendo vetado su uso de forma que comprometa la integridad de los atributos que justifiquen su protección.

La preservación de las áreas delimitadas por el Poder Público no se trata de una facultad, sino una obligación impuesta constitucionalmente a la Unión, Estados, y Municipios de definir espacios mantenidos como parques, reservas ecológicas, entre otros.

Las normas referentes a la protección ambiental llegan a modificar las características de la propiedad privada, imponiendo varias restricciones, por existir en esa propiedad un bien ambiental de relevante valor, que conlleva por eso protección. Las formas de reglamentar esa conservación varían de acuerdo con las especificidades del área natural que es tutelada.

El Espacio Territorial Especialmente Protegido, también denominado de Áreas Especialmente Protegidas, es el área que debido a sus características ambientales es sometida a régimen jurídico propio, con el objetivo de preservación de este espacio y

${ }^{144}$ LEITE, J. R. M. Dano ambiental: cit., p. 74 
limitar y racionalizar la exploración de sus recursos. Tal área no tiene que estar bajo dominio público, pudiendo ser encontrada en propiedad particular. Al propietario sobre el que se encuentra el dominio de los espacios legalmente protegidos son impuestas restricciones de uso y fruición, por tratarse de supremacía del interés colectivo en la preservación del medio ambiente, en contraposición al derecho de propiedad.

Son considerados espacios territoriales especialmente protegidos, entre otros, la Selva Amazónica (art. 225, § 4º , de la Constitución); los Parques e Bosques Nacionales, Estaduales y Municipales, Estaciones y Reservas Ecológicas; las Áreas de Preservación Permanente (Ley n. ${ }^{\circ}$ 12.651/12); las Reservas Extractivitas, las Áreas de Protección a los Manantiales y Naturales Preservadas, las Áreas de Reserva Legal (Ley n. ${ }^{\text {o }}$ 12.651/12) y los Parques Ecológicos.

Las Áreas de Preservación Permanente (APP), creadas por la Ley 6.902/81 y disciplinadas también en la Ley $\mathrm{n}^{\circ}{ }^{\circ}$ 12.651/12, son formadas por extensas áreas cubiertas o no por vegetación nativa, situadas en locales esenciales a la manutención de un medio ambiente sano, como los bosques de ribera. La limitación impuesta a la propiedad por las APPs es en la mayor parte de los casos, parcial, no conllevando desapropiación e indemnización. En el caso de generar impedimento en la utilización normal de la propiedad, cabrá el deber de indemnizar el propietario y el área pasará a ser pública.

La Reserva Legal (RL) fue prevista por primera vez en el revocado Código Forestal (Ley n. ${ }^{\circ} 4771 / 65$ ) en su art. $1^{\circ}, \S 2^{\circ}$, III, y posteriormente, también fue previsto en la Ley n. ${ }^{\circ}$ 12.651/12 que determina que es un área localizada en el interior de una propiedad o posesión rural, delimitada en los términos del art. 12, con la función de asegurar el uso económico de forma sostenible de los recursos naturales de la propiedad rural, auxiliar la conservación y la rehabilitación de los procesos ecológicos y promover la conservación de la biodiversidad, así como el abrigo y protección de fauna silvestre y de la flora nativa. Los recursos existentes en estos espacios pueden ser utilizados, pero de forma sostenible (art.17), previamente aprobado por el órgano competente del Sisnama, de acuerdo con las modalidades previstas en el art. 20 de la Ley 21.651/12. La Reserva Legal no se confunde con los Parques Nacionales ni con las Reservas Biológicas, una vez que estos son áreas exclusivamente de dominio público.

La utilización de esta reserva natural deberá ser especificada en reglamento, pudiendo existir restricción a la utilización de la propiedad, lo que es prohibido es la 
inviabilidad total de su uso. El área de la reserva natural legal debe ser endosado en el registro de inmuebles para ciencia de terceros, pero no lo hacen así, no desobliga el propietario del deber de respetarla. La reserva legal es un encargo que recae sobre la propiedad rural, o sea, el propietario sólo podrá exonerarse caso renuncie al derecho de propiedad.

El Sistema Nacional de Unidades de Conservación (SNUC), disciplinado por la

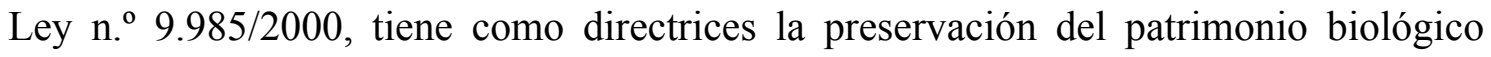
existente en las unidades de conservación (art. 5\%, I), la permisión del uso de estas unidades para la preservación de diversas especies de animales (art. 5\%, VII) y la búsqueda del apoyo y cooperación para el desarrollo de investigaciones científicas (art. $5^{\circ}$, IV). Referida ley disciplina las Unidades de Conservación, sin embargo permite que otras leyes establezcan unidades de conservación. En realidad, cualquier acto del Poder Público, como ley, decreto o resolución, es capaz de crear la unidad de conservación, pero solamente será extinta por ley (art. 225, § $1^{\circ}$, III, de la Constitución).

Las Unidades de Conservación son áreas establecidas por el Poder Público con el objetivo de protección total de los ecosistemas allí existentes, preservando las características naturales que dieron origen a la determinación de creación de esta unidad. Tales espacios pueden ser públicos o particulares.

Las unidades de conservación se dividen en Unidades de Protección Integral y Unidades de Uso Sostenible. Las Unidades de Protección Integral tienen como objetivo la preservación de la naturaleza y la utilización de los recursos en estas áreas sólo es permitida de forma indirecta. Américo Luís Martins da Silva enfatiza que la intervención humana en estos locales debe ser la mínima posible. ${ }^{145}$ Son las Estaciones Ecológicas, Reservas Biológicas, Parques Nacionales, Monumentos Naturales y Refugios de la Vida Silvestre, en los términos del art. $8^{\circ}$, Ley n. ${ }^{\circ}$ 9.985/2000.

Las Unidades de Uso Sostenible tienen como objetivo la combinación de la preservación de la naturaleza con el uso sostenible de sus recursos naturales, o sea, la utilización de sus recursos ocurre normalmente, desde que respetados los límites de la sostenibilidad. El uso de los recursos en este espacio es directo, pero atento a la preservación de los animales y vegetales allí existentes. Son constituidas por el Área de Protección Ambiental, Área de Relevante Interés Ecológico, Reserva Particular del

${ }^{145}$ SILVA, Américo Luís Martins da. Direito do meio ambiente e dos recursos naturais. São Paulo: RT, 2005, p. 214. 
Patrimonio Natural (RPPN), Reserva Extractiva, Reserva de Fauna, Reserva de Desarrollo Sostenible y los Bosques Nacionales (art. 14, Ley n. ${ }^{\circ}$ 9.985/2000).

Las Reservas Particulares del Patrimonio Natural (RPPN) fueron instituidas por el Decreto n. ${ }^{\circ}$ 98.914/90 que fue sustituido por el Decreto n. ${ }^{\circ} 1.922 / 96$ y visa la protección de los recursos ambientales representativos de determinada región. Son áreas de propiedad privada, reconocidas como pertenecientes al patrimonio natural por iniciativa de su propietario, lo que la distingue de otras áreas particulares especialmente protegidas, y por medio de Portaría expedida por el IBAMA.

Dentro de las Unidades de Conservación de Uso Sostenible, es importante destacar las Áreas de Protección Ambiental (APAs) y las Áreas de Relevante Interés Económico (ARIEs) debido a su naturaleza jurídica. Ellas no son intrínsecas a la propiedad y pueden existir tanto en tierras públicas como en tierras privadas, en los términos del art. 16, Ley n. ${ }^{\circ}$ 9.985/2000. Los artículos 15 y 16 del mismo diploma legal disponen que las propiedades privadas existentes en tales áreas pueden sufrir restricciones en su utilización, impuestas por la Constitución Federal (art. 5 , XXII y XXIII; 170, II, III y VI; 182 y 186).

Las restricciones impuestas a la propiedad privada en los locales donde existe área de protección ambiental tienen como objetivos principales proteger la diversidad biológica, disciplinar el proceso de ocupación en el área y asegurar la sostenibilidad del uso de los recursos naturales. En el caso de las áreas de relevante interés económico, las restricciones visan mantener los ecosistemas naturales de importancia regional o local y regular el uso admisible de estas áreas. En estos espacios, el propietario sigue teniendo el dominio, pero tiene que adecuar su propiedad a la función social, es decir, a los requisitos exigidos por la APA y por la ARIE, respetando las limitaciones administrativas que por ventura sean impuestas. De esta forma, la creación de un APA o ARIE no genera al propietario el derecho a indemnización.

El art. 225, § $4^{\circ}$, de la Constitución estableció una protección especial a determinadas áreas, debido a su importancia fundamental, en razón de abrigar especies animales y vegetales únicas, solamente pudiendo allí ser encontradas. Tales espacios constituyen el Patrimonio Nacional, que es formado por la Selva Amazónica, la Mata Atlántica, La Sierra del Mar, el Pantanal Mato-Grossense y la Zona Costera. La utilización de los recursos dentro del espacio definido como patrimonio nacional será 
regulada por ley, respetando los cuidados exigidos para la concreción de la efectiva preservación.

En este aspecto, Motauri Ciocchetti de Souza destaca que cuando la implementación de estas áreas sucede en propiedad particular, pero en consecuencia legal, de carácter general dirigido a propiedades indeterminadas no cabrá indemnización de la desapropiación realizada. El autor completa, que caso la desapropiación no prive el propietario de los derechos inherentes al dominio, la limitación administrativa no conllevará a la indemnización. ${ }^{146}$

En el tema de urbanismo se puede observar que el gran y avasallador crecimiento de los centros urbanos, trajo consigo diversos problemas, entre ellos, un aumento considerable en la búsqueda por los servicios públicos, la alta densidad poblacional generando la desestructuración de la organización habitacional, no observancia de las exigencias de preservación del medio ambiente, entre muchos otros. Como forma de organizar las ciudades, propiciando a los ciudadanos una mejor calidad de vida, el Poder Público busca la implementación de políticas, visando ordenar la ocupación del suelo urbano y el crecimiento de las ciudades.

Las normas municipales son establecidas por el Estatuto de la Ciudad (Ley n. ${ }^{\circ}$ 10.257/01) que determina las directrices generales de la política urbana, ocupándose, además de la organización física de las ciudades, de la obtención de una calidad de vida sana a los ciudadanos. El Plan Director es una ley municipal y cuida de cuestiones específicas, refiriéndose, como es obvio, directamente al municipio para el que es elaborado, presentando características propias y peculiares de cada centro urbano.

El Plan Director, aprobado por la Cámara Municipal, es una exigencia obligatoria para las ciudades con más de veinte mil habitantes y configura el instrumento básico de la política de desarrollo y de expansión urbana. Es importante resaltar que la propiedad urbana cumple su función social cuando atiende a las exigencias fundamentales de ordenación de la ciudad expresas en el plan director, en los términos del art. 182, de la Constitución. El referido documento se guía por los principios del Desarrollo Sostenible, de las Funciones Sociales de la Ciudad y de la Función Social de la Propiedad.

\footnotetext{
${ }^{146}$ SOUZA, Motauri Ciocchetti. Interesses difusos em espécie: temas de direito do consumidor, ambiental e da lei de improbidade administrativa. São Paulo: Saraiva, 2000, p. 169.
} 
E1 Derecho Urbanístico es la disciplina que cuida de las materias referentes a las ciudades, tales como las relaciones de vecindad, las restricciones a la propiedad urbana, entre otras. Es una rama del derecho público, que nació apoyada en el derecho administrativo el que le facilita los instrumentos de actuación. Según el autor Diogo Freitas do Amaral el derecho de urbanismo es un sistema de normas jurídicas que disciplinan la actuación de la Administración Pública y de los particulares visando obtener una ordenación racional de las ciudades y de su expansión. ${ }^{147}$

El Estado tiene la necesidad de intervenir en la propiedad privada en diversas situaciones, como ya mencionado, imponiendo limitaciones en beneficio del interés público. Las principales restricciones impuestas a la propiedad son provenientes del Derecho de Vecindad y del Derecho de Construir. El uso de la propiedad es regulado por la ley, con el objetivo de resguardar la tranquilidad, seguridad y la salud de todos los ciudadanos, haciendo con que el propietario no pueda utilizar la propiedad como quiera, evitando así, causar perturbaciones a sus vecinos.

E1 Derecho de Construir visa disciplinar la forma como deben ser realizadas las edificaciones en los centros urbanos, observando el derecho de vecindad y los reglamentos administrativos. Para que las edificaciones urbanas se inicien, es necesaria la aprobación del proyecto de construcción, que lleva en consideración las exigencias urbanísticas, buscando estandarizar la ocupación del suelo urbano.

Las restricciones impuestas a la propiedad urbana pueden referirse al uso y gozo, como la necesidad de observancia de las posturas municipales, además de la imposición de modelos estéticos en las edificaciones, establecidas por el Plan Director.

El art. 30 de la Constitución Federal disciplina la competencia de los municipios, estableciendo que cabe a ellos legislar sobre asuntos de interés local, en carácter suplementar a la legislación federal y estadual en lo que quepa y promueva adecuado ordenamiento territorial, mediante planificación y control de uso, de la parcelación y de la ocupación del suelo urbano, entre otras atribuciones traídas por el referido artigo.

La Constitución Federal condiciona el libre ejercicio del derecho de propiedad urbana al atendimiento de su función social, que engloba el ofrecimiento efectivo de buenas condiciones de domicilio, transporte, recreación, buenas condiciones de trabajo,

\footnotetext{
${ }^{147}$ AMARAL, Diogo Freitas do. Direito do urbanismo. Lisboa: Almedina, 1993, p. 78.
} 
entre otros factores. Es importante resaltar que la calidad de vida sana es un derecho de todos, indistintamente y, que está directamente relacionada a la preservación del medio ambiente, que es una de las condiciones esenciales para que se pueda disfrutar de buena calidad de vida.

En el mismo sentido, el art. 225 de la Constitución Federal determina que el medio ambiente debe ser preservado para garantía del bienestar de la presente y de las futuras generaciones. La función ambiental urbana es el conjunto de actividades que objetivan garantir a todos el derecho constitucionalmente de disfrutar de un medio ambiente equilibrado y sostenible, en la búsqueda de la sana y satisfactoria calidad de vida (de una mejor calidad de vida).

El gran número de personas viviendo en una ciudad genera un consumo descontrolado de los recursos naturales y acaba por resultar, muchas veces, en la ocupación de áreas de protección ambiental. El problema más grave está en las consecuencias generadas por la habitación en esas áreas, que siempre resulta en supresión completa dos sus recursos. En las urbes, como regla general, las ofertas de ocio relacionadas a un medio ambiente natural y sano son mínimas.

El Estatuto de la Ciudad (Ley n. ${ }^{\circ}$ 10.257/01) trae las normas generales del derecho urbanístico y determina con uno de sus principios la búsqueda del equilibrio ambiental. Tal documento adopta instrumentos típicos de Derecho Ambiental para la política urbana, como el establecimiento de unidades de conservación, la implementación de la zonificación ambiental y el estudio previo de impacto ambiental.

La actividad urbanística se relaciona con la preservación del medio ambiente natural y cultural, porque busca resguardar una sana calidad de vida, así como la sobrevivencia de legados históricos, artísticos y de las bellezas naturales y paisajísticas. Tal relación es necesaria teniendo en cuenta la realidad mundial, como la existencia de un gran número de centros urbanos, cuya dimensión y el número de habitantes son espantosos. Las consecuencias ambientales traídas por las grandes ciudades no se limitan a su circunscripción, extendiéndose a selvas e ríos en su entorno.

Actualmente en las grandes ciudades, el crecimiento cada vez mayor de la población genera la saturación de las estructuras urbanas, una vez que ellas no son suficientes, dificulta también la realización de planificación urbana y habitacional, dando origen a una situación descontrolada. Una parte considerable de los habitantes de los grandes centros urbanos vive en favelas, en laderas de montañas, infringiendo la ley 
para hacer posible su habitación en condiciones precarias, en lugares insalubres y peligrosos.

En este contexto, una de las soluciones encontradas es la Educación Ambiental, que es el conjunto de procesos en los que el individuo y la colectividad construyen valores sociales, conocimientos, habilidades, actitudes y competencias volcadas para la calidad de vida y su sostenibilidad (art. $1^{\circ}$, Ley n..$^{\circ}$ 9.795/99). Algunos estudiosos defienden que es imprescindible que la educación ambiental esté al alcance de todos, incluyendo los currículos escolares, como una de las alternativas para concienciar la población de la urgencia de la necesidad de preservación ambiental.

La Educación Ambiental posee como fundamento en la Constitución Federal el art. $225, \S 1^{\circ}$, VI que determina que la tarea de promoverla incumbe al Poder Público. $\mathrm{Su}$ objetivo es impulsar la realización de acciones y prácticas educativas dentro de la enseñanza en instituciones públicas y privadas en todos los niveles, en el intento de sensibilizar la sociedad para comprometerse con la cuestión ambiental.

La Ley de Educación Ambiental, en su art. 13 establece que el Poder Público deberá incentivar la divulgación por los medios de comunicación de programas, campañas educativas y de información relacionadas al medio ambiente, así como la amplia participación de escuelas, universidades y ONG en la ejecución de programas destinados a la educación ambiental. Determina aun, que el Estado promoverá la participación de empresas públicas y privadas en el desarrollo de programas de educación ambiental y la sensibilización de la sociedad y de los agricultores para a cuestión ambiental.

Es de gran importancia la institución de la educación ambiental por ser un instrumento general y eficaz, pues, de esta manera, llegará a todas las personas, principalmente a las menos favorecidas, que habitan lugares irregulares. La educación ambiental se muestra como un aparato valioso de política urbana que deberá ser utilizado por el Poder Público en la búsqueda de una mejor calidad de vida.

\subsection{El origen de la preocupación sobre la preservación ambiental}

No se pode precisar un hito inicial, en términos históricos, del pensamiento preventivo del hombre frente al medio que le envuelve. Hechos narrados durante la 
historia sugieren la formación de un perfil de su nacimiento y su transformación en un principio, integrándole al ordenamiento jurídico.

El origen de la preservación remonta a la propia origen del hombre. Por gran parte de la historia, la naturaleza y los recursos naturales fueron vistos por la humanidad como respaldo y solución de sus problemas económicos, religiosos y existenciales. La preservación ambiental, como asegura Alves, “estaba relacionada al interés humano en sacar de la naturaleza su mantenimiento, sobrevivencia o aun, en utilizarlo como respuesta para fenómenos y rituales de adoración espiritual"148. Razón por la que originó la codificación de normas específicamente protectoras del medio ambiente en algunos sistemas normativos.

La antigua civilización mesopotámica reveló preocupación del individuo con el medio ambiente. Las primeras civilizaciones del territorio entre los Ríos Tigre y Éufrates eran conocidas como hidráulicas, puesto que vivían de la agricultura y cultivo de la tierra. Las culturas, egipcia, india y china también enfocaban los recursos naturales con conciencia de preservación, por dependieren de los ríos para sustento de sus gentes.

La preservación de los recursos naturales estaba ligada a una conciencia de pose, debiendo cada uno cuidar de lo que es suyo y respetar el derecho de los demás. Así, el causador de daños al bien ajeno resarcía, incluso, con la propia vida. El referido pensamiento sobre la naturaleza y las reglas aplicables de la época puede ser constatado a partir del Código de Hammurabi: “(...) 53. Si uno, negligente en reforzar su dique, no ha fortificado el dique y se produce una brecha en él, y la zona se ha inundado de agua, ese restituirá el trigo que ha destruido.

54. Si no puede restituir el trigo, se venderán su persona y su patrimonio por dinero y las personas de la zona a las que el agua llevó el trigo, se lo repartirán.

63. Si se trata de tierra inculta, roturará el campo a trabajar y lo devolverá al dueño. Por cada año pagará 10 GUR de trigo por cada 10 GAN de superficie". ${ }^{149}$

La civilización griega también fue fundamental para la comprensión de la importancia de la preservación de los recursos naturales para la vida humana. Las contribuciones de los griegos para la civilización occidental ultrapasan la visión de la

\footnotetext{
${ }^{148}$ ALVES, Wagner Antônio. Princípios da precaução e da prevenção no direito ambiental brasileiro. São Paulo: Editora Juarez de Oliveira, 2005, p. 27.

${ }^{149}$ FIGUEIREDO, Amazonas de. A lei das XII tábuas e o código de hamurabi apud Wagner Antônio. Alves, Princípios da precaução e da prevenção no direito ambiental cit, p. 28.
} 
preservación ambiental como clave para el sustento de los pueblos y del pacto religioso. $\mathrm{Su}$ pensamiento filosófico, político y cultural ha elaborado un pensamiento crítico desvinculado de explicaciones religiosas y míticas, y, a partir de la racionalidad e investigación científica, desarrollaron la definición de naturaleza como descripción sistémica y metódica de los fenómenos naturales. Nació, así, la visión de un mundo natural y del derecho natural.

Los romanos fueron imprescindibles para la creación del sistema jurídico occidental. Toda la visión del sistema normativo europeo encontró su origen en la concepción romana sobre dar a cada uno lo que es suyo y no perjudicar a nadie. Uno de los hitos más importantes del período arcaico en el Derecho Romano fue la Ley de las XII Tablas, que ya preveía un reglamento específico para daños envolviendo animales y propiedades.

De acuerdo con la enseñanza de Wagner Antônio Alves, "la preservación quedó ligada, por lo tanto, en la codificación romana, a los institutos de pose y responsabilidad por daños causados a otro. Sin embargo, ya había un interés colectivo en el reconocimiento de la tierra como blanco de protección de la sociedad". ${ }^{150}$

En la Edad Media, entre los siglos V a XIII, el sistema prevalente era el feudalismo, caracterizado por la subordinación entre el noble y el campesino. La preservación ambiental estaba relacionada al uso del suelo, porque había una rotación entre los mantos serviles para que recuperasen su fertilidad.

Con la Revolución Industrial, la búsqueda por la riqueza aceleró la marcha en desfavor de la preservación del medio ambiente. Inglaterra fue el primer país a sufrir los efectos degradantes del desarrollo industrial y, aunque hubiese ley que protegiese la salud en virtud de disturbio ambiental (quema de carbón), la legislación visando proteger el medio ambiente sólo se hizo significativa después de la revolución.

En el siglo XX los países industrializados fueron obligados a ampliar sus políticas de protección ambiental nacionales para contención de los daños generados por su propio desarrollo. Los primeros tratados mundiales de protección al medio ambiente surgieron gracias al intento de los países desarrollados unieren esfuerzos para discusión de problemas ambientales domésticos que estarían afectando sus vecinos.

\footnotetext{
${ }^{150}$ ALVES, Wagner Antônio. Princípios da precaução e da prevenção no direito ambiental cit.,p. 32.
} 
"Surgiendo como necesidad institucional, el primer país a realmente traducir el principio de la precaución en regla legal expresa para contención de la contaminación, fue Alemania (vorsorgeprinzip)". ${ }^{151}$ La Convención sobre la Inmersión de Residuos en el Mar del Norte, que ocurrió en el año de 1972, buscó establecer una forma de aplicar conceptos sobre los principios protectores del medio ambiente, aparte guiar por la aplicación de un principio visando acciones concretas: el principio de la precaución.

Delante de todo lo expuesto, concluimos citando las convenciones y protocolos que más se destacaron y que sedimentaron la necesidad de prevención de los riesgos y daños ambientales de interés global: la Segunda Conferencia para Protección del Mar del Norte en 1987; la Declaración de la Conferencia de Bergen sobre desarrollo durable en 1990; Conferencia de las Naciones Unidas sobre el Medio Ambiente y Desarrollo, realizada en 1992 en Rio de Janeiro; Protocolo de Kioto en 2002; y la Cumbre de la Tierra, en el año de 2002 en Johannesburgo.

\subsection{EI Derecho Ambiental y su relevancia en la actualidad. Características}

La cuestión ambiental es uno de los temas más polémicos de la actualidad, en la exacta medida en que se hace más evidente que el crecimiento económico, y hasta la simple sobrevivencia de la especie humana, no pueden ser pensados sin el saneamiento del Planeta y sin la administración inteligente de los recursos naturales.

El hombre, desde el surgimiento de su especie y de la más simple de sus organizaciones vive en directa e intensa relación con la naturaleza y el medio ambiente, ya que estos son, al mismo tiempo, palco y combustible para su subsistencia y desarrollo.

De esta forma, se puede decir que preservar y restablecer el equilibrio ecológico es cuestión de vida o muerte. Los riesgos globales, la extinción de especies animales y vegetales, así como la satisfacción de nuevas necesidades en términos de calidad de vida, dejan claro que el fenómeno biológico y sus manifestaciones sobre la Tierra están peligrosamente alterados.

\footnotetext{
${ }^{151}$ ALVES, Wagner Antônio. Princípios da precaução e da prevenção no direito ambiental cit., p. 34.
} 
Desde su origen, mismo que inconscientemente, el hombre destaca la importancia del medio ambiente en su vida, percibiendo poco a poco que su acción trae alteraciones agresivas para la naturaleza, pasando a introducir, aún en su incipiente organización, elementos que disciplinen su relación con el medio, la higiene y la salud.

De acuerdo con la enseñanza de Edis Milaré: “Después de la Segunda Guerra Mundial, más precisamente en los años 60, se comienza a tomar una consciencia práctica de la finitud de los recursos naturales, de forma concreta. Materias primas, energía y agua, entre otros bienes proporcionados por la Naturaleza, se convierten más raros y más caros. Los procesos de degradación ambiental, bajo varias modalidades, se van propagando. Nuevas crisis, más serias y globales, se diseñan en el horizonte para una sociedad que, sin embargo, insiste en cerrar ojos y oídos para la realidad. Nubes pesadas se acumulan sobre los destinos del Planeta. Hay un límite para el crecimiento, como hay un límite para la inconciencia. Fue entonces que el clamor y la luz de Estocolmo se hicieron presentes, en serio. A partir de entonces, la consciencia ambiental se ha extendido y se fortalece." 152

La Conferencia de las Naciones Unidas sobre el Medio Ambiente Humano y su futuro, realizada en junio de 1972 en Estocolmo, lanzó un grito de alerta sobre el destino conjunto de la especie humana y del planeta Tierra. Tal conferencia aun se muestra actuante y en constante crecimiento, con el objetivo de atestar que el grado de conciencia de los gobiernos y de la sociedad mantienen vivos la letra y el espíritu de aquella memorable asamblea, considerada un hito en la lucha por la preservación ambiental.

Delante de tal contexto, se puede decir que la crisis ambiental es una consecuencia de la verdadera guerra que se traba en torno de la apropiación de los recursos naturales limitados para satisfacción de necesidades ilimitadas.

El Estado, entre sus innúmeras acepciones, fue reconocido como personificación del orden jurídico. A través del Estado el hombre realiza sus aspiraciones y desarrolla su naturaleza, en una expresión de la voluntad general y colectiva. El hombre, al vivir en sociedad, fija objetivos da vida colectiva, estableciendo como finalidad sus necesidades fundamentales, que están íntimamente ligadas a la búsqueda del valor primordial para todos, el bien común.

${ }^{152}$ MILARÉ, Édis. Direito do ambiente: cit., p.152. 
En este sentido, Cristiane Derani, expone: El Derecho tiene la indispensable tarea de buscar hacer de la vida en comunidad la realidad del 'bien común'. Fuerzas sociales, económicas y políticas son organizaciones pre y post Derecho. El Derecho reacciona ante el desarrollo de estas fuerzas y, por otro lado, provoca reacciones sociales, económicas y políticas. Es una corriente de acción y reacción, de la que no se excluye el Derecho Ambiental. ${ }^{153}$

Entre las varias opciones para intentar reducir la destrucción del medio ambiente, se resalta el recurso al Derecho como elemento esencial para cohibir, con reglas coercitivas, penalidades e imposiciones oficiales, el desorden y la prepotencia generada por los hombres.

Considerando que el embate de intereses para la apropiación de los bienes de la naturaleza se procesa en autentico clima de guerra, la ausencia de postulados reguladores de conducta podría redundar en una lucha permanente y desigual. Surge, entonces, la necesidad de un reglamento jurídico, para que ese juego de intereses pueda establecerse con un mínimo de equilibrio.

A partir de entonces el legislador pasó a transfundir en normas los valores de la convivencia harmoniosa del hombre con la naturaleza, conllevando la aparición de una nueva disciplina jurídica - el Derecho Ambiental -, nascida del incuestionable derecho subjetivo a un ambiente ecológicamente equilibrado y de un derecho objetivo cuyos pasos, aún titubeantes, urge afirmar y acelerar.

Hay que resaltar que la nueva disciplina jurídica emergió gracias a la necesidad comunitaria internacional de controlar y amenizar el instinto predatorio del hombre e sus avanzos tecnológicos en detrimento de la vida sana y cualitativa del Planeta.

Se puede verificar la génesis del Derecho Ambiental en los primordios de la historia de la humanidad, manifestada por medio de costumbres y regulaciones, ya indicando preocupación finalista con la interacción e intervención del hombre en la naturaleza, tales como el Código de Hammurabi, que en el siglo XVIII a.C., ya contenía disposiciones sobre la protección de los animales, prohibiendo su súper exploración. En el mismo sentido, la Ley de las XVII Tablas, 490 a.C., también contenía disposiciones relativas a la preocupación con el medio ambiente.

${ }^{153}$ DERANI, Cristiane. Direito ambiental econômico. $2^{\mathrm{a}}$ ed. São Paulo: Max Limonad, 2001, p. 93. 
De esta forma, siguiendo la historia del hombre, y en la medida en que se exaspera su interrelación con la naturaleza, cada vez más importante es el mantenimiento del medio ambiente sano y equilibrado, convirtiéndose indispensable el desarrollo de instrumentos jurídicos adecuados y eficaces para mantenerlo, dando origen a la noción actual de Derecho Ambiental.

Sobre el surgimiento del Derecho Ambiental en un momento de crisis en el Planeta, Miguel Reale asegura que "si antes recorríamos a la naturaleza para dar una base estable al Derecho (y, en el fondo, esta es la razón del Derecho Natural), vemos, hoy, una trágica inversión, siendo el hombre obligado a recorrer al Derecho para salvar a la naturaleza que muere". 154

El objetivo del Derecho Ambiental no se refiere sólo al medio ambiente como la preservación de las áreas verdes, sino primordialmente, la elevación de la calidad de vida de la población, que vive en el ambiente y con él se interacciona, a través de los más diversos tipos de relaciones.

Teniendo en cuenta el carácter global y la dimensión planetaria que asumen las graves y crecientes perturbaciones del equilibrio ecológico, fue promulgado el Principio 11, en la Declaración de la ECO - 92 sobre Ambiente y Desarrollo, realizada en Rio de Janeiro, que menciona:

Principio 11: Los Estados deberán promulgar legislación ambiental eficaz. Los estándares ecológicos, los objetivos y las prioridades de gestión del ambiente deben reflejar el contexto ambiental y de desarrollo a que se aplican. Los estándares aplicados por algunos Estados pueden no ser convenientes y tener un costo económico y social injustificado para otros países, especialmente para los países en desarrollo.

El Derecho Ambiental, de esta forma, se muestra como una disciplina jurídica específica que congrega nociones y conceptos del derecho público y privado sin estar a ellos vinculado. Protege bienes, intereses colectivos y difusos volcados en los conflictos generados por la contaminación, degradación, agotamiento gradual de recursos naturales del planeta, destrucción de la vida, entre otros y, por eso es caracterizado por su énfasis multidisciplinar.

Justamente por envolver interese de todos los habitantes del globo terrestre, la mayor parte de las normas trazadas en el Derecho Ambiental, aptas a obligar Estados y

${ }^{154}$ REALE, Miguel. Memórias apud Édis Milaré, Direito do ambiente: cit., p.132. 
pueblos, son oriundas de innúmeros principios y reglas aprobados por acuerdos tratados o convenciones internacionales. Se destaca que la fuente principal de esta rama jurídica, en nivel internacional, son los tratados. Sin embargo, en la práctica, muchas de las decisiones y medidas aprobadas por los países en los tratados internacionales cuanto al Medio Ambiente quedan sin adopción objetiva, vez que envuelven intereses económicos que se chocan con la tutela ambiental de determinado orden jurídica.

Sobre lo que fue alegado anteriormente, Braga y Miranda resaltan: Brasil, como ejemplo de país que busca sistematizar y poner en práctica esa legislación ambiental, se ha mostrado exponente y líder mundial en la cuestión de la lucha por la preservación ambiental, conquistando fronteras, defendiendo la alteración de políticas económicas para incentivar aquellas no ofensivas al medio ambiente, viabilizando inversiones de pequeñas y medias empresas en proyectos de desarrollo sostenible. ${ }^{155}$

La posición brasileña en la tratativa de la cuestión ambiental no podría ser diferente, ya que el sistema jurídico constitucional adoptado en el país abraza principios ambientales protectores y los ve como elementos estructurantes del Estado.

Dentro de este aspecto polifacético, en el que se coloca en primer lugar la calidad de vida del ser humano, que serán analizadas las características del Derecho Ambiental.

Se puede listar algunos puntos peculiares que diferencian el Derecho Ambiental de las demás ramas del Derecho. Entre estos pontos, es importante mencionar sobre las dimensiones espaciales indeterminadas y su carácter transnacional, o sea, considerando que no se sabe cuál es el ámbito de extensión de un daño ambiental, se puede decir que el marco en que se desarrolla y aplica el Derecho Ambiental es muchas veces impreciso. De la misma forma se puede referir al carácter transnacional, ya que la amplitud de esta rama jurídica desconoce fronteras administrativas o políticas, siendo necesario conocer los comportamientos contaminantes dentro y fuera de cada particular ecosistema, abriendo espacio para la cooperación entre las naciones.

Se resalta también su carácter preventivo, considerando que los objetivos del Derecho Ambiental se fundamentan en la prevención al daño, mismo que en última

\footnotetext{
${ }^{155}$ BRAGA, Antônio Sérgio; MIRANDA, Luiz Camargo de. (Org.) Comércio e Meio Ambiente: uma agenda positiva para o desenvolvimento sustentável apud Wagner Antônio Alves, Princípios da precaução e da prevenção no direito ambiental cit., p. 25.
} 
instancia se apoye en dispositivos sancionadores, ya que muchos de ellos, en mayor parte, son irreversibles.

Hay que mencionar sobre el substrato técnico metajurídico, ya que muchos de los predicados jurídicos ambientales utilizan prescripciones rigorosamente técnicas que acaban reduciendo la discrecionalidad del jurista y del legislador. Eso no quiere decir que se limite a los resultados científicos, pero permiten modulación y el cruzamiento de informaciones para obtener mejor resultado.

La vocación redistributiva también es una característica del Derecho Ambiental, ya que tiene como uno de los aspectos cardinales la corrección de las deficiencias presentadas en los sistemas de precios, que se eximen de hacer constar en su realidad los costes de la destrucción naturales repasados a la colectividad. Se resalta que los resultados ambientalmente aceptables sólo serán obtenidos después de solucionar esta cuestión.

Con relación a la primacía del interés público, se destaca que el Derecho Ambiental tiene un aspecto eminentemente público, ya que abarca conflictos claramente colectivos, especialmente aquellos relativos a los daños sociales causados por la contaminación, estándares de consumo y de producción, actividades relativas a la calidad de vida, entre otros. Este aspecto, sin embargo, no excluye la posibilidad de hacer valer el Derecho Ambiental en la esfera privada, especialmente en relación a las reparaciones particulares.

Una de las características más peculiares del Derecho Ambiental es su relación con las demás ramas del Derecho. En razón de su aspecto polifacético y multidisciplinar, se relaciona íntimamente con diversas disciplinas jurídicas, dentro de las cuales es posible identificar innúmeros puntos comunes.

El Derecho Administrativo es considerado la rama que mayor impacto recibe de la problemática ambiental, siendo muchas veces el Derecho Ambiental considerado como submodalidad suya. Tal hecho adviene de la responsabilidad del Estado en lo que se refiere a la tutela del medio ambiente, delimitando los aspectos de su función ambiental.

Respecto al Derecho Civil su importancia está relacionada a las consecuencias de la intervención del hombre en la naturaleza, pudiendo afectar negativamente la salud y el bienestar, dando lugar al uso de los postulados de responsabilidad civil contra los autores del daño. 
El Derecho Ambiental posee íntima relación con el Derecho Penal, teniendo en cuenta que el daño ambiental fue llevado a la esfera de delito, en razón del tamaño de su carácter de antijuridicidad, siendo una de las consecuencias más importantes de la preocupación con el medio ambiente, una vez que el carácter punitivo es uno de los principales aspectos de la finalidad preventiva del Derecho Ambiental. En Brasil este aspecto se encuentra delimitado por la Ley de Crímenes Ambientales, Ley n. ${ }^{\circ}$ 9.605/98, que impone severas penas a los responsables por la degradación ambiental.

Con relación al Derecho Agrario, se puede decir que este es considerado uno de los predecesores del Derecho Ambiental, ya que predica por la optimización de los recursos agrícolas, además de diversos postulados ambientales, claramente relacionados a las áreas rurales. Así, en la medida en que el derecho agrario busca fundamentalmente, por medio de la concreción de la Reforma Agraria, incorporar métodos racionales de aprovechamiento del suelo y de los recursos naturales, demostrada está su amplia vinculación con el Derecho Ambiental.

La relación entre el Derecho Ambiental y el Derecho del Trabajo está ligada al hecho de verificarse que este abarca la protección del trabajador en lo que respecta al medio ambiente del trabajo, poseyendo fundamental importancia a la calidad del medio ambiente natural. Aparte eso, como la relación trabajo/medio ambiente es indiscutible, teniendo en cuenta que es por medio del trabajo que el medio ambiente es alterado, se hace necesario incorporar a la producción prácticas e instalaciones compatibles con la preservación ambiental.

En este sentido asegura José Afonso da Silva, "la protección del medio ambiente del trabajo significa protección del ambiente y de la salud de las poblaciones externa a los establecimientos industriales, ya que un ambiente interno contaminado e inseguro lanza contaminantes e inseguridad externa". ${ }^{156}$

A partir del momento en que las naciones comenzaron a darse cuenta que el medio ambiente no estaba solamente a disposición del hombre, la cooperación internacional e inúmeras organizaciones ambientales fueron erguidas en la certeza de que la mayor parte de los problemas ambientales debe ser resuelta internacionalmente, visando la protección integral de todo el sistema planetario. Así el Derecho Ambiental establece una relación intrínseca con el Derecho Internacional, ya que cada vez más es

\footnotetext{
${ }^{156}$ SILVA, José Afonso da. Direito ambiental constitucional. $2^{\text {a }}$ ed. São Paulo: Malheiros, 2001, p. 51.
} 
necesario desarrollar estrechas relaciones entre las autoridades de los diferentes países encargados de administrar los recursos naturales para mantener el equilibrio ecológico mundial.

Con relación al Derecho Económico es importante mencionar las lecciones de Cristiane Derani: "Derecho Económico y Ambiental no sólo se interceptan como comportan, esencialmente, las mismas preocupaciones, a saber: buscar la mejora del bienestar de las personas y la estabilidad del proceso productivo. Lo que los distingue es una diferencia de perspectiva adoptada por el abordaje de los diferentes textos normativos. [...] A despecho de la existencia de dos fundamentos orientando la formación del Derecho Económico y Derecho Ambiental, ambos anhelan, en suma, atender al conjunto de actividades y estados humanos sustantivados en la expresión calidad de vida." 157

Por fin, el Derecho Constitucional es la ancora del Derecho Ambiental, porque es en el núcleo de la Constitución Federal que se encuentran, elevados a la categoría de derechos fundamentales, los derechos relativos al medio ambiente, teniendo en ella su máxima disciplina y protección.

${ }^{157}$ DERANI, Cristiane. Direito ambiental econômico. São Paulo: Max Limonad, 1997, p. 76. 


\section{Capítulo 3 - El agua y los principios ambientales}

\subsection{El Agua y su importancia}

El agua es elemento crucial para el desarrollo de la vida en cualquier ecosistema del medio ambiente y también la molécula más abundante en la superficie terrestre. ${ }^{158}$ Donde no hay agua no hay vida. Todo el medio ambiente depende de ella, algunos animales llegan a tener $98 \%$ de sus cuerpos formados por el agua ${ }^{159}$, los seres humanos, tienen alrededor de $70 \%$ del cuerpo constituido de esta sustancia ${ }^{160}$. Se ha viajado hasta planetas distantes, se ha investido mil millones en investigaciones, sondas fueron mandadas, sonares, robots y satélites a través de sistemas planetarios enteros con el propósito de descubrir si existe un poco más de este tan precioso bien no renovable. -El agua es un elemento clave para el desarrollo sostenible. La necesitamos para la salud, seguridad alimentar y progreso económico, afirmó Ban Ki-moon en su discurso de abertura en la Cumbre del Agua de Budapest el 8 de octubre de 2013.

Ya se decía a mediados de 600 a.C. que todo comienza en el agua, el primer teórico a formular un pensamiento más sistemático fundado en bases racionales fue el griego Tales, que afirmaba que todo se iniciaba en el agua, ella era la fuente y origen de todas las cosas. En la mitología griega el Océano era un Dios reverenciado por otros dioses.

La palabra agua en diferentes culturas está asociada a diversas imágenes y situaciones en función de su elementalidad, resonando en nosotros otros valores como vida, renacimiento, unión, fecundidad y purificación, temas estos, presentes en las religiones que transformaron el agua en uno de los símbolos fundamentales de Dios, lo que hace con que tenga una carga valorativa simbólica muy fuerte.

158 GOMES, Abílio Soares. Propriedades físico-químicas da água. Disponible en: http://www.uff.br/ecosed/PropriedadesH2O.pdf. Acceso en: 27-05-2015.

${ }^{159}$ WATSON, Stephanie. Como funciona a água-viva. Disponible en: http://ciencia.hsw.uol.com.br/aguaviva.htm. Acceso en: 04-06-2015.

160 SCALZO, Marília. Corpo líquido. Disponible en: http://planetasustentavel.abril.com.br/noticia/saude/conteudo_240527.shtml. Acceso en: 04-03-2015. 
El agua surgió con el resfriamiento de la Tierra y puede ser encontrada en tres estados físicos: sólido, líquido y gaseoso, de modo que las tres etapas del agua es llamada ciclo hidrológico ${ }^{161}$.

Es en la atmósfera y en el suelo que ocurre el ciclo hidrológico ${ }^{162}$, o también llamado de ciclo del agua. Por medio de los procesos de evaporación, precipitación interceptación, escorrentía, transpiración e infiltración, y evidencia sus diferentes manifestaciones, originando diversos conceptos y clasificaciones, así como un vocabulario técnico hídrico.

El agua ${ }^{163}$ es un liquido incoloro, inodoro, insípido, compuesto por dos átomos de hidrógeno y uno de oxígeno ${ }^{164}$, siendo esencial a la vida de la mayoría de los organismos vivos y excelente solvente para otras varias sustancias.

${ }^{161}$ Según el Glosario Hidrológico Internacional, hidrología es: "1) Ciencia que estudia las aguas superficiales y subterráneas de la Tierra, y su aparición, circulación y distribución, tanto en el tiempo como en el espacio, sus propiedades biológicas, químicas y físicas, sus reacciones con el entorno, incluyendo su relación con los seres vivos; 2) Ciencia que estudia los procesos que rigen el agotamiento y recarga de los recursos hídricos continentales, y que trata las diversas fases del ciclo hidrológico". Disponible en: <http://webworld.unesco.org/water/ihp/db/glossary/glu/HINDES.HTM>. Acceso en: 3004-2015.

Igual concepto fue dado por el Glossário de Termos Hidrológicos da Agência Nacional de Águas (ANA). ${ }^{162}$ El ciclo hidrológico, como bien presentó de manera resumida, João Alberto Alves Amorim, opera de la siguiente forma: a través de la evaporación de los más variados reservatorios de agua (ríos, mares, lagos naturales o artificiales), el agua, en su estado gaseoso, sube a la atmósfera, donde se junta con aquella proveniente de la transpiración de animales y vegetales y se condensa en forma de nubes, sufriendo la influencia de los vientos y de la presión atmosférica; sobre esta influencia, el agua retorna a la superficie del planeta, precipitada en forma de lluvia o nieve, donde vuelve a integrarse, directamente o a través de filtración o del consumo de animales y vegetales, a las fuentes de donde evaporó. Direito das Águas: O Regime Jurídico da Água Doce no Direito Internacional e no Direito Brasileiro. $2^{\mathrm{a}}$ edição, Editora Atlas, São Paulo-Brasil: 2015, p. 20. Según el Glosario Hidrológico Internacional, ciclo hidrológico es: "Sucesión de fases por las que pasa el agua en su movimiento de la atmósfera a la tierra y en su retorno a la misma: evaporación del agua del suelo, mar y aguas continentales, condensación del agua en forma de nubes, precipitación, acumulación en el suelo o en masas de agua y reevaporación”. Disponible en: <http://webworld.unesco.org/water/ihp/db/glossary/glu/HINDES.HTM>. Acceso en: 3004-2015.

${ }^{163}$ Existe en la Tierra alrededor de 1,6 mil millones de $\mathrm{Km}^{3}$ de agua, siendo 1,35 mil millones de agua salada; 29 millones de $\mathrm{Km}^{3}$ de agua dulce congelada en las heleras y casquetes; 8,6 millones de $\mathrm{Km}^{3}$ de agua dulce en los continentes y sobre ellos; $13 \mathrm{mil} \mathrm{Km}^{3}$ de agua en la atmósfera la forma de vapor. El planeta se quedaría bajo el agua si hubiera una distribución equitativa sobre la superficie terrestre de todo 
De los tres estados físicos del agua, lo que en este trabajo interesa es su estado líquido, una vez que es en este estado que el agua integra no solo la satisfacción de la inmensa mayoría de las necesidades biológicas de los animales y vegetales, sino también los procesos de producción utilizados por los hombres, en el cual sus usos son y serán disciplinados por el Derecho.

De este modo, a lo que pese el agua tener tanta diversidad de conceptos y formas disponibles e indisponibles, necesario se hace resaltar su carácter unitario, unidad que se debe comunicar a la reglamentación de su ciclo, caso contrario, se arriesga a comprometer su protección ${ }^{165}$.

Ninguna cuestión hoy es más importante que la del agua, incluso nuestro futuro depende de ella.

El agua tiene una múltiple utilización, de modo que el mayor usuario es la agricultura, con $75 \%$, la industria con $20 \%$ y el uso doméstico con $5 \%{ }^{166}$. Algunos

el agua de los océanos, ríos, lagos, acuíferos y casquete polar. La renovación del agua es de $43 \mathrm{mil} \mathrm{Km}^{3}$ al año, mientras el consumo total está basado en $6 \mathrm{mil} \mathrm{Km}^{3}$ al año, así que, no hay falta de agua. Disponible en: <http://www.pmmsama.sp.gov.br/agua/>. Acceso en: 19-04-2015.

${ }^{164}$ Diccionario de la Real Academia Española. Disponible en: <http://lema.rae.es/drae/?val=olor $>$. Acceso en: 19-04-2015.

${ }^{165}$ En ese sentido, POMPEU, Cid Tomanik. Fundamentos para a gestão de recursos hídricos: aspectos jurídicos. In: BARTH, Flavio Terra. Modelos para gerenciamento de recursos hídricos. Editora Nobel/ABRH, São Paulo-Brasil: 1999, p.25.

${ }^{166}$ Según Arjen Y. Hoekstra; Mesfin Mekonnen, Brasil es el cuarto mayor (pierde para China, EE.UU y India) consumidor de agua del planeta, con un volumen anual total de más de 300 mil millones de metros cúbicos de agua consumida, principalmente en la producción de granos, carne y otros productos agropecuarios. Además, Brasil ocupa el cuarto lugar en exportaciones de agua virtual, precedidos por EE.UU, China y India, en este orden. The water footprint of humanity. Proceedings of National Academy of Science, 109 (9), Febrero de 2012, pp. 3232-3237. Disponible en: $<$ http://waterfootprint.org/media/downloads/Hoekstra-Mekonnen-2012-WaterFootprint-of-

Humanity.pdf $>$. Acceso en: 04-05-2015. Desde los años 1990 el profesor John Anthony Allan estableció y desarrolló el concepto de agua virtual, considerando la cantidad total de agua gasta en la producción de un determinado bien, siendo obtenida esa cantidad con la sumatoria del volumen de agua consumido en su producción, en todas las etapas de la cadena productiva, en el local de su producción. Virtual water: a strategic resource. Global solutions to regional deficits. In: Groundwater, n. ${ }^{\text {o }}$ 36, v.4, pp. 545-546. ALLAN, John Anthony. Virtual water: a long term solution for water short middle Eastern economies. British Association Festival of Science. Universidad de Leeds, 1997. ALLAN, John Anthony. Virtual water: an essential element in stabilizing the political economies of the middle east. Yale University 
ejemplos serian: abastecimiento humano y industrial, irrigación, producción de energía, navegación y dilución de aguas residuales ${ }^{167}$.

Forestry \& Environmental Studies Bulletin, n. ${ }^{\circ}$ 103, pp. 141-149. ALLAN, John Anthony. Avoiding war over natural resources. In: FLEMING, S. (Ed.) war and water. Ginebra: ICRC Publication Division. ALLAN, John Anthony. Water resources in semi-arid regions: real deficits and economically invisible and politically silent solutions. In: TURTON, A. R.; HENWOOD, R. (Ed.). Hydropolitics in the developing world: a Southern African perspective. Pretoria: African Water Issues Research Unit

(AWIRU), $\quad$ pp. 23-36. Disponible en:
$<$ http://www.internationalwaterlaw.org/bibliography/articles/hydropolitics_book.pdf $>$. Acceso en: 04-052015.

${ }^{167}$ En 2002 el concepto y la metodología de calculo de la huella hídrica (water footprint), que está íntimamente relacionada al concepto de agua virtual, fueron presentados por Hoesktra y Hung. HOESKTRA, A. Y.; HUNG, P. Q. Globalization of water resources: international water flows in relation to crop trade. Global Environmental Change, n. ${ }^{\circ}$ 15, 2005, pp. 45-56. Disponible en: $<\mathrm{http}: / /$ www.bvsde.paho.org/bvsacd/cd16/hoekstra.pdf $>$. Acceso en: 05-05-2015. Ese concepto y metodología vinieron como una manera de fornecer un indicador basado en el consumo, que pudiera generar informaciones respecto al volumen de agua efectivamente consumido en el planeta, más allá del enfoque tradicional sectorial de producción. La huella hídrica revela la amplitud del consumo de agua en relación al consumo de las personas, así como de los países. La huella hídrica interior de un país es definida como el volumen de agua necesario para la producción de bienes y servicios consumidos por sus habitantes. Ya la huella hídrica exterior es definida como el volumen total de agua gasto en otros países, para la producción de los bienes y servicios que importa. Para la determinación de la huella hídrica, cuatro son los factores preponderantes de determinado país: el volumen de consumo (relacionado con el PIB del país), producción agrícola, padrones de consumo y clima. Conforme HOESKTRA, A. Y.; CHAPAGAIN, A. K. Water footprint of nations: water use by people as a function of their consumption pattern. Water Resource Manage, v.21, 2007, pp. 35-48. Disponible en: $<$ http://waterfootprint.org/media/downloads/Hoekstra_and_Chapagain_2007.pdf $>$. Acceso en: 05-052015. Según Arjen Y. Hoekstra; Mesfin Mekonnen el concepto incorpora tres tipos de agua: las aguas que son extraídas de fuentes naturales (ríos, lagos y acuíferos subterráneos) que son llamadas de Agua Azul (Blue Water), las aguas de la lluvia que caen directamente sobre las plantaciones y pastos, llamadas de Agua Verde (Green Water), y el agua que corresponde a la cantidad de agua necesaria para el tratamiento y dilución del agua contaminada hasta una condición de potabilidad o de uso, llamada de Agua Gris (Grey Water). Además, afirman que aproximadamente $20 \%$ de toda huella hídrica del planeta está relacionada a la producción para la exportación, y la huella hídrica global general, entre el periodo de 1996 y 2005, fue de más de 9 billones de m/año (11\% de agua azul, 74\% del agua verde y 15\% de agua gris). National water footprint accounts: the blue, green and gray water footprint of production and consumption. Value of Water Research Report Series, n. ${ }^{\circ} 50$, v. 1, Holland: University of Twente, Twente Water Center, mayo 2011. Disponible en: <http://waterfootprint.org/media/downloads/Report50- 
Indudablemente se puede afirmar que el agua es un bien natural, vital, común e insustituible, que ningún ser vivo humano o no humano puede vivir sin ella.

Llegar a casa y abrir el grifo, ducharse, lavar las vajillas o cocinar, es un lujo que vino con el progreso. El agua tratada y por tubería, para muchos, es una conquista reciente, que hasta hace poco, la cogían directamente de un río o pozo. Todavía, ni todos disfrutan de ese recurso con abundancia o en un nivel de pureza adecuado ${ }^{168}$.

De esta manera, tierras con agua en abundancia ya fueron objeto de disputa y motivo para conflictos armados ${ }^{169}$. En África, Oriente Medio y hasta mismo en algunas regiones de Brasil, el agua tratada o en tubería es considerada objeto de lujo, siendo de extrema importancia en la lucha contra la pobreza y la desnutrición ${ }^{170}$. Un país que tiene

NationalWaterFootprints-Vol1.pdf>. Acceso en: 05-05-2015. La huella hídrica per cápita promedio anual de Brasil es de $2.027 \mathrm{~m}^{3}$, y el país ha tenido en cada sector de consumo, de 1996 a 2005, los siguientes tasas promedio de huella hídrica: producción agrícola - alrededor de 329 billones de $\mathrm{m}^{3} /$ año (siendo aproximadamente, 9 de agua azul, 303 de agua verde y 16 de agua gris); producción industrial - alrededor de 8 billones de $\mathrm{m}^{3}$ /año (siendo aproximadamente, 532,5 mil millones de agua azul y 7,5 mil millones de agua gris); pastos - alrededor de 132 billones de $\mathrm{m}^{3}$ /año (agua verde) y abastecimiento y uso doméstico alrededor de 10 billones de $\mathrm{m}^{3} /$ año (1,2 de agua azul y 8,5 de agua gris). La huella hídrica anual total de Brasil, entre 1996 y 2005, fue de, aproximadamente, 482 billones de $\mathrm{m}^{3}$ (alrededor de 14 de agua azul, 436 de agua verde y 32 de agua gris). HOESKTRA, A. Y.; MEKONNEN, M. M. National water footprint accounts: the blue, green and gray water footprint of production and consumption. Value of Water Research Report Series, n. ${ }^{\circ}$ 50, v. 2, Holland: University of Twente, Twente Water Center, mayo 2011. Disponible en: $\quad<$ http://waterfootprint.org/media/downloads/Report50-NationalWaterFootprintsVol2.pdf>. Acceso en: 05-05-2015.

${ }^{168}$ En Brasil, conforme el Instituto Brasileiro de Geografia e Estatística (IBGE), en una encuesta realizada en 2010, solo $83 \%$ de las viviendas estaban conectadas a una red de abastecimiento de agua. Disponible en: http://www.censo2010.ibge.gov.br/sinopse/index.php?dados=P15\&uf=00. Acceso en: 24-04-2015.

${ }^{169}$ Según la UNESCO, hubo 1.831 interacciones (tanto conflictivas como cooperativas) en los últimos 50 años; 7 disputas con violencia y 507 episodios conflictivos. Disponible en: $<$ http://unesdoc.unesco.org/images/0013/001333/133306e.pdf $>$. Acceso en: 24-04-2015. Los números demuestran que las situaciones de enfrentamiento militar son una pequeña minoría, pasando la idea de que existen pocos conflictos violentos y mucha cooperación relacionados a los recursos hídricos, pero es importante recordar que un acuerdo, por sí mismo, demuestra la existencia de una disputa de intereses entre dos o más partes.

${ }^{170}$ Alrededor de $70 \%$ del cuerpo humano es compuesto por agua. En condiciones normales, perdemos por día con la: respiración: 0,4 litros; orina: 1,2 litros, transpiración: 0,6 litros y evacuación: 0,1 a 0,3 litros, o sea, un total aproximado de 2,5 litros de agua. Así, un cuerpo necesita reponer por día: 1,5 litros de agua a través de su ingestión líquida y 1,0 litro con la ingestión de alimentos. El nutriólogo Álvaro Vitor 
acceso al agua con mayor facilidad tiene mayores propensiones a desarrollarse económicamente y militarmente.

Sumado a todo eso, en este año de 2015, las Naciones Unidas a las vísperas del día Mundial del Agua, alertó que 40\% del agua del mundo puede desaparecer hasta el año 2030 y hizo previsiones que el aumento del agua en la industria será de $400 \%$ hasta 2050 y que el numero de personas sin acceso al agua potable y al saneamiento en áreas urbanas también será ampliado. Mientras crece la demanda, las reservas globales ya están siendo superexplotadas ${ }^{171}$.

Actualmente más de 740 millones de personas aun no tienen acceso al agua potable y al todo, $20 \%$ de los acuíferos del mundo son explotados por encima de sus límites, lo que puede comprometer el abastecimiento futuro.

La población global triplicó en el siglo XX, pero el consumo del agua aumentó siete veces. Para 2050 se espera que la población mundial aumente más tres mil

Teixeira afirma que la vida no existe sin agua, que todos los organismos vivos tienen agua que, como constituyente químico de las células, participa de los principales procesos vitales. El agua es indispensable para el funcionamiento del cuerpo humano. Sin agua los procesos metabólicos entran en colapso y comprometen los órganos. Además, explica que perdemos agua en la orina y sudor, y que si no la reponemos, la sangre se queda espesa, lo que lleva a la obstrucción de pequeñas arterias y venas, causando trombosis, insuficiencia renal y problemas en todos los órganos. También explica que es muy relativo el tiempo en que la falta de ingestión de agua puede llevar a la muerte, pues depende del organismo, su condición de salud, edad y si tiene la costumbre de quedarse largos periodos sin beber agua. En 24 horas empieza la deshidratación y en 48 horas es posible verificar falencia renal. Sin embargo, hay personas que se quedan una semana sin agua y sobreviven. Pero sobrevivir con agua sin un adecuado tratamiento no es lo ideal, pues el liquido no purificado puede contener innúmeros agentes patogénicos que pueden llevar a la muerte. El contagio puede ocurrir con la ingestión del agua contaminada, comiendo alimentos lavados con ella o aun bañándose en locales contaminados. Entre las enfermedades más comunes asociadas al agua están: cólera, hepatitis A, leptospirosis, fiebre tifoidea, gastroenteritis, además del riesgo de contaminación por metales pesados. Disponible en: http://alvarovitor.com.br/corpo-humano-depende-do-liquido-entrevista-para-o-diario-da-manha/. Acceso en: 24-04-2015.

${ }^{171}$ Más informaciones sobre el Informe disponibles en: http://www.unesco.org/new/pt/brasilia/naturalsciences/water-resources/freshwater-sustainability/> y en: <http://www.unesco.org/new/pt/brasilia/aboutthis-office/single-

view/news/urgent_need_to_manage_water_more_sustainably_says_un_report/\#.VT_T1Ys0wwF $>$.

Ambos con acceso en: 23-03-2015. 
millones de personas, lo que hará con que necesitemos de más $80 \%$ de agua sólo para el uso humano, e no sabemos de dónde ella vendrá ${ }^{172}$.

Con la posibilidad de un colapso hídrico global, diagnósticos de la crisis empezaron a ser divulgados por las Naciones Unidas, organismos y asociaciones de investigación, instituciones creadas específicamente para el estudio del tema ${ }^{173}, \mathrm{ONG}$, mostrando el promedio de su uso por actividad, el consumo por habitantes en diferentes países, el número de enfermedades causadas debido a la mala calidad del agua, el aumento del número de ríos contaminado, los valores de inversión necesarios para atenuar la crisis hídrica, entre otros tantos criterios y análisis de la temática, con la intención de despertar y llamar la atención para la contaminación, desperdicio, consumo excesivo y claro, la mala gestión por parte de la Administración Pública que nos lleva a la escasez del agua.

Además, el continuo consumo excesivo y el impacto de las alteraciones climáticas van a disminuir su disponibilidad en muchas regiones más carentes del planeta, de acuerdo con el nuevo informe de la Organización para la Alimentación y Agricultura de la ONU (FAO) ${ }^{174}$. Con el crecimiento de la población y el desarrollo de la sociedad totalmente ligado a la disponibilidad de agua es de extrema importancia que se observe el ejemplo de India, que en 1960 tenía menos de un millón de pozos mecanizados o con utilización de tuberías, con la llegada de la evolución tecnológica y la mejora en la condición de vida de los ciudadanos por los esfuerzos del gobierno local pasó a tener casi 19 millones de pozos en el año de 2000, llevando a algunas regiones del país, como Maharastra y Rayastán un estrés hídrico significativo ${ }^{175}$.

\footnotetext{
${ }^{172}$ La canadiense Maude Barlow, que es una gran especialista en agua y que trabaja en los organismos de las Naciones Unidas hace comentarios sobre el agua en el futuro. Agua: pacto azul, Editora M. Books, São Paulo-Brasil: 2009.

${ }^{173}$ Solo para citar algunos ejemplos de estos organismos específicos: World Water Council (Marsella y Montreal); International Water Secretariat (Montreal); International Water Services Association (Londres) etc.

${ }^{174}$ ONUBR. Demanda por água disparará $55 \%$ entre a população mundial em 2050 , alerta FAO. Disponible en: <http://nacoesunidas.org/demanda-por-agua-disparara-55-entre-a-populacao-mundial-em2050-alerta-fao/> Acceso en: 27-05-2015.

${ }^{175}$ CONNOR, Richard. The united nations world water development report 2015: water for a sustainable world. Disponible en: http://unesdoc.unesco.org/images/0023/002318/231823E.pdf. Acceso en: 02-062015.
} 
Otro ejemplo enfático es el de Asia y de Oceanía que con su astronómico crecimiento económico consiguieron reducir la pobreza, sin embargo aumentaron sus niveles de contaminación del medio ambiente y no consiguieron cumplir los compromisos firmados con la $\mathrm{ONU}^{176}$.

Estos ejemplos muestran de forma clara la dificultad de trabajarse el tema en la práctica, porque para que haya desarrollo es necesario que haya mejora en la condición de vida de la población, sabiendo que es imposible mejorar las condiciones de vida de la población sin que haya una distribución hídrica expresiva, se debe discutir con intensidad las formas viables de hacer el desarrollo sostenible. Las inversiones en todos los sectores de la gestión de los recursos hídricos, de provisión de servicios y de infraestructura (desarrollo, operación y manutención), pueden traer beneficios socioeconómicos significantes. En el sector de la salud, los valores gastos con abastecimiento de agua potable y saneamiento automáticamente se tornan altamente rentables. Las inversiones en prevención de desastres, en el avance de la calidad del agua y en la gestión de efluentes también son altamente rentables.

Para comprobar esta idea la Organización Mundial de la Salud (OMS) publicó una investigación ${ }^{177}$ en la que afirma que, para cada 1 dólar invertido en agua y saneamiento, son economizados 4,3 dólares en costes de salud en el mundo, mientras 2,5 mil millones de personas aún sufren con la falta de acceso a servicios de saneamiento básico y mil millones practican la defecación al aire libre. Eso significaría que sólo con inversiones en saneamiento y agua potable el PIB global podría mejorar unos increíbles $1,5 \%$.

Las interconexiones entre agua y desarrollo sostenible van mucho más allá de sus dimensiones sociales, económicas y ambientales. La salud humana, la seguridad alimentar y energética, la urbanización y el crecimiento industrial, así como los cambios climáticos, son áreas críticas de desafío, en que las políticas y acciones de vital importancia para el desarrollo sostenible pueden ser fortalecidas (o debilitadas) por

176 ZAMAN, Syed Zaid. Milagre asiático gera renda mas polui mais. Disponible en: http://www.pnud.org.br/Noticia.aspx?id=50. Acceso en: 02-06-2015.

${ }^{177}$ World Health Organization. Un-water global analysis and assessment of sanitation and drinking-water (glaas) 2014 report: investing in water and sanitation: increasing access, reducing inequalities. Disponible en: http://apps.who.int/iris/bitstream/10665/139735/1/9789241508087_eng.pdf?ua=1. Acceso en: 03-062015. 
medio del agua. Por esa razón es intrínseco al tema agua la sostenibilidad, que es el manejo y la conservación de la base de recursos naturales, y la orientación del cambio tecnológico e institucional, de manera que asegure la obtención y la satisfacción continua de las necesidades humanas para las generaciones presentes y futuras. Resultando en la conservación del suelo, del agua y de los recursos genéticos animales y vegetales $^{178}$.

Según la $\mathrm{OMS}^{179}$, una mayor inversión en agua y saneamiento reduce drásticamente la mortalidad infantil reduciendo enfermedades relacionadas a la desnutrición y diarrea, aumenta la expectativa de vida del local, además de llevar mejor calidad de vida a todos. El informe afirma también que inversiones en saneamiento que protejan la comunidad del contacto con heces pueden reducir hasta un $70 \%$ las enfermedades diarreicas.

La expectativa es que la demanda de agua mundial para la industria de manufactura aumente aproximadamente de $400 \%$ hasta 2050 , teniendo en cuenta todos sus sectores. Quien hasta el momento tuvo la mayor mejora fueron las grandes corporaciones que han conseguido reducir considerablemente su utilización. Las pequeñas y medias empresas, por no tener tantos recursos como las grandes, poseen menores condiciones para hacer alteraciones en sus cadenas de producción. Para que continúen los cambios benéficos es necesario que haya exploración de nuevas fuentes de datos, mejores modelos y métodos de análisis de datos más eficaces para crear nuevas estrategias que se adapten a los cambios climáticos actualmente inconstantes generados por el efecto invernadero ${ }^{180}$.

Recientemente (24/03/2015) el coordinador de las Naciones Unidas residente en Brasil, Jorge Chediek, discursó en un seminario de la ONU en Brasilia sobre la crisis hídrica en el planeta. Él dijo que los números están alarmando cada vez más los especialistas del área, números como la dificultad de acceso al agua potable a 700 millones de personas en el mundo, además de citar problemas puntuales en Brasil, como la falta de acceso de un $60 \%$ de los brasileños al tratamiento sanitario de

178 PESCOD. Wastewater treatment and use in agriculture. Disponible en: http://www.fao.org/docrep/t0551e/t0551e00.htm. Acceso en: 03-06-2015.

${ }^{179}$ World Health Organization. Un-water global analysis and assessment of sanitation and drinking-water (glaas) 2014 report: investing in water and sanitation: increasing access, reducing inequalities.

${ }^{180}$ CONNOR. The united nations world water development report 2015: water for a sustainable world. 
alcantarillado. ${ }^{181}$ Hasta 2030, el planeta enfrentará un déficit de agua de 40\%, al menos que sea mejorada dramáticamente la gestión de este recurso precioso. Esta es la principal conclusión del Informe de las Naciones Unidas sobre el Desarrollo de los Recursos Hídricos en el Mundo 2015: - Agua para un mundo sostenible ${ }^{182}$. El informe refuerza la necesidad de cambiar la forma como es administrado este recurso indispensable a la vida y también afirma que es necesaria la reforma de los objetivos de desarrollo sostenible establecidos por la ONU.

La comunidad internacional debe prepararse para la era de la - "diplomacia del agua", en la medida en que la amenaza de escasez de agua amenaza sumergir el mundo en un período de tensión geopolítica, porque — el agua es una de las mayores prioridades para el desarrollo y para una vida digna, así como un factor para mantener la paz y la seguridad, dijo el vicesecretario general de la ONU, Jan Eliasson, el 30 de marzo de 2015, en la Asamblea General de la ONU, en Nova York (EE.UU.).

Lo ideal sería un planeta sostenible en el que el Agua y los recursos correlatos son administrados en sumisión al bienestar humano y a la integridad de los ecosistemas en una economía sólida. Recursos hídricos suficientes y seguros siendo disponibles para atender a las necesidades básicas de todas las personas, con estilos de vida y hábitos sanos - fácilmente garantizada por medio de servicios de abastecimiento de agua y saneamiento confiables y accesibles. El agua siendo valorada en sus más amplios aspectos, recordándose siempre de su importancia. Lógico, este es el objetivo que debe ser alcanzado en el más corto plazo posible, antes que la situación ambiental se quede irreversible y que veamos el planeta y junto con ello la vida humana se deterioraren.

Para alcanzar este objetivo es necesaria la protección del medio ambiente por completo, todos los ecosistemas, fauna y flora. Sin que haya una reglamentación de la forma como se utilizarán los recursos, las industrias y también los ciudadanos tienden a agotarlos. Un ejemplo de eso son los Estados Unidos de América, que gastan en media 575 litros de agua por día por persona ${ }^{183}$, siendo que lo recomendado es de 110 litros

181 ONUBR. Seminário da ONU em Brasília discute crise hídrica. Disponible en: http://nacoesunidas.org/seminario-da-onu-em-brasilia-discute-crise-hidrica/. Acceso en: 02-06-2015.

${ }^{182}$ CONNOR. The united nations world water development report 2015: water for a sustainable world. 183 PENA, Rodolfo F. Alves. Consumo de água no mundo. Disponible en: http://www.mundoeducacao.com/geografia/consumo-agua-no-mundo.htm. Acceso en: 04-06-2015. 
por día/per cápita ${ }^{184}$. En la capital del Estado de Río de Janeiro la media es de 329,78 litros por día/per cápita ${ }^{185}$. Ese consumo exagerado, en la mayoría de las veces, es por desperdicio que ocurre en las grandes ciudades.

El desperdicio agrava la escasez. Se estima que en Brasil el desperdicio es de $37 \%$, siendo causado por: tuberías averiadas, grifos defectuosos y deficiencias en la operación e infraestructura para la captación y distribución del agua, datos de $2013^{186}$. Mientras el índice aceptable por la OMS es de un 15\%. Ese número es mayor que el doble. Mientras en Japón ese índice es de un 7\%. Aunque Brasil sea el país con el mayor volumen de agua dulce en el mundo, está pasando por una grave crisis hídrica, en 2014 fue posible visualizar esto, cuando varias ciudades, entre ellas São Paulo, tuvieron que hacer racionamiento de agua, dejando la población horas, o incluso días, sin agua.

Tal escasez es tan grave que además de afectar la población directamente con la falta de agua, la alcanza indirectamente con el aumento del precio de la energía y de los alimentos. La energía aumenta en razón de la falta de agua en las reservas de las usinas hidroeléctricas, que corresponden a un $90 \%$ de la energía eléctrica producida en Brasil $^{187}$. Llevándonos al ejemplo clásico de oferta y demanda, se hay mucha demanda y poca es la oferta, se aumenta el precio del producto. Ya en relación a los alimentos, se sabe que es necesario el agua para su producción, si falta agua, consecuentemente faltarán alimentos, sean los naturales o los industrializados.

Para que se evite el desperdicio y la contaminación del agua, evitando su escasez, es necesaria la inversión por parte de la Administración en gestión para la creación y adopción de métodos funcionales y viebles.

184 WATKINS, Kevin. Human development report 2006. Disponible en: http://hdr.undp.org/sites/default/files/reports/267/hdr06-complete.pdf. Acceso en: 04-06-2015.

${ }^{185}$ BIANCHI, Paula. Rio é o Estado que mais consome água, o dobro do recomendado pela ONU. Disponible en: http://noticias.uol.com.br/cotidiano/ultimas-noticias/2015/02/05/rio-e-o-estado-que-maisconsome-agua-o-dobro-do-recomendado-pela-onu.htm. Acceso en: 04-06-2015.

${ }^{186}$ CALDAS, Cadu. O Brasil conta gotas: entenda as causas e desafios da falta de água que se espalha pelo país. Disponible en: http://zh.clicrbs.com.br/rs/noticias/noticia/2015/01/o-brasil-conta-gotas-entendaas-causas-e-desafios-da-falta-de-agua-que-se-espalha-pelo-pais-4691649.html. Acceso en: 17-06-2015.

187 PENA, Rodolfo F. Alves. Hidrelétricas no Brasil. Disponible en: < http://www.mundoeducacao.com/geografia/hidreletricas-no-brasil.htm>. Acceso en: 17-06-2015. 


\subsection{El agua como bien jurídico fundamental}

La protección del agua comienza con su positivación. De esta forma el Estado posee fundamento para poder protegerla. Tal positivación es necesaria, principalmente en Brasil, en virtud de utilizarse el civil law, en función del principio de legalidad, que retrata que sólo se puede punir algo si hay una ley que prohíbe tal acción. Esta protección está individualizada en las áreas constitucionales, con los derechos fundamentales; civil; administrativo y penal, además, del Derecho Ambiental. Cada área será posteriormente individualizada, comenzando por el Derecho Constitucional.

Se puede clasificar el agua como un derecho fundamental presente en la Constitución Brasileña de 1988, sin embargo tal clasificación está subentendida en el texto constitucional, en virtud de no estar escrito explícitamente en los artículos del Título II de la CF/88.

Para entender que el agua es clasificada de tal modo, es necesario un contexto de explicaciones. Primeramente es indispensable -mismo que ya expuesto en diversas ocasiones al largo de este trabajo- un breve recogido entre derechos humanos y derechos fundamentales, pues hay quien entiende estos dos derechos como sinónimos, y hay quienes los dan connotaciones diferentes, y por consecuencia significados también distintos.

Los derechos humanos, segundo Ingo Wolfgang Sarlet ${ }^{188}$, es el derecho de la persona humana en ámbito internacional, porque identifican el hombre como tal, sin estar precisamente vinculado a un ordenamiento jurídico, y su eficacia alcanza todos los pueblos, es eso que le caracteriza como internacional ${ }^{189}$. Ya los derechos fundamentales son los derechos firmados y adoptados en la legislación de un Estado, o sea, para José Afonso da Silva ${ }^{190}$, los derechos fundamentales son los derechos que relatan cual la ideología política de cada Estado, caracterizados por ser derechos esenciales a la vida.

\footnotetext{
${ }^{188}$ SARLET, Ingo Wolfgang; MARINONI, Luiz Guilherme; MITIDIERO, Daniel. Curso de direito constitucional. São Paulo: Editora Revista dos Tribunais, 2012, p. 251.

189 SARLET, Ingo Wolfganf. A eficácia dos direitos fundamentais: uma teoria geral dos direitos fundamentais na perspectiva constitucional. $10^{\mathrm{a}}$ ed. Porto Alegre: Livraria do Advogado Editora, 2010, p. 29.

190 SILVA, José Afonso da. Curso de direito constitucional positivo. 25 ${ }^{\mathrm{a}}$ ed. São Paulo: Malheiros Editores, 2005, p. 178.
} 
En su discurso, en el calificativo fundamental, se encuentra la indicación de que se trata de situaciones jurídicas sin las cuales el ser humano [...] siquiera sobrevive [...]. Sumando al concepto de este, Luís María Díez-Picazo ${ }^{191}$, afirma que, el respeto por los derechos fundamentales ya no determina sólo la aceptabilidad de un régimen político por parte de sus ciudadanos, sino también la respetabilidad internacional de un país.

Los derechos fundamentales fueron recientemente reconocidos explícitamente en las Constituciones de los países, por ejemplo, el hito inicial de los derechos fundamentales en las Constituciones fue en 1824 con la Constitución del Imperio Brasileño, a pesar de la afirmación de algunos autores que fue la de Bélgica n $1831^{192}$, sin embargo la lucha por el reconocimiento de estos derechos existe ya hace bastante tiempo, y hasta los días de hoy no se ha terminado, porque todavía hay varios derechos para ser distinguidos cristalinamente en los textos constitucionales, y el derecho a agua es uno de ellos. Silva cuenta que tal lucha comenzó cuando los hombres fueron divididos entre propietarios y no propietarios ${ }^{193}$. El autor nombra las condiciones que propiciaron el combate y la consideración de los derechos fundamentales, la primera de ellas es la condición histórica, en virtud de la contradicción del régimen absolutista y la nueva clase (la burguesía) que estaba en expansión, y es en razón de esa contradicción que la burguesía incitó una revolución para poder tener sus derechos reconocidos, una de esas famosas revoluciones es la Revolución Francesa. La otra condición es la subjetiva que es dividida en tres ramas, una es el cristianismo primitivo y no el cristianismo vivido en la época del absolutismo, porque mientras este predicaba la diferencia entre los pueblos y la divinidad de los reyes, aquel enseñaba que todos los hombres son iguales y fueron hechos a la imagen y semejanza de Dios, y es por estas razones que no podrían vivir sin su dignidad; la otra rama es el iusnaturalismo, o derecho natural del hombre que era basado en la naturaleza racional del hombre, compartiendo del pensamiento del cristianismo (pero sólo en este aspecto) que hombres son iguales, pero en este caso es en relación a la naturaleza, y es por eso que no debería

\footnotetext{
${ }^{191}$ MARIA DÍEZ-PICAZO, Luís. Sistema de derechos fundamentales. Madrid: Thomsom Civitas, 2003, p. 39.

${ }^{192}$ SILVA, José Afonso da. Curso de direito constitucional cit., p. 170.

${ }^{193}$ SILVA, José Afonso da. Curso de direito constitucional cit., p. 149.
} 
existir distinción entre ellos; y la última rama e el iluminismo — con sus ideas sobre el orden natural, su exaltación a las libertades $[\ldots]^{194}$.

Después de mostrar la historicidad de los derechos fundamentales es importante también caracterizarlos. Según Silva ${ }^{195}$, tales derechos poseen historicidad (son creados, modificados y evanecidos), inalienabilidad (son inalienables, intransferibles, personalísimos), son imprescriptibles e irrenunciables.

Vale la pena recordar que son divididos en dimensione ${ }^{196}$, la primera dimensión abarcando los derechos individualistas, caracterizados por figurar el hombre delante del Estado, los derechos individuales frente a los sociales, la primacía especialmente de los derechos de defensa, estableciendo un límite para hasta donde el Estado puede actuar en la vida del individuo. La segunda dimensión los derechos económicos, sociales y culturales, tales derechos vinieron derivados de los aspectos económicos que asolaban las poblaciones de cada Estado, tuvieron influencia principalmente de las doctrinas socialistas, no más dejaban el Estado fuera de la vida del hombre, sino caracterizaron el Estado del Bienestar Social. La tercera dimensión es señalada por los derechos a la paz, a la autodeterminación de los pueblos, al medio ambiente y a la calidad de vida, entre otros. Hay quien diga que exista la cuarta dimensión, uno de ellos es Paulo Bonavides ${ }^{197}$ que argumenta que los derechos de tales dimensión son de gran seriedad, porque ellos globalizan los derechos, el autor nos da ejemplo que en esa dimensión están presentes los derechos a la democracia, el derecho a la información y al pluralismo, y la función de eses derechos es globalizar la democracia, globalizar la política. De ese modo, el agua debe ser encajada en la tercera dimensión por ser parte importante del medio ambiente.

Es vital el abordaje sobre las dimensiones de los derechos fundamentales, porque, aunque este siendo centrado en el hombre, a partir de la tercera dimensión la énfasis cambia del hombre individual para la colectividad, lo que distingue por ser una dimensión de derechos colectivos y difusos. Este cambio de paradigma resulta, según

\footnotetext{
${ }^{194}$ SILVA, José Afonso da. Curso de direito constitucional cit., p. 174.

${ }^{195}$ SILVA, José Afonso da. Curso de direito constitucional cit., p. 181.

${ }^{196}$ SARLET, Ingo Wolfgang; MARINONI, Luiz Guilherme; MITIDIERO, Daniel. Curso de direito cit., pp. $260-262$.

${ }^{197}$ BONAVIDES, Paulo. Curso de direito constitucional. $15^{\mathrm{a}}$ ed. São Paulo: Malheiros Editores, 2004, pp. 570-572.
} 
Sarlet ${ }^{198}$, de la acción de desgaste y erosión que estos derechos fundamentales estaban sufriendo, en consecuencia de las tecnologías usadas por el hombre y también por sus actitudes, principalmente en relación al medio ambiente y a la calidad de vida. Sin embargo, los derechos de la tercera dimensión aún no están presentes en los textos normativos de los Estado, diferentemente de los de la primera y de la segunda dimensión, que sí están presentes, sin embargo, aquellos se encuentran cada vez más presentes en el derecho internacional, a través de los tratados, convenios, foros, conferencias y cumbres internacionales ${ }^{199}$.

Entre los tratados internacionales que Brasil es signatario, podemos citar: La Declaración del Agua, del Tribunal Latino Americano del Agua, que reconoce y declara el agua como un derecho fundamental, intrínseco a la vida y a la dignidad de la persona humana ${ }^{200}$; la Declaración de la $\mathrm{ONU}^{201}$, que en 2010 afirmó que el agua potable y el saneamiento son derechos humanos fundamentales; y la Declaración Universal de los Derechos del Agua de $1992^{202}$, cuyo art. $2^{\circ}$ describe el derecho al agua como un derecho fundamental del hombre, principalmente en función del derecho a la vida.

A pesar del derecho al agua (o al medio ambiente) no estar descripto en la lista de los derechos fundamentales en el Título II de la CF/88 nombrado de - De los Derechos y Garantías Fundamentales, la propia Constitución no excluye la idea del derecho al agua ser fundamental. Eso es posible conforme dispone el $\S 2^{\circ}$ del artículo $5^{\circ}, \mathrm{CF} / 88$ : "los derechos y garantías expresos en esta Constitución no excluyen otros derivados del régimen y de los principios por ella adoptados, o de los tratados internacionales en los que la República Federativa do Brasil sea parte". Tales tratados, como los anteriormente citados, cuando Brasil es signatario de ellos, él se insiere en el ordenamiento jurídico y pasa a tener fuerza de ley. Además de los tratados internacionales que garantizan el medio ambiente, consecuentemente el agua, como

\footnotetext{
${ }^{198}$ SARLET, Ingo Wolfgang. A eficácia dos direitos fundamentais: cit., p. 49.

${ }^{199}$ SARLET, Ingo Wolfgang. A eficácia dos direitos fundamentais: cit., p. 49.

${ }^{200}$ Declaração da Água, Tribunal Latino Americano da Água. Disponible en: < http://tragua.com/quienessomos/declaracion-del-agua/>. Acceso en: 22-05-2015.

${ }^{201}$ ONU. Água potável: direito humano fundamental. Disponible en: <http://nacoesunidas.org/aguapotavel-direito-humano-fundamental/>. Acceso en: 22-05-2015.

202 Declaração Universal dos Direitos da Água. Disponible en: $<$ http://www.direitoshumanos.usp.br/index.php/Meio-Ambiente/declaracao-universal-dos-direitos-daagua.html>.Acceso en: 22-05-2015.
} 
derecho humano fundamental, la Constitución Federal en su artículo 225, trata que el derecho ambiental ecológicamente equilibrado es un derecho de todos, siendo incumbencia del Poder Público asegurarlo. Como si no fuera suficiente el derecho al agua ser considerado un derecho humano fundamental, él también es reconocido como un derecho humano inherente a la dignidad de la persona humana, adoptado por la $\mathrm{ONU}^{203}$.

El concepto de dignidad humana últimamente es que cada ser humano posee un valor intrínseco y disfruta de una posición especial en el universo ${ }^{204}$, o sea, cada hombre es único y todos son importantes para todos. Luís Roberto Barroso afirma que esta definición es el valor interno de la dignidad, la parte externa son las responsabilidades del ser humano y sus deberes en relación a terceros. El autor también relata que la parte interna es inviolable. A partir de la dignidad humana es que surgen los derechos fundamentales, ellos están intrínsecamente interconectados, los derechos fundamentales expresan en el Derecho lo que la dignidad retrata en la moral filosófica ${ }^{205}$.

Además es, como había sido explicitado anteriormente, los derechos humanos son de ámbito internacional, derivados de tratados internacionales, de los cuales Brasil es signatario, sumándose a eso, se aprovecha el discurso de Sarlet en el sentido de que no hay dudas que los derechos fundamentales, de cierta forma, son también derechos humanos, en el sentido de que su titular siempre será el ser humano. ${ }^{206} \mathrm{O}$ sea, a pesar de los derechos humanos y derechos fundamentales poseyeren definiciones diferentes, ellos son los derechos considerados más importantes para el ser humano, siendo necesario su explícita positivación y tutela, tanto en el ámbito internacional con el reconocimiento de derechos humanos, como en el ámbito interno con los derechos fundamentales, para que así se eviten dudas respecto a su amplitud y aplicación, y se crien excusas para su incumplimiento.

\footnotetext{
${ }^{203} \mathrm{ONU}$ reconhece acesso à água potável como um direito humano. Notícia por DN Globo. Disponible en: <http://www.dn.pt/inicio/globo/interior.aspx?content_id=1629749\&page=-1>. Acceso en: 21-062015.

${ }^{204}$ BARROSO, Luís Roberto. A dignidade da pessoa humana no direito constitucional contemporâneo. Tradutor: Humberto Laport de Mello. Belo Horizonte: Editora Fórum, 2013, p. 14.

${ }^{205}$ BARROSO, Luís Roberto. A dignidade da pessoa humana no direito constitucional cit., p. 75.

${ }^{206}$ SARLET, Ingo Wolfgang; MARINONI, Luiz Guilherme; MITIDIERO, Daniel. Curso de direito cit., p. 249.
} 
Aunque el Agua no esté explícitamente clasificada como derecho fundamental en el texto de la Carta Magna Brasileña, la misma es considerada como tal, conforme anteriormente demonstrado.

En la visión de Ingo Wolfgang Sarlet, el reconocimiento de un derecho fundamental a un ambiente ecológicamente equilibrado, tal como ha sido designado con frecuencia, se ajusta, como ya enfatizado, a los nuevos enfrentamientos históricos de naturaleza existencial puestos por la "crisis ecológica", complementando los ya ampliamente contemplados, aunque con variaciones importantes, derechos civiles, políticos y socioculturales, aumentando significativamente los niveles de complexidad $^{207}$. Según Sarlet: “el reconocimiento de un derecho fundamental al medio ambiente (o a la protección ambiental) constituye aspecto central de la agenda políticojurídica contemporánea" 208 .

\subsection{Antropocentrismo y ecocentrismo: cosmovisión y bien jurídico} protegido

Al introducirse la temática acerca del medio ambiente, es necesario hacer una breve explanación sobre algunos temas preliminares muy importantes para la comprensión futura de los criterios normativos que indican la necesidad de tutela (o no) por el Derecho, de los elementos que componen la naturaleza y su relación con las necesidades del ser humano.

Para esto, es necesario hacer un comentario sobre la "cosmovisión", 209 (Cosmos: Tierra, Universo; visión: mirar, ver), o sea, las varias formas de observarse el hombre y el mundo, tanto por parte de sus individuos aislados, como la forma como el Estado y las demás instituciones lo ven.

\footnotetext{
${ }^{207}$ SARLET, Ingo Wolfgang; FENSTERSEIFER, Tiago. Direito constitucional ambiental: Constituição, Direitos fundamentais e proteção do ambiente. $2^{\mathrm{a}}$ ed. Rev. e Atual. São Paulo: Editora Revista dos Tribunais, 2012, p. 36

${ }^{208}$ SARLET, Ingo Wolfgang; FENSTERSEIFER, Tiago. Direito constitucional ambiental: cit., p. 36.

${ }^{209}$ Término utilizado por Édis Milaré, Direito do Ambiente. A gestão ambiental em foco. Doutrina. Jurisprudência. Glossário. $7^{\text {a }}$ ed. São Paulo: Revista dos Tribunais, 2011, p. 112.
} 
En este ínterin, la protección ambiental puede ser basada en dos grandes líneas de visión o vertientes: una antropocéntrica, que ve el hombre como el centro gravitacional de las necesidades e interacciones sociales; y, una más modernamente concebida por la Filosofía y, aun prematuramente, por la ciencia del derecho, a saber, la ecocéntrica (también conocida como biocéntrica), que se refiere a la necesidad de posicionarse el hombre como sólo uno más en los componentes del ecosistema que necesitan de protección y tutela jurídica intrínseca ${ }^{210}$.

De acuerdo con Milaré, el antropocentrismo puede ser definido como una concepción genérica que "hace del Hombre el centro del Universo, o sea, la referencia máxima y absoluta de valores, de modo que en su alrededor graviten todos los demás seres por fuerza de un determinismo fatal" ${ }^{\text {211 }}$. Esta vertiente surgió a partir de la tradición judeocristiana y fue reforzada por el racionalismo moderno que posibilitó el descubrimiento de varios secretos de la naturaleza.

Para Morato Leite y Ayala, no sería posible conceptuar el medio ambiente fuera de una visión antropocéntrica, ya que su protección jurídica depende de la actuación humana, incluso, citan como referencia, el Principio 1 de la ECO/92, que menciona que "los seres humanos constituyen el centro de las preocupaciones relacionadas con el desarrollo sostenible. Tienen derecho a una vida saludable y productiva en armonía con la naturaleza"212.

Sin embargo, así como bien destacan los autores citados arriba, la visión antropocéntrica pura o radical ya no puede subsistir sin algunas reservas. Los ideales del pasado, de que el hombre consigue dominar y someter la naturaleza a una explotación ilimitada ya no puede contemporizar con la escasez de recursos y los riesgos globales del siglo XXI. Se impone actualmente, una versión de antropocentrismo más moderado, incluyéndose nuevos valores, tales como la bioética, en la protección jurídica del medio ambiente. Esto incluso puede ser observado más modernamente con la edición de la Ley

\footnotetext{
${ }^{210}$ MILARÉ, Édis. Direito do Ambiente. A gestão ambiental cit., pp. 113-115.

${ }^{211}$ MILARÉ, Édis. Direito do Ambiente. A gestão ambiental cit., pp. 113.

${ }^{212}$ LEITE, José Rubens Morato; AYALA, Patrick de Araújo. Dano Ambiental. Do individual ao coletivo extrapatrimonial. Teoria e prática. 4. ed. São Paulo: Editora Revista dos Tribunais, 2011, pp. 75-76.
} 
11.105/2005 que trata de la regulación a la investigación de los organismos genéticamente modificados $(\mathrm{OGM})^{213}$.

Según Amaral y Leite, hay una tendencia actual de buscarse una cosmovisión mucho menos antropocéntrica, "en que la protección de la naturaleza, por los valores que representa en sí misma, merezca un sustancial incremento. La naturaleza necesita protección per se y por su propio fundamento" 214.

Gracias a los debates emanados por varias vertientes sociales, especialmente por autores ligados a la Ética Ambiental ${ }^{215}$ en materia interrelacional, fue posible avanzarse para lejos de un antropocentrismo exagerado, dotado de una concepción egoistica del hombre en relación a la naturaleza, presente en las ideologías anteriores.

Paul Tiedemann es contrario a la evocación del antropocentrismo en la protección jurídica del medio ambiente, porque ve con aire apelativo la protección orientada para "el propio provecho humano", mientras que así, la protección del medio ambiente no cumpliría la finalidad primordial de promover una dinámica de cambio de

${ }^{213}$ Também en este entendimento, LEITE, José Rubens Morato; AYALA, Patrick de Araújo. Dano Ambiental. Do individual ao coletivo cit., p. 77.

${ }^{214}$ AMARAL, Diogo Freitas. Direito do ambiente. Oeiras: INA, 1994, p. 17 apud LEITE, José Rubens Morato; AYALA, Patrick de Araújo. LEITE, José Rubens Morato; AYALA, Patrick de Araújo. Dano Ambiental. Do individual ao coletivo cit., p. 77.

${ }^{215}$ Sobre una visión ecocéntrica en la Filosofía Ética, conforme citado por Édis MILARÉ, Direito do Ambiente. La gestión ambiental cit., pp. 114-116, importantes são as obras de: Keith Thomas (O Homem e o mundo natural: mudança de atitudes em relação às plantas e aos animais. São Paulo: Companhia das Letras, 1996); de Luc Ferry (A nova ordem ecológica: a árvore, o animal e o homem. Rio de Janeiro: Difel, 2009) e Peter Singer (Ética Prática. São Paulo: Martins Fontes, 1994, cap. 10). Otra obra bastante reciente y que merece respeto es la de Juarez Freitas, Sustentabilidade cit., pp. 57-58, vez que el autor da una importante lección relacionada a la dimensión ética de la sostenibilidad traída en este trabalho: “[...] todos os seres poseen una ligación intersubjetiva y natural, en la que sigue la empática solidaridad como deber-placer universal, por encima de las limitaciones conocidas del formalismo kantiano y en la correcta comprensión darwiniana de la selección natural. [...] La percepción ética habita en todos, conviniendo notar que aquellos que alcancen mayor autoconsciencia resultan con el deber más alto de, sin encoger los hombros, resguardar, al máximo, la integridad de todos los seres, de forma que no provoque daño injusto, por acción u omisión. [...] Una actitud ética supone, especialmente, tarea simultanea: alcanzar bienestar íntimo y bienestar social, con la certeza de que, después de determinado nivel de renta, el fin de la iniquidad es mejor que el mero crecimiento económico, a par de la certeza de que, principalmente, después de ese nivel, el crecimiento económico se convierte, en regla, en fuente de ansiedad, depresión y enfermedades similares". 
consciencia y de comportamiento humano. Para este autor, el concepto antropocéntrico va de encuentro con posiciones doctrinarias utilitaristas, como las de John Rawls y la promovida por el imperativo categórico kantiano. Tiedemann comprende que la naturaleza debe ser observada cuanto a su valor intrínseco, defendiendo así una "ética empática", consubstanciada en el reconocimiento de igualdad con el otro, reconociéndose todos los seres vivos como sujetos portadores de derechos emancipados y específicos ${ }^{216}$.

Según afirma Birnbacher, en sentido opuesto, es a través de una perspectiva "utilitarista" (basada en la búsqueda de la máxima utilidad es que se tiene la mayor felicidad), es que se fundamenta la protección jurídica de la naturaleza por su condición intrínseca. Sea por el argumento metafísico de que se debe respetar la vida en todas sus formas, sea por el argumento estético, de que la vida de la naturaleza tiene el núcleo en sí misma, que todo provecho de protección a la naturaleza no será meramente reportado a ella, sino al hombre en especial ${ }^{217}$.

La contemporaneidad, de cierto modo, trae consigo una nueva forma de comprensión de las dinámicas y complejas interacciones humanas con su ecosistema, permitiendo, sin duda, una nueva perspectiva de actuación de las normas jurídicas.

Sin embargo, como bien observa Milaré, la índole de la Ciencia Jurídica es de conservadorismo, ya que el Derecho existe como ordenamiento formal para la vida humana, trayendo una distinción usual entre hombres y cosas, siendo casi imposible retirar una tendencia natural de los juristas para el antropocentrismo ${ }^{218}$. En que pese esta vocación del Derecho, el autor cree que, el hecho del medio ambiente ser considerado, en la postmodernidad, como un derecho difuso, y, dadas las inquietudes científicas, económicas y políticas relativas a los riesgos globales que amenazan la vida terrestre

\footnotetext{
${ }^{216}$ TIEDEMANN, Paul. Natur als Rechtssubjekt. Die Grundlagen einer empathischen Ethik, Berlin, 1989 apud VICENTE GIMÉNEZ, Teresa (coord.). Justicia ecológica y protección del medio ambiente. Madrid: Editorial Trotta, 2002, p. 43.

${ }^{217}$ BIRNBACHER, Dieter. Sind wir für die Natur Verantwortlich?, en Íd. (ed.), Ökologie und Ethik, Stuttgart, 1988, esp. pp. 121, 126, 130, 131-133 apud VICENTE GIMÉNEZ, Teresa. Justicia ecológica y protección del medio ambiente. Madrid: Editorial Trotta, 2002, p. 44.

${ }^{218}$ MILARÉ, Édis. Direito do Ambiente. A gestão ambiental cit., p. 119.
} 
(principalmente relativas a los cambios climáticos y escasez de agua potable y recursos minerales), confirman que el ser humano no puede olvidar su posición en el mundo ${ }^{219}$.

Conforme hay dilucidado en este trabajo, las influencias de estas nuevas formas de repensarse la función del hombre delante do su entorno en medio a la conjugación de los factores que envuelven la denominada sociedad de riesgo, afectan incluso la forma de actuación del Derecho Penal, que clásicamente fue desarrollado basado en la protección de bienes, valores o intereses jurídicos necesarios para la existencia humana.

Ciertamente la rama más punitiva del ordenamiento jurídico aún enfrenta resistencias y limitaciones dogmáticas acerca de una postura radicalmente ecocéntrica. Lo que se ha notado es la adecuación con el antropocentrismo moderado, en que traduce la misión del Derecho Penal en la tarea de tutelar valores esenciales a la existencia humana sana y en equilibrio con los elementos naturales (tierra, agua, flora y fauna).

Experimentadas algunas nociones indispensables para la comprensión de que tan compleja está la teoría del bien jurídico en la actualidad, necesario se hace, a partir de ahora, situar el medio ambiente en esta problemática, para entonces verificar, de cierta forma, cuales las contribuciones prácticas que estos estudios han proporcionado a la comprensión del tema.

Como ya demostrado, no hay un consenso acerca del contenido material de protección del Derecho Penal, a pesar de que, como defendido por Hefendehl, la teoría del bien jurídico puede tranquilamente prevalecer aunque delante de las objeciones hechas por Stratenwerth, Jakobs, Wohlers y $\operatorname{Hirsch}^{220}$.

Las principales discusiones están en la forma de concebirse el medio ambiente como un bien jurídico colectivo de valor intrínseco o, atendiéndose a los postulados de la teoría personal, siendo así considerado sólo en la dimensión en que exprese una necesidad humana.

\footnotetext{
${ }^{219}$ MILARÉ. Direito do Ambiente. A gestão ambiental em foco. Doutrina. Jurisprudência. Glossário. 7. ed. São Paulo: Revista dos Tribunais, 2011, p. 122.

${ }^{220}$ HEFENDEHL, Roland. De largo aliento: El concepto de bien jurídico. O qué ha sucedido desde la aparición del volumen colectivo sobre la teoría del bien jurídico. La teoría del bien jurídico ¿Fundamento de legitimación del Derecho Penal o juego de abalorios dogmáticos?. Edición española a cargo de Rafael Alcácer, María Martín e Íñigo Ortiz de Urbina. Presentación de Enrique Gimbernat. Madrid: Marcial Pons, 2007, p. 459 y ss.
} 
Para Helena Regina Lobo da Costa, el medio ambiente debe ser tratado como bien jurídico en su acepción de elemento esencial para el desarrollo de la personalidad humana, pero en ninguna hipótesis podrá recibir protección legítima sólo por su valor en sí mismo ${ }^{221}$.

Silveira afirma que el ambiente, como bien jurídico de protección penal, debe ser concebido no sólo en su aspecto individual, sino también en su carácter de colectividad $^{222}$.

Sin embargo, como bien advierte Prado, hay una enorme dificultad en circunscribir con clareza el contenido de protección del bien jurídico "medio ambiente" 223 . Polaino Navarrete ${ }^{224}$ aduce que el bien jurídico ${ }^{225}$ ecológico es polifacético e interrelacional, trayendo un enorme catálogo de elementos que componen su concepto.

Según Prado y Carvalho, antes de comprender el ámbito o elemento a componer el medio ambiente, es necesario entender que hay dos sentidos para expresar su contenido: un global y otro restricto. En la concepción global o unitaria, el medio ambiente es comprendido tanto en relación a los elementos que forman su medio (naturales, artificiales, culturales, estéticos etc.) como a las relaciones que de ellos parten y dependen de un equilibrio entre la destrucción y regeneración. En una concepción restricta $^{226}$, el medio ambiente sólo comprende los elementos naturales de

${ }^{221}$ COSTA, Helena Regina Lobo da. Proteção Penal Ambiental. Viabilidade. Efetividade. Tutela por outros ramos do direito. São Paulo: Saraiva, 2010, p. 23.

${ }^{222}$ SILVEIRA, Renato de Mello Jorge. Direito Penal Supra-Individual. Interesses difusos. São Paulo: RT, 2003, p. 136.

${ }^{223}$ PRADO, Luiz Régis. Direito Penal do Ambiente. $2^{\mathrm{a}}$ ed. São Paulo: RT, 2009, p. 104.

${ }^{224}$ POLAINO NAVARRETE, Miguel. La criminalidad ecológica en la legislación española. Política criminal y reforma penal. L-H. a la memória del Prof. Dr. Juan del Rosal, p. 876.

${ }^{225}$ Ver também o trabalho desenvolvido por ALASTUEY DOBÓN, Maria Carmem. Consideraciones sobre el objeto de protección en el derecho penal del medio ambiente. In: PRADO, Luiz Régis (coord.). Direito Penal Contemporâneo. Estudos em homenagem ao Professor José Cerezo Mir. São Paulo: Editora Revista dos Tribunais, 2007, p. 209 e ss.

${ }^{226}$ Vide también HAVA GARCÍA, Esther. Protección jurídica de la fauna y flora en España. Prólogo de Juan Terradillos Basocco. Madrid: Editorial Trotta, 2000, p. 37. 
titularidad común y de características dinámicas (agua, aire, suelo etc.), y como normalmente, existe una concepción intermedia entre las dos anteriores ${ }^{227}$.

Basado en estas concepciones, innúmeros posicionamientos surgen para explicar el contenido y fundamento de la protección del medio ambiente. De acuerdo con Kristian $\mathrm{Kühl}^{228}$, pueden ser observadas dos grandes líneas dogmáticas para investigarse cuál es el bien jurídico tutelado por el Derecho Penal del Ambiente: la antropocéntrica y la ecocéntrica ${ }^{229}$. Para Régis Prado, hay tres corrientes: a) antropocéntrica absoluta (la protección del ambiente es hecha exclusivamente evitando daños o lesiones al hombre); b) ecocéntrica absoluta (el ambiente es un bien jurídico autónomo) y c) antropo-ecocéntrica o mixta (que acepta bienes jurídicos ambientales autónomos y de carácter antropo-ecocéntrico) ${ }^{230}$.

Existe aún otra interesante clasificación hecha por Hohmann, en la que se vislumbran cuatro líneas diversas: a) formada por una concepción ecológica como bienes de protección autónoma; b) concepción ecológica antropocéntricamente suavizada, según la cual los bienes jurídicos ecológicos tienen valor intrínseco y también sirven de base para las presentes y futuras generaciones; c) una concepción económica, en que los bienes jurídicos estarían protegidos conforme establecido por determinadas autoridades en determinado estado; y, d) concepción personal de bienes jurídicos ambientales como los relativos a la vida, integridad física y salud ${ }^{231}$.

${ }^{227}$ PRADO, Luiz Régis. Direito Penal do cit., pp. 104-106; CARVALHO, Érika Mendes de. O bem jurídico protegido nos delitos florestais. Revista dos Tribunais, São Paulo, v. 89, n. 776, p. 471 e ss., jun. 2000.

${ }^{228}$ KÜHL, Kristian. Antropozentrische oder nichtantropozentrische Rechtsgüter im Unweltstrafrecnt? In: NIDA-RÜMELIN, Julian. PFORDTEN, Dietmar. Okologische Ethik und Rechtstheorie, Baden-Baden: Nomos, 1995, p.245-263. apud COSTA, Helena Regina Lobo da. Proteção Penal cit., pp. 178-179; MILARÉ. Direito do Ambiente. A gestão ambiental cit., p. 23.

${ }^{229}$ Conforme ya diferenciadas las cosmovisiones, importante resaltar que aún es predominante en el Derecho, y más especialmente, en el Derecho Penal, la visión antropocéntrica.

${ }^{230}$ PRADO, Luiz Régis. Direito Penal do cit., pp. 108-109.

${ }^{231}$ HOHMANN, Olaf apud COSTA, Helena Regina Lobo da. Proteção Penal cit., pp.179-187; MILARÉ. Direito do Ambiente. A gestão ambiental em foco. Doutrina. Jurisprudência. Glossário. 7. ed. São Paulo: Revista dos Tribunais, 2011, p. 23. 
La línea ecocéntrica ${ }^{232}$ absoluta considera el medio ambiente como valor en sí mismo, y, dependiendo de la situación, eso puede ser sopesado hasta en desfavor del hombre caso este atente contra los elementos constitutivos: aire, agua, suelo, fauna y flora.

Figueiredo Dias, a pesar de no haber adoptado una línea ecocéntrica exagerada, manifestó, en uno de sus escritos, la posibilidad de existencia de bienes jurídicos ecológicos de valor intrínseco, o sea, que para su protección no tengan que, necesariamente, ser reconducidos a una necesidad o interés puramente humano y personal $^{233}$.

Roxin afirma que en la Constitución alemana es posible concebir una regulación que admite la protección de los fundamentos naturales de la sobrevivencia y los animales, en responsabilidad por las futuras generaciones, lo que, con eso, amplia el concepto de bien jurídico extendiendo para el contrato social, los seres (animales y generaciones futuras) que hacen parte del círculo del hombre ${ }^{234}$.

Sobre este mismo tema, Mendoza Buergo constata que, en Alemania, hubo un cambio de perspectiva de protección a partir de la Reforma de 1980 en los términos del Proyecto Alternativo del Código Penal Alemán sobre las cuestiones ambientales. La autora cita que, antes de la referida reforma, la legislación alemana sólo previa tipos penales ambientales que tuviesen una relación directa de protección ante a los daños y peligros a la vida y a la salud humana. Sin embargo, el legislador alemán, talvez por influencia de las tendencias antropo-ecocéntricas, comenzaron a prescribir conductas típicas que reconocen bienes jurídicos ecológicos independientes, materializados en los elementos tales como agua, aire y suelo ${ }^{235}$.

Andrew von Hirsch resalta que en el Derecho Penal del Ambiente, al protegerse determinados recursos naturales (fauna y flora), por los defensores de la teoría personal del bien jurídico, no sería legítimo proteger el bien jurídico

${ }^{232}$ São partidários de esta forma de se concebir el bien jurídico "ambiente", entre otros, ESER, SANCHEZ-MIGALLON PARRA, JONAS, BLOY, GIUNTA, MILARÉ, SOUZA.

${ }^{233}$ DIAS, Jorge de Figueiredo. Direito Penal. Parte Geral. Tomo I. São Paulo: Editora Revista dos Tribunais; Coimbra: Coimbra Editora, 2007, p. 382.

${ }^{234}$ ROXIN, Claus. A proteção de bens jurídicos como função do Direito Penal. Trad. André Luís Callegari e Nereu José Giacomolli. $2^{\mathrm{a}}$ ed. Porto Alegre: Livraria do Advogado, 2009, p. 20;

${ }^{235}$ MENDOZA BUERGO, Blanca. El derecho penal en la sociedad del riesgo. Madrid: Civitas, 2001, p. 71. 
"manutención de la diversidad" por su carácter intrínseco, apenas justificado en relación a los intereses de las personas. Entretanto, el autor afirma que la sobrevivencia de determinadas especies, por ejemplo, constituye en sí mismo un valor merecedor de protección, porque, según él, no se puede vincular la calidad de vida de las personas, y que tampoco hay una pretensión en relación a los individuos. Lo que sí puede haber es un deber moral de protección de la diversidad ecológica. Además, también no se puede partir de una pretensión de la especie o de sus miembros, como si, por ejemplo, ballenas tuviesen integridad física ${ }^{236}$.

Stratenwerth cuando afirma un Derecho Penal referido al futuro, se manifiesta favorablemente al abandono de una cosmovisión meramente antropocéntrica, típica de la modernidad primaria o de la época del Iluminismo. Para el autor, no sólo los derechos de las generaciones futuras, sino la propia naturaleza en sí debe tener derecho a la protección penal, independientemente de ser postulado como bien jurídico ${ }^{237}$.

Diametralmente opuestos, están los autores ${ }^{238}$ que defienden una visión antropocéntrica (moderada o radical) de los bienes jurídicos colectivos envolviendo el medio ambiente. A este tipo de cosmovisión, clásicamente relacionada al propio Derecho y a las finalidades de este de regular la vida humana y mantener su existencia y dignidad, parece casi que natural de la ciencia jurídica, e, incluso algo redundante afirmar que los bienes jurídicos siguen una línea antropocéntrica, lo que es obvio.

Para Helena Regina Lobo da $\operatorname{Costa}^{239}$ y Juarez Tavares ${ }^{240}$, la protección del medio ambiente sólo se hará de forma legítima si adoptada una concepción antropocéntrica, no de forma a no reconocer el carácter autónomo de protección del medio ambiente, sino, por, enfáticamente, exigir la vinculación de su tutela con un bien jurídico necesario para el ser humano.

\footnotetext{
${ }^{236}$ HIRSCH, Andrew von. El concepto de bien jurídico y el principio del daño. In: HEFENDEHL, Roland (ed.). La teoría del bien jurídico. Madrid: Marcial Pons, 2007, p. 51.

${ }^{237}$ STRATENWERTH, Günter apud GRECO, Luís. Op. cit., pp. 10-11, p. 689.

${ }^{238}$ En la Constitución Brasileña de 1988, el medio ambiente (art. 225) está ubicado dentro de los derechos sociales de la persona humana, e, como enfatizado, está relacionado tanto a las condiciones de equilibrio, cuanto a la indispensabilidad a la sana calidad de vida humana, tanto para las presentes como futuras generaciones.

${ }^{239}$ COSTA, Helena Regina. COSTA, Helena Regina Lobo da. Proteção Penal cit., p. 32.

${ }^{240}$ TAVARES, Juarez. Teoria do injusto penal. $3^{\mathrm{a}}$ ed. Belo-Horizonte: Del Rey, 2003, p. 217.
} 
Para Luiz Régis Prado, el concepto jurídico-penal de ambiente tiene una dimensión antropo-ecocéntrica, lo que significa que debe ser tutelado no sólo cuando útil al hombre, sino porque es, indispensable a su supervivencia. Además, sobre este entendimiento, Rodriguez $\operatorname{Ramos}^{241}$ afirma que este es un bien jurídico meta-individual sistemáticamente autónomo, lo que, le confiere sustantividad propia, no se confundiendo con los demás bienes jurídicos individuales o colectivos (salud pública, propiedad, etc.).

Maria Carmen Alastuey Dobón ${ }^{242}$ hace importante crítica a la concepción antropocéntrica del bien jurídico, en la dimensión en que afirma que los bienes jurídicos supraindividuales -in casu, el medio ambiente-, no son dependientes de los individuales de manera que si aquellos son lesionados, necesariamente habrá una directa afectación de los segundos. Así como Kuhlen ${ }^{243}$ también concluye que el reconocimiento de bienes jurídicos de la generalidad, no implica que ellos deriven de bienes individuales.

Resalta Dobón que aunque incompatible con el Derecho Penal la existencia de una vertiente ecocéntrica radical de bien jurídico del medio ambiente, hay que resguardarle cierto grado de autonomía en relación a los demás bienes colectivos, porque su protección desempeña función positiva para el mantenimiento de las bases imprescindibles para la autorrealización humana y, definitivamente, el libre desarrollo de su personalidad. El grande hito de autonomía es que la conexión que el medio ambiente, como bien jurídico colectivo, tiene con los demás bienes individuales, no se limita a las presentes, como también a las futuras generaciones, estando, por lo tanto, en un grado superior de jerarquía de los demás bienes colectivos ${ }^{244}$. Esta perspectiva para

\footnotetext{
${ }^{241}$ RODRIGUEZ RAMOS, L. Protección penal del medio ambiente, p. 306. apud PRADO, Luiz Régis. Direito Penal Contemporâneo. Estudos em homenagem ao Professor José Cerezo Mir. São Paulo: Editora Revista dos Tribunais, 2007, p. 110.

${ }^{242}$ ALASTUEY DOBÓN, Maria Carmen. Consideraciones sobre el objeto de protección en el derecho penal del medio ambiente. In: PRADO, Luiz Régis. (coord.). Direito Penal Contemporâneo. Estudos em homenagem ao Professor José Cerezo Mir. São Paulo: Editora Revista dos Tribunais, 2007, p. 219.

${ }^{243}$ KUHLEN, Lothar, p. 704 apud ALASTUEY DOBÓN, Maria Carmen. Consideraciones sobre el objeto de protección en el derecho penal del medio ambiente. In: PRADO, Luiz Régis. (coord.). Direito Penal cit., p. 219.

${ }^{244}$ ALASTUEY DOBÓN, Maria Carmen. Consideraciones sobre el objeto de protección en el derecho penal del medio ambiente. In: PRADO, Luiz Régis. (coord.). Direito Penal Contemporâneo. Estudos em homenagem ao Professor José Cerezo Mir. São Paulo: Editora Revista dos Tribunais, 2007, pp. 225-227.
} 
el futuro es coherente con el artículo 45 de la Constitución Española y con el artículo 225 de la Constitución Brasileña.

\subsection{Importancia de los principios para la ciencia: aspectos relevantes de su surgimiento y evolución}

En los tiempos actuales, en que las innovaciones científico-tecnológicas aliadas al desarrollo económico poseen la capacidad de realizar intensas y rápidas transformaciones en el modo de vida de la humanidad, al mismo tiempo en que se presentan nuevas situaciones y relaciones no previstas directamente en los ordenamientos jurídicos de todo el mundo, se exige cada vez más del aplicador del Derecho una decisión político-jurídica, o sea, una opción por valores fundamentales contemplados en las normas: los principios.

La palabra principio denomina inicio, comienzo, fuente, cimientos, punto de partida. En el plan jurídico, sin olvidar totalmente de su sentido etimológico, los principios consisten en enunciados fundamentales que condicionan y dan estructura al sistema, ya que le confieren unidad y coherencia.

De esta forma, cabe señalar la relevancia impar de los principios para el Derecho. Son ello auténticos vectores, líneas directivas, reglas maestras que orientan el intérprete en su actividad hermenéutica, eliminando eventuales antagonismos entre as normas jurídicas. Sirven, aún, como importante instrumento en la materialización de una orientación sensata, eficaz y útil a la sociedad por ocasión de la subsunción del hecho a la ley, además de constituir fuentes basilares para cualquier rama del derecho, influyendo tanto en su formación como en su aplicación.

Los principios son reverenciados como bases o pilares del ordenamiento jurídico sin que a esta veneración sean agregados elementos que permitan mejor comprenderlos y aplicarlos, razón por la que se inicia el presente estudio tejiendo consideraciones importantes sobre ellos.

Toda forma de conocimiento, para que sea reconocida como ciencia o saber filosófico autónomo, debe poseer metodología de pesquisa propia, objeto de estudio auténtico y, lógicamente, traer contribuciones inéditas o, al menos, con enfoque diferenciado. 
Además, cada conocimiento científico debe estar consolidado por principios propios, que serían proposiciones básicas, admitidas como verdaderas y, por ello, capaces de legitimar otras informaciones y orientar la producción de nuevos saberes. Miguel Reale define tales principios como: "[...] ciertos enunciados lógicos admitidos como condición o base de validad de las demás afirmaciones que componen determinado campo del conocimiento. [...] Restringiéndonos al aspecto lógico de la cuestión, podemos decir que los principios son "verdades estructurales" de un sistema de conocimiento, como tales admitidas, por ser evidentes o por haber sido comprobadas, pero también por motivos de orden práctico de carácter operacional, es decir, como presupuestos exigidos por las necesidades de la investigación y de la praxis ${ }^{245}$.

José Joaquim Gomes Canotilho ${ }^{246}$, definiendo los principios jurídicos, añade la idea de que ellos poseen dos dimensiones, una constitutiva, una vez que ellos expresan, indican, denotan o constituyen una comprensión global del ordenamiento positivado; y otra declarativa, porque, en muchos casos, los principios asumen el carácter de súper conceptos, utilizados para denotar la suma de otros principios o de orientaciones comportamentales naturalmente reconocidas.

Reale $^{247}$ al tratar de los principios científicos como un todo, los clasifica como: omnivalentes, que son los válidos para todas las formas de conocimiento, como los principios de identidad; plurivalentes, que corresponden a los aplicables a varios campos de conocimiento, como la causalidad, ampliamente empleada en el seno de las ciencias naturales; y monovalentes, que corresponden a aquellos válidos solamente en el ámbito de una ciencia determinada, como los principios generales de derecho y los principios específicos de cada rama jurídica.

Los principios monovalentes del derecho no se ocupan solamente de conferir seguridad y validad científica a la Ciencia Jurídica, como lo hacen algunos enunciados de otras ramas del conocimiento. Ellos presentan otras funciones de elevada relevancia, como determinar la actuación del Estado y las exigencias sociales direccionadas a ello y al Judicial y dar al sistema jurídico un sentido harmónico, lógico, racional y coherente.

\footnotetext{
${ }^{245}$ REALE, Miguel. Lições preliminares de direito. $21^{\mathrm{a}}$ ed. São Paulo: Saraiva, 1994, p. 299.

${ }^{246}$ Apud LEITE, José Rubens Morato. Dano ambiental: do individual ao coletivo, extrapatrimonial. São Paulo: Revista dos Tribunais, 2000. p. 46.

${ }^{247}$ REALE, Miguel. Lições preliminares de cit., p. 300.
} 
Ellos también son empleados en la realidad práctica del Derecho, desempeñando importante papel en la supresión de lagunas jurídicas, siendo aplicados en la solución de casos e hipótesis no previstos por el derecho positivo.

Además de la integración del Derecho Positivo, los principios de esta ciencia también ayudan la comprensión del conocimiento, condicionando y orientando el estudio y la aplicación de los institutos existentes y orientando la elaboración de nuevas normas. Ellos son, así, empleados tanto en las investigaciones, como en las actualizaciones y en la actuación práctica de este vasto campo del conocimiento científico, pasando a integrarlo de forma efectiva. Miguel Reale refuerza esta naturaleza diferenciada de los principios jurídicos afirmando que: “[...] los principios generales de Derecho no son preceptos de orden moral o económica, sino esquemas que se insieren en la experiencia jurídica, convirtiéndose, de este modo, en elementos componentes del Derecho" $^{248}$.

De esta forma, cabe recordar y resaltar que los principios son normas-claves de todo el sistema jurídico, debiéndose reconocer su superioridad y hegemonía ante las reglas, ya que representan el derecho en toda su extensión, sustancialidad, plenitud y abarcamiento, marcados por extensa carga valorativa.

Los principios no deben ser vistos, por lo tanto, como fuentes supletorias del derecho, sino como fundamento del orden jurídico, puntos de optimización situados en la cumbre de la escala normativa, sirviendo para dar legitimidad a las reglas.

Reale añade, aun, que algunos principios se revisten de gran importancia, siendo transformados en texto legal por los legisladores. Asumen, de esta forma, fuerza coercitiva y pasan a constituir modelos jurídicos, sin sufrir alteración de su sustancia. Pero los principios que no son positivados no dejan de ser relevantes. Son contemplados y consolidados por la doctrina, asumiendo la forma de modelos doctrinarios o dogmáticos fundamentales. ${ }^{249}$

Es importante observar que, aunque importantes e integrantes del sistema jurídico, los principios no se confunden con las reglas establecidas, diferenciación que Canotilho $^{250}$, hace de forma estupenda al decir que "Los principios son standards

\footnotetext{
${ }^{248}$ REALE, Miguel. Lições preliminares de cit., p. 301.

${ }^{249}$ REALE, Miguel. Lições preliminares de cit., p. 301.

${ }^{250}$ Apud LEITE, José Rubens Morato. Dano ambiental: cit., p. 44.
} 
jurídicamente vinculantes, radicados en las exigencias de justicia o en la idea de derecho; las reglas pueden ser norma vinculantes con contenido meramente funcional".

Los principios generales de Derecho, en la calidad de monovalentes, se aplican exclusivamente al estudio y a la práctica jurídica. Pero, delante de la amplitud del Derecho y de las varias ramas en ello existentes, hay aquellos principios que se aplican sólo a determinadas áreas, de acuerdo con su especificidad. Es el caso de los principios que instruyen el Derecho Ambiental, que fundamentan y sistematizan, amparando su consolidación como rama autónoma de la Ciencia Jurídica, pero, en razón del objeto específico y de la existencia de determinados institutos diferenciados, no pueden ser aplicados a otras áreas del Derecho.

Los principios ambientales se encuentran, pues, en el ordenamiento jurídico patrio, con la función de orientar la actuación del legislador y de los poderes públicos en la concreción y cristalización de los valores sociales relativos al medio ambiente, armonizando las normas del ordenamiento ambiental, direccionando su interpretación y la aplicación y resaltando, definitivamente, la autonomía del Derecho Ambiental.

Siendo así, para que el Derecho Ambiental tenga aplicabilidad y efectividad, es de capital importancia que, además de la ciencia de las leyes y de las demás legislaciones ambientales, sean del sentido común sus principios fundamentales, porque son estas las normas de valor genérico que orientan su comprensión, aplicación e integración al sistema jurídico como un todo, estando tales principios positivados o no. Por este aspecto, el Derecho Ambiental no decepciona, ya que, a pesar de nuevo, presenta principios bien definidos y ya consolidados por notable doctrina.

La Edad Media, en el plan del derecho, se caracterizaba por una variedad de órdenes jurídicas, lo que causaba instabilidad en los aspectos político, económico y social, generando la necesidad de orden y autoridad.

El referido Estado Medieval dio lugar a un nuevo orden, el Estado Moderno, en el que se buscó la unidad, caracterizada por un poder soberano, supremo, dentro de una delimitación territorial. Oportuno decir que uno de los elementos esenciales para la existencia de tal Estado fue o elemento formal, que se daba a través del vínculo jurídico, donde las personas encontraban su unidad en la forma del derecho, estableciendo, así, la relación entre el Estado y las personas. 
En esta fase, las normas eran impuestas bajo el pretexto de que habría el beneficio individual con su otorga. Con eso, los teóricos pasaran a construir una forma de proteger las personas contra la agresión que cada uno podría sufrir.

Al final del siglo XVIII el racionalismo sistemático dio lugar al positivismo jurídico, que pasó a ser concebido como aquél puesto por la autoridad en contraposición al Derecho natural, siendo cada vez más escrito, incluso por la gran producción de leyes y sistematización de las costumbres.

Delante del expuesto, la ley pasaba a ser la principal fuente del derecho, que era caracterizado como siendo un sistema normativo, que atendía a las necesidades de seguridad de las personas, sustituyendo el arbitrio de las decisiones.

Por lo tanto, el Derecho puesto, establecido por el Estado ante una visión dogmática, pasa a ser un conjunto de normas, instituciones y decisiones que el jurista debe interpretar.

El positivismo, según Wagner Antônio Alves ${ }^{251}$, torna relevante la comprensión del significado de norma jurídica, teniendo en cuenta que la norma define lo que debe ser, estableciendo al hombre la manera como debe conducirse. Informa aun que determinados hechos tendrán relevancia jurídica cuando las normas le adjudicaren tal relevancia, y que el conjunto de reglas que deben ser seguidas por el hombre, cuando establecidas por el Estado, forman el ordenamiento jurídico.

Con relación al sistema normativo, cumple tejer algunas consideraciones acerca de la discrecionalidad. Durante el siglo XX fue protagonizada gran discusión sobre la posibilidad del juez utilizar o no la discrecionalidad en sus decisiones. Algunos estudiosos defendían el juicio conforme el texto exacto de la ley, temiendo la interpretación judicial e imposición arbitraria de la norma de acuerdo con el antiguo régimen absolutista, como fue el ejemplo del Código de Napoleón, que vedaba a los jueces la posibilidad de interpretar la legislación. En el mismo sentido fue seguido por diversos Códigos Iluministas, dando origen a la fase llamada normativista o mecanicista.

En reacción a los referidos argumentos, la reacción realista proponía que la aplicación del Derecho no podría ser tan fría y mecánica, al contrario de lo que defendía la corriente normativista. Defendía, de esta forma, que el derecho buscase fuera del

\footnotetext{
${ }^{251}$ ALVES, Wagner Antônio. Princípios da precaução e da prevenção no direito ambiental cit., p. 9.
} 
ordenamiento las soluciones posibles para los casos en que no se tuviesen decisiones anteriormente concebidas.

En medio al referido dilema, Herbert Hart consideró que "las decisiones judiciales, siendo resultado de un ser humano venían cargadas de prejuicios, que eran oriundas del juez que estaba insertado en una sociedad" 252 , no exigiendo del magistrado gran esfuerzo, visto que sólo repetía la jurisprudencia en los casos dentro de los patrones. En las hipótesis en que hubiese diferencia del presentado por la norma, el juez podría elegir diversas opciones fornecidas por el ordenamiento.

Delante de la teoría establecida por Hart, Ronald Dworkin, aún en la década de 60 del siglo pasado, afirmó que "la decisión judicial no tiene margen para la discrecionalidad, debiendo utilizar elementos que en realidad no están fuera del sistema jurídico, sino a ello son inherentes". 253

Con tal afirmación el autor estaba refiriéndose a los principios, visto que ellos se encontraban en el ordenamiento jurídico de forma que los jueces, al utilizarlos como criterios, no actúan con discreción, sino dentro del propio ordenamiento.

Así siendo, no hay que hablar en discrecionalidad en la decisión adoptada por el juzgador, sino en la utilización de criterios puestos por el derecho cuando la norma o la ley no ofrece condiciones de juzgar. Los criterios que deben ser utilizados son los principios jurídicos, que se caracterizan como normas que, por prescribir fines para ser alcanzados, sirven de fundamento para la aplicación del ordenamiento constitucional.

Normas, por su parte, son los sentidos construidos a partir de la interpretación sistemática de textos normativos, siendo que un dispositivo puede resultar en varias interpretaciones $\mathrm{y}$, por lo tanto, varias normas $\mathrm{y}$, al contrario, varios dispositivos pueden ser necesarios para la elaboración de una única norma.

Según Humberto Ávila: "Es justamente porque las normas son construidas por el intérprete a partir de los dispositivos que no se puede llegar a la conclusión de que este o aquél dispositivo contiene una regla o un principio. Esa cualificación normativa depende de conexiones axiológicas que no están incorporadas al texto ni le pertenecen, pero son, antes, construidas por el propio intérprete. Esto no significa, como ya afirmado, que el intérprete es libre para hacer las conexiones entre las normas y los fines a cuya realización ellas sirven. El ordenamiento jurídico establece la realización de

\footnotetext{
${ }^{252}$ ALVES, Wagner Antônio. Princípios da precaução e da prevenção no direito ambiental cit., p. 14. ${ }^{253}$ ALVES, Wagner Antônio. Princípios da precaução e da prevenção no direito ambiental cit., p. 14.
} 
fines, la preservación de valores y el mantenimiento o la búsqueda de determinados bienes jurídicos esenciales a la realización de aquellos fines y a la preservación de estos valores. El intérprete no puede despreciar estos puntos de partida. Exactamente por eso la actividad de interpretación traduce mejor una actividad de reconstrucción: el intérprete debe interpretar los dispositivos constitucionales de forma que explique sus versiones de significado de acuerdo con los fines y los valores esbozados en el lenguaje constitucional"254.

\subsection{Los principios como normas jurídicas: estructura normativa del} principio y diferencias entre reglas y principios

En primer lugar es importante hacer algunas consideraciones acerca del concepto de norma jurídica y de la ya reconocida fuerza normativa de los principios, además de las distinciones entre principios y reglas en cuanto especies normativas.

Estudiando el tema, Paulo Bonavides afirma que la juridicidad o normatividad de los principios pasó por tres fases distintas: la iusnaturalista, la positivista y la postpositivista $^{255}$.

En la época de la Revolución Francesa, en la fase iusnaturalista, los principios, concebidos metafísicamente, tenían normatividad "básicamente nula o dudosa" 256 , lo que contrastaba con el reconocimiento de su dimensión ético-valorativa inspiradora de los postulados de justicia.

Aunque en esta fase los principios inspirasen los axiomas jurídicos con el fin de inspirar a los ideales de justicia, no eran considerados como normas, sino como "un conjunto de verdades objetivas derivadas de la ley divina y humana"257.

En el inicio del siglo XIX hasta mediados del siglo XX, en la fase positivista, los principios pasaron a integrar los Códigos como "fuente normativa subsidiaria o,

\footnotetext{
${ }^{254}$ ÁVILA, Humberto. Teoria dos princípios da definição à aplicação dos princípios jurídicos. $5^{\mathrm{a}}$ ed., São Paulo: Malheiros Editores, 2006, pp. 34-35.

${ }^{255}$ BONAVIDES, Paulo. Curso de Direito Constitucional. 25a edição, Editora Malheiros, São PauloBrasil: 2009, p. 232.

${ }^{256}$ BONAVIDES, Paulo. Curso de Direito cit., p.232.

${ }^{257}$ BONAVIDES, Paulo. Curso de Direito cit., p. 234.
} 
según Gordillo Cañas, como 'válvulas de seguridad' que 'garanten el reinado absoluto de la ley ${ }^{258}$. Así, los principios no eran considerados como superiores a las leyes, sino que derivados, extraídos de ella, sin jamás sobreponerla, para cubrir los vacíos normativos que la ley no ha podido predecir ${ }^{259}$.

Por fin, en las últimas décadas del siglo pasado tuvo inicio la fase postpositivista, en la cual los principios conquistan la hegemonía axiológico-normativa en las nuevas Constituciones promulgadas, que los convierte en "pedestal normativo sobre el cual asienta todo el edificio jurídico de los nuevos sistemas constitucionales" 260 .

Desde la segunda mitad del siglo XX, el Derecho no más se encaja en el positivismo jurídico. El acercamiento entre Derecho y norma y su rígida separación de la ética no más correspondían a la etapa civilizatoria y a los intereses de quienes apoyaban las causas de la humanidad. Sin embargo, el discurso científico había impregnado el Derecho. Sus operadores no querían regresar al iusnaturalismo, a los fundamentos vagos, abstractos, o metafísicos de una razón subjetiva. Por lo tanto, el postpositivismo no surge con la intención de deconstruir, sino como una superación del conocimiento convencional. Nace guardando deferencia relativa al ordenamiento positivo, aunque en este reintroduciendo las ideas de justicia y de legitimidad ${ }^{261}$.

\footnotetext{
${ }^{258}$ Idem, p. 235.

${ }^{259}$ En la Lei de Introdução ao Código Civil brasileiro podemos observar un ejemplo de esa concepción en su art. $4^{\circ}$, que relaciona como una de las fuentes de integración, los principios generales de derecho.

${ }^{260}$ BONAVIDES, Paulo. Curso de Direito cit., p. 237.

${ }^{261}$ Además, Luís Roberto Barroso resume las ideas centrales del postpositivismo afirmando que este se presenta, en cierto sentido, como una tercera vía entre las concepciones positivista e iusnaturalista: no trata con insignificancia las demandas del Derecho por claridad, certeza y objetividad, todavía no lo concibe desconectado de una filosofía moral y de una filosofía política. Contesta, por lo tanto, el postulado positivista de separación entre Derecho, moral y política, no para negar la especificidad del objeto de cada uno de esos dominios, sino reconocer la imposibilidad de tratarlos como espacios totalmente segmentados, que no influyen mutuamente. Si es innegable la relación complementaria entre ellos, la tesis de la separación, que es central al positivismo y que dominó el pensamiento jurídico por muchas décadas, rinde homenaje a una hipocresía. Así, concluye que la doctrina postpositivista se inspira en la revalorización de la razón práctica, en la teoría de la justicia y la legitimidad democrática. En este contexto, pretende ir más allá de la estricta legalidad, pero no desprecia el derecho puesto; busca emprender una lectura moral de la Constitución y de las leyes, sin recoger a categorías metafísicas. En el rico y heterogéneo conjunto de ideas que buscan refugio en este paradigma en construcción, se incluyen
} 
El italiano Crisafulli afirmó categórica y precursoramente, en 1952, el carácter normativo de los principios, al conceptuarlos como toda norma jurídica, en cuanto considerada como determinante de una o muchas otras subordinadas, que la presuponen, desarrollando y especificando ulteriormente el precepto en direcciones más particulares (menos generales), de las cuales determinan, y por lo tanto resumen, potencialmente, el contenido: sean, por un lado, estas efectivamente puestas, sean, por otro lado, apenas deducibles del respectivo principio general que las contiene ${ }^{262}$.

Gracias a los trabajos de Crisafulli, Dworkin y Alexy, en la fase postpositivista, que los principios dejan de ser fuentes subsidiarias del Derecho (saliendo de los Códigos para las Constituciones), para se tornaren normas jurídicas vinculantes e imperativas, fuente primacial de todo el sistema normativo ${ }^{263}$.

Buscando sostener la fuerza normativa de los principios, Norberto Bobbio, estudiando la obra de Crisafulli los inserta en el concepto amplio de normas y afirma que los principios generales son apenas normas fundamentales o muy generales del sistema, las normas más generales. Los principios generales son normas como todas las demás, y esta afirmativa está basada en dos argumentos: i) si los principios son extraídos de las normas, a través de un procedimiento de generalización sucesiva, lógicamente es porque ellos también son normas, pues "si abstraigo especies animales obtengo siempre animales, y no flores o estrellas" ${ }^{264}$; ii) "los principios sirven al mismo fin para que sirven las demás normas, o sea, para regular un comportamiento no regulado",265.

la reentronización de los valores en la interpretación jurídica, con el reconocimiento de normatividad a los principios y de su diferencia cualitativa en relación a las reglas; la rehabilitación de la razón práctica y de la argumentación jurídica; la formación de una nueva hermenéutica; y el desarrollo de una teoría de los derechos fundamentales basada en la dignidad de la persona humana. Promoviendo así, en este ambiente, una reaproximación entre Derecho y ética. Fundamentos teóricos e filosóficos do novo direito constitucional brasileiro (pós-modernidade, teoria crítica e pós-positivismo). BARROSO, Luís Roberto (organizador). A nova interpretação constitucional: ponderação, direitos fundamentais e relações privadas. $2^{\mathrm{a}}$ edição, Editora Renovar, Rio de Janeiro-Brasil: 2006, p.1-48.

262 BONAVIDES, Paulo. Curso de Direito cit., p. 230.

${ }^{263}$ BONAVIDES, Paulo. Curso de Direito cit., p. 237-238.

${ }^{264}$ NORBERTO, Bobbio. Teoria do Ordenamento Jurídico. $10^{\mathrm{a}}$ edição, trad. Maria Celeste dos Santos, Editora Universidade de Brasília, Brasília-Brasil: 1999, p. 158.

${ }^{265}$ NORBERTO, Bobbio. Teoria do Ordenamento cit., p. 159. 
Por lo tanto, actualmente, no quedan dudas respecto al carácter normativo de los principios, de suerte que, siendo normas jurídicas, vinculan los comportamientos públicos y privados, obligando los destinatarios a seguir a sus comandos ${ }^{266}$.

Actualmente, existe unanimidad en el reconocimiento de los principios como normas jurídicas vinculantes de los comportamientos públicos y privados.

Esa fuerza normativa hace con que el aplicador del derecho, en el proceso de interpretación, considere, de antemano, los principios, como fuente de aplicación del derecho y tenga el deber de aplicarlos en los casos concretos. Con eso, los principios pasan a obligar comportamientos $\mathrm{y}$, hasta mismo, genera derechos subjetivos, además, pueden pasar a ejercer innúmeras otras funciones importantes en los ordenamientos jurídicos, dependiendo de su densidad normativa.

Para la "teoría de los principios", el modelo analítico que mejor responde a las necesidades de interpretación y aplicación de las normas constitucionales es aquel que torna la norma como genero del cual las reglas y principios son especies ${ }^{267}$.

Como ya se ha señalado, "norma" se difiere del "enunciado normativo" (texto normativo, disposición legal, texto de ley), ya que es el significado que de este se extrae y este, a su vez, es el conjunto lingüístico elegido por el legislador para la formación del texto legal.

Así, de un enunciado normativo es posible extraerse uno o varios significados (normas) que tendrán o la estructura de regla o la estructura de principio. Esas dos formas, regla y principio, son especies de normas, pues ambas dicen con el "deber ser" y pueden ser formuladas con base en expresiones deónticas básicas como la prohibición, la permisión y el mandamiento ${ }^{268}$. Siendo, por lo tanto, un modelo de estructura normativa con dos niveles diversos: el nivel de las reglas y el nivel de los principios.

\footnotetext{
${ }^{266}$ Además, Ruy Samuel Espíndola, Conceito de Princípios Constitucionais: elementos teóricos para uma formulação dogmática constitucionalmente adequada. Editora Revista dos Tribunais, São PauloBrasil: 1998, p. 55, añade que este carácter de norma es predicado no sólo de los principios positivos, sino también de los principios generales de Derecho, reconociendo así, normatividad no sólo a los principios que son expresa y explícitamente, contemplados en el centro de la orden jurídica, sino también a los que, provienen de su sistema, son anunciados por la doctrina y descubiertos en el acto de aplicar el Derecho.

${ }^{267}$ Para una exposición y criticas del modelo puro de reglas o del modelo puro de principios, vide Robert Alexy, Teoría de los derechos fundamentales, traducción de Ernesto Garzón Valdés. Op. cit., 2002, pp. 115-128. Para la exposición del autor sobre el modelo regla/principios, vide, op. cit., pp.129-138.

${ }^{268}$ Robert Alexy, Teoría de los derechos cit., p. 83.
} 
Los principios son normas jurídicas, poseyendo, así, "positividad, vinculatividad, carácter obligatorio" y que comportan "eficacia positiva y negativa sobre comportamientos", contribuyendo para la "interpretación y aplicación de otras normas, como las reglas y otros principios derivados de principios de generalización más abstractas"

El reconocimiento de la eficacia normativa de los principios, los cuales son dotados de mayor densidad valorativa, es consecuencia de la posmodernidad, que demanda un conjunto normativo más flexible y abierto a la subjetividad del aplicador del Derecho. Ya las reglas, dotadas de reducida carga valorativa, no realizan los anhelos de justicia y legitimidad de una sociedad en cuya estructura social vacilan las certezas existenciales y se multiplican las incertidumbres ético-filosóficas. En ese contexto, los principios realizan simultáneamente la reflexión acerca de los deberes de los individuos y la regulación de la vida social, razón por la cual se exige del hermeneuta jurídico el recorrido de un camino más largo entre la aplicación del principio y la realización de la justicia en el caso concreto, a través de la argumentación y de la motivación más elaborada de sus $\operatorname{actos}^{270}$.

Un examen más detallado de la estructura de cada una de esas especies de norma es importante para una mejor comprensión de las diferencias entre los dos niveles, de las reglas y de los principios, y su importancia para el trabajo.

Según la doctrina mayoritaria, los principios y reglas se encuadran en el genero de las normas jurídicas, y desde entonces, diversos criterios (algunos más consistentes que otros) son presentados para hacer una distinción, que ni siempre es precisa, de esas dos especies.

En este trabajo, con una presentación concisa, esperamos contribuir para que se tenga una idea de las diferencias existentes entre ambas especies de norma.

\footnotetext{
${ }^{269}$ ALEXY, Robert. Teoría de los derechos cit., p. 55.

${ }^{270}$ ASSIS, Wilson Rocha. A Normatividade dos princípios e a pós modernidade. Disponible en: $<$ http://jus2.uol.com.br/doutrina/texto.asp?id=8212> acceso: 20-05-2015.
} 


\subsection{Principios y reglas según Ronald Dworkin}

Para Dworkin la diferenciación entre regla y principio, involucra dos distinciones: la primera de naturaleza lógica, que afirma que "las reglas son aplicables en la forma de todo o nada. Dados los hechos que una regla estipula, entonces o la regla es válida, y en este caso la respuesta que ella ofrece debe ser acepta, o no es válida, y en este caso en nada contribuye para decisión" ${ }^{271}$; la segunda, consecuencia de la primera, de dimensión de peso o de importancia ${ }^{272}$.

De este modo, si la regla jurídica es válida, ocurrido determinado hecho que se encuadra en regla, debe ser esta aplicada. Caso contrario, es inválida y, por lo tanto, no aplicable $^{273}$. Eso da a la regla un carácter más radical de cumplimiento o de incumplimiento.

En contrapartida, las reglas pueden traer excepciones, y para que se tenga una mayor precisión en las reglas, estas deberán enumerar todas las excepciones, puesto que: "Si la lista de las excepciones es demasiado larga, sería demasiado torpe repetirla cada vez que la regla fuera citada; todavía, en teoría no hay razón que nos prohíba de incluirlas y cuanto más sean, más exacto va a ser el enunciado"274.

Ya los principios, al contrario de las reglas, pueden no ser aplicados y, ni por eso, dejan de ser válidos. Aunque puedan no aplicarse a un determinado caso, por fuerza de otro principio, siguen válidos, y así, pueden ser aplicados en casos futuros, vez que no se aplican a la manera del todo o nada. Eso significa que un principio no anula el otro, diferentemente de las reglas ${ }^{275}$. En la colisión entre principios, los mismos no pueden entrar en contradicción porque no califican jurídicamente una conducta como lícita o ilícita, apenas consagran un valor. La calificación de una conducta por los principios sólo ocurrirá en el caso concreto, y como resultado de una ponderación entre ellos.

\footnotetext{
${ }^{271}$ DWORKIN, Ronald. Levando os direitos à sério. Trad. Nelson Boeira. Editora Martins Fontes, São Paulo-Brasil: 2002, p. 39.

${ }^{272}$ DWORKIN, Ronald. Levando os direitos cit., p. 38.

${ }^{273} \mathrm{El}$ autor ejemplifica: "Si la exigencia de tres testigos es una regla jurídica válida, ningún testamento va a ser válido cuando firmado por dos testigos". DWORKIN, Ronald. Levando os direitos cit., p. 40.

${ }^{274}$ Idem, p. 40.

${ }^{275}$ Idem, p. 41.
} 
Eso está relacionado con la segunda diferencia apuntada por Dworkin, como consecuencia de la primera, los principios poseen una dimensión de peso o importancia, que sólo ellos tienen, las reglas no ${ }^{276}$.

Establecer una prevalencia, además cuando está en cuestión una duda respecto a la legalidad del procedimiento no es una tarea fácil. Sin embargo, necesario se hace el esfuerzo por parte del Administrador para evaluar y armonizar los principios mismo en la prevalencia de uno sobre el otro, precedencia esta, que sólo en el caso concreto podrá ser determinada ${ }^{277}$.

Por cierto, esta ponderación no puede ser una mensuración exacta y el juzgamiento que determina que un principio o una política particular sea más importante que otra, va a ser a menudo, objeto de controversia ${ }^{278}$.

Además, las excepciones a la aplicabilidad de los principios no son susceptibles de enumeración taxativa, en si considerando que eso no iba a contribuir para un enunciado más exacto o completo del principio $^{279}$.

Ya los conflictos entre reglas, al contrario de los principios, no son resueltos por la ponderación, sino que por la aplicación a manera del todo o nada, puesto que, cuando ocurre, una de las reglas no es válida y por tanto, no puede ser aplicada ${ }^{280}$.

Por otro lado, el sistema jurídico debe buscar solucionar esos conflictos, haciendo uso de otras reglas para resolverlos, una vez que, si dos reglas entran en conflicto, una de ellas no puede ser válida. La decisión de saber cual de ellas es válida y cual debe ser abandonada o reformulada, deberá ser tomada recorriéndose a consideraciones que están más allá de las propias reglas ${ }^{281}$.

\footnotetext{
${ }^{276}$ DWORKIN, Ronald. Levando os direitos cit., p. 42. Constitucionales, Madrid-España: 1998, p. 131.

${ }^{278}$ DWORKIN, Ronald. Levando os direitos cit., p. 42.

${ }^{279}$ DWORKIN, Ronald. Levando os direitos cit., p. 41.

${ }^{280}$ Idem, p. 43.

${ }^{281}$ Idem, p. 43.
}

${ }^{277}$ En ese sentido, Alfonso García FIGUEROA comenta que la diferencia entre regla y principio está en la actuación o no del operador del derecho, pues: "mientras que los principios suelen reclamar la intervención activa del operador jurídico, las reglas no la exigen o bien lo hacen sólo en menor medida". Los principios abren camino a una teoría de argumentación jurídica, que el aplicador del derecho debe desarrollar. FIGUEROA, Alfonso García. Principios y positivismo jurídico - El no positivismo principialista en las teorías de Ronald Dworkin y Robert Alexy. Centro de Estudios Políticos y 
Un sistema jurídico puede regular esos conflictos a través de otras reglas que dan prioridad a la regla promulgada por la autoridad de grado superior, a la regla que más recientemente fue promulgada, a la regla más especifica o otra cosa de ese genero. Un sistema jurídico puede preferir la regla que es sostenida por los principios más importantes $^{282}$.

\subsection{Principios y reglas según Robert Alexy}

Para Alexy, la distinción entre principios y reglas "constituye la base de la fundamentación iusfundamental y es una clave para la solución de problemas centrales de la dogmática de los derechos fundamentales"283.

Haciendo una búsqueda entre los más diversos autores sobre la distinción entre principios y reglas, ponderando que lo más utilizado es el de la "generalidad" - los principios son normas con alto grado de generalidad, al paso que las reglas tienen bajo grado de generalidad $^{284}$.

Además, afirma que: “A menudo, no se contraponen regla y principio sino norma y principio o norma y máxima. (...) Tanto las reglas como los principios son normas porque ambos dicen lo que debe ser. Ambos pueden ser formulados con la ayuda de las expresiones deónticas básicas del mandato, la permisión y la prohibición. Los principios, al igual que las reglas, son razones para juicios concretos de deber ser, aun cuando sean razones de un tipo muy diferente. La distinción entre reglas y principios es pues una distinción entre dos tipos de normas"285.

No obstante, sostiene la tesis de que entre las reglas y principios la distinción existente no es sólo de grado, sino también y, principalmente, cualitativa. Considera para tanto, los principios como mandatos de optimización, que pueden ser cumplidos en diversos grados, de acuerdo con las posibilidades reales y jurídicas.

\footnotetext{
${ }^{282}$ Idem, p. 43.

${ }^{283}$ ALEXY, Robert. Teoría de los derechos cit., p. 81.

${ }^{284}$ ALEXY, Robert. Teoría de los derechos cit., p. 83-84. Los demás criterios, según el autor, son los de la determinabilidad de los casos de aplicación, la origen, el carácter explícito del contenido valorativo, el de la relación con la idea de derecho o con la ley jurídica suprema.

${ }^{285}$ ALEXY, Robert. Teoría de los derechos cit., p. 83.
} 
Así, en sus palabras: "El punto decisivo para la distinción entre reglas y principios es que los principios son normas que ordenan que algo sea realizado en la mayor medida posible, dentro de las posibilidades jurídicas y reales existentes. Por lo tanto, los principios son mandatos de optimización, que están caracterizados por el hecho de que pueden ser cumplidos en diferente grado y que la medida debida de su cumplimiento no sólo depende de las posibilidades reales sino también de las jurídicas. El ámbito de las posibilidades jurídicas es determinado por los principios y reglas opuestos",286.

Además, añade el autor que la diferencia entre principios y normas va a ser siempre desde el aspecto cualitativo, y no sólo haciendo referencia a una graduación entre ambos. Mientras los principios son: "mandatos de optimización, que están caracterizados por el hecho de que pueden ser cumplidos en diferente grado (...). Las reglas son normas que sólo pueden ser cumplidas o no. (...) Toda norma es o bien una regla o un principio" 287 .

Así, las reglas son normas que pueden ser cumplidas o no. Siendo una regla válida, debe hacerse exactamente lo que ella exige. Ni más ni menos.

Eso porque las reglas contienen determinaciones que son jurídica $y$ fácticamente posibles, lo que corrobora la tesis de que la diferencia entre reglas y principios es cualitativa y no de grado ${ }^{288}$.

Para Alexy, la distinción entre reglas y principios se presenta con mayor claridad cuando ocurre una colisión de principios o un conflicto de reglas ${ }^{289}$.

Si los contenidos de ambas las reglas son totalmente exclusivos, la regla inaplicable será declara inválida, debiendo ser excluida del ordenamiento. $\mathrm{Si}$, por su vez, la incompatibilidad es apenas parcial en sus consecuencias jurídicas, puede ser formulada una "cláusula de excepción" en una de ellas.

Un conflicto de reglas sólo admite una de las siguientes soluciones: i) declaración de invalidad de una de las reglas; ii) introducción de una cláusula de excepción que elimine el conflicto ${ }^{290}$.

\footnotetext{
${ }^{286}$ ALEXY, Robert. Teoría de los derechos cit., p. 86.

${ }^{287}$ Idem, p. 87.

${ }^{288}$ Idem, pp. 86-87.

${ }^{289}$ Idem, p. 87.

${ }^{290}$ Idem, p. 88.
} 
Ejemplos para esas dos situaciones pueden ayudar en la comprensión. La construcción de una "cláusula de excepción" para la solución de conflictos entre reglas puede ser encontrada en la previsión constitucional de inviolabilidad de la casa (art. $5^{\circ}$, inciso XI de la $\mathrm{CF} / 88$ : "a casa é asilo inviolável do indivíduo, ninguém nela podendo penetrar sem consentimento do morador, salvo em caso de flagrante delito ou desastre, ou para prestar socorro, ou durante o dia, por determinação judicial" y art. 18.2 de la CE/78: "El domicilio es inviolable. Ninguna entrada o registro podrá hacerse en él sin consentimiento del titular o resolución judicial, salvo en caso de flagrante delito"). En esa previsión constitucional hay una primera parte que se aplica definitivamente, cual sea, "a casa é asilo inviolável do indivíduo, ninguém nela podendo penetrar sem consentimento do morador" y "El domicilio es inviolable. Ninguna entrada o registro podrá hacerse en él sin consentimiento del titular". El constituyente, al hacerlo, buscó proteger, de forma definitiva, de violaciones públicas y particulares, el derecho del individuo a su privacidad e intimidad. Sin embargo, este mismo constituyente creó una "cláusula de excepción" para aquella regla con la finalidad de compatibilizar aquel derecho subjetivo con otros intereses colectivos (i) de evitar el cometimiento de crimen (situación de flagrancia), (ii) de mantener la integridad física o patrimonial en casos de desastres, (iii) de garantizar la prestación de socorro o, aun, (iv) de dar cumplimiento a orden judicial ("por determinação judicial" y "resolución judicial"). Así, en este último caso, fue claro al excepcionar la regla de la inviolabilidad apenas en el período diurno. Con la redacción elegida, ya en nivel constitucional, hubo la creación de una "cláusula de excepción" capaz de compatibilizar las reglas (de derecho a la inviolabilidad y de un no-derecho a la inviolabilidad en una situación específica. Así, delante del caso concreto, cabrá decidir cual regla será aplicada, la regla general de inviolabilidad, o la regla correspondiente a la cláusula de excepción" expuesta en las situaciones (i, ii, iii, iv) citadas. Ya en la segunda hipótesis, aquella en que el conflicto entre reglas produce una incompatibilidad total y, por lo tanto, genera la invalidad de la regla declarada inaplicable, tómese como ejemplo el choque entre el párrafo único del artículo 186 del Código de Processo Penal, después de la redacción emprendida por la Ley n. ${ }^{\circ}$ 10.792/2003 (art.186 y su párrafo único: “Art. 186. Depois de devidamente qualificado e cientificado do inteiro teor da acusação, o acusado será informado pelo juiz, antes de iniciar o interrogatório, do seu direito de permanecer calado e de não responder perguntas que lhe forem formuladas. Parágrafo único. O silêncio, que não importará em confissão, não poderá ser interpretado em prejuízo da defesa”) y el art. 198 del mismo diploma legal, conforme su redacción original desde 1940, determina el art. 198: “Art. 198. O silêncio do acusado não importará em confissão, mas poderá constituir elemento para a formação do convencimento do juiz". Con la inserción del parágrafo único en el citado art. 186 y na no revocación expresa de la segunda parte del art. 198 surge una incompatibilidad total entre las reglas que rigen un mismo punto de la vida. $\mathrm{O}$ apenas el parágrafo único es el válido, ocurriendo perdida de la validad de la referida parte del art. 198, o es esta que debe prevalecer, declarándose el parágrafo único inválido y, por lo tanto, fuera del sistema. Así, la incompatibilidad total siempre va a generar una necesidad de elegir una de las reglas en el conflicto. Definida la incompatibilidad total de las consecuencias jurídicas, el intérprete deberá proceder a la exclusión de una de las dos reglas del ordenamiento jurídico. Para determinarse, en las situaciones concretas, cuál de las dos reglas debe prevalecer, la "teoría de los principios" echa mano de reglas de solución de antinomias como lex posterior 
Diferentemente, cuando ocurre una colisión de principios, el caso no se soluciona con la perdida de validad de uno de ellos o con la introducción de una cláusula de excepción, sino a través de una ponderación de bienes e intereses, o sea, se resuelve por la creación de una "relación condicionada de precedencia"291.

La "relación condicionada de precedencia" es el resultado del método de aplicación de un principio en colisión con otro: el denominado sopesar o ponderar. El método de aplicación de sopesar siempre deberá tener en cuenta las condiciones fáticojurídicas de la contradicción que se quiere decir, son esas peculiaridades (los principios envueltos y la situación práctica conflictiva que se pretende resolver) que traen la idea de "condicionada" a esa "relación de precedencia". Su resultado, teniendo en cuenta las específicas “condiciones", determinará cual principio prevalecerá y en que medida habrá su precedencia (o prevalencia).

Tomándose una colisión apenas entre dos principios, se formula la siguiente "ley de colisión”: “(P1 P P2) C”292. Esa fórmula significa que el principio P1 prevalece - tiene precedencia - (P) sobre el principio P2, en las condiciones $\mathrm{C}^{293}$. Es en ese sentido que se acepta la afirmación de que un principio tenga más peso frente al otro, o

derogat legi priori, lex specialis derogat legi generali y lex superior derogat legi inferiori y, también, de la importancia de las reglas en conflicto, por ejemplo, si poseen jerarquía distintas (constitucional e infraconstitucional). En el citado ejemplo, está declarada la invalidad de la referida segunda parte del art. 198 no sólo por la regla lex posterior derogat legi priori como, también, y por otro sesgo argumentativo, porque la regla definida en el parágrafo único es la materialización infraconstitucional de las actuales normas constitucionales de la amplia defensa (art. $5^{\circ}$, inciso LV de la CF/88) y del derecho del imputado silenciar (art. $5^{\circ}$, inciso LXIII de la CF/88) y sería ilógico y una negación de la propia existencia de esos derechos fundamentales que de sus ejercicios pudiera venir cualquier forma de perjuicio para la esfera jurídica del ciudadano. De eso se extrae que siempre que existe un conflicto entre reglas, existe alguna forma de declaración de invalidad, sea por la formación de "cláusula de excepción" (invalidad parcial) sea por la invalidad total de una de ellas. Es en el plano de la validad que se resuelven los conflictos entre reglas. SILVA, Virgílio Afonso da. Direitos fundamentais: conteúdo essencial, restrições e eficácia. Editora Malheiros, São Paulo-Brasil: 2009, p. 49.

${ }^{291}$ ALEXY, Robert. Teoría de los derechos cit., p. 92.

${ }^{292}$ Las letras citadas en el texto y que determinan los elementos lógicos compositivos de la "ley de colisión" mantiene el criterio de Robert Alexy, eso, buscando auxiliar el lector en eventual estudio comparativo con la obra de ese autor ya tantas veces citada.

${ }^{293}$ ALEXY, Robert. Teoría de los derechos cit., pp. 92-93. 
sea, un principio gana peso mayor en relación al otro con el cual se entrechoque, siempre delante de las condiciones especificas ${ }^{294}$.

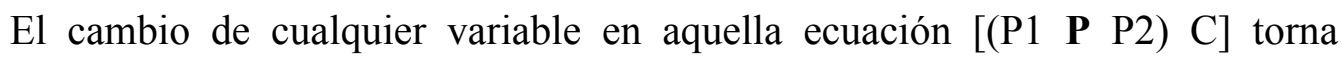
altamente probable el cambio de la "relación de precedencia". "Es posible - y probable - todavía, que en una situación C', sea el principio P2 que prevalece sobre el principio P1, o sea, (P2 P P1) C'. A pesar de tratarse, en los dos casos, de los mismos principios, no es posible formular, em abstracto, una relación de precedencia entre ellos. Esa relación es siempre condicionada a la situación concreta" 295 .

Por esa razón, es posible afirmar que la no prevalencia de un principio en un dado acto, hecho o posición jurídica no lo torna una norma inválida. El principio, desde que este formal y materialmente conforme los padrones iusfundamentales, siempre será válido ante ciertas condiciones casuísticas ${ }^{296}$. No se puede decir que el haya perdido la validad o que será retirado del sistema, una vez que podrá prevalecer si las condiciones cambiaren o si el principio colisión sea otro (P3, por ejemplo).

Para añadir un elemento importante en aquella fórmula ("ley de colisión"), se debe comprender que, a partir del instante en que se determine que el principio P1 tiene mayores razones para prevalecer sobre el principio P2, bajo aquellas condiciones factico- jurídicas específicas, se establece una consecuencia jurídica para el caso concreto: la consecuencia derivada del contenido de P1 (en el caso, el principio prevalece). Así, teniéndose $\mathrm{R}$ como la consecuencia jurídica derivada del principio precedente se tiene: "P1 P P2) $C \Rightarrow R$ "297, o, de una manera más sencilla: "C $\Rightarrow$ R". "Las condiciones bajo las cuales un principio precede a otro constituye el supuesto de hecho de una regla que expresa la consecuencia jurídica del principio precedente"298. El derecho/deber prima facie que está en la norma-principio prevalente (precedente), cuando se convierte en "derecho definitivo", o sea, cuando se aplica al caso después de

\footnotetext{
${ }^{294}$ Idem, pp. 89-90. El autor también afirmar que: "El principio P1 tiene, en un caso concreto, un peso mayor que el principio opuesto P2 cuando existen razones suficientes para que P1 preceda a P2, bajo las condiciones $\mathrm{C}$ dadas en el caso concreto" (op. cit., p. 93).

${ }^{295}$ SILVA, Virgílio Afonso da. Direitos Fundamentais: conteúdo essencial, restrições e eficácia. Editora Malheiros, São Paulo-Brasil: 2009, pp. 50/51.

${ }^{296}$ En ese sentido, vide Robert Alexy, Teoría de los derechos cit., pp. 89-91.

${ }^{297}$ Esa fórmula podría ser leída así: la prevalencia (P) del principio P1 sobre el principio P2, en las condiciones $\mathrm{C}$, determina la consecuencia jurídica $\mathrm{R}$, derivada de $\mathrm{P} 1$.

${ }^{298}$ ALEXY, Robert. Teoría de los derechos cit., p. 94.
} 
haber sopesado los principios, delante de las condiciones del caso, se torna una regla (“derecho definitivo") de consecuencias jurídicas determinadas para el caso específico y que serán integralmente aplicadas ${ }^{299}$. El derecho prima facie se torna derecho definitivo para el caso.

La dependencia constante de las condiciones fático-jurídicas del caso concreto para determinarse las consecuencias jurídicas impide que haya una "relación absoluta de precedencia". Esto es una idea esencial a la "teoría de los principios". El resultado de la "relación condicionada de precedencia", obtenido en dada situación, no garante que el siempre se repetirá caso las condiciones cambien. Por lo tanto, no es posible afirmar que aquella "relación 'condicionada' de precedencia" resultante se tornará una "relación 'absoluta' de precedencia"300.

Por más que se dé fuerza a una argumentación en favor de un principio o de un determinado tipo de principios $^{301}$, ellos no ganan, de antemano, tanto peso en la ponderación que lleguen a cambiar su estructura normativa para "derecho definitivo", o sea, no se transformarán en norma-regla. La ponderación casuística siempre será necesaria. No hay principios que, en el campo abstracto (en su previsión legal o en el campo racional de análisis para su efectivación), tenga su peso aumentado a tal punto que 'siempre' preceda (prevalezca) a los demás o a todo un grupo de principios de forma completa y para cualquier hipótesis concreta. No existe "relación absoluta de precedencia". Eso es la absolutización de los principios, argumento y resultado racional imposibles para la "teoría de los principios".

Aunque se crea una "regla de carga de la argumentación", eso no desobligaría a establecerse, en el caso concreto, las respectiva "condiciones" que van a influir en la "relación de precedencia". Cuando mucho, para expresar hipótesis de norma como

\footnotetext{
${ }^{299}$ En las palabras de Robert Alexy: "como resultado de toda ponderación iusfundamental correcta, puede formularse una norma de derecho fundamental adscripta con carácter de regla bajo la cual puede ser subsumido el caso". Idem, p. 98.

${ }^{300}$ En ese sentido, vide Robert Alexy, Idem, pp. 94-95.

${ }^{301}$ Además, Robert Alexy afirma que: "La decisión de incapacidad procesal ha mostrado que tanto las normas que conceden derechos fundamentales al individuo, como las que ordenan la persecución de intereses de la comunidad, pueden ser concebidas como principios. Es posible introducir una carga de argumentación en beneficio de los principios del primer tipo y en contra de los segundo, es decir, una carga de argumentación en beneficio de los bienes individuales y en contra de los bienes colectivos". Idem, p. 101.
} 
refuerzo argumentativo, podrá darse, apenas em caso de duda, una preferencia constitucional por un principio em relación a otro. Es en esa "preferencia argumentativa constitucional" sobre el proceso racional de ponderación que sobresale con mayor peso, específicamente, la dignidad de la persona humana. Importante dejar claro que: sobresalir no es imponerse de forma amplia y absoluta ${ }^{302}$.

Llevándose en consideración las circunstancias del caso, se establece entre los principios una relación de preferencia condicionada, verificándose cual principio tiene mayor peso, se aplica aquel, mediante la ponderación, que sea lo más adecuado ${ }^{303}$.

De todos modos, el principio que no fue aplicado a un determinado caso, no deja de tener validad, y puede incluso, ser aplicado en otras situaciones en detrimento del otro que antes tenía precedencia.

Un ejemplo formulado por el propio Alexy elucida mejor la cuestión: considerando una norma $\mathrm{N} 1$ y otra $\mathrm{N} 2$, se tiene que, si una de ellas siempre precede la otra, se verifica un conflicto de regla donde la norma N1 vigora salvo si ocurrir N2 (o vice-versa); al paso que, en el caso de colisión de principios, en determinados casos, se aplica la norma $\mathrm{N} 1$ y en otros la norma $\mathrm{N} 2^{304}$.

De eso se deduce que: a) não hay jerarquía de precedencia absoluta entre principios; b) los principios se refieren a situaciones o acciones que no son matemáticamente cuantificables.

Así, el problema del conflicto de reglas se resuelve en la dimensión de su validad, en cuanto lo de los principios, en la dimensión del valor ${ }^{305}$.

Como es intuitivo suponer, no hay apenas colisiones entre principios y conflictos entre reglas, pero, debido la complejidad normativa del sistema jurídico, también ocurren colisiones entre principios y reglas. Todavía, es necesario un mayor cuidado en ese caso de contradicción normativa, pues no es posible la aplicación pura y simple de los métodos anteriores de resolución de conflictos apenas entre reglas o de colisión apenas entre principios.

\footnotetext{
${ }^{302}$ Toda la idea expresa en este párrafo, incluso las expresiones en destaque, está em Robert Alexy, Teoría de los derechos cit., pp. 100-101.

${ }^{303}$ Idem, p. 90.

${ }^{304}$ Idem, p. 92.

${ }^{305}$ Idem, p. 92.
} 
El sopesar (ponderar), método de solución de la colisión de principios, muchas veces determina que una norma sea aplicada parcialmente, delante de las condiciones del caso, alejando en parte sus consecuencias jurídicas. Esa forma parcial de aplicación no sirve a las normas con estructura de "regla", pues o se la aplica como un todo, o no se la aplica ("método todo o nada"). En ese caso, el sopesar no se mostraría coherente con la "teoría de los principios", pues ponderar para aplicar la norma apenas de forma parcial o no aplicarla es negar la estructura no restringible concebida para la aplicación de las normas-reglas (aplicación "todo o nada").

En sentido contrario, la aplicación de la invalidad no se muestra coherente con la estructura concebida por aquella teoría para aplicación de las normas-principios. De tal solución resultaría la invalidad del principio y, con eso, lo tendría que retirar del ordenamiento, lo que inviabilizaría su aplicación en otras situaciones donde las condiciones fuesen diferentes o, aun, si estuviesen frente a otras normas a otras normas (principios y reglas) $^{306}$.

Comúnmente, esa especie de colisión ha sido resuelta por la percepción de que no se está frente a una "regla" propiamente dicha. Se afirma que subyace a la regla en choque con un principio P1 otro principio P2 que la justifica o la conforma. Para los que así comprenden, el método de resolución de la colisión vuelve a ser el "sopesar". Todavía, no el sopesar entre la regla y el principio P1 en colisión, sino entre este (P1) y el principio P2, que está "por detrás" de la norma-regla, subyace y da soporte a ella ${ }^{307}$. La ponderación, en ese caso, siempre se dará de manera aceptable y coherente, sin dañar la estructura y jerarquía normativas si ambos los principios fueren normas constitucionales dispuestas como derechos fundamentales ${ }^{308}$.

\footnotetext{
${ }^{306}$ En el sentido de rechazar la aplicación pura del método de la ponderación o de la aplicación "todo o nada" para la colisión entre principios y reglas, vide Virgílio Afonso da Silva, Direitos fundamentais: conteúdo essencial, restrições e eficácia, Op. cit., 2009, item 2.2.3.3.

${ }^{307}$ Esa forma de solución de la colisión es explicitada por Robert Alexy, Teoría de los derechos cit., p. 86, nota 24 y, de forma más completa, por Virgílio Afonso da Silva, Direitos fundamentais: cit., item 2.2.3.3.

${ }^{308}$ BOROWSKI, Martin. La estructura de los derechos fundamentales. Traducción de Carlos Bernal Pulido. Bogotá: Universidad Externato de Colombia, 2003 (Serie de Teoría Jurídica y Filosofía del derecho n. $\left.{ }^{\circ} 25\right)$, p. 81 y nota 137 , también indica esa forma de restricción de los principios por reglas y esclarece que, sólo cuando se visualiza que por detrás de la regla hay un principio que la forma y conforma, se puede entender cómo una norma constitucional (norma-principio) puede ser legítimamente
} 


\subsection{Principios y reglas según José Joaquim Gomes Canotilho}

Respecto al tema, Canotilho aduce sobre la complejidad de la definición y presenta algunos criterios para diferenciar reglas y principios: a) Grado de abstracción: los principios son normas con un grado de abstracción relativamente elevado; de modo diverso, las reglas poseen una abstracción relativamente reducida; b) Grado de determinabilidad en la aplicación del caso concreto: los principios, como son vagos y indeterminados, carecen de mediaciones precisas (del legislador, del juez), mientras las reglas son susceptibles de aplicación directa; c) Carácter de fundamentalidad en el sistema de fuentes de derecho: los principios son normas de naturaleza estructurante o con un papel fundamental en el ordenamiento jurídico debido a su posición jerárquica en el sistema de las fuentes (ej.: principios constitucionales) o a su importancia estructurante dentro del sistema jurídico (ej.: principio del Estado de Derecho); d) Proximidad de la idea de derecho: los principios son standards jurídicamente vinculantes radicados en las exigencias de "justicia" (Ronald Dworkin) o en la idea de derecho (Karl Larenz); las reglas pueden ser normas vinculantes con un contenido meramente funcional; e) Naturaleza normogenética: los principios son fundamento de reglas, esto es, son normas que están en la base o constituyen la ratio de las reglas jurídicas, desempeñando, por eso, una función normogenética de fundamento ${ }^{309}$.

Además, para Canotilho, la complejidad de la distinción entre principios y reglas deriva de dos cuestiones fundamentales: 1) saber cuál es la función de los

restringida por una regla infraconstitucional, eso ocurre, según ese autor, porque el principio que da soporte aquella norma-regla también posee jerarquía constitucional; luego, la ponderación podrá ser hecha entre los principios sin violación de la jerarquía normativa. En las palabras del autor: "En todo caso de restricción de un derecho fundamental por vía de una regla legal, esta tiene que estar sostenida por principios constitucionales. Esto explica igualmente como es posible la restricción de derechos fundamentales mediante las leyes. Si la restricción de un derecho fundamental proviene únicamente de la ley, dicha restricción no podría nunca ser legitima. Las libertades fundamentales están garantizadas por normas constitucionales. Una restricción que se realiza mediante normas legales de inferior jerarquía en la pirámide del ordenamiento jurídico, vulneraría el principio de la supremacía de la Constitución. Pero, si la restricción se basa materialmente en los principios constitucionales que la sustentan, se presenta formalmente una colisión entre normas de igual jerarquía que puede ser resuelta mediante ponderación" (op. cit., pp. 81-82). En ese sentido, vide Robert Alexy, Teoría de los derechos cit., pp. 272-276.

${ }^{309}$ CANOTILHO, J.J. Gomes. Direito Constitucional e Teoria da Constituição. $7^{\mathrm{a}}$ edição, Editora Almedina, Coimbra-Portugal: 2003, pp. 1160-1161. 
principios, o sea, si tienen una función retórico-argumentativa o si son simplemente normas de conducta; 2) saber si entre principios y reglas existe un denominador común, perteneciente a la misma "familia" y existiendo apenas una diferencia de grado (cuanto a la generalidad, contenido informativo, jerarquía de las fuentes, explicitación del contenido, contenido valorativo), o si, por el contrario, los principios y las reglas son susceptibles de una diferenciación cualitativa ${ }^{310}$.

Contestando la primera cuestión, Canotilho hace una distinción entre principios hermenéuticos, que desempeñan una función argumentativa y permiten a los jueces el desarrollo, integración y complementación del derecho, y los principios jurídicos que son verdaderas normas, y, por lo tanto, son "cualitativamente distintas de las otras categorías de normas, o sea, de las reglas jurídicas" ${ }^{\text {,311. }}$

Las diferencias cualitativas se reflejarán principalmente en los siguientes aspectos. Los principios son normas jurídicas impositivas de una optimización, compatibles con varios grados de concretización, conforme los condicionamientos fácticos y jurídicos; las reglas son normas que prescriben imperativamente una exigencia (imponen, permiten o prohíben) que es o no es cumplida (en los términos de Dworkin: applicable in all-or-nothing fashion); la convivencia de los principios es conflictual (Zagrebelsky), la convivencia de las reglas es antinómica; los principios coexisten, las reglas antinómicas se excluyen ${ }^{312}$.

Como consecuencia de eso, los principios permiten un equilibrio de valores e intereses, de acuerdo con su peso y con la ponderación de otros principios, no obedeciendo la "lógica del todo o nada" ("all or nothing"). Ya las reglas, no dejan espacio para cualquier otra solución, pues, si consideradas válidas, deben ser cumplidas en la exacta medida de sus prescripciones, ni más ni menos ${ }^{313}$.

Los conflictos de principios pueden ser resueltos mediante ponderación o armonización, pues ellos contienen "exigencias" o "standards" que, en prima facie, deben ser realizados; respecto a las reglas, es insostenible la validad simultanea de

\footnotetext{
${ }^{310}$ CANOTILHO, J.J. Gomes. Direito Constitucional e Teoria da cit., p. 1161.

${ }^{311}$ CANOTILHO, J.J. Gomes. Direito Constitucional e Teoria da cit., p. 1161.

${ }^{312}$ CANOTILHO, J.J. Gomes. Direito Constitucional e Teoria da cit., p. 1161.

${ }^{313}$ Idem, pp. 1161.
} 
reglas contradictorias ${ }^{314}$. Los principios son "derechos prima facie" y reglas son "derechos definitivos".

Vale añadir, que los principios suscitan problemas de validad y peso (importancia, ponderación, valor); las reglas colocan apenas cuestiones de validad (si ellas no son correctas deben ser alteradas) ${ }^{315}$.

Delante de una colisión entre principios y reglas, es que vamos a encontrar el campo de la interpretación constitucional, sin embargo, delante de la colisión de principios fundamentales, la mejor salida es buscar la ponderación de los bienes jurídicos en cuestión ${ }^{316}$.

Así, por el hecho de decir lo que "debe ser”, tanto principios como reglas están abarcados por el macroconcepto de norma y ambos son axiológicamente influenciados.

No hay distinción entre principios y normas, los principios son dotados de normatividad, las normas comprenden reglas y principios, la distinción relevante no es, como en los primordios de la doctrina, entre principios y normas, sino entre reglas y principios, siendo las normas el genero, y las reglas y los principios la especie $\mathrm{e}^{317}$.

\subsection{Principios jurídicos aplicables al agua. Consideraciones iniciales}

Toda forma de conocimiento filosófico o científico implica la existencia de principios, es decir, de ciertos enunciados lógicos aceptos como condición o base de validez de las demás aserciones que componen determinado campo del $\operatorname{saber}^{318}$.

Ya enseñaba Carlos Maximiliano que todo conjunto harmónico de reglas nada más es que el resumen, la síntesis, el substratum, de un complejo de altos dictados, el índice materializado de un sistema orgánico, la concretización de una doctrina, serie de

\footnotetext{
${ }^{314}$ Idem, pp. 1162.

${ }^{315}$ Idem, pp. 1162.

${ }^{316}$ PEREIRA, Rodrigo da Cunha. Princípios fundamentais norteadores do Direito de Família. Editora Del Rey, Belo Horizonte-Brasil: 2006, p. 35.

${ }^{317}$ BONAVIDES, Paulo. Curso de Direito cit., p. 255.

318 Además, en el entendimiento del jurista Miguel Reale, principios generales de derecho son enunciaciones normativas de valor genérico, que condicionan y orientan la comprensión del ordenamiento jurídico, sea para su aplicación e integración, sea para la elaboración de nuevas normas. Lições preliminares de direito. 22a Edição, Editora Saraiva, São Paulo-Brasil: 1995, pp. 299-300.
} 
postulados que reúnen principios superiores, constituyéndose en directivas ideales del hermeneuta $^{319}$.

Los principios nunca son suficientes por sí solos. El legislador no puede simplemente establecer principios en la forma de una lista de deseos, sin involucrarse en revisiones concretas. Más bien, él debe legislar área por área, proceso por proceso, con la finalidad de dar plena expresión a esos principios. Por lo tanto, los principios son, en primera instancia destinados a permitir que el legislador los dé vida, a través de leyes que los implementen ${ }^{320}$.

Llevándose en consideración la gran evolución internacional en el tema de aguas y sus reflejos en los derechos internos, no se puede dispensar una previa análisis de los principios aplicables a gestión hidrológica, incluso aquellos que están relacionados al medio ambiente.

Para que se busque la visión integral de todo el cuadro de principios abarcando el tratamiento jurídico de las aguas dulces, es inevitable que se recorra un camino que fluye del derecho internacional público para el derecho interno, haya visto que fue en el campo de las relaciones entre los Estados - en la realidad de la sociedad internacional que la mayoría de los principios hoy adoptados, en relación a los aspectos jurídicos de la gestión ambiental y hidrológica, fue desarrollada y asentado ${ }^{321}$.

\footnotetext{
${ }^{319}$ MAXIMILIANO, Carlos. Hermenêutica e aplicação do direito. 19a Edição, Editora Forense, Rio de Janeiro-Brasil: 2003, p.241.

${ }^{320}$ Ese es el entendimiento de Nicolas Sadeler. Environmental principles, modern and post-modern law, in Richard Macrory et all (eds.), Principles of European Environmental Law, Groningen, Europa Law Publishing, 2004, p. 32.

${ }^{321}$ Es ese el entendimiento de João Alberto Alves Amorim, que además, afirma que algunos de ellos están reflejados no solo en la Constitución Federal brasileña, sino también, en la legislación infraconstitucional que disciplina la tutela del medioambiente, especialmente en la Ley n. ${ }^{\circ}$ 9.433/97, que instituyó la Política Nacional de Recursos Hídricos. Direito das Águas: O Regime Jurídico da Água Doce no Direito Internacional e no Direito Brasileiro. Op. Cit., 2015, p. 31. Blanca Lozano Cutanda respecto a los principios y reglas de la política y el derecho para la protección del medioambiente labrados en el ámbito internacional afirma en su obra: "Del amplio cuerpo de acuerdos internacionales y otros instrumentos que conforman en la actualidad el derecho internacional ambiental, cuyos hitos fundamentales y líneas maestras acabamos de exponer, es posible deducir determinadas reglas y principios que tienen una aplicación general, en el sentido de que pueden ser considerados como expresivos de una pauta de comportamiento exigible a todos los miembros de la comunidad internacional y en relación a todos los aspectos atinentes a la protección del medioambiente. Estos principios y reglas labrados en el ámbito del
} 
Los principios, en la perspectiva del derecho internacional público para el derecho interno son: principio del derecho a una mejor calidad de vida, principio de ubicuidad, principio del uso equitativo e igualitario de los cursos de agua internacionales, principio de cooperación, principio de prevención, principio de precaución, principio del desarrollo sostenible, principio 'quien contamina paga', principio 'usuario pagador', principio de la cuenca hidrográfica como unidad de gestión y principio de comunidad de intereses.

El principio del derecho a una mejor calidad de vida establece que el individuo no posee simplemente derecho a la vida, sino que, derecho a una vida con calidad, en un medio ambiente ecológicamente equilibrado.

Este principio es corolario de las evoluciones y transformaciones sociales que ocurrieron a finales del siglo XIX que cambiaron la concepción liberal del derecho fundamental a la vida para adjetivarlo con el distintivo de la calidad, expresión que viabilizó la inclusión de los derechos sociales en la esfera jurídica fundamental del individuo como consectarios y condicionantes de la vida misma, dentro del espectro de la dignidad de la persona humana.

Las Declaraciones Universales a través o mediante sus correspondientes Tratados, recogen y articulan la conciencia universal ambiental y marcan las pautas del proceso posterior de positivización ${ }^{322}$.

Son cuatro las Declaraciones Universales ambientales adoptadas en el seno de las Naciones Unidas. De forma curiosa, las cuatro se han sucedido a lo largo de tres décadas, con plazo de diez años entre sí. La primera es la Declaración de Estocolmo de las Naciones Unidas sobre el Medio Humano de 16 de junio de 1972 (DEMH), adoptada en la Conferencia de las Naciones Unidas sobre el Medio Humano celebrada en Estocolmo del 5 al 16 de junio de $1972^{323}$. La segunda es la Carta Mundial de la Naturaleza de 28 de octubre de 1982 (CMN), aprobada por la Asamblea General de las

\footnotetext{
derecho internacional informan hoy los sistemas de protección jurídica del medioambiente a nivel regional (como es el caso del derecho ambiental de la Unión Europea) y nacional”. Derecho Ambiental Administrativo. 11ª Edición, Editora La Ley, Madrid-España: 2010, p. 95.

322 JIMÉNEZ DE PARGA, Patricia. Capítulo VII - Reglas y principios estructurales de carácter internacional: canon de civilización ecológica, in BETANCOR RODRÍGUEZ, Andrés. Derecho Ambiental. Editora La Ley, Madrid-España: 2014, p. 399.

${ }^{323}$ ONU, Doc. A/ CONF. 48/14/rev. 1.
} 
Naciones Unidas, a través de la Resolución n. ${ }^{\circ} 37 / 7$ de 28 de octubre de 1982. La tercera es la Declaración de Río de Janeiro sobre el Medio Ambiente y el Desarrollo de 14 de junio de 1992 (DRMAD), aprobada en el seno de la Conferencia de las Naciones Unidas sobre Medio Ambiente y el Desarrollo celebrada en junio de $1992^{324}$. Y la cuarta es la Declaración de Johannesburgo sobre el Desarrollo Sostenible adoptada en la Cumbre Mundial sobre el Desarrollo Sostenible celebrada en Johannesburgo, Sudáfrica, entre el 26 de agosto y el 4 de septiembre de 2002, en la que se reafirma los principios.

Así, en 1972, la vida calificada por la dignidad, oriunda de la percepción de las condiciones sociales de calidad, alcanzó su madurez con el reconocimiento de la condicionante ambiental a una mejor calidad de vida, una vida saludable, en el principio 1 de la Declaración de Estocolmo, que estableció ser el medio ambiente, natural o artificial, esencial para el bienestar y para el goce de los derechos humanos fundamentales, incluso el derecho a la vida misma.

Ese valor fue reafirmado en la Declaración de Río, aprobada durante la ECO92, que estableció ser derecho de todos los seres humanos una vida saludable, en armonía con la naturaleza.

Afirmado por el derecho internacional público y reconocido por los más variados ordenamientos jurídicos internos, el principio del derecho a una mejor calidad de vida fue utilizado como uno de los fundamentos de la sentencia del caso López Ostra, proferido por el Tribunal Europeo de Derechos Humanos - TEDH ${ }^{325}$, que por

${ }^{324}$ ONU, Doc. A/ CONF 151/26/rev. 1.

${ }^{325}$ En este sentido, Juan Antonio Carrillo Donaire y Roberto Galán Vioque, ¿Hacia un Derecho Fundamental a un medio ambiente adecuado? En Eduardo García Enterría (Director), Civitas Revista española de Derecho Administrativo, n. ${ }^{o} 86$ abril/junio, 1995, pp. 271-285, afirman que: "En el fondo de la sentencia laten dos cuestiones fundamentales. Por un lado, vuelve a aparecer el grave y delicado problema del ajuste entre dos sistemas de protección de derechos fundamentales -el establecido por nuestra Constitución en su art. 53.2 y el plasmado en el Convenio europeo- de ámbitos superpuestos y complementarios. Se plantea la duda de si el juego que el doble reenvío que los artículos 10.2 de la Constitución y el 45 del Convenio hacen en relación a la Jurisprudencia del TEDH, le permite a éste ampliar por vía hermenéutica el contenido de los derechos fundamentales reconocidos en los ordenamientos internos o, eventualmente, sus niveles de garantía. La singularidad de este caso radica precisamente en que, de la mano de la jurisprudencia del TEDH, el derecho a un medio ambiente adecuado ha obtenido cara de naturaleza a nivel europeo, de forma mediata y por $<<$ la puerta de atrás $>>$, apoyándose en el artículo $8^{\circ}$ del Convenio, lo que sumerge bajo una peligrosa sombra de incertidumbre al contenido del derecho reconocido en el art. 18.2 de nuestra Constitución. De otro lado, la sentencia refleja 
primera vez enunció que los daños ambientales, aún cuando no sean graves a tal punto de poner en peligro la salud del individuo, pueden igualmente perjudicar su bienestar y privarlo del disfrute del derecho a su domicilio, así como un daño a su vida privada y familiar.

Así, el reconocimiento del derecho a un medio ambiente saludable se configura, en realidad, como extensión del derecho a la vida, sea bajo el enfoque de la propia existencia física y la salud de los seres humanos, sea cuanto al aspecto de la dignidad de esa existencia - la calidad de vida -, que hace con que valga la pena vivir ${ }^{326}$.

El principio de ubicuidad trae a la memoria el valor de la omnipresencia del medio ambiente y de los elementos que lo componen.

Independientemente de su conformación a fronteras de orden política, jurisdiccional o geográfica, cuando se trata de gestión y preservación, es su consideración integral que debe observarse.

El principio de ubicuidad es uno de los principios que según Ramón Martin Mateo ${ }^{327}$ hace parte de los "megaprincipios", o sea, que son de carácter jerárquicamente superior y enlazan con las características inmanentes de la organización de la vida en el planeta.

El autor afirma que: "Prácticamente todas las autoridades públicas encuentran sus competencias implicadas en la defensa del medio, lo que ha hecho inevitable el adaptar estrategias que sustituyan el enfoque sectorial y vertical precedente, por el general y horizontal que hoy es inevitablemente dominante. Todo eso no cabe en un artículo de Constitución ni casa con los presupuestos clásicos del constitucionalismo, es otro enfoque que no estamos por cierto en condiciones de asimilar" ${ }^{\prime 328}$.

claramente las deficiencias del sistema español de protección de los derechos fundamentales y de las libertades públicas” (p. 272). Además, los autores enuncian que: “Quizás la más interesante de las consecuencias que se pueda desprender de la sentencia recaída en el asunto López Ostra es que se fuerce a nuestro Legislador a reflexionar sobre el sistema de protección jurisdiccional de derechos fundamentales" (p. 284).

${ }^{326}$ TRINDADE, Antônio Augusto Cançado. Direitos humanos e meio ambiente: paralelos dos sistemas de proteção internacional. Editora Fabris, Porto Alegre-Brasil: 1993, p.76.

${ }^{327}$ MARTÍN MATEO, Ramón. Manual de Derecho Ambiental. $3^{\text {a }}$ edición, Editora Thomson Aranzadi, Navarra-España: 2003, p. 35.

${ }^{328}$ Siguiendo el raciocinio, Ramón Martín Mateo añade que: "Esta dinámica se visualiza perfectamente en la trayectoria seguida por la Comunidad Europea que en un principio carecía de un apoderamiento 
El principio de ubicuidad viene reflejado en el artículo 130.R.2 del Acta Única Europea de 17-28 de febrero de 1986, según el cual las exigencias de la protección del medio ambiente serán un componente de las demás políticas de la Comunidad, por lo que debe tenerse en cuenta la protección ambiental en las demás políticas de la Unión Europea.

Además, afirma Ramón Martín Mateo que “(...) este fundamental precepto instaura definitivamente la comprensión amplia y ubicua de la protección ambiental, lo que ha sido recibido por la jurisprudencia comunitaria que ha reconocido la prevalencia de este principio sobre las demás políticas de la Comunidad, manteniéndose por la doctrina la exigibilidad de su respeto a través de los diversos cauces abiertos por la legislación"329.

En el último Programa de política y actuación en materia de Medio Ambiente y Desarrollo Sostenible la Comunidad ha señalado que "deben tenerse en cuenta las consideraciones ecológicas a la hora de formular y aplicar políticas económicas y sectoriales, en la decisión de los poderes públicos, en la dirección y el desarrollo de los procesos de producción y en el comportamiento y elecciones personales"330.

Firmado en Maastricht el Tratado de la Unión Europea de 7 de febrero de 1992, avanzó al proclamar que "Las exigencias de la protección del medio ambiente deberán integrarse en la definición y en la realización de las demás políticas de la Comunidad" 331 .

constitucional expreso para desarrollar su política ambiental, por lo que debió inicialmente apoyarse en cláusulas generales como la que autoriza al Consejo a adoptar por unanimidad Directivas para la aproximación de las disposiciones de los Estados miembros que incidan en el funcionamiento del Mercado Común, o la que permite promulgar las disposiciones pertinentes para lograr alguno de los objetivos de la Comunidad, cuando una acción resulte necesaria sin que el Tratado haya previsto las medidas precisas". Manual de Derecho cit., pp. 35-36.

${ }^{329}$ MARTín MATEO, Ramón. Manual de Derecho cit., p. 36.

$330 \quad$ Disponible en: $\quad<\mathrm{http}: / /$ www.ingurumena.ejgv.euskadi.eus/r49-

5832/eu/contenidos/informacion/desa_sostenible/eu_935/adjuntos/quinto_programa_c.pdf $>$. Acceso en: 06-07-2015.

${ }^{331}$ Disponible en: $<$ http://www.boe.es/buscar/doc.php?id=BOE-A-1994-626>. Acceso en: 06-07-2015. Respecto a eso, Ramón Martín Mateo, Manual de Derecho cit., p. 36, comenta que "No me parece que en las Constituciones nacionales exista un precepto de tan amplio y ambicioso propósito, es más, dudo que pronunciamientos semejantes tengan fácil asiento en los textos en vigor". 
Ya el Tratado de Ámsterdam de 2 de octubre de 1997, ha recogido en los preceptos 174 a 176 (Título XIX), los antiguos artículos $130 \mathrm{R}$ a $130 \mathrm{~T}$, por los que la Unión Europea explicitaba por fin directamente sus competencias y objetivos en materia ambiental ${ }^{332}$.

Las Naciones Unidas, únicamente instan a los Estados a promulgar Leyes eficaces sobre el Medio Ambiente, una vez que se ven obligadas por su Carta y por la praxis de las relaciones internacionales a guardar respeto por las soberanías nacionales, no postulando un reconocimiento general de estos derechos en el superior nivel constitucional $^{333}$.

El principio del uso equitativo e igualitario de los cursos de agua internacionales establece que todos los Estados ribereños a un determinado curso de agua internacional poseen igual derecho de uso y disfrute, en la misma cantidad y calidad. Ese principio es de origen pretoriana y fue creado a través de la consolidación de este entendimiento en decisiones de la Corte Permanente de Justicia Internacional y de tribunales arbitrales, como se verá más adelante.

El principio de cooperación se refiere a la actuación conjunta entre Estado y sociedad, tanto en el establecimiento de prioridades como en el proceso de tomada de decisiones. Cooperar es actuar conjuntamente, es sumar esfuerzos. Aquí, cooperación surge como una palabra clave, siempre buscando combatir el enemigo, sea en una sequía, en la reconstrucción de un Estado o región en el periodo posguerra, la contaminación o, incluso, la pobreza.

La cooperación entre Estado y sociedad se da en búsqueda del welfare en todas las áreas sociales, y no solo en cuestiones ambientales.

Importante recordar que los recursos naturales no se someten necesariamente a las fronteras políticas, cabiendo a los Estados que los comparten, actuar de manera coordenada, incluso a lo que se refiere a las acciones internas, visando evitar daños y a racionalizar las medidas de protección que se hicieren necesarias.

Aunque la preocupación con la necesidad de cooperar aparezca en los textos de las declaraciones internacionales sobre aguas y medio ambiente, Ramón Martín Mateo,

\footnotetext{
${ }^{332}$ Los Tratados constitutivos han sido reordenados por el de Ámsterdam, aunque por lo habitual sigue utilizándose de forma mayoritaria la referencia y la numeración del Acta Única. MARTÍN MATEO, Ramón. Manual de Derecho cit., p. 36.

${ }^{333}$ MARTÍN MATEO, Ramón. Manual de Derecho cit., p. 36.
} 
ya en 1977 defendía la idea de que la cooperación internacional en materia de contaminación solo puede realizarse efectivamente por medio de un nuevo cuerpo normativo - acuerdos, convenios y contratos -, en que se establezca una base legal suficiente para "imponer a la comunidad internacional una auténtica disciplina ambiental" en vista de la naturaleza de las relaciones entre los Estados. Esas acciones se consubstanciaron por medio de la "formulación de principios que recomiendan un cuadro de obligaciones y deberes recíprocos entre los Estados [...]"334.

De hecho, la mayoría de los acuerdos internacionales celebrados se refieren más a derechos y obligaciones de los países respecto al agua de lo que a las formas de cooperación en la gestión de los recursos hídricos de las cuencas hidrográficas internacionales. Esa cooperación no puede, por otra parte, ser efectiva, antes de ser convenientemente definidos aquellos derechos y obligaciones, lo que ni siempre es fácil conseguir a contento de las partes interesadas ${ }^{335}$.

Este principio está en la base de los instrumentos normativos creados con objetivos de aumento de la información y de ampliación de participación en los procesos de decisión de la política ambiental, así como en la estabilidad del relacionamiento entre libertad individual y necesidad social ${ }^{336}$.

Como ejemplos de medidas concretas en las que se manifiesta este principio, Blanca Lozano Cutanda señala: "el intercambio de información relevante para la protección del medioambiente, el establecimiento de programas conjuntos de vigilancia y evaluación ambiental, la asistencia técnica y financiera a los países necesitados, o el deber de notificación inmediata de las situaciones de emergencia que pueden producir

\footnotetext{
${ }^{334}$ MARTÍN MATEO, Ramón. Derecho Ambiental. Instituto de Estudios de Administración Local, Madrid-España: 1977, p. 143.

${ }^{335}$ CUNHA, L. Veiga da; GONÇALVES, A. Santos; FIGUEIRA, V. Alves; LINO, Mário. A gestão da água, princípios fundamentais e sua aplicação em Portugal. Fundação Calouste Gulbenkian, LisboaPortugal: 1980, p.272.

${ }^{336}$ DERANI, Cristiane. Direito ambiental econômico. $2^{\mathrm{a}}$ edição, Editora Max Limonad, São Paulo-Brasil: 2001, p. 161. Además, la autora afirma que el principio de la cooperación no es exclusivo del derecho ambiental, una vez que hace parte del Estado Social, que informa una acción conjunta del Estado y sociedad en la elección de los procesos decisorios. El principio de la cooperación orienta la realización de otras políticas relativas al bien común, inherentes a la razón constituidora del Estado. Es un principio de orientación del desarrollo político, por medio del cual se pretende una mayor composición de las fuerzas sociales. Op. cit., p. 157.
} 
efectos nocivos a otros Estados y de ayudar a los Estados que resulten afectados (enunciado por el principio de la Declaración de Río)”337.

Establecido internacionalmente en diversas declaraciones $y$ tratados internacionales, de Estocolmo ${ }^{338}$ a Mar del Plata ${ }^{339}$, de la Carta Europea del Agua ${ }^{340}$ a la

${ }^{337}$ LOZANO CUTANDA, Blanca. Derecho Ambiental cit., pp. 95-96.

${ }^{338}$ La Conferencia de Estocolmo, realizada en 1972, establece dos dispositivos referentes a la cooperación, uno tratando de cooperación en la efectivación de la responsabilidad por daños, otro que enfatiza la necesidad de cooperación para acciones conjuntas. Son ellos: Principio 22. "Los estados deben cooperar para continuar desarrollando el derecho internacional en lo que se refiere a la responsabilidad y a la indemnización a las víctimas de la contaminación y otros daños ambientales que las actividades realizadas dentro de la jurisdicción o bajo el control de tales estados causen a zonas situadas fuera de su jurisdicción". En este principio la obligación de crear reglas de derecho internacional visando facilitar la responsabilidad y la efectividad de las indemnizaciones por daños que un Estado venga a causar a otro; Ya el Principio 24 cuida de las acciones conjuntas, que serán desarrolladas por los Estados: Principio 24. “Todos los países, grandes o pequeños, deben ocuparse, con espíritu de cooperación y de pie de igualdad, en las cuestiones internacionales relativas a la protección y mejoramiento del medio. Es indispensable cooperar, mediante acuerdos multilaterales o bilaterales o por otros medios apropiados, para controlar, evitar, reducir y eliminar eficazmente los efectos perjudiciales que las actividades que se realicen en cualquier esfera puedan tener para el medio, teniendo en cuenta debidamente la soberanía y los intereses de todos los estados".

${ }^{339}$ El Plan de Acción de Mar del Plata, extraído de la Conferencia de Mar del Plata sobre Recursos Hídricos, de 25 de marzo de 1977, determina en su Ítem 85, que: "Los países que comparten recursos hídricos deberían examinar, con la asistencia adecuada de organismos internacionales y de otros órganos de apoyo, a petición de los países interesados, las técnicas existentes y disponibles para la ordenación de las cuencas de los ríos compartidos y cooperar en el establecimiento de los programas, mecanismos e instituciones necesarios para el desarrollo coordinado de tales recursos. Las esferas de cooperación, con el acuerdo de las partes interesadas, pueden incluir la planificación, el desarrollo, la regulación, la ordenación, la protección ambiental, la utilización y la conservación, los pronósticos, etc. Tal cooperación debe constituir un elemento fundamental en un esfuerzo destinado a superar las dificultades mas graves, como la falta de capital y mano de obra capacitada, así como las exigencias del desarrollo de los recursos naturales". Disponible en: http://www.aida-waterlaw.org/PDF/Foros_del_Agua_libro.pdf. Acceso en: 0807-2015.

${ }^{340}$ La Carta Europea del Agua, establece en su artículo 12, que: "El agua no tiene fronteras. Es un bien común que requiere la cooperación internacional". Respecto a los recursos hídricos compartidos, esa cooperación debe ocurrir por medio de tratados específicos, en que los Estados limítrofes establezcan formas conjuntas de actuar, ejemplos de esos tratados celebrados entre Brasil y países vecinos son: Tratado de la Cuenca del Plata (Argentina, Bolivia, Brasil, Paraguay y Uruguay), Tratado de Itaipu 
Declaración de Río ${ }^{341}$, busca imponer responsabilidades recíprocas a los miembros de la sociedad internacional en la gestión ambiental. Además, según Blanca Lozano Cutanda: "El deber de cooperación de los Estados para la protección del medioambiente que impone este principio se manifiesta en un plano general en el deber de promover la conclusión de tratados y otros instrumentos internacionales con esta finalidad, y, en un plano más concreto, en la realización de actividades conjuntas y otras medidas pertinentes a fin de asegurar la aplicación efectiva del derecho internacional para la protección del medioambiente" 342 .

El principio de prevención es el que impone la acción previa a la ocurrencia del daño. O, como enseña Michel Prieur, "la prevención consiste en impedir la

(Brasil y Paraguay), Tratado de Garabí (Brasil y Argentina) y Tratado de Yacyretá (Argentina y Paraguay).

${ }^{341}$ Muchos de los Principios de la Conferencia Río/92 sobre Medio Ambiente y Desarrollo Sostenible tratan de la cooperación. El Principio 5 menciona que: “Todos los Estados y todas las personas deberán cooperar en la tarea esencial de erradicar la pobreza como requisito indispensable del desarrollo sostenible, a fin de reducir las disparidades en los niveles de vida y responder mejor a las necesidades de la mayoría de los pueblos del mundo"; Principio 7. "Los Estados deberán cooperar con espíritu de solidaridad mundial para conservar, proteger y restablecer la salud y la integridad del ecosistema de la Tierra. En vista de que han contribuido en distinta medida a la degradación del medio ambiente mundial, los Estados tienen responsabilidades comunes pero diferenciadas. Los países desarrollados reconocen la responsabilidad que les cabe en la búsqueda internacional del desarrollo sostenible, en vista de las presiones que sus sociedades ejercen en el medio ambiente mundial y de las tecnologías y los recursos financieros de que disponen"; Principio 9. "Los Estados deberían cooperar en el fortalecimiento de su propia capacidad de lograr el desarrollo sostenible, aumentando el saber científico mediante el intercambio de conocimientos científicos y tecnológicos, e intensificando el desarrollo, la adaptación, la difusión y la transferencia de tecnologías, entre estas, tecnologías nuevas e innovadoras"; Principio 14. "Los Estados deberían cooperar efectivamente para desalentar o evitar la reubicación y la transferencia a otros Estados de cualesquiera actividades y sustancias que causen degradación ambiental grave o se consideren nocivas para la salud humana" y, finalmente; Principio 27. "Los Estados y las personas deberán cooperar de buena fe y con espíritu de solidaridad en la aplicación de los principios consagrados en esta Declaración y en el ulterior desarrollo del derecho internacional en la esfera del desarrollo sostenible”. Disponible en: < http://www.un.org/spanish/esa/sustdev/agenda21/riodeclaration.htm>. Acceso en: 08-07-2015.

${ }^{342}$ LOZANO CUTANDA, Blanca. Derecho Ambiental cit., p. 95. 
supervivencia de daños al medio ambiente a través de medidas apropiadas, preventivas, antes de la elaboración de un plan o de la realización de una obra o actividad"343.

Por cierto, aquí está el principio de prevención, en sus elementos centrales: (a) alta e intensa probabilidad (certeza) de daño especial y anómalo; (b) atribución y posibilidad del Poder Público evitar el daño social, económico o ambiental; y (c) carga estatal de producir la prueba excluyente del nexo de causalidad intertemporal ${ }^{344}$.

Presentes los presupuestos, puede anteverse, con seguridad, el resultado insostenible y, correspondientemente, en los límites de las atribuciones, se configura la obligación del Estado tomar las medidas necesarias y adecuadas, interruptoras de la red causal, de suerte a impedir el daño antevisto ${ }^{345}$.

El principio que fundamenta y que más está presente en toda la legislación ambiental y en todas las políticas públicas de medio ambiente es el de prevención, siendo incluso, más importante que la responsabilidad por el daño ambiental ${ }^{346}$.

La dificultad, improbabilidad o mismo imposibilidad de recuperación es la regla cuando se trata de un daño al ambiental. La recuperación de una lesión ambiental, cuando posible, es muy lenta y costosa, de manera que en la mayoría de las veces solo la actuación preventiva puede tener efectividad ${ }^{347}$.

Lo más importante, de hecho y de derecho, es que el Estado sostenible no puede llegar tarde, debiendo tener el Poder Público la obligación de trabajar para el ambiente (natural e institucional) duraderamente sano.

Vale resaltar que el principio de prevención, en Derecho Administrativo y en Derecho Ambiental, hasta incluso más que el de precaución, determina, sin mora o sofismas acomodaticios, el cumplimiento diligente, eficiente y eficaz, de los deberes de impedir el nexo causal de daños perfectamente previsibles, bajo pena de responsabilidad objetiva del Estado ${ }^{348}$

\footnotetext{
${ }^{343}$ PRIEUR, Michel. Droit de l'environnent. Editora Dalloz, Paris-Francia: 1996, p.70.

${ }^{344}$ FREITAS, Juarez. Sustentabilidade: direito ao futuro. $2^{\mathrm{a}}$ ed., Belo Horizonte: Editora Fórum, 2012, p. 285.

${ }^{345}$ FREITAS, Juarez. Sustentabilidade: cit., p. 285.

${ }^{346}$ FARIAS, Talden. Introdução ao Direito Ambiental. Editora Del Rey, Belo Horizonte-Brasil: 2009, p. 46.

${ }^{347}$ FARIAS, Talden. Introdução ao Direito cit., p. 46.

${ }^{348}$ FREITAS, Juarez. Sustentabilidade: cit., p. 284.
} 
Así, el principio de prevención será aplicado ante la hipótesis en que se tenga el conocimiento y la información acerca de la posibilidad de ocurrencia del daño. Tal distinción se coloca de manera imperativa para que se vislumbre la diferencia entre el campo de aplicación de este principio y el de precaución.

El principio de precaución es dotado de eficacia directa e inmediata y, impone al Poder Público diligencias no tergiversables, con la adopción de medidas anticipatorias y proporcionales, mismo cuando haya incertidumbre cuanto a la producción de daños fundadamente temidos (juicio de verosimilitud) ${ }^{349}$.

La precaución es un principio que establece la prohibición de intervenciones en el medio ambiente, salvo cuando existe la certeza de que las alteraciones no causaran reacciones adversas, ya que ni siempre la ciencia puede ofrecer a la sociedad respuestas conclusivas sobre la inocuidad de determinados procedimientos.

En este sentido, Blanca Lozano Cutanda afirma que: "Con este principio, hoy incorporado a numerosos tratados internacionales, se supera el criterio anterior de que las acciones de protección ambiental solo debían llevarse a cabo cuando existiese evidencia científica de que un daño ambiental significativo se estaba produciendo o corría el riesgo de producirse de no adoptarse medidas. Ahora la actuación ambiental no precisa ya estar respaldada por unas beses científicas incontrovertidas (lo que resulta con frecuencia imposible cuando se trata de adoptar medidas de protección para la

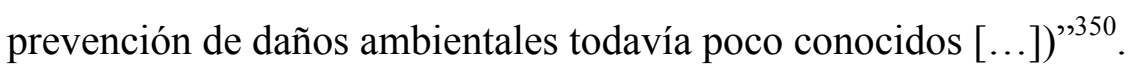

Además, según la autora, el principio de precaución: "ha venido a reforzar el tradicional principio de prevención que informa la protección jurídica del medioambiente. Aunque el significado y alcance de este principio está aún en proceso de desarrollo, el concepto nuclear del mismo es el recogido en la Declaración de Río, cuyo principio 15 afirma: 'Con el fin de proteger el medio ambiente, los Estados

\footnotetext{
${ }^{349}$ FREITAS, Juarez. Sustentabilidade: cit., p. 285. Además, añade el autor que: "La inobservancia de ese deber también configura, o, al menos, tiene la prerrogativa de configurar, omisión antijurídica, especifica, cierta y anómala. Con efecto, a la similitud, de lo que sucede con la ausencia de prevención exigible, la falta o falla de precaución puede generar daño (material y/o moral) injusto y, por lo tanto, indemnizable, aunque dispendiosamente absorbido por la castigada masa de los contribuyentes". Idem, p. 286.

${ }^{350}$ LOZANO CUTANDA, Blanca. Derecho Ambiental cit., p. 97. Añade la autora que en la Unión Europea el principio de precaución fue incorporado al Tratado de la CE (actual Tratado de Funcionamiento de la Unión Europea) por el Tratado de Maastricht, con la denominación de "principio de cautela".
} 
deberán aplicar ampliamente el criterio de precaución conforme a sus capacidades. Cuando haya peligro de daño grave o irreversible, la falta de certeza científica absoluta no deberá utilizarse como razón para postergar la adopción de medidas eficaces en función de los costos para impedir la degradación del medio ambiente,",351.

El principio de precaución está relacionado a los conceptos de alejamiento de peligro y seguridad de las generaciones futuras y de la sostenibilidad ambiental de las acciones humanas, sea por la protección de su ambiente, sea por el mantenimiento de la integridad de la vida humana ${ }^{352}$.

Así, la principal diferencia entre precaución y prevención es que esta cuida de evitar daños cuando la posibilidad de su ocurrencia y los efectos de su extensión son, al menos mínimamente, conocidos; ya aquella buscar asegurar la protección del medio ambiente, y la integridad de la salud humana, en relación a la incertidumbre o al conocimiento de las potenciales consecuencias dañosas que determinada conducta, tecnología o actividad puedan causar.

El principio del desarrollo sostenible surge oficialmente con la adopción del concepto-valor de desarrollo sostenible creado por el Informe Brundtland.

Como bien comentó Blanca Lozano Cutanda: "El logro de un desarrollo sostenible se ha consolidado desde entonces como el objetivo fundamental de la acción ambiental y se halla presente en la actualidad en todos los textos y programas de protección ambiental. Se trata de una aproximación que podemos calificar de 'realista' o incluso 'pragmática' a la problemática ambiental, pues a diferencia del concepto de 'crecimiento cero' que se postulaba para la protección ambiental en los años 70, parte de la acepción de un desarrollo económico indisociable de la calidad de vida de las generaciones presentes, y tiene por finalidad lograr que la explotación y contaminación de los recursos naturales que este desarrollo inevitablemente conlleva se mantenga dentro de unos límites tolerables, que no excedan de la capacidad del medioambiente y que no hipotequen las posibilidades de desarrollo de las generaciones futuras" ${ }^{, 353}$.

Además, M. ${ }^{\mathrm{a}}$ Ángeles González Bustos y Miguel Ángel González Iglesias afirman que: "El principio de desarrollo sostenible se configura como algo más que un

\footnotetext{
${ }^{351}$ LOZANO CUTANDA, Blanca. Derecho Ambiental cit., pp. 96-97.

${ }^{352}$ Cf. WOLFRUM, Rüdiger. O princípio da precaução. In: VARELLA, Marcelo Dias; PLATIAU, Ana Flávia Barros. O princípio da precaução. Editora Del Rey, Belo Horizonte-Brasil: 2004, pp. 15-16.

${ }^{353}$ LOZANO CUTANDA, Blanca. Derecho Ambiental cit., 2010, p. 71.
} 
principio informador, ya que constituye un principio rector de todas las políticas públicas aprobadas por los poderes públicos. De esta forma el principio de desarrollo sostenible ha pasado de ser un principio que nace en el ámbito del Derecho ambiental a ser un principio inspirador de todas las políticas públicas que desarrolle el Estado",354.

Más allá de revelar una directriz, un comportamiento a ser adoptado, el principio del desarrollo sostenible traduce un conjunto de valores ancorados en conductas relacionadas a la producción, para que el resultado sea la compatibilización de la apropiación de los recursos naturales con su mantenimiento y construcción de un bienestar, o, en otras palabras, para su realización, necesario se hace la concretización de los valores y directrices propios al derecho ambiental, al desarrollo social y económico, a la equidad y al bienestar ${ }^{355}$.

Además, Blanca Lozano Cutanda afirma que: "Este objetivo del desarrollo sostenible ha alcanzado un grado de implantación en las normas de protección ambiental que permite calificarlo como un nuevo principio de derecho internacional, aunque su aplicación efectiva a las políticas nacionales de desarrollo económico dista mucho en la actualidad de haberse conseguido, y resulta a nuestro entender muy difícil que se logre si no se modifican radicalmente algunos de los postulados básicos del sistema de consumo que rigen nuestros mercados"356.

Para garantizar el cumplimiento de ese principio, un mecanismo institucional de control de las actividades debe existir, de modo que se pueda comprobar si las normas previstas en la legislación en vigor, acerca de la protección del medio ambiente, están siendo correctamente observadas por los emprendedores. No bastando que inicialmente se compruebe la sostenibilidad de un emprendimiento, sino que se necesita que la misma perdure a lo largo de toda la actividad.

\footnotetext{
${ }^{354}$ GONZÁLEZ BUSTOS, M. ${ }^{\mathrm{a}}$ Ángeles; GONZÁLEZ IGLESIAS, Miguel Ángel, Sostenibilidad y responsabilidad en la edificación. Revista de Derecho Urbanístico y medio ambiente. Don Francisco José Alegría Martínez de Pinillos (Director), año XLIX, n. ${ }^{\circ}$ 301, noviembre 2015, RDU, Madrid, pp. 151-17. (p.153).

355 Conforme DERANI, Cristiane; RIOS, Aurélio Virgílio Veiga. Princípios gerais de direito internacional ambiental. In: RIOS, Aurélio Virgílio Veiga; IRIGARAY, Carlos Teodoro Hugueney. $O$ direito e o desenvolvimento sustentável: curso de direito ambiental. Instituto Internacional de Educação do Brasil, São Paulo-Brasil: 2005, p. 89.

${ }^{356}$ LOZANO CUTANDA, Blanca. Derecho Ambiental cit., p. 71.
} 
Actualmente, lo que se busca evidenciar respecto a la sostenibilidad incluye el aspecto ambiental, político, social, ético y cultural, o sea, extrapola la cuestión económica.

El principio 'quien contamina paga' oficialmente surgió en 26 de mayo de 1972, por intermedio del Consejo de la Organización para la Cooperación y Desarrollo Económico (OCDE) que lo incluyó entre los principios directores referentes a los aspectos económicos de las políticas ambientales en el plano internacional, y significa que el contaminador debe soportar los costos de las medidas de prevención, de la recuperación del área que él haya degradado y del control de la contaminación, para estimular el uso racional de los escasos recursos ambientales y asegurar que el ambiente pueda quedarse en un nivel aceptable ${ }^{357}$.

Según, Jesús Jordano Fraga: "En la actualidad el principio 'quien contamina paga' se encuentra plasmado al más alto nivel posible en el Derecho comunitario. La reforma del Tratado de Roma, operada por el Acta Única, ha consagrado, como hemos visto, en el artículo 130 R. 2 del título VII del Tratado, dicho principio"358.

Además, respecto a la finalidad última que se persigue con la aplicación de este principio, Blanca Lozano Cutanda afirma que: “es el logro de una actividad económica más respetuosa con el medioambiente, que tome en consideración los costes ambientales que conlleva la producción y consumo de bienes económicos. Las fuerzas del mercado, abandonadas a sí mismas, resultan incapaces para proveer a las necesidades humanas sin poner en peligro el medioambiente, lo que se debe a que los precios, que sirven de guía a las decisiones de productores y consumidores, no reflejan

\footnotetext{
${ }^{357}$ RODRIGUES, Marcelo Abelha. Instituições de direito ambiental. Editora Max Limonad, São PauloBrasil: 2002, pp. 139-140.

358 JORDANO FRAGA, Jesús. La Protección del Derecho a un Medio Ambiente Adecuado. Biblioteca de Derecho Privado, 59. Editora J.M. Bosch, Barcelona-España: 1995, p. 137.

En ese sentido, Blanca Lozano Cutanda afirma que: "Donde mayor desarrollo ha alcanzado el principio 'quien contamina paga' es sin duda en el marco de la Unión Europea, donde, como veremos con mayor detenimiento, desde su afirmación en el Primer Programa de Acción Ambiental (1973-1976), ha guiado la acción comunitaria para la protección del medioambiente, aplicándose en varias directivas ambientales, y, desde el Acta Única Europea (que entró en vigor el 1 de julio de 1987), constituye uno de los principios que han de regir la actuación de la Unión Europea para la consecución de los objetivos de protección ambiental atribuidos a la Unión (art. 191.2 del Tratado de Funcionamiento de la UE)”. LOZANO CUTANDA, Blanca. Derecho Ambiental cit., p. 99.
} 
los costes y beneficios derivados del uso del medioambiente, dando lugar a lo que se conoce como 'externalidades negativas': cuando un agente económico realiza una actividad de producción o consumo para su propio beneficio, no tiene que soportar los costes ambientales que esta actividad provoca pues, al no reflejarse en los precios, estos costes o efectos negativos son 'externos' a la misma y repercuten en el conjunto de la sociedad, por lo que el agente económico, llevado por el objetivo de maximización de la utilidad o del beneficio que dirige sus decisiones, tenderá a explotar al máximo el medioambiente, más allá de lo que resulta racional para la preservación futura de los recursos naturales" 359 .

Así, la autora añade que: "Para corregir esta disfunción del mercado es preciso por consiguiente adoptar medidas que, en aplicación del principio 'quien contamina paga', permitan la internalización de los costes sociales derivados de la tutela ambiental o, dicho de otro modo, que los costes sociales derivados del deterioro ambiental se reflejen en los precios y recaigan sobre los sujetos que contaminan. Esta imputación de los costes resultantes de la lucha contra la contaminación a los causantes de ésta, les incita a reducir la contaminación y a buscar productos y tecnologías menos contaminantes, obteniéndose así una utilización más racional de los recursos del medioambiente" 360 .

De esta manera, en el principio 'quien contamina paga', los costes sociales externos que acompañan la actividad económica deben ser internalizados, es decir, deben ser considerados por el emprendedor ${ }^{361}$.

El principio 'usuario pagador' se refiere al uso autorizado de un recurso, observadas las normas vigentes, incluso los estándares legalmente establecidos. Se trata de pagar por el uso privativo de un recurso ambiental de carácter público, dada su escasez, y no como una sanción derivada del ilícito, o sea, es aquel según lo cual el usuario de un bien natural sufre la incidencia de un determinado costo, en razón de esa utilización.

El principio de la cuenca hidrográfica como unidad de gestión fue construido a partir de las declaraciones y normas adoptadas principalmente por la International Law Association, por el Instituto de Derecho Internacional y por la Comisión de

\footnotetext{
${ }^{359}$ LOZANO CUTANDA, Blanca. Derecho Ambiental cit., pp.97-98.

${ }^{360}$ LOZANO CUTANDA, Blanca. Derecho Ambiental cit., p. 98.

${ }^{361}$ Vide principio 16 de la Declaración de Río, de 1992.
} 
Derecho Internacional, y oficializado por la adopción de la Convención y Estatuto para el Desarrollo de la Cuenca del Chad, de 1964, y del Tratado de la Cuenca del Plata, de 1969.

Importante recordar que la noción de cuenca hidrográfica es reciente. De acuerdo con Claude Albert Colliard, esta definición: "aparece todas las veces que un tratado, en vez de limitarse a un único río, también tiene como objetivo sus afluentes",362.

De acuerdo con el art. 1 de la Resolución de la International Law Association de Nueva York, en 1958, Ese principio establece que, para la efectiva gestión hidrológica, se debe analizar y considerar el agua de todo el sistema hídrico de la región, no solo la del río principal, sino que también de sus afluentes, tributarios, aguas subterráneas, acuíferos subterráneos, o sea, aguas superficiales y subterráneas que componen un conjunto intrínsecamente relacionado. En ese sentido, el art. 2 de las Reglas de Helsinki, fijadas en 1967 por la International Law Association, dispone que en una cuenca hidrográfica se consideran las aguas superficiales y subterráneas.

También, dispone la Carta Europea del Agua en su art. 11 que: "La administración del agua debe fundamentarse en las cuencas naturales más que en las

\footnotetext{
${ }^{362}$ En esa orden de ideas, el autor menciona el tratado de Viena, en 1 de mayo de 1616, entre Turquía y Austria, referente al derecho de navegación sobre el Danubio y sobre otros ríos. Más explicito, el tratado concluido en 1618, entre Polonia y Brandemburgo, antes de la navegación sobre el río Oder y sobre sus afluentes. Según el autor, ese último tratado constituye, probablemente, la primera muestra de una teoría de cuenca hidrográfica, aunque fuera más una simple enumeración de ríos, que propiamente una teoría. En Latinoamérica, el Tratado de Paz entre Brasil y la República de las Provincias Unidas del Río de la Plata (Argentina), de 1928, comprende el sistema hidrográfico del Río de la Plata; el Tratado Brasil-Perú, de 1851, dispone acerca de la navegación abierta en el Río Amazonas y sus afluentes, entre los Estados signatarios; el Tratado Argentina-Paraguay, de 1852, ofrece a los barcos de los dos Estados el acceso a los Río Paraguay y a sus afluentes; el Tratado Bolivia-EEUU, de 1858, se refiere a la navegación en las Cuencas del Amazonas y en el río de la Plata; de acuerdo con el Tratado Brasil-Perú, de 1891, todos los ríos comunes y sus afluentes son abiertos a navegación de barcos de los dos Estados; el Tratado BrasilColombia, de 1907, dispone acerca del río Amazonas y sus afluentes. COLLIARD, Claude-Albert. Evolution et Aspects Actuels du Régime des fleuves internationaux. In: Recueil des cours, Paris-Francia, 1968 , v. 3, t. 125 , pp. 404-405.
} 
fronteras políticas y administrativas"363.

Conforme la recomendación de la Conferencia Internacional de Bonn sobre el Agua Dulce, realizada en Bonn, Alemania, en 2001, las cantidades atribuidas a los usuarios deben, como mínimo, garantizar la alimentación de los ecosistemas de modo a permitir la preservación de su integridad ${ }^{364}$.

El principio de comunidad de intereses entiende que debido al hecho de compartir el mismo curso de agua, los Estados deben armonizar sus intereses en el sentido de su aprovechamiento común y equitativo, adoptando, incluso, procesos de comunicación y consulta entre todos para la adopción de actos y medidas, que puedan evitar perjuicio a la calidad, a la cantidad o al uso de las aguas por todo el curso de agua internacional.

\subsection{Principios que instruyen el Derecho Ambiental además del Derecho} de Agua

Los principios generales de derecho son enunciaciones genéricas de valor normativo que representan las bases y los pilares del ordenamiento jurídico. Son fuentes del derecho, utilizados para la aplicación, integración y elaboración de las normas jurídicas. En lo que se refiere al derecho ambiental, no existe un consenso acerca de la nomenclatura y clasificación de sus principios, debido a la forma de abordaje dada por cada autor.

El tema crece de importancia a medida que aumenta la explotación de los recursos naturales hecha de manera irracional y desordenada, siendo que uno de los mayores retos de la actualidad es equilibrar el desarrollo económico con la protección ambiental.

De la colisión de la busca por el lucro con los daños al medio ambiente, es que se pone en riesgo el equilibrio ecológico y la sobrevivencia de las especies del planeta,

363

en:

$<\mathrm{http} / / /$ aiguesdebenissa.com/index.php?option $=$ com_content\&view $=$ article\&id $=6 \&$ Itemid $=2 \& l a n g=e s>$. Acceso en: 13-07-2015.

${ }^{364}$ Disponible en: < http://eur-lex.europa.eu/legal-content/ES/TXT/?uri=CELEX:52002DC0132>. Acceso en: 13-07-2015. 
incluso de la humana. Como ejemplo se puede citar el uso indiscriminado de pesticidas y fertilizantes utilizados por el hombre visando la reducción de costos y ampliación de las márgenes de beneficio, contaminando con eso las capas freáticas, principal fuente de agua dulce del planeta.

Documentos internacionales pasaron a reflexionar sobre esta preocupación, como es el caso de la Declaración de Río sobre el Medio Ambiente y el Desarrollo de 1992, que dispone en sus principios: Principio 1: Los seres humanos constituyen el centro de las preocupaciones con el desarrollo sostenible. Tienen derecho a una vida saludable y productiva, en armonía con la naturaleza.

Principio 4: A fin de alcanzar el desarrollo sostenible, la protección del medio ambiente deberá constituir parte integrante del proceso de desarrollo y no podrá considerarse en forma aislada.

Se deduce, por tanto, que el propósito del Principio del Desarrollo Sostenible es graduar, conciliar, encontrar un punto de equilibrio entre actividad económica y uso adecuado, racional y responsable de los recursos naturales, respetándolos y preservándolos para las generaciones actuales y futuras.

En este mismo sentido, Paulo de Bessa Antunes consigna el Principio del Derecho Humano Fundamental, que dispone que: todos tienen derecho a una vida saludable y productiva en armonía con el medio ambiente. Tal principio deriva del texto expreso en la primera oración del artículo 225 de la Constitución Federal Brasileña, que dispone que "Todos tienen derecho al medio ambiente ecológicamente equilibrado, bien de uso común de la población y esencial a una sana calidad de vida, imponiéndose al Poder Público y a la colectividad el deber de defenderlo y preservarlo para las presentes y futuras generaciones".

Según Édis Milaré, el reconocimiento del derecho a un medio ambiente sano, se configura, en realidad, como extensión del derecho a la vida, sea bajo el enfoque de la propia existencia física y salud de los seres humanos, sea con referencia al aspecto de la dignidad de esa existencia - la calidad de vida -, que hace con que la vida valga la pena.

El aumento poblacional, la exploración desmedida y desordenada de los recursos renovables, además del aumento en la producción, que genera basura, contaminación, residuos, entre otros daños, algunas veces irreversibles, influyen directa y negativamente en el medio ambiente. 
El reconocimiento de que el mercado no actúa tan libremente como está teóricamente estructurado, principalmente por la amplia utilización de subsidios ambientales, a saber, por prácticas económicas que son utilizadas en detrimento de la calidad ambiental y que, en razón de esto, disminuyen artificialmente precios de productos y servicios, hizo con que se estableciese el llamado principio 'quien contamina paga', que fue introducido por la Organización para la Cooperación y Desarrollo Económico - OCDE, mediante la adopción, en 26 de mayo de 1972, de principios de aspectos económicos de las políticas ambientales.

Brasil estableció una relación mínima de los principios de Derecho Ambiental, traída por el Decreto n. ${ }^{\circ}$ 5.098/04 ${ }^{365}$, son ellos, el principio de información, principio de participación, principio de prevención, principio de precaución, principio de reparación y principio 'quien contamina paga'.

Los órganos de la Administración Pública y sus actividades son regidos por normas $\mathrm{y}$, además de reglas específicas a cada actividad, existen preceptos generales que orientan el campo de actuación de la Administración.

Odete Medauar afirma que los principios constituyen "las bases en la que asientan institutos y normas jurídicas" y refiriéndose al Derecho Administrativo, acrecienta que "por ser un derecho reciente y no codificado los principios auxilian la comprensión y consolidación de sus institutos" ${ }^{\text {"366 }}$. Creemos que pasa lo mismo con el Derecho Ambiental.

Por su parte, Álvaro Luiz Mirra afirma que el estudio de los principios posee una “indiscutible relevancia práctica: permitir la visualización global del sistema para mejor aplicación concreta de sus normas"

Analizándose el Derecho Administrativo por el enfoque ambiental, o sea, la tutela administrativa del medio ambiente, se puede concluir que hay una serie de

\footnotetext{
${ }^{365}$ Decreto n. ${ }^{\circ}$ 5.098/04, de 3 de junio de 2004 que Dispõe sobre a criação do Plano Nacional de Prevenção, Preparação e Resposta Rápida a Emergências Ambientais com Produtos Químicos Perigosos-P2R2, e dá outras providências. Disponible en: < http://www.planalto.gov.br/ccivil_03/_ato2004-2006/2004/decreto/d5098.htm>. Acceso en: 16-11-2015. ${ }^{366}$ MEDAUAR, Odete. Direito Administrativo Moderno. $7^{\mathrm{a}}$ ed. rev. e atual. São Paulo: Editora Revista dos Tribunais, 2003, pp. 133-134.

${ }^{367}$ MIRRA, Álvaro Luiz Valery. Princípios fundamentais do Direito Ambiental. Revista de Direito Ambiental. São Paulo: Revista dos Tribunais, n.2, p. 51.
} 
principios informadores que sirven tanto para interpretar normas ya existentes como para solucionar casos no previstos.

Según Antônio Herman V. Benjamin, "son principios de orden pública, que no pueden ser suprimidos por la voluntad de las partes, y que, además, sirven de límite a la discrecionalidad administrativa" 368 .

Cumple recordar las palabras de Celso Antônio Bandeira de Mello que se muestran muy actuales y expresan una lección básica para cualquier análisis sistémica de Derecho: "Violar un principio es mucho más grave que transgredir una norma. La desatención al principio implica ofensa no sólo a un específico mandamiento obligatorio pero a todo el sistema de comandos. Es la más grave forma de ilegalidad o inconstitucionalidad, conforme el grado del principio alcanzado, porque representa insurgencia contra todo el sistema, subversión de sus valores fundamentales, contumelia irremisible a su estructura lógica y corrosión de su estructura maestra"369.

Se resalta que la breve exposición abajo tiene como fin solamente sugerir algunos principios que deben direccionar el licenciamiento ambiental y está lejos de agotar la materia sobre el tema.

Como afirmado en otro momento, el Derecho Ambiental, considerado rama del Derecho Positivo, se somete a los diversos principios generales que lo estructuran, tales como el principio de isonomía y de buena fe. Pero, por tratarse de un campo autónomo y específico, con objeto proprio - el medio ambiente, colectivo o individual - y con institutos jurídicos poco comunes, como la responsabilidad objetiva, aplicada a los causadores de daños ambientales, dispone de otros principios exclusivos. Uno de ellos, denominado de Prevención-Precaución, será más detallado a lo largo de este trabajo, razón la cual será oportunamente abordado. Los demás, aunque no constituyan el núcleo de este estudio, serán rápidamente caracterizados, en función de su importancia para el Derecho Ambiental.

\footnotetext{
${ }^{368}$ BENJAMIN, Antônio Herman V. Os princípios do Estudo de Impacto Ambiental como limites da discricionariedade administrativa. Revista Forense. Rio de Janeiro, v.317, 1992, p. 37.

${ }^{369}$ MELLO, Celso Antônio Bandeira de. Elementos de Direito Administrativo. $2^{\mathrm{a}}$ ed. rev. ampl. e atual. com a Constituição Federal de 1988. São Paulo: Editora Revista dos Tribunais, 1990, p. 300.
} 
3.10.1. Principio del derecho al desarrollo sostenible. El derecho al medio ambiente ecológicamente equilibrado: un derecho fundamental

En primer lugar, es importante resaltar que el problema de los derechos fundamentales es muy complejo, coexistiendo innúmeras corrientes y problemas conceptuales, razón la cual son objeto de análisis más pronfunda en momento oportuno en este trabajo.

Aquí nos limitaremos a indicar un parámetro general de identificación de derechos fundamentales, vinculado a aquél que es el mayor valor tutelado por el orden jurídico, en los términos de la Constitución: la dignidad de la persona humana. Tal parámetro establece: "Cuanto más un derecho tiende a realizar la primacía de la dignidad humana, más esencial él es"370.

A continuación presentaremos tres líneas argumentativas distintas tendientes a la justificación del derecho al ambiente sano como derecho fundamental. Al final de la exposición de estas perspectivas materiales.

Un camino para comprobar los fundamentos normativos del derecho al ambiente sano es comprenderlo como una extensión material del derecho fundamental a la vida, consagrado en caput del artículo $5^{\circ}$ de la Constitución Brasileña ${ }^{371}$, y art. 15 de la Constitución Española. En este sentido Valério Mazzuoli afirma que: En el sentido empleado por el art. 225, del texto constitucional brasileño, el derecho al medio ambiente ecológicamente equilibrado es un "prius lógico" del derecho a la vida, sin el que esta no se desarrolla de forma sana en ninguna de sus difusiones. Es decir, el bien jurídico, vida, depende para su integralidad, entre otros factores, de la protección del

\footnotetext{
${ }^{370}$ SAMPAIO, José Adércio Leite. Direito Fundamental ao meio ambiente saudável, adequado e ecologicamente equilibrado. In: SAMPAIO, José Adércio Leite; WOLD, Chris; NARDY, Afrânio. Principios de direito ambiental: na dimensão internacional e comparada. Belo Horizonte: Del Rey, 2003, p. 93.

${ }^{371}$ BENJAMIN, Antônio Herman V. Direito Constitucional Ambiental brasileiro. In: CANOTILHO, José Joaquim Gomes; LEITE, José Rubens Morato(Orgs.). Direito Constitucional Ambiental Brasileiro. São Paulo: Saraiva, 2007, p. 102: “(...) siendo una extensión material (que salvaguarda sus bases ecológicas vitales) del derecho a la vida, garantido en el art. $5^{\circ}$, caput, reflexamente, recibe de este las bendiciones y acogida(...)". También: TRINDADE, Antonio Augusto Cançado. Direitos humanos e meio ambiente: cit., p. 75: "De esta perspectiva, el derecho a un medio ambiente sano y el derecho a la paz se configuran como extensiones o corolarios del derecho a la vida".
} 
medio ambiente con todos sus efectos, siendo deber del Poder Público y de la colectividad defenderlo y preservarlo para las presentes y futuras generaciones ${ }^{372}$.

Se trata del sustrato mínimo que hace que tenga sentido el derecho a la vida, haciendo del derecho al medio ambiente sano un verdadero derecho humano fundamental: En este sentido, no existe calidad de vida sin calidad ambiental, y es exactamente este eslabón inseparable entre los dos conceptos que erige el derecho al medio ambiente ecológicamente equilibrado a derecho humano fundamental y, más que eso, a una de las especies de los llamados derechos personalísimos ${ }^{373}$.

De los artículos $2^{\circ}$ y $3^{\circ}$ de la Ley $6.938 / 1981$ se nota intrínseca relación entre la vida y el medio ambiente. Sea al instituir que uno de los objetivos de la Política Nacional de Medio Ambiente está relacionado a la "calidad ambiental propicia a la vida" ${ }^{374}$ como al estipular en el concepto de medio ambiente, el conjunto de innúmeros factores que "abriga y rige la vida en todas sus formas"375. Además, la Constitución de 1988, en su dispositivo 225 afirma el derecho al medio ambiente ecológicamente equilibrado como "esencial a la sana calidad de vida”. ¡Pues, sin un medio ambiente sano no hay vida sana! ${ }^{376}$

\footnotetext{
${ }^{372}$ MAZZUOLI, Valério de Oliveira. Direito Internacional Público: parte geral. São Paulo: Editora RT, 2004, p. 181

${ }^{373}$ MILARÉ, Édis; LOURES, Flavia Tavares Rocha. Meio ambiente e os direitos da personalidade. Revista de Direito Ambiental, São Paulo, n. ${ }^{\circ}$ 37, ano 10, jan./mar. 2005, p. 16.

374 “Art. $2^{\circ}$ - La Política Nacional del Medio Ambiente tiene por objetivo La preservación, mejora y recuperación de la calidad ambiental propicia a la vida, visando asegurar, en el País, condiciones al desarrollo socioeconómico, a los intereses de la seguridad nacional y a la protección de la dignidad de la vida humana, atendidos los siguientes principios".

375 “Art. $3^{\circ}$ - Para los fines previstos en esta Ley, se entiende por: I - medio ambiente, el conjunto de condiciones, leyes, influencias e interacciones de orden física, química y biológica, que permite, abriga e rige la vida en todas sus formas".

${ }^{376}$ Importante mencionar la intrínseca correlación entre los artículos $5^{\circ}$ y 225 de la Carta Política, esto es, la co-dependencia lógica y axiológica entre el derecho a la vida y el derecho a un medio ambiente ecológicamente equilibrado. Vivir y conservar el medio ambiente sano no son medidas alternativas o excluyentes, antes de eso son la misma cosa, porque sin entorno sano no hay vida, ni dignidad humana. Así, el derecho fundamental a un ambiente sano constituye verdadera extensión de la manifestación del derecho a la vida, como su más importante proyección ( $\mathrm{CF}$, art. $5^{\circ}$, caput), garantiendo no sólo la existencia física y la salud de los seres humanos, sino también la dignidad de esta existencia.
} 
Nicolao Costa Neto es claro al enunciar esta relación "vida-medio ambiente" es una de las razones del carácter fundamental del derecho al ambiente sano: Su aspecto de fundamental, en una perspectiva antropocéntrica, es resultado del reconocimiento de que una sana calidad de vida, con la manutención de estándares estables de dignidad y bienestar social, requiere un ambiente sano y equilibrado ${ }^{377}$.

Otra vía posible para comprobar la fundamentalidad del derecho al ambiente sano es vincularlo, en una relación instrumental de medio y fin, al postulado de la dignidad de la persona humana, consagrado, por la Constitución Brasileña, en su art. $1^{\mathrm{o}}$, III, como epicentro de todo ordenamiento jurídico ${ }^{378}$.

Lógicamente, la efectividad del valor dignidad de la persona humana depende de un medio ambiente sano, condición primaria y esencial al desarrollo de la persona, mientras ser racional y responsable. Es también la dignidad de la persona humana la base común de los derechos fundamentales: "El presupuesto de que la dignidad humana es sustrato de todo el sistema de derechos fundamentales sirve, por lo tanto, como referencia de contenido para la transformación de un derecho ordinario en derecho fundamental" 379 .

Para asegurar el libre y responsable desarrollo material y espiritual de los seres humanos es necesario ofertar a las personas las condiciones vitales para eso, garantizando un ambiente que propicie los medios materiales (alimentación, recursos hídricos, vivienda) y espirituales (la belleza estética de las riquezas naturales) para ser utilizados en la satisfacción de sus anhelos y en el perfeccionamiento de sus

${ }^{377}$ COSTA NETO, Nicolao Dino de Castro e. Proteção jurídica do meio ambiente - I - Florestas. Belo Horizonte: Del Rey, 2003, p. 17. Además, también afirma (p. 15): "La dimensión fundamental del bien medio ambiente parte, además, de la aceptación de la íntima conexión entre el derecho al ambiente sano y el derecho a la vida".

${ }^{378}$ SILVA, José Afonso da. Fundamentos constitucionais da proteção ao meio ambiente. Revista de Direito Ambiental, São Paulo, n. ${ }^{\circ}$ 27, ano 7, jul./set. 2002, p. 51: "La protección del medio ambiente pasó a ser tema de elevada importancia en las Constituciones contemporáneas. El derecho al medio ambiente ecológicamente equilibrado entra en ellas deliberadamente como derecho fundamental de la persona humana, no más como simple aspecto de la atribución de órganos o de entidades públicas, como pasaba en constituciones más antiguas".

${ }^{379}$ SAMPAIO, José Adércio Leite. Direito Fundamental ao meio ambiente saudável, adequado e ecologicamente equilibrado. In: SAMPAIO, José Adércio Leite; WOLD, Chris; NARDY, Afrânio. Principios de direito ambiental: cit., p. 94. 
capacidades: Como si no bastase la existencia de las condiciones formales de un derecho fundamental, el derecho al medio ambiente ecológicamente equilibrado además goza de relieve especial en la misión de tutelar y de desarrollar el principio de la dignidad de la persona humana o como revelación inmediata de la corresponsabilidad intergeneracional $^{380}$.

La consideración de la dignidad como fundamento del sistema jurídico abarca el reconocimiento de otro derecho fundamental del hombre, que debe también ser garantizado por el Estado Democrático de Derecho: el derecho fundamental al desarrollo. Cada persona tiene el derecho de contribuir y participar del desarrollo cultural, económico, y político del cuerpo social, así como de definir los objetivos que desea alcanzar y las calidades que espera desarrollar, como ser dotado de conciencia y $\operatorname{dignidad}^{381}$.

La lista del artículo $5^{\circ}$ de la Constitución de 1988 no es numerus clausus, siendo meramente ejemplificativa, no obstante sean enormes las hipótesis catalogadas (78 incisos), conforme expreso en el $\S 2^{\circ}$ del art. $5^{\circ}$ de la Carta Magna ${ }^{382}$, contemplativo de otros derechos que no están necesariamente expresos en aquella lista, lo que es reconocido, obviamente, por la dogmática jurídico-constitucional patria. Conforme Manoel Gonçalves, en las Constituciones brasileñas, “desde la de 1891 (art.78), la enumeración de derechos fundamentales tiene carácter ejemplificativo" ${ }^{383}$ : Como se sabe, el listado constitucional de derechos fundamentales no es taxativo, siendo

\footnotetext{
${ }^{380}$ SAMPAIO, José Adércio Leite. Direito Fundamental ao meio ambiente saudável, adequado e ecologicamente equilibrado. In: SAMPAIO, José Adércio Leite; WOLD, Chris; NARDY, Afrânio. Princípios de direito ambiental: cit., p. 98.

${ }^{381}$ MILARÉ, Édis. Direito do Ambiente: cit., p. 148; MARTINS DA SILVA, Américo Luís. Direito do Ambiente e dos Recursos Naturais. Volume 1. São Paulo: RT, 2004, p. 408 e 409; SILVA, Geraldo Eulálio do Nascimento e. Direito Ambiental Internacional. $2^{\mathrm{a}}$ ed. Rio de Janeiro: Thex Editora, 2002, pp. 322 e 328.

382 “Art. $5^{\circ}(\ldots)$. $\S 2^{\circ}$ Los derechos y garantías expresos en esta Constitución no excluyen otros derivados del régimen y de los principios por ella adoptados, o de los tratados internacionales en que la República Federativa de Brasil sea parte".

${ }^{383}$ FERREIRA FILHO, Manuel Gonçalves. Direitos humanos fundamentais. São Paulo: Saraiva, 1996, p.98.
} 
tradición del constitucionalismo internacional, incluso de Brasil, la abertura del texto constitucional a nuevos derechos que vengan ampliar la lista existente ${ }^{384}$.

Por lo tanto, se puede de forma razonable y convincente reconocer que nuestro sistema jurídico, además de los derechos y deberes fundamentales individuales y colectivos listados en el art. $5^{\circ}$ de la $\mathrm{CF} / 88$, consigna, en el caput del art. 225, un nuevo derecho fundamental, destinado a garantir adecuadas condiciones de vida a todos, sin distinción: Pero se ha ido más allá, porque en Brasil el derecho fundamental al medio ambiente, al contrario de lo que ocurre en el derecho portugués, es, por fuerza de la abertura material aseverada en el art. $5^{\circ}, \S 2^{\circ}$, de la Constitución Federal de 1988, cláusula pétrea y sujeta a aplicabilidad directa, aunque no figure en la lista del art. $5^{\circ}$, una vez que el constituyente optó por insertarlo en el ámbito de las disposiciones constitucionales sobre el orden social ${ }^{385}$.

También para Antônio Herman Benjamin, la fundamentabilidad del derecho al medio ambiente ecológicamente equilibrado adviene del hecho de que "en la medida en que la lista del art. $5^{\circ}$, sede principal de derechos y garantías fundamentales, por fuerza de su $\S 2^{\circ}$, no es exhaustivo (derechos fundamentales hay - y muchos - que no están listados en el art. $\left.5^{\circ}\right)^{\natural 386}$. Por fin, una simple mención sobre la problemática del derecho al medio ambiente sano como derecho humano, la Enmienda Constitucional nº45/2004 instituye un nuevo párrafo al artículo $5^{\circ}$, generando discusión candente en la doctrina especializada $^{387}$.

\footnotetext{
${ }^{384}$ MARUM, Jorge Alberto de Oliveira. Meio ambiente e direitos humanos. Revista de Direito Ambiental, São Paulo, n. ${ }^{\circ} 28$, ano 7, out./dez. 2002, p. 135.

${ }^{385}$ MARUM, Jorge Alberto de Oliveira. Meio ambiente e direitos cit., p 105-106. Também en este sentido: José Adércio Leite Sampaio. Direito Fundamental ao meio ambiente saudável, adequado e ecologicamente equilibrado. In: SAMPAIO, José Adércio Leite; WOLD, Chris; NARDY, Afrânio. Princípios de direito ambiental: cit., p. 96: "O todavía a un derecho derivado del régimen y de los principios constitucionalmente adoptados o de los tratados internacionales que Brasil sea parte (art. $5^{\circ}$, par. $\left.2^{\circ}\right)$ ".

${ }^{386}$ BENJAMIN, Antônio Herman. Direito Constitucional Ambiental brasileiro. In: CANOTILHO, José Joaquim Gomes; LEITE, José Rubens Morato(Orgs.). Direito Constitucional Ambiental cit., pp. 101-102. ${ }^{387}$ Trata-se do $\S 3 .^{\text {o: }}$ "Los tratados y convenciones internacionales sobre derechos humanos que fueren aprobados, en cada Casa del Congreso Nacional, en dos turnos, por tres quintos de los votos de los respectivos miembros, serán equivalentes a las enmiendas constitucionales".
} 
Además, este principio enuncia la existencia de dos derechos. Un relativo a las generaciones presentes, de vivieren y desarrollaren sus actividades libremente. Y otro relativo a la necesidad de asegurarse a las generaciones venideras las mismas condiciones favorables de sobrevivencia y trabajo.

De estos derechos a un medio ambiente sano y habitable, resultan, lógicamente, los deberes, tantas veces aquí resaltados, de preservar los recursos ambientales, manteniendo su calidad mínima.

Estos derechos y deberes, a principio tan antagónicos, acabaron creando una teórica incompatibilidad entre desarrollo económico y conservación ambiental. Tal antagonismo, sin embargo, no es coherente, como afirma Édis Milaré: Es falso, de hecho, el dilema "o desarrollo o medio ambiente", en la medida en que, siendo uno fuente de recursos para el otro, deben armonizarse y complementarse. [...] Compatibilizar medio ambiente y desarrollo significa considerar los problemas ambientales dentro de un proceso continuo de planificación, atendiéndose adecuadamente a las exigencias de ambos y observándose sus interrelaciones particulares a cada contexto sociocultural, político, económico y ecológico, dentro de una dimensión tiempo/espacio. En otras palabras, esto implica decir que la política ambiental no se debe erigir en obstáculo al desarrollo, sino en uno de sus instrumentos, al propiciar la gestión racional de los recursos naturales, que constituyen su base material $^{388}$.

A partir de la percepción de la intrínseca relación existente entre el crecimiento económico y la manutención de los recursos ambientales, una vez que estos sirven de base - en la cualidad de materia-prima, por ejemplo - a aquél, surgió y se diseminó el concepto de desarrollo sostenible. Esta expresión, bastante actual y común en las discusiones y documentos sobre la temática ambiental, constituye el objetivo de prácticamente todos los gobiernos y órganos oficiales ambientales, nacionales $\mathrm{e}$ internacionales, y fue conceptuada de la siguiente forma por la Comisión Mundial sobre Medio Ambiente y Desarrollo: “Aquél que atiende a las necesidades del presente sin comprometer la posibilidad de las generaciones futuras atendieren a sus propias necesidades" 389 .

\footnotetext{
${ }^{388}$ MILARÉ, Édis. Direito do Ambiente: cit., p. 42.

${ }^{389}$ Apud MILARÉ, Édis. Direito do Ambiente: cit., p. 122.
} 
De esta definición, se deprende la necesidad de promoverse no sólo una producción sostenible, volcada a disminuir la degradación ambiental, pero también de concienciar la población para el establecimiento de un consumo sostenible, direccionado a la disminución del desperdicio, al reaprovechamiento de materiales y a la reducción del consumo de superfluos, cuya producción termina provocando mayor exploración de materias-primas, que son recursos naturales.

El derecho al desarrollo sostenible también fue contemplado por el ordenamiento brasileño, en las Leyes 6.803/1980 y 6.938/1981. En el ámbito internacional, fue acogido por la Agenda 21 y por el $8^{\circ}$ Principio de la Declaración de Rio de Janeiro ${ }^{390}$.

\subsubsection{Principio de prevención-precaución}

El principio de prevención es denominado también de principio de cautela o da prudencia, según el que, en materia ambiental la ciencia no siempre posee respuestas exactas y concretas a lo que se refiere a la repercusión de determinadas actividades sobre la naturaleza, así como el resultado de las degradaciones por ella sufridas. De esta forma, el derecho debe buscar acautelar, prevenir, de modo que cuando haya duda acerca del impacto de determinada actividad, el Derecho debe prohibirla hasta surgir una solución sostenible. Tal principio es encontrado en el enunciado 8 de la ECO/92, que completa que para alcanzar el desarrollo sostenible y una mejor calidad de vida, los Estados deben reducir y eliminar los sistemas de producción y consumo que no sean sostenibles y crear mecanismos apropiados.

El principio de precaución tiene la función de prevenir la degradación del medio ambiente, visando mantener una calidad de vida sana para la presente y futuras generaciones y la continuidad de la naturaleza existente en el planeta. Con el objetivo de proteger el medio ambiente, los Estados deberán aplicar ampliamente el criterio de precaución conforme sus capacidades. De esta forma, cuando haya peligro de daño grave o irreversible, la falta de certeza científica absoluta no deberá ser utilizada como

\footnotetext{
${ }^{390}$ Principio 8: "Para alcanzar el desarrollo sostenible y una mejor calidad de vida para todas las personas, los Estados deberían reducir y eliminar las modalidades de producción y consumo insostenibles y fomentar políticas demográficas apropiadas".
} 
fundamento para aplazar medidas eficaces en función de los costes para impedir a degradación ambiental (Principio 15 Declaración Rio/92).

El art. 225, $\S 1^{\circ}$, IV de la Constitución Brasileña preve el Estudio de Impacto Ambiental (EIA) para una previa evaluación de los efectos del proyecto que va a ser implantado o de la actividad que va a ser desarrollada, una vez que no siempre es posible recuperar el medio ambiente. Es importante destacar que la prevención no puede ser estática, ella debe actualizarse, adecuándose a la realidad de cada país, para que sea eficiente en la formulación de políticas ambientales de prevención.

El principio de precaución estima por la prevención, la visión anticipada de la degradación ambiental para que sea evitada. Según este principio, siempre que haya peligro de suceso de daño ambiental grave, deberán ser adoptadas medidas preventivas de inmediato, aunque delante de incertidumbres científicas sobre el grado de nocividad de las actividades potencialmente contaminantes. La explicación para eso es que la certeza científica puede suceder cuando el daño ya haya ocurrido y, en regla, lesiones ambientales son irreversibles.

La década de 1970 marcó el inicio de las preocupaciones jurídicas con el medio ambiente y el fortalecimiento de las políticas y movimientos ambientalistas en todo el mundo. Los entendimientos y estudios de esta década y de la siguiente fueron fuertemente influenciados por la idea de protección ambiental, provocando el surgimiento de un conjunto de acciones públicas fundamentadas en: [...] un gobierno central fuerte, en la creación de unidades de conservación y en una estrategia coercitiva y punitiva, de reglamento y control, para evitar la utilización de los recursos naturales de las áreas que sean protegidas de las actividades humanas. Los problemas ambientales deberían ser enfrentados mediante la implementación de un conjunto de leyes rigorosas sobre el uso y acceso a la tierra y de la exclusión de grupos sociales de ecosistemas considerados frágiles o amenazados ${ }^{391}$.

Esta orientación, conocida como estrategia de preservación, fue muy relevante para el inicio de la concienciación de los individuos y de los gobiernos mundiales acerca de la importancia y de la necesidad de preservación ambiental. Pero las ideas que la orientaban eran poco amplias, ya que predicaban la preservación de los recursos naturales, sobre todo los comprendidos por la biodiversidad, aisladamente considerados,

${ }^{391}$ CUNHA, L. H.; COELHO, M. C. N. Política e Gestão Ambiental. In: CUNHA, S. B.; GUERRA, A. J. T. (org.). A questão ambiental: diferentes abordagens. Rio de Janeiro: Bertrand Brasil, 2003, pp. 63-64. 
esto es, por su proprio valor como elementos de la naturaleza, sin considerarlos como reserva o substrato para la vida humana y descuidando la intrínseca relación existente entre el ambiente y el hombre, que acaba por constituir uno de sus elementos.

Así, como prácticamente no existen en el planeta, y ya no existían en la época, locales ajenos a la ocupación humana y, por esto, inmunes a su interferencia, este entendimiento condució las políticas públicas para crear áreas aisladas, protegidas y delimitadas por el Estado, tales como reservas y parques, en las que la biodiversidad pudiese desarrollarse y el equilibrio ecológico pudiese ser mantenido, lejos del contacto humano.

Conservar la biodiversidad, para los preservacionistas, significa minimizar futuras extinciones, preservando intactos los procesos vitales que mantienen la diversidad biológica en ecosistemas libres de disturbios. Se destaca particularmente la función ecológica de los predadores que se encuentran en la cumbre de la cadena alimentar; animales que necesitan de grandes áreas continuas preservadas para la manutención de poblaciones genéticamente viables ${ }^{392}$.

Luís Henrique Cunha y Maria Célia Coelho añaden que autores adeptos de esta ideología defendían la internacionalización de la protección de la naturaleza, bajo los cuidados de una institución supranacional, con recursos igualmente internacionales, y el empleo de fuerza policial para evitar ataques externos a las áreas protegidas ${ }^{393}$. Esta aversión a la ocupación humana se justificaba porque se creía que los mayores obstáculos a la preservación del ambiente estarían relacionados a los problemas sociales, como: [...] superpoblación, desigualdades de poder y riqueza, agotamiento de los recursos naturales, corrupción, falta de leyes, pobreza e intranquilidad social. Las presiones ejercidas por la búsqueda de desarrollo económico y por el crecimiento poblacional serían [...] las principales causas de la destrucción de la naturaleza en los trópicos ${ }^{394}$.

${ }^{392}$ CUNHA, L. H.; COELHO, M. C. N. Política e Gestão Ambiental. In: CUNHA, S. B.; GUERRA, A. J. T. (org.). A questão ambiental: cit., p. 64.

${ }^{393}$ CUNHA, L. H.; COELHO, M. C. N. Política e Gestão Ambiental. In: CUNHA, S. B.; GUERRA, A. J.

T. (org.). A questão ambiental: cit., p. 64.

${ }^{394}$ CUNHA, L. H.; COELHO, M. C. N. Política e Gestão Ambiental. In: CUNHA, S. B.; GUERRA, A. J.

T. (org.). A questão ambiental: cit., p. 64. 
El final de la década de 1980 fue marcado por el surgimiento de un movimiento de crítica a las ideas preservacionistas y a los resultados poco satisfactorios alcanzados por sus políticas de protección estricta de especies y hábitats. La escasez de resultados era ejemplificada por la protección de pequeñas áreas de reservas públicas en detrimento del aumento significativo de la deforestación de enormes áreas de bosque tropical.

Este abordaje, conocido como estrategia conservacionista, también relacionaba la devastación ambiental a los problemas sociales y políticos de la humanidad, pero no privilegiaba la conservación de los recursos naturales distante del contacto humano. Al contrario, consideraba las comunidades locales no como destruidores sino como actores sociales importantes para la conservación de los bienes naturales. También veía la naturaleza como un recurso, disponible a la satisfacción humana, y, a partir de este entendimiento, se desarrolló la noción de manejo sostenible.

Los conservacionistas privilegiaban la estructura y el funcionamiento de los bosques y no su biodiversidad, como hacían los preservacionistas. Esta concepción diferenciada permitió la conciliación entre la manutención y la exploración consciente de la naturaleza.

Ellos también destacaban el papel de la sociedad civil como colaboradora de los agentes gubernamentales en la elaboración y, principalmente, en la ejecución de las políticas de protección ambiental, valorando la gestión participativa de los recursos.

Por fin, el movimiento conservacionista también atentaba para las clases sociales que se beneficiaban y las que eran perjudicadas por las políticas de conservación del ambiente. Sus preocupaciones se extendían a la distribución de los costes y beneficios por los distintos grupos sociales.

Luís Henrique Cunha e Maria Célia Coelho apuntan las características principales de este abordaje conservacionista: El abordaje conservacionista es normalmente identificado con estrategias locales de conservación, en que las comunidades son tomadas como espacio apropiado para ejercer la autoridad sobre las actividades de manejo, en detrimento de esfuerzos centralizadores basados en organismos estatales. Es asociada aun con la noción más amplia de desarrollo sostenible, en que el uso productivo de los recursos naturales, para promover 
crecimiento económico y fortalecer modos de vida locales, camina lado a lado con la conservación de estos recursos para beneficio de las generaciones presentes y futuras ${ }^{395}$.

En este contexto, de abordaje conservacionista, más preocupada con el manejo sostenible y el relacionamiento equilibrado entre hombre y naturaleza, que surge el principio de Prevención-Precaución en Derecho Ambiental.

Una parte de la doctrina trata la prevención y la precaución como un único principio, que tiene raíz única y actuación política propia. Pero, otra parte de la doctrina, los considera aisladamente, por esta razón haremos tratativas para cada uno aisladamente.

Cabe destacar que el intuito aquí es perfeccionar la dogmática ambiental, forneciendo aunque directrices (y no máximas), instrumentos para delimitar cada campo de estos principios, sin tornarlos (ni acercarlos de) figuras aisladas una de la otra que no se comunican. Incluso sería imposible tal tarea, porque además de guardaren muchas similitudes, constituyen las bases del Derecho Ambiental en la sociedad de riesgo: Los contenidos finalistas de uno y otro se identifican, sin duda, ya que ambos se encuentran impregnados de equívoco énfasis preventivo. Por eso que al principio de la prevención también hay que ser atribuido el carácter estructurante otorgado al principio de precaución. Precaución y prevención se penetran de forma recíproca, concretizando la dimensión preventiva esencial a la efectividad del plexo normativo ambiental ${ }^{396}$.

Tal relación es un aspecto poco desarrollado por la doctrina actual por tratarse de tema tortuoso y espinoso conforme ya se resaltó anteriormente, siendo necesarios estudios profundizados. En este sentido, se destacan tres análisis de las relaciones entre estos principios: una sugiere una relación de escala, otra de instrumentalización y por fin hay una interpretativa.

La primera sugiriendo determinada evolución de prevención para precaución, tenemos la ambientalista lusa Ana Gouveia Freitas Martins que entiende que: "El principio de precaución surge, así, como un refuerzo cualificado del principio de prevención, visando la prevención de riesgos cuya intensidad no representa, aún, un

\footnotetext{
${ }^{395}$ CUNHA, L. H.; COELHO, M. C. N. Política e Gestão Ambiental. In: CUNHA, S. B.; GUERRA, A. J. T. (org.). A questão ambiental: cit., p. 66.

${ }^{396}$ COSTA NETO, Nicolao Dino de Castro e. Proteção Jurídica do Meio Ambiente - I - Florestas. Belo Horizonte: Del Rey, 2003, pp.71-72.
} 
peligro efectivo y concreto para el ambiente" ${ }^{397}$. Aun, en ese sentido de complementariedad tenemos Kourilsky y Viney entendiendo la precaución "hoy como un principio complementar al principio de la prevención"398. Interesante resaltar la posición de dos autores Daillier, P. y Pellet, A. citados por Ana Flávia Platiau, considerando que el principio de precaución "fue creado justamente para completar lagunas del principio de prevención"399.

Por otro lado, siguiendo otra línea, tenemos los doctrinadores David Hunter, James Salzman e Durwood Zaelke que piensan ser la prevención un "medio de aplicación del principio de precaución" 400 , así como Warwick Gullet que defiende que la prevención es "elemento de concreción del principio de precaución" "401. No estamos de acuerdo con tal pensamiento, porque parece promover una sustitución de la prevención por la precaución, lo que parece fulminar la diferencia y autonomía de estos principios de derecho ambiental.

La corriente interpretativa adoptada por la jurista portuguesa Carla Gomes y basada en la enseñanza de Canotilho, consiste en dar efectos de precaución al principio de prevención mediante una interpretación más amiga del ambiente, observe: El principio de precaución deberá ser entendido, en nuestra opinión, como derivado de una interpretación cualificada del principio de la prevención (la interpretación más amiga

${ }^{397}$ MARTINS, Ana Gouveia Freitas. O Princípio da Precaução no Direito do Ambiente. Lisboa: Associação Académica da Faculdade Direito Lisboa, 2002, pp.20-21.

${ }^{398}$ KOURILSKY y VINEY apud PLAUTIAU, Ana Flávia Barros. A legitimidade da governança global ambiental e o principio da precaução. In: VARELLA, Marcelo Dias; PLATIAU, Ana Flávia Barros (Orgs.). Princípio da Precaução. Belo Horizonte: Del Rey, 2004, p. 405.

${ }^{399}$ PLAUTIAU, Ana Flávia Barros. A legitimidade da governança global ambiental e o principio da precaução. In: VARELLA, Marcelo Dias; PLATIAU, Ana Flávia Barros (Orgs.). Princípio da cit., p. 404.

${ }^{400}$ HUNTER, David; SALZMAN, James e ZAELKE, Durwood apud SAMPAIO, José Adércio Leite. Direito A Constitucionalização dos princípios de Direito Ambiental. In: SAMPAIO, José Adércio Leite; WOLD, Chris; NARDY, Afrânio. Princípios de direito cit., p. 70.

${ }^{401}$ GULLETT, Warwick apud SAMPAIO, José Adércio Leite. Direito A Constitucionalização dos princípios de Direito Ambiental. In: SAMPAIO, José Adércio Leite; WOLD, Chris; NARDY, Afrânio. Princípios de direito cit., p. 72. 
del ambiente, en las palabras de Canotilho, o sea, obligando a una ponderación agravada del interés ambiental en detrimento de otros intereses, económicos, nombradamente ${ }^{402}$.

Entender la precaución como una interpretación de la prevención es un equívoco, ya que además de quedar bajo el criterio del magistrado, de la discreción y no vinculada a la aplicación del primer, parece generar una confusión, a saber: ¿Serían, entonces, los principios de precaución y de prevención principios hermenéuticos? ${ }^{403}$ No, pues, están ellos contemplados en nuestro ordenamiento jurídico, además de la separación hecha por la doctrina ambiental conforme mencionamos antes. Además, ellos poseen contenido material y no meramente aplicativo.

Nos parece que lo más correcto es tratar la precaución como siendo una evolución del principio de la prevención, surgida después de algunas insuficiencias de esta en tutelar el medio ambiente: "El principio de precaución vino, sin duda, reforzar el principio de prevención" ${ }^{, 404}$. Analizando los documentos internacionales de protección al medio ambiente, tal raciocinio es comprensible, ya que en 1972 durante la Conferencia de Estocolmo no se abordó el principio de precaución, tanto es así que no fue incorporado en la Declaración de principios de la reunión de ámbito mundial.

La precaución tiende a ultrapasar la prevención, no se esperando por las certezas técnicas de que una actividad pueda causar daños al medio ambiente, simplemente se actúa antes de la remota posibilidad de siniestro. Esto se debe a su vínculo con el futuro (principio de la equidad intergeneracional ${ }^{405}$ ), evitando pérdidas a medio y largo plazo, al paso que la prevención solo impide los daños de corto plazo: De

${ }^{402}$ GOMES, Carla Amado. A prevenção à prova no Direito do Ambiente. Coimbra: Coimbra Editora, 2000, p. 53.

${ }^{403}$ CANOTILHO, José Joaquim Gomes. Direito Constitucional e Teoria da Constituição. $7^{\mathrm{a}}$ ed. Coimbra: Almedina, 2003, p. 1.161: "Los principios hermenéuticos desempeñan una función argumentativa, permitiendo, por ejemplo, denotar la ratio legis de una disposición (cfr. infra, cap. $3^{\circ}$, cánones de interpretación) o revelar normas que no son expresas por cualquier enunciado legislativo, posibilitando a los juristas, sobre todo a los jueces, el desarrollo, integración y complementación del derecho (Richterrecht, analogía juris)".

${ }^{404}$ MIRRA, Álvaro Luiz Valery. Direito Ambiental: o princípio da precaução e sua aplicação judicial. Revista de Direito Ambiental. São Paulo, n.21, ano 6, jan./mar.2001, p. 93.

${ }^{405}$ La equidad está direccionada tanto para la preservación del medio ambiente para las generaciones actuales y futuras. Así denominadas de equidad intra(posición interior) e inter(posición intermediaria, reciprocidad)generacional. Volveremos a este principio más tarde, en el momento apropiado, defendiendo que la función de la precaución es garantir la eficacia de aquél. 
inicio, surgieron las medidas de prevención y después las de precaución para prevenir los riesgos ambientales inciertos y crecientes, resultantes de una sociedad industrial fuertemente establecida y de uso generalizado de energía oriunda de fuentes no renovables, fuertemente impactantes al medio ambiente y extremamente peligrosa a la salud, como la energía nuclear ${ }^{406}$.

Además, se puede afirmar que toda actitud precautoria será preventiva, pero no toda prevención puede ser considerada precautoria: "Parece que la precaución parte siempre de una orientación preventiva, pero, en contrapartida, la prevención puede no traducirse en precaución. Se diría que "el principio de precaución tiene un sentido preventivo" 407 .

Gran parte de los autores opta por diferenciar la prevención de la precaución, indicando, así, la existencia de dos principios diferentes, cada uno con su contenido propio. Es el caso del profesor Paulo de Bessa Antunes ${ }^{408}$, que informa que la prevención "se aplica a impactos ambientales ya conocidos y que tengan informaciones sobre ellos", mientras la precaución, asociada por él a la prudencia y a la cautela, "determina que no se produzcan intervenciones en el medio ambiente antes de tener la certeza de que no serán adversas para el medio".

La diferencia entre los dos principios apuntada por este autor consiste en que la precaución nortea la restricción de actividades cuyos efectos son todavía desconocidos e imposibles de ser calculados por medio de los instrumentos científicos disponibles hasta el momento. La prevención, en cambio, orienta las reservas o prohibiciones impuestas a las acciones cuyas consecuencias dañosas ya son conocidas y, por esto, deben ser evitadas. La precaución, diferentemente de la prevención, se justifica, aun, para evitar, en el presente, daños que, por ser desconocidos, talvez en el futuro, cuando fuere posible identificar todos sus efectos, sea irreversible.

Posición semejante a la de Paulo de Bessa Antunes es la de Marcelo Abelha Rodrigues que, al tratar de principio de precaución, argumenta en el sentido de que: Más que un juego de palabras, la asertiva es orientada por una política diversa de la

\footnotetext{
${ }^{406}$ RIOS, Aurélio Virgílio Veiga; DERANI, Cristiane. Princípios gerais do Direito Internacional Ambiental. In: RIOS, Aurélio Virgílio Veiga; IRIGARAY, Carlos Teodoro Hugueney. O direito e o desenvolvimento sustentável: curso de direito ambiental. São Paulo: Peirópolis/IEB, 2005, p. 96.

${ }^{407}$ GOMES, Carla Amado. A prevenção à prova no Direito do cit., p. 37.

${ }^{408}$ ANTUNES, Paulo de Bessa. Direito cit., pp. 35-36.
} 
prevención, porque privilegia la intención de no correr riesgos, incluso porque la precaución se concretiza aunque no se sepa si existen riesgos. Si ya son conocidos, la tarea es prevenirlos ${ }^{409}$.

Otros autores se posicionan de forma diversa a la anteriormente puesta. Es el caso de Cristiane Derani, que se contenta en abordar simplemente el principio de precaución, insertándole también las orientaciones preventivas. Celso Antônio Pacheco Fiorillo, al contrario, privilegia el abordaje del principio de prevención, entendiendo que él abarca toda la orientación preventiva y precautoria característica del Derecho Ambiental. Luís Paulo Sirvinskas, de manera singular, trata las dos denominaciones, prevención y precaución, como correspondientes al mismo contenido de principios.

Édis Milaré y Paulo Affonso Leme Machado mencionan los dos principios, pero privilegian uno de ellos con el abordaje de un contenido más amplio, atribuyendo al otro, importancia secundaria. Milaré trata con más detalles del principio de la prevención, mientras que Machado se concentra más en el principio de precaución ${ }^{410}$.

La argumentación presentada por Antunes y Rodrigues, en el sentido de diferenciar los dos términos, es bastante lúcida y está correcta. En este trabajo, partimos de la concepción de que son principios autónomos, aunque vinculados ontológicamente.

Por otro lado, las similitudes entre estos principios se circunscriben a su taxonomía y a la postura de cuidado del nuevo Derecho Ambiental ${ }^{411}$, porque ambos no trabajan con la reparación del medio ambiente (lo que en algunos casos es imposible e inviable) sino con su protección, visando que el daño se materialice.

De esta forma, la relación con la ciencia será uno de los aspectos diferenciales de los principios de precaución y de prevención, y sin exagerar, consistirá en la principal de ellas. Mientras la prevención funciona como un mero recordatorio de que se deben evitar actividades ya reconocidas como peligrosas, ambientalmente hablando, considerando los resultados científicos obtenidos hasta el momento relacionado a

${ }^{409}$ RODRIGUES, Marcelo Abelha. Instituições de Direito Ambiental. São Paulo: Max Limonad, 2002. v. 1 (Parte Geral), p. 150.

${ }^{410}$ RODRIGUES, Marcelo Abelha. Instituições de Direito cit., p. 151.

${ }^{411}$ Se querrá significar con tal expresión el modelo ambiental preventivo instituido por los principios de la prevención y de precaución en Derecho Ambiental Internacional y en los ordenamientos jurídicos nacionales de los Estados, siendo una evolución al primer escalón ya ultrapasado, representado por el modelo ambiental reparador, muy bien expresado por principios como 'quien contamina paga', desarrollo sostenible, entre otros. 
determinada forma de degradación ambiental, deja claro su subordinación a los resultados obtenidos por conocimiento científico. Observe el siguiente: El contenido cautelar del principio de prevención es dirigido por la ciencia y por la detención de informaciones determinadas y precisas sobre la peligrosidad y el riesgo de la actividad o comportamiento, que, así, revela situación de mayor verosimilitud del potencial lesivo que aquella controlada por el principio de precaución ${ }^{412}$.

Se nota que la certeza del peligro ambiental ya fue concretada anteriormente, sea por medio de degradaciones que ya sucedieron o por investigaciones científicas demasiadamente probadas por experts. En resumen, el daño ya sucedió alguna vez o se tiene certeza de su devastación, incluso de su alcance, y así se visa impedir su repetición: "El objetivo fundamental perseguido en la actividad de aplicación del principio de prevención es, fundamentalmente, la prohibición de la repetición de la actividad que ya se sabe peligrosa",413.

La prevención implica en un "deber jurídico de evitar la consumación de daños previsibles al medio ambiente. Además, conforme el entendimiento doctrinario, el principio de prevención se califica objetivamente porque no existe riesgo potencial, el peligro ya es cierto y conocido" 414 . Importante resaltar en ese sentido que: "En las palabras de Össenbuhl, es preciso distinguir la defensa contra un peligro (Gefahrenabwehr) de la evitación de un peligro (Gefahrenvermeidung)"415.

Ya el principio de precaución está vinculado justamente a la incertidumbre científica, lo que no significa la mitigación o la exclusión de la Ciencia, sino simplemente que esta debe considerar las ignorancias entre los factores que deben ser analizados. Se trata de uno de los anhelos del pensamiento complejo de Edgar Morin, la inserción de la incerteza entre los factores relevantes del conocimiento humano: "La complexidad negocia con la incerteza, no para exorcizarla, lo que es imposible, sino en la perspectiva del establecimiento de puentes provisorios entre el ser-que-busca y el

\footnotetext{
${ }^{412}$ LEITE, José Rubens Morato; AYALA, Patryck de Araújo. Direito Ambiental na sociedade de risco. Rio de Janeiro: Forense Universitária, 2002, pp. 62-63.

${ }^{413}$ LEITE, José Rubens Morato; AYALA, Patryck de Araújo. Direito Ambiental na sociedade cit., pp. 63.

${ }^{414}$ ALVES, Wagner Antônio. Princípios da Precaução e da Prevenção no Direito cit., p. 73.

${ }^{415}$ Apud GOMES, Carla Amado. A prevenção à prova no Direito do cit., p. 34.
} 
desconocido" ${ }^{, 416}$. Por tanto, uno de estos puentes provisorios es justamente el principio de precaución, ya que reconocida la incerteza sobre alguna actividad o emprendimiento humano que pueda causar riesgos considerables al medio ambiente, algo debe ser hecho de forma tal que no ofrezca riesgos significativos a las personas y al medio ambiente (paralizar actividades) y deje buscar soluciones para volver a las actividades (búsqueda de soluciones o perfeccionamiento de la tecnología existente).

Otra diferencia entre los principios está relacionada a los riesgos que deben ser evitados, en realidad, se trata de una consecuencia de la primera diferenciación hecha anteriormente. La prevención debido a su íntima vinculación a la ciencia, trabaja con problemas ambientales ya detectados y analizados, lo que hace con que se vuelva a los riesgos concretos (ya conocidos y materializados), mientras la precaución se responsabiliza por la consideración de las incertidumbres, actuando delante de los riesgos abstractos (posibles). En este sentido, Arruda asevera que: "Los riesgos conocidos se relacionan con el principio de prevención que sobre ellos actúa, al paso que los riesgos potenciales, están ligados al principio de precaución cuya órbita de actuación les envuelve" ${ }^{\text {417. }}$.

De este modo, tenemos, entonces que: "el principio de prevención se da en relación al peligro concreto, mientras que para el principio de precaución, la prevención es volcada al peligro abstracto" ${ }^{\text {418 }}$. En otras palabras, parece ser el entendimiento de Bourg y Schlegel cuando afirman que "hay prevención cuando se conoce el riesgo y precaución cuando el riesgo es desconocido o incierto"419; "Por eso la diferencia entre el principio de precaución y de prevención, porque este último es relativo a un riesgo

\footnotetext{
${ }^{416}$ SILVA, Juremir Machado da. Pensar a vida, viver o presente. In: CLOTET, Joaquim; SILVA, Juremir Machado da (Org.). As duas globalizações: complexidade e comunicação, uma pedagogia do presente. $2^{\mathrm{a}}$ ed. Porto Alegre: Sulina/EDPUCRS, 2002, p.18.

${ }^{417}$ ARRUDA, Domingos Sávio de Barros. A categoria acautelatória da responsabilidade ambiental. Revista de Direito Ambiental, São Paulo, n. ${ }^{\circ} 42$, ano 11, abr./jun. 2006, p.48.

${ }^{418}$ LEITE, José Rubens Morato; AYALA, Patryck de Araújo. Direito Ambiental na sociedade cit., p.62.

${ }^{419}$ BOURG, Dominique; SCHLEGEL, Jean-Louis. Anticiparse a los riesgos: El principio de precaución. Traducción Emma R. Fondevila.Barcelona: Editorial Ariel, 2004, p.153: “(...) hay prevención cuando se conoce el riesgo, y precaución cuando el riesgo no se conoce o es incerto".
} 
determinado, que puede ser asegurado" ${ }^{, 420}$. En otros términos, afirma Össenbuhl: "La prevención presupone a previsibilidad del peligro, mientras la precaución visa anticipar el surgimiento de un peligro, a fin de evitarlo"421.

La diferencia anterior trae una consecuencia, relacionada al momento de aplicación de los principios, o sea, la precaución es aplicada en un primer momento posible, mientras que la prevención es dejada para un momento posterior. De esta forma, se manifiesta la doctrina internacional: "Por fin, el principio de precaución resulta en un paso anterior al principio de prevención" 422 .

Otra diferencia entre los principios, considerando la sociedad de riesgo en que vivimos, puede llevar al siguiente pensamiento: la prevención está relacionada con la sociedad industrial considerada por Ulrich Beck, debido al cálculo de sus daños al medio ambiente y a los conocimientos científicos adquiridos por la ciencia. Ya la precaución se moldea en la sociedad de riesgo ${ }^{423}$, cuya incerteza científica hace parte del cotidiano de cada ciudadano, además de la imposibilidad de cálculo de los desastres y accidentes envolviendo los ingenios humanos de la postmodernidad. Así, como consecuencia de lo expuesto, la "cientificación simple" 424 trabaja con la prevención, mientras la precaución se relaciona con la "cientificación reflexiva".

Concluyendo, se piensa por bien, hacer la siguiente distinción traída por Carla Gomes citando Össenbuhl: "La diferencia entre la prevención y precaución resulta, así,

\footnotetext{
${ }^{420}$ PLATIAU, Ana Flávia Barros. A legitimidade da governança global ambiental e o principio da precaução. In: VARELlA, Marcelo Dias; PLATIAU, Ana Flávia Barros (Orgs.). Princípio da Precaução. Belo Horizonte: Del Rey, 2004, p. 405.

421 ÖSSENBUHL, F. apud GOMES, Carla Amado. A prevenção à prova no Direito do cit., p. 34.

${ }^{422}$ CHANG, Elvira Méndez. El Principio Precautorio y su Aplicación a los Ensayos Nucleares Subterráneos Franceses en el Pacífico Sur. Lima: Fondo Editorial del Pontificia Universidad Católica del Perú, 1996, p. 61.

${ }^{423}$ CARVALHO, Delton Winter de. Dano ambiental futuro: a responsabilização civil pelo risco ambiental. Revista de Direito Ambiental, São Paulo, ano 12, n.45, jan./mar.2007, p.70: "Por esta razón, el Principio utilizado por el Derecho para relacionar con la Sociedad de Riesgo consiste en el de Precaución, cuyo sentido prevé el deber de cautela como orientación a los procesos de tomada de decisión que se refieran a actividades y tecnologías cuyas consecuencias sean marcadas por la incerteza científica".

${ }^{424}$ BECK, Ulrich. La sociedad del riesgo: cit., p.223: "La diferencia de las consecuencias de la cientificación simple, las consecuencias de estas decisiones en investigación son en sí calculables (...)”.
} 
de la línea tenue existente entre el terminus de la previsibilidad de un peligro y el inicio de la consideración de un riesgo" 425 .

\subsubsection{El principio de precaución: características e incertidumbres del} daño ambiental

Por mucho tiempo se utilizó el parámetro de la verdad científica para legitimar la intervención del hombre en la naturaleza. Además, el sentido de progreso era dado a partir de la evolución de las técnicas de dominio de los recursos naturales.

Sin embargo, a partir del crecimiento de los daños causados al medio ambiente, tal verdad científica fue utilizada con recelo antes de justificar una determinada actividad humana que pudiese causar daño al ambiente, porque sus pronósticos podrían ser provisorios, inciertos o no existieren. Surgía así la precaución delante de la incertidumbre del daño ambiental.

En este sentido, la preocupación en prevenir la degradación del medio ambiente en el plan nacional e internacional pasó a ser acepta en las últimas décadas. En Brasil, la Ley de Política Nacional de Medio Ambiente, Ley 6.938/81, tuvo como objetivo la compatibilización entre desarrollo económico-social y la preservación de los recursos ambientales, visando su utilización racional y disponibilidad permanente, tornándose indiscutible la obligación de prevenir o evitar el daño cuando pudiese ser detectado previamente.

A pesar del pionerismo de la referida ley en Latinoamérica, el principio de precaución aún no había sido expresamente introducido en el ordenamiento jurídico brasileño. Ya en el Derecho Alemán, tal principio está presente desde los años 70, en el sentido de que la preocupación no debe ser sólo con la contaminación ya existente, sino que deberá ser combatida desde el inicio, sobre la base de un rendimiento duradero.

Posteriormente, la Conferencia de las Naciones Unidas sobre Medio Ambiente Humano, realizada en Estocolmo, en 1972, y la creación del Programa de las Naciones Unidas para el Medio Ambiente (PNUMA) impulsaron la introducción de referido principio en los debates internacionales sobre la protección del medio ambiente. En la

${ }^{425}$ GOMES, Carla Amado. A prevenção à prova no Direito do cit., p. 34. 
década de los 80 la idea de precaución fue incorporada a los textos de diversas declaraciones y tratados internacionales sobre cuestiones ambientales específicas, especialmente en materia de control de contaminación.

En 1992, fue realizada en Rio de Janeiro la Conferencia de las Naciones Unidas sobre el Medio Ambiente y el Desarrollo, en la que el Principio de Precaución obtuvo su reconocimiento internacional por medio de los siguientes principios: "Principio 15: Con el fin de proteger el medio ambiente, los Estados deberán aplicar ampliamente el criterio de precaución conforme a sus capacidades. Cuando haya peligro de daño grave o irreversible, la falta de certeza científica absoluta no deberá utilizarse como razón para postergar la adopción de medidas eficaces en función de los costos para impedir la degradación del medio ambiente."

“Principio 17: Deberá emprenderse una evaluación del impacto ambiental, en calidad de instrumento nacional, respecto de cualquier actividad propuesta que probablemente haya de producir un impacto negativo considerable en el medio ambiente y que esté sujeta a la decisión de una autoridad nacional competente”.

El principio, objeto de análisis, también fue expresamente incorporado en el ordenamiento jurídico brasileño por medio de la Constitución Federal y de la Ley de Crímenes Ambientales, Ley 9.605/98.

La Constitución Federal de 1988, aunque no mencione explícitamente el principio de precaución en las situaciones de incertidumbres científicas, hace mención a una situación de riesgo, que puede caracterizar una hipótesis en la que se deberá actuar con precaución. El artículo $225, \S 1^{\circ}$, II, IV y V, tratan de la incumbencia estatal de fiscalizar las entidades dedicadas a la investigación y manipulación de material genético; de la tarea de exigir para instalación de obra o actividad potencialmente causadora de significativa degradación del medio ambiente, estudio previo de impacto ambiental, que se dará publicidad; e impone el deber de control de la producción, de la comercialización y del empleo de técnicas, métodos y sustancias que comporten riesgo para la vida, la calidad de vida y el medio ambiente.

En el mismo sentido, dispone el artículo $54, \S 3^{\circ}$ de la Ley de Crímenes Ambientales, Ley 9.605, que “incurre en las mismas penas previstas en el párrafo anterior quien dejar de adoptar, cuando exigido por la autoridad competente, medidas de precaución en caso de riesgo de daño ambiental grave o irreversible". 
En la práctica el referido principio obtuvo el reconocimiento judicial de que en la duda no se debe practicar actos o permitir el uso o la producción de determinadas sustancias, ya que delante de la incertidumbre científica, la prudencia es la mejor opción, evitándose daños que pueden ser irreversibles.

De acuerdo con Paulo de Bessa Antunes, el Principio de precaución es aquél que determina que no se produzcan intervenciones en el medio ambiente antes de que se tenga la certeza de que estas no serán adversas para el medio ambiente[...]. Esto deja claro que el principio de precaución está relacionado al lanzamiento en el ambiente de sustancias desconocidas o que no hayan sido suficientemente estudiadas. La ley de Biodiversidad de Costa Rica, por ejemplo, reconoce el principio in dubio pro ambiente $^{426}$.

Como principio constitucional, la precaución pasa a tener naturaleza de norma, de precepto jurídico con contenido director del sistema jurídico normativo del Derecho Ambiental. La precaución se transforma en pilar de sustentación de las relaciones jurídicas del Estado en cuestiones ambientales. Las decisiones políticas e incluso jurídicas deberán cumplir las directrices establecidas en el contenido de la precaución.

Paulo Affonso Leme Machado explica que dos convenciones internacionales que insertaron el Principio de Precaución fueron firmadas, ratificadas y promulgadas por Brasil:

La Convención de la Diversidad Biológica consigna, entre los considerandos de su Preámbulo: "Observando también que, cuando exista amenaza de sensible reducción o perdida de diversidad biológica, a falta de plena certeza científica no debe ser usada como razón para posponer medidas para evitar o minimizar esa amenaza...”.

La Convención Marco de las Naciones Unidas sobre el Cambio Climático registra en su art. 3": "Principio - 3. Las Partes deberían tomar medidas de precaución para prever, prevenir o reducir al mínimo las causas del cambio climático y mitigar sus efectos adversos. Cuando haya amenaza de daño grave o irreversible, no debería utilizarse la falta de total certidumbre científica como razón para posponer tales medidas, teniendo en cuenta que las políticas y medidas para hacer frente al cambio climático deberían ser eficaces en función de los costos a fin de asegurar beneficios mundiales al menor costo posible" ${ }^{427}$.

\footnotetext{
${ }^{426}$ ANTUNES, Paulo de Bessa. Direito ambiental. $7^{\text {a }}$ ed. Rio de Janeiro: Lumen Juris, 2005, p. 36.

${ }^{427}$ MACHADO, Paulo Affonso Leme. Direito ambiental cit., p. 59.
} 
De esta forma, las dos convenciones mencionadas se diferencian en la redacción del Principio de Precaución, pero apuntan, de la misma forma, que lo mismo deberá ser aplicado delante de la incertidumbre científica sobre el suceso de graves daños ambientales.

La homologación de la precaución en el ordenamiento jurídico patrio representa la adopción de una nueva postura en relación a la degradación del medio ambiente, o sea, ella exige que sean tomadas, por parte del Estado como también por parte de la sociedad, medidas ambientales que impidan el suceso de actividades potencialmente nocivas al medio ambiente.

En este sentido cabe citar la lección de Cristiane Derani: "Precaución es cuidado. El principio de precaución está ligado a los conceptos de alejamiento del peligro y seguridad de las generaciones futuras, como también de sostenibilidad ambiental de las actividades humanas. Este principio es la traducción de la búsqueda de la protección de la existencia humana, sea por la protección de su ambiente como por el aseguramiento de la integridad de la vida humana. A partir de esta premisa, se debe considerar también no sólo el riesgo eminente de una determinada actividad, sino también los riesgos futuros resultados de emprendimientos humanos, que nuestra comprensión y el actual nivel de desarrollo de la ciencia jamás consiguen captar en toda densidad." 428

Cabe enfatizar que la más grande dificultad en la implantación del Principio de Precaución es la resistencia de algunos países en aplicar la legislación ambiental, argumentando que las normas relativas a la protección ambiental implicarían en una estagnación de la economía. Sin embargo, tal argumentación es inadmisible, porque lo que se propone es la utilización de nuevas tecnologías que contribuyan para la manutención del equilibrio ecológico sin perjuicio al desarrollo.

Algunos casos pueden ser destacados como ejemplos del Principio de Precaución y su utilidad práctica, como es el caso que sucedió en Europa, citado por José Adércio Leite Sampaio: Aunque investigaciones realizadas desde la década de los 40 viniesen demostrando que la exposición humana a frecuencias de olas de radio no eran dañosas a la salud, algunos datos eran poco claros, otros, aun controvertidos. Había registros epidemiológicos de algunos efectos biológicos - incluso cancerígenos -

\footnotetext{
${ }^{428}$ DERANI. Cristiane. Direito ambiental econômico. $2^{\mathrm{a}}$ ed. São Paulo: Max Limonad, 2001, p. 167.
} 
producidos por la exposición del hombre a emisiones de radiofrecuencia incluso en bajo nivel. Con todo, nada, que llamase la atención de la comunidad mundial y pudiese ser confirmado de forma independiente (The Royal Society of Canada, 1999). La duda, sin embargo, hizo con que Italia y Suiza tratasen de restringir la instalación de estaciones de base de móviles, por emitir olas de radiofrecuencia arriba de un determinado nivel. El estándar exigido, por cautela, quedara muy debajo de los índices internacionalmente admitidos, sobre todo, en el caso suizo, en áreas residenciales y hospitalarias ${ }^{429}$.

La ingeniería genética aplicada a los alimentos producidos con manipulación por el hombre muestra otra perspectiva de aplicación del Principio de Precaución. Algunos organismos genéticamente modificados también ofrecen riesgos hipotéticos, porque hay precariedad de investigaciones y pruebas para comprobar su seguridad. Aunque siendo incierto el riesgo, deben ser tomadas medidas de precaución visando la protección de las características naturales de los alimentos y de la salud humana.

Paulo Affonso Leme Machado cita un suceso en Estados Unidos, en el que la "Suprema Corte decidió impedir la continuidad de la construcción de una hidroeléctrica porque podría haber la destrucción del hábitat del molusco snail darter”. Menciona aun que el Tribunal se manifestó en el siguiente sentido: "El valor de ese patrimonio genético es incalculable [...]. Es interés de la humanidad limitar las pérdidas de las variaciones genéticas. La razón es simple: ahí se encuentran las claves de los enigmas que somos incapaces de resolver y ellas pueden proporcionar las repuestas a las cuestiones que nosotros no aprendemos a colocar. El más simple egocentrismo nos enseña a ser prudentes" ${ }^{\prime 430}$.

En lo que se refiere a la relación del principio de precaución y a las radiaciones nucleares, surgió la duda de que la radiación nuclear, emitida por la usina nuclear de Krummel, cerca de Hamburgo, estaría alcanzando la población del entorno, generando la enfermedad conocida como leucemia. En este sentido, el Supremo Tribunal Administrativo determinó que la Administración Pública constatase si la radiación de la usina nuclear estaba o no en los límites de "precaución” exigida por la Ley de Energía Atómica. Si los nuevos descubrimientos científicos indicaren que las normas fijadas anteriormente ya no son más suficientes, la Administración debe fijar estándares de

${ }^{429}$ SAMPAIO, José Adércio Leite; WOLD, Chris; NARDY, Afrânio. Princípios de direito ambiental: cit., p. 68.

${ }^{430}$ MACHADO, Paulo Affonso Leme. Direito ambiental cit., p. 61. 
precaución más altos, ya que la investigación y la ponderación de los riesgos es tarea de la Administración ${ }^{431}$.

Antes de discutir sobre las posibilidades de los riesgos, se debe indagar sobre la necesidad de determinada actividad, bajo el punto de vista de mejora y no perjuicio de la calidad de vida. La definición de necesidad pasa por una justa adecuación de los intereses relacionados, lo que no se puede es partir del riesgo para evaluar la viabilidad socioambiental de un emprendimiento. La base de la precaución es la necesidad, por más tormentosa que sea su identificación, porque en el cuestionamiento sobre la propia razón de existir de una determinada actividad, surge el inicio de la práctica de la precaución.

A pesar de las varias formulaciones existentes sobre el principio de precaución, es posible destacar tres elementos que componen su contenido: el reconocimiento de que determinado producto, técnica o emprendimiento presente algún riesgo potencial; el reconocimiento de que existen incertidumbres científicas sobre los impactos inmediatos o futuros relacionados a la implantación de determinado emprendimiento o uso de determinado producto o técnica y la necesidad de actuar adoptándose medidas de precaución.

El principio de Precaución posee características importantes, que proporcionan diferentes reflejos, por eso hay la necesidad de un examen profundo acerca de su extensión.

Durante mucho tiempo los instrumentos jurídicos internacionales se limitaban a enunciar que las medidas ambientales que serán adoptadas deberían basarse en posiciones científicas, suponiendo que este tributo a la Ciencia bastaba para asegurar la idoneidad de los resultados. Sin embargo, este pensamiento comenzó a mudar para una actitud más cautelosa y también más severa, que llevase en cuenta las incertidumbres científicas y los daños a veces irreversibles que podrían resultar de la actuación fundada y premisas científicas, que luego podrían mostrarse equivocadas.

Conforme enseña Machado, "en caso de certeza del daño ambiental, este debe ser prevenido. En caso de duda o de incertidumbre, también se debe actuar previniendo. Esta es la gran innovación del principio de precaución. La duda científica, expresa con argumentos razonables, no dispensa la prevención” ${ }^{\natural 32}$.

\footnotetext{
${ }^{431}$ MACHADO, Paulo Affonso. Direito ambiental cit., p. 60.

${ }^{432}$ MACHADO, Paulo Affonso Leme. Direito ambiental cit., p. 64.
} 
De esta forma, el principio de precaución no exige que el daño sea científicamente comprobado, aunque sea cierto su suceso o determinados sus efectos. Basta la duda para autorizar la utilización de este principio, porque el daño propiamente dicho puede ser entendido bajo varios aspectos.

Cabe entonces hacer breve relato sobre el daño, que consiste en la situación entre el estado actual del patrimonio que sufre y el que tendría si el evento dañoso no hubiese sucedido.

La Constitución Brasileña amparó el medio ambiente, elevándolo a la categoría de bien de uso común general y esencial a la calidad de vida sana, para las presentes y futuras generaciones. Así, cualquier lesión al medio ambiente, bien jurídico constitucionalmente amparado, puede ser apuntada como daño ambiental.

El daño ambiental también pode ser conceptuado a partir de los dispositivos contenidos en el artículo 225 de la Constitución Federal, conforme expone Álvaro Mirra: Toda degradación del medio ambiente, incluyendo los aspectos naturales, culturales y artificiales, que permiten y condicionan la vida, visto como bien unitario, inmaterial, colectivo e indivisible, y de los bienes ambientales y sus elementos corpóreos e incorpóreos específicos que lo componen, caracterizadora de la violación del derecho difuso y fundamental de todos a la calidad de vida sana en un ambiente sano y ecológicamente equilibrado ${ }^{433}$.

A partir de tal conceptuación, se concluye que el daño ambiental es una categoría general de la que hace parte el daño ecológico, daño a la salud, daño a la seguridad, daño al bienestar, entre otros.

Visando la adopción de medidas protectoras del medio ambiente, muchas técnicas de previsión de impactos fueron adoptadas en Brasil y en el mundo, tales como la Evaluación de Impactos Ambientales, el Estudio de Impacto Ambiental y la Zonificación Ambiental, con el objetivo de estimar un daño potencial y así, evitar su materialización.

Aunque el daño al medio ambiente sea la violación de derecho fundamental y, por lo tanto, presente en la rama de los derechos difusos, la amenaza y el riesgo de

${ }^{433}$ MIRRA, Álvaro Luiz Valery. Ação civil pública e a reparação do dano ao meio ambiente apud ALVES, Wagner Antônio. Princípios da precaução e da prevenção no direito ambiental brasileiro. São Paulo: Editora Juarez de Oliveira, 2005, p. 51. 
daños también son relevantes para resguardar la colectividad y su interés en la calidad de vida sana.

\subsubsection{La imposibilidad de tipificación de riesgo, peligro y amenaza} ambientales. Gestión de los riesgos ambientales

La expresión amenaza de daños, expresa en el Principio 15 de la Eco-92, simboliza la protección ambiental independiente de la materialidad de la lesión. Para el Principio de Precaución y para el Derecho Ambiental, la amenaza significa la existencia de situación factual que lleva el responsable por la protección ambiental a creer que el daño sucederá y, anticipándose, evita la lesión.

Por lo tanto, el término amenaza expresa el significado de peligro en su aspecto objetivo. Se nota que el peligro no es nada más que una realidad e importa una modificación del mundo exterior capaz de generar el daño, que aunque no suceda, no deja de existir como estado de hecho potencialmente capaz de causar una lesión. Para el Derecho Ambiental es desnecesaria la previsibilidad y certeza del daño.

Cabe diferenciar el peligro presumido y el peligro concreto. El peligro presumido o abstracto es considerado el comportamiento positivo o negativo, que se presume poder resultar en perjuicio o lesión a otras personas. La presunción, en este caso, no admite prueba en sentido contrario. La conducta en si es peligrosa, independiente de causar resultado material, o sea, es desnecesaria a la concretización del daño.

El peligro concreto, por otro lado, necesita de prueba para su caracterización, considerando la exigencia de acontecimiento real o anterior que comprometa el bien jurídico tutelado.

Varios autores, como Luiz Regis Prado, entienden que sería inconstitucional el peligro abstracto, porque tal especie de peligro encierra la presunción absoluta y no siempre resultará en peligro concreto, penalizándose el agente sólo por la violación de la norma, aunque el peligro sea inocuo en la práctica.

A pesar de la discusión doctrinaria acerca del asunto, el Derecho Ambiental prevé tratamiento diferenciado para actividades peligrosas y potencialmente dañosas de las que puedan resultar lesiones al medio ambiente, porque, después de la violación 
fática, difícil o imposible es la recuperación del status quo ante del bien afectado por el daño.

En este sentido, Alves expone que "la solución puede ser parecida a la adopción del elemento normal de la conducta, porque al desviarse de esta conducta normal, aunque no intencionalmente, la autoridad responsable tiene poder para utilizar el principio de precaución" 434 .

Cabe resaltar que si los peligros son en regla prohibidos o no sucede con los riesgos. Mientras que el peligro se muestra, en la mayoría de los casos, prohibido y potencialmente sufre sanciones en las esferas penales, administrativas y civiles, los riesgos siempre existirán, ya que ellos no pueden ser excluidos, porque siempre permanece la probabilidad, pero pueden ser minimizados.

De esta forma, la precaución es la anticipación a un riesgo o peligro, siendo que el principio de precaución indica la necesidad de adopción de medidas cuando no se conoce el impacto y efectos resultantes sobre el medio ambiente. Tal principio no es ligado de forma general a la protección ambiental, pero su alcance sirve como fundamento para aplicabilidad y eficacia de las normas, sea en el sistema jurídico sea en las decisiones administrativas. El núcleo del principio de precaución es la amenaza seria e irreversible del daño y no el daño serio e irreversible.

El principio de precaución no se resume en impedir o actuar o hacer. Envuelve la identificación de efectos potencialmente peligrosos, envuelve el riesgo potencial. Habiendo duda sobre el riesgo de cierta actividad, comportamiento o proceso a ser desarrollado por el hombre, no comprobado por la evaluación científica o tecnológica disponible, sin detección de la amplitud y efectos que podrían modificar el medio ambiente, se debe adoptar la evaluación de riesgos.

Considerando lo expuesto anteriormente, y de acuerdo con los enseñamientos de Alves, debe ser adoptado el siguiente procedimiento: Primeramente, identificase la situación de riesgo. De este análisis se constata que los resultados de la actividad o proceso demuestran verosimilitud o convicción de nocividad potencial o hipotética. En un segundo paso debe certificarse la existencia de efectos hipotéticamente peligrosos y el nexo de causalidad con la conducta. En otras palabras, la caracterización del peligro, la determinación de los riesgos a los que se atribuye la nocividad. Existiendo la

\footnotetext{
${ }^{434}$ ALVES, Wagner Antônio. Princípios da precaução e da prevenção no direito ambiental cit., p. 55.
} 
imposibilidad de mensurar y delimitar riesgos y su respectivo grado de lesividad, autorizada está la aplicabilidad del principio de precaución. ${ }^{435}$

Delante del análisis de la tipificación de los riesgos ambientales, cabe abrir un paréntesis y mencionar sobre la obligatoriedad del control del riesgo para la vida, la calidad de vida y el medio ambiente, característica esta listada en los estudios de Paulo Affonso Leme Machado.

El riesgo para la vida, la calidad de vida y el medio ambiente no es materia que pueda ser relegada por el Poder Público, teniendo en cuenta que la Constitución Federal, en su artículo $225, \S 1^{\circ}$, inciso $\mathrm{V}$, determina que él no se omita en el examen de las técnicas y métodos utilizados en las actividades humanas que propician riesgo para la salud humana y el medio ambiente.

Basado en lo que fue expuesto, Machado informa que: "Controlar el riesgo es no aceptar cualquier riesgo. Hay riesgos inadmisibles, como aquel que coloca en peligro valores constitucionales protegidos, como el medio ambiente ecológicamente preservado, los procesos ecológicos esenciales, el manejo ecológico de las especies y ecosistemas, la diversidad y la integridad del patrimonio biológico - incluido el genético - y la función ecológica de la fauna y de la flora"436.

La agresión al medio ambiente y a los elementos que lo componen no siempre traerá como consecuencia el perjuicio a su calidad, resaltando que habría un rigor excesivo admitir que todas las variaciones ambientales serían perjudiciales, caso en que se estaría negando que el medio ambiente no es estático y habituado a cambios e innovaciones.

Cabe mencionar que la tolerabilidad para la agresión ambiental fue reconocida en la Conferencia del Medio Ambiente y Desarrollo de 1992, en Rio de Janeiro. De este modo, cuando superados los estándares de admisibilidad de la modificación del medio ambiente, surge la intervención de la autoridad para la aplicación de los principios protectores.

Así, la tolerabilidad también debe integrar la gestión de los riesgos, para que el responsable por la protección ambiental y de la sociedad evalúe cual es el nivel aceptable de riesgo para cierta conducta.

\footnotetext{
${ }^{435}$ ALVES, Wagner Antônio. Princípios da precaução e da prevenção no direito ambiental cit., p. 54.

${ }^{436}$ MACHADO, Paulo Affonso Leme. Direito ambiental cit., p. 65.
} 
A lo que se refiere a la gestión de riesgos también es fundamental la observancia, por el Poder Público del control de producción, comercialización y empleo de técnicas, métodos y sustancias que puedan producir riesgo para la vida, medio ambiente calidad de vida, conforme expreso en la Magna Carta, en su artículo 225, $\S 1^{\circ}$, inciso $\mathrm{V}$.

Sobre el expuesto, afirma Cristiane Derani: "El criterio general para la realización de determinada actividad sería su necesidad bajo el punto de vista de mejora y no perjuicio de la calidad de vida. Este criterio debe operar, especialmente, en los tres momentos en que la actividad humana es potencialmente dañosa al ambiente: apropiación de recursos naturales, transito de productos, emisiones industriales" ${ }^{\natural 37}$.

\subsubsection{Costes de las medidas de prevención y su aplicación inmediata}

Otra cuestión a ser enfrentada es el coste de las medidas de prevención en relación al país, a la región o al local. Esta característica consiste en que las medidas adoptadas para enfrentar los problemas ambientales deben ser eficaces en función de los costes, de modo que asegure beneficios al menor coste posible.

El coste excesivo debe ser ponderado de acuerdo con la realidad económica de cada país, porque la responsabilidad ambiental es común a todos los países, pero de forma diferenciada.

De acuerdo con los enseñamientos de Cristiane Derani, cabe mencionar: La participación del Poder Público no se direccionaría exactamente a la identificación y posterior supresión de los riesgos de determinada actividad. A la pregunta ‘¿causaría A un daño?’ sería opuesto la indagación ‘¿necesitamos de A?’. No es el riesgo, cuya identificación se torna resbaladiza en el campo político y técnico-científico, causado por una actividad que debe provocar alteraciones en el desarrollo linear de la actividad económica. Sino, el aclaramiento de la razón final de lo que se produce sería el punto de partida de una política que considere el bienestar de una comunidad. En el cuestionamiento sobre la propia razón de existir de una determinada actividad se colocaría el inicio de la práctica del principio de precaución ${ }^{438}$.

${ }^{437}$ DERANI, Cristiane. Direito ambiental cit., p. 172.

${ }^{438}$ WINTER, Gerd apud DERANI, Cristiane. Direito ambiental cit., p. 167. 
Sobre la implementación inmediata de las medidas de prevención, cabe mencionar que los documentos internacionales, tales como a Declaración de Rio de Janeiro de 1992, la Convención de la Diversidad Biológica y la Convención Marco sobre el Cambio Climático, entienden que las medidas de prevención no deben ser pospuestas.

Se resalta que la precaución no sólo debe estar presente para impedir el perjuicio ambiental, aunque incierto, que pueda resultar de las acciones u omisiones humanas, como debe actuar para la prevención oportuna de este perjuicio. Se evita el daño ambiental, por medio de la prevención al tiempo cierto.

Con relación a lo expuesto, Machado enseña que la necesidad del aplazamiento de las medidas de precaución en acuerdos administrativos o en acuerdos efectuados por el Ministerio Público debe ser exhaustivamente probada por el órgano público ambiental o por el propio Ministerio Público. Habiendo duda, se opta por la solución que proteja inmediatamente el ser humano y conserve el medio ambiente (in dubio pro salute o in dubio pro natura). ${ }^{439}$

\subsubsection{La inversión de la carga de la prueba. Instrumentos de} efectividad y la relación con las demás ramas del Derecho. Críticas a la efectiva aplicación del principio de precaución

Como última característica del principio de precaución hay la posibilidad de inversión de la carga de la prueba para posibilitar la eficacia de in dubio pro ambiente.

El principio de precaución es un instrumento de política ambiental basado en la inversión de la carga de la prueba, esto significa que, para no adoptar medida preventiva o correctiva, es necesario demostrar que determinada actividad no dañifica seriamente el ambiente y que esta actividad no causa daño irreversible.

El autor del potencial riesgo deberá comprobar que su conducta no reverterá en daños al medio ambiente, de forma que la carga procesal normal se invierte. Habiendo comprobación de que tal conducta o sustancia causa daño o carece de defensa, el agente quedará inhibido para practicar su acción. Por otro lado, será suprimida la medida

\footnotetext{
${ }^{439}$ MACHADO, Paulo Affonso Leme. Direito ambiental cit., p. 67.
} 
preventiva o de corrección cuando explicitado que la actividad no perjudica, dañifica o altera en niveles intolerables el ambiente o que no cause lesiones irreparables o desproporcionales a capacidad de reacción y tolerabilidad del medio ambiente.

La relación de causalidad es presumida con el objetivo de evitar el suceso de daño. La aplicación del Principio de Precaución invierte la carga de la prueba e impone al potencial autor probar, con anterioridad, que su acción no causará daños al medio ambiente.

En Brasil, por la Ley de Política Nacional del Medio Ambiente, Ley 6.938/81, se aplica la Responsabilidad Objetiva, conforme dispuesto en su artículo $14, \S 1^{\text {o440 }}$.

Por lo tanto, debe ser resaltado que no cabe a los titulares de derechos ambientales probar efectos negativos de emprendimientos levados a la apreciación del Poder Público, se impone a los potenciales degradadores la carga de probar que su actividad es inofensiva.

El principio de precaución determina que las actividades potenciales o comprobadamente degradadoras del medio ambiente sufran limitaciones y fiscalización directa de los órganos estatales y de la sociedad en general.

Las medidas de control y preservación ambiental efectuadas con fundamento en el Principio de Precaución fueron indicadas como eficientes métodos para inhibir las agresiones ambientales. La influencia popular en las políticas ambientales y la actuación estatal son demostraciones reales de aplicación del referido principio.

La Ley $n^{\circ}$ 6.938/81 establece, en su artículo $4^{\circ}$, os objetivos de la Política Nacional del Medio Ambiente, entre los que se destacan la compatibilidad del desarrollo económico-social con la preservación de la calidad del medio ambiente y del equilibrio ecológico; la difusión de tecnologías de manejo del medio ambiente, divulgación de datos de informaciones ambientales y formación de conciencia pública sobre la necesidad de preservación de la calidad ambiental y del equilibrio ecológico;

${ }^{440}$ Artículo 14 - "Sin perjuicio de las penalidades por la legislación federal, estadual y municipal, el nocumplimiento de las medidas necesarias a la preservación o corrección de los inconvenientes y daños causados por la degradación de la calidad ambiental sujetará los transgresores:

$\S 1^{\circ}$ - Sin obstar la aplicación de las penalidades previstas en este artículo, es el contaminador obligado, independientemente de la existencia de culpa, a indemnizar o reparar los daños causados al medio ambiente y a terceros, afectados por su actividad. El Ministerio Público de la Unión y de los Estados tendrá legitimidad para proponer acción de responsabilidad civil y criminal por daños causados al medio ambiente". 
preservación y restauración de los recursos ambientales visando su utilización racional y disponibilidad permanente, convergiendo para la manutención del equilibrio ecológico propicio a la vida.

No obstante, para que sean alcanzados tales objetivos la Política Nacional del Medio Ambiente presentó instrumentos que propician la preservación del medio ambiente y permiten la implementación del Principio de Precaución como frenos a la degradación ambiental, tales como el Licenciamiento Ambiental, la Zonificación Ambiental y la Evaluación de Impactos Ambientales, comprueban la estrecha relación entre el Principio de Precaución y el Derecho Administrativo.

Así, es importante decir que el Derecho Ambiental guarda íntima relación con el Derecho Administrativo en la medida que este establece las normas reguladoras de las relaciones entre la Administración Pública y la colectividad, teniendo por objetivo principal el bien de la sociedad.

El Poder de Policía es el medio por el que la Administración Pública restringe derechos individuales en beneficio de la colectividad. Utilizando tal poder la administración llega al orden público anhelado.

De acuerdo con Paulo de Bessa Antunes, la policía del medio ambiente, anhelando asegurar a las normas ambientales, podrá actuar preventivamente o represivamente. La actuación preventiva o represiva se hace mediante la utilización de medidas de policía ambiental ${ }^{441}$.

La Licencia ambiental se encuentra entre tales medidas de policía y política ambiental, y está definida en el artículo $1^{\circ}$, inciso I de la Resolución CONAMA n. ${ }^{\circ}$ 237/97, que dispone:

Licencia ambiental: procedimiento administrativo por el que el órgano ambiental competente licencia la localización, instalación, ampliación y la operación de emprendimientos y actividades utilizadoras de recursos ambientales, consideradas efectiva o potencialmente contaminantes o de aquellas que, bajo cualquier forma, puedan causar degradación ambiental, considerando las disposiciones legales y reglamentarias y las normas técnicas aplicables al caso.

Licencia ambiental es, por tanto, un procedimiento administrativo, un conjunto de actos sucesivos objetivando una decisión final de la administración, la licencia

\footnotetext{
${ }^{441}$ ANTUNES, Paulo de Bessa. Direito ambiental cit., p. 97.
} 
ambiental, así definida en el artículo $1^{\circ}$, inciso III, de la Resolución CONAMA n. ${ }^{\circ}$ 237/97, como sigue el texto normativo: Licencia Ambiental: acto administrativo por el que el órgano ambiental competente, establece las condiciones, restricciones y medidas de control ambiental que deberán ser obedecidas por el emprendedor, persona física o jurídica, para localizar, instalar, ampliar y operar emprendimientos o actividades utilizadoras de los recursos ambientales consideradas efectiva o potencialmente contaminantes o aquellas que, bajo cualquier forma, puedan causar degradación ambiental.

La Licencia ambiental tiene de tres etapas, a saber: Licencia Previa (LP), Licencia de Instalación (LI) y Licencia de Operación (LO). La LP es concedida en la fase preliminar del planeamiento del emprendimiento o actividad, aprobando su ubicación y concepción, atestando la viabilidad ambiental y estableciendo los requisitos básicos y condicionantes que deben ser atendidos en las próximas fases de su implementación. La LI autoriza la instalación del emprendimiento o actividad de acuerdo con las especificaciones constantes de los planes, programas y proyectos aprobados, incluyendo las medidas de control ambiental y demás condicionantes, que constituyen motivo determinante. Por fin, la LO autoriza la operación de la actividad o emprendimiento, después de la verificación del efectivo cumplimiento de lo que consta de las licencias anteriores, con las medidas de control ambiental y condicionantes determinados para la operación, conforme descrito en el artículo $8^{\circ}$ de la Resolución CONAMA n. ${ }^{\circ} 237 / 97$.

Se resalta que entre una fase y otra puede haber la necesidad de Estudio de Impacto Ambiental (EIA) e Informe de Impacto Ambiental (RIMA) siendo, estos, por lo tanto, parte integrante de la Licencia Ambiental.

Se nota, por lo expuesto, que la actividad de policía, en la licencia ambiental, está amparada en el principio de precaución, porque al exigir el informe de impacto sobre el medio ambiente, se está anticipando al daño al ambiente o a la posibilidad de su suceso.

Con relación a la zonificación ambiental, consiste en la definición de sectores o zonas en una unidad de conservación con objetivos de manejo y normas específicas, con el propósito de proporcionar los medios y las condiciones para que todos los objetivos de la unidad puedan ser alcanzados de forma armónica y eficaz, así dispuesto en el 
artículo $2^{\circ}$ de la Ley n. ${ }^{\circ}$ 9.985/00, que instituyó el Sistema Nacional de Unidades de Conservación de la Naturaleza.

La zonificación tiene como objetivo ordenar la ocupación, utilización y destino das zonas de interés ambiental buscando proteger, preservar y recuperar la calidad ambiental de tales áreas.

De acuerdo con Machado, cabe explicitar: "La zonificación ambiental es uno de los aspectos del poder de policía administrativa que actúa con la finalidad de garantizar la salubridad, la tranquilidad, la paz, la salud, el bienestar del pueblo. La zonificación al discriminar usos, representa una limitación del derecho de los ciudadanos. La propiedad no podrá ser utilizada de la manera deseada únicamente por el propietario" 442 .

Su fundamento constitucional está previsto en el artículo $225, \S 1^{\circ}$, inciso III, de la $\mathrm{CF} / 88$ que sucintamente describe la necesidad de creación de las unidades de conservación de la naturaleza en el territorio nacional.

En este sentido cabe citar Wagner Antônio Alves: "La zonificación ambiental es, por imposición unilateral de orden pública, condicionante del ejercicio del derecho de propiedad o actividades sociales, sujetando el uso del espacio territorial a una destinación de interés público, pasando tal espacio a ser especialmente protegido. Tal intervención, es consecuencia del poder de policía, que es indisociable de la Administración Pública y se exterioriza en las imposiciones unilaterales e imperativas bajo la tríplice modalidad positiva (hacer), negativa (no hacer) o permisiva (dejar de hacer). No observados los criterios de ocupación y destinación del espacio protegido y especificado en ley (art. $2^{\circ}$, inciso I, de la Ley $n^{\circ} 9.985 / 2000$ ), el infractor deberá sufrir las sanciones legales impuestas por el Poder Judicial y por la Administración Pública, teniendo en cuenta la prioritaria preservación del medio ambiente"443.

Se puede decir, por tanto, que la zonificación ambiental materializa las medidas de control y gestión exigidas por el Principio de Precaución, y también por el Principio de la Prevención, a lo que se refiere a la conservación del medio ambiente.

Respecto al proceso de Evaluación de Impacto Ambiental (AIA), que fue tratado en Brasil por la Ley n. ${ }^{\circ} 6.803 / 80$, que, en su artículo $10, \S 3^{\circ}$, explícitamente,

\footnotetext{
${ }^{442}$ MACHADO, Paulo Affonso Leme. Direito ambiental cit., pp. 175-176.

${ }^{443}$ ALVES, Wagner Antônio. Princípios da precaução e da prevenção no direito ambiental cit., p. 84.
} 
impuso la evaluación de impacto como estudio para establecimiento de zonificación urbana.

Y fue con la Ley de la Política Nacional del Medio Ambiente, Ley n. ${ }^{\circ}$ 6.938/81, que la Evaluación de Impacto Ambiental pasó a ser un hito en la protección y preservación de los recursos naturales, con el objetivo de establecer el desarrollo económico sostenible.

El Consejo Nacional del Medio Ambiente, por medio de la Resolución CONAMA n. ${ }^{o}$ 1/1986, aplicó la evaluación de impacto ambiental a los emprendimientos públicos, además de los privados, lo que indujo todos los sectores a movilizarse para implementarla.

La Constitución Federal, en su artículo 225, $\S 1^{\circ}$, inciso IV, incumbió al Poder Público la tarea de exigir el Estudio de Impacto Ambiental, en la forma de la ley, para instalación de obra o actividad potencialmente causadora de significativa degradación al medio ambiente. La legislación ordinaria, posteriormente, determinó que el Estudio de Impacto Ambiental debe ser efectuado en momento anterior a la autorización de la actividad u obra.

Importante recordar que el Estudio de Impacto Ambiental (EIA) engloba el Informe de Impacto Ambiental (RIMA), siendo que este revelará las conclusiones del EIA, como se denota de la Resolución CONAMA nº $1 / 1986$.

En las palabras de Paulo Affonso Leme Machado, el informe transmite - por escrito - las actividades totales del EIA, importando acentuar que no se puede crear una parte transparente de las actividades (el RIMA) y una parte no transparente de las actividades (el EIA). Disociado del EIA, el RIMA pierde la validad ${ }^{444}$.

Se concluye con eso, que el Estudio de Impacto Ambiental es parte integrante del proceso de Licencia Ambiental, como dicho anteriormente, además viabiliza el conocimiento del grado de reversibilidad e irreversibilidad del impacto y expone la evaluación de los riesgos que deben ser gestionados. Tal estudio, en otras palabras, permite que sea conocida la certeza o incerteza del daño.

Además de los medios, anteriormente citados, de actuación de la Administración Pública, que actúan preventivamente al daño, hay que mencionar

${ }^{444}$ MACHADO, Paulo Affonso Leme. Direito ambiental cit., p. 207. 
también sobre la acción represiva de la administración ante la práctica de una infracción contra el medio ambiente.

La Ley $n^{\circ} 9.605 / 98$ establece, en su artículo $3^{\circ}$, que la autoridad ambiental que se entere de la práctica de infracción ambiental está obligada a promover su apuración inmediata, mediante proceso administrativo propio, so pena de responsabilidad.

La represión administrativa se produce por medio de multas, interdicción de actividades, aprensión de bienes relacionados a la degradación ambiental, instrumentos utilizados en la práctica de la infracción, entre otros. Tales medidas, coercitivas, son realizadas con la utilización, por el Estado, del Poder de Policía, caracterizado por la actividad estatal de limitar la libertad y la propiedad incorporándola a los intereses colectivos.

El alcance de la represión por parte de la Administración Pública se da debido a la coercitividad, que consiste en la imposición de la voluntad estatal independientemente del consentimiento del particular, y el auto ejecutoriedad, que la administración promueve las medidas por sí misma, sin la intervención del Poder Judicial.

Uno de los instrumentos utilizados por los órganos estatales encargados de la prevención y represión al daño ambiental es el Auto de Infracción ambiental. El auto es destinado a formalizar la aplicación de sanciones a aquellos que causan lesiones a los bienes ambientales. La responsabilización administrativa por medio del Auto de Infracción ambiental no impide la aplicación de las medidas necesarias en la esfera penal, cuando el hecho, además de constituir infracción administrativa también fuere definido como delito.

La cuestión atada a la responsabilidad penal en la esfera del medio ambiente deriva de los términos de la Ley 9.605, de 12.02.1998 - Ley de los Crímenes Ambientales. Tal legislación fue promulgada con el objetivo de establecer sanciones criminales aplicables a las actividades lesivas al medio ambiente, teniendo como elemento determinante de la responsabilidad la culpa del agente por el daño.

Entretanto, con relación a la aplicación del principio de precaución, hay que mencionar el Derecho Penal Ambiental, rama que cuida de la protección ambiental del medio ambiente y que atiende no sólo a los postulados de la dogmática penal, pero también a los principios jurídicos de la protección ambiental, delineados por la 
Constitución Federal y por leyes de carácter general, como la Ley de Política Nacional del Medio Ambiente, Ley 6.938/81.

Por lo tanto, la prevención a los daños y la precaución de los riesgos es el principal objetivo de la protección jurídica del medio ambiente. Se identifica, de esta forma, la previsión de crímenes de peligro como la forma más eficaz de hacer, en el ámbito de la tutela penal del medio ambiente el Principio de Precaución.

Delante de lo expuesto, Ana Paula Cruz elucida que se desarrolla la tesis de que la criminalización de conductas de peligro en la protección del bien ambiental es la manera más sensible de hacer incidir la tutela preventiva del medio ambiente. El delito de peligro no aguarda la consumación del daño para incidir y punir la conducta del que infringe el cuidado de peligro requerido. Él pune el simple hecho de 'poner en peligro' el bien tutelado, antes mismo que la lesión se efectúe. Se consubstancia en la amenaza de daño que la conducta puede traer al bien ${ }^{445}$.

La criminalización del peligro, en el Derecho Penal Ambiental, refleja el principio de precaución a la medida en que, al anticipar la punición de una conducta potencialmente dañosa al bien jurídico tutelado (el medio ambiente sano), dispensa la producción del resultado (daño) y promueve la tutela preventiva del bien ambiental por no esperar el suceso efectivo de la lesión.

Cabe resaltar que el delito de peligro es verificado siempre que la ley transfiere el momento de consumación del delito de 'lesión' para el de 'amenaza', perfeccionándose el crimen en el instante en que el bien tutelado se encuentra en una condición objetiva de posible o probable lesión.

El delito de peligro abstracto, a su vez, se configura cuando una acción considerada crea un riesgo determinable a priori y objetivamente desaprobado, aunque independiente de que el riesgo o el peligro afecte o no el objeto en que se concretiza el bien jurídico protegido. En cambio, el delito de peligro concreto es el que el ordenamiento jurídico exige la colocación en peligro de un objeto en el que se concretiza el bien jurídico junto con una probabilidad de lesión suficiente.

Cabe decir que los delitos de peligro concreto, con relación a la tutela del medio ambiente, son, en la práctica, de difícil aplicación, en razón de la dificultad de comprobarse el suceso del peligro. Entretanto, los delitos de peligro abstracto atienden

${ }^{445}$ DA CRUZ, Ana Paula Fernandes Nogueira. Crimes de perigo e riscos ao ambiente. Revista de Direito Ambiental, n. 42. São Paulo: Editora Revista dos Tribunais, 2006, p. 6. 
más plenamente al Principio de Precaución, visto que encuentran su descripción típica en el simple incumplimiento de normas administrativas de cautela.

De esta forma, cabe mencionar que los delitos de peligro representan una anticipación de la tutela penal, en el aspecto del derecho material, porque al punir la mera probabilidad del daño, evitan, en la mayoría de los casos, la finalización de una conducta tendente a su consumación.

Por lo tanto, se puede concluir que la tutela penal es necesaria para efectuar la protección reclamada por el bien ambiental, considerando que la construcción de una tutela penal amparada en el aspecto de la prevención del daño y de la precaución a los riesgos es también una forma de cohibirse la práctica de conductas agresoras al bien ambiental que, caso sean realizadas, causan una lesión irremediable.

En la esfera civil, cabe resaltar la relación entre el principio de precaución y la reparación civil de los daños al medio ambiente. La responsabilidad civil ambiental tiene como objetivo determinar los parámetros para la verificación del daño causado y la responsabilización del agente causador, sea él persona física o jurídica, de derecho público o privado.

La Ley de Política Nacional del Medio Ambiente asegura como uno de sus objetivos la "imposición al contaminador y al predador de la obligación de recuperar y/o indemnizar los daños causados", conforme artículo $4^{\circ}$, inciso VII de la Ley 6.938/81. Además, posibilita el reconocimiento de la responsabilidad del contaminador en indemnizar y/o reparar los daños causados al medio ambiente y a los terceros afectados por su actividad, independientemente de la existencia de culpa, en los moldes del artículo $14, \S 1^{\circ}$ del dispositivo legal anteriormente mencionado.

El referido encuadramiento difiere de aquél existente en el derecho privado, esto porque en la esfera del daño ambiental no hay necesidad del acto ser ilícito y no se investiga la culpa del autor del daño. Como ejemplo se puede mencionar el caso de una determinada empresa que está obedeciendo todos los límites de contaminación legalmente establecidos, pero aun así ser responsabilizada por los daños causados al medio ambiente, esto porque su responsabilidad deriva del riesgo asumido en el desarrollo da su actividad.

Siguiendo tal línea de posicionamiento, para la caracterización del daño ambiental solamente es necesaria la demonstración do causador de la conducta o actividad/omisión, el daño ambiental y finalmente el nexo causal. 
De este modo, se torna indiscutible la naturaleza objetiva de la responsabilidad civil imputada al causador de daño al medio ambiente. Además, desde 1969, cuando fue promulgada la Convención Internacional sobre Responsabilidad Civil en Daños Causados por Contaminación por Aceite y, ocho años después, cuando fue editada la Ley n. $^{\circ}$ 6.453/77, relativa a los daños provenientes de actividad nuclear, que la responsabilidad objetiva insurreccionar en nuestro ordenamiento jurídico, como forma no sólo de punir, sino también de educar los responsables por prácticas lesivas al medio ambiente.

De acuerdo con Machado, no interesa que tipo de obra o actividad sea ejercida por el que degrada, porque no hay necesidad de que ella sea peligrosa o presente riesgo. Se busca quien fue alcanzado y, si es el medio ambiente y el hombre, se inicia el proceso lógico-jurídico de la imputación civil objetiva ambiental. Sólo después es que se entrará en la fase del estabelecimiento del nexo de causalidad entre la acción u omisión y el daño. Es contra el Derecho enriquecerse o tener lucro con la degradación del medio ambiente ${ }^{446}$.

La responsabilidad objetiva ambiental significa que el que dañificar el ambiente tiene el deber jurídico de repararlo. No se pregunta la razón de la degradación para que haya el deber de indemnizar y/o reparar. La responsabilidad sin culpa tiene incidencia en la indemnización o en la reparación de los daños causados al medio ambiente y a los terceros afectados por su actividad.

En suma, se debe siempre tener en cuenta que en el ámbito del derecho ambiental la responsabilidad por el daño es objetiva, y para su caracterización basta la comprobación de que el perjuicio derivó del resultado de determinada actividad y no del comportamiento do agente, o sea, indepiende de dolo o culpa.

Cabe concluir, por lo tanto, que desde el inicio de la década de los 80 , la cuestión ambiental ganó amplitud legislativa, tanto en la esfera constitucional como en la esfera ordinaria, residual, viabilizando la posibilidad de ser responsabilizado civil, administrativa y criminalmente, persona física o jurídica, que infringir las leyes y normas aplicables a la especie.

${ }^{446}$ MACHADO, Paulo Affonso Leme. Direito ambiental cit., p. 328. 
Conforme expuesto al largo de este capítulo, el principio de precaución se encuentra bien definido y consolidado por la doctrina, tanto en el ámbito nacional como internacional.

$\mathrm{Su}$ concepto es bien delimitado, a pesar de algunos autores consideraren precaución y prevención como sinónimos, en la medida en que enfatiza su actuación en la prevención de daños inciertos, o sea, se evita la práctica de actividades cuyos resultados aún no son conocidos, o al menos previsibles.

Entretanto, la aplicación del principio de precaución, así como los demás recursos utilizados para la defensa del medio ambiente, aún carecen de más vigor. Actualmente es posible observar emprendimientos en funcionamiento, cuyas actividades presentan alto riesgo al medio ambiente, cuyas medidas de precaución admisibles son ignoradas.

Cabe, en estos casos, tanto al judicial como a los órganos administrativos, responsables por la regularización ambiental de tales emprendimientos, el debido control y fiscalización, actuando de forma preventiva frente a los posibles daños ambientales.

Kazuo Watanabe hace las siguientes críticas a la efectividad de la tutela jurisdiccional de los derechos difusos: Organización judicial más adecuada y modernizada, con base en investigación permanente actualizada de las causas de la litigiosidad y de los medios de su solución, es un aspecto de superlativa importancia. Tanto en lo que se refiere a su infraestructura material, con su permanente modernización, como también, y principalmente, en lo que se refiere a la infraestructura personal, con reclutamiento y entrenamiento de auxiliares de Justicia competentes y bien remunerados [...]. Otro punto de vital importancia es el reclutamiento optimizado de jueces y su permanente perfeccionamiento cultural, ante la creciente complexidad de las relaciones sociales ${ }^{447}$.

El perfeccionamiento referido por el autor no debe ser restricto solamente al ámbito judicial, sino a todas aquellas personas responsables por tutelar de alguna forma (por medio de la fiscalización, concesiones de licencias, emisiones de permisos) el patrimonio ambiental.

\footnotetext{
${ }^{447}$ MILARÉ, Édis (Coord). Ação civil pública (Lei 7.347/85 - reminiscências e reflexões após dez anos de aplicação). São Paulo: Revista dos Tribunais, 1995. pp. 326-328.
} 
Jueces, agentes, fiscales y técnicos responsables por la defensa del medio ambiente deben estar preparados e instruidos para que analicen con la cautela necesaria todas las cuestiones referentes a posibles daños al ambiente, teniendo en cuenta que es en este momento que el principio de precaución debe ser aplicado, o sea, antes de la efectuación del daño, ya que, en la mayoría de los casos, son irreversibles.

Además del referido perfeccionamiento, cabe resaltar la necesidad de adopción de política pública ambiental de concienciación, preventiva y, quizás, sancionatoria, y que abarque los diversos sectores educacionales, públicos o privados, medios de comunicación, así como entidades no gubernamentales interesadas legítimamente en la cuestión, para que pueda surtir los efectos deseados por la norma impositiva, pues, el medio ambiente es un “bien de uso común general”, conforme preceptúa el artículo 225 de la Magna Carta.

Tales consideraciones se tornan importantes y necesarias en la medida en que se depara con la dificultad, en el mundo moderno, de obtenerse efectiva eficacia para las reglas del derecho ambiental, en el sentido de hacer preservar la naturaleza.

Por tanto, además del perfeccionamiento de la tutela ambiental, es pertinente aseverar que la capacitación del ciudadano, por medio de la educación ambiental, formará personas más conscientes con el medio ambiente y formalmente aptas a buscar la mejora de la calidad de vida, preservando este bien transcendental y de carácter universal: el medio ambiente.

\subsubsection{El principio de prevención propiamente dicho}

Este principio tuvo origen en el Derecho Ambiental nacional alemán, bajo la denominación de Vorsorgeprinzip. Su adopción en este ordenamiento interno, según relata Paulo Affonso Leme Machado ${ }^{448}$ sucedió aún en la década de 70 , con la aprobación de la Ley de Protección de las Aguas cuando la preocupación ambiental comenzaba a ganar importancia en la esfera internacional ${ }^{449}$.

\footnotetext{
${ }^{448}$ MACHADO, Paulo Affonso Leme. Direito Ambiental cit., p. 56.

${ }^{449}$ SAMPAIO, J. A. L. Constituição e Meio Ambiente na perspectiva do Direito Constitucional Comparado. In: SAMPAIO, J. A. L.; WOLD, C.; NARDY, A. J. F. Princípios de Direito Ambiental. Belo Horizonte: Del Rey, 2003, p. 59.
} 
Las referencias internacionales a este principio comenzaron de forma disimulada, una vez que, al inicio, él no era mencionado explícitamente en los documentos internacionales, sino sólo era utilizado como referencia para acciones y políticas públicas. Rüdiger Wolfrum informa que: Antes, había apenas referencias explícitas a determinados instrumentos internacionales, ya que el contenido del principio estaba consagrado en varios documentos de política internacional ${ }^{450}$.

Fue lo que sucedió en la primera gran conferencia internacional en materia ambiental, realizada en 1972 en Estocolmo, que originó la Declaración de Estocolmo sobre Medio Ambiente Humano. Este documento reconocía, en su principio segundo, la necesidad de salvaguardar los recursos naturales por medio de planeamientos y gerenciamientos, visando preservar el derecho de las generaciones futuras. La Carta Mundial para la Naturaleza también reconocía la necesidad de evitarse actividades que presentasen potenciales riesgo o daños al ambiente. Lo mismo se pasó con la Convención sobre la Contaminación Atmosférica de Larga Distancia, adoptada en 13 de noviembre de 1979, en Ginebra. Aunque todos estos documentos internacionales se refiriesen a la importancia de las acciones preventivas, ninguno trataba explícitamente de la prevención ni de la precaución.

La primera referencia explícita a este principio en el ámbito internacional sucedió en noviembre de 1984, y fue hecha por la Declaración Ministerial de la Segunda Conferencia Internacional sobre la Protección del Mar del Norte: [...] a fin de proteger el Mar del Norte de posibles efectos dañosos de la mayor parte de las sustancias peligrosas, un abordaje de precaución es necesaria, que puede exigir acción para controlar los insumos de tales sustancias aunque antes que un nexo causal haya sido establecido por evidencia científica clara y absoluta ${ }^{451}$.

En Latinoamérica, los primeros indicios de la orientación preventiva surgieron con la aprobación de la Ley Federal Brasileña de número 6.938, en 31 de agosto de

\footnotetext{
${ }^{450}$ WOLFRUM, R. O Princípio da Precaução. In: VARELlA, M. D.; PLATIAU, A. F. B. (org. e coautores). Princípio da Precaução. Belo Horizonte: Del Rey, 2004, p. 14.

${ }^{451}$ In: WOLFRUM, R. O Princípio da Precaução. In: VARELLA, M. D.; PLATIAU, A. F. B. (org. e coautores). Princípio da Precaução. Belo Horizonte: Del Rey, 2004, p. 14. Este autor nos informa que, embora a Conferência tenha ocorrido em 1984, a Declaração Ministerial pedindo a redução da poluição foi firmada três anos mais tarde, em 25 de novembro de 1987.
} 
1981. Según Machado ${ }^{452}$, ella no representó la adopción expresa del principio en nuestro ordenamiento, pero fue significativa para la introducción de las nociones de prevención y precaución como orientación del Derecho Ambiental, atendiendo a las directrices conservacionistas antes expuestas.

Aunque sea incontestable la necesidad de aplicación de este principio en la orientación de las actividades potencialmente degradantes del ambiente, existe, en el núcleo de la Ciencia Jurídica, una pequeña controversia acerca de su correcta denominación y de su contenido.

\subsubsection{El principio de prohibición de retroceso}

El Derecho a un medio ambiente equilibrado y sano, armonizado con las exigencias de la dignidad de la persona humana está expreso en la Constitución Brasileña, siendo considerado un derecho fundamental de carácter social ${ }^{453}$, debido a su aspecto colectivo y difuso, tratándose más recientemente en la doctrina en derechos fundamentales socioambientales.

Como se sabe, las normas constitucionales definidoras de derechos no poseen la misma aplicabilidad, siendo algunas, auto aplicables y otras de aplicabilidad diferida, cabiendo a los órganos estatales actuar para concretar los derechos expresos constitucionalmente por medio de la legislación infraconstitucional y políticas públicas. Esto es lo que ocurre con los derechos fundamentales sociales y ambientales que desarrollan su eficacia con base y en la medida de la legislación infraconstitucional, siendo también designados derechos-medida ${ }^{454}$.

El Supremo Tribunal Federal brasileño se pronunció en 1995, afirmando que el medio ambiente es derecho fundamental, así se pronunciando el Ministro Celso de Mello al relatar el Mandato de Seguridad envolviendo desapropiación de inmueble rural para fines de reforma agraria ya nos advertía: "El derecho a la integridad del medio

\footnotetext{
${ }^{452}$ MACHADO, Paulo Affonso Leme. Direito Ambiental cit., p. 56.

${ }^{453}$ SCHULT, Bernd. Direitos Fundamentais Segurança Social e Proibição de Retrocesso. Revista da AJURIS, ano XXXII, no 99, setembro de 2005, p. 261.

${ }^{454}$ SCHULT, Bernd. Direitos Fundamentais Segurança Social e Proibição de Retrocesso. Revista da AJURIS, ano XXXII, n 99 , setembro de 2005, p. 261.
} 
ambiente - típico derecho de tercera generación - constituye prerrogativa jurídica de titularidad colectiva, reflejando, dentro del proceso de afirmación de los derechos humanos, la expresión significativa de un poder atribuido, no al individuo identificado en su singularidad, pero en un sentido verdaderamente más abarcador, a la propia colectividad social. Mientras los derechos de primera generación (civiles y políticos) que comprenden las libertades clásicas, negativas o formales - realzan el principio de la libertad y los derechos de segunda generación (derechos económicos, sociales y culturales) - que se identifica con las libertades positivas, reales o concretas - acentúan el principio de la igualdad, los derechos de tercera generación, que materializan poderes de titularidad colectiva atribuidos genéricamente a todas las formaciones sociales, consagran el principio de la solidaridad y constituyen un momento importante en el proceso de desarrollo, expansión y reconocimiento de los derechos humanos, caracterizados, como valores fundamentales indisponibles, con la clara característica de ser inagotables".

Pero el hecho de que estos derechos dependen de concreción por medio de la producción legislativa, no significa que el desarrollo de los preceptos insertados en la Constitución constituya una liberalidad para el poder estatal. La directriz impuesta por un derecho fundamental debe ser obligatoriamente atendida, teniendo en cuenta la vinculación de estos derechos con la dignidad de la persona humana, el principio basilar del orden constitucional.

El Poder Legislativo posee, por lo tanto, el deber de conferir efectividad a la norma constitucional definidora del derecho, no poseyendo la disponibilidad de alterar la esencia del precepto expreso por esta norma. La alteración del sentido norma, o la limitación o reducción del derecho que de ella emana, comprometería la lista de los derechos fundamentales como un todo, porque este catálogo fue establecido por la Constitución visando proteger las condiciones mínimas de vida que deben ser ofrecidas por el Estado a la colectividad para que se pueda atender al principio de la dignidad.

Después de la consolidación en la esfera infraconstitucional, los derechos sociales fundamentales adquieren, al mismo tiempo, la condición de derechos subjetivos a ciertas prestaciones estatales y de una garantía institucional, de tal forma que no se localizan más en la plena órbita de disponibilidad del legislador. Así estos derechos adquiridos ya no pueden ser disminuidos o suprimidos, so pena de evidente infracción al principio de la protección de la confianza, principio este directamente extraído del 
principio del Estado de Derecho ${ }^{455}$. Se trata del principio de prohibición del retroceso, según el que, una vez realizado y efectuado el núcleo esencial de un derecho social, este debe ser considerado constitucionalmente garantido, siendo inconstitucional cualquier medida estatal que, sin la creación de otros sistemas alternativos o compensatorios, se traduzca, práctica, en una anulación, revocación o aniquilación pura y simple de ese núcleo esencial. ${ }^{456}$ Esto porque cualquier reducción al alcance del derecho social, se traduce en un ataque a la efectividad de la norma que tendría sido alcanzada por medio de la reglamentación infraconstitucional. Es lo que se percibe al apuntar que, al complementar la eficacia de una norma constitucional, el legislador está tornando viable el ejercicio de un derecho que dependía de su intermediación, no pudiendo así, posteriormente, revocar el acto legislativo, retornando a la situación de omisión legislativa anterior ${ }^{457}$.

Además, según Felipe Derbli, el principio de la prohibición de retroceso social posee carácter retrospectivo, ya que propone preservar un estado de cosas ya conquistado contra su restricción o supresión arbitraria, mediante revocación pura y simple o edición de acto normativo que comprometa la concreción ya alcanzada. Significando no sólo una mera manutención del status quo ante, sino también la obligación del avance social, en el sentido de elevar los niveles de protección social ${ }^{458}$.

La existencia de este principio es ampliamente acepta en el derecho extranjero, notoriamente en Alemania, y gana cada vez más espacio en el derecho portugués, siendo que el Tribunal Constitucional de Portugal declaró inconstitucional una ley que revocaba gran parte de la Ley del Servicio Nacional de Salud, porque la revocación atentaba contra el derecho fundamental a la salud, además teniéndose en cuenta que este debería ser realizado justamente mediante la creación de un servicio nacional, general y gratuito de salud, quedando evidente el retroceso ${ }^{459}$.

\footnotetext{
${ }^{455}$ COSTA, Elaine Romero. O principio da proibição de retrocesso social no atual marco jurídicoconstitucional brasileiro. Revista de Direito Constitucional, ano 18, nº 73, out-dez 2010, p. 148.

${ }^{456}$ COSTA, Elaine Romero. O princípio da proibição de retrocesso social no atual marco jurídicoconstitucional cit., p. 149.

${ }^{457}$ COSTA, Elaine Romero. O princípio da proibição de retrocesso social no atual marco jurídicoconstitucional cit., p. 151.

${ }^{458}$ DERBLI, Felipe. O principio da proibição de retrocesso social na Constituição de 1998. Rio de Janeiro: Renovar, 2007.

${ }^{459}$ Juzgado n. ${ }^{\circ} 39$ de 1984.
} 
En el ordenamiento nacional la prohibición del retroceso no es un principio expreso de forma clara y amplia, pero proviene del orden jurídico-constitucional, al entenderse que una ley, al reglamentar un comando constitucional, instituye cierto derecho, este pasa a integrar el patrimonio jurídico de la ciudadanía y no puede ser arbitrariamente eliminado. Es así fundamentado por los principios del Estado de Derecho, el principio de la dignidad de la persona humana, el principio de máxima eficacia y efectividad de las normas definidoras de derechos fundamentales, así como el principio de la seguridad jurídica y sus consecuencias.

Es importante mencionar que este principio de prohibición del retroceso también se encuentra expresamente dispuesto en el ámbito del Derecho del Trabajo conforme el caput del art. $7^{\circ}$ de la Constitución Federal Brasileña, al disponer que: son derechos de los trabajadores aquellos apuntados en sus incisos "además de otros que visen la mejora de su condición social”. Está postulado en este dispositivo el interés por la mejora progresiva de la condición social, y aunque supuestamente vinculado sólo a la esfera laboral, no es posible afirmar que el orden Constitucional vise garantir una calidad de vida elevada únicamente en lo que se refiere a la relación de trabajo, teniendo en cuenta la incidencia absoluta y generalizada de la lista de los derechos fundamentales sociales.

Los derechos fundamentales sociales, entre ellos el derecho al medio ambiente sano, gozan de garantías de suma rigidez que vinculan todos los poderes estatales, siendo intangibles e irreductibles, tornando inconstitucional cualquier acto que intente restringirlos.

Por este motivo, es inaceptable el entendimiento de que el legislador posee plena libertad para determinar el contenido del objeto de los derechos sociales bajo el argumento de la existencia de una omisión constitucional, que permitirá volver hacia atrás en las propias decisiones, reduciendo el alcance anteriormente conferido al derecho.

Según Ingo Wolfgang Sarlet, tal autonomía del legislador se encuentra aún limitada por el principio de la confianza, y caso si admitiese una inexistencia de vinculación mínima del Poder Legislativo, así como de los demás órganos estatales en general, al núcleo esencial ya concretizado en la esfera de los derechos sociales y de los otros mandamientos constitucionales en objeto de justicia social, significaría la realización de una fraude a la Constitución. Al legislador no es permitido meramente 
suprimir o restringir las normas infraconstitucionales que concretizan los derechos sociales, porque eso sería lo mismo que sacar de las normas constitucionales su eficacia jurídica. El cumplimento de un comando constitucional acaba por convertirse en el impedimento de apagar la coyuntura instaurada por el legislador ${ }^{460}$.

En el caso específico de la legislación ambiental que busca dar operatividad al deber constitucional de protección del ambiente, debe ser asegurada su blindaje contra retrocesos que la tornen menos rigorosas o flexible, teniendo en cuenta la serie de amenazas que comprometen cada vez más la calidad ambiental que será disfrutada por las generaciones futuras, como la disminución de los recursos naturales, la pérdida creciente de la cobertura vegetativa, los altos índices de contaminación, la degradación del suelo y toda la variedad enorme de problemas resultantes del uso irresponsable del medio ambiente.

Diferentemente de los demás derechos sociales -aun precariamente efectuados, se encuentran en ascensión a partir de la mejora de la condición económica del país- la calidad ambiental es degradada diariamente, de forma que, permitir retrocesos en su protección, representa una seria violación a los objetivos constitucionales, una vez evidente la insuficiencia de la protección anterior, ya suficientemente desobediente de la directriz impuesta por la Constitución, aún sufrió una restricción ulterior. En la teorización de Canotilho sobre el retroceso ecológico-ambiental, sabiéndose que el agua, los suelos, la fauna y la flora poseen un límite de agotamiento, una reducción en el nivel de protección puede llevar a la transgresión de este límite, agravando la situación ecológica global. Siempre que verificarse tal agravamiento debido a cualquier forma de desreglamentación, estará presente el retroceso. Habrá entonces una violación del deber de protección a que el Estado se encuentra obligado, porque la protección conferida es insuficiente ${ }^{461}$.

La prohibición de la protección deficiente es uno de los aspectos del principio de la proporcionalidad, según la doctrina alemana, y guarda estrecha relación con la prohibición del retroceso, por la cual el Estado debe buscar maximizar la efectividad de

\footnotetext{
${ }^{460}$ SARLET, Ingo Wolfgang. Direitos Fundamentais Sociais e Proibição de Retrocesso: algumas notas sobre o desafio da sobrevivência dos direitos sociais num contezto de crise. Revista da AJURIS, ano XXXI, no 95 , setembro de 2004, p. 106.

${ }^{461}$ QUEIROZ, Cristina. O principio da não reversibilidade dos direitos fundamentais sociais. Coimbra: Coimbra Editora, 2006, p. 75.
} 
los derechos mínimamente exigibles, de forma que lo que ya fue garantizado o concretizado no pueda ser suprimido o reducido por cualquier ato estatal ${ }^{462}$.

El principio de la seguridad jurídica también posee importante relación con el principio de la prohibición del retroceso, en la medida en que, existiendo una conquista social por medio de la legislación infraconstitucional, se adquiere una situación jurídica que debe ser preservada, estableciéndose la llamada seguridad social. Lo que puede y debe ser relacionado con la cuestión ambiental, debido a la naturaleza colectiva y difusa del derecho fundamental a la calidad ambiental. Por eso la prohibición del retroceso puede ser entendida como una de las vertientes esenciales de la seguridad jurídica, en el sentido de una seguridad socioambiental.

Negar el principio de la prohibición del retroceso, significaría, poner fin, aprobar que los órganos legislativos (así como todo el poder público en general), a pesar de estar indudablemente ligados a los derechos fundamentales y a las normas constitucionales, disponen de autonomía para decidir lo que quieren libremente aunque en flagrante violación a la voluntad expresada por el Constituyente ${ }^{463}$.

A través del reconocimiento de la prohibición del retroceso se busca inhibir la frustración de la efectividad constitucional, al privilegiar la atención a los derechos fundamentales, en el sentido de la concreción de las medidas facilitadoras de la mejora de la condición socioambiental de la población, en atención a los principios del Estado de Derecho.

Si el medio ambiente es derecho fundamental o en el sentido más amplio “derechos humanos", queda evidente que cualquier disminución de la protección a los bienes ambientales es claramente inconstitucional, en especial, por afrontar el principio que prohíbe el retroceso ambiental.

Más que una construcción meramente doctrinaria, entendemos que el aludido principio posee soporte normativo y es perfectamente aplicable para fulminar cualquier artículo de ley (en sentido lato) que importe en reducción del nivel mínimo de protección a los derechos socioambientales.

\footnotetext{
${ }^{462}$ HOMEM DE SIQUIERA, Julio Pinheiro Faro. Da reserva do possível e da proibição do retrocesso social. Revista do Tribunal de Contas do Estado de Minas Gerais, julho - setembro 2012, v. 26 - n. 3 ano XXVIII, p. 7.

${ }^{463}$ SARLET, Ingo Wolfgang. Direitos Fundamentais Sociais e Proibição de Retrocesso: cit., p. 125.
} 
El principio de la prohibición del retroceso encuentra amparo en los principios constitucionales de la Prevalencia de los Derechos Humanos y de la Cooperación entre los Pueblos para o progreso de la Humanidad expresamente definidos en el art. $4^{\circ}$, II y IX de la Constitución Federal ${ }^{464}$.

Una vez que el Estado brasileño, por medio de la Carta Magna, se comprometió en hacer prevalecer los derechos humanos ante los intereses meramente económicos y contribuir para el progreso, no puede aceptar acto legislativo que implique en retroceso en los niveles de protección del más fundamental de los derechos humanos: el derecho a la vida sana y equilibrada para las presentes y futuras generaciones.

El principio en estudio también deriva de la seguridad jurídica resultante de la protección al derecho adquirido (art. $5^{\circ}$, XXXVI de la Constitución Federal) de la sociedad.

Además, Brasil es signatario del "Pacto de San José de Costa Rica", el cual fue debidamente aprobado por el Decreto n. $^{\circ}$ 678, del 06 de noviembre de 1992 y determina en su artículo 26, entre otros, que los países signatarios se obligan a adoptar medidas progresivas para la implementación de los derechos fundamentales positivados en sus respectivas Constituciones.

\footnotetext{
${ }^{464}$ Art. $4^{\text {o. }}$ "La República Federativa de Brasil se rige en sus relaciones internacionales por los siguientes principios:

(...)

II - prevalencia de los derechos humanos;

(...)

IX - cooperación entre los pueblos para el progreso de la humanidad;".
} 


\section{Capítulo 4 - El agua en el derecho brasileño}

\subsection{Las características del federalismo brasileño y las Constituciones}

El federalismo brasileño puede ser mejor comprendido cuando se describe las constituciones anteriores a 1988, eso porque las Cartas Magnas reflejaran los trapicheos políticos y territoriales que se sucedieron al largo de la historia del país. Aparte eso, mientras reflejaban los cambios en los regímenes políticos, esas constituciones también mantuvieron o fortalecieron muchos dispositivos constitucionales anteriores, con pocas excepciones $^{465}$.

Los debates sobre la división territorial de poder comenzaron mucho antes del fin de la era colonial y el principal objetivo del movimiento republicano era el federalismo y no la libertad ${ }^{\mathbf{4 6 6}}$. A pesar de inspirada en la experiencia de los Estados Unidos de América, la opción por el federalismo en Brasil no fue una simples copia de aquél sistema, porque su adopción fue precedida de debates y por el interés de las elites regionales a la descentralización, vista como siendo algo alcanzable por un sistema federal y no por un sistema unitario. Aunque algunas instituciones norteamericanas hayan sido adoptadas como bases de las instituciones políticas brasileñas, Brasil construyó su propia historia constitucional al largo de la elaboración de sus siete constituciones $^{467}$.

La primera Constitución escrita de Brasil fue promulgada en el 1824, delegando poderes administrativos a las 16 provincias de la época, y aunque estas no tuvieran autonomía política formal o informal, la delegación de poderes fue interpretada como una abertura de camino para una futura federación.

Promulgada después de la República, la Constitución de 1891 siguió la promesa descentralizadora del tema republicano: centralización, secesión; descentralización, unidad. Con esa Constitución, recursos públicos fueron canalizados para algunos pocos Estados, mostrando que la federación brasileña nasció bajo la égida

${ }^{465}$ SOUZA, Celina. Federalismo, desenho constitucional e instituições federativas no Brasil pós-1988. Rev. Sociol. Polít., Curitiba, pp. 105-121, jun.2005.

${ }^{466}$ CARVALHO, J. M. Federalismo y centralización en el imperio brasileño: historia y argumento. In: CARMAGnANI, M. (Org.). Federalismos latinoamericanos: México, Brasil, Argentina. Ciudad de México: El Colegio de México, 1993.

${ }^{467}$ SOUZA, Celina. Federalismo, desenho constitucional e instituições federativas cit., p.107. 
de la concentración de recursos y escasas relaciones, caracterizando ese período como el de una federación aislada ${ }^{468}$.

Ese aislamiento fue interrumpido en 1930 con el golpe de estado de Getúlio Vargas. Una de las primeras medidas fue el perdón de las deudas de los Estados con la Unión Federal, incluso la de São Paulo (la más grande de todas), que se refería a los subsidios a la caficultura, promocionando la pacificación de los posibles descontentes de las elites regionales ${ }^{469}$.

La Constitución de 1934 introdujo la tendencia a la constitucionalización de cuestiones socioeconómicas y expandió las relaciones intergubernamentales por la autorización para que el gobierno federal concediese recursos propios a las instancias subnacionales, que serían por ellas colectados, pasando, también, a recibir parcela de un impuesto estadual. "La peculiaridad de esa Constitución frente a las demás es que el Senado Federal fue reducido a órgano colaborador de la Cámara de los Diputados" ${ }^{\$ 70}$.

La Constitución de 1937 fue promulgada por Vargas después del golpe militar por él liderado. Hubo el cierre del Congreso Nacional y de las Asambleas Estaduales, sustituyendo los gobernadores electos por interventores. Existe consenso de que una de las principales razones del golpe sería neutralizar la importancia de los intereses regionales a fin de construir la unidad política y administrativa necesaria para promover una 'modernización social y económica del país'. Uno de los actos más simbólicos de Vargas en contra los intereses regionales fue quemar todas las banderas estaduales en plaza pública. Los gobiernos subnacionales perdieron ingresos para la esfera federal, pero la medida más importante fue delegar al gobierno federal la atribución para legislar sobre las relaciones fiscales externas y entre los estados. "Al negar a los gobiernos estaduales [...] la definición de las reglas de permuta de mercancías, Vargas pavimentó el camino para la industrialización" ${ }^{471}$. Con esa determinación, no solamente

\footnotetext{
${ }^{468}$ SOUZA, Celina. Federalismo, desenho constitucional e instituições federativas cit., p.107.

${ }^{469}$ LOVE, J. L. Federalismo y regionalismo en Brasil, 1889-1937. In: CARMAGNANI, M. (Org.). Federalismos latinoamericanos: México, Brasil, Argentina. Ciudad de México: El Colegio de México, 1993.

${ }^{470}$ SOUZA, Celina. Federalismo, desenho constitucional e instituições federativas cit., p.108.

${ }^{471}$ MAHAR, J. D. Federalismo fiscal no Brasil: a experiência histórica. In: Rezende, F. (org.). Politica fiscal e programação dos gastos do governo. Rio de Janeiro: Instituto de Pesquisas Econômicas Aplicadas (IPEA), 1976, p.415.
} 
persistieron los desequilibrios financieros entre los estados, sino que, en 1945, 70\% de los ingresos estaduales se concentraban en tres de ellos.

Con la vuelta del régimen democrático, una nueva Constitución fue escrita, la de 1946. Inicialmente influenciada por ideales liberales, estos no han prevalecido debido al reconocimiento de que era necesario perseguir rápido crecimiento económico bajo la egida del gobierno federal. Sin embargo, como democracia y descentralización se fueron transformando, al largo de la historia, en 'afinidades electivas', los recursos para los gobiernos locales fueron privilegiados, mucho más que los de los estados ${ }^{472}$. La Constitución de 1946 introdujo el primer mecanismo de transferencias intergubernamentales de la esfera federal para las municipales, excluidos los estados, en el intento de disminuir los desequilibrios verticales de ingresos, pero el criterio de transferencia no contenía ningún mecanismo de ecualización fiscal, porque consistía en dividir el importe a ser transferido por el número de municipios existentes ${ }^{473}$.

El golpe militar de 1964 colocó o Brasil en la lista de los regímenes autoritarios que pasaron a gobernar los países de Latinoamérica en los años 1960. Los militares no promulgaron inmediatamente nueva Constitución, aunque hicieron varias enmiendas a la Constitución de 1946. La nueva Carta Magna del régimen solamente fue promulgada en 1967 y, en 1969, una larga enmienda constitucional fue editada ${ }^{474}$. Así, la Constitución de 1967-1969 y la reforma tributaria de 1966 centralizaron en la esfera federal el poder político y tributario, afectando el federalismo y sus instituciones. Sin embargo, eso no significó la eliminación del poder de los gobernadores tampoco de los alcaldes de las principales capitales. En realidad, los gobernantes subnacionales fueron grandes legitimadores del régimen militar y contribuyeron para formar las coaliciones necesarias a su larga supervivencia ${ }^{475,476}$.

\footnotetext{
${ }^{472}$ MELO, Marcus André. Municipalismo, nation-building e a modernização do Estado no Brasil. Rev. Brasileira de Ciências Sociais, São Paulo, v. 23, n. ${ }^{\circ}$ 8, pp. 83-100.

${ }^{473}$ REZENDE, F. Finanças públicas e transferências intergovernamentais. In: REZENDE, F. (Org.). Política fiscal e programação dos gastos do governo. Instituto de Pesquisas Econômicas Aplicadas (IPEA), Rio de Janeiro-Brasil: 1976, p. 238.

${ }^{474}$ SOUZA, Celina. Federalismo, desenho constitucional e instituições federativas cit., p.108.

${ }^{475}$ AMES, B. Political survival: politicians and public policy in Latin America. Berkeley: University of California, 1987.

${ }^{476}$ MEDEIROS, A. Politics and intergovernmental relations in Brazil: 1964-1982. New York: Garland, 1986.
} 
Aunque los Estados tengan constituciones propias, todas aprobadas en 1989, y a pesar de las reglas constitucionales federales establecieren que ellas deben obedecer a los principios de la constitución Federal, la mayoría das constituciones estaduales es mera repetición de los mandamientos federales. "Los pocos intentos de crear reglas no explícitamente especificadas por la constitución federal, pero no prohibidas, fueron declaradas inconstitucionales por el Supremo Tribunal Federal (STF)"477. Se entiende que eso sea por el hecho de que la Constitución de 1988 es extremamente detallada y de que las constituciones y leyes estaduales, sometidas al tamiz del STF, deben cumplir lo que dispone la Ley federal. La Unión detiene el mayor y el más importante abanico de competencias legislativas exclusivas, dejando poco espacio para el ejercicio de la competencia legislativa residual.

Las constituciones brasileñas siempre detallaron las competencias legislativas de los tres niveles de gobierno y, en lo que se refiere a las competencias concurrentes, los constituyentes de 1988 promovieron, en la práctica, grandes distancias entre lo que prevé la Constitución y su aplicación. Así, prevalece un sistema complejo de frenos y contrapesos. En ese proceso el STF puede declarar la inconstitucionalidad de ley aprobada por los poderes ejecutivos federal y estaduales, así como anular decisiones tomadas por el Congreso Nacional. Los recursos del poder judicial provienen del presupuesto federal aprobado por el Congreso. Medidas iniciadas únicamente por el Ejecutivo deben ser sometidas al Congreso. La Cámara de los Diputados puede instaurar proceso en contra el Presidente de la República, cuyo juicio es del Senado Federal. Este, por su turno, es la institución que más tiene incumbencias en el sistema de frenos y contrapesos, siendo responsable por el juicio de miembros del STF, por la ratificación de nombres indicados por el Presidente de la República para varios cargos del poder Ejecutivo y por la decisión sobre pedidos de préstamos internos y externos de los tres niveles de gobierno ${ }^{478}$.

Para un sistema federativo funcionar eficientemente, es necesario un mecanismo asegurando que la división de la autoridad estatuida por el instrumento orgánico sea fielmente obedecida. En ese sentido, la Suprema Corte asumió ese rol al

\footnotetext{
${ }^{477}$ SOUZA, Celina. Federalismo, desenho constitucional e instituições federativas cit., p.111.

${ }^{478}$ SOUZA, Celina. Federalismo, desenho constitucional e instituições federativas cit., p.114.
} 
garantizar el cumplimiento de la Constitución y realizar los temperamentos necesarios entre las competencias del gobierno federal e de los estaduales ${ }^{479}$.

El federalismo brasileño trae una innovación única en el Derecho Constitucional contemporáneo: la inclusión de los municipios como miembros de la federación. De acuerdo con Paulo Bonavides ${ }^{480}$, no existe una única forma federativa contemporánea en la que el principio de la autonomía municipal haya alcanzado grado tan alto de caracterización político-jurídica como aquél que figura de la definición constitucional del nuevo modelo implantado en Brasil con la Carta de 1988, que impone a los aplicadores de principios y reglas constitucionales una visión mucho más amplia en lo que se refiere a la defensa y confirmación de aquella garantía.

El federalismo brasileño también registra el gran mérito de haber dado oportunidad a la participación popular en las decisiones políticas generales, ya que crea un sistema de descentralización del poder y autonomía a diversos centros de poder coordinados entre $\mathrm{si}^{481}$. Como afirma Alexandre de Moraes ${ }^{482}$, la adopción de la especie federal de Estado gravita en torno del principio de la autonomía y de la participación política, y presupone la consagración de ciertas reglas constitucionales tendientes no sólo a su configuración, sino también a su manutención e indisolubilidad.

En el Estado Federal, hay que distinguirse soberanía y autonomía y sus respectivos titulares. En la actualidad, ya está definido que el Estado Federal, como persona reconocida por el derecho internacional, es el único titular de la soberanía, considerada poder supremo consistente en la capacidad de autodeterminación. Los Estados federados, por lo tanto, son titulares solamente de autonomía, comprendida como un gobierno propio dentro del círculo de competencias diseñadas por la Constitución de $1988^{483}$.

\footnotetext{
${ }^{479}$ FELIX, Renan Paes. Federalismo e democracia: os caminhos da experiência brasileira. Revista CEJ, Brasília, v.11, n.38, p.22-27, jul.-set. 2007.

${ }^{480}$ BONAVIDES, Paulo. Curso de Direito Constitucional. Editora Malheiros, São Paulo-Brasil: 2004.

${ }^{481}$ CAVALCANTI, A. Regime federativo e república brasileira. Universidade de Brasília UnB, BrasíliaBrasil: 1983, p.109.

${ }^{482}$ MORAES, A. Constituição do Brasil interpretada e legislação constitucional. Editora Atlas, São Paulo: 2005, p.639.

${ }^{483}$ SILVA, J. A. Curso de Direito Constitucional Positivo. $15^{\mathrm{a}}$ ed. Editora Malheiros, São Paulo-Brasil: 1998, p. 104.
} 
Se pueden citar, en ese sentido, lecciones de Hely Lopes Meirelles ${ }^{484}$ : la autonomía no es poder originario, sino prerrogativa política concedida y limitada por la Constitución Federal. Tanto los Estados-miembros como los Municipios tienen su autonomía garantizada constitucionalmente no como un poder de autogobierno decurrente de la soberanía nacional, sino como un derecho público subjetivo de organizar su gobierno y proveer su administración en los límites que la Ley mayor les señala.

En realidad, tanto la democracia como el federalismo visan controlar el poder de las autoridades, para que los destinos del país sean diseñados de forma cohesiva y ordenada, y el pueblo, verdadero detentor de la soberanía, pueda participar activamente de las decisiones políticas de Brasil ${ }^{485}$.

\subsection{El histórico de la protección hídrica. Agua como bien jurídico en} Brasil

La Constitución Federal de 1988 fue la que más abordó el agua en su texto, aunque desde el Imperio se tiene esa prerrogativa, las utilidades del agua eran completamente diferentes de las actuales.

La Constitución de 1824, la imperial, fue omisa en relación al tema. En publicación sobre la 'Gestión Participativa de las Aguas', la Secretaria de Medio Ambiente de São Paulo ${ }^{486}$ informa que la primera norma en materia ambiental que se conoce en Brasil son las llamadas 'Posturas Municipales' editadas por D. Pedro I en la Ley de 1 de octubre de 1828, que en su artículo 66, designaba para las cámaras municipales, los concejales eran los competentes para legislar sobre la limpieza y conservación de: acueductos, chafarices, pozos, estanques, alcantarillado de pantanos y cualquier estancamiento de aguas infectas.

\footnotetext{
${ }^{484}$ MEIRELLES, H. L. Direito Municipal Brasileiro. 6a ed. Editora Malheiros, São Paulo-Brasil: 1993, p.81.

${ }^{485}$ FELIX, R. P. Federalismo e democracia: os caminhos da experiência cit., p.26.

${ }^{486}$ São Paulo (Estado). Secretaria do Meio Ambiente. Coordenadoria de Planejamento Ambiental Estratégico e Educação Ambiental. Gestão participativa das águas. Texto: SENA, L. B. R.; SZTIBE, R. São Paulo: SMA/CPLEA, 2004.
} 
La Constitución de 1891 también suprimió el tema, delegando la competencia para el Código Civil de 1916, pero el foco del tratamiento recaía sobre las propiedades en las que había incidencia de agua.

La Constitución de 1934 fue la primera a abordar el tema de forma clara y precisa, tratando de aspectos de desarrollos: económicos, sociales, y de generación de energía. Además, determinó que incumbe privativamente a la Unión legislar sobre el agua $^{487}$, y estableció que los lagos y cualquier corriente que bañe más de un Estado pertenezcan a la Unión ${ }^{488}$, y además que si el agua es utilizada para aprovechamiento industrial dependerá de autorización de la Unión ${ }^{489}$.

La Constitución de 1937 determinaba como competencia privativa de la Unión legislar sobre el agua y la energía hidráulica, pero no fue tan abarcadora como la anterior, pero importa destacar la necesidad de autorización ${ }^{490}$ del gobierno federal, para la explotación del agua, aunque sea en propiedad privada.

La Constitución de 1946 era también volcada para el orden económico y social, y la competencia de legislar sobre el agua era de la Unión, pero permitía que los estados legislasen sobre las aguas termales de aplicación medicinal y en el aparato de las estancias destinadas a su uso. ${ }^{491}$

Las Constituciones de $1967^{492}$ y $1969^{493}$ son muy parecidas, ellas quitaron la competencia suplementar del Estado, y legislaron sobre el agua, de forma semejante, además de establecer que para haber la utilización de los potenciales de energía es necesaria la autorización o concesión federal.

La Constitución de 1988 determina como bien de la Unión ${ }^{494}$ : los lagos, ríos y cualesquier corrientes de agua en terrenos de su dominio, o que bañen más de un Estado, sirvan de límites con otros países, o se extiendan a territorio extranjero o provengan de él, así como los terrenos marginales y las playas fluviales, los recursos naturales de la plataforma continental y de la zona económica exclusiva, los

\footnotetext{
${ }^{487}$ Art. $5^{\circ}$, XIX, J, CF/1934.

${ }^{488}$ Art. $20^{\circ}$, II, CF/1934.

${ }^{489}$ Art. $119^{\circ} \mathrm{CF} / 1934$.

${ }^{490}$ Art. 143, CF/1937.

${ }^{491}$ Art. 153, CF/1946

${ }^{492}$ Art. 161, CF 1967.

${ }^{493}$ Art. 168, CF1969.

${ }^{494}$ Art. 20, CF 1988.
} 
potenciales ${ }^{495}$ de energía hidráulica. Las actividades económicas como los potenciales de energía, también fueron disciplinadas.

Algunos bienes pasaron a pertenecer a los Estados ${ }^{496}$, tales como como: las aguas superficiales o subterráneas, fluyentes, emergentes, las áreas, en las islas oceánicas y costeras, que estuvieren en su dominio, excluidas aquellas bajo el dominio de la Unión, Municipios o terceros, las tierras baldías no comprendidas entre las de la Unión.

Ya los Municipios no disponen de aguas de su dominio. Y pueden legislar sobre temas de interés locale y suplementan la legislación federal y estadual, en lo que quepa (arts. 29 y 30, I y II).

Se estableció que la Unión debiese legislar ${ }^{497}$ sobre la energía, pero igualmente se permitió que ella delegue para los Estados esa prerrogativa. Hay la determinación que todos los entes de la federación defiendan el medio ambiente, entonces se subentiende que también cumple a estos entes legislar sobre el combate a la contaminación e no sólo a la Unión ${ }^{498}$.

La Constitución hizo algunos importantes cambios, tenemos como ejemplos: la clasificación del agua como recurso económico, la prohibición de la privatización de los recursos hídricos, porque el agua es un bien público, entonces cuando se estipula un precio hace que todos puedan usufructuar de ella, de ese modo no es más posible utilizar el agua para obtener beneficio si la utilizó de forma gratuita, los ríos fueron considerados cuencas hidrográficas, así se posibilita la gestión integrada de los recursos hídricos.

Aunque el agua sea considerada un recurso económico muy importante, su lado social también fue establecido, favoreciendo a todos al establecer que pudiesen utilizar de sus beneficios, resaltando que el agua es una necesidad de todo ser humano. Además de las constituciones, desde el Brasil Colonial hubo: ordenaciones, leyes y decretos que legislaron sobre derecho ambiental, de tal modo se analizará el agua con más detalles.

Uno de los primeros códigos a preocuparse con la cuestión ambiental fue las Ordenaciones Filipinas del 11 de enero de 1603 que vigoró por case tres siglos, siendo

\footnotetext{
${ }^{495}$ Art. 176, CF 1988.

${ }^{496}$ Art. 26, CF 1988.

${ }^{497}$ Art. 22, da CF 1988.

${ }^{498}$ Art. 23, da CF de 1988.
} 
revocada por el Código Civil de 1916, en su Libro V, Título LXXXVIII ${ }^{499}$ decía que si alguien tirase a los ríos y lagos algo que matase los peces, en la primera vez que lo hiciese pagaría tres mil réis y quedaría un año en África, si lo hiciese nuevamente, quedaría dos años en África, aparte tener que pagar la multa, se fuere hidalgo o alguna posición de mayor destaque. Caso fuese alguien de posición inferior tendría equivalente a la pena de vergüenza pública, es decir, azote en público con cuerda le apretando la garganta, mientras se predicaba el delito al público en una plaza. Pero vale resaltar que ese título no era preocupado sólo con los peces, sino también con protección de las lagunas y ríos en los que los ganados bebían agua.

Con la promulgación del Código Civil de 1916, se separó un capítulo exclusivo para el Agua, que va del artículo 563 al 568, sin embargo esa protección era volcada para la propiedad y no para el agua como un derecho fundamental. Había un gran desfase en la legislación, ella era obsoleta y no se preocupaba con las necesidades e interés de la colectividad nacional, entre ellas estaban: el incentivo al aprovechamiento industrial de las aguas, energía hidráulica exigía medidas que facilitasen y garantiesen su aprovechamiento racional ${ }^{500}$ por eso existía la necesidad de la creación de un código específico para su reglamentación. El 10 de julio de 1934, fue decretado el Código de Aguas, (Decreto n. ${ }^{\circ}$ 24.643), que buscaba sanar ese vicio.

El Código de Aguas alteró profundamente el Código Civil de 1916, porque ese se preocupaba con la propiedad privada y poseía valor económico limitado, el código además de tener en cuenta la salubridad de los recursos hídricos, colocaba el agua como necesidad para el desarrollo, porque la electricidad está ligada directamente con la industrialización del país, con eso ese tema necesitaba de mayor relevancia do Estado.

Con el nacimiento del código fue posible la clasificación del agua en tres categorías: públicas, comunes y particulares. Las aguas públicas son divididas en: de uso común y dominicales. ${ }^{501}$ Las de uso común ${ }^{502}$ son: el mar territorial, corrientes, canales, lagos, reservatorios públicos, mientras que las dominicales son las aguas

\footnotetext{
${ }^{499}$ Ordenações Filipinas, 11 de janeiro de 1603, Livro V, Título LXXXVIII, Disponible en: http://www1.ci.uc.pt/ihti/proj/filipinas/15p1238.htm . Acceso en: 21-05-2015.

${ }^{500}$ Preâmbulo do decreto ${ }^{\circ}$ : 24.643.

${ }^{501}$ Art. 1. ${ }^{\circ}$ do Código das Águas.

${ }^{502}$ Art. 2. ${ }^{\circ}$ do Código das Águas.
} 
situadas en dominio público dominical. Las de uso común ${ }^{503}$ son las no navegables o fluctuantes, y las particulares ${ }^{504}$ son las nacientes y las que no son clasificadas ni como dominio público o común. El Código de Aguas no revocó el Código Civil, al contrario, aunque hay repeticiones de normas, ellas se completan.

El Código Civil de de 1916 fue revocado por el de 2002 que también trae una sección separada para el agua, siendo que el Código de Agua legisla sobre utilización de las aguas públicas y privadas, mientras que o Código Civil sólo sobre las particulares, estableciendo reglas para que el agua sea utilizada de manera correcta. Como establece el artículo 1.291 del código civil que el que posee inmueble superior no podrá contaminar las aguas indispensables a las primeras de la vida de los que poseen inmuebles inferiores. El propietario tiene derecho de construir diques, azudes, pero no puede invadir el terreno ajeno, si así lo hace tendrá que indemnizar el propietario por el daño sufrido deducido el valor del beneficio obtenido ${ }^{505}$.

La Ley n. ${ }^{\circ}$ 9.433, del 8 de enero de 1997 creó la Política Nacional de Recursos Hídricos (PNRH) que además de establecer el agua como dominio público ${ }^{506}$, comenzaba a cobrar ${ }^{507}$ la utilización de los recursos hídricos, buscando acabar con la apropiación de ellos, porque al establecer un precio los usuarios perciben su valor además de obtener recursos financieros para financiar proyectos y obras para beneficiar a la colectividad. Además colocó el Estado como responsable por la captación y lanzamiento de efluentes en los cuerpos de agua.

Los objetivos ${ }^{508}$ a seren alcanzados eran: asegurar el uso adecuado de los recursos hídricos, de forma integrada y racional buscando asegurar agua con nivel de calidad para las futuras generaciones.

Por eso hay la necesidad de diferenciar agua de recursos hídricos, según Cid Tomanik Pompeu, agua es el género, porque es natural y está descomprometido su uso o utilización, en cambio recursos hídricos es el agua como utilidad y con fines

\footnotetext{
${ }^{503}$ Art. 7. ${ }^{\circ}$ do Código das Águas.

${ }^{504}$ Art. 8. ${ }^{\circ}$ do Código das Águas.

${ }^{505}$ Art. 1.292 do Código Civil de 2002.

${ }^{506}$ Art. 1. ${ }^{\circ}$ da Lei n ${ }^{\circ} 9433$.

${ }^{507}$ Art. 2. ${ }^{\circ}$ da Lei no $9.433 / 97$.

${ }^{508}$ Art. 2. ${ }^{\circ}$ da Lei n ${ }^{\circ} 9.433 / 97$.
} 
económicos $^{509}$. Por consecuencia el código de aguas disciplina el elemento líquido en sentido genérico, y la Política Nacional de Recursos Hídricos trata sobre el agua como condición de bien económico.

La Política Nacional de Recursos Hídricos precisaba de un órgano para auxiliarla, por eso la necesidad da creación de la Agencia Nacional de Aguas (ANA) por la Ley Federal n. ${ }^{\circ}$ 9.984, con la función de definir como los recursos hídricos serían utilizados, buscando el equilibrio de los usos y las diferentes necesidades de cada local, para que uno no se sobreponga al otro.

Entre las atribuciones ${ }^{510}$ de la Agencia Nacional de Aguas están: mantener: supervisar, controlar y evaluar las acciones y actividades relativas al cumplimento de la legislación federal pertinente a los recursos hídricos, fiscalizar los usos de recursos hídricos en los cuerpos de agua de dominio de la Unión, estimular la investigación y la capacitación de recursos humanos para la gestión de recursos hídricos. Esas funciones pretenden el aprovechamiento del agua de la mejor manera posible.

El Presidente da República es el responsable por escoger la dirección de la Agencia Nacional de Agua, que es compuesta por cinco miembros con mandato de cuatro años, la elección de estos miembros no es de forma simultánea. También es función del Jefe del Ejecutivo escoger el presidente del órgano. Esa elección es hecha entre los componentes de la dirección y el mandato es igualmente de cuatro años. Si quien es elegido ya esté en la dirección el plazo será el restante do su mandato.

El Cuadro 2 presenta la evolución de la protección hídrica en el país.

\section{Cuadro 2 - El agua en las Constituciones de Brasil ${ }^{511}$}

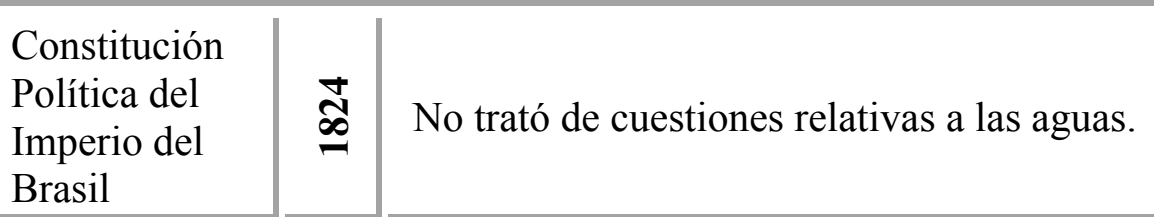

\footnotetext{
${ }^{509}$ POMPEU, Cid Tomanik. O Direito de águas no Brasil. Revista dos Tribunais - novembro de 2009 $98^{\circ}$ ano.

${ }^{510}$ Art. 4 da Lei $n^{\circ}$ 9984/2000.

${ }^{511}$ Adaptado de Cid Tomanik Pompeu, Direito de Águas no Brasil, Editora RT, São Paulo-Brasil: 2006, pp. $46-48$.
} 


\begin{tabular}{|c|c|c|}
\hline $\begin{array}{l}\text { Constitución } \\
\text { da República } \\
\text { dos Estados } \\
\text { Unidos del } \\
\text { Brasil }\end{array}$ & $\bar{\partial}$ & $\begin{array}{l}\text { Sin tratar el dominio hídrico, la Constitución del } 1891 \text { atribuyó al } \\
\text { Congreso Nacional competencia para legislar sobre navegación de los } \\
\text { ríos que bañaran más de un Estado o se extendiera a territorios } \\
\text { extranjeros }\left(\operatorname{art.~} 34, \S 6^{\circ}\right) \text {. }\end{array}$ \\
\hline $\begin{array}{l}\text { Constitución } \\
\text { da República } \\
\text { de los Estados } \\
\text { Unidos del } \\
\text { Brasil }\end{array}$ & ڤ్ & $\begin{array}{l}\text { Declaró dominio de la Unión los bienes que en aquella época le } \\
\text { pertenecían, en los términos de las leyes en vigor, así como los lagos y } \\
\text { cualesquier corrientes en terrenos de su dominio, o que bañasen más de } \\
\text { un Estado, sirvieran de límites con otros países o se extendieran a } \\
\text { territorio extranjero (art. 20, I e II). } \\
\text { A los Estados, fueron conferidos los bienes de su propiedad, conforme } \\
\text { legislación en vigor, con excepción de los atribuidos a la unión, y } \\
\text { también a las márgenes de los ríos y lagos navegables destinados al uso } \\
\text { público, si por algún título no fueran del dominio federal, municipal o } \\
\text { particular (art. } 21 \text {, I e II). } \\
\text { El aprovechamiento industrial de las aguas y de la energía hidráulica, } \\
\text { aunque de propiedad privada, dependía de le autorización o concesión } \\
\text { federal, en la forma de la ley, en el caso el Código de Aguas (art. 119), } \\
\text { a ella incorporado }{ }^{512} \text {. }\end{array}$ \\
\hline $\begin{array}{l}\text { Constitución } \\
\text { de los Estados } \\
\text { Unidos del } \\
\text { Brasil }\end{array}$ & $\hat{\sigma}$ & $\begin{array}{l}\text { En términos de aguas y márgenes, los art. } 36, a \text { e } b \text {, e art. } 37, a \text { e } b \\
\text { reprodujeron las disposiciones de la Constitución de } 1934 \text {. }\end{array}$ \\
\hline $\begin{array}{l}\text { Constitución } \\
\text { de los Estados } \\
\text { Unidos del } \\
\text { Brasil }\end{array}$ & $\stackrel{0}{\beth}$ & $\begin{array}{l}\text { Mantuvo entre los bienes de la Unión los lagos y cualesquier corrientes } \\
\text { de agua en terrenos de su dominio o que bañaran más de un Estado, } \\
\text { sirvieran de límite con otros países o se extendieran a territorio } \\
\text { extranjero (art. } 34, \mathrm{I}) \text {. } \\
\text { Al extinguir la categoría de los ríos municipales, alteró } \\
\text { substancialmente el dominio hídrico de Estados y Municipios. }\end{array}$ \\
\hline $\begin{array}{l}\text { Constitución } \\
\text { de Brasil }\end{array}$ & $\hat{\sigma}$ & $\begin{array}{l}\text { Reprodujo los términos de la anterior y colocó, entre los bienes de la } \\
\text { Unión, además de los que en aquella época le pertenecían, los lagos y } \\
\text { cualesquier corrientes de agua "en terrenos de su dominio", o que } \\
\text { bañase más de un Estado, sirvieran de límite con otros países o se } \\
\text { extendieran a territorio extranjero. } \\
\text { Los Estados permanecieron con "los lagos y ríos en terrenos de su } \\
\text { dominio" y los que tuvieran naciente y desembocadura en el territorio } \\
\text { estadual (art. } 4^{\circ} \text {, II e V, e } 5^{\circ} \text { ). }\end{array}$ \\
\hline $\begin{array}{l}\text { Emenda } \\
\text { Constitucional } \\
1\end{array}$ & ڤे & $\begin{array}{l}\text { Siguió la línea de la Constitución del } 67 \text {, conservando con la Unión, } \\
\text { además de los que en aquella época le pertenecían, el dominio hídrico } \\
\text { anterior. Para los Estados y Territorios, quedaron los lagos en terrenos } \\
\text { de su dominio y los ríos que en ellos tuvieran nacimiento y } \\
\text { desembocadura (art. } 4^{\circ} \text {, II, e art. } 5^{\circ} \text { ). }\end{array}$ \\
\hline
\end{tabular}

${ }^{512}$ CRETELLA JÚNIOR., José. Comentários à Constituição Brasileira de 1988, v. 8, Editora Forense, Rio de Janeiro-Brasil: 1990, p. 4145. 
Pompeu ${ }^{513}$ destaca la importancia del respeto a los derechos y a las garantías constitucionalmente protegidos, y recuerda que a partir de la Constitución de 1934 ha sido peculiaridad la definición de ‘dominio hídrico' de las entidades que componen la federación.

\subsection{La tutela del agua en Brasil a partir de 1988: dispositivos explícitos y dispositivos implícitos en la Constitución Brasileña de 1988}

El medio ambiente se encuentra conceptuado y caracterizado en el Titulo VIII, Del Orden Social, Capítulo VI, de la Constitución de la República Federativa del Brasil (CF/1988).

Es entendimiento de algunos ${ }^{514}$ que la Constitución de la República Federativa del Brasil de 1988 no incluye el agua como un derecho fundamental. Pese a que la coloque en el status constitucional, se la traslada para el Título III, De la Organización del Estado, como bien de la Unión y de los Estados.

En realidad, eso emana, más, en la visión de José Afonso da Silva"515, "la cuestión ambiental permea el texto constitucional mediante referencias explícitas al medio ambiente", y siendo el agua uno de sus elementos, eso hace con que a ella se aplique el enunciado del caput del art. 225 de la $\mathrm{CF} / 88$ : "todos tienen derecho al medio ambiente ecológicamente equilibrado, bien de uso común general (...)”. En otras palabras, el 'ambiente' en la $\mathrm{CF} / 88$ es un bien difuso, sin titular definido, pero el agua no.

Además de ese, hay otros dispositivos, tanto explícitos como implícitos, en que los valores ambientales se presentan bajo otros enfoques de la normatividad constitucional.

\footnotetext{
${ }^{513}$ POMPEU. Cid Tomanik. Direito de Águas no cit., p.48.

${ }^{514}$ Dentre os quais Erivaldo Moreira BARBOSA, Água doce: direito fundamental da pessoa humana, 2007, cit.

${ }^{515}$ SILVA, José Afonso da. Comentário Contextual à Constituição. $3^{\mathrm{a}}$ ed., Malheiros Editores, São Paulo-Brasil: 2007, p. 834.
} 
La primera referencia expresa a los recursos ambientales se sitúa en el art. 50, LXXIII, que confiere legitimación a cualquier ciudadano para proponer acción popular que se proponga a anular acto lesivo al medio ambiente y al patrimonio histórico y cultural.

En seguida, en el Título III, De la Organización del Estado, el art. 20, II, considera, entre los bienes de la Unión, las tierras deshabitadas indispensables a la preservación del medio ambiente. En el art. 20, $\S 1^{\circ}$, fue asegurada a los Estados, Distrito Federal, Municipios y a órganos de la Administración directa de la Unión participación en el resultado de la explotación de recursos hídricos para la producción de energía eléctrica y de otros recursos minerales en el respectivo territorio, en la plataforma continental, en el mar territorial o en la zona económica exclusiva, o compensación financiera por esa exploración.

Con la finalidad de incentivar la irrigación en las regiones Centro-Oeste y Nordeste, la Unión debe aplicar, a partir de 05 de octubre de 1988 y por los veinte y cinco años siguientes, un veinte por ciento (20\%) en la región Centro-Oeste y un cincuenta por ciento (50\%) en la región Nordeste de los recursos destinados a esa finalidad, preferencialmente en el semiárido ${ }^{516}$.

Limitando la actuación de la Unión, la CF/1988 (art. 21, XII, b) determina que, para la exploración de servicios e instalaciones de energía eléctrica y el aprovechamiento energético de los cursos de agua, directamente o mediante autorización, concesión o permisión, ella necesita de articulación con los Estados donde se sitúan los potenciales hidroenergéticos. Sin eso, la exploración será constitucionalmente imposible. La simple manifestación de los Comités de Bacías Hidrográficas no significa anuencia por parte del Estado, que debe ser dada por el Gobernador o autoridad competente para ello ${ }^{517}$.

\footnotetext{
${ }^{516}$ Art. 42, I e II, del Ato das Disposições Constitucionais Transitórias (ADCT), con redacción dada por el art. $1^{\circ}$ de la Emenda Constitucional (EC) 43, de 15 de abril de 2004. Información constante en Cid Tomanik POMPEU, Direito de Águas no cit., p. 48.

${ }^{517}$ POMPEU, Cid Tomanik. Direito de Águas no cit., p. 50.
} 
La competencia legislativa de la Unión, Estados y Municipios y del Distrito Federal está señalada en la $\mathrm{CF} / 1988^{518}$. La Unión "legisla privativamente sobre aguas $^{519,}$, pudiendo ley complementar autorizar los Estados a hacerlo sobre cuestiones específicas de la materia (art. 22, IV, y $\S$ único). Sin esa promulgación, la competencia permanece exclusiva de la Unión.

El art. 23 reconoce la competencia de la Unión, Estados, Distrito Federal y Municipios para "proteger los paisajes naturales notables y el medio ambiente", "combatir la polución en cualquier de sus formas", y "preservar los bosques, la fauna y la flora”.

En los incisos VI, VII y VIII del art. 24, hay competencia concurrente de la Unión, Estados y Distrito Federal para legislar sobre "bosques, caza, pesca, fauna, conservación de la naturaleza, defensa del suelo y de los recursos naturales, protección al medio ambiente y control de la polución"; sobre "protección al patrimonio histórico, cultural, artístico, turístico y paisajístico", así como sobre "responsabilidad por daño al medio ambiente, al consumidor, a bienes y derechos de valor artístico, estético, histórico, turístico y paisajístico".

Hasta la CF/88, no había dominio definido para las aguas subterráneas, permaneciendo como res nullius ${ }^{520}$. A partir de entonces, esas fueron incluidas entre los bienes de los Estados y, por analogía, del Distrito Federal (art. 26, I).

Más adelante, en el art. 91, $\S 1^{\circ}$, III, se encuentra, entre las atribuciones del Conselho de Defesa Nacional, la responsabilidad de opinar sobre el efectivo uso de las

\footnotetext{
${ }^{518}$ Art. 22 - competência privativa da União; art. 24 - competência concorrente entre União, Estados e Distrito Federal; art. 25, $\S 1^{\circ}$ - competência dos Estados; art. 30, I e II - competência dos Municípios; art. $32, \S 1^{\circ}$ - competência do Distrito Federal.

${ }^{519}$ Conviene analizar el alcance de esa disposición constitucional. Como las aguas estaduales son bienes públicos del dominio de las unidades federadas, a estas cabe administrarlas y ejercer la respectiva autotutela administrativa, editando las normas necesarias, muchas veces en forma de leyes. En el campo hídrico, la Unión posee doble competencia: crea el derecho sobre aguas cuando legisla privativamente; y edita normas administrativas sobre las aguas de su dominio, en forma de ley o no. Los Estados, aunque hayan recibido vasto dominio hídrico, solamente disponen de competencia para editar normas administrativas sobre las aguas de su dominio, mismo mediante leyes, cuando necesario. POMPEU, Cid Tomanik. Direito de Águas no cit., pp. 50-51.

${ }^{520}$ POMPEU, Cid Tomanik. Um estudo sobre águas subterrâneas. O Estado de São Paulo, São PauloBrasil: 04 de maio 1980, p.63.
} 
áreas indispensables a la guardia del territorio nacional, especialmente en la franja de fronteras y en las áreas relacionadas a la preservación y a la exploración de los recursos naturales, de cualquier tipo.

El inciso III del art. 129 establece ser, también, una de las funciones institucionales del Ministerio Público, la de promover el averiguación previa y la acción civil pública para la protección del patrimonio público y social, del medio ambiente, y de otros intereses difusos y colectivos.

Relevante $^{521}$ es el art. 170, VI, que reputa la defensa del medio ambiente como uno de los principios del orden económico, lo que considera que toda actividad económica sólo puede desarrollarse legítimamente caso atienda a ese principio, entre otros relacionados en el mismo artículo, convocando, en caso de no atendimiento, la aplicación de la responsabilidad de la empresa y de sus dirigentes en la forma prevista en el art. $173, \S 5^{\circ}$.

En el $\S 3^{\circ}$ del art. 174, la $\mathrm{CF} / 88$ determina que el Estado favorezca la organización de la actividad de búsqueda de metales y piedras preciosas en cooperativas, teniendo en cuenta la protección del medio ambiente, además de la promoción económico-social de los buscadores que realizan esta actividad. Así, si el medio ambiente no estuviere debidamente protegido, el Estado estará prohibido de autorizar la organización de la actividad de los buscadores.

La utilización adecuada de los recursos naturales disponibles y la preservación del medio ambiente constituyen, en los términos del art. 186, II, un requisito de la función social de la propiedad rural, cuya no observancia puede propiciar desapropiación, para fines de reforma agraria (art. 184) ${ }^{522}$.

En el Titulo VIII, Del Orden Social, constan los valores de la calidad de vida:

Art. 200, VIII - expresamente se declara que al Sistema Único de Salud compete, además de otras atribuciones, "colaborar en la protección al medio ambiente, en el comprendido el del trabajo". Esta alusión al trabajo remete al art. $7^{\circ}$, XXII, que trata del derecho del trabajador a un ambiente higiénico en su actividad laboral;

Art. 216, V - contiene referencia importante a "conjuntos urbanos y sitios ecológicos" como bienes integrantes del patrimonio cultural brasileiro;

\footnotetext{
${ }^{521}$ SILVA, José Afonso da. Comentário Contextual à cit., p. 835.

${ }^{522}$ SILVA, José Afonso da. Comentário Contextual à cit., p.835.
} 
Art. $220, \S 3^{\circ}$, II - determina ser competencia de ley federal establecer los medios legales que garanticen a las personas y a la familia la posibilidad de defenderse “de la propaganda de productos, prácticas y servicios que puedan ser nocivos a la salud y al medio ambiente".

Las referencias implícitas al medio ambiente se refieren a un sector o a un recurso ambiental.

El art. 20 es pleno de recursos ambientales, cuando define, entre los bienes de la Unión: Inciso III - los lagos, ríos y cualesquier corrientes de agua en terrenos de su dominio, o que bañen más de un Estado, sirvan de límites con otros países o se extiendan a territorio extranjero o proveniente de él, así como los terrenos marginales y las playas fluviales; Inciso $\mathrm{V}$ - los recursos naturales de la plataforma continental y de la zona económica exclusiva; Inciso VI - el mar territorial; Inciso VIII - los potenciales de energía hidráulica; e Inciso XIX - los recursos minerales, incluso los subterráneos.

En el inciso XIX del art. 21, consta "competir a la Unión [...] instituir sistema nacional de gerenciamiento de recursos hídricos y definir criterios de otorga de derechos de su uso". Así, menciona uno de los recursos ambientales más importantes, el agua.

En el art. 26, I, consta como incluidas entre los bienes de los Estados "las aguas superficiales o subterráneas, fluentes, emergentes y en depósito".

Desde 1990, todos los niveles de gobierno han sido influenciados por una serie de tendencias internacionales, que estimularon mayor flexibilidad de mercado, la descentralización y la participación de la sociedad civil en el proceso de tomada de decisión en el sector público, alterando la situación anterior y estableciendo el régimen democrático. La política de gestión de los recursos hídricos en Brasil ha acompañado esa tendencia, siendo influenciada de manera significativa por los debates internacionales ${ }^{523}$

\footnotetext{
${ }^{523}$ FRANK, B. (Org.) Projeto Marca D’Água: seguindo as mudanças na gestão das Bacias Hidrográficas do Brasil. Caderno 2: Comitês de Bacia sob o olhar dos seus membros. Blumenau: FURB, 2008, p.7.
} 


\subsection{EI Sistema Nacional de Gestión de Recursos Hídricos - SINGREH. La} evolución histórica de la gestión de recursos hídricos en Brasil

La década de 1930 significó un momento de génesis de la política ambiental brasileña, cuando fue editada la legislación básica sobre el tema. Además del código referente a las aguas, fueron editados: el Código Forestal ${ }^{524}$, el Código de Minas ${ }^{525}$ y el Código de Pesca ${ }^{526}$.

El Código de Aguas $^{527}$ fue el primer diploma legal que posibilitó al Poder Público disciplinar el aprovechamiento industrial de las aguas y, de modo especial, el aprovechamiento y explotación de la energía hidráulica. El proyecto fue elaborado en 1907 por el jurista Alfredo Valladão atendiendo a pedido del entonces, Ministro de la Industria, Transporte y Obras Públicas. Encaminado a la Cámara de los Diputados, se quedó en fase de tramitación por casi tres décadas. Las razones presentadas para ese largo retraso fueron su inadecuación a los dispositivos constitucionales vigentes en aquella época y los problemas relacionados a las sequías en el semiárido nordestino ${ }^{528}$. Ese escenario se cambiaría substancialmente frente al cuadro político institucional que emergió con la Revolución de 1930. Además de la ruptura política y económica con el Estado oligárquico, el nuevo proyecto político trajo, entre sus metas, un esfuerzo de modernización técnica y administrativa del aparato del Estado y de gestión directa de los servicios públicos ${ }^{529}$.

El Código de Aguas fue editado en la forma de Decreto y no de ley, por ser acto del Gobierno Provisorio decurrente de la Revolución de 1930. Se constituye texto antiguo, pero todavía vigente, no obstante haya sido muy modificado por leyes posteriores $^{530}$.

La implementación del Código de Aguas fue encargada a órganos federales en lo que se refería a las aguas de dominio de la Unión, y de órganos estaduales en las de

\footnotetext{
${ }^{524}$ Brasil. Código Florestal. Decreto 23.793, de 23 de janeiro de 1934.

${ }^{525}$ Brasil. Código de Minas. Decreto 24.642, de 10 de julho de 1934.

${ }^{526}$ Brasil. Código de Pesca. Decreto 794, de 19 de julho de 1938.

${ }^{527}$ Brasil. Código de Águas. Decreto 24.643, de 10 de julho de 1934.

${ }^{528}$ ASSUNÇÃO, F. N. A.; BURSZTYN, M. A. As políticas das águas no Brasil. III Encuentro de las aguas: agua, vida y desarrollo. Anais, Santiago, Chile, 2001.

${ }^{529}$ São Paulo (Estado). Gestão participativa das águas, 2004, cit., p. 29.

${ }^{530}$ MILARÉ, Édis. Direito do Ambiente: cit., p. 382.
} 
dominio de los Estados. En órbita federal, esa competencia era del Departamento Nacional de Aguas y Energía Eléctrica (DNAEE), de forma compartida con el Departamento Nacional de Obras Contra las Sequías (DNOCS) en las áreas sujetas al flagelo de las sequías. Los Estados también constituyeron órganos para aplicar el Código de Aguas, y sus actos más importantes eran las 'otorgas' para la derivación de aguas y para el aprovechamiento de energía hidroeléctrica ${ }^{531}$.

Se nota que las preocupaciones con el uso del agua para fines energéticos están presentes en la organización institucional, teniendo en cuenta la creación, también en 1934, del Departamento Nacional de Produção Mineral (DNPM) y del Conselho Nacional de Águas e Energía Elétrica (CNAEE). Estos órganos son ejemplos de esa política con fuerte orientación nacionalista e intervencionista, indicativa de la hegemonía que el sector eléctrico iba a tener sobre la gestión de los recursos hídricos en las décadas siguientes ${ }^{532}$.

Según Milaré ${ }^{53}$, la gestión de aguas se limitaba a la gestión de su cantidad, sin cualquier preocupación con la calidad. Para Pompeu ${ }^{534}$, el Código de Aguas, en los arts.

${ }^{531}$ MILARÉ, Édis. Direito do Ambiente: cit., p. 386.

${ }^{532}$ São Paulo (Estado). Gestão participativa das águas, 2004, cit., p. 30.

${ }^{533}$ MILARÉ, Édis. Direito do Ambiente: cit., p. 387.

${ }^{534}$ POMPEU, Cid Tomanik. Direito de Águas cit., pp. 136, 205-206, 210 y 273. Además, respecto al Conselho Nacional de Águas e Energia Elétrica: “O CNAEE foi criado em março de 1939 com a finalidade de estudar o problema da exploração e utilização da energia elétrica no país, em especial a de origem hidráulica. Era integrado por cinco membros, todos nomeados pelo presidente da República. A criação do CNAEE procurava colocar em prática as disposições contidas no Código de Águas de 1934. Sua finalidade principal era proporcionar uma atuação coordenada do Estado no âmbito da produção hidrelétrica, até então entregue quase exclusivamente à iniciativa privada. Na década de 1960, após a criação da Eletrobrás e do Departamento Nacional de Águas e Energia, o CNAEE foi perdendo gradualmente suas funções. Foi extinto em 1969". Disponible en: $<$ https://cpdoc.fgv.br/producao/dossies/AEraVargas1/anos37-

45/EstadoEconomia/ConselhoAguasEnergia>. Acceso en: 17-05-2010. "Em 1920, no Serviço Geológico e Mineralógico do Brasil, órgão do então Ministério da Agricultura, Indústria e Comércio, foi criada uma Comissão de Estudos de Forças Hidráulicas. Mais tarde, em princípios de 1933, foi conferida uma nova organização ao Serviço Geológico e Mineralógico do Brasil, sendo instituída na ocasião, uma DIRETORIA DE ÁGUAS que veio, posteriormente, a transformar-se em SERVIÇO DE ÁGUAS. Em agosto de 1934, com a Reforma Juarez Távora, surgiu o DEPARTAMENTO NACIONAL DA PRODUÇÃO MINERAL - DNPM, abrangendo, entre outros, o SERVIÇO DE ÁGUAS. Pelo Regimento do Departamento Nacional da Produção Mineral, baixado com o Decreto ${ }^{\circ}$ 6.402, de 28 de outubro de 
$109-112^{535}, 115-116^{536}, 138^{537}$ e $143^{538}$, deja claro la preocupación, también, con la calidad de las aguas.

1940, o Serviço Geológico e Mineralógico do Brasil foi transformado na Divisão de Geologia e Mineralogia, e o SERVIÇO DE ÁGUAS tornou-se DIVISÃO DE ÁGUAS. No ano de 1961, o Departamento Nacional da Produção Mineral foi desligado do Ministério da Agricultura, passando a integrar o Ministério das Minas e Energia, criado pela Lei no 3.782, de 22 de julho de 1960”. Disponible en: <http://www.aneel.gov.br/area.cfm?idArea=8>. Acceso en: 17-05-2010. Departamento Nacional de Produção Mineral "teve origem na Diretoria do Serviço Geológico e Mineralógico do Brasil, criado em 10 de janeiro de 1907 pelo Decreto n ${ }^{\circ}$ 6.323, subordinada ao Ministério dos Negócios da Agricultura, Indústria e Comércio. O Departamento Nacional de Produção Mineral foi instituído no dia 8 de março de 1934, pelo Decreto n 23.979, permanecendo na pasta da Agricultura até 22 de julho de 1960. Trinta anos mais tarde, o DNPM teve sua estrutura profundamente modificada com a criação do Ministério da Infraestrutura -MINFRA, resultante da fusão dos Ministérios das Minas e Energia, Comunicações e dos Transportes, bem como de parte do Ministério da Indústria e Comércio. Em decorrência dessa mudança, o DNPM perdeu a condição de órgão central de direção superior e ficou subordinado à Secretaria Nacional de Minas e Metalurgia. As suas unidades regionais -12 Distritos - foram extintas, tendo suas funções repassadas às então criadas Delegacias do Ministério da Infraestrutura, com representação em todas Unidades da Federação. Durante a segunda reforma realizada em abril de 1992, o Mistério de Minas e Energia foi restabelecido, mas mantida a mesma estrutura de subordinação. Em maio de 1994, foi sancionada a Lei $\mathrm{n}^{\circ} 7.876$ que transformava o DNPM em Autarquia e o Decreto $\mathrm{n}^{\circ} 1.324$, de 2 de dezembro de 1994 o instituiu com uma estrutura de representação em todos os Estados, iniciando-se então o processo de resgate de sua identidade. Em 2010, foi publicado o Decreto no 7.092 que aprovou a nova Estrutura Regimental e o Quadro Demonstrativo dos Cargos em Comissão, das Funções Gratificadas e das Funções Comissionadas. Com a nova estrutura ficou estabelecido que o DNPM tem por finalidade promover o planejamento e o fomento da exploração mineral e do aproveitamento dos recursos minerais e superintender as pesquisas geológicas, minerais e de tecnologia mineral, bem como assegurar, controlar e fiscalizar o exercício das atividades de mineração em todo o território nacional, na forma do que dispõem o Código de Mineração, o Código de Águas Minerais, os respectivos regulamentos e a legislação que os complementa". Disponible en: <http://www.dnpm.gov.br/dnpm/documentos/carta-de-servicos-do-dnpm>. Acceso en: 17-05-2010.

${ }^{535}$ Art. 109. A ninguém é lícito conspurcar ou contaminar as águas que não consome, com prejuízo de terceiros. Art. 110. Os trabalhos para a salubridade das águas serão executados á custa dos infratores, que, além da responsabilidade criminal, se houver, responderão pelas perdas e danos que causarem e pelas multas que lhes forem impostas nos regulamentos administrativos. Art. 111. Se os interesses relevantes da agricultura ou da indústria o exigirem, e mediante expressa autorização administrativa, as águas poderão ser inquinadas, mas os agricultores ou industriais deverão providenciar para que as se purifiquem, por qualquer processo, ou sigam o seu esgoto natural. Art. 112. Os agricultores ou industriais deverão 
Esa gestión estaba fundamentalmente condicionada a las concesiones para el aprovechamiento hidroeléctrico, tanto en las aguas federales como en las estaduales. En la década de los 70, surgió la preocupación con la contaminación en general, con enfoque más preciso en las aguas. Los Estados más industrializados (São Paulo y Río de Janeiro) pasaron a legislar sobre el control de contaminación de las aguas, del aire y del suelo, controlando todas las aguas de su territorio y sin limitación cuanto a su dominio.

El período de creación de las autarquías, orientación que marcó toda la década de 1950, fue marcado también por la búsqueda de mayor autonomía de los servicios de saneamiento en relación a la administración directa. Las críticas a la administración centralizada de los servicios de saneamiento apuntaban, por un lado, las interferencias y subordinación a los intereses externos $\mathrm{y}$, por otro, la dependencia financiera $\mathrm{y}$ presupuestaria como resultado de la ausencia de recaudación propia. El período siguiente fue caracterizado por un modelo de gestión empresarial, en la que fueron creadas varias empresas de economía mixta, en la búsqueda de mayor racionalización y eficiencia en la asignación de recursos y autonomía presupuestaria por intermedio de ingresos tarifarios ${ }^{539}$.

indenizar a União, os Estados, os Municípios, as corporações ou os particulares que pelo favor concedido no caso do artigo antecedente, forem lesados.

${ }^{536}$ Art. 115. Ao proprietário assiste a obrigação de indenizar os trabalhos feitos, pelo pagamento de uma taxa de melhoria sobre o acréscimo do valor dos terrenos saneados, ou por outra forma que for determinada pela administração pública. Art. 116. Se o proprietário não entrar em acordo para a realização dos trabalhos nos termos dos dois artigos anteriores, dar-se-á a desapropriação, indenizado o mesmo na correspondência do valor atual do terreno, e não do que este venha a adquirir por efeito de tais trabalhos.

${ }^{537}$ Art. 138. As servidões urbanas de aqueduto, canais, fontes, esgotos sanitários e pluviais, estabelecidos para serviço público e privado das populações, edifícios, jardins e fábricas, reger-se-ão pelo que dispuseram os regulamentos de higiene da União ou dos Estados e as posturas municipais.

${ }^{538}$ Art. 143. Em todos os aproveitamentos de energia hidráulica serão satisfeita exigências acauteladoras dos interesses gerais: a) da alimentação e das necessidades das populações ribeirinhas; b) da salubridade pública; c) da navegação; d) da irrigação; e) da proteção contra as inundações; f) da conservação e livre circulação do peixe; g) do escoamento e rejeição das águas.

${ }^{539}$ São Paulo (Estado). Gestão participativa das águas, 2004, cit., p.31. 


\subsubsection{La interfaz con el saneamiento ambiental}

Analizando la historia del saneamiento brasileño, del período colonial hasta la elaboración del Plano Nacional de Saneamiento (PLANASA) en 1971, Costa ${ }^{540}$ identifica seis fases:

(1) Período colonial caracterizado por la ausencia casi total del Estado en relación a las acciones de saneamiento;

(2) Primeras concesiones de servicios de aguas y alcantarillado a la iniciativa privada;

(3) Adopción de los servicios de saneamiento por el Estado, tomándose por base la ruptura de las concesiones a la iniciativa privada;

(4) Busca de autonomía de los servicios en relación a la administración directa con la creación de autarquías y de mecanismos de financiamiento;

(5) Busca aún mayor de autonomía por intermedio de la adopción de un modelo de gestión empresarial marcado por la creación de empresas de economía mixta, principalmente en el ámbito estadual;

(6) Elaboración del Plano Nacional de Saneamento (PLANASA), que representó una "divisoria de aguas" en el sector.

Con la implantación del PLANASA, se consolidó el conjunto de tendencias de gestión que se desarrollaban desde los años 1950: las directrices pasaron a dirigirse para la autonomía de los servicios, la auto-sustentación tarifaria, el financiamiento con recursos retornables y la gestión por intermedio de las compañías estaduales de saneamiento.

Con el PLANASA, la política de saneamiento pasó a ser centralizada por el gobierno federal. Los acuerdos financieros y operacionales para la viabilidad del Pan ya existían: el Banco Nacional de la Habitación (BNH), creado en 1965, como órgano gestor, y el Fondo de Garantía por Tiempo de Servicio (FGTS), del mismo año, como la principal fuente de recursos para la implantación del Plan. El Fondo de Financiamiento

\footnotetext{
${ }^{540}$ COSTA, A. M. Análise histórica do saneamento no Brasil. Dissertação (Mestrado, Fundação Oswaldo Cruz). Rio de Janeiro: Fundação Oswaldo Cruz, 1994.
} 
para el Saneamiento, de 1967, y el Sistema Financiero de Saneamiento, creado en el año siguiente, proveyeron la estructura institucional al PLANASA ${ }^{541}$.

Integrando el Plan de metas y Bases para la Acción del Gobierno, el PLANASA presentaba metas específicas hasta 1980: atender $80 \%$ de la población urbana del país con abastecimiento de agua e integrar a las redes 50\% del alcantarillado de esa misma población. Aparte eso, pretendía también extender el atendimiento a todas las sedes municipales y poblados brasileños con población superior a cinco mil habitantes hasta el año de 1985. En 1967, un 53\% de la población urbana era contemplada con el sistema público de abastecimiento de agua $\mathrm{y}$, de todo el país, solamente un $27 \%$ contaba con ese beneficio ${ }^{542}$.

El PLANASA representó enorme avance en términos de atendimiento a las demandas de abastecimiento de agua y coleta, además de alejamiento de alcantarillado. Sin embargo, las consecuencias de esa política fueron el aumento extraordinario de carga de efluentes domésticos lanzados en los cuerpos de agua, porque los financiamientos de los sistemas de tratamiento del alcantarillado casi no fueron contemplados $^{543}$.

\subsubsection{Las políticas ambientales brasileñas}

Al analizar la política ambiental brasileña, Ascelrad ${ }^{544}$ distingue el período anterior a los años 1970 como 'políticas ambientales implícitas' y el período posterior como 'políticas ambientales explícitas'. La creación de la Secretaría Especial de Medio Ambiente (SEMA) en 1973 marcaría el inicio de le nueva institucionalidad política, que tiene por objeto el medio ambiente.

\footnotetext{
${ }^{541}$ SETTI, A. A. Diagnóstico sobre a situação dos mananciais. Brasília: Ministério do Meio Ambiente, Programa Nacional do Meio Ambiente, 1998.

${ }^{542}$ Organização Panamericana de Saúde. OPS. Relatório, 1967.

${ }^{543}$ São Paulo (Estado). Gestão participativa das águas, 2004, cit., p.32.

${ }^{544}$ ASCELRAD, H. Políticas ambientais e construção democrática. In: Viana, g.; Silva, M.; Diniz, N. (org.). O desafio da sustentabilidade: um debate socioambiental no Brasil. Editora Fundação Perseu Abramo, São Paulo: 2001.
} 
El surgimiento de esa institución fue contemporáneo de procesos similares en los que agencias y mecanismos institucionales públicos fueron creados en grande número de países - fundamentalmente industrializados, en paralelo a los debates de la Conferencia de la Organización de las Naciones Unidas (ONU) sobre Medio Ambiente Humano, realizado en Estocolmo en 1972. En Brasil, la SEMA surgió en pleno régimen dictatorial, de forma reactiva, con aspectos fuertemente burocráticos y sin ninguna articulación con la sociedad, salvo por el hecho de que buscó ofrecer respuesta formal al movimiento que, en el inicio de los años 70 , se levantó contra la contaminación causada por una fábrica de celulosa ubicada en Porto Alegre, $\mathrm{RS}^{545}$.

El panorama político brasileño se marcaba por el deterioro del Estado autoritario y por los movimientos de resistencia y de construcción de otra institucionalidad democrática. Eses movimientos fueron importantes para la consolidación de nuevas relaciones entre el Estado y la sociedad civil, pudiéndose notar que las últimas décadas de la historia brasileira han visto, cada vez más, esa relación ser permeada por la idea de la participación y control social en la gestión de la cosa pública $^{546}$.

Cuando se analizan las políticas volcadas especialmente a los recursos hídricos, se nota claramente que la década de 1980 representó nueva "divisoria de aguas" para el sector. La degradación de los cuerpos de agua, los frecuentes crises de abastecimiento urbano, los diversos conflictos de uso, y la competición entre diferentes sectores por su apropiación son elementos constantes, presentes en casi todos los diagnósticos realizados. A estos elementos, se puede acrecentar gestión sectorial orientada por principios exclusivamente técnico-burocráticos y por niveles de decisión centralizados. Ese era el cuadro de la situación de los recursos hídricos en la época.

En esa coyuntura extremamente favorable de reconstrucción de las instituciones democráticas; de surgimiento de movimientos populares; y de creación de nuevas organizaciones de la sociedad civil, las demandas de los ciudadanos y usuarios reivindicando calidad y oferta para el abastecimiento público se acabaron sumando a las ganas de técnicos y especialistas que, por intermedio de sus asociaciones, lanzaron directrices que pasarían a orientar la nueva política brasileña de recursos hídricos.

\footnotetext{
${ }^{545}$ ASCELRAD, H. Políticas ambientais e construção democrática. In: Viana, G.; Silva, M.; Diniz, N. (org.). O desafio da sustentabilidade cit., p.79.

${ }^{546}$ São Paulo (Estado). Gestão participativa das águas, 2004, cit., p.34.
} 


\subsubsection{La gestión contemporánea de las aguas}

El Código de Aguas trataba de 'aguas nocivas' en sus art. 109 a 116, determinando que era prohibido "agredir o contaminar las aguas en perjuicio de terceros". Esas disposiciones retratan el espíritu del tiempo: la preocupación no era con el agua propiamente dicha tampoco con la flora y la fauna, sino con el perjuicio a terceros. Eso fue reconsiderado y corregido por la legislación ambiental, Ley 6.938, de 31 de agosto de 1981.

Desde 1916, como en otros países, hubo en Brasil inicialmente una 'legislación con repercusión ambiental', que objetivaba disciplinar las relaciones entre los individuos, proteger su salud y regular la repartición de los recursos naturales más utilizados $^{547}$. Ejemplos ${ }^{548}$ pueden ser encontrados en la 'legislación sanitaria' que, incluso cuando se refería a la calidad del agua, del aire, del suelo y del medio urbano, visaba proteger la salud del individuo y no los recursos naturales. El Código Civil de 1916, en el 'derecho de vecindad', regulaba el uso nocivo de la propiedad, los árboles vecinos, el paso de acceso, las aguas, os límites entre edificios, el derecho a construir y el derecho de tapar el edificio (murar, vallar, empalizar, cercar) ${ }^{549}$. Los Códigos de Agua, de Explotación Minera, Forestal y de Pesca son ejemplos de normas con el objetivo de proteger los recursos naturales más intensamente utilizados por el hombre, y no el ambiente propiamente dicho ${ }^{550}$. De acuerdo con el espíritu de la época, el Plano Nacional de Desenvolvimento (PND-I 1972-1974) dedicó más énfasis a los aspectos económico-sociales que al ambiente ${ }^{551}$.

Con la creación de la Secretaría Especial del Medio Ambiente (SEMA) en 1973, comenzó a surgir en Brasil una legislación apoyada, posteriormente, en el II Plano Nacional de Desenvolvimento (PND-II 1975-1979) que, de forma coherente al entendimiento de la década, dio gran destaque al control de la calidad ambiental ${ }^{552}$.

\footnotetext{
${ }^{547}$ CANO, G. J. A legal and institutional framework for natural resources management. Legislative studies, 9/3-4. Roma: FAO, 1975.

${ }^{548}$ POMPEU, Cid Tomanik. Direito de Águas no cit., 2010, p. 135

${ }^{549}$ Código Civil de 1916, arts. 554 a 558.

${ }^{550}$ POMPEU, Cid Tomanik. Direito de Águas no cit., 2010, p. 135.

${ }^{551}$ Lei 5.727, de 04 de novembro de 1971.

${ }^{552}$ Lei 6.151, de 04 de dezembro de 1974.
} 
Declarando ser importante el combate a la contaminación, el documento preveía una política de medio ambiente destinada al área urbana, para evitar acciones contaminantes del aire y del agua, y una política para la protección de los recursos naturales, visando la correcta utilización del aire, del agua, del suelo y subsuelo, de la flora y fauna, el control de la polución industrial y la institución de programas especiales de preservación de medio ambiente.

La Ley 6.938/1981 dispone sobre la Política Nacional de Meio Ambiente e instituyó el Sistema Nacional do Meio Ambiente (SISNAMA) integrado por órganos federales, estaduales, distrital y municipales, responsables por la protección del ambiente. El órgano superior de ese Sistema es el Conselho Nacional do Meio Ambiente (CONAMA), al cual compite, entre otras atribuciones, "establecer normas, criterios y paradigmas relativos al control y a la manutención de la calidad del medio ambiente objetivando el uso racional de los recursos ambientales, principalmente los hídricos" ${ }^{~} 53$.

La Ley 6.938/1981 también destaca las aguas al definir los recursos ambientales como siendo "la atmosfera, las aguas interiores, superficiales y subterráneas, los estuarios, el mar territorial, el suelo, el subsuelo, los elementos de la biosfera, la fauna y la flora" 554 .

En el ejercicio de su competencia, el CONAMA editó la Resolución 020, de 18 de junio de 1986, que inauguró, en el ámbito nacional, la gestión de la calidad de las aguas, con reflejos relevantes en la Política Nacional de Recursos Hídricos ${ }^{555}$.

En 1988, la Constitución Federal incorporó a su texto disposiciones sobre la protección al medio ambiente ${ }^{556}$.

La Ley $9.433^{557}$ instituyó la Política Nacional de Recursos Hídricos (PNRH) y creó el Sistema Nacional de Gestión de Recursos Hídricos (SINGREH). En esa ley, hay

\footnotetext{
${ }^{553}$ Brasil. Lei 6.938/1981, art. 8 , VII.

${ }^{554}$ Brasil. Lei 6.938/1981, art. 3ํ, V.

555 MILARÉ, Édis. Direito do Ambiente: cit., p.387. Más informaciones disponibles en: < http://www.mma.gov.br/port/conama/res/res86/res2086.html>.

${ }^{556}$ POMPEU, Cid Tomanik. Proteção do meio ambiente e Constituição. Jornal O Estado de São Paulo, p. 49, 09 de junho de 1985.

${ }^{557}$ Brasil. Ley 9.433. 08 de enero de 1997. Esa Ley usó como modelo la Ley 7.663, de 30.12.1991, del Estado de São Paulo, incluso al mencionar, indebidamente, el art. 36, del Código de Aguas, entre las penalidades. Art. 12, $\S 1^{\circ}$, Ley 7.663: - En el caso de los incisos III e IV, independientemente de la pena de multa, serán cobradas del infractor los gastos que tener la Administración para hacer efectivas las
} 
imposición de la necesidad de ser editadas varias normas reglamentarias, lo que todavía se está haciendo e ha alterado, profundamente, la disciplina de la aplicación del Código de Aguas.

La Ley 9.984, de 17 de julio de 2000, creó la Agencia Nacional de Aguas (ANA) como entidad federal de implementación de la Política Nacional de Recursos Hídricos e integrante del Sistema Nacional de Recursos Hídricos. En ese mismo año, el Decreto 3.692, de 19 de diciembre, contempló la estructura organizacional y operacional de la ANA.

No se olvida que, a pesar de conexos, la defensa del ambiente y la gestión de las aguas deben, preferencialmente, ser hechas por leyes y organismos administrativos especializados en cada sector, ya que se rigen por principios y regímenes jurídicos propios $^{558}$. En relación al ambiente que, por su propia naturaleza no está incluido entre los bienes de ningún de ellos, la competencia legislativa de los entes federados es concurrente, competiendo a la Unión la edición de ley sobre normas generales. Las aguas, sin embargo, por disposición constitucional expresa están puestas entre los bienes de la Unión y de los Estados y, por analogía, entre los del Distrito Federal. Sobre ellas, la Unión crea el derecho, pero, por ser bienes públicos que deben ser 'administrados' por los respectivos titulares, esta actividad cabe, igualmente, a las tres personas jurídicas, públicas y políticas ${ }^{559}$.

Los usos de las aguas, muchas veces, deben ser objeto de fomento, lo que no ocurre con el ambiente, lo mismo sucede con os respectivos fondos financieros, que poseen finalidades diversas. Así, los organismos que componen el Sistema Nacional de Gerenciamiento de Rrecursos Hídricos tienen misiones diferentes de las cometidas a los integrantes del Sistema Nacional del Medio Ambiente. En estos casos, no hay relación de titularidad entre el Poder Público y el objeto de la protección. Aparte eso, los ingresos advenidos de su utilización no se integran entre los 'ingresos originarios'

medidas previstas en los citados incisos, en la forma de los artículos 36, 53, 56 e 58 del Código de Aguas, sin perjuicio de responder por la indemnización de los daños que causar. Art. 50, $\S 2^{\circ}$, Ley 9.433: exactamente igual.

${ }^{558}$ SETTI, A. A et al. Introdução ao gerenciamento de recursos hídricos: aspectos legais, econômicos e sociais. Brasília: Agência Nacional de Energia Elétrica (ANEEL); Agência Nacional de Águas (ANA), 2001.

${ }^{559}$ POMPEU, Cid Tomanik. Direito de Águas no cit., p. 136. 
decurrentes del uso de bienes públicos, a ser pagos a aquellos que los tienen entre sus bienes. Por eso, aunque conexos, son sistemas diferentes ${ }^{560}$.

Para la comprensión de la gestión de las aguas, hay que basarse en los fundamentos constantes del art. $1^{\circ}$ de la Ley 9.433/97 en relación a la Política Nacional de Recursos Hídricos:

1. El agua es un bien de $\mathrm{e}^{561,562,563}$ dominio público;

2. El agua es un recurso natural limitado, dotado de valor económico;

3. En situaciones de escasez, el uso prioritario de los recursos hídricos es el consumo humano y bebedero de animales;

4. La gestión de recursos hídricos debe siempre proporcionar el uso múltiple de las aguas;

5. La cuenca hidrográfica es la unidad territorial para implementación de la Política Nacional de Recursos Hídricos y actuación del Sistema Nacional de Gestión de Recursos Hidricos;

6. La gestión de los recursos hídricos debe ser descentralizada y contar con la participación del Poder Público, de los usuarios y de la comunidad.

El SINGREH funciona por intermedio de instituciones que, en sus composiciones, cuentan con la participación de diversos sectores de la sociedad. Así, como su objetivo mayor, establece la gestión descentralizada del uso del agua, en la que todos poseen el derecho constitucionalmente garantido de participar de las negociaciones y de las tomadas de decisiones. Este tipo de gestión encuentra fundamento jurídico internacional en la Ley Francesa de 1964, en el Principio $2^{\circ}$ de la Conferencia Internacional de Agua y Medio Ambiente (International Conference on

${ }^{560}$ POMPEU, Cid Tomanik. Direito de Águas no cit., p. 137.

${ }^{561}$ Debería ser "del" dominio e no "de" dominio. No se trata de propiedad, pero, según Hely Lopes Meirelles, del dominio eminente, del poder politico por el cual el estado somete a su voluntad todas las cosas de su territorio. Cf. Direito Administrativo Brasileiro. 13ª ed. São Paulo: RT, 1987, p. 423.

${ }^{562}$ También en GRAF, Ana Cláudia Bento. A tutela dos Estados sobre as águas. In: FREITAS, Vladimir Passos de (Coord.) Águas: aspectos jurídicos e ambientais. 2a ed., Editora Juruá, Curitiba-Brasil: 2002, p.55: "se debe tener presente que, aunque sean en gran parte bienes de uso común, las aguas públicas no son bienes difusos, con titularidad transindividual".

${ }^{563}$ POMPEU, Cid Tomanik. Direito e administração de águas no Brasil. RT-899, Doutrina Civil, Segunda Seção, set. 2010, p.51. As águas públicas "contam com titulares definidos no texto constitucional". 
Water and the Environment - ICWE) mantenida en la ciudad Dublín en 1992, en la Declaración Ministerial de La Haya sobre Seguridad Hídrica en el Siglo XXI (2000), entre muchos otros tratados internacionales. En el ámbito nacional, como abordado, es fundamentado en el caput del art. 225 de la CF/88 y en el art. $1^{\circ}$, VI, de la Ley $9.433 / 1997^{564}$.

Conforme el art. 33 de la Política Nacional de Recursos Hídricos, alterado por la Ley 9.984, de 17 de julio de 2000, los miembros integrantes del SINGREH son: el Consejo Nacional de Recursos Hídricos; la Agencia Nacional de Aguas; los Consejos de Recursos Hídricos Estaduales y del Distrito Federal; los Comités de Cuenca Hidrográfica; los órganos de los poderes públicos federal, estaduales, del Distrito Federal y municipales, cuyas competencias se relacionen con la gestión de recursos hídricos; y las Agencias de Agua.

Es importante recordar que el SINGREH no puede interferir en la organización administrativa de los Estados ${ }^{565}$ porque, si así lo hace, estará hiriendo las respectivas autonomías, garantidas por la Constitución Federal.

Sin embargo, a ese respeto, en decisión de Apelación Civil ${ }^{566}$, la Cámara Especial del Medio Ambiente del Tribunal de Justicia de São Paulo, además de desconsiderar varios dispositivos de la Constitución, en especial el art. 25, decidió lo contrario, afirmando que "Brasil siempre fue y sigue siendo un Estado unitario, bajo la forma federalista meramente formal", y que no se debe invocar "la vulneración al Federalismo, solución que existe apenas formalmente en un Brasil unificado y centralizador en su configuración de poder estatal”. Según entendimiento del Juez Relator, Renato Nalini, “el ordenamiento editado para la persona jurídica de derecho público interno de mayor jerarquía debe prevalecer en la especie".

Cid Tomanik Pompeu ${ }^{567}$ observa que esa sentencia, además de herir frontal e inexplicablemente el principio federativo implantado por la $\mathrm{CF} / 1988$, dejó de considerar

\footnotetext{
${ }^{564}$ OLIVEIRA, C. M. Sistema Nacional de Gerenciamento de Recursos Hídricos e as alternativas para o formato jurídico das agências de água no Brasil. Revista de Direito Ambiental - RDA, São Paulo, n.46, 2007, p. 43.

${ }^{565}$ Art. 25, Lei 9.433/1997.

${ }^{566}$ TJSP, A. Civ. 772.747.5/2-00/Barretos, SP, Câmara Especial do Meio Ambiente, Rel. Des. Renato Nalini, j.04.06.2009.

${ }^{567}$ POMPEU, Cid Tomanik. Direito e administração de águas no Brasil cit. RT-899, set. 2010, p. 52.
} 
el hecho de que la abolición de la forma federativa del Estado brasileño no puede ser

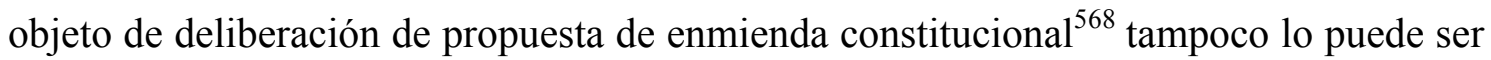
por alguna decisión judicial. Así, dejar de reconocer, principalmente bajo el enfoque del derecho constitucional, que Brasil sea una federación, es negar validad a la Constitución de 1988 y a todas las Cartas republicanas anteriores.

La elección de la cuenca hidrográfica como unidad territorial para la gestión de las aguas es la grande y radical innovación de la Ley, pero también el mayor desafío para la implementación del SINGREH. No se puede olvidar que los Comités de Cuenca estaduales son colegiados insertados en la estructura administrativa de la persona jurídica pública 'Estado', criados e organizados por el Consejo Estadual de Recursos Hídricos (CRH) y a él vinculados. Este Consejo dispone, incluso, de competencia para reformar las deliberaciones de los Comités, en conformidad con la legislación del Estado de São Paulo ${ }^{569}$. Además de eso, en cuanto las Agencias de Agua son integrantes del sistema y deben desempeñar rol determinante en la gestión de recursos hídricos juntamente a otras instituciones, se hace relevante evaluar sus atribuciones y competencia en el mundo jurídico de las aguas.

La vinculación de la gestión de recursos hídricos con la gestión del medio ambiente definida en el texto legal aumenta la responsabilidad de los agentes de las dos políticas nacionales, envolviendo, también, la creciente participación de las comunidades, en particular en el área de las cuencas hidrográficas ${ }^{570}$. La Ley de São Paulo, tomada como modelo por la Ley federal, se basó en la Constitución Estadual de 1989, que determina que el gerenciamiento de aguas en el Estado debe congregar órganos estaduales, municipales y la sociedad civil.

Así, la participación de la sociedad civil organizada en la estructura de la administración pública es vista actualmente como indispensable a la construcción de un modelo en el cual se busque alcanzar el desarrollo sostenible.

\footnotetext{
${ }^{568}$ Art. $60, \S 4^{\mathrm{o}}, 1, \mathrm{CF} / 1988$.

${ }^{569}$ POMPEU, Cid Tomanik. Direito e administração de águas no Brasil cit. RT-899, set.2010, p. 52.

${ }^{570}$ MILARÉ, Édis. Direito do Ambiente: cit., 2001, p. 393.
} 


\subsubsection{Las competencias del SINGREH y el Sistema Nacional de Informaciones en Recursos Hídricos (SNIRH)}

Como el SINGREH posee sus directrices generales de acción en la PNRH, el art. $3^{\circ}$ de la Ley 9.433/97 las establece:

I. La gestión sistemática de los recursos hídricos, sin disociación de los aspectos de cantidad y calidad; II. La adecuación de la gestión de recursos hídricos a las diversidades físicas, bióticas, demográficas, económicas, sociales y culturales de las diversas regiones del país; III. La integración de la gestión de recursos hídricos con la gestión ambiental; IV. La articulación del planeamiento de recursos hídricos con el de los sectores y usuarios y con los planeamientos regional, estadual y nacional; V. La articulación de la gestión de recursos hídricos con la del uso del suelo; VI. La integración de la gestión de las cuencas hidrográficas con la de los sistemas estuarios y zonas costeras.

Los objetivos del SINGREH ${ }^{571}$ abarcan la coordinación de la gestión integrada de las aguas; el arbitraje administrativo de los conflictos relacionados a los recursos hídricos; la implementación de la Política Nacional de Recursos Hídricos; el planeamiento, la reglamentación y el control del uso, preservación y la recuperación de aquellos recursos; y la promoción del cobro por su uso.

En 2002, diversas acciones fueron desarrolladas visando la consolidación del Sistema Nacional de Informaciones en Recursos Hídricos (SNIRH), así como definidas las metas para que los datos e informaciones pudieran componer el Sistema de manera ágil y consistente. El Sistema fue concebido como una red para acceso a los usuarios y es coordinado de forma unificada. Entre sus objetivos, se pueden destacar: la divulgación de datos e informaciones sobre la situación cualitativa y cuantitativa de los recursos hídricos en Brasil y la provisión de subsidios para la elaboración de los Planes de Recursos Hídricos ${ }^{572}$.

La Figura 1 ilustra el proceso de planeamiento de los recursos hídricos, destacando los tres medios en los cuales se desarrolla.

\footnotetext{
${ }^{571}$ Lei 10.683, de 28 de maio de 2003, alterada pelas Leis 10.869, de 13 de maio de 2004, e Lei 11.2004, de 05 de dezembro de 2005.

${ }^{572}$ São Paulo (Estado). Gestão participativa das águas, 2004, cit., p. 45.
} 
MEDIO SOCIAL Y POLÍTICO
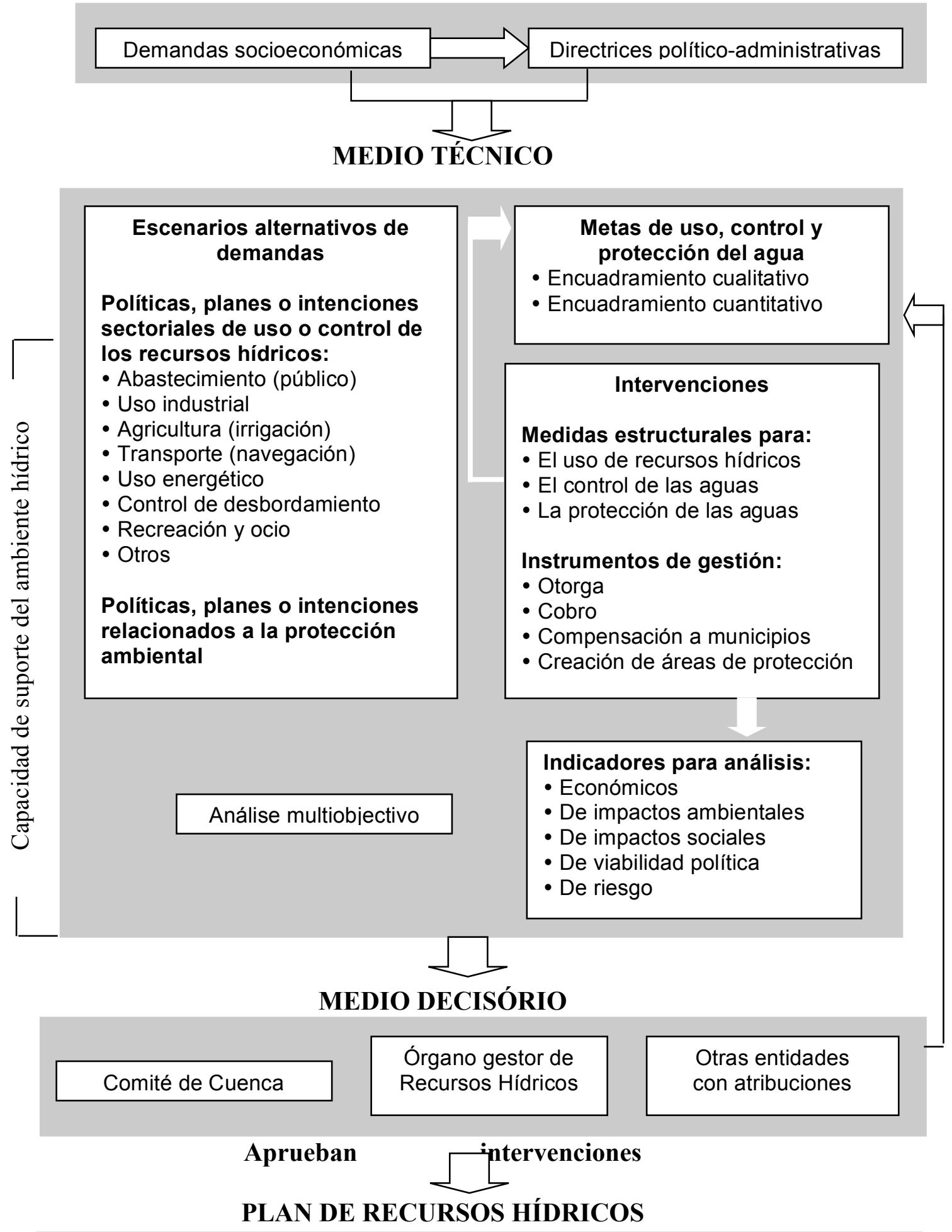

Figura 1 - Proceso de planeamiento de los recursos hídricos ${ }^{573}$

\footnotetext{
${ }^{573}$ São Paulo (Estado). Gestão participativa das águas, 2004, cit., p. 40.
} 
Actualmente, hay consenso creciente en el sentido de que el conocimiento y la capacidad sean condiciones preliminares para el desarrollo. El conocimiento puede ser obtenido de varias formas: como bases de datos; competencia para integrar, interpretar datos y crear subsidios para mejores decisiones; capacidad de generar nuevos datos e informaciones, identificar fallas, aprender por medio de experiencias pasadas y explorar el futuro; y por medio de mecanismos educacionales y de diseminación ${ }^{574}$.

Un sistema del conocimiento se extiende más allá de los datos que pertenecen a los parámetros físicos y técnicos. Envolviendo la sociedad civil y la participación cada vez mayor de la comunidad, promueve mayor comprensión de las interacciones de los procesos sociales y ambientales complejos presentes en cualquier gestión, que permite repensar algunos parámetros para un desarrollo eficaz ${ }^{575}$. La base do conocimiento es compuesta por bases de datos, documentos, modelos, procedimientos, herramientas y productos. En la visión de Snowden ${ }^{576}$, incluye también el conocimiento que no pode ser explícitamente disponible por ser contextual, cultural y no relacionarse a las habilidades, a la heurística, a la experiencia y a los talentos naturales (tales como el conocimiento local o el indígena). Ese conocimiento implícito abre camino para la capacidad de actuar o la competencia para resolver problemas, pero aun describiendo y comunicando ese conocimiento implícito, permanece el desafío.

El desarrollo de la capacidad es el proceso por el cual los individuos, las organizaciones, las instituciones y las sociedades desarrollan habilidades (individual y colectivamente) para ejecutar funciones, resolver problemas, establecer y lograr objetivos $^{577,578}$. Esto abarca no solamente capacidades individuales (recursos humanos),

${ }^{574}$ VAN HOFWEGEN, P. Capacity-building for water and irrigation sector management with application in Indonesia. Capacity Development in Irrigation and Drainage Issues, Challenges and the Way Ahead. (FAO Water Reports, 26), Rome, FAO. Report. UNESCO, 2004.

${ }^{575}$ VAN HOFWEGEN, P. Capacity-building for water and irrigation sector management with application in Indonesia. Capacity Development in Irrigation and Drainage Issues, Challenges and the Way Ahead. (FAO Water Reports, 26), Rome, FAO. Report. UNESCO, 2004.

${ }^{576}$ SNOWDEN, D. Complex Knowledge. Presentation at the Gurteen Knowledge Conference, June 2003, Cynefin Centre for Organizational Complexity IBM, UK, 2003.

${ }^{577}$ UNDP. United Nations Development Programme. Capacity development, Technical advisory paper 2. New York, UNDP: Management Development and Governance Division, Bureau for Policy Development, 1997. 
sino también eficacia, flexibilidad y adaptabilidad de procesos organizacionales (capacidad institucional), aliados a una estructura que permita y estimule la gerencia ${ }^{579}$.

Eses tres niveles del desarrollo de la capacidad son presentados en la Figura 2, considerando sus actividades asociadas, salidas y objetivos.

Se nota por la Figura 2 que el desarrollo de recursos humanos significa un proceso continuo que objetiva la difusión de conocimientos, desarrollo de habilidades y cambio de actitudes y comportamientos, lo que permite la maximización de los beneficios de los procesos de reparto de conocimiento y de participación. Aunque todos los niveles de desarrollo por la capacidad, traducidos por los recursos humanos; por la capacidad institucional y el ambiente de habilitación posean igual importancia; un cuadro de personal debidamente cualificado para desarrollar prácticas legalmente bien fundamentadas (políticas, normas, organización, reglamentación y procedimientos) y las necesarias instituciones constituyen punto de partida de cualquier iniciativa bien sucedida.

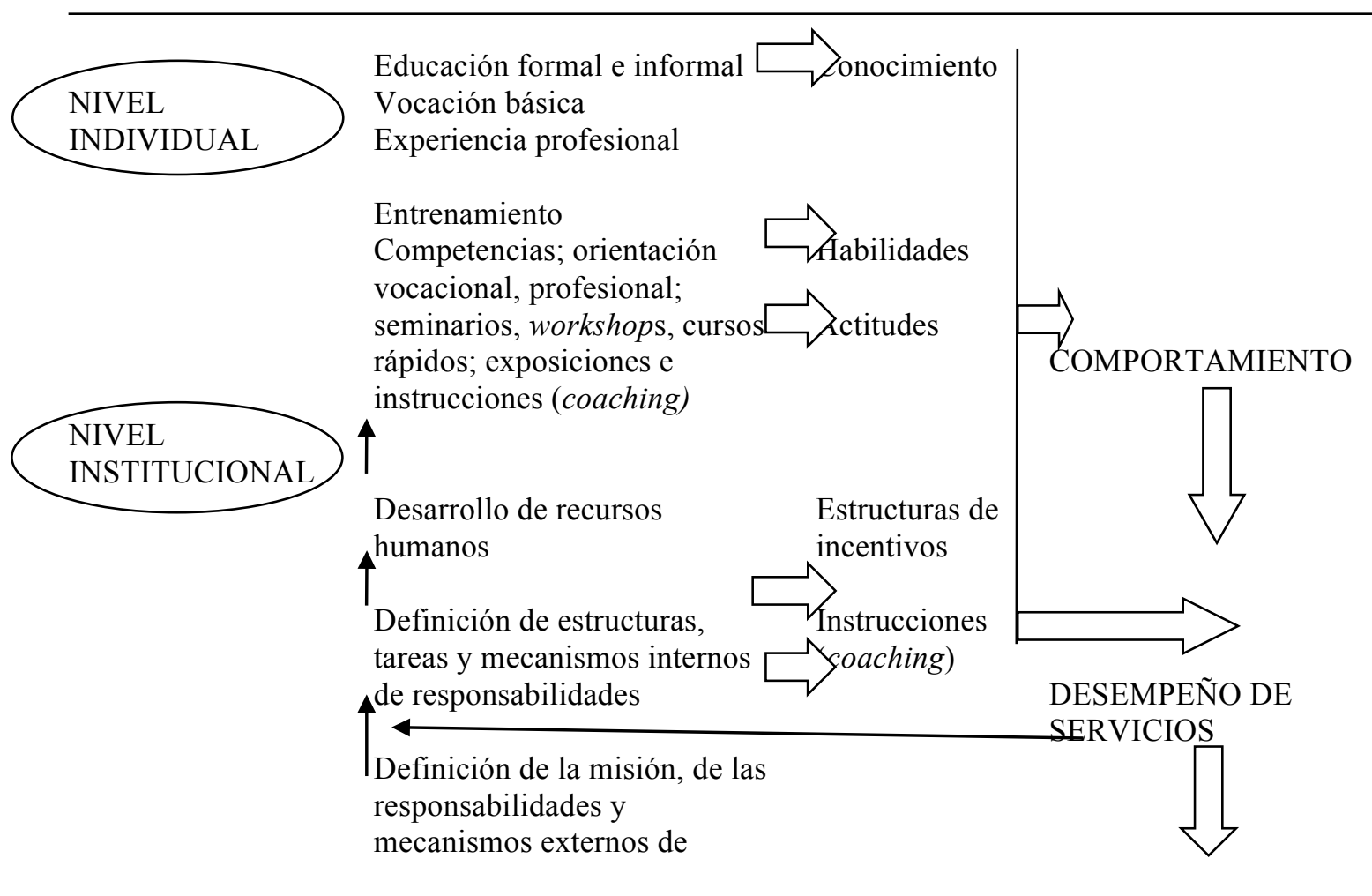

${ }^{578}$ LOPES, C.; THEISHN, T. Ownership, Leadership and Transformation: can we do better for capacity development? London, UNDP and Earthscan Publishing: UNDP, 2003.

${ }^{579}$ WALKER, B.; CARPENTER, S.; ANDERIES, J.; Abel, N.; et al. Resilience management in socialecological systems: a working hypothesis for a participatory approach. Conservation Ecology, [s.1.], v.6, n.1, p.14, 2002. Disponible en: <www.consecol.org/vol6/iss1/art14/main.html>. Acceso en: 16-02-2009. 


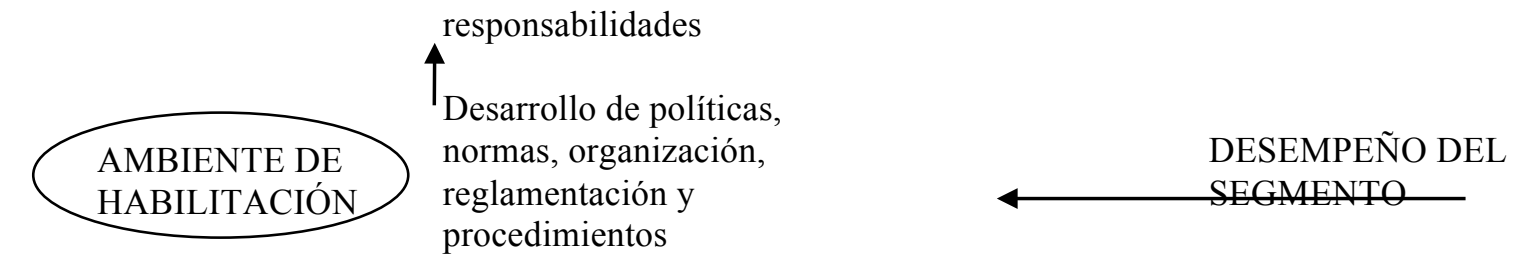

Figura 2 - Desarrollo de capacidades: niveles, actividades, rendimientos y metas ${ }^{580}$

En todos los esfuerzos de desarrollo de capacidades, la actitud; el comportamiento; la educación y formación; así como los incentivos de la mano de obra; el plan de carrera y los mecanismos de responsabilidad en todos los locales de trabajo influencian la capacidad de decisiones basadas en el conocimiento, y significan componentes críticos del desarrollo de recursos humanos. Así, Van Hofwegen ${ }^{581}$ afirma que el desarrollo de conocimientos por el reparto eficaz y entre cada nivel de desarrollo de capacidades es uno de los más importantes desafíos en cualquier sector.

Por consecuencia, hay la necesidad de construir, en el desarrollo de la capacidad, el entendimiento de que individuos poseen habilidades para innovar cuando enfrentan problemas no usuales, como también proporcionar una flexibilidad estructural que no penalice, sino recompense y capitalice las innovaciones ${ }^{582}$.

Las capacidades deben ser desarrolladas en los tres niveles, debido al hecho de que estas camadas de capacidad son mutuamente interdependientes $\mathrm{y}$, se fueren consideradas aisladas, el desarrollo se quedará comprometido y, por lo tanto, ineficaz ${ }^{583}$.

Se nota, por lo tanto, que serán necesarias competencias individuales y mucho perfeccionamiento para enfrentar el reto de la gestión de las aguas en este siglo XXI.

\footnotetext{
${ }^{580}$ VAN HOFWEGEN, P. Capacity-building for water and irrigation sector management with application in Indonesia, 2004, cit.

${ }^{581}$ VAN HOFWEGEN, P. Capacity-building for water and irrigation sector management with application in Indonesia, 2004, cit.

${ }^{582}$ VAN HOFWEGEN, P. Capacity-building for water and irrigation sector management with application in Indonesia, 2004, cit.

${ }^{583}$ FUKUDA-PARR, Sakiko.; LOPES, Carlos.; MALIK, Khalid. (Eds.). Capacity for Development: New Solutions to Old Problems. London, UK; Sterling, VA: Earthscan and United Nations Development Program, 2002. Disponible en $\quad<$ http://sakikofukudaparr.net/wpcontent/uploads/2013/01/CapacityForDevelopmentBook2002.pdf>. Acceso en: 10-02-2015.
} 


\subsection{El Consejo Nacional de Recursos Hídricos (CNRH)}

La Ley 9.433/1997, sobre la Política Nacional de Recursos Hídricos, en su art. 36, creó el Consejo Nacional de Recursos Hídricos (CNRH), adelante abordado. Sin embargo, el referido artículo solamente determina por quien el Consejo será administrado y, para enterarse de su composición, se debe verificar otra norma jurídica, el Decreto 4.613, de 11 de marzo de 2003, teniendo como competencia lo estipulado en el art. 35 de la Ley 9.433, de 8 de enero de 1997.

\subsubsection{La Agencia Nacional de Aguas (ANA)}

La entidad federal de implementación de la PNRH fue creada en 17 de julio de 2000 por la Ley 9.984, estableciendo reglas para su actuación, su estructura administrativa y sus fuentes de recursos. Se trata de autarquía bajo régimen especial, con autonomía administrativa y financiera, vinculada al Ministerio del Medio Ambiente, integrando el SINGREH. Su principal función ${ }^{584}$ es la de actuar como entidad federal responsable por la implementación de la PNRH, obedeciendo a sus fundamentos, objetivos e instrumentos, conjuntamente con otros órganos y entidades públicas y privadas.

Compete a la ANA recaudar, distribuir y aplicar los ingresos aportados por intermedio del cobro por el uso de recursos hídricos del dominio de la Unión, debiendo el ingreso ser mantenido en cuenta única del Tesoro Nacional, mientras no es destinado a las respectivas programaciones.

El $\S 4^{\circ}$ del art. 21 de la Ley 9.984/2000 establece que las prioridades de aplicación de recursos a que se refiere el art. 22 de la Ley 9.433/1997 sean definidas por el CNRH, en articulación con los respectivos Comités. Se nota, en las diferentes formas, una alteración de posicionamiento.

Las prioridades de aplicación son definidas por el CNRH en articulación con los Comités ${ }^{585}$ de Cuenca Hidrográfica, de acuerdo con lo que dispone el art. 22 de la

\footnotetext{
${ }^{584}$ Art. $4^{\circ}$, Lei $9.984 / 2000$.

${ }^{585}$ Se aplica solamente a los federales.
} 
Ley 9.433/1997, que establece que los recursos deben ser destinados, prioritariamente, a la cuenca en que sean generados y utilizados.

\subsection{Los Consejos de Recursos Hídricos Estaduales y del Distrito Federal}

Los primeros Estados que crearon sus Consejos de Recursos Hídricos fueron São Paulo (1987), Ceará y Santa Catarina (1994), Goiás, Minas Gerais y Río Grande do Sul (1995), adelantándose a la Ley 9.433/1997.

Los Consejos Estaduales de Recursos Hídricos integran el SINGREH conforme determina el art. 33, II. Se constituyen como órganos consultivos y deliberativos, instancia máxima en su esfera de competencia, con atribuciones para arbitrar los recursos relativos a las decisiones de los Comités de Cuencas Hidrográficas y aprobar y acompañar los Planes Estaduales de Recursos Hídricos ${ }^{586}$.

En la definición de los entes estaduales integrantes del SINGREH, los Estados se organizan y se pautan por las Constituciones y leyes que adoptan, observados los principios de la Constitución Federal ${ }^{587}$.

La composición y competencia de los Comités son establecidas de acuerdo con las características de cada unidad federada.

El Cuadro 3 presenta las legislaciones de cada Estado brasileño.

Cuadro 3 - Consejos Estaduales de Recursos Hídricos y su legislación

\begin{tabular}{|l||l||}
\hline $\begin{array}{c}\text { Unidades de la } \\
\text { Federación }\end{array}$ & \multicolumn{1}{c|}{ Legislación } \\
\hline Alagoas & $\begin{array}{l}\text { Decreto 33.784, de 22 de octubre de 1988, publicado en 23 } \\
\text { de octubre de 1988. Reglamenta el Consejo Estadual de } \\
\text { Recursos Hídricos. }\end{array}$ \\
\hline Bahia & $\begin{array}{l}\text { Ley 7.354, de 14 de septiembre de 1998. Crea el Consejo } \\
\text { Estadual de Recursos Hídricos y da otras providencias. }\end{array}$ \\
\hline Ceará & $\begin{array}{l}\text { Decreto 23.039, de 10 de febrero de 1994. Aprueba el } \\
\text { Regimiento Interno del Consejo Estadual de Recursos } \\
\text { Hídricos - CONERH. }\end{array}$ \\
\hline Distrito Federal & $\begin{array}{l}\text { Decreto 22.787, de 13 de marzo de 2002. Dispone sobre la } \\
\text { reglamentación del Consejo Estadual de Recursos Hídricos }\end{array}$ \\
\hline
\end{tabular}

\footnotetext{
${ }^{586}$ São Paulo (Estado). Gestão participativa das águas, 2004, cit., p.48.

${ }^{587}$ Art. $25, \mathrm{CF} / 1988$.
} 


\begin{tabular}{|c|c|}
\hline & del Distrito Federal y da otras providencias. \\
\hline Espírito Santo & $\begin{array}{l}\text { Decreto 038-R, de } 6 \text { de abril de 2000. Dispone sobre el } \\
\text { Consejo Estadual de Recursos Hídricos - CERH. }\end{array}$ \\
\hline Goiás & $\begin{array}{l}\text { Decreto 4.468, de } 19 \text { de junio de 1995. Dispone sobre el } \\
\text { Consejo Estadual de Recursos Hídricos - CERH. }\end{array}$ \\
\hline Mato Grosso & $\begin{array}{l}\text { Decreto 3.952, de } 6 \text { de marzo de 2002. Reglamenta el } \\
\text { Consejo Estadual de Recursos Hídricos. }\end{array}$ \\
\hline Minas Gerais & $\begin{array}{l}\text { Decreto } 37.191 \text {, de } 28 \text { de agosto de 1995. Dispone sobre el } \\
\text { Consejo Estadual de Recursos Hídricos - CERH-MG y da } \\
\text { otras providencias. }\end{array}$ \\
\hline Paraná & $\begin{array}{l}\text { Decreto } 2.314 \text {, de } 14 \text { de julio de } 2000 \text {. Crea el Consejo } \\
\text { Estadual de Recursos Hídricos. } \\
\text { Decreto } 4.320 \text {, de } 29 \text { de junio de } 2001 \text {. Nombramiento de los } \\
\text { integrantes del Consejo Estadual de Recursos Hídricos. }\end{array}$ \\
\hline Pernambuco & $\begin{array}{l}\text { Decreto 20.269, de } 24 \text { de diciembre de 1997. Dispone sobre } \\
\text { la Política Estadual de Recursos Hídricos y el Plan Estadual } \\
\text { de Recursos Hídricos. Instituye el Sistema Integrado de } \\
\text { Gestión de Recursos Hídricos. }\end{array}$ \\
\hline Paraíba & $\begin{array}{l}\text { Decreto } 18.824 \text {, de } 2 \text { de abril de } 1997 . \text { Crea el Consejo } \\
\text { Estadual de Recursos Hídricos. }\end{array}$ \\
\hline Rio de Janeiro & $\begin{array}{l}\text { Decreto } 27.208 \text {, de } 2 \text { de octubre de } 2000 \text {. Dispone el Consejo } \\
\text { Estadual de Recursos Hídricos y da otras providencias. }\end{array}$ \\
\hline $\begin{array}{l}\text { Rio Grande do } \\
\text { Norte }\end{array}$ & $\begin{array}{l}\text { Decreto } 13.284 \text {, de } 22 \text { de marzo de } 1997 \text {. Reglamenta el } \\
\text { Sistema Integrado de Gestión de Recursos Hídricos - } \\
\text { SIGERH, y da otras providencias. }\end{array}$ \\
\hline Rio Grande do Sul & $\begin{array}{l}\text { Decreto } 36.055 \text {, de } 04 \text { de julio de } 1995 \text {. Reglamenta el art. } 7 \text { o } \\
\text { de la Ley } 10.350 \text {, de } 30 \text { de diciembre de 1994, que instituye } \\
\text { el Sistema Estadual de Recursos Hídricos. } \\
\text { Decreto } 40.505 \text {, de } 8 \text { de diciembre de } 2000 \text {. Altera el Decreto } \\
\text { 36.055, de } 4 \text { de julio de 1995, que trata del Consejo Estadual } \\
\text { de Recursos Hídricos. }\end{array}$ \\
\hline Rondônia & Decreto 10.114 , de 20 de septiembre de 2002 . \\
\hline Santa Catarina & $\begin{array}{l}\text { Ley } 6.739 \text {, de } 16 \text { de diciembre de } 1985 \text {, alterada por las leyes } \\
\text { 10.644, de } 7 \text { de enero de } 1998,8.360 \text {, de } 26 \text { de septiembre } \\
\text { de } 1991 \text {, y } 10.007 \text {, de } 18 \text { de diciembre de } 1995 \text {. }\end{array}$ \\
\hline
\end{tabular}




\begin{tabular}{|l|l||}
\hline \multicolumn{1}{|c|}{$\begin{array}{c}\text { Unidades de la } \\
\text { Federación }\end{array}$} & \multicolumn{1}{c|}{ Legislación } \\
\hline \multirow{1}{*}{ São Paulo } & $\begin{array}{l}\text { Decreto 27.576, de 11 de noviembre de 1987. Crea el Consejo } \\
\text { Estadual de Recursos Hídricos, dispone sobre el Plan Estadual } \\
\text { de Recursos Hídricos y el Sistema Estadual de Gestión de } \\
\text { Recursos Hídricos y da otras providencias. } \\
\text { Ley 7.663, de 30 de diciembre de 1991: instituye la Política } \\
\text { Estadual de Recursos Hídricos y el Sistema Integrado de } \\
\text { Gestión de Recursos Hídricos. } \\
\text { Decreto 36.787, de 18 de mayo de 1993. Adapta el Consejo } \\
\text { Estadual de Recursos Hídricos - CRH y el Comité Coordinador } \\
\text { del Plan Estadual de Recursos Hídricos - CoRHI, creados por } \\
\text { el Decreto 27.576/1987, a las disposiciones de la Ley }\end{array}$ \\
$\begin{array}{l}\text { 7.663/1991. } \\
\text { Ley 10.020, de 3 de julio de 1998: autoriza el Poder Ejecutivo } \\
\text { a participar de la constitución de Fundaciones Agencias de } \\
\text { Cuencas Hidrográficas. } \\
\text { Ley 12.183, de 29 de diciembre de 2005: dispone sobre el } \\
\text { cobro por la utilización de los recursos hídricos del dominio } \\
\text { del estado de São Paulo, los procedimientos para fijación de } \\
\text { sus límites, condicionantes y valores. }\end{array}$ \\
\hline $\begin{array}{l}\text { Decreto 18.099, de 26 de mayo de 1999. Dispone sobre el } \\
\text { Consejo Estadual de Recursos Hídricos - ConERH/SE y da } \\
\text { otras providencias correlacionadas. }\end{array}$ \\
\hline $\begin{array}{l}\text { Decreto 637, de 22 de julio de 1998. Crea el Consejo Estadual } \\
\text { de Recursos Hídricos y da otras providencias. }\end{array}$ \\
\hline
\end{tabular}

Como consecuencia de la autonomía de los Estados, los Comités Estaduales son bastante variados, de acuerdo con las peculiaridades de cada unidad federada ${ }^{588}$.

La mayor parte de las normas que estructuran la competencia de los Consejos Estaduales no está insertada en la Ley 9.433/1997. Para Machado ${ }^{589}$, al legislar sobre esa competencia, los Estados no pueden alterar las competencias de los otros órganos del Sistema Nacional, como los Comités de Cuenca Hidrográfica y las Agencias de Agua. Los Estados pueden suplementar las reglas de la Ley 9.433/1997 desde que no las incumplan. Para Cid Tomanik Pompeu ${ }^{590}$, esa visión es contraria al sistema federativo, garantido por la $\mathrm{CF} / 1988$. No se está delante de normas ambientales, como

\footnotetext{
${ }^{588}$ POMPEU, Cid Tomanik. Direito de Águas no cit., p. 341.

${ }^{589}$ MACHADO, Paulo Affonso Leme. Recursos Hídricos cit., p.104.

${ }^{590}$ POMPEU, Cid Tomanik. Direito de Águas no cit., pp. 283 y ss.
} 
equivocadamente se piensa, sino ante la organización administrativa de los Estados, regida por sus Constituciones y leyes, conforme dispone el art. 25, de la CF/1988. No se trata de principio constitucional, sino de competencia constitucional expresa. Si el legislador estadual no puede interferir en la organización administrativa del Estado, por tratarse de iniciativa privativa del Gobernador, ¿cómo podrían hacerlo el legislador federal y el CNRH?

La posibilidad dada por la Constitución de 1988 a los Estados (desde que autorizados por ley complementar federal) para legislar sobre cuestiones específicas relativas a las aguas solamente puede suceder en lo que se refiere a la 'creación del derecho', porque estos siempre pudieron editar normas administrativas para la gestión de sus aguas ${ }^{591}$. La definición de los criterios de otorga de derechos de uso de recursos hídricos, prevista en la Constitución Federal ${ }^{592}$ es competencia de la Unión porque consta del texto constitucional, pero, en la práctica, podría ser de los Estados, por no ser, materialmente, de índole constitucional. Los criterios deben ser jurídicos, ya que los de oportunidad o conveniencia, económicos, financieros, sanitarios, hidrológicos y geológicos caben al titular del bien que, como se sabe, puede no pertenecer a la unión. Hasta que sean alterados, los criterios a que se refiere la Constitución ${ }^{593}$ son los establecidos en el Código de Aguas ${ }^{594}$, que fueron por ella acogidos por no estar en conflicto con su texto ${ }^{595}$.

El art. 35, IV, de la Ley sobre la PNRH, establece que los Consejos Estaduales pueden encaminar cuestiones para que sean deliberadas por el CNRH. Les compite, también, deliberar sobre cuestiones encaminadas por los Comités de Cuenca en relación a asuntos relacionados a acumulaciones, derivaciones, captaciones y lanzamientos de poca expresión, para efecto de exención de la obligatoriedad de otorga de derechos de uso de recursos hídricos. Decisiones de los Comités de Cuenca pueden ser reevaluadas por los Consejos Estaduales conforme determina el $\S$ único del art. 35 supra citado.

\footnotetext{
591 POMPEU, Cid Tomanik. Recursos Hídricos na Constituição de 1988. Revista de Direito Administrativo, v.186. Rio de Janeiro: Renovar/Fundação Getúlio Vargas, out.-dez. 1991, pp. 10-25. 
Los Consejos Estaduales tienen competencia para deliberar sobre "las acumulaciones, derivaciones, captaciones y lanzamientos de poca expresión, para efecto de exención de la obligatoriedad de otorga de derechos de uso de recursos hídricos"596 (art. 38, V), cuando estos recursos sean del dominio estadual.

Pompeu ${ }^{597}$ observa que para la gestión de las aguas de acuerdo con sus características, los Estados deberían tener competencia supletoria o complementar, respetando la ley federal, como constaba en la Constitución Brasileña de 1946, y no solamente quedarse adstringidos a una eventual autorización por ley complementar federal.

Hay que tener en cuenta que las aguas públicas, aunque sean en mayor parte 'bienes de uso común', no son bienes 'difusos' con titularidad trasindividual ${ }^{598}$, pero cuentan con titulares definidos en el texto constitucional ${ }^{599}$.

La creación de las Agencias de Agua o Cuenca en ríos estaduales es de la competencia de los Estados ${ }^{600}$. La ANA debe celebrar contratos de gestión con las entidades denominadas delegatarias de sus funciones relativas a las aguas de dominio de la Unión ${ }^{601}$.

\footnotetext{
${ }^{596}$ Art. 38, V, Lei 9.433/1997.

${ }^{597}$ POMPEU, Cid Tomanik. O direito de águas no Brasil. Revista dos Tribunais, São Paulo, n. 889, p. 65, nov. 2009.

${ }^{598}$ GRAF, A. C. B. A tutela dos estados sobre as águas. In: FREITAS, V. P. (Coord.) Águas: aspectos jurídicos e ambientais. $2^{\text {a }}$ ed. Curitiba: Juruá, 2002, p. 55.

${ }^{599}$ POMPEU, Cid Tomanik. Direito de Águas no cit., 2010, pp. 135-136.

${ }^{600}$ Parágrafo único, art. 42, Lei 9.433/97. A criação das Agências de Água será autorizada pelo Conselho Nacional de Recursos Hídricos ou pelos Conselhos Estaduais de Recursos Hídricos mediante solicitação de um ou mais Comitês de Bacia Hidrográfica.

${ }^{601}$ Lei $10.881 / 2004$.
} 


\subsubsection{Ríos y cuencas hidrográficas}

Varios son los conceptos dados al término "río", pero su origen viene del latín rius, rivus, arroyo $^{602}$. Independiente de la diversidad de conceptos que muchas veces hace con que su definición e importancia nos lleve a la origen de la historia humana, actualmente, los ríos son considerados como unidades de un sistema mayor, la Cuenca hidrográfica, o Cuenca de Drenaje, compuesta no solo por grandes ríos y sus tributarios $^{603}$, pero también por lagunas, igarapés, aguas subterráneas y acuíferos subterráneos ${ }^{604}$. De hecho, en el Glossário de Termos Hidrológicos da ANA, la definición de río es hecha de forma integrada a la de Cuenca Hidrográfica ${ }^{605}$.

${ }^{602}$ En el diccionario de la Real Academia Española, Río es: "Corriente de agua continua y más o menos caudalosa que va a desembocar en otra, en un lago o en el mar". Disponible en: $<$ http://lema.rae.es/drae/?val=forma $>$. Acceso en: 05-05-2015.

Según el Glosario Hidrológico Internacional, río es: "Corriente de agua de grandes dimensiones que sirve de canal natural de drenaje en una cuenca de drenaje". Disponible en: $<$ http://webworld.unesco.org/water/ihp/db/glossary/glu/ES/GF1041ES.HTM>. Acceso en: 05-05-2015.

${ }^{603}$ Tributario: curso de agua que desemboca en un curso mayor o en un lago. Definición según el Glossário de Termos Hidrológicos da Agência Nacional de Águas y el Glosario Hidrológico Internacional.

Disponible

en:

$<$ http://webworld.unesco.org/water/ihp/db/glossary/glu/ES/GF1306ES.HTM>. Acceso 06-05-2015.

${ }^{604}$ La definición dada para Curso de Agua (Watercourse), por el Convenio de las Naciones Unidas sobre la Utilización de Cursos de Agua Internacionales para Fines otros que la navegación, y que guarda en sí la idea de integración presente en el concepto de cuenca, es: "un sistema de aguas de superficie y subterráneas que, en virtud de su relación física, constituyen un conjunto unitario y normalmente fluyen a una desembocadura común”. Así, en conclusión, el concepto es centrado en el flujo de agua y en la unidad del sistema, lo que aleja la idea arcaica de curso de agua simplemente como un río o regato. Disponible en: < http://www.un.org/spanish/waterforlifedecade/transboundary_waters.shtml>. Acceso en: 06-05-2015.

${ }^{605}$ En el Glossário de Termos Hidrológicos da Agência Nacional de Águas, Rio es: "Curso de água de grande dimensão que serve de canal natural para a drenagem de uma bacia”. El art. $2^{\circ}$, IV de la Instrução Normativa (IN) n. ${ }^{o}$ 4, de 21-6-2000, del Ministério do Meio Ambiente, define "Bacia Hidrográfica: área de drenagem de um curso d'água ou lago". Disponible en: <http://www.ambiente.sp.gov.br/wpcontent/uploads/cea/IN.MMA04-00.pdf> Acceso en: 06-05-2015. Según el profesor Claude Albert Colliard: "la noción de cuenca fluvial significa el conjunto constituido por un río, sus afluentes y mismo agua subterráneas, formando lo que se llama de sistema hidrográfico". Évolution et aspects actuels du régime juridique des fleuves internationaux. The Hague Academy of International Law, Recueil des Cours, v. III, t. 125, 1968, p.398. 
Como visto anteriormente, existen diferentes formas de clasificación de los ríos, sin embargo, para el Derecho, la primera definición que se presenta a la tutela jurídica de las aguas dulces es aquella que divide los ríos en interiores o nacionales ${ }^{606} \mathrm{e}$ internacionales ${ }^{607}$

El concepto de cuenca hidrográfica como ampliación del concepto de río, principalmente para efectos de tutela jurídica nacional e internacional, tardó y solo ha obtenido éxito en función de los esfuerzos y estudios de la Comisión de Derecho Internacional de las Naciones Unidas ${ }^{608}$.

Es denominada cuenca hidrográfica internacional la que cubre el territorio de dos o más Estados soberanos. Las normas de Helsinki, preparadas por el Comité sobre Usos de las Aguas de los Ríos Internacionales, aprobadas por la Asociación de Derecho Internacional en 20 de Agosto de 1966, de la 52 ${ }^{\text {a }}$ Conferencia de Asociación, en Helsinki, en el Artículo $2^{\circ}$, define cuenca hidrográfica internacional como "la zona geográfica que se extiende por el territorio de dos o más Estados determinada por la línea divisoria de un sistema hidrográfico de aguas superficiales y freáticas que fluyen hacia una salida común"609.

La Secretaria de Recursos Hídricos, do Ministério do Meio Ambiente (SRH/MMA), en 1998, siguiendo la metodología ya adoptada en Brasil, codificó las cuencas hidrográficas de Sudamérica. Fueron atribuidos dígitos pares: 2, 4, 6 y 8, en sentido horario, alrededor del continente, partiendo de las cuatro mayores cuencas que drenan directamente para el mar. Con dígitos impares: 1, 3, 5, 7 y 9, las demás áreas fueron agrupadas en regiones hidrográficas, de modo que la región hidrográfica 3 se quedó entre las cuencas 2 y 4 , la 5 entre las cuencas 4 y 6 y así sucesivamente. El dígito

\footnotetext{
${ }^{606}$ Río interior o nacional tiene su curso, desde la naciente hasta la desembocadura, enteramente dentro del territorio de un solo país.

${ }^{607}$ Conforme el Dicionário Houaiss, en la palabra Río, Río internacional es uno cuyo el curso pasa por más de un país, pudiendo ser limítrofe, contiguo o sucesivo, en relación al modo como el rio atraviesa el territorio de los respectivos países. Conforme Dicionário Houaiss da língua portuguesa, Editora Objetiva, Rio de Janeiro-Brasil: 2001.

${ }^{608}$ SOARES, Guido Fernando Silva. Direito internacional do meio ambiente: emergência, obrigações e responsabilidades. $2^{\mathrm{a}}$ edição, Editora Atlas, São Paulo-Brasil: 2003, p. 110.

${ }^{609}$ INELA, Incyth. Reglas de Helsinki: sobre los usos de las aguas de los ríos internacionales. Talleres Gráficos del Instituto de Economía, Legislación y Administración del Agua, Mendoza-Argentina: 1976, p. 2.
} 
0 fue atribuido a la región hidrográfica que drena para el Lago Titicaca, determinando de esa manera, la subdivisión de nivel 1 , del continente.

A partir de esa codificación, con diez regiones hidrográficas (nivel 1), fue efectuada nueva subdivisión con la finalidad de obtener el nivel 2 de cuencas para el continente, suponiendo, por lo tanto, como desembocadura ${ }^{610}$ el punto de descarga (exutorio) de la cuenca a ser dividida. El análisis fue realizada de la desembocadura para montante, identificando las confluencias y distinguiendo el río principal de sus tributarios. Río principal es el que drena la mayor área y tributarios los demás, que drenan áreas menores. Esta codificación fue adoptada por el Conselho Nacional de Recursos Hídricos (CNRH). Como será visto a seguir.

En primer lugar, la codificación de la subdivisión del área drenada por el río principal requiere la identificación de sus cuatro mayores tributarios, de acuerdo con el área drenada, que son clasificadas como cuencas y reciben, adicionalmente, el código aplicado en el nivel 1, los dígitos pares: 2, 4, 6 y 8, en el orden que son encontrados, desde aguas abajo hacia aguas arriba ${ }^{611}$, a lo largo del río principal. En seguida, los otros tributarios del río principal son agrupados en las demás áreas, clasificadas como regiones hidrográficas, y reciben adicionalmente, al código aplicable en el nivel 1 y en el orden que son encontrados, de aguas abajo hacia aguas arriba, a lo largo del río principal, los dígitos impares: 1, 3, 5, 7 y 9 (Figura 3).

Figura 3:

Representación de las Regiones Hidrográficas ${ }^{612}$

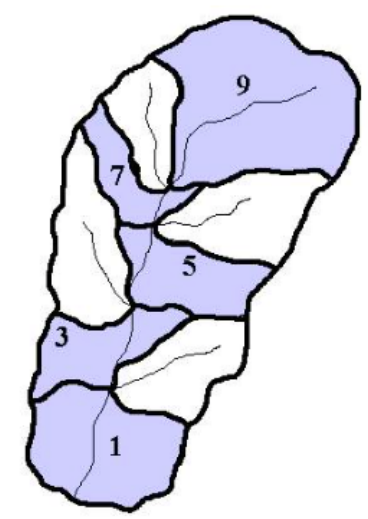

\footnotetext{
${ }^{610}$ En portugués se dice "foz".

${ }^{611}$ En portugués se dice "de jusante para montante".

${ }^{612}$ Fuente: Anexo I, Resolução n. ${ }^{\text {o } 30 / 2002 ~ d o ~ C N R H . ~}$
} 
En una cuenca codificada con el dígito 7, por ejemplo, el nivel 2 será así subdividido: área 71 es la región hidrográfica comprendida entre la desembocadura del río principal y la confluencia del río de la cuenca 72; área 73, región entre a confluencia del río de la cuenca 72 y la confluencia del río de la cuenca 74; área 75, región entre a confluencia del río de la cuenca 74 y la confluencia del río de la cuenca 76; área 77 región entre las cuencas 76 y 78; y área 79 va a ser siempre el área de cabecera del río principal a partir de la cuenca 78 , y, normalmente, drena área mucho mayor que la cuenca 78 , por la definición (Figura 4).

\section{Figura 4}

Ejemplo de subdivisión de la Cuenca Hidrográfica ${ }^{613}$

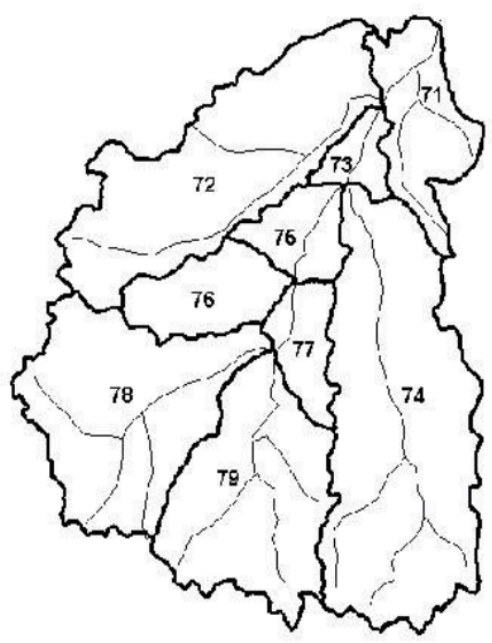

Para Sudamérica, la codificación de cuencas (nivel 1) es la siguiente: Región Hidrográfica 0 (del Titicaca); Región Hidrográfica 1 (Costera del Pacífico); 2 Cuenca Hidrográfica del río Orenoco; Región Hidrográfica 3 (Costera del Atlántico Norte); 4 Cuenca Hidrográfica del río Amazonas; Región Hidrográfica 5 (del Marajó); 6 Cuenca Hidrográfica del río Tocantins; Región Hidrográfica 7 (Costera del Atlántico Sur, incluyendo, entre otras, las cuencas de los ríos Parnaíba, São Francisco, Doce, Paraíba do Sul y Uruguay); 8 Cuenca Hidrográfica del río Paraná; Región Hidrográfica 9 (de los Pampas) (Figura 5).

\footnotetext{
${ }^{613}$ Fuente: Anexo I, Resolução n. ${ }^{\circ}$ 30/2002 do CNRH.
} 


\section{Figura 5}

Codificación de Cuencas Hidrográficas de Sudamérica (Nivel 1) ${ }^{614}$ :

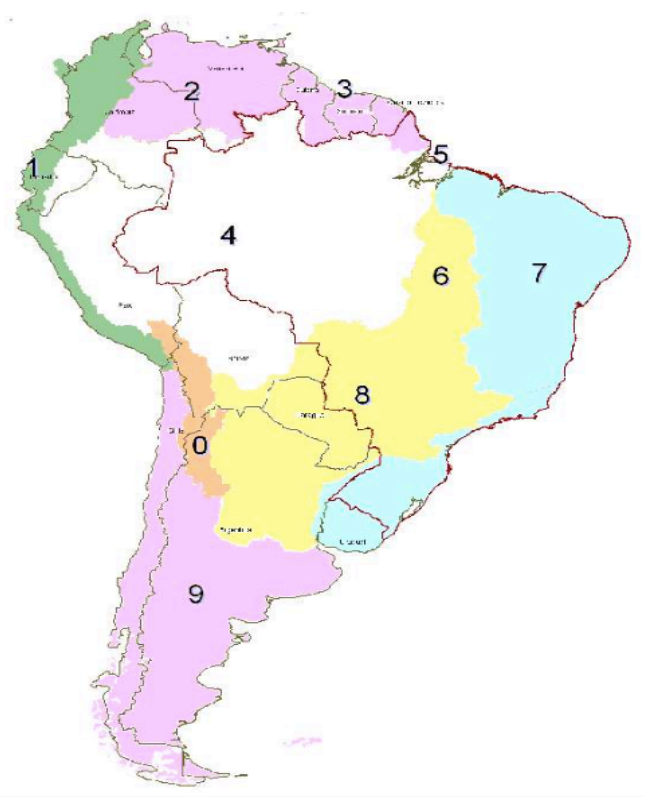

\begin{tabular}{|c|l||}
\hline CÓDIGO & \multicolumn{1}{|c|}{ DENOMINAÇÃO } \\
\hline \hline 0 & Região Hidrográfica 0 \\
\hline \hline 1 & Região Hidrográfica 1 \\
\hline 2 & Bacia Hidrográfica do rio Orenoco \\
\hline \hline 3 & Região Hidrográfica 3 \\
\hline \hline 4 & Bacia Hidrográfica do rio Amazonas \\
\hline \hline 5 & Região Hidrográfica 5 \\
\hline \hline 6 & Bacia Hidrográfica do rio Tocantins \\
\hline 7 & $\begin{array}{l}\text { Região Hidrográfica 7 (inclui, entre outras, as bacias dos rios } \\
\text { Parnaíba, São Francisco, Doce, Paraíba do Sul e Uruguai) }\end{array}$ \\
\hline \hline 8 & Bacia Hidrográfica do rio Paraná \\
\hline 9 & Região Hidrográfica 9 \\
\hline
\end{tabular}

En términos de Brasil: Región Hidrográfica 39; Región Hidrográfica 41; 42 Cuenca Hidrográfica del río Xingú; Región Hidrográfica 43; 44 Cuenca Hidrográfica del río Tapajós; Región Hidrográfica 45; 46 Cuenca Hidrográfica del río Madeira; Región Hidrográfica 47; 48 Cuenca Hidrográfica del río Negro; Región Hidrográfica 49; Región Hidrográfica 61; 62 Cuenca Hidrográfica del río Itacaiúnas; Región Hidrográfica 63; 64 Cuenca Hidrográfica del río Tocantins; Región Hidrográfica 65; 66 Cuenca Hidrográfica del río Javés; Región Hidrográfica 67; 68 Cuenca Hidrográfica del río das Mortes; Región Hidrográfica 69; Región Hidrográfica 71; 72 Cuenca Hidrográfica del río Parnaíba; Región Hidrográfica 73; 74 Cuenca Hidrográfica del río São Francisco; Región Hidrográfica 75; 76 Cuenca Hidrográfica del río Doce; Región Hidrográfica 77; 78 Cuenca Hidrográfica del río Uruguay; 84 Cuenca Hidrográfica del río Paraná; Región Hidrográfica 87; y Región Hidrográfica 89 (Figura 6) ${ }^{615}$.

\footnotetext{
${ }^{614}$ Fuente: Anexo II, Resolução n. ${ }^{\mathrm{o}}$ 30/2002 do CNRH.

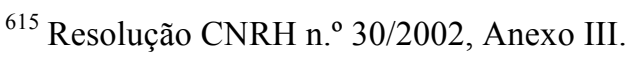


Figura 6:

Codificación de las Cuencas Hidrográficas (Nivel 2)

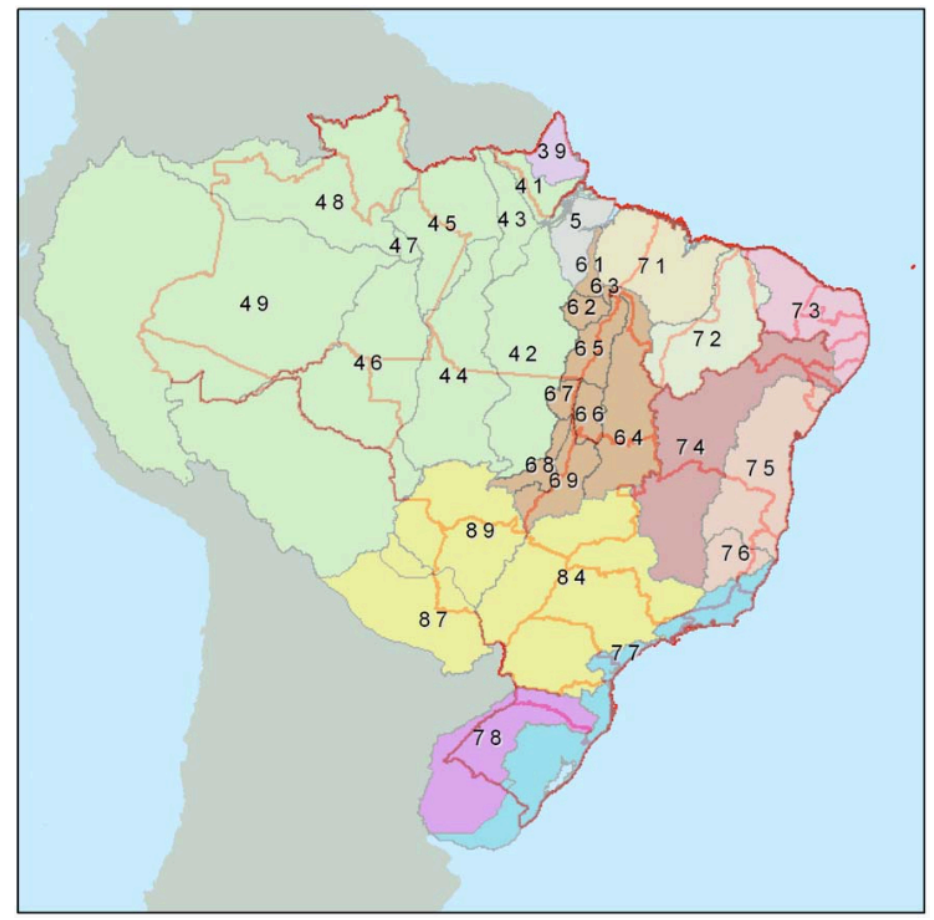

Fuente: Anexo III, Resolução n. ${ }^{\circ}$ 30/2002 do CNRH

La división Hidrográfica Nacional en regiones, con la finalidad de orientar, fundamentar e implementar el Plano Nacional de Recursos Hidricos ${ }^{616}$, fue instituida por el $\mathrm{CNRH}^{617}$. Los espacios territoriales brasileños, comprendidos por una cuenca, o grupo de cuencas o subcuencas hidrográficas contiguas, con características naturales, sociales y económicas homogéneas o semejantes, con intención de orientar la planificación y gerenciamiento de los recursos hídricos, fueron considerados regiones hidrográficas ${ }^{618}$.

La división es la siguiente: Región Hidrográfica Amazónica: cuenca hidrográfica del río Amazonas, ubicada en el territorio nacional y, también, por las cuencas hidrográficas de los ríos de la Isla de Marajó, además de las cuencas de los ríos ubicados en el Estado del Amapá, que desaguan en el Atlántico Norte; Región Hidrográfica del Tocantins/Araguaia: cuenca hidrográfica del río Tocantins, hasta su

\footnotetext{
${ }^{616}$ Aprobado por la Resolución CNRH n. ${ }^{\circ}$ 58, de 30-01-2006.

${ }^{617}$ Resolución CNRH n. ${ }^{\text {3 } 32, ~ d e ~ 15-10-2003, ~ A n e x o s ~ I ~ e ~ I I ~}$

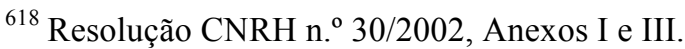


desembocadura en el Océano Atlántico; Región Hidrográfica del Atlántico Nordeste Occidental: cuencas hidrográficas de los ríos que desaguan en el Atlántico - tramo Nordeste, limitada a oeste por la región hidrográfica del Tocantins/Araguaia, exclusive, y a este por la Región Hidrográfica del río Parnaíba; Región Hidrográfica del Parnaíba: cuenca Hidrográfica del río Parnaíba; Región Hidrográfica del Atlántico Nordeste Oriental: cuencas hidrográficas de los ríos que desaguan en el Atlántico - tramo Nordeste, limitada a oeste por la región hidrográfica del Parnaíba y al sur por la región del São Francisco; Región Hidrográfica del São Francisco: cuenca hidrográfica del río São Francisco; Región Hidrográfica del Atlántico Este: cuencas hidrográficas de los ríos que desaguan en el Atlántico - tramo Este, limitada al norte y al oeste por la región hidrográfica del São Francisco y al sur por las cuencas hidrográficas de los ríos Jequitinhonha, Mucuri y São Mateus, inclusive; Región Hidrográfica del Atlántico Sudeste: cuencas hidrográficas de los ríos que desaguan en el Atlántico - tramo Sudeste, limitada al norte por la cuenca hidrográfica del río Doce, inclusive, al oeste, por las regiones hidrográficas del São Francisco y del Paraná y, al sur, por la del río Ribeira, inclusive; Región Hidrográfica del Paraná: cuenca hidrográfica del río Paraná, en el territorio nacional; Región Hidrográfica del Uruguay: cuenca hidrográfica del río Uruguay, en el territorio nacional, limitada al norte y al oeste por la región hidrográfica del Paraná, al oeste por Argentina y al sur por Uruguay; Región Hidrográfica del Atlántico Sur: : cuencas hidrográficas de los ríos que desaguan en el Atlántico - tramo Sur, limitada al norte por las cuencas hidrográficas de los ríos Ipiranguinha, IririaiaMirim, Candapuí, Serra Negra, Tabagaça y Cachoeira, inclusive, al oeste por las regiones hidrográficas del Paraná y del Uruguay y al sur por el Uruguay; y Región Hidrográfica del Paraguay: cuenca hidrográfica del río Paraguay, en el territorio nacional (Figura 7). 
Figura 7:

División Hidrográfica Nacional

DIVISÃO HIDROGRÁFICA NACIONAL

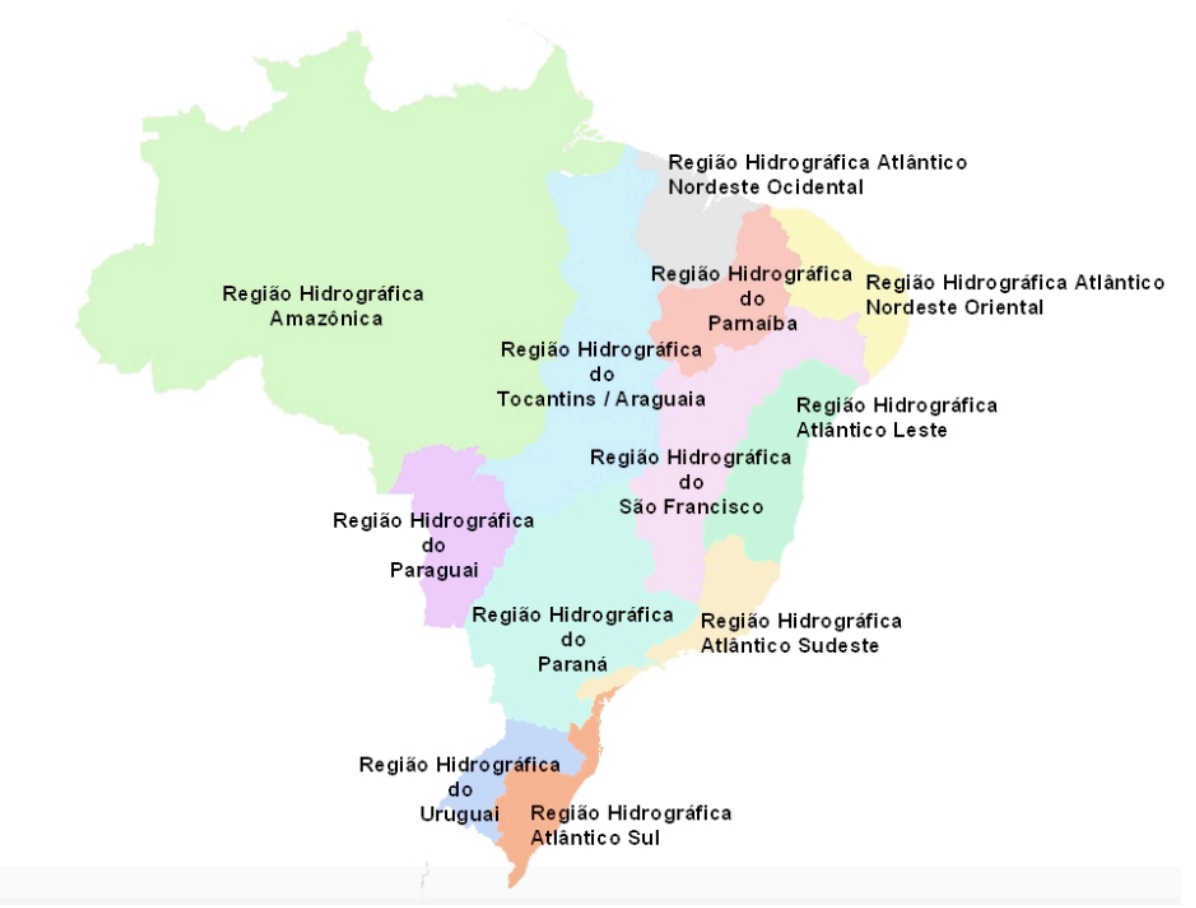

Fuente: Anexo I, Resolução n. ${ }^{\circ}$ 32/2003 do CNRH. 
4):

\begin{tabular}{|c|c|}
\hline Região Hidrográfica Amazônica & $\begin{array}{l}\text { É constituída pela bacia hidrográfica do rio Amazonas situada no } \\
\text { território nacional e, também, pelas bacias hidrográficas dos rios } \\
\text { existentes na Ilha de Marajó, além das bacias hidrográficas dos } \\
\text { rios situados no Estado do Amapá que deságuam no Atlântico } \\
\text { Norte. }\end{array}$ \\
\hline $\begin{array}{l}\text { Região Hidrográfica } \quad \text { do } \\
\text { Tocantins/Araguaia }\end{array}$ & $\begin{array}{l}\text { É constituída pela bacia hidrográfica do rio Tocantins até a sua } \\
\text { foz no Oceano Atlântico. }\end{array}$ \\
\hline $\begin{array}{l}\text { Região Hidrográfica } \quad \text { Atlântico } \\
\text { Nordeste Ocidental }\end{array}$ & $\begin{array}{l}\text { É constituída pelas bacias hidrográficas dos rios que deságuam } \\
\text { no Atlântico - trecho Nordeste, estando limitada a oeste pela } \\
\text { região hidrográfica do Tocantins/Araguaia, exclusive, e a leste } \\
\text { pela região hidrográfica do Parnaíba. }\end{array}$ \\
\hline Região Hidrográfica do Parnaíba & É constituída pela bacia hidrográfica do rio Parnaíba. \\
\hline $\begin{array}{l}\text { Região Hidrográfica } \quad \text { Atlântico } \\
\text { Nordeste Oriental }\end{array}$ & $\begin{array}{l}\text { E constituída pelas bacias hidrográficas dos rios que deságuam } \\
\text { no Atlântico - trecho Nordeste, estando limitada a oeste pela } \\
\text { região hidrográfica do Parnaíba e ao sul pela região hidrográfica } \\
\text { do São Francisco. }\end{array}$ \\
\hline Região Hidrográfica do São Francisco & É constituída pela bacia hidrográfica do rio São Francisco. \\
\hline Região Hidrográfica Atlântico Leste & $\begin{array}{l}\text { É constituída pelas bacias hidrográficas de rios que deságuam no } \\
\text { Atlântico - trecho Leste, estando limitada ao norte e a oeste pela } \\
\text { região hidrográfica do São Francisco e ao sul pelas bacias } \\
\text { hidrográficas dos rios Jequitinhonha, Mucuri e São Mateus, } \\
\text { inclusive. }\end{array}$ \\
\hline Região Hidrográfica Atlântico Sudeste & $\begin{array}{l}\text { E constituída pelas bacias hidrográficas de rios que deságuam no } \\
\text { Atlântico - trecho Sudeste, estando limitada ao norte pela bacia } \\
\text { hidrográfica do rio Doce, inclusive, a oeste pelas regiões } \\
\text { hidrográficas do São Francisco e do Paraná e ao sul pela bacia } \\
\text { hidrográfica do rio Ribeira, inclusive. }\end{array}$ \\
\hline Região Hidrográfica do Paraná & $\begin{array}{l}\text { É constituída pela bacia hidrográfica do rio Paraná situada no } \\
\text { território nacional. }\end{array}$ \\
\hline Região Hidrográfica do Uruguai & $\begin{array}{l}\text { E constituída pela bacia hidrográfica do rio Uruguai situada no } \\
\text { território nacional, estando limitada ao norte pela região } \\
\text { hidrográfica do Paraná, a oeste pela Argentina e ao sul pelo } \\
\text { Uruguai. }\end{array}$ \\
\hline Região Hidrográfica Atlântico Sul & $\begin{array}{l}\text { E constituída pelas bacias hidrográficas dos rios que deságuam } \\
\text { no Atlântico - trecho Sul, estando limitada ao norte pelas bacias } \\
\text { hidrográficas dos rios Ipiranguinha, Iririaia-Mirim, Candapuí, } \\
\text { Serra Negra, Tabagaça e Cachoeria, inclusive, a oeste pelas } \\
\text { regiões hidrográficas do Paraná e do Uruguai e ao sul pelo } \\
\text { Uruguai. }\end{array}$ \\
\hline Região Hidrográfica do Paraguai & $\begin{array}{l}\text { É constituída pela bacia hidrográfica do rio Paraguai situada no } \\
\text { território nacional. }\end{array}$ \\
\hline
\end{tabular}

Fuente: Anexo II, Resolución n. ${ }^{\circ}$ 32/2003 do CNRH. 


\subsubsection{Los Comités de Cuenca Hidrográfica (CBH)}

Los Comités de Cuenca Hidrográfica de acuerdo con la Ley 9.433/1997 son solamente los federales, porque la Unión no puede legislar sobre la organización de los Estados tampoco en nombre de un sistema nacional de gestión de recursos hídricos ${ }^{619}$. Con relación a los Comités Federales, el SINGREH posee actuación legítima y Cid Tomanik Pompeu ${ }^{620}$ afirma que en lo que se refiere a las unidades federadas, la Ley federal es inconstitucional cuando determina que los Comités Estaduales sean instituidos por Decreto y les confiere atribuciones. Si por un lado esas cuestiones hieren la autonomía das unidades federadas, por el otro, el restante del texto no está claro, originando duda si estaría o podría estar refiriéndose a Comités estaduales. Al tratar de las atribuciones del colegiado, la Ley menciona la Agencia de Agua, mientras que la mayor parte de los Estados previó la creación de Agencias de Cuenca Hidrográfica y, en el Río Grande do Sul, de Agencias de Regiones Hidrográficas.

La reglamentación de la creación de los Comités federales de Cuenca Hidrográfica se encuentra en la Resolución 5 del CNRH, de 10 de abril de 2000. Son órganos colegiados con atribuciones normativas, deliberativas y consultivas a ser ejercidas en las cuencas hidrográficas de su área de actuación.

Para Paulo Affonso de Leme Machado ${ }^{621}$, las expresiones 'Comité Federal de Cuenca' y 'Comité Estadual de Cuenca', aunque expresan la realidad del dominio de las aguas, no fueron consagradas textualmente en la Ley tampoco en la Resolución 5/2000 del CNRH. Cuando un río federal y un río estadual hagan parte de una misma cuenca (o sub-cuenca), estuvieren ellos en la situación de principal o de afluente, la realidad podría indicar un Comité 'Mixto' de Cuenca, en el que habría duplo dominio público y gestión compartida, incluso en el área de otorga de los derechos de uso de los recursos hídricos. El autor afirma desconocer regla legal que establezca que el río principal (siendo bien de la Unión) y los cursos de agua afluentes (de los Estados) pertenecerían a una cuenca o sub-cuenca de la Unión. El art. 20, III, de la Constitución Federal, clasifica 'lagos, ríos y cualesquier corrientes de agua' como bienes de la Unión, pero no hace referencia a cuencas o sub-cuencas hidrográficas como bienes de la Unión. Esa

\footnotetext{
${ }^{619}$ POMPEU, Cid Tomanik. Direito de Águas no cit., p. 341.

${ }^{620}$ POMPEU, Cid Tomanik. Direito de Águas no cit., pp. 342-343.

${ }^{621}$ MACHADO, Paulo Affonso Leme. Recursos Hidricos cit., p. 105.
} 
cuestión fue abordada por el Consejo Nacional de Recursos Hídricos ${ }^{622}$, que dispuso: 'los Comités de Cuenca Hidrográfica, cuyo curso de agua principal sea de dominio de la Unión, serán vinculados al Consejo Nacional de Recursos Hídricos'.

Así, en la opinión de Machado ${ }^{623}$, la vinculación de estos Comités al Consejo Nacional de Recursos Hídricos solamente será obligatoria si en los cursos de aguas estaduales y tributarios del curso principal de la Unión no hayan sido establecidos Comités en su sub-cuenca hidrográfica, como permite el art. 37, II.

Cid Tomanik Pompeu discrepa de ese entendimiento, afirmando que la $\mathrm{CF} / 1988$ no trata de 'cuencas', sino de 'aguas'. Cuenca es concepto territorial. Esa visión de supremacía de la Unión sobre los bienes de los Estados no es amparada por la $\mathrm{CF} / 88$. La forma de pacto entre los Comités estaduales y federales es materia de acuerdo administrativo y no de mandamiento legal de la Unión. Esa visión jerárquica había sido puesta en la Ley 6.938, en la que de los actos de Gobernador cabría recurso a Ministro. De tan absurda, fue posteriormente revocada ${ }^{624}$.

Según Moreira ${ }^{625}$, el Comité de río estadual afluente de río federal debe responder, directamente, al Comité de aquél río federal, y debe adecuar la gestión de las aguas a las diversidades físicas, bióticas, demográficas, económicas, sociales y culturales de su área de alcance. El CNRH sólo debe intervenir en Comité de Cuenca Hidrográfica cuando haya manifiesta infracción al dispuesto en la Ley 9.433/1997 y en la Resolución, pero asegurada su defensa amplia ${ }^{626}$.

El art. 37 de la Ley 9.433/1997 dispone que los Comités de Cuenca Hidrográfica tengan como área de actuación:

I - la totalidad de una cuenca hidrográfica; II - sub-cuenca hidrográfica de tributario del curso de agua principal de la cuenca, o de tributario de ese tributario; o III - grupo de cuencas o sub-cuencas hidrográficas contiguas. Párrafo único. La institución

\footnotetext{
${ }^{622}$ Resolução CNRH-5/2000, art. $1^{\circ}, \S 2^{\circ}$.

${ }^{623}$ MACHADO, Paulo Affonso Leme. Recursos Hidricos cit., p.106.

${ }^{624}$ POMPEU, Cid Tomanik. Direito de Águas no cit., pp. 343-344.

${ }^{625}$ MOREIRA, M. M. M. A. A Política Nacional de Recursos Hídricos: avanços recentes e novos desafios. In: FELICIDADE, N.; MARTINS, R. C.; LEME, A. A. Uso e gestão dos recursos hídricos no Brasil. Editora Rima, São Carlos, SP- Brasil: 2001.

${ }^{626}$ POMPEU, Cid Tomanik. Direito de Águas no cit., p.346.
} 
de Comités de Cuenca Hidrográfica en ríos de dominio de la Unión será efectuada por acto del Presidente de la República.

El inciso II muestra que en una cuenca hidrográfica pode haber división de espacio en los varios segmentos allí mencionados. La ley no dejó opción para crearse más de tres Comités en el interior de una cuenca hidrográfica ${ }^{627}$. Ese criterio podrá ser adecuado para cuencas no extensas y en cambio, inadecuado para otras, como la del Río São Francisco, con un área de $640.000 \mathrm{~km}^{2}$ y una población de 9,7 millones, y la del río Paraíba do Sul, con $330.000 \mathrm{~km}^{2}$ y población de 2,9 millones ${ }^{628}$, así como en cuencas de la Amazonia.

Sus competencias están establecidas en el art. 38 de la Ley 9.433/1997 y en el art. $7^{\circ}$ de la Resolución 5/2000 del CNRH.

Las acciones de los Comités de Cuenca Hidrográfica en ríos del dominio de los Estados, afluentes a ríos de dominio de la Unión deben ser desarrolladas por medio de articulación de la Unión con las respectivas unidades federadas, observados los criterios y las normas establecidas por los Consejos Nacional, Estaduales y Distrital de Recursos Hídricos $^{629}$.

Los ríos estaduales deben ser gestionados por los Estados, de acuerdo con el sistema de gestión estadual, que debe estar de acuerdo con la legislación federal ${ }^{630}$, y desde que haya articulación previa.

El Cuadro 5 informa sobre los siete actuales Comités de Cuencas Hidrográficas brasileñas en ríos federales.

\footnotetext{
${ }^{627}$ MACHADO, Paulo Affonso Leme. Recursos Hídricos cit., p.107.

${ }^{628}$ SETTI, A. A. A necessidade do uso sustentável dos recursos hídricos. Brasília: MMA, 1994.

${ }^{629}$ POMPEU, Cid Tomanik. Direito de Águas no cit., p. 346.

${ }^{630}$ OLIVEIRA, C. M. Sistema Nacional de Gerenciamento de Recursos Hídricos e as alternativas para o formato jurídico das agências de água no Brasil, 2007, cit., p.46.
} 
Cuadro 5 - Comités de Cuencas Hidrográficas - Ríos federales

\begin{tabular}{|l|l||}
\hline \multicolumn{1}{|c|}{ Cuencas Hidrográficas } & \multicolumn{1}{c|}{ Unidades de la Federación } \\
\hline $\begin{array}{l}\text { Comité de la Cuenca Hidrográfica del } \\
\text { Río Doce }\end{array}$ & Minas Gerais y Espírito Santo \\
\hline $\begin{array}{l}\text { Comité de la Cuenca Hidrográfica del } \\
\text { Río Muriaé y Pomba }\end{array}$ & Minas Gerais y Rio de Janeiro \\
\hline $\begin{array}{l}\text { Comité da Cuenca Hidrográfica del Río } \\
\text { Paraíba do Sul - CEIVAP }\end{array}$ & São Paulo, Rio de Janeiro y Minas Gerais \\
\hline $\begin{array}{l}\text { Comité da Cuenca Hidrográfica del Río } \\
\text { Paranaíba }\end{array}$ & Minas Gerais \\
\hline $\begin{array}{l}\text { Comité da Cuenca Hidrográfica del Río } \\
\text { Piracicaba, Capivari e Jundiaí }\end{array}$ & Minas Gerais y São Paulo \\
\hline $\begin{array}{l}\text { Comité da Cuenca Hidrográfica del Río } \\
\text { São Francisco - CEIVASF }\end{array}$ & $\begin{array}{l}\text { Minas Gerais, Goiás, Distrito Federal, } \\
\text { Bahia, Pernambuco, Sergipe y Alagoas }\end{array}$ \\
\hline $\begin{array}{l}\text { Comité de Cuenca Hidrográfica del Río } \\
\text { Piranhas Açu }\end{array}$ & Paraíba y Rio Grande do Norte \\
\hline
\end{tabular}

El Cuadro 6 especifica el número actual de comités en ríos estaduales por unidad de la federación.

Cuadro 6 - Comités de Cuencas Hidrográficas - Ríos estaduales y distritales

\begin{tabular}{|c|c|c|c|}
\hline $\begin{array}{c}\text { Unidades de la } \\
\text { Federación }\end{array}$ & Comités & $\begin{array}{c}\text { Unidades de la } \\
\text { Federación }\end{array}$ & Comités \\
\hline Alagoas & 5 & Paraíba & 3 \\
\hline Amazonas & 1 & Paraná & 5 \\
\hline Bahia & 10 & Pernambuco & 6 \\
\hline Ceará & 10 & Piauí & 1 \\
\hline Distrito Federal & 3 & Rio de Janeiro & 8 \\
\hline Espírito Santo & 10 & Rio Grande do Norte & 1 \\
\hline Goiás & 2 & Rio Grande do Sul & 22 \\
\hline Mato Grosso & 1 & Santa Catarina & 16 \\
\hline Mato Grosso do Sul & 1 & São Paulo & 21 \\
\hline Minas Gerais & 32 & Sergipe & 3 \\
\hline
\end{tabular}

Los criterios generales para la elaboración de los planes de recursos hídricos fueron objeto de la Resolución CNRH 17/2001, siendo proveído término de referencia 
básico actualizado de carácter orientativo para los planes de recursos hídricos de cuencas hidrográficas ${ }^{631}$.

\subsubsection{Las aguas subterráneas}

En sentido amplio, son consideradas 'aguas subterráneas' todas las que se sitúan debajo de la superficie de la tierra ${ }^{632}$. La doctrina y la jurisprudencia suelen dividir las aguas ubicadas debajo de la tierra en 'subálveas' (derivadas de las corrientes naturales, que escurren bajo el lecho o álveo de las aguas superficiales ${ }^{633}$ ), 'freáticas' (acuíferos ${ }^{634}$ más cercanos de la superficie de la tierra; emanan naturalmente a la superficie y el punto donde eso ocurre tiene el nombre de 'fuente, manantial o vertiente ${ }^{, 635}$ ) y 'subterráneas o circulantes' (jurídicamente todas las aguas que no sean superficiales) ${ }^{636}$.

En 1835, Lobão ${ }^{637}$ afirmaba que "el dominio de cualquier edificio no se limita solamente a su superficie: él comprende todo el aire perpendicular hasta el cielo, y todo lo que está debajo hasta los Infiernos”. Este entendimiento provenía del concepto romano de propiedad y fue traído por los intérpretes de la Edad Media ${ }^{638}$.

Los códigos civiles elaborados bajo la inspiración del Código Napoleónico siguieron el principio de que la propiedad del suelo se extiende al subsuelo, con todo

\footnotetext{
${ }^{631}$ Conjunto de normas legais: recursos hídricos. $4^{\mathrm{a}}$ ed. Brasília: Ministério do Meio Ambiente, Secretaria de Recursos Hídricos, 2006, p.136-140. Informação obtida em Cid Tomanik POMPEU, Aquífero Guarani: aspectos legais e institucionais da gestão. Revista dos Tribunais, São Paulo, v.881, p.82, março de 2009.

${ }^{632}$ Decreto-lei 2.848, de 07 de dezembro de 1940, com alterações posteriores.

${ }^{633}$ POMPEU, Cid Tomanik. Direito de Águas no cit., p. 189.

${ }^{634}$ Conforme Cid Tomanik Pompeu, Direito de Águas no cit., p. 189, basado en el Webster's $3^{\text {rd }}, 1966$, subsección 0038 conceptúa acuífero como: "Formação porosa (camada ou estrato) de rocha permeável, areia ou cascalho, capaz de armazenar e fornecer quantidades significativas de água.

${ }^{635}$ POMPEU, Cid Tomanik. Direito de Águas no cit., p. 189.

${ }^{636}$ POMPEU, Cid Tomanik. Direito de Águas no cit., p. 190.

${ }^{637}$ LOBÃO, Manoel Almeida e Souza de. Dissertação II: sobre as águas subterrâneas. Tractado practico e compendiario das águas: dos rios públicos, fontes públicas, ribeiros e nascentes dellas. Lisboa: Imprensa Nacional, 1835, p.226, citado por POMPEU, Cid Tomanik. Direito de Águas no cit., p. 190. ${ }^{638}$ COULANGES, Foustel de. A cidade antiga. $10^{\mathrm{a}}$ ed. Lisboa: Livraria Clássica, 1971, pp. 69-82.
} 
aquello que en él esté contenido; el propietario puede hacer cualquier excavación que no haga daño al vecino ${ }^{639}$.

En el derecho moderno, la extracción de aguas subterráneas es disciplinada por el Estado, independientemente de su clasificación como pública, privada o nullius (sin dueño) $)^{640}$.

El derecho brasileño sufrió gran evolución en materia de propiedad del subsuelo $^{641}$, pero lo que importa en este estudio es su relación con los Planes de Recursos Hídricos. En estos, deben ser considerados los usos múltiples de las aguas subterráneas, las peculiaridades de función del acuífero y los aspectos de calidad y cantidad, para la promoción del desarrollo social ambientalmente sostenible ${ }^{642}$.

Los acuíferos son caracterizados con la presentación de las interrelaciones entre [...] los demás cuerpos hídricos, superficiales y subterráneos, con el medio ambiente, visando a la gestión sistémica, integrada y participativa de las aguas. Para los acuíferos subyacentes a grupos de cuencas o sub-cuencas hidrográficas contiguas, corresponde a los Comités de Cuenca Hidrográfica establecer los criterios para elaboración, sistematización y aprobación de los respectivos planes de forma articulada, debiendo ser previsto la inspección de la cantidad y calidad de sus aguas. Las acciones potencialmente impactantes en las aguas subterráneas y las de protección y mitigación que serán emprendidas deben ser diagnosticadas y previstas, incluidas las medidas de emergencia que serán adoptadas en caso de contaminación y contaminación accidental $^{643}$.

Así, las formas de prevención, protección, conservación y recuperación deben ser explicitadas para garantir los múltiples usos y la manutención de sus funciones ambientales. Los Planes de Recursos Hídricos deberán, aún, elaborar resúmenes de medidas, programas y los plazos de realización para alcanzar los objetivos, pudiendo ser incluso creadas 'áreas de uso restricto'.

\footnotetext{
${ }^{639}$ Código Civil de Italia, art. 840; Código Civil de Brasil (1916), art. 526; Código Civil de Brasil (2002), art. 1229; y Código Civil de Bélgica, art. 641, entre otros. Información obtenida en POMPEU, Cid Tomanik. Direito de Águas no cit., p. 191.

${ }^{640}$ POMPEU, Cid Tomanik. Direito de Águas no cit., p.191.

${ }^{641}$ POMPEU, Cid Tomanik. Direito de Águas no cit., p. 193.

${ }^{642}$ Resolução CNRH 22, de 24.05.2002.

${ }^{643}$ POMPEU, Cid Tomanik. Direito de Águas no cit., p. 198.
} 


\subsubsection{Los miembros de los Comités de Cuenca}

En pesquisa realizada en el año de $2004^{644}$, se constató que el miembro típico del Comité de Cuenca hidrográfica es del sexo masculino, tiene entre 40 y 49 años, vive en el área de la cuenca, posee curso superior, trabaja en el sector público (más de $40 \%$ de los que representan los grandes usuarios y la sociedad civil) y tiene renta superior a diez salarios mínimos. Aunque los Comités presentan composición diversificada, las características socioeconómicas de los miembros no demuestra la realidad de la sociedad brasileña, porque se trata de grupo privilegiado. Además de tener alto nivel de estudios y formación multidisciplinar, los miembros poseen, aún, experiencia de más de cinco años en diversas áreas relacionadas a la gestión de recursos hídricos.

Los miembros entrevistados afirmaron que el uso del conocimiento (técnicocientífico, práctico y local) en la gestión de recursos hídricos puede facilitar el proceso de tomada de decisión, porque contribuye para el entendimiento de las condiciones físico-naturales, socioeconómicas, culturales y políticas en el contexto de las cuencas: $67 \%$ informaron poseer dominio sobre la cuestión de los impactos ambientales; $71 \%$ sobre los modelos hidrológicos; y $88 \%$ demostraron tener conocimiento sobre la calidad del agua. Así, además de proporcionar subsidios para mejor tomada de decisión, el conocimiento puede contribuir también para la mediación de conflictos, como, por ejemplo, promover consenso por medio de esclarecimiento de disputas sobre cuestiones ambiguas o inciertas ${ }^{645}$.

Pese algunas dificultades de participación que los miembros de los Comités enfrentan, tales como falta de tiempo, coste de transporte y tiempo de viaje, el nivel de participación es, de cierta forma, significativo. Muchos de ellos, además de comparecer a las reuniones plenarias, se pronuncian y presentan propuestas. La mayoría dedica algún tiempo a otras actividades del Comité, como 'facilitar la negociación entre miembros', 'colaborar con otros miembros', 'participar de grupos y comisiones', y 'organizar eventos y seminarios', entre otras. Se nota, entonces, que se encuentran empeñados en participar de forma más efectiva del proceso de gestión del agua ${ }^{646}$.

\footnotetext{
${ }^{644}$ FRANK, B. (Org.) Comitês de Bacia sob o olhar dos seus membros cit., p. 21.

${ }^{645}$ FRANK, B. (Org.) Comitês de Bacia sob o olhar dos seus membros cit., p. 24.

${ }^{646}$ FRANK, B. (Org.) Comitês de Bacia sob o olhar dos seus membros cit., p. 32.
} 
La interacción y la comunicación entre miembros de los Comités y los grupos que representan son importantes mecanismos por medio de los cuales los miembros pueden incorporar las preferencias de su base, así como mantenerla informada sobre las decisiones tomadas. Esta es una forma de fortalecer la representación responsable, lo que hace la participación en el proceso de tomada de decisión más amplia y representativa ${ }^{647}$. Sin embargo, menos de un tercio de los miembros toma decisiones según orientaciones de su entidad o categoría. Los datos sugieren que a que pese las bases se movilizaren para participar del proceso decisorio, eso no se traduce, necesariamente, en su mayor influencia sobre sus representantes ${ }^{648}$.

La falta de recursos financieros para proyectos y actividades de los Comités de Cuenca es apuntada como la principal dificultad que afecta su funcionamiento. El cobro por el uso del agua sería un instrumento capaz de, además de promover el uso racional del agua, generar recursos financieros para proyectos y actividades de gestión de recursos hídricos. La opinión de los entrevistados es que debe pagar por el uso del agua quien la consume o contamina más. Podría también inducir órganos gubernamentales a trabajar en conjunto para implementar acciones financiadas con recursos de cobro. Aun así, la mayor parte de los miembros cree que los Comités no serían desactivados por la falta de cobro ${ }^{649}$.

\subsubsection{Las Agencias de Agua o de Cuenca Hidrográfica}

Las Agencias de Agua o de Cuenca Hidrográfica son organismos con personalidad jurídica creadas para dar apoyo a los Comités de Cuenca, recaudar y gestionar los recursos advenidos del cobro por el uso del agua. Ejercen la función de secretaria ejecutiva de los Comités de Cuenca, siendo posible existir una única Agencia para uno o más Comités. Sin embargo, queda condicionada su creación a la previa

\footnotetext{
${ }^{647}$ FRANK, B. (Org.) Comitês de Bacia sob o olhar dos seus membros cit., p. 40.

${ }^{648}$ ABERS, R. N.; FORMIGA-JOHNSSON, R. M.; FRANK, B.; KECK, M. E; LEMOS, M. C. Organismos de bacia hidrográfica e democratização da gestão das águas: análise preliminar da Marca d’Água Survey. XVII Simpósio Brasileiro de Recursos Hídricos, São Paulo, Anais, 2007.

${ }^{649}$ FRANK, B. (Org.) Comitês de Bacia sob o olhar dos seus membros cit., p.45.
} 
existencia del respectivo (o respectivos) Comités de Cuenca y la viabilidad financiera asegurada por el cobro del uso de los recursos hídricos en su área de actuación.

La Ley no define la naturaleza jurídica de la Agencia de Cuenca, pero por el hecho de en su esencia ser ligada a uno o más Comités de Cuenca no debe tener personalidad jurídica de derecho público, pero constituirse entidad de derecho privado y sin fines lucrativos ${ }^{650}$. En la visión de Pompeu ${ }^{651}$, la ley considera 'organizaciones civiles de recursos hídricos los consorcios y las asociaciones intermunicipales de cuencas hidrográficas, las asociaciones regionales, locales o sectoriales de usuarios, las organizaciones técnicas y de enseñanza e investigación con interés en el área de recursos hídricos ${ }^{652}$, las organizaciones no-gubernamentales con objetivos de defensa de intereses difusos o colectivos' de la sociedad, así como otras organizaciones reconocidas por los Consejos Nacional y Estaduales, desde que legalmente constituidas. De preferencia, deberán adoptar las figuras jurídicas previstas en las Leyes 9.637/1998 y 9.790/1999, respectivamente 'Organización Social' (OS) o 'Organización de la Sociedad Civil de Interés Público' (OSCIP), entidades no-gubernamentales autorizadas a ejecutar funciones de interés público ${ }^{653}$.

Sobre esto, Pompeu observa que las agencias no tienen finalidades sociales para encuadrarse como OSs u OSCIPs. En São Paulo, la preferencia fue la forma jurídica de 'fundación intergubernamental de derecho privado' con la participación del Estado, municipios y sociedad civil ${ }^{654}$.

Cabe notar, sin embargo, sea cual fuere su naturaleza jurídica, que las Agencias de Cuenca son siempre dependientes del Comité, del cual son secretarias ejecutivas. En el ámbito federal, los términos de los contratos de gestión para el ejercicio de funciones

\footnotetext{
${ }^{650}$ KELMAN, J.; FREJTAG, D. K. Agências reguladoras. ABRH Notícias, Revista Informativa da Associação Brasileira de Recursos Hidricos, Brasília, n. 3 3, 2000, p. 16.

${ }^{651}$ POMPEU, Cid Tomanik. Direito de Águas no cit., 2010, p. 351.

${ }^{652}$ Son denominadas civiles, mismo que públicas.

${ }^{653}$ KELMAN, J.; FREJTAG, D. K. Agências reguladoras cit., p.16.

${ }^{654}$ Modelo recomendado por Cid Tomanik Pompeu, em Parecer para el CBH-PCJ estatal, en 30.12.1994 (no publicado), y adoptado por el Estado de São Paulo, conforme Ley 10.020/2005, que autorizó el Poder Ejecutivo a participar de la constitución de Fundações Agências de Bacia Hidrográfica.
} 
de competencia de las Agencias de Agua ${ }^{655}$ deben ser sometidos al Comité de Cuenca y merecer la aprobación del Ministro del Medio Ambiente ${ }^{656}$.

El art. 44 da Ley 9.433/1997 enumera sus atribuciones, y algunas de ellas son típicamente de órgano de apoyo técnico:

I - mantener balance actualizado de la disponibilidad de recursos hídricos e su área de actuación; IX - promover los estudios necesarios para la gestión de los recursos hídricos en su área de actuación; X - elaborar el Plan de Recursos Hídricos para apreciación del respectivo Comité de Cuenca Hidrográfica; XI - proponer al respectivo (o respectivos) Comité(s) de Cuenca Hidrográfica: (a) el encuadramiento de los cuerpos de agua en las clases de uso. Esas atribuciones independen del cobro por el uso da agua. Otras son esencialmente ligadas a ese cobro: III - efectuar, mediante delegación del otorgante, el cobro por el uso de recursos hídricos; IV - analizar y emitir pareceres sobre os proyectos y obras que sean financiados con recursos generados por el cobro por el uso de Recursos Hídricos y encaminarlos a la institución financiera responsable por la administración de eses recursos; V - acompañar la administración financiera de los recursos recaudados con el cobro por el uso de recursos hídricos en su área de actuación; XI - proponer al respectivo (o respectivos) Comité(s) de Cuenca Hidrográfica: (b) los valores que sean cobrados por el uso de recursos hídricos.

La Agencia de Agua o de Cuenca Hidrográfica es órgano controlador del cobro y de la administración financiera de los recursos recaudados, pero no es y tampoco puede ser institución financiera. No es depositaria ni aplicadora de recursos. Por eso, debe ser elegida una institución financiera, banco o "Caixa Econômica" para ser depositaria de los recursos y los aplicará, para rendimiento financiero, obedecidas las instrucciones de la Agencia y las directrices del Plan de Cuenca ${ }^{657}$.

Aunque la elección del instituto de derecho que se adoptará para otorga de los derechos de uso de las aguas (autorización, permisión, concesión, etc.) aún no hubiera sido definida, la ley que creó la ANA estatuyó que las otorgas por ella emitidas ocurrieran por 'autorización' administrativa ${ }^{658}$.

\footnotetext{
${ }^{655}$ Relativos a la delegación del CNRH, objeto del art. 51 de la Ley 9.433/1997, para el ejercicio por plazo determinado.

${ }^{656}$ Lei $10.881 / 2004$.

${ }^{657}$ MILARÉ, Édis. Direito do Ambiente, 2001, cit., p. 408.

${ }^{658}$ Lei 9.984/2000.
} 
No obstante, se trata de norma de carácter federal y no nacional, para lo que deberían estar siendo aplicados por los Estados y el Distrito Federal el art. 43 y siguientes del Código de Aguas, porque fueron incorporados a la Constitución Federal de 1988, siendo 'concesión administrativa' para fines de utilidad pública y 'autorización administrativa' para los demás ${ }^{659}$.

A propósito de 'autorización administrativa', cabe en tiempo citar algunos entendimientos pertinentes. Cid Tomanik Pompeu ${ }^{660}$ observa que insertando ese instituto en la esfera del ejercicio del 'poder de policía' por el Estado, muchos autores se refieren a la autorización administrativa como teniendo por beneficiario solamente el particular y no órganos o entidades de la Administración, cuando, sin embargo, la última hipótesis es bastante común en términos de la otorga de autorizaciones internas.

Además de eso, cabe señalar que la manifestación de la voluntad de la Administración, hecha conforme los fines reconocidos por el ordenamiento jurídico, la autorización administrativa puede ser incluida en la categoría de los 'actos administrativos de negocios'. Como debe siempre haber norma jurídica estableciendo su exigencia para la generalidad de los casos, la autorización administrativa es la condictio juris para la práctica del acto autorizado. Ese instituto no altera la capacidad jurídica del sujeto, sino solamente su capacidad de actuar. La autorización es constitutiva de derecho y no declaratoria, porque [...] el beneficiario, antes de la otorga, de ella no tenía derecho, sino solamente interés. Cuando la autorización administrativa fuere la condictio juris para la práctica de un acto, suya será condición de validad; cuando fuere elemento accesorio, será condición de su eficacia. Otorgada en relación a acto determinado, la autorización solamente aprueba los actos anteriormente practicados si la autoridad otorgante tuviere el deber de examinarlos ${ }^{661}$.

La otorga conferida por la autorización administrativa es concretizada por medio de acto administrativo (formal u orgánico si es editado en el ámbito del Poder Ejecutivo y material o substancial si es emanado de los Poderes Legislativo o Judicial),

\footnotetext{
${ }^{659}$ POMPEU, Cid Tomanik. Direito de Águas no cit., p. 73.

${ }^{660}$ POMPEU, Cid Tomanik. Autorização administrativa. $3^{\text {a }}$ ed., Editora Revista dos Tribunais, São Paulo: 2009, p. 202.

${ }^{661}$ POMPEU, Cid Tomanik. Autorização administrativa cit., p. 203.
} 
pudiendo ser expresa o tácita, conforme dispusiere la ley. El objeto o contenido de la autorización administrativa es la práctica de acto o el ejercicio de actividad material ${ }^{662}$.

Por faltar unidad de objeto entre la autorización administrativa y el acto autorizado, no existe ato complejo. Como regla, en el campo doctrinario, la autorización es acto administrativo precario y, por lo tanto, revocable. Por eso, Pompeu ${ }^{663}$ entiende que para evitar confusión entre los institutos, cuando se fuere tipificar la autorización administrativa, así como la concesión, la permisión, la licencia y la aprobación, en el predicado, deben ser utilizados vocablos de la lengua común, tales como otorga, anuencia, asentimiento y consentimiento. En su opinión, se debe tener presente que el derecho administrativo solamente alcanzará la precisión terminológica ya conseguida por las ramas más antiguas del derecho después de la fijación del concepto de cada uno de sus institutos y desde que haya empeño de la doctrina, de la legislación y de la jurisprudencia en emplear los vocablos en el sentido técnico correcto.

\subsection{La representatividad de la sociedad en el SINGREH. EI histórico de la} representación de la sociedad en el Derecho Romano

Una de las peculiaridades más importantes del Estado Romano era la base familiar de la organización, y el Estado primitivo, la civitas, habría sido resultado de la unión de grupos familiares (gens), razón por la cual siempre fueron concedidos privilegios especiales a los miembros de las familias patricias, compuestas por los descendientes de los fundadores del Estado. Así como en el Estado Griego, en el Estado Romano, durante muchos siglos, el pueblo participaba directamente del gobierno, pero la noción de 'pueblo' era muy restricta, comprendiendo sólo parte de la población. Los gobernantes supremos eran los magistrados $\mathrm{y}$, en lenta evolución, otras camadas sociales fueron adquiriendo y ampliando derechos, pero permanecieron la base familiar y la ascendencia de nobleza tradicional. Sólo cuando ya despuntaba la idea de Imperio, que sería una de las marcas del Estado Medieval, Roma pretendió realizar la integración

\footnotetext{
${ }^{662}$ POMPEU, Cid Tomanik. Autorização administrativa cit., p. 202.

${ }^{663}$ POMPEU, Cid Tomanik. Autorização administrativa cit., p. 204.
} 
jurídica de los pueblos conquistados, pero, aun así, buscando mantener un sólido núcleo de poder político que asegurara la unidad y la ascendencia de la Ciudad de Roma ${ }^{664}$.

La sociedad medieval era pluralista, constituida por diversos agrupamientos sociales, cada uno disponiendo de ordenamiento jurídico propio. El Derecho se presentaba como fenómeno social producido no por el Estado, sino por la sociedad civil $^{665}$.

En la visión de Dalmo de Abreu Dallari ${ }^{666}$, en el plan de Estado, la época medieval fue uno de los períodos más difíciles, porque era instable y heterogéneo, no siendo tarea simple la búsqueda de las características de un Estado Medieval. Sin embargo, pueden ser citados tres elementos presentes en la sociedad política de la época, conjugándolos para su caracterización: el cristianismo, las invasiones de los bárbaros y el feudalismo. Se debe resaltar que mismo donde y cuando las formaciones políticas revelaban intenso fraccionamiento del poder y una nebulosa noción de autoridad, estaba presente una aspiración a la unidad y, cuanto más fragilidad se revelaba, más acentuado se hacía el deseo de unidad y de fuerza tendiendo para una gran unidad política, eficaz como era el de Roma.

El germen de la creación del Estado Moderno se dio por los siguientes conflictos de orden política, económica y social existentes: [...] un poder superior, ejercido por el Imperador, con una infinita pluralidad de poderes menores, sin jerarquía definida; una incontable multiplicidad de órdenes jurídicas, comprendiendo el orden imperial, el orden eclesiástico, el derecho de las monarquías inferiores, un derecho comunal que se desarrolló extraordinariamente; las ordenaciones de los feudos y las reglas establecidas al fin de la Edad Media por las corporaciones de oficios ${ }^{667}$.

Con la formación del Estado Moderno, la sociedad asumió una estructura monista, en el sentido de que el Estado concentraba en sí todos los poderes, en primer lugar el de crear el Derecho: no se contentaba en concurrir para esta creación, pero quería ser el único a establecer el Derecho, o directamente por intermedio de leyes, o

\footnotetext{
${ }^{664}$ DALLARI, Dalmo de Abreu. Elementos de Teoria Geral do Estado. 29 ed. São Paulo: Saraiva, 2010, p. 65.

${ }^{665}$ BOBBIO, Norberto. O positivismo jurídico: lições de filosofia do direito. Trad. M. PUGLIESE; E. BINI; C. E. RODRIGUES. Ícone, São Paulo-Brasil: 2006, p. 27.

${ }^{666}$ DALLARI, Dalmo de Abreu. Elementos de Teoria Geral do Estado cit., p. 66. ${ }^{667}$ DALLARI, Dalmo de Abreu. Elementos de Teoria Geral do Estado cit., p. 70.
} 
indirectamente, por medio de reconocimiento y control de las normas de formación consuetudinaria $^{668}$.

El proceso de monopolización de la producción jurídica, por parte de los Estados modernos, encuentra gran precedente en la compilación de Justiniano. El derecho romano era, típicamente, un derecho de formación social, constituyéndose, gradualmente, por medio de un desarrollo secular según las costumbres ${ }^{669}$ y la elaboración de los jurisprudentes. Todo ese complejo de normas fue recogido, por iniciativa de Justiniano, en el Corpus juris civilis, de modo que tales normas perdieron el carácter de derecho de origen social para asumir aquel de derecho, que encuentra el fundamento de validad en la voluntad del príncipe, según la fórmula del Codex, una de las cuatro partes del Corpus. Así, en el desarrollo histórico sucesivo, el derecho romano es considerado un derecho impuesto por el Estado ${ }^{670}$.

\subsubsection{La noción jurídica de pueblo. El pueblo, el Estado y el Derecho}

En la Grecia antigua la expresión ‘ciudadano’ indicaba sólo el miembro activo de la sociedad política, o sea, aquel que podía participar de las decisiones políticas. En Roma, se usó, inicialmente, el término 'pueblo' para indicar el conjunto de ciudadanos (exactamente como en Grecia), ampliándose más tarde su sentido para significar el propio Estado romano. Aunque en esa época no se encuentre el sentido moderno de 'pueblo', ya existía connotación jurídica, porque la calidad de ciudadano implicaba la titularidad de derechos públicos ${ }^{671}$.

Durante la Edad Media, la noción de 'pueblo' fue menos precisa, porque la extensión de los derechos a nuevas camadas de la población y la movilidad de esta, hasta que fueran delineados los trazos tradicionales del Estado Moderno, perturbó los padrones tradicionales. La realidad de la época indicaba el pueblo de un mismo Estado dividido en diferentes ordenaciones sin un centro unificador eficaz, lo que no podía ser concebido como una unidad. Los derechos políticos eran atribuidos a los ciudadanos,

\footnotetext{
${ }^{668}$ BOBBIO, Norberto. O positivismo jurídico cit. p. 27.

${ }^{669}$ Jurisdição pretoriana, cujos resultados foram consagrados no Edictum perpetuum.

${ }^{670}$ BOBBIO, Norberto. O positivismo jurídico cit., p. 30.

${ }^{671}$ DALLARI, Dalmo de Abreu. Elementos de Teoria Geral do Estado cit., p. 97.
} 
pero estos no pertenecían, necesariamente, a una clase social superior, ya que eran conferidos también a burgueses. A pesar de eso, hubo evidente avance en el sentido de 'pueblo', con la extensión de los derechos públicos a un contingente mucho más numeroso de los componentes del Estado ${ }^{672}$.

Mientras prevaleció la monarquía absoluta, durante el primer período del Estado Moderno, se fue generalizando la designación de 'ciudadano', lo que iría influenciar para que el concepto se ampliara. Por la ascensión política de la burguesía por medio das revoluciones del siglo XVIII, apareció en textos constitucionales a la idea de pueblo, libre de cualquier noción de clase y cualquier discriminación entre los componentes del Estado. Dallari ${ }^{673}$ observa que, en realidad, las discriminaciones no desaparecieron, pero se inició un esfuerzo doctrinario en el sentido de efectuar, en términos jurídicos, la extensión plena de la ciudadanía. En ese aspecto, fue de gran importancia la contribución dogmática alemana del siglo XIX, especialmente de Gerber y de la doctrina dos 'Derechos Públicos Subjetivos', encontrándose en la obra de Jellinek, publicada en 1900, una completa construcción doctrinaria, fijando la noción jurídica de pueblo y disciplinando su participación en la vida del Estado.

El punto de partida de la doctrina de Georg Jellinek ${ }^{674}$ es la distinción entre un aspecto subjetivo y otro objetivo del pueblo:

El Estado es sujeto del poder público y el pueblo, como su elemento componente, participa de esa condición. Este es el 'aspecto subjetivo' del pueblo. Por otro lado, el mismo pueblo es objeto de la actividad del Estado y, bajo este ángulo, es que se tiene el pueblo en su 'aspecto objetivo'. Cuanto al aspecto subjetivo, [...] la simple circunstancia de reunirse una pluralidad de hombres y someterlos a una autoridad común no llegaría a constituir un Estado. Pero si esa pluralidad de personas fuere asociada a otros elementos, en un momento jurídico, se forma una unidad, surgiendo entonces el Estado. Y cada individuo integrante del pueblo participa también de la naturaleza de sujeto, derivándose, por lo tanto, dos situaciones: (a) los individuos mientras objetos del poder del Estado están en una relación de subordinación y son, por lo tanto, sujetos de deberes; (b) mientras miembros del Estado, los individuos se

\footnotetext{
${ }^{672}$ DALLARI, Dalmo de Abreu. Elementos de Teoria Geral do Estado cit., p.97.

${ }^{673}$ DALLARI, Dalmo de Abreu. Elementos de Teoria Geral do Estado cit., p.98.

${ }^{674}$ JELLINEK, Georg. Teoría General del Estado. Buenos Aires: Albatros, 1954.
} 
descubren ante a él y ante los demás individuos en una relación de coordinación, siendo, en este caso, sujetos de derechos.

La raíz de esa teoría está en Jean-Jacques Rousseau ${ }^{675}$, que reconoce derechos subjetivos entre los asociados (que componen la sociedad) y el Estado, reuniendo, colectivamente, lo que puede ser llamado de pueblo, correspondiéndoles la designación particular de 'ciudadanos' cuando participan de la autoridad soberana y de 'sujetos' cuando sometidos a las leyes del Estado.

En la Edad Media, el derecho romano fue difundido con el nombre de jus commune $^{676}$ : esa fórmula se conecta a la definición de derecho natural dada por los griegos (koinói nómoi, según la expresión de Aristóteles) y por los romanos (jus gentium), como derecho común a todos los pueblos. La conexión es inconsciente, pero no casual, a medida en que el derecho romano, en la época, tenía precisamente valor de derecho común a todos los pueblos, siendo considerado expresión de la propia razón ${ }^{677}$.

De la misma forma que en la antigüedad clásica el jus gentium se contraponía al jus civile, en la Edad Media el jus commune se contraponía al jus proprium, o sea, el derecho propio de las diversas instituciones sociales. En la sociedad medieval, cada grupo social poseía su propio derecho: había el derecho feudal, o de las corporaciones, el de las comunas o civitates $^{678}$, y el derecho de los reinos. Todos esos eran subordinados al Derecho Romano, así como todas las organizaciones sociales eran subordinadas al Imperio. De forma paulatina, los reinos (en particular el de la Francia), y en seguida los civitates proclamaron su autonomía e independencia del Imperio, declarándose dotados del poder de crear el propio derecho y se autodenominaron civitates sibi principes (reinos independientes de príncipes, o sea, del Imperador) ${ }^{679}$.

Se creó, entonces, un conflicto entre el jus commune y el jus proprium y, en esa divergencia, el derecho puesto por el ente público organizado (comuna o reino, esto es, Estado) pasó, poco a poco, a prevalecer sobre el primer, hasta la afirmación final,

\footnotetext{
${ }^{675}$ ROUSSEAU, Jean-Jacques. O contrato social, livro 1, cap. 6.

${ }^{676}$ Derecho común.

${ }^{677}$ BOBBIO, Norberto. O positivismo jurídico cit., p. 31.

${ }^{678}$ Llamado también de 'derecho estatutario', porque los actos que le constituían se llamaban 'estatutos'.

${ }^{679}$ BOBBIO, Norberto. O positivismo jurídico cit., p. 32.
} 
según la cual el derecho común tiene vigor y es aplicable solamente con la permissione principis ${ }^{680}$. En ese período, todo el derecho se reduce a derecho del Estado.

En esa perspectiva, se recuerdan lecciones de Hobbes ${ }^{681}$ :

Antes de someternos a la autoridad del Estado, nadie poseía por sí mismo, pero todo era común a todos. Por lo tanto, pregunto: ¿de dónde surgió la propiedad individual? Del Estado. Y ¿dónde la encontró el Estado? En el hecho de que todos le transfirieron sus derechos.

Para el Código Civil brasileño (CC/2002), los bienes son públicos o privados. Los públicos son del Estado y los demás, de los particulares. Son públicos los bienes del dominio $^{682}$ nacional pertenecientes a las personas jurídicas de derecho público interno, todos los demás son particulares, sea cual fuere la persona a que pertenecieren ${ }^{683}$. Los públicos pueden ser: de uso común general, tales como los ríos, mares, estradas e plazas; de uso especial, tales como edificios o terrenos destinados a servicio o establecimiento de administración federal, estadual territorial o municipal, incluso de sus autarquías; y los dominicales, que constituyen el patrimonio de las personas jurídicas de derecho público, como objeto de derecho personal o real, de cada una de esas entidades. ${ }^{684}$

La CF/1988 definió el medio ambiente como bien de uso común general. ${ }^{685}$

En la Roma clásica, había la categoría de bienes, que eran de propiedad del pueblo, y nadie podía disponer de ellos individualmente. Colectivamente, cualquier ciudadano podría salir en su defensa, accionando el magistrado que, incluso, aceptaba el homenaje del postulante más habilitado a hacer prosperar la demanda de interés colectivo. Los romanos no conocieron esa ficción jurídica denominada 'persona jurídica'. El pueblo romano era una corporación, y como tal, todos sus miembros, constituyendo un cuerpo (cives Romani), eran coproprietarios del patrimonio común

\footnotetext{
${ }^{680}$ Apenas cuando sea aprobado por el soberano.

${ }^{681}$ HOBBES, T. Do cidadão. São Paulo: Martins Fontes, 1996. Citação encontrada em Bobbio, Norberto. Locke e o Direito Natural. Trad. Sérgio Bath. $2^{\mathrm{a}}$ ed., Editora da Universidade de Brasília, Brasília-Brasil: 1997, p. 190.

${ }^{682}$ La expresión del dominio no encierra derecho de propiedad, pero, de dominio eminente, cuando el Estado cela por el bien para garantir su uso y respeto por todos.

683 Art. 98.

684 Art. 99, incisos I a III.

${ }^{685}$ Art. 225, CF/1998.
} 
(res publicae), patrimonio al cual se aplicaban reglas diferentes de aquellas a que eran sometidos los bienes particulares. La ciudad, el municipio, el princeps, el aerarium populi Romani (los impuestos recaudados) eran, individualmente, una corporación ${ }^{686}$.

4.8. La evolución de la representación de la sociedad en la gestión de aguas en Brasil. Las definiciones y clasificaciones de Sociedades Civiles. La génesis

A despecho de acciones aisladas de algunos Estados, la respuesta institucional a la protección ambiental en Brasil ocurrió con la creación de la Secretaria Especial de Medio Ambiente (SEMA) en 1973. Sin embargo, se considera como hito histórico de la protección y gestión sostenible del medio ambiente y de los recursos naturales la promulgación de la Ley Federal 6.938, de 31 de agosto de 1981, que instituyó la Política Nacional del Medio Ambiente (PNMA) y creó el Sistema Nacional del Medio Ambiente (SISNAMA). Este es integrado por el Consejo Nacional de Medio Ambiente (CONAMA) y por los órganos y entidades de la Unión, de los Estados, del Distrito Federal, de los Municipios y por las fundaciones instituidas por el Poder Público, responsables por la protección y mejoría de la calidad ambiental.

Sin embargo, la legislación supra referenciada dejaba poco espacio para la participación de la sociedad civil (o participación pública) en la protección do medio ambiente. Esto puede ser atribuido, entre otros factores, al hecho de ella haber sido promulgada anteriormente a la Constitución Federal de 1988 y en un momento en el cual la filosofía administrativa derivaba de políticas que no consideraban la descentralización y la participación civil en la gestión pública. Importante recordar que, aquella época, el País estaba saliendo de un régimen totalitario que se inició con la Revolución de 1964 y se prolongó hasta 1989, con la elección de Tancredo Neves por el Colegio Electoral, se inició la llamada Nueva República.

La sociedad debe ser considerada como el conjunto de relaciones tanto de los individuos entre sí, como de los Estados unos con los otros, que tienden a organizarse y vivir dentro de un orden internacional. En el ámbito internacional, ejerce su función constitutiva en tres dimensiones: (1) como explicación para el funcionamiento del

\footnotetext{
${ }^{686}$ PILATI, José Isaac. Função social e tutelas coletivas: contribuição do direito romano a um novo paradigma. Disponible en: <http://dirrom.blogspot.com.br/2008/01/funo-social-e-tutelas-coletivas.html>.
} 
sistema internacional; (2) como respuesta teórica para la ausencia de una autoridad única en la esfera internacional; y (3) como categoría central para estudiar la difusión mundial del sistema europeo occidental ${ }^{687}$.

A partir de estas dimensiones, pueden ser presentados tres sentidos para el término Sociedad Internacional: (1) Realismo, dentro del cual Sociedad Internacional se refiere a la relación entre los Estados, basada en normas compartidas y entendimientos: (2) Transnacionalismo, que se refiere a la emergencia de lazos no estatales de economía, política, asociación, cultura y de ideología que trascienden las fronteras de los Estados y constituyen sociedad que ultrapasa esas mismas fronteras; y (3) Homogeneidad, que indica relación entre la estructura interna de las sociedades y la de la Sociedad Internacional, investigando de qué manera, teniendo en cuenta las presiones internacionales, los Estados son compelidos a la conformación de sus arreglos internos con los demás, porque el funcionamiento interno de los Estados se relaciona con los procesos internacionales ${ }^{688}$.

La Sociedad Civil no está estabilizada dentro de su composición tampoco dentro de sus reivindicaciones. El éxito de la fórmula es el producto de la mezcla de cierto número de individuos y de organizaciones comprometidas con la acción política y social. Ha sido favorecida por todas las Conferencias de las Naciones Unidas que se sucedieron desde la Conferencia de Estocolmo sobre la población, las mujeres, la vivienda y el medio ambiente. Cada una de estas es la ocasión de un encuentro con la participación de cuantidad enorme de actores que, normalmente, no tienen acceso al ámbito internacional y, por lo tanto, la mezcla (generalmente por intermedio de organizaciones no-gubernamentales - ONG) asegura cierta perennidad de movilización política $^{689}$.

El término Sociedad Civil, asociado a la idea de democracia política y social y da participación de ciudadanos, tanto en la formación del espíritu público como en las decisiones de interés de la colectividad, fue usado por primera vez por Aléxis de

\footnotetext{
${ }^{687}$ BATIFFOL, H. La Philosophie du Droit [1960]. 7ème ed. Paris: PUF, 1987, p. 37. ${ }^{688}$ HALLIDAY, F. Repensando as relações internacionais. Editora da UFRGS e FAPA, Porto Alegre: 1999, p. 107.

${ }^{689}$ GHERARI, H.; SZUREK, S. (Coord.). L'émergence de la société civile internationale: vers la privatisation du droit international? Cedin Paris X, Cahiers Internationaux, n. 18, 1991. Dijon-Quetigny: Imprimerie Darantière, 2003, p. 20.
} 
Tocqueville (1805-1859) en su obra 'Democracia en la América' ${ }^{690}$. Hoy, traspasado para la esfera internacional, el término indica, al mismo tiempo, una realidad y un mito político poderosamente movilizador ${ }^{691}$.

El Derecho Internacional, variable de la Sociedad Internacional, siempre evolucionó acompañando la infraestructura económica, política, social y tecnológica mundial, de donde extrae su fundamento. En ese contexto, en el Cuadro 5 es presentada la evolución del Derecho Internacional desde la Antigüedad, pasando por la Edad Media y por el Estado Moderno hasta los días actuales ${ }^{692}$. Cuadro 7 - Evolución del Derecho Internacional 693

\begin{tabular}{|c|c|c|c|}
\hline ANTIGÜEDAD & EDAD MÉDIA & $\begin{array}{c}\text { EDAD } \\
\text { MODERNA }\end{array}$ & $\begin{array}{c}\text { EDAD } \\
\text { CONTEMPORÁNEA }\end{array}$ \\
\hline $\begin{array}{l}\text { 3.100 a.C. } \\
\text { Tratado entre } \\
\text { Ennatum y los } \\
\text { hombres de } \\
\text { Umma } \\
\text { (Mesopotamia), } \\
\text { determinando } \\
\text { fronteras. } \\
\text { 1.694 a.C. (siglo } \\
\text { XVIII sic) } \\
\text { Código de } \\
\text { Hammurabi } \\
\text { (Babilonia) } \\
\text { 1291 a.C. } \\
\text { Tratado entre } \\
\text { Ramsés II y } \\
\text { Hattisuli (Hititas) }\end{array}$ & $\begin{array}{l}\text { Iglesia } \\
\text { Poder papal, } \\
\text { incluso } \\
\text { confiriéndole la } \\
\text { facultad de } \\
\text { libertar un jefe } \\
\text { de Estado del } \\
\text { cumplimento de } \\
\text { un tratado. } \\
\text { Paz de Dios } \\
\text { Beligerantes y } \\
\text { no beligerantes. } \\
\text { Tregua de Dios } \\
\text { 15:00h de } \\
\text { sábado a las } \\
\text { 06:00h de lunes }\end{array}$ & $\begin{array}{l}\mathbf{2 4 . 1 0 . 1 6 4 8} \\
\text { Paz de Westfalia: } \\
\text { Tratados de } \\
\text { Münster } \\
\text { (católicos) y de } \\
\text { Osnabrück } \\
\text { (protestantes) } \\
\mathbf{1 7 1 3} \\
\text { Paz de Utrecht: } \\
\text { Principio del } \\
\text { equilibrio de } \\
\text { fuerzas y del } \\
\text { equilibrio europeo. } \\
\text { Primeros } \\
\text { sistematizadores } \\
\text { del Derecho } \\
\text { Internacional: }\end{array}$ & $\begin{array}{l}\text { Revolución Francesa } \\
\text { Principio de las } \\
\text { nacionalidades, } \\
\text { Declaración Universal } \\
\text { de los Derechos del } \\
\text { Hombre (1795). } \\
\text { Santa Alianza (1815): } \\
\text { Rusia / Prusia / Austria } \\
\text { + Inglaterra + Francia. } \\
\text { Doctrina Monroe } \\
\text { (1823): } \\
\text { Pan-americanismo. } \\
\text { Acta General de } \\
\text { Berlín (1885): } \\
\text { Colonialismo. }\end{array}$ \\
\hline
\end{tabular}

\footnotetext{
${ }^{690}$ Para Tocqueville, una sociedad democrática posee tendencia a creer en la perfección indefinida de la naturaleza humana y, en ella, predomina la movilidad social. En una sociedad democrática, lo normal es reinar la pasión por la igualdad, que tendrá más fuerza que el gusto por la libertad. La sociedad se preocupará más en apagar las desigualdades entre los individuos y los grupos que en mantener el respeto por la legalidad y la independencia personal.

${ }^{691}$ GHERARI, H.; SZUREK, S. (Coord.). L’émergence de la société civile internationale, 2003, cit., p. 18.

${ }^{692}$ SILVA, R. L. Direito Internacional Público. $2^{\mathrm{a}}$ ed., Editora Del Rey, Belo Horizonte: 2002, p. 20.

${ }^{693}$ SILVA, R. L. Direito Internacional Público cit., p. 21.
} 


\begin{tabular}{|c|c|c|c|}
\hline $\begin{array}{l}\text { de alianza contra } \\
\text { los enemigos, paz } \\
\text { perpetua, entrega } \\
\text { de criminales } \\
\text { políticos y } \\
\text { comercio. } \\
\text { Judea } \\
\text { Talmud } \\
\text { Grecia } \\
\text { Arbitraje, tratados, } \\
\text { inviolabilidad de } \\
\text { los embajadores, } \\
\text { asilo. } \\
\text { Roma } \\
\text { Jus Gentium, Jus } \\
\text { Fetiale, tratados } \\
\text { (amicitia, } \\
\text { hospitium e } \\
\text { foedus). } \\
\text { India } \\
\text { Código de Manu. }\end{array}$ & 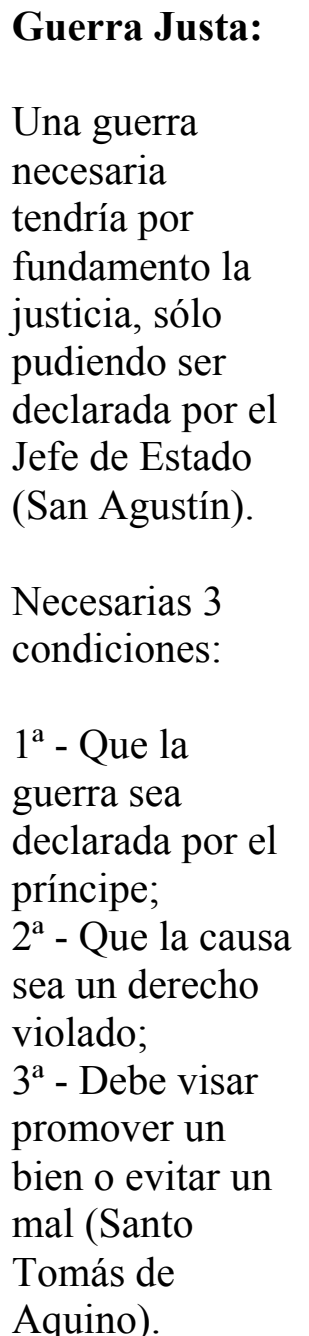 & $\begin{array}{l}\text { Francisco de } \\
\text { Vitoria (1486 - } \\
\text { 1546): } \\
\text { Guerra por causa } \\
\text { justa, libertad de } \\
\text { los mares; } \\
\text { Francisco Suárez } \\
\text { (1548 - 1617): } \\
\text { Guerra justa = } \\
\text { causa justa } \\
\text { Alberico Gentilli } \\
\text { (1552 - 1608): } \\
\text { Guerra pública = } \\
\text { guerra privada } \\
\text { (bandidismo); } \\
\text { Hugo Grotius } \\
\text { (1585 - 1645): } \\
\text { Primer estudio } \\
\text { sistemático del } \\
\text { Derecho } \\
\text { Internacional. }\end{array}$ & $\begin{array}{l}\text { Conferencia de Paz } \\
\text { de La Haya (1899 / } \\
\text { 1907): } \\
\text { Corte Permanente de } \\
\text { Arbitraje. } \\
\text { I Guerra Mundial: } \\
\text { Liga de las Naciones. } \\
\text { II Guerra Mundial: } \\
\text { ONU. } \\
\text { Nuevo Orden } \\
\text { Internacional (1989): } \\
\Rightarrow \text { política } \\
\Rightarrow \text { económica } \\
\Rightarrow \text { comercial } \\
\text { ○ Redefinición del rol } \\
\text { do Estado. }\end{array}$ \\
\hline
\end{tabular}

Para Fausto Quadros ${ }^{694}$, las Comunidades son “organizaciones supranacionales, y, como tal, representan una nueva categoría de organizaciones internacionales. La supranacionalidad consiste en nueva descubierta del Derecho Internacional, aunque con naturaleza especial y con especificidades". Por ello el Derecho Comunitario parece constituirse un sector del Derecho Internacional Público. No obstante, el Derecho Comunitario no es Derecho Supranacional. La confusión y la consecuente imprecisión a respecto de la idea de supranacionalidad se deben a los vocablos 'supranacional' y 'supranacionalidad'.

La supranacionalidad entró en el vocabulario jurídico por la mano del art. $9^{\circ}$ del $\mathrm{CECA}^{695}$, en su versión francesa, donde se contenían dos referencias a ella: en el

\footnotetext{
${ }^{694}$ QUADROS, F. Direito das Comunidades Europeias e Direito Internacional Público. Gráfica de Coimbra, Lisboa-Portugal: 1991, p. 40.

${ }^{695}$ CECA: Comunidad Europea del Carbón y del Acero.
} 
par.(5) se imponía a los miembros de la Alta Autoridad que, en el desempeño de sus cargos, se abstuvieran de cualquier acto incompatible con el caractère supranational de sus funciones; y en el par.(6), los Estados miembros se comprometían a respetar ese carácter o esa naturaleza supranacional ${ }^{696}$.

Los movimientos transnacionales de opinión se desarrollan y se ramifican por todo el mundo, ejerciendo influencia sobre las decisiones tomadas por diplomáticos y políticos. Sociedad de redes, esta reciente efervescencia de comunidades sin fronteras teje la tela de sus solidaridades espontaneas al sabor de la instantaneidad de las comunicaciones que ofrece la cibernética. Ultrapasan, a veces, el código y los estatutos preestablecidos de los poderes intermedios que los gobernantes tienen, hace mucho tiempo, consintiendo a los representantes poseedores de intereses colectivos.

Considerando, decididamente, que la diplomacia es demasiado seria para que se deje solamente entregue a los diplomáticos, los actores no estatales se designan para ejercer tal función, arriesgándose a cometer arbitrariedades. Estos actores reivindican un derecho de injerencia en los asuntos de Estados, contestando la exclusividad del poder estatal de decisión, tanto en el orden internacional como en ámbito interno.

Delante de la extrema rapidez del desarrollo del fenómeno de la sociedad civil, sociólogos, estudiosos de política y juristas reflexionan sobre la necesidad de hacer la conexión entre la Sociedad y el Estado.

En su discurso anual de 2000, el Secretario General de las Naciones Unidas, Kofi Anan, se dio cuenta del fenómeno, refiriéndose "a una nueva forma de gobernar en una escala global" 697 .

Ahora, el Derecho Internacional debe saber contar con una "opinio juris" distinta de los Estados, pero también vehiculada a los intereses colectivos proyectados y ensanchados a una escala mundial. Los ámbitos interno e internacional pasan a ser confundidos, ya que no existen fronteras entre ambos.

El término Sociedad Civil surgió en Francia al largo del siglo XVI, como traducción del latín societas civilis, en que hay equivalencia a la koinonia politike que, en la visión de Aristóteles, quiere decir Comunidad Política.

Para Habib Gherari y Sandra Szurek ${ }^{698}$, la sociedad civil se constituye construcción intelectual que sirve a (o se encaja en) un proyecto político como fórmula

\footnotetext{
${ }^{696}$ QUADROS, F. Direito das Comunidades Europeias e Direito Internacional Público cit., p. 131.

${ }^{697}$ New forms of global governance.
} 
utilizada, durante siglos, por diversos autores de la filosofía política recibiendo, conforme la época, sentidos diferentes. Se recuerda, por cierto, como ocurrió la expansión de la sociedad civil internacional, que fue iniciada por medio de las siguientes relaciones económicas:

Los Lombardos, comerciantes en el siglo XVI - Con la introducción de la morera durante la Edad Media en la región de la Lombardía (posesión de los Lombardos), en Italia, la alimentación de los gusanos de seda fue iniciada y alcanzó tal éxito que, en 1906, la producción era de 15 millones de kilos de los capullos en 16.000 telares, con 36.000 trabajadores. Otras industrias surgieron como consecuencia, trabajando la madera y el hierro para maquinaria, carruajes, líneas férreas, muebles, iniciándose negocios, empresas y gráficas. El crecimiento del comercio generó pronto la necesidad de rápido medio de comunicación y las carreteras, hasta 1840 , totalizaban 850.000 millas y los ferrocarriles 1.115 .000 millas, cubriendo aquella región italiana e interconectándola a los demás centros comerciales;

Los banqueros de Ginebra y de Londres en el siglo XVIII - El origen del sistema capitalista en el pasaje de la Edad Media para la Edad Moderna fecha del renacimiento urbano y comercial de los siglos XIII y XIV, surgiendo en Europa una nueva clase social, la burguesía, que buscaba el lucro por medio de actividades comerciales. En ese contexto, surgieron también los banqueros y cambistas, cuyas ganancias estaban relacionadas al dinero que circulaba, en una economía que estaba en pleno desarrollo. Historiadores y economistas identifican en esa burguesía y también en los cambistas y banqueros los ideales embrionarios del sistema capitalista: lucro, acumulación de riquezas, control de los sistemas de producción y expansión de los negocios. Ese período se extendió del siglo XVI al XVIII, iniciándose con las Grandes Navegaciones y Expansiones Marítimas Europeas, momento en el que la burguesía mercante comenzó a buscar riquezas en otras tierras fuera de Europa. Los comerciantes y la nobleza estaban en la búsqueda de oro, plata, especias y materias-primas no encontradas en suelo europeo, siendo financiados por reyes y nobles. Así, pueden ser identificadas las siguientes características capitalistas: búsqueda de lucros, uso de mano-de-obra asalariada, moneda sustituyendo el sistema de trueques, relaciones bancarias, fortalecimiento del poder de la burguesía y desigualdades sociales.

${ }^{698}$ GHERARI, H.; SZUREK, S. (Coord.). L'émergence de la société civile internationale cit., p.20. 
Siempre invocada en oposición a cualquier cosa, la sociedad civil cambia de contenido de acuerdo con su contradicción. Cuando se opone a la turba, a la multitud, asume el sentido de comunidad política (Aristóteles), de sociedad política (Hobbes), y de visión de Estado (Rousseau). Cuando se opone a la ciudad de Dios, donde reinan la justicia y la concordancia sobre el pueblo unido por el amor recíproco (San Agustín), exprime la ciudad terrestre (donde domina el amor de sí mismo, en que cada individuo busca aprovechar los bienes de este mundo en el seno de una multitud que conviene administrar por las leyes y una coerción necesaria) ${ }^{699}$. Para Marx, “en una ciudad terrestre por esencia conflictiva, la sociedad civil es la expresión de una lucha de clase radical entre la burguesía y el proletariado" ${ }^{\natural 00}$.

Presente a partir de Aristóteles hasta el inicio del siglo XX, la noción de sociedad civil conoció un período de eclipse en la época de la Segunda Guerra Mundial. En decadencia en Europa, fue redescubierta por la ciencia política americana en los años 1960-1970. Se colocó, en la época, en una lógica oponente entre ciudadanos y el Estado, y dentro de una reivindicación de mayor autonomía de los primeros ante la presencia vista como excesiva por parte del segundo. El impreciso neoliberalismo que aturdió el mundo entero después de los “años Reagan” contribuyó para la popularización de esta acepción de la sociedad civil.

"El concepto neoliberal considera que la Sociedad Civil consiste en un conjunto social que traspasa la estricta lógica individual y se sitúa en alguna parte entre el mercado y el Estado" ${ }^{701}$. Para Dallari ${ }^{702}$, se puede afirmar que predomina, actualmente, la aceptación de que la sociedad es resultante de una necesidad natural del hombre, sin excluir la participación de su consciencia y de su voluntad.

En los años 70-80, la utilización mediadora de la noción de sociedad civil y su introducción en el lenguaje corriente fueron favorecidas por los movimientos en reacción contra el totalitarismo del este europeo y contra las dictaduras militares en Latinoamérica. La fórmula pasó a determinar una sociedad que escapa al control del

\footnotetext{
${ }^{699}$ GHERARI, H.; SZUREK, S. (Coord.). L’émergence de la société civile internationale cit., p.18.

${ }^{700}$ Esta visión se opone a la visión angelical del Estado pacificador que garante el interés de los individuos y da a la sociedad civil su existencia política efectiva, versión moderna de la Ciudad Celeste. GHERARI, H.; SZUREK, S. (Coord.) L’émergence de la société civile internationale cit., p.19.

${ }^{701}$ GHERARI, H.; SZUREK, S. (Coord.). L'émergence de la société civile internationale cit., p. 19.

${ }^{702}$ DALLARI, Dalmo de Abreu. Elementos de Teoria Geral do Estado cit., p. 19.
} 
Estado, existiendo y exprimiéndose en los locales de socialización más o menos clandestinos y, eventualmente, alterando su función anterior. Se puede constatar que la fuerza del movimiento Solidarnosc en Polonia marcó etapa decisiva en la alteración de los rumbos políticos. Para Timothy $\mathrm{Ash}^{703}$, la sociedad civil continuó a existir en Checoslovaquia en los años más sombríos. En contexto diferente a todas las otras consideraciones, la antropóloga Fariba Adelkah ${ }^{704}$ mostró como una sociedad civil vibrante, en Irán, se exprimía por medio de la utilización de jardines públicos, cafés y de locales funerarios ${ }^{705}$.

Transpuesto al ámbito internacional a partir de 1990, el concepto de sociedad civil ha sido utilizado en los foros internacionales, buscándose definir fórmulas de reglas inéditas, especialmente en el dominio de la economía política y en el desarrollo social. La invocación de las Comunidades de Base (Grass Root Organizations), organizaciones no-gubernamentales (ONG), pueblos indígenas, además de movimientos sociales, se convirtió ejercicio obligatorio en las discusiones internacionales ${ }^{706}$.

La sociedad civil puede ser encontrada en gran parte de los tratados multilaterales y relacionados, desde cerca o desde lejos, al desarrollo sostenible. Actualmente se acepta, al menos en el discurso, que la gestión mundial por una redefinición permanente de las reglas de ámbito internacional (la gobernabilidad) no puede tener efectividad si las poblaciones no estuvieren comprometidas.

Al inicio del siglo 21, la sociedad civil ha sido invocada eventualmente por los liberales contra la empresa del Estado y por los adversarios de la globalización para quienes la sociedad civil, al contrario, es una fuerza que se opone a las leyes deshumanas de un capitalismo decadente. Para estos últimos, la invocación a la sociedad civil es una crítica de la modernidad en sus tres dimensiones: individualidad, burocratización, comercialización (trilogía puesta en evidencia por Anthony Giddens). Son recusadas, por lo tanto, la reducción del individuo a su dimensión única de homo economicus racional egoísta; la dominación de administraciones nacionales e

\footnotetext{
${ }^{703}$ ASH, T. G. La Chaudière: Europe Centrale, 1980-1990. Paris: Gallimard, 1990.

${ }^{704}$ ADELKAH, F. Etre moderne en Iran. Paris: Karthala, 1998.

${ }^{705}$ GHERARI, H.; SZUREK, S. (Coord.). L'émergence de la société civile internationale cit., p. 19.

${ }^{706}$ GHERARI, H.; SZUREK, S. (Coord.). L'émergence de la société civile internationale cit., p. 20.
} 
internacionales dogmáticas e ignorantes de las realidades sociales; y la colocación en el mercado de todos los aspectos de la vida humana individual y colectiva ${ }^{707}$.

De esta forma, la invocación a la sociedad civil es la invocación a una forma de participación política que permite a las poblaciones tener sus demandas atendidas sobre los objetivos que les interesa, así como a una forma de democratización de ámbito internacional, en el cual las elites ya no serán las únicas a tener acceso a la palabra y a las decisiones internacionales.

El concepto de sociedad civil no es, por lo tanto, un concepto definido de una realidad social, pero un concepto crítico utilizado con la finalidad de movilización ${ }^{708}$.

\subsubsection{La representación de la sociedad civil en el Sistema de Recursos}

\section{Hídricos}

A partir de la Ley francesa 1.245, de 16 de diciembre de 1964, las acciones públicas pasaron a ser más dirigidas al agua tanto en términos cualitativos como cuantitativos, especialmente los primeros ${ }^{709}$. Según Cid Tomanik Pompeu ${ }^{710}$, sin perjuicio de la visión sobre el desarrollo regional por valles o cuencas hidrográficas, la protección de las aguas contra contaminación y respectiva legislación existen, igualmente, hace muchos años.

Son citados: el Rivers Pollution Prevention Act (1876), de Gran Bretaña; el Rivers and Harbors Act (1899), de los Estados Unidos de América, y la ley francesa de 1917 sobre establecimientos peligrosos, insalubres e incómodos ${ }^{711}$.

El modelo francés, con alteraciones decurrentes de las respectivas peculiaridades de cada país, fue seguido por varios Estados, incluso Brasil que, hasta

\footnotetext{
${ }^{707}$ GHERARI, H.; SZUREK, S. (Coord.). L'émergence de la société civile internationale cit., pp. 19-20.

${ }^{708}$ GHERARI, H.; SZUREK, S. (Coord.). L'émergence de la société civile internationale cit., p. 20.

${ }^{709}$ CHERET, I. Experiência francesa e implantação da organização francesa de água: lei francesa de 1964. Anais do Seminário Internacional de Gestão de Recursos Hídricos: MME/DNAEE, Minter/Sema, SEPLAN/CNPq e CEEIBH, vol.1. Brasília, 1983, p.82.

${ }^{710}$ POMPEU, Cid Tomanik. Direito de Águas no cit., p. 328.

${ }^{711}$ POMPEU, Cid Tomanik. Regime Jurídico da Polícia das Águas Públicas: polícia da qualidade. São Paulo: CETESB, 1976, p.53-103. Información constante también en Cid Tomanik POMPEU, Direito de Águas no cit., p. 328.
} 
llegar al sistema vigente, pasó por inúmeras experiencias que sirvieron de punto de partida.

Se puede constatar que desde cuando comenzaron a ser discutidos los principios y las directrices del modelo de gestión o de aguas que sería implantado (y eso aún en la segunda mitad dos años 1980), los técnicos, gestores y especialistas debatían entre sí con el desafío de romper el desinterés de la sociedad y promover el comprometimiento de políticos y legisladores. Se entendió que la estrategia debería ser elaborada basada en dos ejes de actuación: por un lado, en la necesidad de movilización de fuerzas de apoyo. Eso se concretizaría en la idea de que personas empeñadas en llevar adelante una política de recursos hídricos moldeada por los valores ambientalistas precisarían dedicarse a la tarea de despertar el interés y conquistar el apoyo de fuerzas sociales significativas. Por otro, que sería imperativa la reorganización de las estructuras estatales. Estos dos ejes se interrelacionarían y se realimentarían ${ }^{712}$.

\subsubsection{La representación de la sociedad civil en el Consejo Nacional de}

\section{Recursos Hídricos}

El Consejo Nacional de Recursos Hídricos (CNRH) fue inicialmente objeto de reglamentación por el Decreto 2.612, de 03 de junio de 1998, ocupando la instancia más alta en la jerarquía del SINGREH, creado por la Ley 9.433, de 08 de enero de 1997, y se reúne en carácter ordinario a cada seis meses en Distrito Federal ${ }^{713}$.

Para comprender la representación de la sociedad civil en el CNRH, cumple mencionar sus responsabilidades:

I - promover la articulación del planeamiento de recursos hídricos con los planeamientos nacional, regional, estaduales y de los sectores usuarios; II - arbitrar, en

${ }^{712}$ MARTINS, C. E. Uma estratégia para a politização da questão dos recursos hídricos. Revista Águas e energia Elétrica, São Paulo, n. ${ }^{\circ}$ 12, 1987, p. 50.

713 "E extraordinariamente, sempre que convocado pelo Presidente, por iniciativa própria ou a requerimento de um terço de seus membros. $\S 1^{\circ} \mathrm{A}$ convocação para a reunião ordinária será feita com trinta dias de antecedência e para a reunião extraordinária, com quinze dias de antecedência. $\S 2^{\circ}$ As reuniões extraordinárias poderão ser realizadas fora do Distrito Federal, sempre que razões superiores assim o exigirem, por decisão do Presidente do Conselho Nacional de Recursos Hídricos" (art. $5^{\circ}$, Decreto 5.263/2004). 
última instancia administrativa, los conflictos existentes entre Consejos Estaduales de Recursos Hídricos; III - deliberar sobre los proyectos de aprovechamiento de recursos hídricos cuyas repercusiones sobrepasen el ámbito de los Estados en que serán implantados; IV - deliberar sobre las cuestiones que le hayan sido encaminadas por los Consejos Estaduales de Recursos Hídricos o por los Comités de Bacía Hidrográfica; V analizar propuestas de alteración de la legislación pertinente a recursos hídricos y la Política Nacional de Recursos Hídricos; VI - establecer directrices complementares para implementación de la Política Nacional de Recursos Hídricos, aplicación de sus instrumentos y actuación del Sistema Nacional de Gerenciamiento de Recursos Hídricos; VII - aprobar propuestas de institución de los Comités de Cuenca Hidrográfica y establecer criterios generales para la elaboración de sus regimientos; VIII - (VETADO); IX - acompañar la ejecución y aprobar el Plano Nacional de Recursos Hídricos y determinar las providencias necesarias al cumplimiento de sus metas; (Redacción dada por la Ley 9.984, de 2000); X - establecer criterios generales para la otorga de derechos de uso de recursos hídricos y para el cobro por su uso.

Desde 1997, hubo varias revocaciones ${ }^{714} \mathrm{y}$, conforme el art. $2^{\circ}$ del Decreto 5.263, de 05 de noviembre de 2004, los 57 miembros del Consejo se encuentran así distribuidos:

El Consejo Nacional de Recursos Hídricos será presidido por Ministro de Estado del Medio Ambiente y tendrá la siguiente composición: I - un representante de cada uno de los siguientes Ministerios: (a) de Hacienda; (b) de Planeamiento, Presupuesto y Gestión; (c) de Relaciones Exteriores; (d) de los Transportes; (e) de Educación; (f) de la Justicia; g) de la Salud; (h) de Cultura; (i) de Desarrollo Agrario; (j) de Turismo; e 1) de las Ciudades; II - dos representantes de cada uno de los siguientes Ministerios: (a) de la Integración Nacional; (b) de la Defensa; (c) del Desarrollo, Industria y Comercio Exterior; (d) de Agricultura, Pecuaria y Abastecimiento; y (e) de Ciencia y Tecnología; III - tres representantes de cada uno de los siguientes Ministerios:

\footnotetext{
${ }^{714}$ Decreto 2.612, de 3 de junho de 1998, que regulamenta o Conselho Nacional de Recursos Hídricos, e dá outras providências. Decreto 3.978, de 22 de outubro de 2001 (revogado): altera dispositivos do Decreto $\mathrm{n}^{\circ}$ 2.612, de 3 de junho de 1998. Decreto 4.174, de 25 de março de 2002 (revogado): altera dispositivos do Decreto $\mathrm{n}^{\circ}$ 2.612, de 3 de junho de 1998. Decreto 4.613, de 11 de março de 2003 (revogado). Decreto 5.263, de 05 de novembro de 2004. Diário Oficial da União, 06 de novembro de 2004.
} 
(a) de Medio Ambiente; y (b) de Minas y Energía; IV - un representante de cada una de las siguientes Secretarías Especiales de la Presidencia de la República: (a) de Acuicultura y Pesca; y (b) de Políticas para las Mujeres.

El inciso V establece ser diez los representantes de los Consejos Estaduales de Recursos Hídricos, y que sus suplentes deberán, obligatoriamente, ser de otro Estado.

El inciso VI define en doce los representantes de usuarios de recursos hídricos (art. $2^{\circ}, \S 3^{\circ}$, Decreto 5.263/2004). Eses y sus suplentes serán indicados, respectivamente: I - dos, por la irrigación; II - dos, por las instituciones encargadas de la prestación de servicio público de abastecimiento de agua y de alcantarillado sanitario; III - dos, por las concesionarias y autorizadas de generación hidroeléctrica; IV - dos, por el sector hidroviario, siendo uno indicado por el sector portuario; V - tres, por la industria, siendo uno indicado por el sector minero metalúrgico; y VI - uno, por los pescadores y usuarios de recursos hídricos con la finalidad de ocio y turismo.

El inciso VII del art. $2^{\circ}$ establece en seis los representantes de organizaciones civiles de recursos hídricos (art. $2^{\circ}, \S 4^{\circ}$, Decreto 5.263/2004). El $\S 5^{\circ}$ determina que los representantes de que tratan los incisos V, VI e VII sean designados por el Presidente del Consejo Nacional de Recursos Hídricos, teniendo mandato de tres años, y el $\S 6^{\circ}$ que el titular de la Secretaria de Recursos Hídricos del Ministerio do Medio Ambiente sea el Secretario-Ejecutivo del Consejo.

Las atribuciones y la forma de funcionamiento del $\mathrm{CNRH}$, establecidas por el Decreto que lo reglamentó, fueron detalladas por el Regimiento Interno. El Consejo delibera, durante sus reuniones, de carácter ordinario o extraordinario, mediante la aprobación de Resoluciones y Mociones. Las Resoluciones son emitidas visando el establecimiento de directrices y normas de carácter general y de amplitud nacional y, las Mociones visan acatar manifestaciones o propuestas de estudios sobre una cuestión o cualquier problema que refleje en los recursos hídricos y demande un posicionamiento del Consejo. Conforme el $\S 9^{\circ}$ del art. $2^{\circ}$ del Decreto 5.263/2004, "el regimiento interno del Consejo Nacional de Recursos Hídricos definirá la forma de participación de instituciones directamente interesadas en asuntos que estén siendo objeto de análisis por el plenario".

Las Cámaras Técnicas fueron creadas para el desarrollo de actividades pertinentes a las atribuciones previamente definidas, objetivando subsidiar los Consejeros en sus deliberaciones, en los diferentes asuntos traídos a aquel Órgano. Son 
ellas: Asuntos Legales e Institucionales; Plano Nacional de Recursos Hídricos; Análisis de Proyectos; Integración de Procedimientos, Acciones de Otorga y Acciones Reguladoras; Gestión de los Recursos Hídricos Transfronterizos; Ciencia y Tecnología; Aguas Subterráneas; y Cobro por el Uso de los Recursos Hídricos.

Las Cámaras se encuentran en pleno funcionamiento, poseyendo composición que varía entre siete a trece Consejeros, con mandato de dos años. Las reuniones ocurrieron en media a cada 30 días y son abiertas, pudiendo contar con la participación de invitados, especialistas en los temas en discusión o de cualquier otro interesado. Por el Regimiento Interno del CNRH, cada entidad o órgano representado pode participar, simultáneamente, caso le interese, en todas las Cámaras Técnicas Permanentes. Es importante resaltar que el resultado de esa manera de actuar fue la ampliación de la base de discusión con la sociedad, usuarios y entidades gubernamentales, posibilitando el comprometimiento, mensualmente, de alrededor de 200 técnicos de todo el país en discusiones sobre asuntos de alta relevancia para la implementación de la Política y el funcionamiento del Sistema Nacional de Gerenciamiento de Recursos Hídricos ${ }^{715}$.

Desde su instalación y hasta $2007^{716}$, el CNRH realizó varias reuniones en que fueron aprobadas 83 Resoluciones.

\subsubsection{La representación de la sociedad civil en los Consejos Estaduales de Recursos Hídricos}

Los Consejos son órganos colegiados integrantes del Sistema Estadual de Gestión de Recursos Hídricos (SEGRHI), con atribuciones normativas, consultivas y deliberativas. Son formados por el presidente, plenario, Secretaria Ejecutiva y Cámaras Técnicas, cuyos miembros electos representan órganos públicos, sociedad civil y usuarios de agua.

Las funciones del presidente, electo para mandato de dos años, son presidir las reuniones, nombrar y dar pose al Plenario, encaminar al Gobernador del Estado las

\footnotetext{
${ }^{715}$ KETTELHUT, J. T. S. Breve histórico do Conselho Nacional de Recursos Hídricos, 2003. Disponible en <http://www.cnrh-srh.gov.br/>. Acceso en:16-03-2009.

${ }^{716}$ Conselho Nacional de Recursos Hídricos: conjunto de normas legais. Ministério do Meio Ambiente, Secretaria de Recursos Hídricos e Ambiente Urbano. 5ª ed. Brasília: MMA, 2008, pp. 95-102.
} 
deliberaciones del Consejo y cuidar por el cumplimiento de las disposiciones del Regimiento Interno.

La Secretaria Ejecutiva del Consejo desempeña, entre otras actividades, la coordinación y elaboración del Plan Estadual de Recursos Hídricos y el soporte administrativo a las actividades del Plenario y de las Cámaras Técnicas.

El Decreto 2.612/1998, que reglamentó el CNRH, había definido en cinco el número de indicados por los Consejos Estaduales de Recursos Hídricos, lo que estaba en desacuerdo con la Ley 9.433/1997, por la cual el Colegiado es compuesto por representantes indicados por los Consejos Estaduales, o sea, todos. El nuevo reglamento duplicó el número, pero aún no abarcó la totalidad de las unidades federadas. El hecho de los suplentes pertenecieren a diferentes Estados no garante que tengan el mismo punto de vista de los respectivos titulares, los cuales pueden hasta ser contrarios. Los Estados que se sintieren discriminados pueden pleitear el cumplimiento de la ley.

\subsubsection{La representación de la sociedad civil en los Comités (federales) de} Cuencas Hidrográficas

El Comité funciona como el parlamento de la Cuenca correspondiente, donde son tomadas las principales decisiones políticas sobre la utilización de las aguas. Compite al Presidente de la República instituir comités de Cuenca en ríos de dominio de la Unión. Implícitamente, cabe a quien de derecho, en el ámbito estadual, instituir Comités de Cuenca en ríos del dominio de los Estados ${ }^{717}$. El número de representantes de cada sector y los criterios para su indicación en los Comités federales son establecidos en los respectivos Regimientos, limitada a la representación de los Poderes Ejecutivos federal, estaduales, distrital y municipales a la mitad del total de los $\operatorname{miembros}^{718}$.

Así determina el art. 38 de la Ley 9.433/97:

Compite a los Comités de Cuenca Hidrográfica, en el ámbito de su área de actuación: I - promover el debate de las cuestiones relacionadas a recursos hídricos y articular la actuación de las entidades intervinientes; II - arbitrar, en primera instancia

\footnotetext{
${ }^{717}$ MILARÉ, Édis. Direito do Ambiente cit., p. 406.

${ }^{718}$ POMPEU, Cid Tomanik. Direito de Águas no cit., p. 339.
} 
administrativa, los conflictos relacionados a los recursos hídricos; III - aprobar el Plan de Recursos Hídricos de la cuenca; IV - acompañar la ejecución del Plan de Recursos Hídricos de la cuenca y sugerir las providencias necesarias al cumplimiento de sus metas; V - proponer al Consejo Nacional y a los Consejos Estaduales de Recursos Hídricos las acumulaciones, derivaciones, captaciones y lanzamientos de poca expresión, para efecto de exención de la obligatoriedad de otorga de derechos de uso de recursos hídricos, de acuerdo con los dominios de estos; VI - establecer los mecanismos de cobro por el uso de recursos hídricos y sugerir los valores a ser cobrados; VII (VETADO); VIII - (VETADO); IX - establecer criterios y promover el reparto de coste de las obras de uso múltiple, de interés común o colectivo. Párrafo único. De las decisiones de los Comités de Cuenca Hidrográfica cabrá recurso al Consejo Nacional o a los Consejos Estaduales de Recursos Hídricos, de acuerdo con su esfera de competencia.

La alusión por la ley a los Consejos Estaduales de Recursos Hídricos es inconstitucional, porque invade área de competencia organizacional de las unidades federadas $^{719}$.

El art. 39 establece la formación de los Comités:

Los Comités de Cuenca Hidrográfica son compuestos por representantes: I - de la Unión; II - de los Estados y del Distrito Federal cuyos territorios se sitúen, aunque parcialmente, en sus respectivas áreas de actuación; III - de los Municipios situados, en totalidad o en parte, en su área de actuación; IV - de los usuarios de las aguas de su área de actuación; V - de las entidades civiles de recursos hídricos con actuación comprobada en la cuenca. $\S 1^{\circ}$ El número de representantes de cada sector mencionado en este artículo, así como los criterios para su indicación, serán establecidos en los regimientos de los comités, limitada la representación de los poderes ejecutivos de la Unión, Estados, Distrito Federal y Municipios a la mitad del total de miembros. $\S 2^{\circ}$ En los Comités de Cuenca Hidrográfica de Cuencas de ríos fronterizos y transfronterizos de gestión compartida, la representación de la Unión deberá incluir un representante del Ministerio de las Relaciones Exteriores. $\S 3^{\circ}$ En los Comités de Cuenca Hidrográfica de Cuencas cuyos territorios abarquen tierras indígenas deben ser incluidos representantes: I - de la Fundación Nacional del Indio - FUNAI, como parte de la representación de la

\footnotetext{
${ }^{719}$ POMPEU, Cid Tomanik. Direito de Águas no cit., p.340.
} 
Unión; II - de las comunidades indígenas allí residentes o con intereses en la cuenca. $\S$ $4^{\mathrm{o}}$ La participación de la Unión en los Comités de Cuenca Hidrográfica con área de actuación restricta a cuencas de ríos bajo dominio estadual, será en la forma establecida en los respectivos regimientos. Art. 40. Los Comités de Cuenca Hidrográfica serán dirigidos por un Presidente y un Secretario, electos entre sus miembros.

Los Comités tienen como área de actuación la totalidad de una cuenca hidrográfica, la sub-cuenca de tributario del curso principal de la cuenca o de su tributario y grupo de cuencas o sub-cuenca contiguas.

En virtud de la autonomía de los Estados, en el sentido de organizarse y ser regidos por Constituciones y leyes que adoptaren, los comités estaduales son bastante variados, de acuerdo con las características de cada unidad federada ${ }^{720}$.

En los regimientos de los Comités (federales) de Cuencas Hidrográficas, deben constar:

(1) el número de votos de los representantes de los Poderes Ejecutivos de la Unión, Estados, Distrito Federal y Municipios, obedecido el límite de 40\% (cuarenta por ciento) del total de votos; (2) el número de representantes de entidades civiles, proporcional a la población residente en el territorio de cada Estado y del Distrito Federal, cuyos territorios se sitúen, aunque parcialmente, en sus respectivas áreas de actuación, con al menos $20 \%$ (veinte por ciento) del total de votos, garantida la participación, mínima, de un representante por Estado y del Distrito Federal; (3) el número de representantes de los usuarios de los recursos hídricos, con obediencia al límite de 40\% (cuarenta por ciento) del total de votos; y (4) el mandato de los representantes y los criterios de renovación o sustitución ${ }^{721}$.

Las reuniones y votaciones de los Comités son públicas, dando a su convocación amplia divulgación, con encaminamiento simultáneo, a los representantes, de la documentación completa sobre los asuntos objeto de deliberación. Las alteraciones en los regimientos de los Comités solamente pueden ser votadas en reunión extraordinaria convocada especialmente para ese fin, y con antecedencia mínima de treinta días, debiendo ser aprobadas por el voto de $2 / 3$ (dos tercios) de los miembros del Comité $^{722}$.

\footnotetext{
${ }^{720}$ POMPEU, Cid Tomanik. Direito de Águas no cit., p. 340.

${ }^{721}$ Resolução CNRH 24/2002.

${ }^{722}$ Resolução CNRH 24/2002.
} 
En la institución de Comité de Cuenca Hidrográfica $(\mathrm{CBH})$ cuyo río principal sea del dominio de la Unión, la propuesta puede ser encaminada al CNRH si es subscrita por al menos tres entre las siguientes categorías ${ }^{723}$ : (1) Secretarios de Estado responsables por la gestión de recursos hídricos de, al mínimo, 2/3 (dos tercios) de los Estados de la cuenca hidrográfica respectiva, considerado, cuando fuere el caso, el Distrito Federal; (2) Alcaldes Municipales cuyos municipios tengan territorio en la cuenca hidrográfica, en porcentual de al menos 40\% (cuarenta por ciento); (3) entidades representativas de usuarios legalmente constituidas, de al menos tres de los usos indicados en las letras 'a' y 'f' del art. 14 de la Resolución 5/2000 724 , con, al mínimo, cinco entidades; y (4) entidades civiles de recursos hídricos, con actuación comprobada en la cuenca hidrográfica, que podrán ser cualificadas como Organizaciones de la Sociedad Civil de Interés Público (OSCIP), legalmente constituidas, con, al mínimo, diez entidades, pudiendo este número ser reducido, a criterio del Consejo, en función de las características locales y justificativas elaboradas por, al menos, tres entidades civiles $^{725}$.

Se percibe, por lo expuesto arriba, que, de acuerdo con la ley, existe al menos un norte en la participación de la sociedad en los Comités de Cuenca, y que Brasil ya recorrer buena distancia en la implantación del sistema integrado de gestión de las aguas y en el uso de sus instrumentos. Sin embargo, todavía hay un largo camino adelante ${ }^{726}$.

\footnotetext{
${ }^{723}$ Resolução CNRH 5, de 10 de abril de 2000, art. $9^{\circ}$.

${ }^{724}$ Resolução CNRH 5, de 10 de abril de 2000, art.14 Os usos sujeitos à outorga, mencionados no inciso III (*) do art. $8^{\circ}$ desta Resolução, serão classificados pelo Conselho Nacional de Recursos Hídricos, em conformidade com a vocação da bacia hidrográfica, entre os seguintes setores usuários: a) abastecimento urbano, inclusive diluição de efluentes urbanos; b) indústria, captação e diluição de efluentes industriais; c) irrigação e uso agropecuário; d) hidroeletricidade; e) hidroviário; f) pesca, turismo, lazer e outros usos não consuntivos. (*) III - número de representantes dos usuários dos recursos hídricos, cujos usos dependem de outorga, obedecido quarenta por cento do total de votos; a) o usuário somente terá direito a voto se sua outorga estiver plenamente vigente. b) participação dos usuários será habilitada, à medida que sejam expedidas outorgas pelos poderes públicos competentes, considerando os critérios de renovação a serem definidos pelo Comitê. Disponible $<$ http://www.cnrh.gov.br/index.php?option=com_content\&view=article\&id=14>.

${ }^{725}$ Siendo objetivo de esas organizaciones atender al ciudadano-usuario. Cid Tomanik Pompeu entiende ser inaplicables al caso. Direito de Águas no cit., p. 299, nota 57.

${ }^{726}$ São Paulo (Estado). Gestão participativa das águas, 2004, cit., p.51.
} 
Ocurre que el hombre actúa fundamentalmente por una necesidad natural, porque asociarse a otros seres humanos es para él condición esencial de vida. Solamente con tales uniones y con el concurso de los otros es que el hombre puede conseguir todos los medios necesarios para la satisfacción de sus necesidades y, por lo tanto, conservarse y mejorar, consiguiendo alcanzar los fines de su existencia. Desde 1948, Oreste Ranelletti ${ }^{727}$ afirma que solo en la convivencia y con la cooperación de sus pares el hombre puede beneficiarse de las energías, conocimientos, producción y de la experiencia de los otros, acumuladas a través de generaciones, obteniendo, así, los medios necesarios para poder alcanzar sus ideales, desarrollando todo su potencial de perfeccionamiento, en el campo intelectual y técnico.

Se sabe que la gestión de aguas sin la participación de los usuarios se hace deficiente o incompleta. En varias localidades, fueron instituidas Asociaciones de Usuarios de las Aguas, con la finalidad de organizarlos para esa importante tarea ${ }^{728}$. Cumple, también, a los usuarios, promover la protección ambiental y de desarrollo sostenible de los recursos hídricos ${ }^{729}$.

Las entidades asociativas ligadas a las aguas, como la Asociación Brasileira de Aguas Subterráneas (ABAS); la Asociación de Ingeniería Sanitaria y Ambiental (ABES); la Asociación Brasileña de Irrigación y Drenaje (ABID); la Asociación Brasileña de Recursos Hídricos (ABRH); la Asociación Brasileña de Geología de Ingeniería (ABGE); y la Sociedad Brasileña de Geología (SBG), además de participar de varios organismos públicos colegiados, ha sido excelente foro de debate para las cuestiones hídricas y geológicas bajo los más diversos aspectos ${ }^{730}$.

\footnotetext{
${ }^{727}$ RANELLETTI, Oreste. Istituzioni di diritto pubblico: il nuovo diritto pubblico della repubblica italiana. 13 $3^{\text {a }}$ edizione, Parte Generale. Milano: Dott. A. Giuffrè, 1948, p. 3. Citación encontrada en DALLARI, Dalmo de Abreu. Elementos de Teoria Geral do Estado. $29^{\mathrm{a}}$ ed., Editora Saraiva, São PauloBrasil: 2010, p. 11.

${ }^{728}$ Costa, F. J. L. o sistema de gerenciamento de recursos hídricos do Estado do Paraná: um modelo com base em associações de usuários. In: MONTICELLI, J. J. (Coord.) Organismos de bacias hidrográficas. Editora Semads, Rio de Janeiro: 2002, pp. 74-78.

${ }^{729}$ POMPEU, Cid Tomanik. O direito de águas no cit., p. 73.

${ }^{730}$ POMPEU, Cid Tomanik. O direito de águas no cit., p. 73.
} 
Según Novaes y Jacobi ${ }^{731}$, un comité puede ser considerado eficiente cuando consigue cumplir al máximo sus objetivos de garantir la cuantidad y la cualidad de las aguas en la cuenca, pero, también, cuando consigue actuar como foro democrático, pluralista y participativo, no sólo porque esa es la mejor estrategia para la buena gestión de las aguas, pero como un objetivo en sí mismo.

La abertura de la gestión pública a la participación de la sociedad civil es proceso que necesita ser constantemente revisado y actualizado. Además de eso, depende del desarrollo de una cultura de aprendizaje para el avance y el perfeccionamiento de las organizaciones colegiadas $y$ de todos los actores relacionados $^{732}$. No se puede negar la diversidad de abordaje y soluciones encontradas en momentos distintos de la historia brasileña. Sin embargo, a pesar de las diferencias, algunas características han permanecido constantes y, entre ellas, una postura de reacción a los problemas encontrados; la baja efectividad de los planeamientos; la discontinuidad de los programas y políticas; la falta de evaluación sistemática de los resultados; la definición de estructuras centralizadas para tomadas de decisión; la ausencia o la fragilidad de mecanismos para poner en ecuación los conflictos y el uso; y el alcance limitado de la atención a la población ${ }^{733}$.

En la visión de $\operatorname{Vargas}^{734}$, desde la revolución industrial, el modelo de gestión orientado por la estrategia de la oferta y de la extensiva explotación del recurso que marcó el desarrollo de las técnicas y políticas volcadas a la gestión de las aguas ha sido sustituida. Actualmente, existe un modelo orientado por la estrategia de la demanda, de gestión sostenible y corresponsabilizada, fundada en el principio de la participación de los usuarios, planeadores y decisores políticos, en todos los niveles. El Cuadro 8 presenta las características de la lógica de la oferta y de la lógica de la demanda.

\footnotetext{
${ }^{731}$ NOVAES, R. C; JACOBI, P. R. Comitês de bacia, capital social e eficiência institucional, Anais, 2002, cit.

${ }^{732}$ São Paulo (Estado). Gestão participativa das águas, 2004, cit., p.51.

${ }^{733}$ São Paulo (Estado). Gestão participativa das águas, 2004, cit., p.52.

${ }^{734}$ VARGAS, M. C. O gerenciamento integrado dos recursos hídricos como problema socioambiental. Ambiente \& sociedade, São Paulo, ano II, n.5, $2^{\circ}$ sem. 1999.
} 
Cuadro 8 - Modelos de Gestión de Aguas ${ }^{735}$

\begin{tabular}{|l|l|}
\hline Modelo extensivo - lógica de la oferta & Modelo intensivo - lógica de la demanda \\
\hline $\begin{array}{l}\text { Oferta social y espacialmente } \\
\text { generalizada de grandes volúmenes de } \\
\text { agua potable a precios subsidiados. }\end{array}$ & $\begin{array}{l}\text { Cobro por el uso y la contaminación del } \\
\text { agua, tarifa que cubre integralmente la } \\
\text { recuperación de costes directos e indirectos. }\end{array}$ \\
\hline $\begin{array}{l}\text { Evacuación inmediata de las aguas } \\
\text { servidas mediante redes subterráneas de } \\
\text { alcantarillado y drenaje urbano } \\
\text { instaladas en el espacio público. }\end{array}$ & $\begin{array}{l}\text { Técnicas alternativas de saneamiento y } \\
\text { drenaje, que implican participación activa de } \\
\text { propietarios y usuarios (alcantarillado de } \\
\text { condominio, cuencas de retención, etc.). }\end{array}$ \\
\hline $\begin{array}{l}\text { Estímulo al consumo abundante, } \\
\text { negligencia con desperdicios y la } \\
\text { manutención de las redes. }\end{array}$ & $\begin{array}{l}\text { Incitación social a la economía de agua, por } \\
\text { medio de programas que abarcan la } \\
\text { conservación de recursos hídricos. }\end{array}$ \\
\hline $\begin{array}{l}\text { Ausencia de responsabilidad y } \\
\text { desconocimiento de las mejores } \\
\text { prácticas de consumo de los usuarios. }\end{array}$ & $\begin{array}{l}\text { Responsabilidad, información y } \\
\text { participación de los usuarios, con } \\
\text { investigaciones sobre consumo, } \\
\text { comportamiento y percepción. }\end{array}$ \\
\hline $\begin{array}{l}\text { Abordaje correctivo de la } \\
\text { contaminación hídrica, mediante } \\
\text { innovaciones en tecnología de } \\
\text { tratamiento. }\end{array}$ & $\begin{array}{l}\text { Abordaje preventivo, con políticas de } \\
\text { protección a los manantiales subterráneos y } \\
\text { superficiales. }\end{array}$ \\
\hline $\begin{array}{l}\text { Competición abierta entre usos } \\
\text { concurrentes de los recursos hídricos } \\
\text { por la apropiación sectorizada de los } \\
\text { manantiales. }\end{array}$ & $\begin{array}{l}\text { Uso múltiple de los manantiales por medio } \\
\text { del planeamiento descentralizado, integrado } \\
\text { participativo de las cuencas hidrográficas. }\end{array}$ \\
\hline $\begin{array}{l}\text { Negligencia con la conservación, la } \\
\text { protección y la recuperación de la } \\
\text { calidad de las aguas. }\end{array}$ & $\begin{array}{l}\text { Políticas de conservación de los recursos } \\
\text { hídricos, protección y recuperación de } \\
\text { manantiales. }\end{array}$ \\
\hline
\end{tabular}

Por todo lo que fue abordado, entendemos que la promoción del uso racional y la economía de agua, evitando consumos exagerados, desperdicios y pérdidas, debe ser directriz y objetivo permanente de la gestión de aguas y no sólo recurso utilizado durante períodos de crisis y de estiaje.

Además de las campañas publicitarias institucionales y educacionales dirigidas a los usuarios domésticos, con políticas de incentivo a la reducción de la demanda, un programa de uso racional del agua debe contemplar amplios sectores e incluir los usuarios urbanos, industriales y rurales.

\footnotetext{
${ }^{735}$ Adaptado de VARGAS, M. C. O gerenciamento integrado dos recursos hídricos como problema socioambiental cit.
} 
Como el ser humano posee la necesidad de la cooperación de sus pares para la consecución de los fines de su existencia, y consciente de que necesita de la vida social, el hombre la desea y la busca favorecer. Eso no ocurre con los irracionales, que se agrupan por mero instinto y de manera siempre uniforme, no registrando perfeccionamiento $^{736}$.

En este sentido, se retoma Rousseau ${ }^{737}$, mismo considerando el desfase del tiempo (1762 y 2010): cuando es imposible aumentarse la fuerza de cada individuo, el hombre, consciente de que la libertad y la fuerza constituyen los instrumentos fundamentales de su conservación, piensa en una forma de combinarlos. El acto de asociación produce un cuerpo moral y colectivo, que es el Estado, como mero ejecutor de decisiones, siendo 'soberano' cuando ejercita un poder de decisión. Por lo tanto, el soberano sigue siendo el conjunto de las personas asociadas, mismo después de creado el Estado, siendo la soberanía inalienable e indivisible.

La 'voluntad general' deriva de la asociación de los individuos que actúan siempre en el interés del todo, que engloba el interés de cada componente. Así, tiene voluntad propia, lo que no significa una simple suma de voluntades individuales, sino una síntesis, y tiende, de forma constante, a la utilidad pública. En otras palabras, "el contractualismo ejerció y sigue ejerciendo gran influencia práctica, debiéndose reconocer su presencia distintiva en la idea contemporánea de democracia”,738.

La Constitución Federal de 1988, considerada el hito formal del proceso de redemocratización del País, afirmó la participación del ciudadano mediante representantes o directamente como uno de los fundamentos de la República. Se puede observar, en la esfera infraconstitucional, la proliferación de normas jurídicas estableciendo mecanismos de participación en las más variadas áreas, más algunos estudios realizados en el ámbito de la ciencia política demuestran que tales espacios de gestión colegiada y participativa han sido mal aprovechados.

Desde la década de 70 surgió la preocupación con la contaminación en general, con enfoque más preciso en aguas. Los Estados más industrializados (São Paulo y Río de Janeiro) pasaron a legislar sobre el controle de contaminación de las aguas, del aire y

\footnotetext{
${ }^{736}$ DALLARI, Dalmo de Abreu. Elementos de Teoria Geral do Estado cit., p. 11;

${ }^{737}$ ROUSSEAU, Jean-Jacques. O Contrato Social, Livro I, Cap. VI. Entendimiento constante en DALLARI, Dalmo de Abreu. Elementos de Teoria Geral do Estado cit., p. 17.

${ }^{738}$ DALLARI, Dalmo de Abreu. Elementos de Teoria Geral do Estado cit., p. 19.
} 
del suelo, controlando todas las aguas de su territorio y sin limitación cuanto a se dominio. En 1991, São Paulo editó la Ley 7.663, estableciendo la participación de los ciudadanos en los organismos colegiados, materia transcrita en la ley federal de 1997.

A grande evolución de la gestión de recursos hídricos e inclusión de las aguas en Constituciones y leyes estaduales, incluyendo la participación de los municipios, de la sociedad civil y de los usuarios, fueron acogidas por la Ley Federal 9.433/1997.

Conforme autores aquí citados, el ordenamiento jurídico brasileño sobre las aguas debería y podría haber sido actualizado, principalmente en lo que se refiere a las áreas asoladas por las sequías y cuanto a la Región Amazónica. Eso se refiere a la necesidad de actualización del Código de Aguas, que es de 1934. Además, mismo la Ley 9.433/1997 que enfocó las aguas en su sistema de gestión, principios, institutos, acciones del poder Público y estructura del SINGREH, no trató del derecho de aguas en totalidad.

Siguiendo Constituciones y leyes estaduales, las diversas organizaciones y asociaciones proactivas en defensa de las aguas han tenido relevante importancia para el efectivo cumplimiento de las políticas federales.

En realidad, pasados dieciocho años de la Ley que creó el SINGREH, diversos aspectos jurídicos todavía se encuentran sin definición de reglas complementares, y muchos de los problemas relacionados a los aspectos prácticos de la gestión de recursos hídricos aún no poseen definición legal, provocando impasses y controversias en la búsqueda de las soluciones y acciones. Esa situación lleva a un proceso de no uniformidad, o mismo de falta de fundamento jurídico, en algunos casos, de las acciones de gestión de los recursos hídricos en todo el territorio brasileño. Además de estos aspectos jurídicos, hay la cuestión de la participación de la sociedad, uno de los factores indispensables para la solución de los problemas hídricos.

La gestión integrada, descentralizada y participativa del agua de los Comités (federales) de Cuenca ni siempre resulta en la democratización del proceso decisorio y en el aumento de su eficiencia. Se constituye proceso complejo y de largo plazo y, por ser reciente, todavía carece del enfrentamiento de muchos retos: participación inclusiva, representación responsable, apoyo financiero, técnico y administrativo. Sin embargo, sus miembros poseen formación y experiencia multidisciplinar, lo que puede contribuir mucho en el proceso, pero la falta de apoyo institucional pode condenar los Comités (federales) a irrelevancia. 


\subsection{Las necesidades de regulación y los problemas encontrados}

En las últimas décadas las políticas y legislaciones sobre aguas han reconocido que la gestión de los recursos hídricos no puede más ser concebida y practicada de manera aislada, sin levar en cuenta los demás recursos naturales existentes en el territorio $^{739}$.

Se debe observar que la participación en los órganos colegiados de gestión no significa transferencia de poder y responsabilidad del Estado para la sociedad civil, sino una forma de control directo de los ciudadanos sobre decisiones de políticas públicas, que afectan intereses colectivos y la vida de cada uno. Sin embargo, en un país con cultura política marcada por relaciones clientelistas e paternalistas, la implantación de un modelo de gestión participativa acaba siendo permeada por contradicciones y ambigüedades. Además de los conflictos y divergencias de intereses, los agentes que están comprometidos se deparan con asimetrías de poder, conocimientos y habilidades, legitimidad de representaciones, prácticas arraigadas de gestión tecnocrática y centralizada, es decir, con todos los tipos de dificultades ${ }^{740}$.

Para que haya eficiencia institucional, entendemos que los siguientes parámetros pueden ser considerados:

- La realización de los objetivos y metas previstos en la legislación, en los estatutos y regimientos internos;

- La elaboración de un Plan de Cuenca, o, al menos, de una Agenda de Prioridades;

- La asignación de recursos en las áreas priorizadas en el Plan de Cuenca;

- La pluralidad de las fuerzas sociales representadas en el escenario;

- La legitimidad de la representación;

- La participación y la presencia de quórum en las reuniones;

${ }^{739}$ BURCHI, S. Tendenze ed orientamenti attuali nel diritto delle acque: un' analisi di diritto comparato. Rivista di Diritto Agrario, Milano, Giuffrè, n. 2, 1991, p. 200.

${ }^{740}$ São Paulo (Estado). Gestão participativa das águas cit., p. 51. 
- El comprometimiento del Comité con cuestiones regionales relevantes relativas a los recursos hídricos, al medio ambiente y al desarrollo económico y social de la Cuenca ${ }^{741}$.

El Consejo Nacional de Recursos Hídricos es el órgano de la cúpula del Sistema. Su composición actual se resiente de mayor participación de los Estados, conforme preconiza el inciso II del art. 34 de la Ley 9.433/97, que hace referencia a representantes indicados 'por los' Consejos Estaduales, lo que significa 'todos' y no 'algunos'. Una de las principales acciones de este colegiado, que todavía no se hizo sentir, es la de la articulación del planeamiento de recursos hídricos con los planeamientos nacional, regional, estaduales y de los sectores usuarios. Son articulaciones intragubernamentales e intergubernamentales de grandísima importancia para el desarrollo sostenible del país, porque de ellas debe venir la observancia de los planes nacionales de energía eléctrica, navegación y otros, por los Planes de Cuenca Hidrográfica y, por consecuencia, por el Plano Nacional de Recursos Hídricos ${ }^{742}$.

La historia del nuevo modelo de gestión de recursos hídricos en Brasil es reciente, y por eso es natural que Comités de Cuenca se deparen con retos para implementar el modelo de gestión preconizado en la Política Nacional de Recursos Hídricos. Algunos de estos están relacionados al establecimiento de participación inclusiva y representación responsable, transferencia de autoridad de decisión significativa a los Comités, apoyo financiero, técnico y administrativo para asegurar su funcionamiento, e implementación de sus decisiones, entre otros. La falta de apoyo institucional puede condenar los Comités a la irrelevancia. Sin embargo, la capacidad de innovación y emprendedurismo de los Comités se puede constituir en factor adicional e importante para que alcancen mejor desempeño dentro de un contexto institucional limitante ${ }^{743}$.

\footnotetext{
${ }^{741}$ NOVAES, R. C.; JACOBI, P. R. Comitês de bacia, capital social e eficiência institucional: reflexões preliminares sobre influências recíprocas. Associação Nacional de Pós-graduação e Pesquisa em Ambiente e Sociedade, São Paulo, I Encontro Anual. Anais, 2002.

${ }^{742}$ POMPEU, Cid Tomanik. O papel do Conselho Nacional de Recursos Hídricos (CNRH). In: MACHADO, C.. J. S. (Org.) Gestão das Águas. Ciência \& Cultura Núcleo Temático, Sociedade Brasileira para o Progresso da Ciência, São Paulo, n. ${ }^{\circ}$ 4, out.-dez. 2003, pp. 42-44.

${ }^{743}$ FFRANK, B. (Org.) Comitês de Bacia sob o olhar dos seus membros cit., p. 52.
} 
Los Comités de Cuenca presentan composición bastante diversificada, mostrando que un mismo segmento puede incluir diversas categorías. El segmento sociedad civil, en particular, es muy heterogéneo, abarcando entidades de naturaleza variada (entidades religiosas, organizaciones no-gubernamentales, sindicatos de trabajadores, universidades, y otros) y así, su clasificación es de difícil caracterización. Sin embargo, el porcentual de los miembros de la sociedad civil encima del mínimo determinado por la legislación sugiere que estos grupos, tradicionalmente excluidos del proceso de tomada de decisión, están siendo contemplados en los Comités de Cuenca ${ }^{744}$. Para algunos, en los Comités de Cuenca, industriales y productores rurales de grande porte y, principalmente, usuarios públicos, eran los que tenían poder de influencia en las decisiones. Estudios cualitativos más profundizados indican haber todavía su predominancia en negociaciones específicas en el ámbito de los Comités ${ }^{745}$.

La democracia es elemento fundamental en los procesos participativos, de manera que las decisiones tomadas en el ámbito de los Comités deben tener en cuenta el interés público, al revés de favorecer determinados grupos. A pesar de evaluar positivamente la democracia en los procesos de decisión, algunos miembros de los Comités revelan haber sectores más influyentes que otros en la definición de las pautas de reuniones y actividades del Comité. Entienden, por lo tanto, que hay desigualdades, principalmente de conocimiento, entre los miembros. La reducción de estas desigualdades sería esencial para que se estableciera un proceso decisorio más democrático, en que todos tuvieran condiciones de argumentar y negociar sobre sus intereses y necesidades, así como influenciar las decisiones y acciones de los Comités de forma más equitativa. La falta de confianza en el gobierno, en las instituciones y en los grupos constituye óbice que debe ser superado para establecerse una gestión más participativa en la gestión brasileña del agua ${ }^{746}$.

Examinando la cuestión por otro enfoque, Cid Tomanik Pompeu afirma que los planeamientos de recursos hídricos no lograrán sus objetivos si no consideraren, por ejemplo, los planes nacionales para aprovechamiento de los potenciales

\footnotetext{
${ }^{744}$ FRANK, B. (org.) Comitês de Bacia sob o olhar dos seus membros cit., p. 14.

${ }^{745}$ ABERS, R. N.; FORMIGA-JOHNSSON, R. M.; FRANK, B.; KECK, M. E; LEMOS, M. C. Organismos de bacia hidrográfica e democratização da gestão das águas: análise preliminar do Survey Marca d'Água. XVII Simpósio Brasileiro de Recursos Hídricos, São Paulo, Anais, 2007.

${ }^{746}$ FRANK, B. (Org.) Comitês de Bacia sob o olhar dos seus membros cit., p. 39.
} 
hidroenergéticos y para los transportes acuaviarios, así como los de la actividad minera y del saneamiento básico, que deben servir de condicionantes para la elaboración de los Planes de Cuencas Hidrográficas y del $\mathrm{PNRH}^{747}$.

Cabe al CNRH establecer 'criterios generales para la otorga de derechos de uso de recursos hídricos' y para el respectiva 'cobro'. En la visión de Cid Tomanik Pompeu $^{748}$, aunque bajo el aspecto de la definición del instituto de derecho a ser adoptado (autorización, permisión y concesión), estos criterios todavía no han sido definidos por el CNRH, que sólo hace referencia al 'acto administrativo,749, la ley que creó la ANA estatuye que las otorgas por ella emitidas sean mediante 'autorización administrativa ${ }^{750}$

Pese al hecho de que el Decreto 4.613/2003, alterado por el Decreto 5.263/2004, declare que la composición del CNRH podría ser revista después de dos años, contados de su publicación, a otro decreto le cumpliría alterarlo a cualquier tiempo. La forma de participación de instituciones directamente interesadas en asuntos que estén siendo objeto de análisis por el plenario es definida en el regimiento interno del Consejo, aprobado por la mayoría absoluta de sus miembros ${ }^{751}$.

En razón de la autonomía de los Estados, hay restricta previsión de competencia de los Consejos Estaduales en la Ley sobre la PNRH. Hay quien entienda que sería eficaz que los Estados organizasen sus Consejos de la misma forma que los respectivos Comités de Cuenca Hidrográfica, lo que, en realidad, es hecho, por ejemplo, por São Paulo, donde los colegiados son de tres partes, formados por el Estado, por los municipios y por la sociedad civil.

\footnotetext{
${ }^{747}$ Aprovado pela Resolução CNRH 58/2006.

${ }^{748}$ POMPEU, Cid Tomanik. Direito de Águas no cit., p. 290.

${ }^{749}$ Resolução CNRH 16/2001.

${ }^{750}$ Lei $9.984 / 2000$.

${ }^{751}$ POMPEU, Cid Tomanik. Direito de Águas no cit., p. 292. E1 Decreto 3.978, de 22 de octubre de 2001, había alterado o art. $7^{\circ}$, parágrafo único, del Decreto 2.612/1998, disponiendo que el regimiento interno del CNRH sería aprobado por sus miembros, e no más por mayoría absoluta, y publicado mediante Portaría del Ministro de Estado del Medio Ambiente. El Decreto 4.613/2003, que revocó ambos, en el art. $7^{\circ}$ no más repitió la redacción anterior, y otra vez declaró que sería 'por la mayoría absoluta de sus miembros'. Siendo así, la aprobación del regimiento, por la Portaría 377, de 19 de septiembre de 2003, de la Ministra de Estado, cabría a la Resolución del CNRH, de la cual era presidente.
} 
Conforme previsión de la Ley 9.433/1997, el SINGREH es compuesto por diversos integrantes, entre ellos, los Comités de Cuenca Hidrográfica (CBH's). Estos órganos de naturaleza colegiada son la base de este sistema y, de acuerdo con el inciso II del artículo 38, de la Ley $n^{\circ} 9.433 / 97$, poseen competencia para arbitrar conflictos por el uso de recursos hídricos. ${ }^{752}$.

En el ámbito de la Unión, los valores oriundos del cobro por el uso del agua son de competencia de la ANA, que puede delegarla a las Agencias de Agua según el inciso III del art. 44 de la Ley 9.433/1997 $7^{753}$.

Aunque el CNRH haya decidido que las otorgas deben obedecer a la clase en que estuviere encuadrado el cuerpo hídrico, en conformidad a la legislación ambiental; y que la otorga no libra del cumplimiento de la legislación ambiental pertinente o de las exigencias que sean hechas por otros órganos y entidades, las otorgas relativas a la calidad aún necesitan de mejor reglamentación ${ }^{754}$.

Como una agencia en cada cuenca dificultaría la ejecución de actividades a ellas atribuidas, el Estado de Río Grande do Sul fue dividido en tres grandes regiones hidrográficas estaduales, creando una Agencia de Aguas para cada una, teniendo como fundamento la Ley Estadual 10.350, de 30 de diciembre de $1994^{755}$.

Según Milaré ${ }^{756}$, para la gestión de cuencas compartidas es indispensable que ambos los poderes otorgantes (Unión y Estados), titulares del dominio de aguas, entren en acuerdo a respeto de la política de precios a adoptar, evitando conflictos desnecesarios.

Para Vivacqua ${ }^{757}$, la inexistencia de normas que reglen la práctica de arbitraje y el control de las actividades jurisdiccionales de los Comités de Cuencas Hidrográficas; la debida protección jurídica de los derechos e intereses en juego; y la garantía de más

\footnotetext{
${ }^{752}$ VIVACQUA, M. D. Gestão de Recursos Hídricos, Comitês de Bacia Hidrográfica e processo administrativo de arbitragem de conflitos pelo uso da água, 2004, cit., p. 12.

${ }^{753}$ Art. 44, III, Lei 9.433/1997 - efetuar, mediante delegação do outorgante, a cobrança pelo uso de recursos hídricos.

${ }^{754}$ POMPEU, Cid Tomanik. Direito de Águas no cit., p. 230.

${ }^{755}$ OLIVEIRA, C. M. Sistema Nacional de Gerenciamento de Recursos Hidricos e as alternativas para o formato jurídico das Agências de Água no Brasil cit., p. 48.

${ }^{756}$ MILARÉ, Édis. Direito do Ambiente cit., p. 408.

${ }^{757}$ VIVACQUA, M. D. Gestão de Recursos Hídricos, Comitês de Bacia Hidrográfica e processo administrativo de arbitragem de conflitos pelo uso da água cit., p. 12.
} 
una forma de acceso a la justicia, que justifique la necesidad de abordar el tema del arbitraje de conflictos de interés por el uso de recursos hídricos por parte de los CBH's.

Conforme Coelho y $\mathrm{Nobre}^{758}$, con relación a la ampliación de los espacios institucionales para decisiones compartidas, no hay clara definición en relación a las atribuciones de cada entidad, una vez que la inserción de nuevos actores en el proceso decisorio resulta muchas veces en conflicto de competencias. Un ejemplo clásico de superposición de competencias entre órganos colegiados deliberativos y el administrador público puede ser encontrado en el caso del Estado de São Paulo, en el que la gestión de los recursos hídricos es dividida entre la Compañía Estadual de Saneamiento Básico (SABESP); el Departamento de Aguas y Energía Eléctrica (DAEE) y la hoy Compañía Ambiental del Estado de São Paulo (CETESB), además del Consejo Estadual de Recursos Hídricos (CERH) y los Comités de las Cuencas Hidrográficas $(\mathrm{CBH})$ ubicados total o parcialmente en su territorio.

Consultado a respeto del tema, Cid Pompeu no comulga de la opinión de Coelho y Nobre, porque cada entidad tiene la respectiva competencia definida en ley o reglamento, sin superposiciones. La gestión de la cuantidad compete al DAEE en lo que se refiere a las otorgas y su fiscalización. La Secretaria de Agua del Medio Ambiente (SMA), el Consejo y los Comités actúan de acuerdo con las competencias definidas. A la CETESB incumbe el control de la calidad. La SABESP no participa de la gestión, ya que es sólo una usuaria. En los colegiados y en las Agencias de Cuenca de São Paulo, un tercio es del Estado, un tercio de los Municipios y un tercio de la sociedad civil. Ya sucedió (Cuenca del Piracicaba, Capivari y Jundiaí) de predominar la voluntad de los Municipios y de la sociedad civil, contra la del Estado, titular del agua, que acabó votando en el mismo sentido que ellos.

En la actualidad, puede ser constatada la escasa existencia de mecanismos de coordinación y cooperación intergubernamentales, tanto verticales como horizontales, cohibiendo la creación de canales de negociación que disminuyan la competición entre los entes federados ${ }^{759}$.

\footnotetext{
${ }^{758}$ COELHO, V. S.; NOBRE, M. (Org.) Participação e Deliberação: Teoria Democrática e experiências Institucionais no Brasil Contemporâneo. São Paulo, Editora 34, 2004.

${ }^{759}$ SOUZA, C. Federalismo, desenho constitucional e instituições federativas no Brasil pós-1988 cit., p. 119 , jun. 2005.
} 


\subsection{El agua en Brasil}

De manera sencilla, el agua líquida puede ser clasificada de dos formas, agua salada, encontrada en mares y océanos, y agua dulce, encontrada en acuíferos, ríos, lagos y represas ${ }^{760}$. El principal enfoque será dado al agua dulce, sin adentrar a su especie agua mineral, que en Brasil tiene legislación específica ${ }^{761}$.

En relación a la clasificación jurídica brasileña de las aguas en general, la Resolución n. ${ }^{\circ}$ 357, del "Conselho Nacional do Meio Ambiente (CONAMA)", de $17 / 03 / 2005^{762}$, dispone sobre la clasificación de los cuerpos de agua y directrices ambientales para el encuadramiento de estos, además de establecer las condiciones y padrones de descarga de efluentes.

La Resolución n. 357 está clavada en la Ley n. ${ }^{\circ}$ 9.433/97 $7^{763}$ y en los principios establecidos por la Ley . $^{\circ} 6.938 / 81^{764}$, por eso, considera que el agua integra las preocupaciones $^{765}$ del desarrollo sostenible, y basa sus deliberaciones y definiciones en

${ }^{760}$ Del total de agua existente en la Tierra, 97,5\% (alrededor de 1,386 mil millones de $\mathrm{km}^{3}$ ) es salada y 2,5\% (alrededor de 34,7 mil millones de $\mathrm{km}^{3}$ ) es dulce. Así, el agua dulce es la menor y más importante porción de agua que compone la Tierra.

${ }^{761}$ En el ordenamiento jurídico brasileño, el Decreto-Ley n. ${ }^{\circ} 7.841$ de 08/08/1945, publicado en el Diário Oficial da União - DOU el 20/08/1945, que estableció el Código de Águas Minerais, dio definición específica al agua mineral en su art. $1^{\circ}$, caput: "provenientes de fontes naturais ou de fontes artificialmente captadas que possuam composição química ou propriedades físicas ou físico-químicas distintas das águas comuns, com características que lhes confiram uma ação medicamentosa." Según esta definición legal, gran parte de las aguas embotelladas y comercializadas actualmente no es "mineral", como mucho puede ser clasificada como agua potable, en función de la ausencia de propiedades físicoquímicas que la confiere acción medicamentosa.

${ }^{762}$ Clasificación traída por la Resolución n. ${ }^{\circ}$ 20, de 18-06-1986, del Conama, publicada en el Diário Oficial da União (DOU), de 30-07-1986, que fue revocada por la Resolución n. ${ }^{\circ} 357$, de 17-03-2005, publicada en el DOU de 18-03-2005, que fue complementada y alterada por las Resoluciones n. ${ }^{\circ} 410$ de 04-05-2009 y n. ${ }^{\circ} 430$ de 13-05-2011, publicadas respectivamente, en el $D O U$ de 05/05/2009 y 16/05/2011. La Resolución n. 357 mantuvo las referidas definiciones en su art. $2^{\circ}$. Disponible en: < http://www.mma.gov.br/port/conama/legiano1.cfm?ano=todos\&codlegitipo=3> y en: http://www.mma.gov.br/port/conama/res/res05/res35705.pdf $>$. Ambos con acceso en: 27-04-2015.

${ }^{763}$ Que instituyó la Política Nacional de Recursos Hídrico.

${ }^{764}$ Que instituyó la Política Nacional do Meio Ambiente.

${ }^{765}$ Fue promulgado el Decreto S/N, de la Presidencia de la República, de 22-03-2005, que instituyó la Década Brasileira da Água, iniciada en la misma fecha. 
los principios de la función ecológica de la propiedad ${ }^{766}$, de prevención $^{767}$, de precaución, 'quien contamina paga', de 'usuario pagador' y de integración ${ }^{768}$, así como en el valor intrínseco de la naturaleza.

El encuadramiento de los cuerpos de agua, establecido por la Resolución n. ${ }^{\circ}$ 357 expresa metas finales obligatorias que deben ser alcanzadas, así como deben encuadrarse los cuerpos de agua y las condiciones y padrones de descarga de efluentes de acuerdo con las reglas del Convenio de Estocolmo, sobre Contaminantes Orgánicos Persistentes $(\mathrm{COPs})^{769}$. Es en aquella Resolución que surge la regla jurídica brasileña que sirve para la clasificación de las aguas y cuerpos hídricos, como también para la aplicación de las metas y principios de las "Políticas Nacionais de Recursos Hídricos e de Meio Ambiente" 770 .

${ }^{766}$ Aplicada al área ambiental, ese principio es una extensión del principio de la función social de la
propiedad.
${ }^{767}$ Sobre los principios de prevención, precaución, de 'quien contamina paga' y de 'usuario pagador',
vide Capítulo 3 .
${ }^{768}$ Principio en que las decisiones gubernamentales y comunitarias deben estar integradas con la cuestión
de protección ambiental.
${ }^{769}$ El Convenio de Estocolmo fue firmado el 22 de mayo de 2001 en Estocolmo y entró en vigor el 17 de
mayo del 2004 en: $<$ http://chm.pops.int/Countries/StatusofRatifications/PartiesandSignatories/tabid/252/Default.aspx > .

Acceso en: 27-04-2015. En Brasil, fue promulgada el 20 de junio de 2005, por el Decreto n. ${ }^{\circ}$ 5.472, y cuida de eliminar Contaminantes Orgánicos Persistentes, o sea, aquellos que no son degradados por el

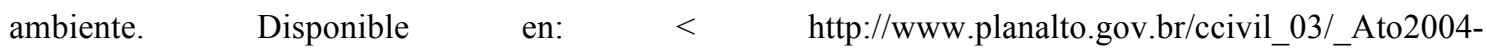
2006/2005/Decreto/D5472.htm>. Acceso en: 27-04-2015.

${ }^{770}$ Cuanto al uso predominante (sistemas de clases de calidad): (i) aguas dulces: aguas con salinidad igual o inferior a $0,50 \%$; (ii) aguas salobres: aguas con salinidad igual o inferior a $0,5 \%$ e $30 \%$; (iii) aguas salinas: aguas con salinidad igual o superior a 30\%. Art. $2^{\circ}$ de la Resolución n. ${ }^{\circ} 430$, de 13-05-2011, del Conama, publicada en el DOU de 16-5-2011.Cuanto a la ubicación: (i) aguas subterráneas: aguas que corren naturalmente o artificialmente en el subsuelo (Art. $2^{\circ}$ de la Resolución n. ${ }^{\circ} 396$, de 03-04-2008, del Conama, publicada en el DOU de 07-04-2008); (ii) aguas superficiales: "agua que no se escoa o se acumula en la superficie del suelo". (Departamento de Águas e Energía Elétrica (DNAEE), Glossário de termos hidrológicos. Brasília: 1976, n. 1.085). Cuanto a la potabilidad: “...água potável é a água para consumo humano, cujos parâmetros microbiológicos, físicos, químicos y radioativos atendam al padrão de potabilidade, e que não oferece risco à saúde" (Portaria 36/GM, de 19-01-1990, do Ministério da Saúde. Portaria 469, de 29-12-2000, publicada no DOU de 19-02-2001. La Resolución n. ${ }^{\circ}$ 357, además de establecer los conceptos jurídicos ya mencionados, aun clasifica en Brasil los cuerpos hídricos de acuerdo con sus clases de uso. Las aguas dulces, salobres y salinas son clasificadas, según la calidad requerida 
para los usos preponderantes, en trece clases de calidad, pudiendo las aguas de mejor calidad ser aprovechadas en uso menos exigente, desde que este no perjudique la calidad del agua, atendidos otros requisitos pertinentes. Además, la Resolución presenta otros conceptos legales, tales como: ambiente lêntico, ambiente lótico, carga poluidora, classe de qualidade, qualificação, condição de qualidade, condição de lançamento, corpo receptor, enquadramento, padrão, parâmetro de qualidade de água, tributário (ou curso d'água afluente), vazão de referência, zona de mistura, visualmente ausentes, classe especial, classe 1, classe 2, classe 3, classe 4.La Resolución n. ${ }^{0}$ 396, dispone sobre la clasificación y directrices ambientales para el encuadramiento de las aguas subterráneas, y también establece los conceptos jurídicos de términos jurídicos como: água subterrâneas, aquifero, classe de qualidade, condição de qualidade, efetivação de enquadramento, enquadramento, Limite de Deteç̧ão de Método (LDM), Limite de Quantificação Praticável (LQP), Limite de Quantificação de Amostra (LQA), metas, monitoramento, padrão de qualidade, parâmetro de qualidade da água, remedição, teste de toxicidade, usos preponderantes, Valor de Referência de Qualidade (VRQ) e Valor Máximo Permitido (VMP). Para los efectos del encuadramiento de las aguas subterráneas, la Resolución establece seis clases: classe especial, classe 1, classe 2, classe 3, classe 4, classe 5. La Resolución n. ${ }^{\circ}$ 129, de 29-06-2011, del Conselho Nacional de Recursos Hídricos (CNRH), publicada en el DOU de 26-09-2011, establece directrices generales para la definición de caudales mínimos restantes de cursos de agua. La Resolución n. ${ }^{\circ}$ 141, de 10-07-2012, del Conselho Nacional de Recursos Hídricos (CNRH), publicada en el DOU de 24-08-2012, establece criterios y directrices para la implementación de los instrumentos de concesión de derecho de uso de recursos hídricos y de encuadramiento de los cuerpos de agua en clases, según usos predominantes del agua, en ríos intermitentes y efémeros. Ya la Resolución n. ${ }^{\circ} 374$, de 01-10-2009, del Departamento Nacional de Produção Mineral, do Ministério de Minas e Energia, aprueba las Normas Técnicas sobre las especificaciones técnicas para el aprovechamiento de agua mineral, termal, gaseosa y potable de mesa, establece los conceptos de: aquifero, fonte, captação, contaminantes, envasamento, fontanário e rinsagem. El Decreto n. ${ }^{\circ}$ 5.440, de 04-05-2005, que establece definiciones y procedimientos sobre el control de calidad del agua de los sistemas de abastecimiento, y instituye mecanismos e instrumentos para la divulgación de información al consumidor, sobre la calidad del agua para el consumo humano, también trae conceptos jurídicos importantes sobre el agua, como por ejemplo los conceptos de: água potável, sistema de abastecimento de água para consumo humano, solução alternativa coletiva de abastecimento de água para consumo humano, controle de qualidade de água para consumo humano, vigilância da qualidade da água para consumo humano, sistemas isolados, sistemas integrados, ligação predial. La Portaria n. ${ }^{\circ}$ 2.914, de 12-11-2011, del Ministério da Saúde, dispone sobre procedimientos de control de vigilancia de la calidad del agua para consumo humano y su padrón de potabilidad, además, estable conceptos de: água para consumo humano, água potável, padrão de potabilidade, padrão organoléptico, água tratada, sistema de abastecimento de agua para consumo humano, solução alternativa coletiva de abastecimento de agua para consumo humano, solução alternativa individual de abastecimento de agua para consumo humano, rede de distribuição, interrupção, intermitência e controle da qualidade da água para consumo humano. Según João Alberto Alves AMORIM, respecto a la calidad del agua, en 1998 fue celebrado el Convenio n. ${ }^{\circ}$ 447/98 entre el 
Brasil es un país de dimensiones continentales ${ }^{771}$ y con relación a la disponibilidad hídrica también lo es, del total de agua dulce disponible en el planeta, alrededor de $12 \%$, o sea, cerca de 5,4 billones de metros cúbicos está en su territorio, además, abriga el mayor río en extensión y volumen del planeta, el río Amazonas ${ }^{772}$, también posee uno de los principales acuíferos subterráneos ${ }^{773}$.

Instituto Brasileiro do Meio Ambiente e dos Recursos Naturais Renováveis (IBAMA) y la Secretaria de Recursos Hidricos do Ministério do Meio Ambiente (SRH/MMA), con el objetivo inicial de que el IBAMA iba a instrumentalizarse técnica y operacionalmente para ejercer las acciones de control y de monitoreo ambiental de las aguas de dominio de la Unión, así como apoyar la SRH/MMA en la implantación de la Política Nacional de Recursos Hídricos. Como resultado de ese Convenio surgieron: cadastro de cuerpos de agua, con informaciones sobre los cuerpos de agua federales y estaduales; cadastro de estaciones de monitoreo y cadastro de laboratorios públicos y privados en el país, además, el desarrollo del Sistema de Informação de Vigilância da Qualidade da Água para o consumo (SISÁGUA). Direito das Águas: O Regime Jurídico da Água Doce no Direito Internacional e no Direito Brasileiro. Editora Lex Editora S.A, São Paulo-Brasil: 2009, p. 36.

${ }^{771}$ Brasil posee un área de $8.547 .403,5 \mathrm{~km}^{2}$,que ocupa $47 \%$ del área de Sudamérica y según el censo del Instituto Brasileiro de Geografia e Estatística (IBGE), tiene una población de más de 204 millones de habitantes, siendo así, el quinto país del mundo tanto en extensión como en población. Disponible en: $<$ http://www.ibge.gov.br/apps/populacao/projecao/>. Acceso en: 30-04-2015.

${ }^{772}$ En Brasil hay algunas de las mayores concentraciones de agua encontradas en el planeta: uno de los mayores ríos del mundo, el Río Amazonas con 7.025 km de extensión; cascadas de agua con los mayores flujos de agua del Planeta: Guaíra con 13.301.000 $\mathrm{m}^{3}$ por segundo (hoy encubierta por el lago de Itaipu), cascada de Paulo Afonso en el Río São Francisco con $2.830 .00 \mathrm{~m}^{3}$ por segundo y Urubupungá en el Río Paraná con 2.745.000 $\mathrm{m}^{3}$ por segundo. Además, aun tiene uno de los mayores lagos del planeta, la "Lagoa dos Patos" con $10.144 \mathrm{~km}^{2}$ de área y una profundidad de 6,75 m. Información disponible en el sitio de la Agência Nacional de Águas (ANA): <http://www2.ana.gov.br/Paginas/default.aspx> . Acceso en: 29-042015.

${ }^{773}$ El acuífero Guarani es el mayor del mundo, con cerca de $1.195 .200 \mathrm{~km}^{2}$, penetra en Paraguay $(71.700$ $\left.\mathrm{km}^{2}\right)$, Uruguay $\left(58.400 \mathrm{~km}^{2}\right)$ y Argentina $\left(225.300 \mathrm{~km}^{2}\right)$. Apenas en territorio brasileño, está en un área de $839.800 \mathrm{~km}^{2}$. La espesura total del acuífero varia de 50 a 800 metros, en si considerando una espesura mediana acuífera de 250 metros y porosidad efectiva de $15 \%$. Se calcula que las reservas de agua subterránea de la parte brasileña están estimadas en $48.000 \mathrm{~km}^{3}$, alcanzando temperaturas superiores a $30^{\circ}$ $\mathrm{C}$ y poseen una óptima calidad para consumo doméstico, industrial e irrigación. Su tiempo de renovación es de 300 años. Sin embargo, hasta reservas como esa están amenazadas por la contaminación ambiental por pesticidas, por la deforestación no sostenible, por la irrigación artificial de áreas agrícolas y por las alteraciones del régimen pluvial debido a factores como el calentamiento global. Disponible en: $<$ http://revistaplaneta.terra.com.br/secao/meio-ambiente/agua-doce-o-ouro-do-seculo-21>. Acceso en: 2904-2015. Ya se sabe que existen elementos químicos utilizados en la industria y agricultura, tales como: 
El país tiene una frecuencia pluviométrica de más de $3.000 \mathrm{~mm} / \mathrm{año}$ en un área superior a $90 \%$ de su territorio, posee índice pluviométrico menor, entre 400 e 800 $\mathrm{mm} / \mathrm{año}$, en el semiárido nordestino, lo que corresponde a $400.000 \mathrm{~km}^{2}$ de su extensión territorial $^{774}$.

Lo que pone Brasil hídricamente rico, según las Naciones Unidas, es que tal intensidad pluviométrica genera importantes excedentes hídricos, que desaguan en una de las más extensas y densas redes hidrográficas perenes del mundo, cuya descarga total mediana de largo periodo es de $182.633 \mathrm{~m}^{3} / \mathrm{s}$ ó $5.753 \mathrm{~km} 3 / \mathrm{año}^{775}$.

pesticidas, nitratos, petroquímicos, arsénico, metales pesados, sales y flúor, que promueven la contaminación y que hace mucho son conocidos por los científicos. Respecto a eso, SAMPAT, Payal afirma: "Since 1945, about 3,000 cases have been reported worldwide - nearly half of them in Hungary, where private wells have particularly high concentration of nitrates... Begin with industrial agriculture. Farm runoff is a leading cause of groundwater pollution in many parts of Europe, the United States, China, and India. Lessening its impact calls for adopting practices that sharply reduce this runoff-or, better still that require far smaller inputs to begin with. In most places current practices are excessively wasteful. In Colombia for example growers spray flowers with as much as 6,000 liters of pesticide per hectare. In Brazil, orchards get almost 10,000 liters per hectare. Experts at the UN Food and Agricultural Organization say that with modified application techniques, these chemicals could be applied at one-tenth those amounts and still be effective. But while using more efficient pesticide applications would constitute a major improvement, there is also the possibility of reorienting agriculture to use very little synthetic pesticide at all". SAMPAT, Payal. Groundwater shock: the polluting of the world's major freshwater stores. World Watch Magazine, v. 13, n. 1, January-February: 2000, Worldwatch Institute, pp. 15 y 20-21. Disponible en: $<$ http://www.worldwatch.org/system/files/EP131A.pdf>. Acceso en: 06-05-2015.

${ }^{774}$ REBOUÇAS, Aldo. Proteção dos Recursos Hidricos. In: Revista de Direito Ambiental, n. ${ }^{\circ}$ 32, ano 8, outubro-dezembro de 2003, Editora RT, p.34.

775 Entre 10.000 y $100.000 \quad \mathrm{~m}^{3} / \mathrm{anno}$ per cápita. Disponible en: $<$ http://www.outorga.com.br/pdf/Artigo\%20033\%20\%20Demanda\%20de\%20Água\%20no\%20Mundo.pdf $>$. Acceso en: 30-04-2015. Aldo REBOUÇAS en su artículo comenta la disponibilidad hídrica, per cápita, de la población brasileña, $33.841 \mathrm{~m}^{3} /$ año obtenida a través de la división del volumen total de escorrentía por los ríos brasileños por el número total de habitantes del país, según datos del IBGE, es que, se solo 25\% de la tasa de recarga de las aguas almacenadas en los acuíferos subterráneos $\left(3.144 \mathrm{~km}^{3} / \mathrm{año}\right)$ fuera retirada, generaría una oferta de agua dulce a la población de 4.000 m³/año. Proteção dos Recursos Hídricos. In: Revista de Direito Ambiental, n. ${ }^{\circ} 32$, ano 8, outubro-dezembro de 2003, Editora RT, pp. 34-35. 
Mismo siendo una potencia hídrica, Brasil sufre una desigualdad en su distribución, eso porque, 72\% del agua dulce está en la región Amazónica, 16\% en el Centro-Oeste, $8 \%$ en el Sur y Sudeste y $4 \%$ en el Nordeste.

A pesar de Brasil ser el primer país en disponibilidad hídrica en ríos del mundo, la contaminación y el uso inadecuado comprometen ese recurso en varias regiones del país. Además, delante de tanta abundancia, no sabe utilizar el agua, pues $37 \%$ del agua tratada es desperdiciada ${ }^{776}$, lo que seria suficiente para abastecer toda Francia, Bélgica, Suiza y Norte de Italia ${ }^{777}$.

${ }^{776}$ Es común asociar la idea de desperdicio del agua a hábitos domésticos, tales como: uso indiscriminado de la ducha, grifo mal cerrado, utilización indebida del agua o no reaprovechamiento, entre otros. Sin embargo, esa cuestión puede ir más allá del desperdicio residencial. Por ejemplo, existe el desperdicio durante el propio abastecimiento del agua, causado muchas veces por fallas técnicas en las tuberías y sistemas públicos de distribución o hasta por desvíos ilegales realizados por algunas personas que buscan beneficio propio. En Brasil, según el informe del Ministerio de las Ciudades, alrededor de 37\% de toda el agua tratada en el país es desperdiciada, lo que equivale a un número inigualable de litros no aprovechados y cerca de 8 mil millones de reales al año en perjuicio. Todo ese dinero que es "tirado", corresponde a $80 \%$ de lo que el país emplea en saneamiento. Disponible en: $<$ http://g1.globo.com/bomdia-brasil/noticia/2015/03/brasil-perde-r-8-bilhoes-por-ano-com-desperdicio-de-agua.html $>$. Acceso en: 01-05-2015. En algunas regiones, como en el Norte y Nordeste del país, ese índice ultrapasa los 50\%, revelando una carencia de medidas para el combate al desperdicio que va más allá de la mera concientización social de la población. En São Paulo, cerca de 32\% del agua distribuida es desperdiciada, conforme la Agência Reguladora de Saneamento e Energia do Estado (ARSESP), o que hace un total de casi 990 mil millones de litros perdidos. En países como EE.UU. y Alemania, el nivel de desperdicio en el abastecimiento de agua no ultrapasa los $9 \%$. Así, son necesarias medidas de mantenimiento de las tuberías comprometidas, además de una mayor fiscalización sobre conexiones hidráulicas irregulares. Otro tipo de desperdicio de agua ocurre en la agricultura. En muchos casos, sistemas inadecuados de irrigación o aprovechamiento hacen con que parte del agua utilizada en las plantaciones no sean aprovechadas, tanto por su uso incorrecto cuanto por las altas tasas de evaporación. Además, la contaminación de los suelos, de la capa freática y de algunos ríos en razón del uso de pesticidas también se transforman en agravantes del problema en cuestión. Para combatir el desperdicio del agua en la agricultura, es necesario utilizar métodos de irrigación volcados a ese intuito. En la industria también ocurre problemas semejantes. En algunos modos de producción, el agua es utilizada para el enfriamiento de equipamientos, lo que podría ser más efectuado con agua de reúso y otros métodos de mayor economía. Además de eso, casos de fugas de agua o manejo incorrecto en la captación de sistemas locales de abastecimiento también pueden generar una gran cantidad de desperdicio. Por esa razón, es importantes que haya una gran fiscalización de las industrias con la finalidad de que ellas también participen del proceso de conservación de los recursos hídricos, lo que también sirve para los demás 
De esta manera, sectores de la sociedad, incluso el Estado, deben adoptar medidas para disminuir el desperdicio del agua, pues el éxito en esta tarea traería más efectos positivos que cualquier otra política de uso del agua, garantizando así, su uso sostenible. Por eso, se hace urgente un nuevo padrón cultural en relación a ese bien tan esencial $^{778}$.

Los procesos vitales como la fertilidad del suelo, estabilidad de la temperatura, solvente universal, equilibrio y preservación del medio ambiente, entre otros, son atribuidos al agua. Tal riqueza de usos y funciones revela la importancia de la preservación de este recurso que actualmente está escaso y amenazado.

La actual situación de la fuerte escasez de agua potable que afecta una parte del Sudeste brasileño, donde se ubican grandes ciudades como São Paulo, Rio de Janeiro y Belo Horizonte, como nunca antes, nos obliga a pensar la cuestión del agua y a desarrollar una cultura de cuidado, acompañada por sus famosos erres (r): reducir, reusar, reciclar, respetar y reforestar ${ }^{779}$.

Mismo siendo dueño del mayor potencial hídrico del planeta, Brasil corre grave riesgo de quedarse con problemas de abastecimiento de agua en más de la mitad de sus municipios en $2015^{780}$.

Alrededor del $72 \%$ de la reserva brasileña está en el Norte del país, donde viven menos de $10 \%$ de la población, ya en las regiones populosas la situación es

sectores, tales como construcción civil y comercio. Disponible en:
$<$ http://diariodepetropolis.com.br/integra/brasil-desperdica-o-equivalente-a-37-da-agua-distribuida64052> . Acceso en: 19-04-2015.

${ }^{777}$ Como bien ejemplifica Leonardo Boff, A água no mundo e sua escassez no Brasil. Disponible en: $<$ https://leonardoboff.wordpress.com/2015/02/02/a-agua-no-mundo-e-sua-escassez-no-brasil/> . Acceso en: 19-04-2015.

778 Conforme Leonardo Boff, A água no mundo e sua escassez no Brasil. Disponible en: $<$ https://leonardoboff.wordpress.com/2015/02/02/a-agua-no-mundo-e-sua-escassez-no-brasil/>. Acceso en 19-04-2015.

${ }^{779}$ Interesante análisis respecto al agua hecha por Leonardo Boff, A água no mundo e sua escassez no Brasil Disponible en: <https://leonardoboff.wordpress.com/2015/02/02/a-agua-no-mundo-e-sua-escassezno-brasil/>. Acceso en: 22-04-2015.

${ }^{780}$ El diagnostico está en el Atlas Brasil - Abastecimento Urbano de Água, lanzado por na Agência Nacional de Águas (ANA). Disponible en: $<$ http://www2.ana.gov.br/Paginas/resultana.aspx?k=Pesquisar...atlas\%20brasil\%202015>. Acceso en: 2204-2015. 
crítica, pues el consumo es mucho mayor y la contaminación causada por las industrias y los vertidos residenciales reducen el volumen del agua disponible para el uso ${ }^{781}$.

Además de la contaminación de aguas superficiales y subterráneas que ocurren por falta de políticas urbanas eficientes y coherentes, lo que preocupa gran parte de los brasileños es el aumento indiscriminado de la urbanización sin planificación. La ocupación irregular, además de causar la deforestación, la destrucción de nacientes, la sedimentación de ríos y lagos, eso sin olvidarnos de los vertidos que varias veces son tirados in natura en ríos y represas ${ }^{782}$, causan la impermeabilización del suelo, impidiendo el regreso del agua a las fuentes, además de perjudicar la evaporación, afectando así, el mantenimiento y equilibrio del agua.

De este modo, se puede afirmar que falta una postura sostenible, o sea, una postura bioética (auto determinada, materialmente justa, no maleficente y benéfica), ecológicamente responsable y segura, que jamás llevará sacrificios desproporcionados a la dignidad de la vida. Lo que, cabe señalar, es mucho más que defender áreas de preservación permanente y reservas legales, a pesar de la importancia evidente de esas luchas $^{783}$.

\footnotetext{
${ }^{781}$ Por ejemplo, la cuenca del río Tietê, en la región metropolitana de São Paulo, donde los habitantes tienen acceso a un volumen de agua menor que el recomendado para una vida sana. Información disponible en el sitio de la Secretaria de Saneamento e Recursos Hídricos do Estado de São Paulo: $<$ http://www.saneamento.sp.gov.br/site_manaciais/default.asp?ASP=introducao\&Parm=Apresentacao $>$. Acceso en: 22-04-2015.

${ }^{782}$ Los sitios donde ocurren esas ocupaciones irregulares, solo para citar algunos ejemplos, es la presa de Guarapiranga, responsable por el abastecimiento de 3,7 millones de paulistanos y la presa Billings, también responsable por el abastecimiento de São Paulo. Ese manantial es rumbo final de las aguas contaminadas que son bombeadas de los ríos Tietê y Pinheiros para mantener su curso. La alternativa fue traer el agua de una cuenca hidrográfica vecina, la del río Piracicaba-Jundiaí-Capivari, que abastece la mitad de la metrópoli paulistana, lo que ocasionó una disputa regional, en total, 58 municipios comparten ese manantial, y la solución fue crear un Banco de Aguas, un acuerdo que establece cuotas de captación para la región metropolitana de São Paulo (31 metros cúbicos por segundo) y para el conjunto de municipios de la región de Piracicaba (5 metros cúbicos por segundo). En ese sistema, tanto un lado como el otro pueden ir más allá de esos límites como compensación, caso haya retirado menor cantidad de agua en periodos anteriores. Disponible en: http://planetasustentavel.abril.com.br/noticia/ambiente/conteudo_345578.shtml. Acceso en: 20-04-2015. ${ }^{783}$ FREITAS, Juarez. Sustentabilidade: cit., p. 74.
} 
Otra cuestión importante, es la disminución de la lluvia en Brasil ${ }^{784}$, lo que llevó gobierno y ciudadanos a un estado de alerta. Uno de los Sistemas más importantes de abastecimiento de agua en el Estado de São Paulo, Sistema Cantareira, viene siendo tema de la prensa todos los días en razón de su bajo nivel de agua ${ }^{785}$.

Como si la disminución de la lluvia no fuera suficiente, cuando las ciudades la reciben, en la mayoría de las veces, asisten a su inmediato escurrimiento para las galerías subterráneas, donde se mesclan a los vertidos urbanos y enseguida es transportada a los río, lagos y mares, afectando la disponibilidad de agua limpia como un todo.

Además, Brasil es uno de los países que más tiene ríos fuera de su curso natural por causa de las hidroeléctricas, lo que aumenta la degradación y el riesgo de sedimentación $^{786}$.

${ }^{784}$ Conforme esclarece Viktor Leinz; Sérgio Estanislau do Amaral: “A quantidade de precipitação anual varia muito de região para região. A evaporação é mais intensa sobre os mares do que sobre os continentes, enquanto as precipitações são mais ou menos equivalentes, nas proporções aproximadas de suas respectivas áreas. Assim, temos um excesso anual de precipitações sobre a evaporação dos continentes de cerca de $37.000 \mathrm{~km}^{3}$ de água". Geologia Geral. 14ª edição, Editora Nacional, São PauloBrasil: 2003, pp. 76-77.

${ }^{785}$ De toda la lluvia que hubo en el mes de abril en el Sistema Cantareira, o sea, 45,1 mm, corresponde a sólo $50 \%$ de lo esperado para el mes. Según en Informe de la Companhia de Saneamento Básico do Estado de São Paulo (Sabesp), el nivel de agua de los reservatorios del Sistema Cantareira, que abastece la capital y región metropolitana de São Paulo (es el Estado más poblado de Brasil), sufrió otra caída después de haberse mantenido estable en casi tres meses. El volumen del reservatorio cayó de 20,1\% para $20 \%$, lo que hace con que la situación sea crítica, pues estamos en el período de sequilla y apenas la segunda cuota del volumen muerto fue recuperada. Entre otros cinco manantiales que abastecen la Gran São Paulo, el Alto Tiête, Alto Cotia y Rio Grande se mantuvieron estables, ya el Guarapiranga cayó y apenas el Rio Claro subió. Delante de eso, la Sabesp anunció que una nueva aductora permitirá que el Sistema Rio Grande abastezca algunos barrios de la Zona Sur de São Paulo, y que será necesario una inversión de 7,6 millones de reales para la obra que quiere aliviar el Sistema Cantareira, que pasa por la peor crisis de la historia. El número de personas atendidas por el Sistema Cantareira, que ya fue de 9 millones en la Gran São Paulo y estaba en 5,6 millones, ahora es de 5,4 millones. Disponible en: $<$ http://g1.globo.com/sao-paulo/noticia/2015/04/nivel-do-sistema-cantareira-tem-primeira-queda-emquase-3-meses.html>. Acceso en: 28-04-2015.

${ }^{786}$ Existe una permanente y dialéctica interacción entre la actividad humana y el medio ambiente, en que se incluye, la relación de interdependencia entre sociedad y recursos hídricos. El proceso del ciclo hidrológico como afirmó Thomas, Harold E. "para el hidrólogo, hay una necesidad de saber, lo más 
A lo que se refiere a la escasez del agua, Brasil está entre los países con bajo riesgo, todavía, las Naciones Unidas alertó que la prioridad debe ser la gestión del agua y el uso sostenible para garantizar las reservas en el futuro. Una gestión más sostenible de este recurso no renovable es urgente.

perfectamente posible, las modificaciones que el hombre produce en el ciclo hidrológico - pasadas, presentes y futuras -, en la esperanza de que el hombre puede aumentar progresivamente su capacidad de modificar el ciclo hidrológico en su beneficio. Al trabajar con la naturaleza, adaptando sus necesidades al ciclo hidrológico o adaptando el ciclo hidrológico a ellas, el ser humano puede obtener los mejores beneficios sobre el uso del agua”. Es decir, "el ciclo hidrológico es, pues, una forma de representación del agua que surgió dentro de un determinado contexto histórico para cumplir con los propósitos políticos”. Al asumir que en términos políticos, "el agua fluye, cada vez más, siguiendo el flujo de capital”, los defensores de este nuevo enfoque constatan que, prácticamente todas las fuentes de agua del planeta tienen una marca de la acción humana. De esta observación, establecen el concepto de ciclo hidrosocial del agua como un proceso socionatural, en el que el agua y la sociedad crean y recrean una a la otra en el espacio y en el tiempo, reduciendo las desigualdades e injusticias producidas a través del agua. Son tres las principales ideas: (1) La organización de la sociedad esta relacionada con la gestión de las aguas, pues esta organización social, afecta la distribución (y la gestión) del agua, y así, sucesivamente, llevando a un cuestionamiento: (¿Qué significa el agua para la sociedad?); (2) En razón de esa relación, agua y sociedad están intrínsecamente relacionadas, lo que significa que relaciones sociales específicas producen diferentes "tipos" de agua, y vice-versa (¿cómo el agua se torna conocida o percibida?); (3) Esos tipos de producción de agua, y a pesar de sus representaciones sociales, las propiedades materiales del agua desempeñan un papel activo en el proceso hidrosocial, tanto estableciendo cuanto destruyendo relaciones sociales (¿de qué modo el agua internaliza relaciones sociales, poder social y tecnología?). Changes in quantities and qualities of ground and surface water. In: THOMAS JR., W.L. (Ed.). Man's role in changing the face of the earth. University of Chicago Press, 1956, p. 542-563, apud LINTON, J.; BUDDS, J. The hydrosocial cycle: defining and mobilizing a relation-dialectical approach to water. Geoforum

Disponible

en: $<$ http://www.sciencedirect.com/science/article/pii/S0016718513002327>. Acceso en: 04-05-2015. Además, como afirma Demetrio Loperena Rota, El agua como Derecho Humano. In Santiago GonzálezVaras Ibáñez (Coordinador), Nuevo Derecho de Aguas. Navarra: Aranzadi, 2007, p. 84: “Los derechos forman una complicada red de interdependencia que los juristas, debemos conocer para saber en caso de colisión cual prevalece. Pero en la mayoría de los casos esta interdependencia no requiere criterios para la resolución de los posibles conflictos. Nos hallamos ante interdependencias carentes del rasgo de colisionabilidad. Este parece ser el caso del derecho al agua con respecto a estos otros derechos que no pueden ejercerse sin aquél: Derecho a la vida, Derecho a la dignidad humana, Derecho a la salud física y mental, Derecho a la alimentación, Derecho a una vivienda adecuada, Derecho al desarrollo, Derecho a la educación, Derecho al medio ambiente adecuado, Derecho a la paz, Derecho al saneamiento”. 


\section{Capítulo 5 - El agua en el derecho español}

\subsection{El medio ambiente en la Constitución española de 1978. Su}

consideración como principio rector en materia económica y social. La inclusión del agua

Este estudio hace un abordaje de la protección del medio ambiente en España. Trae la previsión constitucional sobre el medio ambiente y las diversas formas de abordaje delante del Sistema Judicial español. Además, estudia la correcta determinación de la competencia de los Tribunales en España.

La Constitución española de 1978 vino a establecer en su artículo 45, dentro del Título Primero 'De los derechos y deberes fundamentales', en su capítulo III, 'De los principios rectores de política social y económica', el derecho de todos a 'disfrutar de un medio ambiente adecuado para el desarrollo de la persona'. Este artículo dispone:

"1. Todos tienen el derecho a disfrutar de un medio ambiente adecuado para el desarrollo de la persona, así como el deber de conservarlo.

2. Los poderes públicos velarán por la utilización racional de todos los recursos naturales, con el fin de proteger y mejorar la calidad de la vida y defender y restaurar el medio ambiente, apoyándose en la indispensable solidaridad colectiva.

3. Para quienes violen lo dispuesto en el apartado anterior, en los términos que la ley fije se establecerán sanciones penales o, en su caso, administrativas, así como la obligación de reparar el daño causado".

De este modo, como bien comenta Jesús Jordano Fraga: "El medio ambiente ha recibido un reconocimiento constitucional como derecho-deber (art. $45 \mathrm{CE}$, apartado 1) y como función administrativa, (art. 45 CE, apartado 2, en relación con los arts. 148, 1, 9 y 149, 1, 23 CE). El Derecho ambiental, producto de una larga decantación histórica, ha adquirido, desde el punto de vista constitucional, el sentido de ser el desarrollo garantizador y realizador del derecho y la función pública constitucionalmente consagrados. Desde el punto de vista de las técnicas jurídicas a utilizar en esta misión, el artículo 45 ha realizado un esquema básico, preventivo, reconociendo implícitamente la planificación (<<utilización racional $>>$ ), y represivo (sanciones penales, 
administrativas y responsabilidad civil)" ${ }^{, 787}$.

Por lo tanto, la Constitución española, se ubica en el grupo de textos constitucionales que configuran al medio ambiente como un derecho-deber, que debe ser tutelado por los poderes público, a los que en el apartado 2 se les confiere el mandato de "velar por una utilización racional" sustentada "en la indispensable solidaridad colectiva".

Probablemente, el leitmotiv de la inclusión de este artículo fue el deseo de apertura a una Europa desarrollada, pero hoy no cabe duda de que el valor ambiental está sufriendo un proceso de integración en el Ordenamiento jurídico español, que todavía no ha alcanzado un nivel equiparable a los países más avanzados en esta materia $^{788}$.

El artículo 46 establece, aún, especificaciones sobre el patrimonio histórico, cultural y artístico:

Artículo 46.

“Los poderes públicos garantizarán la conservación y promoverán el enriquecimiento del patrimonio histórico, cultural y artístico de los pueblos de España y de los bienes que lo integran, cualquiera que sea su régimen jurídico y su titularidad. La ley penal sancionará los atentados contra este patrimonio".

La previsión constitucional de traer en un primer momento el derecho a un medio ambiente adecuado, para en otro artículo tratar del patrimonio histórico, cultural y artístico genera notoria controversia en el medio jurídico español respecto al concepto y alcance de medio ambiente, incluso para efecto de tutela estatal.

Una evidente controversia encontrada entre los juristas españoles dice respecto al concepto jurídico de medio ambiente o la extensión de que se considera medio ambiente. Son encontradas posiciones que traen el sentido amplio (con la inclusión de elementos históricos, culturales y sociales), y sentido estricto (considerado meramente el campo físico). La Constitución española no trae un concepto de medio ambiente y tampoco enumera los elementos que lo integran, dejando así, esta tarea a los doctrinadores y a la jurisprudencia. Los doctrinadores divergen, principalmente, cuanto

\footnotetext{
${ }^{787}$ JORDANO FRAGA, Jesús. La protección del derecho a un medio ambiente adecuado. J.M. Bosch Editor, Barcelona-España: 1995, pp. 53-54.

${ }^{788}$ PAREJO ALFONSO, Luciano y otros. Manual de Derecho Administrativo. Vol. II, Ed. Ariel Derecho, Barcelona-España:1998, p. 225.
} 
a la inclusión o no de la conceptuación de medio ambiente, de elementos no físicos o naturales. De ahí a encontrarse quien defienda un concepto de medio ambiente 'amplio' y otros que defiendan un sentido 'estricto'.

\subsubsection{Concepto de medio ambiente en un sentido estricto}

La primera posición doctrinal que postula una comprensión estricta del concepto jurídico de medio ambiente, se encuadran las opiniones de Martín Mateo, Escribano Collado, López González, Rodríguez Ramos y Quintana López.

Merece especial atención la posición defendida por Martín Mateo, vez que, las nociones comunes de medio ambiente acuñan un concepto demasiado amplio, razón por la cual él propone una delimitación del concepto de medio ambiente, delimitación esta, que guiaría la inspiración que debe tener el Derecho Ambiental.

En este sentido, Jesús Jordano Fraga, comentando la posición de Martín Mateo, enseña que: "El autor más destacado entre los que defienden esta posición es, sin duda, Martín Mateo, el cual descarta que el ambiente sea el territorio global objeto de ordenación y gestión, y rechaza la identificación medio ambiente-naturaleza, sin desconocer la relación de ambos elementos naturales objeto de una protección jurídica especifica. Para Martín Mateo, el ámbito conceptual del ambiente $<<$ incluye aquellos elementos naturales de titularidad común y de características dinámicas; en definitiva, el agua, el aire, vehículos básicos de transmisión, soporte y factores esenciales para la existencia del hombre sobre la tierra $>>$, descartando, como elemento integrante del ámbito conceptual del medio ambiente, el suelo, pues aunque para este autor $<<$ puede pensarse que entre tales elementos cabría incluir el suelo $>>,<<$ la gestión del suelo, o bien se reconduce a la ordenación global del territorio y a la lucha contra la erosión con trascendencia más amplia que la propia gestión ambiental, o bien, a la postre, se conecta con los ciclos del agua y del aire, bien en cuanto a eventuales alteraciones de estos ciclos al perturbarse las condiciones meteorológicas por obra, por ejemplo, de la deforestación $>>$. La definición del ámbito conceptual del medio ambiente que hace Martín Mateo es quizá demasiado restrictiva. Pese a ello, la construcción está dotada de una inicial coherencia, al agruparse el núcleo conceptual de medio ambiente en torno a aquellos elementos naturales de titularidad común, bases sobre las que se asienta lo que 
con gran acierto el propio autor denomina $<<$ el meollo de la problemática ambiental $>>$. Sin embargo, pese a la innegable solidez del planteamiento, éste no se halla exento de ser objeto de ulteriores matizaciones. La concepción de Martín Mateo presenta algunas quiebras, que se derivan de poner el acento, como categoría unificadora o cohesionadora, en la titularidad o régimen jurídico de los elementos integrantes del concepto de medio ambiente, criterio que sirve para explicar la inclusión del aire y del agua, pero que excluye otros elementos. Ciertamente, en todo lo medioambiental parece existir desde el punto de vista jurídico algo que hace pensar en bienes situados por encima del ámbito de la esfera de actuación del sujeto. Este dato innegable de la presencia de intereses colectivos es identificado o traducido por Martín Mateo en el dato jurídico cohesionador de la titularidad común, pero ello, pese a su indudable valor de constatación del régimen y de la titularidad de determinados elementos fundamentales o nucleares en el ámbito conceptual del medio ambiente, no es predicable de todos. Esta es la idea que parece más adecuada para aplicar a los distintos elementos, naturales o no, integrantes del medio ambiente" ${ }^{789}$.

Entre los autores que han señalado los inconvenientes de las posiciones amplias, y que adoptaron así una concepción de medio ambiente en sentido estricto, se encuentra, Escribano Collado y López González.

Sobre ellos, Jesús Jordano Fraga, enseña: "Para Escribano Collado y López González, el medio ambiente estaría formado por $<<$ aquellos recursos y sistemas naturales primarios de los que depende la existencia y el normal funcionamiento de la naturaleza en su conjunto, y que jurídicamente tienen la categoría de bienes comunes (aire y agua principalmente) $>>$, y por, $<<\operatorname{los}$ ecosistemas, constituidos por la flora, la fauna e, incluso, por las bellezas naturales (paisajes y espacios naturales, en cuanto portadores de ecosistemas que se pretende conservar) $>>$. Además, el autor sigue el raciocinio y comenta la influencia que Larumbe Biurrum sufrió de Martín Mateo, afirmando que ese: "concibe el ambiente como $<<$ un conjunto de elementos naturales que son objeto de protección especial del Derecho $>>$. Según Larumbe Biurrum, los elementos que lo componen están caracterizados por la notas de titularidad común y dinamismo. En él se incluye al agua y al aire, excluyendo, como Martín Mateo, el suelo. Además de estos elementos, Larumbe Biurrum considera pertenecientes al

\footnotetext{
${ }^{789}$ JORDANO FRAGA, Jesús. La protección del derecho a un medio ambiente cit., pp. 57-58.
} 
ordenamiento ambiental $<<$ las materias del ruido -cuya transmisión se produce por el aire- y las agresiones de origen radiactivo sobre el agua y el aire",790.

Del mismo modo, Rodríguez Ramos, en análisis del articulo 45 de la Constitución Española, se propende por considerar que la concepción constitucional del medio ambiente se limita a los aspectos físicos de éste. Para él, el término medio ambiente en la Constitución significa 'recursos naturales', que son: el agua, el aire y el suelo; la 'gea', la flora y la fauna; las materias primas, tanto energéticas como alimentarias o de otra índole. Pero la significación del medio ambiente en la Constitución Española es para Rodríguez Ramos, la de 'ser objeto de un derecho y de un deber personal y colectivo de disfrute y conservación, ${ }^{, 791}$.

Finalmente, igualmente partidario de una concepción estricta del medio ambiente está Quintana López, que mismo reconociendo 'las estrechas conexiones entre el medio ambiente y su protección con temas específicos de la economía, culturales, etc.', o sea, a pesar de que la inclusión de elementos de carácter económico, social y cultural junto a factores de índole natural sea una posición atrayente, para él, ha de descartarse, pues 'conduce a la inoperancia del concepto, al invadir campos cuya gestión exige una perspectiva propia, ${ }^{792}$.

Importante observar que con una visión más amplia de medio ambiente, Jesús Jordano Fraga afirma que: "Las posiciones doctrinales que postulan una concepción del medio ambiente en un sentido estricto, a pesar de haber supuesto una aportación fundamental y, a veces, pionera al Derecho ambiental y a la construcción del concepto del medio ambiente, presentan el inconveniente de su separación de la realidad jurídica, en la cual, [...], el medio ambiente presenta un ámbito conceptual más extenso"793.

\footnotetext{
${ }^{790}$ JORDANO FRAGA, Jesús. La protección del derecho a un medio ambiente cit., p. 59.

${ }^{791}$ RODRÍGUEZ RAMOS apud JORDANO FRAGA, Jesús. La protección del derecho a un medio ambiente cit., p. 60.

${ }^{792}$ QUINTANA LÓPEZ apud JORDANO FRAGA, Jesús. La protección del derecho a un medio ambiente cit., p. 60.

${ }^{793}$ JORDANO FRAGA, Jesús. La protección del derecho a un medio ambiente cit., p. 60.
} 


\subsubsection{Concepto de medio ambiente en un sentido amplio}

Ya, en las posiciones doctrinales que postulan una concepción de medio ambiente en un sentido amplio, hay los autores que se encuadran junto a posiciones amplísimas que postulan consciente, o inconscientemente, un concepto extensísimo y hay también junto a la posición amplísima, los que defienden una concepción del medio ambiente que engloba además de los aspectos físicos, elementos culturales ${ }^{794}$. Sin embargo, también hay los autores que salen del extremo y que defienden una concepción amplia del medio ambiente.

Dentro del grupo que se encuadra el concepto de medio ambiente en un sentido amplísimo, están Mola de Esteban, que con un concepto extensísimo, define medio ambiente humano como 'el hombre y su entorno vital; esto es, el marco comprensivo y mutable de los elementos, condiciones y circunstancias de todo orden -físicas y orgánicas- en el que el hombre desenvuelve su vida. Por tanto, nada es absolutamente extraño al concepto de medio ambiente ${ }^{, 795}$ y Zaquenöd de Zögon, que define el medio ambiente como 'la síntesis histórica de las relaciones de intercambio entre sociedad y naturaleza en términos de tiempo y espacio ${ }^{, 796}$.

En la misma línea está Fuentes Bodelón que defiende una relación íntima o una interacción entre el medio ambiente físico o natural (agua, aire, tierra) o del medio humano. En esta conceptuación, el hombre forma parte de la naturaleza pero a la vez la modifica, es criatura y además crea nuevas formas y estilos de vida. Los llamados bienes culturales, costumbres o fiestas populares, tradiciones ocupaciones artesanales antiguas, que revelan la identidad histórica de un pueblo, forman parte indiscutible de

\footnotetext{
${ }^{794}$ Interesante cometario hace Jesús Jordano Fraga, La protección del derecho a un medio ambiente cit., p. 61: "Junto a estas posiciones amplísimas, otro grupo de autores ha formulado una concepción del medio ambiente que engloba junto a aspectos físicos elementos culturales. Así pues, el medio ambiente integra para este sector de la doctrina tanto el medio ambiente natural como el cultural. Estas posiciones, que pueden calificarse de amplias por desbordar un ámbito estrictamente físico, en realidad postulan un acotamiento del ámbito conceptual del medio ambiente, de manera que el resultado que obtienen no resulta privado de operatividad.

${ }^{795}$ MOLA DE ESTEBAN apud JORDANO FRAGA, Jesús. La protección del derecho a un medio ambiente cit., p. 61.

${ }^{796}$ ZAQUENÖD DE ZÖGON apud JORDANO FRAGA, Jesús. La protección del derecho a un medio ambiente cit., p. 61.
} 
los bienes ambientales ${ }^{797}$.

Otros autores que se sitúan en esta línea, pero con un menor grado de concreción, son: López Ramón, Trenzado Ruiz, Gálvez Montes, Corella Monedero, Barrero Rodríguez y Pérez Moreno ${ }^{798}$.

También partidario de una concepción amplia, con menor grado de concreción, aparece, Alberto Palomar Olmeda, por la justificación que se le da a dicha concepción amplia de medio ambiente, la misma que considera que dicho proceso de expansión "conlleva inmediatamente una mayor reglamentación en cada uno de los sectores implicados”, y “juntamente con ello, o quizá derivado de este mismo proceso, una más amplia intervención administrativa"799 . Además, afirma el autor que: "el nuevo concepto de medio ambiente abarca la protección de otras cuestiones, como el suelo, las aguas, el mar, los recursos naturales, el medio ambiente urbano, etc.” ${ }^{, 800}$, o sea, para él, el medio ambiente en un sentido moderno es más que el aire puro y las formas de preservar a éste de las contaminaciones, y añade que medio ambiente es: "un bien jurídico, patrimonio de la comunidad, y que debe ser protegido de cuantos ataques puedan dirigírsele" 801 . Sin embargo, como bien comenta Jesús Jordano Fraga: “[ ...] decir que el medio ambiente es un bien jurídico es una afirmación vacía de contenido si no va acompañada de ulteriores matizaciones. Es necesario decir en qué sentido es un bien jurídico, qué clase de bien es, y cómo es; en definitiva, es necesario explicar cuál es el alcance de inclusión del medio ambiente en dicha categoría jurídica” ${ }^{„ 802}$.

\footnotetext{
${ }^{797}$ FUENTES BODELÓN apud JORDANO FRAGA, Jesús. La protección del derecho a un medio ambiente cit., p. 61.

${ }^{798}$ Conforme Jesús Jordano Fraga, La protección del derecho a un medio ambiente cit., pp. 61-62, comentando Trenzano Ruiz y Gálvez Montes, enseña que: "El primero de estos autores concibe, con menor grado de concreción, el medio ambiente como 'el conjunto de condiciones que cooperan al ciclo vital de los seres animados', incluyendo dentro del término condiciones 'tanto los recursos naturales como las de índole cultural', y entendiendo por recursos 'el aire, el agua y el suelo'. GÁLVEZ MONTES, con menor concreción si es posible, estima que el medio ambiente es 'el conjunto de elementos naturales o culturales que determinan las condiciones de vida características de un integrante humano geográfica y temporalmente delimitado"”.

${ }^{799}$ PALOMAR OLMEDA, Alberto, La protección del Medio Ambiente en materia de aguas, Revista Administración Pública, n. ${ }^{\circ} 110,1986$. pp. 107 y ss.

${ }^{800}$ PALOMAR OLMEDA, Alberto, La protección del Medio Ambiente en materia cit., pp. 107-108.

${ }^{801}$ PALOMAR OLMEDA, Alberto, La protección del Medio Ambiente en materia cit., p. 110.

${ }^{802}$ JORDANO FRAGA, Jesús. La protección del derecho a un medio ambiente cit., p. 62.
} 
Para Corella Monedero, el medio ambiente es "el conjunto de elementos que constituyen el cuadro, el medio y las condiciones de ejercicio de las actividades humanas tal como son o como se sienten, con la incidencia que tales actividades tienen en el mantenimiento de las condiciones de vida de nuestro planeta”. El autor concibe, además, el medio ambiente como el entorno formado por elementos que condicionan las actividades del individuo constituido por factores naturales y artificiales, esto es, "el paisaje rural y el paisaje urbano, el ambiente atmosférico natural y el ambiente atmosférico contaminado pero tolerable, las aguas potables y las aguas residuales, los productos silvestres y los productos cultivados" ${ }^{\sharp 03}$.

Comentando la escuela sevillana, Jesús Jordano Fraga enseña que: “[...] desde la perspectiva del patrimonio histórico, BARRERO RODRÍGUEZ considera que la Constitución de 1978 en sus artículos 45, 46 y 47 ha adoptado un acepción $<<$ omnicomprensiva y global del medio ambiente $>>$, entendido como $<<$ el marco o entorno de la vida humana $>>$, en el que se incluyen $<<$ tanto el medio ambiente natural como el que podríamos denominar urbano, constituyendo el patrimonio histórico artístico una parcela propia y especifica del mismo>>.PÉREZ MORENO, uno de los pioneros en la construcción de un concepto expansivo, ha calificado como $<<$ grupo normativo cultural $>>$ el conjunto de preceptos constituido por los artículos 45, 46 y 47 CE. DOMPER FERRANDO es quien, hasta el momento, ha adoptado un criterio que aporta elementos esclarecedores. Piensa este autor, y no sin razón, que deben distinguirse elementos del medio ambiente, los agentes capaces de perturbar su estado natural y las técnicas útiles o necesarias para evitar o reducir los efectos de dichos agentes. Estos extremos, en su opinión, $<<$ no aparecen siempre diferenciados en la doctrina $>>$, determinando un totum revolutum. Los elementos que componen el medio ambiente son, para DOMPER FERRANDO, el aire, el agua, el suelo y la naturaleza en general (flora, fauna y espacios naturales), <<extendiéndose cada vez más la idea de que deberían incluirse también el patrimonio histórico e incluso otros bienes culturales" $" 804$.

Ya Marcos Fernando Pablo afirma que: “[...] después de medio siglo de desarrollo del derecho ambiental moderno, existe ya cierto consenso en que, pese a la

${ }^{803}$ CORELLA MONEDERO apud JORDANO FRAGA, Jesús. La protección del derecho a un medio ambiente cit., p. 63.

${ }^{804}$ JORDANO FRAGA, Jesús. La protección del derecho a un medio ambiente cit., p. 63. 
admitida generalidad (el medio como relación del hombre con su entorno, incorporando a éste no sólo el medio natural, sino también determinados aspectos del propio medio generado por la especie, el medio humano cultural), pese a su generalidad, decíamos, no deja de ocultar una antítesis original, reflejo de las diferentes necesidades de las diversas sociedades humanas. Desde la Declaración sobre el Medio Ambiente de la Conferencia Independiente del Dai-Dong, reunida en Graninge Stiftsgard, Saltsjó-Boo, Suecia, el 6 de junio de 1972, foro ya $<<$ alternativo $>>$ a las más oficial Conferencia de Estocolmo, que se admite como $<<$ fundacional $>>$ del derecho ambiental contemporáneo, el derecho al desarrollo y acceso a mayores niveles de calidad de vida (acceso al agua, a la vivienda, a la higiene y sanidad mínimas) como aspiración de los países menos desarrollados, se contrapone al puro $<<$ conservacionismo $>>$ más propio de los países desarrollados. La ya muy manoseada expresión $<<$ desarrollo sostenible $>>$ trata de dar respuesta a estos aspectos implicados, insistimos, desde el origen mismo del derecho ambiental actual" ${ }^{\prime 805}$

Importante destacarse la figura de Giannini ${ }^{806}$ responsable en la doctrina italiana del debate sobre el concepto jurídico de medio ambiente y quien ha sido el predecesor de la discusión en la doctrina española. Así, Giannini concibió tres acepciones del ambiente: en cuanto conservación del paisaje, incluyendo tanto las bellezas naturales como los centros históricos; el medio ambiente en cuanto normativa relacionada con la defensa del suelo, del aire y del agua; y el ambiente en cuanto objeto de disciplina urbanística.

Ya Canosa Usera ${ }^{807}$, al abordar este tema, pone en cuestión incluso el carácter reiterativo del término medio ambiente, afirmando que sería mejor, sólo 'ambiente'. Parece que el término es producto del lenguaje administrativo que se caracteriza por preferir la expresión más prolija a la más breve. No obstante, desde su empleo por la legislación de los años 70 se ha ido consagrando jurídicamente. En cuanto al contenido del concepto, debido a la fuerza atractiva del ambiental, se tiende la adopción de un concepto amplísimo, inabarcable de medio ambiente, ya que, si nos atenemos a la

\footnotetext{
${ }^{805}$ FERNANDO PABLO, Marcos M. El derecho ambiental tras la Ley 42/2007 de Patrimonio Natural y de la Biodiversidad. Revista Aranzadi de Derecho Ambiental, n. ${ }^{\circ}$ 15, 2009, Thomson Reuters, p. 24.

${ }^{806}$ GIANNINI, Massimo Severo. Ambiente: aspectos jurídicos. RTDP, fasc. I, 1973 pp. 15-53.

${ }^{807}$ CANOSA USERA, Raúl. Constitución y medio ambiente. Editorial S.L.- Dykinson, Madrid-España: 2000, pp. 36 y ss.
} 
realidad, 'ambiente' es todo lo que nos rodea. Sin embargo, este concepto tan amplio debilitaría su valor jurídico. Según el autor, el objetivo de los ordenamientos jurídicos debe ser delimitar qué bienes pueden calificarse de ambientales.

Además, Cano Usera afirma que: "El proceso descrito está todavía lejos de terminar: la madurez científica de la disciplina jurídico-ambiental aún ha de lograrse. Es más, ni siquiera hay un concepto pacífico de medio ambiente $\mathrm{y}$, al no haberlo, desconocemos el alcance del Derecho ambiental, cuya primera característica relevante es la de ser controvertido desde el momento mismo en que se polemiza a propósito del concepto de medio ambiente; conviven doctrinalmente conceptos amplísimos junto a otros muy restringidos, sin que, todavía, nuestro derecho positivo se haya pronunciado. Las definiciones aportadas por documentos internacionales ayudan en la indagación, pero no disipan la polémica que no se resolverá hasta que el legislador español inequívocamente determine el significado del término «medio ambiente» recogido en la Constitución española" ${ }^{808}$.

De este modo, se puede afirmar que el constituyente español de 1978 adoptó un concepto de medio ambiente poco nítido, apenas perfilado en su significado jurídico. La tarea clarificadora corresponde al legislador ordinario, que habrá de concretar este concepto en la anhelada ley básica ambiental. En cuanto a la jurisprudencia del Tribunal Constitucional, al unísono con ciertos sectores de la doctrina, han apostado por un concepto funcional de medio ambiente: estaríamos ante una norma ambiental cuando su "centro de gravedad" estuviera en lo ambiental, es decir, cuando su principal finalidad fuera la tutela ambiental, el "mantenimiento de un alto nivel de protección del ciclo de la vida" ${ }^{, 09}$.

Otro problema fundamental que se plantea la doctrina ante el medio ambiente es el de su pretendido contenido normativo en el art.45 CE. Dentro de la Teoría General del Derecho Ambiental pueden constatarse dos teorías claramente diferenciadas: un primer sector en el que se encuadran las opiniones de Martín Mateo, Escribano Collado,

\footnotetext{
${ }^{808}$ CANOSA USERA, Raúl. Aspectos constitucionales del Derecho Ambiental. Revista de Estudios políticos (Nueva Época), n. ${ }^{\circ}$ 94, Octubre-Diciembre: 1996, pp. 75-76.

${ }^{809}$ GÓMEZ PUERTO, Ángel B. Aspectos jurídicos y administrativos de la protección del medio ambiente en España (I). Disponible en: <http://www.egov.ufsc.br/portal/conteudo/aspectosjur\%C3\%ADdicos-y-administrativos-de-la-protección-del-medio-ambiente-en-españa-i>. Acceso en: 21$10-2015$.
} 
López Menudo y Parejo Alfonso, que niegan que el derecho al medio ambiente sea un derecho subjetivo. Dicha postura la fundamentan atendiendo a su ubicación constitucional: el Capítulo III del Título I "De Los Principios Rectores de la Política Social y Económica”. Atendiendo a la dicción literal artículo 53.3 CE estos principios “ informarán la legislación positiva, la práctica judicial y la actuación de los poderes públicos", pero no ha lugar a su alegación directa, sino "de acuerdo con las leyes que lo desarrollen"; un segundo sector, en el que se adhieren las opiniones de Jordano Fraga, Pérez Luño, Bassols Coma, Rodríguez Ramos y Martín Rebollo, entre otros, reconocen la categoría de derecho subjetivo al derecho a disfrutar de un medio ambiente adecuado. Jordano Fraga se apoya en varios argumentos: 1) Una interpretación literal del artículo $45 \mathrm{CE}$, al utilizar el término "derecho". 2) Una interpretación sistemática con los diferentes textos internacionales en los que se inserta el espíritu constitucional. 3) Una interpretación "lato sensu" del artículo 53.3 $\mathrm{CE}^{810}$.

De este modo, el medio ambiente es el objeto de un derecho y un deber constitucionalmente consagrados por el artículo $45 \mathrm{CE}$. La noción del medio ambiente como objeto de un derecho-deber coincide en su ámbito de extensión con la noción del medio ambiente como bien jurídico. Es precisamente el reconocimiento con rango constitucional del derecho 'a un medio ambiente adecuado al desarrollo de la persona' el que eleva a bien constitucional al medio ambiente. La delimitación del bien jurídico medio ambiente no es por ello una cuestión meramente doctrinal y carente de todo interés, pues las conclusiones que se obtengan de la cualificación del derecho al medio ambiente, como derecho subjetivo, serán extensibles al ámbito de su objeto. La jurisprudencia del Tribunal Supremo Español ha comenzado a definir el objeto del Derecho consagrado por la Constitución en el artículo $45^{811}$.

Como enuncia Jesús Jordano Fraga: "Ejemplo prístino de esta tarea de construcción jurisprudencial es la STS de 7 de noviembre de 1990, Ar. 8750 (Sala 3. ${ }^{\text {a }}$ sección 5. ${ }^{\mathrm{a}}$ ponente GONZÁLEZ NAVARRO). [...] Pues bien, en la Sentencia de 7 de

\footnotetext{
${ }^{810}$ DEL CASTILLO MORA, Daniel. El medio ambiente: derecho y competencia en el ordenamiento jurídico español y autonómico. Análisis particular del caso andaluz tras la Ley Orgánica 2/2007, de 19 de marzo, de reforma del Estatuto de Autonomía para Andalucía. Disponible en: $<$ http://www.juntadeandalucia.es/institutodeadministracionpublica/aplicaciones/boletin/publico/Boletin26 /Articulos_26/RAAP_MEDIO_AMBIENTE.pdf>. Acceso en: 21-10-2015, p. 138.

811 JORDANO FRAGA, Jesús. La protección del derecho a un medio ambiente cit., p. 81.
} 
noviembre de 1990 el TS ha considerado que el derecho a un medio ambiente adecuado implica el derecho a un medio ambiente acústicamente no contaminado ${ }^{812}$. En el fundamento de Derecho tercero el TS afirmó: "La Administración ha concedido lo que se le pedía -licencia para apertura de un pub- pero con los condicionamientos legales aplicables al caso, condicionamientos consistentes en no sobrepasar un determinado número de decibelios a fin de hacer compatible los legítimos derechos del recurrente con los no menos legítimos de los vecinos. Con la particularidad de que el de éstos a gozar de un medio ambiente adecuado es un derecho constitucional por cuyo respeto han de velar -y a ello les conmina la Constitución los poderes públicos (art. 45). Es claro, por tanto, que el recurrente tenía que saber que si su local es al aire libre en su casi totalidad, no podía pretender que ese derecho al medio ambiente adecuado- que implica, entre otras cosas, medio ambiente acústicamente no contaminado- deba verse abatido en su beneficio. Los vecinos tienen derecho al descanso y a la salud, y uno y otro se ven gravemente conculcados si no se respeta la moderación en la música ambiental. En este problema del respeto por el medio ambiente -en cualquiera de sus manifestaciones, la acústica entre ellas- los Ayuntamientos y, en general, todos los poderes públicos -por tanto, también los Tribunales- tienen que mostrarse particularmente rigurosos. Y este Tribunal Supremo, con machacona insistencia, así lo viene recordando con apoyo precisamente en el art. 45 de la Constitución. Y, obviamente, esto no es una moda jurisprudencial más o menos pasajera, porque ante preceptos constitucionales tan claros como el citado, no hay opción distinta de la aquí postulada. Y esto sin necesidad de recordar que el grave deterioro del medio ambiente en todos sus aspectos ha transformado el problema de su conservación en un problema esencial, cuya solución es urgente e ineludible, pues muchos de sus aspectos afectan a la supervivencia, y otros, como el de la contaminación acústica a la salud y a la convivencia civilizada. Es notorio que se han elevado voces autorizadas procedentes del campo de la medicina denunciando cómo afecta al oído y al corazón el sometimiento continuado del individuo a un excesivo número de decibelios. Y lo único que hay que lamentar es que todavía haya poderes públicos que manifiesten una cierta pasividad en la adopción de medidas eficaces en defensa contra las múltiples agresiones al medio ambiente que se dan todos los días y en todas partes. El Ayuntamiento de Roca-fort, al

\footnotetext{
${ }^{812}$ JORDANO FRAGA, Jesús. La protección del derecho a un medio ambiente cit., p. 81.
} 
imponer la adecuada reducción en el número de decibelios, no ha hecho otra cosa que ajustarse ejemplarmente a lo que manda la Constitución" ${ }^{\text {,13. }}$.

Ya, el Tribunal Constitucional realiza una aproximación en relación al concepto jurídico de medio ambiente. Así, en el fundamento jurídico de la Sentencia $64 / 1982^{814}$, de 4 de noviembre, la define del modo siguiente: "Este es el caso del medio ambiente que gramaticalmente comienza con una redundancia y que, en el lenguaje forense, ha de calificarse como concepto jurídico indeterminado con un talante pluridimensional y por tanto interdisciplinar". Además, esta Sentencia, en el fundamento jurídico 2 establece que: “[...] no puede considerarse como objetivo primordial y excluyente la explotación al máximo de los recursos naturales, el aumento de la producción a toda costa, sino que se ha de armonizar la 'utilización racional' de ésos recursos con la protección de la naturaleza, todo ello para el mejor desarrollo de la persona y para asegurar una mejor calidad de vida [...]" 815 .

Por otro lado la STC $102 / 1995^{816}$, de 26 de junio, recoge en sus fundamentos

${ }^{813}$ Sentencia disponible en: <http://supremo.vlex.es/vid/-209083475>. Acceso en: 26-10-2015.

814 Sentencia disponible en el sitio del Tribunal Constitucional de España: $<$ http://hj.tribunalconstitucional.es/HJ/en-US/Resolucion/Show/SENTENCIA/1982/64>. Acceso en: 26$10-2015$.

${ }^{815}$ En este sentido, Dionisio Fernández de Gatta Sánchez, Derecho ambiental: aspectos generales sobre la protección jurídica del cit., pp. 2-3, enseña que: "Esta función protectora del medio ambiente que lleva a cabo el Derecho no se realiza de cualquier forma, sino que ha de partir del concepto de "calidad de vida" como aspiración situada en primer plano por el Preámbulo de la Constitución (STC 102/1995, de 26 de Junio, FJ no 4), y tiene dos ejes principales: el desarrollo y progreso económico y social (basado en la libertad de empresa, en el marco de la economía de mercado, y sin perjuicio de preverse la intervención pública en ésos ámbitos) y la preservación del medio ambiente y del sistema natural (que constituye título habilitante y obligación, al mismo tiempo, para la intervención del Derecho y de los Poderes Públicos). Siendo, así, necesario, pues, compatibilizar y armonizar estos dos ejes. Como señala la STC 64/1982, de 4 de Noviembre".

${ }^{816}$ Disponible en: <https://www.boe.es/buscar/doc.php?id=BOE-T-1995-18444>. Acceso en: 26-102015. Conforme Dionisio Fernández de Gatta Sánchez, Derecho ambiental: aspectos generales sobre la protección jurídica del cit., p. 3: "Se trataría, de este modo, de intentar alcanzar el "desarrollo sostenible", equilibrado y racional que no olvida las generaciones futuras, como señala la STC 102/1995, de 26 de Junio (FJ n. $\left.{ }^{\circ} 4\right)$, con mención expresa al contenido del informe BRUNDTLAND, "Nuestro futuro común”, de 1987. Modelo, este, que está previsto tanto en la Constitución como en el ámbito europeo, tanto en el Tratado de la Unión Europea (1992-1993), según la reforma de Niza (2001-2003), como en la futura Constitución Europea (2003-2004). Además, debe tenerse en cuenta la esencial intervención de los 
jurídicos una teoría muy elaborada respecto al concepto de medio ambiente: los elementos que lo integran.

En relación a ello, el concepto de medio ambiente esta compuesto por "el conjunto de circunstancias físicas, culturales, económicas y sociales que rodean a las personas ofreciéndoles un conjunto de posibilidades para hacer su vida [...] En una descomposición factorial analítica comprende una serie de elementos o agentes geológicos, climáticos, químicos, biológicos y sociales que rodean a los seres vivos y actúan sobre ellos para bien o para mal, condicionando su existencia, su identidad, su desarrollo y más de una vez su extinción, desaparición o consunción”.

En cuanto a los elementos que lo integran, el Tribunal Constitucional, en su sexto fundamento, señala que el medio ambiente lo compone "En definitiva, la tierra, el

Poderes Públicos y, en particular, de las Administraciones Públicas en la protección del medio ambiente. En efecto, la progresiva degradación ambiental ha propiciado un importante cambio de perspectiva para el Ordenamiento que regula y protege los recursos naturales. La regulación jurídica tradicional de estos bienes presentó siempre un acentuado enfoque patrimonial, con diversos objetivos según el bien protegido, que provocó la reducción del alcance mismo de su protección. Así, p. ej., en relación a las aguas, el principal objetivo de la Legislación histórica era lograr un mayor rendimiento de la riqueza hidráulica disponible, con la finalidad de satisfacer las cada vez mayores necesidades de agua de la población y de la industria; objetivo que tenía primacía sobre todos los demás. Lo mismo puede decirse de la riqueza forestal o de las marismas. La importante degradación del medio ambiente, plasmada y criticada desde los años 60 y 70 del siglo XX, y que aún es bien visible, provoca el abandono, parcial y nunca completo, del objetivo de lograr la más amplia explotación económica de los recursos naturales, en beneficio de la inclusión, como objetivo del Derecho, de una disminución de la degradación y el agotamiento progresivo de los mismos; separándose del enfoque patrimonial. Es más, esta percepción es aceptada mayoritariamente al ser conscientes de que los recursos naturales son la base, pero también los límites, del crecimiento económico (como señaló con claridad el Tercer Programa Ambiental de la entonces Comunidad Económica Europea, 1982-1986) y de que se puede estar poniendo en peligro la propia existencia de la vida en la Tierra, incluyendo la supervivencia humana. Es decir, se pasa a concebir y valorar el medio ambiente como un bien colectivo. Además, esta nueva perspectiva le dará al Derecho Ambiental un eminentemente carácter público, al derivar la misma de la percepción de que tal protección ambiental es una exigencia de la supervivencia humana, ya que los recursos naturales son escasos, y, por ello, se requiere un uso racional de los mismos. Es más, en ésa preservación del medio ambiente debe tenerse en cuenta no sólo el presente sin también las generaciones futuras, con la finalidad de permitirles vivir en condiciones adecuadas de habitabilidad; es decir, tener en cuenta el concepto del desarrollo sostenible. 
suelo, el espacio natural, como patrimonio de la Humanidad, produce unos rendimientos o "rentas", los recursos, que son sus elementos y cuyo conjunto forma un sistema, dentro del cual pueden aislarse intelectualmente, por abstracción, otros subsistemas [...] así, el medio ambiente como objeto de conocimiento desde una perspectiva jurídica, estaría compuesto por los recursos naturales, concepto menos preciso hoy que otrora por obra de la investigación científica cuyo avance ha hecho posible, por ejemplo, el aprovechamiento de los residuos o basuras, antes desechables, con el soporte físico donde nacen, se desarrollan y mueren. La flora y la fauna, los animales y los vegetales y plantas, los minerales, los tres "reinos" clásicos de la naturaleza con mayúsculas, en el escenario que suponen el suelo y el agua, el espacio natural".

Además de los elementos naturales, en el mismo fundamento jurídico se señala que "se incorporan otros elementos que no son naturaleza, sino Historia, los monumentos, así como el paisaje, que no es sólo una realidad objetiva sino un modo de mirar, distinto en cada época y cada cultura [...] por otra parte, ligado a todo lo inventariado está el paisaje, noción estética, cuyos ingredientes son naturales -la tierra, la campiña, el valle, la sierra y el mar- y culturales, históricos, con una referencia visual, el panorama o la vista, que a finales del pasado siglo obtiene la consideración de recurso, apreciado antes como tal por las aristocracias, generalizado hoy como bien colectivo, democratizado en suma y que, por ello, ha de incorporarse al concepto constitucional del medio ambiente como reflejan muchos de los Estatutos de Autonomía".

Importante destacar, que la interpretación y el alcance del término medio ambiente dados por el Tribunal Constitucional van a ser de gran importancia para la comprensión de los juzgados encontrados en los Tribunales Superiores de España, así como sus objetos.

\subsection{Acceso a la justicia}

Aunque el estudio del acceso a las vías de tutela administrativo o judicial del bien colectivo medio ambiente excede de las pretensiones de este trabajo, creemos necesario una visualización general para que se pueda aclarar algunos puntos.

Si bien el artículo 45.1 de la Constitución española establece que: "Todos 
tienen el derecho a disfrutar de un medio ambiente adecuado para el desarrollo de la persona", hay notoria duda respecto a la eficacia normativa del dispositivo. Eso porque estaría sumiso a la existencia de legislación específica (artículo 45.3), todavía inexistente. Debemos señalar que el artículo $53.3^{817}$ dispone que los principios del Capítulo Tercero del Título I, donde se encuentra el artículo 45, "Sólo podrán ser alegados ante la Jurisdicción ordinaria de acuerdo con lo que dispongan las leyes que los desarrollen".

De ahí a concluir que la mera invocación del artículo 45.1 no bastaría para la obtención de la protección judicial, por falta de amparo legal. Resulta decir que el artículo 45.1 no regula un derecho subjetivo absoluto, garantizado constitucionalmente, razón la cual no serían tuteladas las situaciones jurídicas individuales.

El acceso a la justicia, es decir, el derecho a iniciar un procedimiento judicial o administrativo para oponerse a las acciones $\mathrm{u}$ omisiones de los particulares y las autoridades públicas que infrinjan las normas de medio ambiente, contribuye a subsanar las deficiencias en la aplicación del derecho medioambiental y por tanto a defender y proteger el medio ambiente.

El Principio 10 de Río se refiere también a la necesidad de "proporcionar un acceso efectivo a los procedimientos judiciales y administrativos, entre éstos el resarcimiento de daños y los recursos pertinentes". El Convenio de Aarhus ${ }^{818}$ dispone

${ }^{817}$ Artículo 53.

“1. Los derechos y libertades reconocidos en el Capítulo segundo del presente Título vinculan a todos los poderes públicos. Sólo por ley, que en todo caso deberá respetar su contenido esencial, podrá regularse el ejercicio de tales derechos y libertades, que se tutelarán de acuerdo con lo previsto en el artículo 161, 1, a).

2. Cualquier ciudadano podrá recabar la tutela de las libertades y derechos reconocidos en el artículo $14 \mathrm{y}$ la Sección primera del Capítulo segundo ante los Tribunales ordinarios por un procedimiento basado en los principios de preferencia y sumariedad y, en su caso, a través del recurso de amparo ante el Tribunal Constitucional. Este último recurso será aplicable a la objeción de conciencia reconocida en el artículo 30 .

3. El reconocimiento, el respeto y la protección de los principios reconocidos en el Capítulo tercero informarán la legislación positiva, la práctica judicial y la actuación de los poderes públicos. Sólo podrán ser alegados ante la Jurisdicción ordinaria de acuerdo con lo que dispongan las leyes que los desarrollen".

${ }^{818}$ El Convenio de Aarhus sobre el acceso a la información, la participación del público en la toma de decisiones y el acceso a la justicia en asuntos ambientes, de 1998, establece las reglas básicas para promover la participación de los ciudadanos en asuntos ambientales y en el cumplimiento de la 
que cada Parte velará por que los miembros del público que reúnen los criterios eventuales previstos por su derecho interno puedan entablar procedimientos administrativos o judiciales para impugnar las acciones u omisiones de particulares o de autoridades públicas que vayan en contra de las disposiciones del derecho nacional ambiental.

Además, una vía muy importante de actuación es el acceso a la justicia para que tanto la Administración como los tribunales aseguren el cese de las prácticas ilegales lesivas del entorno y el efectivo cumplimiento de las medidas ambientales adoptadas por el legislador, tanto respecto de las actuaciones privadas como de la conducta de la Administración. La potenciación de las acciones de los particulares, y en especial de las asociaciones ecologistas, en defensa del bien colectivo resultan fundamentales para que la Administración y los tribunales puedan garantizar un escrupuloso cumplimiento de las normas ambientales ${ }^{819}$.

El mayor problema que suscita el ordenamiento español para instar la actuación de la administración y de los tribunales en la defensa del bien jurídico medio ambiente y exigir, en su caso, la responsabilidad que corresponda, es que las acciones están pensadas, por lo general para supuestos en los que existen derechos o intereses individuales lesionados, y se reducen mucho cuando se trata de daños al medio ambiente que no afectan a ningún derecho o interés particular concreto ${ }^{820}$.

En el año 2006, la ley 27/2006, de 18 de julio, regula los derechos de acceso a la información, de participación pública y de acceso a la justicia en materia de medio

legislación ambiental. El Convenio se apoya sobre tres pilares: el derecho de acceso a la información ambiental; el derecho a participar en los procesos de toma de decisiones; y el acceso a la justicia, es decir, el derecho a entablar un proceso administrativo o judicial para oponerse a las acciones u omisiones de los particulares y las autoridades públicas que infrinjan las normas de medio ambiente. Instrumento de Ratificación del Convenio sobre el acceso a la información, la participación del público en la toma de decisiones y el acceso a la justicia en materia de medio ambiente, hecho en Aarhus (Dinamarca), el 25 de junio de 1998. Disponible en: < https://www.boe.es/buscar/doc.php?id=BOE-A-2005-2528>. Acceso en: 27-10-2015.

${ }^{819}$ Mecanismos legales para la defensa del medio ambiente. Elaborado por el Instituto Internacional de Derecho y Medio Ambiente. Disponible en: $<$ http://www.iidma.org/privado/Archivos/Guiamecanismosport.pdf>. Acceso en: 28-10-2015.

${ }^{820}$ Mecanismos legales para la defensa del medio ambiente. Elaborado por el Instituto Internacional de Derecho y Medio Ambiente. Disponible en: $<$ http://www.iidma.org/privado/Archivos/Guiamecanismosport.pdf>. Acceso en: 28-10-2015. 
ambiente, incorporando las Directivas 2003/4/CE y 2003/35/CE, en cuya exposición de motivos se señala que configurado en el art. 45 Constitución Española el medio ambiente como un bien jurídico, de su disfrute son titulares todos los ciudadanos y su conservación es una obligación que comparten los poderes públicos y la sociedad en su conjunto.

La Constitución Española otorga a todos el derecho a exigir a los poderes públicos que adopten las medidas necesarias para garantizar la adecuada protección del medio ambiente, para disfrutar del derecho a vivir en un medio ambiente sano. $\mathrm{Y}$ correlativamente, impone, igualmente a todos, la obligación de preservar y respetar ese mismo medio ambiente, al que el art. 45 Constitución Española se refiere expresamente como recursos naturales ${ }^{821}$.

El Tribunal Constitucional en esa labor de concreción interpretativa de los derechos constitucionales y su extensión, ha incluido en sus sentencias dentro de esta categoría de recurso natural: al aire, a la atmósfera y al agua, cuyo carácter de recursos vitales es evidente (STC 227/1988); la tierra, el suelo y el subsuelo, el espacio natural (STC 102/1995); y también quedan protegidas la fauna y la flora (STC 102/ 1995).

Doctrina reiterada del Alto Tribunal también ha considerado incluidos en el concepto otros elementos que no son naturaleza propiamente dicha, sino que tienen un carácter histórico-cultural, como son los monumentos y, en parte, el paisaje (STC 102/1995). Sosteniendo que el Medio Ambiente no puede reducirse a la mera suma o yuxtaposición de los recursos naturales y su base física, sino que es el entramado complejo de las relaciones de todos esos elementos, cuya interconexión les dota de un significado trascendente (Sentencia anteriormente citada del Tribunal Constitucional, 102/1995).

Pero, para que los ciudadanos, individual o colectivamente, puedan participar en esa tarea de protección de forma real y efectiva, resulta necesario disponer de los medios instrumentales adecuados, cobrando en este ámbito especial significación la participación en el proceso de toma de decisiones públicas, pues a tal efecto los arts. 9.2 y $105 \mathrm{CE}$, garantizan el funcionamiento democrático de las sociedades e introducen

\footnotetext{
${ }^{821}$ SANJURJO REBOLLO, Beatriz. Medio ambiente y acción popular. Artículo publicado en el Boletín "Urbanismo", el 1 de enero de 2011. Disponible en: <
} http://www.elderecho.com/tribuna/administrativo/Medio-ambiente-accion-popular_11_233680001.html>. Acceso en: 05-11-2015. 
mayor transparencia en la gestión de los asuntos públicos; y más concretamente la acción popular.

\subsubsection{Solapamiento del contenido del derecho al medio ambiente con el} contenido de otros derechos de diferente rango

El supuesto contenido del derecho a disfrutar del medio ambiente es enorme, quizá inalcanzable y, por tanto, de muy difícil concreción legislativa. Se suma a esta situación la indeterminación de los mecanismos de defensa. Para que la defensa del medio ambiente no resulte letra muerta, se ve la posibilidad de superponer el contenido del derecho al medio ambiente con algunos contenidos de otros derechos establecidos normativamente.

Así, otros derechos y medios de protección sirven alternativamente como una forma de ejecución. Eso explica por que las vías legales de protección del derecho ambiental son tan numerosas y variadas (lo que se denota en diversos sistemas jurídicos), pues una pretensión basada en otra ley sirve también para proteger el medio ambiente.

Al tratar de los aspectos constitucionales del Derecho Ambiental, Raúl Canosa Usera, comenta sobre esa superposición, apuntando diversos casos y afirma que: “[...] resulta obvio que ciertas pretensiones ambientalistas pueden cobijarse en el contenido de otros derechos más desarrollados y protegidos. Sin duda el derecho a la vida y a la integridad física y moral (art. $15 \mathrm{CE}$ ) amparan el mínimo ambiental exigible y pueden, en consecuencia, exigirse la tutela de los mismos desde una perspectiva ambientalista. No obstante, es cierto también que no todo el supuesto contenido del derecho al entorno cabe en el derecho a la vida porque el primero evoca un ambiente óptimo, la calidad de vida, para el desarrollo de la persona y el derecho recogido en el artículo $15 \mathrm{CE}$ protege un mínimo vital, aunque de la forma más enérgica que prevé el Ordenamiento. La vida es un bien absoluto, la calidad de vida y el medio ambiente adecuado para el desarrollo de la persona son más bien desiderata, bienes jurídicos relativos cuyo disfrute pleno no puede realizarse de inmediato ni es, por tanto, exigible ante los Tribunales ${ }^{\text {}} 822$.

${ }^{822}$ CANOSA USERA, Raúl. Aspectos constitucionales del Derecho cit., p. 90. 
Se produce solapamiento también con el derecho a la protección de la salud, regulado en el Capítulo III del Título I de la Constitución (art. 4 CE). Sin embargo, la protección de este derecho está mucho más perfilada que la del derecho al entorno y puede éste cobijarse bajo aquél cuando el Ordenamiento lo permita ${ }^{823}$.

También el derecho a la privacidad (artículo 18) da amparo a ciertas pretensiones ambientalistas. En este sentido, Raúl Canosa Usera comenta que: "Recuérdese el caso de la depuradora de Lorca, resuelto por el Tribunal Europeo de Derechos Humanos a favor de los recurrentes, afirmando, precisamente, que se vulneró el derecho a la intimidad de los mismos y que tal vulneración la produjo la contaminación. Sin entrar en la quizá caprichosa interpretación del Tribunal Europeo de Derechos Humanos, que antes no realizó nuestro Tribunal Constitucional, llama la atención la amplísima proyección de lo ambiental en otras esferas de la subjetividad, forzando, como en esta ocasión, una interpretación de las mismas en clave ambiental. Parece como si lo medio-ambiental se estuviera erigiendo en canon general de interpretación del Orden jurídico" ${ }^{, 824}$.

No siempre la relación del derecho español con otros es de coincidencia y solapamiento. En muchas ocasiones encontramos mutuas limitaciones. Varios derechos se ven potencialmente afectados por la tutela del entorno: la libertad de circulación y residencia (artículo $19 \mathrm{CE}$ ); el derecho de reunión y manifestación (artículo $35 \mathrm{CE}$ ); el derecho de trabajo (artículo $53 \mathrm{CE}$ ), o el derecho a la educación. Medidas protectoras del entorno con frecuencia limitan el disfrute de ciertos derechos, como los señalados. Se pone así de manifiesto que la presencia de un interés jurídico, nuevo y emergente, obliga a acomodar otros intereses ya consolidados, pero que han de hacer hueco para la proyección del recién llegado.

Con el derecho a la propiedad y la libertad de empresa (artículos 33 y $38 \mathrm{CE}$ ), el derecho a disfrutar del entorno se relaciona de manera ambivalente y compleja. Por un lado, el solapamiento si el derecho de propiedad se esgrime, como puede hacerse, para la tutela de los intereses ambientalistas del propietario. Y, por otro, la mutua limitación, cuando el disfrute de la propiedad deteriora el ambiente. El conflicto latente entre ambos derechos refleja la tensión entre desarrollo económico y preservación del entorno. La libertad económica, motor de ese desarrollo, queda constreñida por la

\footnotetext{
${ }^{823}$ CANOSA USERA, Raúl. Aspectos constitucionales del Derecho cit., pp. 90-91.

${ }^{824}$ CANOSA USERA, Raúl. Aspectos constitucionales del Derecho cit., p. 91.
} 
protección que ha de dispensarse al entorno. El equilibrio entre los dos intereses lo determina el Estado, pero vinculado por los fines constitucionales (artículo $45 \mathrm{CE}$ ) que le dirigen a la consecución de un medio ambiente adecuado para el desarrollo del individuo $^{825}$. El derecho de disfrutar del entorno es derecho económico-social ${ }^{826}$, y los derechos de esta naturaleza complican la proyección de los derechos clásicos, al limitarlos, exigiendo una ponderación entre todos ellos.

Existen diversas formas de protección de intereses medioambientales frente a los poderes públicos y frente a los particulares, por vías jurisdiccionales ${ }^{827}$, cuyas principales vamos a comentar.

\subsubsection{Vías alternativas}

Aunque no existe una configuración legal del hipotético derecho al goce del entorno $\mathrm{y}$, en consecuencia, no hay previstas acciones específicas de defensa, pueden determinadas pretensiones ambientalistas encontrar protección de los tribunales, solapándose en el contenido de derechos subjetivos reconocidos en el Ordenamiento español $^{828}$.

\footnotetext{
${ }^{825}$ Idem, p. 91-92.
}

${ }^{826}$ En este sentido, como bien comenta Dionisio Fernández de Gatta Sánchez, Derecho ambiental: aspectos generales sobre la protección jurídica del cit., p. 5: "En efecto, el art. 45 de la Constitución recoge el derecho y el deber de proteger el medio ambiente, incluyendo el mismo como un principio económico y social, como la fijación de un fin de los Poderes Públicos, siguiendo las pautas del Estado Social. Su párrafo segundo establece claramente la obligación de todos los Poderes Públicos de proteger el medio ambiente, es decir, asume la consideración de la protección ambiental como una función pública. Finalmente, el párrafo tercero establece las consecuencias por el incumplimiento de la normativa ambiental: sanciones administrativas, sanciones penales y reparación del daño ambiental causado".

${ }^{827}$ Conforme Raúl Canosa Usera, Aspectos constitucionales del Derecho cit., p. 92: "El derecho a gozar del entorno poseería una dimensión personalísima, pero es obvio que su disfrute o alcanza a todos o no alcanza a ninguno. Un entorno deteriorado impide a todos disfrutarlo y, a la inversa, un medio adecuado beneficia a todos. Tal y como acontece con los derechos económico-sociales, la proyección uti socius acompaña a su dimensión individual, uti singulis. Para su protección convendría, pues, atribuir acciones de defensa tanto a los individuos, como a los grupos. Sólo con la defensa individual tendríamos un verdadero derecho subjetivo, pero la acción colectiva haría más eficaz la defensa".

${ }^{828}$ CANOSA USERA, Raúl. Aspectos constitucionales del Derecho cit., p. 92. 
Sin embargo, el derecho a la vida tiene protección máxima en el Orden Jurídico español, recibiendo así, las mayores garantías posibles, de este modo, si se encuadra algún aspecto del derecho al medio ambiente dentro del derecho a la vida, habrá la máxima protección. Lo mismo ocurre con el derecho a la integridad física o moral. En estos supuestos el ambiente protegido sería el mínimo indispensable para el bienestar humano. También cabría dar cobertura a ciertos contenidos subjetivos medioambientales, al proteger el derecho a la intimidad o hacerlo a través del derecho a la protección de la salud. Sin olvidar las vías de defensa del derecho de propiedad, muy útiles en algunos caso para defender intereses ambientales ${ }^{829}$.

La ausencia de medios específicos de protección necesarios para procesar las causas que involucran el medio ambiente y la estrecha relación de este con diversos aspectos de la vida social, permiten utilizar de todos los medios para formular reclamaciones medioambientales apoyadas en pretensiones de otro género que ya tienen acomodo y satisfacción procesal.

Según Raúl Canosa Usera: "En resumidas cuentas, la inexistencia de vías específicas de tutela obliga a tramitar toda reclamación medioambiental convertida en pretensión atendible por los Tribunales, bien solapándose con otros derechos, bien invocándose intereses legítimos. En este contexto, el artículo 7.3 de la Ley Orgánica del Poder Judicial, cuando regula de manera generosa la legitimación activa, sirve para cimentar sobre él una evolución jurisprudencial aperturista y se apoya, además, en el artículo 24.1 de la Constitución" $" 830$.

${ }^{829}$ CANOSA USERA, Raúl. Aspectos constitucionales del Derecho cit., p. 93.

${ }^{830}$ CANOSA USERA, Raúl. Aspectos constitucionales del Derecho cit., pp. 93-94. Además, en nota de pie de página 49, p. 93 el autor comenta que varios autores destacan las posibilidades aperturistas de la legitimación permitida por el artículo 7.3 de la Ley Orgánica del Poder Judicial (LOPJ): F . Gómez Liaño: «La legitimación colectiva y el artículo 7 de la LOPJ», y Delgado Piqueras. Así quedarían completadas las vías clásicas del orden civil, las relaciones de vecindad, que explican, entre otros, Pérez Luño y Delgado Piqueras. La interpretación «generosa» del artículo 28 de la Ley de la Jurisdicción Contencioso-Administrativa ofrecería posibilidades de articular la defensa concreta del interés medioambiental, Delgado Piqueras; Alonso García resalta, por su parte, la posible y necesaria participación de los Tribunales nacionales en la aplicación y control de la legislación ambiental comunitaria. La acción popular en materia de medio ambiente, deducible, ajuicio de López Menudo, directamente del artículo 45.1, y en combinación con la LOPJ concretaría así el derecho a la protección del medio ambiente. Hay que destacar también la generosa redacción del artículo 31 de la Ley 32/1992 de Régimen Jurídico de las Administraciones Públicas y del Procedimiento Administrativo Común. El citado 
Lo expuesto resulta evidente con las llamadas relaciones de vecindad, sobre las que subyacen reclamaciones medioambientales. Además, en ámbito administrativo es posible aprovechar la legitimación procesal activa que la legislación otorga a los administrados para impugnar actos y disposiciones de la Administración. La primera de las vías, la civil, hace factible, sobre todo, el disfrute del entorno frente a las intromisiones de los particulares; la segunda posibilita exigir la anulación de actos administrativos contrarios a la legalidad medioambiental y es, también, vía indirecta de protección frente a los particulares.

\subsubsection{Relaciones de vecindad y reparación del daño causado}

Las relaciones de vecindad aseguran el uso pacífico del derecho de propiedad y protege su titular de toda intromisión ilegítima (ruidos, emisiones desagradables, olores, invasiones, etc.) realizada por vecinos. Por cierto que las acciones contaminantes de los vecinos pueden encuadrarse como actividades molestas para la propiedad y pueden generar resarcimientos en el ámbito civil, apelando al expediente de las relaciones de vecindad.

Hay quien defienda que esta forma representa una buena salida para la protección ambiental, desobligando una actuación estatal, onerosa y muchas veces menos efectiva de lo que la realizada por los particulares.

En este sentido, Raúl Canosa Usera afirma que: “Aunque los resultados medioambientales, obtenidos por esta vía, son hasta la fecha en España muy modestos, muchos opinan que la expansión de esta vía protectora generará beneficios medioambientales y apuestan por centrar aquí la protección del entorno. Detrás de esta opinión laten ideologías teme- rosas de la actividad del Estado que consideran peligrosa

precepto detalla quiénes tienen la condición de interesados en los procedimientos administrativos, defendiendo intereses individuales o colectivos. El número 2 del artículo 31 afirma que: «Las asociaciones y organizaciones representativas de intereses económicos y sociales serán titulares de intereses legítimos colectivos en los términos que la ley establezca.» Aunque se haga una remisión a otra ley, se regula una legitimación colectiva en el procedimiento administrativo. Esta sería la vía, aún por concretar, para la defensa de intereses colectivos medioambientales esgrimidos por organizaciones sociales. 
para el ambiente y onerosa para el erario público. La concepción liberal pretende limitar la actividad administrativa de vigilancia medio-ambiental y encomendar su protección a los propios particulares. Desconfían de la acción estatal y prefieren que sean los particulares quienes, cada cual, defendiendo su propiedad frente a otros propietarios, mantengan ese medio ambiente adecuado, al que se refiere la Constitución. Cada cual sabrá lo que le conviene y entre todos, actuando por su propio interés, se preservará el entorno" 831 .

\subsubsection{La vía administrativa y contencioso-administrativa}

La vía administrativa y contencioso-administrativa, es sin duda la que más posibilidades ofrece para ejercitar acciones dirigidas a la protección del entorno. La mayor parte de los litigios de carácter ambiental se sustancian en la actualidad ante la Administración o la Jurisdicción contencioso-administrativa, lo que responde al papel preponderante de los poderes públicos y del derecho administrativo en la ordenación y protección de los bienes ambientales ${ }^{832}$.

La Constitución Española de 1978 influyó directamente en la jurisdicción Contencioso-administrativa, dado el contenido de sus artículos $1.1^{\circ}, 9.3^{\circ}, 10.1^{\circ}, 106.1^{\circ}$, 117 y ss., $103.1^{\circ}$, y singularmente el artículo 24 , que contiene un derecho fundamental a la tutela judicial efectiva, también aplicable frente a la administración pública ${ }^{833}$.

Importante destacar, que según Marcos M. Fernando Pablo y M. ${ }^{\mathrm{a}}$ Ángeles Gonzáles Bustos: "Hay que recordar, no obstante, que las exigencias de alguno de estos precepto ya estaban atendidas (aunque a veces con menor intensidad de lo reclamado por la CE) por el texto de la Ley de la Jurisdicción de 1956. Por una parte, ésta Ley culminó el proceso de judicialización de los órganos contencioso-administrativos (exigido ahora por el art. $117 \mathrm{CE}$ ) al suprimir los anteriores Tribunales Administrativos

\footnotetext{
${ }^{831}$ CANOSA USERA, Raúl. Aspectos constitucionales del Derecho cit., pp. 94-95.

${ }^{832}$ LOZANO CUTANDA, Blanca. Derecho Ambiental Administrativo. $1^{\mathrm{a}}$ ed., La Ley, Madrid-España: 2010 , p. 371.

${ }^{833}$ FERNANDO PABLO, Marcos M.; GONZÁLES BUSTOS, M. ${ }^{\mathrm{a}}$ Ángeles. Tema 3: El control jurisdiccional de las administraciones públicas. Cuadernos de Derecho Administrativo II. Garantías jurídico-administrativas. $2^{\mathrm{a}}$ ed., Ratio Legis, Salamanca-España: 2013, pp. 51-74.
} 
Provinciales (antes de composición mixta: Presidente de la Audiencia, dos magistrados y dos Diputados Provinciales con título de Letrado); por otra, profundizó el sistema de cláusula general $\left(1.1^{\circ}, 9.3^{\circ}\right.$ y art. 106-CE), eliminando la exclusión de las potestades discrecionales y la materia reglamentaria, al tiempo que, finalmente, permitió actuar ya en defensa no sólo de derechos perfectos sino también de interés legítimos (como reclama el art. $24 \mathrm{CE})^{\text {}} 834$.

El artículo 45.1 de la Constitución Española dispone que los poderes públicos velaran por la utilización racional de todos los recursos naturales, con el fin de proteger y mejorar la calidad de la vida y defender y restaurar el medio ambiente.

Así, ante las pretensiones que los ciudadanos pueden ejercitar en la vía contencioso-administrativa para la protección del medio ambiente podemos destacar: la anulación de un acto administrativo o de un reglamento ilegales; el cese de la actividad dañosa y/o la indemnización de los daños y perjuicios; y la efectiva adopción por la Administración de las medidas a que la obligue el ordenamiento y que redunden a favor del medio ambiente (utilizando el denominado 'recurso por inactividad de la Administración) $)^{835}$.

En este sentido, Marcos M. Fernando Pablo y M. Ángeles Gonzáles Bustos: "El primer rasgo decisivo es que el proceso contencioso, la jurisdicción contenciosa es,

${ }^{834}$ FERNANDO PABLO, Marcos M.; GONZÁLES BUSTOS, M. ${ }^{a}$ Ángeles. Tema 3: El control jurisdiccional de las administraciones cit., p. 55. Interesante análisis hace Ricardo RIVERO ORTEGA, Introducción al Derecho Público Económico, Edit. Ratio Legis, 1999, Salamanca, en el cuarto tema abordado por el autor en su obra, él trata del Principio de Legalidad y Sistemas de Potestades de la Administración, como vinculación positiva completa del Derecho, llamando la atención sobre la atribución de poderes discrecionales a la Administración autónoma y el enunciado de cláusulas generales de apoderamiento que dificultan la previsibilidad de las intervenciones económicas de la administración en el ejercicio de las potestades, y su control jurisdiccional. Además el autor afirma que los Tribunales españoles han ido desarrollando una serie de técnicas que facilitan la prevención de desviaciones y abusos (revisión de conceptos jurídicos indeterminados o nociones abstractas contenidas por las normas; control de los elementos reglados; control de los hechos determinantes; sujeción de toda la potestad a los principios generales del Derecho; etc.). Asimismo, el autor analiza las potestades administrativas (potestades-funciones, como de sanción, de inspección, de autorización, de tarifas, etc.) y el privilegio de autotutela de Administración. En efecto, la actuación administrativa generalmente es imperativa, aplicable y produce efectos de manera inmediata, en cuanto los actos administrativos son ejecutivos y ejecutorios, en cuanto pueden ser ejecutados por la propia Administración.

${ }^{835}$ LOZANO CUTANDA, Blanca. Derecho Ambiental cit., p. 371. 
históricamente, de naturaleza impugnatoria ("recurso" dice nuestra terminología tradicional). Todavía hoy (aunque se evite muchas veces en legislación) se observa cómo se admite recurso contra (arts. 25 y ss. LJCA) una actuación o inactividad de la administración, o bien se indica que los tribunales controlan la actuación administrativa ( art. $106 \mathrm{CE}$ ). Hay que tener en cuenta que, dada la posición de autotutela administrativa que la administración va consolidando, el recurso contencioso ante los tribunales de ese orden se configurará, justamente, como una suerte de "segunda instancia" o apelación a lo decidido previamente por la administración. Así, el sistema se entendió en el sentido de que antes de que la cuestión pudiera llegar a los tribunales, debía existir una previa decisión administrativa que era el objeto del posterior proceso. Este se transformó en un recurso que "revisaba" la legalidad de esta previa decisión, que aparecía como el verdadero objeto del proceso. Se dio así a esta jurisdicción una naturaleza revisora nota de la cual la jurisprudencia extrajo diferentes consecuencias que disminuían la protección que esta jurisdicción ofrecía a los derechos e intereses" ${ }^{\$ 36}$.

Sin embargo, los autores afirman que actualmente: "La nueva $\operatorname{LRJCA}^{837}$ ha superado definitivamente el carácter revisor de la jurisdicción, y aunque regula un solo proceso, en él admite que se ejerciten diferentes acciones, en función del tipo de pretensión que se ejercite. Son éstas, y no el acto previo, el objeto del proceso, y, por ello, se admite ahora recurso contencioso ante la inactividad de la administración y ante actuaciones puramente materiales en vía de hecho. Así, lo expresa la Exposición de Motivos: (se trata de) "de superar la tradicional y restringida concepción del recurso

${ }^{836}$ FERnANDO PABLO, Marcos M.; GONZÁles BUSTOS, M. ${ }^{a}$ Ángeles. Tema 3: El control jurisdiccional de las administraciones cit., p. 56.

${ }^{837}$ Legislación consolidada de la Ley 29/1998, de 13 de julio, reguladora de la Jurisdicción Contenciosoadministrativa. Disponible en: <https://www.boe.es/buscar/act.php?id=BOE-A-199816718\& $\mathrm{p}=20131210 \& \mathrm{tn}=2>$. Acceso en: 28-10-2015. Importante destacar lo que enseñan Marcos M. Fernando Pablo y M. ángeles Gonzáles Bustos, Tema 3: El control jurisdiccional de las administraciones cit., p. 54 respecto a la evolución del sistema español de jurisdicción contenciosoadministrativo: "El sistema permaneció materialmente inalterado (aunque la Ley Maura de 5 de abril de 1904 trasladó las competencias del órgano central a una nueva sala del Tribunal Supremo) prácticamente hasta la Ley de la Jurisdicción Contenciosa de 2 de diciembre de 1956, que constituyó una de las bases del derecho administrativo español actual. La vigencia de ésta ley soportó durante veinte años, con algunos matices relevantes introducidos por la jurisprudencia constitucional, la vigencia de la Constitución y, en gran medida, por tanto, su espíritu está presente aún en el texto vigente que es la Ley 29/98 de 13 de julio". 
contencioso-administrativo como una revisión judicial de actos administrativos previos, es decir, como un recurso al acto, y de abrir definitivamente las puertas para obtener justicia frente a cualquier comportamiento ilícito de la Administración"”,838.

Hasta ahora, el obstáculo fundamental con que se encontraban todas las acciones en esta vía, dirigidas a la protección del medio ambiente en cuanto bien jurídico colectivo, era la necesidad de acreditar un derecho o interés legítimo afectado por la actividad o inactividad administrativa ${ }^{839}$.

En el ámbito del contencioso-administrativo, la Ley de Jurisdicción Contencioso-administrativa ${ }^{840}$ permite la fiscalización de la actividad de la Administración por iniciativa de los administrados, para que la Administración actúe dentro de la legalidad. Como la legalidad está también relacionada a las normas ambientales, que la Administración deberá cumplir y hacer cumplir, el uso del derecho racional o la invocación de intereses legítimos conduce a la eliminación de actos y disposiciones ilegales de la Administración y preserva el medio ambiente.

Los administrados pueden impugnar, mediante interposición de recurso contencioso-administrativo ordinario, actos o disposiciones de la Administración cuando haya interés directo e ilegalidad de acto administrativo. En este caso, se debe pleitear el reconocimiento del derecho, la adopción de medidas necesarias a su restablecimiento y, caso sea necesario, también el resarcimiento por los daños. Además, los administrados pueden, individual o colectivamente, formular recursos cuando la actuación administrativa perjudique sus intereses ambientales protegidos por el ordenamiento jurídico.

Esta vía consiste en el acceso a la justicia ante la jurisdicción contenciosoadministrativa, es decir, aquellos tribunales competentes para tratar asuntos en los que

\footnotetext{
${ }^{838}$ FERNANDO PABLO, Marcos M.; GONZÁlES BUSTOS, M. ${ }^{\mathrm{a}}$ Ángeles. Tema 3: El control jurisdiccional de las administraciones cit., p. 57.

${ }^{839}$ Exigida con carácter general por los arts. 68 y 107, respectivamente, de la Ley 30/1992, de 26 de noviembre, de Régimen Jurídico de las Administraciones Públicas y del Procedimiento Administrativo Común (LRJAP) para iniciar un procedimiento administrativo y para interponer recursos administrativos, y por el art. 19.1.a) de la Ley de Jurisdicción Contencioso-administrativa (LJCA) para interponer un recurso ante los tribunales de este orden jurisdiccional. LOZANO CUTANDA, Blanca. Derecho Ambiental cit., p. 372.

${ }^{840}$ Disponible en: < https:/www.boe.es/buscar/act.php?id=BOE-A-1998-16718>. Acceso en: 28-102015.
} 
la Administración Pública es una de las partes en litigio ${ }^{841}$. Además, es la vía que más posibilidades ofrece para ejercitar acciones dirigidas a la defensa del medio ambiente. Pero, al igual que en el caso del acceso a los procedimientos administrativos, nos encontramos con determinados obstáculos derivados de las restricciones relativas a la legitimación activa.

La vía del contencioso-administrativo no reconoce la acción popular que, como veremos, sí está reconocida en la vía penal. El artículo 19.1.a ${ }^{842}$ de la Ley reguladora de

${ }^{841}$ Según Marcos M. Fernando Pablo y M. a Ángeles Gonzáles Bustos, Tema 4: El proceso contenciosoadministrativo. Cuadernos de Derecho Administrativo II. Garantías juridico-administrativas. $2^{\mathrm{a}}$ ed., Ratio Legis, Salamanca-España: 2013, pp. 75-103: "La primera consideración es que, en el proceso contencioso, la Administración ocupará, generalmente, la más cómoda posición de "demandado", ya que en virtud de sus potestades de autotutela, se traslada al afectado la carga de recurrir. Un supuesto, singular, corresponde al caso en que las pretensiones contra un acto se funden en la ilegalidad de la disposición general (reglamento) aplicada, en cuyo caso "se considerará también parte demandada (además de la administración autora del acto recurrido) a la administración autora de la disposición" (art. 21 LJCA). La posición ordinaria de demandada que ocupa la administración, sin embargo, se excepciona, por una parte, cuando la administración impugna un acto propio anterior, previa declaración de lesividad (art. 103 Ley 30/92 y 19-2 LJCA), o cuando, sin necesidad de este requisito, impugna las resoluciones de los órganos especiales de recursos en materia de contratación; por otra, cuando una administración actúa, como demandante, defendiendo sus competencias frente a otra, tal como habilita el art. 19 de la LJCA11. Finalmente, en aquellos casos en los que la administración solicita una autorización de entrada domiciliaria o medidas que requieran afectar a derechos fundamentales judicialmente protegidos, (dentro del ámbito de ésta jurisdicción) la administración requiere, como demandante, la intervención de la jurisdicción contenciosa”.

${ }^{842}$ Artículo 19.

“1. Están legitimados ante el orden jurisdiccional contencioso-administrativo:

a) Las personas físicas o jurídicas que ostenten un derecho o interés legítimo.

b) Las corporaciones, asociaciones, sindicatos y grupos y entidades a que se refiere el artículo 18 que resulten afectados o estén legalmente habilitados para la defensa de los derechos e intereses legítimos colectivos.

c) La Administración del Estado, cuando ostente un derecho o interés legítimo, para impugnar los actos y disposiciones de la Administración de las Comunidades Autónomas y de los Organismos públicos vinculados a éstas, así como los de las Entidades locales, de conformidad con lo dispuesto en la legislación de régimen local, y los de cualquier otra entidad pública no sometida a su fiscalización.

d) La Administración de las Comunidades Autónomas, para impugnar los actos y disposiciones que afecten al ámbito de su autonomía, emanados de la Administración del Estado y de cualquier otra Administración u Organismo público, así como los de las Entidades locales, de conformidad con lo 
la Jurisdicción Contencioso-Administrativa reconoce con carácter general legitimación para recurrir ante sus tribunales únicamente a "las personas físicas o jurídicas que ostenten un derecho o interés legítimo". A continuación la Ley dispone la posibilidad de que cualquier ciudadano pueda acudir a esta jurisdicción en ejercicio de la acción

dispuesto en la legislación de régimen local.

e) Las Entidades locales territoriales, para impugnar los actos y disposiciones que afecten al ámbito de su autonomía, emanados de las Administraciones del Estado y de las Comunidades Autónomas, así como los de Organismos públicos con personalidad jurídica propia vinculados a una y otras o los de otras Entidades locales.

f) El Ministerio Fiscal para intervenir en los procesos que determine la Ley.

g) Las Entidades de Derecho público con personalidad jurídica propia vinculadas o dependientes de cualquiera de las Administraciones públicas para impugnar los actos o disposiciones que afecten al ámbito de sus fines.

h) Cualquier ciudadano, en ejercicio de la acción popular, en los casos expresamente previstos por las Leyes.

i) Para la defensa del derecho de igualdad de trato entre mujeres y hombres, además de los afectados y siempre con su autorización, estarán también legitimados los sindicatos y las asociaciones legalmente constituidas cuyo fin primordial sea la defensa de la igualdad de trato entre mujeres y hombres, respecto de sus afiliados y asociados, respectivamente.

Cuando los afectados sean una pluralidad de personas indeterminada o de difícil determinación, la legitimación para demandar en juicio la defensa de estos intereses difusos corresponderá exclusivamente a los organismos públicos con competencia en la materia, a los sindicatos más representativos y a las asociaciones de ámbito estatal cuyo fin primordial sea la igualdad entre mujeres y hombres, sin perjuicio, si los afectados estuvieran determinados, de su propia legitimación procesal.

La persona acosada será la única legitimada en los litigios sobre acoso sexual y acoso por razón de sexo.

2. La Administración autora de un acto está legitimada para impugnarlo ante este orden jurisdiccional, previa su declaración de lesividad para el interés público en los términos establecidos por la Ley.

3. El ejercicio de acciones por los vecinos en nombre e interés de las Entidades locales se rige por lo dispuesto en la legislación de régimen local.

4. Las Administraciones públicas y los particulares podrán interponer recurso contencioso-administrativo contra las decisiones adoptadas por los órganos administrativos a los que corresponde resolver los recursos especiales y las reclamaciones en materia de contratación a que se refiere la legislación de Contratos del Sector Público sin necesidad, en el primer caso, de declaración de lesividad.

5. Tendrán legitimación para recurrir ante el orden jurisdiccional contencioso-administrativo las resoluciones del Tribunal Administrativo del Deporte que se dicten en asuntos de disciplina deportiva en materia de dopaje, todas las personas mencionadas en el artículo 40.4 de la Ley Orgánica de Protección de la Salud del Deportista y Lucha contra el Dopaje en la Actividad Deportiva". 
popular pero sólo en los casos que esté así previsto por las leyes (art. 19.1.h) ${ }^{843}$. A diferencia de este uso prudente del instituto de la acción pública por la legislación estatal, en el ámbito autonómico son incontables las normas ambientales que la reconocen, especialmente en el ámbito de la protección del medio ambiente. Entre las leyes autonómicas que sí reconocen con gran amplitud la acción pública en materia de medio ambiente están: la Ley de la Región de Murcia de Protección Ambiental ${ }^{844}$, la Ley General de Protección del Medio Ambiente del País Vasco ${ }^{845}$, la Ley de la Comunidad Autónoma de Castilla-León de intervención ambiental ${ }^{846}$, entre otras.

No obstante, con carácter de legislación básica estatal, la Ley 27/2006 ha venido a sumarse a estas normas, reconociendo además de la acción pública para denunciar las infracciones a sus preceptos, lo podríamos denominar una 'acción pública de carácter corporativo' a las asociaciones ambientales. Dos son las prescripciones en materia de legitimación que contiene esta Ley en su Título IV: art. 20 en relación con el art. $2 ; \mathrm{y}$ arts. 18 y $23^{847}$. El reconocimiento de la legitimación puede calificarse como amplio en cuanto a las entidades a las que se les atribuye, pues abarca a 'cualquiera personas jurídicas sin ánimo de lucro' que tengan entre los fines acreditados en sus estatutos la protección del medio ambiente, sin necesidad de que éste sea un fin principal, con lo que podrían actuar ante la Administración y los tribunales para la protección del entorno, además de las ONG ambientales, otras entidades como sindicatos, asociaciones de consumidores y usuarios, etc.

\footnotetext{
${ }^{843}$ Según Blanca Lozano Cutanda, Derecho Ambiental cit., p. 372: “Cada vez son más, sin embargo, las leyes de protección ambiental que introducen la acción pública en defensa de su ordenación, con una tendencia mucho más acusada a su reconocimiento en la legislación autonómica. Además, en el ámbito de la legislación básica estatal, durante mucho tiempo, únicamente se previó la acción pública en materia urbanística (ya establecida en 1956 y hoy reconocida por el art. 4.f y 48 TRLS); y desde la aprobación de la Constitución, se ha implantado en otros tres ámbitos: en materia de patrimonio histórico (art.8 LPHE), de costas (art. 109.1 LC y art. 202 de su Reglamento, aprobado por el Real decreto 1471/1989, de 1 de diciembre) y de parques nacionales (art. 22 de la Ley 5/2007, de 3 de abril, de la Red de Parques Nacionales)".

${ }^{844}$ Ley $1 / 1995$, de 8 de marzo.

${ }^{845}$ Ley 3/1988, de 27 de febrero.

${ }^{846}$ Ley $11 / 2003$, de 8 de abril.

${ }^{847}$ LOZANO CUTANDA, Blanca. Derecho Ambiental cit., p. 373.
} 
Sin olvidar los requisitos de legitimación, se puede pedir a este orden jurisdiccional: la nulidad de un acto administrativo o reglamento ilegales cuando la administración otorga o aprueba un Reglamento contrario a la Ley y al Derecho y ocasiona con ello perjuicios ambientales; el cese de la actividad dañosa y/o la indemnización del daño causado.

Recordando que quien puede ocasionar el daño es la Administración misma y no sólo un particular. En este caso los ciudadanos, en base a los requisitos de legitimación, pueden denunciarlo ante las autoridades administrativas responsables ${ }^{848} \mathrm{y}$, en caso de no ser atendidos, pueden acudir a los Tribunales contenciosoadministrativos; la adopción de las medidas a las que está obligada la Administración en virtud del ordenamiento para la protección del medio ambiente. Pero en este caso, sólo se puede acudir a esta vía cuando la Administración, en virtud de un acto, contrato o convenio administrativo, esté obligada a realizar una prestación concreta a favor de una o varias personas y sólo pueden interponer este recurso quienes tuvieran derecho a dicha prestación (art. 29 LJCA); la exigencia de responsabilidad a la Administración por los daños ambientales que haya originado ya sea por acción o por omisión de su deber de velar por la conservación de los recursos naturales.

Cuando se produce un daño ambiental derivado del funcionamiento de los servicios públicos, la petición de responsabilidad se fundamenta en el régimen de responsabilidad patrimonial de las administraciones públicas ${ }^{849}$, en virtud del cual la Administración responde por los daños causados por el funcionario de los servicios públicos, salvo en los casos de fuerza mayor.

\footnotetext{
${ }^{848}$ El recurso de inactividad permite a los ciudadanos, tras una reclamación previa en vía administrativa, 'pretender del órgano jurisdiccional que condene a la Administración al cumplimiento de sus obligaciones en los concretos términos en que estén establecidas' (artículo 32 LJCA).

${ }^{849}$ Artículo 106.2 de la Constitución Española y artículos 139 y siguientes de la Ley, 30/1992, de 26 de noviembre, de Régimen Jurídico de las Administraciones Públicas y del Procedimiento Administrativo Común (LRJAP-PAC). Disponible en: <https://www.boe.es/buscar/pdf/1992/BOE-A-1992-26318consolidado.pdf $>$. Acceso en: 28-10-2015.
} 


\subsubsection{Acción popular y acción pública}

Son considerados interesados en un procedimiento administrativo, por así decir, quienes lo promuevan como titulares de derechos o intereses legítimos individuales o colectivos, los que, sin haber iniciado el procedimiento, tengan derechos que puedan resultar afectados por la decisión que en el mismo se adopte, y aquellos cuyos intereses legítimos, individuales o colectivos, puedan resultar afectados por la resolución y se personen en el procedimiento en tanto no haya recaído resolución definitiva ${ }^{850}$.

En España, los procedimientos administrativos pueden iniciarse de oficio o a solicitud de persona interesada. El concepto de interesado es muy limitado.

La Ley 30/1992 que Regula el Régimen Jurídico de las Administraciones Públicas y del Procedimiento Administrativo Común de 26 de noviembre ${ }^{851}$, prevé que las asociaciones y organizaciones representativas de intereses económicos y sociales pueden ser titulares de intereses legítimos colectivos en los términos que la Ley reconozca. En este caso se habla de legitimación difusa ya que la legitimación para la defensa de intereses multiparticulares se basa en la alegación de un específico interés legítimo por ser miembros de una determinada colectividad. En España se han aprobado leyes que habilite a las organizaciones de defensa ambiental ${ }^{852} \mathrm{y}$ particulares a ser

${ }^{850}$ Mecanismos legales para la defensa del medio ambiente. Elaborado por el Instituto Internacional de Derecho y Medio Ambiente. Disponible en: $<$ http://www.iidma.org/privado/Archivos/Guiamecanismosport.pdf>. Acceso en: 28-10-2015.

${ }^{851}$ Disponible en: < https:/www.boe.es/buscar/doc.php?id=BOE-A-1992-26318>. Acceso en: 28-102015.

${ }^{852}$ Conforme enseña Blanca Lozano Cutanda, Derecho Ambiental Administrativo. $1^{\mathrm{a}}$ ed., La Ley, MadridEspaña: 2010, p. 363: "En el derecho español esta exigencia ha sido cumplida por la Ley 27/2006, que reconoce a cualquier persona jurídica sin ánimo de lucro que cumpla los requisitos que se especifican y que veremos al exponer el acceso a la justicia para la protección ambiental, legitimación para recurrir todos los actos y, en su caso, las omisiones imputables a las autoridades públicas que vulneren las normas relacionadas con el medioambiente, enumeradas -en términos muy amplios- en el art. 18.1 de la Ley (arts. 22 y 23). A estas organizaciones se les reconoce asimismo como $<<$ personas interesadas $>>$ para ejercer los derechos de información y de participación reconocidos en el texto cuando se requiera esta condición (art. 2.2 en relación con el 23). La Ley de Responsabilidad Medioambiental otorga asimismo, legitimación activa a estas organizaciones para instar las medidas de prevención o de reparación de los daños ambientales. Puede considerarse, por tanto, que existe ya una habilitación legal general en nuestro 
ordenamiento de legitimación de las asociaciones ambientales para actuar en defensa del medioambiente, y además se les reconoce el $<<$ derecho a la asistencia jurídica gratuita en los términos previstos en la Ley 1/1996, de 10 de enero, de Asistencia Jurídica Gratuita $>$ (art. 23.2)”. Además, Julia ORTEGA BERNARDO, “¿Quién ha apostado por la efectiva implantación del derecho de acceso a la justicia a favor de las organizaciones no gubernamentales en defensa del medio ambiente?”. Actualidad Jurídica Ambiental, 03-10-2011, pp. 1-14 hace una interesante análisis: "Si bien es cierto que el reconocimiento en nuestro ordenamiento jurídico a las personas jurídicas sin ánimo de lucro del acceso a la justicia venía propiciado por la ratificación por España y por la Unión Europa del Convenio Aarhus, y que asimismo la Directiva 2003/4, del Parlamento Europeo y del Consejo, de 28 de enero de 2003 y la Directiva 2003/35 del Parlamento Europeo y del Consejo, de 26 de mayo de 2003, obligaban al Estado español a incorporar el reconocimiento de esta posibilidad de acción judicial por lo que se refiere a la vulneración de los derechos de acceso a la información ambiental, por un lado, y la participación en los procesos de toma de decisiones referidos a la autorización ambiental integrada y la evaluación de impacto ambiental, por otro; el resultado de dicho reconocimiento no era una consecuencia que automáticamente se extrajese de la aplicación del Derecho internacional ni del Derecho de la Unión. La novedad que en este punto ha introducido en nuestro Derecho la Ley 27/2006, de 18 de julio, que regula los derechos de acceso a la información, de participación pública y de acceso a la justicia en materia de medio ambiente ha de ser celebrada como un gran paso. Significa el reconocimiento de una legitimación activa de estas asociaciones para supuestos que abarcan más allá de la vulneración de los derechos de acceso a la información o de participación en cuestiones ambientales y que van más allá del propio ámbito material de protección que a estos efectos dispensa el Derecho de la Unión europea. Además, aunque la tutela judicial funcione fundamentalmente como un control a posteriori no se puede dudar de que las anulaciones de los actos y actuaciones gubernativas y administrativas contrarias a las normas de protección ambiental y las correspondientes, en su caso, condenas a la Administración por omisión también pueden tener consecuencias favorables que conduzcan a una evitación de daños que, en definitiva, activen el principio de prevención en materia de medio ambiente”. Además, según la autora: “Así, tras la entrada en vigor del capítulo IV de la Ley 27/2006 (20 octubre de 2006: ex disposición adicional primera), pero antes de que esta ley pudiera resultar efectivamente aplicable a los casos objeto de enjuiciamiento judicial, se han dictado varias sentencias, en las que se pone de manifiesto una clara evolución de la jurisprudencia española, que resulta así pionera en abrir nuevas vías procesales para favorecer el acceso a la justicia de las ONG ambientales. La evolución de la jurisprudencia en este sentido constituye, a mi juicio, realmente un hito. Las sentencias plasman una doctrina, - de la que cabe citar como exponente e iniciadora de la misma a la STS de 25 de junio de 2008 (caso de la construcción del aeropuerto de Castellón), a la que siguen, entre otras, la STS de 1 de diciembre de 2009, la STS de 25 de mayo de 2010 y las sentencias del Tribunal Superior de Justicia de Madrid de 17 de diciembre de 2009 y de 21 de junio de 2010 - conforme a la cual ya no es admisible seguir la tesis de que a las asociaciones ambientales no les corresponde defender una acción popular en el ámbito ecológico, salvo en los aspectos urbanísticos y atmosféricos. Para llevar a cabo esta afirmación el Tribunal Supremo no se apoya en el art. 19.1.h) - pues, insisto, aun no resulta aplicable al caso, aunque esté vigente, la nueva regulación 
titulares de intereses legítimos colectivos. Esta situación se dio a la luz del Convenio de Aarhus y de la Directiva de acceso a la justicia.

Esta participación popular en materia de medioambiente internacional consta en el Convenio de la Comisión Económica para Europa de Naciones Unidas, donde se trata del acceso a la información, de la participación del público en la toma de decisiones y del acceso a la justicia en materia de medio ambiente. Fue firmado en Aarhus, el 25 de junio de 1998. Conocido como el Convenio de Aarhus, que parte del postulado de que para que los ciudadanos puedan disfrutar del derecho a un medio ambiente saludable y cumplir el deber de respetarlo y protegerlo, previamente deben tener acceso a la información medioambiental relevante, estando legitimados para participar en los procesos de toma de decisiones de carácter ambiental y, sobre todo, deben tener acceso a la justicia cuando tales derechos les sean negados o vulnerados ${ }^{853}$. Estos derechos constituyen los tres pilares sobre los que se asienta el Convenio de Aarhus, a saber:

- El pilar de acceso a la información medioambiental, como esencial en la concienciación y educación ambiental de la sociedad y que divide en: el derecho a obtener información que esté en poder de las autoridades públicas, y el derecho a recibir información ambientalmente por parte de las autoridades públicas.

- El pilar de participación del público en el proceso de toma de decisiones, la autorización de actividades, la aprobación de planes y la elaboración de disposiciones de carácter general de rango legal o reglamentario.

contenida en la Ley 27/2006 - sino que realiza una interpretación extensiva de la norma procesal, concretamente del art. 19.1.b) de la Ley 29/1998, de la jurisdicción contencioso-administrativa, con la que trata de optimizar el principio de protección del medio ambiente del art. $45 \mathrm{CE}$. Precisamente es el mandato de optimización contenido en este principio rector lo que le lleva a configurar (ex art. 53.3 CE) de modo más amplio el ámbito de legitimación en esta materia y a considerar así que la asociación ambiental recurrente está "investida de un especial interés legítimo colectivo". Esta defensa de los intereses colectivos no la identifica el Tribunal con el ejercicio exclusivo de defensa de la legalidad vigente, que se reconduce a un supuesto de acción popular, sino que se requiere, lógicamente, que tales intereses colectivos queden afectados por el carácter positivo o negativo de la decisión”. pp. 3-6.

${ }^{853}$ SANJURJO REBOLLO, Beatriz. Medio ambiente y acción popular. Artículo publicado en el Boletín "Urbanismo", el 1 de enero de 2011. Disponible en: < http://www.elderecho.com/tribuna/administrativo/Medio-ambiente-accion-popular_11_233680001.html>. Acceso en: 05-11-2015. 
- Y el tercer y último pilar del Convenio de Aarhus, constituido por el derecho de acceso a la justicia. Tiene por objeto garantizar el acceso de los ciudadanos a los tribunales para revisar las decisiones que potencialmente hayan podido violar los derechos que en materia de democracia ambiental les reconoce el propio Convenio.

Se pretende así asegurar y fortalecer, a través de la garantía que dispensa la tutela judicial, la efectividad de los derechos que el Convenio de Aarhus reconoce a todos y, por ende, la propia ejecución del mismo. Finalmente, se introduce en su texto una previsión que habilita al público a entablar procedimientos administrativos o judiciales dirigidos a impugnar cualquier acción $u$ omisión imputable, bien a otro particular, bien a una autoridad pública, que constituya una vulneración de la legislación ambiental. España ratificó el Convenio de Aarhus en diciembre de 2004, entrando en vigor el 31 de marzo de 2005. Y la propia Unión Europea, al igual que todos los Estados miembros, también firmó este Convenio.

La Unión Europea ha elaborado un proyecto de Reglamento comunitario para la aplicación del Convenio y dos Directivas que incorporan obligaciones para los Estados UE del Convenio Aarhus. Se trata de la Directiva 2003/4/CE, del Parlamento Europeo y del Consejo, de 28 de enero de 2003, sobre el acceso del público a la información ambiental, y la Directiva 2003/35/CE, del Parlamento Europeo y del Consejo, de 26 de mayo de 2003, que establece medidas para la participación del público en determinados planes y programas relacionados con el medio ambiente ${ }^{854}$.

Estos antecedentes hacen que el objeto de la Ley española 27/2006, tenga por finalidad definir un marco jurídico que a la vez responda a los compromisos internacionales asumidos con la ratificación del meritado Convenio y, al tiempo, lleve a cabo la transposición de las Directivas europeas mencionadas al ordenamiento interno de España, como país miembro de la Unión Europea.

Bajo el articulado de esta Ley 27/2006, el ejercicio de la acción popular, se dibuja como el medio procesal idóneo para la protección de esos derechos colectivos. Y se ejercen para evitar el daño contingente, para hacer cesar el peligro, la amenaza, la vulneración o agravio sobre los derechos e intereses colectivos medioambientales, o restituir las cosas a su estado anterior cuando esto fuera posible. Como un medio procesal, dirigido contra cualquier acción u omisión, ya proveniente de la autoridad, ya

${ }_{854}$ Por la que se modifican, en lo que se refiere a la participación pública y el acceso a la justicia, las Directivas 85/337/CEE y 96/61/CE. 
de los particulares, que violen o amenacen con violar el derecho a los intereses colectivos de protección de recursos naturales ${ }^{855}$.

Importante destacar que, en España, determinadas leyes (anteriores al Convenio de Aarhus y a las Directiva 2003/4/CE y Directiva 2003/35/CE) que inciden en la protección del medio ambiente contemplan la legitimación popular ${ }^{856}$. Por tanto, cualquier persona, por el mero hecho de invocar su condición ciudadana estaría legitimada para iniciar un procedimiento administrativo o impugnar un acto determinado, sin necesidad de invocar la lesión de un derecho subjetivo o interés legítimo alguno, para asegurar el respeto al derecho. La acción popular se reconoce a

${ }^{855}$ LOPERENA ROTA, D., El derecho al medio ambiente adecuado, Civitas, Madrid, 1998; MATEO RAMÓN, M., Tratado de derecho ambiental, Vol. 1, Civitas, Madrid, 1991; LIFANTE VIDAL, I., La interpretación jurídica en la teoría del derecho contemporánea, Centro de Estudios Políticos y Constitucionales, Madrid, 1999.

${ }^{856}$ Un ciudadano podrá ejercer la acción popular en defensa del medio ambiente según las leyes: Ley 1/1970 de Caza. Artículo 47.1.b): "El conocimiento y resolución de los expedientes instruidos por infracciones definidas en esta Ley como administrativas y la fijación de las indemnizaciones por daños originados a la riqueza cinegética que, en su caso, procedan, corresponderán al Ministerio de Agricultura, a través del Servicio de Pesca Continental, Caza y Parques Nacionales. A estos efectos, deberá tenerse en cuenta: [...] b) Que la acción para denunciar estas infracciones es pública y caduca a los dos meses, contados a partir de la fecha en que fueren cometidas"; Decreto 833/1975 que desarrolla la Ley 32/1972 de Protección Ambiente Atmosférico. Articulo 16: "Cualquier persona, natural o jurídica, pública o privada, podrá dirigirse por escrito motivado al Alcalde, Gobernador civil o Director general de Sanidad expresando razonadamente la situación de contaminación y solicitando la tramitación del expediente para la declaración, si procede, de zona de atmósfera contaminada"; Ley 16/1985 del Patrimonio HistóricoArtístico. Artículo 8.2.: "Será pública la acción para exigir ante los órganos administrativos y los Tribunales contencioso-administrativos el cumplimiento de lo previsto en esta Ley para la defensa de los "bienes" integrantes del Patrimonio Histórico español”; Ley 22/1988 de Costas. Artículo 119.1: "Será pública la acción para exigir ante los órganos administrativos y los Tribunales la observancia de lo establecido en esta Ley y en las disposiciones que se dicten para su desarrollo y aplicación"; El Texto Refundido de la Ley sobre el Régimen del Suelo y la Ordenación Urbana aprobado por Real Decreto Legislativo 1/1992. Artículo 304.1: "Será pública la acción para exigir ante los Órganos administrativos y los Tribunales Contencioso Administrativos la observancia de la legislación urbanística y de los Planes, Programas, Proyectos, Normas y Ordenanzas"; y las leyes que establecen el régimen jurídico de los Parques Nacionales ${ }^{856}$ recogen en su articulado el reconocimiento de la acción popular "para exigir ante los órganos administrativos y los Tribunales contencioso-administrativos la estricta observancia de las normas de protección del Parque Nacional" correspondiente, lo que también se está produciendo en el ámbito autonómico. 
todos los ciudadanos y no sólo a aquellos que pertenezcan a una colectividad o grupo quienes también tienen acceso a la acción popular.

Sin embargo, como bien afirma Beatriz Sanjurjo Rebollo: "La acción popular crea polémica, puede pagarse muy caro su ejercicio al tiempo que la doctrina misma del Tribunal Constitucional (SSTC 8/2008 y 311/2006) define la imposibilidad de continuar con un procedimiento sólo a instancias de la acusación popular, porque, según el artículo 782.1 LECrim: 'si el Ministerio Fiscal y el acusador particular solicitan el sobreseimiento de la causa por cualquiera de los motivos que prevén los artículos 637 y 641, lo acordará el juez'. Esta línea jurisprudencial limita el derecho constitucional a la acción popular, un derecho que legalmente permite que cualquier ciudadano, perjudicado o no por el delito, pueda por su propia voluntad presentar una acusación independientemente de los intereses del perjudicado y en contra del criterio del Fiscal (casos Botín e Ibarretxe). [...] En el caso Botín una interpretación literal del artículo 782.1 LECrim., establece la exclusión de la acción popular en las causas tramitadas por el procedimiento abreviado en las que ni Fiscalía ni acusación particular deseen continuar, de tal manera que si el Ministerio Fiscal y el acusador particular -que representa a los directamente afectados- solicitase el sobreseimiento, ese: 'lo acordará el juez’, lo que excluiría en estos casos, a la acusación popular, pues no lo menciona” ${ }^{\circledR 557}$.

La manifestación del principio democrático está en la participación ciudadana en la administración de justicia, y una interpretación excluyente priva a asociaciones de ciudadanos de su derecho a ejercitar la acción judicial, lesionando el principio constitucional a la tutela judicial efectiva del art. 24.1 CE que permite la actuación de ciudadanos en materia de ambiental ${ }^{858}$.

${ }^{857}$ SANJURJO REBOLLO, Beatriz. Medio ambiente y acción popular. Artículo publicado en el Boletín "Urbanismo", el 1 de enero de 2011. Disponible en: < http://www.elderecho.com/tribuna/administrativo/Medio-ambiente-accion-popular_11_233680001.html>. Acceso en: 05-11-2015.

${ }^{858}$ En este sentido, Beatriz Sanjurjo Rebollo, Medio ambiente y acción popular. Artículo publicado en el Boletín "Urbanismo", el 1 de enero de 2011 enseña que: "Pero la realidad es que necesitamos la colaboración de todos, desde los ciudadanos a los gobiernos, para lograr un único fin, hacer que el desarrollo sostenible sea una realidad, que la preservación de los recursos naturales se convierta en un hecho palpable que conviva con el desarrollo de los pueblos y su mejora de calidad de vida. Y en la intención de que todo ello no quede relegado a papel mojado, a una protección poco efectiva, el papel de la acción popular ha de erigirse como ejercicio de derechos democráticos de defensa por colectivos ante 


\subsubsection{La vía penal}

La vía penal se abre para todas las causas basadas en supuestos cometimientos de delitos ambientales. La acción popular permite la participación de los ciudadanos como acusadores en el proceso.

El sistema de protección penal del medio ambiente se encuentra en el Código Penal junto con los delitos relativos a la ordenación del territorio y a la protección del patrimonio histórico-artístico.

Son tres los requisitos necesarios para que podamos hablar de delito contra el medio ambiente ${ }^{859}$ : que haya un incumplimiento de las disposiciones de una ley u otra disposición de carácter general protectora del medio ambiente. Es decir, incumplimiento de una norma administrativa; que exista provocación o realización directa o indirecta de emisiones, vertidos, y el resto de actividades relacionadas en el texto del artículo $325^{860}$;

vulneración de derechos colectivos. La lucha ahora no solo se presenta contra infractores directos del medio ambiente a preservar, sino lamentablemente de las propias decisiones jurisdiccionales que se decantan hacia la obstaculización de su ejercicio, impidiendo jurídicamente la reclamación de responsabilidades cuando se retira la acusación particular y el Ministerio Fiscal, o desde un modo práctico con imposición de costas millonarias, contra quienes se molestan en luchar por defender el medio ambiente ante la inactividad de los propios poderes públicos. El respeto a los recursos Naturales se ha convertido en la llave de la supervivencia de nuestra generación y de generaciones futuras. Se trata de luchar por impedir que la defensa del Medio Ambiente pueda difuminarse por la propia inoperancia de la acción popular como se pretende".

${ }^{859}$ Mecanismos legales para la defensa del medio ambiente. Elaborado por el Instituto Internacional de Derecho y Medio Ambiente. Disponible en: $<$ http://www.iidma.org/privado/Archivos/Guiamecanismosport.pdf>. Acceso en: 28-10-2015.

${ }^{860}$ Artículo 325.

“1. Será castigado con las penas de prisión de seis meses a dos años, multa de diez a catorce meses e inhabilitación especial para profesión u oficio por tiempo de uno a dos años el que, contraviniendo las leyes u otras disposiciones de carácter general protectoras del medio ambiente, provoque o realice directa o indirectamente emisiones, vertidos, radiaciones, extracciones o excavaciones, aterramientos, ruidos, vibraciones, inyecciones o depósitos, en la atmósfera, el suelo, el subsuelo o las aguas terrestres, subterráneas o marítimas, incluido el alta mar, con incidencia incluso en los espacios transfronterizos, así como las captaciones de aguas que, por sí mismos o conjuntamente con otros, cause o pueda causar daños sustanciales a la calidad del aire, del suelo o de las aguas, o a animales o plantas.

2. Si las anteriores conductas, por sí mismas o conjuntamente con otras, pudieran perjudicar gravemente el equilibrio de los sistemas naturales, se impondrá una pena de prisión de dos a cinco años, multa de 
y que exista la posibilidad de perjudicar gravemente el equilibrio de los sistemas naturales.

Siempre que se produzca el delito descrito en el artículo 325, la pena que se imponga será superior cuando concurran una de las siguientes circunstancias: que la industria o actividad funcione clandestinamente, sin haber obtenido la preceptiva autorización o aprobación administrativa de sus instalaciones; que se hayan desobedecido las órdenes expresas de la autoridad administrativa de corrección o suspensión de las actividades tipificadas en el artículo anterior; que se haya falseado $\mathrm{u}$ ocultado información sobre los aspectos ambientales de la misma; que se haya obstaculizado la actividad inspectora de la Administración; que se haya producido un riesgo de deterioro irreversible o catastrófico; o que se produzca una extracción ilegal de aguas en período de restricciones ${ }^{861}$.

Cuando un ciudadano tenga conocimiento de los hechos que describe el Código Penal puede iniciar la vía penal. Esta vía penal puede ejercitarse siempre para denunciar la comisión de un delito contra el medio ambiente, pues se reconoce con carácter general la acción pública o acción popular, que permite que cualquier ciudadano pueda acudir a los tribunales para denunciar la comisión de un hecho ilícito sin necesidad de alegar un interés legítimo lesionado. La acción popular puede ejercerla tanto las personas físicas como las jurídicas, lo que reviste especial importancia en el ámbito de la protección ambiental dado el protagonismo de las asociaciones de defensa ambiental en el control social de las actividades, públicas y privadas, que afectan al medio ambiente.

En este sentido, según Blanca Lozano Cutanda: "La vía penal puede ejercitarse siempre para denunciar la comisión de un delito o falta contra el medioambiente, pues se reconoce con carácter general la denominada acción pública o acción popular, que permite que cualquier ciudadano pueda acudir a los tribunales para denunciar la

ocho a veinticuatro meses e inhabilitación especial para profesión u oficio por tiempo de uno a tres años. Si se hubiera creado un riesgo de grave perjuicio para la salud de las personas, se impondrá la pena de prisión en su mitad superior, pudiéndose llegar hasta la superior en grado". Disponible en: $<$ https://www.boe.es/buscar/act.php?id=BOE-A-1995-25444>. Acceso en: 28-10-2015.

${ }^{861}$ Mecanismos legales para la defensa del medio ambiente. Elaborado por el Instituto Internacional de Derecho y Medio Ambiente. Disponible en: $<$ http://www.iidma.org/privado/Archivos/Guiamecanismosport.pdf>. Acceso en: 28-10-2015. 
comisión de un hecho ilícito sin necesidad de alegar un interés legítimo lesionado. Esta acción pública se configura como un cauce muy valioso de participación ciudadana en la protección del entorno por los Tribunales, pues, como ha reconocido el Tribunal Supremo en relación a la materia del urbanismo, su fundamento $<<$ no es otro que el clásico de suscitar la colaboración ciudadana en la función de control de la legalidad $>>$ (Sentencia de 24 de mayo de 1980)" ${ }^{\prime 862 .}$

Además, vale recordar que esta vía también puede ser iniciada tanto con la presentación de una denuncia como una querella.

\subsubsection{La Vía civil}

Conviene tener presente que la vía civil o vía del Derecho privado tiene un papel secundario en la protección del medio ambiente. Esto se debe a las dificultades que supone la tutela o protección de un bien colectivo, como es el medio ambiente, a través de figuras de carácter marcadamente individualistas como las del Derecho Civil destinadas a resolver conflictos entre los particulares o, como mucho, entre éstos y la Administración cuando ésta también actúa como privado. Sus soluciones son, por tanto, individualistas y no sirven en la actualidad para dirimir otros conflictos que no sean estrictamente entre particulares, aunque indirectamente ello pueda contribuir también a la protección general del entorno si se ejerce la acción negatoria para pedir el cese de las inmisiones que están perjudicando una cosecha, por ejemplo, ninguna duda cabe de que al mismo tiempo se está protegiendo el medio natural ${ }^{863}$.

Importante destacar aquí que mismo que España ha introducido en su ordenamiento la Ley 27/2006, de 18 de julio, que regula los derechos de acceso a la información, de participación pública y de acceso a la justicia en materia de medio ambiente, dicha Ley en el rol de legitimados para ejercer la acción popular, artículo $23^{864}$, no ha incluido la figura de la persona física, solamente ha incluido personas

\footnotetext{
${ }^{862}$ LOZANO CUTANDA, Blanca. Derecho Ambiental cit., p. 370.

${ }^{863}$ LOZANO CUTANDA, Blanca. Derecho Ambiental cit., p. 370.

${ }^{864}$ Artículo 23. Legitimación.

“1. Están legitimadas para ejercer la acción popular regulada en el artículo 22 cualesquiera personas jurídicas sin ánimo de lucro que acrediten el cumplimiento de los siguientes requisitos:
} 
jurídicas, razón la cual los daños al medio ambiente que producen perjuicios individuales todavía carecen de una mayor protección.

En la vía civil existen dos vías para que los particulares actúen en la defensa del medio ambiente: la responsabilidad civil por daño al medio ambiente y la acción negatoria.

\subsubsection{La responsabilidad civil por daño ambiental}

Para que la figura de la responsabilidad civil entre en juego debe existir un daño, pero también una actividad humana que, bien por acción u omisión, lo provoca. Por tanto, su función no es preventiva sino inminentemente indemnizatoria o reparadora del daño causado. Al hablar del daño ambiental debemos distinguir dos tipos de daños: daño al medio ambiente, determinado por la alteración del equilibrio ecológico o la destrucción de elementos naturales de titularidad común, es decir, daño ecológico; y daño sufrido por los particulares en sus bienes patrimoniales o en su salud o bienestar físico o psíquico, como consecuencia de agresiones al medio ambiente.

La diferenciación es importante porque los mecanismos propios del Derecho privado permiten sin dificultad proteger a los particulares contra lo que podríamos denominar "daño ambiental particular". Así, para poder utilizar la vía de la responsabilidad extracontractual, el ciudadano debe haber sufrido un daño individual derivado de agresiones al medio ambiente, de lo contrario esta vía no podrá utilizarse.

a) Que tengan entre los fines acreditados en sus estatutos la protección del medio ambiente en general o la de alguno de sus elementos en particular.

b) Que se hubieran constituido legalmente al menos dos años antes del ejercicio de la acción y que vengan ejerciendo de modo activo las actividades necesarias para alcanzar los fines previstos en sus estatutos.

c) Que según sus estatutos desarrollen su actividad en un ámbito territorial que resulte afectado por la actuación, o en su caso, omisión administrativa.

2. Las personas jurídicas sin ánimo de lucro a las que se refiere el apartado anterior tendrán derecho a la asistencia jurídica gratuita en los términos previstos en la Ley 1/1996, de 10 de enero, de Asistencia Jurídica Gratuita”. Disponible en: <https://www.boe.es/buscar/act.php?id=BOE-A-2006-13010>. Acceso en: $28-10-2015$. 
La exigencia de responsabilidad extracontractual presenta dos cauces jurídicos distintos en el ordenamiento español, según se trate de daños causados por los particulares o por la Administración.

A la hora de regular la responsabilidad por daños al medio ambiente causados por particulares se parte de un régimen de responsabilidad civil subjetiva basado en la existencia probada de una acción u omisión culposa o negligente por parte del responsable del hecho dañoso, además entiende la jurisprudencia que otros elementos deben concurrir para que pueda exigirse esta responsabilidad, dichos elementos son: la realidad del daño, esto es, la prueba de un daño efectivo; y la exigencia, también probada, de la relación de causalidad entre la acción u omisión culposa o negligente y el daño causado.

Esto se trata del sistema de responsabilidad civil clásico, derivado del derecho romano, denominada también aquiliana y que se regula en los artículos 1902 a 1919 del Código Civil aunque pueda existir algún caso concreto en que se dé además una relación contractual. Incluso la jurisprudencia en ocasiones aplica el régimen de responsabilidad extracontractual aunque exista relación obligatoria previa, siempre que el daño no haya sido causado en la "estricta órbita de lo pactado",865.

Ya el daño ambiental derivado del funcionamiento de los servicios públicos (responsabilidad de la Administración), la petición de responsabilidad se fundamenta en el régimen de responsabilidad patrimonial de las Administraciones Públicas reconocido por el art. 106.2 de la Constitución y desarrollado por los arts. 139 y siguientes de la Ley de Régimen Jurídico de las Administraciones Públicas (LRJAP 30/1992, de 26 de noviembre), en virtud del cual la Administración responde por los daños causados por el funcionamiento de los servicios públicos, salvo en los casos de fuerza mayor ${ }^{866}$.

\footnotetext{
${ }^{865}$ Argumenta la STS de 14 de mayo de 1963 (art. 2699) que no puede excusar de responsabilidad al causante de un daño, el haber cumplido formulariamente todos los requisitos reglamentarios a que viene obligado, cuando la realidad se impone demostrar que las medidas adoptadas no dieron resultado. GONZÁLEZ HERNÁNDEZ, Rut. La responsabilidad civil por daños al medio ambiente. Anuario Jurídico y Económico Escurialense, XLV (2012) 177-192, pp.189-190.

${ }^{866}$ En este sentido, Blanca Lozano Cutanda, Derecho Ambiental cit., pp. 387-388: “Aunque la LRJAP se refiere a la responsabilidad de la Administración por $<<$ funcionamiento normal o anormal $>>$ de los servicios públicos, la responsabilidad objetiva de la Administración, si bien reconocida con carácter muchos más amplio que en el ámbito civil, no opera con carácter general, pues además de que la propia Ley excluye la responsabilidad por los llamados "daños del desarrollo" -al precisar que $<<$ no serán
} 


\section{El Código Civil Español acogía la responsabilidad por culpa como regla}

general, operando como excepción la responsabilidad objetiva aunque este sistema se ha flexibilizado y en materia de responsabilidad ambiental se ha tendido a un sistema de responsabilidad objetiva ${ }^{867}$.

indemnizables los daños que deriven de hechos o circunstancias que no se hubiesen podido prever o evitar según el estado de la ciencia o de la técnica existentes en el momento de producción de aquellos $>>$ (art. 141.1)-, la jurisprudencia limita los supuestos en los que la Administración responde cuando el servicio ha funcionado normalmente. Uno de estos supuestos es, al igual que en la responsabilidad civil, el título de creación de un riesgo. En palabras del TS, $<<$ es de recordar que, como esta Sala $3 .^{\mathrm{a}}$ del Tribunal Supremo ha tenido ocasión de decir en más de una ocasión, la Administración asume la responsabilidad derivada de los riesgos por ella creados $>>$ (S. De 25 de mayo de 1999, recurso n. 1673/1995)". También afirma la autora que: [...] cuando se trata del mal funcionamiento, o como dice la Ley, del <<funcionamiento anormal de los servicios públicos $>>$, la jurisprudencia aplica la responsabilidad por daños ambientales a un abanico muy amplio de conductas, que incluye tanto los daños derivados directamente de la actuación administrativa como aquellos que, aunque provocados por particulares, pueden imputarse a la actividad o falta de vigilancia de las actividades con impacto ambiental. Así, de acuerdo con la jurisprudencia, comprende también 'la omisión o la pasividad, cuando la Administración está obligada a comportarse de un modo determinado' [SSTS, entre otras, de 18 de diciembre de 1995 , recurso n. ${ }^{\circ} 824 / 1993$; de 18 de abril de 2007, n. ${ }^{\circ}$ de procedimiento 1152/2003, y de 25 de octubre de 2008, n. ${ }^{\circ}$ de procedimiento 148/2007]”.

${ }^{867}$ En este sentido, Rut González Hernández, La responsabilidad civil por daños al medio cit., p. 181: "La jurisprudencia ha evolucionado desde la originaria posición de responsabilidad extracontractual fundada en la culpa acreditada del causante del daño, a un sistema de responsabilidad fundada esencialmente en la causación del riesgo. Un ejemplo de esta postura jurisprudencial lo representa la STS de 24 de mayo de 1993 (RJ 1993/3727), en cuyo FD $4^{\circ}$ manifiesta: (....) y es por ello por lo que se ha ido transformando la apreciación del principio subjetivista, ora por el acogimiento de la llamada "teoría del riesgo", ora por el cauce de la inversión de la carga de la prueba, presumiendo culposa toda acción u omisión generadora de un daño indemnizable, sin que sea bastante, para desvirtuarla, el cumplimiento de Reglamentos, pues estos no alteran la responsabilidad de quienes lo cumplan, cuando las medidas de seguridad y garantías se muestran insuficientes en la realidad para evitar eventos lesivos”. También, Blanca Lozano Cutanda, Derecho Ambiental Administrativo. $1^{\mathrm{a}}$ ed., La Ley, Madrid-España: 2010, pp. 386-387 en este sentido, cita entre otras Sentencias del TS: de 29 mayo y de 13 de julio de 1999, recursos n. ${ }^{\circ}$ 2962/1994 y 3619/1994, respectivamente; de 24 de septiembre de 2002; y de 5 de noviembre de 2004. Además, esta autora enseña que: "Esta concepción objetiva de la responsabilidad por daños derivados de actividades productoras de riesgo ha comenzado a ser incorporada al ámbito legislativo (pueden citarse, entre otras, la Ley de caza, la Ley reguladora de la navegación aérea, el Texto Refundido de la Ley general para la defensa de los consumidores o usuario, aprobado por RD Legislativo 1/2007, de 17 de noviembre -que la impone para la responsabilidad civil por bienes o productos defectuosos- o el texto articulado de la Ley 
En estos casos, aún no existiendo culpa, se responde del daño infligido a otro porque la ley, si bien permite, que sean usadas ciertas cosas, que proporcionan un beneficio a unos, crean también un riesgo, sólo lo permite sobre la base de que el que se beneficie de ellas, repare al que padezca el daño ${ }^{868}$.

Además, se puede decir que cuando una actividad desarrollada por una persona o empresa representa una fuente de provecho para ella y un riesgo adicional y extraño para el resto, ya sean personas o bienes, el resarcimiento de daños y perjuicios se configura como una especie de contrapartida de la utilidad proporcionada por la actividad peligrosa, ubi emolumentum, ibi onus aunque el daño haya sido inevitable a pesar de haber adoptado las precauciones técnicas prescritas. Esta doctrina del riesgo se aplica, fuera de los supuestos legalmente previstos, con un sentido limitativo, no a todas las actividades de la vida sino sólo a aquellas que impliquen un riesgo considerablemente anormal en relación con los estándares medios ${ }^{869}$.

Descansa sobre el principio ubi commodum ibi incommodum, que actúa en justa compensación, quien se beneficia de una situación debe también, soportar las cargas de la misma. En términos matemáticos podríamos decir que desarrollo y riesgo son dos factores inversamente proporcionales.

El artículo 1908 del Código Civil interpretado extensivamente puede servir como base de la responsabilidad civil por daños causados al medio ambiente. De esta manera, lo interpreta doctrina y jurisprudencia. En este precepto el legislador tuvo en cuenta simplemente los accidentes industriales más frecuentes en su tiempo,

sobre Tráfico, Circulación de vehículos a motor y Seguridad Vital). Algunas leyes ambientales anteriores a la Ley de Responsabilidad Medioambiental han establecido también régimen de responsabilidad objetiva, pudiendo señalarse en este sentido: la Ley reguladora de la energía nuclear ( Ley 25/1964, de 29 de abril); la Ley básica de Residuos (ley 10/1998, de 21 de abril) por lo que respecta a las obligaciones de limpieza y restauración de suelos declarados contaminados; y el régimen jurídico establecido para los residuos tóxicos y peligrosos (Reglamento de Residuos Tóxicos y Peligrosos, aprobado por Real Decreto 833/1988, de 20 de julio y modificada por Real Decreto 952/1997, de 20 de junio)".

${ }^{868}$ ALBALADEJO GARCÍA, Manuel, apud GONZÁLEZ HERNÁNDEZ, Rut. La responsabilidad civil por daños al medio cit., p. 181.

${ }^{869}$ En el fondo, lo que se persigue es proyectar sobre el agente causante directo o indirecto de un evento dañoso o perjudicial las consecuencias económicas del daño, lesión o perjuicio, con independencia absoluta de la diligencia, intencionalidad o negligencia de su conducta. Además, no existe vinculo jurídico previo entre el obligado a resarcir y el sujeto preceptor de la indemnización. GONZÁLEZ HERNÁNDEZ, Rut. La responsabilidad civil por daños al medio cit., p. 182. 
estableciendo regímenes específicos para ellos pero susceptibles de ser aplicados por analogía en la actualidad. El desarrollo tecnológico experimentado en los últimos años ha traído consigo el aumento de riesgos, por lo que los presupuestos que establece el artículo 1908 del Código Civil son insignificantes respecto a los existentes hoy día, sin embargo este artículo no es limitativo sino meramente enunciativo. Además, hay que tener en cuenta que una gran parte de los daños causados al medio ambiente se producen como consecuencia de fallos en los dispositivos técnicos de control, por lo que a priori la responsabilidad objetiva parece un medio adecuado para tratar este tipo de daños ${ }^{870}$.

Así, desde el aspecto de la responsabilidad la ley establece un doble sistema: de responsabilidad objetiva y responsabilidad por culpa ${ }^{871}$.

Importante tener en cuenta que la legislación ambiental y sus efectos son de inspiración esencialmente administrativa. Las autoridades públicas competentes están facultadas para adoptar las medidas preventivas o reparadoras en cualquier caso, inclusive aquéllos en que no se puede identificar al operador que causó el daño o el riesgo inminente de daño, aquéllos en que el operador sí puede ser identificado pero resulta insolvente o, finalmente, cuando dicho operador no debe asumir el coste de las medidas de reparación o restauración. Se establece una responsabilidad del poder público subsidiaria para la reparación y prevención de daños al medio ambiente ${ }^{872}$.

${ }^{870}$ GONZÁLEZ HERNÁNDEZ, Rut. La responsabilidad civil por daños al medio cit., p. 182. Conforme enseña Jésus Jordano Fraga, Responsabilidad civil por daños al medio ambiente en Derecho público: última jurisprudencia y algunas reflexiones de lege data y contra lege ferenda, en Civitas - Revista española de Derecho Administrativo, n. ${ }^{\circ}$ 107, 2000, pp. 351-371, los daños al medio ambiente en sí mismo que no producen ninguna lesión individualizada podemos denominar "daños públicos ambientales" o "daños ambientales autónomos", se derivan del hecho de que el medio ambiente está fundamentalmente integrado por bienes públicos (ya sean bienes pertenecientes al dominio público, como el agua, las costas, los montes públicos, ya sean bienes que con independencia de su propiedad pública o privada están adscritos a su conservación y al uso público compatible con la misma, como es el caso de los espacios naturales protegidos, o se trate, por último, de bienes carentes de titularidad, como es el caso de la atmósfera, pero de utilización pública por todos los ciudadanos), por lo que existen multitud de atentados ambientales que no producen ningún perjuicio individual.

${ }^{871}$ Opta por la adopción de un sistema dual de responsabilidad: un régimen de responsabilidad objetiva para las actividades inherentemente peligrosas y un régimen de responsabilidad por culpa para los daños derivados de actividades no peligrosas (determinadas actividades).

${ }^{872}$ GONZÁLEZ HERNÁNDEZ, Rut. La responsabilidad civil por daños al medio ambiente. Anuario 
Para cubrir las deficiencias que presenta la cobertura de los daños ambientales mediante los sistemas tradicionales de responsabilidad extracontractual, y que resultan comunes, por lo demás, a la generalidad de los Estados miembros de la Unión Europea, la Comunidad consideró necesario intervenir y aprobó la Directiva 2004/35/CE ${ }^{873}$, del

Jurídico y Económico Escurialense, XLV (2012) 177-192, pp.189-190.

${ }^{873}$ Directiva 2004/35/CE del Parlamento Europeo y del Consejo de 21 de abril de 2004 sobre responsabilidad medioambiental en relación con la prevención y reparación de daños medioambientales. Disponible en: $<$ http://eurlex.europa.eu/LexUriServ/LexUriServ.do?uri=OJ:L:2004:143:0056:0075:es:PDF>. Acceso en: 28-102015. Fue alterada por la Directiva 2006/21/CE del Parlamento Europeo y del Consejo, de 15 de marzo de 2006, sobre la gestión de los residuos de industrias extractivas y por la que se modifica la Directiva 2004/35/CE. Disponible en: <http://eur-lex.europa.eu/legal-content/ES/TXT/?uri=celex:32006L0021>. Acceso en: 28-10-2015. Posteriormente alterada por la Directiva 2009/31/CE del Parlamento Europeo y del Consejo, de 23 de abril de 2009, relativa al almacenamiento geológico de dióxido de carbono y por la que se modifican la Directiva 85/337/CEE del Consejo, las Directivas 2000/60/CE, 2001/80/CE, 2004/35/CE, 2006/12/CE, 2008/1/CE y el Reglamento (CE) n ${ }^{\circ}$ 1013/2006 del Parlamento Europeo y del Consejo. Disponible en: <http://eur-lex.europa.eu/legal-content/ES/TXT/?uri=celex:32009L0031>. Acceso en: 28-10-2015. Posteriormente alterada por la Directiva 2013/30/UE del Parlamento Europeo y del Consejo, de 12 de junio de 2013, sobre la seguridad de las operaciones relativas al petróleo y al gas mar adentro, y que modifica la Directiva 2004/35/CE. Disponible en: <http://eur-lex.europa.eu/legalcontent/ES/TXT/?uri=celex:32013L0030>. Acceso en: 28-10-2015. Además, el Informe de la Comisión al Consejo, al Parlamento Europeo, al Comité Económico y Social Europeo y al Comité de las Regiones de conformidad con el artículo 14, apartado 2, de la Directiva 2004/35/CE, sobre responsabilidad medioambiental en relación con la prevención y reparación de daños medioambientales, de 12 de octubre de 2010, concluyó que "Los resultados de los estudios realizados a efectos del presente informe, y la experiencia obtenida a través de la aplicación de la Directiva, indican que cabe emprender diferentes medidas para mejorar la aplicación y la efectividad de la Directiva: 4. Promover el intercambio de información y la comunicación entre las principales partes interesadas (operadores, autoridades competentes, proveedores de garantías financieras, asociaciones sectoriales, expertos gubernamentales, ONG y Comisión).5. Las asociaciones profesionales, las asociaciones de proveedores de garantías financieras y las autoridades competentes encargadas de aplicar la Directiva deben seguir fomentando la sensibilización de los distintos operadores y proveedores de garantías financieras merced a actuaciones de sensibilización. 6. Desarrollar directrices de interpretación acerca de la aplicación de la DRM y, en particular, elaborar directrices de la UE en lo relativo al anexo II. Las definiciones y los conceptos clave, tales como «daño medioambiental», «daños significativos», «estado básico» que hayan dado lugar a divergencias de aplicación a nivel nacional, deben ser debatidas en el grupo de expertos gubernamentales sobre responsabilidad medioambiental, y ser debidamente precisadas y aplicadas uniformemente. 7. Se recomienda que los Estados miembros establezcan archivos y registros de los casos que surjan en el 
Parlamento Europeo y del Consejo, sobre responsabilidad ambiental en materia de prevención y restauración de los daños ambientales con el objetivo, como declara en sus consideraciones (a efectos también de justificar que la norma responde al principio de subsidiariedad que rige en esta materia compartida), de establecer 'un marco común para la prevención y la reparación de los daños ambientales a un coste razonable para la sociedad', en tanto dicho objetivo 'no puede ser alcanzado de manera suficiente por los Estados miembros y, por consiguiente [...] puede lograrse mejor a nivel comunitario'.

La Ley de Responsabilidad Medioambiental (LRM), Ley 26/2007 ${ }^{874}$, de 23 de octubre, ha venido a transponer la Directiva $2004 / 35 / \mathrm{CE}^{875}$. Se ha aprobado asimismo,

ámbito de la DRM[21]. Esto proporcionaría conocimientos sobre cómo aplicar mejor la Directiva en beneficio de las partes interesadas. Facilitaría además el cumplimiento por parte de los Estados miembros de las obligaciones que les impone el artículo 18, apartado 1, de la Directiva, y permitiría evaluar la eficacia de la Directiva a través de casos reales". $\operatorname{COM}(2010) 581$ final. Disponible en: <http://eurlex.europa.eu/legal-content/ES/TXT/?uri=celex:52010DC0581>. Acceso en: 28-10-2015.

874 Ley 26/2007, de 23 de octubre, de Responsabilidad Medioambiental. Disponible en: $<$ http://www.boe.es/buscar/doc.php?id=BOE-A-2007-18475>. Acceso en: 28-10-2015. Posteriormente la Ley 11/2014, de 3 de julio, modifica la ley 26/2007, de 23 de octubre, de Responsabilidad Medioambiental. Disponible en: < http://www.boe.es/buscar/doc.php?id=BOE-A-2014-7009>. Acceso en: 28-10-2015.

${ }^{875}$ En estudio realizado en el marco del Proyecto de investigación SEJ 2004-01046/JURI, régimen jurídico de los recursos naturales del Ministerio de Educación y Ciencia, Jesús Jordano Fraga, Responsabilidad por daños al medio ambiente. Derecho del Medio Ambiente y Administración Local, Fundación Democracia y Gobierno Local, pp. 427-460 afirma que: "El primer problema que plantea la Directiva 2004/35 es que permite una diversidad de regulación en el espacio de la Unión Europea. Este aspecto, con finalidad contraria (unificación a la baja ya fue argumentado en una enmienda en segunda lectura). Este efecto mosaico resulta especialmente criticable en materia de daños ambientales, donde es fácilmente probable la producción de daños transfronterizos que con la directiva pueden tener distinta regulación en diferentes estados. Los agravios potenciales -estamos hablando de supuestos de exclusión de responsabilidad- son difícilmente justificables desde el prisma de la protección ambiental como valor en el sistema jurídico de la Unión, del principio de no-discriminación, e incluso del mercado único europeo. En la regulación se registran importantes carencias. Se echa de menos una mayor concreción en la valoración de los daños ambientales. Se echa igualmente de menos la introducción de los daños punitivos en una materia donde la prevención general debe ser la regla. Esta omisión se salva por la posible consideración de los atentados al medio ambiente como delito ecológico o infracción administrativa y la compatibilidad de dicha consideración en los ordenamientos con la reparación. Así lo declara expresamente el artículo 45.3 de la Constitución española. Pero no hubiera estado de más una armonización en tal sentido construyendo un mínimo común uniforme sancionador ambiental en el 
mediante Real Decreto 2090/2008 ${ }^{876}$, de 22 de diciembre, el Reglamento que desarrolla parcialmente la Ley, en el que se regulan aspectos fundamentales para la aplicación de la misma (como el método y los criterios para la determinación de los daños ambientales y para el cálculo de la garantía que deben prestar los operadores).

Esta ley tiene como objetivo, de acuerdo con la Directiva que transpone, regular "la responsabilidad de los operadores de prevenir, evitar y reparar los daños medioambientales, de conformidad con el artículo 45 de la Constitución y con los principios de prevención y de que «quien contamina paga»" (artículo 1 LRM). En definitiva, el objetivo que se persigue es evitar que el daño ambiental quede sin reparación.

Por tanto, la Directiva y la LRM establecen las líneas fundamentales de un régimen dirigido a la prevención y restauración de determinados daños ambientales autónomos. Cabe destacar, que la LRM no contempla los daños a las personas o a sus

Derecho europeo. También añade el autor: "Se echa de menos la institución de un actor europeo o nacional independiente y con medios (un fiscal ambiental, un defensor público ambiental). La inactividad en estos ámbitos y la propia actividad de las asociaciones ecologistas son muestras palpables de esta necesidad y denuncia de la inoperatividad de los mecanismos existentes. Estamos ante un primer paso de la regulación de la responsabilidad por daños ambientales. Se ha puesto una primera piedra en una norma "horizontal" destinada a ser una de las líneas esenciales del Derecho ambiental de la Unión Europea". En conclusión el autor afirma que: "Estamos hablando de solución del problema en la escala nacional, y esta visión, cuando se trata de medio ambiente, es un planteamiento muy pobre. Los problemas ambientales son globales por naturaleza. Debe avanzarse hacia un sistema internacional que convierta en verdaderas normas jurídicas coercibles (esto es Derecho según Kelsen) el grupo normativo ambiental de acuerdo con las pautas expuestas. El día que esto sea una realidad habremos puesto la primera piedra del Estado ambiental de derecho a escala global" (pp.454-455 y 457). Disponible en: $<$ http://repositorio.gobiernolocal.es/xmlui/bitstream/handle/10873/1122/medio_ambiente_26_jordano.pdf ?sequence $=1>$. Acceso en: 18-11-2015.

${ }^{876}$ Real Decreto 2090/2008, de 22 de diciembre, por el que se aprueba el Reglamento de desarrollo parcial de la Ley 26/2007, de 23 de octubre, de Responsabilidad Medioambiental. Disponible en: $<$ http://www.boe.es/diario_boe/txt.php?id=BOE-A-2008-20680>. Acceso en: 28-10-2015. Posteriormente hubo la Corrección de errores del Real Decreto 2090/2008, de 22 de diciembre, por el que se aprueba el Reglamento de desarrollo parcial de la Ley 26/2007, de 23 de octubre, de Responsabilidad Medioambiental. Disposiciones generales del Ministerio de Medio Ambiente, y Medio Rural y Marino. Boletín Oficial del Estado, de 26 de marzo de 2009. Disponible en: < http://www.magrama.gob.es/es/calidad-y-evaluacion-ambiental/temas/responsabilidadmediambiental/real_decreto_2090_correcciones_tcm7-3203.pdf>. Acceso en: 28-10-2015. 
propiedades, se centra en el daño ecológico puro ${ }^{877}$.

\subsubsection{Acción negatoria}

El propietario o poseedor de un inmueble puede ejercer una acción negatoria contra todo tipo de perturbaciones. Su finalidad fundamental es la cesación de una determinada actividad desarrollada por un tercero. Así, esta acción constituye un medio de defensa apto para repeler las inmisiones ilícitas, pudiendo obtenerse la adopción de medidas precautorias necesarias para evitar las inmisiones dañosas y, en su caso, si no es posible encontrar un remedio técnico que permita eliminar la inmisión, la cesación de la actividad perturbadora. Esta acción puede ejercerse sin necesidad de que exista un daño, por lo que se trata de un mejor instrumento para la protección del medio ambiente por tratarse de una acción preventiva.

Dado que la noción de "inmisión” alude a la penetración, en la propiedad ajena de sustancias o fuerzas provocadas por una actividad humana y que tiene consecuencias dañosas, la acción negatoria como mecanismo apto para repeler las inmisiones ilícitas (aquellas que provocan un daño o molestia que excede lo que se considera tolerable) se convierte en un instrumento dirigido a hacer cesar las perturbaciones ambientales derivadas de la actividad ${ }^{878}$.

La singularidad de la acción negatoria según José Esteve Pardo se radica en tres notas que la caracterizan decisivamente:

"Una está en lo que con ella se pretende tutelar. No se trata del derecho al medio ambiente, ni del derecho a la salud, ni tampoco el interés general a la protección del medio ambiente. El objeto de tutela es el derecho de propiedad: que la propiedad no se vea afectada por humos, olores, ruidos o, más recientemente, por inmisiones electromagnéticas.

\footnotetext{
${ }^{877}$ Entre los recursos naturales que son objeto de protección por la LRM se incluye las 'aguas' en su concepto definido en el Texto Refundido de la Ley de Aguas (Real Decreto Legislativo 1/2001).

${ }^{878}$ Mecanismos legales para la defensa del medio ambiente. Elaborado por el Instituto Internacional de Derecho y Medio Ambiente. Disponible $<$ http://www.iidma.org/privado/Archivos/Guiamecanismosport.pdf>. Acceso en: 28-10-2015.
} 
La segunda singularidad está en su cobertura o apoyatura legal. Una apoyatura que se encuentra, básicamente, en el Código Civil. Se trata de una norma más que centenaria que no pudo desde luego contemplar la actual problemática medioambiental. Los artículos en los que se pretende fundar esta acción -sobre todo el 590, 1902 y el 1908- se centran en las relaciones de vecindad en el entorno propio de finales del siglo XIX cuando se aprueba el Código Civil (Cc).

Aunque se trata de unas determinaciones muy genéricas -superadas en muchos aspectos por la legislación de industria y la urbanística- los Tribunales civiles las siguen aplicando, convenientemente adaptadas, para reconocer la acción negatoria de los sujetos afectados por actividades nocivas, decidiendo en su caso la paralización de esas actividades e imponiendo en su caso el pago de una indemnización por las molestias causadas.

La tercera singularidad está en el objeto de la pretensión, que es, como su nombre indica, negatoria: lo que con ella se pretende fundamentalmente no es una indemnización , o una actuación reparadora o restauradora, sino el cese de la actividad o el cierre de la instalación que origina esos perjuicios o molestias, aunque la sentencia pueda llevar aparejada una indemnización por los daños causados"879.

\subsubsection{La vía de Amparo ante el Tribunal Constitucional}

El medio ambiente es un bien jurídico constitucionalizado y como tal, el resto del ordenamiento jurídico debe respetarlo conforme a las disposiciones de la Constitución. El medio ambiente, como interés difuso o colectivo que es, al ser reconocido como derecho por el ordenamiento jurídico, asume una doble vertiente, por una parte como derecho personal de cada individuo, y, por otra, de toda la colectividad $^{880}$.

\footnotetext{
${ }^{879}$ ESTEVE PARDO, José. Derecho del medio ambiente. $2^{\mathrm{a}}$ ed., Marcial Pons, Madrid-España: 2008, pp. 89-90.

${ }^{880}$ Según Sánchez Morón, citado por Blanca Lozano Cutanda, Derecho Ambiental Administrativo. $1^{\text {a }}$ ed., La Ley, Madrid-España: 2010, p. 149: "La Administración interviene de esta forma en la actividad de los particulares mediante técnicas de ordenación y control. Con estas medidas se pretende conciliar el respeto a la libertad y a la iniciativa privada con las exigencias del interés general, en este caso representado por
} 
Esta característica es reconocida en el artículo 45.1 de la Constitución Española, cuando afirma que todos tienen el derecho a disfrutar y el deber de conservar el medio ambiente, configurándolo como un bien no de titularidad individual sino perteneciente a todas las personas. Ahora bien, este artículo está incluso en el texto constitucional dentro de su Título I, "De los derechos y deberes fundamentales", pero no lo hace en el Capítulo II sobre "Derechos y Libertades", sino en el tercero titulado "De los principios rectores de la política social y económica". En razón de esta ubicación se derivan las siguientes consecuencias prácticas: que el derecho al medio ambiente no está considerado por la Constitución como un derecho fundamental de la persona, de aquí la imposibilidad de plantear un recurso de amparo ante el Tribunal Constitucional basado directamente en la violación del derecho al medio ambiente, ya que, de acuerdo con lo establecido en el artículo 161.1.b. ${ }^{881}$ de la Constitución, dicho recurso se limita a la violación de derechos y libertades a los que se refiere el artículo 53.2, es decir, a los reconocidos en el artículo $14^{882}$ y en la Sección $1^{\mathrm{a}}$ del Capítulo II; y,

la defensa de determinados bienes colectivos, esto es, intereses de naturaleza difusa que no tienen un titular determinado, sino que afectan a la sociedad en su conjunto o a amplios grupos sociales y que constituyen elementos esenciales de nuestro modelo de convivencia".

${ }^{881}$ Artículo 161.

“1. El Tribunal Constitucional tiene jurisdicción en todo el territorio español y es competente para conocer:

a) Del recurso de inconstitucionalidad contra leyes y disposiciones normativas con fuerza de ley. La declaración de inconstitucionalidad de una norma jurídica con rango de ley, interpretada por la jurisprudencia, afectará a ésta, si bien la sentencia o sentencias recaídas no perderán el valor de cosa juzgada.

b) Del recurso de amparo por violación de los derechos y libertades referidos en el artículo 53, 2, de esta Constitución, en los casos y formas que la ley establezca.

c) De los conflictos de competencia entre el Estado y las Comunidades Autónomas o de los de éstas entre sí.

d) De las demás materias que le atribuyan la Constitución o las leyes orgánicas.

2. El Gobierno podrá impugnar ante el Tribunal Constitucional las disposiciones y resoluciones adoptadas por los órganos de las Comunidades Autónomas. La impugnación producirá la suspensión de la disposición o resolución recurrida, pero el Tribunal, en su caso, deberá ratificarla o levantarla en un plazo no superior a cinco meses".

${ }^{882}$ Artículo 14. "Los españoles son iguales ante la ley, sin que pueda prevalecer discriminación alguna por razón de nacimiento, raza, sexo, religión, opinión o cualquier otra condición o circunstancia personal o social". 
no se configura como un derecho de inmediata protección jurisdiccional; así el artículo 53.3 de la Constitución declara que los principios rectores de la política social y económica "sólo podrán ser alegados ante la jurisdicción ordinaria de acuerdo con lo que dispongan las leyes que los desarrollen”. El Tribunal Constitucional ha declarado que "no puede ignorarse que el artículo 45 de la Constitución enuncia un principio rector, no un derecho fundamental. Los Tribunales deben velar por el respeto al medio ambiente, sin duda, pero de acuerdo con lo que dispongan las leyes que desarrollen el precepto constitucional" ${ }^{\prime 883}$.

Importante destacar, que esta pretensión no puede apoyarse a penas en el artículo 45.1 de la Constitución Española, dada la previsión del artículo 53.2, sin embargo, se entiende posible tal invocación en conjunto con el derecho a la vida, a la integridad física o moral, o a la libertad de circulación, entre otros reconocidos como auténticos derechos fundamentales.

Por lo tanto, es tolerable e incluso normal esperar que el Tribunal Constitucional no acoja el amparo por infracción al artículo 45.1 de la Constitución, pero podrá hacerlo si ocurrir conjugación entre derechos, lo que tal vez explique la motivación psicológica del recurrente, y llevará a análisis para confirmar si hubo o no infracción de derecho fundamental.

El recurso de amparo es el instrumento procesal de defensa más importante de los derechos y libertades de los ciudadanos ante el Tribunal Constitucional. Cumple una misión doble: actúa como remedio último de protección de los derechos, y sirve de instrumento defensor de la constitucionalidad al interpretar los Derechos Fundamentales.

Al tratar cómo se contempla el medio ambiente en la Constitución Española, observamos que no se contempla como un derecho fundamental $\mathrm{y}$, consiguientemente, no se puede acudir en su defensa ante el Tribunal Constitucional. Sin embargo, en los últimos años algunos derechos fundamentales han ido adquiriendo una dimensión ambiental a través de la interpretación de los tribunales. De esta manera, en determinados casos de especial gravedad, ciertos daños al medio ambiente pueden poner en peligro la salud a de personas, $\mathrm{y}$ atentar por consiguiente contra el derecho fundamental a la vida y a la integridad física, o bien, aún sin poner en peligro estos

${ }^{883}$ Sentencias 32/183, 149/1991 y 102/1995. 
derechos, atentan contra el derecho fundamental de los ciudadanos al respeto de su vida privada y familiar, privándoles del disfrute de su domicilio y vulnerando por esta vía los derechos a la intimidad personal y familiar y a la inviolabilidad del domicilio.

La lesión por los daños ambientales de estos derechos fundamentales abre a los particulares la posibilidad de utilizar la vía fundamental de interposición del recurso de amparo ante el Tribunal Constitucional previo agotamiento, en su caso, de la vía judicial previa. Por tanto, el recurso de amparo tiene carácter subsidiario. El acceso a esta vía de defensa de los derechos y libertades sólo es posible si previamente: se han agotado los instrumentos ordinarios de defensa de los derechos y libertades; se ha sido parte en el proceso judicial correspondiente, es decir, se haya acudido previamente a los tribunales en defensa del derecho menoscabado. Sólo en el caso de que no exista vía judicial previa podrá acudirse directamente en amparo ante el Tribunal Constitucional; y que el derecho vulnerado se haya invocado previamente ante los tribunales.

En definitiva, se trata de que los órganos judiciales hayan previamente conocido y discutido sobre la cuestión, y se agote por tanto la vía judicial previa.

Está legitimado para interponer este tipo de recurso cualquier persona natural o jurídica que invoque un interés legítimo, es decir, que se haya visto afectada de forma más o menos directa por el acto u omisión recurrido. También pueden interponer este recurso el Defensor del Pueblo y el Ministerio Fiscal, pero de forma excepcional, justificada por razones de interés general, puesto que el Defensor del Pueblo tiene atribuida la función de defensor de los Derechos Fundamentales y el Ministerio Fiscal la de defensor de la legalidad ${ }^{884}$.

Este recurso se articula únicamente frente a las lesiones a los derechos fundamentales ocasionadas por los poderes públicos ya sean del Estado, Comunidades Autónomas y demás entes públicos de carácter territorial, corporativo o institucional, así como de sus funcionarios o agentes. Sin embargo, el Tribunal Constitucional extiende los supuestos a casos de lesiones de derechos procedentes de particulares. En estos casos, el recurso de amparo se fundamenta no en la lesión del derecho fundamental por el particular sino en la indebida denegación de su protección por las Administraciones públicas o los tribunales ordinarios.

${ }^{884}$ Mecanismos legales para la defensa del medio ambiente. Elaborado por el Instituto Internacional de Derecho y Medio Ambiente. Disponible en: $<$ http://www.iidma.org/privado/Archivos/Guiamecanismosport.pdf>. Acceso en: 28-10-2015. 


\subsubsection{Cuestiones de inconstitucionalidad}

El Tribunal Constitucional, a través de la cuestión de inconstitucionalidad, al igual que a través del recurso de inconstitucionalidad, garantiza la supremacía de la Constitución y enjuicia la conformidad o disconformidad con ella de las leyes, disposiciones normativas y actos con fuerza de ley del Estado y de las Comunidades Autónomas.

La cuestión de inconstitucionalidad sólo puede ser promovida, de oficio o a instancia de parte, por Jueces y Tribunales y han de hacerlo cuando consideren que una norma con rango de ley aplicable al proceso del que conocen y de cuya validez dependa la decisión que hayan de adoptar en el mismo pueda ser contraria a la Constitución ${ }^{885}$.

El órgano judicial ha de plantear la cuestión una vez concluso el proceso y dentro del plazo para dictar sentencia o la resolución judicial que proceda, debiendo concretar la ley o norma con fuerza de ley de cuya constitucionalidad duda, el precepto constitucional infringido y especificar o justificar en qué medida la decisión del proceso depende de la validez de la norma cuestionada.

Antes de adoptar el Auto en el que se acuerde el planteamiento de la cuestión de inconstitucionalidad, el órgano judicial debe oír a las partes y al Ministerio Fiscal para que en el plazo común e improrrogable de diez días puedan alegar lo que deseen sobre la pertinencia de plantear la cuestión de inconstitucionalidad. Seguidamente, sin más trámite, el órgano judicial resolverá en el plazo de tres días sobre su planteamiento $^{886}$.

El órgano judicial ha de elevar al Tribunal Constitucional el Auto de planteamiento de la cuestión de inconstitucionalidad junto con los testimonios de los autos principales y las alegaciones efectuadas por las partes y el Ministerio Fiscal. El planteamiento de la cuestión de inconstitucionalidad determina la suspensión provisional de las actuaciones en el proceso judicial hasta que el Tribunal

\footnotetext{
885 Información disponible en el sitio del Tribunal Constitucional de España: $<$ http://www.tribunalconstitucional.es/es/tribunal/competencias/Paginas/COMPT_02_CI.aspx $>$. Acceso en: 30-10-2015.

886 Información disponible en el sitio del Tribunal Constitucional de España: $<\mathrm{http}: / /$ www.tribunalconstitucional.es/es/tribunal/competencias/Paginas/COMPT_02_CI.aspx>. Acceso en: $30-10-2015$.
} 
Constitucional se pronuncie sobre su admisión y, de ser admitida, hasta que resuelva definitivamente la cuestión.

El Tribunal Constitucional puede rechazar en trámite de admisión, mediante Auto y previa audiencia al Fiscal General del Estado, la cuestión de inconstitucionalidad cuando falten las condiciones procesales para su planteamiento o fuera notoriamente infundada ${ }^{887}$.

La admisión a trámite de la cuestión de inconstitucionalidad ha de publicarse en el Boletín Oficial del Estado, pudiendo personase en el proceso constitucional, en el plazo de los quince días siguientes a dicha publicación, quienes sean parte en el procedimiento judicial en cuyo seno se ha promovido. Asimismo, el Tribunal ha de dar traslado de la cuestión al Congreso de los Diputados, al Senado, al Fiscal General del Estado, al Gobierno y, en caso de afectar a una ley o disposición normativa con fuerza de ley de una Comunidad Autónoma, a sus órganos ejecutivo y legislativo para que puedan personarse en el procedimiento y formular alegaciones en el plazo de quinces días. Concluido este plazo, el Tribunal Constitucional dictará Sentencia ${ }^{888}$.

Las sentencias recaídas en este tipo de procedimientos tienen valor de cosa juzgada, vinculan a todos los poderes públicos y producen efectos generales desde la fecha de su publicación en el Boletín Oficial del Estado.

De esta manera, los particulares que sean partes en un proceso judicial tienen la oportunidad de hacer valer intereses ambientales, sea suscitando frente al Juez a quo la inconstitucionalidad de una ley por infracción del artículo 45 de la Constitución Española, sea participando en el contradictorio que será abierto antes de ser remitido al Tribunal.

\footnotetext{
887 Información disponible en el sitio del Tribunal Constitucional de España: $<$ http://www.tribunalconstitucional.es/es/tribunal/competencias/Paginas/COMPT_02_CI.aspx $>$. Acceso en: 30-10-2015.

888 Información disponible en el sitio del Tribunal Constitucional de España: $<$ http://www.tribunalconstitucional.es/es/tribunal/competencias/Paginas/COMPT_02_CI.aspx >. Acceso en: $30-10-2015$.
} 


\subsection{El papel de la Administración en la defensa del medio ambiente}

La interdependencia ecológica del planeta no respeta las fronteras de los Estados y problemas que, previamente, se consideraban asuntos de interés nacional, ahora tienen implicaciones internacionales. Actualmente la Tierra se enfrenta a una serie de retos ambientales que van en aumento y tienen un origen muy diverso, y sólo a través de la cooperación internacional conseguiremos resolverlos.

El desarrollo de controles legales de las actividades se inició, fundamentalmente, en el plano internacional con la adopción de instrumentos jurídicos de protección que se fueron trasladando a los ámbitos regionales, como es el caso de la Unión Europea, y nacionales. Hoy en día, España cuenta con un amplio marco normativo de protección ambiental regulado tanto a nivel internacional, como comunitario y también nacional.

La Constitución Española de 1978 ya hacía referencia a la protección del medio ambiente, sin embargo, el derecho ambiental español vino a desarrollarse con la incorporación de España a la entonces Comunidad Económica Europea en 1986. Desde entonces se han promulgado un gran número de leyes sectoriales dirigidas tanto a la protección del medio como a la regulación de agentes contaminantes y de los problemas ambientales concretos. Estas leyes sectoriales se combinan con otra serie de normas ${ }^{889}$ ambientales de carácter horizontal que introducen instrumentos de protección ambiental aplicables en diversos sectores o ámbitos de actividad.

Los poderes públicos, conforme determina el artículo 45 de la Constitución tienen la función de "defender y restaurar el medio ambiente, apoyándose en la indispensable solidaridad colectiva". El cumplimiento de este mandato constitucional se lleva a cabo fundamentalmente mediante normas de derecho público y el papel central lo desempeña la Administración, lo que es consecuencia del carácter de interés o bien jurídico colectivo que tiene el medio ambiente y de la necesidad de que su protección se realice, como dice la Constitución Española, velando "por la utilización racional de

\footnotetext{
${ }^{889}$ Estas normas son promulgadas a nivel estatal, autonómico y local de conformidad con la distribución de competencias recogida en la Constitución.
} 
todos los recursos naturales", o sea, interviniendo en la utilización y disfrute de los recursos para evitar una pérdida o deterioro ${ }^{890}$.

De este modo, los poderes públicos desempeñan un papel central en la protección del medio ambiente, sin embargo, es importante destacar que eso no implica que sean los únicos llamados a protegerlo. Conforme establece el artículo 45 de la Constitución Española "Todos tienen el derecho a disfrutar de un medio ambiente adecuado para el desarrollo de la persona, así como el deber de conservarlo", y el Derecho dispone los medios para permitir una participación, cada vez más activa, de los ciudadanos en la protección ambiental, mediante acuerdos voluntarios o la custodia del territorio, a la vez que exige responsabilidades para quienes incumplan los mandatos y prohibiciones en los que se concreta el deber de protección en las leyes.

Por otro lado, Blanca Lozano Cutanda, citando E. Alonso, comenta que: “[...] el desarrollo del derecho público ambiental, junto a la propia conciencia ecológica de las personas, impulsa el fenómeno conocido como $<<$ la vida privada del derecho público $>>$, que consiste en el surgimiento de todo un mundo de derecho privado contractual y extracontractual- que regula relaciones jurídicas exclusivamente inter privatos $^{, 891}$. La autora sigue y afirma que: “[...] el objetivo primordial [...] el derecho administrativo para la protección del medioambiente, lo primero que hay que destacar es que con él se trata de prevenir los daños ambientales, para lo cual la Administración utiliza toda la panoplia de técnicas de prestación, de limitación y de fomento que arbitra el ordenamiento jurídico. Las normas e instrumentos del derecho privado van a desempeñar un papel que puede calificarse de subsidiario de esta protección administrativa, en cuanto en este ámbito de lo que se trata es de la tutela y reparación de intereses particulares cuando ya han sido o están siendo conculcados, una vez que han fallado los mecanismos de prevención, lo que se lleva a cabo por medio de las normas de vecindad, por la doctrina del abuso de derecho, y, en especial, por las reglas de responsabilidad por daños $" 892$.

La Constitución encomienda a los poderes públicos la función de defender y restaurar el medio ambiente. Este mandato constitucional se cumple fundamentalmente

\footnotetext{
${ }^{890}$ LOZANO CUTANDA, Blanca. Derecho Ambiental Administrativo. $1{ }^{\mathrm{a}}$ ed., La Ley, Madrid-España: 2010 , p. 145.

${ }^{891}$ ALONSO GARCÍA, E. citado por LOZANO CUTANDA, Blanca. Derecho Ambiental cit., p. 145.

${ }^{892}$ LOZANO CUTANDA, Blanca. Derecho Ambiental cit., p. 146.
} 
a través de la aprobación de normas y su control. El papel central lo desempeña la Administración (tanto estatal, autonómica como local).

La primera nota que caracteriza la acción de la Administración en defensa del medio ambiente es su carácter preventivo. La Administración utiliza técnicas de intervención en la actividad o derechos de los particulares basadas en la regulación, limitación y control así como técnicas de incentivo o fomento económico tales como medidas fiscales, ayudas y subvenciones. Los poderes públicos intentan, de esta forma, obtener la colaboración de la sociedad en una tarea, la protección ambiental, que es hoy responsabilidad de todos.

La Administración en defensa del medio ambiente, presenta como una de sus acciones, su carácter preventivo, previsto en el párrafo $3^{\circ}$ del artículo 45 de la Constitución: "Para quienes violen lo dispuesto en el apartado anterior, en los términos que la ley fije se establecerán sanciones penales o, en su caso, administrativas, así como la obligación de reparar el daño causado", aunque operan cuando el daño al medio ambiente ya se ha consumado, desempeñan también una finalidad última preventiva muy importante, en cuanto la amenaza de sanción actúa como elemento de disuasión de las conductas que se pretende evitar.

El incumplimiento de los mandatos, prohibiciones y condicionamientos que establece el ordenamiento jurídico español para la protección ambiental determina la aplicación al infractor de medidas de carácter represivo, tanto penales como administrativas, así como la obligación de restituir, reparar o, en su caso, indemnizar por los perjuicios derivados del ilícito.

En el desempeño de esta función de protección ambiental, Blanca Lozano Cutanda enseña que: “[...] la Administración utiliza una enorme variedad de técnicas jurídicas, heredadas en gran parte de instrumentos arbitrados con anterioridad al surgimiento del derecho ambiental como valor autónomo para la gestión de recursos naturales de especial valor en la vida social y económica (los montes, las aguas, las minas, la caza y la pesca), o para la protección de la salubridad e higiene (medidas de policía sanitaria en las ciudades), y procedentes en otros casos de instrumentos específicamente ambientales, que son por lo general de origen estadounidense y se han introducido en nuestro país por vía de la Unión Europea, como es el caso del 
procedimiento de evaluación de impacto ambiental o de la fijación de estándares de emisión"893.

La Administración Pública ha perfeccionado los medios mediante los cuales se imponen medidas represivas para una mejor protección del medio ambiente. No se limitando a las clásicas sanciones, sino que su elenco abarca una gran cantidad de figuras. Entre ellas: Clausura de la actividad, caducidad o revocación de la autorización, decomiso, restitución y reposición, indemnizaciones y por último las sanciones ${ }^{894}$.

Con arreglo al criterio del efecto que la actividad administrativa causa en la libertad de acción y los derechos particulares, estas técnicas tienden a situarse en dos polos antagónicos de la acción administrativa, pues o bien supone medidas de limitación o policía, denominadas, usualmente, en el ámbito de la protección ambiental, como 'técnica de regulación y control', que restringen, fuertemente en ocasiones, la esfera de libertad privada, o bien tratan de buscar la colaboración de los ciudadanos a través de fórmulas de incentivo o desincentivo de la iniciativa privada, englobables en un sentido amplio en la conocida como actividad de fomento o incentivo ${ }^{895}$.

De este modo, los poderes públicos precisan intervenir para introducir y hacer respetar el valor de preservación del ecosistema, sea con actuaciones orientadoras o limitadoras de los intereses económicos particulares que logren su armonización con los intereses generales ambientales en un modelo de desarrollo sostenible. La defensa y restauración del medio ambiente se configura así como un título de intervención de la Administración en la actividad y los derechos de los particulares, justificado por el interés social de la protección ambiental, e implícitamente reconocido por el artículo 45 de la Constitución Española cuando asigna a los poderes públicos una acción tuitiva para la defensa y restauración del medio ambiente que ha de apoyarse en 'la indispensable solidaridad colectiva ${ }^{, 896}$.

\footnotetext{
${ }^{893}$ Idem, p. 146.

${ }^{894}$ IBÁÑEZ MÉNDEZ, Inés. Los poderes públicos y la defensa del medio ambiente. Observatorio medioambiental 2003, 6, 45-71.

${ }^{895}$ LOZANO CUTANDA, Blanca. Derecho Ambiental cit., pp. 146-147.

${ }^{896}$ LOZANO CUTANDA, Blanca. Derecho Ambiental cit., pp. 148-149.
} 
Importante destacar que la Administración también debe estar sujeta a las obligaciones ambientales cuando lleva a cabo cualquier actividad o proyecto potencialmente lesivo del entorno y sometido por ello a normas ambientales ${ }^{897}$.

Esta doble condición de la Administración ${ }^{898}$ como defensora del medio ambiente pero a su vez como potencial agresora del mismo explica la importancia que en este ámbito tiene la actuación ciudadana en defensa del medio ambiente ${ }^{899}$.

La modificación o alteración del ambiente es susceptible de afectar intereses difusos de la ciudadanía, ya que sin perturbar directamente a cada individuo, lo afecta como parte integrante de la sociedad. En algunos casos, la degradación del medio ambiente puede llevar también a que una persona en particular se vea afectada de forma directa.

Al fin y al cabo, la responsabilidad de proteger el medio ambiente y los recursos naturales es compartida, nos incumbe a todos: poderes públicos y ciudadanía.

La Constitución Española reconoce a los ciudadanos una responsabilidad directa en la conservación de un medio ambiente adecuado. De esta responsabilidad se

${ }^{897}$ Tales como: obras públicas sometidas a evaluación de impacto, actividades clasificadas, vertidos, operaciones de producción y gestión de residuos, etc.

${ }^{898}$ Sobre esta doble condición de la Administración, Blanca Lozano Cutanda, Derecho Ambiental cit., p.154, enseña que: “( ...) como defensora del bien jurídico situado bajo su tutela pero a la vez potencial agresora del mismo, constituye una singularidad del derecho ambiental que explica por un lado la importancia que en este ámbito tiene, como veremos, la participación pública en la defensa del medioambiente, y por otro el hecho de que no sólo los particulares, sino también las Administraciones públicas deben quedar sujetas a los postulados ambientales cunado llevan a cabo cualquier actividad o proyecto potencialmente lesivo al entorno y someterse a los sistemas de control previo ambientales, que actúan en estos supuestos como técnicas de $<<$ autocontrol $>>$ de los poderes públicos: técnicas de evaluación de impacto de proyectos, planes y programas, autorización ambiental integrada, licencias ambientales, etc.".

${ }^{899}$ Conforme dispone el Principio 10 de la Declaración de Río: "El mejor modo de tratar las cuestiones ambientales es con la participación de todos los ciudadanos interesados, en el nivel que corresponda. En el plano nacional, toda persona deberá tener acceso adecuado a la información sobre el medio ambiente de que dispongan las autoridades públicas, incluida la información sobre los materiales y las actividades que encierran peligro en sus comunidades, así como la oportunidad de participar en los procesos de adopción de decisiones. Los Estados deberán facilitar y fomentar la sensibilización y la participación de la población poniendo la información a disposición de todos. Deberá proporcionarse acceso efectivo a los procedimientos judiciales y administrativos, entre éstos el resarcimiento de daños y los recursos pertinentes". 
deriva la obligación de una conducta cívica comprometida con la preservación del entorno, pero también la necesidad de que existan vías adecuadas que permitan a los ciudadanos cumplir con ese deber de conservación ${ }^{900}$.

En la actualidad cada vez son más los ámbitos en los que los ciudadanos están legitimados para participar activamente en el curso de los procedimientos administrativos o mediante el ejercicio de acciones judiciales, en la promoción y defensa de intereses de carácter público y colectivo como es el medio ambiente.

Los ciudadanos tradicionalmente han canalizado su participación en el desarrollo y aplicación del derecho ambiental a través de las actividades de las organizaciones de defensa ambiental. Sin embargo, la creciente relación entre los derechos humanos y la protección ambiental ha conducido a que los ciudadanos puedan presentar por sí mismos recursos y quejas en esta materia. De este modo, los particulares son también responsables de velar por el cumplimiento de las obligaciones ambientales. Para ello existen mecanismos que permiten presentar denuncias, quejas y acudir a los tribunales ${ }^{901}$.

Otro papel fundamental en la protección del entorno es el desempeñado por las organizaciones no gubernamentales (ONG), en particular, las organizaciones de defensa ambiental, también denominadas ecologistas, vez que, colaboran con los poderes públicos que muchas veces tienen deficiencias tanto por falta de decisión o de recursos, para asegurar una efectiva aplicación de las normas y medidas de tutela ambiental. Además, las organizaciones y los ciudadanos, al ejercer el derecho de participar, actúan como un elemento de control para la propia Administración, pues, como hemos visto, los poderes públicos, pueden aparecer también, y aparecen con frecuencia, como agresores del medio.

Dado que muchos de los bienes que integran el medio ambiente son públicos, bien porque son de dominio público, como las aguas y las costas o bien porque son de

\footnotetext{
${ }^{900}$ Mecanismos legales para la defensa del medio ambiente. Elaborado por el Instituto Internacional de Derecho y Medio Ambiente. Disponible en: http://www.iidma.org/privado/Archivos/Guiamecanismosport.pdf>. Acceso en: 27-10-2015.

${ }^{901}$ Mecanismos legales para la defensa del medio ambiente. Elaborado por el Instituto Internacional de Derecho y Medio Ambiente. Disponible en: http://www.iidma.org/privado/Archivos/Guiamecanismosport.pdf>. Acceso en: 27-10-2015.
} 
utilización publica como es el caso de la atmósfera, los individuos no van a actuar o no van a estar en posición de actuar para su defensa, principalmente en vía judicial, si se les exige para ello la lesión o un interés, o sea es exigida legitimación activa para la interposición de un recurso administrativo o para que se inicie la vía judicial. Por tanto, resulta esencial para una protección ambiental eficaz, esta legitimación activa de las asociaciones de defensa ambiental frente a la Administración y a los Tribunales para defender los intereses ecológicos que constituyen su razón de.

\subsection{Distribución territorial de competencias en materia de medio} ambiente (Estados, Comunidades Autónomas y Administraciones Locales)

Desde el momento, a mediados del siglo XX, en que las cuestiones ambientales comenzaron a singularizarse y a configurar un sector normativo propio, el Estado ${ }^{902}$ asumió la imprescindible responsabilidad, tanto normativa como de ejecución, en materia de medio ambiente, hasta que, a partir de 1978, con la instauración del Estado de las Autonomías, se establece un sistema de distribución territorial de competencias entre el Estado y las comunidades autónomas ${ }^{903}$.

Una de las consecuencias lógicas del proceso progresivo de intervención legislativa sobre el medio ambiente como bien afirma Jesús Jordano Fraga: "ha sido la definición de los campos de actuación de las distintas Administraciones Públicas en

${ }^{902}$ Respecto a la consolidación de la política europea ambiental, Blanca Lozano Cutanda, Derecho Ambiental Administrativo. 1a ed., La Ley, Madrid-España: 2010, p. 155, afirma que: "Sin embargo, una vez consolidada la política europea ambiental, su implantación efectiva se va a encomendar a partir de los años ochenta a los Estados, de tal forma que las competencias ambientales de la Unión europea se entiende siempre que son compartidas con las de los Estados y su ejercicio se rige por el principio de subsidiariedad, en virtud del cual, la Unión intervendrá solo en la medida en que los objetivos de la acción pretendida no puedan ser alcanzados de manera suficiente por los Estados miembros. Pero, además, incluso en aquellos ámbitos en los que la Unión interviene, los Estados no pierden por ello su competencia en la materia, pues podrán siempre desarrollar la medida comunitaria en el margen que ésta permita y mantener o adoptar disposiciones más protectoras del medioambiente, y les corresponde además en exclusiva la responsabilidad de la ejecución de la normativa comunitaria”.

${ }^{903}$ LOZANO CUTANDA, Blanca. Derecho Ambiental Administrativo. $1^{\text {a }}$ ed., La Ley, Madrid-España: 2010, p. 155. 
presencia. Dicha definición, en un Estado de $<<$ autonomías integradas $>>$, abarca aspectos de gestión y de producción normativa como consecuencia del reconocimiento de la capacidad legislativa a instancias territoriales distintas del Estado"904.

La Constitución Española de 1978 contempla, entre las materias en que corresponde la competencia exclusiva del Estado ${ }^{905}$, la legislación básica sobre protección del ambiente, sin perjuicio de las facultades de las Comunidades Autónomas de establecer normas adicionales de protección ${ }^{906}$. Por su parte incluye entre las materias en que las Comunidades Autónomas podrán asumir competencias a la gestión en materia de protección del ambiente ${ }^{907}$. No podemos olvidarnos, que el Estado, como

\footnotetext{
${ }^{904}$ JORDANO FRAGA, Jesús. La protección del derecho a un medio ambiente cit., p. 82.

${ }^{905}$ Blanca Lozano Cutanda, Derecho Ambiental cit., pp. 154-155, hace interesante comentario respecto a
} la primera manifestación de protección jurídica del medio ambiente, afirmando que esta manifestación se dio en las ciudades, en las actuaciones que las Corporaciones locales llevaban a cabo para preservar las condiciones de comodidad y salubridad de las poblaciones, consolidándose en el siglo XIX la policía sanitaria como una de las actividades o funciones típicas de la Administración local. Además, añade la autora: "Pero aunque la Administración local fuera la primera en velar por la salubridad de las poblaciones, lo que incluía evitar los humos, olores o ruidos que actualmente forman parte del concepto de calidad ambiental, la gestación de la política y el derecho para la protección del medioambiente no solo no se ha realizado a nivel local, sino ni siquiera nacional, pues, [...] la adopción de medidas para frenar el deterioro de nuestro ecosistema fue impulsada inicialmente en el ámbito internacional, pudiendo situarse en la Declaración de la Conferencia de Estocolmo sobre el Medio Humano organizada por las Naciones Unidas en 1972 el punto de partida del derecho ambiental en sentido moderno".

${ }^{906}$ Artículo 149.

"1. El Estado tiene competencia exclusiva sobre las siguientes materias:

$[\ldots]$

23. ${ }^{\text {a }}$ Legislación básica sobre protección del medio ambiente, sin perjuicio de las facultades de las Comunidades Autónomas de establecer normas adicionales de protección. La legislación básica sobre montes, aprovechamientos forestales y vías pecuarias”.

${ }^{907}$ Artículo 148 .

“1. Las Comunidades Autónomas podrán asumir competencias en las siguientes materias:

$[\ldots]$

9. "La gestión en materia de protección del medio ambiente".

Según Ramón Martín Mateo, Manual de Derecho Ambiental, $3^{\mathrm{a}}$ ed., Thompson Aranzadi, NavarraEspaña: 2003, p. 85: "La distribución competencial se ha simplificado recientemente al haberse homogeneizado a este respecto el régimen de las competencias ambientales de todas las Comunidades Autónomas por la Ley Orgánica 9/1992 de 23 de diciembre, que iguala a todas ellas limando las diferencias que antes existían entre las que denominábamos de autonomía plena por haber llegado en sus 
dispone el artículo 137 de la Constitución Española "se organiza territorialmente en municipios, en provincias y en las Comunidades Autónomas que se constituyan”. Los municipios y las provincias ostentan importantes competencias en relación con el medio ambiente. Estas competencias les han sido atribuidas por la dispersa legislación ambiental, tanto anteriores ${ }^{908}$ como posteriores a la Constitución de 1978. Con carácter genérico, la Ley reguladora de las bases del régimen local de 2 de abril de 1985 incluyó entre las competencias propias de las entidades locales al medio ambiente ${ }^{909}$.

Como hemos visto, la Constitución Española no dice qué se entiende por medio ambiente, pero como enuncia Ramón Martín Mateo: “es claro que sea cualquiera el concepto que tuviera in mente los constituyentes, debe entenderse que $<<$ la

Estatutos al tope competencial que para ellas establecía la Constitución, y las de autonomía gradual, que podrían mejorar sus competencias. [...] Además del ejercicio de las competencias ordinarias de las Comunidades Autónomas, todas tienen en este momento atribución para establecer normas adicionales de protección con base en la ya citada Ley Orgánica 9/1992”.

${ }^{908}$ Como por ejemplo el Reglamento de actividades molestas, insalubres, nocivas y peligrosas y la Ley de protección de medio ambiente atmosférico. JORDANO FRAGA, Jesús. La protección del derecho a un medio ambiente cit., p. 82.

${ }^{909}$ JORDANO FRAGA, Jesús. La protección del derecho a un medio ambiente cit., p. 82. En este sentido, Ramón Martín Mateo, Manual de Derecho cit., pp. 87-88, enseña que: "Las entidades locales son cualificadas y excepcionales protagonistas de la defensa del ambiente. Todas las agresiones que se producen surgen en territorios controlados por Municipios o sus equivalentes y el grueso de ellas, las más importantes, proceden de áreas urbanas. De aquí que estas Administraciones se sitúen en primera línea de la reacción anticontaminante. La gestión de los residuos urbanos y de las aguas residuales, la intervención frente al ruido, el control de las emisiones de los vehículos que circulan por las ciudades, la participación en el remedio de accidentes mayores, cae inevitablemente en la órbita de las preocupaciones municipales". Además, afirma el autor: "Los Municipios disponen de facultades propias dentro del marco de la legislación general, estatal y autonómica, para reglamentar vía ordenanzas sus actuaciones, organizar la intervención ambiental, autorizar nuevas actividades, controlar las existentes y prestar servicios ambientales básicos. Aunque las Comunidades Autónomas pueden modular el marco de la autonomía municipal no pueden sin embargo modificar o derogar lo dispuesto en la Ley de Bases de Régimen Local de 3 de abril de 1985, que apodera a los Municipios para ejercer competencias en materia de protección del Medio Ambiente y que asigna a todos ellos como competencia indisponible la recogida de residuos, limpieza viaria y alcantarillados, lo que se amplía para los de población superior a 5.000 habitantes al tratamiento de residuos. El artículo 86 por su parte reserva además, quizás innecesariamente, a las Entidades locales, la recogida tratamiento y aprovechamiento de residuos, que ya estaba asignado a los Municipios, adicionando la depuración de aguas, lo que han desconocido por cierto algunas Comunidades Autónomas". 
protección $>>$ está referida a su conservación frente a su deterioro o contaminación, lo que incluye desde luego a los sistemas aquí manejados: agua, aire y suelo. La Sentencia del TC de 26 de junio de 1995 (RTC 1995, 102) intentó, aclarar esta problemática. Pero las competencias del Estado en esta materia no se agotan en la promulgación de normas básicas, hay sectores ambientales para los que se le reservan facultades más amplias como es el caso de los cursos de aguas que discurran por más de una Comunidad Autónoma, sobre los que el Estado tiene también competencias de desarrollo legislativo y ejecución según se desprende de artículo 149.1.22 $2^{910,911 .}$

En virtud de la interpretación que ha realizado el Tribunal Constitucional de este sistema de distribución de competencias y, en particular, del contenido que ha de darse al concepto 'legislación básica' que define la competencia exclusiva estatal, se considera que esta legislación básica condiciona la capacidad normativa de las comunidades autónomas con el objetivo de "el encuadramiento de una política global del medio ambiente, haciendo viable la solidaridad colectiva y garantizando su disfrute por todos, así como el correlativo deber de conservación en régimen de igualdad"912. Sin embargo, permite un margen para la intervención normativa autonómica.

En este sentido, Blanca Lozano Cutanda afirma que: "la doctrina del Tribunal Constitucional ha experimentado cambios en distintas etapas, pero de acuerdo con la actualmente imperante se considera que $<<$ la legislación básica del Estado no cumple en este caso una función de uniformidad relativa, sino más bien de ordenación mediante mínimos que han de respetarse en todo caso, pero que pueden permitir que cada una de las comunidades autónomas, con competencias en la materia, establezca niveles de protección más altos (...). En definitiva, la protección concedida por la Ley estatal puede ser ampliada y mejorada por las leyes de las comunidades autónomas; lo que resulta constitucionalmente improcedentes es que resulte restringida o disminuida $>>$ (STC 166/2002, de 18 de septiembre, por la que se declaró la inconstitucionalidad de

${ }^{910}$ Artículo 149.

“1. El Estado tiene competencia exclusiva sobre las siguientes materias:

22. ${ }^{a}$ La legislación, ordenación y concesión de recursos y aprovechamientos hidráulicos cuando las aguas discurran por más de una Comunidad Autónoma, y la autorización de las instalaciones eléctricas cuando su aprovechamiento afecte a otra Comunidad o el transporte de energía salga de su ámbito territorial”.

${ }^{911}$ MARTÍN MATEO, Ramón. Manual de Derecho cit., pp. 85-86.

${ }^{912}$ STC 102/1995, de 26 de junio, FJ 8. Disponible en: <https://www.boe.es/buscar/doc.php?id=BOE-T1995-18444>. Acceso en: 02-11-2015. 
determinados preceptos de la Ley de la Fauna Silvestre, Caza y Pesca Fluvial de la Región de Murcia, y, en el mismo sentido, véanse las SSTC 102/1995, de 26 de junio; 156/1995, de 26 de octubre; 196/1996, de 28 de noviembre y 16/1997, de 30 de enero)"913.

Según ha precisado el Tribunal Constitucional, respecto a los instrumentos mediante los cuales el Estado puede establecer la normativa básica, habrán de ser "en principio, un conjunto de normas legales, aun cuando también resulten admisibles -con carácter excepcional, sin embargo- las procedentes de la potestad reglamentaria que la Constitución encomienda al Gobierno de la Nación (art. 97 C.E.), siempre que resulten imprescindibles y se justifiquen por su contenido técnico o por su carácter coyuntural o estacional, circunstancial y, en suma, sometido a cambios o variaciones frecuentes e inesperadas. Ahora bien, el contenido normativo de lo básico en esta materia no significa la exclusión de otro tipo de actuaciones que exijan la intervención estatal" cuando concurran circunstancias de esta índole ${ }^{914}$.

\footnotetext{
${ }^{913}$ LOZANO CUTANDA, Blanca. Derecho Ambiental Administrativo. $1^{\text {a }}$ ed., La Ley, Madrid-España: 2010, p. 156. Además, la autora, pp. 156-157 enseña que: "Este criterio se aplica a las medidas de protección ambiental, incluidas las normas que establecen infracciones y sanciones (de hecho, dos de los preceptos de la Ley murciana son declarados inconstitucionales en la STC 166/2002 por establecer uno sanciones más leves y otro un plazo de prescripción para las infracciones más corto de lo previsto en la Ley estatal de Conservación de los Espacios Naturales y de la Fauna y la Flora y Silvestres). También se aplica a las subvenciones pues, como ha reiterado el TC, la subvención no constituye un título de atribución de competencias por lo que hay que atender para delimitarlas a la materia sobre la que opera el gasto o subvención (así lo declaró ya en la Sentencia 39/1992, de 15 de diciembre; 59/1995, de 17 de marzo; 148/1998, de 10 de julio; y 242/1999, de 21 de diciembre). En algunas de las últimas leyes orgánicas aprobadas de reforma de los Estatutos de Autonomía, esta distribución de competencias se enuncia de forma diversa, aunque permite, o exige según los casos, su interpretación acorde con la Constitución".

${ }^{914}$ Concurren circunstancias excepcionales que pueden llegar a justificar actos de ejecución del Gobierno de la Nación, según precisa la Sentencia del Tribunal Constitucional 102/1995, de 26 de junio, "solución ciertamente excepcional a la cual sólo podrá llegarse cuando no quepa establecer ningún punto de conexión que permita el ejercicio de las competencias autonómicas o cuando además del carácter supraautonómico del fenómeno objeto de la competencia, no sea posible el fraccionamiento de la actividad pública ejercida sobre él y, aun en este caso, siempre que dicha actuación tampoco pueda ejercerse mediante mecanismos de cooperación o de coordinación y, por ello, requiera un grado de homogeneidad que sólo pueda garantizar su atribución a un único titular, forzosamente el Estado, y cuando sea necesario recurrir a un ente supraordenado con capacidad de intereses contrapuestos de sus
} 
Sin embargo, salvo la concurrencia de circunstancias excepcionales de esta índole, la competencia de ejecución o gestión en materia ambiental corresponde en exclusiva a las comunidades autónomas. Actualmente, el Tribunal Constitucional interpreta este principio de un modo muy riguroso, afirmando que el contenido del concepto de gestión se configura como 'competencia normal o habitual de las comunidades autónomas' y que solo residualmente, en ciertos supuestos límite como los señalados, puede participar en ella el Estado ${ }^{915}$ (STC 102/1995, FJ 22).

Las Comunidades Autónomas, con las salvedades antes expuestas, disponen en general del desarrollo legislativo y de la posibilidad de dictar normas adicionales de protección, normas que harán más exigente en su territorio la tutela ambiental, y que no son un mero ejercicio atenuado de la potestad reglamentaria como parece entender, a este respecto, la desafortunada Sentencia del Tribunal Constitucional 188/1991 de 17 de octubre (RTC 1991, 188) sobre la Ley de Costas ${ }^{916}$.

Este sistema general de distribución de competencias entre el Estado y las comunidades autónomas, conforme explica Blanca Lozano Cutanda: "resulta aplicable en los mismos términos a aquellos sectores relacionados con la protección del medio ambiente que no constituyen un título competencial específico en el sistema constitucional de distribución de competencias pero que son enunciados en los Estatutos de Autonomía como una materia diferenciada (la división de los bloques materiales que

componentes parciales, sin olvidar el peligro inminente de daños irreparables, que nos sitúa en el terreno del estado de necesidad".

${ }^{915}$ STC 194/2004, de 10 de noviembre, que declare por este motivo contraria al orden constitucional de distribución de competencias la fórmula de cogestión de los Parques Nacionales establecida por el artículo 22 de la LCEN. Entre las Sentencias del Tribunal Constitucional en este sentido, véanse también la 33/2005 y la 32/2006. LOZANO CUTANDA, Blanca. Derecho Ambiental Administrativo. $1^{\mathrm{a}}$ ed., La Ley, Madrid-España: 2010, p. 159.

${ }^{916}$ MARTÍN MATEO, Ramón. Manual de Derecho cit., pp. 86-87. Además, añade el autor: "por supuesto que corresponde a la Administración autonómica la ejecución de la normativa ambiental, salvo excepciones puntuales y respetando el juego de las competencias municipales. Las relaciones UE, Estado, Comunidades Autónomas no son fáciles; por una parte, estas últimas tienen competencias constitucionales no desconocibles en el campo ambiental, normalmente de ejecución, pero también en exclusividad: pesca en aguas interiores, montes. Pero el interlocutor de la UE es el Estado y éste carece de potestades para disciplinar ambientalmente a aquéllas, lo que hace que algunas de las condenas del Tribunal de Justicia Europeo se deban a acciones u omisiones no imputables al Estado, impotente para reaccionar". 
se observa en muchos Estatutos de Autonomía tuvo por objeto, como explica J. Domper Ferrando, evitar, ante la incertidumbre inicial sobre la extensión de cada materia, que pudiera considerarse que se renunciaba a las competencias sobre las submaterias no relacionadas en las listas al no atribuírselas específicamente por medio del Estatuto, y entenderlas entonces residenciadas en el Estado por aplicación de la previsión del número 3 del art. 149)"917.

El sistema de distribución competencial en materia de protección del medio ambiente instaurado por la Constitución Española se ha caracterizado desafortunadamente hasta el presente por una gran complejidad y conflictividad, en un ámbito que demanda más que ninguno una actuación coordinada, a nivel nacional y transnacional, si se quiere dar una respuesta eficaz a los problemas que afectan al entorno, que no conocen de fronteras o divisiones territoriales.

Como elemento positivo de este reparto competencial en materia ambiental hay que señalar, sin embargo, que en ocasiones las leyes autonómicas toman la iniciativa en nuevos ámbitos de protección medioambiental y ejercen un efecto de 'estímulo o acicate' sobre otras autonomías y sobre la legislación estatal ${ }^{918}$.

Si bien a primera vista el reparto competencial en esta materia no parece plantear problemas excesivos, existe un alto grado de complejidad en relación con la delimitación de la materia, más aún cuando se relaciona con lo dispuesto en materia de aguas. La razón es que al tratar sobre los recursos hídricos se puede contemplar junto al precepto mencionado que asigna al Estado la legislación básica dejando en las Comunidades Autónomas las facultades de desarrollo legislativo, de ejecución o gestión y de aprobación de normas adicionales de protección, lo establecido en el apartado

\footnotetext{
${ }^{917}$ LOZANO CUTANDA, Blanca. Derecho Ambiental cit., p. 160. El Tribunal Constitucional ha declarado en este sentido, en relación al título competencial en materia de vertidos, que, con independencia de que las comunidades autónomas asuman competencias en la materia y de la amplitud con que lo hagan (por lo general, asumen expresamente la competencia únicamente en relación a los vertidos "vertidos industriales y contaminantes"), que da integrado en el título más amplio de protección del medio ambiente, de tal forma que "las comunidades autónomas que han asumido competencias para la ejecución de las normas sobre protección del medio ambiente son también competentes para llevar a cabo los actos de ejecución que impliquen la aplicación de las normas sobre vertidos, sea cual fuere el género de éstos y su destino" (Sentencia 149/1991, de 4 de julio). Disponible en: $<$ http://www.boe.es/diario_boe/txt.php?id=BOE-T-1991-19353>. Acceso en: 02-11-2015.

${ }^{918}$ LOZANO CUTANDA, Blanca. Derecho Ambiental cit., p. 161.
} 
analizado en la primera parte que atribuye al Estado las competencias sobre legislación, ordenación y concesión de recursos y aprovechamientos hidráulicos cuando las aguas discurran por más de un Comunidad Autónoma; así como lo establecido en los respectivos Estatutos de Autonomía ${ }^{919}$.

\subsection{Distribución territorial de competencias en materia de aguas (Estados, Comunidades Autónomas y Administraciones Locales)}

En el Título VIII ‘De la Organización Territorial del Estado’, Capítulo Primero 'Principios generales', el artículo $137^{920}$ de la Constitución Española organiza el Estado territorialmente en municipios, provincias y comunidades autónomas ${ }^{921}$, gozando todas

${ }^{919}$ CARO-PATÓN CARMONA, I. y MACERA, B. F. El reparto de competencias entre el Estado y las Comunidades Autónomas en materia de protección ambiental y aguas. Secretariado de Publicaciones e Intercambio Editorial, Universidad de Valladolid, Valladolid-España: 2002, pp. 18-19.

${ }^{920}$ Artículo 137. "El Estado se organiza territorialmente en municipios, en provincias y en las Comunidades Autónomas que se constituyan. Todas estas entidades gozan de autonomía para la gestión de sus respectivos intereses".

${ }^{921}$ Respecto a normas vigentes que disponen sobre aguas en las Comunidades Autónomas hay: Andalucía: Ley 9/2010, de 30 de julio, de Aguas de Andalucía; Aragón: Ley 10/2014, de 27 de noviembre, de Aguas y Ríos de Aragón, y Ley 2/1999, de 24 de febrero, de Pesca en Aragón; Principado de Asturias: Ley 1/1994, de 21 de febrero, sobre Abastecimiento y Saneamiento de Aguas en el Principado de Asturias, Ley 6/2002, de 18 de junio, sobre protección de los ecosistemas acuáticos y de regulación de la pesca en aguas continentales, y Ley 5/2002, de 3 de junio, sobre vertidos de aguas residuales industriales a los sistemas públicos de saneamiento; Baleares: Ley 9/1991, de 27 de noviembre, reguladora del canon de saneamiento de aguas, y Ley 6/2006, de 12 de abril, balear de caza y pesca fluvial; Canarias: Ley 12/1990, de 26 de julio, de Aguas; Cantabria: Ley 2/2002, de 29 de abril, de Saneamiento y Depuración de las Aguas Residuales de la Comunidad Autónoma de Cantabria, Ley 2/1988, de 26 de octubre, de fomento de ordenación y aprovechamiento de los balnearios y de las aguas mineromedicinales y/o termales de Cantabria, Ley 3/2007, de 4 de abril, de Pesca en Aguas Continentales, y Ley 2/2014, de 26 de noviembre, de Abastecimiento y Saneamiento de Aguas de la Comunidad Autónoma de Cantabria; Cataluña: Ley 22/2009, de 23 de diciembre, de ordenación sostenible de la pesca en aguas continentales, y Decreto Legislativo 3/2003, de 4 de noviembre, por el que se aprueba el Texto refundido de la legislación en materia de aguas de Cataluña; Castilla-La Mancha: Ley 8/1990, de 28 de diciembre, de Aguas Minerales y Termales de Castilla-La Mancha, Ley 1/1992, de 7 de mayo, de Pesca Fluvial, Ley 12/2002, de 27 de junio, Reguladora del Ciclo Integral del 
estas entidades de autonomía para la gestión de sus propios intereses.

En el marco del estado autonómico (artículo $2^{922} \mathrm{CE}$ ), basándose en el principio de autonomía anterior y en el de descentralización territorial, el Estado y las Comunidades Autónomas (CCAA) ostentan competencias de distinto rango sobre las diferentes materias. Las competencias a ejercer pueden ser legislativas (potestad de dictar leyes), reglamentarias (potestad de dictar reglamentos) y ejecutivas (cumplir y hacer cumplir las anteriores). La forma de repartirse estas competencias sobre cada una

Agua, Ley 6/2009, de 17 de diciembre, por la que se crea la Agencia del Agua de Castilla-La Mancha, y Ley 8/2011, de 21 de marzo, del Consejo del Agua de Castilla-La Mancha; Castilla y León: Ley 9/2013, de 3 de diciembre, de Pesca de Castilla y León; Extremadura: Ley 6/1994, de 24 de noviembre, de Balnearios y de Aguas Minero-Medicinales y/o Termales, y Ley 11/2010, de 16 de noviembre, de pesca y acuicultura de Extremadura; Galicia: Ley 9/2010, de 4 de noviembre, de aguas de Galicia, Ley 15/2008, de 19 de diciembre, del impuesto sobre el daño medioambiental causado por determinados usos y aprovechamientos del agua embalsada, Ley 5/1995, de 7 de junio, de regulación de las aguas minerales, termales, de manantial y de los establecimientos balnearios de la Comunidad Autónoma de Galicia, Ley 7/1992, de 24 de julio, de Pesca Fluvial, y Ley 5/2006, de 30 de junio, para la protección, la conservación y la mejora de los ríos gallegos; Madrid: Ley 17/1984, de 20 de diciembre de 1984, reguladora del abastecimiento y saneamiento de agua en la Comunidad de Madrid, Ley 10/1993, de 26 de octubre, sobre Vertidos Líquidos Industriales al Sistema Integral de Saneamiento, y Real Decreto 2528/1979, de 7 de septiembre, sobre el Plan integral de abastecimiento y saneamiento de la provincia de Madrid; Región de Murcia: Ley 3/2000, de 12 de julio, de Saneamiento y Depuración de Aguas Residuales de la Región de Murcia e Implantación del Canon de Saneamiento, Ley 3/2002, de 20 de mayo, de Tarifa del Canon de Saneamiento, Ley 6/2006, de 21 de julio, sobre incremento de las medidas de ahorro y conservación en el consumo de agua en la Comunidad Autónoma de la Región de Murcia, y Ley 7/1995, de 21 de abril, de la fauna silvestre, caza y pesca fluvial; Comunidad Foral de Navarra: Ley Foral 10/1988, de 29 de diciembre, de Saneamiento de las Aguas Residuales de Navarra, y Ley Foral 17/2005, de 22 de diciembre, de Caza y Pesca de Navarra; País Vasco: Ley 1/2006, de 23 de junio, de Aguas; La Rioja: Ley 5/2000, de 25 de octubre, de Saneamiento y Depuración de Aguas Residuales de La Rioja, y Ley 2/2006, de 28 de febrero, de Pesca de La Rioja; Comunidad Valenciana: Ley 2/1992, de 26 de marzo, del Gobierno Valenciano, de saneamiento de aguas residuales de la Comunidad Valenciana, y Ley 7/1986, de 22 de diciembre, sobre la utilización de aguas para riego. Todas disponibles en el Código de Aguas Normativa

Autonómica: $<$ http://boe.es/legislacion/codigos/codigo.php?id=139_Codigo_de_Aguas_Normativa_Autonomica\&mod $\mathrm{o}=1>$. Acceso en: 02-12-2015.

${ }^{922}$ Artículo 2. "La Constitución se fundamenta en la indisoluble unidad de la Nación española, patria común e indivisible de todos los españoles, y reconoce y garantiza el derecho a la autonomía de las nacionalidades y regiones que la integran y la solidaridad entre todas ellas". 
de las materias entre el Estado y las Comunidades Autónomas hace que se hable de: competencias exclusivas: cuando uno de los dos entes ostenta competencia plena sobre una materia; competencias compartidas: cuando cada uno de los entes se reparte las facultades $^{923}$; y, competencias concurrentes: cuando los dos entes ostentan las mismas facultades sobre la misma materia.

Así mismo, la Constitución Española establece en el artículo $148^{924}$ las

${ }^{923}$ José María Muñoz Jiménez, Manual del texto refundido de la Ley de Aguas. Autor Editor, 2001, ejemplifica diciendo que el Estado dicta la legislación básica sobre una materia y la Comunidad Autónoma desarrolla la ley y la ejecuta.

${ }^{924}$ Artículo 148.

“1. Las Comunidades Autónomas podrán asumir competencias en las siguientes materias:

1. ${ }^{\text {a }}$ Organización de sus instituciones de autogobierno.

2. ${ }^{\text {a }}$ Las alteraciones de los términos municipales comprendidos en su territorio y, en general, las funciones que correspondan a la Administración del Estado sobre las Corporaciones locales y cuya transferencia autorice la legislación sobre Régimen Local.

3 a $^{\text {a }}$ Ordenación del territorio, urbanismo y vivienda.

4. ${ }^{\mathrm{a}}$ Las obras públicas de interés de la Comunidad Autónoma en su propio territorio.

5. ${ }^{\text {a }}$ Los ferrocarriles y carreteras cuyo itinerario se desarrolle íntegramente en el territorio de la Comunidad Autónoma y, en los mismos términos, el transporte desarrollado por estos medios o por cable.

6. ${ }^{\mathrm{a}}$ Los puertos de refugio, los puertos y aeropuertos deportivos y, en general, los que no desarrollen actividades comerciales.

7. ${ }^{\text {a }}$ La agricultura y ganadería, de acuerdo con la ordenación general de la economía.

8. ${ }^{\mathrm{a}}$ Los montes y aprovechamientos forestales.

9. ${ }^{a}$ La gestión en materia de protección del medio ambiente.

10. ${ }^{\mathrm{a}}$ Los proyectos, construcción y explotación de los aprovechamientos hidráulicos, canales y regadíos de interés de la Comunidad Autónoma; las aguas minerales y termales.

11. ${ }^{\text {a }}$ La pesca en aguas interiores, el marisqueo y la acuicultura, la caza y la pesca fluvial.

$12 .^{\text {a }}$ Ferias interiores.

13. ${ }^{\text {a }}$ El fomento del desarrollo económico de la Comunidad Autónoma dentro de los objetivos marcados por la política económica nacional.

14. . La artesanía.

15. ${ }^{\mathrm{a}}$ Museos, bibliotecas y conservatorios de música de interés para la Comunidad Autónoma.

16. ${ }^{a}$ Patrimonio monumental de interés de la Comunidad Autónoma.

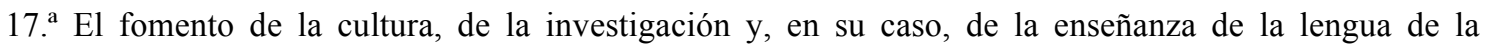
Comunidad Autónoma.

18. Promoción y ordenación del turismo en su ámbito territorial.

19. ${ }^{\text {a }}$ Promoción del deporte y de la adecuada utilización del ocio.

20. ${ }^{\mathrm{a}}$ Asistencia social. 
materias cuya competencia pueden asumir las Comunidades Autónomas en sus Estatutos y en el artículo $149^{925}$ las que son competencia del Estado. Establece

21. ${ }^{\mathrm{a}}$ Sanidad e higiene.

22. ${ }^{\text {a }}$ La vigilancia y protección de sus edificios e instalaciones. La coordinación y demás facultades en relación con las policías locales en los términos que establezca una ley orgánica.

2. Transcurridos cinco años, y mediante la reforma de sus Estatutos, las Comunidades Autónomas podrán ampliar sucesivamente sus competencias dentro del marco establecido en el artículo 149".

${ }^{925}$ Artículo 149.

"1. El Estado tiene competencia exclusiva sobre las siguientes materias:

1. ${ }^{\mathrm{a}}$ La regulación de las condiciones básicas que garanticen la igualdad de todos los españoles en el ejercicio de los derechos y en el cumplimiento de los deberes constitucionales.

2. ${ }^{a}$ Nacionalidad, inmigración, emigración, extranjería y derecho de asilo.

3. ${ }^{\mathrm{a}}$ Relaciones internacionales.

4. ${ }^{\mathrm{a}}$ Defensa y Fuerzas Armadas.

5. ${ }^{\text {a }}$ Administración de Justicia.

6. ${ }^{a}$ Legislación mercantil, penal y penitenciaria; legislación procesal, sin perjuicio de las necesarias especialidades que en este orden se deriven de las particularidades del derecho sustantivo de las Comunidades Autónomas.

7. a Legislación laboral; sin perjuicio de su ejecución por los órganos de las Comunidades Autónomas.

8. a Legislación civil, sin perjuicio de la conservación, modificación y desarrollo por las Comunidades Autónomas de los derechos civiles, forales o especiales, allí donde existan. En todo caso, las reglas relativas a la aplicación y eficacia de las normas jurídicas, relaciones jurídico-civiles relativas a las formas de matrimonio, ordenación de los registros e instrumentos públicos, bases de las obligaciones contractuales, normas para resolver los conflictos de leyes y determinación de las fuentes del Derecho, con respeto, en este último caso, a las normas de derecho foral o especial.

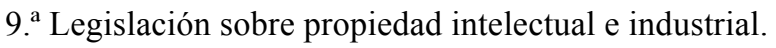

10. ${ }^{a}$ Régimen aduanero y arancelario; comercio exterior.

11. ${ }^{\text {a }}$ Sistema monetario: divisas, cambio y convertibilidad; bases de la ordenación de crédito, banca y seguros.

12. ${ }^{a}$ Legislación sobre pesas y medidas, determinación de la hora oficial.

13. ${ }^{a}$ Bases y coordinación de la planificación general de la actividad económica.

14. ${ }^{\text {a }}$ Hacienda general y Deuda del Estado.

15. ${ }^{\text {a }}$ Fomento y coordinación general de la investigación científica y técnica.

16. ${ }^{\text {a }}$ Sanidad exterior. Bases y coordinación general de la sanidad. Legislación sobre productos farmacéuticos.

17. ${ }^{\text {a }}$ Legislación básica y régimen económico de la Seguridad Social, sin perjuicio de la ejecución de sus servicios por las Comunidades Autónomas.

18. ${ }^{a}$ Las bases del régimen jurídico de las Administraciones públicas y del régimen estatutario de sus 
funcionarios que, en todo caso, garantizarán a los administrados un tratamiento común ante ellas; el procedimiento administrativo común, sin perjuicio de las especialidades derivadas de la organización propia de las Comunidades Autónomas; legislación sobre expropiación forzosa; legislación básica sobre contratos y concesiones administrativas y el sistema de responsabilidad de todas las Administraciones públicas.

19. ${ }^{a}$ Pesca marítima, sin perjuicio de las competencias que en la ordenación del sector se atribuyan a las Comunidades Autónomas.

20. ${ }^{\mathrm{a}}$ Marina mercante y abanderamiento de buques; iluminación de costas y señales marítimas; puertos de interés general; aeropuertos de interés general; control del espacio aéreo, tránsito y transporte aéreo, servicio meteorológico y matriculación de aeronaves.

21. ${ }^{a}$ Ferrocarriles y transportes terrestres que transcurran por el territorio de más de una Comunidad Autónoma; régimen general de comunicaciones; tráfico y circulación de vehículos a motor; correos y telecomunicaciones; cables aéreos, submarinos y radiocomunicación.

22. ${ }^{a}$ La legislación, ordenación y concesión de recursos y aprovechamientos hidráulicos cuando las aguas discurran por más de una Comunidad Autónoma, y la autorización de las instalaciones eléctricas cuando su aprovechamiento afecte a otra Comunidad o el transporte de energía salga de su ámbito territorial.

23. ${ }^{a}$ Legislación básica sobre protección del medio ambiente, sin perjuicio de las facultades de las Comunidades Autónomas de establecer normas adicionales de protección. La legislación básica sobre montes, aprovechamientos forestales y vías pecuarias.

24. ${ }^{a}$ Obras públicas de interés general o cuya realización afecte a más de una Comunidad Autónoma.

$25 .^{a}$ Bases de régimen minero y energético.

26. ${ }^{a}$ Régimen de producción, comercio, tenencia y uso de armas y explosivos.

27. ${ }^{a}$ Normas básicas del régimen de prensa, radio y televisión y, en general, de todos los medios de comunicación social, sin perjuicio de las facultades que en su desarrollo y ejecución correspondan a las Comunidades Autónomas.

28. ${ }^{a}$ Defensa del patrimonio cultural, artístico y monumental español contra la exportación y la expoliación; museos, bibliotecas y archivos de titularidad estatal, sin perjuicio de su gestión por parte de las Comunidades Autónomas.

29. ${ }^{a}$ Seguridad pública, sin perjuicio de la posibilidad de creación de policías por las Comunidades Autónomas en la forma que se establezca en los respectivos Estatutos en el marco de lo que disponga una ley orgánica.

30. ${ }^{a}$ Regulación de las condiciones de obtención, expedición y homologación de títulos académicos y profesionales y normas básicas para el desarrollo del artículo 27 de la Constitución, a fin de garantizar el cumplimiento de las obligaciones de los poderes públicos en esta materia.

31. Estadística para fines estatales.

32. a Autorización para la convocatoria de consultas populares por vía de referéndum.

2. Sin perjuicio de las competencias que podrán asumir las Comunidades Autónomas, el Estado considerará el servicio de la cultura como deber y atribución esencial y facilitará la comunicación cultural entre las Comunidades Autónomas, de acuerdo con ellas. 
diferentes grados de competencia y, en el artículo $150^{926}$, la posibilidad de transferir competencias estatales mediante leyes marco y leyes de transferencia.

Pues bien, la gestión del agua afecta a numerosas materias de las recogidas en la Constitución, como pueden ser medio ambiente, pesca, agricultura, energía, sanidad, deporte y ocio, protección civil, etc., sobre la que cada una de las entidades territoriales tiene algún grado de competencia.

\subsubsection{Principios generales de la Administración Pública del Agua}

- Unidad de gestión, tratamiento integral, economía del agua, desconcentración, descentralización, coordinación, eficacia y participación de los usuarios;

- Respeto a la unidad de la cuenca hidrográfica, de los sistemas hidráulicos y del ciclo hidrológico; y,

- Compatibilidad de la gestión pública del agua con la ordenación del

3. Las materias no atribuidas expresamente al Estado por esta Constitución podrán corresponder a las Comunidades Autónomas, en virtud de sus respectivos Estatutos. La competencia sobre las materias que no se hayan asumido por los Estatutos de Autonomía corresponderá al Estado, cuyas normas prevalecerán, en caso de conflicto, sobre las de las Comunidades Autónomas en todo lo que no esté atribuido a la exclusiva competencia de éstas. El derecho estatal será, en todo caso, supletorio del derecho de las Comunidades Autónomas".

${ }^{926}$ Artículo 150 .

“1. Las Cortes Generales, en materias de competencia estatal, podrán atribuir a todas o a alguna de las Comunidades Autónomas la facultad de dictar, para sí mismas, normas legislativas en el marco de los principios, bases y directrices fijados por una ley estatal. Sin perjuicio de la competencia de los Tribunales, en cada ley marco se establecerá la modalidad del control de las Cortes Generales sobre estas normas legislativas de las Comunidades Autónomas.

2. El Estado podrá transferir o delegar en las Comunidades Autónomas, mediante ley orgánica, facultades correspondientes a materia de titularidad estatal que por su propia naturaleza sean susceptibles de transferencia o delegación. La ley preverá en cada caso la correspondiente transferencia de medios financieros, así como las formas de control que se reserve el Estado.

3. El Estado podrá dictar leyes que establezcan los principios necesarios para armonizar las disposiciones normativas de las Comunidades Autónomas, aun en el caso de materias atribuidas a la competencia de éstas, cuando así lo exija el interés general. Corresponde a las Cortes Generales, por mayoría absoluta de cada Cámara, la apreciación de esta necesidad”. 
territorio, la conservación y protección del medio ambiente y la restauración de la naturaleza.

La Demarcación Hidrográfica, como principal unidad a efectos de la gestión de cuencas, constituye el ámbito espacial al que se aplican las normas de protección de las aguas contempladas en la Ley de Aguas. La cuenca hidrográfica es indivisible como unidad de gestión.

Se distinguen dos tipos de cuencas hidrográficas a efectos de distribución de competencias $^{927}$ :

- Cuencas Intercomunitarias: su territorio se extiende por más de una Comunidad Autónoma.

- Cuencas Intracomunitarias: su territorio está comprendido íntegramente dentro del territorio de una Comunidad Autónoma.

\subsubsection{Funciones del Estado en relación con el Dominio Público Hidráulico}

- La planificación hidrológica y la realización de los planes estatales de infraestructuras hidráulicas o cualquier otro estatal que forme parte de aquéllas;

- La adopción de las medidas precisas para el cumplimiento de los acuerdos y convenios internacionales en materia de aguas;

- El otorgamiento de concesiones referentes al dominio público hidráulico en las cuencas hidrográficas intercomunitarias; $\mathrm{y}$,

- El otorgamiento de autorizaciones referentes al dominio público hidráulico, así como la tutela de éste, en las cuencas hidrográficas intercomunitarias. No obstante, la tramitación de las mismas podrá ser encomendada a las Comunidades Autónomas.

\subsubsection{Régimen jurídico básico aplicable a las Comunidades Autónomas}

La Comunidad Autónoma que en virtud de sus Estatutos de Autonomía ejerza

927 Disponible en el sitio de Hispagua Sistema Español de información sobre el agua: < http://hispagua.cedex.es/instituciones/distribucion\#5>. Acceso en: 27-10-2015. 
competencias sobre el dominio público hidráulico en cuencas hidrográficas comprendidas íntegramente dentro de su territorio, deberá ajustar el régimen jurídico de su administración hidráulico a las siguientes bases:

- A los principios recogidos anteriormente

- La representación de los usuarios en los órganos colegiados de la Administración hidráulica no será inferior al tercio de los miembros que los integren

Los actos y acuerdos que infrinjan la legislación hidráulica del Estado o no se ajusten a la planificación hidrológica y afecten a su competencia en materia hidráulica pueden ser impugnados ante jurisdicción contencioso-administrativa.

\subsubsection{Marco competencial en materia de aguas}

En el medio hídrico existen diversidad de elementos de distinta naturaleza: gea, flora o fauna, cuyos regímenes jurídicos son distintos y sus correspondientes competencias están distribuidas, de forma exclusiva o compartida, entre el Estado y las Comunidades Autónomas, de acuerdo con lo establecido en la Constitución y en los respectivos Estatutos de Autonomía.

La Constitución Española establece el siguiente marco competencial, en el que se incluyen otros aspectos relacionados con la gestión del agua:

- Son competencias exclusivas del Estado en materia de aguas, las siguientes:

Artículo 149.1.22 de la Constitución: legislación, ordenación y concesión de recursos y aprovechamientos hidráulicos cuando las aguas discurran por más de una Comunidad Autónoma (cuencas intercomunitarias) y la autorización de las instalaciones eléctricas cuando su aprovechamiento afecte a otra Comunidad o el transporte de energía salga de su ámbito territorial.

Artículo 149.1.24 de la Constitución: Obras públicas de interés general o cuya realización afecte a más de una Comunidad Autónoma.

Artículo 149.1.23 de la Constitución: legislación básica sobre protección del medio ambiente, sin perjuicio de las facultades de las Comunidades Autónomas de establecer normas adicionales de protección. 
- $\quad$ Y son competencias que las Comunidades Autónomas pueden asumir:

- Artículo 148.1.10 de la Constitución: los proyectos, construcción y explotación de los aprovechamientos hidráulicos, canales y regadíos de interés de la Comunidad Autónoma; las aguas minerales y termales.

- $\quad$ Artículo 148.1.11 de la Constitución: la pesca en aguas interiores, el marisqueo y la acuicultura, la caza y la pesca fluvial.

- $\quad$ Artículo 148.1.9 de la Constitución: la gestión en materia de protección del medio ambiente.

Todas las comunidades autónomas han asumido la competencia exclusiva en materia de ordenación y concesión de recursos y aprovechamientos hidráulicos cuando las aguas discurran íntegramente por el ámbito territorial de la comunidad autónoma.

Excepto Ceuta y Melilla, que han asumido únicamente funciones ejecutivas sobre proyectos, construcción y aprovechamientos hidráulicos.

Así, de la propia Constitución parte un tratamiento diferente de la competencia estatal y autonómica, pues en tanto el criterio de asunción de la competencia autonómica relativa a los aprovechamientos, canales y regadíos es el del interés (art. 1481.10), la competencia estatal se rige por el criterio territorial (cuando las aguas discurran por más de una Comunidad Autónoma).

En la franja intermedia que puede hallarse entre ambos preceptos ha sido posible que las Comunidades Autónomas asuman estatutariamente competencias más allá de lo previsto en el art. 148.1.10, pero siempre con la limitación territorial que deriva de lo previsto en el art. 149.1.22.

En el marco de estos preceptos constitucionales, los Estatutos de Autonomía han recogido la competencia en materia de aguas del siguiente modo:

- Aprovechamientos hidráulicos, canales y regadíos (Libro Blanco del Agua, $2000^{928}$ ). Las Comunidades Autónomas que accedieron a la autonomía a través

${ }^{928}$ El presente documento Libro Blanco del Agua en España ha sido redactado, bajo la dirección de la Secretaría de Estado de Aguas y Costas del Ministerio de Medio Ambiente, por la Dirección General de Obras Hidráulicas y Calidad de las Aguas, con la colaboración, asistencia y soporte técnico del Centro de Estudios Hidrográficos del CEDEX (CEH-CEDEX). El libro blanco fue redactado por el Ministerio de Medio Ambiente (MIMAM) en el año 2000 con el objetivo de conseguir un mejor conocimiento de los problemas del agua en España, y una vez descrita la situación en ese momento, estimar la evolución previsible y el establecimiento de opciones y prioridades en el uso del agua y servir de apoyo a la redacción de los planes hidrológicos de cuenca. Texto complete disponible en: < 
del artículo $151^{929}$ de la Constitución asumieron en sus Estatutos la competencia exclusiva en materia de aprovechamientos hidráulicos, canales y regadíos cuando las aguas discurran íntegramente dentro del territorio de la Comunidad Autónoma. Las Comunidades Autónomas que accedieron a la autonomía por la vía del artículo $143^{930}$

http://www.magrama.gob.es/es/agua/temas/planificacion-hidrologica/libro-blanco-del-agua/>. Acceso en: 27-10-2015.

${ }^{929}$ Artículo 151.

"1. No será preciso dejar transcurrir el plazo de cinco años, a que se refiere el apartado 2 del artículo 148, cuando la iniciativa del proceso autonómico sea acordada dentro del plazo del artículo 143.2, además de por las Diputaciones o los órganos interinsulares correspondientes, por las tres cuartas partes de los municipios de cada una de las provincias afectadas que representen, al menos, la mayoría del censo electoral de cada una de ellas y dicha iniciativa sea ratificada mediante referéndum por el voto afirmativo de la mayoría absoluta de los electores de cada provincia en los términos que establezca una ley orgánica.

2. En el supuesto previsto en el apartado anterior, el procedimiento para la elaboración del Estatuto será el siguiente:

1. ${ }^{\circ}$ El Gobierno convocará a todos los Diputados y Senadores elegidos en las circunscripciones comprendidas en el ámbito territorial que pretenda acceder al autogobierno, para que se constituyan en Asamblea, a los solos efectos de elaborar el correspondiente proyecto de Estatuto de autonomía, mediante el acuerdo de la mayoría absoluta de sus miembros.

2. ${ }^{\circ}$ Aprobado el proyecto de Estatuto por la Asamblea de Parlamentarios, se remitirá a la Comisión Constitucional del Congreso, la cual, dentro del plazo de dos meses, lo examinará con el concurso y asistencia de una delegación de la Asamblea proponente para determinar de común acuerdo su formulación definitiva.

$3 .^{\circ}$ Si se alcanzare dicho acuerdo, el texto resultante será sometido a referéndum del cuerpo electoral de las provincias comprendidas en el ámbito territorial del proyectado Estatuto.

4. ${ }^{\circ} \mathrm{Si}$ el proyecto de Estatuto es aprobado en cada provincia por la mayoría de los votos válidamente emitidos, será elevado a las Cortes Generales. Los plenos de ambas Cámaras decidirán sobre el texto mediante un voto de ratificación. Aprobado el Estatuto, el Rey lo sancionará y lo promulgará como ley.

$5 .^{\circ}$ De no alcanzarse el acuerdo a que se refiere el apartado 2 de este número, el proyecto de Estatuto será tramitado como proyecto de ley ante las Cortes Generales. El texto aprobado por éstas será sometido a referéndum del cuerpo electoral de las provincias comprendidas en el ámbito territorial del proyectado Estatuto. En caso de ser aprobado por la mayoría de los votos válidamente emitidos en cada provincia, procederá su promulgación en los términos del párrafo anterior.

3. En los casos de los párrafos $4 .^{\circ}$ y $5 .^{\circ}$ del apartado anterior, la no aprobación del proyecto de Estatuto por una o varias provincias no impedirá la constitución entre las restantes de la Comunidad Autónoma proyectada, en la forma que establezca la ley orgánica prevista en el apartado 1 de este artículo".

${ }^{930}$ Artículo 143 .

“1. En el ejercicio del derecho a la autonomía reconocido en el artículo 2 de la Constitución, las 
de la Constitución, limitadas originalmente por el artículo $148.1 .10^{\mathrm{a}}$, asumieron la competencia en materia de proyectos, construcción y explotación de los aprovechamientos hidráulicos, canales y regadíos de interés de la Comunidad Autónoma, si bien todos los Estatutos añadieron una cláusula de territorialidad: cuando las aguas discurran íntegramente dentro del territorio de la Comunidad Autónoma. Posteriormente, la Ley Orgánica 9/1992, de 23 de diciembre ${ }^{931}$, de transferencia de competencias a las Comunidades Autónomas que accedieron a la autonomía por vía del artículo 143 de la Constitución, transfirió a las Comunidades Autónomas de Asturias, Cantabria, La Rioja, Región de Murcia, Aragón, Castilla - La Mancha, Extremadura, Islas Baleares, Madrid y Castilla y León la competencia exclusiva en materia de ordenación y concesión de recursos y aprovechamientos hidráulicos cuando las aguas discurran íntegramente por el ámbito territorial de la Comunidad Autónoma, competencia recogida posteriormente en las reformas de todos los Estatutos de Autonomía de las Comunidades afectadas. Las ciudades de Ceuta y Melilla han asumido únicamente funciones ejecutivas sobre proyectos, construcción y explotación de aprovechamientos hidráulicos ${ }^{932}$.

- $\quad$ Aguas minerales, termales y subterráneas (Libro Blanco del Agua, 2000) Actualmente todas las Comunidades Autónomas tienen competencia exclusiva sobre las aguas minerales y termales. Sobre aguas subterráneas han asumido competencia exclusiva las siguientes Comunidades Autónomas: País Vasco, Cataluña, Galicia, Andalucía, Comunidad Valenciana, Navarra, Murcia, Aragón, Castilla - La Mancha y

provincias limítrofes con características históricas, culturales y económicas comunes, los territorios insulares y las provincias con entidad regional histórica podrán acceder a su autogobierno y constituirse en Comunidades Autónomas con arreglo a lo previsto en este Título y en los respectivos Estatutos.

2. La iniciativa del proceso autonómico corresponde a todas las Diputaciones interesadas o al órgano interinsular correspondiente y a las dos terceras partes de los municipios cuya población represente, al menos, la mayoría del censo electoral de cada provincia o isla. Estos requisitos deberán ser cumplidos en el plazo de seis meses desde el primer acuerdo adoptado al respecto por alguna de las Corporaciones locales interesadas.

3. La iniciativa, en caso de no prosperar, solamente podrá reiterarse pasados cinco años".

${ }^{931}$ Disponible en: < http://www.boe.es/diario_boe/txt.php?id=BOE-A-1992-28426>. Acceso en: 27-102015.

932 Disponible en el sitio de Hispagua Sistema Español de información sobre el agua: $<$ http://hispagua.cedex.es/instituciones/distribucion\#5>. Acceso en: 27-10-2015. 
Madrid. No obstante, en todos los textos de reforma de los Estatutos pendientes de aprobación en el Congreso, excepto el de Baleares (es decir, los de Asturias, Cantabria, La Rioja, Extremadura y Castilla y León), también se recoge dicha competencia. Los Estatutos de Andalucía, Murcia, Castilla - La Mancha y Madrid, así como los textos pendientes de aprobación en el Congreso de los Estatutos de Cantabria y Extremadura, recogen una cláusula de territorialidad en relación con las aguas subterráneas cuando discurran íntegramente por el ámbito territorial de la Comunidad Autónoma. El Estatuto de Canarias se refiere a las aguas, en todas sus manifestaciones, incluyendo este concepto, tanto las aguas minerales y termales como las subterráneas. Por otra parte, cabe señalar que los artículos 137 y $140^{933}$ de la Constitución Española recogen la garantía constitucional de la autonomía local, lo que, aún sin referencia específica al agua, alude al necesario respeto otorgado constitucionalmente al núcleo de intereses propios locales, dentro de los que se incluyen algunos aspectos relacionados con este recurso $^{934}$.

Esta distribución constitucional de competencias se clarifica en la Sentencia del Tribunal Constitucional, Pleno, 227/1988, de 29 de noviembre ${ }^{935}$, por la que se resolvieron diversos recursos de inconstitucionalidad y conflictos positivos de competencias interpuestos por varias Comunidades Autónomas frente a lo establecido en la Ley 29/1985, de Aguas ${ }^{936}$, de 2 de agosto.

\footnotetext{
933 Artículo 140. "La Constitución garantiza la autonomía de los municipios. Estos gozarán de personalidad jurídica plena. Su gobierno y administración corresponde a sus respectivos Ayuntamientos, integrados por los Alcaldes y los Concejales. Los Concejales serán elegidos por los vecinos del municipio mediante sufragio universal, igual, libre, directo y secreto, en la forma establecida por la ley. Los Alcaldes serán elegidos por los Concejales o por los vecinos. La ley regulará las condiciones en las que proceda el régimen del concejo abierto".

934 Disponible en el sitio de Hispagua Sistema Español de información sobre el agua: $<$ http://hispagua.cedex.es/instituciones/distribucion\#5>. Acceso en: 27-10-2015.

${ }^{935}$ Disponible en: < http://www.boe.es/diario_boe/txt.php?id=BOE-T-1988-29199>. Acceso en: 27-102015.

${ }^{936}$ Disponible en: < http://www.boe.es/diario_boe/txt.php?id=BOE-A-1985-16661>. Acceso en: 27-102015.
} 


\subsubsection{La distribución de otras competencias}

La descripción de los criterios específicos que rigen la distribución competencial en materia de aguas -en los que, como ya ha quedado expuesto, resulta decisivo el concepto de cuenca hidrográfica-, resultaría incompleto sin reseñar que, al propio tiempo, las aguas constituyen también el soporte físico de una pluralidad de actividades en las que tanto el Estado como las Comunidades Autónomas poseen competencias sectoriales.

La concurrencia en el mismo espacio físico de competencias de distintas Administraciones Públicas con distinto objeto jurídico es un fenómeno habitual en distintos ámbitos y se refleja también en la STC 227/1988, que en su FJ 14 afirma que [...] las normas que distribuyen competencias entre el Estado y las Comunidades Autónomas sobre bienes de dominio público no prejuzgan necesariamente que la titularidad de los mismos corresponda a éste o a aquéllas, y que son, en principio, separables la propiedad pública de un bien y el ejercicio de competencias públicas que lo utilizan como soporte natural.

En este marco, se resume a continuación el sistema de distribución de competencias en aquellas materias que presentan una incidencia más clara en el sistema de gestión de las aguas continentales.

Distribución de competencias que establece la Constitución Española en las materias más significativas relacionadas con el Dominio Público Hidráulico ${ }^{937}$ (cuadro 9).

\footnotetext{
937 Disponible en el sitio de Hispagua Sistema Español de información sobre el agua: $<$ http://hispagua.cedex.es/instituciones/distribucion\#5>. Acceso en: 27-10-2015.
} 


\section{Cuadro 9:}

\begin{tabular}{|c|c|c|}
\hline Materia & Art. CE & Administración \\
\hline Pesca Fluvial y Acuicultura & 148.1 .11 & Comunidad Autónoma \\
\hline Agricultura y ganadería & 148.1 .7 & Comunidad Autónoma \\
\hline $\begin{array}{l}\text { Puertos no comerciales en aguas } \\
\text { interiores }\end{array}$ & 148.1 .6 & Comunidad Autónoma \\
\hline Aguas minerales y termales & 148.1.10 & Comunidad Autónoma \\
\hline Medio Ambiente & $\begin{array}{l}148.1 .9 \\
149.1 .23\end{array}$ & $\begin{array}{c}\text { Comunidad Autónoma. Gestión y protección Estado.-Legislación } \\
\text { Básica }\end{array}$ \\
\hline Deporte y Ocio & 148.1 .19 & Comunidad Autónoma \\
\hline Turismo & 148.1 .18 & Comunidad Autónoma \\
\hline $\begin{array}{l}\text { Aprovechamientos hidráulicos, } \\
\text { canales y regadíos }\end{array}$ & $\begin{array}{l}148.1 .10 \\
149.1 .22\end{array}$ & $\begin{array}{c}\text { Comunidad Autónoma } \\
\text { Estado, cuando el agua discurra por más de una CA, o el } \\
\text { transporte de energía salga de la CA }\end{array}$ \\
\hline Montes & $\begin{array}{l}148.1 .8 \\
149.1 .23\end{array}$ & $\begin{array}{l}\text { Comunidad Autónoma } \\
\text { Estado.-Legislación Básica }\end{array}$ \\
\hline Sanidad & $\begin{array}{l}148.1 .21 \\
149.1 .16\end{array}$ & $\begin{array}{c}\text { Comunidad Autónoma } \\
\text { Estado.-Legislación Básica y sanidad exterior }\end{array}$ \\
\hline Minas y energía & 149.1 .25 & $\begin{array}{l}\text { Comunidad Autónoma } \\
\text { Estado.-Legislación Básica }\end{array}$ \\
\hline Obras públicas & 148.1 .4 & $\begin{array}{l}\text { Comunidad Autónoma } \\
\text { Estado.-De interés general o afecten a más de una CA }\end{array}$ \\
\hline
\end{tabular}

El Texto Refundido de la Ley de Aguas $^{938}$, aprobado por el Real decreto Legislativo, 1/2001, de 20 de julio establece funciones dentro del marco competencial definido en la Constitución Española: agricultura, deporte y ocio, energía, medio ambiente y vertidos, obras hidráulicas, pesca fluvial, protección civil y sanidad.

\subsubsection{Competencias asumidas en los Estatutos de Autonomía}

A continuación se presenta un listado en el que se indica dónde se recogen estas competencias en los Estatutos de Autonomía (Cuadro 10) ${ }^{939}$ :

\footnotetext{
${ }^{938}$ Disponible en: < http://www.boe.es/diario_boe/txt.php?id=BOE-A-2001-14276>. Acceso en: 27-102015.

939 Disponible en el sitio de Hispagua Sistema Español de información sobre el agua: $<\mathrm{http}$ :/hispagua.cedex.es/instituciones/distribucion\#5>. Acceso en: 27-10-2015.
} 
- C.A. de Andalucía LO 2/2007, de 19 de marzo, de reforma del Estatuto de Autonomía para Andalucía.(arts. 50 y 51)

- C.A. de Aragón (LO 5/2007, de 20 de abril, de reforma del Estatuto de Autonomía de Aragón. (art. 72)

- Ppdo. Asturias (LO 7/81 de 30 de diciembre, Estatuto de Autonomía, art. 10)

- C.A. Illes Balears LO 1/2007, de 1 de marzo, por la cual se aprueba el Estatuto de Autonomía de las Islas Baleares (art. 30, 32,71

- C.A. Canarias LO 10/82, de 10 de agosto, Estatuto de Autonomía, Art. 30

- C.A. de Cantabria (LO 8/81, de 30 de diciembre, Estatuto de Autonomía, Art. 24)

- C. Castilla y León LO 14/2007, de 30 de noviembre, de Reforma de Estatuto de Autonomía de Castilla y León

- C.A. Castilla-La Mancha (LO 9/82, de 10 de agosto, Estatuto de Autonomía de Castilla La Mancha, Art. 31)

- C.A. Cataluña Ley Orgánica 6/2006, de 19 de julio, de reforma del Estatuto de Autonomía de Cataluña. (Art.117)

- C.A. Extremadura LO 1/2001, de 28 de enero, de reforma del Estatuto de Autonomía de Extremadura

- C.A. Madrid (LO 3/83, de 25 de febrero, Estatuto de Autonomía de la Comunidad de Madrid, Art. 26)

- C.A. Reg. de Murcia (LO 4/82, de 9 de junio, Estatuto de Autonomía de la Región d, Art. 10)

- C. Foral de Navarra (Ley Orgánica 13/82, de 10 de agosto, de reintegración y amejoramiento del Régimen Foral de Navarra, Art. 44)

- C. A. País Vasco (LO 3/79, de 18 de diciembre, Estatuto de Autonomía, Art. 10)

- C.A. La Rioja (LO 3/82, de 9 de junio, Estatuto de Autonomía, Art. 8)

- C. Valenciana LO 1/2006, de 10 de abril, de reforma de la Ley Orgánica 5/82, de 1 de julio, de Estatuto de Autonomía de la Comunidad Valenciana (art.55)

- Ciudad de Ceuta (Ley Orgánica 1/1995, de 13 de marzo, de Estatuto de Autonomía, Art. 21)

- Ciudad de Melilla (Ley Orgánica 2/1995, de 13 de marzo, de Estatuto de Autonomía, Art. 21)

\subsubsection{Concurrencia de competencias}

En los casos en que sobre un mismo acto concurren competencias de distintas administraciones la regla general, dejando a salvo los supuestos de informe previo, es 
que se precisan las autorizaciones de todas y cada una de las administraciones competentes, sin que el disponer de una de ellas exima de disponer de las demás. A continuación se muestra el cuadro $11^{940}$ con las competencias y Administraciones que más frecuentemente concurren en el Dominio Público Hidráulico

\begin{tabular}{|c|c|c|c|}
\hline Administración & Norma & Organismo & Materia \\
\hline Estado & $\begin{array}{l}\text { Art. } 149 \text { CE } \\
\text { TRLA* }\end{array}$ & Confederación & Dominio Público Hidráulico \\
\hline $\begin{array}{l}\text { Comunidad } \\
\text { Autónoma }\end{array}$ & $\begin{array}{lr}\text { Art. } & 148 \\
\text { Constitución }\end{array}$ & Consejería & $\begin{array}{l}\text { Proyectos, construcción y explotación de los aprovechamientos } \\
\text { hidráulicos, canales y regadíos de interés para la Comunidad } \\
\text { Autónoma. } \\
\text { Sanidad } \\
\text { Minas } \\
\text { Medio ambiente } \\
\text { Caza } \\
\text { Pesca } \\
\text { Montes } \\
\text { Urbanismo } \\
\text { A. minerales y termales } \\
\text { Deporte, ocio y turismo } \\
\text { Agricultura y ganadería }\end{array}$ \\
\hline Ayuntamientos & LBRL** & Concejalía & $\begin{array}{c}\text { Urbanismo } \\
\text { Abastecimiento } \\
\text { Saneamiento } \\
\text { Recogida de residuos }\end{array}$ \\
\hline
\end{tabular}

5.6. El sistema normativo y administrativo de protección, acceso y gestión del agua en España: Texto Refundido de la Ley de Aguas de 2001 y sus normas de desarrollo. Administración Hidráulica. Uso del agua por los particulares

La base para la construcción de un derecho al agua surgió el 10 de diciembre de 1948 en la afirmación del artículo 25.1 de la Declaración de Derechos Humanos: "Toda persona tiene derecho a un nivel de vida adecuado que le asegure, así como a su familia, la salud y el bienestar, y en especial la alimentación, el vestido, la vivienda, la asistencia médica y los servicios sociales necesarios", la misma fue recogida en los mismos términos en el artículo 11 del Pacto internacional de Derecho Económicos, Sociales y Culturales de 1966.

940 Disponible en el sitio de Hispagua Sistema Español de información sobre el agua: $<\mathrm{http} / /$ hispagua.cedex.es/instituciones/distribucion\#5>. Acceso en: 27-10-2015. En la tabla: *Texto Refundido de la Ley de Aguas y ** Ley Reguladora de Bases del Régimen Local. 
El Pacto no menciona directamente el derecho al agua, sin embargo, su intérprete más autorizado lo consideró implícitamente en la referencia a la alimentación en el citado artículo $11^{941}$ y lo relacionó a los derechos a la protección de la salud y a la vivienda. Lo define como "el derecho de todos a disponer de agua suficiente, salubre, aceptable, accesible y asequible para el uso personal y doméstico"942. La Asamblea

${ }^{941}$ Artículo 11.

“1. Los Estados Partes en el presente Pacto reconocen el derecho de toda persona a un nivel de vida adecuado para sí y su familia, incluso alimentación, vestido y vivienda adecuados, y a una mejora continua de las condiciones de existencia. Los Estados Partes tomarán medidas apropiadas para asegurar la efectividad de este derecho, reconociendo a este efecto la importancia esencial de la cooperación internacional fundada en el libre consentimiento.

2. Los Estados Partes en el presente Pacto, reconociendo el derecho fundamental de toda persona a estar protegida contra el hambre, adoptarán, individualmente y mediante la cooperación internacional, las medidas, incluidos los programas concretos, que se necesitan para:

a) Mejorar los métodos de producción, conservación y distribución de alimentos mediante la plena utilización de los conocimientos técnicos y científicos, la divulgación de principios sobre nutrición y el perfeccionamiento o la reforma de los regímenes agrarios de modo que se logren la explotación y la utilización más eficaces de las riquezas naturales;

b) Asegurar una distribución equitativa de los alimentos mundiales en relación con las necesidades, teniendo en cuenta los problemas que se plantean tanto a los países que importan productos alimenticios como a los que los exportan".

${ }^{942}$ En el párrafo 1 del artículo 11 del Pacto se enumeran una serie de derechos que dimanan del derecho a un nivel de vida adecuado, "incluso alimentación, vestido y vivienda adecuados", y son indispensables para su realización. El uso de la palabra "incluso" indica que esta enumeración de derechos no pretendía ser exhaustiva. El derecho al agua se encuadra claramente en la categoría de las garantías indispensables para asegurar un nivel de vida adecuado, en particular porque es una de las condiciones fundamentales para la supervivencia. Además, el Comité ha reconocido anteriormente que el agua es un derecho humano amparado por el párrafo 1 del artículo 11 (véase la Observación general n. 6 (1995)). El derecho al agua también está indisolublemente asociado al derecho al más alto nivel posible de salud (párrafo 1 del artículo 12) y al derecho a una vivienda y una alimentación adecuadas (párrafo 1 del artículo 11) en la Carta Internacional de Derechos Humanos, en primer lugar el derecho a la vida y a la dignidad humana. Comité de Derechos Económicos, Sociales y Culturales del Consejo Económico y Social de las Naciones Unidas. $29^{\circ}$ período de sesiones. Ginebra, 11 a 29 de noviembre de 2002. Tema 3 del programa. Cuestiones sustantivas que se plantean en la aplicación del Pacto Internacional de Derechos Económicos, Sociales y Culturales. Observación general n. ${ }^{\circ} 15$ (2002) El derecho al agua (artículos 11 y 12 del Pacto Internacional de Derechos Económicos, Sociales y Culturales). Disponible en: < http://www.solidaritat.ub.edu/observatori/general/docugral/ONU_comentariogeneralagua.pdf $>$. Acceso en: 30-10-2015. 
General de Naciones Unidas en su Resolución 64/292, de 28 de julio de 2010, reconoce que el derecho al agua potable salubre y al saneamiento es un derecho humano esencial para el pleno disfrute de la vida y de todos los derechos humanos. En consecuencia, exhorta a los Estados y las organizaciones internacionales a que intensifiquen los esfuerzos por proporcionar a toda la población un acceso económico al agua potable y al saneamiento ${ }^{943}$.

A su vez, la Carta Social europea de $1961^{944}$ reconoció el derecho a la protección de la salud en su artículo $11^{945}$, el derecho a protección contra pobreza y la exclusión social en su artículo $30^{946}$ y el derecho a la vivienda en su artículo $31^{947}$, sin

${ }^{943}$ Información disponible en el sitio de Naciones Unidas. Decenio Internacional para la Acción 'El agua fuente de vida' 2005-2015:

http://www.un.org/spanish/waterforlifedecade/human_right_to_water.shtml>.Acceso en: 31-10-2015.

${ }^{944}$ Versión revisada de 1996.

${ }^{945}$ Artículo 11. Derecho a la protección de la salud.

"Para garantizar el ejercicio efectivo del derecho a la protección de la salud, las Partes se comprometen a adoptar, directamente o en cooperación con organizaciones públicas o privadas, medidas adecuadas para, entre otros fines:

1. eliminar, en lo posible, las causas de una salud deficiente;

2. establecer servicios educacionales y de consulta dirigidos a la mejora de la salud y a estimar el sentido de responsabilidad individual en lo concerniente a la misma;

3. prevenir, en lo posible, las enfermedades epidémicas, endémicas y otras, así como los accidentes". Disponible en: $<$ https://www.coe.int/t/dghl/monitoring/socialcharter/Presentation/ESCRBooklet/Spanish.pdf $>$. Acceso en: 31-10-2015.

${ }^{946}$ Artículo 30. Derecho a protección contra la pobreza y la exclusión social.

"Para garantizar el ejercicio efectivo del derecho a protección contra la pobreza y la exclusión social, las Partes se comprometen:

a) a adoptar medidas en el marco de un

planteamiento global y coordinado para promover el acceso efectivo, en particular al empleo, a la vivienda, a la formación, a la enseñanza, a la cultura, y a la asistencia social y médica, de las personas que se encuentren o que corran el riesgo de encontrarse en una situación de exclusión social o de pobreza, así como de sus familias;

b) a revisar estas medidas con vistas a su adaptación, si resulta necesario". Disponible en: $<\mathrm{https} / / /$ www.coe.int/t/dghl/monitoring/socialcharter/Presentation/ESCRBooklet/Spanish.pdf $>$. Acceso en: 31-10-2015.

${ }^{947}$ Artículo 31. Derecho a la vivienda. 
embargo, no hace ninguna referencia expresa al agua. Tampoco, la Carta de derechos fundamentales de la Unión Europea de $2000^{948}$ hace referencia al agua, pero sí al derecho a la protección a la salud en su artículo $35^{949}$ y al principio de desarrollo sostenible para la protección del medio ambiente y la mejora a su calidad en el artículo $37^{950}$.

Las declaraciones internacionales que reconocen expresamente el derecho al agua como un derecho humano que debe ser garantizado por los poderes públicos se han multiplicado en los últimos años. Una de las primeras fue la Declaración de Mar del Plata de la Conferencia de las Naciones Unidas sobre el Agua de 1977, cuyo preámbulo proclama que "todas las personas, sin importar su estado de desarrollo y su condición económico social, tienen el derecho a acceder a agua potable en cantidad y calidad equivalente para cubrir sus necesidades básicas". El Programa 21, surgido de la Conferencia de Río sobre el medio ambiente y el desarrollo celebrada en 1992, partiendo de que el agua satisface necesidades vitales, marca el objetivo general de "velar por que se mantenga un suministro suficiente de agua de buena calidad para toda la población del planeta" ${ }^{951}$, pero no lo configura como 'derecho' ${ }^{952}$.

"Para garantizar el ejercicio efectivo del derecho a la vivienda, las Partes se comprometen a adoptar medidas destinadas:

1. a favorecer el acceso a la vivienda de un nivel suficiente;

2. a prevenir y paliar la situación de carencia de hogar con vistas a eliminar progresivamente dicha situación;

3. a hacer asequible el precio de las viviendas a las personas que no dispongan de recursos suficientes". Disponible en:

$<$ https://www.coe.int/t/dghl/monitoring/socialcharter/Presentation/ESCRBooklet/Spanish.pdf $>$. Acceso en: $31-10-2015$.

948 2000/C 364/01. Disponible en el sitio del Parlamento Europeo: < http://www.europarl.europa.eu/charter/pdf/text_es.pdf>. Acceso en: 31-10-2015.

${ }^{949}$ Artículo 35. Protección de la salud.

"Toda persona tiene derecho a la prevención sanitaria y a beneficiarse de la atención sanitaria en las condiciones establecidas por las legislaciones y prácticas nacionales. Al definirse y ejecutarse todas las políticas y acciones de la Unión se garantizará un alto nivel de protección de la salud humana”.

${ }^{950}$ Artículo 37. Protección del medio ambiente.

"Las políticas de la Unión integrarán y garantizarán con arreglo al principio de desarrollo sostenible un alto nivel de protección del medio ambiente y la mejora de su calidad".

${ }^{951}$ Programa 21: Capítulo 18. "Protección de la calidad y el suministro de los recursos de agua dulce: aplicación de criterios integrados para el aprovechamiento, ordenación y uso de los recursos de agua 
En 2001, fue adoptada la Carta Europea de los recursos de agua, con carácter de 'recomendación' por el Comité de Ministros del Consejo de Europa, y declara que "toda persona tiene derecho a disponer de agua suficiente para satisfacer sus necesidades esenciales". Importante destacar, que como hemos observado anteriormente, la Carta de los derechos fundamentales de la Unión Europea de 2000 no menciona este derecho, pero podría entenderse implícito en el de acceso a los servicios de interés económico general, previsto en el artículo 36, que son, según la Directiva de servicios (Directiva 2006/123/CE), los que se prestan en ejecución de una tarea especial de interés público confiada al prestador por el Estado miembro en cuestión ${ }^{953}$. Entre ellos figuran, sin duda, los servicios de distribución y suministro de aguas y los de aguas residuales, aunque no les sea aplicable la libertad de prestación (artículo 17.d).

Al establecer los objetivos de la política de medio ambiente, el Tratado de Funcionamiento de la Unión Europea, faculta al Consejo para adoptar medidas que afecten a la ordenación territorial y "la gestión cuantitativa de los recursos hídricos o que afecten directa o indirectamente a la disponibilidad de dichos recursos" (artículo 192.2.b). Hay, pues, espacio para el despliegue de una política hidráulica de la Unión Europea, tanto en los aspectos cuantitativos como en los cualitativos, pues la calidad del agua afecta directamente a su disponibilidad. La preocupación por la calidad inspira a la Directiva marco del agua ${ }^{954}$, porque "la buena calidad del agua contribuirá a garantizar

dulce":

“18.2 El agua se necesita en todos los aspectos de la vida. El objetivo general es velar por que se mantenga un suministro suficiente de agua de buena calidad para toda la población del planeta y preservar al mismo tiempo las funciones hidrológicas, biológicas y químicas de los ecosistemas, adaptando las actividades humanas a los límites de la capacidad de la naturaleza y combatiendo los vectores de las enfermedades relacionadas con el agua. Es preciso contar con tecnologías innovadoras, entre ellas las tecnologías locales mejoradas para aprovechar plenamente los recursos hídricos limitados y protegerlos contra la contaminación”. Disponible en: $<$ http://www.un.org/spanish/esa/sustdev/agenda21/agenda21spchapter18.htm>. Acceso en: 31-10-2015.

${ }^{952}$ Los principales "hitos del agua", auspiciados por la ONU (Foros mundiales del agua e informaciones sobre el desarrollo de los recursos hídricos en el mundo) pueden consultarse en: < http://www.unesco.org/new/es/natural-sciences/environment/water/wwap/>. Acceso en: 31-10-2015.

${ }^{953}$ Directiva 2006/123/CE, relativa a los servicios en el mercado interior, considerado 70.

${ }^{954}$ Directiva 2000/60/CE del Parlamento Europeo y del Consejo, de 23 de octubre de 2000, por la que se establece un marco comunitario de actuación en el ámbito de la política de aguas. Diario Oficial n. ${ }^{\circ}$ L 327 de 22/12/2000. Según Lucía Casado Casado, Principales repercusiones de la Directiva Marco de Aguas 
el abastecimiento de agua potable a la población" (considerando 24). De ahí que uno de sus objetivos básicos sea "garantizar el suministro suficiente de agua superficial o subterránea en buen estado, tal como requiere un uso del agua sostenible, equilibrado y equitativo" (art. $1^{\circ}$ ). La Directiva inicia su parte expositiva con una afirmación precisa: "el agua no es un bien comercial como los demás, sino un patrimonio que hay que proteger, defender y tratar como tal". La Directiva no configura expresamente un derecho al agua, sin embargo, considera este recurso como un "patrimonio" que hay que proteger para que pueda ser utilizado de forma sostenible para la satisfacción de las necesidades humanas. El suministro domiciliario de agua, así como la recogida de las aguas residuales y su posterior depuración son 'servicios' (de interés económico general) cuya prestación deben garantizar los Estados a través de las modalidades que prevea el derecho interno. Obviamente, disponibilidad de agua no significa gratuidad. Al contrario, la Directiva establece el principio de la recuperación de los costes de los servicios relacionados con el agua (art. 9) ${ }^{955}$. Los programas de medidas son el

en el ordenamiento jurídico español. In Santiago González-Varas Ibáñez (Coordinador), Navarra: Aranzadi, 2007, p. 163: "La Directiva marco de aguas nace con vocación de acometer una revisión fundamental de la política comunitaria de aguas desde un enfoque básico de protección de los recursos hídricos y, así, cubrir la necesidad de una mayor coherencia de la regulación existente en este ámbito, puesta de relieve por las propias instituciones comunitarias. Así se pone de manifiesto en el Considerando 18 de la Directiva".

${ }^{955}$ Artículo 9.

Recuperación de los costes de los servicios relacionados con el agua

“1. Los Estados miembros tendrán en cuenta el principio de la recuperación de los costes de los servicios relacionados con el agua, incluidos los costes medioambientales y los relativos a los recursos, a la vista del análisis económico efectuado con arreglo al anexo III, y en particular de conformidad con el principio de que quien contamina paga.

Los Estados miembros garantizarán, a más tardar en 2010:

- que la política de precios del agua proporcione incentivos adecuados para que los usuarios utilicen de forma eficiente los recursos hídricos y, por tanto, contribuyan a los objetivos medioambientales de la presente Directiva,

- una contribución adecuada de los diversos usos del agua, desglosados, al menos, en industria, hogares y agricultura, a la recuperación de los costes de los servicios relacionados con el agua, basada en el análisis económico efectuado con arreglo al anexo III y teniendo en cuenta el principio de que quien contamina paga.

Al hacerlo, los Estados miembros podrán tener en cuenta los efectos sociales, medioambientales y económicos de la recuperación y las condiciones geográficas y climáticas de la región o regiones 
instrumento clave para la consecución de los objetivos de calidad en cada demarcación hidrográfica (artículo $11^{956}$ ).

afectadas.

2. Los Estados miembros incluirán en los planes hidrológicos de cuenca información sobre las medidas que tienen la intención de adoptar para la aplicación del apartado 1 y que contribuyan al logro de los objetivos medioambientales de la presente Directiva, así como sobre la contribución efectuada por los diversos usos del agua a la recuperación de los costes de los servicios relacionados con el agua.

3. Lo dispuesto en el presente artículo no impedirá la financiación de medidas preventivas o correctivas específicas con objeto de lograr los objetivos de la presente Directiva.

4. Los Estados miembros no incumplirán la presente Directiva si deciden no aplicar, de acuerdo con prácticas establecidas, las disposiciones de la segunda frase del apartado $1 \mathrm{y}$, a tal fin, las disposiciones correspondientes del apartado 2, para una determinada actividad de uso de agua, siempre y cuando ello no comprometa ni los fines ni el logro de los objetivos de la presente Directiva. Los Estados miembros informarán en los planes hidrológicos de cuenca de los motivos por los que no han aplicado plenamente la segunda frase del apartado 1 ".

Artículo 2. Definiciones.

“A efectos de la presente Directiva se entenderá por:

38) "servicios relacionados con el agua": todos los servicios en beneficio de los hogares, las instituciones públicas o cualquier actividad económica, consistentes en:

a) la extracción, el embalse, el depósito, el tratamiento y la distribución de aguas superficiales o subterráneas;

b) la recogida y depuración de aguas residuales, que vierten posteriormente en las aguas superficiales".

${ }^{956}$ Artículo 11. Programa de medidas.

“1. Los Estados miembros velarán por que se establezca para cada demarcación hidrográfica, o para la parte de una demarcación hidrográfica internacional situada en su territorio, un programa de medidas, teniendo en cuenta los resultados de los análisis exigidos con arreglo al artículo 5, con el fin de alcanzar los objetivos establecidos en el artículo 4. Estos programas de medidas podrán hacer referencia a medidas derivadas de la legislación adoptada a nivel nacional y que cubran la totalidad del territorio de un Estado miembro. En su caso, un Estado miembro podrá adoptar medidas aplicables a todas las demarcaciones hidrográficas y/o a las partes de demarcaciones hidrográficas internacionales situadas en su territorio.

2. Cada programa de medidas incluirá las "medidas básicas" especificadas en el apartado 3 del presente artículo y, cuando sea necesario, "medidas complementarias".

3. Las "medidas básicas" son los requisitos mínimos que deberán cumplirse y consistirán en:

a) las medidas necesarias para cumplir la normativa comunitaria sobre protección de las aguas, incluidas las medidas exigidas en virtud de los actos legislativos especificados en el artículo 10 y en la parte A del anexo VI;

b) las medidas que se consideren adecuadas a efectos del artículo 9;

c) medidas para fomentar un uso eficaz y sostenible del agua con el fin de evitar comprometer la 
consecución de los objetivos especificados en el artículo 4;

d) las medidas para cumplir lo dispuesto en el artículo 7, incluyendo las destinadas a preservar la calidad del agua con el fin de reducir el nivel del tratamiento de purificación necesario para la producción de agua potable;

e) medidas de control de la captación de aguas dulces superficiales y subterráneas y de embalse de aguas dulces superficiales, con inclusión de un registro o registros de las captaciones de agua y un requisito de autorización previa para la captación y el embalse. Dichos controles se revisarán periódicamente y, cuando proceda, se actualizarán. Los Estados miembros podrán eximir de dichos controles las captaciones o embalses que no repercutan de manera significativa en el estado del agua;

f) medidas de control, con inclusión de un requisito de autorización previa, de la recarga artificial o el aumento de masas de agua subterránea. El agua que se utilice podrá obtenerse de cualquier agua superficial o subterránea, siempre que el uso de la fuente no comprometa la consecución de los objetivos medioambientales establecidos para la fuente o la masa de agua recargada o aumentada. Dichos controles se revisarán periódicamente y, cuando proceda, se actualizarán;

g) para los vertidos de fuente puntual que puedan causar contaminación, un requisito de reglamentación previa, como la prohibición de la entrada de contaminantes en el agua, o el requisito de autorización previa, o el de registro basado en normas generales de carácter vinculante, que establezca controles de la emisión de los contaminantes de que se trate, incluyendo controles con arreglo a lo dispuesto en los artículos 10 y 16. Dichos controles se revisarán periódicamente y, cuando proceda, se actualizarán;

h) para fuentes difusas que puedan generar contaminación, medidas para evitar o controlar la entrada de contaminantes; los controles podrán consistir en un requisito de reglamentación previa, como la prohibición de la entrada de contaminantes en el agua, el requisito de autorización previa o el de registro basado en normas generales de carácter vinculante, cuando este requisito no esté establecido de otra forma en la legislación comunitaria. Dichos controles se revisarán periódicamente y, cuando proceda, se actualizarán;

i) para cualquier otro efecto adverso significativo sobre el estado del agua, a que se refieren el artículo $5 \mathrm{y}$ el anexo II, medidas para garantizar en particular que las condiciones hidromorfológicas de las masas de agua estén en consonancia con el logro del estado ecológico necesario o del buen potencial ecológico de las masas de agua designadas como artificiales o muy modificadas. Los controles realizados con este fin podrán consistir en el requisito de autorización previa o de registro basado en normas generales de carácter vinculante, cuando este requisito no esté establecido de otra forma en la legislación comunitaria. Dichos controles se revisarán periódicamente y, cuando proceda, se actualizarán;

j) la prohibición de vertidos directos de contaminantes en las aguas subterráneas, sin perjuicio de las disposiciones siguientes:

Los Estados miembros podrán autorizar la reinyección en el mismo acuífero de aguas utilizadas con fines geotérmicos.

También podrán autorizar, indicando las condiciones para ello:

- la inyección de aguas que contengan sustancias resultantes de las operaciones de exploración y extracción de hidrocarburos o actividades mineras, así como la inyección de aguas por razones técnicas 
en formaciones geológicas de las que se hayan extraído hidrocarburos u otras sustancias, o en formaciones geológicas que por razones naturales no sean apropiadas, de manera permanente, para otros fines. Tales inyecciones no contendrán sustancias distintas de las resultantes de las operaciones antedichas,

- la reinyección de aguas subterráneas bombeadas procedentes de minas y canteras o asociadas a la construcción o al mantenimiento de obras de ingeniería civil,

- la inyección de gas natural o de gas licuado de petróleo (GLP) con fines de almacenamiento en formaciones geológicas que por razones naturales no sean apropiadas, de manera permanente, para otros fines,

- la inyección de gas natural o de gas licuado de petróleo (GLP) con fines de almacenamiento en otras formaciones geológicas en las que haya necesidad imperiosa de garantizar el abastecimiento de gas y cuando la inyección se haga de manera que se evite cualquier riesgo actual o futuro de deterioro de la calidad de todas las aguas subterráneas receptoras,

- obras de construcción, ingeniería civil y edificación y actividades similares sobre o dentro del terreno que esté en contacto con aguas subterráneas. A dicho efecto, los Estados miembros podrán determinar que dichas actividades se traten como si hubieran sido autorizadas siempre y cuando se lleven a cabo de conformidad con las normas generales de carácter vinculante establecidas por los Estados miembros relativas a dichas actividades,

- vertidos de pequeñas cantidades de sustancias con fines científicos para la caracterización, protección o restauración de las masas de agua limitadas a la cantidad estrictamente necesaria para los fines en cuestión,

siempre que dichos vertidos no pongan en peligro el logro de los objetivos medioambientales establecidos para esa masa de agua subterránea;

k) de conformidad con las medidas adoptadas con arreglo al artículo 16, medidas para eliminar la contaminación de las aguas superficiales por las sustancias que figuran en la lista de sustancias prioritarias acordada de conformidad con el apartado 2 del artículo 16, y para reducir progresivamente la contaminación por otras sustancias que de lo contrario impediría a los Estados miembros lograr los objetivos establecidos en el artículo 4 para las masas de agua superficial;

1) cualesquiera medidas necesarias para prevenir pérdidas significativas de contaminantes procedentes de instalaciones industriales y para prevenir o reducir los efectos de las contaminaciones accidentales, por ejemplo como consecuencia de inundaciones, entre otras cosas mediante sistemas para detectar esos fenómenos o alertar sobre ellos, incluyendo, en caso de accidentes que no pudieran haberse previsto razonablemente, todas las medidas apropiadas que deban adoptarse para reducir el riesgo de daños al ecosistema acuático.

4. Las "medidas complementarias" son aquellas concebidas y aplicadas con carácter adicional a las medidas básicas con el propósito de lograr los objetivos establecidos en virtud del artículo 4. La parte B del anexo VI contiene una lista no exhaustiva de posibles medidas de esta índole.

Los Estados miembros podrán asimismo adoptar otras medidas complementarias encaminadas a la consecución de una protección adicional o de una mejora de las aguas a que se refiere la presente 
En España, la consideración de las aguas como dominio público (sólo las “corrientes” en la legislación del siglo XIX y a partir de 1985 todas las integrantes del ciclo hidrológico) ha hecho innecesaria la configuración de un derecho subjetivo a su utilización, justamente porque el uso público de este recurso incluía la satisfacción de las necesidades domésticas en una época mucho menos exigente que la actual en cuanto a las condiciones de acceso. El uso público o aprovechamiento común del agua obligaba a buscarla donde se encontrase (fuentes, ríos y otras corrientes), pero no incluía el derecho al suministro en la propia vivienda. Eso explica, seguramente, que se

Directiva, y también cuando apliquen los acuerdos internacionales pertinentes a que se refiere el artículo 1 .

5. Cuando los datos en virtud de actividades de seguimiento u otros datos indiquen que probablemente no se lograrán los objetivos establecidos en el artículo 4 para una masa de agua, el Estado miembro velará por que:

- se investiguen las causas de esa posible carencia,

- se examinen y revisen adecuadamente los permisos y autorizaciones pertinentes,

- se revisen y ajusten adecuadamente los programas de seguimiento, y

- se establezcan las medidas adicionales que sean necesarias para lograr dichos objetivos, incluido, cuando proceda, el establecimiento de normas de calidad medioambiental más estrictas con arreglo a los procedimientos del anexo $\mathrm{V}$.

Cuando esas causas resulten de circunstancias debidas a causas naturales o de fuerza mayor que sean excepcionales y no hayan podido preverse razonablemente, en particular graves inundaciones y sequías prolongadas, el Estado miembro podrá determinar que no es factible adoptar medidas adicionales, de conformidad con el apartado 6 del artículo 4 .

6. Al aplicar medidas de conformidad con el apartado 3, los Estados miembros adoptarán todas las medidas adecuadas para que no aumente la contaminación de las aguas marinas. Sin perjuicio de la normativa vigente, la aplicación de medidas adoptadas de conformidad con el apartado 3 no podrá originar bajo ningún concepto, ni directa ni indirectamente, una mayor contaminación de las aguas superficiales. Este requisito no regirá en caso de que la aplicación de esta disposición acarreara una mayor contaminación del medio ambiente en su conjunto.

7. Los programas de medidas se establecerán a más tardar nueve años después de la entrada en vigor de la presente Directiva y todas las medidas serán operativas a más tardar doce años después de esa misma fecha.

8. Los programas de medidas se revisarán y, cuando proceda, se actualizarán en un plazo máximo de quince años a partir de la entrada en vigor de la presente Directiva, y posteriormente cada seis años. Toda medida nueva o revisada establecida en virtud de un programa actualizado será operativa en un plazo de tres años a partir de su establecimiento". 
considerase gratuito ${ }^{957}$.

Por el contrario, el abastecimiento a la población era el primero de los aprovechamientos especiales o privativos y, por ello, requería la obtención de un título jurídico (normalmente una concesión), que constituía un verdadero derecho subjetivo al uso (y consumo) del caudal concedido. La configuración del abastecimiento como servicio público de competencia municipal conllevó la preferencia de los Ayuntamientos para la obtención de las concesiones respectivas, pero determinó también el carácter obligatorio de la prestación, aunque el suministro domiciliario no lo fuera hasta bien entrado el siglo XX. La legislación de aguas de 1866-79 estableció al respecto una dotación mínima de 50 litros diarios por habitante, de los que 20 habrían de ser potables. Esta cifra servía como referencia para legitimar la expropiación de otros aprovechamientos en beneficio de las poblaciones cuya dotación no alcanzase esa cifra. La legislación de régimen local incrementó su cuantía, que se ha mantenido en la legislación sanitaria, aunque la vigente Ley de aguas no la mencione. Estos datos apoyan la tesis de que el derecho al agua, entendido como disponibilidad de la precisa para satisfacer las necesidades domésticas, nunca ha sido una abstracción, porque, al menos desde la ley de aguas de 1866, hay elementos suficientes para perfilar su contenido $^{958}$.

En 2006 fue elaborado por el Ministerio de Medio Ambiente el frustrado anteproyecto de ley de reforma de la de aguas, que tenía la preocupación por cuantificar ese contenido ${ }^{959}$. El texto incluía entre los principios rectores de la gestión de las aguas la "garantía del derecho de los ciudadanos, al margen de su capacidad económica, al suministro de agua potable en cantidad y calidad adecuadas", añadiendo que "las Administraciones competentes deberán promover las condiciones necesarias para proporcionar un mínimo de 60 litros por habitante y día"960.

\footnotetext{
${ }^{957}$ MENÉNDEZ REXACH, Ángel. El derecho al agua en la Legislación española. AFDUC 15, 2011, ISSN: 1138-039X: 53-84, p.58.

${ }^{958}$ MENÉNDEZ REXACH, Ángel. El derecho al agua en la Legislación cit., pp.58-59.

${ }^{959}$ GIMÉNEZ CASALDUERO, María; BABIANO AMELIBIA, Luis. El reconocimiento europeo del derecho humano al agua y al saneamiento: garantía ciudadana para el disfrute de los servicios públicos, pp. 332-343. Nota de pie de página 11, p. 337. Disponible en: $<$ http://revistas.lis.ulusiada.pt/index.php/8cigpa/article/viewFile/665/697>. Acceso en: 31-10-2015.

${ }^{960}$ Por la misma época, el derecho al agua surgió con fuerza en los nuevos Estatutos de Autonomía, en el contexto de la polémica sobre las transferencias de recursos entre cuencas. La impugnación del artículo
} 
El presente estudio busca hacer un análisis de la evolución de la legislación española referente al agua. El derecho al agua que aquí interesa es el que garantiza la disponibilidad del recurso para la satisfacción de las necesidades vitales y domésticas (alimento, higiene, salubridad), no para el riego, usos industriales u otras actividades, aunque puedan constituir el medio de vida de los usuarios. En la Constitución Española de 1978, el derecho al agua se puede considerar inherente al derecho a la vida y, en cuanto "servicio" de prestación obligatoria está vinculado a tres de los principios rectores de la política social y económica más importantes: el derecho a la protección de la salud, al medio ambiente y a la vivienda digna y adecuada ${ }^{961}$. De ahí que sean pertinentes algunas reflexiones sobre el derecho al agua y el principio del Estado social.

\subsubsection{El principio del Estado Social y su relación con el derecho al agua}

La protección del medio ambiente es uno de los contenidos básicos del principio del Estado social, que comprende el conjunto de medidas necesarias para el mantenimiento y mejora de las condiciones naturales de vida, entre ellas, al menos, el aire, el agua, el suelo y la biosfera (espacios naturales, fauna y flora) ${ }^{962}$. Está claro que no todos los contenidos del Estado social tienen el mismo significado jurídico. Hay que distinguir entre verdaderos derechos subjetivos y mandatos o directrices a los poderes públicos. La Constitución Española de 1978 incluye entre los "principios rectores de la política social y económica" el derecho a la protección de la salud (artículo 43), al medio ambiente (artículo 45) y a una vivienda digna y adecuada (artículo 47). Es incuestionable que vinculan a todos los poderes públicos, pero no son, en principio, verdaderos derechos subjetivos, ya que sólo pueden ser alegados ante los órganos jurisdiccionales "de acuerdo con lo que dispongan las leyes que los desarrollan"

correspondiente del Estatuto valenciano por el Gobierno de Aragón fue resuelta por el TC en el sentido de vaciar de contenido al precepto impugnado sin declararlo inconstitucional: ese derecho estatutario no es un derecho subjetivo, sino un principio rector de la actuación de los poderes públicos, que, además, sólo vincula a los autonómicos. MENÉNDEZ REXACH, Ángel. El derecho al agua en la Legislación cit., p. 59.

${ }^{961}$ MENÉNDEZ REXACH, Ángel. El derecho al agua en la Legislación cit., p. 60.

${ }^{962}$ STERN citado por MENÉNDEZ REXACH, Ángel. El derecho al agua en la Legislación cit., p. 60. 
(artículo 53.3 CE). Por consiguiente, los contenidos efectivos del Estado social dependen de las decisiones del legislador. A este respecto, se ha señalado que del reconocimiento constitucional del principio del Estado social sólo deriva inmediatamente la garantía de un "mínimo existencial"963, que también se vincula a la dignidad de la persona humana ${ }^{964}$. En ese mínimo existencial se incluye, según Ángel Menéndez Rexach: "el derecho a disponer de agua suficiente para la satisfacción de las necesidades vitales, que es inherente al derecho a la vida y está implícito en los tres derechos sociales mencionados (protección de la salud, medio ambiente y vivienda). Pero la concreción de las condiciones (cantidad, calidad, coste, modalidad de acceso, etc.) depende de las decisiones del legislador" 965 .

El derecho al agua, en una primera aproximación, tiene dos facetas: a) libertad

${ }^{963}$ Conforme definición de Alejandra Celi Maldonado. Mínimo vital. Diccionario Iberoamericano de Derechos Humanos y Fundamentales. "A pesar de no existir un concepto generalmente aceptado, podemos decir que el derecho al mínimo vital es el derecho a gozar de unas prestaciones e ingresos mínimos, que aseguren a toda persona su subsistencia y un nivel de vida digno, así como también, la satisfacción de las necesidades básicas. Sin embargo, éste derecho no se ha reconocido expresamente en el Derecho Internacional ni en las Constituciones de los Estados iberoamericanos, se trata de un derecho “innominado" y desarrollado principalmente desde la jurisprudencia y la doctrina”. Además, afirma la autora que: “Cabe señalar que el mínimo vital no se refiere únicamente a la dotación de ingresos mínimos (como la Renta Básica Universal o la Renta Mínima de Inserción), por el contrario, puede implicar la prestación de servicios públicos necesarios para satisfacer las necesidades básicas u otros derechos como el derecho al AGUA o a la vivienda". Disponible en: $<$ http://diccionario.pradpi.org/inicio/index.php/terminos_pub/view/9>. Acceso en: 31-10-2015. También, en este sentido, Ángel Menéndez Rexach, El derecho al agua en la Legislación cit., pp. 60-61, enseña que: "Sin duda por influencia de las declaraciones internacionales, el derecho al agua está reconocido en las Constituciones de algunos Estados, especialmente en Iberoamérica y África. En Europa, no hay una afirmación expresa del derecho, sino un mandato a los poderes públicos para satisfacer las demandas de la población. En Francia, la Carta del medio ambiente de 2004, incorporada al preámbulo de la Constitución, proclama el derecho de todos a vivir en un entorno equilibrado y respetuoso de la salud (art. $1^{\circ}$ ). El Código del medio ambiente establece que la gestión equilibrada de las aguas debe permitir prioritariamente la satisfacción de las demandas de salud, salubridad pública, seguridad civil y alimentación de la población con agua potable". El autor, termina diciendo que: "[...] el derecho al agua parece darse por supuesto, pero no se regula".

${ }^{964}$ E. SCHMIDT-ASSMANN citado por MENÉNDEZ REXACH, Ángel. El derecho al agua en la Legislación cit., p. 60.

${ }^{965}$ MENÉNDEZ REXACH, Ángel. El derecho al agua en la Legislación cit., p. 60. 
de acceso al recurso para los usos comunes, que son los vinculados a la satisfacción de las necesidades vitales; b) derecho al suministro domiciliario de agua potable. Las dos facetas no son excluyentes. La primera es una manifestación de la libertad personal que puede considerarse inherente al derecho a la vida (como el derecho a alimentarse o a respirar). La segunda implica la prestación de un servicio que es responsabilidad de los poderes públicos, tanto si lo prestan directamente como si lo hacen a través de empresas privadas. Representa un estadio superior frente a la libertad de acceso, ya que implica el derecho a recibir un servicio, lo que obliga a los poderes públicos a garantizar determinadas prestaciones imprescindibles para satisfacer las necesidades vitales ${ }^{966}$.

\subsubsection{España: legislación histórica y actual}

Importante aclarar que un estudio histórico riguroso excedería el objeto del trabajo, razón la cual no llevaremos a cabo. Además, expertos ya lo han realizado ${ }^{967}$.

\footnotetext{
${ }^{966}$ MENÉNDEZ REXACH, Ángel. El derecho al agua en la Legislación cit., p. 60.

${ }^{967}$ Como bien afirmó María Valentina Erice en su tesis doctoral La protección de las aguas subterráneas en el Derecho de Aguas Español, Universidad de Navarra, Pamplona, 2012, nota de pie de página 73, p.
} 53: "Entre los numerosos estudios que analizan la legislación de aguas histórica española: ARRAZOLA, L. (1849), voz "Agua”, en Enciclopedia Española de Derecho y Administración, pp. 247-346; BRANCHÁT, V. (1784), Tratado de los Derechos y Regalías que corresponden al real patrimonio en el reyno de Valencia y en la jurisdicción del intendente, t. I, Imprenta de Joseph y Tomas de Orga, Valencia; DEL SAZ, S. (1990), Aguas subterráneas, aguas públicas (El nuevo Derecho de aguas), Marcial Pons, Madrid; MIGUEL GARCÍA, P. de (1980), "Régimen jurídico para la protección de las aguas subterráneas", Documentación Administrativa, núm. 187, pp. 5-43; ESCRICHE, J. (1858), voz "Agua", en Diccionario razonado de legislación y jurisprudencia, pp. 106-110; GALLEGO ANABITARTE, A.; MENÉNDEZ REXACH, A. y DÍAZ LEMA, J. M. (1986), El Derecho de aguas en España, t. I, Centro de Publicaciones Secretaría General Técnica, Ministerio de Obras Públicas y Urbanismo, Madrid; JORDANA DE POZAS, L. (1962), "La evolución del Derecho de las aguas en España y en otros países", Revista de Administración Pública, núm. 37, pp. 9-61 y (1962), El Derecho español de aguas y la oportunidad de su revisión, Real Academia de Jurisprudencia y Legislación, Madrid; LATOUR BROTÓNS, J. (1955), Antecedentes de la primitiva Ley de aguas, Ilustre Colegio de Abogados de Elche, Madrid; MARTÍN MATEO, R. (1992), Tratado de Derecho ambiental, vol. I, Trivium, Madrid; MARTÍN-RETORTILlO, S. (1960), "La elaboración de la Ley de aguas de 1866”, Revista de Administración Pública, núm. 32, pp. 11-54, (1963), "La Ley de aguas de 1866, antecedentes y elaboración, Centro de Estudios Hidrográficos, Madrid y (1997), Derecho de aguas, Civitas, Madrid; y 
Sin embargo no podríamos dejar de comentar sobre el Tribunal de las Aguas de Valencia ${ }^{968}$ que es sin dudas la más antigua institución jurídica de Europa. Ello soluciona problemas del agua en el territorio de Valencia desde los tiempos del Imperio Romano $^{969}$.

Las denuncias juzgadas por el tribunal son principalmente sobre: robo de agua en días de escasez, rupturas de canales o diques limítrofes generando exceso de agua en campos vecinos dañificando la cosecha, utilización de drenaje sucio estorbando la circulación del agua y regadío ${ }^{970}$.

El juicio ocurre de manera tradicional. Una persona es acusada el jueves y en el próximo encuentro ella debe comparecer para defenderse, nunca fue necesaria la fuerza pública para obligar el acusado a comparecer en juicio. Si no hay acusación formal es preguntado al reo que él ha hecho. Los procesos son todos orales y no hay abogados, las personas hacen autodefensa, eso evita la gastos y morosidad. El juicio es hecho por ocho hombres, que utilizan camisas negras que eran usadas originalmente por estancieros locales. Ellos deciden cómo será la distribución del agua entre los ocho canales que irrigan los vales donde hay plantación de frutas y arroz. Los resultados de

NIETO, A. (1968), “Aguas subterráneas: subsuelo árido y subsuelo hídrico”, Revista de Administración Pública, núm. 56, pp. 9-92”. Disponible $\quad$ en: http://dadun.unav.edu/bitstream/10171/23721/1/Tesis\%20Valentina\%20Erice.pdf $>$. Acceso en: 19-102015.

968 Todos los jueves a las 12 horas hay juicios en la Plaza de la Catedral de Valencia, que puede ser visto por cualquier persona, desde turistas a visitas escolares. El inicio de la sesión es marcado por el toque de una campana. Por su importancia, la UNESCO en 2009 la reconoció como Patrimonio Cultural Inmaterial de la Humanidad.

${ }^{969}$ En el original: The Court of Waters of the fertile valley of Valencia is the oldest existing institution of justice in Europe. Although some legal institution that solved the water problems of the territories of Valencia would already exist from Roman, Disponible en: <http://www.tribunaldelasaguas.org/en/eltribunal-ing/historia-ing>. Acceso en: 31-05-2015.

${ }^{970}$ En el original: As far as the denunciations are concerned, they are mainly about: water theft in days of shortage, rupture of channels or walls, 'sorregar' throwing water in neighbouring fields that damage the harvest by excess of this one, altering the irrigation turns taking the water the day that does not come, having dirty drains preventing the water from circulating with regularity, raising 'parada' when an irrigator is using his turn, watering without turn request. Disponible en: < http://www.tribunaldelasaguas.org/en/el-tribunal-ing/funcionamiento-ing>. Acceso en: 17-06-2015. 
los juzgados van para un libro de registro que contienen: el denunciado, razón de la denuncia y la fecha.

La Corte atrae personas de renombre de todo el mundo para estudiar como es el funcionamiento del tribunal, entre esas personas podemos citar Thomas F. Glick ${ }^{971}$ profesor de historia de la ciencia y tecnología en Harvard, por medio de su estudio lanzó el libro - Regadío y sociedad en la Valencia medieval ${ }^{972}$ en 1970.

La función del tribunal es sin duda la defensa de la región fértil de Valencia juntamente con la utilización del agua de forma adecuada. De esta manera los habitantes de Valencia han resuelto sus problemas de agua dulce desde los tiempos más remotos sin problemas burocráticos de retraso y cumpliendo con uno de los derechos elementares de los seres humanos: justicia ${ }^{973}$.

Ya, a nivel nacional, el 3 de agosto de 1866, apareció la primera Ley de Aguas $^{974}$ de España, que representa el primer intento de regular específicamente las aguas territoriales españolas, aunque no llegó a entrar en vigor debido el periodo revolucionario que dio lugar a la primera república. Sin embargo, esta Ley de 1866 consideró de dominio público de la Nación las cosas "cuyo uso es común por su propia naturaleza o por el objeto a que se hallan destinadas". Sin embargo, esta consideración no implicaba un régimen unitario de utilización, sino que la citada Ley distinguió dos modalidades de aprovechamientos -comunes o especiales- con un régimen jurídico muy diferente. En el marco de la legislación de aguas de 1866-1879, se ha puesto de relieve la inadecuación de la categoría "uso común" para construir un derecho al agua adaptado a las circunstancias actuales. Tampoco desde la modalidad del uso privativo o

\footnotetext{
${ }^{971}$ Disponible en: http://www.thomasfglick.com/. Acceso en: 17-06-2015.

972 En el original: - Irrigation and Society in Medieval Valenciall. Disponible en: http://www.tribunaldelasaguas.org/en/el-tribunal-ing/proyeccion-exterior-ing. Acceso en: 17-06-2015.

${ }^{973}$ En el original: In this simple way, so effective and respected by all the members of an agricultural community, the laborious Valencian people have solved their water problems from the most remote times $[\ldots]$ no long bureaucratic proceedings that delay what constitutes the most elementary of the human rights: justice, Disponible en: < http://www.tribunaldelasaguas.org/en/el-tribunal-ing/funcionamientoing > . Acceso en: 17-06-2015.

${ }^{974}$ Informaciones importantes acerca de la elaboración de la Ley de Aguas de 1866 son dadas por Sebastián Martín-Retortillo, en su artículo titulado La elaboración de la Ley de Aguas de 1866.
} 
aprovechamiento especial, puesto que no hay un derecho a obtener la concesión ${ }^{975}$. Esta opinión es asumible en cuanto que el derecho al agua no se puede identificar con ninguna de esas dos modalidades de utilización, pero tampoco se puede desligar de ellas, porque ambas contribuyen a la efectividad del derecho ${ }^{976}$.

Los principios básicos de la Ley de 1866, no obstante, pasaron en gran parte a la Ley de $1879^{977}$ entre ellos el del dominio público de todas las corrientes naturales, los cauces y riberas de los ríos. No se incluyeron las aguas subterráneas, que pertenecen al propietario del terreno en donde se alumbraran. Este precepto continuó en vigor hasta su modificación no retroactiva por la Ley de 1985.

La Ley de Aguas de 1879 declaró bienes de dominio público solamente las aguas superficiales y las subálveas, mientras que la mayoría de las subterráneas podían ser propiedad de quien las alumbrase. Se inició una gestión separada de las aguas que retrasó la consideración, en la planificación hidrológica, de las escorrentías subterráneas como una parte del flujo hídrico natural. Asimismo, esta ley instaura por primera vez el régimen concesional para los distintos usos del agua -abastecimiento, regadío y usos

${ }^{975}$ EMBID IRUJO, A. (director). Gestión del agua y descentralización política, Aranzadi, Cizur Menor 2009, en nota 1, p. 35 y ss., en especial 42-43.

${ }^{976}$ MENÉNDEZ REXACH, Ángel. El derecho al agua en la Legislación cit., p. 62. Además, el autor afirma que: "El uso común es libertad de acceso al agua corriente mientras discurra por sus cauces naturales (también por los artificiales) para beber y satisfacer las necesidades domésticas. La situación es muy distinta si lo que se pretende es el abastecimiento (domiciliario) de agua y, además, en las condiciones adecuadas de potabilidad que permitan su consumo. La legislación histórica de aguas también se refiere a este supuesto, pero ya no como uso común sino como un aprovechamiento especial, que requiere la previa obtención de un título (normalmente, la concesión y, en la legislación histórica, también la usucapión veintenal o los denominados aprovechamientos “eventuales”), con la particularidad de que el titular puede ser usuario directo del agua o prestador de un servicio a los usuarios finales. En este marco, el usuario lo es, a la vez, de un bien y de un servicio, lo que justifica que tenga que abonar una contraprestación, en contraste con la gratuidad del uso común”.

${ }^{977}$ La Ley de 1879, incluye el derecho al aprovechamiento privativo del agua vinculado a una concesión administrativa. La Ley regula de manera muy precisa tanto el procedimiento y las reglas generales sobre la concesión de aguas públicas así como disposiciones específicas para los distintos aprovechamientos (abastecimiento a poblaciones, riegos, establecimientos industriales, etc.). En el caso de los regadíos, además, el derecho al uso del agua va unido al de propiedad de la tierra. 
industriales- y estableció como base territorial para la gestión del agua a la provincia división administrativa básica del territorio español- ${ }^{978}$.

Con el restablecimiento de la democracia en España surgen nuevas circunstancias económicas, sociales y políticas, que suscitaban la necesidad de cambios urgentes en la gestión del agua. Durante largas décadas, la política hídrica se había estado desarrollando al margen del ciclo hidrológico y era necesario pasar de ser un mero instrumento ejecutor de obras de ingeniería a conseguir una gestión unitaria de los recursos hídricos. Para ello se hacía necesario preparar una nueva legislación que sustituyese a la Ley de Aguas de 1879, pues su vigencia no podría afrontar los nuevos retos planteados.

En 1985 se aprueba en España la nueva Ley de Aguas (Ley 29/1985, de 2 de Agosto), que hace públicas todas las aguas, las superficiales y las subterráneas alumbradas con posterioridad al 1 de enero de $1986^{979}$-ambas se han de administrar y gestionar conjuntamente, introduciendo así el concepto del ciclo hidrológico-. Además, moderniza las Confederaciones Hidrográficas y hace de la planificación hidrológica el eje central de la Ley. Además, plantea algunas cuestiones medioambientales como la contaminación, la regulación de los vertidos y la necesidad de gestionar la calidad de las aguas. Asimismo, al describir los contenidos de los Planes de Cuenca se establece que éstos reserven un volumen anual de agua con finalidad ecológica. Aunque será la Directiva Marco del Agua la que profundice más en estas cuestiones ${ }^{980}$.

978 SÁNCHEZ-MARTÍNEZ, Ma Teresa; RODRÍGUEZ-FERRERO, Noelina; SALAS-VELASCO, Manuel. La gestión del agua en España. La unidad de Cuenca. Revista de Estudios Regionales n. ${ }^{\circ} 92$, 2011:199-220, p.202.

${ }^{979}$ La Ley de Aguas de 1985 declaró públicas todas las aguas, sean superficiales o subterráneas renovables, como bienes integrantes del dominio público del Estado, su asignación y uso requiere previa concesión administrativa. Los particulares solo adquieren el derecho de aprovechamiento, no la propiedad del agua, salvo los derechos adquiridos al amparo de la legislación anterior que la Ley respeta. Sin embargo, la publificación quedo muy desvirtuada por los criterios adoptados en las Disposiciones Transitorias de dicha ley, pudiendo hablarse de la coexistencia de aguas subterráneas privadas (las alumbradas con anterioridad al 1 de enero de 1986) y aguas subterráneas públicas (las alumbradas después de dicha fecha). SÁNCHEZ-MARTÍNEZ, Ma Teresa; RODRÍGUEZ-FERRERO, Noelina; SALAS-VELASCO, Manuel. La gestión del agua en cit., nota de pie de página 5 p. 204.

${ }^{980}$ Conforme $M^{\mathrm{a}}$ Teresa Sánchez-Martínez, Noelina Rodríguez-Ferrero, y Manuel Salas-Velasco, La gestión del agua en cit., pp. 204-205: "De cara a la regulación de caudales, este modelo ofrecía la ventaja de contar con dos sistemas de regulación, el que constituyen los embalses construidos y el del conjunto de 
Desde la aprobación de la Ley de Aguas de 1985, se han promulgado varias intervenciones normativas, dando lugar al Texto Refundido de la Ley de Aguas (TRLA), aprobado por Real Decreto-Legislativo 1/2001, que es la pieza central del derecho español de aguas en la actualidad. No obstante, este último también ha sido objeto de varias modificaciones legislativas, lo que da idea del gran dinamismo que en términos jurídicos se está produciendo actualmente en España, frente al estatismo de la Ley de Aguas de 1879, que estuvo vigente más de un siglo. Como se indica en los siguientes apartados, los motivos de todos estos cambios normativos en la gestión del agua se deben, entre otros motivos, a la entrada en vigor de la Directiva Marco del Agua $^{981}$, así como a los procesos de constitución y posteriores reformas de los Estatutos de Autonomía de las Comunidades Autónomas ${ }^{982}$.

acuíferos existentes en la cuenca. Parece claro que el uso conjunto de ambos sistemas dará la solución óptima a la regulación. Se puede decir que en este estadio comienza la gestión unitaria del agua. Para conseguir esta finalidad la Ley establecía que los organismos de cuenca llevaran un Registro de Aguas de carácter público. Sin embargo, la falta de control real sobre los pozos existentes y la debilidad de los instrumentos legales con que contaba la Administración en esta tarea ingente y, por otra parte, la proliferación de los sondeos ilegales han impedido la eficacia del citado modelo. No obstante, aunque la Ley parte de la base de que todas las aguas subterráneas son públicas, de hecho y de derecho, la gran mayoría de las aguas captadas siguen siendo privadas. La Ley crea un órgano consultivo superior, el Consejo Nacional del Agua, en el que, junto con la Administración del Estado y la de las Comunidades Autónomas (CC. AA.), estarán representados los entes locales, los organismos de cuenca así como las organizaciones profesionales y económicas más representativas, de ámbito nacional, relacionadas con los distintos usos del agua, cuya misión es realizar informes preceptivos sobre la planificación hidrológica y otras disposiciones de carácter general sobre los recursos hídricos y demás bienes del dominio público hidráulico".

${ }^{981}$ Conforme $\mathrm{M}^{\mathrm{a}}$ Teresa Sánchez-Martínez, Noelina Rodríguez-Ferrero, y Manuel Salas-Velasco, La gestión del agua en cit., p. 210: "La gestión del agua adquiere tras la DMA una extraordinaria complejidad y exige profundas reformas de los Derechos nacionales y, lo que es más importante, obliga a modificar arraigados hábitos y asumir una nueva cultura del agua. Su transposición ha producido significativas modificaciones en la legislación española de aguas, aunque hasta el momento no se han diseñado todos los instrumentos normativos adecuados para hacer realidad el cumplimiento de los objetivos de la DMA, entre otros, administración por cuencas, recuperación de costes y participación de los usuarios. En España, un país con un régimen hidrológico muy irregular y con escasos recursos hídricos, la gestión integrada del agua es un factor clave, cuyos principales elementos han de ser: el uso de recursos no convencionales como desalación y aguas residuales depuradas, la gestión conjunta de aguas superficiales y subterráneas, así como aspectos de su cantidad y calidad, el desarrollo de las obras hidráulicas de regulación y conducción de caudales, el uso de tecnologías eficientes de ahorro de agua y 
Importante resaltar que en España existen los llamados Códigos electrónicos y en materia de aguas hay el Código de Aguas Normativa Estatal y el Código de Aguas Normativa Autonómica, sin embargo, diferentemente de Brasil, estos Códigos se tratan de compilaciones de las principales normas vigentes del ordenamiento jurídico y son permanentemente actualizadas ${ }^{983}$. A lo largo de este capítulo hablaremos de algunas de estas normas vigentes.

\subsubsection{La gestión del agua en España. Marco regulador y agentes} implicados

Establecidos en la Ley de Aguas de 1985, los principios generales de gestión del agua en España consideran este recurso como un bien de dominio público ${ }^{984}$, y a la cuenca hidrográfica como unidad básica de gestión y planificación, la cual se considera indivisible. Pese a que, la Ley tenía que conciliar el hecho de que los límites de las cuencas hidrográficas, unidad de gestión y planificación de las aguas, no coincidían con los límites político-administrativos de las Comunidades Autónomas. Con este propósito instituyó dos tipos de cuencas: las intracomunitarias, cuyo territorio pertenecía a una sola Comunidad Autónoma y serían competencia exclusiva de dicha Comunidad y las intercomunitarias, cuyo territorio se extiende por más de una Comunidad Autónoma, gestionadas por el Estado mediante las Confederaciones Hidrográficas.

la gestión planificada de los hechos extremos como las sequias e inundaciones".

${ }^{982}$ La Constitución Española de 1978 organizó el territorio nacional en 17 Comunidades Autónomas. El Estatuto de Autonomía es la norma institucional básica de la Comunidad Autónoma. Define los derechos y deberes de los ciudadanos de esa región, las instituciones políticas de la misma, sus competencias, relaciones con el Estado y su financiación.

${ }^{983}$ Código de Aguas Normativa Estatal y Código de Agua Normativa Autonómica, disponibles en: $<\mathrm{http}$ :/www.boe.es/legislacion/codigos/>. Acceso en: 03-12-2015.

${ }^{984}$ Según Ángel MENÉNDEZ REXACH, El agua como bien jurídico global: el Derecho Humano al agua. AFDUAM 16, 2012, p.187: "En España, el agua es un bien público de titularidad estatal, lo que es una garantía (relativa) de su utilización con criterios de solidaridad frente a las tendencias actuales a la «territorialización» de esas decisiones. Es una paradoja que el derecho al agua no sea un verdadero derecho subjetivo en los nuevos Estatutos de Autonomía que lo proclaman, mientras que sí lo es en las leyes administrativas que, sin reconocerlo expresamente, lo dan por supuesto, al configurar el suministro como un servicio municipal obligatorio”. 
La integración de las competencias en materia de aguas resulta especialmente compleja teniendo en cuenta las atribuciones encargadas a cada una de las administraciones implicadas pues, no solo el Estado y las Comunidad Autónoma, sino también las corporaciones locales y las comunidades de usuarios gozan de determinadas competencias en materias de aguas. Debe diferenciarse, por una parte, la gestión del agua en alta que consiste en llevarla desde las grandes obras de captación (embalses), plantas de tratamiento (potabilización) y grandes canalizaciones hasta los depósitos de cabecera; por otra parte, la gestión del agua en baja que transporta el agua desde los depósitos de cabecera hasta los usuarios finales (abastecimiento urbano, recogida y tratamiento de aguas residuales urbanas, regadío y usos industriales).

Al Estado corresponde la gestión del agua en alta, que tiene las competencias sobre planificación hidrológica y planes estatales de infraestructuras hidráulicas, y el otorgamiento de concesiones, autorizaciones y tutela del dominio público hidráulico en las cuencas intercomunitarias. Solamente las Comunidad Autónoma insulares, o sea, Canarias y Baleares, y las cuencas intracomunitarias tienen transferidas las competencias de la gestión del agua. Reguladas a través del Derecho Público, se han creado, en unos casos, sociedades o agencias propias, en otros, se ha absorbido el organismo autónomo estatal (organismo de cuenca) adscribiéndolo a la estructura administrativa de la Comunidad Autónoma. Por fin, para la gestión de las cuencas internacionales, compartidas con Portugal ${ }^{985}$, Francia ${ }^{986}$, Andorra y Marruecos, hay acuerdos sobre cantidad y calidad del recurso que España debe dejar entrar al país vecino y sobre explotación hidroeléctrica de los tramos fronterizos.

La Ley prevé, en este período de la gestión, la participación de los usuarios del

${ }^{985}$ El 30 de noviembre de 1998, España y Portugal firmaron el "Convenio de cooperación para la protección y el aprovechamiento sostenible de las aguas de las cuencas hidrográficas hispanoportuguesas", más conocido como el Convenio de la Albufeira. Es aplicable a las cuencas de los ríos Miño, Limia, Duero, Tajo y Guadiana, que representan el $41 \%$ de la superficie total de España y el $62 \%$ de la de Portugal. Disponible en: $<$ http://www.magrama.gob.es/es/agua/legislacion/conveniodealbufeira_tcm7-28658.pdf>. Acceso en: 0211-2015. El 4 de abril de 2008 se aprueba un protocolo de revisión del Convenio. Disponible en: < http://boe.vlex.es/vid/convenio-hidrograficas-portuguesas-albufeira-74617539>. Acceso en: 02-11-2015.

${ }^{986}$ El 15 de febrero de 2006, es firmado en Toulouse en Acuerdo administrativo entre España y Francia sobre gestión del agua. Disponible en: < http://www.boe.es/buscar/doc.php?id=BOE-A-2006-14633>. Acceso en: 02-11-2015. 
agua en el Consejo Nacional del Agua y en las Asambleas de los Organismos de Cuenca. De estas últimas se configuran otros órganos de participación tales como la Comisión de Desembalse, Junta de Gobierno, Consejo del Agua, Juntas de Explotación, Comunidades de Vertidos y Juntas de Obras, entre otros ${ }^{987}$.

En primer lugar se encontrarían en la gestión del agua en baja, las corporaciones locales: municipios, mancomunidades o entidades metropolitanas o provinciales. A los municipios son atribuidas las competencias en abastecimiento urbano, alcantarillado y depuración de agua urbanas. Sin embargo, pese a que la gestión de estos servicios es una competencia de los municipios, va íntimamente ligada a las competencias autonómicas y estatales de aguas y medio ambiente, por lo tanto, se hace necesario la colaboración entre las distintas administraciones. Además, es importante destacar que este servicio es prestado directamente por los municipios, en régimen de mancomunidad o a través de empresas públicas, mixtas o privadas en régimen de concesión.

En segundo lugar, el sector privado también realiza una función importante en la gestión del agua como usuario final. Las Comunidades de Regantes -consideradas en España como Corporaciones de Derecho Público con participación activa en las Asambleas de las Confederaciones Hidrográficas- gestionan la distribución, reparto y mantenimiento de las redes que llevan el agua desde los canales principales y secundarios hasta la parcela de cada uno de sus miembros. Las Comunidades de Regantes de base pueden estar agrupadas en Comunidades Generales de Usuarios en la que intervienen también, en algunos casos, usuarios urbanos e industriales. Para las posibles situaciones conflictivas estas comunidades tienen Tribunales y Jurados de Riego $^{988}$.

Como contraprestación de los servicios del agua por parte de los diferentes agentes, cuyo objetivo es recuperar los costes de los servicios y asegurar el equilibrio financiero en la prestación de éstos, existen tasas, tarifas, cánones, impuestos y derramas. Sin embargo, esta cuestión es objeto de debate público sobre si estas figuras logran realmente recuperar la totalidad de estos costes. La existencia de subvenciones,

\footnotetext{
987 SÁNCHEZ-MARTÍNEZ， M ${ }^{\mathrm{a}}$ Teresa; RODRÍGUEZ-FERRERO, Noelina; SALAS-VELASCO, Manuel. La gestión del agua en cit., nota de pie de página 7, p. 208.

988 SÁNCHEZ-MARTÍNEZ, M ${ }^{\mathrm{a}}$ Teresa; RODRÍGUEZ-FERRERO, Noelina; SALAS-VELASCO, Manuel. La gestión del agua en cit., nota de pie de página 7, p. 208.
} 
especialmente en la agricultura, es un elemento distorsionador sobre el uso eficiente del agua ya que no reflejan la escasez del recurso, y por tanto son un aspecto especialmente preocupante en un país donde el agua es un recurso escaso ${ }^{989}$.

La importancia de la gestión del agua requiere de una regulación jurídica que establezca unas normas, además de velar por su cumplimiento. Es importante que el marco jurídico de rango nacional tenga en cuenta directrices de orden superior, o supranacionales, precisamente por las visiones geoística ${ }^{990}$ y holística ${ }^{991}$ que deben

${ }^{989}$ Informe integrado de recuperación de costes de los servicios de agua en España. Artículo 5 y anejo III de la Directiva Marco de Agua. Por ello, el Ministerio de Medio Ambiente, con la colaboración de otros organismos públicos y privados, ha hecho un esfuerzo por recoger y poner esta información a disposición de los ciudadanos. Se han recogido y analizado datos muy diversos sobre lo que cuesta la prestación de los servicios de agua; sobre los pagos realizados por parte de los usuarios; sobre el alcance de las ayudas y subvenciones recibidas; sobre las consideraciones sociales en la tarificación; y sobre las estructuras tarifarias, así como si éstas proporcionan incentivos para un uso más eficiente del agua. Ha habido y hay importantes debates públicos sobre los precios del agua y sobre si éstos reflejan o no los costes de prestación de los servicios. La existencia de subvenciones, especialmente a la agricultura, es un importante elemento de debate sobre el uso eficiente del agua. Se ha planteado que la actual legislación sobre el agua es insuficiente para asegurar la recuperación de costes de los servicios prestados por los organismos de cuenca y para asegurar la autosuficiencia financiera recogida como objetivo en la propia Ley de Aguas. También se ha considerado que los precios bajos, que no reflejan la escasez del recurso, son un aspecto especialmente preocupante en un país donde el agua es un recurso escaso. Las pérdidas en las conducciones e infraestructuras -algunas escandalosas- y el derroche de agua -inaceptable social, económica y ambientalmente- son otros elementos a tener en cuenta en este debate crucial para la calidad de vida de las personas y de nuestros ecosistemas. Ministerio de Medio Ambiente, 2007. Disponible en: $<$ http:/hispagua.cedex.es/sites/default/files/especiales/Tarifas_agua/precios_costes_servicios_\%20agua.p df $>$. Acceso en: 03-11-2015.

${ }^{990}$ Para una comprensión de lo que sería una visión geoística, es necesario comprender la definición de geoísmo, para tanto, Antonio Lamela y Fernando Moliní, Geoísmo y Cosmoísmo, enseñan que: "El Geoísmo se puede definir como una propuesta de disciplina y de práctica profesional que pretende contribuir a ordenar territorialmente, en primer lugar, el Planeta en su conjunto, dando respuesta a los problemas globales, entre otros posibles métodos a través de directrices e indicadores mundiales, y, en segundo lugar, a partes del mismo, con enfoques más locales, mediante la planificación supramunicipal, que tendría en cuenta aquellas directrices y que se evaluaría respecto a tales indicadores. El Geoísmo, desde una perspectiva de gestión global del Planeta, propugna ordenar el territorio a diferentes niveles: mundial, continental, nacional y supramunicipal. Puede contribuir a hacer operativos conceptos como el de desarrollo sostenible (WCDE, 1987), al ser un instrumento útil para concretar alguna de las preguntas clave (TRZYNA, T.C., 1995, 16) que sobre el mismo se plantean: ¿cómo se puede medir?; ¿cómo se 
subyacer en la consideración del agua como recurso ${ }^{992}$. En el caso de España, se trata de la Directiva Marco del Agua (DMA), normativa europea que emplaza a los Estados miembros a que en 2015 todas sus aguas tengan, al menos, un 'buen estado ecológico y químico', es decir, sanitario y saludable.

El Real Decreto Legislativo 1/2001, de 20 de julio, por el que se aprueba el Texto Refundido de la Ley de Aguas - transposición de la Directiva Marco del Agua-, y la Ley 22/1988, de 28 de julio, de Costas conforman el marco jurídico básico a nivel nacional en cuanto a la gestión del agua y de la propia costa se refiere. El ámbito de intervención de estas dos normativas son los dominios públicos hídricos -que comprende las aguas continentales superficiales y las subterráneas renovables, además de la gestión del uso del agua- y el dominio marítimo-terrestre, respectivamente.

La esencia de dicha normativa se basa en que el agua no es un bien privativo y comercial, sino un patrimonio social que se debe proteger, pero esto, en ocasiones, choca con malas prácticas fuertemente arraigadas y con privilegios adquiridos que retrasan su efectivo cumplimiento. Además, el desarrollo de una política integral comunitaria de aguas se encuentra, en la práctica, con la dificultad de adaptación a dicha directiva, aparte de la demora en los plazos de cumplimiento; pero es el inicio de una postura más estricta respecto al valioso recurso del agua que debe superar todo tipo de fronteras antrópicas, si es que deseamos ponerlo en su verdadero lugar ${ }^{993}$.

puede convertir el concepto en acción?; y ¿cuáles son los aspectos en que hay que concentrarse? El Geoísmo no debería ser sólo la práctica de una planificación territorial mundial, sino también una disciplina aplicada. Por homología con el urbanismo y la ordenación del territorio, el Geoísmo sería el conjunto de conocimientos y de prácticas de ámbito mundial relativos a la proposición y coordinación de la política medioambiental, económica, social y cultural de los Estados y de los Pueblos, tendente a potenciar sinergias y a evitar disfunciones, para mejor satisfacer las necesidades de la vida humana de las generaciones presentes y futuras, particularmente para disminuir la pobreza y las desigualdades, así como para preservar al máximo la Naturaleza que todavía está poco alterada por el Hombre. Disponible en: $<$ http://www.uam.es/personal_pdi/filoyletras/geoinova/geoismo/definiciones.html>. Acceso en: 02-112015.

${ }^{991}$ En las definiciones del diccionario de la Real Academia Española, Holístico: Perteneciente o relativo al holismo. Definición de holismo: Doctrina que propugna la concepción de cada realidad como un todo distinto de la suma de las partes que lo componen. Disponible en: $<$ http://dle.rae.es/?w=holismo\&o=h $>$. Acceso en: 02-10-2015.

${ }^{992}$ LAMELA, Antonio. El agua en España: nuevos lagos sustentables. Ed. Leo, Madrid-España: 2014.

${ }^{993}$ LAMELA, Antonio. El agua en España: nuevos lagos sustentables. Ed. Leo, Madrid-España: 2014. 


\subsubsection{Dominio público hidráulico}

El dominio público está constituido por el conjunto de bienes que, siendo propiedad de un ente público, están afectos a un uso público, a un servicio público o al fomento de la riqueza nacional. El objetivo de la declaración de dominio público tiene como finalidad fundamental excluir un bien del tráfico privado y alcanzar diferentes objetivos de interés general. Si bien exista una titularidad pública, está orientada hacia el desarrollo de determinadas funciones de interés público ${ }^{994}$.

Tomando como referencia el respeto al ciclo hidrológico y al considerar el agua como un recurso unitario, el artículo 1.2 de la Ley de Aguas de 1985, actual artículo 1.3 del Texto Refundido de la Ley de Aguas, proclamó que todas las aguas continentales, tanto las superficiales como las subterráneas renovables, constituyen parte del dominio público hidráulico ${ }^{995}$. Quedan fuera, pues, del ámbito de aplicación de la Ley las aguas no renovables, que no forman parte del dominio público estatal, y las aguas minerales y termales que según el anterior apartado 4 del precepto, vigente apartado 5, se van a regular por su legislación específica, salvo en lo que hace referencia a las normas básicas de protección de las aguas en el que sí les serán de aplicación las normas de la Ley de Aguas ${ }^{996}$.

Sin embargo, el artículo 2 visa especificar cuáles bienes concretos hacen parte del dominio público hidráulico del Estado, de cualquier modo, dicho precepto debe ser

${ }^{994}$ VILLANUEVA RÍO, Ángel; SAINZ SASTRE, Juan Antonio. Agua. La situación del agua en España. Recursos, gestión y tendencias. Colección EOI Medio Ambiente, 2008, p.16.

995 Según M. a Ángeles Gonzáles Bustos, Tema 1: Los bienes públicos. Cuadernos de Derecho Administrativo IV. Bienes públicos. Ratio Legis, Salamanca-España: 2014, pp. 11-23: “Bienes de demanio necesario, o demaniales por naturaleza, que sólo pueden pertenecer al Estado se comprende [...] el demanio hídrico (ríos, torrentes, lagos, aguas corrientes superficiales y subterráneas, álveos y riberas de los ríos y puertos para la navegación interna)". Además, afirma la autora: "Los bienes demaniales son inalienables, imprescriptibles e inembargables, y por tanto los actos de enajenación sobre ellos son nulos. Para que un bien sea calificado como bien demanial hay que tener en cuenta no sólo que las leyes lo clasifiquen como tal sino también que concurra el elemento del destino, es decir la afectación del bien a una finalidad pública, es decir a un uso o servicio público o al fomento de la riqueza nacional. (Las aguas se afectan al uso público: bañarse, lavar la ropa, navegar...; y también se afectan a la riqueza nacional como por ejemplo su utilización para el riego o para la producción de energía eléctrica)".

${ }^{996}$ GONZÁLES IGLESIAS, Miguel Á. Tema 8: Dominio público hidráulico. Cuadernos de Derecho Administrativo IV. Bienes públicos. Ed. Ratio Legis, Salamanca-España: 2014, p. 142. 
analizado concomitantemente con otros del mismo texto legal en los que van a establecer determinadas excepciones al mismo.

De este modo, no todas las aguas continentales hacen parte del dominio público hidráulico, vez que, a pesar de la declaración general de demanialidad de las mismas que se efectúa en el artículo 1.2, se mantiene la existencia de aguas privadas en determinados casos, al respetarse los derechos adquiridos con arreglo a la Ley de Aguas de $1866-1879^{997}$

Además, el dominio público hidráulico abarca tierra o formaciones geológicas por las que discurre o en las que se contiene agua, o sea, abarca elementos que no son agua.

Importante destacar que en aquellos casos en que excepcionalmente se admite la posible existencia de titularidad privada sobre elementos que, en principio, dada la declaración general de demanialidad, podrían integrarse en el dominio público, como es el caso de las aguas subterráneas, de los lechos de los lagos, lagunas y charcas, o de determinados cauces $^{998}$, la Ley de Aguas somete su propiedad privada a importantes limitaciones ${ }^{999}$.

De forma sencilla, según la Ley de Aguas, constituye el dominio público hidráulico las aguas superficiales y subterráneas, las aguas continentales superficiales $^{1000}$, el terreno que ocupan los cauces, lagos, lagunas, y embalses

${ }^{997}$ Como bien ejemplifica Miguel Á. Gonzáles Iglesias, Dominio público cit., p. 143: "tal es el caso de ciertas aguas superficiales y de ciertos lagos, lagunas y charcas, de las aguas pluviales, y de las aguas subterráneas conforme al régimen transitorio regulado por la Ley de Aguas de 1985.”

${ }^{998}$ De acuerdo con el artículo 2.b del Texto Refundido de la Ley de Aguas, forman parte del dominio público hidráulico los cauces de corrientes naturales, continua o discontinua. Además, los artículos 4, 4.2, 5, 5.2, 8, 9, 11 y 49, todos del Texto Refundido de la Ley de Aguas y los artículos 11 y 14, ambos del RDPH, y el artículo 28.2 de la Ley 10/2001, del Plan Hidrológico Nacional precisan algunos puntos.

${ }^{999}$ GONZÁLES IGLESIAS, Miguel Á. Dominio público cit., p. 143.

${ }^{1000}$ Se integran en el dominio público hidráulico las aguas continentales corrientes, ya sean continuas o discontinuas. Después de la Ley de Aguas de 1985, las aguas de lagos y lagunas son aguas superficiales que se integran, en principio, en el dominio público, salvo en aquellos casos en que existieran inscripciones expresas sobre su titularidad privada en el Registro de la Propiedad, en cuyo caso mantendrán, en virtud de la Disposición Adicional Primera de la Ley de Aguas, el carácter dominical que tuvieran en el momento de entrar en vigor la Ley. En el caso de las charcas, a las que también se aplica la anterior Disposición Adicional, el artículo 10 expresa, además, que en aquellos casos en que estén situadas en predios de titularidad privada se considerarán como parte integrante de los mismos. En suma, 
superficiales $^{1001}$, además de los acuíferos ${ }^{1002}$ y las aguas de desalación ${ }^{1003}$. La consideración como públicos de todos estos elementos conforma un instrumento que permite su ordenación racional.

Aunque no forman parte del dominio público hidráulico, hay zonas que están asociadas, esencialmente los márgenes, que son terrenos que lindan con los cauces, y están sujetos en toda su extensión longitudinal a una zona de servidumbre de 5 metros paralela y contigua al cauce para diferentes fines ${ }^{1004}$ y zona de policía de 100 metros de anchura en la que está condicionado el uso del suelo y las actividades que se desarrollan, además de tener una destacada relevancia en la protección del régimen de corrientes, pudiéndose ampliar esta zona, cuando sea necesario para la seguridad de las

las charcas pueden ser de titularidad privada cuando sobre ellas existan inscripciones en el Registro de la Propiedad con anterioridad a la entrada en vigor de la Ley de Aguas de 1985, pero también, y sin existir dicha inscripción, cuando se encuentre en terrenos de propiedad privada, si bien en este último caso estarán sujetas a la limitación de uso prevista en el artículo 10 del Texto Refundido de la Ley de Aguas y, en concreto, a la de destinar dicho agua al servicio exclusivo de tales predios. Por último, debe decirse que el Texto Refundido de la Ley de Aguas no precisa de forma expresa nada sobre la titularidad de las aguas pluviales. Sin embargo, tal y como señala el artículo 54.1 de dicha Ley, los propietarios de terrenos pueden aprovechar las aguas pluviales y las estancadas, dentro de sus linderos, sin más limitaciones que las establecidas en la presente Ley y las que se deriven de derechos de tercero y de la prohibición del abuso del derecho.

${ }^{1001}$ Los lechos de los lagos y lagunas y los de los embalses superficiales en cauces públicos tal y como aparecen en el artículo 9 del Texto Refundido de la Ley de Aguas, forman parte del dominio público hidráulico. Ello debe entenderse sin perjuicio de lo dispuesto en la Disposición Adicional Primera del Texto Refundido de la Ley de Aguas sobre la titularidad privada de los lagos y lagunas. Ya los terrenos que pueden resultar inundados durante las crecidas no ordinarias de los lagos, lagunas y embalses, dispone el artículo 11 del Texto Refundido de la Ley de Aguas, que para estos casos que mantendrán la calificación jurídica o la titularidad dominical que originalmente tuvieren, siéndoles de aplicación sus disposiciones sobre posibles limitaciones, por motivos de seguridad, a los usos de dichas zonas inundables.

${ }^{1002}$ Los acuíferos subterráneos forman parte del dominio público hidráulico, conforme disponen los artículos 2.d, 12, art. 54.2 y 40 bis, todos del Texto Refundido de la Ley de Aguas.

${ }^{1003}$ Las aguas procedentes de la desalación de mar forman parte del dominio público hidráulico de acuerdo con lo que disponen los artículos 2.e y 13 apartados 2, 3 y 4, ambos del Texto Refundido de la Ley de Aguas.

1004 Tales como: protección del ecosistema fluvial, paso público peatonal, vigilancia, pesca fluvial, salvamento, varado y amarre de embarcaciones. 
personas y bienes ${ }^{1005}$.

La delimitación de estos terrenos que forman parte del dominio público puede producir conflictos con los colindantes que el Derecho trata de evitar mediante un procedimiento llamado deslinde ${ }^{1006}$. Éste trata de delimitar el cauce de un río, lago [...] con el fin de establecer cuáles son los terrenos de dominio público y cuáles propiedad privada de fincas colindantes.

Por último, hay elementos del medio acuático que pueden no adentrar el ámbito del dominio público hidráulico, como las aguas minerales y termales ${ }^{1007}$, cauces por los que ocasionalmente discurran aguas pluviales, en tanto atraviesen desde su origen únicamente fincas de propiedad particular, charcas si están en predios de propiedad privada y su uso es exclusivo, y lagos, lagunas y charcas sobre los que existan inscripciones expresas en el Registro de la Propiedad.

Respecto a las aguas subterráneas, una de las novedades más importantes de la Ley de Aguas de 1985 consistió en la demanialización de dichas aguas, aunque esta declaración está sujeta a importantes excepciones que han permitido que sigan existiendo bajo dominio privado importantes masas de este recursos ${ }^{1008}$.

${ }^{1005}$ VILlANUEVA RÍO, Ángel; SAINZ SASTRE, Juan Antonio. Agua. La situación del agua en España. Recursos, gestión y tendencias. Colección EOI Medio Ambiente, 2008, p.16.

${ }^{1006}$ Según Ángel Villanueva Río Y Juan Antonio Sainz Sastre, Agua. La situación del agua en cit., p.16: "acto delimitador de una superficie de una finca respecto de las colindes".

${ }^{1007}$ El artículo 1.4 del Texto refundido de la Ley de Aguas remite la regulación de las aguas minerales y termales a su legislación específica, o sea, la Ley 22/1973, de 21 de julio, de Minas.

${ }^{1008}$ Conforme Miguel Á. Gonzáles Iglesias, Dominio público cit., p. 143: "No podemos olvidarnos que las aguas subterráneas constituyen un recurso particularmente importante ya que se estima que dicho agua proporciona alrededor del $65 \%$ de toda el agua potable en la Unión Europea y que el 60\% de las ciudades europeas explotan en exceso sus recursos de agua subterránea. En España se calcula que una tercera parte de la población se abastece para los usos urbanos con aguas subterráneas y que los regadíos españoles que se alimentan de aguas subterráneas son notablemente más productivos que aquellos que utilizan aguas superficiales". Además, el autor, p.144, enseña que: "Los arts. 1 y 2 de la LA de 1985 declararon, con carácter general, que las aguas subterráneas renovables formaban parte del dominio público hidráulico. Pero la misma LA compatibilizó la declaración legal del dominio público de las aguas subterráneas (hasta ese momento se atribuía su propiedad al particular que las alumbrase) con el respeto a las situaciones jurídicas privadas preexistentes mediante una fórmula que permitía a los titulares de aguas privadas conforme a la Ley de 1879 elegir entre el mantenimiento de esas titularidades privadas o la conservación de la propiedad de las aguas en derechos de aprovechamiento sobre las mismas con la protección del Registro de Aguas regulado por la LA de 1985". 
De este modo, las aguas subterráneas podían pasar al dominio público o permanecer en la esfera de lo privado $^{1009}$, pero sin la tutela administrativa que ha de facilitar a los derechos de usos privativos sobre el dominio público hidráulico la inscripción en el Registro de Aguas, regulado en el artículo $80^{1010}$ del Texto Refundido de la Ley de Aguas. También, el legislador estableció que el carácter opcional de la alternativa eximía a la Administración de cualquier obligación compensatoria, siendo este sistema considerado conforme con la Constitución Española en la Sentencia del Tribunal Constitucional 227, $1988^{1011}$.

Ya las aguas subterráneas no renovables o también denominadas aguas fósiles se puede deducir que están excluidas del dominio público hidráulico, en virtud del artículo 2.a del Texto refundido de la Ley de Aguas, vez que dispone que forman parte del dominio público hidráulico las aguas subterráneas renovables con independencia del tiempo de su renovación. Así, de esta disposición y del artículo 1.3 de la referida Ley, quedan fuera del dominio público hidráulico.

Por fin, según Miguel Á. Gonzáles Iglesias: “debe señalarse que para superar la situación en que se encuentra el uso de las aguas subterráneas, sean públicas o privadas, es necesario el que se refuerce la operatividad de los organismos responsables de la gestión de las cuencas hidrográficas y, con ello, del Registro de Aguas y del Catálogo de Aguas Privadas como instrumentos esenciales para articular una correcta gestión del recurso desde el conocimiento y control de los aprovechamientos existentes" ${ }^{, 1012}$.

${ }^{1009}$ Interesantes comentarios acerca de las aguas privadas fueron hechos por Miguel Á. Gonzáles Iglesias, Dominio público cit., pp. 145 y ss.

${ }^{1010}$ Artículo 80. Características del Registro de Aguas.

“1. Los Organismos de cuenca llevarán un Registro de Aguas en el que se inscribirán de oficio las concesiones de agua, así como los cambios autorizados que se produzcan en su titularidad o en sus características. La organización y normas de funcionamiento del Registro de Aguas se fijarán por vía reglamentaria.

2. El Registro de Aguas tendrá carácter público, pudiendo interesarse del Organismo de cuenca las oportunas certificaciones sobre su contenido.

3. Los titulares de concesiones de aguas inscritas en el Registro correspondiente podrán interesar la intervención del Organismo de cuenca competente en defensa de sus derechos, de acuerdo con el contenido de la concesión y de lo establecido en la legislación en materia de aguas.

4. La inscripción registral será medio de prueba de la existencia y situación de la concesión”.

1011 GONZÁLES IGLESIAS, Miguel Á. Dominio público cit., p. 145.

1012 GONZÁLES IGLESIAS, Miguel Á. Dominio público cit., p. 147. 


\subsubsection{Administración de los recursos hídricos}

El Título II, 'De la Administración pública del agua' del Texto Refundido de la Ley de Aguas, contiene un primer capítulo sobre los principios generales aplicables a dicha administración, y dos capítulos más en los que se regulan el Consejo Nacional del Agua, como órgano consultivo y de participación de ámbito nacional, y los Organismos de Cuenca, responsables de la planificación, gestión y protección del dominio público hidráulico.

Aun así, pese a definirse como corporaciones de derecho público encontramos en el Título IV ‘De la utilización del dominio público hidráulico’ la regulación de las comunidades de usuarios ${ }^{1013}$.

Las aguas de una misma cuenca forman un conjunto integrado que debe ser gestionado de manera homogénea. El criterio de cuenca hidrográfica como unidad de gestión permite una administración equilibrada de los recursos con independencia de la división administrativa o política.

Los Principios rectores de la gestión en materia de aguas están dispuestos en el artículo $14^{1014}$ del Texto Refundido de la Ley de Aguas. Estos principios trazan el perfil de los rasgos esenciales de la organización de la Administración hidráulica en España, especialmente, los principios de unidad de gestión, desconcentración, descentralización, coordinación, eficacia, participación de los usuarios respeto a la unidad de la cuenca hidrográfica.

Importante destacar que la distribución de competencias que deriva de la Constitución Española se va a concretar y perfilar en la Ley de Aguas de 1985 sobre la base del principio de unidad de gestión de cada cuenca hidrográfica, que fue aceptado como conforme el artículo 149.1.22 de la Constitución por la Sentencia del Tribunal

\footnotetext{
${ }^{1013}$ Idem, p. 151.

${ }^{1014}$ Artículo 14. Principios rectores de la gestión en materia de aguas.

"El ejercicio de las funciones del Estado, en materia de aguas, se someterá a los siguientes principios:

1. Unidad de gestión, tratamiento integral, economía del agua, desconcentración, descentralización, coordinación, eficacia y participación de los usuarios.

2. ${ }^{\circ}$ Respeto a la unidad de la cuenca hidrográfica, de los sistemas hidráulicos y del ciclo hidrológico.

3. ${ }^{\circ}$ Compatibilidad de la gestión pública del agua con la ordenación del territorio, la conservación y protección del medio ambiente y la restauración de la naturaleza".
} 
Constitucional 227/1988, de 29 de noviembre ${ }^{1015}$, con los siguientes argumentos: "el criterio de la cuenca hidrográfica como unidad de gestión permite una administración equilibrada de los recursos hidráulicos que la integran, en atención al conjunto de intereses afectados que, cuando la cuenca se extiende al territorio de mas de una comunidad autónoma, son manifiestamente supracomunitarios”.

Además, la Ley de Aguas concreta las definiciones ${ }^{1016}$ de cuenca y demarcación hidrográfica y determina el respeto a la unidad de cuenca hidrográfica

${ }^{1015}$ Pleno. Sentencia 227/1988, de 29 de noviembre. Recursos de inconstitucionalidad 824, 944, 977, 987 y 988/1985 y conflictos positivos de competencia 995/1986 y 512 y 1.208/1987 (acumulados). Promovidos los cuatro primeros, respectivamente, por la Junta de Galicia, por 59 Senadores, por el Consejo de Gobierno de las Islas Baleares, por el Gobierno Vasco y por el Consejo de Gobierno de la Diputación Regional de Cantabria, todos ellos en relación con la Ley 29/1985, de 2 de agosto, de Aguas, y los tres siguientes planteados por el Gobierno Vasco en relación, respectivamente, con el Real Decreto 849/1986, de 11 de abril; la Orden de 23 de diciembre de 1986 del Ministerio de Obras Públicas y Urbanismo, y el Real Decreto 650/1987, de 8 de mayo. Disponible en: < http://www.boe.es/diario_boe/txt.php?id=BOE-T-1988-29199>. Acceso en: 03-11-2015.

${ }^{1016}$ Artículo 16. Definición de cuenca hidrográfica.

"A los efectos de esta ley, se entiende por cuenca hidrográfica la superficie de terreno cuya escorrentía superficial fluye en su totalidad a través de una serie de corrientes, ríos y eventualmente lagos hacia el mar por una única desembocadura, estuario o delta. La cuenca hidrográfica como unidad de gestión del recurso se considera indivisible".

Artículo 16 bis. Demarcación hidrográfica

“1. Se entiende por demarcación hidrográfica la zona terrestre y marina compuesta por una o varias cuencas hidrográficas vecinas y las aguas de transición, subterráneas y costeras asociadas a dichas cuencas.

Son aguas de transición, las masas de agua superficial próximas a la desembocadura de los ríos que son parcialmente salinas como consecuencia de su proximidad a las aguas costeras, pero que reciben una notable influencia de flujos de agua dulce.

Son aguas costeras, las aguas superficiales situadas hacia tierra desde una línea cuya totalidad de puntos se encuentra a una distancia de una milla náutica mar adentro desde el punto más próximo de la línea de base que sirve para medir la anchura de las aguas territoriales y que se extienden, en su caso, hasta el límite exterior de las aguas de transición.

2. Las aguas costeras se especificarán e incluirán en la demarcación o demarcaciones hidrográficas más próximas o más apropiadas.

3. Los acuíferos que no correspondan plenamente a ninguna demarcación en particular, se incluirán en la demarcación más próxima o más apropiada, pudiendo atribuirse a cada una de las demarcaciones la parte de acuífero correspondiente a su respectivo ámbito territorial, y debiendo garantizarse, en este caso, una 
gestión coordinada mediante las oportunas notificaciones entre demarcaciones afectadas.

4. La demarcación hidrográfica, como principal unidad a efectos de la gestión de cuencas, constituye el ámbito espacial al que se aplican las normas de protección de las aguas contempladas en esta ley sin perjuicio del régimen específico de protección del medio marino que pueda establecer el Estado.

5. El Gobierno, por real decreto, oídas las comunidades autónomas, fijará el ámbito territorial de cada demarcación hidrográfica que será coincidente con el de su plan hidrológico".

Importante resaltar que el Real Decreto 125/2007, de 2 de febrero, por el que se fija el ámbito territorial de las demarcaciones hidrográficas dispone que: "El artículo 16 bis 5 del Texto Refundido de la Ley de Aguas aprobado por el Real Decreto Legislativo 1/2001, de 20 de julio, encomienda al Gobierno de la Nación la fijación mediante real decreto, oídas las comunidades autónomas, del ámbito territorial de las demarcaciones hidrográficas añadiendo, además, que éste será coincidente con el de su plan hidrológico. El precepto indicado lleva a cabo la necesaria habilitación para completar, en el ámbito de las competencias de la Administración General del Estado, la regulación jurídica correspondiente a la incorporación al derecho de aguas español del concepto de demarcación hidrográfica creado por la Directiva 2000/60/CE del Parlamento Europeo y del Consejo de 23 de octubre de 2000, por la que se establece un marco comunitario de actuación en el ámbito de la política de aguas. A los efectos de dar cumplimiento a lo previsto en el artículo 16 bis 5 mencionado y, consiguientemente, de fijar las demarcaciones hidrográficas cuyo ámbito territorial afecte a más de una comunidad autónoma, se han tenido en cuenta principios distintos. En primer lugar, y obviamente, se ha procurado el estricto cumplimiento del concepto de demarcaciones hidrográficas tal y como resulta de su incorporación al derecho español y teniendo en cuenta a efectos interpretativos el contenido del artículo 3 de la Directiva 2000/60/CE. En el caso específico de España, ese concepto no puede operar sobre el presupuesto de un hipotético vacío previo, sino, al contrario, sobre una estructura de cuencas hidrográficas más que consolidada y ajustada en líneas generales a la estructura organizativa y de división competencial entre el Estado y las comunidades autónomas. Por eso se ha optado por mantener, en la medida de lo posible, la actual estructura de cuencas hidrográficas mediante la correspondiente adición de las aguas de transición y las costeras según resulta también del contenido del artículo 16 bis del Texto Refundido de la Ley de Aguas. Los límites entre las aguas costeras de demarcaciones vecinas se han establecido mediante líneas definidas por el punto terrestre por el que pasan y su orientación con respecto al Norte geográfico. Por otra parte, el real decreto ha optado por considerar incluidas en cada demarcación todas las aguas subterráneas situadas bajo los límites definidos por las divisorias de las cuencas hidrográficas de la correspondiente demarcación. La gestión de esas aguas se realiza en la actualidad mediante las unidades hidrogeológicas, debiendo articularse en su caso, a la largo del proceso de planificación y una vez definidas las masas de agua subterránea que sustituyan a dichas unidades, los mecanismos de coordinación entre los Organismos competentes de cada demarcación que garanticen la consecución de los objetivos ambientales establecidos para dichas masas. El real decreto se ocupa del caso especial de las cuencas compartidas con Estados vecinos. En el supuesto de las cuencas compartidas con Portugal, al margen de las decisiones que ahora se tomen, en el futuro deberán definirse por los dos Estados unas demarcaciones hidrográficas internacionales no pudiendo España hacer otra cosa ahora que señalar la 
que se considera como indivisible. Por ello, cada cuenca debe ser administrada por una autoridad única, de manera que sólo se admitirían competencias autonómicas en cuencas comprendidas íntegramente en su territorio.

Respecto al principio de la unidad de cuenca, el Texto Refundido de la Ley de Aguas precisa las funciones que va a ejercer el Estado en aquellas cuencas que excedan del ámbito territorial de una Comunidad Autónoma, también denominadas como cuencas intercomunitarias. El artículo 17 de dicha Ley especifica estas funciones:

“Artículo 17. Funciones del Estado en relación con el dominio público hidráulico.

En relación con el dominio público hidráulico y en el marco de las competencias que le son atribuidas por la Constitución, el Estado ejercerá, especialmente, las funciones siguientes:

correspondiente parte española de esas demarcaciones internacionales. En ese plano, este real decreto adopta igualmente decisiones en torno a pequeñas superficies que forman parte de cuencas compartidas entre Francia y España. Dichas superficies no son muy significativas dentro del conjunto de la cuenca compartida en cuanto a extensión, por lo que en estos casos no se estima necesario definir una demarcación internacional, atendiendo a la innecesaria complicación que supondría para la gestión. Por último, tomando también como punto interpretativo el artículo 3 de la Directiva 2000/60/CE, se prevé la resolución del supuesto particular relativo a Andorra, Ceuta y Melilla. La disposición transitoria única tiene la finalidad de aclarar que la inclusión de determinadas cuencas hidrográficas en el ámbito de alguna demarcación hidrográfica reviste carácter provisional en aquellos casos en que se trate de cuencas comprendidas en su totalidad en una comunidad autónoma determinada y que hasta la fecha no hayan sido objeto de traspaso. Dicha provisionalidad finalizará cuando las comunidades autónomas afectadas asuman de manera efectiva las competencias sobre dichas cuencas. En ese momento deberán revisarse las demarcaciones hidrográficas correspondientes. La revisión de la Demarcación Hidrográfica del Júcar deberá respetar, en todo caso, lo resuelto por la Sentencia del Tribunal Supremo de 20 de octubre de 2004. El resto de supuestos a los que se refiere este real decreto pueden ser entendidos perfectamente, sin necesidad de explicación adicional alguna, en función de la aplicación del criterio general ya indicado de respeto a la situación tanto hidrográfica como de división competencial preexistente. Finalmente, en el procedimiento de elaboración de esta norma se ha consultado, entre otros, a las comunidades autónomas y al Consejo Nacional del Agua”. Información disponible en las páginas 251-252 del Código de Aguas Normativa

Estatal: https://www.boe.es/legislacion/codigos/codigo.php?id=032_Codigo_de_Aguas_Normativa_Estatal\&mod $\underline{\mathrm{o}=1}$. Acceso en: 02-12-2015. 
a) La planificación hidrológica y la realización de los planes estatales de infraestructuras hidráulicas o cualquier otro estatal que forme parte de aquéllas.

b) La adopción de las medidas precisas para el cumplimiento de los acuerdos y Convenios internacionales en materia de aguas.

c) El otorgamiento de concesiones referentes al dominio público hidráulico en las cuencas hidrográficas que excedan del ámbito territorial de una sola Comunidad Autónoma.

d) El otorgamiento de autorizaciones referentes al dominio público hidráulico, así como la tutela de éste, en las cuencas hidrográficas que excedan del ámbito territorial, de una sola Comunidad Autónoma. La tramitación de las mismas podrá, no obstante, ser encomendada a las Comunidades Autónomas".

También, el Texto Refundido de la Ley de Aguas sienta las bases que han de respetarse por las Comunidades Autónomas cuando, con arreglo a sus Estatutos de Autonomía, ejerzan competencias sobre el dominio público hidráulico en cuencas hidrográficas comprendidas íntegramente dentro de su territorio o cuencas intracomunitarias también denominadas. De este modo, el artículo 18 de dicha Ley señala:

“Artículo 18. Régimen jurídico básico aplicable a las Comunidades Autónomas.

1. La Comunidad Autónoma que, en virtud de su Estatuto de Autonomía, ejerza competencia sobre el dominio público hidráulico en cuencas hidrográficas comprendidas íntegramente dentro de su territorio, ajustará el régimen jurídico de su administración hidráulica a las siguientes bases:

a) Aplicación de los principios establecidos en el artículo 14 de esta Ley.

b) La representación de los usuarios en los órganos colegiados de la Administración hidráulica no será inferior al tercio de los miembros que los integren”.

Por otro lado, la Administración del agua, vertebrada territorialmente sobre la base de la distinción entre las cuencas hidrográficas intercomunitarias e intracomunitarias, no sólo responde al principio de descentralización político-territorial sino que va a quedar en manos de entes públicos instrumentales (los Organismos de cuenca), especializados en la planificación, gestión y protección de este recurso, respondiendo también así al principio de descentralización funcional, y cuya organización interna se articula conforme al principio de descentralización de 
competencias entre órganos jerárquica, funcional y espacialmente organizados ${ }^{1017}$.

Por lo que toca, los principios de participación y coordinación el Texto Refundido de la Ley de Aguas va a establecer, en la Administración hidráulica de competencia estatal, órganos de composición mixta en los que se van a integrar, participando en el ejercicio de sus funciones, representantes de la Administración General del Estado, de las Comunidades Autónomas y de los Entes Locales, así como de los usuarios de las aguas ${ }^{1018}$.

El Consejo Nacional del Agua está dispuesto el artículo 19 del Texto Refundido de la Ley de Aguas e está regulado como órgano consultivo y de participación, además, especifica que forman parte del mismo: la Administración General del Estado, las Comunidades autónomas, los Entes locales a través de la asociación de ámbito estatal con mayor implantación, los Organismos de cuenca, las organizaciones profesionales y económicas más representativas de ámbito estatal relacionadas con los distintos usos del agua, las organizaciones sindicales y empresariales más representativas en el ámbito estatal, las entidades sin fines lucrativos de ámbito estatal cuyo objeto esté constituido por la defensa de intereses ambientales.

Además, la presidencia del Consejo Nacional del Agua recaerá en el titular del Ministerio de Medio Ambiente. Su composición y estructura orgánica se determinarán por Real Decreto.

Sin embargo, compete al Consejo Nacional del Agua, conforme determina el artículo 20 del Texto Refundido de la Ley de Aguas:

a) El proyecto del Plan Hidrológico Nacional, antes de su aprobación por el Gobierno para su remisión a las Cortes.

b) Los planes hidrológicos de cuenca, antes de su aprobación por el Gobierno.

c) Los proyectos de las disposiciones de carácter general de aplicación en todo el territorio nacional relativas a la protección de las aguas y a la ordenación del dominio público hidráulico.

d) Los planes y proyectos de interés general de ordenación agraria, urbana, industrial y de aprovechamientos energéticos o de ordenación del territorio en tanto afecten sustancialmente a la planificación hidrológica o a los usos del agua.

e) Las cuestiones comunes a dos o más organismos de cuenca en relación con

\footnotetext{
${ }^{1017}$ GONZÁLES IGLESIAS, Miguel Á. Dominio público cit., pp. 152-153.

${ }^{1018}$ GONZÁLES IGLESIAS, Miguel Á. Dominio público cit., p. 153.
} 
el aprovechamiento de recursos hídricos y demás bienes del dominio público hidráulico.

Asimismo, emitirá informe sobre todas aquellas cuestiones relacionadas con el dominio público hidráulico que pudieran serle consultadas por el Gobierno o por los órganos ejecutivos superiores de las Comunidades Autónomas.

El Consejo podrá proponer a las Administraciones y organismos públicos las líneas de estudio e investigación para el desarrollo de las innovaciones técnicas en lo que se refiere a obtención, empleo, conservación, recuperación, tratamiento integral y economía del agua.

Si una cuenca comprende varias Comunidades Autónomas, la gestión es del Estado (cuencas intercomunitarias) a través de organismos de cuenca denominados Confederaciones Hidrográficas, que son organismos autónomos adscritos a efectos administrativos al Ministerio de Medio Ambiente (artículo $22^{1019}$ del Texto Refundido de la Ley de Aguas). Si una cuenca está íntegramente comprendida en el territorio de una Comunidad Autónoma (cuencas intracomunitarias) las competencias serán ejercidas por ésta, por lo que en este caso la gestión de las aguas recae sobre la Administración hidráulica autonómica. En la actualidad, parte de las cuencas internas son gestionadas por las Confederaciones Hidrográficas, situación que se irá

${ }^{1019}$ Artículo 22. Naturaleza y régimen jurídico de los organismos de cuenca.

“1. Los organismos de cuenca, con la denominación de Confederaciones Hidrográficas, son organismos autónomos de los previstos en el artículo 43.1.a) de la Ley 6/1997, de 14 de abril, de Organización y Funcionamiento de la Administración General del Estado, adscritos, a efectos administrativos, al Ministerio de Medio Ambiente.

2. Los organismos de cuenca dispondrán de autonomía para regir y administrar por sí los intereses que les sean confiados; para adquirir y enajenar los bienes y derechos que puedan constituir su propio patrimonio; para contratar y obligarse y para ejercer, ante los Tribunales, todo género de acciones, sin más limitaciones que las impuestas por las Leyes. Sus actos y resoluciones ponen fin a la vía administrativa.

3. Su ámbito territorial, que se definirá reglamentariamente, comprenderá una o varias cuencas hidrográficas indivisas, con la sola limitación derivada de las fronteras internacionales.

4. Los organismos de cuenca se rigen por la Ley 6/1997, de 14 de abril, y demás disposiciones de aplicación a los organismos autónomos de la Administración General del Estado, así como por la presente Ley y por los Reglamentos dictados para su desarrollo y ejecución”. 
paulatinamente corrigiendo al asumir estas competencias la Administración autonómica $^{1020}$.

El ámbito territorial de los organismos de cuenca se define legalmente comprendiendo una o varias cuencas hidrográficas indivisas, con la limitación derivada de las fronteras internacionales (artículo 22.3 del Texto Refundido de la Ley de Aguas).

La regulación general de las Confederaciones Hidrográficas está recogida, actualmente, en el Título II 'De la administración pública del agua', del Texto Refundido de la Ley de Aguas, en los artículos 21 a 39.

Además, importante destacar, conforme dispone Real Decreto 126/2007, de 2 de febrero, por el que se regulan la composición, funcionamiento y atribuciones de los comités de autoridades competentes de las demarcaciones hidrográficas con cuencas intercomunitarias: "El artículo 36 bis del Texto Refundido de la Ley de Aguas, aprobado por el Real Decreto Legislativo 1/2001, de 20 de julio, dispone la existencia en el caso de las demarcaciones hidrográficas con cuencas intercomunitarias, de un órgano de cooperación denominado Comité de Autoridades Competentes. Determinadas por el Real Decreto 125/2007, de 2 de febrero, las demarcaciones hidrográficas tal y como dispone el artículo 16 bis 5 del citado texto refundido, se debe proceder a regular la composición, funcionamiento y atribuciones de los Comités de Autoridades Competentes a los efectos de posibilitar su funcionamiento efectivo. Este real decreto desarrolla lo previsto en el artículo 3.2 de la Directiva 2000/60/CE del Parlamento Europeo y del Consejo, de 23 de octubre de 2000, por la que se establece un marco comunitario de acción en el ámbito de la política de aguas, y en el apartado tercero del artículo 36 bis del Texto Refundido de la Ley de Aguas, adoptando en lo relativo a la Administración General del Estado las decisiones concretas sobre el número y la distribución de miembros que deben estar presentes en los Comités de Autoridades Competentes, igualándose aquel con el número de representantes de las comunidades autónomas, tal y como exige el párrafo a) del artículo 36 bis.3 del citado texto refundido. En relación a las comunidades autónomas, el real decreto se limita a fijar las que deberán estar presentes en los Comités de Autoridades Competentes a partir de la

${ }^{1020}$ De acuerdo a los principios de unidad de gestión, descentralización y respeto a la unidad de la cuenca hidrográfica, los Organismos de cuenca van a ser las únicas Administraciones encargadas de la gestión del agua en cada cuenca o grupos de pequeñas cuencas hidrográficas. 
mera constatación de cuáles son las que tienen su territorio, en todo o en parte, dentro del ámbito de la demarcación hidrográfica. Finalmente, se destaca la representación de las entidades locales. En relación al funcionamiento de los Comités, parece claro que su carácter de órgano de cooperación y su vinculación al Organismo de cuenca de la Demarcación hidrográfica determinan que deba contar con un apoyo específico de los servicios de la presidencia del Organismo de cuenca dado que el Presidente de estos Organismos es por determinación legal, a su vez, Presidente del Comité de Autoridades Competentes. Finalmente se fijan las atribuciones de los Comités de Autoridades Competentes a partir del esquema básico presente en el apartado primero del artículo 36 bis del Texto Refundido de la Ley de Aguas complementado con la referencia del artículo 99 bis.3. Para ello se ha tenido buen cuidado en respetar su carácter fundamental de órgano de cooperación y lo que debe ser, lógicamente, objetivo fundamental del Comité, como es su participación en los procesos relativos a la formación y revisión de la planificación hidrológica, todo ello, claro está, desde la perspectiva específica que sirve de base a la creación de este órgano como es la protección de las aguas. Este real decreto adopta las decisiones fundamentales mediante las cuales pueda constituirse este nuevo órgano en cada demarcación hidrográfica, para así proceder al cumplimiento de las funciones y atribuciones que le otorga el Texto Refundido de la Ley de Aguas. Finalmente, en el procedimiento de elaboración de esta norma se ha consultado, entre otros, a las comunidades autónomas y al Consejo Nacional del Agua"1021.

Respecto a las demarcaciones hidrográficas y el Comité de autoridades competentes, por influjo de la Directiva Marco del Agua, el Texto Refundido de la Ley de Aguas amplia su ámbito de aplicación, en los que se refiere a tutela de la calidad y del buen estado ecológico de las aguas más allá de las aguas continentales para abarcar también a las aguas costeras (artículo 16 del Texto Refundido de la Ley

\footnotetext{
${ }^{1021}$ Así, es objeto del Real Decreto 126/2007, de 2 de febrero, la regulación de la composición, funcionamiento y atribuciones de los Comités de Autoridades Competentes de las demarcaciones hidrográficas con cuencas intercomunitarias previstos en el artículo 36.bis del Texto Refundido de la Ley de Aguas, aprobado por el Real Decreto Legislativo 1/2001, de 20 de junio. Información disponible en las páginas 257-258 del Código de Aguas Normativa Estatal: https://www.boe.es/legislacion/codigos/codigo.php?id=032_Codigo_de_Aguas_Normativa_Estatal\&mod $\underline{\mathrm{o}=1}$. Acceso en: 02-12-2015.
} 
de Aguas) cuya calidad va a depender fundamentalmente de la cantidad y calidad de los aportes de agua dulce de los ríos ${ }^{1022}$.

El Derecho de Aguas Español recoge fórmulas históricas de autoadministración de las aguas como es el caso de las Comunidades de Regantes, previsto en la Ley de Aguas de 1866-1879. Esta figura fue recogida por la Ley de Aguas de 1985, sin embargo, fue generalizada para todos los tipos de usos del agua y otros bienes del dominio hidráulico de una misma toma o concesión que puedan llevarse a cabo de forma colectiva. De este modo, en la regularización actual, cuando el destino dado a las aguas sea esencialmente el riego, van a seguir denominándose Comunidades de Regantes; en otro caso, las comunidades recibirán el calificativo que caracterice el destino del aprovechamiento colectivo (artículo $80^{1023}$ del Texto Refundido de la Ley de Aguas).

Artículo 199.2 del Reglamento del Dominio Público Hidráulico dispone que

${ }^{1022}$ Conforme Miguel Á. Gonzáles Iglesias, Dominio público cit., p. 156: “A dichos efectos se crea, precisamente, en el art. 16 bis TRLA la figura de la Demarcación Hidrográfica, que se define como la zona terrestre y marina compuesta por una o varias cuencas hidrográficas vecinas y las aguas de transición, subterráneas y costeras asociadas a dichas cuencas. Pues bien, para poder abarcar la protección de todas esas aguas, desde las continentales a las costeras, la demarcación hidrográfica se configura como la principal unidad a efectos de la gestión de las cuencas (art. 16 bis apartado $4^{\circ}$ TRLA), incluyendo en su ámbito las aguas costeras asociadas a las cuencas. En definitiva, las demarcaciones hidrográficas se constituyen como el nuevo espacio administrativo en el que se aplican las normas de protección de las citadas aguas y que viene a suponerse al tradicional utilizado en nuestro Derecho como ámbito territorial de gestión administrativa de las aguas: la cuenca hidrográfica. Además, el ámbito de los planes hidrológicos va a extenderse, por lo tanto, para acoger también las zonas marinas y las aguas costeras (art. 42 TRLA)".

${ }^{1023}$ Artículo 80. Características del Registro de Aguas.

“1. Los Organismos de cuenca llevarán un Registro de Aguas en el que se inscribirán de oficio las concesiones de agua, así como los cambios autorizados que se produzcan en su titularidad o en sus características. La organización y normas de funcionamiento del Registro de Aguas se fijarán por vía reglamentaria.

2. El Registro de Aguas tendrá carácter público, pudiendo interesarse del Organismo de cuenca las oportunas certificaciones sobre su contenido.

3. Los titulares de concesiones de aguas inscritas en el Registro correspondiente podrán interesar la intervención del Organismo de cuenca competente en defensa de sus derechos, de acuerdo con el contenido de la concesión y de lo establecido en la legislación en materia de aguas.

4. La inscripción registral será medio de prueba de la existencia y situación de la concesión”. 
las Comunidades de Usuarios realizan, por mandato de la Ley y con la autonomía que en ella se les reconoce, las funciones de policía, distribución y administración de las aguas que tengan concedidas por la Administración.

Las principales características de los usuarios están dispuestas en el artículo 198 del Reglamento del Dominio Público Hidráulico ${ }^{1024}$ y en el artículo 81 del Texto Refundido de la Ley de Aguas.

Muchos son los organismos que intervienen en la gestión del agua en España, por lo que el componente institucional es clave y las estructuras administrativas que lo soporta son esenciales. De éstos hay que destacar dos por su especial importancia: las Confederaciones Hidrográficas, o Administraciones hidráulicas equivalentes en cuencas intracomunitarias, y las Comunidades de regante. Las primeras, por ser el órgano administrativo básico competente en la materia, y las segundas, por ser las depositarias de la mayor parte del uso consultivo de agua en España ${ }^{1025}$.

Por exigencia del Derecho Ambiental Europeo, a través de la Directiva 2003/4/CE, del Parlamento y del Consejo, relativa al acceso del público a la información medioambiental y la Directiva 2003/35/CE, por la que se establecen medidas para la participación del público en la elaboración de determinados planes y programas relacionados con el medio ambiente, se han ido introduciendo una serie de disposiciones tendentes a posibilitar una mejor información y participación del público en relación con las actuaciones administrativas que afecten a la gestión y al estado de las aguas.

Además, el artículo 15 del Texto Refundido de la Ley de Aguas reconoce que todas las personas físicas o jurídicas tienen derecho a acceder a la información en materia de aguas en los términos previstos en la Ley $27 / 2006$, de 18 de julio ${ }^{1026}$.

${ }^{1024}$ Real Decreto 849/1986, de 11 de abril, por el que se aprueba el Reglamento del Dominio Público Hidráulico, que desarrolla los títulos preliminar I, IV, V, VI y VII de la Ley 29/1985, de 2 de agosto, de Aguas. Disponible en: < https:/www.boe.es/buscar/act.php?id=BOE-A-1986-10638>. Acceso en: 03-112015.

${ }^{1025}$ VILLANUEVA RÍO, Ángel; SAINZ SASTRE, Juan Antonio. Agua. La situación del agua en cit., p. 18.

${ }^{1026}$ Ley 27/2006, de 18 de julio, por la que se regulan los derechos de acceso a la información, de participación pública y de acceso a la justicia en materia de medio ambiente (incorpora las Directivas 2003/4/CE y 2003/35/CE). Disponible en: < https:/www.boe.es/buscar/doc.php?id=BOE-A-200613010>. Acceso en: 03-11-2015. En este sentido, Miguel Á. Gonzáles Iglesias, Dominio público cit., p. 
También la Ley $10 / 2001$, de 5 de julio ${ }^{1027}$, por la que se aprobó el Plan Hidrológico Nacional incluyó disposiciones ordenando al Ministerio competente la

161, afirma que: "Sin perjuicio de que dicha Ley contempla ciertos límites y excepciones al derecho de acceso a la información sobre medio ambiente, para salvaguardar ciertos intereses públicos o determinados derechos subjetivos, en ella se consagra un concepto de información sobre medio ambiente bastante amplio, comprendiendo la información sobre cualquier situación o actuación administrativa que, directa o indirectamente, pueda afectar al medio ambiente acuático, incluida la información sobre concesiones -que pueden repercutir negativamente en los caudales ecológicos o en la explotación racional de los acuíferos-, o sobre planes o programas sectoriales que, aunque no incidan directamente sobre la gestión o protección de las aguas, puedan tener un impacto significativo sobre las mismas".

1027 Ley 10/2001, de 5 de julio, del Plan Hidrológico Nacional. Disponible en: $<$ https://www.boe.es/buscar/doc.php?id=BOE-A-2001-13042>. Acceso en: 03-11-2015. Además, los artículos 1 y 2 de la citada Ley dispone que:

Artículo 1. Objeto de la Ley.

"El objeto de la presente Ley es la regulación de las materias a que se refiere el artículo 43 de la Ley 29/1985, de 2 de agosto, de Aguas, como contenido del Plan Hidrológico Nacional, así como el establecimiento de aquellas previsiones normativas necesarias para garantizar su cumplimiento".

Artículo 2. Objetivos de la Ley.

"1. Son objetivos generales de la presente Ley:

a) Alcanzar el buen estado del dominio público hidráulico, y en particular de las masas de agua.

b) Gestionar la oferta del agua y satisfacer las demandas de aguas presentes y futuras a través de un aprovechamiento racional, sostenible, equilibrado y equitativo del agua, que permita al mismo tiempo garantizar la suficiencia y calidad del recurso para cada uso y la protección a largo plazo de los recursos hídricos disponibles.

c) Lograr el equilibrio y armonización del desarrollo regional y sectorial, en aras a conseguir la vertebración del territorio nacional.

d) Optimizar la gestión de los recursos hídricos, con especial atención a los territorios con escasez, protegiendo su calidad y economizando sus usos, en armonía con el medio ambiente y los demás recursos naturales.

2. Para la consecución de estos objetivos la presente Ley regula:

a) Las medidas necesarias para la coordinación de los diferentes Planes Hidrológicos de cuenca.

b) La solución para las alternativas que se proponen en los Planes Hidrológicos de cuenca.

c) La previsión y las condiciones de las transferencias de recursos hidráulicos entre ámbitos territoriales de distintos Planes Hidrológicos de cuenca.

d) Las modificaciones que se prevean en la planificación del uso del recurso y que afecten a aprovechamientos existentes para el abastecimiento de poblaciones y regadíos". Disponible en la página

340 del Código de Aguas Normativa Estatal:

$<$ http://boe.es/legislacion/codigos/codigo.php?id=032_Codigo_de_Aguas_Normativa_Estatal\&modo=1 $>$. 
adopción de medidas activas tendentes a mejorar la información sobre el estado del agua puesta a disposición del público (artículos 33, 35, 41 y 42.1.i del Texto Refundido de la Ley de Aguas).

Por fin, el Real Decreto $907 / 2007$, de 6 de julio ${ }^{1028}$, por el que se aprueba el Reglamento de Planificación Hidrológica, en su Título II dispone sobre los aspectos procedimentales de elaboración y aprobación de los planes hidrológicos, donde diversos artículos desarrollan las previsiones de participación pública contenida en los artículos 41 y 42 del Texto Refundido de la Ley de Aguas.

\subsubsection{Planificación hidrológica. Marco normativo}

Con la Ley de Aguas de 1985 es abierta una nueva etapa en la planificación hidrológica, vez que, por primera vez, y a diferencia de los planteamientos anteriores $^{1029}$, se intenta armonizar con el resto de planes sectoriales y con la planificación económica de forma expresa. La coordinación entre las planificaciones económica e hidráulica no plantea en principio graves problemas, ya que ambas competencias son atribuidas al Estado; en cambio, la coordinación entre planificación hídrica y algunas sectoriales -ordenación territorial y agrícola, urbanismo y medio ambiente- presenta mayor complejidad práctica, puesto que estas últimas son competencia de las Comunidades Autónomas.

La planificación hidrológica se lleva a cabo a través del Plan Hidrológico Nacional (PHN) y de los Planes Hidrológicos de Cuenca (PHCs). Estos últimos tienen como objetivo conseguir la mejor satisfacción de las demandas de agua y armonizar el desarrollo regional y sectorial. Es la Confederación Hidrográfica la encargada de elaborar su propio Plan de Cuenca en todo su ámbito territorial.

\footnotetext{
Acceso en: 02-12-2015.

${ }^{1028}$ Disponible en: < http://www.boe.es/diario_boe/txt.php?id=BOE-A-2007-13182>. Acceso en: 03-112015. Disponible también en las páginas 379 y ss. del Código de Aguas Normativa Estatal: < http://boe.es/legislacion/codigos/codigo.php?id=032_Codigo_de_Aguas_Normativa_Estatal\&modo=1>.

${ }^{1029}$ La planificación en España, entendida como idea de racionalización del aprovechamiento del agua, se remite a principios del siglo XX. SÁNCHEZ-MARTÍNEZ, M ${ }^{\mathrm{a}}$ Teresa; RODRÍGUEZ-FERRERO, Noelina; SALAS-VELASCO, Manuel. La gestión del agua en cit., nota de pie de página 7, p. 205.
} 
El Plan Hidrológico Nacional es un instrumento de ordenación y reequilibrio hídrico. Tiene tres funciones asignadas: la coordinación de los distintos Planes de Cuenca (que han de ser previamente aprobados al Plan Hidrológico Nacional), la previsión de trasvases de unas cuencas a otras y la salvaguardia de los aprovechamientos existentes en materias de abastecimientos a poblaciones y de regadíos. El Plan Hidrológico Nacional intenta conseguir la mejor satisfacción de las demandas de agua y equilibrar y armonizar el desarrollo regional y sectorial, incrementándolas disponibilidades del recurso, protegiendo su calidad, economizando su empleo y racionalizando sus uso en armonía con el medio ambiente y los demás recursos naturales. Por tanto, su objetivo es corregir los problemas de dotación existentes tanto para el abastecimiento a la población como para diversas actividades económicas, singularmente el regadío, y a eliminar el problema de degradación del dominio público hidráulico y sobreexplotación de acuíferos; además debe buscar la conciliación entre los intereses generales y autonómicos.

Los primeros Planes de Cuenca se aprobaron entre 1998 y 2001, tras un complejo y largo proceso. El actual Plan Hidrológico Nacional fue aprobado por el Congreso en 2005, casi veinte años después de la promulgación de la Ley de Aguas. Este Plan modificó al primer Plan Hidrológico Nacional del 2001, que prácticamente ignoraba las directrices en materia medioambiental de la recién aprobada Directiva Marco del Agua, y que seguía la tradición hidráulica española de realización de grandes infraestructuras ${ }^{1030}$.

Los planes hidrológicos de cuenca actualmente en vigor se aprobaron en cumplimiento de lo establecido en la Ley 29/1985, de 2 de agosto, de Aguas, mediante Real Decreto 1664/1998, de 24 de julio (Norte I, Norte II, Norte III, Duero, Tajo, Guadiana I, Guadiana II, Guadalquivir, Sur, Segura, Júcar, Ebro y cuencas intracomunitarias de Cataluña), Real Decreto 378/2001, de 6 de abril (Illes Balears) y

\footnotetext{
${ }^{1030}$ Según Ma Teresa Sánchez-Martínez, Noelina Rodríguez-Ferrero, y Manuel Salas-Velasco, La gestión del agua en cit., p. 206, como por ejemplo el trasvase de aguas desde la desembocadura del Ebro a las cuencas hidrográficas del Júcar y del Segura, y a la provincia de Almería. Dicho trasvase fue derogado por el Real Decreto-Ley 2/2004 y la Ley 11/2005 de modificación del Plan Hidrológico Nacional y sustituido por el Programa AGUA (Actuaciones para la Gestión y Utilización del Agua), en el que se establecen un conjunto de obras de desalación de aguas de mar, depuración, reutilización e implementación de medidas de ahorro de agua.
} 
Real Decreto 103/2003, de 24 de enero (Galicia-Costa) ${ }^{1031}$.

El retraso observado en la elaboración, aprobación y aplicación de los planes hidrológicos (los de cuenca y el nacional) ha conllevado graves problemas para la administración racional del agua, tanto desde el punto de vista ecológico como desde el económico, con asuntos tan importantes como el de la contaminación y el deficiente tratamiento económico del recurso hídrico, por citar los más sobresalientes a nuestro juicio. La gravedad de la situación que ha originado la paralización de hecho de la planificación hidrológica, eje principal de la Ley de Aguas de 1985, ha llevado a algunos especialistas a plantear la disyuntiva de aprobar la planificación o modificar la legislación de aguas ${ }^{1032}$.

El esquema de planificación previsto en la Ley de Aguas se completó con: el Real Decreto 927/1988, de 29 de julio, por el que se aprueba el Reglamento de la Administración Pública del Agua y de la Planificación Hidrológica; la Orden de 24 de septiembre de 1992, por la que se aprueban las instrucciones y recomendaciones técnicas complementarias para la elaboración de los planes hidrológicos de cuencas intercomunitarias; y la Ley10/2001, de 5 de julio, por la que se aprueba el Plan Hidrológico Nacional.

Posteriormente, y con el objeto de incorporar al ordenamiento jurídico español la Directiva 2000/60/CE, del Parlamento Europeo y del Consejo, de 23 de octubre de 2000, por la que se establece un marco comunitario en el ámbito de la política de aguas:

- Se modifica el texto refundido de la Ley de Aguas (Real Decreto

${ }^{1031}$ Información disponible en el sitio del Ministerio de Agricultura, Alimentación y Medio Ambiente. Marco normativo la planificación hidrológica: $<$ <ttp://www.magrama.gob.es/es/agua/legislacion/Marco_normativo_planificacion.aspx>. Acceso en: 02-11-2015. Según Ángel Villanueva Río Y Juan Antonio Sainz Sastre, Agua. La situación del agua en cit., p. 26: “Con los planes hidrológicos de cuenca actuales, parte del espíritu en relación con la planificación establecida por la Directiva Marco del Agua, transpuesta al ordenamiento jurídico español en 2003, ya estaba instaurada en España pero ésta establece diferentes aspectos novedosos en relación con la organización y contenido que debe darse en los nuevos planes hidrológicos. Los nuevos planes hidrológicos de cuenca realizados al amparo de la Directiva Marco del Agua incluirán el ámbito territorial de cada demarcación, por lo que habrá tantos planes como demarcaciones, incluirán las aguas de transición y las costeras, y deberán ser aprobados como tarde en el año 2009”.

1032 SÁNCHEZ-MARTÍNEZ, M ${ }^{\mathrm{a}}$ Teresa; RODRÍGUEZ-FERRERO, Noelina; SALAS-VELASCO, Manuel. La gestión del agua en cit., nota de pie de página 7, p. 207. 
Legislativo 1/2001, de 20 de julio) mediante el artículo 129 de la Ley 62/2003, de 30 de diciembre, de medidas fiscales administrativas y del orden social. Esto permite modificar el título III del texto refundido de la Ley de Aguas, correspondiente a la planificación hidrológica, en los aspectos estrechamente relacionados con el proceso de planificación hidrológica y la consecución de sus fines:

-Nuevos conceptos: demarcación hidrográfica, redefinición de cuenca hidrográfica;

- Modificaciones en la Administración Pública del Agua: creación del Consejo del Agua de la demarcación y el Comité de Autoridades Competentes;

- Nuevos objetivos medioambientales, estado de las masas de agua y programas de medidas para la consecución de tales objetivos;

-Registro de zonas protegidas;

- Principio de recuperación de los costes de los servicios relacionados con la gestión de las aguas; y

- Plazos para la consecución de los objetivos ambientales y para la participación pública.

- Se deroga la parte relativa a planificación hidrológica del Reglamento de la Administración Pública del Agua y de la Planificación Hidrológica, mediante el Real Decreto 907/2007, de 6 de julio, del Reglamento de la Planificación Hidrológica.

- Se aprueba la Orden ARM/2656/2008, de 10 de septiembre, de la Instrucción de Planificación Hidrológica, modificada por la Orden ARM/1195/2011, de 11 de mayo. El objeto de esta instrucción es el establecimiento de los criterios técnicos para la homogeneización y sistematización de los trabajos de elaboración de los planes hidrológicos de cuenca, conforme a lo establecido en el Reglamento de la Planificación Hidrológica (Real Decreto 907/2007, de 6 de julio).

En 2005, con la Ley $11 / 2005$, de 22 de junio ${ }^{1033}$, por la que se modifica la Ley 10/2001, de 5 de julio ${ }^{1034}$, del Plan Hidrológico Nacional, se modifica a su vez el texto

\footnotetext{
${ }^{1033}$ Disponible en: < http://www.boe.es/diario_boe/txt.php?id=BOE-A-2005-10622>. Acceso en: 03-112015.

${ }^{1034}$ El Plan Hídrico Nacional se aprobó por la Ley 10/2001 y fue modificado posteriormente por el Real Decreto-Ley 2/2004, que fue posteriormente convalidado y tramitado como Ley, dando lugar a la Ley 11/2005 que deroga los preceptos del Plan Hídrico Nacional que regulaban el trasvase del Ebro y se incorporaron dos nuevos anexos al Plan Hídrico Nacional, el Anexo III y el Anexo IV.
} 
refundido de la Ley de Aguas, estableciendo una definición de caudales ecológicos, la figura de las reservas naturales fluviales y un nuevo apartado relativo a las obras hidráulicas de interés general.

De este modo, se puede decir que la planificación hidrológica es uno de los pilares sobre los que se asienta la gestión del agua en España, la cual es una competencia estatal y tiene por objeto conseguir un buen estado y adecuada protección del dominio público hidráulico, la satisfacción de las demandas de agua, el equilibrio y armonización del desarrollo regional y sectorial, incrementando las disponibilidades del recurso, protegiendo su calidad, economizando su empleo y racionalizando sus usos en armonía con el medio ambiente y los demás recursos naturales ${ }^{1035}$.

\subsubsection{Utilización del dominio público hidráulico}

El Título IV del Texto Refundido de la Ley de Aguas, se denomina 'De la utilización del dominio público hidráulico'. En ello se regula la forma en que las aguas integradas en el dominio público hidráulico pueden ser utilizadas o aprovechadas por los particulares, así como por las Administraciones públicas.

De acuerdo con la definición dispuesta en el artículo 40 bis, letra j del Texto Refundido de la Ley de Aguas, por usos del agua debe entenderse "las distintas clases de utilización del recurso, así como cualquier otra actividad que tenga repercusiones significativas en el estado de las aguas. A efectos de la aplicación del principio de recuperación de costes, los usos del agua deberán considerar, al menos, el abastecimiento de poblaciones, los usos industriales y los usos agrarios".

De este modo, el Texto Refundido de la Ley de Aguas distingue entre los usos comunes, generales o especiales y usos privativos. Independientemente de cual sea el uso de las aguas, este debe efectuarse de forma que se logre una utilización racional y una protección adecuada del recurso, exigencias en las que los planes hidrológicos van a jugar un papel esencial y que van a reiterar en muchos de los preceptos que integran el Título IV de dicha Ley (entre ellos, los artículos 50.2, 50.4, 59.2 y 77.2) ${ }^{1036}$.

${ }^{1035}$ VILLANUEVA RÍO, Ángel; SAINZ SASTRE, Juan Antonio. Agua. La situación del agua en cit., p. 24.

${ }^{1036}$ GONZÁLES IGLESIAS, Miguel Á. Dominio público cit., p. 165. 
El agua y el resto de los bienes de dominio público pueden ser utilizados por los particulares. Estos usos pueden ser comunes, que no excluyen la utilización por un tercero, o privativos, que supone uso exclusivo. Dentro de estos usos podemos distinguir y definir los siguientes:

- Comunes generales (artículo $50^{1037}$ del Texto Refundido de la Ley de Aguas): de intensidad débil (beber, bañarse, abrevar ganado y otros usos domésticos) y que no alteran básicamente la calidad ${ }^{1038}$. Estos usos pueden ser hechos por todos, y no

${ }^{1037}$ Artículo 50. Usos comunes.

“1. Todos pueden, sin necesidad de autorización administrativa y de conformidad con lo que dispongan las Leyes y Reglamentos, usar de las aguas superficiales, mientras discurren por sus cauces naturales, para beber, bañarse y otros usos domésticos, así como para abrevar el ganado.

2. Estos usos comunes habrán de llevarse a cabo de forma que no se produzca una alteración de la calidad y caudal de las aguas. Cuando se trate de aguas que circulen por cauces artificiales, tendrán, además, las limitaciones derivadas de la protección del acueducto. En ningún caso, las aguas podrán ser desviadas de sus cauces o lechos, debiendo respetarse el régimen normal de aprovechamiento.

3. La protección, utilización y explotación de los recursos pesqueros en aguas continentales, así como la repoblación acuícola y piscícola, se regulará por la legislación general del medio ambiente y, en su caso, por su legislación específica.

4. La Ley no ampara el abuso del derecho en la utilización de las aguas ni el desperdicio o mal uso de las mismas, cualquiera que fuese el título que se alegare”.

${ }^{1038}$ Respecto a la calidad de las aguas vide: Real Decreto-ley 11/1995, de 28 de diciembre, por el que se establecen las normas aplicables al tratamiento de las aguas residuales urbanas; Real Decreto 509/1996, de 15 de marzo, de desarrollo del Real Decreto-ley 11/1995, de 28 de diciembre, por el que se establecen las normas aplicables al tratamiento de las aguas residuales urbanas; Real Decreto 822/2008, de 16 de mayo, por el que se crea la Oficina del Fondo de Cooperación para Agua y Saneamiento; Real Decreto $817 / 2015$, de 11 de septiembre, por el que se establecen los criterios de seguimiento y evaluación del estado de las aguas superficiales y las normas de calidad ambiental; Real Decreto 1341/2007, de 11 de octubre, sobre la gestión de la calidad de las aguas de baño; Real Decreto 140/2003, de 7 de febrero, por el que se establecen los criterios sanitarios de la calidad del agua de consumo humano; Real Decreto 261/1996, de 16 de febrero, sobre protección de las aguas contra la contaminación producida por los nitratos procedentes de fuentes agrarias; Real Decreto 1620/2007, de 7 de diciembre, por el que se establece el régimen jurídico de la reutilización de las aguas depuradas; Real Decreto 2618/1986, de 24 de diciembre, por el que se aprueban medidas referentes a acuíferos subterráneos al amparo del artículo 56 de la Ley de Aguas; Real Decreto 1514/2009, de 2 de octubre, por el que se regula la protección de las aguas subterráneas contra la contaminación y el deterioro. Todos disponibles en el Código de Aguas Normativa Estatal:

http://boe.es/legislacion/codigos/codigo.php?id=032_Codigo_de_Aguas_Normativa_Estatal\&modo=1>. 
necesita autorización ni concesión administrativa.

- Comunes especiales (artículo $51^{1039}$ del Texto Refundido de la Ley de Aguas): concluyen circunstancias especiales por peligrosidad, intensidad de uso y rentabilidad, que colocan al usuario en situación especial respecto del resto del público (derivaciones temporales de agua, navegaciones, plantaciones, cortas de arbolado, aprovechamiento de pastos, extracción de áridos, vertidos, etc.) ${ }^{1040}$. Estos usos requieren 'autorización administrativa', que es un acto administrativo por el que se ejerce un control sobre actividades que pueden afectar al dominio público e incluye un condicionado, o requiere un previa declaración responsable, a la que se refiere el artículo 3.9 de la Ley 17/2009, de 23 de noviembre, sobre el libre acceso de las actividades de servicios y su ejercicio, deberá presentarse con un período mínimo de antelación de quince días, para que pueda comprobarse la compatibilidad de dichos usos con los fines del dominio público hidráulico art. 51.2).

Además, ciertas actuaciones en las zonas colindantes al dominio público hidráulico pueden precisar de autorización administrativa previa (art. 100 del Texto Refundido de la Ley de Aguas y arts. 245 y ss. del Reglamento del Dominio Público Hidráulico), por ejemplo, aquellas que supongan alteraciones sustanciales del relieve natural, tal como los vertidos de aguas residuales y de productos susceptibles de contaminar las aguas continentales o cualquier otro elemento del dominio público hidráulico.

- Privativos: la utilización en exclusiva de bienes del dominio público limita o

Acceso en: 02-12-2015.

${ }^{1039}$ Artículo 51. Usos comunes especiales sujetos a declaración responsable.

“1. El ejercicio de los siguientes usos comunes especiales requerirá previa declaración responsable:

a) La navegación y flotación.

b) El establecimiento de barcas de paso y sus embarcaderos.

c) Cualquier otro uso, no incluido en el artículo anterior, que no excluya la utilización del recurso por terceros.

2. La declaración responsable, a la que se refiere el artículo 3.9 de la Ley 17/2009, de 23 de noviembre, sobre el libre acceso de las actividades de servicios y su ejercicio, deberá presentarse con un periodo mínimo de antelación de quince días, para que pueda comprobarse la compatibilidad de dichos usos con los fines del dominio público hidráulico".

${ }^{1040}$ Artículos 77 y 78 del Texto Refundido de la Ley de Aguas y artículos 70 a 77 del Reglamento del Dominio Público Hidráulico. 
excluye el uso por los demás usuarios o interesados (abastecimiento de poblaciones, riegos, usos industriales, etc.). Este derecho a uso privativo se adquiere por disposición legal o 'concesión administrativa' (art. 52 del Texto Refundido de la Ley de Aguas), que es un acto administrativo que otorga a un particular el disfrute exclusivo y condicionado de un bien de dominio público, por lo que la Administración transfiere parte de sus facultades, manteniendo la titularidad de las actividades o bienes citados. Todos los derechos para uso privativo de las aguas se inscriben en el Registro de Aguas. Tiene carácter público y es la evidencia de la existencia y características de la concesión. Aquí se incluyen también los aprovechamientos de aguas privadas. Las concesiones son temporales con límite máximo de setenta y cinco años.

Respecto a su extinción, la misma tendrá lugar, conforme establece el artículo 53.1 del Texto Refundido de la Ley de Aguas:

“1. El derecho al uso privativo de las aguas, cualquiera que sea el título de su adquisición, se extingue:

a) Por término del plazo de su concesión.

b) Por caducidad de la concesión en los términos previstos en el artículo 66 .

c) Por expropiación forzosa.

d) Por renuncia expresa del concesionario".

En los casos de derechos adquiridos por disposición legal se perderán según lo establecido en la norma que los regule o, en su defecto, por disposición normativa del mismo rango (art. 53.5 del Texto Refundido de la Ley de Aguas).

También, de acuerdo con el art. 66.2 del Texto Refundido de la Ley de Aguas, el derecho al uso privativo de las aguas, cualquiera que sea el título de su adquisición, podrá declararse caducado por la interrupción permanente de la explotación durante tres años consecutivos siempre que aquélla sea imputable al titular.

Importante destacar que en el plan hidrológico de cada cuenca se especifica el orden de prioridades, aunque siempre respetando la supremacía del abastecimiento de población (artículo 59.7 del Texto Refundido de la Ley de Aguas).

Hay otros aspectos de interés en relación con la utilización del dominio público hidráulico y su entorno ${ }^{1041}$ :

- Se puede realizar una 'cesión de los derechos para el uso privativo' de las

${ }^{1041}$ VILLANUEVA RÍO, Ángel; SAINZ SASTRE, Juan Antonio. Agua. La situación del agua en cit., p. 28. 
aguas a otro concesionario, siempre en la forma regulada legalmente y se inscriben en Registro de Aguas.

- Los organismos de cuenca, en determinadas situaciones, están autorizados para realizar 'ofertas públicas de adquisición de derechos' de uso del agua, para posteriormente cederlos a otros usuarios mediante el precio que el propio organismo ofrezca.

- La actividad de 'desalación de agua marina o salobre' queda sometida al régimen general establecido para el uso privativo del dominio público hidráulico, sin perjuicio de otras autorizaciones y concesiones que sean necesarias conforme a la legislación de costas.

- Las actividades de 'reutilización de aguas' quedan sometidas a concesión, o autorización en caso de que ésta fuera solicitada por el titular de la autorización de vertido de aguas ya depuradas. Desde 2007 se encuentran establecidas las condiciones básicas para la reutilización de las aguas depuradas según diferentes usos previstos, en concreto urbano, agrícola, industrial, recreativo y ambiental. En todo caso, la reutilización de aguas residuales requiere un informe favorable de las autoridades sanitarias y queda prohibido su utilización para el consumo humano, así como otros usos con riesgos para la salud (baño, cría de moluscos filtrados, etc.).

- La Administración por razones de interés público, por ejemplo, para conservación o recuperación del medio natural, puede retener (la llamada reserva) para sí el uso de aguas y terrenos. Esto quedará fijado en los planes hidrológicos de cuenca.

- No se podrá iniciar la construcción de una obra hidráulica ${ }^{1042}$ que comporte concesión de nuevos usos de agua, sin que previamente se obtenga o declare la correspondiente concesión, autorización o reserva.

\footnotetext{
${ }^{1042}$ Según Ángel Villanueva Río y Juan Antonio Sainz Sastre, Agua. La situación del agua en cit., p. 28: "Obra hidráulica: la construcción de bienes que tengan naturaleza inmueble destinada a la captación, extracción, desalación, almacenamiento, regulación, conducción, control y aprovechamiento de las aguas, así como saneamiento, depuración, tratamiento y reutilización de las aprovechadas y las que tengan como objeto la recarga artificial de acuíferos, la actuación sobre cauces, corrección del régimen de corrientes y la protección frente a avenidas, tales como presas, embalses, canales de acequias, azudes, conducciones, y depósitos de abastecimiento a poblaciones, instalaciones de saneamiento, depuración y tratamiento, estaciones de aforo, piezómetro, redes de control de calidad, diques y obras de encauzamiento y defensa contra avenidas, así como aquellas actuaciones necesarias para la protección del dominio público hidráulico".
} 
- En las zonas inundables ${ }^{1043}$, los permisos de uso del suelo por la Administración compete en ordenación del territorio y urbanismo tendrá que tener en cuenta este carácter de inundable, para lo cual la Administración hidráulica debe informar convenientemente.

\subsubsection{Protección del dominio público hidráulico}

En el Título V del Texto Refundido de la Ley de Aguas, se denomina 'De la protección del dominio público hidráulico y de la calidad de las aguas', y su artículo $92^{1044}$ establece toda una serie de objetivos de protección del dominio público hidráulico para acomodarse los dictados de la Directiva Marco del Agua, que consisten, principalmente, en la prevención, protección y mejora de las aguas y de los ecosistemas acuáticos, en su uso sostenible y en la reducción progresiva de los vertidos de sustancias

${ }^{1043}$ Artículo 11.1 del Texto Refundido de la Ley de Aguas define: "Zonas inundables: terrenos que pueden resultar inundados durante crecidas no ordinarios de los lagos, lagunas, embalses, ríos o arroyos". ${ }^{1044}$ Artículo 92. Objetivos de la protección.

"Son objetivos de la protección de las aguas y del dominio público hidráulico:

a) Prevenir el deterioro, proteger y mejorar el estado de los ecosistemas acuáticos, así como de los ecosistemas terrestres y humedales que dependan de modo directo de los acuáticos en relación con sus necesidades de agua.

b) Promover el uso sostenible del agua protegiendo los recursos hídricos disponibles y garantizando un suministro suficiente en buen estado.

c) Proteger y mejorar el medio acuático estableciendo medidas específicas para reducir progresivamente los vertidos, las emisiones y las pérdidas de sustancias prioritarias, así como para eliminar o suprimir de forma gradual los vertidos, las emisiones y las pérdidas de sustancias peligrosas prioritarias.

d) Garantizar la reducción progresiva de la contaminación de las aguas subterráneas y evitar su contaminación adicional.

e) Paliar los efectos de las inundaciones y sequías.

f) Alcanzar, mediante la aplicación de la legislación correspondiente, los objetivos fijados en los tratados internacionales en orden a prevenir y eliminar la contaminación del medio ambiente marino.

g) Evitar cualquier acumulación de compuestos tóxicos o peligrosos en el subsuelo o cualquier otra acumulación que pueda ser causa de degradación del dominio público hidráulico.

h) Garantizar la asignación de las aguas de mejor calidad de las existentes en un área o región al abastecimiento de poblaciones". 
contaminantes $^{1045}$.

Para que pueda cumplir con dichos objetivos la Administración hidráulica posee una serie de potestades diversas que le permiten utilizar una amplia variedad de técnicas e instrumentos, tanto de carácter preventivo como represivo, y que están encaminadas tanto a proteger la integridad como la identidad del dominio público hidráulico $^{1046}$.

De este modo, como el conjunto de bienes de dominio público hidráulico son susceptibles de sufrir impactos por las actividades antropogénicas, es necesario hacer una evaluación para posteriormente adoptar las medidas preventivas o correctoras que sean necesarias. El contexto de estas actuaciones está regulado por la normativa legal de evaluación de impacto ambiental que no es especifica del ámbito acuático ${ }^{1047}$.

Sobre la regulación legal específica para la protección de la cantidad y calidad de los recursos hídricos, entendiendo éstos como el agua, terrenos que la soportan y colindantes, son muchas las herramientas administrativas, como por ejemplo, la planificación hidrológica que entre otras cosas exige la determinación de los caudales ecológicos ${ }^{1048}$ y las reservas naturales fluviales. También hay como herramientas la declaración de acuíferos sobreexplotados y la definición de acciones y perímetros de protección, el proceso de deslinde de los cauces de dominio público o el condicionado impuesto en las concesiones o autorizaciones por uso de bienes de dominio público hidráulico, que deben asegurar un uso compatible con el respeto del medio ambiente y garantizar los caudales ecológicos o demandas ambientales previstas.

Importante destacar que los Planes Hidrológicos de Cuenca tienen papel fundamental a la hora de proteger la calidad de las aguas, vez que tendrá que establecer

${ }^{1045}$ Las disposiciones sobre protección de las aguas en el derecho español se han modificado con motivo de la transposición y ejecución de la Directiva Marco del Agua. De este modo, el art. Una de dicha Directiva fue contemplado en el art. 92 de Texto Refundido de la Ley de Aguas. Además, se acoge el concepto de contaminación previsto en el art. 2 de la Directiva Marco del Agua.

${ }^{1046}$ GONZÁLES IGLESIAS, Miguel Á. Dominio público cit., p. 181.

${ }^{1047}$ VILLANUEVA RÍO, Ángel; SAINZ SASTRE, Juan Antonio. Agua. La situación del agua en cit., p. 30.

${ }^{1048}$ Conforme Ángel Villanueva Río y Juan Antonio Sainz Sastre, Agua. La situación del agua en cit., nota de pie de página 8, p. 31: “Caudales ecológicos: caudal que contribuye a alcanzar en el buen estado o buen potencial ecológico en los ríos o en aguas transición y mantiene, como mínimo, la vida piscícola que de manera natural habitaría o pudiera habitar el río, así como la vegetación de ribera”. 
la lista de objetivos ambientales para las distintas masas de aguas y zonas protegidas, además de los plazos previstos para conseguirlos.

No obstante, deberán adoptarse programas de medidas para alcanzar esos objetivos en cada Demarcación Hidrográfica, claro, como medida complementaria, en los que han de concretarse las actuaciones y las previsiones necesarias a dichos efectos, y cuya regulación está en los artículos 43 a 58 del Real Decreto 907/2007, de 6 de julio, por el que se aprueba el Reglamento de la Planificación Hidrológica.

Además, conforme dispuesto en la Disposición Adicional Undécima del Texto Refundido de la Ley de Aguas, los objetivos medioambientales del artículo 92 bis deberán alcanzarse antes del 31 de diciembre de 2015, salvo el primer objetivo para las aguas superficiales, el de prevenir su deterioro, exigible desde la entrada en vigor de la Ley 62/2003, de 30 de diciembre, con lo que se impone la conservación de su calidad con arreglo a los parámetros registrados en dicho momento ${ }^{1049}$.

Acerca de las autorizaciones de vertidos, estarán establecidas de tal modo que los vertidos de aguas residuales autorizados tendrán establecidos unos valores límite de emisión ${ }^{1050}$ que deberán respetar las norma de calidad ambiental ${ }^{1051}$, y además estarán sometidas a otras exigencias como son las actividades de autocontrol y comunicación periódica de la Administración hidráulica. En este sentido existe regulación legal general para la prohibición o limitación de sustancias en vertidos susceptibles de contaminar las aguas continentales o cualquier elemento del dominio público hidráulico, así como legislación específica que establece límites de emisión a diferentes actividades que vierten sustancias peligrosas o para vertidos de aguas residuales urbanas. Respecto a estas últimas, una de las principales responsables de la degradación de la calidad de las aguas continentales, las autorizaciones de vertido otorgadas a las entidades locales y Comunidades Autónomas por sus vertidos directos a dominio público hidráulico, exige la elaboración de un plan de saneamiento y control de vertidos

\footnotetext{
${ }^{1049}$ GONZÁLES IGLESIAS, Miguel Á. Dominio público cit., p. 183.

${ }^{1050}$ El artículo 245.5.b del Reglamento del Dominio Público Hidráulico define: "Valor límite de emisión: la cantidad de concentración de contaminantes o grupo de contaminantes cuyo valor debe superarse por el vertido".

${ }^{1051}$ El artículo 245.5.a del Reglamento del Dominio Público Hidráulico define: "Norma de calidad ambiental: concentración de contaminantes o grupo de contaminantes en el agua, en los sedimentos o en la biota, que no debe superarse con el fin de proteger la salud humana y el medio ambiente".
} 
a sus colectores (vertidos indirectos y programas de reducción de sustancias peligrosas a éstos $^{1052}$.

Sobre el medio receptor de contaminación, la normativa legal establece una serie de valores de parámetros físico-químicos y microbiológicos que no deben ser superados en los diferentes elementos del medio acuático. En este sentido se han establecido valores máximos de carácter general, especialmente de sustancias peligrosas, valores específicos para una determinada cuenca recogidos en su correspondiente plan hidrológico y valores para proteger las aguas en función de sus usos (baño, protección piscícola, etc.). por fin, existen criterios en relación de evaluación y actuación en masas de agua que se encuentren afectadas o con riesgo de contaminación difusa por aporte de nitratos de origen agrícola y ganadero ${ }^{1053}$.

Las zonas húmedas ${ }^{1054}$ deben ser inventariadas y delimitadas y toda actividad que las afecte requerirá autorización o concesión. Sólo se podrá promover su desecación en caso de su declaración como insalubres o cuyo saneamiento se considere de interés público, previo informe favorables de la autoridad ambiental. Se establece la necesidad de coordinación de las diferentes Administraciones, central y autonómica, hidráulica y medioambiental, para la protección, gestión y recuperación de las zonas húmedas (artículos 275 a 283 del Reglamento del Dominio Público Hidráulico).

Ya la contaminación de las aguas, especialmente, las subterráneas pueden ser consecuencia de la contaminación de los suelos. En este sentido concurren órganos competentes, uno, generalmente estatal, en materia de dominio público hidráulico y otro, autonómico, en materia de suelos contaminados. En estas situaciones la legislación específica sobre suelos contaminados establece la necesidad de informar a la Administración hidráulica en caso de evidencias o indicios de contaminación de las

\footnotetext{
${ }^{1052}$ Una de las mejores técnicas para la protección de la calidad de las aguas es el control de la contaminación en la fuente misma a través de la fijación de unos valores límites de emisión para los vertidos contaminantes. Todo ello se regula en los artículos 97 a 105 del Texto Refundido de la Ley de Aguas y artículos 245 a 271 y 289 a 295 del Reglamento del Dominio Público Hidráulico.

${ }^{1053}$ VILLANUEVA RÍO, Ángel; SAINZ SASTRE, Juan Antonio. Agua. La situación del agua en cit., pp. 31-32.

${ }^{1054}$ El artículo 275.1 del Reglamento del Dominio Público Hidráulico define zonas húmedas como zonas pantanosas o encharcadizas, incluso las creadas artificialmente.
} 
aguas subterráneas, por lo que es necesaria la coordinación de planes y esfuerzos de las administraciones competentes para una gestión adecuada ${ }^{1055}$.

Con un ámbito más sanitario que medio ambiental, la ley estableció una serie de criterios de calidad y para el control de las aguas de consumo humano directo, buscando proteger la salud de las personas de los efectos adversos derivados de cualquier tipo de contaminación de las aguas, y son las autoridades sanitarias las responsables por la vigilancia del cumplimiento de estos criterios.

Respecto al estado cualitativo y cuantitativo de los recursos hídricos, cabrá a la Administración hidráulica su vigilancia y control, vez que cuenta con diferentes redes de control. Entre estas redes se encuentran estaciones de control periódico que aportan información cualitativa y cuantitativa de los recursos superficiales y subterráneos. Respecto a los medios humanos, Ángel Villanueva Río y Juan Antonio Sainz Sastre enseñan que: "las comisarias de aguas de los Organismos de cuenca cuentan con los guardias fluviales y la reciente figura del agente medioambiental con carácter de autoridad publica y facultades para practicar diligencias, tomas de muestras... También los medios humanos de las Administraciones hidráulicas autonómicas tienen la responsabilidad de la custodia y vigilancia de las aguas, sus cauces y zonas colindantes. Estos Organismos cuentan tienen colaboración de otros agentes de la autoridad en la vigilancia del dominio público hidráulico, fundamentalmente el Servicio de Protección de la Naturaleza de la Guardia Civil (SEPRONA), así como de entidades, fundamentalmente privadas, colaboradoras de la Administración hidráulica en materia de control y vigilancia de la calidad de las aguas y de gestión de los vertidos al dominio público hidráulico" ${ }^{\text {"1056. }}$.

Finalmente, la actuación de la Administración para evitar o detener el deterioro del bien, restituir lo dañado y exigir una sanción administrativa o penal como consecuencia de la violación de una norma de protección del dominio público hidráulico es exigida para la adecuada protección del medio hídrico. Así, el Derecho ha creado una serie de instrumentos jurídicos, tal como la responsabilidad administrativa, penal y civil, previstos en la propia Constitución Española, en su artículo 45.3.

\footnotetext{
${ }^{1055}$ VILLANUEVA RÍO, Ángel; SAINZ SASTRE, Juan Antonio. Agua. La situación del agua en cit., p. 32.

${ }^{1056}$ VILLANUEVA RÍO, Ángel; SAINZ SASTRE, Juan Antonio. Agua. La situación del agua en cit., p. 33.
} 
La responsabilidad administrativa, la ley tipifica las infracciones administrativas por uso indebido de los bienes de dominio publico hidráulico y zona de policía de leves a muy graves, determinando, asimismo, las sanciones que podrán recaer por comisión de las infracciones tipificadas, que se pueden complementar con la indemnización de los daños producidos al dominio público y la obligación de reposición de las cosas a su estado anterior ${ }^{1057}$.

${ }^{1057}$ VILLANUEVA RÍO, Ángel; SAINZ SASTRE, Juan Antonio. Agua. La situación del agua en cit., p. 33. 


\section{Capítulo 6 - Sostenibilidad y agua en el derecho internacional y en el derecho de la Unión Europea. Convenciones y Tratados}

\subsection{Sostenibilidad}

Desde los primordios hasta hace poco, la protección del ambiente no hacía parte de la cultura humana, que siempre ha querido conquistar y dominar la naturaleza. Al largo de la historia, el hombre sigue sin dominarla y ha conseguido, de manera voraz, cada vez más agotar los recursos naturales.

La preocupación con la manutención de los recursos naturales solo vino más tarde, con el pensamiento en los límites del crecimiento. Surge así, una inquietud en la humanidad.

Fue en la década de 70 que por primera vez se utilizó la comunidad científica ${ }^{1058}$ del término "sostenible", como una jerga técnica para designar la posibilidad de un ecosistema no perder su resistencia ${ }^{1059}$, y solamente en la década de 80 se utilizó para calificar el término "desarrollo" que fue puesto bajo sospecha y rechazo, tanto por los de derecha como los de izquierda ${ }^{1060}$.

Pasados varios años, todavía seguimos sin un concepto definido para el término sostenibilidad. Seguramente, sostenibilidad no debe ser entendida solo como un concepto vacío o como una simple herramienta del hombre para emplear de manera equivocada o falsa, su uso, sin en realidad aplicarla.

La sostenibilidad en un concepto general está basada en por lo menos dos criterios: primero, hay que analizar los efectos de las acciones humanas en el tiempo cronológico, incluso presente y futuro; segundo, para realizar un pronostico del futuro,

\footnotetext{
${ }^{1058}$ Fue el club de Roma, formado en 1968 por un pequeño grupo de científicos y políticos, que encargó al Instituto Tecnológico de Massachusetts (MIT) y publicó en 1972 el informe titulado Los Límites al crecimiento, que también es conocido como informe del Club de Roma o Informe Meadows, que trataba de problemas cruciales para el futuro desarrollo de la humanidad. MEADOWS, Donella H. The Limits to Growth: a Report for the Club of Rome's Project on the Predicament of Mankind. New York: Universe Books, 1972. Disponible en: < http://www.clubofrome.org/?p=375>. Acceso en: 17-05-2015.

${ }^{1059}$ En el sentido de capacidad de un ecosistema absorber tensiones ambientales sin perceptiblemente cambiar su estado ecológico.

${ }^{1060}$ VEIGA, José Eli da. Sustentabilidade: a legitimação de um novo valor. Senac, São Paulo, 2010, p. 12.
} 
necesario se hace una investigación para saber cuales efectos seguirán y sus consecuencias.

Necesariamente, en un primero concepto de sostenibilidad, no hay que hablar en equidad intergeneracional, una vez que esta noción solo compone el cuadro de los elementos de la sostenibilidad ambiental, que de ahí, pasa a tener tres elementos a considerar: el tiempo, la duración de los efectos y la relación de la situación medio ambiental con el presente y el futuro.

Cuando el crecimiento económico tomó proporciones excesivas y cada vez más degradante, convictos de la imposibilidad del retroceso humano, seguros de mantener la busca del crecimiento económico, aparece el presupuesto ideal de crecer consciente, el desarrollo sostenible, preocupado en precaver y prevenir los impactos ambientales, disminuyendo la degradación resultante de las acciones humanas.

En esa perspectiva, también surgió un ideal de sostenibilidad y la imprescindibilidad de un ambiente cualitativo, que garantice no solo el equilibrio del medio ambiente con una explotación consciente por parte de las presentes generaciones, pero que además, conceda calidad de vida para las futuras generaciones, combatiendo los males sociales en diversas dimensiones, considerando todos indispensables.

Más allá del interés económico y de crecimiento, las grandes cuestiones ambientales deben ser entendidas, simultáneamente, como cuestiones naturales, económicas y sociales ${ }^{1061}$. La sostenibilidad no puede existir en medio al culto de la inmediatez, pues es a través de ella que mantenemos la sobrevivencia de la vida humana y no humana, además de garantizar el crecimiento económico.

Como bien conceptuó Valentín Cabero, sostenibilidad es: "Saber conjugar el pasado con el futuro, recogiendo las buenas prácticas sociales en la gestión del medio y transmitirlas con realismo a las generaciones venideras, incorporando formas creativas y perdurables, no simplemente arrasando y destruyendo. La sostenibilidad necesariamente ha de ser solidaria entre sociedades pobres y ricas, entre medios frágiles y condiciones más estables, en fin, entre el campo y la ciudad, en un nuevo modelo de relaciones territoriales y sociales que debe recuperar el sentido de los límites, de la prudencia y de la sensibilidad ciudadana por el mantenimiento y conservación de la diversidad de los paisajes naturales y ecoculturales." 1062

\footnotetext{
${ }^{1061}$ FREITAS, Juarez. Sustentabilidade: cit., p.31.

1062 CABERO DIÉGUEZ, Valentín. Incertidumbre, Crisis Ambiental y Comportamiento Social, en
} 


\subsubsection{Riesgos ambientales}

No hay como hablar de cuestiones ambientales sin hablar de sostenibilidad, actualmente se puede afirmar que gran parte de la problemática ambiental que vivimos, eso para no decir que toda ella, es consecuencia de su falta.

Es un tema que está en la boca de todos ${ }^{1063}$, empezando por los científicos hasta los intelectualmente menos favorecidos. Todos están sufriendo con el calentamiento global, la escases del agua, el nítido agotamiento de los recursos naturales, la contaminación letal del agua y del aire, así como otros innúmeros ejemplos que a diario son vehiculados en los más diversos medios de comunicación y que pasan a ser temas de debates.

Actualmente, es muchísimo más fácil enterarnos de las consecuencias de la degradación ambiental, sin límite, para las presentes y futuras generaciones. La evolución tecnológica, social, industrial y científica nos ayuda cada vez más, pero la crisis ambiental sigue siendo indesmentible. La era de las certezas se acabó.

La humanidad corre real peligro de extinción, y eso debido a su estilo de vida sin freno, compulsivo y poco amigable que a cada día, por vanidad, quiere más y más, llevándonos a maltratar nuestro entorno $\mathrm{y}$, desde ahí, el propio ecosistema terrestre.

Estamos delante de la cultura de la insaciabilidad patrimonialista, del antropocentrismo excesivo, del deseo sin fin, en búsqueda del nada.

Con esta línea de raciocinio es fácil diagnosticar en un primer plan que bastaría un cambio comportamental, ocurre que para tanto, varias barreras mentales tendrían que caer, y eso no es tan sencillo cuando estamos delante de una sociedad de consumo insano.

Para salir de esa rutina insana, sin caer en la apatía o en la desesperación, es esencial que la sociedad de conocimiento se transforme en una sociedad de autoconocimiento, volcada, por un lado, a la construcción del bienestar universalizado y

ESPINOZA, Luis E; CABERO DIÉGUEZ, Valentín, Sociedad y Medio Ambiente, 1.a edición, Aquilafuente, Ediciones Universidad de Salamanca, Salamanca-España: 2006, p. 13.

1063 Aunque no exista un concepto definido, según VEIGA, José Eli da, el término "sostenibilidad" se ha convertido en algo trivial y ampliamente acepto y utilizado por "griegos y troyanos" cuando desean expresar ambiciones de continuidad, perennidad o durabilidad que remetan al futuro. Sustentabilidade: $a$ legitimação de um novo valor. Op. Cit., p. 12. 
de la homeostasis social ${ }^{1064} \mathrm{y}$, por otro lado, utilizar lo que el hombre tiene de mejor, la capacidad de proyectar y experimentar los hechos antes mismo que ocurran, disminuyendo así los escollos, y claro, aprendiendo con los errores sin necesitar cometerlos $^{1065}$.

La sostenibilidad, tiene el poder de fornecer a la humanidad condiciones propicias al bienestar físico y psíquico en el presente, sin empobrecer y inviabilizar el bienestar del mañana ${ }^{1066}$.

No al acaso, intenta combatir la insaciabilidad rampante que se ha apoderado de la sociedad que está repleta de vicios y que incluso se mantiene en una política insostenible.

Necesario se hace un cambio de paradigma ${ }^{1067}$, con transformaciones en las actitudes que suelen ser de omisión o basadas en conceptos ya superados, como el concepto de sostenibilidad presentado en el Informe Brundtland ${ }^{1068}$ (notable avance), todavía centrado en necesidades materiales.

${ }^{1064}$ Vide Damásio R., António, in E o cérebro criou o homem. Editora Companhia das Letras, São PauloBrasil: 2011, p. 44, a propósito de la homeostasis sociocultural que va en búsqueda del bienestar. Homeostasis en el sentido de autorregulación de la constancia de las propiedades de otros sistemas influidos por agentes exteriores. Disponible en: <http://lema.rae.es/drae/?val=homeostasis $>$. Acceso en: 20-03-2015.

1065 TODD GILBERT, Daniel, in Stumbling on Happiness. Editora Vintage, New York-Estados Unidos de América: 2007, p.262. Apud FREITAS, Juarez. Sustentabilidade: direito ao futuro, Editora Fórum, $2^{\mathrm{a}}$ edição, Belo Horizonte-Brasil: 2012, p.25.

${ }^{1066}$ FREITAS, Juarez, en su obra completa enuncia interesantes reflexiones sobre el abandono de conceptos usuales insatisfactorios. Sustentabilidade: direito ao futuro, Op. Cit., pp. 15 y ss.

${ }^{1067}$ Conforme Paulo Márcio Cruz; Zenildo Bodnar, paradigma debe ser entendido como el criterio de racionalidad epistemológica reflexiva que predomina, informa, orienta y direcciona la resolución de problemas, desafíos, conflictos y del propio funcionamiento de la sociedad. O Novo Paradigma do Direito na Pós-Modernidade. Revista de Estudos Constitucionais, Hermenêutica e Teoria do Direito (RECHTD), vol. $3, \quad$ n. $1: \quad 75-83$ janeiro-junho 2011. Disponible en: http://revistas.unisinos.br/index.php/RECHTD/article/view/777. Acceso en: 25 de marzo de 2014.

${ }^{1068}$ La Comisión Mundial sobre el Medio Ambiente y el Desarrollo, creada en la Organización de las Naciones Unidas con el objetivo de proponer nuevas medidas para combatir la degradación ambiental y la mejora en las condiciones de vida de los pobres, de la cual resultó el Informe Brundtland, titulado "Nuestro futuro común", que denomina desarrollo sostenible como "desarrollo que satisface las necesidades del presente sin poner en peligro la capacidad de las generaciones futuras para satisfacer sus propias necesidades". 
En medio a tantos debates surge en el escenario mundial una nueva mirada sobre el concepto de sostenibilidad que pasa a ser un estimulante de la preservación ambiental y su posible salvación.

\subsubsection{Desarrollo Sostenible}

Como muchos creen, el dolor trae el aprendizaje, quizá sea esta la razón que en el siglo pasado una nueva etapa de la historia fue diseñada en medio a crisis económica $^{1069}$, social y ambiental. La humanidad tomó consciencia de que las amenazas

${ }^{1069}$ Interesante análisis sobre la crisis económica y su reacción frente al medio ambiente hace Miren Sarasíbar Iriarte, Las oportunidades de la crisis económica en el derecho ambiental. en concreto, el fondo de carbón. Revista Aragonesa de Administración Pública, n. ${ }^{\circ}$ 41-42, Zaragoza, 2013, pp. 287-306: "Parece que la desigualdad se ofrece como el principal causante de las crisis económicas. Hace ya unos años que el sistema económico internacional entró en una fase de desaceleración. En un principio todo parecía apuntar al shock bursátil más severo desde la Gran Depresión como principal responsable de la situación que se avecinaba. El epicentro de la recesión se localizó en EE.UU. en 2006, pero sus efectos se fueron extendiendo al resto de las economías del mundo, poniendo en riesgo a la totalidad del entramado financiero internacional. Pese a que la Globalización parece sugerir un fenómeno novedoso, la realidad demuestra que no se ha conseguido todavía si se analiza la evolución del capitalismo en perspectiva histórica. La globalización como tal, no ha variado, lo que sí lo ha hecho, es el sistema económico y social en el que ha tenido lugar. Por tanto, cada proceso globalizador ha estado directamente supeditado a la lógica del sistema en el que se encontraba inmerso, el cual ha condicionado tanto su interacción como sus efectos" (p. 288). Además, concluye la autora: "Nuestro país atraviesa una situación económica muy crítica que está afectando de forma considerable a todos los ámbitos. Si se puede vislumbrar alguna ventaja como consecuencia de esta crisis es el sector ambiental, ya que algunas de las medidas adoptadas para afrontar esta crisis económica favorecen al medio ambiente, destacando de forma especial el sector de los transportes. El ámbito de las energías renovables parecía que podía salir reforzado de esa situación pero, en la actualidad, con la aprobación de diferentes normas desde hace algo más de un año se ha producido un duro golpe para el sector de las renovables. La Ley de Economía Sostenible ha pretendido implantar el «crecimiento verde» intentando buscar la forma para conseguir el equilibrio entre un desarrollo económico y una adecuada protección ambiental en diferentes sectores. Y como medida concreta, en el ámbito del cambio climático, destaca la existencia de los Fondos de Carbono que se crearon para la compra de créditos de carbono, con la finalidad de generar actividad económica y nuevas oportunidades de generación de empleo por parte de las empresas españolas en los nuevos sectores asociados a una economía baja en carbono" (p. 306). Disponible en: $<$ http://www.aragon.es/estaticos/GobiernoAragon/Organismos/InstitutoAragonesAdministracionPublica/ 
que el modelo económico de aquel momento, generado por la sociedad posindustrial y de riesgo, a cada día empeoraba, tornándose más reales y cercanas.

Incuestionable decir que el Informe Brundtland fue innovador, pero con el avance del tiempo nos enteramos de que debemos caminar rumbo a nuevos valores ansiados por la naturaleza y sociedad, siendo necesario una reformulación del concepto de sostenibilidad, que merece ser vista como valor y como principio al mismo tiempo.

Poco después del concepto que el Informe Brundtland introdujo sobre desarrollo sostenible, viene la Conferencia de Río - ECO 92, que reafirma los preceptos de la Conferencia de Estocolmo de 1972 y, además, en virtud de la positiva situación mundial, la Conferencia sobre Medio Ambiente y Desarrollo trae resultados prácticos reales y muy importantes, corroborando, sin valor jurídico alguno, con la perspectiva del "desarrollo sostenible" en la Agenda 21 ("Programa Global para el Desarrollo Sostenible en el siglo XXI") ${ }^{1070}$.

Diez años después, en 2002, las Naciones Unidas organizan la Cúpula Mundial sobre Desarrollo Sostenible en la ciudad de Johannesburgo (Sudáfrica), los resultados más significativos obtenidos en la Cumbre de Johannesburgo incluyen el ajuste o la reafirmación de las metas de erradicación de la pobreza, agua y saneamiento, salud, productos químicos peligrosos, pesca y biodiversidad; la inclusión de dos temas de difícil progreso en numerosas negociaciones previas (energías renovables y responsabilidad corporativa); la decisión política de crear el fondo mundial de solidaridad para la erradicación de la pobreza; y el compromiso con el desarrollo sostenible ${ }^{1071}$.

Delante del actual desarrollo que fue construido junto a un capitalismo salvaje que prioriza la ganancia económica, para muchos es una utopía hablar en desarrollo sostenible, pues creen que sostenibilidad es un término contrario al desarrollo y que los dos no consiguen caminar juntos.

La sociedad de consumo tendrá que pasar, el cuanto antes, por una síndrome de abstinencia para libertarse del vicio mental del crecimiento por el crecimiento, cuanto más tardar en cambiar, más difícil será, entretanto ya es inevitable. La humanidad tiene

Documentos/docs2/07\%20Miren\%20Saras\%C3\%ADbar.pdf>. Acceso en: 17-11-2015.

1070 DE GATTA SANCHÉZ, Dionisio Fernández. Sistema Jurídico-Administrativo de Protección del Medio Ambiente, $3^{\mathrm{a}}$ edición, Editora Ratio Legis, Salamanca-España: 2014, p. 44.

${ }^{1071}$ Vide: www.un.org/. Acceso en: 19-03-2015. 
que despegarse de las previas comprensiones desastrosas y remodelar el sistema en que vive. El cambio que necesitamos requiere una evolución el los valores humanos, políticos y en las expectativas personales ${ }^{1072}$.

Compatibilizar medio ambiente con desarrollo significa considerar los problemas ambientales dentro de un proceso continuo de planificación, acogiendo de manera adecuada a las exigencias de uno y de otro, observando sus interrelaciones en los contextos económico, ecológico, sociocultural y político, dentro de una dimensión de tiempo y espacio ${ }^{1073}$. Eso seria para muchos, lo ideal de desarrollo sostenible.

Dentro de la crisis global, con amplias dimensiones, la crisis ambiental es apenas una de sus vertientes. Estudios científicos comprueban que no podemos más ignorar la crisis y sus múltiples facetas: económica, política, social, ambiental y cultural, pues sus consecuencias son además de desastrosas, irreversibles ${ }^{1074}$.

El desarrollo económico no se confunde con desarrollo, es imprescindible comprender que los dos no son sinónimos, pues el desarrollo debe ser material e inmaterial, y que además de las ya conocidas e indisolubles dimensiones (social, ambiental y económica) ${ }^{1075}$ la sostenibilidad tiene de ser asimilada también en su

${ }^{1072}$ En ese sentido vide GILDING, Paul, in The Great Disruption: Why the Climate Crisis Will Bring on the End of Shopping and the Birth of a New World. Bloomsbury, New York-Estados Unidos de América: 2011, p. 122.

${ }^{1073}$ MILARÉ, Édis. Direito do Ambiente: doutrina, jurisprudência. $6^{\mathrm{a}}$ Edição. Editora Revista dos Tribunais São Paulo-Brasil: 2009, p. 65.

${ }^{1074}$ PNUMA - GEO 5 - Panorama Ambiental Global - Programa Das Nações Unidas Para O Meio Ambiente. Traducción de Claudia Vargas. Nairobi: 2012. Disponible en: http://www.pnuma.org.br/publicacoes_detalhar.php?id_publi=97. Acceso en: 5 de enero de 2015.

${ }^{1075}$ En 2002 en Johannesburgo la Cúpula de la Tierra sobre Desarrollo Sostenible revisa algunas cuestiones principales y lagunas existentes en la Agenda 21, introduciendo las dimensiones en su formación tríade: económico, social y ambiental.

Al entrar en las dimensiones de la sostenibilidad se intenta llenar algunos vacíos encontrados alrededor del concepto una vez que en su significado generalizado se permite numerosas consideraciones y distorsiones, que siempre cuelgan hasta el sesgo económico. La consideración de sostenibilidad bajo espectro de estas tres dimensiones a hecho más claro y objetivo, sin embargo aún distante de las necesidades y aspiraciones de la sociedad actual. Más informaciones sobre la Agenda 21 ver http://www.un.org/spanish/esa/sustdev/agenda21/. 
dimensión jurídico-política ${ }^{1076}$ - una vez tratarse de un principio constitucional generador de nuevas obligaciones, así como en su dimensión ética ${ }^{1077}$.

El objetivo del desarrollo sostenible ${ }^{1078}$ es definir un modelo económico que sea capaz de generar riquezas y bienestar, y que simultáneamente favorezca la cohesión social e impida la degradación ambiental. El desarrollo debe ser sostenible, duradero y continuo.

En un concepto actual de sostenibilidad tenemos que pensarlo no más con tres dimensiones, sino que con cinco, o sea, social, ambiental, económica, jurídico-política y ética, eso porque es imposible no hacer un análisis jurídico-político y comportamental

${ }^{1076}$ FREITAS, Juarez. Sustentabilidade: cit., p. 24.

${ }^{1077}$ FREITAS, Juarez. Sustentabilidade: cit., p. 24.

${ }^{1078}$ Comenta Jésus Jordano Fraga, Un desafío para los ordenamientos en el siglo XXI: el desarrollo sostenible. En: $Q D L, 16$, febrero de 2008, Fundación Democracia y Gobierno Local, pp. 61-74: “En un plano externo o del Derecho internacional la tensión medio ambiente-desarrollo en áreas sensibles se ha resuelto en favor de los valores de preservación del medio ambiente. [...] En el plano interno, nuestro Tribunal Constitucional se ha pronunciado especialmente sobre esta materia en las sentencias 64/1982, de 4 de noviembre; 25/1989, de 3 de febrero; 170/1989, de 19 de octubre; 73/2000, de 14 de marzo, y 164/2001, de 11 de julio, que pasamos a examinar a continuación. La STC 64/1982 resolvió el recurso de inconstitucionalidad núm. 114/1982, promovido por el presidente del Gobierno contra la Ley 12/1981, de 24 de diciembre, del Parlamento de Cataluña, por la que se establecían normas adicionales de protección de los espacios de especial interés natural afectados por actividades extractivas” (p. 63). Además, comenta el autor: "La doctrina del Tribunal Constitucional que consagra como modelo constitucional el desarrollo sostenible contrasta con la progresiva afirmación de la prevalencia del bien jurídico medio ambiente en el Derecho Ambiental de la Unión Europea y en la doctrina del TJCE. Con respaldo constitucional, se ha optado por una vía intermedia que podríamos denominar de desarrollo ecológico, en la cual no se descarta en determinados supuestos la constitucionalidad de la prevalencia del bien jurídico ambiental sobre el desarrollo de determinadas actividades económicas en los casos en que el ejercicio de éstas sea incompatible con los objetivos de la preservación del medio ambiente" (p.72). El autor concluye que: "En fin, el desarrollo sostenible como una aspiración justa de la humanidad requiere reformas estructurales no sólo jurídicas. La preservación del medio ambiente sin justicia social a escala nacional y planetaria es una quimera. Por eso quienes deseamos un mundo más ecológico queremos también un mundo más justo. Convertir este sueño en realidad es la principal misión del Derecho Ambiental y debiera serlo también de nuestros gobernantes" (p.73). Disponible en: $<$ http://repositorio.gobiernolocal.es/xmlui/bitstream/handle/10873/351/qd116_09_est06_jordano.pdf?sequ ence $=3>$. Acceso en: 17-11-2015. 
de la sociedad ${ }^{1079}$. Estas dimensiones, en el nuevo paradigma, son indivisibles e interdependientes cuando relacionadas al término sostenibilidad.

El actual paradigma de la sociedad es la sostenibilidad, y esta consiste en el deseo de proponer medios para perpetuarse en el tiempo en condiciones dignas. La sostenibilidad comprende no solo la relación entre económico y ambiental, sino que, en un equilibrio humano frente a las demás problemáticas ${ }^{1080}$.

La búsqueda por la solución de los riesgos dentro del cambio paradigmático hace con que emerja una nueva racionalidad ambiental, un nuevo paradigma, el de la sostenibilidad, que debe ser construido para solidificar las relaciones jurídico-políticaeconómica, posibilitando la cohabitación de diversos sistemas jurídicos y armonización de los sistemas axiológicos.

Según Ulrich Beck ${ }^{1081}$, el riesgo seria la previsión y/o el control, o la tentativa de controlar las futuras consecuencias de la acción humana, principalmente las no previstas por la modernización. Ya, sociedad de riesgo, es aquella que puede sufrir a cualquier tiempo las consecuencias de una catástrofe ambiental, en función de su continuo crecimiento económico ${ }^{1082}$.

En una sociedad de riesgo es necesario desarrollar capacidades adicionales para la sobrevivencia, como por ejemplo: anticipar peligros, soportarlos, tratarlos en términos políticos y biográficos. Saber hacer frente a esas nuevas capacidades se ha convertido en una calificación civilizacional decisiva ${ }^{1083}$.

${ }^{1079}$ FREITAS, Juarez expresa que la sostenibilidad evolucionada del concepto del Informe Brundtland, hace con que se asuma las demandas relacionadas al bienestar físico y psíquico, a largo plazo, superando así, las necesidades materiales. Además, todo y cualquier desarrollo será tenido como insostenible cuando, a largo plazo, tornarse negador de la dignidad de los seres vivos en general, aun que pague elevados impuestos. Sustentabilidade: cit., 2012, p. 48.

${ }^{1080}$ FERRER, Gabriel Real. Calidad de vida, medio ambiente, sostenibilidad y ciudadanía. ¿Construimos juntos el futuro? Revista NEJ - Electrónica, Vol. 17 - n. 3 - sep-dic 2012, p. 319. Disponible en: http://siaiweb06.univali.br/seer/index.php/nej/search/search. Acceso en 24 de marzo de 2015.

1081 BECK, Ulrich. Sociedade de risco: Rumo a uma outra modernidade. Traducción: Sebastião Nascimento, Editora 34, São Paulo-Brasil: 2010, p. 93.

${ }^{1082}$ MORATO LEITE, José Rubens. Direito Constitucional Ambiental Brasileiro. Editora Saraiva, São Paulo-Brasil: 2007, p. 133.

${ }^{1083}$ BECK, Ulrich. Sociedade de risco: Rumo a uma outra modernidade. Op. Cit., p.93.

LEITE, José Rubens Morato. Direito Constitucional Ambiental Brasileiro. Editora Saraiva, São PauloBrasil: 2007, p. 133. 
A todo instante es necesario que estemos conectados con la realidad y con ganas de verla tal y cual se nos presente, para que así podamos reflexionar sobre los hechos e intentar buscar maneras de mejorar nuestras vidas. Un ejemplo de algo que deberíamos cambiar es la medición del desarrollo económico a través del Producto Interior Bruto - PIB.

El PIB no mide la calidad de vida ${ }^{1084}$ y tampoco considera la sostenibilidad como un factor de rendimiento económico. De que sirve tener, como Brasil, el séptimo PIB del mundo si la renta per cápita, la calidad de enseñanza, la confiabilidad en el mercado interior, la probidad en las relaciones públicas y privadas, dejan demasiadamente a desear.

Hay que tener en cuenta las diferencias entre cantidad y calidad del crecimiento, es muy difícil deducir el bienestar de una población a partir de su renta per cápita. Alternativas al PIB ya existen e incluso son más apropiadas para medir el bienestar $^{1085}$, pero infelizmente, políticos y economistas aun siguen utilizando el PIB.

\footnotetext{
${ }^{1084}$ Jesús Jordano Fraga hace un importante análisis sobre el concepto de calidad de vida, afirmando que el concepto ha sido recogido por los ordenamientos jurídicos alcanzando, incluso, el reconocimiento constitucional en España. "Nuestra Constitución contempla la calidad de vida tanto en su preámbulo como en distintos preceptos". Además, el autor cita en su obra que "El término calidad de vida, según PRIEUR, fue utilizado por primera vez en su sentido actual por B. De JOUVENEL en 1958. Con posteridad, en Francia ha alcanzado mayos difusión la expresión $<<$ marco de vida $>>$ (cadre de vie), que, para PRIEUR, es en realidad un sinónimo del medio ambiente dentro de su sentido arquitectural y urbanístico, $<<$ es en realidad el paisaje urbano y el espacio diario de los habitantes $>>$ (Droit de l'environnement, cit., pp. 6-7). En contra de la interpretación mantenida por Jesús Jordano, lo mismo cita MARTÍN MATEO "quien afirma una inutilidad del macroconcepto de calidad de vida, pues $<<$ es imposible extraer consecuencias jurídicas concretas de comprensiones excesivamente amplias, aunque útiles en términos filosóficos y políticos $>$. En un concepto de calidad de vida para MARTÍN MATEO, con un sentido trascendente para el Derecho, $<<$ es el relacionado con el marco físico de la existencia humana >>". Así que para MARTÍN MATEO la promoción del bienestar mediante la utilización de los recursos naturales renovables, es lo esencial. (<<La calidad de vida como valor jurídico $>>$, RAP, n. ${ }^{\circ} 117$, septiembre-diciembre de 1988, pp. 51-70. El mismo trabajo puede verse en: Estudios sobre la Constitución española. Homenaje al Profesor García de Enterría, t.II). In: La Protección Del Derecho a un Medio Ambiente Adecuado. Editora J.M.Bosch Editor, S.A., Barcelona-España: 1995, pp. 105-106. El término calidad de vida también está contemplado en el preámbulo del art. 225 de la CF/88.

${ }^{1085}$ Como ejemplo de índices para medir el bienestar social de un país tenemos: Índice de Bienestar Económico Sostenible (IBES); Índice de Progreso Real (IPR) o Índice de Progreso Genuino (IPG); Índice de Desarrollo Humano (IDH), y otros tantos.
} 
Desde luego, la sostenibilidad implica que, al combatir problemas ambientales, estamos en busca de soluciones duraderas, no de "jeitinhos" a corto plazo. Tenemos que pensar a medio y largo plazo y desarrollar estrategias que se extiendan en el tiempo. Existe la obligación por nuestra parte de considerar de cual modo las políticas actuales afectarán la vida de los que todavía no nacieron ${ }^{1086}$.

Por esta razón, es incorrecto pensar que solo las poblaciones desarrolladas deberían preocuparse con cuestiones ambientales, pues de esta manera, estaríamos delante de un desarrollo irracional, haciendo con que la vida se torne inviable en la Tierra.

Se hace urgente la disminución del ritmo de crecimiento, hablando de un todo, de la propia población, de contaminantes y principalmente, del uso desmedido de recursos naturales.

Las poblaciones y padrones de vida no se mantienen indefinidamente, la multiplicación de la población en un espacio corto de tiempo, es decir, en menos de 50 años, se ha multiplicado por tres, y juntamente con ella, el consumo de energía.

Entretanto, poco a poco se observa el despertar da comprensión de que as disipaciones de energía pueden provocar daños ambientales de difícil reparación o irreversibles, revelándose fundamental rever la relación entre vida y economía ${ }^{1087}$.

El hombre tiene la tecnología a su favor, y economía con tecnología puede ser la mescla perfecta, como por ejemplo, los vehículos eléctricos, las células solares, los biocombustibles y el grafeno ${ }^{1088}$. Lo que no se puede es caer en la trampa del optimismo, no existe milagro, la transformación surge de la adaptación, innovación y reforma.

En el art. 45 de la CE/78 aparece implícitamente el principio de la sostenibilidad, ya en el art. 225 de la CF/88 explícitamente, pero en ambos, la sostenibilidad surge, como calificación constitucional insuprimible del desarrollo.

\footnotetext{
${ }^{1086}$ GIDDENS, Anthony. A Politica da Mudança Climática. Editora Zahar, Rio de Janeiro, 2010, p.88.

${ }^{1087}$ FREITAS, Juarez. Sustentabilidade: cit., 2012, p. 45.

${ }^{1088} \mathrm{El}$ grafeno es considerado varias veces más fuerte que el acero y su densidad es aproximadamente la misma que la de la fibra de carbono, siendo, más ligero que el acero. El Premio Nobel de Física de 2010 se les otorgó a Andréy Gueim y a Konstantín Novosiólov por sus revolucionarios descubrimientos acerca de este material.
} 
El desarrollo debe estar condicionado por la sostenibilidad, además de constituirse mutuamente con ella, y no siendo así, será inconstitucional. Decididamente, la sostenibilidad es que debe condicionar, infundir y adjetivar sus características en el desarrollo, nunca el contrario. No puede ser vaciada por el crecimiento económico, ingeniosamente, sin criterio y agresivo. Por esa razón, es preferible hablar en sostenibilidad, en lugar de desarrollo sostenible. Para enfatizar que la Constitución quiere que la sostenibilidad determine, prepondere, modele. De hecho y de derecho, la sostenibilidad, es en sentido fuerte, principio fundamental que genera nuevas obligaciones y determina la salvaguardia del derecho al futuro ${ }^{1089}$.

\subsubsection{Agua y Desarrollo Sostenible}

El agua en la Tierra es prácticamente la misma durante los últimos millones de años ${ }^{1090}$. Puede ser encontrada en diferentes formas y localizaciones.

A través de los siglos, el agua dulce es considerada como la principal fuente para la manutención de la vida, siendo este el motivo de grandes preocupaciones, en especial las destinadas al consumo humano. El agua está en la orden del día.

Hoy, pasan sed en el mundo 748 millones de personas, a pesar de que otras 2,3 mil millones han obtenido acceso al agua en los últimos 25 años. La desigualdad en el

${ }^{1089}$ FREITAS, Juarez. Sustentabilidade: cit., 2012, p. 54. Dionisio Fernández de Gatta Sánchez enseña que: "El concepto del desarrollo sostenible no se utiliza en la constitución española de 1978 ya que el debate sobre el mismo aún no se había iniciado, a pesar de ciertos antecedentes en la conferencia de Estocolmo de 1972, e incluso antes. No obstante, las ideas de la utilización racional de los recursos naturales, de la calidad de vida y de la solidaridad colectiva, recogidas en el art. 45.2.o, por su proyección hacia el futuro, pueden enmarcarse en el mismo, y en cierta manera así lo ha plasmado la ya citada STC 102/1995, de 26 de junio, que menciona expresamente el principio. previsiones de calidad ambiental (o, si se quiere, utilizando las nuevas ideas, de sostenibilidad) que deben armonizarse o compatibilizarse (en el sentido de lo señalado por las SSTC 64/1982, de 4 de noviembre, y 102/1995, de 26 de junio) con otros bienes previstos, y protegidos, por la misma constitución española, como el derecho a la propiedad privada, la libertad de empresa, el progreso económico y social, la intervención pública en la economía o la modernización de los sectores económicos, entre otros (arts. 33, 38, 40, 128 y 130)”. El Régimen de la Sostenibilidad Medioambiental, in Revista Jurídica de Castilla y León, n. ${ }^{\circ}$ 25, septiembre 2011, pp. $175 / 176$.

${ }^{1090}$ REBOUÇAS, Aldo. Uso Inteligente da água. Editora Escrituras, São Paulo-Brasil: 2004, p. 22. 
acceso al recurso, la contaminación de ríos y manantiales y la falta de preparo para la escasez ${ }^{1091}$, son desafíos para los próximos años.

En el ámbito internacional, las Naciones Unidas, instituyó el 22 de marzo de todos los años, como el Día Mundial del Agua, a partir de $1993^{1092}$, eso después de los eventos posteriores a la Conferencia de Mar del Plata (1977), y considerando las disposiciones del capitulo 18 de la Agenda 21, adoptado en la Conferencia del Medio Ambiente y Desarrollo (Río 92).

En el Día Mundial del Agua, deben ser objeto de discusión local, regional e internacional la preservación y el desarrollo sostenible, además de las informaciones de lo que fue y de lo que no fue hecho en el periodo anterior con relación a ese recurso natural.

A cada año un tema es elegido por las Naciones Unidas para direccionar las acciones y los estudios hasta el siguiente año.

El año 2003 fue también intitulado de "El Año Internacional del Agua Dulce" 1093 .

En el día 22 de marzo de 2005 comenzó el Decenio Internacional para la Acción: el agua, fuente de vida, la Asamblea General, basada en las recomendaciones

\footnotetext{
${ }^{1091}$ Como ha escrito Alberto A. Herrero de la Fuente: "La escasez de agua no sólo puede llevar a un desastre ecológico y humano y, desde luego, frenar el desarrollo, sino que puede llevar, por sus consecuencias, a constituir una amenaza para la paz y la seguridad internacionales...Indudablemente, la falta de un elemento vital como es el agua produce declive económico, pobreza, enfermedades, muertes prematuras que son origen de tensión social e inestabilidad política que fácilmente originan conflictos internos que pueden convertirse en internacionales". Apud JUSTE, José. El derecho al agua en el marco internacional, in: EMBRID IRUJO, Antonio (Director), El Derecho al Agua, Editora Aranzadi, NavarraEspaña: 2006, p. 276.

${ }^{1092}$ Cuidar de nuestros recursos hídricos es cosa de todos (1994); Mujer y agua (1995); Aguas para ciudades sedientas (1996); El agua en el mundo: ¿resulta suficiente? (1997); Aguas subterráneas - el recurso invisible (1998); Todos vivimos aguas abajo (1999); Agua para el siglo XXI (2000); Agua y salud (2001); Agua para el desarrollo (2002); Agua para el futuro (2003); El agua y los desastres (2004); Agua el fuente de vida (2005); Agua y cultura (2006); Afrontar la escasez de agua (2007); Saneamiento (2008); Compartiendo el agua compartiendo oportunidades (2009); Agua limpia para un mundo sano (2010); Aguas para las ciudades: responder un desafío urbano (2011); El mundo tiene sed porque tenemos hambre (2012); Cooperación en la esfera del agua (2013); y Agua y energía (2014). Disponible en: http://www.un.org/es/events/waterday/pastobs.shtml ${ }^{1093}$ A/Res. 55/196, de 20.12.2000.
} 
de los fórums mundiales ocurridos, determinó el periodo que va de 2005 a 2015, con el objetivo de reducir a la mitad el porcentaje de personas sin acceso al agua $\mathrm{y}$ saneamiento.

El Secretario General de las Naciones Unidas así declaró: "Estamos ante un asunto urgente de desarrollo humano y de dignidad humana. En este Día Mundial del Agua, adoptemos la decisión de trabajar más para proporcionar agua potable y apta para el consumo a todas las personas del mundo. Asimismo, reafirmemos nuestro compromiso de ordenar mejor los recursos hídricos mundiales, que son nuestro único medio de supervivencia y de conseguir un desarrollo sostenible en el siglo XXI."1094

Para eso, necesario se hace la comprensión de que el medio ambiente es uno e indivisible, y que engloba un todo, siendo imprescindible el equilibrio para la existencia de la vida.

Así como la vida es un ciclo, el agua también lo es, y no hay como visualizar el problema del agua sin considerar el cambio climático, que altera directamente la velocidad de este ciclo ${ }^{1095}$, aumentando el ritmo de evaporación y precipitación. ${ }^{1096}$

${ }^{1094}$ http://www.un.org/es/events/waterday/2005/

${ }^{1095}$ El ciclo hidrológico es el principio unificador de todos los procesos naturales referentes al agua en nuestro planeta y tres son los estados físicos del agua que compone ese ciclo, solido, liquido y gaseoso. El agua dulce existente en el mundo es mantenida a través del ciclo hidrológico que se repite indefinidamente. JUSTE, José. El derecho al agua en el marco internacional, in: EMBRID IRUJO, Antonio (Director), El Derecho al Agua, Op. Cit., 2006, p. 251. Es la radiación solar, que promueve la evaporación, y los vientos, que transportan los vapores del agua, que hacen mover el ciclo hidrológico. Su velocidad cambia de una era geológica para la otra como también la proporción total de aguas dulces y oceánicas en el relacionadas. TUNDISI, José Galizia. TUNDISI, Takako Matsumura. Água no Século XXI - Enfrentando a Escassez. Editora RiMa, Instituto Internacional de Ecologia, 2003, p. 17. Mireya Castillo Daudí explica que "Las aguas dulces constituyen un recurso limitado pero perpetuamente renovable: a escala mundial, el agua que abandona la masa terrestre retorna en cantidad igual. Este proceso se desarrolla sin solución de continuidad". La Protección y preservación de los cursos de agua internacionales: el Convenio sobre el derecho de los usos de los cursos de agua internacionales para fines distintos de la navegación de 21 de mayo de 1997, Anuario de Derecho Internacional, vol. XV, 1999, p. 116. Según Cid Tomanik Pompeu el legislador deberá considerar siempre la unidad del ciclo hidrológico cuando tratar de las aguas en cualquier de sus fases o estado. La falta de preocupación y de precisión, en ese sentido, puede llevar a la edición de normas estancadas, que disponen sobre las aguas superficiales y subterráneas, con graves inconvenientes para la gestión de ambas.

${ }^{1096}$ CLARKE, Robin; KING, Jannet. O Atlas da Água - O Mapeamento Completo do Recurso mais Precioso do Planeta, Publifolha, São Paulo-Brasil: 2005, p. 11. 
Podemos relacionar el cambio climático, la degradación de los recursos, y la escasez cuantitativa y cualitativa, como motivos de gran preocupación para la supervivencia de los seres vivos.

Uno de los síntomas y causa de la crisis del agua es el estado de pobreza de un amplio porcentaje de la población mundial.

El informe de las Naciones Unidas sobre el Desarrollo de los Recursos Hídricos en el Mundo ${ }^{1097}$ enseña que es posible erradicar la pobreza con la facilitación del acceso a un agua mejor gestionada, además para hacer frente a una crecente escasez de agua, es necesario una mejor gestión del recurso.

Tal como ha indicado la Comisión sobre el Desarrollo Sostenible ${ }^{1098}$ en 2002: “Erradicar la pobreza, cambiar los patrones de producción y consumo insostenibles y proteger y administrar los recursos naturales del desarrollo social y económico constituyen los objetivos primordiales y la exigencia esencial de un desarrollo sostenible." 1099

${ }^{1097}$ Conocido como: The World Water Development Report (WWDR).

${ }^{1098}$ Conocido como: Commission for Sustainable Development (CSD).

1099 Consultado en la página de las Naciones Unidas: http://www.un.org/esa/sustdev/sdissues/water/WWDR-spanish-129556s.pdf. Acceso en: 30-03-2015.

Un índice mundial de pobreza del agua, cuya sigla en inglés es WPI, Water Poverty Index, revela que algunas de las más ricas naciones del mundo, como Estados Unidos y Japón, están mal posicionados en el ranking, mientras países en desarrollo figuran entre los Diez Más, según UK’s Centre for Ecology \& Hydrology y especialistas del World Water Council. Brasil está en el bloco intermedio alto, ocupando la $50^{\mathrm{a}}$ posición, sin embargo, aparece entre los diez peores cuando relacionado al acceso al agua para su población. Brasil con la mayor población de América del Sur, obtuvo 61,2 WPI puntos, con variables bajas para el uso y medio ambiente. Comparativamente, países con menor población tuvieron altas puntuaciones, como Venezuela con números altos de capacidad per cápita completado por acceso y gerenciamiento relativamente buenos. Mientras la capacidad de Argentina es alta, su índice para uso es bajo reflejando en cierto grado de ineficiencia particularmente en los sectores industriales y agrícolas. Semejante a eso, en Uruguay, los altos índices en acceso y capacidad no encuentran correspondencia en el uso y medio ambiente. Con una puntuación de 68,9 , Chile obtuvo buenos o moderadas puntuaciones en cada componente. El WPI fue desarrollado por un equipo de 31 investigadores en consulta a más de 100 profesionales del agua alrededor del mundo. Esos investigadores destacaron la estrecha relación entre pobreza, privación social, integridad ambiental, disponibilidad del agua y salud, permitiendo así, a los formuladores de políticas identificar donde existen problemas y cuales son las medidas más apropiadas a tomar. Una escala internacional clasifica 147 países de acuerdo con cinco diferentes medidas: recursos, acceso, capacidad, uso e impacto ambiental para enseñar dónde están las mejores y peores situaciones. 
El consumo del agua se ha aumentado, somos actualmente, más de 6 millones de seres humanos en la Tierra, en contrapartida, el volumen de agua no se ha aumentado $^{1100}$. El uso del agua tiene crecido a una tasa dos veces mayor que el

Según la WPI, las Diez Más ricas naciones en agua son: Finlandia, Canadá, Islandia, Noruega, Guyana, Surinam, Austria, Irlanda, Suecia y Suiza. Los más pobres son todos los países en desarrollo: Haití, Níger, Etiopia, Eritrea, Malawi, Djibouti, Tchad, Benin, Ruanda y Burundi. Los diez países con mayor número de personas sin acceso al agua son: China, India, Nigeria, Indonesia, Etiopia, Vietnam, Brasil, Turquía, Pakistán y Congo. Los países en desarrollo tienen problemas por cuestiones del índice negativo de saneamiento. En Estados Unidos la incidencia de enfermedades de origen hídrica bajó de ocho casos por 1000 habitantes/año entre 1920 y 1940 para menos de 4 entre 1970 y 1990 a la excepción del episodio de Minneapolis, en 1993 que tuvo 400 mil casos causados por Cryptosporidium resultando en 100 muertes. El nuevo índice demuestra la fuerte conexión entre pobreza del agua y baja renta, que fue el principal tema del $3^{\circ}$ Foro Mundial del Agua, en inglés, 3rd World Water Forum, realizado en el año 2003 en Kioto - Japón, donde más de 10.000 representantes gubernamentales, de organizaciones internacionales y $\mathrm{ONG}$, industrias y especialistas discutieron la crisis del agua y las posibles soluciones. Disponible en: http://ecoviagem.uol.com.br/noticias/ambiente/nossa-agua/wpi-apresentou-um-novoindice-mostrando-as-dez-mais-ricas-nacoes-em-agua-2053.asp. Acceso en: 01-04-2015.

${ }^{1100}$ Aproximadamente dos tercios de la superficie de nuestro planeta están cubiertos por agua (aproximadamente 1,386 mil millones $\mathrm{km}^{3}$ ). De este total, 97,5\% (aproximadamente 1,350 mil millones $\mathrm{km}^{3}$ ) compone los océanos y mares, dejando, por lo tanto, solo 2,5\% (aproximadamente 34,7 millones $\mathrm{km}^{3}$ ), de toda el agua existente en el planeta, como dulce. Siendo el agua Dulce la menor porción de agua que compone el llamado planeta azul. In: LEMOS, Haroldo de Matos. O Século 21 e a Crise da Água. Comitê Brasileiro do Programa das Nações Unidas para o Meio Ambiente (PNUMA). Disponible en: www.estadao.com.br/ext/ciencia/agua/odireitodebeber_1.htm. Acceso en: 07-10-2013. Vide también: SHIKLOMANOV, I. World Water Resources: A New Appraisal and Assessment for the 21st Century. IHP, Unesco, 1998, apud TUNDISI, José Galizia. TUNDISI, Takako Matsumura. A Água. Coleção Folha Explica, Publifolha, São Paulo: 2005. Tres cuartos, o sea, 75\% de toda agua dulce existente está atrapada en glaciares e icebergs; ocho millones de quilómetros cúbicos, aproximadamente, están en acuíferos subterráneos, y una cantidad alrededor de 200 mil quilómetros cúbicos componen los acuíferos superficiales, en ríos y lagos $(0,4 \%)$, quedando solo un total aproximado de $1 \%$ de toda agua dulce existente componiendo el cuerpo de animales y vegetales, la humedad del aire atmosférico $(0,035 \%)$ y del suelo. In: BAREY, R.G. The World Hydrological Cycle, apud SETTE-CAMARA, José. Pollution of International Rivers, The Hague Academy of International Law, Recueil des Cours, 1984, III, Tomo 186, p. 125. Vide también: LEMOS, Haroldo de Matos. Op. Cit. Entre todas nuestras actividades, la agricultura es la que más consume agua, cerca de $70 \%$ de toda agua disponible en el mundo, que ya no es mucha, es utilizada por la irrigación. En Brasil, este índice llega a 72\%. De los 30\% que restan, 19\% son gastos por las industrias y solo $11 \%$ para el uso doméstico. Disponible en: 
crecimiento de la población a lo largo del ultimo siglo. La tendencia es que para 2025 el gasto sea elevado en hasta $50 \%$ en los países en desarrollo, y $18 \%$ en los desarrollados ${ }^{1101}$.

Se trata de una crisis de gestión de los recursos hídricos, esencialmente causada por la utilización de métodos inadecuados, además, se denota el despilfarro y el uso ineficiente del agua.

Como bien resaltó Valentín Cabero: "es necesario repensar las formas de entender el territorio y los espacios en que vivimos, así como cuestionar las políticas y prácticas cotidianas que están en la base misma de los problemas medioambientales, de las desigualdades sociales y de los desequilibrios territoriales." 1102

Los efectos en la calidad ${ }^{1103}$ y cantidad de agua disponible, relacionados con el rápido crecimiento de la población mundial y con la concentración de esa población en megalópolis, ya son evidentes en varias partes del mundo ${ }^{1104}$.

http://planetasustentavel.abril.com.br/noticia/desenvolvimento/conteudo_261013.shtml. Acceso en: 3103-2015.

1101 Disponible en: http://nacoesunidas.org/alertando-para-escassez-de-agua-doce-onu-pede-esforcosglobais-para-proteger-recursos-naturais/. Acceso en: 23-05-2014

${ }^{1102}$ CABERO DIÉGUEZ, Valentín. Por una lectura crítica del territorio: Repensar el Oikoumene, in ESPINOZA, Luis Enrique; CABERO DIÉGUEZ, Valentín. Sociedad y Medio Ambiente, $1^{\text {a }}$ edición, Aquilafuente, Ediciones Universidad de Salamanca, Salamanca - España: 2006, p. 182. Además, en este sentido Vescijudith Fernandes Moreira. La eficacia del sistema de protección y reutilización del agua en España y Brasil. Un análisis jurídico-ambiental derivado de la política de la Unión Europea. Tesis doctoral presentada en la Universidad de Salamanca, 2011, p. 33 afirma que: "Al largo de los años, el concepto de ambiente se ha ampliado y consecuentemente los elementos materiales y técnicos para su mantenimiento y protección, en vistas de las acciones humanas y naturales. A pesar del avance de la legislación para la protección del medio ambiente, su preocupación inicial se dio en vista de la economía, que enseguida enfatizó el social y finalmente la concepción de proteger el natural como manera de garantizar las intenciones para los demás sectores. Así como el intento de comprender los intereses vitales y necesarios, se tornó necesaria la atención al cuidado multisectorial para el momento presente, entre tanto con vistas para la posteridad. $\mathrm{Y}$ en ese sentido, se hizo preciso entrelazar los objetivos pertinentes, tomando por base la materia prima".

${ }^{1103}$ Se puede decir que la preocupación con la calidad del agua en la historia, comenzó aumentar con los impactos negativos que surgieron en el siglo XVIII, por la Revolución Industrial y, el Posguerra de la Segunda Guerra Mundial, seguido del desarrollo económico, los ríos ya no eran más los mismos, se produjo un desequilibrio entre el medio natural y las demandas solicitadas por la humanidad, en ese sentido Dionisio Fernández de Gatta Sanchéz. El régimen jurídico del control integrado de la 
Mapa de la escasez de agua por motivos naturales y económicos (Figura 8) ${ }^{1105}$ :

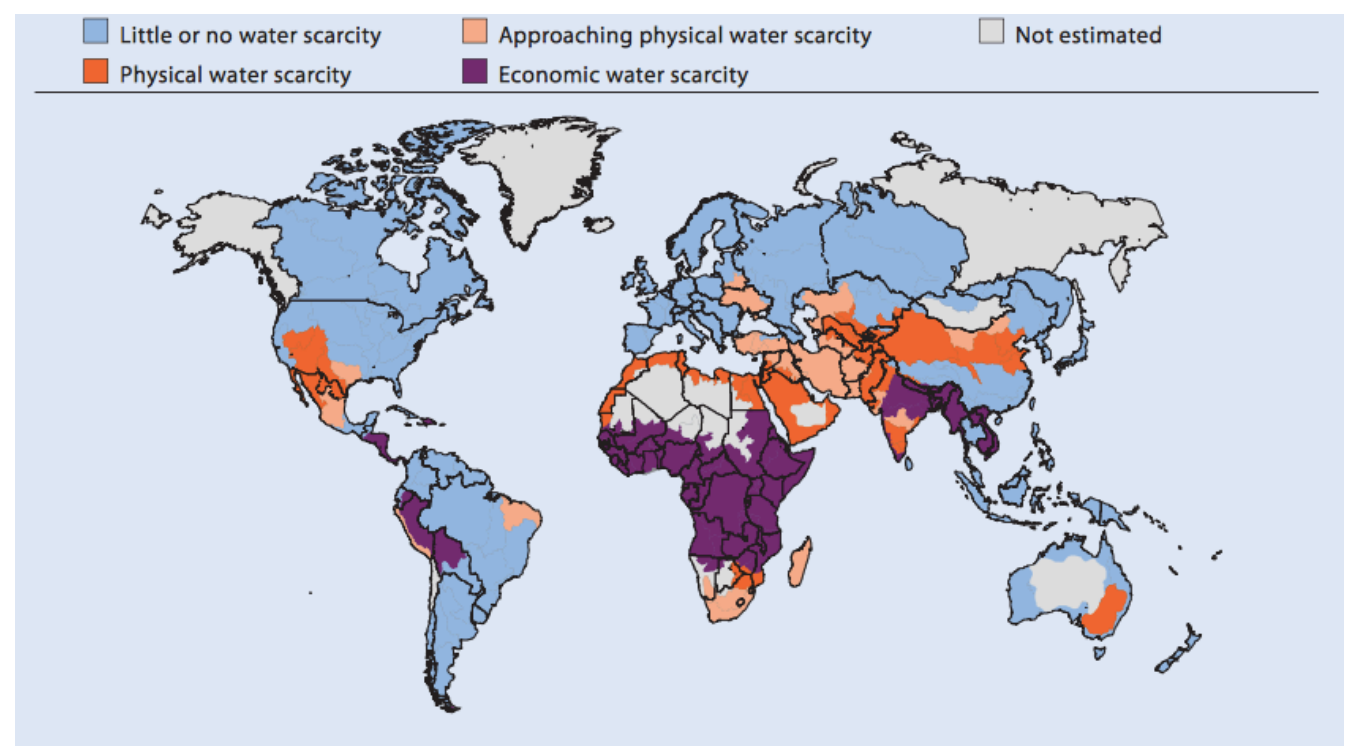

La crisis del agua influye en la supervivencia de los seres vivos humanos ${ }^{1106} \mathrm{y}$ no humanos, y en la de nuestro planeta, la falta del agua en altos niveles, puede hasta inviabilizar nuestra existencia.

contaminación, Revista de Derecho Ambiental, n. ${ }^{2} 22$, España: 1999, p. 20. El control de la calidad de los recursos hídricos deben ser asumidos no solo por el Poder Público, sino también por la sociedad, a través de programas de naturaleza participativa, como por ejemplo la atención con el agua parada (evitando contaminación por el mosquito de la "dengue"), la limpieza de reservatorios domésticos y de condominios, la denuncia de liberaciones ilegales de aguas residuales y eliminación de basura en el agua pluvial y arroyos. La población, por lo general, debe ser bien informada respecto a la calidad del agua fornecida. De ahí la conveniencia de los diversos índices de calidad para usos específicos, haciendo con que todas las informaciones sean públicas y que exista una constante vigilancia sobre los recursos hídricos no solo por parte del Poder Público, como también por parte de todos los ciudadanos.

${ }^{1104}$ Datos del Fondo de las Naciones Unidas para la infancia (Unicef) y de la Organización Mundial de Salud (OMS) revelan que casi mitad de la población mundial, o sea, 2,6 mil millones de personas no tienen acceso al saneamiento básico y que una en cada seis personas, cerca de 1,1 mil millones de personas, aun no poseen sistema de abastecimiento de agua adecuado. Las proyecciones de la Organización de las Naciones Unidas indican que, se eso sigue, en 2050 más de 45\% de la población mundial estará viviendo en países que no podrán garantizar la cuota mínima diária de 50 litros de agua por persona. Disponible en: http://www.mma.gov.br/estruturas/secex_consumo/_arquivos/3\%20\%20mcs_agua.pdf. Acceso en: 31-03-2015.

1105 Fuente: International Water Management Institute. Disponible en: http://www.iwmi.cgiar.org/About_IWMI/PDF/Strategic_Plan_2009-2013.pdf. Acceso en: 31-03-2015. 
El llamado planeta azul ${ }^{1107}$ cuando visto de cerca ya no es tan azul, está secando y quedándose cada vez más sediento, el agua dulce es la menor porción de agua que lo compone y está comprometida.

Ante las transformaciones de la sociedad y del Estado, necesario se hace realizar una especie de control de validez de las concepciones tradicionales, lo que en realidad, corresponde a la propia idea de ciencia $^{1108}$.

En los próximos diez años la discusión sobre agua deberá girar en torno de cómo administrar mejor el recurso, conductas pasarán por cambios, en un escenario de largos periodos de sequía, que a cada día se quedan más comunes, combatirla no será la solución, la población tendrá que aprender a convivir con ella.

Aun existe un largo camino a ser recorrido, y para recorrerlo será necesario una cantidad enorme de dinero, una fortuna para investir hasta que el agua esté disponible a las personas. Algunos desafíos ${ }^{1109}$ son observados en el transporte por distancias cada

${ }^{1106}$ Las conclusiones del informe Glass 2014, informe este que es realizado a cada dos años por la OMS, fue intitulado "Investir en agua y saneamiento, aumentar el acceso, reducir las desigualdades."

El texto recordó que el acceso al agua potable y al saneamiento adecuado tiene consecuencias en varios aspectos, desde la reducción de la mortalidad infantil, pasando por la salud materna, al combate de enfermedades infecciosas, la reducción de los costos sanitarios y al medio ambiente. El estudio reveló que em las dos ultimas décadas 2,3 mil millones de personas pasaron a tener acceso a fuentes de agua mejoradas.

En ese mismo periodo el número de muertes de niños por enfermedades diarreica - relacionadas muchas veces con el saneamiento precario - bajó de 1,5 millón en 1990 para 600 mil en 2012. Disponible en: http://exame.abril.com.br/mundo/noticias/oms-indica-que-750-milhoes-de-pessoas-nao-tem-agua-potavel y en: http://nacoesunidas.org/quase-750-milhoes-de-pessoas-ainda-nao-tem-acesso-a-agua-potaveladequada-alerta-unicef/. Accesos en: 01-04-2015. Es inaceptable que aun mueran alrededor de 1.400 niños al día de enfermedades relacionadas a falta de agua y saneamiento. La infraestructura de recursos hídricos no será completa sin agregar la trilogía preconizada por la OMS para su gerenciamiento cualitativo, cual sea: vigilancia, monitoreo y levantamientos que buscan detectar la observancia o violación de padrones.

${ }^{1107}$ El primer ser humano puesto en órbita de la Tierra, el cosmonauta soviético Yuri Gagarin, transmitió la primera impresión sobre el planeta visto del espacio en 12 de abril de 1961: "La Tierra es Azul." ${ }^{1108}$ Conforme Odete Medauar en las conclusiones de su libro O Direito Administrativo em Evolução. Editora Revista dos Tribunais, São Paulo-Brasil: 1992, p. 226.

${ }^{1109}$ El primer problema es el desequilibrio en la distribución, un desequilibrio que comienza por la geografía física y sigue por la economía. Algunos países tienen mucho más agua de lo necesita su población, como es el caso de Canadá, Islandia y Brasil. Otros están situados en regiones 
vez mayores, el tratamiento e, claro, después de utilizada, su purificación para que pueda retornar al medio ambiente y a su ciclo.

No hay una solución mágica para la crisis del agua, los especialistas son unánimes en afirmar que la única salida es que la humanidad aprenda a regir los recursos hídricos. Además, si considerar el crecimiento poblacional ${ }^{1110}$.

El agua siempre fue tema de preocupación, desde el mundo Greco-Romano, principalmente en la Antigua Grecia, que tanto la seguridad física, como la psíquica, estaban relacionadas con el agua. Por esa razón, los romanos no tardaron en absorber la cultura griega y cuando conquistaron el mediterráneo, pusieron en practica, con sabiduría, las ideas sanitarias, con construcciones de sistema de alcantarillados, de instalaciones sanitarias y de baños, y también de acueductos ${ }^{111}$.

extremadamente secas, como el norte de África, el Oriente Medio y el Norte de China. Como resultado de esta mala distribución, un canadiense puede gastar hasta 600 litros de agua por día, mientras un africano dispone de menos de 30 litros para beber, cocinar, limpiar la casa, hacer la higiene, irrigar la plantación y mantener el ganado. Las poblaciones que habitan las áreas más áridas de la Tierra viven lo que se llama “estrés hídrico" (desequilibrio entre la oferta y la demanda en determinada región), una reunión de factores ambientales, tal como falta de lluvia y socioeconómico, como el alto crecimiento demográfico, que al final resulta en demasiada gente para poco agua. El África Subsahariana no es de todo desproveída de recursos hídricos, pues en esa parte se atraviesan grandes ríos, y mismo que algunas áreas sufren periodos de seca, el índice pluviométrico en es general alto. El problema consiste em que los países de la región no tiene recursos de infraestructura para aprovechar más de 3,8\% del total del caudal de sus ríos. Resultado: más de 94\% del agua potable vuelve al mar sin atender las necesidades de la población. Por esa razón, 22 de esos países están en la lista de los 24 con mayores estrés hídrico. Son naciones de acelerado crecimiento demográfico y de pocos recursos para proteger los manantiales y ofrecer saneamiento básico a los habitantes. Disponible en: http://planetasustentavel.abril.com.br/noticia/desenvolvimento/conteudo_261013.shtml?func=2. Acceso en: 02-04-2015.

${ }^{1110}$ El crecimiento poblacional va a exigir cada vez más agua. Se estima que en 2030 vamos a ser 8 mil millones de habitantes en la Tierra y que para alimentarnos, la producción de alimentos tendrá que subir $60 \%$, lo que significa un aumento de $14 \%$ en el consumo del agua, comprometiendo todavía más el acceso al agua para otras finalidades. Disponible en: http://planetasustentavel.abril.com.br/noticia/desenvolvimento/conteudo_261013.shtml?func=2. Acceso en: 02-04-2015.

${ }^{1111}$ FIORILLO, Celso Antônio Pacheco, en su libro Tutela Jurídica das Águas no Direito Brasileiro e o Novo Código Civil (Lei n. ${ }^{\circ}$ 10.406/02), narra como la cultura griega influenció a los romanos. In: FIORILlO, Celso Antônio Pacheco (Coordinador), Revista Brasileira de Direito Ambiental, Ano 1, n. ${ }^{\circ}$, Editora Fiuza, São Paulo-Brasil: Abril-Junio 2005, pp. 236-237. 
Además de eso, incluso en los Alcázares ${ }^{112}$, había un patio con un declive, que servía como un sistema de captación de agua de la lluvia. En varios edificios históricos se observa también pozos para recoger el agua.

Cuando se dice que el agua es el elemento ${ }^{113}$ fundamental a la vida, es debido al hecho de que sin ella no existe respiración, reproducción, quimiosíntesis, fotosíntesis ${ }^{1114}$ y tampoco hábitats y nichos ecológicos para la mayoría de las especies existentes. Su ausencia o contaminación, implica en consecuencias de degradación de la propia vida $^{1115}$.

El agua para las diversas civilizaciones, desde las más remotas, que habitaron y que todavía habitan la Tierra, tiene no solo una importancia biológica, sino también, en el desarrollo cultural, agrícola, religioso y militar ${ }^{1116}$.

${ }^{1112}$ Alcázar es un término español utilizado para designar a un castillo o palacio fortificado. Muchas ciudades de España también lo utilizan para nombrar a antiguos palacios musulmanes que fueron reconstruidos por los reyes cristianos posteriores.

${ }^{1113} \mathrm{El}$ agua, juntamente con el aire, fuego y tierra, era uno de los cuatro elementos fundamentales en la ciencia de la antigüedad. Eran considerados como fuerzas de la naturaleza, y en diversas ocasiones los utilizaban como fundamento de explicación de los fenómenos naturales.

${ }^{1114}$ MARTIN MATEO, Ramón, hace un análisis de la importancia del agua para el proceso de la fotosíntesis. Cultura y Tecnología del Agua, in Revista Española de Derecho Administrativo, n. ${ }^{\circ} 62$, Editora Civitas, Madrid-España: 1989, pp. 173-186.

${ }^{1115}$ FIORILLO, Celso Antônio Pacheco, RODRIGUES, Marcelo Abelha. Manual de Direito Ambiental e Legislação aplicável. Editora Max Limonad, São Paulo-Brasil: 1997, p. 272.

${ }^{1116}$ Conforme Barlow, Maude, Clarke, Tony, algunas civilizaciones, a lo largo de la historia siempre supieron que el agua podría agotarse y por esta razón mantuvieron un saludable respecto por la conservación de cualquier agua encontrada, diferentemente de las personas del siglo XXI, en la antigüedad, varias civilizaciones tenían como divinidades dioses y diosas del agua, como por ejemplo el dios del agua Enki, en Mesopotamia y la diosa del agua Nuliajuk, de la población Inuit. Además, en la antigua China, hay un mito que surgió del peligro de la sequía, que dice que un arquero tiró en nueve de diez soles para impedir que la Tierra se secara. La tradición china afirma también que el agua y los demás elementos de la naturaleza existen en un equilibrio que no puede ser perturbado. Ouro Azul - Como as Grandes Corporações Estão se Apoderando da Água Doce do Nosso Planeta. Editora M. Books do Brasil, São Paulo-Brasil: 2003.

Incluso en las tres religiones monoteístas, Moisés, Jesús y Mahoma hicieron milagros relacionados con el agua. In: BOURGUERRA, Mohamed Larbi. As Batalhas da Água. Editora Campo das Letras, Porto: 2005, pp.34-51. 
Infelizmente, mismo que la importancia y la definición del agua remonten al origen de la historia humana, la misma pasó por una trivialización, principalmente con el proceso de globalización, donde las actitudes, las culturas e incluso las mentes se uniformizaron.

La humanidad, en un sentido, siempre buscó reglas para el uso del agua, siendo su carácter restrictivo o no, proporcional a su escasez. Las influencias recibidas de determinados factores, así como la cantidad de agua disponible, hizo con que ocurriera una primera gran división entre el derecho originario de las regiones húmedas y aquel oriundo de las regiones secas ${ }^{117}$.

La concienciación de la importancia ambiental y del papel del agua en la vida, no solo relacionado a cuestiones económicas, necesidades humanas y no humanas, calidad, cantidad y ahorro, sirvieron para despertar el hombre sobre el valor del agua, y con eso, la necesidad de la existencia de un derecho de aguas ${ }^{1118}$.

A medida que las relaciones sociales evolucionan, el concepto de derecho de aguas evoluciona, pues nuevas preocupaciones surgen y hacen con que el mundo jurídico se adecue.

Con base en un dispositivo legal, valido y en vigor es que la Administración Pública se ve autorizada y obligada a actuar en el control del uso de las aguas ${ }^{1119}$, por eso, la ley tiene un papel fundamental.

${ }^{1117}$ Según Cid Tomanik Pompeu, de ahí surgieron normas de derecho vigente en las regiones secas y del aplicable a las húmedas, encontradas en grandes sistemas de derecho y reflejadas en sus normas, como por ejemplo el Código de Manu, en India, el Talmud, de los hebreos, y el Alcorán, de los musulmanes. Direito de Águas no Brasil. Editora Revista dos Tribunais, 2ª edição, São Paulo-Brasil: 2010, pp. 43-44.

${ }^{1118}$ En ese sentido Antonio Martinez Nieto afirma que "El Derecho de aguas tiene la misión de regular un preciado bien común - el denominado $<<$ oro azul $>>-$ por cuya posesión se ha desencadenado una peligrosa lucha que es necesario reconducir en términos de justicia y en beneficio del interés general". $E l$ Derecho de Aguas en España. Claves Jurídicas para una gobernanza del agua sin fronteras interiores. Diario la Ley n. ${ }^{0}$ 7366, Sección Tribuna Editorial La Ley, Años XXXI, Madrid-España: 22 de marzo de 2010. Disponible en: http://diariolaley.laley.es. Acceso en: 06-04-2015.

${ }^{1119}$ De acuerdo con el principio de la legalidad, fijado en el art. 37, caput, de la CF/88, así como de cualquier otra actividad basada en este principio.

En España, como poder público, la Administración Pública se encuentra sometida a los principios constitucionales que enumera el texto fundamental en el art. 9.3. Por lo que se refiere al origen del principio de legalidad, cabe subrayar que este principio constituye una de las bases fundamentales del Estado de derecho, desde su nacimiento en el siglo XVIII a partir de los postulados de las revoluciones 
En un concepto más moderno, en si considerando la importancia de la gestión de los recursos hídricos, se pude definir derecho de aguas como el conjunto de principios y normas jurídicas que disciplinan el dominio, las competencias y el gerenciamiento de las aguas, visando la preservación y el planeamiento de los usos, así como la defensa de sus efectos dañosos, provocados o no por la acción humana ${ }^{1120}$.

Delante de tantos problemas, a cada día que pasa, la adopción de políticas basadas en los principios de derecho humano al agua conjugado con el del ambiente equilibrado y desarrollo sostenible deben ser aplicados para garantizar la calidad y cantidad del recurso y su garantía a las demás necesidades.

El agua preexiste al derecho, pues es elemento de la naturaleza. A medida que el hombre, en el desarrollo de sus actividades, de ella necesita, y considerando que hay cada vez más personas necesitándola, tiende el conflicto de intereses a ser cada vez más intenso $^{1121}$.

Con los acontecimientos fueron surgiendo políticas sobre el tema. En cuanto no había la existencia de un conflicto de intereses entre los diversos tipos de uso, no había razón alguna para se establecer cualquier especie de política. El contenido de toda relación jurídica es el interés ${ }^{122}$.

Es importante añadir lo que bien colocó Jesús Jordano Fraga: “El moderno Derecho ambiental no partió de la nada, y su armazón técnico-jurídico se construyó sobre mecanismos preexistentes, generalizándose en este período algunos ya ensayados, como la fijación de estándares para limitar la contaminación y aportándose otros nuevos. La verdadera revolución ocurrió en el campo de los conceptos. El medio ambiente como objeto de Derecho surge de forma decidida y en su dimensión actual en

liberales. En términos más concretos, para la Administración Pública - como aparato público establecido para servir los intereses generales - supone que su funcionamiento y actuación están sometidos a la ley y al derecho (art. $103.1 \quad$ CE). Disponible en: http://dugidoc.udg.edu/bitstream/handle/10256/714/unidad3.html. Acceso en: 13-04-2015. ${ }^{1120}$ GRANZIERA, Maria Luiza Machado. Direito de Águas: Disciplina Jurídica das Águas Doces. Editora Atlas Jurídico, $3^{\text {a }}$ edição, São Paulo-Brasil: 2006, p. 24.

${ }^{1121}$ GRANZIERA, Maria Luiza Machado. Op. Cit., 2006, p. 26.

${ }^{1122}$ Según Miguel Reale el interés es el contenido de toda relación jurídica. Lições preliminares de direito. Editora Saraiva, 22a edição, São Paulo-Brasil: 1995, p.336. 
esta época, arrastrando sectores igualmente preexistentes, para construir un concepto aglutinador y superador" ${ }^{\prime 123}$.

En el derecho de aguas la división entre derecho público y derecho privado no debe existir, una vez que a lo que se refiere a los recursos hídricos, la prevalencia del interés público sobre el privado es indudable ${ }^{1124}$.

Según Lorenzo Mellado Ruiz: "Todo el Derecho se reduce, en última instancia, a un sistema de límites, de injerencias, en mayor o menor medida, del Estado en la sociedad. El Derecho trata de la ordenación exógena de las conductas privadas. Pero el Estado ambiental, y el Derecho ambiental, poseen una característica nuclear que los diferencia del resto de sectores normativos. El Derecho ambiental limita para acrecentar nuestras posibilidades (y las de las generaciones venideras). Restringe y ordena para permitir que sigamos poblando - y desarrollándose como seres inteligentes - el planeta Tierra. Paradójicamente, limita para avanzar y coarta para permitir. Puede decirse que el

${ }^{1123} \mathrm{El}$ autor también hace un comentario respecto al período postconstitucional español, "El medio ambiente ha recibido un reconocimiento constitucional como derecho-deber (art.45 CE, apartado 1) y como función administrativa, (art. $45 \mathrm{CE}$, apartado 2, en relación con los arts. 148, 1, 9 y 149, 1, $23 \mathrm{CE}$ ). El Derecho ambiental, producto de una larga decantación histórica, ha adquirido, desde el punto de vista constitucional, el sentido de ser el desarrollo garantizador y realizador del derecho y la función pública constitucionalmente consagrados. Desde el punto de vista de las técnicas jurídicas a utilizar en esta misión, el artículo 45 ha realizado un esquema básico, preventivo, reconociendo implícitamente la planificación (<<utilización racional $>>$ ), y represivo (sanciones penales, administrativas y responsabilidad civil)". La Protección Del Derecho a un Medio Ambiente Adecuado. Op. Cit., 1995, p. $52 / 54$.

${ }^{1124}$ En Brasil, la Ley n. ${ }^{\circ}$ 9.433/97 y en España, la propia Constitución en su art. 45.2, declaran los recursos hídricos como bienes de dominio público. En ese sentido, RUIZ, Lorenzo Mellado comenta que el agua "tiene la naturaleza no sólo de elemento o recurso natural, sino de bien colectivo, de titularidad global, y de objeto de preservación y gestión racional por parte de los poderes públicos, en virtud del art. 45.2 de la Constitución”. Aguas y Ordenación del Territorio en el Contexto de la Reforma Estatutaria, Editorial Comares, Granada-España: 2010, p.24.

La Constitución Española tiene tres preceptos que van a determinar algunos de los principales rasgos del Derecho de Aguas en España: el primer precepto es el art. 45 que trata de la protección del medio ambiente; el segundo es el art. 132, cuyo dos primeros apartados hacen referencia a los bienes de dominio público, y el tercer precepto es el art. 149, que enumera las competencias exclusivas del Estado y, por lo tanto fija el límite de las que pueden ser asumidas por las Comunidades Autónomas en sus respectivos Estatutos de Autonomía. GONZÁLEZ IGLESIAS, Miguel Á. Dominio Público Hidráulico, Cuadernos de Derecho Administrativo (IV): Bienes Públicos, Editora Ratio Legis, Salamanca-España: 2014, p. 131. 
Derecho ambiental es un conjunto de normas y principios de limitación u ordenación proyectivas. El Estado Ambiental de Derecho puede considerarse, así, como el nivel pleno (último, definitivo etc.) de organización social del hombre, puesto que los principios democráticos, de respeto de la legalidad y de compensación entre el poder y las libertades revierten, a la vez, y de forma indirecta, en un beneficio impagable para el mismo: la conservación del ambiente natural y el aprovechamiento racional de los recursos naturales" ${ }^{, 125}$.

Por eso, la evolución del derecho en el sentido no solo de decir que el agua es material susceptible de valoración, como estableciendo, para su utilización, restricciones, sea de cuño administrativo, sea de naturaleza financiera, como es la cobranza por el uso de los recursos hídricos ${ }^{1126}$.

La utilización de los recursos hídricos en diferentes procesos productivos, hace con que sea conceptuado como un bien económico, además de ser un bien ambiental. Imposible hablar de un desarrollo económico a largo plazo, sin observar la conservación de la naturaleza.

Importante destacar que mismo buscando conservar la naturaleza, la humanidad aun sigue con un ritmo insostenible de producción industrial, que no solo causa diversos tipos de contaminación, sino que, aumenta el efecto invernadero, impactando en el cambio climático. También, no se puede olvidar que con el ciclo hidrológico, la contaminación del agua causada por la agricultura e la industria, que después de utilizarla la devuelve a la naturaleza con sustancias contaminantes en la mayoría de las veces, para no decir todas, causa un fenómeno nocivo a la sostenibilidad hídrica.

Los usos del agua deben siempre ser compatibles con la preservación de su calidad, requisito esencial de la salud pública y el equilibrio ambiental. La calidad del agua está constantemente amenazada por dos principales grupos de riesgo: la

${ }^{1125}$ Gestión Sostenible del Agua y Evaluación de Impacto Ambiental de Obras Hidráulicas, Colección Estudios de Derechos Administrativo, Dirigida por ARANA GARCÍA, Estanislao, Editorial Colmares, S. L., Granada - España: 2004, p. 84.

${ }^{1126}$ GRANZIERA, Maria Luiza Machado. Op. Cit., 2006, p. 26.

En ese sentido, en Brasil, la Ley n. ${ }^{\circ}$ 9.433/97, que en su art. $1^{\circ}$, inciso II, como el fundamento de la "Política Nacional de Recursos Hídricos", adopta que el agua es un recurso natural limitado, dotado de valor económico. Ese valor económico se refiere a la institución del cobro. 
modificación de las características físicas y químicas de los cuerpos de agua y la contaminación por microorganismos patogénicos ${ }^{127}$.

En consecuencia a tantos actos dañosos vienen los impactos directos, tales como extinción de especies de flora y fauna, inundaciones, obstrucción o reducción de volumen en los cursos de agua y, sedimentación de ríos ${ }^{1128}$.

Además, incluso el ambiente marino sufre con la contaminación del agua dulce cuando de su desagüe ${ }^{1129}$.

Importante resaltar que además del mal uso del agua, se pude verificar una degradación ambiental difusa causada por devastación de la fauna y flora, deforestación y actividades agrícolas agresivas. La destrucción de bosques en gran escala afecta la

${ }^{1127}$ MILARÉ, Édis. Direito do Ambiente, Editora Revista dos Tribunais, $9^{a}$ edição, São Paulo-Brasil: 2014, p. 526.

${ }^{1128}$ URBAN, Teresa. Quem vai falar pela Terra? in: NEUTZILING, Inácio (Org.), Água: Bem Público Universal, Editora Unisinos, São Leopoldo-RS - Brasil: 2004, p.103.

Por todo, resulta particularmente oportuno recordar las orientaciones contenidas en el capítulo XVIII del Programa 21, cuyo apartado 18.2 afirma en particular que: "La escasez generalizada de recursos de agua Dulce, su destrucción gradual y su creciente contaminación, así como la implantación progresiva de actividades incompatibles en muchas regiones del mundo, exigen una planificación y una ordenación integradas de los recursos hídricos. Esa integración ha de abarcar todos los tipos de masas interrelacionadas de agua dulce, tanto las aguas superficiales como las subterráneas, y ha de tener debidamente en cuenta los aspectos de la cantidad y calidad del agua. Debe reconocerse el carácter multisectorial del aprovechamiento de los recursos hídricos en el contexto del desarrollo urbano, la generación de energía hidroeléctrica, la pesca en aguas interiores, el transporte, las actividades recreativas, la ordenación de las tierras bajas y las planicies y otras actividades. Los sistemas racionales de utilización del agua para el aprovechamiento de las fuentes de suministros de agua, sean de superficie, subterráneas u otras posibles, deben estar apoyadas por medidas concomitantes encaminadas a conservar el agua y reducir al mínimo el derroche. Sin embargo, cuando sea necesario, habrá de darse prioridad a las medidas de prevención y control de las inundaciones, así como el control de la sedimentación". Agenda 21, par. 18.3.

${ }^{1129}$ Según Dinah Shelton; Alexandre Kiss mismo teniendo regímenes jurídicos distintos, sea por factores geográficos, sociales, políticos y económicos, es imprescindible el cuidado de uno para que interfiera en la protección del otro. Es una interacción que merece más énfasis. Op. Cit., 2008, p.59. 
renovación de agua en el subsuelo ${ }^{1130}$, reduciendo así, la oferta de agua dulce en las regiones deforestadas.

Cuando ocurre la deforestación o el derrumbe de árboles de manera insostenible, la integridad de las cuencas hidrográficas locales es amenazada o destruida, entre tanto cuando son mantenidas en su estado salvaje o explotadas de manera planificada, pueden ejecutar sus funciones como válvulas de seguridad para los ríos y sus cuencas hidrográficas ${ }^{1131}$.

Las masas forestales tienen un papel importantísimo y vital en la protección y purificación de las fuentes de agua dulce, eso porque atrapan o filtran los contaminantes del agua antes de llegar a los lagos y ríos y, reducen al mínimo la erosión del suelo localmente, lo que disminuye los sedimentos en las masas de agua, tales como humedales, estanques, arroyos, lagos y ríos, evitando también las inundaciones. Ahora, la contribución más significativa de los bosques al agua, consiste en mantener una elevada calidad de la misma.

En cualquier país, los bosques son esenciales para el ciclo del agua, una vez que hacen parte de la infraestructura natural, sirviendo para capturar y almacenar agua, pudiendo desempeñar una importante función en el suministro de agua potable para millones de personas en las megalópolis de la Tierra.

La Organización de las Naciones Unidas para la Agricultura y la Alimentación - FAO, en el año 2011 afirmó que: "Es consabido que una planificación forestal y prácticas de gestión prudentes pueden influir en el agua que utilizan los bosques y reducirla, por ejemplo plantando las especies convenientes de árboles. Los países están fortaleciendo sus políticas y las actividades de sus proyectos para incrementar las superficies forestales a fin de proteger los suelos y el agua. El 8\% de los bosques del mundo tienen como principal objetivo la conservación del suelo y el agua. Si bien cada hectárea de bosque hace una gran contribución a la regulación de los ciclos del agua, en el mundo hay unos 330 millones de hectáreas de los bosques del mundo destinadas a la conservación del suelo y el agua, control de aludes, estabilización de dunas, lucha

${ }^{1130}$ Interesantes comentarios sobre el consumo de las reservas del subsuelo en el Manual Judicial de Direito Ambiental, por SHELTON, Dinah; KISS, Alexandre, PNUMA, Versión en Portugués, 2008, pp. 59-78.

${ }^{1131}$ BARLOW, Maude; CLARKE, Tony. Oro Azul, $1^{\text {a }}$ ed., Editora M. Books do Brasil Ltda., São PauloBrasil: 2003, p. 46. 
contra la desertificación o protección costera. Esta superficie aumentó 59 millones de hectáreas de 1990 a 2010 y hoy representa el 8\% de la superficie forestal del mundo. El aumento reciente se debe en gran parte a la plantación en gran escala realizada en China con fines de protección" ${ }^{\prime 132}$.

La presente crisis en materia de agua y saneamiento lleva la humanidad a una pobreza, desigualdad y relaciones de poder desequilibradas, siendo exacerbadas por desafíos ambientales y sociales, urbanización acelerada, alteraciones climáticas y aumento de la contaminación.

En búsqueda de una respuesta a esta crisis, la comunidad internacional reconoció el derecho al agua y saneamiento como un derecho humano. Tal ocurrió el 28 de Julio de 2010, cuando la Asamblea General de las Naciones Unidas adoptó la resolución 64/292, en la cual reconoce el agua potable y el saneamiento como un derecho humano esencial para la plenitud de la vida y de todos los derechos humanos, instando los Estados y organizaciones internacionales a asegurar los recursos financieros, formación y transferencia de tecnologías necesarias, a través de asistencia y cooperación internacionales, con vista a mejorar el acceso al agua y al saneamiento.

Como consecuencia, el Consejo de Derechos Humanos de las Naciones Unidas, en el día 30 de Septiembre de 2010 reafirmó la decisión de la Asamblea General de las Naciones Unidas, Resolución 15/9, especificando además que el derecho al agua y saneamiento constituye un componente del derecho a un nivel de vida adecuado, tal como el derecho a la alimentación y vivienda. De esta manera el Consejo de Derechos Humanos puso el derecho al agua y saneamiento a pié de igualdad con un conjunto de otros derechos humanos ya reconocidos a decenas de años, tales como el derecho a la vida, salud, educación y trabajo.

Por último, el tercero Documento-Clave es la Resolución 68/157, aprobada por la Asamblea General de las Naciones Unidas, el 18 de Diciembre de 2013, que reafirma el contenido de los dos documentos anteriores ${ }^{1133}$.

\footnotetext{
${ }^{1132}$ Los bosques son indispensables para un suministro de agua de calidad. Hace falta una mejor ordenación forestal para optimizar los beneficios forestales relacionados con el agua. Artículo Publicado el 18-03-2011, en el sitio de la FAO: http://www.fao.org/news/story/es/item/53463/icode/. Acceso en: 1704-2015.

${ }^{1133}$ La relatora especial de las Naciones Unidas sobre el derecho humano al agua y saneamiento, Catarina de Albuquerque, realizó una misión oficial al Brasil entre los días 9 y 19 de diciembre de 2013 para
} 
evaluar las mejorías y los desafíos que el país aun enfrenta en la realización de los derecho humanos al agua y al saneamiento, entre sus observaciones, respecto al marco legal, afirmó que aun que la constitución brasileña de 1988 no incluye un reconocimiento explicito del derecho humano al agua y al saneamiento, la misma reconoce otros derechos, como los derechos a la salud, vivienda y alimentación, que están directamente ligados con el anterior. Resaltó que de todos modos seria importante una Emenda Constitucional que tuviera por objetivo incluir el derecho al agua y saneamiento explícitamente en el texto constitucional. Añadió, que por otro lado, la Ley de Saneamiento Básico (Ley n. ${ }^{\circ} 11.445$ de 2007) incorporó una visión de derechos humanos en los servicios de abastecimiento del agua y vertidos sanitarios, reflejados en los principios de universalización del acceso, transparencia de las acciones, preservación de la salud pública y medio ambiente, calidad y regularidad de los servicios, accesibilidad económica y control social. La prioridad al uso del agua para consumo humano también está asegurada en la Ley de Gerenciamiento de los Recursos Hídricos (Ley n. 9.433 de 1997). Disponible en: http://nacoesunidas.org/declaracao-oficial-da-relatora-especial-sobre-o-direito-humano-a-agua-esaneamento-ao-finalizar-a-sua-visita-ao-brasil-em-dezembro-de-2013/. Acceso en: 17-04-2015. El Ministerio de Asuntos Exteriores y de Cooperación de España, divulgó la nota de prensa 226, sobre la Aprobación de la Resolución "El derecho humano al agua potable y al saneamiento" presentada por España en Naciones Unidas, dicha nota afirma que: "Esta es una muestra más del compromiso de España con los derechos humanos, y en concreto, con el derecho al agua potable y saneamiento, que está estrechamente vinculado al logro de los Objetivos de Desarrollo del Milenio (ODM) y a la efectiva realización de otros derechos humanos (salud, educación, alimentación). Asimismo, la iniciativa constituye una de las piezas clave de los diversos planes y estrategias que España ha puesto en marcha este año 2013 en el marco del Año Internacional del Agua. Esta resolución resulta de fundamental importancia porque pasará a ser una referencia esencial en la Asamblea General en materia del derecho humano al agua y al saneamiento. En esta ocasión, se ha conseguido una consagración universal de este derecho y se ha reforzado sustancialmente lo conseguido en la Cumbre de Desarrollo Sostenible Rio+20, tanto por el hecho de haber sido adoptada esta resolución por consenso como por el altísimo número de copatrocinios que ha recibido. Esta resolución es un paso histórico para el reconocimiento de este derecho por la comunidad internacional. España seguirá trabajando para subrayar la obligación de los Estados de proveer un igual acceso al agua potable y el saneamiento, sin discriminación, de forma asequible y en todos los ámbitos de la vida". Nota de Prensa 226, Publicada el: 25-11-2013. Disponible en:

http://www.exteriores.gob.es/Portal/es/SalaDePrensa/NotasDePrensa/Paginas/Articulos/20131125_NOT A226.aspx. Acceso en: 17-04-2015. En 2014 la Unión Europea, a través de la primera Iniciativa Ciudadana Europea (ICE - que es una herramienta de democracia participativa en Europa que entró en vigor el 1 de abril de 2012), "Right2water", culminada con éxito, una vez que casi dos millones de firmas declararon el acceso al agua y al saneamiento como "un derecho humano en la legislación europea y, como consecuencia, en las legislaciones nacionales, para asegurar de ese modo una gestión pública, democrática, transparente y ecológica". De momento, la respuesta de la Comisión Europea ha sido favorable en lo relativo al derecho humano, y confirma el agua como un derecho humano, también se 
La realización de este derecho humano implica que el agua y el saneamiento estén disponibles, sean de calidades aceptables, física y económicamente accesibles. Por otro lado, los derechos humanos permiten también que estos derechos sean realizados de manera progresiva, en el límite máximo de los recursos disponibles en cada Estado, sin cualquier tipo de discriminación. El régimen jurídico de los derechos humanos determina igualmente la obligación de los gobiernos crearen mecanismos a través de los cuales las personas puedan responsabilizar el Estado, participar en la definición de políticas públicas y tener acceso a la información ${ }^{1134}$.

Falta a la humanidad buenos hábitos de consumo para que sepa como utilizar el agua de manera inteligente. La consciencia de la población, la educación ambiental y las políticas públicas correctas, contribuirán para eso. La urgencia para una tomada de postura es visible.

Delante de ese escenario, las preocupaciones y búsqueda por un futuro más sostenible es sin fin, tanto es, que entre los días 12 y 17 de abril de este año de 2015, va a ocurrir en Daegu Gyeongbuk- República de Corea el $7^{\circ}$ Foro Mundial del Agua ${ }^{1135}$

compromete a promover el acceso universal al agua y al saneamiento en su política de cooperación al desarrollo, incluyendo la promoción de acuerdos público-comunitarios. Pero la Comisión no propone legislación que reconozca este derecho. El Parlamento Europeo está trabajando en un informe sobre la iniciativa, que será votado en los próximos meses, aun en este año de 2015. Disponible en: http://www.euroxpress.es/index.php/noticias/2015/3/22/dia-mundial-del-agua-derecho-humano-vsrecurso-comercial/ en: http://europa.eu/geninfo/query/index.do?queryText=derecho+humano+al+agua\&summary=summary\&m ore_options_source $=$ global\&more_options_date=-

$31 \&$ more_options_date_from $=\&$ more_options_date_to $=\&$ more_options_language $=$ es\&more_options_f_f ormats $=* \&$ swlang=es, y también en: http://www.right2water.eu. Todos con acceso en: 17-04-2015. Así, como bien observa Sergio Salinas Alcega, El derecho al agua como Derecho humano. Contenido normativo y obligaciones de los Estados. In Antonio Embid Irujo, Navarra: Aranzadi, 2006, p. 101: "La afirmación de Norberto Bobbio de que el problema de fondo en relación con los derechos humanos es hoy no tanto el de su justificación como el de su protección, es trasladable al derecho al agua en la medida en que, sea como derecho autónomo o como componente esencial de otros derechos, forma ya parte del cuerpo de derechos de cuya garantía se ocupan diversos mecanismos de protección”.

${ }^{1134}$ Más informaciones sobre el tema de derecho al agua y saneamiento pueden ser encontradas en la Folleto Informativo n. 35 del Alto Comisariado de las Naciones Unidas para los Derechos Humanos. Disponible en: http://www.ohchr.org/Documents/Publications/FactSheet35sp.pdf. Acceso en: 13-042015.

${ }^{1135}$ El Consejo Mundial del Agua (WWC - World Water Council) fue creado en 1996 y congrega 
mayor evento sobre recursos hídricos del mundo, realizado a cada tres años - que tiene como tema "Agua para nuestro futuro", y tratará de cuestiones volcadas a solucionar los desafíos del agua.

Ya se determinó que el $8^{\circ}$ Foro Mundial del Agua, irá ocurrir en BrasiliaBrasil, en Marzo de $2018^{1136}$.

alrededor de 350 miembros representando 60 países. Tiene como misión promover la consciencia sobre agua, crear compromiso político e incentivar acciones en todos los niveles de la sociedad, incluso tomadores de decisión, con el fin de conservar, proteger, desarrollar, gestionar y utilizar eficazmente este recurso vital, es esencial fomentar y fortalecer el intercambio y diálogo multidisciplinario multi-actores, e intersectorial. Con la finalidad de impactar las acciones relacionadas con el agua de manera positiva, todas las perspectivas deben considerarse en la reflexión y el debate continuo para asegurar un futuro seguro de agua para el mundo. Disponible en: www.worldwatercouncil.org. Acceso en: 08-04-2015. Cuatro temas principales que agrupa 16 temas constituyen el marco temático del $7^{\circ}$ Foro Mundial del agua: Abastecimiento de agua potable para todos; Agua para el desarrollo y la prosperidad; Agua para la sostenibilidad: la armonización de los seres humanos y naturaleza y, Construir mecanismos de aplicación factible. Disponible en: http://www.worldwatercouncil.org/es/. Acceso en: 08-04-2015. Para la temática del $7^{\circ}$ Foro, Brasil seleccionó para ser abordado prioritariamente por los miembros brasileños los siguientes temas: Cambios Climáticos, Gobernanza de los Recursos Hídricos, Nexo Agua e Saneamiento, Agua y Energía y Agua y Alimento, y Ecosistemas Acuáticos. Disponible en: http://aguasdobrasil.org/edicao-10/os-preparativos-do-brasil-para-o-7o-forum-mundial-da-agua.html. Acceso en: 08-04-2015.

${ }^{1136}$ El Gobierno brasileño recibió con satisfacción la elección, el 26 de febrero de 2014, de Brasilia, por parte del Consejo Mundial del Agua (CMA) para ser la sede del $8^{\circ}$ Foro Mundial del Agua (FMA) en 2018. El FMA es hoy el principal ámbito de diálogo internacional entre los distintos sectores involucrados a la temática de los recursos hídricos, contando con una amplia participación de la sociedad civil. La candidatura brasiliense fue promovida por los Gobiernos Federal y del Distrito Federal. Además de las discusiones temáticas, el evento cuenta también con una Exposición orientada al público en general, visando construir también una oportunidad de negocios para las empresas del sector. La elección de Brasilia como sede del Foro Mundial del Agua es un reconocimiento a la relevancia del país respecto al tratamiento del tema en el escenario internacional. La realización del $8^{\circ}$ Foro Mundial del Agua, en marzo de 2018, representará una oportunidad para promover un amplio debate sobre los desafíos y oportunidades vinculados a la cuestión del agua en un ámbito nacional e internacional. Disponible en: http://www.itamaraty.gov.br/index.php?option=com_tags\&view=tag\&id=124-água\&lang=pt-BR. Acceso en: 16-04-2015. 


\subsection{El agua en el derecho internacional}

La Declaración de Dublín Sobre Agua y Desarrollo Sostenible ${ }^{1137}$, se dio como conclusión de la Conferencia Internacional sobre el Agua y el Medio Ambiente mantenida en la ciudad de Dublín (Irlanda) entre el 20 y el 31 de enero de 1992. Su objetivo esencial fue concienciar todos los individuos de todos los pueblos y naciones del esfuerzo, por intermedio de la educación y de la enseñanza, en desarrollar el respeto a los derechos y obligaciones en relación a las aguas y asumir, con medidas progresivas de orden nacional e internacional, su reconocimiento y su aplicación efectiva. Esa Declaración sugiere, entre otros aspectos, que el desarrollo y la gestión del agua deben ser basados en la participación de los usuarios, de los planeadores y de los tomadores de decisión, en todos los niveles ${ }^{1138}$.

Sin embargo, desde 1971, la Comisión de Derecho Internacional (CDI), integrante de la Organización de las Naciones Unidas (ONU) había inscrito en su programa de trabajo, durante su $23^{\mathrm{a}}$ sesión, el tema 'Derecho de los usos de los cursos de agua internacionales para fines distintos de la navegación', cumpliendo la Resolución 2.669 (XXV), de 08 de diciembre de 1970, de la Asamblea General de la $\mathrm{ONU}^{1139}$.

La 'Convención sobre el Derecho de los Usos de los Cursos de Agua Internacionales para Fines Distintos de la Navegación' seria adoptada y abierta a la adhesión solamente el 21 de mayo de 1997, por intermedio de la Resolución 51/229 de la ONU. Hubo 104 votos a favor, 26 abstenciones y tres votos en contra (Burundi, China e Turquía) ${ }^{1140}$.

La expresión 'curso de agua internacional' es entendida como un curso de agua cuyas partes se encuentran en países diferentes (Resolución 51/229, ONU, art. $2^{\circ}$, b). También puede ser entendida como 'aguas transfronterizas, y estando en ella insertados

\footnotetext{
${ }^{1137}$ Resultado de la Conferencia Internacional sobre el Agua y Medio Ambiente.

${ }^{1138}$ SETTI, A. A.; LIMA, J.; CHAVES, A. G. M.; PEREIRA, I. C. Introdução ao gerenciamento de recursos hídricos, 2 ed. Brasília: Agência Nacional de Energia Elétrica, Agência Nacional de Águas, 2001.

${ }^{1139}$ MACHADO, Paulo Affonso Leme. Recursos Hídricos: Direito brasileiro e internacional. Malheiros Editores, São Paulo: 2002, p. 125.

${ }^{1140}$ ARCARI, M. Il regime giuridico delle utilizzazioni dei corsi d'acqua internazionali. Padua: CEDAM, 1998, p. 36.
} 
los 'ríos transfronterizos, denominación adoptada por la Ley Brasileña de la Política Nacional de Recursos Hídricos (Ley 9.433, de 08 de enero de $1997^{1141}$ ), artículo 39, § $2^{\text {o }}$ 'Curso de agua' es definido como "un sistema de aguas de superficie y de aguas subterráneas, constituyendo, por el hecho de sus relaciones físicas, un conjunto unitario, terminando normalmente en un ponto de común de llegada" (Resolución 51/229, ONU, artículo $2^{\circ}$, a).

No consta de la Convención sobre el Derecho de los Usos de los Cursos de Agua Internacionales para Fines Distintos de la Navegación una definición del 'sistema' (Resolución 51/229, ONU, artículo $2^{\circ}$, a), pero la Comisión de Derecho Internacional (CDI) interpreta el artículo como siendo el sistema hidrológico el lugar donde corre el agua, tanto en la superficie como en el subterráneo, siendo compuesto por número específico número de elementos: ríos, lagos, acuíferos, glaciares, reservatorios y canales que, interconectados, hacen parte de curso de agua ${ }^{1142}$. "Constituyendo, por el hecho de sus relaciones físicas, un conjunto unitario”, parte del inciso, explica el significado.

Aguas internacionales son las aguas transfronterizas compuestas por ríos y cuencas hidrográficas que abarcan los territorios de dos o más naciones. Pueden ser ríos contiguos (sirven de línea divisoria, frontera) o ríos sucesivos (que cortan más de un Estado) (ANA $\left.{ }^{1143}, 2007\right)$. El concepto de cuenca hidrográfica internacional ${ }^{1144}$ (Directiva 200/60/CE) determina que ríos principales o secundarios de un rio internacional también sean considerados internacionales.

Los defensores de la no-inclusión del concepto de cuenca hidrográfica argumentan que [...] se debe considerar como internacionales solamente las vías de agua

\footnotetext{
${ }^{1141}$ Ley 9.433 de 8 de enero de 1997. Instituye la Política Nacional de Recursos Hídricos, crea el Sistema Nacional de Gerenciamento de Recursos Hídricos, reglamenta el inciso XIX del art. 21 de la Constitución Federal y altera el art. $1^{\circ}$ de la Ley 8.001, de 13 de marzo de 1990, que modificó la Ley 7.990, de 28 de diciembre de 1989.

${ }^{1142}$ MACHADO, Paulo Affonso Leme. Recursos Hidricos: cit., p. 128.

${ }^{1143}$ Agência Nacional das Águas, art. 2º, Resolução nº 467, 30 de octubre de 2006.

${ }^{1144}$ Esa es la ordenación en la Unión Europea, que, por medio da Directiva 200/60/CE, estableció: "En el caso de una demarcación hidrográfica internacional situada totalmente en territorio comunitario, los Estados miembros garantizarán la coordinación con objeto de elaborar un único plan hidrológico de cuenca internacional. Si no se elabora dicho plan hidrológico de cuenca internacional, los Estados miembros elaborarán planes hidrológicos de cuenca que abarquen al menos las partes de la demarcación hidrográfica internacional situadas en su territorio, para lograr los objetivos de la presente Directiva.”.
} 
que separan o cruzan el territorio de los Estados y no el fragmento físico de tierra. Las cuencas fluviales pueden extenderse en fracciones limitadas, pero también muy extensas. En ese caso, la CDI no podría formular reglas para regiones tan vastas, e imponer una especie de doble soberanía o múltiple ${ }^{1145}$.

En la sesión de Nueva York de 1958, la International Law Association (ILA) definió 'cuenca de drenaje' como "un sistema de ríos y lagos que debe ser tratado como un conjunto integrado". Sin embargo, "la idea de unidad de cuenca hidrográfica implicaría los Estados interesados aceptaren determinadas limitaciones emanadas de reglas establecidas para gobernar el régimen da cuenca" ${ }^{1146}$. Brasil es signatario do Tratado de la Cuenca del Plata y, en su derecho interno ${ }^{1147}$, adoptó la cuenca hidrográfica como unidad territorial para la ejecución de la Política Nacional de Recursos Hídricos y para la actuación del Sistema Nacional de Gerenciamento dos Recursos Hídricos. El gobierno brasileño buscó explicar su aparente contradicción al posicionarse en contra la inserción del concepto de 'cuenca de drenaje' en la convención de Nueva York de 1997 afirmando ser un concepto territorial, el cual puede, bajo características locales y acciones territoriales pertinentes, constituir no más que una unidad apropiada para ciertos proyectos de desarrollo e integración física, como es el caso del Tratado de la Cuenca del Río de la Plata ${ }^{1148}$.

La divergencia de opiniones no impidió el Grupo de Trabajo de la Asamblea General de la ONU incluir, en el texto adoptado en abril de 1997, una definición de 'curso de agua' basada en la noción de 'sistema', y de 'recurso de agua compartido'. Esto parece confirmar que, si la solución presentada por la CDI no resuelve todos los problemas relacionados a la definición, representa, quizás, un compromiso en términos de aceptabilidad por parte de los Estados ${ }^{1149}$.

${ }^{1145}$ BUIRETTE, P. Genèse d'un droit fluvial international général. Revue Générale de Droit International Public XCV. Paris: Éditions A. Pedone, 1991, p.23.

${ }^{1146}$ SETTE-CÂMARA, J. Pollution of international rivers. Recueil des Cours de l'Académie de Droit International de La Haye, t.3, 1984, p.129.

${ }^{1147}$ Lei $9.433 / 1997$, art. $1^{\circ}, \mathrm{V}$.

${ }^{1148}$ ARCARI, M. Il regime giuridico delle utilizzazioni dei corsi d'acqua internazionali, 1998, cit., p.38.

${ }^{1149}$ MACHADO, Paulo Affonso Leme. Recursos Hidricos: cit., p.130; ARCARI, M. Il regime giuridico delle utilizzazioni dei corsi d'acqua internazionali, 1998, cit., p.151. 
De acuerdo con Yahn Filho ${ }^{1150}$, el surgimiento del concepto 'recurso de agua compartido' en el Derecho Internacional lleva al entendimiento de que las fronteras son tridimensionales y que la contaminación y cualquier otro daño a la naturaleza es responsabilidad de toda la humanidad, ya que ella no conoce límites geográficos.

La Directiva Marco del Agua - DMA (European Water Framework Directive 2000/60/CE) ya demostraba claramente que es lo que se desea para el bienestar mundial, y el Informe de Desarrollo Humano del Programa de las Naciones Unidas para el Desarrollo (PNUD) ${ }^{1151}$ prevé una grave realidad: para el año de 2025, más de tres mil millones de personas podrán estar viviendo en países sujetos a presión sobre los recursos hídricos, y 14 países van a pasar de una situación de presión sobre os recursos hídricos para una de escasez efectiva. Países densamente poblados, como China e India, integraran el club mundial dos amenazados por falta de agua.

La Directiva 2000/60/CE determina la base de conocimientos y datos sobre la disponibilidad de recursos de agua, su gerencia, los criterios de sostenibilidad y la protección del agua.

Para eso, las Agencias de los Distritos de las Cuencas Hidrográficas y las autoridades competentes del gobierno y los Estados-miembros deben reorientar sus políticas hídricas y, por consecuencia, los proyectos realizados por compañías privadas también deberán ser adaptados. Específicamente, esa directiva orientadora busca identificar 'dónde' y 'como' las actividades humanas pueden influir en los objetivos ambientales de la directiva orientadora y en la realización de un adecuado estatus ecológico, químico y cuantitativo del agua. Los criterios de gerencia deben ser aplicados como una clave para la identificación, caracterización y análisis del estatus de los cursos de agua. Esto incluye la identificación de los impactos de actividades humanas sobre la calidad y la cantidad de recursos de agua, el análisis de sus contaminadores y la caracterización de su fuente. En lo que se refiere a la contaminación, la directiva orientadora establece que la reversión de las tendencias de aumento significativo en la concentración de la polución en las aguas subterráneas debe

${ }^{1150}$ YAHN FILHO, A. G. Aspectos Jurídico-Ambientais da Utilização dos Cursos d'Água Internacionais. Boletim Cientifico, Escola Superior do Ministério Público da União (ESMPU), Brasília, Ano II, n.9, 2003.

${ }^{1151}$ Relatório de Desenvolvimento Humano, Programa das Nações Unidas para o Desenvolvimento (PNUD) 2007/2008, p.136. 
ser obtenida, así como la detención de nuevas formas de polución. Estas exigencias implicarán directamente en la orientación de proyectos de consultoría ambiental y, simultáneamente, van a generar nuevas oportunidades de trabajo en el campo de estudios de la gerencia hídrica, del planeamiento de recursos ambientales, del uso de nuevas metodologías y de técnicas alternativas de recuperación ${ }^{1152}$.

Actualmente, el agua es fuente de conflictos jurídicos, sociales, económicos, ambientales, políticos y éticos. El problema de la escasez hídrica es oriundo, básicamente, de la no adopción de un modelo de gestión integrada, del crecimiento extremado de las demandas, de la degradación de la calidad del agua y del modelo excluyente de desarrollo económico, además del crecimiento poblacional ${ }^{1153}$.

La discusión ambiental es relativamente nueva, ya que existe desde la década de los años 60, época en la que se empezó a formar la consciencia de no existieren Estados aislados, y que la preservación exigiría la cooperación y la formulación de normas internacionales. Aunque se hayan producidos muchos documentos, dependen de la aceptación y de la subordinación de cada signatario. A partir de entonces cabe a la sociedad civil, de forma organizada y participativa, exigir la aplicación de lo que fue pactado y proponer nuevos avances. Y más, que estos avances lleven generaciones para concretizarse, el despertar ya concede alguna ventaja ${ }^{1154}$.

\subsection{Fuentes de Derecho Internacional Público}

Después de analizar la influencia del derecho internacional público en el derecho interno, necesario se hace verificar la origen de su normatividad, a través de la

${ }^{1152}$ GUIMERÁ, J. European Water Framework Directive (200/60/CE): implications in groundwater management. 07 May 2005. Disponible en: <http://www.portofentry.com/site/root/resources/ case_study/2823.html>. Acceso en: 04-07-2009.

${ }^{1153}$ BARBOSA, E. M. Água doce: direito fundamental da pessoa humana. Revista Âmbito Jurídico, 2007. Disponible en <http://www.ambito-juridico.com.br/pdfsGerados/artigos/3172.pdf>. Acceso en: 15-022009.

${ }^{1154}$ MOUSQUER, A. R. Águas transfronteiriças e transnacionais: as nações e o uso interdependente da água. Revista de Doutrina da $4^{a}$ Região, Porto Alegre, n. ${ }^{\circ}$ 29, abr. 2009. Disponible en: $<$ http://www.revistadoutrina.trf4.jus.br/artigos/edicao029/ana_mousquer.html>. Acceso en: 09-07-2009. 
análisis de sus fuentes, y la raíz de su obligatoriedad, a través del estudio de su fundamento.

Fuente jurídica o fuente de Derecho es una estructura normativa con capacidad de instaurar normas jurídicas en función de hechos y valores, debido al poder que es a ella inherente ${ }^{1155}$.

Lo que diferencia fuente de derecho internacional de fundamento de derecho internacional es que fuente es de donde surge su normatividad y fundamento es de donde proviene su obligatoriedad.

A finales del siglo XIX, los estudios de las fuentes de derecho internacional, además de ganar el interés de los miembros de la sociedad internacional, crece su importancia, con fulcro en el positivismo jurídico, con el surgimiento de los movimientos pacifistas que postulaban el establecimiento de soluciones pacíficas de controversias internacionales, como alternativa a la guerra.

En 1907, al final de la II Conferencia de Paz de la Haya (Convenio XII de la Haya de 18 de octubre de 1907), fue celebrado, entre otros tratados, el acuerdo constitutivo del Tribunal Internacional de Presas. Mismo que el tratado constitutivo nunca ha entrado en vigor $^{1156}$, la importancia de este tribunal internacional está en el hecho de que, por cuidar de establecer incumbencia formal de jueces para la solución de litigios internacionales, su negociación abarcó el establecimiento y el reconocimiento, por parte de los Estados contratantes, de un rol de fuentes de derecho

${ }^{1155}$ Conforme Miguel Reale, Fontes e modelos de direito: para um novo paradigma hermenêutico. Editora Saraiva, São Paulo-Brasil: 1999, p. 15, además afirma que el poder inherente a la fuente, y que es el propio contenido, es aquel: "legislativo, costumeiro, jurisdicional ou negocial, capaz de instaurar vínculos de caráter coercitivo". Para Norberto Bobbio, O positivismo jurídico, Editora Ícone, São PauloBrasil: 1999, p. 161, las fuentes de Derecho son: "aqueles fatos ou aqueles atos aos quais um determinado ordenamento jurídico atribui a competência ou a capacidade de produzir normas jurídicas".

${ }^{1156}$ A pesar de haber sido firmada por 31 países, sólo uno la ratificó. Desde el siglo XVIII fueron registrados varios intentos para la creación de un órgano semejante. En diferentes oportunidades, comisiones internacionales o procedimientos arbitrales llegaron a ser establecidos, bilateralmente (Conforme lo disponible en: < https://www.icrc.org/ihl/INTRO/235?OpenDocument>. Acceso en: 27-072015). 
internacional, al cual los magistrados deberían acudir para dictar el derecho vigente que fundamentaría sus decisiones ${ }^{1157}$.

El tratado del Tribunal Internacional de Presas reconocía como fuentes de derecho internacional: los tratados y convenciones y, en la falta expresa de esos, la costumbre (o reglas de derecho internacional, generalmente reconocidas), los principios generales de Derecho y la equidad, necesariamente en ese orden.

Como resultado de los tratados de Washington, en aquel mismo año, se establecería la primera experiencia judicial internacional efectiva de solución de controversia: la Corte Centroamericana de Justicia ${ }^{1158}$, que funcionó diez años, de 1908 hasta 1918 .

Los primeros avanzos del Rule of Law en el plano internacional fue dado por la Corte Centroamericana de Justicia ${ }^{159}$. Su competencia permitía la sumisión de casos tanto por los Estados-parte, cuanto por individuos y, en relación a las fuentes de derecho internacional, aunque expresamente no utilice esa nomenclatura, su tratado constitutivo establecía, en sus artículos XXI y XXIII, que los jueces deberían decidir con base en sus libres convencimientos y en los principios del derecho internacional, además de ser la Corte competente para interpretar tratados y convenciones relativas a las cuestiones hacia ella planteadas.

Mismo habiéndose quedado restricta al ámbito regional, y a solo cinco Estados-parte, la Corte Centroamericana de Justicia fue la primera experiencia concreta de solución judicial de litigios internacionales, aunque gran parte de los iusinternacionalistas no se recuerden de ella.

En ámbito global, la primera experiencia de un tribunal judicial internacional surgiría con el establecimiento de la Corte Permanente de Justicia Internacional o

${ }^{1157}$ En realidad, la divergencia entre las partes estaba justamente en ese punto. Tanto que, después de su conclusión, y delante de inexistente sumisión a las disposiciones, fue realizada en Londres, en 1908 y 1909, otra reunión diplomática que culminó con la Declaración de Londres Relativa a las Leyes de la Guerra Naval. Esa Declaración, a pesar de reiterar básicamente mucho de lo que ya estaba convenido en tratados, no tuvo el efecto deseado en relación a las reglas aplicables al Tribunal de Presas.

${ }^{1158}$ Más informaciones disponibles en: < http://portal.ccj.org.ni/ccj2/Historia/tabid/57/Default.aspx>. Acceso en: 28-07-2015.

${ }^{1159}$ Conforme Antônio Augusto Cançado Trindade, Os tribunais internacionais contemporâneos, Ed. FUNAG, Brasília-Brasil: 2013, p. 10. Inicialmente, la Corte fue instalada en la ciudad de Cartago, Costa Rica, siendo, posteriormente, transferida para San José. En sus diez años de existencia, juzgó diez casos. 
Tribunal Permanente de Justicia Internacional, era un órgano de justicia internacional, instalada en 1920 en Haya, Holanda, en un tratado independiente al Pacto de la Sociedad de Naciones, fruto de pactos celebrados después del termino de la $1^{\text {a }}$ Guerra Mundial, y cuyo Estatuto, en el art. 38, disponía sobre la materia. Fue el primero Tribunal de alcance universal, dotado de competencia para juzgar litigios entre Estados. Aunque la Corte se concibió a través de y por obra de la Sociedad de Naciones, no era parte de la Sociedad. La Corte dejo de funcionar en 1940, pero solo en 1946 fue formalmente extinta y fue su estatuto el primero documento internacional de ámbito no regional a traer un rol de fuentes de derecho internacional formalmente establecido y reconocido $^{1160}$.

El Estatuto de la Corte Permanente de Justicia Internacional establecía en su artículo 38 que la Corte debería aplicar: las convenciones internacionales, generales o particulares, reconocidas por las partes litigantes; la costumbre internacional, como evidencia de práctica general acepta como Derecho; los principios generales de derecho, reconocidos por las naciones civilizadas; sin perjuicio de la Corte decidir con base en la equidad, la jurisprudencia y doctrina, como fuentes auxiliares.

Las principales fuentes listadas por el Estatuto de la Corte Permanente de Justicia Internacional son las mismas que habían sido establecidas en el estatuto del Tribunal Internacional de Presas, con una importante diferencia: en la Corte Permanente no se establecía jerarquía entre ellas.

Sucesora de la Sociedad de Naciones, la Organización de las Naciones Unidas, cuando de su creación, trajo inserida en su estructura orgánica principal la Corte Internacional de Justicia, órgano judicial para la solución de litigios internacionales entre Estados.

Como homenaje a los relevantes servicios prestados por la Corte Permanente de Justicia Internacional a la sociedad internacional y al derecho internacional, la Corte Internacional de Justicia fue constituida en idéntico formato al de su antecesora incluyendo la reproducción de su Estatuto, guardadas las debidas adecuaciones, y siendo instalada en la misma ciudad.

Razón por la cual es el único de los órganos principales de la Organización de las Naciones Unidas que no tiene sede en los Headquarters de la organización, en

${ }^{1160}$ Disponible en: $<$ http://www.un.org/es/icj/permanent.shtml>. Acceso en: 06-07-2015. 
Nueva York, sino que en la ciudad holandesa de la Haya. Por esta razón es también conocida como Tribunal de La Haya.

La Corte Internacional de Justicia, principal órgano judicial de la Organización de las Naciones Unidas, establecida y disciplinada por el art. 92 de su Carta constitutiva, tuvo su Estatuto aprobado también en 1945, para disciplinar su funcionamiento, composición y procedimiento, lo cual en materia de fuentes de derecho internacional público, dispone:

“Artículo 38 - 1. La Corte, cuya función es decidir conforme al derecho internacional las controversias que le sean sometidas, deberá aplicar:

a. las convenciones internacionales, sean generales o particulares, que establecen reglas expresamente reconocidas por los Estados litigantes;

b. la costumbre internacional como prueba de una práctica generalmente aceptada como derecho;

c. los principios generales de derecho reconocidos por las naciones civilizadas;

d. las decisiones judiciales y las doctrinas de los publicistas de mayor competencia de las distintas naciones, como medio auxiliar para la determinación de las reglas de derecho, sin perjuicio de lo dispuesto en el Artículo 59.

2. La presente disposición no restringe la facultad de la Corte para decidir un litigio ex aequo et bono, si las partes así lo convinieren" $" 1161$.

Así, según el Estatuto de la Corte Internacional de Justicia, son fuentes principales de derecho internacional los tratados, la costumbre internacional y los principios generales de Derecho, $y$, fuentes auxiliares, la jurisprudencia internacional y la doctrina, además de la equidad, cuando las partes con ella acordaren.

Durante mucho tiempo, ese fue el rol exhaustivo de fuentes reconocidas por el derecho internacional y refrendado por la gran mayoría de la doctrina iusinternacionalista. Todavía, la propia jurisprudencia de la Corte Internacional de Justicia ha cuidado de reconocer otras fuentes de derecho internacional: los actos unilaterales de los Estados y las decisiones de las organizaciones internacionales.

La obligatoriedad de los actos unilaterales de los Estados es admitida, como fuente de derecho internacional, desde el caso referente a la Groenlandia Oriental, entre Dinamarca y Noruega, decidido por la CPJI, en 1933. Cuanto a las decisiones de las

${ }^{1161}$ Disponible en: < http://www.icj-cij.org/homepage/sp/icjstatute.php>. Acceso en: 07-07-2015. 
organizaciones internacionales, la CIJ reconoció su papel de fuente de derecho internacional en diversas oportunidades, como, por ejemplo: Accordance with International Law of the Unilateral Declaration of Independence in Respect of Kosovo (Opinión Consultiva, I.C.J. Reports 2010, para. 84); Legal Consequences for States of the Continued Presence of South Africa in Namibia (South West Africa) notwithstanding Security Council Resolution 276 (1970) (Opinión Consultiva, I.C.J. Reports 1971, p. 16); Questions of Interpretation and Application of the 1971 Montreal Convention arising from the Aerial Incident at Lockerbie (Libyan Arab Jamahiriya v. United Kingdom) (Provisional Measures, Order of 14 April 1992, I.C.J. Reports 1992, p. 15, párrafos 39-41 y pp. 126-127, párrafos $42-44)^{1162}$.

El desarrollo del derecho internacional contemporáneo, con fuerte influencia y contribución de la práctica de los principales órganos de la Organización de las Naciones Unidas y de otras importantes instituciones internacionales, se encargó de reconocer también la existencia de normas imperativas - perentorias - de derecho internacional general, también conocidas como normas de ius cogens - cuya obligatoriedad se encuentra por en cima de la voluntad de los Estados y no admite derogación, o sea, solo puede sufrir modificaciones por medio de otra de la misma naturaleza, además, generan obligaciones erga omnes, frente a todos los miembros de la sociedad internacional, independientemente de su acuerdo, como, por ejemplo, respecto a la dignidad de la persona humana.

A pesar de la influencia positivista Alfred Verdross ya analizaba y discutía en 1937, la existencia - y la necesidad - de normas imperativas, de ius cogens, en el derecho internacional: "La existencia de tales normas en el derecho internacional general es particularmente contestada por aquellos autores que basan toda la comunidad internacional en el acuerdo de voluntad entre los Estados; Consecuentemente, ellos no conocen ningún otro derecho internacional, que no sea el derecho de los tratados. Sin embargo, ellos dejan de considerar que cada tratado presupone un número de normas necesarias a la propia existencia de un tratado internacional. [...] Estos principios, relacionados a las condiciones de validad de los tratados, no pueden ser considerados como habiendo sido acordados por tratados; ellos deben ser considerados como válidos, independientemente de la voluntad de las partes contratantes". Verdross afirmaba ser

${ }^{1162}$ Disponible en: < http://www.icj-cij.org/docket/index.php?p1=3\&p2=2>. Acceso en: 07-07-2015. 
esta la razón por la cual la existencia de normas imperativas de derecho internacional general, las cuales, por lo tanto, limitarían la libertad de los Estados para la conclusión de tratados, no podría ser negada a priori $^{1163}$.

Hans Kelsen al escribir sobre los principios de derecho internacional público, también reconoció la existencia de dos géneros de normas de derecho internacional: el que denomina de derecho internacional general (o común), compuesto por "las normas de derecho internacional que son válidas para todos los Estados del mundo" (que para él, serían, en el momento, representadas apenas por reglas de derecho consuetudinario, o, en teoría, por normas derivadas de tratados de los que eran miembros todos los Estados del mundo), y que denomina de derecho internacional particular, que comprendería las normas válidas apenas para determinados Estados participantes de un pacto $^{1164}$.

Específicamente, en relación a la doctrina, en cuanto fuente de derecho internacional público, la Corte Internacional de Justicia adopta, preferencialmente, aquella que surge de los cursos impartidos por la Academia de Derecho Internacional de La Haya, creada en 1923 y con sede en la ciudad holandesa de La Haya, dentro del perímetro de las instalaciones del Palacio de la Paz, sede de la anterior Corte Permanente de Justicia Internacional y de la actual Corte Internacional de Justicia ${ }^{1165}$.

Esos cursos son publicados en su Recueil des Cours, transformándose así, en fuente doctrinaria, puesto que derivan de los conocimientos impartidos por los mayores iusinternacionalistas de las más variadas orígenes, pensamientos y nacionalidades ${ }^{1166}$.

Está claro que los cursos impartidos en la Academia no son la única fuente doctrinaria a que los jueces de la Corte utilizan, pero se constituyen en una de las más

${ }^{1163}$ VERDROSS, Alfred von. Forbidden treaties in international law: comments on professor Garner's report on "The law of the treaties". The American Journal of International Law, v. 31, n". 4, oct. 1937, pp. 571-577.

${ }^{1164}$ Conforme KELSEN, Hans. Principios de Derecho Internacional Público, trad. cast. de H. Caminos y E. C. HERMIDA, Librería el Ateneo editorial, Buenos Aires-Argentina: 1965, p. 161. Vide también KELSEN, Hans. El Contrato y El Tratado, trad. de Eduardo García Máynez, 2a edición, Editorial Colofón, México: 2002, pp. 34-35.

${ }^{1165}$ Disponible en: < https://www.hagueacademy.nl/about/history/>. Acceso en: 08-07-2015.

${ }^{1166}$ Disponible en: < https://www.hagueacademy.nl/publications/about-the-publications/>. Acceso en: 0807-2015. 
importantes bases doctrinarias para la análisis y el estudio del derecho internacional, tanto público, como privado. Además, la Corte Internacional de Justicia reconoce como fuente doctrinaria las doctrinas producidas por los principales centros de estudios de derecho internacional, como la International Law Association, el UNIDROIT (International Institute for the Unification of Private Law) y algunas de las principales universidades y centros de estudios alrededor del mundo.

\subsection{Convenciones de Viena de 1969 y 1985 sobre Derecho de los Tratados} entre Estados, entre Estados y Organizaciones Internacionales, 0 entre Organizaciones Internacionales entre sí.

En este momento del trabajo, nos limitaremos a hablar de las normas pertinentes de las dos Convenciones de Viena sobre el Derecho de los Tratados son los artículos 26, 27 y 46.

En la Parte III - sección primera - Observancia de los tratados, se encuentran el artículo 26: "Pacta sunt servanda". Todo tratado en vigor obliga a las partes y debe ser cumplido por ellas de buena fe; y, el artículo 27 que dispone lo siguiente: "El derecho interno y la observancia de los tratados. Una parte no podrá invocar las disposiciones de su derecho interno como justificación del incumplimiento de un tratado. Esta norma se entenderá sin perjuicio de lo dispuesto en el artículo 46".

Ya el artículo 46 está en la Parte V - sección segunda - Nulidad de los tratados, y establece: "Disposiciones de derecho interno concernientes a la competencia para celebrar tratados. 1. El hecho de que el consentimiento de un Estado en obligarse por un tratado haya sido manifiesto en violación de una disposición de su derecho interno concerniente a la competencia para celebrar tratados no podrá ser alegado por dicho Estado como vicio de su consentimiento, a menos que esa violación sea manifiesta y afecte a una norma de importancia fundamental de su derecho interno. 2. Una violación es manifiesta si resulta objetivamente evidente para cualquier Estado que proceda en la materia conforme a la práctica usual y de buena fe".

Con estos tres artículos, se puede concluir que las Convenciones de Viena sobre Derecho de los Tratados adoptaron una concepción monista con preeminencia del Derecho Internacional con excepción de una violación manifiesta de una norma 
fundamental de su Derecho interno concerniente a la competencia para celebrar $\operatorname{tratados}^{1167}$.

\subsection{La teoría monista en España}

Todos los Estados, en su calidad de sujetos de Derecho Internacional, están obligados a la observancia del Derecho Internacional, dadas las obligaciones que este impone en la materia.

La propia jurisprudencia internacional ha sostenido invariablemente el postulado de la primacía del Derecho Internacional, primacía esta, que no se sustenta en las constituciones de los Estados miembros, sino en la naturaleza y caracteres específicos del propio Derecho Internacional y de la Comunidad Internacional. Independientemente de los preceptos constitucionales, todo Estado, como miembro de la Comunidad Internacional, está obligado a respetar sus compromisos internacionales ${ }^{1168}$.

La Constitución española de 1978 contiene referencias indirectas al Derecho Internacional General, o sea, no dice de forma expresa cual es su posición sobre el tema. Ante casos similares, la doctrina iusnaturalista europea trata de explicar la ausencia de una recepción formal del Derecho Internacional General, por la existencia de una norma tácita de adopción automática de las normas consuetudinarias en todo orden jurídico

${ }^{1167}$ VANOSSI, J. Y DALLA, A. Régimen constitucional de los Tratados, $2^{a}$ ed., Ed. Abeledo Perrot, Buenos Aires-Argentina: 2000.

1168 “La Unión Europea cuenta para el cumplimiento de sus fines, con recursos humanos y materiales, con recursos financieros y con instrumentos normativos. El Derecho comunitario tiene primacía sobre el derecho nacional para poder garantizar su uniformidad en todos los Estados miembros. Por otra parte, el Derecho comunitario tiene autonomía con respecto al Derecho interno de los Estados. Además, confiere derechos e impone obligaciones directas tanto a las instituciones comunitarias como a los Estados miembros y a sus ciudadanos, en el marco del denominado efecto directo del Derecho comunitario. El Derecho comunitario se compone de los Tratados constitutivos y de los Tratados de adhesión (Derecho originario) y de las normas contenidas en los actos aprobados por las instituciones comunitarias en aplicación de dichos Tratados (Derecho derivado)". Disponible en: < http://www.exteriores.gob.es/RepresentacionesPermanentes/EspanaUE/es/quees2/Paginas/El-Derechocomunitario.aspx>. Acceso en: 31-07-2015. 
interno. Así, salvo norma constitucional en contrario, se considera que todo ordenamiento posee una norma tácita de recepción automática que se funda en el propio orden jurídico internacional.

Dos vías garantizan la armonía entre la norma interna y la internacional, son ellas: 1) Ordinaria: de acuerdo con el artículo $96^{1169}$ se garantiza por la publicación en que se incorpora automáticamente al sistema jurídico interno las reglas contenidas en el tratado internacional válidamente concertado, así como su inderogabilidad por ley interna posterior mientras subsista la obligación internacional; y, 2) Extraordinaria: cuando el tratado transfiera competencia prevista en la Constitución a favor de una Organización Internacional se requiere autorización mediante ley orgánica (art. 93 ${ }^{1170}$ ). En relación a los tratados que contengan disposiciones contrarias a la Constitución, los mismos no podrán ser ratificados sin previa revisión constitucional, como determina el artículo 95.1. ${ }^{1171}$ Conforme el artículo $95.2^{1172}$ el Gobierno o cualquier de las Cámaras puede acudir al Tribunal Constitucional a fin de que se declare la compatibilidad o incompatibilidad entre la Constitución y el proyectado tratado internacional.

La recepción del Derecho Internacional convencional en el ordenamiento español viene regulada constitucionalmente en el artículo 96, párrafo 1, que además, formula la obligación de la publicidad de forma amplia, sin concretar en una determinada publicación oficial.

\footnotetext{
${ }^{1169}$ Artículo 96. 1. "Los tratados internacionales válidamente celebrados, una vez publicados oficialmente en España, formarán parte del ordenamiento interno. Sus disposiciones sólo podrán ser derogadas, modificadas o suspendidas en la forma prevista en los propios tratados o de acuerdo con las normas generales del Derecho internacional". 2. "Para la denuncia de los tratados y convenios internacionales se utilizará el mismo procedimiento previsto para su aprobación en el artículo 94”.

${ }^{1170}$ Artículo 93. "Mediante la ley orgánica se podrá autorizar la celebración de tratados por los que se atribuya a una organización o institución internacional el ejercicio de competencias derivadas de la Constitución. Corresponde a las Cortes Generales o al Gobierno, según los casos, la garantía del cumplimiento de estos tratados y de las resoluciones emanadas de los organismos internacionales o supranacionales titulares de la cesión".

${ }^{1171}$ Artículo 95. 1. "La celebración de un tratado internacional que contenga estipulaciones contrarias a la Constitución exigirá la previa revisión constitucional".

${ }^{1172}$ Artículo 95. 2. "El Gobierno o cualquiera de las Cámaras puede requerir al Tribunal Constitucional para que declare si existe o no esa contradicción".
} 
Por un lado, en el artículo 1. $5^{1173}$ del Código Civil español figuran dos precisiones de interés en relación al art. 96.1 de la Constitución española, se concreta la publicación en el Boletín Oficial del Estado - BOE y se inserta el termino "aplicación directa" 1174 .

${ }^{1173}$ Artículo 1. 1. "Las fuentes del ordenamiento jurídico español son la ley, la costumbre y los principios generales del derecho". 2. "Carecerán de validez las disposiciones que contradigan otra de rango superior". 3. "La costumbre sólo regirá en defecto de ley aplicable, siempre que no sea contraria a la moral o al orden público, y que resulte probada. Los usos jurídicos que no sean meramente interpretativos de una declaración de voluntad, tendrán la consideración de costumbre". 4. "Los principios generales del derecho se aplicarán en defecto de ley o costumbre, sin perjuicio de su carácter informador del ordenamiento jurídico". 5. "Las normas jurídicas contenidas en los tratados internacionales no serán de aplicación directa en España en tanto no hayan pasado a formar parte del ordenamiento interno mediante su publicación íntegra en el «Boletín Oficial del Estado»". 6. "La jurisprudencia complementará el ordenamiento jurídico con la doctrina que, de modo reiterado, establezca el Tribunal Supremo al interpretar y aplicar la ley, la costumbre y los principios generales del derecho". 7. "Los Jueces y Tribunales tienen el deber inexcusable de resolver en todo caso los asuntos de que conozcan, ateniéndose al sistema de fuentes establecido".

${ }^{1174}$ José Manuel SERRANO ALBERCA, Sinopsis artículo 96 de la Constitución española, afirma que: "Desde una perspectiva diferente, el tratado es una fuente indirecta del derecho interno mientras no ha sido publicado y, por tanto, la publicación es la forma que adopta la recepción especial para transformar el derecho internacional en derecho interno. El precepto constitucional que comentamos sigue las directrices marcadas por el artículo 1.5. del Código Civil. No obstante, contiene algunas diferencias formales que lo hacen técnicamente más perfecto y más ajustado a la realidad. Se puede decir que la Constitución ha racionalizado algunos aspectos de las relaciones entre derecho internacional convencional y derecho interno, convirtiendo en norma estricta una serie de prácticas que eran de usual aplicación. El precepto aborda directamente o indirectamente los tres problemas básicos: sistema de integración, aplicación directa, naturaleza y jerarquía del tratado. Conforme a la redacción constitucional, el tratado se integra en el ordenamiento interno mediante la publicación, siempre que haya sido válidamente celebrado. No se exige un acto normativo interno que transforme el contenido del tratado ni puede tampoco interpretarse que la simple conclusión del tratado sin publicación es suficiente para su aplicabilidad interna. Se exige la publicación y la celebración válida. Este último requisito no tenía sentido antes de la Constitución, toda vez que la celebración válida de un tratado no podía ser controlada por el Juez. Ahora en cambio sí lo tiene porque el Tribunal Constitucional puede controlar esta validez". Disponible en:

http://www.congreso.es/consti/constitucion/indice/sinopsis/sinopsis.jsp?art=96\&tipo=2>. Acceso en: 3107-2015. 
Por otro lado, el artículo 29 del Decreto 801/1972 $2^{1175}$, de 24 de marzo, establece que la publicación se llevará a cabo mediante la inserción del texto integro del Tratado en el BOE, incluidas, en su caso, las reservas o declaraciones formuladas y cualquier otro documento anejo al tratado o complementario al mismo.

Cerrando la publicación del Tratado, habrá que constar una comunicación suscrita por el Secretario general técnico del Ministerio de Asuntos Exteriores en la que indicará la fecha en la que el tratado obliga a España y debe, por tanto, procederse a su aplicación.

España está obligada a las normas contenidas en los Tratados desde su entrada en vigor en el ordenamiento internacional en la fecha pactada por las Partes. En cuanto tales tratados, son fuentes directa y plenamente eficaces en el Derecho interno una vez publicados oficialmente, siendo susceptibles de crear por sí mismos derechos y obligaciones directamente exigibles por los particulares y recurrible ante los órganos administrativos y judiciales.

El tratado internacional, al integrarse el en Derecho español, conserva su naturaleza de norma internacional y su especial eficacia jurídica. Como tal norma internacional, sustenta en el propio Derecho Internacional su primacía sobre el derecho interno y independe de un reconocimiento al efecto por parte de la constitución. Como miembro de la Comunidad Internacional, todo Estado está obligado a respetar sus compromisos internacionales aceptando la superior jerarquía del Derecho Internacional, independientemente de los precepto de su ordenamiento interno. Si por alguna razón un Estado dejar de aplicar un tratado para aplicar una ley interna que posee disposiciones contrarias a ese, estará cometiendo un hecho ilícito internacional e incurrirá en responsabilidad internacional ante la otra u otras Partes del Tratado.

\footnotetext{
${ }^{1175}$ Artículo veintinueve. "Los tratados en los cuales España sea parte se publicarán en el «Boletín Oficial del Estado». La publicación se llevará a cabo: Uno. Mediante la inserción del texto íntegro del instrumento de ratificación o de adhesión de España a dicho tratado. Dos. Mediante la inserción del texto integro del tratado, ya conste éste en un instrumento único o en dos o más instrumentos conexos, así como, en su caso, de las reservas o declaraciones formuladas, y de cualquier otro documento anejo al tratado o complementario del mismo, en el caso de que España se hubiere obligado por la firma de su representante". Importante resaltar que el Decreto 801/1972, de 24 de marzo, relativo a la Ordenación de la actividad de la Administración del Estado en materia de Tratados Internacionales se quedó en vigencia desde 28 de abril de 1972 hasta el 18 de diciembre de 2014.
} 
Según parte de la doctrina, los tratados tienen superior jerarquía a la ley ${ }^{1176}$, mismo que la constitución española no declare directamente eso, dicha primacía se afirma de forma indirecta, pero inequívoca, en el artículo 96.1 de la CE, donde expresa que las disposiciones de un tratado sólo podrán ser modificadas, suspendidas o derogadas en la forma prevista en el mismo tratado o conforme el Derecho Internacional general $^{1177}$, mediante la voluntad concertada de los Estados Partes que concurrieron en

${ }^{1176}$ En ese sentido, José Manuel Serrano Alberca, op. cit., explica que: "Hemos mantenido que el tratado tiene un rango superior a la ley y que esta afirmación se deriva del último inciso del artículo 96.1. Podría entenderse que todos los tratados, en principio, incluso los que no necesitan autorización de las Cortes, tienen rango superior a las leyes porque sólo se pueden modificar o derogar en la forma prevista en el propio tratado, con lo cual una ley posterior no podría modificar un tratado, incluso en aquellos casos en que no se exija autorización parlamentaria. Sin embargo, la cuestión ha de ser entendida de otra forma. En efecto, los tratados que no exigen autorización parlamentaria no afectan a la materia de la reserva de ley, pues si contuvieran materia legislativa serían inconstitucionales y si no la contienen, su rango es inferior a la ley. Ésta es la doctrina que mantiene el Consejo de Estado (Dictamen 46.901 de 7 de marzo de 1985). Por último una precisión: las normas dictadas en ejecución de un tratado autorizadas por las Cortes se contagian de su rango supralegal. La denuncia de un tratado exige el mismo procedimiento que para su aprobación exige el artículo 94, dice el texto constitucional. Pero la aplicación de la denuncia exige que se efectúa de conformidad con lo establecido en el tratado estipulado, pues en otro caso la denuncia sería inconstitucional. Es claro, además, que la denuncia de un tratado del artículo 93 exige ley orgánica y que la de un tratado del artículo 94 exige la autorización de las Cortes". Disponible en: < http://www.congreso.es/consti/constitucion/indice/sinopsis/sinopsis.jsp?art=96\&tipo=2>. Acceso en: 3107-2015.

${ }^{1177}$ José Manuel Serrano Alberca, op. cit., enseña que: "Para derogar un tratado ha de seguirse o bien el procedimiento señalado en el propio tratado o bien las normas generales de Derecho Internacional. La derogación de las normas contenidas en un tratado se puede realizar por uno de los procedimientos de terminación o por enmienda, o modificación. La Convención de Viena de 1969, reconoce, con carácter general, los procedimientos para la modificación o terminación de los tratados y da primacía a lo establecido por el propio tratado que es la regla también reconocida en nuestra Constitución. Entre los procedimientos de terminación de los tratados (consentimiento de las partes, derogación tácita, imposibilidad de cumplimiento, cambio de las circunstancias, etc.) la denuncia es la única a la que expresamente se refiere la Constitución. La denuncia es una forma de terminación que se manifiesta de forma unilateral por un Estado. La intervención del Parlamento en estos casos es la garantía de la no modificación de los tratados que afectan a materia de competencia de las Cortes Generales por un procedimiento diferente al de su celebración. En resumen, un tratado válidamente concluido no es todavía fuente directa del derecho interno español, sino sólo fuente indirecta. Para llegar a ser fuente directa necesita el requisito de su publicación. Los internacionalistas han considerado que la exigencia de la publicación no afecta al sistema de recepción automática seguido tradicionalmente por nuestro Derecho. 
el mismo, y no de forma unilateral. Además, en consecuencia, las leyes internas se quedan inaplicadas caso haya contradicción con un Tratado que esté en vigor para España.

Existiendo diferencias entre los tratados y la Constitución, una de las opciones está en que el propio ordenamiento podrá ofrecer el mecanismo de las reservas para salvar situaciones de conflicto con el Derecho interno, caso no sea posible, o sea, si no se puede hacer uso de las reservas y se duda de la conformidad de un tratado sobre el que se proyecta manifestar el consentimiento, surge otra opción en el artículo 95.2 de la CE la cual da la posibilidad de un control previo de constitucionalidad de los tratados internacionales. Si tuviera que hacer una reforma en la Constitución (en los términos de los artículos 166 a169 ${ }^{1178}$ ) para que España pueda ser Parte del Tratado, se estaría

Para llegar a esta conclusión consideran que la publicación o es un requisito formal constitutivo o es una condición suspensiva. El tratado válido, una vez publicado podrá crear obligaciones y derechos para los particulares. A este efecto se le denomina "aplicación directa" del tratado sin necesidad de una norma que lo desarrolle, pero sólo se producirá una vez que el tratado se haya publicado y si la naturaleza del mismo lo permite. El tratado concluido válidamente y publicado tiene, en todo caso, valor superior al de la ley aunque inferior a la Constitución, por lo que podrá ser objeto del recurso de inconstitucionalidad en el caso de violar un precepto de la norma fundamental. La publicación no es un requisito de validez ni de eficacia del tratado, pero sí un requisito para su aplicabilidad". Disponible en: < http://www.congreso.es/consti/constitucion/indice/sinopsis/sinopsis.jsp?art=96\&tipo=2>. Acceso en: 31 07-2015.

1178 “TÍTULO X - De la reforma constitucional

Artículo 166. La iniciativa de reforma constitucional se ejercerá en los términos previstos en los apartados 1 y 2 del artículo 87.

Artículo 167.

1. Los proyectos de reforma constitucional deberán ser aprobados por una mayoría de tres quintos de cada una de las Cámaras. Si no hubiera acuerdo entre ambas, se intentará obtenerlo mediante la creación de una Comisión de composición paritaria de Diputados y Senadores, que presentará un texto que será votado por el Congreso y el Senado.

2. De no lograrse la aprobación mediante el procedimiento del apartado anterior, y siempre que el texto hubiere obtenido el voto favorable de la mayoría absoluta del Senado, el Congreso, por mayoría de dos tercios, podrá aprobar la reforma.

3. Aprobada la reforma por las Cortes Generales, será sometida a referéndum para su ratificación cuando así lo soliciten, dentro de los quince días siguientes a su aprobación, una décima parte de los miembros de cualquiera de las Cámaras.

Artículo 168

1. Cuando se propusiere la revisión total de la Constitución o una parcial que afecte al Titulo preliminar, 
evidenciando que, el ordenamiento constitucional cede ante el interés tutelado por la norma de Derecho Internacional. Además, sea mediante el control previo de la constitucionalidad de los tratados (art. $95 \mathrm{CE}$ ), sea mediante el control a posteriori (art. $\left.161 \mathrm{CE}^{1179}\right)$, los Tratados deben respetar y ajustarse a la Constitución.

Así, en este sentido, un Tratado que ya hace parte del ordenamiento interno español, podría ser objeto de control de constitucionalidad por parte del Tribunal Constitucional por medio del recurso de inconstitucionalidad y la cuestión de inconstitucionalidad.

De este modo, compite exclusivamente al Tribunal Constitucional el control de constitucionalidad, que no puede declarar la nulidad del Tratado como lo hace con relación a la ley. La nulidad es puramente interna, declarando el Tratado, en este caso,

al Capítulo segundo, Sección primera del Título I, o al Título II, se procederá a la aprobación del principio por mayoría de dos tercios de cada Cámara, y a la disolución inmediata de las Cortes.

2. Las Cámaras elegidas deberán ratificar la decisión y proceder al estudio del nuevo texto constitucional, que deberá ser aprobado por mayoría de dos tercios de ambas Cámaras.

3. Aprobada la reforma por las Cortes Generales, será sometida a referéndum para su ratificación.

Artículo 169

No podrá iniciarse la reforma constitucional en tiempo de guerra o de vigencia de alguno de los estados previstos en el artículo 116". Disponible en: <https://www.boe.es/buscar/act.php?id=BOE-A-1978$31229 \& \mathrm{tn}=1 \& \mathrm{p}=20110927 \& \mathrm{vd}=\# \mathrm{a} 166>$. Acceso en: 03-08-2015.

1179 “Artículo 161

1. El Tribunal Constitucional tiene jurisdicción en todo el territorio español y es competente para conocer:

a) Del recurso de inconstitucionalidad contra leyes y disposiciones normativas con fuerza de ley. La declaración de inconstitucionalidad de una norma jurídica con rango de ley, interpretada por la jurisprudencia, afectará a ésta, si bien la sentencia o sentencias recaídas no perderán el valor de cosa juzgada.

b) Del recurso de amparo por violación de los derechos y libertades referidos en el artículo 53, 2, de esta Constitución, en los casos y formas que la ley establezca.

c) De los conflictos de competencia entre el Estado y las Comunidades Autónomas o de los de éstas entre sí.

d) De las demás materias que le atribuyan la Constitución o las leyes orgánicas.

2. El Gobierno podrá impugnar ante el Tribunal Constitucional las disposiciones y resoluciones adoptadas por los órganos de las Comunidades Autónomas. La impugnación producirá la suspensión de la disposición o resolución recurrida, pero el Tribunal, en su caso, deberá ratificarla o levantarla en un plazo no superior a cinco meses". Disponible en: <https://www.boe.es/buscar/act.php?id=BOE-A-1978$31229 \& \operatorname{tn}=1 \& p=20110927 \& v d=\# a 166>$. Acceso en: 03-08-2015. 
inaplicable, una vez que la nulidad de un Tratado sólo puede fundarse en las causas previstas en el Derecho Internacional, no puede ser declarado de manera unilateral por cualquiera de las Partes. Vale resaltar, que la no aplicación del Tratado significaría incurrir en responsabilidad internacional, lo que llevaría España a una variedad de opciones, en las cuales ninguna iba a ser fácil.

Por un lado, quedándose constatado a través de sentencia del Tribunal Constitucional la inconstitucionalidad del procedimiento seguido por la manifestación del consentimiento, esa sentencia respecto a la inconstitucionalidad extrínseca o externa permitiría a España la alegación internacional de nulidad del tratado, siguiendo el procedimiento previsto en los artículos 65 a $68^{1180}$ de la Convención de Viena. Todavía,

${ }^{1180}$ En la sección cuarta - Procedimiento - de la Convención de Viena:

“Artículo 65. Procedimiento que deberá seguirse con respecto a la nulidad o terminación de un tratado, el retiro de una parte o la suspensión de la aplicación de un tratado. 1. La parte que, basándose en las disposiciones de la presente Convención, alegue un vicio de su consentimiento en obligarse por un tratado o una causa para impugnar la validez de un tratado, darlo por terminado, retirarse de él o suspender su aplicación, deberá notificar a las demás partes su pretensión. En la notificación habrá de indicarse la medida que se proponga adoptar con respecto al tratado y las razones en que esta se funde.

2. Si, después de un plazo que, salvo en casos de especial urgencia, no habrá de ser inferior a tres meses contados desde la recepción de la notificación, ninguna parte ha formulado objeciones, la parte que haya hecho la notificación podrá adoptar en la forma prescrita en el articulo 67 la medida que haya propuesto.

3. Si. por el contrario, cualquiera de las demás partes ha formulado una objeción, las partes deberán buscar una solución por los medios indicados en el articulo 33 de la Carta de las Naciones Unidas.

4. Nada de lo dispuesto en los párrafos precedentes afectara a los derechos o a las obligaciones de las partes que se deriven de cualesquiera disposiciones en vigor entre ellas respecto de la solución de controversias.

5. Sin perjuicio de lo dispuesto en el artículo 45, el hecho de que un Estado no haya efectuado la notificación prescrita en el párrafo 1 no le impedirá hacerla en respuesta a otra parte que pida el cumplimiento del tratado o alegue su violación.

Artículo 66. Procedimientos de arreglo judicial de arbitraje y de conciliación. Si, dentro de los doce meses siguientes a la fecha en que se haya formulado la objeción, no se ha llegado a ninguna solución conforme al párrafo 3 del artículo 65, se seguirán los procedimientos siguientes:

a) cualquiera de las partes en una controversia relativa a la aplicación o la interpretación del artículo 53 o el artículo 64 podrá, mediante solicitud escrita, someterla a la decisión de la Corte Internacional de Justicia a menos que las partes convengan de común acuerdo someter la controversia al arbitraje:

b) cualquiera de las partes en una controversia relativa a la aplicación o la interpretación de cualquiera de los restantes artículos de la parte $\mathrm{V}$ de la presente Convención podrá iniciar el procedimiento indicado en el anexo de la Convención presentando al Secretario general de las Naciones Unidas una solicitud a tal 
también se podría reparar el vicio del consentimiento iniciándose otra vez, de manera correcta, el procedimiento previsto en la Constitución española para la prestación del consentimiento.

Por otro lado, en si constatando a través de la sentencia del Tribunal Constitucional, el conflicto entre el Tratado y la Constitución por razones sustanciales o inconstitucionalidad intrínseca o interna, distintas opciones podrían ser utilizadas, entre ellas: pactarse con la otra parte $\mathrm{u}$ otras partes para que el Tratado sea dado por terminado o suspendido, de forma parcial o total; el en punto en cuestión, cambiarlo de común acuerdo; dar inicio al procedimiento de reforma de la Constitución con la finalidad de hacerla compatible con el Tratado y, después de eliminado el conflicto entre ambos, el tratado podría ser plenamente aplicado y, también, podría denunciarse si el tratado lo permite, aunque la denuncia no tendría efectos hasta que el plazo de preaviso fuera agotado, haciendo frente en todo caso a la responsabilidad internacional a que hubiese lugar por el período de inaplicación.

Ya el artículo 10, párrafo 2 de la Constitución española dice: "Las normas relativas a los derechos fundamentales y a las libertades que la Constitución reconoce se interpretarán de conformidad con la Declaración Universal de Derechos Humanos y los tratados y acuerdos internacionales sobre las mismas materias ratificados por España”. Los tratados se constituyen así en pauta de interpretación para la aplicación de la normatividad interna y permite la expansión de los derechos humanos así como para la aplicación de la jurisprudencia de la Corte Europea de Derechos Humanos. No obstante,

efecto

Artículo 67. Instrumentos para declarar la nulidad de un tratado, darlo por terminado, retirarse de él o suspender su aplicación. 1. La notificación prevista en el párrafo 1 del artículo 65 habrá de hacerse por escrito.

2. Todo acto encaminado a declarar la nulidad de un tratado, darlo por terminado, retirarse de él o suspender su aplicación de conformidad con las disposiciones del tratado o de los párrafos 2 ó 3 del artículo 65, se hará constar en un instrumento que será comunicado a las demás partes. Si el instrumento no está firmado por el Jefe del Estado, el Jefe del Gobierno o el Ministro de Relaciones Exteriores, el representante del Estado que lo comunique podrá ser invitado a presentar sus plenos poderes.

Artículo 68. Revocación de las notificaciones y de los instrumentos previstos en los artículos 65 y 67 . Las notificaciones o los instrumentos previstos en los artículos 65 y 67 podrán ser revocados en cualquier momento antes de que surtan efecto". Disponible en: < http://www.derechos.org/nizkor/ley/viena.html>. Acceso en: 03-08-2015. 
es importante distinguir la función interpretativa que cumple este art. 10.2 CE frente a la función integradora o de recepción que se opera en el art. $96 \mathrm{CE}$.

Respecto a la competencia, compete a todas las Instituciones del Estado: legislativo, ejecutivo y judicial, tanto en el orden estatal como en el autonómico, la aplicación de los tratados internacionales.

Siendo el contenido del tratado suficientemente preciso e incondicional (con disposiciones directamente aplicables o de auto ejecución ${ }^{1181}$ ) tendrá eficacia directa e inmediata y afectará a los derechos y a las obligaciones de los particulares, debiendo los órganos administrativos y judiciales del estado y de las Comunidades Autónomas asumir la vigilancia, aplicación y protección de los derechos y obligaciones establecidos por el tratado.

Por otro lado, en algunos casos, no es posible que el tratado o parte de sus disposiciones sean aplicados directamente (con disposiciones de no auto ejecución ${ }^{1182}$ ), haciendo con que vengan a precisar de un desarrollo legislativo, que corresponderá a las Cortes Generales o al legislativo autonómico (cuando afectada la competencia de una Comunidad Autónoma) si la materia a la que se refiere el tratado es objeto de reserva legal o exige modificación de leyes anteriores, o puede precisar de un desarrollo reglamentario, que corresponderá al Gobierno de la Nación o al ejecutivo autonómico.

Pese a que el art. 149. 1. $3^{\mathrm{a} 1183}$ de la Constitución española dice lo que dice, una interpretación sistemática del mismo debe ser hecha con base en los principios que rigen la Constitución y en la origen del actual art. 149. 1. $3^{\mathrm{a}}$, entendiendo que este precepto da competencia exclusiva en la proyección exterior de la actividad del Estado, como son la conclusión de los tratados, la representación del Estado, dirección de la política exterior y responsabilidad internacional.

\footnotetext{
${ }^{1181}$ Auto ejecución es un término que surge del inglés self-executing.

${ }^{1182}$ No Auto ejecución es un término que surge del inglés not self-executing.

1183 “Artículo 149

1. El Estado tiene competencia exclusiva sobre las siguientes materias:

1. ${ }^{a}$ La regulación de las condiciones básicas que garanticen la igualdad de todos los españoles en el ejercicio de los derechos y en el cumplimiento de los deberes constitucionales.

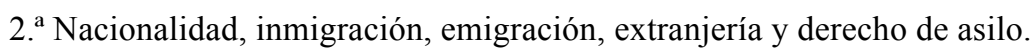

3. "Relaciones internacionales". (...). Disponible en: <https:/www.boe.es/buscar/act.php?id=BOE-A1978-31229\&tn=1\&p=20110927\&vd=\#a166> . Acceso en: 03-08-2015.
} 
Conforme determina el art. 2 de la Constitución: "La Constitución se fundamenta en la indisoluble unidad de la Nación española, patria común e indivisible de todos los españoles, y reconoce y garantiza el derecho a la autonomía de las nacionalidades $\mathbf{y}$ regiones que la integran y la solidaridad entre todas ellas", la distribución interna de las competencias entre el Estado y las Comunidades Autónomas debe ser respetada al aplicarse el tratado internacional. De este modo, todas las Comunidades Autónomas asumieron expresamente en sus Estatutos de Autonomía competencia de desarrollo normativo y ejecución de los tratados internacionales en materia de su competencia.

Cuando España es Parte de un tratado internacional, la ejecución es una actividad interna del estado y puede corresponder a cualquiera de los poderes públicos estatales. Así pues, aunque el párrafo 2 del artículo 93 de la CE, confía a las Cortes o al Gobierno, según los casos, la garantía del cumplimiento de los tratados, está claro que todos los poderes públicos deben ejercer sus competencias para el correcto cumplimiento de los tratados.

De todos modos, si un tratado es violado, España, como Estado, asume la responsabilidad internacional por eventual incumplimiento del tratado, no importando que institución o poderes del Estado lo haya violado (puede ser un órgano del legislativo, ejecutivo, judicial del Estado o de una Comunidad Autónoma u otras entidades territoriales u organismos públicos). Se atribuye únicamente al Estado en su conjunto, el incumplimiento del tratado que genera un hecho ilícito internacional, y por lo tanto, debe ese asumir la correspondiente responsabilidad internacional.

Respecto a las organizaciones internacionales, cuando estas adoptan normas jurídicas obligatorias, caben a los Estados miembros, cumplirlas y velar por su cumplimiento. A pesar de la importancia significativa que han cobrado desde la segunda mitad del siglo XX, los Constituciones no hacen referencia en el Derecho interno a la inserción de los actos de las organizaciones internacionales. Así, la solución planteada es la aplicación del mismo procedimiento de recepción que los tratados internacionales, reconociendo a estas normas jurídicas obligatorias la misma jerarquía que a los tratados.

Como el Derecho en España no regula expresamente la cuestión, se entiende que son aplicables los artículos 96 de la Constitución y 1.5 del Código Civil, de modo que desde su entrada en vigor internacional, los actos de las organizaciones 
internacionales obligan a España y deben ser publicados oficialmente, o bien, podrían también ejecutarse mediante normas internas, dadas las características de estas Resoluciones.

El Derecho derivado de la Unión Europea, emanado de las organizaciones internacionales, es el que mayor impacto jurídico, social y económico tiene, debido, entre otras razones, a que numerosas disposiciones tienen eficacia directa para los particulares, creando derechos y obligaciones que estos pueden invocar en sus relaciones entre sí (relaciones horizontales) y ante las administraciones públicas (relaciones verticales) y que deberán ser protegidas por los jueces nacionales.

Además, todos los reglamentos se publican en el Diario Oficial de la Unión Europea (DOUE) y entran en vigor en la fecha que dichas normas fijen o, a falta de ella, a los veinte días de su publicación.

Conforme previsto en la primera parte del artículo 93: "Mediante ley orgánica se podrá autorizar la celebración de tratados por los que se atribuya a una organización o institución internacional el ejercicio de competencias derivadas de la Constitución”, la Constitución española de 1978 ofrece aquí, un marco jurídico suficiente para permitir una atribución de competencias derivadas de la Constitución a organizaciones o instituciones internacionales.

Desde la fecha de entrada en vigor pactada el en Tratado de Adhesión del Reino de España y la República Portuguesa a la Comunidad Europea, o sea, desde el $1^{\circ}$ de enero de $1986^{1184}$, los tratados constitutivos de las Comunidades Europeas han pasado a formar parte integrante del Derecho Interno. La aceptación de los Tratados constitutivos implicó a su vez la aceptación del Derecho derivado anterior y posterior a la adhesión, con la obligatoriedad y eficacia jurídica establecida en los Tratados.

La publicación oficial exigida por España para los tratados internacionales, conforme determina el artículo 96.1 de la Constitución, y que es extensible análogamente a los actos de los Organismos internacionales, ha quedado exceptuada por el artículo 93 de la Constitución para los actos de las Instituciones comunitarias. Desde que España adhirió a la Comunidad Europea esa competencia se ejerce de forma directa por las Instituciones comunitarias, que publican dichos actos en lengua española en el

${ }^{1184}$ Vale recordar que coincidió la fecha de publicación en el BOE de todos los Tratados constitutivos de las Comunidades. Disponible en: < http://www.boe.es/buscar/doc.php?id=BOE-A-1986-1>. Acceso en: 04-08-2015. 
Diario Oficial de la Unión Europea. Sin embargo, como el Derecho derivado adoptado con anterioridad a la adhesión - el llamado acervo comunitario - había que ser incorporado al Derecho interno, se llevó a cabo una publicación oficial y especial en castellano en el DOUE, que agrupó por materias todos los actos de las Instituciones que estaban en vigor a $1^{\circ}$ de enero de 1986.

De este modo, se puede afirmar que tanto los Tratados constitutivos de las Comunidades europeas, como los actos de las Instituciones comunitarias gozan de primacía sobre las normas internas. Además, en los artículos 93 y 96 de la Constitución española se puede apoyar la prevalencia de las normas comunitarias, una vez que no pueden ser modificadas, derogadas o suspendidas por normas internas, prevaleciendo así, en caso de contradicción, los tratados comunitarios y los actos de las Instituciones.

\subsection{La teoría monista en Brasil}

La Constitución Federal de 1988 consagró el sistema monista a través del $\S 2^{\circ}$, de su artículo $5^{\circ}$, lo cual establece clausula general de recepción para tratados que versen sobre derechos y garantías individuales ratificados por el país. A esta regla, se añadió, por la Emenda Constitucional n ${ }^{\circ}$. 45/2004, la posibilidad de norma internacional promulgada, cuando versar sobre derechos humanos y cumplir rito específico de tramitación, tener efecto de emenda constitucional ${ }^{1185}$.

Revelando su postura monista, la Constitución Federal brasileña aun establece la aplicabilidad de los tratados, e su reconocimiento como norma internacional y no interna, al "Supremo Tribunal Federal" (art. 102, III, b), al "Superior Tribunal de Justiça" (art. 104, III, a) y a la "Justiça Federal" (art. 109, III), cuando los confiere la competencia para juzgar cuestiones fundadas en tratados.

El ordenamiento infraconstitucional también está repleto de ejemplos normativos en que se reconoce expresamente la norma internacional como fuente directa de derecho interno, así como reconoce en ello valor normativo directo en el derecho interno brasileño.

\footnotetext{
${ }^{1185}$ Cuando alcanzado quórum de tres quintos, en duplo turno de votación de la norma de promulgación del tratado en la orden interna (Conforme $\S 3^{\circ} \mathrm{del}$ art. $5^{\circ}$ de la $\mathrm{CF} / 88$ ).
} 
Los tratados promulgados en el ordenamiento interno adquieren fuerza de ley interna sin dejar de ser norma internacional, funcionando el decreto de promulgación que los introdujo como un vehículo de trasposición del plano internacional para el plano interno ${ }^{1186} \mathrm{y}$ como acto que confiere validez interna a su poder normativo.

Cuestión controvertida es la de la posibilidad de encerramiento de la eficacia de la regla puesta en tratado internacional promulgado en el ordenamiento interno, por la edición de norma posterior, o especial, derogatoria.

La doctrina y tribunales divergen en este punto. Para algunos ${ }^{187}$, siendo los tratados reconocidos en el orden interno brasileño como normas internacionales, los mismos no pueden ser revocados, integral o parcialmente, expresa o tácitamente, por acto de derecho interno del Poder Legislativo.

Es decir, por la edición de acto normativo interno posterior, por parte del Congresso Nacional, una vez que su promulgación en el orden interno se da por actos del Jefe del Poder Ejecutivo y del Poder Legislativo, de modo que compite aquel, por fuerza constitucional (art. 84, VIII), la actuación internacional de establecimiento de relaciones internacionales y celebración de tratados ${ }^{1188}$.

${ }^{1186}$ El Congresso Nacional, para el ejercicio de competencia conferida al inciso I del art. 49 de la Constitución Federal, se utiliza del Derecho de Aprobación, que, como revela su nombre, aprueba el texto del tratado firmado por el Jefe de Estado, o su plenipotenciario, y por lo cual autoriza, en el plano interno, el Jefe de Estado a ratificar el tratado, dentro de la discrecionalidad y del carácter personalísimo que este acto reserva. Una vez ratificada la norma internacional, el Presidente de la República edita el Decreto de Promulgación, acto que introduce, en el país, el texto del tratado ratificado en el orden internacional. La diferencia entre los dos actos es fundamental: uno es un Decreto Legislativo, exclusivo del Poder Legislativo, y aprueba el texto de norma internacional para que el Poder Ejecutivo la ratifique, si y cuando desear; el otro es un Decreto Ejecutivo, exclusivo del Poder Ejecutivo, y que confiere vigencia normativa interna a las disposiciones del tratados. La actuación del Congresso Nacional en ese proceso se da no como órgano legisferante, de creación de leyes, sino que, como órgano de representación política y democrática tanto de la sociedad (Cámara de los Diputados) cuanto de los entes que componen la federación (Senado) en relación a la obligación internacional que el país, como un todo, está a punto de asumir. Además de eso, esa actuación es hecha en el ámbito de la función del Congresso Nacional, dentro del sistema constitucional de frenos y contrapesos.

${ }^{1187}$ Entre ellos, Paulo Borba Casella. A integração econômica e seu tratado; Hildebrando Accioly, op. cit.; y Luiz Roberto Barroso, Interpretação e aplicação da Constituição, conforme enseña Pedro Bohomoletz de Abreu Dallari, op. cit., 2003.

${ }^{1188}$ Conforme XAVIER, Alberto. Direito tributário internacional do Brasil. $6^{\mathrm{a}}$ ed., Ed. Forense, Rio de Janeiro-Brasil: 2004, p. 150. 
Ya otros defienden que el Congresso Nacional es quien guarda la competencia constitucional principal para la edición de normas jurídicas en el derecho interno.

Mejor comprensión, sin embargo, nos parece ser la que refleja los conceptos elementares y fundamentales involucrados en el tema.

Cuando de la promulgación, el texto del tratado no pasa por el proceso legislativo ordinario, no siendo, por lo tanto, en momento alguno, convertido en ley, siendo que el Decreto de Promulgación apenas lo empresta el status de ley.

El Congresso Nacional actúa en la evaluación y referendo - es esta la letra expresa de la determinación constitucional y de su competencia en este propósito - de las disposiciones de un tratado internacional como órgano que congrega los representantes elegidos tanto de la sociedad (Cámara de los Diputados) como de la federación (Senado Federal). Y no en el ejercicio de su poder legisferante.

Además de eso, la participación del Poder Legislativo federal también se da como órgano investido de función constitucional de ejercicio del sistema de frenos y contrapesos, como aquel a quien la Constitución confirió el poder-deber de supervisar la actuación del Poder Ejecutivo por delante de la representación y de la actuación internacionales del país, incluso para, eventualmente, anular excesos y abusos de poder que puedan comprometer el país en el orden internacional y el patrimonio nacional.

Y esa actuación no se confunde - nunca, jamás - con la del ejercicio del poder legisferante. La fuente productora de norma internacional no está en el poder legislativo de los Estados, sino que, está sí, en la actuación internacional de los respectivos poderes ejecutivos.

Así, no hay que decir que el Congresso Nacional legisla, en el sentido estricto del término, cuando edita el Decreto Legislativo que aprueba el texto del tratado firmado por el Poder Ejecutivo, y tampoco se puede pensar que Brasil sea, por razones de esta actuación del Congresso Nacional, un país dualista.

Por lo tanto, son España y Brasil países de sistema legal monista. Y es exactamente debido a esto que se justifica el enfoque utilizado en el trabajo. Como países monistas, se puede verificar, la repercusión en el orden interno español y brasileño de los cambios y de la evolución del régimen jurídico del agua dulce en el derecho internacional público. 


\subsection{La protección internacional del agua. Eventos y foros sobre el agua}

Los países en todos los continentes han preocupado con ese recurso fácilmente agotable, el agua potable. Hoy aproximadamente un 70\% de toda la superficie terrestre es cubierta por agua, sin embargo, la mayor preocupación que las organizaciones internacionales tienen es que sólo un $2,5 \%$ son de agua dulce, siendo que casi un $70 \%$ da gua dulce están retenidas en casquetes glaciares. ${ }^{1189}$ Es decir que sólo aproximadamente un $1,75 \%$ de toda el agua presente en el planeta estaría disponible para consumo. Valor este que estaría disminuyendo con la constante contaminación de ríos, lagos y acuíferos y la desertificación cada vez mayor de las áreas que rodean las nacientes, llevando a una reducción o incluso extinción del flujo que por ella era emanado. La principal organización sobre estos recursos es la Organización Mundial de la Salud (OMS). Ella ha desarrollado investigaciones cada vez más prácticas para descubrir formas sostenibles de satisfacer la necesidad hídrica mundial de casi 750 millones de personas que aún no poseen acceso adecuado a agua potable. Ella ayudó al Fondo de las Naciones Unidas para la Infancia (UNICEF) a crear e incentivar todas las naciones a ella afiliadas a comprometerse a cumplir algunos objetivos, los Objetivos de Desarrollo del Milenio de la ONU (ODM), creados en el año 2000. Entre estos objetivos está el de respeto al medio ambiente, o sea, Promover el desarrollo sostenible, reducir la pérdida de diversidad biológica y reducir por la mitad, hasta 2015, la proporción de la población sin acceso a agua potable y alcantarillado ${ }^{1190}$.

En razón de esa preocupación que es necesario destacar los innúmeros foros internacionales $^{1191}$, que a pesar de no poseyeren fuerza coercitiva, formaron grandes

${ }^{1189}$ CERQUEIRA, Wagner de. Água. Disponible en: http://www.brasilescola.com/geografia/agua.htm. Acceso en: 22-06-2015.

${ }^{1190}$ Objetivos de desarrollo del milenio. Disponible en: http://www.objetivosdomilenio.org.br/objetivos. Acceso en: 22-06-2015.

${ }^{1191}$ Según Jorge González González, El acceso al agua potable como derecho humano: su dimensión internacional. Alicante: Editorial Club Universitario, 2014, p. 89: “A lo largo de los años, sobre todo en la década de los noventa y la primera del siglo XXI, las conferencias y foros internacionales relacionados con el agua han ido fructificando y llevando a cabo una labor de estudios e implementación de medidas con el fin de paliar esa escasez y degradación en la cantidad y la calidad del agua". En este sentido, Aniza García, El derecho humano al agua. Madrid: Editorial Trotta, 2008, p. 149 afirma que: "En el ámbito supra-nacional, existen numerosos instrumentos destinados a regular los usos, el aprovechamiento y la 
conceptos que pudieron ser utilizados por los países para la construcción de sus leyes; es posible relatar también sobre el Tribunal de las Aguas de Valencia, un ejemplo a ser seguido; y claro, la Década del Agua (2005-15) de las Naciones Unidas (ONU) que creó mecanismos para la solución de la falta de agua y saneamiento básico en el mundo.

La Carta Europea del Agua ${ }^{1192}$ fue proclamada el 06 de mayo de 1968, en Francia por el Consejo de Europa. Esa carta establece doce tópicos destacando el porqué del agua tener importancia para la humanidad. Entre ellos podemos destacar que, no hay vida sin agua. Es un tesoro para toda la humanidad ${ }^{1193}$; los recursos de agua no son inagotables. Es necesario conservarlos, controlarlos y, siempre que sea posible, incrementarlos ${ }^{194}$; cuando el agua residual es devuelta al cauce, lo debe ser de tal forma que no impida usos posteriores ${ }^{1195}$; el agua no conoce fronteras; como fuente común requiere la cooperación internacional. ${ }^{1196}$

Entre los días 5 a 16 de junio de 1972, en Estocolmo hubo la Conferencia de las Naciones Unidas sobre el Medio Ambiente, objetivaba la creación de principios comunes para protección del medio ambiente humano ${ }^{1197}$. Podemos citar el segundo principio que afirma que los recursos naturales deben ser preservados para las generaciones presentes y futuras, o sea, una preocupación con la sostenibilidad.

La Primera Conferencia de las Naciones Unidas sobre el Agua ocurrió en Mar del Plata, en 1977 e identificó por la primera vez el agua potable como derecho de todos los pueblos, independiente de su estado de desarrollo y condiciones sociales. Esa conferencia también se preocupó con el surgimiento de una crisis del agua en medio o

gestión de los recursos hídricos; sobre todo en las últimas décadas han proliferado las conferencias y acuerdos dirigidos a la protección del medio ambiente y los recursos naturales. Además, se han multiplicado también los instrumentos que favorecen la protección del acceso al agua en términos de derecho, y a partir de los cuales, se ha generado un amplio repertorio de normas de diferente vinculatoriedad que ha ido precisando los contornos jurídicos del derecho al agua hasta dotarlo de un nivel de concreción equivalente al de otros derechos internacionales".

${ }^{1192}$ Carta Europea de Agua Disponible en: http://www.apdconsumo.pt/CARTA_EUROPEIA_AGUA.pdf Acceso en: 30-05-2015.

${ }^{1193}$ Princípio I de la Carta Europea de Agua.

${ }^{1194}$ Princípio II de la Carta Europea de Agua.

${ }^{1195}$ Princípio X de la Carta Europea de Agua.

${ }^{1196}$ Princípio XII de la Carta Europea de Agua.

${ }^{1197}$ Preámbulo de la Conferencia de las Naciones Unidas sobre el Medio Ambiente Humano. 
largo plazo debido al aumento do consumo de agua. En su Plan de Acción determinaba que fuesen realizados programas anticipados, de esa manera la crisis podría ser suavizada.

En 1992 fue realizada en Dublín la Conferencia Internacional sobre el Agua y el Medio Ambiente, en la que los participantes pedían nuevos abordajes fundamentales para la evaluación, desarrollo y gestión de recursos de agua dulce, que sólo pueden ser realizados por medio del empeño político y de la participación de los más altos niveles de gobierno hasta las menores comunidades. Ese comprometimiento debe ser seguido de inversiones sustanciales e inmediatas, campañas de concienciación pública, cambios legislativos y programas de capacitación ${ }^{1198}$. Las acciones deben ser basadas en los principios de que: el agua es esencial para la manutención de la vida y esencial para el medio ambiente; la gestión debe ser basada en la participación de usuarios, gobiernos, participación de las mujeres para la capacitación y tomada de decisiones; además de establecer el agua como un bien económico.

Río de Janeiro fue sede de la Conferencia de las Naciones Unidas sobre el Medio Ambiente y Desarrollo, en junio de 1992 (Eco-92). La Agenda 21 es el resultado de ese congreso y busca promover el desarrollo sostenible. Es importante destacar el capítulo 18 que confirmó la Conferencia de Mar del Plata al afirmar que todos los pueblos tienen derecho a tener acceso al agua potable, eso recibió el nombre de -la premisa acordada en común.

El Primer Foro Mundial del Agua fue realizado en Marruecos en 1997, tenía el tema -Visión sobre el Agua, Vida y el Ambiente en el Siglo XXI ${ }^{199}$, participaron de este evento personas influyentes en el mundo sobre el tema de aguas.

En 1998, Paris fue la sede de la Conferencia Internacional sobre Agua y Desarrollo Sostenible, fue acordado que el agua dulce es esencial al desarrollo sostenible además de establecer que los valores del agua son interconectados, son ellos:

1198 Conferencia Internacional sobre el Agua $y$ el Medio Ambiente, Disponible en: http://www.wmo.int/pages/prog/hwrp/documents/english/icwedece.html. Acceso en: 31-05-2015.

$1199 \quad 1^{\circ} \quad$ Foro Mundial de Agua, Disponible en: http://www2.ana.gov.br/Paginas/imprensa/noticia.aspx?id_noticia=12417\%20. Acceso en: 31-05-2015. 
los sociales, económicos y ambientales ${ }^{1200}$. Igualmente, vale destacar que quedó establecido que los recursos hídricos son imprescindibles para las necesidades humanas desde la salud a la producción de energía eléctrica.

El Segundo Foro Mundial del Agua, ocurrió en La Haya, en 2000, siendo el tema, Seguridad Hídrica en el Siglo XXI. Establece el agua como requisito para el desarrollo de los países. La demanda de agua dulce está cada vez menor y amenazada por la contaminación, uso desenfrenado y cambios climáticos. Por eso se tiene cada vez más la necesidad de promoverse el desarrollo sostenible y la estabilidad política, porque sólo de esta manera el acceso al agua será posible a todos.

El Tercer Foro Mundial del Agua ocurrió en Kioto, entre los días 22 y 23 de marzo de 2003 y en la oportunidad fue reconocida la necesidad de intensificarse la prevención a la contaminación buscando reducir los riesgos al medio ambiente y a la salud. Además de priorizarse la provisión de información pública y educación, se preocupaba principalmente con los niños, porque ellos serían educados para evitar la contaminación y el uso insostenible de los recursos hídricos a largo plazo ${ }^{1201}$. Los países se comprometieron a minimizar los daños causados y a compartieren informaciones ${ }^{1202}$.

El Cuarto Foro Mundial se reunió en Ciudad de México en 2006 y abordó sobre -Acciones locales para un Reto Global. Fueron debatidos cinco temas: agua para el desarrollo y el crecimiento, agua y saneamiento para todos, manejo de riesgos, agua para la alimentación y el medio ambiente e instrumentación de la gestión integrada de los recursos hídricos ${ }^{1203}$.

Estambul fue la ciudad elegida para el Quinto Foro Mundial del Agua, que ocurrió en 2009. Fueron debatidos seis grandes temas: el cambio global y la gestión del riesgo, el impulso al desarrollo humano y los objetivos de desarrollo del milenio, gestión y protección de los recursos hídricos, eficacia en la administración y la gestión

${ }^{1200}$ Preámbulo de la Conferencia Internacional sobre Agua y Desarrollo Sostenible, Paris, 1998, Disponible en: http://www.meioambiente.uerj.br/emrevista/documentos/paris.htm. Acceso en: 31-052015.

1201 Declaración $\mathrm{n}^{\mathrm{o}} 23 \mathrm{del}$ Foro Mundial de Agua de Kyoto, Disponible en: http://www.projetoagua.dape.net/kiotobiologia. Acceso en: 31-05-2015.

1202 Declaración $\mathrm{n}^{\mathrm{o}} 28 \mathrm{del}$ Foro Mundial de Agua de Kyoto, Disponible en: http://www.projetoagua.dape.net/kiotobiologia. Acceso en: 31-05-2015.

1203 Temas debatidos en el IV Foro de Agua, Disponible en: < http://www.folhadomeio.com.br/publix/fma/folha/2006/03/2agua166.html>. Acceso en: 31-05-2015. 
del agua, aspectos financieros de un sector hídrico sostenible, educación, conocimiento y desarrollo de las capacidades ${ }^{1204}$.

Las sucesivas ediciones del Foro Mundial del Agua han sido como trampolines para la colaboración global sobre problemas del agua. El Foro ofrece a la comunidad y líderes de todo el mundo la oportunidad única de hacer recomendaciones para garantizar la seguridad de los recursos hídricos en las diferentes partes del mundo ${ }^{1205}$.

El sexto Foro del Agua fue realizado en Marsella, en 2012 teniendo como objetivo enfrentar los retos que el mundo está pasando y traer el agua para el centro del debate político. No habrá desarrollo sostenible mientras las cuestiones del agua permanecieren sin solución. Esa es la primera prioridad, pero en la totalidad la comisión desarrollo 12 prioridades para el trabajo, y tres condiciones para el éxito ${ }^{1206}$.

Entre las 12 prioridades se pode destacar: garantizar el acceso al agua y el derecho al agua, mejorar la higiene y salud gracias al agua y al saneamiento, promover la cooperación y la paz gracias al agua, promover la seguridad alimentaria mediante el uso óptimo del agua, armonizar el agua y la energía, mejorar la calidad de los recursos hídricos y ecosistemas ${ }^{1207}$. Sin embargo, para lograr estos compromisos y prioridades hay que observar tres condiciones de éxito, a saber: buena gobernanza, financiar el agua para todos, crear condiciones favorables ${ }^{1208}$.

1204 F $\quad$ Foro Agua, Estambul, Disponible http://www.worldwaterforum5.org/index.php?id=1897\&L=onf...blurLink\%2528this\%2529\%2520title\%2 53D\%2520target\%253D\%2520target $\% 253 \mathrm{D} \% 2520 \operatorname{target} \% 253 \mathrm{D} \% 2520 \operatorname{target} \% 253 \mathrm{D} \% 2520 \operatorname{target} \% 253$ D\%2520target\%253D\%2520target\%253D\%2520target\%253D\%2520target $\% 253 \mathrm{D} \% 2520 \operatorname{target} \% 253 \mathrm{D} \%$ $2520 \operatorname{target} \% 253 \mathrm{D} \% 2520 \operatorname{target} \% 253 \mathrm{D} \% 2520 \operatorname{target} \% 253 \mathrm{D}$. Acceso en: 31-05-2015.

${ }^{1205}$ Objetivos del Foro, Disponible en: http://www.worldwaterforum5.org/index.php?id=1875. Acceso en: 31-05-2015.

${ }^{1206} 6^{\circ}$ Foro Mundial del Agua, Disponible en: http://www.worldwaterforum6.org/commissions/thematic/. Acceso en: 31-05-2015.

1207 Prioridades de acción, Disponible en: http://www.worldwaterforum6.org/index.php?id=17\#getinvolve. Acceso en: 31-05-2015. En el original: Guarantee access to water for all and the Right to water, Contribute to hygiene and health through water and sanitation, Contribute to Cooperation and Peace through water, Contribute to food security by optimal use of water, Harmonize water and energy, Improve the quality of water resources and ecosystems.

${ }^{1208}$ Conditions for Success, Disponible en: $<$ http://www.worldwaterforum6.org/index.php?id=17\#getinvolve $>$. Acceso en: 31-05-2015. 
El Séptimo Foro del Agua ocurrió este año de 2015 en Daegu y Gyeongbuk, República de Corea, y buscaba identificar cuales temas tienen mayor prioridad y exigen atención inmediata, y establecer cuales elementos van a efectuar este cambio. Fueron establecidos 16 temas, entre ellos: tener suficiencia de agua saludable y saneamiento adecuado para todos, agua para comida, agua y energía y agua y ciudades, gestionar y restaurar ecosistemas para servicios de agua y biodiversidad ${ }^{1209}$.

La única ciudad brasileña que expuso en el Foro Mundial del Agua fue Uberlândia, representada por su alcalde, ella fue elegida por ser una de las ciudades con mejor saneamiento básico del país. Él presentó los proyectos de Protección y Recuperación de Nacientes, que lleva el nombre de Buritis además de los proyectos Agua Legal y Escuela Agua Ciudadana que buscan conscienciar jóvenes y niños ${ }^{1210}$.

Los Foros Mundiales del Agua se llevan a cabo cada tres años y tienen el objetivo de aumentar el debate sobre el agua, intercambiar experiencias para los retos existentes y los futuros así como profundizar las discusiones sobre el agua. El próximo foro será en 2018 en la ciudad de Brasília, Brasil.

\subsection{Década del Agua}

La ONU declaró que la década 2005-2015 sería la Década del Agua. El Decenio se inició el 22 de marzo de 2005, día en el que se celebra el día Mundial del Agua y se extiende hasta diciembre de 2015. Durante estos diez años fueron realizados eventos para debatir y formular ideas para el manejo del recurso hídrico.

En abril de 2005 fueron definidas acciones para la década. Entre ellas podemos citar: la necesidad de reforma en la Ley de Agua de Sudáfrica, para liberar 200 litros más de agua por día para cada casa; la construcción de 5,6 mil estanques de almacenaje

1209 Temas do $7^{\mathrm{o}}$ Fórum Mundial da Água, Disponible en: http://eng.worldwaterforum7.org/introduce/program/thematic.asp. Acceso en: 31-05-2015.

No original : Enough Safe Water for All, Integrated Sanitation for All, Water for Food, Water and Energy, Water and Cities, Managing and Restoring Ecosystems for Water Services and Biodiversity.

${ }^{1210}$ G1 do Triângulo Mineiro. Uberlândia é a única cidade brasileira a expor no $7^{\circ}$ Fórum Mundial da Água, Disponible en: http://g1.globo.com/minas-gerais/triangulo-mineiro/noticia/2015/04/uberlandia-eunica-cidade-brasileira-expor-no-7-forum-mundial-da-agua.html. Acceso en: 31-05-2015. 
de agua de la lluvia en China; la creación de una gestión de cuencas Hidrográficas para el abastecimiento de agua en Estados Unidos de América; la creación de un programa de saneamiento rural en Bangladesh y en Indonesia; la necesidad de haber alcantarillado condominial en Brasil, entre muchas otras.

En el mes de diciembre de 2006 declaró que el año de 2008 sería el año Internacional del Saneamiento, como forma de complementariedad a la década del agua, porque es indispensable haber agua potable y saneamiento básico para todos. La meta era disminuir por la mitad el número de 2,6 mil millones de personas sin saneamiento básico hasta $2015^{1211}$.

En 2010 en el día Mundial del Agua ocurrió en Nueva York un diálogo sobre la década del agua. Fueron presentados los documentos: el agua, la paz y la seguridad: la cooperación en la gestión de las aguas transfronterizas; revisión de la organización de la década del agua; agua, cambio climático y desastres, el agua y los objetivos de desarrollo convenidos internacionalmente ${ }^{1212}$.

E1 28 de julio de 2010 la Resolución A/RES/64/29292 declaró el agua limpia y segura y el saneamiento básico como un derecho humano esencial con 122 votos favorables y ninguno contrario.

Fue establecido en 2011, que 2013 sería el año Internacional de Cooperación por el Agua, además de establecer el saneamiento sostenible pretendiendo acabar con las alcantarillas a cielo abierto, mejorando así la salud y la equidad social.

El año de 2013 fue el año que se preocupó con el manejo sostenible de las aguas potables del mundo, porque la mayoría de los ríos y lagos pertenecen a más de un país, o sea, son transfronterizos. La cooperación está más allá de la necesidad de la distribución igualitaria y sostenible del agua, está vinculado también en mantener la convivencia pacífica entre los países.

Al final de la década ya se percibe los resultados, de 1990 a 2012 casi dos mil millones de personas tuvo acceso al saneamiento básico, sin embargo es necesario esperar el fin del año para saber si las metas fueron alcanzadas. No obstante es necesario a la cooperación internacional para seguir con los avances, porque ellos

1211 Dia Mundial da Água: saneamento básico ainda é precário, Disponible en: http://www.inesc.org.br/noticias/noticias-gerais/2008/marco/dia-mundial-da-agua-saneamento-basicoainda-e-precario. Acceso en: 17-06-2015.

${ }^{1212}$ Disponible en: http://www.un.org/waterforlifedecade/milestones.shtml. Acceso en: 17-06-2015. 
ocurren paulatinamente. Como el agua es un derecho fundamental, ella tiene que ser asegurada tanto de forma cuantitativa como cualitativa, para que el ser humano viva con dignidad.

\subsection{La vida y la dignidad de la persona humana en una dimensión} ecológica

La dignidad de la persona humana constituye concepto sometido a permanente proceso de reconstrucción, cuidándose de una noción histórico-cultural en permanente transformación cuanto a su sentido y alcance, lo que implica su apertura permanente a los desafíos puestos por la vida social, política, económica y cultural, principalmente debido al impacto de la sociedad tecnológica y de la información.

Actualmente, se puede decir que los valores ecológicos tomaron asiento definitivo en el contenido del principio de la dignidad de la persona humana. Por tanto, en el contexto constitucional contemporáneo, se consolida el formateo de una dimensión ecológica que incluya la dignidad de la persona humana, que abarque la idea alrededor de un bienestar ambiental, así como de un bienestar social indispensable a una vida digna, saludable y segura. De esta comprensión, se puede concebir la indispensabilidad de un nivel mínimo de calidad ambiental para la concretización de la vida humana en niveles dignos. Debajo de tal estándar ecológico, la vida y la dignidad humana estarían siendo violadas en su núcleo esencial. La calidad (y seguridad) ambiental, basadas en tales consideraciones, pasarían a figurar como elemento integrante del contenido normativo del principio de la dignidad humana, siendo, por tanto, fundamental al desarrollo de todo el potencial humano en un cuadrante de completo bienestar existencial.

No se puede concebir la vida - con dignidad y salud - sin un ambiente natural, saludable y equilibrado. La vida y la salud humanas solo están aseguradas en el ámbito de determinados estándares ecológicos. El ambiente está presente en las cuestiones más vitales y elementares de la condición humana, además de ser esencial a la supervivencia del ser humano como especie natural. De tal suerte, el propio concepto de vida hoy se desarrolla más allá de un concepto estrictamente biológico o físico, una vez que los adjetivos "digna" y "saludable" acaban por implicar un concepto más amplio, que 
guarda sintonía con la noción de un desarrollo pleno de la personalidad humana, para el cual la calidad del ambiente pasa a ser un componente nuclear.

En esta perspectiva, cumple todavía señalar que la relación entre dignidad y derechos de la personalidad es, de hecho, muy cercana, en vista de que ambos están directamente comprometidos con la concretización de la vida humana de modo pleno y calificado y, por tanto, saludable también.

La tutela atribuida a la personalidad humana representa una amplia protección frente a todas las posibilidades de su violación, lo que debe, necesariamente, acompañar la evolución y la complejidad de las relaciones sociales contemporáneas, captando la dimensión ecológica de esas.

Con el fin de caracterizar la personalidad como un valor abierto (y en constante proceso de mutación) de nuestro ordenamiento, Bodin de Moraes afirma que "la personalidad es, por tanto, no un 'derecho', pero un valor, el valor fundamental del ordenamiento, que está en la base de una serie (abierta) de situaciones existenciales, en las cuales se traduce su incesantemente mutable exigencia de tutela"1213.

En vista de la apertura conceptual inherente a la tutela de la personalidad (como derecho y valor de nuestro ordenamiento), con el fin de contextualizarla delante de los riesgos existenciales creados por la "sociedad de riesgo" contemporánea, se debe inserir la calidad ambiental como uno de los elementos clave de la tutela de la personalidad humana, en vista de la relación intrínseca que aquella guarda con la condición existencial (presente y futura) del ser humano. La vida situada en un cuadro ambiental degradado compromete el libre desarrollo de la personalidad humana, especialmente respecto a la integridad psicofísica del ser humano que comporta, en las palabras de Bodin de Moraes, un "amplísimo derecho a la salud”, comprendiendo un “completo bienestar psicofísico y social"1214. En la misma línea, Robson da Silva pone el equilibrio ambiental como crucial para que la personalidad humana tenga un "curso normal de desarrollo", lo que, principalmente en las grandes y medianas ciudades, está constantemente comprometido en razón de las "descompostura emocionales y físicas" provocadas por la contaminación sonora, atmosférica, hídrica etc., afectando toda la

${ }^{1213}$ MORAES, Maria Celina Bodin de. Danos à pessoa humana: uma leitura civil-constitucional dos danos morais. Ed. Renovar, Rio de Janeiro-Brasil: 2003, p.121.

${ }^{1214}$ MORAES, Maria Celina Bodin de, Op. cit., 2003, p. 94. 
sociedad y el individuo en particular ${ }^{1215}$. De tal suerte, la calidad y el equilibrio de los fundamentos naturales que dan sostenimiento a la vida son determinantes para el libre desarrollo de la personalidad humana, contemplado en la Declaración Universal de los Derechos Humanos de 1948 de las Naciones Unidas, artículo 22, y, por tanto, para asegurar una vida digna y saludable al individuo y a la colectividad, de modo a consolidar la idea en torno de una dimensión ecológica para la dignidad de la persona humana.

Es de conocimiento de todos que la matriz filosófica moderna de la concepción de dignidad humana tiene sido reconducida esencialmente y en la mayoría de los casos al pensamiento del filósofo alemán Immanuel Kant. Hasta hoy la formula elaborada por Kant informa la gran mayoría de las conceptuaciones jurídico-constitucionales de la dignidad de la persona humana ${ }^{1216}$. La formulación kantiana coloca la idea de que el ser humano no puede ser empleado como simple medio (o sea, objeto) para la satisfacción de cualquier voluntad ajena, pero siempre debe ser tomado como fin en sí mismo (o sea, sujeto) en cualquier relación ${ }^{1217}$, sea frente al Estado sea frente los particulares. Esto se debe, en gran medida, al reconocimiento de un valor intrínseco a cada existencia humana, ya que la fórmula de siempre tornar el ser humano como un fin en sí mismo está directamente vinculada a las ideas de autonomía, de libertad, de racionalidad y de autodeterminación inherentes a la condición humana. La protección - ética y jurídica del ser humano contra cualquier reificación de su existencia y el respeto a su condición de sujeto en las relaciones sociales e intersubjetivas son seguramente manifestaciones de la percepción kantiana de dignidad humana, sin embargo, por cierto, encontradas ya en pensadores anteriores.

Sin que se vaya - aún - cuestionar algunos aspectos de la conceptuación kantiana y volviéndonos al derecho constitucional positivo, hay como partir de la premisa de que la Constitución española, en su artículo 10.1 y la Constitución brasileña,

${ }^{1215}$ SILVA, José Robson da. Paradigma biocêntrico: do patrimônio privado ao patrimônio ambiental. Ed. Renovar, Rio de Janeiro-Brasil: 2002, p. 254.

${ }^{1216}$ Vide el artículo I de la Declaración Universal de los Derechos Humanos (1948): “Todos los seres humanos nacen libres e iguales en dignidad y derechos y, dotados como están de razón y conciencia, deben comportarse fraternalmente los unos con los otros". Disponible en: < http://www.un.org/es/documents/udhr/>. Acceso en: 12-08-2015.

${ }^{1217}$ KANT, Immanuel. Crítica da razão pura e outros textos filosóficos (Coleção Os Pensadores). Ed. Abril Cultural, São Paulo-Brasil: 1974, p. 229. 
en su artículo $1^{\circ}$, inciso III, consagran expresamente la dignidad de la persona humana como principio fundamental edificante del Estado social y democrático de Derecho, y, en el caso de Brasil, del Estado democrático de Derecho, y, por tanto, como punto de partida y fuente de legitimación de todo el orden estatal, con destaque aquí para el sistema jurídico patrio. La dignidad de la persona humana, como, de hecho, ya ha sido ampliamente difundido, asume la condición de matriz axiológica del ordenamiento jurídico, visto que es a partir de este valor y principio que los demás principios (así como las reglas) se proyectan y reciben impulsos que dialogan con sus respectivos contenidos normativos-axiológicos, lo que no implica aceptación de la tesis de que la dignidad es el único valor a cumplir tal función y tampoco adhesión al pensamiento de que todos los derechos fundamentales (especialmente si así considerados los que fueron como tales consagrados por la Constitución) encuentran su fundamento directo y exclusivo en la dignidad de la persona humana ${ }^{1218}$.

Así, la dignidad humana, además de ser también un valor constitucional, se configura como siendo - juntamente con el respeto y la protección de la vida - el principio de mayor jerarquía de las Constituciones española y brasileña y de todas las demás ordenes jurídicas que la reconocieron ${ }^{1219}$. La dignidad de la persona humana se presenta, además, como la piedra basilar de la edificación constitucional del Estado (social, democrático y ambiental) de Derecho, en la medida en que, se adhiere a la trayectoria consolidada especialmente a partir del II Posguerra e inspirada fuertemente en la visión humanista de Kant y tantos otros, el constituyente reconoció que el Estado que existe en función de la persona humana, y no el contrario, ya que el ser humano constituye la finalidad precipua, y no medio de actividad estatal ${ }^{1220}$, lo que, por así decir, demarca la equiparación de fuerzas en la relación Estado-ciudadano, en vista de la protección y afirmación existencial de ese ultimo, especialmente respecto a la tutela y promoción de sus derechos fundamentales.

\footnotetext{
1218 Sobre este tópico vide SARLET, Ingo Wolfgang, Dignidade da pessoa humana e direitos fundamentais na Constituição Federal de 1988. $8^{\text {a }}$ ed., Livraria do Advogado, Porto Alegre-Brasil: 2010, pp. 87 y ss.

${ }^{1219}$ Conforme Ingo Wolfgang Sarlet, Dignidade cit., p. 85.

${ }^{1220}$ Conforme Ingo Wolfgang Sarlet, Dignidade cit., p. 68.
} 
En el ámbito de un Estado Socioambiental de Derecho ${ }^{1221}$, tal cual consagrado en las Constituciones española y brasileña, por lo menos como se sugiere en el presente estudio, la dignidad de la persona humana es tomada como el principal, pero no exclusivo fundamento (y tarea) de la comunidad estatal ${ }^{1222}$, proyectando su luz sobre todo el ordenamiento jurídico-normativo y así, vinculando de manera directa todos los entes públicos y privados. Además de una fuerza normativa autónoma como principio (y también valor) jurídico, la dignidad de la persona humana se proyecta especialmente en conjunto con toda una gama de derechos tanto de naturaleza defensiva (negativa) como prestacional (positiva), implicando también toda una gama de deberes fundamentales, aunque no sean necesariamente todos directamente deducidos de la dignidad de la persona humana, generalmente también actúan como concreciones en mayor o menor medida de esta dignidad y que también por esta razón pueden igualmente (como el principio de la dignidad individualmente considerado) ser colocado tanto frente al Estado cuanto frente a los particulares ${ }^{1223}$. Con eso, desde luego se afirma - aunque sin posibilidad de mayor desarrollo en el presente contexto - la necesidad de reconocimiento de la eficacia de los derechos fundamentales (y principalmente de la dignidad humana) también en las relaciones entre particulares, así como el reconocimiento de la dimensión normativa (vinculante) del principio (¡es deber!) constitucional de solidaridad y de los deberes jurídicos-constitucionales (más allá de la dimensión ética y moral) inherentes a ello.

En fin, lo que se afirma es que a partir del principio constitucional de la dignidad humana, aunque en la mayoría de las veces en articulación con otros valores y bienes jurídicos-constitucionales, se proyecta todo un conjunto de posiciones jurídicas subjetivas y objetivas, con la función precipua de tutelar la condición existencial

\footnotetext{
${ }^{1221}$ Entre otros fundamentos aptos a justificar la defensa de un Estado Socioambiental, se verifica que existe todo un trayecto social, económico, político, cultural y jurídico no concluido por el Estado Social, al que hoy se agrega la protección ambiental. Para mayores desarrollos, vide SARLET, Ingo Wolfgang (Org.). Estado Socioambiental e direitos fundamentais. Livraria do Advogado, Porto Alegre-Brasil: 2010. 1222 HÄBERLE, Peter. A dignidade humana como fundamento da comunidade estatal. In: SARLET, Ingo Wolfgang (Org.). Dimensões da dignidade: ensaios de Filosofia do Direito e Direito Constitucional. Livraria do Advogado, Porto Alegre-Brasil: 2005, p.116.

${ }^{1223}$ Cuanto al desarrollo teórico de la dignidad como límite y tarea del Estado, de la comunidad y de los particulares, vide Ingo Wolfgang Sarlet, Dignidade cit., especialmente, pp. 126-134.
} 
humana contra cualesquier violaciones de su ámbito de protección, asegurando el libre y pleno desarrollo de la personalidad de cada ser humano.

Aun en ese contexto, es posible destacar una dimensión social (o comunitaria) inherente al principio de la dignidad de la persona humana, ya que, en un primer plano siempre se encarga de la dignidad de la persona concreta, individualmente considerada, cuando en realidad, su comprensión constitucionalmente adecuada - principalmente bajo la idea de un Estado Social - implica necesariamente también una permanente mirada hacia el otro, visto que individuo y comunidad son elementos integrantes de una misma (y única) realidad político-social. En otras palabras, la dignidad del individuo nunca es la del individuo aislado o socialmente irresponsable, exigiendo también igual dignidad de todos los integrantes del grupo social ${ }^{1224}$.

\subsection{Tratados Internacionales y Tratados Europeos}

Como visto anteriormente, en la Convención de Viena sobre el derecho de los tratados, celebrada el 23 de mayo de 1969, se estableció que los tratados son acuerdos formales celebrados por escrito entre Estados (pueden ser bilaterales o multilaterales) y regidos por los principios del derecho internacional.

La expresión tratado se utiliza para instrumentos de gran importancia y solemnidad, los cuales tienen características comunes y se rigen por las mismas normas. Por ello, las convenciones, los acuerdos y los protocolos también se consideran tratados, pero la única diferencia es que son menos formales.

El Derecho Comunitario Europeo es conceptuado como un sistema jurídico sui generis, que no se confunde ni con el derecho interno de los países, pues sus normas son editadas por órganos de naturaleza comunitaria y tienen aplicabilidad inmediata en los

\footnotetext{
${ }^{1224}$ En ese sentido, como bien afirma Cármen Lúcia Antunes ROCHA. Vida digna: direitos, ética e ciência. In: ROCHA, Cármen Lúcia Antunes (Coord.). O direito à vida digna. Editora Fórum, Belo Horizonte-Brasil: 2004, p. 78, desde una perspectiva fundada en el principio constitucional de la solidaridad, "a dignidade humana - mais que aquela garantida à pessoa - é a que se exerce como outro", con lo que apenas enfatiza la perspectiva relacional de la persona humana frente al cuerpo social que integra, así como el compromiso jurídico (y no solo moral) del Estado y de los particulares en la composición de un cuadro social de dignidad para (y con) todos.
} 
ordenes jurídicos internos de esos Estados, ni tampoco con el Derecho Internacional Público, pues la aplicación de sus normas se rigen por principios propios.

Así, este derecho constituye un nuevo sistema jurídico, distinto de cualquier otro existente, habiendo sido desarrollado a partir de los tratados constitutivo de la Unión Europea, que se adaptaron a las necesidades del bloque económico con reglas, principios y procedimientos propios. Importante resaltar que el Derecho Comunitario está basado en los principios del Derecho Internacional clásico, sin embargo, los órganos de la Unión Europea tienen autonomía de competencias y funciones, actuando según los intereses de la propia comunidad.

La Unión Europea se basa en el Estado de Derecho. Esto significa que todas las acciones que emprende se basan en los tratados, que han sido aprobados voluntaria y democráticamente por todos sus países miembros. Así por ejemplo, si los tratados no citan un determinado ámbito de actuación, la Comisión no puede proponer legislación sobre él ${ }^{1225}$.

Un tratado es un acuerdo vinculante entre los países miembros de la Unión Europea. Establece los objetivos de la Unión Europea, las normas aplicables a sus instituciones, la manera en que se toman las decisiones y la relación existente entre esta y sus países miembros ${ }^{1226}$. Además, los tratados pueden modificarse para aumentar la eficacia y la transparencia de la Unión Europea, para preparar la llegada de nuevos países miembros y para introducir nuevos ámbitos de cooperación.

En virtud de los tratados, las instituciones de la Unión Europea pueden adoptar la legislación, que a continuación es aplicada por los países miembros.

\subsection{Los Tratados Europeos y el agua}

Desde hace un tiempo el agua se tornó una preocupación para la integración económica europea. Mismo cuando no se mencionaba expresamente en los Tratados constitutivos de las Comunidades Europeas que se firmaron hace más de medio siglo, la

\footnotetext{
${ }^{1225}$ Información disponible en el sitio de la Unión Europea: <http://europa.eu/eu-law/decisionmaking/treaties/index_es.htm>. Acceso en: 03-12-2015.

1226 Información disponible en el sitio de la Unión Europea: <http:/europa.eu/eu-law/decisionmaking/treaties/index_es.htm>. Acceso en: 03-12-2015.
} 
actuación comunitaria se apoyaba tanto en la necesidad de la armonización de las legislaciones nacionales que afectasen al funcionamiento del mercado común como su consideración en los sucesivos programas comunitarios de medio ambiente que se adoptaron a partir de la década de los años $70^{1227}$.

Respecto a los antecedentes y evolución de la Política Ambiental de la Unión Europea, afirma Dionisio Fernández de Gatta Sánchez que: "Las Comunidades Europeas iniciaron las actuaciones en materia de medio ambiente a finales de los años 60 del siglo XX sin tener ninguna base jurídica general en los Tratados Europeos originales (Tratado de la Comunidad Europea de Carbón y Acero de 1951, Tratado de la Comunidad Europea de la Energía Atómica de 1957 y Tratado de la Comunidad Económica Europea de 1957), por razones prácticas: evitar que las legislaciones ambientales de los Estados Miembros afectaran al buen funcionamiento del mercado común; asumir que los procesos de contaminación son reales y que no se detienen en las fronteras, y porque el art. 2-TCEE incluía una referencia a la 'calidad de vida'. Por ello, se utilizará la cláusula de competencias implícitas (art. 235-TCEE)”1228.

Sin embargo, fue en 1987, con el Acta Única Europea (AUE), que por primera vez se atribuyó competencias ambientales a la Comunidad Europea - que hasta aquel momento era denominada Comunidad Económica Europea (CEE) - consagrando, en el Tratado de Roma, un nuevo Título, el VII sobre Medio Ambiente (artículos $130^{\circ} \mathrm{R}$, $130^{\circ} \mathrm{S}$ y $130^{\circ} \mathrm{T}$ ) que permiten a la Comunidad la conservación, la protección y la mejora de la calidad del medio ambiente, la protección de la salud de las personas y la utilización prudente y racional de los recursos naturales. Acrecentando así, entre la

\footnotetext{
${ }^{1227}$ Como bien enseña Dionisio Fernández de Gatta Sánchez, Sistema Jurídico-Administrativo de protección del medio ambiente, Ratio Legis Ediciones, Salamanca-España: 2014, p. 73, "La Comisión Europea inició una reflexión sobre la relación entre el medio ambiente y las Comunidades Europeas en diversos documentos de 1970 a 1972, en materia de Política Industrial, Política Económica y ya sobre Política de Medio Ambiente. Seguidamente, la Cumbre de Jefes de Estado y/o de Gobierno de los Estados Miembros, celebra en París los días 19 y 20 de Octubre de 1972, iniciará la Política Ambiental comunitaria, tal como había anunciado en la Conferencia de Estocolmo, en el mes de junio. Después de la reunión de los Ministros de Medio Ambiente de los Estados Miembros, celebrada en Bonn (Alemania), el 31 de Octubre de 1972, en la que se adoptaron los principios de esta nueva Política, la misma se articulará a través de los Programas de Acción en materia de Medio Ambiente".

${ }^{1228}$ FERNÁNDEZ DE GATTA SÁNCHEZ, Dionisio. Sistema Jurídico-Administrativo de protección cit., p. 73.
} 
misiones de la Comunidad, la de aumento de la calidad de vida. A partir del 1 de noviembre de 1993, con el Tratado de la Unión Europea (TUE) - segunda revisión solemne - es que se empieza a hacer referencia a la gestión de los recursos hídricos.

En este sentido, David Ordóñez Solís afirma que: "La constitucionalización en virtud del Acta Única Europea de 1986 de una política comunitaria del medio ambiente ha permitido una evolución y un desarrollo particularmente importante del acervo de la Unión Europea en materia de aguas. Asimismo, la consagración de nuevos ámbitos de actuación de la Unión como el de la salud y de la protección de los consumidores, que están vinculados directa o indirectamente al agua, ha abierto nuevas perspectivas en la aplicación de una política europea sobre las aguas" ${ }^{\text {1229 }}$.

A lo largo de los años, especialmente en la década de los noventa y la primera del siglo XXI, los foros y conferencias internacionales relacionados con el agua han dado frutos y han llevado a cabo una labor de estudios e implementación de medidas con el fin de suavizar esa escasez y degradación en la calidad y cantidad del agua. Sin embargo, actualmente esa labor sigue permanente y pendiente, este año de 2015, entre el 12 y el 17 de abril, hemos tenido el séptimo Foro Mundial del Agua, que se celebró en las ciudades de Daegu y Gyeongbuk, en Corea del Sur y ya vamos por el octavo Foro Mundial del Agua, que será celebrado en la ciudad de Brasilia, en Brasil, en marzo de 2018.

De ese modo, se puede afirmar que las preocupaciones ambientales de la Comunidad Económica Europea, curiosamente, surgieron y se manifestaron primero por la adopción de actos de derecho derivado y solo después a través de la consagración de los Tratados ${ }^{1230}$.

Eso ocurrió como consecuencia de un compromiso político, tanto por parte de las Instituciones de la Comunidad como por parte de los gobiernos de los Estados Miembros, que, sin embargo, en los primeros años, no ha tenido ningún reflejo en los

${ }^{1229}$ ORDÓÑEZ SOLÍS, David. Aguas, medio ambiente y Unión Europea - la política comunitaria europea de aguas: armonización y financiación. In: Santiago González-Varas Ibáñez (Coord.). Nuevo derecho de aguas. Editorial Aranzadi, Navarra-España: 2007, p. 101.

${ }^{1230}$ En este sentido, José Joaquim Gomes Canotilhoy José Rubens Morato Leite (Organizadores), Direito Constitucional Ambiental Brasileiro, Editora Saraiva, São Paulo-Brasil: 2007, p. 15, además afirman que: "Fazendo uma analogia com o direito interno, isto significaria que primeiro surgiam as leis materialmente inconstitucionais - e só depois a consagração constitucional da competência para a adoção de tais leis". 
Tratados. Solo después de unos seis años, los Estados ratificarían, a través de la revisión de los Tratados, las competencias auto-asumidas por las Instituciones Comunitarias, dando, finalmente, una base convencional a la Política Comunitaria de Ambiente.

\subsubsection{EI Tratado de la Comunidad Económica del Carbón y Acero}

Con el fin de la Segunda Guerra Mundial, en 1945, Europa se encontraba devastada no solo en términos físicos y económicos, sino también en términos políticos, demográficos y culturales, además de la grave crisis financiera y económica. Con esto, empezó una nueva lucha, la de la reconstrucción, en que las varias Naciones europeas buscaron recuperarse, reconstruirse y recomenzar, visando así, la paz, la tolerancia y principalmente, una cooperación económica y política. Más que una necesidad, la población europea demostraba un fuerte deseo en dicha cooperación. Incluso, Winston Churchill ${ }^{1231}$, en 19 de septiembre de 1946, en el famoso Discurso de Zúrich, habló de la urgencia de la construcción de los "Estados Unidos de Europa", apuntando la reconciliación franco-alemana como el primer paso para una Europa pacificada.

Fue en la Declaración de Robert Schuman, Ministro de Asuntos Exteriores de Francia, en mayo de 1950, que se propuso que la producción franco-alemana de carbón y acero fuera colocada bajo los cuidados de un organismo supranacional de explotación conjunta de los recursos minerales de Centroeuropa, abierta a la entrada de otras Naciones europeas.

Bajo la idea de cooperación entre antiguos enemigos, en 18 de abril de 1951, que Alemania y Francia, junto a otros cuatro países europeos, Italia, Bélgica, Holanda y Luxemburgo fundaron la Comunidad Europea del Carbón y Acero (CECA o Montanunion) ${ }^{1232}$, con el objetivo de introducir la libre circulación del carbón y acero, así como el libre acceso a las fuentes de producción. El Tratado de la CECA entró en

\footnotetext{
${ }^{1231}$ El primer ministro británico nunca ha dejado de referirse al ejemplo que era la Commonwealth (sistema de gobierno dedicado a aumentar la en bienestar social o la riqueza común, también llamada de mancomunidad), en términos de cooperación e integración económica.

${ }^{1232}$ El Tratado fue firmado en Paris, Francia.
} 
vigor el 24 de julio de 1952 y tenía una vigencia limitada de 50 años, o sea, hasta el 23 de julio de 2002 .

De este modo, los objetivos de la CECA visaban la promoción de la expansión económica, el aumento del empleo y nivel de vida ${ }^{1233}$. Simultáneamente, se estimulaba el incremento del comercio internacional y la búsqueda por métodos más eficaces de producción. Centrándose en la idea de mercado común, el Tratado estableció la libre circulación de productos, sin derechos aduaneros y encargos. Además, fueron prohibidos los encargos especiales impuestos por el Estado, y, también, las medidas o prácticas discriminatorias.

Al nivel institucional, fue creada una estructura con la finalidad de organizar y fiscalizar las metas de la CECA, y para tanto, estableció una Alta Autoridad ${ }^{1234}$, una

${ }^{1233}$ Tal como referido en el artículo $2^{\text {o }}$ del Tratado: "La Comunidad Europea del Carbón y del Acero tendrá por misión contribuir, en armonía con la economía general de los Estados miembros y mediante el establecimiento de un mercado común en las condiciones fijadas en el artículo 4, a la expansión económica, al desarrollo del empleo y a la elevación del nivel de vida en los Estados miembros. La Comunidad deberá proceder al establecimiento de condiciones que aseguren por sí mismas la distribución más racional posible de la producción al más alto nivel de productividad, al mismo tiempo que garanticen la continuidad del empleo y eviten provocar, en las economías de los Estados miembros, perturbaciones fundamentales $\quad \mathrm{y} \quad$ persistentes”. Disponible en: http://www.boe.es/legislacion/enlaces/documentos/ue/Tratados(0397-0475).pdf>. Acceso en: 17-082015. Vale resaltar, que fue a partir de la intención de mejorar el nivel de vida que se extendió la idea de cuidado con el hombre y de todo lo necesario para que ello tenga una vida equilibrada, siendo esta preocupación el pilar que mantiene el entorno natural como fundamento de todo lo que existe. Así, la economía sirvió como punto de partida para el progreso legislativo a lo que se refiere al derecho ambiental, puesto que la calidad de vida era establecida acompañando el crecimiento económico, pasando de esta manera, a un nuevo concepto de vida, lo cual incluye el ambiente humano y natural. Por esta razón, la Alta Autoridad podría intervenir, bajo condiciones especificadas por el Tratado, en situaciones de sueldos muy bajos y de reducciones salariales.

${ }^{1234}$ La Alta Autoridad era un órgano ejecutivo colegiado e independiente, cuyas tareas pasaban por garantizar la prosecución de los objetivos fijados en el Tratado, actuando en el interés general de la Comunidad. Estaba compuesta por nueve miembros - de manera que, no era permitida la presencia de más de dos miembros referentes a un mismo Estado - que administraban por un período de seis años. Como se trataba de una institución con carácter de supranacional, a través de su poder de decisión, era de su responsabilidad promover la modernización de la producción, y buscar una mejoría de su calidad por el fornecimiento de productos en condiciones idénticas (producción masificada), por el desarrollo de la exportación común y por la mejoría de condiciones de trabajo en las industrias del carbón y del acero. La Alta Autoridad tomaba decisiones, formulaba recomendaciones y emitía pareceres. Era asistida por un 
Asamblea $^{1235}$, un Consejo de Ministros ${ }^{1236}$ y un Tribunal de Justicia ${ }^{1237}$. Dotando la Comunidad de personalidad jurídica. Con todo eso, el Tratado establecía un constante dialogo entre las empresas, que deberían fornecer a la Alta Autoridad informaciones diversificadas sobre la presente y futura producción de los varios minerales. Para tal, la CECA aplicaba poderes de consulta y verificación de estos datos.

No hay dudas sobre el enorme éxito que fue la CECA. La Comunidad supo enfrentar las crisis y dificultades que se presentaban, asegurando un desarrollo equilibrado de la producción y la distribución de los recursos, así como facilitando las reestructuraciones y reconversiones industriales que se hacían necesarias. Todo eso, recordando que el en el inicio de su funcionamiento, en razón del postguerra, fue confrontada con una fuerte reducción en busca de carbón y acero, lo que podría haber puesto Europa en una peligrosa recesión económica.

Importante resaltar que el Tratado de la CECA no hacía mención directa al medio ambiente, su preocupación era apenas por la calidad de vida ${ }^{1238}$, lo que motivó,

comité consultivo compuesto por representantes de los productores, de los trabajadores, de los utilizadores y de los comerciantes, buscando así, una mayor proximidad entre tomadores de decisiones/consumidores, además de garantir que sus necesidades fuesen llevadas en consideración.

${ }^{1235}$ La Asamblea era compuesta por 78 diputados provenientes de los Parlamentos de cada Estadomiembro, siendo que, 18 eran para Alemania, Francia e Italia, 10 para Bélgica y Países Bajos, y, 4 para Luxemburgo. Conforme dispuesto en el Tratado, este órgano tenía un poder de control sobre el carácter de las políticas y resoluciones tomadas por la Comunidad.

${ }^{1236}$ El Consejo integraba seis representantes delegados de los Gobiernos nacionales. La presidencia del Consejo era ejercida con alternancia por cada miembro, por un periodo de tres meses. El Consejo estaba destinado a armonizar la acción de la Alta Autoridad y la política económica general de los gobiernos. Su parecer favorable era imperativo para las importantes tomadas de decisiones por la Alta Autoridad.

${ }^{1237}$ El Tribunal de Justicia era compuesto por siete jueces nombrados por unanimidad por los Gobiernos de los Estados-Miembros, durante seis años. Aseguraba que la interpretación y aplicación de los Tratados seguían los principios generales de Derecho.

${ }^{1238}$ Conforme Dionisio Fernández de Gatta Sánchez, Evolución y regulación actual de la Política Ambiental Comunitaria, in Revista Noticias de la Unión Europea, n. ${ }^{1}$ 153, España: 1997, p. 94, los Tratados Fundacionales de la Comunidad Europea no preveían una competencia global y general en materia ambiental, quizás porque en esa época los problemas ambientales no eran muy graves, pero ya existían y la concienciación de los ciudadanos no era muy amplia. Delante de esas convicciones, confiere que el medio ambiente no estaba tan ajeno a los Tratados: El Tratado CECA (Arts. 54 y 55), permitía ciertas investigaciones y ciertas inversiones en la materia; el Tratado CEEA (Arts. 2 y 30 - 39), establecía medidas de protección contra las radiaciones ionizantes; y el Tratado CEE, incluía referencias al medio 
por medio de su art. 55, el Parlamento Europeo a argumentar respecto a la competencia comunitaria general en materia ambiental en la Resolución de 18 de abril de 1972 (DOCE C 46, de 9 de mayo) $^{1239}$.

ambiente en materia de libre circulación de productos (Arts. 30 al 34 y 36), transportes (Art. 75), ayudas estatales (Art. 92 y 93), política social (Arts. 117 y 118), Banco Europeo de Inversiones (Art. 130) y relaciones exteriores (Arts. 228 a 231).

${ }^{1239}$ Según Gonzalo Junoy, Sesiones del Parlamento Europeo - primera parte, In: Revistas de Instituciones Europeas, Crónicas de las instituciones comunitarias, v. 1, n. ${ }^{\circ}$ 2, 1974, p. 668, "La sesión del día 18 se abrió con la discusión por el Parlamento del informe relativo a la primera comunicación de la Comisión, sobre la política de la Comunidad en materia de medio ambiente. El informe fue presentado por el señor Jahn (cristianodemócrata alemán), en nombre de la comisión de asuntos sociales y de la sanidad pública. Comenzó su discurso el señor Jahn señalando que no era la primera vez que el Parlamento europeo se preocupaba de problemas de medio ambiente. Ya se había ocupa- do en 1970 del tema de la lucha contra la polución de las aguas fluviales y posterior- mente sobre la necesidad de una acción comunitaria en la lucha contra la polución del aire. Para el señor Jahn es preciso que hagamos «triunfar en el seno de nuestros Parlamentos nacionales y ante nuestros Gobiernos respectivos la idea de que se impone una política comunitaria de protección del medio ambiente». Pero es necesario, que también actúe la Comisión. Es preciso movilizar a la opinión pública mediante una campaña de información que aborde los peligros de la polución del medio ambiente. La Comisión debe intensificar en este terrena su actividad de información a la opinión pública. Se refirió el señor Jahn a que los tratados que instituyen las Comunidades Europeas proporcionan las bases jurídicas para tomar medidas comunitarias eficaces en este campo. Más adelante expuso las conclusiones a las que había llegado la comisión de asuntos sociales: hay que resolver el problema de la eliminación de los residuos sólidos, preservar los recursos naturales, transformar los espacios, obligar a las nuevas instalaciones de cierta importancia a utilizar los procedimientos, las técnicas y los materiales más eficaces para reducir la polución. Para resolver estos problemas hay que tomar medidas coordinadas. Terminado el discurso del señor Jahn, el señor Armengaud (liberal, francés), en nombre de la comisión jurídica, expuso el informe, íntimamente conectado con el tema anterior, acerca de las posibilidades que ofrecen los tratados comunitarios en materia de lucha contra la polución del medio ambiente". Además, Luis Ortega Álvarez afirma que "el artículo 54 permitía la promoción por parte de la Comisión de programas de inversión con relación a los objetivos del artículo 46 del mismo Tratado. Entre esos objetivos se encontraba el de la "evaluación de la posibilidad de mejora de las condiciones de vida y de trabajo" de los trabajadores de las industrias del sector del carbón y del acero, así como de "los riesgos que amenacen tales condiciones de vida". Una interpretación amplia de estos preceptos posibilitó financiación no de una nueva evaluación, sino de actuaciones directas de mejoras de las condiciones de vida de los trabajadores, como la construcción de viviendas que tuvieran en cuenta conceptos innovadores en cuanto a la calidad de vida. El art. 55, por su parte, permite la promoción de la investigación con relación, entre otros objetivos, a la seguridad en el trabajo de las industrias carboníferas y siderúrgicas. "Con base en ese precepto fueron financiadas 
Cincuenta años después de su entrada en vigor, el Tratado caducó, tal como había sido legalmente previsto, en 23 de julio de 2002. Durante su vigencia, fue objeto de sucesivas alteraciones por otros tratados, entre ellos el Tratado de Niza, lo cual había adjunto un protocolo relativo a las consecuencias financieras de la caducidad del Tratado de la CECA y al Fondo de Investigación del Carbón y Acero. Este protocolo establece la transferencia del patrimonio activo y pasivo de la CECA para la Comunidad Europea. El valor de ese patrimonio se destina a la investigación en los sectores relacionados a la industria de carbón y acero.

Eso hace con que nos deparemos en aquel momento, con una Europa con bases comunes de desarrollo económico, que busca mantener relaciones pacíficas, a través de la solidaridad, preocupada, sobre todo, con la elevación del nivel de vida, preparando así, el camino para la actual Unión Europea.

\subsubsection{Tratado de Roma - El Tratado Constitutivo de la Comunidad} Económica Europea - CEE

En marzo de 1957 fue firmado por Bélgica, Holanda, Luxemburgo, Francia, Italia y Alemania (los 6 que ya habían constituido el Tratado de la CECA) ${ }^{1240}$ y la Comunidad Europea de Energía Atómica - EURATOM o CEEA, la primera buscando integrar la economía de los países miembros con el establecimiento de un mercado común y de la unión aduanera, ya la segunda, con el objetivo de fomentar la cooperación en el desarrollo y utilización de energía nuclear y elevación del nivel de vida de los países miembros. Ambos entraron en vigor el 1 de enero de 1958.

El Tratado de Roma visaba una unión económica de hecho, una vez que se intentaba una política común para los productos agrícolas, para los transportes y para

investigaciones relativas a la contaminación, a la prevención de enfermedades respiratorias y al establecimiento de mecanismos de medición de elementos nocivos o contaminantes." El Concepto de Medio Ambiente, in ORTEGA ÁLVAREZ, Luis, (Coordinador), Lecciones de Derecho del Medio Ambiente, Editorial Lex Nova S.A., $4^{\text {a }}$ Edición, Valladolid-España: 2005, pp. 57-58.

${ }^{1240}$ Sólo en 1973 ocurrió la primera ampliación con la entrada del Reino Unido, Irlanda y Dinamarca. En 1981, hubo la incorporación de Grecia y apenas casi treinta años después de su inicio, en 1986, España y Portugal y así siguieron hasta los actuales 27 Estados Miembros. 
todos los importantes sectores económicos, además de reglas comunes referentes a la competencia, con la coordinación de la política económica de los Estados miembros. Como el propio Preámbulo del Tratado determinaba, se pretendía, mediante una acción común, una unión cada vez más estrecha entre los pueblos europeos, el progreso económico y social de sus países (con una mejora en la calidad de vida y de trabajo), eliminando las barreras que dividían Europa ${ }^{1241}$.

${ }^{1241}$ Según, Blanca Lozano Cutanda, Derecho ambiental administrativo, $1^{\circ}$ edición en La Ley, MadridEspaña: 2010, pp. 214-215, “Los tres Tratados constitutivos de la Comunidad no contenían ninguna disposición que reconociera competencia a las instituciones europeas para actuar en materia de medio ambiente $\mathrm{y}$, es más, las palabras $<<$ medioambiente $>>$, $<<$ ecología $>>0$ lucha contra la contaminación $>>$ ni siquiera aparecían en su texto. Ello es lógico si tenemos en cuenta que estos Tratados fundacionales fueron aprobados en los años cincuenta con el fin de promover la paz y el desarrollo económico de una Europa arruinada por las guerras, y cuando todavía existía una conciencia generalizada sobre el carácter limitado de los recursos naturales y la necesidad de frenar el proceso de deterioro de nuestro ecosistema". Sin embargo, Enrique Alonso García, El Derecho Ambiental de la Comunidad Europea. El Marco Constitucional de la Política Comunitaria de Medio Ambiente. Aplicación de la Legislación Ambiental Comunitaria, Volumen 1, Editorial Civitas, S.A., 1a edición, Madrid-España: 1993, pp. 27-28, al hacer referencia sobre "El Problema de la Ausencia de Título Competencial hasta el Acta Única Europea" afirma que los tres Tratados originarios sirvieron de base, especialmente, para posteriores normas ambientales, a pesar de que ninguno de ellos hacían referencias directas al medio ambiente. Destaca la citación de A. Haagsma, que «la inserción del título del medio ambiente en el Acta Única no tuvo por finalidad cambiar nada, por lo que la interpretación del Acta Única debe hacerse a partir de la interpretación de los fundamentos constitucionales existentes con anterioridad». Destacando que "Lo más cercano, siempre en el campo de la salud laboral — y pública en el segundo caso-, eran los artículos 54 y 55 del Tratado CECA y 30 al 39 del Tratado EURATOM. El artículo 54, en relación con el 46.5, ambos del Tratado CECA, permite a la Comisión la ejecución de programas de inversiones en el marco del objetivo general de reunir la información necesaria para la evaluación de las posibilidades de mejora de las condiciones de vida y de trabajo de los trabajadores en las industrias del carbón y del acero y de los riesgos que amenacen estas condiciones de vida. El artículo 55 del Tratado CECA autoriza a la Comisión para fomentar la investigación técnica y económica relacionada con la seguridad en el trabajo de las industrias del carbón y del acero. El Capítulo III (artículos 30 al 39) del Título II del Tratado EURATOM, que lleva por rúbrica «Protección Sanitaria», incluye toda la regulación de la protección sanitaria de la población y de los trabajadores contra los peligros de radiaciones ionizantes. En cualquier caso, resulta obvio que, si se incluye la seguridad nuclear en el denominado derecho del medio ambiente, las previsiones del Tratado EURATOM son fundamentales. Para apreciarlo, basta con observar que el artículo 35 dispone que «cada Estado Miembro creará las instalaciones necesarias a fin de controlar de modo permanente el índice de radiactividad de la atmósfera, de las aguas y del suelo, así como la observancia de las normas básicas» sobre, entre otras cosas, dosis, exposiciones y contaminaciones 
Los años siguientes a la firma del Tratado son de éxito, con grandes progresos económicos y una mayor posibilidad de cooperación en otros sectores, llevando países europeos a se asociaren en un esfuerzo común.

Cuando del inicio del Tratado ${ }^{1242}$, la estructura funcional, según el artículo 3, estaba formada por la Asamblea ${ }^{1243}$ (que posteriormente, a partir de 1960, pasó a ser oficialmente designada de Parlamento Europeo), el Consejo de Ministros ${ }^{1244}$, la Comisión $^{1245}$ y el Tribunal de Justicia ${ }^{1246}$. Tanto el Tribunal como la Asamblea eran

máximas. El artículo 38 permite a la CEE dirigir a los Estados Miembros recomendaciones sobre el índice de radiactividad de la atmósfera, de las aguas y del suelo. Por consiguiente, tanto la política sectorial del medio ambiente relacionada con el uso de la energía nuclear como la relacionada con el medio ambiente laboral en las empresas del carbón y del acero estaban plenamente contempladas en los Tratados constitutivos. El propio Parlamento Europeo, en su Resolución de 18 de abril de 1972, DOCE C 46, de 9 de mayo, sobre «las posibilidades que ofrecen los tratados comunitarios en materia de lucha contra la contaminación del medio y las modificaciones que eventualmente deben proponerse», utilizó estos artículos (explícitamente el artículo 55 del Tratado CECA) para justificar la competencia comunitaria general en materia de medio ambiente". En este sentido, Blanca Lozano Cutanda, Derecho ambiental administrativo, $1^{\circ}$ edición en La Ley, Madrid-España: 2010, pp. 214-215, afirma que: "Los tres Tratados constitutivos de la Comunidad no contenían ninguna disposición que reconociera competencia a las instituciones europeas para actuar en materia de medio ambiente y, es más, las palabras $<<$ medioambiente $>>$, $<<$ ecología $>>$ o $<<$ lucha contra la contaminación $>>$ ni siquiera aparecían en su texto. Ello es lógico si tenemos en cuenta que estos Tratados fundacionales fueron aprobados en los años cincuenta con el fin de promover la paz y el desarrollo económico de una Europa arruinada por las guerras, y cuando todavía existía una conciencia generalizada sobre el carácter limitado de los recursos naturales y la necesidad de frenar el proceso de deterioro de nuestro ecosistema".

${ }^{1242}$ Vale recordar que muchos de los artículos referentes al Tratado de la CEE fueron modificados por el Tratado de Niza, como se puede observar en: < http://www.boe.es/legislacion/enlaces/documentos/ue/Trat_EC_consol.pdf>. Acceso en: 21-08-2015.

${ }^{1243}$ La Asamblea estaba formada por los delegados de los Parlamentos Nacionales y al principio solo disponía de competencia para la emisión de pareceres, una vez que era un órgano de naturaleza consultiva.

${ }^{1244}$ El Consejo de Ministros, es un órgano de poder deliberativo, donde las decisiones eran tomadas por la mayoría de los representantes de gobierno de los Estados-miembros que lo componía.

${ }^{1245}$ La Comisión es órgano de poder legislativo, tiene sus miembros nominados por los gobiernos, además, posee poder para fiscalizar la aplicación de los Tratados y, poder de ejecución en la aplicación de las políticas comunes, y, también, propone actos comunitarios al consejo de ministros. 
comunes a las CECA, EURATOM y CEE. Además, había el Comité Económico y Social, que era un órgano consultivo que podría intervenir en el proceso de decisión y estaba constituido por representantes de los principales grupos económicos de los Estados Miembros, tales como los sindicatos, empresarios, consumidores y agricultores.

En aquel momento, delante del escenario del postguerra, los países que integraban el Tratado no estaban plenamente recuperados, razón por la cual fue priorizado el proceso tecnológico y científico, la expansión urbana e industrial, el crecimiento económico y como no podría dejar de ser, el desarrollo. En este sentido, al hacer un análisis de la historia ambiental sumada a la idea de desarrollo, Jacques Grinevald, afirma que: "La amalgama entre progreso científico y técnico, la expansión de la urbanización y la industrialización, el crecimiento económico y el desarrollo se impuso tras la II Guerra Mundial, en los años 1950-60, época de la guerra fría y de la descolonización, en la doctrina internacional de Naciones Unidas, en un momento en que la ideología del sistema científico-militar-industrial era dominante y proclamaba el dogma del progreso científico-técnico y del crecimiento económico. Se trataba de la época de la $<<$ locura del crecimiento $>>$, "the growthmania”, como dijo Ezra J. Mishan en su obra iconoclasta The Costs of Economic Growth (Londres, 1967). A partir de esa época, no faltaron las críticas que volvían a poner en tela de juicio el mito o la teoría económica del crecimiento ilimitado, más curiosamente ese dogma del crecimiento sigue constituyendo más que nunca la obsesión de las políticas nacionales y del mundillo de la economía internacional (...). La controversia no había hecho más que iniciarse a comienzo de los años 1970; en esa época, todo el mundo empezó a hablar de la $<<$ crisis ambiental $>>$, pero muy pocos economistas, empresarios o políticos conocían los informes científicos de la $<<$ crisis ecológica $>>$, sobre todo a escala de la Tierra. La idea de analizar las relaciones entre la expansión demográfica y tecnológica de la especie humana y los límites de la Biosfera parecía entonces totalmente nueva ${ }^{1247}$.

\footnotetext{
${ }^{1246}$ El Tribunal de Justicia visa garantizar el respeto del derecho en la aplicación e interpretación del Tratado. Vale resaltar que otros órganos también fueron creados, tales como el Tribunal de Cuentas y el Banco Europeo de Financiación, cada cual con su función.

${ }^{1247}$ GRINEVALD, Jacques. Ideas y preocupaciones acerca del papel de la especie humana en la biosfera, in NAREDO, José Manuel; GUTIËRREZ, Luís (Editores), La incidencia de la especie humana sobre la faz de la Tierra (1955-2005), Editora Universidad de Granada, Granada-España, pp. 20-21. Disponible en:
} 
Por otro lado, el Tratado seguía sin hacer ninguna mención en sus dispositivos respecto al agua, ni como elemento ambiental. Sin embargo, como enseña Blanca Lozano Cutanda: "El fundamento jurídico en los Tratados constitutivos de la protección del medio ambiente como objetivo propio de la Comunidad Europea se buscó en el artículo 2 del Tratado de Roma, pues aunque ninguna referencia se hacía en él al medioambiente, se interpretó de un modo amplio que al establecer como misión de la Comunidad la promoción de «un desarrollo más armonioso de las actividades económicas en el conjunto de la Comunidad» y «una expansión continua y equilibrada», la consecuencia de este objetivo requería necesariamente la adopción de una política ambiental comunitaria. Así lo declaró el Consejo al aprobar en 1972 el Primer Programa comunitario de acción ambiental ${ }^{1248}$, en cuyo Preámbulo leemos: «conforme al artículo 2 del Tratado, es tarea de la CEE promover en la Comunidad un desarrollo armonioso de actividades económicas y una expansión continua y equilibrada, que ahora no pueden concebirse sin una lucha eficaz contra las contaminaciones y perturbaciones ni sin mejorar la calidad de vida y la protección del medio ambiente (...)»»"1249. Y fue a través de esta interpretación que apoyada en el artículo 235 del Tratado de la CEE (actual art. 352 del Tratado de Funcionamiento de la Unión Europea - TFUE) que la materia medioambiental vino a hacer parte de la acción comunitaria $^{1250}$.

http://www.fcmanrique.org/recursos/publicacion/4d399d90la\%20incidencia $\% 20 \mathrm{de} \% 201 \mathrm{a} \% 20$ especie $\% 20$ humana\%20(parte\%201).pdf>. Acceso en: 25-08-2015.

${ }^{1248}$ Como bien comentó Blanca Lozano Cutanda, Derecho ambiental cit., pp. 219-220, "Especial importancia revistió la aprobación, el 22 de noviembre de 1973, del Primer Programa Comunitario de Acción en materia de medioambiente (vigente en el periodo 1973-1976), en el que se establecieron los principios generales de la política ambiental comunitaria, se definieron sus objetivos y se fijaron las acciones prioritarias y las medidas a adoptar en los años siguientes. En el marco de este Programa, la acción ambiental comunitaria experimentó un rápido desarrollo durante la década de los setenta, con la aprobación de más de un centenar de normas, fundamentalmente directivas, dirigidas a la protección del entorno".

${ }^{1249}$ LOZANO CUTANDA, Blanca. Derecho ambiental cit., p. 216. También en LOZANO CUTANDA, Blanca; PLAZA MARTÍN Carmen. La Política de Medio Ambiente - Capítulo XX, in LINDE PANIAGUA, Enrique (Coordinador), Políticas de la Unión Europea, Editorial Colex, $3^{\text {a }}$ edición, MadridEspaña: 2006, p. 707.

${ }^{1250}$ En este sentido, respecto a la interpretación del art. 2 del Tratado de Roma, Blanca Lozano Cutanda. Derecho ambiental cit., p. 216, afirma que: "Esta interpretación abrió la puerta a la acción comunitaria en 
Importante destacar que fue en 1962, durante este Tratado, que fue creada la Política Agrícola Común - PAC ${ }^{1251}$, que tenía como principales objetivos garantizar el

esta materia fundada en el art. 235 del Tratado CEE (actual art. 352 del TFUE), en virtud del cual la existencia de un objetivo dado implica la de cualesquiera poderes razonablemente necesarios para alcanzarlo. Se trata de la $<<$ doctrina de los poderes implícitos $>>$ que permite paliar las insuficiencias de los poderes que se le han conferido a la Comunidad para la consecución de sus objetivos, disponiendo que $<<$ cuando una acción de la Comunidad resulte necesaria para lograr, en el funcionamiento del mercado común, uno de los objetivos de la Comunidad, sin que el presente Tratado haya previsto los poderes de acción necesarios al respecto, el Consejo, por unanimidad, a propuesta de la Comisión y previa consulta a la Asamblea (actual Parlamento), adoptará las disposiciones pertinentes $>>$.

${ }^{1251}$ La Política Agrícola Común - PAC de la UE cumple varios objetivos: ayuda a los agricultores a producir suficientes alimentos para Europa; garantiza que los alimentos sean seguros (por ejemplo, a través de la trazabilidad); protege a los agricultores de la excesiva volatilidad de precios y de las crisis de mercado; les ayuda a invertir en la modernización de sus explotaciones; mantiene comunidades rurales viables, con economías diversificadas; crea y mantiene puestos de trabajo en la industria alimentaria; y, protege el medio ambiente y el bienestar de los animales. Respecto a los cambios en la política agrícola de la UE se puede afirmar que ha evolucionado considerablemente en las últimas décadas con la finalidad de ayudar a los agricultores a hacer frente a nuevos retos y adaptarse a la evolución de las actitudes ciudadanas. Las sucesivas reformas han llevado a los agricultores a basar su producción en la demanda del mercado y no en las decisiones venidas de Bruselas. Las reformas más recientes (2013) inclinaron las prioridades hacia: las prácticas agrarias más sostenibles; la investigación y la divulgación de los conocimientos; un sistema más justo de ayudas a los agricultores; y, una posición más fuerte de los agricultores en la cadena alimentaria. Otras metas que también son importantes: ayudar a los consumidores a elegir sus alimentos con conocimiento de causa gracias a sistemas de etiquetado de calidad de la UE que, al indicar el origen geográfico y el uso de ingredientes o métodos tradicionales (incluida la producción ecológica) también hacen que los productos agrícolas europeos sean competitivos en los mercados mundiales; fomentar la innovación en la agricultura y la transformación de alimentos, con la ayuda de proyectos de investigación europeos, para incrementar la productividad y reducir el impacto medioambiental (aprovechando, por ejemplo, los subproductos y los residuos de las cosechas para producir energía); y, Impulsar las relaciones comerciales justas con los países en desarrollo, suspendiendo las subvenciones a las exportaciones de productos agrícolas europeos y facilitando las exportaciones con destino a la UE desde esos países. Sobre los Retos futuros, se espera que la producción mundial de alimentos se duplique hasta 2050 para hacer frente al crecimiento de la población y al aumento del consumo de productos animales entre las personas que cuentan con más medios. Además, habrá que abordar las repercusiones del cambio climático (pérdida de biodiversidad, deterioro de la calidad del suelo y del agua, etc.). La PAC busca asesorar a los agricultores sobre la inversión y la innovación necesarias para que realicen esas tareas. La política agrícola es uno de los ámbitos en los que los países de la UE aceptaron centralizar plenamente sus competencias, además de la financiación pública 
abastecimiento regular de géneros alimenticios, mantener el equilibrio entre ciudad y campo, asegurar a los agricultores un ingreso en conformidad con sus rendimientos, además de valorar los recursos naturales y preservar el ambiente. Sin embargo, en aquél momento, no había la preocupación con el agua ni como elemento ambiental en sus dispositivos.

Así, en 27 junio de 1967, fue promulgada la primera Directiva comunitaria en materia de medio ambiente ${ }^{1252}$, que según Blanca Lozano Cutanda: "No será hasta finales de los años sesenta cuando se promulgue la que se considera como la primera Directiva comunitaria en materia de medio ambiente: la de 27 de junio de 1967, relativa a la clasificación, el etiquetado y el embalaje de sustancias peligrosas (a la que siguieron otras dos, en 1970, sobre niveles de ruido de los vehículos de motor y sobre emisiones de gases contaminantes procedentes de los motores de estos vehículos). En estas primeras directivas se trataba únicamente de aproximar las legislaciones nacionales a fin de evitar un progresivo levantamiento de "barreras verdes" entre los Estados miembros, esto es, la aparición de obstáculos a la libre circulación de mercancías o distorsiones de la competencia como consecuencia de la adopción por los Estados de normas ambientales (por ejemplo, por excluir un Estado miembro la comercialización de determinados productos de otros Estados miembros al considerarlos nocivos para el medio ambiente, o por obtener las empresas radicadas en Estados miembros con menores niveles de protección ambiental una ventaja económica frente a las establecidas en Estados con estándares de protección más altos), por lo que se dictaron al amparo del Art.100 del Tratado CEE (correspondiente al actual artículo 94), que permitía al Consejo adoptar "por unanimidad y a propuesta de la Comisión, directivas

necesaria. Por lo tanto, las decisiones y las ayudas no están en manos de cada país, sino que son responsabilidad de la UE en su conjunto. El porcentaje del gasto agrícola en el presupuesto de la UE ha descendido drásticamente: tuvo un máximo histórico de casi el 70\% en los años setenta, pero ronda el $38 \%$ en nuestros días. Esto refleja tanto el aumento de las competencias de la UE en otros sectores como el ahorro derivado de las reformas (por ejemplo, desde 2004 la UE ha acogido a trece nuevos países miembros sin aumentar el gasto agrícola). Todo conforme el propio sitio de la Unión Europea: $<$ http://europa.eu/pol/agr/index_es.htm>, con acceso el: 02/09/2015.

${ }^{1252}$ DO 367 L 0548 67/548/CEE: Directiva del Consejo, de 27 de junio de 1967, relativa a la aproximación de las disposiciones legales, reglamentarias y administrativas en materia de clasificación, embalaje y etiquetado de las sustancias peligrosas. Disponible en: < http://eur-lex.europa.eu/legalcontent/ES/TXT/?uri=CELEX:11994NN01/08/D>. Acceso en: 02-09-2015. 
para la aproximación de las disposiciones legales, reglamentarias y administrativas de los Estados miembros que incidan directamente en el establecimiento y funcionamiento del mercado común"

De ahí, se puede decir que el artículo 100 del Tratado de la CEE en conjunto con el artículo 235 del Tratado de la CEE (actual art. 352 del Tratado de Funcionamiento de la Unión Europea - TFUE), fueron los responsables por la intervención de la Comunidad Europea en materia medioambiental, principalmente a lo que se refiere al agua, a través de la armonización de las regulaciones nacionales respecto a su calidad para determinados usos, buscando evitar que estas criasen obstáculos al libre comercio o espacios de "dumping ecológico"1254. Así, los actos

${ }^{1253}$ LOZANO CUTANDA, Blanca. Derecho ambiental cit., p. 215. En sentido contrario, Dionisio Fernández De Gatta Sánchez, in Revista de Derecho Ambiental, n. ${ }^{o}$ 22, España: 1999, p. 23, afirma que antes de los años 70 la Comunidad Europea se dedicó a legislar en materia de contaminación del agua y del aire, que son los medios más afectados. Para tanto, utilizó normas reguladoras de los productos y de los procesos de producción, normas de calidad completadas con normas de emisión. Además, delante de una posible insuficiencia instrumental en la fuente contaminadora, a partir de los años 80, comenzó a utilizar instrumentos preventivos como la evaluación de impacto ambiental, auditoría ambiental, entre otros. El autor añade en diferente artículo que: "En particular, esos instrumentos se potencian en los años 90. Se trataría de superar la contradicción entre medio ambiente y desarrollo económico incrementando la compatibilidad ambiental de las actividades productivas". Auditorías y Sistemas de Gestión Ambientales en la Unión Europea: Evolución, régimen vigente y perspectivas futuras, in Revista Noticias de la Unión Europea, n. ${ }^{\text {o } 228, \text { España: 2004, p. } 50 .}$

${ }^{1254}$ Conforme Pablo García-Almonacid: "Dumping significa en Economía que un producto se vende al exterior a un precio más alto del que se puede consumir en el interior de un país. Por ejemplo si exporto tuercas a un país que carece de IVA y otros impuestos. Esto me abarata el coste y por tanto me puedo permitir el lujo de exportar más cantidad con un precio más barato. Últimamente se ha hablado de dos nuevos conceptos de dumping: el dumping social y el dumping ecológico. El social se da cuando la empresa exportadora puede abaratar sus costes (vendiendo más cantidad a un precio menor) mediante la contratación de niños u otros grupos sociales a los que se les paga un salario ínfimo, con unas condiciones pésimas y por supuesto, sin seguridad social. El dumping ecológico usa el medio ambiente como tablero para abaratar los costes. El respeto al medio ambiente cuesta siempre dinero (catalizadores, control administrativo en redes pesqueras, tratamiento de residuos industriales,...) A pesar de que hay unos estándares, hay países donde se controla más esto. Sin embargo, en otros países no existen estos controles. Imaginemos el caso de una industria papelera de Barcelona que tiene una producción encarecida, entre otras cosas, por su tratamiento de vertidos al Mediterráneo y otras medidas benevolentes con el medio ambiente. Por otro lado tenemos en el Cairo otra papelera que no tiene tales costes pues vierte todos sus residuos directamente al mar. Estas dos empresas compiten en un marco internacional y 
legislativos de la Comunidad, en un primer momento, determinaban objetivos de calidad para las aguas de consumo humano, las superficiales y destinadas al baño, la vida de los peces, la cría de moluscos, además del control de las emisiones de sustancias peligrosas, principalmente las de origen industrial, y los vertidos en aguas subterráneas $^{1255}$.

Y fue en la ciudad francesa de Estrasburgo, el 6 de mayo de 1968 (un año después de la primera Directiva), que el Consejo de Europa redactó la Carta Europea del Agua $^{1256}$, la cual integra 12 principios básicos para la gestión y salvaguardia de este recurso tan valioso ${ }^{1257}$, o sea, el final de la década de sesenta fue el indicador de que el crecimiento económico y el proceso de industrialización predatoria estaban trayendo

al final, la empresa de Barcelona tiene que cerrar porque no puede competir con la del Cairo, que pasa además a suplir la demanda que deja tras de sí la empresa de Barcelona. El resultado: la papelera de Barcelona, respetando el medio ambiente debe cerrar pues no puede competir contra los precios de la egipcia. La papelera del Cairo, ha abaratado sus costes, produce más y todo a costa del deterioro medioambiental del Mediterráneo". Disponible en: < http://www.internatura.org/opinion/dumping.html>. Acceso en: 02-09-2015.

${ }^{1255}$ Francisco Delgado Piqueras explana sobre la importancia del artículo 235 como fundamento para la intervención ambiental y la calidad de las aguas desde esa primera etapa. La Protección Ambiental de las Aguas Continentales, in ORTEGA ÁlVAREZ, Luis (Director), Lecciones de Derecho del Medio Ambiente, Editorial Lex Nova S.A., 4ª Edición, Valladolid-España: 2005, p. 169. Respecto al tema, Blanca Lozano Cutanda, Derecho ambiental cit., pp. 216-217 afirma que: “(...) en caso de que el art. 100 no bastase para justificar una acción comunitaria ambiental (lo que ocurría cada vez con mayor frecuencia, pues cuanto mayor iba siendo el carácter puramente ambiental de las directivas comunitarias menor solía ser su incidencia directa en los aspectos económicos propios de un mercado común), ésta podía fundarse en el artículo 235, que se utilizó con mucha frecuencia en combinación con el anterior. La denominada teoría de la 'doble fundamentación', formulada por el TJCE, suponía '(...) para aquellos supuestos en los que la competencia de una institución tuviera como base jurídica dos disposiciones diferentes, la obligatoriedad de esta última de adoptar el acto en cuestión sobre la base conjunta acumulada de las dos normas'. Por ello, hasta el Acta Única de 1986 la gran mayoría de las directivas atinentes a cuestiones ambientales estaban basadas en los arts. 100 y 235 del Tratado invocados conjuntamente"

${ }^{1256}$ Los 12 principios de la Carta Europea del Agua están disponibles en: < http://tragua.com/wpcontent/uploads/2012/04/Carta_Europea_del_Agua.pdf $>$. Acceso en: 02-09-2015.

${ }^{1257}$ Respecto al tema, Francisco Delgado Piqueras, in Luis Ortega Álvarez (Director), Op. Cit., 2005, p.170, hace una reflexión sobre el análisis de la problemática situación de los recursos hídricos en el continente, afirmando que el agua es un elemento de primera necesidad, tanto para los hombres como para los animales y plantas: "sin agua no hay vida posible". 
resultados desastrosos para el Planeta. Preocupada con la contaminación del agua, del aire y del suelo, con el acumulo de residuos y el surgimiento de casos críticos de degradación ambiental, Suecia propone a las Naciones Unidas la realización de una conferencia internacional para discutir los principales problemas ambientales que ya alcanzaban una dimensión global, relacionándolos a cuestiones socioeconómicas, en especial a la presión del crecimiento demográfico sobre los recursos naturales en los países pobres $^{1258}$.

Sin embargo, fue durante la década de los setenta que la protección medioambiental alcanzó sustantividad propia como política comunitaria ${ }^{1259}$. Es en estos años que la conciencia ambiental eclosiona a nivel internacional, constituyendo en este sentido un hito fundamental la Conferencia de las Naciones Unidas sobre el Medio

${ }^{1258}$ FELDMANN, Fábio José (Org.). Guia da ecologia. Editora Guias Abril, São Paulo-Brasil: 1992, p.17.

${ }^{1259}$ Blanca Lozano Cutanda, Derecho ambiental cit., p. 58, hablando de la evolución histórica del derecho internacional del medioambiente afirma que: "Un primer periodo, que podríamos calificar como $<<$ la prehistoria $>>$ del derecho internacional del medioambiente, comienza a finales del siglo XIX y concluye con la creación de las nuevas organizaciones internacionales en 1945. En Esta época tienen lugar los primeros intentos de desarrollar reglas internacionales de carácter ambiental cuyo objeto es la protección de formas de vida salvaje (pájaros, focas, recursos pesqueros) y, más limitadamente, la protección de espacios naturales vírgenes, de ríos y de ámbitos marinos. Se trataba en todo caso de convenios esporádicos, con un enfoque limitado y que no contenían ninguna fórmula institucional para administrar sus disposiciones y hacer efectiva su ejecución". La autora, sigue en el tema y afirma que: "Una segunda fase en el desarrollo del derecho internacional ambiental es la que va desde la creación de las Naciones Unidas y sus agencias especializadas en 1945 hasta la Conferencia de Estocolmo de 1972. En este periodo, las organizaciones internacionales a nivel regional y mundial comienzan a actuar en el ámbito de la protección del entorno. Aunque la Carta de las Naciones Unidas no incluyó disposiciones sobre protección ambiental, los amplios objetivos de esta organización, que comprenden la consecución de una cooperación internacional para la solución de los problemas internacionales de carácter económico, social, cultural o humanitario, proporcionaron una base a su actuación en este ámbito. Así, en 1949 tuvo lugar la Conferencia de las Naciones Unidas sobre la conservación y utilización de los recursos (UNCCUR), que, aunque se limitó al intercambio de ideas y experiencias sin la adopción de ninguna recomendación, supuso la confirmación de la competencia de las Naciones Unidas en asuntos ambientales y dio un importante impulso a la acción internacional en defensa del medio ambiente. A partir de entonces se adoptaron un número creciente de convenios internacionales, a nivel regional o mundial, cuyo objeto es la lucha contra las fuentes de contaminación y la conservación de los recursos naturales de ámbitos como el medio marino, las aguas terrestres y las zonas húmedas”. Derecho ambiental cit., pp. 59-60. 
Ambiente Humano ${ }^{1260}$ realizada en Estocolmo, del 5 al 16 de junio de 1972, con la participación de 113 países, 250 organizaciones no gubernamentales y organismos de la Organización de las Naciones Unidas. Los principales resultados de esta Conferencia fueron la creación del Programa de las Naciones Unidas para el Medio Ambiente PNUMA o United Nations Environment Programme - UNEP ${ }^{1261}$ y la aprobación de la

${ }^{1260}$ Durante sus trabajos surgieron dos vertientes: a) las conservacionistas, vertiente radical, liderados por países desarrollados, que defendieron la suspensión de la intervención del hombre en el medio ambiente; y las b) desarrollistas, compuesta por países en desarrollo, entre los cuales, Brasil, que afirmaban, en síntesis, que los países en desarrollo aceptaban la contaminación y que la preocupación debería ser con el crecimiento económico. Al su término, se editó la Declaración de Estocolmo sobre Medio Ambiente Humano, con 26 principios referentes al comportamiento y responsabilidades, que se destinan a nortear los procesos decisorios de relevancia para la Cuestión Ambiental. En su Principio 1, la Declaración reconoce el medio ambiente con calidad como derecho fundamental, como se ve: "El hombre tiene el derecho fundamental a la libertad, la igualdad y el disfrute de condiciones de vida adecuadas en un medio de calidad tal que le permita llevar una vida digna y gozar de bienestar, y tiene la solemne obligación de proteger y mejorar el medio para las generaciones presentes y futuras. Disponible en: < http://www.jmarcano.com/educa/docs/estocolmo.html>. Acceso en: 06-09-2015. Es de observar que la Conferencia de Estocolmo no se preocupó específicamente con el tema del desarrollo sostenible, limitándose al medio ambiente humano. Esa temática, aún, ha tenido inserción en la agenda mundial con el Informe Brundtland (Nuestro Futuro Común). Importante resaltar que la Declaración de Estocolmo trae consigo la cooperación internacional para la protección del medio ambiente como principio general de Derecho Internacional, aunque con énfasis en el libre intercambio de experiencias científicas y en la tecnología ambiental, formalmente prevista en el Principio 20: "Se deben fomentar en todos los países en desarrollo, la investigación y el desarrollo científicos referentes a los problemas ambientales, tanto nacionales como multinacionales. A este respecto, el libre intercambio de información científica actualizada y de experiencias sobre la transferencia de ser objeto de apoyo y asistencia, a fin de facilitar la solución de los problemas ambientales; las tecnologías ambientales deben ponerse a disposición de los países en desarrollo en condiciones que favorezcan su amplia difusión sin que constituyan una carga económica excesiva para esos países". A partir de este documento metas especificas fueron fijadas, con eso, eran dados los primeros pasos para la formación de una "suave legislación" centrada en cuestiones internacionales relativas al medio ambiente. Respecto a la legislación brasileña, la Declaración de Estocolmo fue una de las bases para la redacción del artículo 225 de la Constitución Federal de 1988, según el cual: "Todos têm direito ao meio ambiente ecologicamente equilibrado, bem de uso comum do povo e essencial à sadia qualidade de vida, impondo-se ao Poder Público e à coletividade o dever de defendê-lo e preservá-lo para as presentes e futuras gerações”.

${ }^{1261}$ Según Jorge González González, El acceso al agua potable como derecho humano. Editorial Club Universitario. Alicante-España: 2014, p. 90: "Para dar continuidad a las decisiones que se adoptaron, las Naciones Unidas crearon en 1973 el Programa de las Naciones Unidas para el Medio Ambiente 
Declaración sobre el Medio Ambiente Humano ${ }^{1262}$. Con eso, pasa a ser un marco del derecho ambiental a nivel mundial. Además, en octubre de este mismo año, cuando en la Conferencia de Jefes de Estado y de Gobierno de París, que supuso la aprobación definitiva del proceso de unión económica de la CEE, asumiéndose decididamente la

(PNUMA), con sede central en Nairobi (Kenia), cuyo propósito es promover la administración equilibrada de los recursos naturales para que puedan constituir la base para el desarrollo del medio ambiente". Además, Blanca Lozano Cutanda, Derecho ambiental cit., p. 65, menciona que: "se trata de una institución cuya sede está en Nairobi y que está compuesta por un Consejo de Administración, integrado por 58 miembros elegidos por la Asamblea General de Naciones Unidas, y por una Secretaría al frente de la cual se encuentra el Director Ejecutivo de la UNEP. Los fines de esta institución están dirigidos a promover, orientar e implementar los programas de cooperación internacional en materia ambiental desarrollados en el marco de las Naciones Unidas (en la actualidad dirige sus esfuerzos a la implantación de la dimensión ambiental de la Agenda 21, adoptada por la Conferencia de Río en 1992). A pesar de su limitado estatus como un programa de Naciones Unidas (en vez de cómo una Agencia especializada) y de que su presupuesto es bastante reducido, la UNEP ha desempeñado desde su creación un papel muy importante en el desarrollo del derecho internacional del medioambiente. La Conferencia de Estocolmo abrió un periodo de espectacular desarrollo del derecho internacional ambiental. En el plano de los instrumentos jurídicos se adoptaron numerosos convenios especializados, tanto a escala regional como mundial. Muchos de estos convenios fueron promovidos por la UNEP o bien se adoptaron al margen de esta institución pero dentro del sistema de las Naciones Unidas". United Nations Environment Programme. Disponible en: $<$ http://www.unep.org $>$. Comitê Brasileiro do Programa das Nações Unidas para o Meio Ambiente. Disponible en: < http://brasilpnuma.org.br > y también en: < http://web.unep.org/regions/brazil/>. Acceso en: 04-09-2015.

${ }^{1262}$ La Conferencia de Estocolmo también aprobó el Plan de Acción para el Medio Humano, compuesto de 109 recomendaciones teniendo por base la cooperación internacional en materia de medio ambiente y destinado a posibilitar la implementación de la Declaración de Principios. Dichas recomendaciones referidas al medio humano y a los recursos naturales, seis (Recomendación 20.b.ii y Recomendación 51 a la 55) de ellas se refieren específicamente a las cuencas fluviales y otros temas relacionados con el agua. En este sentido de que en el Plan de Acción concentraron los principios fundamentales sobre la ordenación jurídica del agua, que marcó el punto de partida y base para la política de aguas comunitaria, Francisco Delgado Piqueras. In ORTEGA ÁlVAREZ, Luis (Director), Op. Cit., 2005, p. 170, afirma que: “(...) marcan una lúcida pauta a seguir de cerca por las legislaciones nacionales: a) el carácter de bien común del agua, y el consiguiente deber de todos de usarla adecuadamente y no desperdiciarla; b) la consideración de las cuencas hidrográficas como unidad básica de gestión de las aguas superficiales y subterráneas; c) la planificación como instrumento indispensable para una política de administración racional de los recursos a corto y largo plazo; d) la participación de los usuarios en la planificación y administración de los recursos hídricos; e) la elaboración de leyes generales de aguas, que den a éstas un tratamiento jurídico unitario". 
protección del medio ambiente como política comunitaria ${ }^{1263}$. En la Declaración

${ }^{1263}$ Es cierto que existen trabajos anteriores a la celebración de las citadas conferencias, como es el caso del Informe sobre Política Industrial de la Comunidad, que fue entregue al Consejo, el 20 de marzo de 1970. Este informe, apunta la idea de una política industrial que tenga en cuenta la mejora cualitativa de las condiciones del hombre. Conforme María Jesús Sánchez Muñoz, Treinta años de actuación en materia medio ambiental en la Unión Europea, Disponible en: <http://ccoo.webs.upv.es/files/MedioAmbiente/2006/Politica-de-Medio-ambiente-en-Europa-en-30-anos.pdf>. Acceso en: 08-09-2015, "Avanzando en el calendario, llegamos al 22 de junio de 1971, fecha en que la Comisión adopta la primera Comunicación sobre Política de la Comunidad en materia ambiental, donde justificaba sus competencias en esta materia, estableciendo un programa general de acciones que contemplen los siguientes objetivos: reducción de la contaminación, protección del medio natural, sistema de armonización de medidas ambientales de información, medidas en Organismos Internacionales y acciones para difundir y mejorar la información ambiental". Además, Dionisio Fernández de Gatta Sánchez, Unión Europea y cambio climático: el régimen europeo del comercio de derechos de emisión

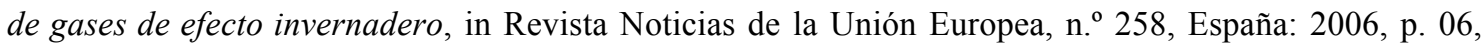
enseña que: "Desde los años 70 del siglo XX, con carácter general, el medio ambiente se protege mediante normas jurídicas destinadas específicamente a esta función, convirtiendo dicha protección en una función pública”. En este sentido, según José Luis de la Cuesta Arzamendi, La Tutela Penal de las Aguas Continentales (Especial consideración de delito contra el ambiente: artículo 347 bis CP), in EMBID IRUJO, Antonio (Director), La calidad de las aguas, Madrid-España: 1994, p. 172, resalta que visando amparar con mayor eficacia la protección ambiental, surge a la vuelta de los años 1970, su instrumentalización en la esfera penal, que nace como resultado de la creciente preocupación por los ataques al entorno, consecuencia del desarrollismo desenfrenado de las décadas anteriores, dando inicio a la determinación de una instrumentalización de políticas de todo orden, incluso jurídicas, dirigidas a la conservación y tutela del medio natural. Ya Antonio Vercher Noguera, Avanzando Hacia un Derecho Penal Ambiental Comunitario, in VERCHER NOGUERA, Antonio (Director), Derecho Europeo Medioambiental: La Protección del Medio Ambiente en la Unión Europea. Aspectos Críticos, Editorial Consejo General del Poder Judicial, Estudios de Derecho Judicial, n. ${ }^{o}$ 134, Editora Lerko Print S.A., Madrid - España: 2008, pp. 51-52, comenta que la llegada del Derecho Penal al sistema comunitario fue fruto de la más pura necesidad práctica, "a medida que el Derecho comunitario ha ido creciendo resultaba ciertamente difícil evitar que su contenido se extendiera por lo que constituyen los dominios del Derecho penal. A pesar del principio soberanista, que implica que la UE debe respectar la soberanía de los Estados miembros y con eso, no puede ni tipificar acciones de manera que las mismas pasen a constituir delito, ni establecer las sanciones penales aplicables a tales hechos delictivos, la realidad práctica ha sido distinta. El TJCE, en Sentencia de 21 de septiembre de 1989, Comisión contra Grecia, Asunto C-68/88, conocido como 'caso del maíz griego', dejó claro que los Estados miembros no son absolutamente libres a la hora de asociar sanciones penales a violaciones de preceptos del Derecho Comunitario". Interesante reflexión respecto al derecho penal para la protección ambiental es hecha por Rosario de Vicente Martínez, Derecho Penal del Medio Ambiente, in ORTEGA ÁlVAREZ, Luis (Coordinador), Lecciones de 
acordada en esta Cumbre se subraya 'la importancia de una política ambiental en la Comunidad', y se urge a las instituciones comunitarias a desarrollar un programa de acción en esta materia ${ }^{1264}$. El Programa de acción Comunitaria en materia de ambiente fue presentado al Consejo en 24 de marzo de 1972 y aprobado en 22 de noviembre de 1973, el cual constituye el primero de una serie de siete programas de acción en esta materia $^{1265}$.

La Declaración de Estocolmo no tenía valor vinculante, pero sirvió de inspiración y guía para preservar y mejorar el medio ambiente. En este momento el agua está asociada a los demás elementos de la naturaleza, razón por la cual es considerada un elemento ambiental, y a partir de ahí, en 1977, se celebró la Primera Conferencia

Derecho del Medio Ambiente, 4⿳a edición, Ed. Lex Nova, Valladolid, 2005, p.537.

${ }^{1264}$ LOZANO CUTANDA, Blanca. Derecho ambiental cit., pp. 215-216. En ese sentido, Judith Domínguez Serrano, El funcionamiento del sistema de protección ambiental de la Unión Europea: principios, instituciones, instrumentos, in Revista Estudios Demográficos y Urbanos, Vol. 22, n. 3 (66), p. 691, México-DF: 2007, afirma que: “La preocupación ambiental en la Unión Europea y en Estados Unidos surgió en la década de los setenta, y a raíz de la Declaración de Estocolmo sobre el Medio Humano de 1972 se adoptó el Primer Programa de Protección Ambiental de la Unión Europea. A partir de éste varios programas comunitarios en materia de medio ambiente han incorporado de manera gradual diversos principios y medidas que van desde el principio correctivo hasta el de prevención, y que han evolucionado a partir de una tímida protección para un mejor funcionamiento del mercado interno hasta convertirse en uno de los sistemas más protectores del medio ambiente". Disponible en: <http://codex.colmex.mx:8991/exlibris/aleph/a18_1/apache_media/66CS1DF5IT3VEDRKVQIITMFKF NTTXU.pdf $>$. Acceso en: 07-09-2015. Además, respecto al tema, Lucía Casado Casado, Los Vertidos de Aguas Continentales. Las Técnicas de Intervención Administrativa, Colección Estudios de Derecho Administrativo, Editorial Comares, Granada-España: 2004, p. 67, comenta que fue por medio de una Resolución, y por tanto, con carácter soft law que se estableció el Primer Programa de Acción de la Comunidad Europea en materia ambiental. Así, afirma la autora que la protección ambiental de los recursos hídricos encuentra reflejo en multitud de instrumentos internacionales, tanto de soft law carentes de fuerza jurídica obligatoria, como de hard law, siendo estos últimos las fuentes internacionales más relevantes en esta materia, por su naturaleza jurídica vinculante.

1265 Según José Joaquim Gomes Canotilhoy José Rubens Morato Leite (Organizadores), Direito Constitucional Ambiental cit., p. 17: “(...) esta abertura inicial à proteção do ambiente no âmbito da Comunidade Europeia foi, até 1987, muito limitada, pois os Tratados só permitiam a adoção de medidas de uniformização em matérias que estivessem incidência directa no estabelecimento ou no funcionamento do mercado comum (art. $100^{\circ}$ do Tratado, actual artigo $94^{\circ}$ ), o que, em teoria, deixaria por harmonizar importantes domínios da proteção do ambiente. 
Mundial sobre el agua en Mar del Plata ${ }^{1266}$, Argentina, donde los lideres mundiales tomaron consciencia de la grandeza de los problemas relacionados con el acceso al agua, tanto en calidad como en cantidad, y de los riesgos asociados a la escasez y degradación del suministro. La Conferencia de Mar del Plata expuso los hechos básicos y convirtió el agua en uno de los temas principales de la agenda política internacional $^{1267}$.

Dando secuencia al desarrollo de la política ambiental, se llega a la prosecución y a la ejecución del Segundo Programa de Acción de las Comunidades Europeas en materia de Medio Ambiente ${ }^{1268}$ (1977-1981) aprobado el 17 de mayo de $1977^{1269}$. Fueron utilizados para ello los mismos mecanismos, aunque se ha introducido un nuevo ${ }^{1270}$ que exactamente da carácter a este Programa. Dicho Programa es

${ }^{1266}$ E/CONF. 70/29. Informe de la Conferencia de las Naciones Unidas sobre el agua, Mar del Plata, 14 al 25 de marzo de 1977, Naciones Unidas, Nueva York, 1977.

${ }^{1267}$ GONZÁLEZ GONZÁLEZ, Jorge. El acceso al agua potable cit., p. 89. Además, añade el autor que: "La Conferencia de las Naciones Unidas sobre el Agua de 1977 fue un evento internacional de características especiales, ya que se tornó por primera vez el agua como elemento natural indispensable que debía ser considerado de manera integrada. Hasta ese momento, todas las reuniones y acuerdos anteriores habían tomado en cuenta el agua como recurso para ser utilizado en un sector específico. A pesar de todo, la gestión del agua no fue objeto regulado por esos tratados o acuerdos específicos. Para ello, se requería una visión interdisciplinaria e interjurisdiccional, y esa complejidad en el asunto fue precisamente lo que impulsó a convocar una conferencia que trata la gestión del agua desde una perspectiva multidisciplinar". El acceso al agua potable cit., pp. 89-90.

${ }^{1268}$ Haciendo referencia a los Programas de la Acción Ambiental de la Unión Europea, Blanca Lozano Cutanda, Derecho ambiental cit., pp. 278-279 explica que: "Los cinco Programas de Acción en materia de medioambiente adoptados hasta el Sexto Programa se han aprobado mediante actos comunitarios atípicos, que han revestido la forma de $<<$ Declaración $>>$ (el primero) o de $<<$ Resolución $>>$ (los demás) del Consejo y de los representantes de los Gobiernos de los Estados miembros, lo que es muy expresivo del carácter controvertido que tenía la competencia de la Comunidad Europea en materia de medioambiente, que llevaba a otorgar un carácter $<<$ intergubernamental $>>$ a estos Programas de Acción y a muchas de las medidas adoptadas para su aplicación. De esta forma, los Programas se configuraban como meros instrumentos de carácter político, sin fuerza normativa o carácter vinculante alguno, aunque marcaban las directrices que habían de seguir las normas de la Comunidad Europea en la materia".

${ }^{1269}$ DOC C 139/46, de 13-06-1977.

${ }^{1270}$ Conforme Resolución del Consejo de las Comunidades Europeas y de los Representantes de los Gobiernos de los Estados Miembros reunidos en el seno del Consejo: "Considerando, en particular, que en materia de reducción de contaminaciones y ruidos ambientales, ha de otorgarse prioridad a las medidas relativas a la protección de las aguas y a las de la contaminación del aire, y que la lucha contra el ruido 
continuista en los objetivos, principios y acciones de la política ambiental, razón por la cual se pretende una modificación orientada hacia la prevención de los problemas más que hacia su solución. Así, según María Jesús Sánchez Muñoz: “(...) los principios básicos se centran en la prevención, por lo que la política óptima, estriba en impedir desde el origen la aparición de contaminaciones o de perturbaciones antes que en combatir después sus efectos. En este sentido se considera necesaria la adopción de nuevos instrumentos (evaluación de impacto ambiental y planificación) para evitar cualquier tipo de explotación de los recursos y del medio natural que cause daños sensibles al equilibrio ecológico"1271.

Con la conclusión del calendario del Segundo Programa, se procede a lo largo de 1982 a la elaboración del Tercer Programa de Acción ${ }^{1272}$, que entiende que la política de medio ambiente es una política estructural que debe proseguir independientemente de los azares coyunturales ${ }^{1273}$. Aquí se repiten los principios, los objetivos, las prioridades de los Programas anteriores, sin embargo, establece que los esfuerzos que habrán de realizar durante los años de 1982-1986, no sólo hay que continuar, sino que deben redoblar ${ }^{1274}$, además, reestructuró el marco de actuación de la política comunitaria, como global y preventiva y fijó líneas de actuación preferente.

debe ser objeto de nuevas medidas; que conviene, además, reforzar el carácter preventivo de la política relativa al medio ambiente y conceder una atención especial a la protección y a la gestión racional del espacio, del medio y de los recursos naturales". Disponible en: < http://eur-lex.europa.eu/legalcontent/ES/TXT/?uri=CELEX:41977X0613>. Acceso en: 08-09-2015.

${ }^{1271}$ SÁNCHEZ MUÑOZ, María Jesús. Treinta años de actuación en materia medio ambiental en la Unión Europea, Disponible en: <http://ccoo.webs.upv.es/files/Medio-Ambiente/2006/Politica-de-Medioambiente-en-Europa-en-30-anos.pdf>. Acceso en: 08-09-2015.

${ }^{1272}$ Aprobado posteriormente mediante la Resolución del Consejo de las Comunidades Europeas y de los representantes de los Gobiernos de los Estados miembros reunidos en el seno del Consejo de 7 de febrero de 1983 relativa a la prosecución y ejecución de una Política y de un Programa de Acción de las Comunidades Europeas en materia de Medio Ambiente. DOC C 46/1 de 17-02-83.

1273 Idem. Disponible en: <http://ccoo.webs.upv.es/files/Medio-Ambiente/2006/Politica-de-Medioambiente-en-Europa-en-30-anos.pdf>. Acceso en: 08-09-2015.

${ }^{1274}$ Como bien expuso María Jesús Sánchez Muñoz: "El principio preventivo es el que da carácter al programa y a la evolución de la política ambiental, por lo que para reforzar las anteriores acciones y establecer una política preventiva, la Comunidad propugna la integración de las preocupaciones medio ambientales con el desarrollo económico, favoreciendo así la creación de una estrategia global basada en tres principios: nivel adecuado de actuación, prevención y restauración. Dicha estrategia debe tratar de 
En este periodo, diversos instrumentos programáticos que influenciaron el ulterior desarrollo del derecho internacional ambiental fueron adoptados, entre los que destaca en especial la Carta Mundial de la Naturaleza, aprobada por la Asamblea General de las Naciones Unidas mediante Resolución de 28 de octubre de 1982, en la que se establecieron diversas reglas y principios mundiales para la conservación de la naturaleza con un carácter decididamente ecológico, superador de la visión antropocéntrica y centrada en ventajas para el hombre de los instrumentos anteriores, pues se enfatiza la protección de la naturaleza como un fin en sí mismo. Se trata de un instrumento de carácter vinculante y sus declaraciones son muy generales, sin embargo, sus principios de ética ambiental pueden verse reflejados en la actualidad en muchos $\operatorname{tratados}^{1275}$.

Delante de todo eso, se puede afirmar que el derecho ambiental fue lentamente revelándose, desde el inicio, cuando el único interés estaba volcado al uso de los recursos naturales visando el crecimiento económico, hasta que en razón de sus drásticas consecuencias, ha impuesto una mayor preocupación y valoración garantizando así ese derecho que comprende a todo lo que existe. De este modo, cada vez que surgían los problemas, nuevos instrumentos aparecían con la finalidad de acudir a las necesidades.

De esa manera, lo que se observa es que a finales de la década de 50, cuando las Comunidades Europeas fueron creadas, no fueron atribuidas a ellas cualesquier competencias en materia ambiental. Sin embargo, esto no impidió que, menos de dos décadas después, la Comunidad Económica Europea adoptase algunas directivas de protección ambiental, cuyo objetivo no era apenas la realización del mercado común, sino directamente la protección del ambiente ${ }^{1276}$. Motivo suficiente para llevar varios

conseguir un desarrollo económico duradero que tenga en cuenta la interdependencia entre el desarrollo, el medio ambiente, la población y los recursos o lo que es lo mismo, el posteriormente denominado desarrollo sostenible". Treinta años de actuación en materia medio ambiental en la Unión Europea, Disponible en: <http://ccoo.webs.upv.es/files/Medio-Ambiente/2006/Politica-de-Medio-ambiente-enEuropa-en-30-anos.pdf $>$. Acceso en: 08-09-2015.

${ }^{1275}$ LOZANO CUTANDA, Blanca. Derecho ambiental cit., pp. 68-69.

${ }^{1276}$ Primero fue la Directiva n. ${ }^{\text {7 } 75 / 439}$, relativa a los aceites usados, después la Directiva n. ${ }^{\text { }} 75 / 442$, relativa a los residuos. A esas dos, varias otras siguieron, entre ellas, relativa a las aguas continentales, las aguas costeras y las aguas subterráneas. Además, fueron publicadas Directivas para el Control de Vertidos de Sustancias Peligrosas, de Parámetros de Calidad de las Aguas, de Tratamiento de las Aguas 
Estados Miembros a cuestionar judicialmente la validad de tales disposiciones, pretendidamente incompatibles con los Tratados ${ }^{1277}$.

Oportunidad esta, de oro, que permitió a las Comunidades contornar hábilmente los argumentos nacionales y fundamentar jurídicamente la competencia comunitaria en materia ambiental, consagrando de este modo, definitivamente, el alargamiento de sus competencias ${ }^{1278}$.

Así, delante de la propia naturaleza transnacional de los componentes ambientales y de los fenómenos de contaminación fue percibida una Política Comunitaria del Ambiente, vez que el ambiente no conoce fronteras ${ }^{1279}$, y de ahí, cualquier iniciativa meramente estatal de protección ambiental estaría, necesariamente, condenada al fracaso. La armonización de las normas sobre la calidad del medio receptor es el primer paso para una protección ambiental eficaz e integrada ${ }^{1280}$.

Residuales Urbanas, de Contaminación Difusa por Nitratos Agrícolas y la Evaluación del Impacto Ambiental en general, aplicable a las Obras Hidráulicas.

${ }^{1277}$ Como por ejemplo el proceso ${ }^{\circ}{ }^{\circ} \mathrm{C}-240 / 83$, un reenvío perjudicial de un Tribunal francés relativo a la validad de la Directiva n. ${ }^{\circ}$ 75/439. GOMES CANOTILHO, José Joaquim; MORATO LEITE, José Rubens (Organizadores), Direito Constitucional Ambiental cit., p. 13.

${ }^{1278}$ GOMES CANOTILHO, José Joaquim; MORATO LEITE, José Rubens (Organizadores), Direito Constitucional Ambiental cit., p. 13.

${ }^{1279}$ En las palabras de Nicolas MOUSSIS, "neste mosaico de Estados que se chama Europa, o mercado comum da poluição, formara-se mais cedo do que o mercado comum das mercadorias...O ar e as águas poluídas circulavam livremente através das fronteiras, muito antes de se pensar em as abrir aos cidadãos e às mercadorias estrangeiras". As políticas da Comunidade Europeia. Apud José Joaquim Gomes Canotilho y José Rubens Morato Leite (Organizadores), Direito Constitucional Ambiental cit., , p. 14.

${ }^{1280}$ Según José Joaquim Gomes Canotilho y José Rubens Morato Leite (Organizadores), Direito Constitucional Ambiental cit., p. 14, "Um bom exemplo deste tipo de abordagem normativa é a proteção comunitária das águas superficiais, cuja eficácia depende absolutamente de normas uniformes de proteção do domínio hídrico". 


\subsubsection{La afirmación del medio ambiente con el Acta Única Europea -}

AUE

\section{El Acta Única Europea ${ }^{1281}$, firmada en 1986 y con entrada en vigor el 1 de julio} de 1987, agregó el medio ambiente a los Tratados constitutivos, mediante la inclusión

${ }^{1281}$ El AUE, fue firmada en Luxemburgo el 17 de febrero de 1986 por nueve Estados miembros y el 28 de febrero del mismo año, en La Haya, firmaron su aprobación Dinamarca, Italia y Grecia, supone la primera modificación de gran alcance del Tratado constitutivo de la Comunidad Económica Europea (CEE). El Acta Única entró en vigor el 1 de julio de 1987, después de los problemas tenidos por Irlanda y solucionados a finales de mayo también por referéndum. Los Estados Miembros que firmaron el AUE fueron Alemania Occidental, Francia, Países Bajos, Luxemburgo, Reino Unido, Bélgica, Irlanda, España y Portugal. Al caer el Muro de Berlín, en 1990 las dos Alemanias se unieron en una. Más informaciones disponibles en: <http://eur-lex.europa.eu/legal-content/ES/TXT/?uri=URISERV\%3Axy0027>. Conforme Dionisio Fernández De Gatta Sánchez, Sistema Jurídico-Administrativo de protección del medio ambiente, Ratio Legis Ediciones, Salamanca-España: 2014, pp. 73-74, “(...) será el Acta Única Europea (1986-1987) el Tratado que consolidará definitivamente la base jurídica de las competencias de la Comunidad Europea en materia ambiental, al modificar el Tratado CEE, e incluir un nuevo Título VII, sobre 'Medio Ambiente' (arts. 130 R a 130 T- Tratado CEE), y cuyo esquema normativo se mantendrá hasta la actualidad. Con una adecuada ordenación sistemática, los nuevos artículos del Tratado CEE establecen los objetivos de la Política Ambiental, sus principios, los elementos o condiciones a tener en cuenta para elaborar las medidas ambientales, las características de la Política, el proceso decisorio en materia ambiental y la relación entre el mercado interior y el medio ambiente”. En este sentido, Fernando Menéndez Mariño, en el Prólogo, in PICON RISQUEZ, Juan (Coord.), Derecho Medioambiental de la Unión Europea, Monografía Ciencias Jurídicas, Editora McGraw-Hill, Madrid-España: 1996, afirma que desde su modificación por el art. 25 del AUE, el Tratado de Roma pasó a incorporar un nuevo título (Título VII), dedicado específica y exclusivamente al medio ambiente: "Si bien cuando aquél se adoptó ya estaba en vigor una apreciable serie de normas comunitarias medioambientales establecidas esencialmente sobre la base de los artículos 100 y 235 TCEE y dentro del marco de los sucesivos «Programas» comunitarios, lo cierto es que fue en el Acta Única donde se definió y estableció legislativamente el objetivo de una política medioambiental autónoma, los principios en que ella debería basarse y él régimen de distribución de competencias, así como el del procedimiento para adoptar decisiones en la materia". Importante análisis sobre la situación de España es hecha por Luis Franco Sala, La politica medioambiental comunitaria: planteamientos, instrumentos y resultados. Afers Internacionals, n. ${ }^{\circ}$ 34-35: 67-78, p. 70: “España, junto con Portugal, se integra en las Comunidades Europeas por el Tratado de Adhesión del 12 de junio de 1985 (B.O.E., 1, del 1 de enero de 1986). La integración implica en esta materia, al igual que en las demás, la recepción del acervo comunitario (Antes de producirse la adhesión de España a las Comunidades ya se habían tenido en cuenta a la hora de elaborar normas relacionadas con el medio ambiente diversas directivas comunitarias. Un ejemplo de ello 
del Título VII, o sea, un Título específico que traía la expresión 'Medio Ambiente', en el que aparecían los objetivos, principios y las condiciones de actuación de la Comunidad en esta materia, así como su competencia para celebrar acuerdos internacionales sobre la misma.

Sin embargo, vale resaltar, que antes mismo de la celebración del Acta Única Europea, es cierto que la comunidad europea ya adoptaba medidas de protección ambiental, no obstante estas tenían poco o ningún efecto sobre el mercado común ${ }^{1282}$.

En la esfera nacional, surgieron y fueron puestas al más alto nivel, las varias dudas respecto a la constitucionalidad de tales actos jurídicos comunitarios, lo que permitió al Tribunal Europeo defender que el verdadero fundamento para la adopción de estas medidas fue verdaderamente la protección del medio ambiente que, debía ser considerado como un objetivo esencial de la Comunidad Europea. Esta sorprendente conclusión era resultado de la interpretación de la afirmación contenida en el preámbulo del Tratado sobre la mejoría de las condiciones de vida y de trabajo de las personas ${ }^{1283}$.

lo constituye la Ley de Aguas de 1985). Al no haber formulado España, en materia de medio ambiente, cláusulas de salvaguarda o de derecho transitorio, a diferencia de Portugal (Anexo XXXVI.III del Acta de Adhesión), la entrada en vigor en el territorio español de las directivas con plazos de adaptación vencidos y los reglamentos debía de efectuarse el 1 de enero o el 1 de marzo de 1986 (según los casos conforme al artículo 2 del Acta de Adhesión en relación con los artículos 392 a 399 del mismo cuerpo legal). Ello obligaba a una rápida transposición de las directivas comunitarias al derecho interno español (Compromiso recogido, por otro lado, en el artículo 395 del Acta de Adhesión). Dado el poco espacio de tiempo existente y el gran volumen de actos comunitarios, se siguió la técnica de la delegación legislativa para efectuar una primera gran transposición en bloque al derecho interno, aprobándose a tal efecto la Ley 47/1985, del 27 de diciembre, de Bases de Delegación al Gobierno para la aplicación del Derecho de las Comunidades Europeas (B.O.E.,312, del 30 de Diciembre de 1985). Desde ese momento inicial han surgido numerosos actos comunitarios relativos al medio ambiente o se han modificado los existentes, debido tanto al dina- mismo de esta materia (las directivas aprobadas sufren continuas modificaciones para adecuarse a los avances científicos y técnicos, así como a las circunstancias de cada momento) como a una expansión de la materia regulada (cada vez se abarcan más sustancias concretas y nuevos aspectos). Ello obliga a realizar una adaptación continua del ordenamiento español”.

${ }^{1282}$ Por ejemplo la Directiva n. ${ }^{\circ}$ 79/409 relativa a la protección de las aves salvajes y de sus hábitats.

${ }^{1283}$ Respecto al tema, José Joaquim Gomes Canotilho y José Rubens Morato Leite (Organizadores), Direito Constitucional Ambiental cit., , p. 18, enseñan que: "Foi no processo de reenvio prejudicial n. 240/83 que o Tribunal de Justiça declarou expressamente que a proteção do ambiente contra o perigo da poluição era um dos objetivos essenciais da Comunidade. Este processo de reenvio prejudicial foi formulado por um Tribunal francês a propósito da Diretiva n. 75/439, relativa aos óleos usados, na qual, 
Conforme Blanca Lozano Cutanda, citando H. Somsen: “(...) este Título dedicado al medioambiente que incorporó el Acta Única Europea constituye más una codificación de la práctica comunitaria anterior a 1987 que una nueva orientación en cuanto a la relación entre la acción de la Comunidad y de los objetivos ambientales, como lo muestra la coincidencia entre los objetivos y principios contenidos en este nuevo Título y los incluidos en los tres Programas de Acción en materia de medioambiente aprobados hasta entonces" $" 1284$.

El Acta Única Europea pretendía superar el objetivo de Mercado Común ${ }^{1285}$ para alcanzar el objetivo de Mercado Interior ${ }^{1286}$ que implicaría un espacio sin fronteras

em homenagem ao princípio da prevenção dos danos ao ambiente, se estabelecia o dever de os Estados Membros tomarem as medidas necessárias para garantir a recolha e tratamento de óleos usados por regeneração, com preferência absoluta sobre a combustão. Este regime levou a Associação de Defesa dos Incineradores de Óleos Usados a questionar a validade da Diretiva comunitária, que considerava violadora dos Tratados, não só pelo desrespeito dos princípios da liberdade de circulação de mercadorias (os óleos usados) e da liberdade de concorrência, como sobretudo pela falta de atribuições da Comunidade Europeia para legislar em matéria de ambiente. Neste processo de reenvio prejudicial iniciado pelo Tribunal de Grand Instance de Créteil, o Tribunal de Justiça das Comunidades afirmou que 'o princípio da liberdade de comércio não deve ser visto em termos absolutos mas está sujeito a certos limites justificados pelo objetivo de interesse geral prosseguido pela Comunidade, desde que os direitos em questão não sejam substancialmente afetados. (...) Não há razão para concluir que a diretiva tenha excedido esses limites. (...) A diretiva deve ser vista na perspectiva da proteção do ambiente, que é um dos objetivos essenciais da Comunidade'. Despois deste julgamento, esta afirmação, relativa à proteção do ambiente como objeto essencial das Comunidades, foi frequentemente repetida pelo Tribunal de Justiça noutros processos, mesmo após o Ato Único Europeu".

${ }^{1284}$ SOMSEN, H.. Derecho comunitario del medio ambiente: tratado, instituciones, procedimiento de decisión e instrumento jurídico, en la obra colectiva citada Derecho medioambiental de la Unión Europea. Apud LOZANO CUTANDA, Blanca. Derecho ambiental cit., p. 220.

1285 “El mercado común, principal objetivo del Tratado de Roma, fue establecido a través de la unión aduanera de 1968, la eliminación de las cuotas, la libre circulación de ciudadanos y trabajadores, y cierta armonización fiscal mediante la introducción generalizada del IVA en 1970. No obstante, el libre comercio de mercancías y servicios y la libertad de establecimiento seguían estando limitados debido a la persistencia de prácticas anticompetitivas impuestas por las autoridades públicas". Disponible en: < http://www.europarl.europa.eu/ftu/pdf/es/FTU_3.1.1.pdf>. Acceso en: 12-09-2015.

${ }^{1286}$ Respecto a la instauración del mercado interior en los años ochenta y el Acta Única Europea se puede afirmar que: "La falta de avances en la consecución del mercado común se atribuyó en gran medida a la elección de un método de armonización legislativa demasiado minucioso y a la imposición de la regla de la unanimidad en la toma de decisiones del Consejo. Según el informe Cecchini, denominado «El coste 
interiores, en el que la libre circulación ${ }^{1287}$ de mercancías, personas, servicios y capitales estaría garantizada.

Los principales puntos del Acta fueron el establecimiento de las condiciones jurídicas para la creación de un mercado único, que hizo realidad el 1 de enero de 1993; la aparición de un capítulo dedicado a la cohesión económica y social; el fortalecimiento del sistema de cooperación política europea, en los campos de investigación, la tecnología y el medio ambiente; se menciona por primera vez en un documento de derecho primario la Cooperación Política Europea en materia de política exterior y de seguridad y defensa; mejora de las estructuras de decisión de la Comunidad Europea, con el fortalecimiento de los derechos del Parlamento Europeo; establecimiento del Tribunal de Justicia de Primera Instancia de la Unión Europea para que asista al Tribunal de Justicia de la Unión Europea en su trabajo.

En este momento, por medio del Tratado Constitutivo de la CE a través del Acta Única Europea ${ }^{1288}$ fue introducido el principio de subsidiariedad ${ }^{1289}$, que

de la no Europa», que se presentó en marzo de 1988, este estancamiento resultó extremadamente caro para la economía, con un coste aproximado de entre el 4,25 \% y el 6,5\% del PIB. A mediados de los años ochenta, el debate político sobre esta cuestión llevó a la CEE a considerar un enfoque más riguroso en relación con el objetivo de la supresión de las barreras comerciales: el mercado interior. El Acta Única Europea, que entró en vigor el 1 de julio de 1987, fijó un plazo concreto para la realización del mercado interior, a saber, el 31 de diciembre de 1992. Asimismo, reforzó los mecanismos decisorios en el marco del mercado interior, introduciendo la votación por mayoría cualificada en ámbitos como el arancel aduanero común, la libre prestación de servicios, la libre circulación de capitales y la aproximación de las legislaciones nacionales. Cuando se cumplió el plazo previsto, más del $90 \%$ de los actos legislativos enumerados en el Libro Blanco de 1985 ya habían sido aprobados, principalmente por mayoría cualificada". Parlamento Europeo: Fichas técnicas sobre la Unión Europea. Disponible en: $<$ http://www.europarl.europa.eu/ftu/pdf/es/FTU_3.1.1.pdf $>$. Acceso en: 12-09-2015.

${ }^{1287}$ El objetivo de libre circulación ya estaba recogido en los Tratados iniciales, pero ante el escaso éxito alcanzado, salvo en la circulación de mercancías, el Acta Única Europea se propuso lograr el objetivo en un plazo fijo: 31 de diciembre de 1992. Este Tratado sembró las bases de una política económica y monetaria que llevaría a la creación de una moneda única.

${ }^{1288}$ Acta Única Europea, DO, L n. ${ }^{\circ}$ 169/1 de 29-06-1987. "El Acta aplica una política comunitaria de cohesión económica y social para contrarrestar los efectos sobre los Estados miembros con menor nivel de desarrollo de la realización del mercado interior y para reducir las divergencias de desarrollo entre las regiones. La intervención comunitaria se realiza a través del Fondo Europeo de Orientación y de Garantía Agrícola (FEOGA) y del Fondo Europeo de Desarrollo Regional (FEDER). Respecto a la investigación y al desarrollo técnico, el artículo 130F del Tratado CEE tiene como objetivo «fortalecer las bases 
científicas y tecnológicas de su industria y favorecer el desarrollo de su competitividad internacional». Para ello, el Acta prevé la aplicación de programas marco plurianuales adoptados por el Consejo por unanimidad. La preocupación relativa a la protección del medio ambiente a escala comunitaria ya estaba presente en el Tratado de Roma. Hay tres nuevos artículos (artículos 130R, 130S y 130T del Tratado CEE) que permiten a la Comunidad «la conservación, la protección y la mejora de la calidad del medio ambiente, la protección de la salud de las personas y la utilización prudente y racional de los recursos naturales». Se precisa que la Comunidad únicamente intervendrá en materia de medio ambiente cuando esta acción pueda realizarse mejor a escala comunitaria que en los Estados miembros (subsidiariedad). El artículo 30 prevé que los Estados miembros se esfuercen en formular y aplicar una Política Exterior Común Europea. Para ello, se comprometen a consultarse sobre las cuestiones de Política Exterior que pudieran tener un interés para la seguridad de los Estados miembros. La Presidencia del Consejo es responsable en este ámbito de la iniciativa, la coordinación y la representación de los Estados miembros frente a países terceros". Disponible en: $<$ http://eur-lex.europa.eu/legalcontent/ES/TXT/?uri=URISERV\%3Axy0027>. Acceso en: 14-09-2015.

${ }^{1289}$ Respecto al Principio de Subsidiariedad: "El Parlamento Europeo fue el precursor del concepto de subsidiariedad al proponer, el 14 de febrero de 1984, con ocasión de la aprobación del proyecto de Tratado de la Unión Europea, la inclusión de una disposición que preveía que, cuando el Tratado otorgara a la Unión una competencia compartida con los Estados miembros, la acción de los Estados miembros podría ejercerse allí donde la Unión no hubiera legislado. Además, en la propuesta se destacaba que la Unión solo debería intervenir para desempeñar las misiones que pudieran realizarse en común de manera más eficaz que si los Estados actuaran por separado. El Parlamento Europeo reiteró estas propuestas en numerosas resoluciones (entre otras, las de 23 de noviembre de 1989, de 14 de diciembre de 1989, de 12 de julio de 1990, de 21 de noviembre de 1990 y de 18 de mayo de 1995), en las que recordó su adhesión al principio de subsidiariedad". Además, Sobre la definición de ese principio, afirma que: "El principio de subsidiariedad tiene como función general garantizar un cierto grado de independencia a una autoridad inferior respecto de una instancia superior, en particular un poder local respecto de un poder central. Se refiere, por consiguiente, al reparto de las competencias entre los diferentes niveles de poder, principio que constituye la base institucional de los Estados federales. Aplicado en el marco de la Unión Europea, el principio de subsidiariedad sirve de criterio regulador del ejercicio de las competencias no exclusivas de la Unión. Excluye la intervención de la Unión en aquellos casos en que los Estados miembros estén en condiciones de regular una materia de forma eficaz a escala nacional, regional o local y legitima la intervención de la Unión cuando los Estados miembros no puedan alcanzar de manera suficiente los objetivos de una acción pretendida y cuando la acción a escala de la Unión pueda aportar un valor añadido". Parlamento Europeo: Fichas Técnicas sobre la Unión Europea. Subsidiariedad, consultado en el sitio de la Unión Europea: <http://www.europarl.europa.eu/ftu/pdf/es/FTU_1.2.2.pdf>. Acceso en: 14-092015. 
estableció una importante restricción de competencia comunitaria en materias ambientales $^{1290}$. Presentó también, tres nuevos artículo $\left(130 \mathrm{R}^{1291}, 130 \mathrm{~S}^{1292}\right.$ y $\left.130 \mathrm{~T}^{1293}\right)$

${ }^{1290}$ FERNÁNDEZ DE GATTA SÁNCHEZ, Dionisio. La incidencia del Acta Única Europea en la política ambiental de la Comunidad Europea, en Actualidad y perspectiva del Derecho Público a finales del siglo XX: homenaje al profesor Garrido Falla, Universidad Complutense de Madrid, Madrid-España: 1992, pp. 1921-1948.

${ }^{1291}$ Artículo $130 \mathrm{R}$.

"1. La acción de la comunidad, por lo que respecta al medio ambiente, tendrá por objeto:

Conservar, proteger y mejorar la calidad del medio ambiente.

Contribuir a la protección de la salud de las personas.

Garantizar una utilización prudente y racional de los recursos naturales.

2. La acción de la comunidad, en lo que respecta al medio ambiente, se basara en los principios de acción preventiva, de corrección, preferentemente en la fuente misma, de los ataques al medio ambiente y de quien contamina paga. Las exigencias de la protección del medio ambiente serán un componente de las demás políticas de la comunidad.

3. En la elaboración de su acción en relación con el medio ambiente, la comunidad tendrá en cuenta:

Los datos científicos y técnicos disponibles.

Las condiciones del medio ambiente en las diversas regiones de la comunidad.

Las ventajas y las cargas que puedan resultar de la acción o de la falta de acción.

El desarrollo económico y social de la comunidad en su conjunto y el desarrollo equilibrado de sus regiones.

4. La comunidad actuara, en los asuntos de medio ambiente, en la medida en que los objetivos contemplados en el apartado 1 puedan conseguirse en mejores condiciones en el plano comunitario que en el de los estados miembros considerados aisladamente. Sin perjuicio de determinadas medidas de carácter comunitario, los estados miembros asumirán la financiación y la ejecución de las demás medidas.

5. En el marco de sus respectivas competencias, la comunidad y los estados miembros cooperaran con los terceros países y las organizaciones internacionales competentes. Las modalidades de la cooperación de la comunidad podrán ser objeto de acuerdos entre esta y las terceras partes interesadas, que serán negociados y concluidos con arreglo al articulo 228.

El párrafo precedente se entenderá sin perjuicio de la competencia de los estados miembros para negociar en las instituciones internacionales y para concluir acuerdos internacionales". Importante resaltar que la redacción del Acta única Europea fue basada en los principios ambientales que procedían del Primer Programa de Acción Ambiental. Principios estos que aunque generales, han proporcionado una mayor amplitud para generar otros principios en los Programas de Acción Ambiental y demás normativas. Disponible en: <https://www.boe.es/diario_boe/txt.php?id=BOE-A-1987-15279>. Acceso en: 14-092015.

${ }^{1292}$ Artículo 130 S. "El consejo, por unanimidad, a propuesta de la comisión y previa consulta al Parlamento Europeo y al Comité Económico y Social, decidirá la acción que la Comunidad deba 
que permiten a la Comunidad la conservación, la protección y la mejora de la calidad del medio ambiente, la protección de la salud de las personas y la utilización prudente y racional de los recursos naturales.

Así, la política del medio ambiente estaba orientada por tres objetivos: mantenimiento y mejoría del medio ambiente, protección de la salud y utilización racional de los recursos naturales.

Según Blanca Lozano Cutanda: "Las medidas para llevar a cabo los objetivos de la política ambiental debían ser adoptadas (conforme disponía el art. $130 \mathrm{~S}$ ), por unanimidad del Consejo y previo dictamen consultivo del Parlamento Europeo, pero se introdujo, además, un nuevo art. $100 \mathrm{~A}$ en el que se reconoció expresamente la competencia de la Comunidad para adoptar, por mayoría cualificada del Consejo y con la cooperación del Parlamento (procedimiento regulado entonces en el art. 149 Tratado $\mathrm{CEE}$ ), medidas relativas a la aproximación de disposiciones legales, reglamentarias y administrativas de los Estados miembros que tuviesen por objeto el establecimiento y mantenimiento del mercado interior en materias como, entre otras, el medioambiente" $" 1294$.

Además, afirma la autora que: "Este precepto incrementó notablemente las posibilidades de adopción por la Comunidad de medidas más rigurosas para la protección del medioambiente, tanto por la introducción de la regla de la mayoría para la adopción de los acuerdos como por la mayor intervención que se confiere al Parlamento Europeo en el proceso decisorio, dado que este órgano, en el que están representa dos diversos partidos 'verdes', presiona constantemente a las demás instituciones comunitarias para que se adopten estándares ambientales más rigurosos. Debe destacarse además que en el propio art. 100 A se precisó que las propuestas que la Comisión presentase para la armonización de legislaciones nacionales en el ámbito,

emprender.

El Consejo determinará, en las condiciones previstas en el párrafo precedente, las cuestiones que deben regirse por decisiones que habrá que tomar por mayoría cualificada". Disponible en: $<$ https://www.boe.es/diario_boe/txt.php?id=BOE-A-1987-15279>. Acceso en: 14-09-2015.

${ }^{1293}$ Artículo 130 T. "Las medidas de protección adoptadas conjuntamente en virtud del articulo $130 \mathrm{~S}$ no serán obstáculo para el mantenimiento y adopción, por parte de cada estado miembro, de medidas de mayor protección compatibles con el presente tratado". Disponible en: $<$ https://www.boe.es/diario_boe/txt.php?id=BOE-A-1987-15279>. Acceso en: 14-09-2015.

${ }^{1294}$ LOZANO CUTANDA, Blanca. Derecho ambiental cit., p. 221. 
entre otros, del medioambiente, habían de basarse en 'un nivel de protección elevado" "1295.

Pasado el tiempo, casi simultáneamente con la introducción del Acta Única Europea, a través de la Resolución del Consejo de las Comunidades Europeas y de los representantes de los Gobiernos de los Estados miembros reunidos en el seno del Consejo de 19 de octubre de 1987, relativa a la continuación y aplicación de una política y de un programa de acción de las Comunidades Europeas en materia de medio ambiente, se adopta el Cuarto Programa de Acción Ambiental para el período de 1987 a $1992^{1296}$ indica claramente que la evolución en el pensamiento sobre el medio ambiente sigue. Ya no habiéndose más duda de que la política de protección cumple una función primordial en el conjunto de las políticas comunitarias y que ésta debe considerarse un factor fundamental en la toma de decisiones económicas. Además, dentro de estas orientaciones de política general, se entiende que la protección del medio ambiente mejora la calidad de vida y resguarda los recursos naturales, pudiendo utilizarse para la consecución de estos objetivos diversas medidas y procedimientos como la regulación legal relativa a productos, procesos, emisiones y desechos, así como la aplicación de diversos instrumentos económicos tales impuestos, cargas, cánones, ayudas estatales, permiso de vertidos, etc. Por último se reitera que la educación en medio ambiente es fundamental para sensibilizar al público; de ahí que el año 1987 es proclamado por el Consejo Europeo como el año europeo del medio ambiente ${ }^{1297}$.

\footnotetext{
${ }^{1295}$ LOZANO CUTANDA, Blanca. Derecho ambiental cit., p. 221.

${ }^{1296}$ DOC C 328/1 de 07-12-1987.
}

${ }^{1297}$ SÁNCHEZ MUÑOZ, María Jesús. Treinta años de actuación en materia medio ambiental en la Unión Europea, Disponible en: <http://ccoo.webs.upv.es/files/Medio-Ambiente/2006/Politica-de-Medioambiente-en-Europa-en-30-anos.pdf>. Acceso en: 08-09-2015. Los "Años Europeos" son organizados por el Parlamento Europeo y el Consejo de la Unión Europea, a propuesta de la Comisión Europea. El concepto consiste en dedicar todo un año a un tema de importancia para la UE, llamando la atención de los gobiernos nacionales sobre esta cuestión. Además, “En 1987, el 'Año Europeo del Medio Ambiente (European Year of the Environment), la Fundación para la Educación Ambiental en Europa (FEEE) presentó el concepto francés de la Comisión Europea, y el Programa Bandera Azul (Blue Flag) fue lanzado como una de las acciones del año por la comunidad. Además del tratamiento de aguas residuales y calidad de las aguas balnearias, los criterios para la obtención de una bandera azul a nivel europeo incluyen otras áreas de gestión ambiental, tales como la gestión de residuos y la planificación costera y de protección. En 1987, la Bandera Azul fue atribuida a 244 playas y 208 puertos en diez países europeos. En 2001 la FEE se ha convertido en una organización global y cambió su nombre de FEEE a 
En el plano internacional, según Dionisio Fernández de Gatta Sánchez: "Las catástrofes ambientales producidas en el ámbito de la Unión Europea (Seveso, Amoco, Cádiz, Sandoz, etc.) y la consolidación de su Política Ambiental, principalmente, a partir del Acta Única Europea, de 1986-1987, obligaron a plantearse, a nivel comunitario, la regulación de un sistema de responsabilidad civil por daños ecológicos. En efecto, desde el Acta Única Europea, se incluyeron, como principios de la Política

FEE (Foundation for Environmental Education). Desde entonces, muchas organizaciones y autoridades fuera de Europa que deseen colaborar en la difusión del Programa Bandera Azul a hecho solicitudes a FEE. Con la expansión del programa, los criterios se tornaran más estrictos y se unificaron. A partir de 2006 un conjunto internacional de criterios está siendo usado con algunas variaciones con el fin de reflejar las condiciones ambientales específicas de determinadas regiones". Durante el año, se programan acciones a escala europea y nacional que contribuyan a su promoción y ayuden a los ciudadanos europeos a conocerlo y tomar conciencia de lo que aún queda por hacer. Disponible en: http://www.marinacostabella.com.br/blue-flag.php. Acceso en: 14-09-2015. "Bandera Azul es un galardón anual y un sistema de certificación de la calidad ambiental desarrollado por la FEE desde 1987. Promueve y premia la participación en iniciativas ambientales voluntarias de las autoridades municipales, la población local y visitante y los agentes del sector del turismo. Los criterios para obtener la Bandera Azul se agrupan en cuatro áreas: Calidad de las aguas de baño, Información y educación ambiental, Gestión ambiental y Seguridad, servicios e instalaciones. La Bandera Azul es concedida por un Jurado Internacional, presidido por la FEE y participación, entre otros, de las Agencias de N.N.U.U. para el Medioambiente y el Turismo, entre las candidaturas seleccionadas por los Jurados Nacionales. En el Jurado para España, presidido por ADEAC, participan las CCAA litorales, la FEMP y los Ministerios, Fundaciones y Universidades implicadas. En España, los casi 250 municipios y más de 100 puertos deportivos participantes, presentan anualmente unas 800 candidaturas a Bandera Azul, que representan más del 85\% de la población litoral local y visitante. En 2015, España mantuvo su liderazgo con 678 Banderas Azules de playas y de puertos, lo que equivale a una de cada seis de las concedidas en el mundo. Bandera Azul constituye ya un símbolo, reconocido y valorado por decenas de millones de usuarios de playas y puertos, y un estándar mundial de ecocalidad turística, promovido por la OMT (Organización Mundial del Turismo) y el PNUMA (Programa de Naciones Unidas para el Medio Ambiente). Su éxito global se debe a que responde a una "necesidad" social universal, sentida y atendida por la FEE, desde hace más de 25 años con criterios obligatorios comunes consensuados y renovados periódicamente. Bandera Azul constituye la iniciativa voluntaria en favor de la sostenibilidad, estímulo y certificación de la calidad, en el sector del turismo con mayor: antigüedad y continuidad, desde 1984; cooperación y apoyos institucionales del PNUMA-UNEP, OMT, UICN, gobiernos, fundaciones, etc.; extensión e implantación geográfica en 46 estados de cinco continentes; y, rapidez en su extensión y potencial actual de crecimiento". Disponible en: http://www.adeac.es/bandera_azul. Acceso en: 16-092015. 
Ambiental Comunitaria, el principio preventivo y el principio 'quien contamina, paga'. En la actualidad, el art. 174 del Tratado de la Comunidad Europea (según redacción del Tratado de la Unión Europea, de 1992-1993, modificado por el Tratado de Ámsterdam, de 1997-1999, y teniendo en cuenta el Tratado de Niza, de 2001-2003) incluye como principios de ésa Política los de cautela y acción preventiva y el de 'quien contamina, paga'. La futura Constitución de la Unión Europea también los recoge en su texto. Pues bien, tales principios se relacionan estrechamente con el principio fundamental y universal del Derecho Civil europeo, según el cual toda persona que produce un daño debe repararlo. Además, la Comunidad Europea tuvo en cuenta los posibles perjuicios derivados de la existencia de varios regímenes de responsabilidad según los sistemas normativos de los Estados Miembros, en particular a la seguridad jurídica y porque causaba discriminaciones a la libre competencia; así como los compromisos adquiridos a nivel internacional (respecto a la seguridad marítima, principalmente) y en el Cuarto (1987-1992) y Quinto (1993-2000) Programas Ambientales de la Comunidad"1298.

Y fue en el Cuarto Programa que se consolidó el principio de 'quien contamina paga', que vino a servir de guía para la política ambiental europea.

En mayo de 1997, la Comisión aprobó la primera Comunicación ${ }^{1299}$ titulada "Hacia una política urbana para la Unión Europea", en la que visaba examinar las políticas de la UE desde el punto de vista de su repercusión en las ciudades, y de aumentar la integración de las políticas a nivel urbano. El Marco de actuación de la UE para el desarrollo urbano sostenible va dirigido a coordinar y orientar mejor la intervención comunitaria en los problemas urbanos y se organiza en torno a cuatro objetivos de actuación independientes: acrecentar la prosperidad económica y el empleo en las pequeñas y grandes ciudades; fomentar la igualdad, la integración social y la regeneración en las zonas urbanas; proteger y mejorar el medio ambiente urbano: hacia una sostenibilidad local y mundial; y, por último, contribuir a un buen gobierno urbano

${ }^{1298}$ FERNÁNDEZ DE GATTA SÁNCHEZ, Dionisio. Derecho ambiental: aspectos generales sobre la protección jurídica del medio ambiente. Este trabajo constituye el texto de la conferencia actualizada impartida en el Seminario sobre "El Derecho y la Cooperación Ibérica", organizado por el Centro de Estudios Ibéricos en la ciudad de Guarda (Portugal) el 16 de Abril de 2004.

${ }^{1299}$ COM (1997) 0197 final. 
y a la participación ciudadana ${ }^{1300}$. En esta Comunicación, además de otros sectores, aparece la preocupación sobre el tratamiento de las aguas residuales urbanas, una vez que es uno de los mayores problemas y fuentes de contaminación puntuales ${ }^{1301}$.

En octubre de 1998, es aprobada la segunda Comunicación ${ }^{1302}$, titulada "Marco de Actuación para el desarrollo urbano sostenible en la Unión Europea”, donde entre los objetivos anejos sobre el agua aparecen la fiabilidad y calidad de los suministros de agua potable, la gestión de las aguas superficiales y subterráneas, y para alcanzarlos, se entiende necesaria la mejor aplicación y expedición de una nueva legislación, reforzar el control de la contaminación.

${ }^{1300}$ En el Dictamen del Comité de las Regiones - Hacia una política urbana integrada para la Unión Europea, consultado en el sitio de la Unión Europea, Parlamento Europeo, disponible en: < http://www.europarl.europa.eu/meetdocs/2014_2019/documents/regi/dv/cor-2013-06902_/cor-2013-

06902_es.pdf>. Acceso en: 20-09-2015. Afirma que: "Ya en 1997, la Comisión publicó una Comunicación sobre una agenda urbana para la UE pero, pese toda una serie de declaraciones y actividades, este programa sigue sin materializarse casi dos decenios después. La UE debe garantizar que las ciudades y las regiones urbanas pueden demostrar plenamente sus capacidades y su potencial, como motores del crecimiento económico, el empleo y la inclusión social. Con la Carta de Leipzig se sienta una buena base para ello. Esta agenda deberá integrar la totalidad de los enfoques del desarrollo urbano sostenible, a saber el social, el económico y el medioambiental".

${ }^{1301}$ Conforme Carlos Javier Velásquez Muñoz, La protección del medio ambiente urbano en la Unión Europea, Revista de Derecho, Barranquilla, Universidad del Norte, n. ${ }^{\circ}$ 24: 156-186, 2005, pp.165-166, "Para 1990, año de la promulgación del Libro verde de la Comisión sobre el medio ambiente urbano, las preocupaciones con respecto a la contaminación de las aguas se centraban, grosso modo, en tres aspectos: por un lado, la contaminación producida por los vertidos producidos por el proceso de expansión demográfica y desarrollo industrial; segundo lugar, la utilización de redes de alcantarillado diseñadas y construidas a fines del siglo XIX, que dañaban la calidad de las aguas, y como tercer y último punto, la poca atención prestada a la calidad de las aguas como lugar de recreo. Quince años después, la mayoría de todas estas preocupaciones parecen haber sido superadas, y sólo unos pocos ciudadanos europeos sufren la devastadora escasez y mala calidad del agua que experimentan millones de habitantes en muchas otras partes del mundo. Las redes de alcantarillado han sido renovadas casi en su totalidad, y las aguas como lugar de recreo tienen ahora inusitada importancia, contando incluso con herramientas de derecho que propugnan por su protección y calidad (respecto a la calidad han sido expedidas y actualizadas la Directiva 76/160/CEE del Consejo, de 8 de diciembre de 1975, relativa a la calidad de las aguas de baño, la Directiva 80/778/CEE del Consejo, de 15 de julio de 1980, relativa a la calidad de las aguas destinadas al consumo humano ,y la Directiva 91/271/CEE del Consejo, de 21 de mayo de 1991, sobre el tratamiento de las aguas residuales urbanas)".

${ }^{1302}$ COM (1998) 605 final. 
En febrero de 2004, la tercera Comunicación ${ }^{1303}$ titulada "Hacia una estrategia temática sobre el medio ambiente urbano" es aprobada. Entre los temas tratados está la gestión urbana sostenible del agua, el tratamiento correcto de las aguas residuales urbanas, la eficiencia del consumo de agua y el aprovechamiento del agua de lluvia y del agua subterránea ${ }^{1304}$.

En enero de 2006, fue desarrollada la Estrategia Temática para el Medio Ambiente Urbano, con la finalidad de contribuir a una mejor aplicación de la política y legislación ambiental de la Unión Europea a nivel local, prestando apoyo y animando a las autoridades locales a adoptar enfoques integrados de gestión urbana sostenible ${ }^{1305}$.

La competencia de la Unión Europea es limitada en relación con los aspectos concernientes a las aglomeraciones urbanas. La UE entiende que instaurar la sostenibilidad en el espacio urbano es tarea fundamental de las autoridades locales, de las cuales reclama el compromiso y voluntad necesarios para adelantar este proceso de la mano de los ciudadanos y demás actores presentes en las ciudades ${ }^{1306}$.

En si considerando el crecimiento y actual situación de Europa, el tema urbano es uno de los que más preocupa la Unión Europea ${ }^{1307}$ exigiendo nuevas y ambiciosas

${ }^{1303}$ COM (2004) 60 final. Además, vale resaltar que una de las iniciativas para la gestión urbana sostenible fue la implementación del Sistema Comunitario de Gestión y Auditoría Medioambiental EMAS; otra fue a través del Programa 21 local, autoevaluación de las administraciones locales. Más informaciones disponibles en: < http://eur-lex.europa.eu/legal-content/ES/TXT/?uri=URISERV:128022> $\mathrm{y}<\mathrm{http}$ ://eur-lex.europa.eu/legal-content/ES/TXT/?uri=CELEX:52004DC0060>. Ambos con Acceso en: 20-09-2015.

1304 Más informaciones disponibles en: $<$ http://www.upv.es/contenidos/CAMUNISO/info/U0512367.pdf>. Acceso en: 20-09-2015.

${ }^{1305}$ COM (2005) 718 final. Disponible en: < http://ec.europa.eu/transparency/regdoc/rep/1/2005/ES/12005-718-ES-F1-1.Pdf>. Acceso en: 20-09-2015.

${ }^{1306}$ VELÁSQUEZ MUÑOZ, Carlos Javier. La protección del medio ambiente urbano en la Unión Europea, Revista de Derecho, Barranquilla, Universidad del Norte, n. ${ }^{\text {2 } 24: ~ 156-186, ~ 2005, ~ p . ~} 181$.

${ }^{1307}$ Respecto a la migración de los refugiados de Siria, el ministro de la Suprema Corte de Justicia de la Nación, José Ramón Cossío afirma que: "La narración uniforme del fenómeno migración, guerra en Siria y el Estado Islámico, ha permitido acoger a las personas como refugiados. A quienes vienen de un conflicto militar, sujetándolo a los patrones que determinaron regulaciones intra-europeas por las dos guerras mundiales. En la construcción de la universalidad que tanto debe a la mejor Europa, a todos debe darse el mismo trato porque todos son iguales. La construcción fue hecha para un nosotros dotado ya con un sentido previo, determinado por linajes, guerras, historia común y posibilidades civilizatorias del mundo primitivo habitado por los otros. Hoy son esos otros los que llegan y reclaman un trato igualitario 
soluciones que deben ser desarrolladas primeramente a nivel local (vez que las ciudades no tienen infraestructura para acomodar tantos inmigrantes, hay que pensar en una planificación urbana) y enseguida a nivel global, llegando hasta la raíz del problema.

Delante de eso, es de extrema importancia la búsqueda de estrategias para reunir y poner en práctica los principios ambientales para la reconstrucción y construcción de una nueva sociedad, visando una gestión integrada con el medio

basado en la universalidad que le sirve de fundamento. El reto europeo es dramático. Es también magnífico. Se trata de saber si más allá de simplificaciones causales, puede sostenerse el discurso y los símbolos con acciones concretas, cotidianas y reiteradas. Para colonizar se hizo universal y para mantenerse como unidad se generalizó, proclamó y juridificó. Lo que hoy se enfrenta es más complejo: mantener la pretensión diferenciadora entre un nosotros y frente a los otros. Para incorporar a los migrantes, repetida y constantemente, como parte del propio nosotros, hasta borrar las diferencias. El volumen del proceso en marcha genera ya tensiones, cuotas, rechazos y violencias. También acogidas, cercanías, incorporaciones y empatías. En unos y otros se verá lo mejor y lo peor de los europeos. A las cálidas muestras de los últimos días deberán sobrevenir los arribos de quienes no vengan expulsados directamente por el Estado Islámico, cuando los números se multipliquen por los años transcurridos. El resultado final determinará lo que Europa sea, no sólo por lo dicho, sino por lo hecho como conjunto. Actualizar los supuestos de no intervención, unirse contra enemigos comunes, atender causas y no sólo efectos. La paradoja de todo esto es que impulsada por elementos ajenos, Europa será distinta de lo que hoy es y la identifica. Europa también migrará". Reportaje del periódico El País, titulada "Refugiados: la migración de Europa", publicada el: 08-09-2015. Disponible en: $<$ http://internacional.elpais.com/internacional/2015/09/08/actualidad/1441747441_378803.html >. Acceso en: 21-09-2015. Además, otra reportaje del periódico El País, titulada "El naufragio de Europa: la UE debe asumir que la emigración es su principal problema y actuar ya”, publicada el 03-09-2015, afirma que: "Durante todo el verano se ha planteado el debate en términos que enfrentan la seguridad con la solidaridad. Pero hasta la fecha, los principales líderes europeos no parecen haberse dado cuenta de que no se trata de buscar soluciones coyunturales levantando vallas o distribuyendo fondos a los que creen centros de acogida. El problema es mucho mayor y exige soluciones globales, estructurales y que lleguen hasta la raíz. Es el momento de hacer una reflexión profunda sobre el papel que tiene que jugar la UE frente a los millones de personas que buscan la tierra prometida. Lo primero que deben hacer los políticos es reconocer esta dimensión y decir en voz alta que la oleada de emigrantes obliga a soluciones nuevas y ambiciosas. Y no hay remedio posible si no se hace el diagnóstico correcto. Es imprescindible que una cumbre de líderes europeos - y no solo los ministros de Interior y Justicia citados el próximo día 14valore la situación y actúe lo antes posible a corto y medio plazo, con medidas económicas y geoestratégicas para llegar hasta las causas del problema. Europa puede reencontrar su camino y parte de la legitimidad y el liderazgo global perdidos si es capaz de afrontar este desafío. Es la única salida posible. Disponible en: < http://elpais.com/elpais/2015/09/02/opinion/1441213709_408502.html>. Acceso en: 21-09-2015. 
ambiente.

6.11.4. El Tratado de Maastricht o Tratado de la Unión Europea - TUE y la gestión de los recursos hídricos

Firmado en la ciudad de Maastricht, Países Bajos, el 7 de febrero de $1992^{1308}$ y que después de haber sido ratificado por todos los Estados, entró en vigor el 1 de noviembre de 1993, con el que la 'Comunidad Económica Europea' pasó a denominarse 'Comunidad Europea'. Además de crear una nueva organización internacional regional en Europa, la Unión Europea ${ }^{1309}$, vino aun introducir algunas alteraciones en los Tratados entonces en vigor, trayendo un poco más de verde al Derecho Constitucional Europeo $^{1310}$.

Este Tratado reforzó aún más el reconocimiento en el derecho originario de la política ambiental como una misión propia de la Comunidad, vez que, por primera vez, se incorpora la protección del medio ambiente entre los fines de la integración europea previstos en la Primera Parte del TCE (arts. $2^{1311}$ y $3^{1312}$ ), y la obtención de un

${ }^{1308}$ Diario Oficial n. ${ }^{\circ} \mathrm{C} 191$ de 29 de julio de 1992.

${ }^{1309}$ José Joaquim Gomes Canotilho y José Rubens Morato Leite (Organizadores), Direito Constitucional Ambiental cit., p. 20, enseñan que con la creación de la Unión Europea la Comunidad Europea siguió existiendo, funcionando ambas en un cuadro institucional. Los Estados Miembros y el territorio de la Comunidad y de la Unión Europea también son los mismos y solo las atribuciones y las formas de su ejercicio son distintas para cada una de estas organizaciones. Además, afirman los autores que: "Agora, 'o desenvolvimento sustentável e não inflacionista que respeite o ambiente' é a nova missão comunitária a acrescer às já existentes no art. $2^{\circ}$ do Tratado de Roma".

${ }^{1310}$ José Joaquim Gomes Canotilho y José Rubens Morato Leite (Organizadores), Direito Constitucional Ambiental cit., p. 21 afirman que: "O Tratado da União Europeia é também um reflexo do mesmo movimento de reforma ecológica do Direito Constitucional Europeu, ao consagrar como objetivo da União a 'promoção de um progresso económico e social equilibrado e sustentável'”.

${ }^{1311}$ Artículo 2. "La Comunidad tendrá por misión promover, mediante el establecimiento de un mercado común y de una unión económica y monetaria y mediante la realización de las políticas o acciones comunes contempladas en los artículos 3 y $3 \mathrm{~A}$, un desarrollo armonioso y equilibrado de las actividades económicas en el conjunto de la Comunidad, un crecimiento sostenible y no inflacionista que respete el medio ambiente, un alto grado de convergencia de los resultados económicos, un alto nivel de empleo y de protección social, la elevación del nivel y de la calidad de vida, la cohesión económica y social y la solidaridad entre los Estados miembros". Disponible en: <http://europa.eu/eu-law/decision- 
making/treaties/pdf/treaty_on_european_union/treaty_on_european_union_es.pdf $>$. Acceso en: 21-092015.

${ }^{1312}$ Artículo 3. "Para alcanzar los fines enunciados en el artículo 2, la acción de la Comunidad implicará, en las condiciones y según el ritmo previstos en el presente Tratado:

a) la supresión, entre los Estados miembros, de los derechos de aduana y de las restricciones cuantitativas a la entrada y salida de las mercancías, así como de cualesquiera otras medidas de efecto equivalente,

b) una política comercial común,

c) un mercado interior caracterizado por la supresión, entre los Estados miembros, de los obstáculos a la libre circulación de mercancías, personas, servicios y capitales,

d) medidas relativas a la entrada y circulación de personas en el mercado interior, conforme a las disposiciones del artículo $100 \mathrm{C}$,

e) una política común en los ámbitos de la agricultura y de la pesca,

f) una política común en el ámbito de los transportes,

g) un régimen que garantice que la competencia no será falseada en el mercado interior,

h) la aproximación de las legislaciones nacionales en la medida necesaria para el funcionamiento del mercado común,

i) una política en el ámbito social que incluya un Fondo Social Europeo,

j) el fortalecimiento de la cohesión económica y social,

k) una política en el ámbito del medio ambiente,

1) el fortalecimiento de la competitividad de la industria de la Comunidad;,

m) el fomento de la investigación y del desarrollo tecnológico,

n) el fomento de la creación y del desarrollo de redes transeuropeus,

o) una contribución al logro de un alto nivel de protección de la salud,

p) una contribución a una enseñanza y a una formación de calidad, así como al desarrollo de las culturas de los Estados miembros,

q) una política en el ámbito de la cooperación al desarrollo,

r) la asociación de los países y territorios de Ultramar, a fin de incrementar los intercambios y continuar en común el esfuerzo por el desarrollo económico y social,

s) una contribución al fortalecimiento de la protección de los consumidores,

t) medidas en los ámbitos de la energía, de la protección civil y del turismo".

Artículo 3 A.

“1. Para alcanzar los fines enunciados en el artículo 2, la acción de los Estados miembros y de la Comunidad incluirá, en las condiciones y según el ritmo previstos en el presente Tratado, la adopción de una política económica que se basará en la estrecha coordinación de las políticas económicas de los Estados miembros, en el mercado interior y en la definición de objetivos comunes, y que se llevará a cabo de conformidad con el respeto al principio de una economía de mercado abierta y de libre competencia.

2. Paralelamente, en las condiciones y según el ritmo y procedimientos previstos en el presente Tratado, dicha acción implicará la fijación irrevocable de tipos de cambio con vistas al establecimiento de una moneda única, el ecu, la definición y la aplicación de una política monetaria y de tipos de cambio única 
desarrollo económico sostenible se reconoce expresamente como uno de los objetivos de la Unión (artículo B ${ }^{1313}$ del Tratado de la Unión Europea).

cuyo objetivo primordial sea mantener la estabilidad de precios y, sin perjuicio de dicho objetivo, el apoyo a la política económica general de la Comunidad, de conformidad con los principios de una economía de mercado abierta y de libre competencia.

3. Dichas acciones de los Estados miembros y de la Comunidad implican el respeto de los siguientes principios rectores: precios estables, finanzas públicas y condiciones monetarias sólidas y balanza de pagos estable".

Artículo 3 B. "La Comunidad actuará dentro de los límites de las competencias que le atribuye el presente Tratado y de los objetivos que éste le asigna.

En los ámbitos que no sean de su competencia exclusiva, la Comunidad intervendrá, conforme al principio de subsidiariedad, sólo en la medida en que los objetivos de la acción pretendida no puedan ser alcanzados de manera suficiente por los Estados miembros, y, por consiguiente, puedan lograrse mejor, debido a la dimensión o a los efectos de la acción contemplada, a nivel comunitario.

Ninguna acción de la Comunidad excederá de lo necesario para alcanzar los objetivos del presente Tratado". Disponible en: <http://europa.eu/eu-law/decisionmaking/treaties/pdf/treaty_on_european_union/treaty_on_european_union_es.pdf $>$. Acceso en: 21-092015.

${ }^{1313}$ Artículo B. "La Unión tendrá los siguientes objetivos:

- promover un progreso económico y social equilibrado y sostenible, principal mente mediante la creación de un espacio sin fronteras interiores, el fortalecimiento de la cohesión económica y social y el establecimiento de una unión económica y monetaria que implicará, en su momento, una moneda única, conforme a las disposiciones del presente Tratado,

- afirmar su identidad en el ámbito internacional, en particular mediante la realización de una política exterior y de seguridad común que incluya, en el futuro, la definición de una política de defensa común que podría conducir, en su momento, a una defensa común,

- reforzar la protección de los derechos e intereses de los nacionales de sus Estados miembros, mediante la creación de una ciudadanía de la Unión,

— desarrollar una cooperación estrecha en el ámbito de la justicia y de los asuntos de interior,

- mantener íntegramente el acervo comunitario y desarrollarlo con el fin de examinar, con arreglo al procedimiento previsto en el apartado 2 del artículo $\mathrm{N}$, la medida en que las políticas y formas de cooperación establecidas en el presente Tratado deben ser revisadas, para asegurar la eficacia de los mecanismos e instituciones comunitarios.

Los objetivos de la Unión se alcanzarán conforme a las disposiciones del presente Tratado, en las condiciones y según los ritmos previstos y en el respeto del principio de subsidiariedad tal y como se define en el artículo 3 B del Tratado constitutivo de la Comunidad Europea". Disponible en: $<$ http://europa.eu/eu-law/decision- 
El principio de la subsidiariedad ${ }^{1314}$ (artículo $3 \mathrm{~B}-\mathrm{TUE}$ ) es retomado como norma general por el Tratado de la Unión Europea y determina que cuando una competencia no sea exclusiva de la Comunidad, esta solo podrá intervenir si los objetivos pueden realizarse mejor a escala comunitaria que a nivel nacional. El Tratado incluso, prevé (artículo $\mathrm{A}^{1315}$ ) que la Unión adopte las decisiones que estén más próximas a los ciudadanos. Además, introdujo los principios de precaución, cautela y proporcionalidad $^{1316}$, y con destaque al principio del desarrollo sostenible dentro del

making/treaties/pdf/treaty_on_european_union/treaty_on_european_union_es.pdf $>$. Acceso en: 21-092015.

${ }^{1314}$ Blanca Lozano Cutanda, Derecho ambiental cit., p. 223, citando R. Alonso, respecto al principio de subsidiariedad afirma que: “(...) como un 'mecanismo corrector' de la actividad de la Comunidad introducido por los Estados miembros a fin de establecer 'una delimitación de la incidencia en sus respectivos ordenamientos de un proceso decisorio sobre el cual han dejado de ejercer un control absoluto".

${ }^{1315}$ Artículo A

"Por el presente Tratado, las Altas Partes Contratantes constituyen entre sí una Unión Europea, en lo sucesivo denominada «Unión».

El presente Tratado constituye una nueva etapa en el proceso creador de una Unión cada vez más estrecha entre los pueblos de Europa, en la cual las decisiones serán tomadas de la forma más próxima posible a los ciudadanos.

La Unión tiene su fundamento en las Comunidades Europeas completadas con las políticas y formas de cooperación establecidas por el presente Tratado. Tendrá por misión organizar de modo coherente y solidario las relaciones entre los Estados miembros y entre sus pueblos". Disponible en: $<$ http://europa.eu/eu-law/decision-

making/treaties/pdf/treaty_on_european_union/treaty_on_european_union_es.pdf $>$. Acceso en: 21-092015.

${ }^{1316}$ Según Judith Serrano Domínguez, El funcionamiento del sistema de protección ambiental de la Unión cit., p. 696, " La exigencia de un nivel de protección ambiental elevado constituye uno de los objetivos esenciales de la política comunitaria y se aplica teniendo en cuenta la diversidad de situaciones existentes en las distintas regiones de la Comunidad. Los principios de cautela y precaución obligan a actuar aun cuando no exista evidencia científica de los efectos de determinada actividad, producto o proceso en el medio ambiente, después de un análisis de riesgo previo a la toma de decisiones. La precaución o cautela, introducida por el Tratado de Maastricht, pretende dar respuesta en la zona de incertidumbre de conocimiento; "supone tomar medidas bajo el umbral de peligro", conforme Schutte, 2000: 54, para definir metas éticas, políticas y jurídicas a largo plazo, ante la necesidad de establecer un umbral de racionalidad práctica y de prever medidas protectoras ante el riesgo identificable de acuerdo al principio de proporcionalidad. Este principio encontró su base jurídica en diversos artículos del Tratado 
Quinto Programa de Acción Ambiental ${ }^{1317}$, con inicio en ese período y que se convirtió el eje central para su futura política ambiental ${ }^{1318}$.

consolidado de la Comunidad Europea, concretamente en el art. 174 que establece que "la politica de la Comunidad [...] se basará en los principios de cautela y de acción preventiva". Disponible en: $<$ http://codex.colmex.mx:8991/exlibris/aleph/a18_1/apache_media/66CS1DF5IT3VEDRKVQIITMFKF NTTXU.pdf $>$. Acceso en: 21-09-2015. Ya el principio de proporcionalidad está en el artículo 3 B - TCE, en el que "Ninguna acción de la Comunidad excederá de lo necesario para alcanzar los objetivos del presente Tratado".

${ }^{1317}$ Según María Jesús Sánchez Muñoz, Treinta años de actuación en materia medio ambiental en la Unión Europea, Disponible en: <http://ccoo.webs.upv.es/files/Medio-Ambiente/2006/Politica-de-Medioambiente-en-Europa-en-30-anos.pdf $>$. Acceso en: 21-09-2015, “(...) el Tratado de la Unión Europea firmado el 7 de febrero de 1992 introduce como objetivo principal de la Comunidad promover un crecimiento sostenible. Según este documento, el término 'sostenible' es reflejo de una política y una estrategia de desarrollo económico y social en equilibrio armónico con el medio ambiente. Esta percepción se plasma en el informe Brundtland de la Comisión Mundial para el medio ambiente y el desarrollo de 1987, donde se considera que "la actividad humana tiene que desarrollarse de manera sostenible para todo el planeta en el camino hacia el futuro, entendiéndose ese desarrollo sostenible como el que satisface las necesidades del presente, sin poner en peligro la capacidad de las generaciones futuras para satisfacer sus propias necesidades. El V Programa para conseguir que el desarrollo sea sostenible propugna las novedades siguientes: integración plena de la política de medio ambiente en las demás políticas, racionalización, responsabilidad compartida, prevención y subsidiariedad. Es evidente que el objetivo del desarrollo sostenible no se ha conseguido en tan corto periodo de tiempo como ha sido la vigencia del V Programa, debido a que ni los Estados miembros ni los sectores contemplados por dicho Programa han llegado a integrar, de manera plena, las preocupaciones ambientales dentro de sus políticas". Además, concluye la autora que: "En definitiva, podemos concluir poniendo de manifiesto que los cuatro primeros programas de acción se han basado en un enfoque vertical y sectorial de los problemas ambientales; en cambio, a partir del Quinto Programa comienza una acción comunitaria horizontal y transversal, donde la política medioambiental se integra en las demás políticas, aspecto que se confirma tras la Comunicación de 1998 relativa a la integración del medio ambiente en las políticas de la Unión, así como por el Consejo Europeo de Viena del mismo año".

${ }^{1318}$ Según Dionisio Fernández de Gatta Sánchez, El régimen de la sostenibilidad Medioambiental, Revista jurídica de Castilla y León. n. ${ }^{\circ}$ 25. septiembre 2011: 163-218, p. 172, afirma que: “(...) el Quinto programa comunitario sobre medio ambiente, de 1993, precisamente tiene como eje central el desarrollo sostenible". El autor, en otro obra hace importantes reflexiones sobre el principio del desarrollo sostenible en el Quinto Programa de Acción Ambiental. FERNÁNDEZ DE GATTA SÁNCHEZ, Dionisio. La Política Ambiental Comunitaria en el Tratado de la Unión Europea, Revista de Derecho Ambiental, n. ${ }^{\circ}$ 12, España:1994, p. 92. 
Según Dionisio Fernández de Gatta Sánchez el Tratado de la Unión Europea “(...) reforzará aún más la consideración de la Política Ambiental como una Política comunitaria propia de la nueva Unión Europea. Así, el Tratado de la Unión Europea incluye entre los objetivos de la nueva Unión el de "promover un progreso económico y social equilibrado y sostenible" (Preámbulo y art. B-TUE). No obstante, será el renovado Tratado de la Comunidad Europea (en el que la supresión del adjetivo de "Económica" es de todo un símbolo) el que incluya las novedades ambientales más destacables. Así, como novedades más destacables, se incluyen el crecimiento sostenible, la protección del medio ambiente y la elevación del nivel de vida entre las misiones de la Comunidad (art. 2- TCE); se menciona, como una más, la Política Ambiental entre las Políticas Europeas (art. 3, K-TCE); se mejora la redacción y se añade objetivos y principios de esta Política nuevos; se prevé la posibilidad de que la Comunidad adopte medidas fiscales, acciones de ordenación del territorio y utilización del suelo, medidas de gestión de recursos hídricos y acciones energéticas, en el contexto de la Política Ambiental; se menciona los Programas Ambientales; se ratifican las obligaciones de los Estados Miembros y se establece el instrumento financiero ambiental por excelencia, que es el Fondo de Cohesión" $" 1319$.

${ }^{1319}$ FERNÁNDEZ DE GATTA SÁNCHEZ, Dionisio. Sistema Jurídico-Administrativo de protección del medio cit., p. 74. En este sentido, Blanca Lozano Cutanda, Derecho ambiental cit., p. 222, afirma que: "La protección ambiental alcanza el estatus de $<<$ política comunitaria $>>$ (reconocida así por el art. 3 junto a la comercial común, de la agricultura y pesca, la de transportes, la social, la de cooperación al desarrollo), lo que supone un campo de actuación permanente de la Comunidad para el que habrá de dotarse de un conjunto de medios completo y sistemático". Importante resaltar que en ese paso se puede observar una reforma institucional reveladora del carácter político adoptado ya por la Unión Europea, conforme previsto en el propio Tratado de Maastricht sobre la Unión Europea: "En la prolongación del Acta Única Europea, el papel del Parlamento Europeo se ve aún incrementado por el Tratado de Maastricht. El ámbito de aplicación del procedimiento de cooperación y el procedimiento del dictamen conforme se amplía a nuevos ámbitos. Además, el Tratado crea un nuevo procedimiento de codecisión, que permite al Parlamento Europeo adoptar actos conjuntamente con el Consejo. Este procedimiento implica contactos reforzados entre el Parlamento y el Consejo para llegar a un acuerdo. Además, el Tratado asocia al Parlamento con el procedimiento de investidura de la Comisión. Se reconoce el papel de los partidos políticos europeos en la integración europea. Contribuyen a la formación de una conciencia europea y a la expresión de la voluntad política de los ciudadanos europeos. En cuanto a la Comisión, la duración de su mandato se amplia de cuatro a cinco años para igualarlo al del Parlamento Europeo. Como el Acta Única, este Tratado amplía el recurso al voto por mayoría cualificada en el Consejo para la 
Además, una vez que la consecución de un desarrollo sostenible se haya configurado como uno de los objetivos principales de la Unión y como uno de los fines de la integración europea implica que los objetivos y acciones meramente económicos ya no deberían predominar, al menos el teoría, sobre los relacionados con la protección del medio ambiente, sino que debería de buscarse el punto de equilibrio entre ellos, como impone el concepto de desarrollo sostenible. Por lo que respecta a los objetivos, principios y condiciones de actuación comunitaria en la materia, el Tratado mantuvo sustancialmente, con algunas modificaciones, los ya establecidos por el Acta Única ${ }^{1320}$.

El Tratado de Unión Europea amplió de forma sustancial el ámbito de la mayoría cualificada a lo que corresponde al procedimiento para la toma de decisiones en esta materia, o sea, las decisiones atinentes al medio ambiente se adoptarán por regla general por mayoría cualificada mediante un procedimiento de cooperación en el que se acentúa el protagonismo del Parlamento, reconociendo un derecho de veto provisional, que obliga al Consejo, para superarlo, a pasar de la regla de la mayoría a la de unanimidad, así lo disponía el artículo $130 \mathrm{~S}$ en relación con el $189 \mathrm{~B}^{1321}$.

mayoría de las decisiones que dependen del procedimiento de codecisión y para todas las decisiones adoptadas según el procedimiento de cooperación. Para reconocer la importancia de la dimensión regional, el Tratado instituye el Comité de las Regiones. Compuesto de representantes de las colectividades regionales, este Comité tiene carácter consultivo". Disponible en: $<$ http://europa.eu/legislation_summaries/economic_and_monetary_affairs/institutional_and_economic_fr am ework/treaties_maastricht_es.htm>. Acceso en: 21-09-2015.

${ }^{1320}$ LOZANO CUTANDA, Blanca. Derecho ambiental cit., p. 222.

${ }^{1321}$ Artículo $130 \mathrm{~S}$.

“1. El Consejo, con arreglo al procedimiento del artículo 189 C y previa consulta al Comité Económico y Social, decidirá las acciones que deba emprender la Comunidad para la realización de los objetivos fijados en el artículo $130 \mathrm{R}$.

2. No obstante lo dispuesto en el apartado anterior, y sin perjuicio del artículo $100 \mathrm{~A}$, el Consejo, por unanimidad, a propuesta de la Comisión y previa consulta al Parlamento Europeo y al Comité Económico y social, adoptará: disposiciones esencialmente de carácter fiscal; medidas de ordenación territorial y de utilización del suelo con excepción de la gestión de los residuos y las medidas de carácter general, así como medidas relativas a la gestión de los recursos hídricos; medidas que afecten de forma significativa a la elección por un Estado miembro entre diferentes fuentes de energía y a la estructura general de su abaste cimiento energético.

El Consejo, en las condiciones previstas en el primer párrafo, podrá definir las materias mencionadas en el presente apartado sobre las cuales las decisiones deban ser tomadas por mayoría cualificada. 
3. En otros ámbitos, el Consejo adoptará, con arreglo al procedimiento previsto en el artículo 189 B y previa consulta al Comité Económico y Social, programas de acción de carácter general que fijen los objetivos prioritarios que hayan de alcanzarse.

El Consejo adoptará, en las condiciones previstas en el apartado 1 o en el apartado 2, según el caso, las medidas necesarias para la ejecución de dichos programas.

4. Sin perjuicio de determinadas medidas de carácter comunitario, los Estados miembros tendrán a su cargo la financiación y la ejecución de la política en materia de medio ambiente.

5. Sin perjuicio del principio de quien contamina paga, cuando una medida ad optada con arreglo a lo dispuesto en el apartado 1 implique costes que se consideren desproporcionados para las autoridades públicas de un Estado miembro, el Consejo establecerá, en el propio acto de adopción de dicha medida, las disposiciones adecuadas en forma de:

- excepciones de carácter temporal;

- apoyo financiero con cargo al Fondo de Cohesión que será creado a más tardar el 31 de diciembre de 1993 de conformidad con lo dispuesto en el artículo 130 D,

o ambas posibilidades". Disponible en: <http://europa.eu/eu-law/decisionmaking/treaties/pdf/treaty_on_european_union/treaty_on_european_union_es.pdf >. Acceso en: 21-092015.

Artículo 189 B.

"1. Cuando, en el presente Tratado, para la adopción de un acto, se haga referencia al presente artículo, se aplicará el procedimiento siguiente:

2. La Comisión presentará una propuesta al Parlamento Europeo y al Consejo.

El Consejo adoptará por mayoría cualificada, previo dictamen del Parlamento Europeo, una posición común. Ésta será transmitida al Parlamento Europeo. El Consejo informará plenamente al Parlamento Europeo de los motivos que le hubieren conducido a adoptar su posición común. La Comisión informará plena mente sobre su posición al Parlamento Europeo.

$\mathrm{Si}$, transcurrido un plazo de tres meses desde esa comunicación, el Parlamento Europeo

a) aprobare la posición común, el Consejo adoptará definitivamente dicho acto con arreglo a su posición común;

b) no tomare ninguna decisión, el Consejo adoptará el acto en cuestión con arreglo a su posición común;

c) indicare, por mayoría absoluta de sus miembros, que su intención es rechazar la posición común, informará de ello inmediatamente al Consejo. El Consejo podrá convocar una reunión del Comité de Conciliación a que se refiere el apartado 4 para dar una más amplia explicación de su posición. Seguidamente, el Parlamento Europeo deberá, o bien confirmar, por mayoría absoluta de sus miembros, su rechazo de la posición común, en cuyo caso el acto

propuesto se considerará no adoptado, o bien proponer enmiendas conforme a lo dispuesto en la letra d) del presente apartado;

d) propusiere enmiendas de la posición común por mayoría absoluta de sus miembros, el texto modificado será transmitido al Consejo y a la Comisión, que emitirá un dictamen sobre estas enmiendas. 
Además, afirma Blanca Lozano Cutanda que: "No obstante, en el marco del Título de Medio Ambiente, determinadas materias seguirán siendo adoptadas por decisión unánime del Consejo y previa consulta del Parlamento y del Comité

3. Si en un plazo de tres meses desde la recepción de las enmiendas del Parlamento Europeo, el Consejo las aprobare por mayoría cualificada todas ellas, éste modificará en consecuencia su posición común y adoptará el acto en cuestión; no obstante, el Consejo deberá pronunciarse por unanimidad sobre aquellas enmiendas que hayan sido objeto de un dictamen negativo de la Comisión. Si el Consejo no adoptare el acto en cuestión, el presidente del Consejo, de acuerdo con el presidente del Parlamento Europeo convocará sin demora una reunión del Comité de Conciliación.

4. El Comité de Conciliación, que estará compuesto por los miembros del Consejo o sus representantes y por un numeró igual de representantes del Parlamento Europeo, procurará alcanzar un acuerdo sobre un texto conjunto, por mayoría cualificada de los miembros del Consejo y por mayoría simple de los representantes del Parlamento Europeo. La Comisión participará en los trabajos del Comité de Conciliación y adoptará todas las iniciativas necesarias para favorecer un acercamiento de las posiciones del Parlamento Europeo y del Consejo.

5. Si en el plazo de seis semanas después de haber sido convocado, el Comité de Conciliación aprobare un texto conjunto, el Parlamento Europeo y el Consejo dispondrán de seis semanas a partir de dicha aprobación para adoptar el acto en cuestión conforme al texto conjunto, pronunciándose respectivamente por mayoría absoluta de votos emitidos y por mayoría cualificada. Si una de ambas instituciones no aprobare el acto propuesto, éste se considerará no adoptado.

6. Si el Comité de Conciliación no aprobare un texto conjunto, el acto propuesto se considerará no adoptado, salvo que el Consejo confirmare, por mayoría cualificada, en un plazo de seis semanas desde la expiración del plazo concedido al Comité de Conciliación, la posición común que haya acordado antes de iniciarse el procedimiento de conciliación, junto, en su caso, con las enmiendas propuestas por el Parlamento Europeo. En este supuesto, el acto en cuestión será finalmente adoptado, salvo que el Parlamento Europeo rechace el texto por mayoría absoluta de sus miembros, en un plazo de seis semanas a partir de su confirmación

por el Consejo, en cuyo caso el acto propuesto se considerará no adoptado.

7. Los períodos de tres meses y de seis semanas a que se refiere el presente artículo podrán ampliarse en un mes y dos semanas, respectivamente, como máximo, de común acuerdo entre el Parlamento Europeo y el Consejo. El período de tres meses a que se refiere el apartado 2 se ampliará automáticamente en dos meses de aplicarse lo dispuesto en la letra c) de dicho apartado.

8. El procedimiento a que se refiere el presente artículo podrá extenderse a otros ámbitos, con arreglo al procedimiento previsto en el apartado 2 del artículo $\mathrm{N}$ del Tratado de la Unión, sobre la base de un informe que la Comisión deberá presentar al Consejo a más tardar en 1996". Disponible en: $<$ http://europa.eu/eu-law/decision-

making/treaties/pdf/treaty_on_european_union/treaty_on_european_union_es.pdf $>$. Acceso en: 21-092015. 
Económico y Social, puesto que en el apartado 2 del art. $130 \mathrm{~S}$ (que permanece en los mismos términos en la actualidad como art. 192.2 TFUE) se reservó a tal procedimiento las $<<$ disposiciones esencialmente de carácter fiscal $>>$, las $<<$ medidas de ordenación territorial y de utilización del suelo con excepción de la gestión de los residuos $>>$, así como las medidas relativas a la gestión de los recursos hídricos $>>$, y las $<<$ medidas que afecten significativamente la elección por un Estado miembro entre diferentes fuentes de energía y a la estructura general de su abastecimiento energético $>>$ (en estas materias solo es posible la adopción de disposiciones por mayoría cualificada cuando el Consejo, por unanimidad y previa consulta al Comité Económico y Social así lo establezca)" ${ }^{\prime 1322}$.

De este modo, se mantuvo el principio de la unanimidad a lo que se refiere a los procedimiento legislativos, con consulta al Parlamento Europeo, no obstante, medidas relativas a la gestión de los recursos hídricos no incluyen las referentes a contaminación de aguas, sino todas aquellas que podrían referirse a la regulación y usos del agua, aunque habría áreas de conflicto ${ }^{1323}$.

Respecto a la situación medioambiental, Luis Franco Sala afirma que: "Aún existiendo una concienciación medioambiental y una acción comunitaria decidida en este campo, como se desprende de lo expuesto en los apartados precedentes, la situación existente presenta importantes aspectos aún muy insatisfactorios. Los datos citados a continuación son una pequeña muestra de ello ${ }^{1324}$. En materia de aguas se han efectuado importantes progresos desde principios de los años setenta en que se adoptaron las primeras directivas. Desde entonces éstas han sido múltiples, dirigiéndose tanto a fijar los estándares de calidad como a limitar o prohibir ciertos vertidos. No obstante, existen aspectos y situaciones deficientes. Así, por ejemplo, el porcentaje de la población total abastecida por una planta depuradora varía de países donde prácticamente se engloba al conjunto de la población, como son los casos de Dinamarca (98\%) o Suecia (95\%), a

\footnotetext{
${ }^{1322}$ LOZANO CUTANDA, Blanca. Derecho ambiental cit., p. 223.

${ }^{1323}$ RIECHENBERG, Kurt, Capítulo I - Derecho Comunitario Ambiental - Evolución y análisis de la acción comunitaria en materia de medio ambiente. Su tratamiento en el Tratado de la Comunidad Europea, in: MAR CAMPINS i ERITJA; ISABEL PONT i CASTEJÓN (Coord.), Perspectivas de Derecho Comunitario Ambiental, Edición Instituto Universitario de Estudios Europeos, Bellaterra Barcelona - España: 1997, p. 9.

${ }^{1324}$ Los datos son de Eurostat (1995).
} 
otros en los que no se alcanza ni a la mitad, como son Grecia, Portugal, Italia o Irlanda. España se encuentra en una situación discreta dentro del conjunto, si bien es negativa en términos absolutos, con un $48 \%$ de la población en 1989. A la vista de estos y otros ejemplos resulta evidente que no es posible estar satisfechos con el resultado de la política ambiental comunitaria. La evolución de la misma, indudablemente, ha sido importante y se ha ido dotando de un amplio conjunto de instrumentos; sin embargo, no es suficiente. Es preciso continuar reforzando esta política y aplicándola de forma prioritaria en todos los Estados miembros, si se desea ir hacia un desarrollo sostenible $^{, 1325}$.

\subsubsection{El Tratado de Ámsterdam}

El Tratado de Ámsterdam fue firmado en esta ciudad el 2 de octubre de 1997 y que, después de haber sido ratificado por todos los Estados, entró en vigor el 1 de mayo de 1999. Su principal función fue simplificar y sistematizar las disposiciones de los Tratados constitutivos, aunque también se introdujeron algunas modificaciones sustanciales en su articulado ${ }^{1326}$.

${ }^{1325}$ FRANCO SALA, Luis. La política medioambiental comunitaria: planteamientos, instrumentos y resultados. Afers Internacionals, n. ${ }^{\circ}$ 34-35: 67-78, pp. 74-76.

${ }^{1326}$ En definitiva, la evolución de la construcción europea ha permitido establecer disposiciones acordes con la importancia de la problemática medioambiental. Sin embargo, este lento progreso paso a paso también ha sido la fuente de algunas incoherencias, como la existencia de bases jurídicas contradictorias o la diversidad de procedimientos decisorios. El Tratado de Ámsterdam se redactó para resolver estos problemas y para dar respuesta a la necesidad de elaborar una política medioambiental clara y eficaz. Síntesis de la legislación de la Unión Europea, consultado en el sitio de la Unión Europea, legislaciones y publicaciones de la UE, disponible en: <http://eur-lex.europa.eu/legalcontent/ES/TXT/?uri=URISERV:a15000>. Acceso en: 23-09-2015. Según Dionisio Fernández de Gatta Sánchez, Sistema Jurídico-Administrativo de protección del medio cit., p. 74, respecto al Tratado de Ámsterdam, afirma que: “(...) modifica el Tratado de la Unión Europea de manera importante. Respecto al medio ambiente, el nuevo Tratado incluye el principio de integración ambiental (o de horizontalidad o transversalidad) en el art. 6-TCE, y las cooperaciones reforzadas (que permiten a algunos Estados Miembros, ocho en aquellos años, adoptar medidas y acciones comunes, aunque el resto de los Estados Miembros no les acompañe; además, se modifican algunas redacciones de los artículos señalado". Además, el autor, en su obra titulada Articulación y perspectiva del desarrollo sostenible en la Unión 
Según Blanca Lozano Cutanda: "Por lo que respecta al medioambiente, la protección ambiental gana más fuerza en la nueva redacción que se da a los fines de la integración europea, pues se incorpora como misión de la Comunidad en el art. $2^{\circ}$ del Tratado, el logro de un alto nivel de protección y de mejora de la calidad del ambiente, que se añade a la ya consagrada y ahora más enfatizada de promover un desarrollo armonioso, equilibrado y sostenible de las actividades económicas en el conjunto de la Comunidad. Otra modificación significativa es el traslado al frontispicio del Tratado,

Europea, Revista Noticias de la Unión Europea, n. ${ }^{\circ}$ 264, España: 2007, pp. 36-37, enseña que: "El principio de integración ambiental en las políticas de la Unión constituye actualmente uno de los fundamentos de la actuación comunitaria en la esfera ambiental; y contribuye expresamente a cumplir la filosofía y los objetivos del desarrollo sostenible" y también afirma que el principio de integración "se convierta, quizás, en el más importante de todos, ya que, si el medio ambiente se ve afectado por otras políticas sectoriales (agricultura, transporte, energía etc.), ése mismo medio exige una permanente y constante inspiración de todas ésas mismas políticas que le afectan”. En sentido contrario, José Joaquim Gomes Canotilho y José Rubens Morato Leite (Organizadores), Direito Constitucional Ambiental cit., p. 21, afirman que: “As alterações introduzidas, em 1997, pelo Tratado de Amsterdã, no quadro constitucional da Política Comunitária do Ambiente não foram muito significativas e resumiram-se à introdução do desenvolvimento sustentável no preâmbulo do Tratado da União Europeia e à recolocação sistemática do princípio da integração na Parte I do Tratado, sobre os princípios". Estos autores en la nota de pie de página 36, p. 74, además explican: "Para além de uma alteração formal que melhorou significativamente a compreensibilidade dos Tratados: a renumeração sequencial dos artigos atribuindo aos antigos $130^{\circ} \mathrm{R}, 130^{\circ} \mathrm{S}$ e $130^{\circ} \mathrm{T}$, respectivamente, os novos números $174^{\circ}, 175^{\circ}$ e $176^{\circ}$ '. Y en la nota de pie de página 37, p. 74, comentan sobre el cambio en el preámbulo del TUE: "Onde se lê agora: '(...) determinados a promover o progresso económico e social dos povos, tendo em consideração o desenvolvimento sustentável, no contexto da realização do mercado interno e do reforço da coesão e da proteção do ambiente (...)"”. También en la nota de pie de página 38, p. 74, enseñan que: "O princípio da integração estava, desde 1986, na parte III do Tratado, no artigo $130^{\circ} \mathrm{R}$ relativo à Política Comunitária Ambiental". Sobre el principio de integración ambiental, lo mismo empezó con la jurisprudencia del Tribunal, con la Sentencia del Tribunal de Justicia de 7 de febrero de 1985, relativa a la Asociación de Defensa de Quemadores de Aceites Usados, que afirmó el carácter prioritario de la protección ambiental, enseguida asegurado por el Acta Única Europea, en el artículo 130 R-2 ${ }^{\circ}$ - TCEE y después en el Tratado de la Unión Europea, en el Quinto Programa de Acción Ambiental (DO C 138, de 17-05-1993. Fue aprobado por Resolución del Consejo y de los Representantes de los gobiernos de los Estados miembros, reunidos en el seno del Consejo, de 1 de febrero de 1993, sobre un Programa Comunitario de Política y Actuación en Materia de Medio Ambiente y Desarrollo Sostenible) y su revisión - mediante Decisión n. ${ }^{\circ}$ 2.179/98/CE, del Parlamento Europeo y del Consejo, de 24 de septiembre de 1988 (DOCE L 275, 10-101998) - hasta llegar al Tratado de Ámsterdam. 
dentro de la Primera Parte dedicada a los principios de la Comunidad Europea, del principio de integración de las exigencias de la protección del ambiente en la definición y en la realización de las demás políticas y acciones de la Comunidad (actual art. 6), que antes figuraba en el título dedicado al ambiente dentro de las políticas de la Comunidad, con lo que se subraya su importancia como principio general inspirador de toda actuación comunitaria"1327.

Gran destaque fue dado al medio ambiente en el Tratado de Ámsterdam, una vez que fue atribuido un título específico, con tres artículos (arts. 174 al 176) ${ }^{1328}$, donde los objetivos que deberían ser alcanzados estaban previstos en el artículo 174 (antiguo art. $130 \mathrm{R}$ ), tales como la conservación, la protección y la mejora de la calidad del ambiente, la protección de la salud de las personas, la utilización prudente y racional de los recursos naturales, el fomento de medidas a escala internacional destinadas a hacer frente a los problemas regionales o mundiales del ambiente, que de modo generalizado,

${ }^{1327}$ LOZANO CUTANDA, Blanca. Derecho ambiental cit., pp. 223-224. El Tratado de la Unión Europea estipula que "las exigencias de la protección del medio ambiente deberán integrarse en la definición y en la realización de las demás políticas de la Comunidad". Esta condición es indispensable para lograr un crecimiento sostenible y respetuoso con el medio ambiente. El Tratado de Ámsterdam pretende consolidar las garantías actuales que ofrecen el Acta Única y el Tratado de la Unión Europea mediante la inserción del concepto de desarrollo sostenible y la adición de un nuevo artículo en el Tratado constitutivo de la Comunidad Europea. Este principio ha sido consagrado en el preámbulo y en los objetivos del Tratado de la Unión Europea. Figura asimismo en el artículo 2 del Tratado constitutivo de la Comunidad Europea, donde se establece la misión de la Comunidad. El nuevo artículo 6 presenta en las primeras páginas del Tratado la cláusula que impone la integración de los requisitos de protección medioambiental en la definición y aplicación de otras políticas, que ya figura en el artículo 174 (antiguo artículo $130 \mathrm{R}$ ). También se menciona que esa integración es una forma de fomentar el desarrollo sostenible. Este nuevo artículo debe leerse desde la perspectiva de la declaración sobre la evaluación del impacto ambiental adjunta al Acta final de la Conferencia intergubernamental que redactó el Tratado de Ámsterdam. En esta declaración, la Comisión se compromete a preparar estudios de evaluación del impacto ambiental cuando presente propuestas que puedan tener una incidencia significativa en el medio ambiente. Medio Ambiente. Síntesis de la legislación de la Unión Europea, consultado en el sitio de la Unión Europea, legislaciones y publicaciones de la UE, disponible en: <http://eur-lex.europa.eu/legalcontent/ES/TXT/?uri=URISERV:a15000>. Acceso en: 23-09-2015.

${ }^{1328}$ En la numeración anterior: Título XVI - arts. $130 \mathrm{R}, 130 \mathrm{~S}$ y $130 \mathrm{~T}$, en la nueva numeración del Tratado de Ámsterdam, se quedo respectivamente Título XIX, arts. 174, 175 y 176. Disponible en: < http://europa.eu/eu-law/decision-making/treaties/pdf/treaty_of_amsterdam/treaty_of_amsterdam_es.pdf $>$. Acceso en: 23-09-2015. 
dan oportunidad para que los planes de las acciones y directivas puedan especificar las metas comunes, así como ya citados en el Tratado anterior. Con eso, se puede decir que el principal objetivo era la busca por un ambiente equilibrado, donde exista un armonía en la utilización de los recursos naturales por entre hombre.

En cuestiones procedimentales, la codecisión (artículo 251) pasó a ser el procedimiento de deliberación institucional normal en materia de medio ambiente sustituyendo el procedimiento anterior de cooperación institucional, del artículo 252 pasando a ser obligatoria la consulta previa del Comité de las Regiones además del Comité Económico y Social.

En este sentido, Blanca Lozano Cutanda afirma que: "En cuanto al proceso de toma de decisiones relativas al medioambiente, el Tratado de Ámsterdam sustituyó el procedimiento de cooperación por el de codecisión (art. 175 en relación con el 251 TCE, actual art. 192 en relación con el 294 TFUE), con lo que se eliminó la dualidad de procedimientos que existía anteriormente según se tratase de aprobar este tipo de decisiones o medidas de aproximación de legislaciones nacionales para la consecución del mercado único (a las que ya se aplicaba el procedimiento de codecisión), y se acentuó aún más el protagonismo del Parlamento en la toma de decisiones ambientales. Se mantiene sin embargo la necesidad de que, en las áreas concretas ya citadas, las decisiones se adopten, por regla general, por unanimidad del Consejo, a propuesta de la Comisión y previa consulta al Parlamento Europeo, al Comité Económico Social y al Comité de las Regiones"

${ }^{1329}$ LOZANO CUTANDA, Blanca. Derecho ambiental cit., p. 224. Además, la autora afirma que: "El Tratado de Ámsterdam introdujo, por otra parte, el principio de 'flexibilidad' o 'cooperación reforzada' (antiguos arts. 43 y 44 del Tratado de la Unión Europea y art. 11 del TEC, actuales art. 20 del TUE y arts. 226 a 334 TFUE), que permite que un grupo de Estados miembros pueda avanzar hacia una mayor integración en un área determinada al margen de los Estados que no quieran participar. Para ello, es preciso que se cumplan determinados límites y condiciones y que el Consejo conceda la autorización, por mayoría cualificada y a propuesta de la Comisión. En el ámbito de la política ambiental esto puede permitir que se empiecen a establecer, para un determinado grupo de Estados miembros, medidas comunes en ámbitos como la fiscalidad ambiental, en los que, a pesar de existir bastantes Estados claramente favorables a la aplicación de medidas de este tipo, la necesidad de obtener la aprobación por unanimidad permite que determinados Estados obstaculicen su adopción”. LOZANO CUTANDA, Blanca. Derecho ambiental cit., pp. 224-225. Sobre el proceso decisorio en el Tratado de la Unión Europea, lo mismo estableció un procedimiento decisorio más eficaz para la política medioambiental al sustituir la unanimidad por el voto por mayoría en el Consejo como regla general. No obstante, este 
De este modo, se constata que hubo una simplificación del proceso decisorio, puesto que el procedimiento de codecisión vino a sustituir el de cooperación, reduciendo así, a dos el número de procedimientos, facilitando la lectura de los Tratados y reduciendo el riesgo de conflictos entre bases jurídicas distintas ${ }^{1330}$.

proceso continuaba siendo complejo ya que coexistían varios procedimientos distintos: el procedimiento de codecisión para los programas de acción de carácter general; el procedimiento de cooperación para la política medioambiental; el procedimiento de consulta simple con la aprobación unánime por parte del Consejo de las disposiciones de naturaleza fiscal o de ordenación del territorio, uso del suelo y abastecimiento de energía. Además, a veces se producía una cierta ambigüedad entre los ámbitos del medio ambiente (artículo 175, antiguo artículo $130 \mathrm{~S}$ ) y de la aproximación de las legislaciones sobre el mercado interior (artículo 95, antiguo artículo 100 A). Puesto que el procedimiento de codecisión se aplicaba a la aproximación de las legislaciones, existía el riesgo de conflicto entre las bases jurídicas que proporcionan el artículo $100 \mathrm{~A}$ y el artículo $130 \mathrm{~S}$ en relación con una acción que afectara al medio ambiente. La entrada en vigor del Tratado de Ámsterdam ha simplificado la situación ya que el procedimiento de cooperación se ha sustituido por el de codecisión. Esta reorganización tiene la ventaja de reducir a dos el número de procedimientos, ya que los Estados miembros expresaron su deseo de mantener la unanimidad en los campos mencionados anteriormente. De esta forma se facilita la lectura de los Tratados y se reduce el riesgo de conflictos entre bases jurídicas distintas. Medio Ambiente. Síntesis de la legislación de la Unión Europea, consultado en el sitio de la Unión Europea, legislaciones y publicaciones de la UE, disponible en: < http://eur-lex.europa.eu/legalcontent/ES/TXT/?uri=URISERV:a15000>. Acceso en: 23-09-2015.

${ }^{1330}$ El Tratado constitutivo de la Comunidad Europea establece que en lo sucesivo todas las propuestas de la Comisión deben basarse en un alto nivel de protección medioambiental. Anteriormente, una vez adoptada una medida de armonización por el Consejo, los Estados miembros podían no obstante aplicar disposiciones nacionales diferentes, si se justificaban por necesidades imperiosas relacionadas con la protección del medio ambiente. El Estado miembro debía notificarlo a la Comisión de forma que ésta pudiera verificar que las disposiciones en cuestión no constituían una discriminación arbitraria o una restricción del comercio encubierta entre los Estados miembros. Este mecanismo ha sido completado y ahora se distinguen dos casos (artículo 95, antiguo artículo $100 \mathrm{~A}$ ). Los Estados miembros pueden: o bien mantener las disposiciones nacionales en vigor relativas a la protección del medio ambiente; o bien introducir nuevas disposiciones nacionales relativas a la protección del medio ambiente. En el primer caso, el Estado miembro debe notificar a la Comisión esa decisión e indicar las razones del mantenimiento de las disposiciones nacionales de que se trate. En el segundo caso, el Estado miembro está obligado a notificar a la Comisión las nuevas disposiciones nacionales y a explicar las razones por las que hayan sido introducidas. Además, las medidas nacionales deben basarse en nuevas pruebas científicas y responder a un problema específico de ese Estado miembro que haya surgido después de la adopción de la medida de armonización. En ambos casos, la Comisión debe examinar si las medidas nacionales adoptadas constituyen o no una forma de discriminación arbitraria, una restricción encubierta del 
En el periodo de vigencia de este Tratado, un marco comunitario de actuación en el ámbito de la política de aguas para la protección de las aguas superficiales continentales, de transición, costeras y subterráneas, fue establecido para prevenir o reducir la contaminación, promover el uso sostenible, proteger el ambiente, mejorar el estado de los ecosistemas acuáticos y atenuar los efectos de las inundaciones y sequías $^{1331}$.

Dando cumplimiento al principio de integración de la dimensión ambiental en las políticas europeas, la Comunidad elabora Estrategias de desarrollo sostenible ${ }^{1332}$, adoptada en 2001 y revisada en $2005^{1333}$, enseguida, en junio de $2006^{1334}$, una nueva

comercio entre Estados miembros o un obstáculo al funcionamiento del mercado interior. La Comisión dispone de seis meses para decidir si aprueba o rechaza la medida. Este plazo se podrá ampliar a otros seis meses en determinadas condiciones. A falta de una decisión, las disposiciones nacionales se consideran aprobadas. Medio Ambiente. Síntesis de la legislación de la Unión Europea, consultado en el sitio de la Unión Europea, legislaciones y publicaciones de la UE, disponible en: < http://eurlex.europa.eu/legal-content/ES/TXT/?uri=URISERV:a15000>. Acceso en: 23-09-2015.

${ }^{1331}$ Directiva - 2000/60/CE del Parlamento Europeo y del Consejo de 23 de octubre de 2000, por la que se establece un marco comunitario de actuación en el ámbito de la política de aguas. Diario Oficial n. ${ }^{\circ} \mathrm{L}$ 327 de 22-12-2000, pp. 1-73. Disponible en: < http://eur-lex.europa.eu/legalcontent/ES/TXT/?uri=CELEX:32000L0060>. Acceso en: 23-09-2015.

${ }^{1332}$ COM (2005) 658 final. "Los europeos valoran la calidad de vida. Desean prosperidad, buena salud, protección y equidad sociales y un medio ambiente limpio. Y no sólo para ellos sino también para sus hijos y sus nietos. En un mundo que cambia con rapidez - en el cual el ritmo de los cambios puede amenazar la capacidad de adaptación de la economía, el tejido social y la naturaleza -, Europa debe modernizarse y permanecer al frente del cambio. El reto principal reside en mantener una dinámica que permita que el crecimiento económico, el bienestar social y la protección del medio ambiente se refuercen recíprocamente. El Consejo Europeo celebrado en Gotemburgo en 2001 reconoció ese reto, así como la necesidad del cambio, mediante la adopción de la Estrategia para un desarrollo sostenible, a la cual se añadió una dimensión exterior en 2002, en el Consejo Europeo de Barcelona. Al adoptar los principios rectores del desarrollo sostenible en junio de 2005, el Consejo Europeo reafirmó los principios y objetivos del desarrollo sostenible (prosperidad económica, equidad social, protección del medio ambiente y responsabilidad internacional), en los que se centraron asimismo los debates de la reunión de Jefes de Estado y de Gobierno europeos en Hampton Court en octubre de 2005". Disponible en: < http://eur-lex.europa.eu/LexUriServ/LexUriServ.do?uri=COM:2005:0658:FIN:ES:PDF>. Acceso en: 2309-2015.

${ }^{1333}$ COM (2005) 658 final.

1334 “Las líneas principales de la estrategia propuesta en 2001 por la Comisión se incluyeron en las conclusiones del Consejo Europeo de Gotemburgo de junio de 2001 y formaron parte de los trabajos 
Estrategia es aprobada.

Sobre el tema, afirma Dionisio Fernández de Gatta Sánchez: “(...) el Consejo Europeo de Bruselas, celebrado los días 15 y 16 de junio de 2006, considera el desarrollo sostenible como uno de los objetivos fundamentales de la unión, asumiendo totalmente su bien conocido significado, y adopta «una Estrategia Renovada de Desarrollo Sostenible de la Unión Europea ambiciosa y amplia» (doc. 10117/06, cuyo texto final se remite por la Secretaría del Consejo de la UE a los Estados Miembros el 26 de junio de 2006, doc. 10917/06); texto que ratifica el compromiso de la unión con el desarrollo sostenible, reiterando que es asumido tanto en los Tratados como en la actividad comunitaria ordinaria, y cuyo objetivo general es elaborar medidas que permitan a la unión mejorar continuamente la calidad de vida para las actuales y las futuras generaciones, mediante la creación de comunidades sostenibles capaces de gestionar los recursos eficazmente, aprovechar el potencial de innovación tecnológica y social que ofrece la economía y garantizar la prosperidad, la protección del medio

preparatorios de la Unión Europea para la Cumbre mundial de 2002 sobre el desarrollo sostenible (Río + 10) que se celebró en Johannesburgo. La Comisión presentó antes de esa Cumbre otra Comunicación sobre la posible contribución de la Unión al desarrollo sostenible en el mundo, cuyos elementos se integraron en la estrategia en el momento de la revisión. Tras la entrada en funciones de la nueva Comisión, en el año 2004, se organizó una consulta pública sobre la estrategia de desarrollo sostenible. La Comisión presentó asimismo una visión de conjunto de los avances registrados merced a la estrategia de desarrollo sostenible, que incluía los principales resultados de esa consulta y las grandes orientaciones para la revisión de la estrategia. Por su parte, el Consejo Europeo de Bruselas de junio de 2005 reafirmó los objetivos clave del desarrollo sostenible y recordó los principios rectores que deben servir de base para la renovación de la estrategia. En diciembre de 2005, la Comisión adoptó una Comunicación en la que: determina los principales ámbitos que requieren un nuevo impulso en los próximos años; recuerda que esos ámbitos son interdependientes e implican respuestas basadas en la cooperación y la solidaridad, la investigación y la innovación, y la educación de los ciudadanos; propone que se tenga más en cuenta la incidencia de las políticas internas de Europa en el desarrollo sostenible mundial; propone métodos para medir los avances registrados y reexaminar periódicamente las prioridades nacionales y comunitarias; recomienda un diálogo permanente con las personas y las organizaciones (empresarios, poderes públicos regionales y locales, organizaciones no gubernamentales $[\mathrm{ONG}]$, etc.) comprometidas con el desarrollo sostenible. Esa Comunicación sirvió de base para adoptar la nueva estrategia de la UE en favor del desarrollo sostenible en el Consejo Europeo de Bruselas en junio de 2006". Estrategia en favor del desarrollo sostenible. Síntesis de la legislación de la UE. Disponible en: <http://eur-lex.europa.eu/legalcontent/ES/TXT/?uri=URISERV:128117>. Acceso en: 23-09-2015. 
ambiente y la cohesión social"1335.

Además, en el día 15 de mayo de 2001 se destacó la Comunicación de la Comisión - Desarrollo Sostenible en Europa para un mundo mejor: Estrategia de la Unión Europea para un Desarrollo Sostenible - Propuesta de la Comisión ante el Consejo Europeo de Gotemburgo ${ }^{1336}$.

Importante resaltar que estas Estrategias de desarrollo sostenible incluyen entre sus principios rectores la promoción y protección de los derechos fundamentales, de solidaridad intra e intergeneracional, garantía de una sociedad abierta y democrática, participación de los ciudadanos, empresas e interlocutores sociales, coherencia e integración de las políticas, explotación de los mejores conocimientos disponibles y los principios de precaución y de 'quien contamina paga'.

Así, la Unión Europea, elabora una estrategia de desarrollo sostenible en mayo de 2001, y al aprobar esta estrategia, el Consejo Europeo de Gotemburgo reconoció que era conveniente desarrollar su dimensión exterior e invitó asimismo a la Comisión a estudiar la contribución de la Unión al desarrollo sostenible a escala mundial. La presente Comunicación responde a esa petición y contribuye a la elaboración de la postura de la UE para la cumbre mundial sobre desarrollo sostenible celebrada en 2002 en Johannesburgo ${ }^{1337}$.

${ }^{1335}$ FERNÁNDEZ DE GATTA SÁNCHEZ, Dionisio. El régimen de la sostenibilidad Medioambiental, Revista jurídica de Castilla y León. n. ${ }^{\circ}$ 25. septiembre 2011: 163-218, p. 173.

1336 COM (2001) 264 final. Disponible en: $<$ http://eur-
lex.europa.eu/LexUriServ/LexUriServ.do?uri=COM:2001:0264:FIN:EN:PDF>. Acceso en: 23-09-2015. ${ }^{1337} \mathrm{La}$ Comunicación parte de la idea de que la globalización es un potente motor que alimenta el crecimiento mundial y aporta medios para responder a los problemas mundiales de la salud, la educación y el medio ambiente. No obstante, las fuerzas del mercado, por sí solas, generan e incrementan las desigualdades, fomentan la exclusión y corren el riesgo de dañar de forma irremediable el medio ambiente. Por consiguiente, la globalización debe ir acompañada de medidas para evitar o atenuar estos efectos. En los ámbitos cruciales del comercio, la financiación del desarrollo, la gestión del medio ambiente, la lucha contra la pobreza y la criminalidad, es indispensable continuar los esfuerzos para elaborar reglas colectivas aplicadas y controladas efectivamente. Es necesario también mejorar la gobernanza mundial, es decir, promover una dirección más eficiente de la interdependencia. La comunicación presenta una serie de acciones para contribuir al desarrollo sostenible mundial que complementan la estrategia de desarrollo sostenible de mayo de 2001 y que abarcan los aspectos económicos, sociales, medioambientales, financieros, de coherencia de las políticas comunitarias y de gobernanza a todos los niveles. Asociación mundial para el desarrollo sostenible. Síntesis de la 
Además, con el objetivo de reducir antes de 2015 la pobreza extrema en el mundo, entre las acciones que se deberían llevar a cabo en el ámbito del desarrollo sostenible mundial, aparece la integración en los aspectos de la distribución y de la depuración del agua en las políticas sanitarias y educativas ${ }^{1338}$.

Importante destacar que esta estrategia establece un marco político a escala de la Unión Europea para permitir el desarrollo sostenible, buscando responder a las necesidades del presente sin comprometer la capacidad de las generaciones futuras a la hora de satisfacer sus propias necesidades. El desarrollo sostenible está basado en cuatro pilares -económico, social, medioambiental y gobernanza mundial- que deben reforzarse mutuamente. Las consecuencias económicas, sociales y medioambientales de todas las políticas deben examinarse de forma coordinada y tenerse en cuenta en el momento de su elaboración y adopción. La UE debe asumir asimismo sus responsabilidades internacionales en materia de desarrollo sostenible: éste debe promoverse fuera de la UE, incluidos los aspectos relativos a la democracia, la paz, la seguridad y la libertad. Además, el objetivo de esta estrategia, que es complementaria de la Estrategia de Lisboa, debe ser el de servir de catalizador ante la opinión pública y los responsables políticos para influir en el comportamiento del conjunto de la sociedad. Se basa en medidas sobre los principales desafíos identificados, así como en medidas transversales, financiación adecuada, la participación de todas las partes interesadas y una aplicación y seguimiento eficaces de las políticas ${ }^{1339}$.

Respecto a la gestión de los recursos naturales la Comunicación de la Comisión al Consejo y al Parlamento Europeo, de 9 de febrero de 2005, titulada 'Revisión en 2005 de la Estrategia de la Unión Europea para un desarrollo sostenible:

\footnotetext{
legislación de la UE. Disponible en: $<$ http://eur-lex.europa.eu/legalcontent/ES/TXT/?uri=uriserv:128015> . Acceso en: 23-09-2015.

1338 Otras acciones son: centrar la política de desarrollo de la UE en la reducción de la pobreza; conseguir que las políticas de la Unión contribuyan a luchar contra el hambre; integrar la dimensión del género en las políticas de la Unión; aumentar la inversión en los sectores de la salud, la educación, la formación y las enfermedades contagiosas; promover la investigación en el campo del desarrollo sostenible.

${ }^{1339}$ Estrategia en favor del desarrollo sostenible. Síntesis de la legislación de la UE. Disponible en: $<$ http://eur-lex.europa.eu/legal-content/ES/TXT/?uri=URISERV:128117>. Acceso en: 23-09-2015.
} 
Primer balance y orientaciones futuras ${ }^{1340}$, expone que: "Las últimas décadas ya han presenciado pérdidas muy importantes en prácticamente todos los tipos de ecosistemas y especies (animales, plantas, bosques, agua dulce, tierra fértil, etc.). El agua dulce es otro precioso recurso natural amenazado. En general, la crisis mundial del agua pone en peligro vidas, el desarrollo sostenible y, en definitiva, la paz y la seguridad. Las iniciativas internacionales incluyen la iniciativa de la UE «Agua para la vida», a raíz de la Cumbre Mundial sobre el Desarrollo Sostenible".

Delante de lo aquí expuesto, se puede afirmar que estos instrumentos e intenciones están relacionados de alguna manera con el agua, desde el inicio, con la precaución y prevención hasta el desarrollo sostenible, el buen estado de las aguas y su acceso equitativo, todas las acciones están basadas en las propias instituciones del Tratado vigente, mismo cuando no aparecen de forma expresa, están contenidas en sus objetivos principales, una vez que quedarían expresos en la Política Ambiental Comunitaria y en las Correspondientes Directivas.

\subsubsection{El Tratado de Niza y la gestión de los recursos hídricos}

Aprobado por el Consejo Europeo en 2000, fue firmado en esta ciudad el 26 de febrero de 2001 y que, una vez ratificado por todos los Estados, entró en vigor el 1 de febrero de $2003^{1341}$. Su principal finalidad fue adecuar el sistema institucional comunitario para acoger a los nuevos Estados miembros ${ }^{1342}$ (totalizando 27 Estados miembros). Frente a este elevado número de Estados la Unión Europea necesita para seguir funcionando eficazmente que su sistema de toma de decisiones se haga más fácil, y por ello el Tratado de Niza introdujo nuevas normas sobre el tamaño y la composición

\begin{tabular}{llllll}
\hline 1340 & COM & (2005) & 37 & final. & Disponible
\end{tabular}
http://www.europarl.europa.eu/meetdocs/2004_2009/documents/com/com_com(2005)0037_/com_com(2 005)0037_es.pdf>,pp.16-17. Acceso en: 23-09-2015.

${ }^{1341}$ Diario Oficial n. ${ }^{\circ}$ C 80 de 10 de marzo de 2001.

${ }^{1342}$ Hacen parte del Tratado de Niza los mismos países del Tratado anterior, sin embargo, dentro del período de vigencia ingresaron algunos países más. En 2004: Polonia, Republica Checa, Hungría, Eslovaquia, Lituania, Letonia, Eslovenia, Estonia, Chipre, Malta; y en 2007: Rumania y Bulgaria. Completando, así, 27 países miembros. Su población total es de aproximadamente 495 millones de personas. Son países candidatos: Turquía, Croacia y Antigua Republica Yugoslava de Macedonia. 
de las instituciones de la Unión y el sistema de adopción de decisiones. Estas reformas se dirigen principalmente a la composición del Tribunal de Justicia y del Tribunal de Primera Instancia, al reparto de competencias entre ambos organismos, reforzando así, las atribuciones del Tribunal de Primera Instancia, a los procedimientos para la adopción del Estatuto y del Reglamento de Procedimiento de los mismos, así como al tratamiento de los litigios relativos a los títulos comunitarios de propiedad industrial ${ }^{1343}$.

Este Tratado introdujo reformas en el Tratado CE dirigidas fundamentalmente a preparar el marco institucional y los procesos de toma de decisión de la Comunidad para la quinta y mayor ampliación de la historia de la Unión, con el fin de hacer viable el funcionamiento de una Unión con prácticamente el doble de miembros - reformas que habían quedado pendientes de llevar a cabo en el Tratado de Ámsterdam.

En materia de medio ambiente el tratado de Niza no introdujo modificaciones sustanciales, aunque sin duda alguna las novedades que incorporó en relación con las instituciones y los procesos de decisión repercutieron también en el desarrollo del derecho ambiental.

Puede destacar, en este sentido, como bien afirma Blanca Lozano Cutanda: “(...) la potenciación de las cooperaciones reforzadas como fórmula para combinar la voluntad de algunos países de avanzar con mayor rapidez o profundidad que otros en la construcción europea y para evitar una posible parálisis en una Unión con 27 Estados miembros. Pero lo cierto es que, a pesar de introducir facilidades para llevarlas a cabo (se eliminó la exigencia de una mayoría de miembros para su propuesta, bastando con ocho, y el derecho de veto a los Estados que reconocía la regulación anterior), este mecanismo previsto en el Tratado todavía no ha sido utilizado en la práctica"1344.

En el ámbito de la política medioambiental, el Tratado de Niza introdujo algunos retoques menores en la redacción del apartado 2 del art. 175 Tratado $E^{1345}$,

${ }^{1343}$ Sistema jurisdiccional de la Unión Europea: Tribunal de Justicia y Tribunal de Primera Instancia. Síntesis de la legislación de la UE. Disponible en: <http://eur-lex.europa.eu/legalcontent/ES/TXT/?uri=URISERV:xy0018>. Acceso en: 24-09-2015.

${ }^{1344}$ LOZANO CUTANDA, Blanca. Derecho ambiental cit., p. 225.

${ }^{1345}$ El apartado 2 del artículo 175 del Tratado CE tiene su redacción así modificada:

“Artículo 2 (Tratado de Niza)

1. El Tratado Constitutivo de la Comunidad Europea queda modificado de conformidad con lo dispuesto en el presente artículo. El apartado 2 del artículo 175 se sustituye por el texto siguiente:

"2. No obstante el procedimiento de toma de decisiones contemplado en el apartado 1, y sin perjuicio del 
para aclarar su alcance ${ }^{1346}$. La regulación del Tratado de Ámsterdam es mantenida, sin embargo, la protección ambiental es tratada como un objetivo fundamental de los estados miembros. De este modo, el artículo 2 del Tratado CE precisa que se buscará un alta protección y mejora del medio ambiente, con la existencia de una política ambiental e introduce el principio de subsidiariedad.

También, se introduce la posibilidad de que la Comunidad Europea adopte medidas cuantitativas de gestión de los recursos hídricos, como se puede verificar en la línea 'b' -apartado 2 del artículo 175 (texto sustituido). Aquí, se observa la gran preocupación con el agua, desde la toma de decisiones hasta su acceso cualitativo y cuantitativo. Debido a eso, surge la necesidad de compilar todos los aspectos sociales, políticos y económicos, con inclusión de la eficiencia del desarrollo tecnológico, visando responder a su acceso equitativo.

Así, en el Tratado de Niza se hace presente la gestión del agua, como forma de garantizar la sostenibilidad en su uso, dando espacio a una legislación interna más firme en este aspecto. Debido a que las aguas de la Comunidad Europea están sometidas a la creciente presión que supone el continuo crecimiento de su demanda, de buena calidad y en cantidades suficientes para todos los usos, surge la necesidad de tomar medidas para proteger las aguas tanto en términos cualitativos como cuantitativos y garantizar

artículo 95, el Consejo, por unanimidad, a propuesta de la Comisión y previa consulta al Parlamento Europeo, al Comité Económico y Social y al Comité de las Regiones, adoptará:

a) disposiciones esencialmente de carácter fiscal;

b) las medidas que afecten a:

- la ordenación territorial;

- la gestión cuantitativa de los recursos hídricos o que afecten directa o indirectamente a la disponibilidad de dichos recursos;

- la utilización del suelo, con excepción de la gestión de los residuos.

c) las medidas que afecten de forma significativa a la elección por un Estado miembro entre diferentes fuentes de energía y a la estructura general de su abastecimiento energético. El Consejo, en las condiciones previstas en el párrafo primero, podrá definir las materias mencionadas en el presente apartado sobre las cuales las decisiones deban ser tomadas por mayoría cualificada." Disponible en: < http://www.boe.es/legislacion/enlaces/documentos/ue/Trat_niza_es.pdf>. Acceso en: 24-09-2015.

${ }^{1346}$ PLAZA MARTÍN, Carmen. La política y el derecho de medio ambiente de la Unión Europea: su desarrollo y evolución a través de los Tratados, in Estudios de la Unión Europea, L. Ortega Álvarez, y S. De La Sierra Morón (Directores), Centro de Estudios de la Unión Europea, Universidad de Castilla-La Mancha, 2011, p. 318. 
así su sostenibilidad. Éste es el reto de la Directiva Marco Europea del Agua $(\mathrm{DMA})^{1347}$.

Además, en el Acta Final del Tratado de Niza se enumera 24 Declaraciones adoptadas por la Conferencia, entre ellas, la Declaración 9, relativa al artículo 175 del Tratado Constitutivo de la Comunidad Europea, que en materia ambiental establece que: "Las Altas Partes Contratantes tienen la firme voluntad de velar por que la Unión Europea desempeñe una función impulsora de la protección del medio ambiente tanto en la Unión como en el plano internacional, para perseguir el mismo objetivo a escala mundial. Deberán aprovecharse plenamente todas las posibilidades que ofrece el Tratado con miras al logro de este objetivo, incluido el recurso a incentivos e instrumentos orientados al mercado y destinados a fomentar el desarrollo sostenible" ${ }^{, 1348}$.

En este período, en el año 2002, entró en vigor el Sexto Programa de Acción Comunitario en Materia de Medio Ambiente, llamado 'Medio Ambiente 2010: el futuro está en nuestras manos', adoptado por Decisión del Parlamento Europeo y del Consejo, de 22 de julio (Decisión n. ${ }^{\circ}$ 1600/2002/CE) ${ }^{1349}$, que se quedó vigente hasta finales de 2010. Este Programa encauza la acción comunitaria ambiental de acuerdo con las decisiones políticas y mantiene las pautas del Quinto Programa (para el período 1992$2000)^{1350}$.

${ }^{1347}$ La Directiva Marco Europea del Agua (DMA) nace como respuesta a la necesidad de unificar las actuaciones en materia de gestión de agua en la Unión Europea. Además, la DMA permitirá establecer unos objetivos medioambientales homogéneos entre los Estados Miembros para las masas de agua y avanzar juntos en su consecución, compartiendo experiencias. La DMA surge tras un largo periodo de gestación de más de cinco años, y que culminó con su entrada en vigor el 22 de diciembre de 2000, siendo fruto de un proceso extenso de discusión, debate y puesta en común de ideas entre un amplio abanico de expertos, usuarios del agua, medioambientalistas y políticos, que por consenso sentaron los principios fundamentales de la gestión moderna de los recursos hídricos y que constituyen hoy por hoy los cimientos de esta Directiva. Disponible en: $<$ http://www.magrama.gob.es/es/agua/temas/planificacion-hidrologica/marco-del-agua/default.aspx>. Acceso en: 24-09-2015.

${ }^{1348}$ Disponible en: < http://www.boe.es/legislacion/enlaces/documentos/ue/Trat_niza_es.pdf>. Acceso en: 24-09-2015.

${ }^{1349}$ DOCE L 242, 10-09-2002.

${ }^{1350}$ Conforme enseña Dionisio Fernández De Gatta Sánchez, El Séptimo Programa Ambiental de la Unión Europea, 2013-2020. Revista Aragonesa de Administración Pública ISSN 1133-4797, núm. 41-42, 
El Sexto Programa se concentra en cuatro ámbitos prioritarios, el cambio climático, la biodiversidad, el medio ambiente y la salud y la gestión sostenible de los recursos y de los residuos. Para cada uno de estos ámbitos, el Programa define el problema, marca los objetivos y metas a conseguir, y propone las acciones, medidas e instrumentos para alcanzarlos ${ }^{1351}$. Este Programa prevé la adopción de siete estrategias temáticas referidas a: contaminación atmosférica [COM (2005) 446 final]; medio marino [COM (2005) 504 final]; uso sostenible de los recursos [COM (2005) 670 final]; prevención y reciclado de residuos [COM (2005) 666 final]; uso sostenible de los pesticidas [COM (2006) 372 final]; protección de los suelos [COM (2006) 231 final]; y, medio ambiente urbano [COM (2006) 718 final].

En este sentido, Dionisio Fernández de Gatta Sánchez afirma que: “Además, el

Zaragoza, 2013, pp. 71-121, respecto al Sexto Programa, "El Programa pretende superar el marco estrictamente normativo y crear un enfoque estratégico, que deberá utilizar los diferentes instrumentos y medios para influir en la toma de decisiones de las empresas, de los ciudadanos y de las autoridades públicas. Esta nueva estrategia se articula en cinco ejes: mejorar la aplicación de la normativa vigente (mediante informes de aplicación, mejoras en la inspección, lucha contra los delitos ambientales, promoción de la actuación del Tribunal de Justicia y potenciación de la red IMPEL, sobre aplicación de la legislación); integrar el medio ambiente en otras políticas (mediante indicadores ambientales y mecanismos complementarios); colaborar con el mercado (mediante la publicación de los resultados ambientales de las empresas, sistemas de recompensas a las empresas respetuosas con el medio ambiente, fomento de los acuerdos voluntarios, política integrada de productos, etiquetas ecológicas, política de contratación pública «verde», responsabilidad ambiental); implicar a los ciudadanos y modificar sus comportamientos (mediante más información o mejoras del comportamiento), y tener en cuenta la incidencia ambiental de las decisiones sobre ordenación y gestión de territorio (mediante la aplicación de la Directiva EIA, integración del medio ambiente en otras políticas, difusión de las mejores prácticas de planificación $\quad$ sostenible, medidas agrarias)". Disponible en: $<$ http://www.aragon.es/estaticos/GobiernoAragon/Organismos/InstitutoAragonesAdministracionPublica/ Areas/03_Revista_Aragonesa_Formacion/02\%20Dionisio\%20Fernández.pdf>. Acceso en: 03-10-2015, pp. 76-78.

${ }^{1351}$ Conforme Blanca Lozano Cutanda, Derecho ambiental cit., pp. 281-282, "Interesa señalar, entre estos ámbitos de actuación prioritarios, el reconocimiento por primera vez en un Programa comunitario ambiental de la vinculación existente entre un medioambiente y la calidad de vida y la salud de las personas. En el ámbito 'medioambiental y salud' se persigue el objetivo de 'contribuir a un alto nivel de calidad de vida y bienestar social de los ciudadanos, proporcionando un medioambiente en el que los niveles de contaminación no tengan efectos perjudiciales sobre la salud humana y el medioambiente y fomentando un desarrollo urbano sostenible"”. 
Sexto Programa se concentra en cuatro ámbitos de acción prioritarios: cambio climático, naturaleza y biodiversidad; medio ambiente y salud, y gestión de los recursos naturales y de los residuos. Como novedad, el Programa incluye la obligación de elaborar Estrategias Temáticas, en ámbitos prioritarios, en las que se incluyan todas las medidas en cada ámbito de forma coherente e integrada, en materia de suelo, medio ambiente marino, plaguicidas, aire, medio ambiente urbano, residuos y gestión y uso sostenible de los recursos. Finalmente, el Programa prevé medidas de ámbito internacional y para conseguir una base científica sólida. De acuerdo con lo previsto en el propio Programa, la Comisión presentó la Comunicación relativa a «La Revisión intermedia del Sexto Programa de Acción Comunitario en materia de Medio Ambiente» [COM (2007) 225 final, Bruselas, 30.4.2007], que se estructura sobre los ámbitos relativos a la situación del medio ambiente; crecimiento, empleo y medio ambiente; evaluación de las prioridades del Programa (cambio climático; naturaleza y biodiversidad; medio ambiente, salud y calidad de vida; recursos naturales y residuos), y perspectivas para mejorar la elaboración de políticas (mejora de la cooperación internacional, principios del proceso «Legislar mejor» en la elaboración de políticas ambientales, promoción de la integración de las políticas, y mejora de la aplicación y el cumplimiento del propio texto). Seguidamente, la Comunicación menciona la Estrategia Revisada de Desarrollo Sostenible de 2006, en la que se confirma el desarrollo sostenible como un objetivo general de la Unión Europea que rige todas las políticas y actividades de la Unión, y añade que el Sexto Programa Ambiental proporciona la dimensión medioambiental de la Estrategia; asumiendo que «el concepto de desarrollo sostenible se basa en las sinergias que existen entre los elementos económico, social y medioambiental», y que «un medio ambiente limpio y saludable es esencial para el bienestar humano y para unas buenas condiciones sociales»; añadiendo que «unas políticas medioambientales bien diseñadas pueden contribuir también a otros objetivos, como incrementar la competitividad y promover el crecimiento económico y la creación de empleo». Además, el documento señala que el Programa tiene entre sus objetivos disociar el crecimiento económico de la degradación ambiental, considerando que sigue siendo el marco adecuado para la futura actuación" ${ }^{\prime 352}$.

${ }^{1352}$ FERNÁNDEZ DE GATTA SÁNCHEZ, Dionisio. El Séptimo Programa Ambiental de la Unión Europea, 2013-2020. Revista Aragonesa de Administración Pública ISSN 1133-4797, núm. 41-42, 
Importante destacar el avance de este Programa en relación al Quinto Programa, pues, conforme el artículo 2, apartado 1 de la Decisión n. ${ }^{\circ}$ 1600/2002/CE, el Sexto Programa está sujeto a los principios de subsidiariedad, de 'quien contamina paga', de cautela y de acción preventiva, y de corrección de la contaminación en su fuente. Además, en el considerando 4, afirma que subsisten algunos problemas ambientales que requieren nuevas actuaciones, y el considerando 33, marca la importancia de la información adecuada, transparente, actualizada y fácilmente comprensible ${ }^{1353}$.

Respecto al agua, el artículo 7, apartado 2.e, determina sobre su uso sostenible y su calidad elevada, no obstante, insiste en la adopción por los Estados miembros para transponer la Directiva Marco sobre Aguas, reforzando también la introducción de prioridades en materia de ambiente y salud en otras políticas y en la correspondiente legislación, visando garantizar la aplicación de la normativa correspondiente.

Todas esas acciones se acompañan de dos consideraciones, de un lado, la dimensión internacional de los problemas ambientales, y el papel que debe jugar la Unión Europea en éste ámbito; y, de otro, la necesidad de que la política ambiental comunitaria se funde en los más sólidos conocimientos científicos disponibles ${ }^{1354}$. Así,

Zaragoza, 2013, pp. 71-121. Además, el autor enseña que: "En cuanto a los planteamientos e instrumentos estratégicos del Programa, se destaca su carácter complementario de las Estrategias de Lisboa (en materia económica, social y tecnológica) y de Desarrollo Sostenible, la integración ambiental en otros ámbitos (singularmente, al destacarse su incidencia en los gastos de las políticas generales) y avanzar en la coherencia ambiental al elaborar los textos y acciones de las restantes políticas (particularmente, en las Políticas Agraria o de Cohesión), su contribución a la iniciativa «legislar mejor» y un mayor uso de los instrumentos de mercado en la política ambiental; si bien, se estima que ha de avanzarse más en la coherencia entre los distintos objetivos del propio Programa y en el proceso de adopción y ejecución de las acciones, en la mejora por los Estados Miembros en la aplicación de la legislación medioambiental europea y en completar los datos y estadísticas oficiales en la materia". Disponible

en: $<$ http://www.aragon.es/estaticos/GobiernoAragon/Organismos/InstitutoAragonesAdministracionPublica/ Areas/03_Revista_Aragonesa_Formacion/02\%20Dionisio\%20Fernández.pdf $>$. Acceso en: 03-10-2015, pp. $77-78$ y $80-81$.

$1353 \quad$ Disponible $\quad$ en: $\quad<\quad$ http://eur-lex.europa.eu/legalcontent/ES/TXT/PDF/?uri=CELEX:32002D1600\&from=ES>. Acceso en: 05-10-2015.

${ }^{1354}$ ORTEGA ÁlVAREZ, Luis, in ORTEGA ÁlVAREZ, Luis, (Coordinador), Lecciones de Derecho del cit., p. 74. 
se puede decir que las Directivas sobre agua aprobadas en ese periodo fueron en el sentido de ampliar y mejorar las anteriores.

En diciembre de 2003, hubo la primera Revisión de la Política de Medio Ambiente, realizada por la Comisión, en la que se analizó el nuevo contexto de la política ambiental de la Unión Europea desde la entrada en vigor del Sexto Programa. Después de haber examinado las principales amenazas ambientales y las respuestas de la política comunitaria a las mismas, puso el acento en que es necesario acelerar las reformas para mejorar el estado del ambiente a escala europea e internacional ${ }^{1355}$.

En marzo de 2003, con el fin de concretar los objetivos fijados en Johannesburgo y de consolidar las prioridades de la Estrategia de la Unión en pro del desarrollo sostenible, el Consejo Europeo formuló unas prioridades de actuación, centradas, entre otras cosas, en el fomento del comercio sostenible y equitativo, la continuación de las iniciativas de la Unión "Agua para la vida" y "Energía para la erradicación de la pobreza y el desarrollo sostenible", la gestión sostenible de los recursos naturales, el fomento de unos modos de producción y consumo sostenibles y la gobernanza internacional en asuntos de medio ambiente ${ }^{1356}$.

En diciembre de ese mismo año, al examinar los progresos registrados en el cumplimiento de los compromisos asumidos por la Unión Europea en aquel momento, la Comisión Europea repasa las medidas tomadas tanto dentro como fuera de las fronteras de la Unión. Constatando así, que es indispensable conseguir una mayor coherencia política, a lo que contribuirá una evaluación de los diferentes impactos internos y externos de las propuestas políticas de la UE. La gestión sostenible de los recursos naturales y el fomento del consumo y la producción sostenibles también son indispensables para alcanzar los objetivos de la Cumbre. Por último, la ampliación de la UE constituye una importante aportación independiente al desarrollo sostenible.

En 2004, la Unión Europea crea un Fondo para el agua para los países de África, del Caribe y del Pacífico (ACP) firmantes del Acuerdo de Cotonú. Dotado con un presupuesto de 500 millones de euros, este Fondo pretende estimular la mejora del

\footnotetext{
${ }^{1355}$ Sobre el tema, vide Blanca Lozano Cutanda, Derecho Ambiental cit., pp. 214-220.

${ }^{1356}$ Un año después de la Cumbre Mundial sobre el Desarrollo Sostenible. Síntesis de la legislación de la UE. Disponible en: < http://eur-lex.europa.eu/legal-content/ES/TXT/?uri=URISERV:128142>. Acceso en: 24-09-2015.
} 
acceso al agua potable y del saneamiento para las poblaciones desfavorecidas de estos países abordando de forma activa la cuestión del déficit de financiación ${ }^{1357}$.

El 20 de diciembre de 2005, los Presidentes de la Comisión, del Parlamento y del Consejo firmaron la nueva declaración de política de desarrollo de la UE titulada 'El consenso europeo sobre desarrollo, ${ }^{1358}$. Este consenso define, por primera vez en cincuenta años de cooperación, el contexto de principios comunes en el que la UE y sus Estados miembros aplicarán sus respectivas políticas de desarrollo con un espíritu de complementariedad. Considera también que el objetivo fundamental de reducción de la pobreza abarca los objetivos complementarios que son el fomento de la buena gobernanza y el respeto de los derechos humanos, valores comunes que constituyen los cimientos de la UE. La lucha contra la pobreza implica también alcanzar un equilibrio entre las actividades vinculadas al desarrollo humano, la protección de los recursos naturales y el crecimiento económico, y la creación de riqueza en favor de las poblaciones pobres ${ }^{1359}$.

En 2006, la Comunicación de la Comisión al Consejo y al Parlamento Europeo, de 22 de junio de 2006, Informe anual 2006 sobre la Política de Desarrollo de la Comunidad Europea y la ejecución de la ayuda exterior en 2005, en el que la UE se comprometió a duplicar de aquí a 2010 su nivel actual de ayuda oficial al desarrollo $(\mathrm{AOD})^{1360}$.

En 2007, la Comunicación de la Comisión al Parlamento Europeo, al Consejo, al Comité Económico y al Comité de las Regiones, de 30 de abril, relativa a la revisión intermedia del Sexto Programa de Acción Comunitario en Materia de Medio Ambiente ${ }^{1361}$, siguiendo las indicaciones del Programa, una vez transcurridos cuatro años desde su adopción se llevó a cabo y se afirmó que: “se ha progresado

1357 COM (2004) 43 final. Disponible en: < http://eur-lex.europa.eu/legalcontent/ES/TXT/?uri=celex:52004DC0043>. Acceso en: 24-09-2015.

${ }^{1358}$ Diario Oficial C 46 de 24 de febrero de 2006.

${ }^{1359}$ El consenso europeo sobre desarrollo. Síntesis de la legislación de la UE. Disponible en: < http://eurlex.europa.eu/legal-content/ES/TXT/?uri=uriserv:r12544>. Acceso en: 24-09-2015.

${ }^{1360}$ COM (2006) 43 final. Disponible en: < https://ec.europa.eu/europeaid/sites/devco/files/annual-report2006-highlights-ec-development-policy-external-assistance-com2006326_es_5.pdf>. Acceso en: 24-092015.

${ }^{1361}$ COM (2007) 225 final. Disponible en: < http://ec.europa.eu/transparency/regdoc/rep/1/2007/ES/12007-225-ES-F1-1.Pdf>. Acceso en: 24-09-2015. 
considerablemente en ámbitos como la reducción de las emisiones de gases de efecto invernadero, la conservación de los humedales, las practicas de silvicultura sostenibles y la gestión de los residuos. Sin embargo, la conclusión general es que, a pesar de los progresos realizados, la magnitud de muchos problemas medioambientales también está aumentando y Europa no se encuentra aún en la senda de un desarrollo verdaderamente sostenible". La Comisión procede a la evaluación de los cuatro ámbitos prioritarios del Programa de Acción y en cada uno de ellos destaca determinados desafíos que deben abordarse. Además, se presenta una lista de mejoras estratégicas de la política de medio ambiente, lo que significa en particular mejorar la cooperación internacional.

En el punto 4.3 reservado para el 'Medio Ambiente, Salud y Calidad de Vida' afirma que deben intensificarse los esfuerzos relativos a la aplicación nacional de la DMA, para lo cual es preciso que las autoridades nacionales prevean financiación suficiente. Asimismo afirma que la mejora de la aplicación de la Directiva sobre el tratamiento de las aguas residuales urbanas y de la legislación sobre aguas subterráneas reducirá sustancialmente las emisiones de fuentes puntuales.

También en el año 2007, la Comunicación de la Comisión, de 22 de octubre, titulada Informe provisional sobre la Estrategia de Desarrollo Sostenible $2007^{1362}$ considera que: "La situación relativa a recursos específicos como agua, aire y suelo, así como con respecto a la biodiversidad y a la pesca es diversa y compleja y a menudo carecemos de datos para el conjunto de la UE-27. Entre 2000 y 2003, la mayoría de los Estados miembros para los cuales se dispone de datos parecen haber reducido la presión sobre los recursos hídricos, disminuyendo su extracción de agua subterránea. La situación del agua de superficie no está tan clara. El agotamiento de las poblaciones de peces sigue siendo un problema y gran parte de las capturas de pescado en aguas gestionadas por la UE procede de existencias que ya están por debajo de sus límites biológicos seguros, particularmente para las especies de gran valor (pescados blancos). (...) Las iniciativas clave de la UE para estimular la conservación de los recursos y la biodiversidad incluyen: la aplicación en curso de las Directivas marco sobre calidad del aire y del agua así como de las Directivas sobre aves y hábitats; la aplicación del nuevo Fondo Europeo de Pesca; la Estrategia Temática para la Protección del Suelo y la iniciativa relativa a la gestión, la gobernanza y el comercio en el ámbito forestal

${ }^{1362}$ COM (2007) 642 final. 
(FLEGT). (...) La mayor parte de los Estados miembros han hecho esfuerzos para mejorar la gestión y evitar la sobre explotación de los recursos naturales renovables, en especial en las áreas de agricultura, silvicultura y pesca, promoviendo la biodiversidad y la gestión del agua y de los residuos. Todos están aplicando activamente las Directivas marco sobre residuos, calidad del aire y del agua, aunque lógicamente la atención prioritaria difiere según el Estado miembro, ya que los nuevos, por ejemplo, están más afectados por el tratamiento de las aguas residuales" ${ }^{\prime 1363 .}$

Respecto a los retos y desafíos inmediatos del Derecho Ambiental, Jésus Jordano Fraga afirma que: "Si el problema fundamental del Derecho ambiental en muchos países es su falta de eficacia real, las líneas futuras deben orientarse a mecanismos que garanticen la efectiva aplicación del mismo. La resolución COM 2008/773 18 de noviembre 2008 de la Comisión al Parlamento, al Consejo y CES sobre la aplicación de la legislación ambiental europea ha señalado tres problemas en dicha aplicación :1) falta capacidad administrativa; 2)falta inversión y 3) falta de conocimientos; Como soluciones propone fundamentalmente tres líneas de acción: la prevención de las infracciones; mejorar la información y la importancia ciudadanos. Un último documento europeo, la Comunicación COM 2012/95, de 7 de marzo de 2012, de la Comisión al Parlamento, al Consejo y CE, pide sacar mejor partido a las medidas ambientales. El argumento es economicista: el coste de no aplicar es mayor: 50.000 millones de euros y calcula la pérdida de 400.000 empleos en residuos. El problema, según la Comunicación COM 2012/95, de 7 de marzo de 2012, de la Comisión al Parlamento, al Consejo y CE es la aplicación, por ello las medidas pasan por mejorar acceso justicia, la información incluyendo jurídica, mejorar los sistema de denuncias, inspecciones, y establecer criterios marco para la actuación para fiscales en infracciones administrativas y penales"1364.

Sobre los avances políticos realizados a escala europea tras la adopción de la estrategia europea en favor del desarrollo sostenible, la Comunicación de la Comisión al Parlamento Europeo, al Consejo, al Comité Económico y Social Europeo y al Comité

${ }^{1363}$ Disponible en: < http://eur-lex.europa.eu/legal-content/ES/TXT/?uri=celex:52007DC0642>. Acceso en: 23-09-2015.

1364 JORDANO FRAGA, Jésus. El futuro del Derecho Ambiental. Disponible en: $<\mathrm{http} / /$ huespedes.cica.es/gimadus/24/01_el_futuro_del_derecho_medioambiental.html $>$. Acceso en: 1711-2015. 
de las Regiones, de 24 de julio de 2009, titulada 'Incorporación del desarrollo sostenible en las políticas de la UE: informe de 2009 sobre la estrategia de la Unión Europea para el desarrollo sostenible"1365, afirma que: "A este respecto, la Unión Europea desempeña un papel primordial en la lucha contra el cambio climático y la promoción de una economía con bajas emisiones de carbono. Sin embargo, aún son necesarios avances en materia de desarrollo sostenible, por lo que el informe lanza una reflexión sobre la forma de mejorar la estrategia. Es necesario que esta estrategia esté mejor coordinada con las demás estrategias políticas europeas, en particular con la Estrategia de Lisboa para el crecimiento y el empleo. Su puesta en práctica debe racionalizarse mejor con el fin de mejorar su gestión y sus resultados efectivos". Además informa que: "Mientras que ha habido progresos positivos por lo que se refiere al estado y el uso del agua y del aire, la actividad humana continúa amenazando la biodiversidad y los hábitats naturales"1366.

Por fin, los 'restos de Ámsterdam' deberían haberse resuelto en el Tratado de Niza. Sin embargo, este Tratado solo pudo preparar de manera parcial a la Unión Europea para las importantes ampliaciones al este y al sur que tuvieron lugar el 1 de mayo de 2004 y el 1 de enero de 2007. Así pues, a raíz de las cuestiones planteadas en

${ }^{1365}$ COM (2009) 400 final. Sobre eso, Dionisio Fernández de Gatta Sánchez, Unión Europea: Liderazgo en cambio climático, mirando al futuro, en LOPÉZ RAMÓN, Fernando (coord.) y otros, Observatorio de Politicas Ambientales 2011, Ed. Thomson Reuters-Aranzadi, Cizur Menor (Navarra), 2011, pp. 57-76 afirma que: "De la misma forma, la Estrategia de Desarrollo Sostenible de la Unión ha seguido su curso, una vez publicado en 2009 el informe de aplicación [COM (2009) 400 final], que es acogido satisfactoriamente por el dictamen del Comité Económico y Social Europeo, de 5 de noviembre de 2009 (DOUE C 128, 18 mayo 2010), reiterando las áreas prioritarias sugeridas por la Comisión (economía de baja emisión de carbono, biodiversidad, agua y recursos naturales, inclusión social y dimensión internacional del desarrollo sostenible), y avalado por el Informe de la Presidencia sobre la misma de 1 de Diciembre (Consejo de la UE, doc. 16818/09, Bruselas), y confirmado por el Consejo Europeo de 10 y 11 de diciembre de 2009 (doc. EUCO 6/09, Bruselas, 11 diciembre 2009). El año 2010 ha sido el primero en que los nuevos Tratados de la Unión han estado en vigor. Aplicación que se ha producido en materia ambiental con absoluta normalidad, mencionándose las nuevas bases normativas en los distintos textos aprobados. No obstante, ha sido visible cierta tensión en algunas reuniones internacionales en relación con la dirección de los aspectos exteriores de la política de la Unión, no haciéndose tangible una única voz europea en las mismas". pp.58-59.

1366

Disponible

en:

http://eur-

lex.europa.eu/LexUriServ/LexUriServ.do?uri=COM:2009:0400:FIN:ES:PDF>. Acceso en: 23-09-2015. 
la Declaración de Laeken, de 15 de diciembre de 2001, la Convención sobre el futuro de Europa se esforzó por crear un nuevo fundamento jurídico para la Unión bajo la forma del Tratado por el que se establece una Constitución para Europa, que no fue ratificado a causa del resultado negativo de los referendos celebrados en dos Estados miembros ${ }^{1367}$.

Sobre el Tratado de Niza, Dionisio Fernández de Gatta Sánchez enseña que: "Posteriormente se inició un proceso de reforma que se plasmó en el Tratado por el que se establece una Constitución para Europa, firmado en Roma el 29 de octubre de 2004, pero que no será aprobado por los Estados Miembros (después de la negativa en referéndum de Francia y Países Bajos). No siendo tan innovador como se señaló, el texto incluye el desarrollo sostenible y la protección del medio ambiente entre los objetivos de la Unión, integra la protección del medio ambiente en la Carta de Derechos Fundamentales de la Unión, regula la distribución de competencias entre la Unión y los Estados Miembros, incluyendo la política ambiental entre las competencias compartidas, ratifica las cooperaciones reforzadas y, en la larguísima Parte III del Tratado, se regula la Política Ambiental sin introducir modificaciones relevantes respecto a los Tratados vigentes. Además, sorprendentemente, se mantenía la vigencia del Tratado de la Comunidad Europea de la Energía Atómica"1368.

${ }^{1367}$ El Tratado de Niza y la Convención sobre el futuro de Europa. consultado en el sitio de la Unión Europea, Parlamento Europeo, Disponible en: <http:/www.europarl.europa.eu/ftu/pdf/es/FTU_1.1.4.pdf >. Acceso en: 24-09-2015.

${ }^{1368}$ FERNÁNDEZ DE GATTA SÁNCHEZ, Dionisio. Sistema Jurídico-Administrativo de protección del medio cit., pp. 74-75. Importante destacar que se añadió un apartado al artículo 7 del TUE, con vistas a abordar los casos en los que, sin existir una vulneración evidente de los derechos fundamentales, existiera un «riesgo claro» de que pudiera llegar a producirse dicha violación. El Consejo, por mayoría de cuatro quintos de sus miembros y previo dictamen conforme del Parlamento Europeo, debía constatar la existencia de tal riesgo y dirigir recomendaciones adecuadas al Estado miembro en cuestión. Se proclamó una Carta de los Derechos Fundamentales no vinculante. El Tratado de Niza y la Convención sobre el futuro de Europa. consultado en el sitio de la Unión Europea, Parlamento Europeo, Disponible en: $<$ http://www.europarl.europa.eu/ftu/pdf/es/FTU_1.1.4.pdf >. Acceso en: 24-09-2015. Sobre la Carta de los Derechos Fundamentales, esta enumera los derechos básicos que la Unión ha de respetar, así como los Estados miembros cuando aplican el Derecho de la Unión. Se trata de un instrumento jurídicamente vinculante, elaborado para reconocer formalmente y dar visibilidad al papel que desempeñan los derechos fundamentales en el ordenamiento jurídico de la Unión. La Carta de los Derechos Fundamentales de la 
Delante de todo eso, se puede decir que la historia de la Unión Europea no ha discurrido siempre por una senda tranquila. El rechazo de la Constitución Europea en los referendos francés y holandés de mayo y junio de 2005, provocó una paralización en el proceso de ratificación de varios países, a pesar de que la mayoría de los países europeos habían ratificado ya el texto. Después de dos años de reflexión, y a la vista de que era necesario retomar el impulso europeo que había quedado plasmado en la Constitución Europea, en el último Consejo Europeo de la Presidencia alemana de junio de 2007, se estableció un mandato detallado para la elaboración de un nuevo Tratado antes de que finalizara el año. El rechazo al Tratado Constitucional provocó una crisis institucional en la Unión Europea que se ha superado con la ratificación y entrada en vigor del Tratado de Lisboa ${ }^{1369}$.

\subsubsection{EI Tratado de Lisboa y el desarrollo sostenible}

El 13 de diciembre de 2007, los Jefes de Estado y de Gobierno reunidos en la capital lusa, aprobaron y firmaron el Tratado de Lisboa, un tratado que recoge la mayoría de los avances establecidos en el Tratado Constitucional ${ }^{1370}$.

Tras un largo y complejo proceso de ratificación ${ }^{1371}$, el 1 de diciembre de 2009, el Tratado de Lisboa entró en vigor. Este nuevo texto "inaugura la nueva Europa del

Unión Europea. Disponible en: < http://www.europarl.europa.eu/ftu/pdf/es/FTU_1.1.6.pdf $>$. Acceso en: 24-09-2015.

${ }^{1369}$ Disponible en: http://www.hablamosdeeuropa.es/panorama/historia/constitucion-a-lisboa. Acceso en: 24-09-2015.

${ }^{1370}$ Conforme Blanca Lozano Cutanda, Derecho ambiental cit., pp. 209-210, "En el plano político, tras el fracaso de la Constitución Europea por el 'no' de los franceses y holandeses, el Consejo Europeo de 21 y 22 de junio de 2007 decidió convocar una nueva conferencia intergubernamental (CIG) encargada de redactar y adoptar un nuevo Tratado para la Unión Europea. Este Tratado de Reforma, más conocido como 'Tratado de Lisboa', fue firmado el 13 de diciembre de 2007 y, tras superar los obstáculos que se presentaron en el proceso de ratificación (ocasionados por el resultado contrario a la ratificación del referéndum celebrado en Irlanda, primero, y por las objeciones planteadas por el presidente checo, después, lo que exigió sendas declaraciones del Consejo Europeo asumiendo sus reivindicaciones), entró finalmente en vigor el 1 de diciembre de 2009".

${ }^{1371}$ Como bien enseña Dionisio Frenández de Gatta Sánchez, Política ambiental de la Unión Europea: las insuficiencias estatales para garantizar el cumplimiento de las exigencias comunitarias, en LOPÉZ 
siglo XXI", y refuerza la democracia, la transparencia, la dimensión exterior de la Unión $^{1372}$.

RAMÓN, Fernando (coord.) y otros, Observatorio de Políticas Ambientales 2009, Ed. Thomson ReutersAranzadi, Cizur Menor (Navarra), 2009, pp. 71-101, "Una vez firmado, el Consejo Europeo de Bruselas, celebrado el día 14 de diciembre de 2007 (Conclusiones de la Presidencia, doc. 16616/07, Bruselas, 14.12.2007), se congratuló del acuerdo alcanzado en Lisboa e hizo un llama- miento para una rápida ratificación del nuevo Tratado con el objeto de que pudiera entrar en vigor el 1 de enero de 2009. Sin embargo, el referéndum celebrado en Irlanda el 12 de junio de 2008 fue negativo a la ratificación del nuevo Tratado (con un 53'4\% de los votos), provocando que otros Estados Miembros paralizaran sus respectivos procesos de ratificación (como la República Checa), imposibilitando cumplir la fecha prevista para su entrada en vigor e introduciendo ciertas dudas y zozobras en el proceso de integración europea. Ante esta situación, el Consejo Europeo de Bruselas, de 19 y 20 de junio de 2008 (Conclusiones de la Presidencia, doc. 11018/1/08, Rev. 1, Bruselas, 17.7.2008), tomó nota del resultado del mismo y acordó volver a tratar el asunto en la sesión de octubre, asumiendo las gestiones a realizar durante este período de tiempo por parte de Irlanda. El Consejo Europeo de Bruselas, de 15 y 16 de octubre de 2008 (Conclusiones de la Presidencia, doc. 14368/08, Concl. 4, Bruselas, 16.10.2008), escuchó el informe de situación del Primer Ministro irlandés, Sr. Cowen, y acordó abordar la cuestión en la sesión de diciembre. En efecto, el Consejo Europeo de Bruselas, de 11 y 12 de diciembre de 2008 (Conclusiones de la Presidencia, doc. 17271/08, Concl. 5, Bruselas, 12.12.2008), toma nota cuidadosamente de ciertas preocupaciones de Ir- landa (en cuestiones institucionales y materiales del proceso europeo), garantizando su seguimiento y asumiendo el compromiso de Irlanda, por ello, de conseguir la ratificación del Tratado antes del final del mandato de la actual Comisión (31 de octubre de 2009). Por tanto, la entrada en vigor del Tratado de Lisboa queda pendiente de su ratificación y entrada en vigor hasta, al menos, el año 2009". pp. 74-75.

${ }^{1372}$ Conforme Dionisio Fernández de Gatta Sánchez, Sistema Jurídico-Administrativo de protección del medio cit., p. 77, "Fracasado el Tratado Constitucional Europeo de 2004, y de acuerdo con la 'Declaración de Berlín', de 25 de Marzo de 2007, en la conmemoración del 50 Aniversario de los Tratados de Roma de 1957, se inicia una nueva etapa del proceso europeo con la solemne firma del Tratado de Lisboa por el que se modifican el Tratado de la Unión Europea y el Tratado constitutivo de la Comunidad Europea, que se llevó a cabo en la capital portuguesa el 13 de Diciembre de 2007 (DOUE C 306, 17.12.2007, corrección de errores en DOUE C 290, 30.11.2009), y que finalmente, y después de un complejo proceso de ratificación, entró en vigor el 1 de Diciembre de 2009 (Instrumentos de Ratificación del Reino de España de 26 de Septiembre de 2008, BOE de 27 de Noviembre de 2009; corrección de errores en BOE de 16 de Febrero de 2010). Las versiones consolidadas de los nuevos Tratados de la Unión Europea y de Funcionamiento de la Unión Europea y de la Carta de Derechos Fundamentales de la Unión Europea se han publicado en DOU C 326, 26.10.2012". como bien comenta Blanca Lozano Cutanda, Derecho ambiental cit., p. 210, "El Tratado de Lisboa vino a recoger en gran medida, mutatis mutandis, una parte sustancial de las reformas que incorporaba la Constitución Europea, si bien 
El Tratado de Lisboa diferentemente de la Constitución europea, no unifica los Tratados, por lo que se mantiene los tres existentes con las modificaciones que introduce este nuevo instrumento, aunque el Tratado de la Comunidad Europea pasará a denominarse Tratado de Funcionamiento de la Unión Europea, unido a él, se mantiene el Tratado de Unión Europea y el Tratado constitutivo de la Comunidad Europea de la Energía Atómica, y el término 'Unión' sustituye a lo largo del texto de los Tratados el término 'Comunidad', reconociéndose expresamente personalidad jurídica a la Unión Europea.

Una de las diferencias más importantes del Tratado de Lisboa con el Tratado por el que se establecía una Constitución para Europa es que ya no se trata de un tratado nuevo que refunda la Unión, sino que vuelve a la fórmula clásica de Tratado de reforma que incorpora novedades y modificaciones a los Tratados fundacionales de la Unión y de la Comunidad Europea. Se mantiene, además, la dualidad de Tratados (Tratado de Funcionamiento de la Unión Europea ${ }^{1373}$ y Tratado Constitutivo de la Comunidad

despojadas de toda etiqueta o elemento con 'tinte' constitucional. Además, la autora citando R. Alonso, Sistema Jurídico de la Unión Europea, Thomson-Civitas, 2a ed., Madrid:2010, enuncia que: "la operación de Lisboa mantuvo prácticamente intacto el cuerpo de la Constitución Europea, la cual fue desnudada, eso sí, de revestimiento constitucional, de tal forma que no solo cayó la propia denominación de ‘Constitución' europea, sino que también lo hicieron los símbolos y la terminología que pudieran hacer pensar en la creación de una suerte de macro-Estado (desapareciendo, por ejemplo, la denominación de 'Ministros de Asuntos Exteriores de la Unión')".

1373 Conforme destaca Dionisio Fernández de Gatta Sánchez, Sistema Jurídico-Administrativo de protección del medio cit., p. 78, "No obstante, las mayores novedades se han plasmado en el destacable Tratado de Funcionamiento de la Unión Europea, que tiene el mismo valor jurídico que el anterior y que constituye a su mismo nivel un texto complementario imprescindible. Su importancia deriva de que es el texto que regula detalladamente las políticas y acciones de la Unión, y su funcionamiento institucional. Así, entre las novedades del Tratado sobresale la regulación de la distribución de competencias entre la Unión y los Estados Miembros; pasando posteriormente a regular con detalle las distintas políticas y acciones de la Unión (incluyendo las nuevas políticas en materia de energía, turismo, protección civil y cooperación administrativa), el sistema institucional y de funcionamiento de la misma, para finalizar con las disposiciones financieras". Más adelante, el autor habla de las reformas que el Tratado de Funcionamiento de la Unión Europea introduce y que tienen el mismo nivel jurídico que el Tratado anterior (arts. 1-TUE y 1-TFUE). En este mismo sentido, comenta el autor en su artículo titulado Unión Europea: la política ambiental tras la entrada en vigor del Tratado de Lisboa, en LOPÉZ RAMÓN, Fernando (coord.) y otros, Observatorio de Políticas Ambientales 2010, Ed. Thomson Reuters-Aranzadi, Cizur Menor (Navarra), 2010, pp. 59-80. 
Europea de la Energía Atómica) frente a la refundición que pretendía realizar la Constitución Europea. Como consecuencia, el nuevo texto del Tratado resulta tan complejo y difícil de manejar como las reformas anteriores (si bien se utilizan textos consolidados, elaborados por la propia Comisión europea pero sin carácter oficial) ${ }^{1374}$.

Sin embargo, el Tratado de Lisboa aumentó la capacidad de la Unión Europea y de su Parlamento para actuar y pronunciarse. Amplió las plenas competencias legislativas del Parlamento a más de 40 nuevos ámbitos, como la agricultura, la seguridad energética, la inmigración, la justicia y los fondos de la Unión Europea, y lo puso en pie de igualdad con el Consejo, que representa a los Gobiernos de los Estados miembros. El Parlamento también obtuvo competencias para aprobar la totalidad del presupuesto de la Unión Europea junto con el Consejo ${ }^{1375}$.

Además, el Tratado de Lisboa no sólo concedió al Parlamento las mismas competencias legislativas que al Consejo, sino que también le otorgó poder para establecer el rumbo político de Europa. En virtud de las modificaciones del Tratado, el Parlamento elige al Presidente de la Comisión, el órgano ejecutivo de la Unión Europea, y esta decisión debe reflejar los resultados de las elecciones europeas y, por lo tanto, de la elección de los votantes.

${ }^{1374}$ LOZANO CUTANDA, Blanca. Derecho ambiental cit., p. 210. Dionisio Fernández de Gatta Sánchez, Sistema Jurídico-Administrativo de protección del medio cit., p. 77 afirma que: "El Tratado de Lisboa consta únicamente de siete artículos (y 13 Protocolos y 65 Declaraciones, complejos y variados), aunque su complejidad proviene de los dos primeros preceptos: el art. 1 modifica el tratado de la Unión Europea (TUE) y el art. 2 modifica de forma importante el anterior Tratado de la Comunidad Europea, que ahora pasa a denominarse Tratado de Funcionamiento de la Unión Europea (TFUE), siendo ambos, con el mismo valor y nivel jurídico, el fundamento de la Unión (arts. 1-3 ${ }^{\circ}$-TUE y 1-TFUE). Por otra parte, y sorprendentemente, se mantiene el Tratado de la Comunidad de la Energía Atómica (modificándose en el Protocolo n. ${ }^{\circ} 2$ anejo al Tratado de Lisboa). Asimismo, debe destacarse que se reconoce la personalidad jurídica de la Unión (art. 47-TUE).

${ }^{1375}$ Los diputados al Parlamento Europeo, a los que se les otorgó el poder de anular los acuerdos internacionales, no dudaron en utilizarlo para suspender el controvertido Acuerdo Comercial de Lucha contra la Falsificación (ACTA) que muchos temían que restringiría las libertades fundamentales. Este episodio demostró que, como resultado del aumento de sus competencias, las decisiones tomadas por los diputados tienen un impacto aún mayor en la vida cotidiana de los europeos. Disponible en: $<$ http://www.europarl.europa.eu/aboutparliament/es/20150201PVL00008/El-Tratado-de-Lisboa>. Acceso en: 26-09-2015. 
Por ser la única institución de la Unión Europea elegida directamente por los ciudadanos, el Parlamento tiene las competencias y la responsabilidad de exigir que las instituciones de la Unión Europea rindan cuentas. El Parlamento es el guardián de la Carta de los Derechos Fundamentales ${ }^{1376}$, integrada en el Tratado de Lisboa, así como

${ }^{1376}$ La Carta de los Derechos Fundamentales de la Unión es un texto que reúne los derechos fundamentales en vigor en la Unión Europea y que fue aceptada solemnemente por los Presidentes del Parlamento Europeo, de la Comisión y del Consejo, en la Conferencia Intergubernamental (CIG) celebrada en Niza em 2000. Se optó entonces, sin embargo, por no incluir la Carta en el texto del Tratado de Niza - aneja al Acta final se insertó una declaración en la que se hacía constar la intención de tomar una decisión en un marco de reforma más amplio - careciendo así, de valor jurídico vinculante, sin embargo, estaba dotada de eficacia interpretativa, siendo sido mencionada por Sentencias del TJUE (como la sentencia de 27 de junio de 2006, caso Parlamento Europeo v. Consejo, relativa a la Directiva 2003/86/CE sobre el derecho de reagrupación familiar) y en las exposiciones de motivos de normas, tanto comunitarias como de los Estados miembros, que inciden en la regulación de derechos fundamentales. Posteriormente, la Carta fue adaptada y reafirmada solemnemente en la ciudad de Estrasburgo, Francia, el 12 de diciembre de 2007 y finalmente el Tratado de Lisboa ha incorporado al Tratado de Funcionamiento de la Unión Europea un precepto (art. 6.1) en el que se afirma que 'la Unión reconoce los derechos, libertades y principios enunciados en la Carta de los Derechos Fundamentales de la Unión Europea (...), la cual tendrá el mismo valor jurídico que los Tratados. La Carta de los Derechos Fundamentales. Síntesis de la legislación de la UE. Disponible en: < http://eur-lex.europa.eu/legalcontent/ES/TXT/?uri=uriserv:133501> y también en: $<$ http://europa.eu/pol/pdf/consolidatedtreaties_es.pdf $>$. Ambos con acceso en: 26-09-2015. Además, en el propio el sitio del Parlamento Europeo, en las fichas técnicas sobre la Unión Europea, La Carta de los Derechos Fundamentales de la Unión Europea, dispone que: "La Carta de los Derechos Fundamentales se divide en siete títulos, seis de los cuales enumeran tipos específicos de derechos, mientras que el último define el ámbito de aplicación de la Carta y los principios que rigen su interpretación. Una característica significativa de la Carta es su innovador método de agrupación de los derechos, que abandona la tradicional distinción entre derechos civiles y políticos, por una parte, y derechos económicos y sociales, por otra. Al mismo tiempo, la Carta distingue claramente los derechos de los principios. Estos últimos, con arreglo al artículo 52, apartado 5, de la Carta, deben aplicarse mediante actos legislativos adicionales y solo podrán alegarse ante los tribunales en los casos relativos a la interpretación y legalidad de dichos actos.

La parte dispositiva de la Carta presenta la siguiente división:

Título I (Dignidad): confirma los derechos a la dignidad humana, la vida y la integridad de la persona, y reafirma la prohibición de la tortura y la esclavitud.

Título II (Libertades): confirma los derechos a la libertad y el respeto de la vida privada y familiar, el derecho a contraer matrimonio y a fundar una familia, y los derechos a la libertad de pensamiento, conciencia y religión, expresión y reunión; afirma asimismo los derechos a la educación, a trabajar, a la propiedad y de asilo. 
del derecho de iniciativa ciudadana de reciente creación, que permite que los ciudadanos soliciten nuevas propuestas políticas si un millón de personas han firmado una petición en tal sentido ${ }^{1377}$.

Así, este Tratado fortalece al Parlamento Europeo, amplía la responsabilidad de los Parlamentos nacionales en la determinación del curso de la política europea y otorga a los ciudadanos europeos el derecho de iniciativa, reforzando los poderes del Parlamento, convirtiéndolo en un colegislador plenamente reconocido con mayores

Título III (Igualdad): reafirma el principio de igualdad y no discriminación, así como el respeto de la diversidad cultural, religiosa y lingüística; también protege concretamente los derechos del niño, las personas mayores y las personas discapacitadas.

Título IV (Solidaridad): garantiza la protección de los derechos de los trabajadores, incluidos el derecho de negociación y acción colectiva y el derecho a unas condiciones de trabajo justas y equitativas; reconoce asimismo derechos y principios adicionales, como el derecho a la seguridad social y a la protección de la salud y los principios de protección del medio ambiente y de los consumidores.

Título V (Ciudadanía): enumera los derechos de los ciudadanos de la Unión, a saber, el derecho de sufragio activo y pasivo en las elecciones al Parlamento Europeo y en las elecciones municipales, el derecho a una buena administración y los derechos de petición, acceso a los documentos, protección diplomática y libertad de circulación y residencia (2.1.1).

Título VI (Justicia): reafirma los derechos a la tutela judicial efectiva y a un juez imparcial, el derecho de defensa, los principios de legalidad y de proporcionalidad de los delitos y las penas y el derecho a no ser juzgado o condenado penalmente dos veces por la misma infracción.

La Carta reafirma, en su mayor parte, los derechos que ya existían en los Estados miembros y que han sido reconocidos como parte de los principios generales del Derecho de la Unión, pero innova en algunos aspectos. Por ejemplo, se prohíbe explícitamente la discriminación por razón de discapacidad, edad y orientación sexual. Además, la Carta incluye una serie de derechos «modernos», tal como ilustra la prohibición de la clonación reproductora de seres humanos.

No obstante, el mayor valor de la Carta no reside en su carácter innovador, sino en el reconocimiento expreso del papel capital que los derechos fundamentales desempeñan en el ordenamiento jurídico de la Unión. Así pues, la Carta reconoce de forma expresa que la Unión es una comunidad de derechos y de valores y que los derechos fundamentales de los ciudadanos ocupan un lugar central en la Unión Europea". Disponible en: $<$ http://www.europarl.europa.eu/atyourservice/es/displayFtu.html?ftuId=FTU_1.1.6.html $>$. Acceso en: 27-09-2015.

${ }^{1377}$ Disponible en: <http://www.europarl.europa.eu/aboutparliament/es/20150201PVL00008/El-Tratadode-Lisboa>. Acceso en: 26-09-2015. 
competencias presupuestarias. También otorga al Parlamento un papel fundamental en la elección del Presidente de la Comisión Europea ${ }^{1378}$.

En el ámbito general, el Tratado de Lisboa trae novedades, y las más importantes son las siguientes: supresión de la estructura anterior de la UE en tres pilares (las Comunidades Europeas, la política exterior y de seguridad común, y la cooperación judicial en materia penal) ${ }^{1379}$, y se atribuye personalidad jurídica a la UE (hasta entonces la tenía la Comunidad Europea); la distribución de competencias entre la UE y los Estados miembros pasa a ser más clara; regulación detallada de las distintas políticas y acciones de la Unión, incluyendo nuevas políticas en materia de energía, turismo, protección civil, y cooperación administrativa ${ }^{1380}$; el procedimiento de codecisión se generaliza como procedimiento legislativo, ampliándose a numerosos ámbitos, razón por la cual pasa a denominarse ‘procedimiento legislativo ordinario'. Juntamente con ello, amplían notablemente los asuntos en los que el Consejo decide por mayoría cualificada, con el fin de agilizar las decisiones e incrementar su eficiencia, a la vez que se coloca al Parlamento en pie de igualdad con el Consejo en procedimiento legislativo; el principio de subsidiariedad es reforzado al otorgarse a los Parlamentos nacionales poderes de supervisión y control de su respeto por los actos legislativos de la $\mathrm{UE}^{1381}$; la 'iniciativa ciudadana' es reconocida, vez que pueden pedir a la Comisión que

${ }^{1378}$ Disponible en: < http://www.europarl.europa.eu/aboutparliament/es/20150201PVL00022/El-PE-ylos-Tratados>. Acceso en: 26-09-2015.

${ }^{1379}$ El Tratado de Lisboa define con más claridad el papel de la Unión Europea en el ámbito de los asuntos exteriores y de la política de seguridad. Las decisiones sobre asuntos de defensa seguirán requiriendo la aprobación unánime de los veintisiete Estados miembros de la UE. Disponible en: $<$ https://www.euskadi.eus/r48-

contaeue/es/contenidos/informacion/v2_ue_euskadi/es_lisboa/adjuntos/su_guia_tratado_lisboa_es.pdf $>$. Acceso en: 27-09-2015.

${ }^{1380}$ El Tratado de Lisboa intensifica los objetivos sociales de la Unión Europea, estableciendo que, en todas sus políticas y acciones, la Unión Europea tendrá en cuenta la promoción de un nivel de empleo elevado. Además, establece una nueva base para la cooperación entre los Estados miembros en campos como el deporte, la ayuda humanitaria, la protección civil, el turismo y la investigación espacial. Disponible en:

$<$ https://www.euskadi.eus/r48contaeue/es/contenidos/informacion/v2_ue_euskadi/es_lisboa/adjuntos/su_guia_tratado_lisboa_es.pdf > Acceso en: 27-09-2015.

${ }^{1381}$ El Tratado aumenta el número de ámbitos en los que el Parlamento Europeo compartirá la toma de decisiones con el Consejo. Eso significa que los eurodiputados elegidos directamente por los ciudadanos 
haga propuestas de legislación ${ }^{1382}$; la posibilidad a los Estados miembros de abandonar la UE a través de la cláusula de retirada voluntaria; llevan a cabo importantes reformas

podrán tener más voz acerca de la legislación y del presupuesto de la Unión Europea. A escala nacional, los Parlamentos nacionales tendrán mayores oportunidades de contribuir directamente a la toma de decisiones de la UE. Un nuevo sistema de alerta rápida da a los Parlamentos nacionales el derecho a pronunciarse sobre los proyectos legislativos y a verificar que la UE no rebasa sus competencias tratando asuntos que pueden abordarse mejor a nivel nacional o local. El Tratado de Lisboa racionaliza los procedimientos de toma de decisiones de la UE. En el Consejo, se ampliará la adopción de decisiones por mayoría cualificada, en vez de por unanimidad. De esa manera, se actuará de forma más rápida y eficaz. La mayoría cualificada significa que, desde 2014, las decisiones del Consejo habrán de ser aprobadas por el $55 \%$ de los Estados miembros, que reúnan como mínimo el $65 \%$ de la población europea. De esta forma las decisiones tienen una doble legitimidad. Toda propuesta de transferir nuevas áreas políticas a la decisión por mayoría estará sometida a reglas estrictas. Cada Estado miembro deberá ponerse de acuerdo sobre los cambios de esa índole y los Parlamentos nacionales tendrán derecho de veto. Sin embargo, se exigirá la unanimidad en ámbitos políticos importantes como la fiscalidad y la defensa. Uno de los principales objetivos del Tratado de Lisboa es modernizar las instituciones que gobiernan la UE y hacerlas más democráticas. Se creará un nuevo cargo de Alto Representante de la Unión para Asuntos Exteriores y Política de Seguridad/Vicepresidente de la Comisión a fin de promover la acción de la UE en la escena internacional y de defender sus intereses y sus valores en el exterior. Para impulsar su labor con continuidad y coherencia, el Consejo Europeo elegirá a un Presidente del Consejo Europeo por un máximo de cinco años. De ese modo, las acciones de la UE serán más visibles y más coherentes. El Presidente de la Comisión será 'elegido' por el Parlamento Europeo a propuesta del Consejo Europeo. El Tratado de Lisboa reafirma y actualiza muchas de las disposiciones económicas incluidas en anteriores Tratados de la Unión Europea. El Tratado de Lisboa contiene nuevas e importantes disposiciones que fortalecen la capacidad de la Unión Europea para luchar contra la delincuencia transfronteriza internacional, la inmigración ilegal, la trata de seres humanos y el tráfico de armas y de drogas. Con la simplificación propuesta por el Tratado de Lisboa se consigue mayor transparencia en este campo, se refuerza el papel del Parlamento Europeo y el del Tribunal de Justicia de las Comunidades Europeas, y la toma de decisiones se acelera al adoptar más decisiones por mayoría cualificada. Disponible en: $<$ https://www.euskadi.eus/r48-

contaeue/es/contenidos/informacion/v2_ue_euskadi/es_lisboa/adjuntos/su_guia_tratado_lisboa_es.pdf $>$. Acceso en: 27-09-2015.

${ }^{1382}$ Gracias al Tratado de Lisboa, se oirá mejor las voces de los ciudadano en la toma de decisiones. Una nueva iniciativa ciudadana significa que un millón de personas - de una población de 500 millones - de un conjunto de Estados miembros puede solicitar a la Comisión Europea, mediante una petición, que presente nuevas propuestas legislativas. De esa forma, y por vez primera, podrá el ciudadano pronunciarse directamente sobre la legislación de la UE. Para mejorar la información sobre cómo adopta 
de las instituciones europeas; y, la otorga de valor jurídico vinculante a la Carta de Derechos Fundamentales de la $\mathrm{UE}^{1383}$.

El Tratado de Lisboa establece claramente la finalidad y los valores de la Unión Europea: paz, democracia, respeto de los derechos humanos, justicia, igualdad, Estado de Derecho y sostenibilidad. Además, establece que la Unión Europea: ofrecerá a sus ciudadanos un espacio de libertad, seguridad y justicia sin fronteras interiores; obrará en pro del desarrollo sostenible de Europa basado en un crecimiento económico equilibrado y en la estabilidad de los precios, en una economía social de mercado altamente competitiva, tendente al pleno empleo y al progreso social, $\mathrm{y}$ en un nivel elevado de protección del medio ambiente; combatirá la exclusión social y la discriminación y promoverá la justicia y la protección sociales; fomentará la cohesión económica, social y territorial y la solidaridad entre los Estados miembros; mantendrá su compromiso con la unión económica y monetaria, con el euro como moneda; afirmará y promoverá sus valores en sus relaciones con el resto del mundo y contribuirá a la paz, la seguridad, el desarrollo sostenible del planeta, la solidaridad y el respeto mutuo entre los pueblos, el comercio libre y justo, y la erradicación de la pobreza; y, contribuirá a la protección de los derechos humanos, especialmente los derechos del niño, así como al estricto respeto y al desarrollo del Derecho internacional, en particular el respeto de los principios de la Carta de las Naciones Unidas. Este Tratado está concebido para dotar a la UE de los medios para alcanzar estos objetivos cruciales ${ }^{1384}$.

la Unión Europea, a partir de ahora el Consejo tendrá que celebrar sesiones públicas cuando estudie y someta a votación los proyectos legislativos. ${ }^{1382}$ Disponible en: <https://www.euskadi.eus/r48contaeue/es/contenidos/informacion/v2_ue_euskadi/es_lisboa/adjuntos/su_guia_tratado_lisboa_es.pdf $>$. Acceso en: 27-09-2015.

${ }^{1383}$ Interesante análisis sobre el tema es hecha por Blanca Lozano Cutanda, Derecho ambiental cit., pp. 226-227. Más informaciones también están disponibles en: <https://www.euskadi.eus/r48contaeue/es/contenidos/informacion/v2_ue_euskadi/es_lisboa/adjuntos/su_guia_tratado_lisboa_es.pdf $>$. Acceso en: 27-09-2015. El Tratado de Lisboa reconoce los derechos, libertades y principios enunciados en la Carta de Derechos Fundamentales, haciendo que esta sea jurídicamente vinculante. Esto significa que cuando la Unión Europea proponga y aplique la legislación, deberá respetar los derechos establecidos en la Carta, y los Estados miembros también tendrán que hacerlo cuando apliquen la legislación de la Unión Europea.

$1384 \quad$ Disponible en: $\quad<\mathrm{https} / / / \mathrm{www}$. euskadi.eus/r48contaeue/es/contenidos/informacion/v2_ue_euskadi/es_lisboa/adjuntos/su_guia_tratado_lisboa_es.pdf $>$. Acceso en: 27-09-2015. 
En este sentido, en el ámbito de la protección del medio ambiente, Blanca Lozano Cutanda enseña cuales fueron las novedades o modificaciones más relevantes que el Tratado de Lisboa introduce: "El principio de desarrollo sostenible aparece en términos más elaborados que en los Tratados anteriores. El art. 3 del TUE (sobre la finalidad de la Unión) precisa así que 'la Unión obrará en pro del desarrollo sostenible de Europa basado en un crecimiento económico equilibrado y en la estabilidad de los precios, en una economía social de mercado altamente competitiva, tendente al pleno empleo y al progreso social, y en un nivel elevado de protección y mejora de la calidad del medio ambiente ${ }^{1385}$. El principio de integración de las exigencias de protección del medioambiente en las políticas y acciones de la Unión cobra mayor visibilidad en el nuevo Tratado, al incluirse, además de su reconocimiento general (art. 11 TFUE), disposiciones expresas al respecto en el marco de algunas de las políticas con un particular potencial o impacto en la protección del medioambiente ${ }^{1386}$. En cuanto a los

\footnotetext{
${ }^{1385}$ Además, la autora afirma que: "Este precepto dispone además que la Unión fomentará 'la solidaridad entre las generaciones' - elemento consustancial al desarrollo sostenible y cuya mención se incluye por vez primera en el Tratado - y establece, también por primera vez, que, en sus relaciones con el resto del mundo, la Unión contribuirá al 'desarrollo sostenible del planeta"'. Blanca Lozano Cutanda, Derecho ambiental cit., p. 228.

${ }^{1386}$ La autora sigue diciendo que: “Así, por ejemplo, en la regulación de la política exterior de la Unión, en la que se incluye el objetivo de apoyar el desarrollo sostenible en los países en desarrollo, o en la política en materia de Energía, en cuya regulación se dispone que 'en el contexto del establecimiento y funcionamiento del mercado interior y atendiendo a la necesidad de preservar y mejorar el medioambiente, la política energética de la Unión aspirará, con un espíritu de solidaridad entre los Estados miembros', entre otros objetivos, a 'fomentar la eficiencia energética y el ahorro energético así como el desarrollo de energías nuevas y renovables' (art. 176 A, apartado c)”. En el mundo actual, otros dos asuntos merecen especial atención: El cambio climático, el Tratado da prioridad al objetivo de la Unión Europea de fomentar el desarrollo sostenible en Europa, basado en un alto nivel de protección y mejora del medio ambiente. Además, contempla la promoción, a nivel internacional, de medidas para combatir los problemas ambientales a escala regional y mundial, y en particular el cambio climático; Energía, el Tratado incluye nuevas normas para garantizar el buen funcionamiento del mercado de la energía, en particular por lo que se refiere al abastecimiento energético, y al fomento de la eficiencia y del ahorro energéticos, así como al desarrollo de energías nuevas y renovables. Para todos los Estados miembros, la seguridad del abastecimiento energético es un elemento crucial para el futuro. El Tratado afirma el compromiso de la UE con una política europea unida sobre energía sostenible. ${ }^{1386}$ Disponible en:

$<$ https://www.euskadi.eus/r48-
} 
objetivos de la política ambiental de la Unión, se mantienen los ya consagrados (el art. 191 TFUE reproduce el contenido del anterior art. 174 TCE), si bien se añade la referencia expresa a la necesidad de 'luchar contra el cambio climático'. Se introduce, como un nuevo principio rector de la acción de la Unión el principio de bienestar de los animales $^{1387}$. Importante analizar, por último, la incidencia que la Carta Europea de Derechos Fundamentales (a la que ahora se dota del mismo valor jurídico que los Tratados) puede tener en materia medioambiental. La protección del medioambiente se reconoce expresamente en el Título IV, dedicado a la 'solidaridad'. Este reconocimiento carece, sin embargo, de excesivo relieve, pues en el art. 37 se establece que 'las políticas de la Unión integrarán y garantizarán con arreglo al principio de desarrollo sostenible un alto nivel de protección del medioambiente y la mejora de su calidad'. La protección del medioambiente se configura, de este modo, como un derecho de prestación que obliga a las instituciones europeas, por lo que viene a coincidir sustancialmente con el principio de integración de las exigencias ambientales en el desarrollo de cualquier política o acción de la Unión Europea. Todo ello sin perjuicio, claro está, de que los derecho de la persona reconocidos en la Carta (tales como los derechos a la vida y a la integridad de la persona o el respeto a la vida privada y familiar) incorporen, de acuerdo con la doctrina del TEDH, una dimensión ambiental que permite invocarlos frente a las afecciones derivadas de daños ambientales"1388.

Entre algunas de las innovaciones que afectan a la política ambiental de la Unión Europea cabe destacar que ha introducido algunas modificaciones generales que pueden afectar la configuración del derecho ambiental derivado de la actividad de las instituciones de la Unión, en particular las modificaciones relacionadas con la

contaeue/es/contenidos/informacion/v2_ue_euskadi/es_lisboa/adjuntos/su_guia_tratado_lisboa_es.pdf $>$. Acceso en: 27-09-2015.

${ }^{1387}$ Conforme al nuevo art. 13 TFUE, 'al formular y aplicar las políticas de la Unión en materia de agricultura, pesca, transporte, mercado interior, investigación y desarrollo tecnológico y espacio, la Unión y los Estados miembros tendrán plenamente en cuenta las exigencias en materia de bienestar de los animales como seres sensibles, respetando al mismo tiempo las disposiciones legales o administrativas y las costumbres de los Estados miembros relativas, en particular, a ritos religiosos, tradiciones culturales y patrimonio regional'.

${ }^{1388}$ LOZANO CUTANDA, Blanca. Derecho ambiental cit., pp. 228-230. 
distribución y ejercicio de competencias por parte de la Unión, la reforma institucional, los procesos de toma de decisiones, y los actos resultantes de los mismos ${ }^{1389}$.

En el ámbito del medio ambiente la principal modificación fue la introducción del objetivo de lucha contra el cambio climático, poniendo de relieve la preeminencia que este objetivo ha alcanzado en la Unión; por otra parte, el nuevo Tratado pone un mayor énfasis en el principio de integración de las exigencias de protección del medio ambiente en el resto de las acciones y políticas de la Unión, así como en el objetivo de un desarrollo sostenible ${ }^{1390}$, incluso en lo que se refiere a su política internacional ${ }^{1391}$.

El desarrollo sostenible es destacado e incrementado a través del Tratado de Lisboa, vez que ya aparecía anteriormente en los Tratados, en este momento aparece con más precisión y como uno de los objetivos fundamentales.

De este modo, se puede observar que en el proceso de evolución de la política medio ambiental de la Unión Europea, la preocupación ambiental ha sido incorporada a todas las políticas que tuvieron repercusiones sobre el medio ambiente, formando actualmente, parte integrante de todas las políticas económicas de desarrollo.

Importante señalar, respecto a eso, que fue a partir del Tratado de Ámsterdam, cuando las instituciones comunitarias comenzaron a poner en marcha una serie de iniciativas, articuladas bajo el denominado Proceso de Cardiff ${ }^{1392}$, con la finalidad de hacer efectivo el principio de integración.

${ }^{1389}$ PLAZA MARTÍN, Carmen. La política y cit., p. 319.

${ }^{1390}$ PLAZA MARTÍN, Carmen. La política y cit., pp. 319-320. Además, como dispone el artículo 3.3 del Tratado de la Unión Europea: "La Unión establecerá un mercado interior. Obrará en pro del desarrollo sostenible de Europa basado en un crecimiento económico equilibrado y en la estabilidad de los precios, en una economía social de mercado altamente competitiva, tendente al pleno empleo y al progreso social, y en un nivel elevado de protección y mejora de la calidad del medio ambiente. Asimismo, promoverá el progreso científico y técnico". Disponible en: < http://www.boe.es/doue/2010/083/Z00013-00046.pdf>. Acceso en: 29-09-2015.

${ }^{1391}$ Dispone el artículo 21.2.f) Del Tratado de la Unión Europea, que la UE se compromete a "elaborar medidas internacionales de protección y mejora de la calidad del medio ambiente y de la gestión sostenible de los recursos naturales mundiales, para lograr el desarrollo sostenible”. Disponible en: < http://www.boe.es/doue/2010/083/Z00013-00046.pdf>. Acceso en: 29-09-2015.

${ }^{1392}$ Sin duda el denominado Proceso de Cardiff, iniciado en el Consejo Europeo celebrado en dicha ciudad en 1998, el instrumento fundamental para la integración, ya que tiene como objetivo desarrollar una estrategia para integrar el medio ambiente en la definición y aplicación de las políticas sectoriales comunitarias, dando así cumplimiento al mandato establecido en el artículo 6 del Tratado de Ámsterdam. 
Hoy día, el desarrollo sostenible y el mantenimiento de un nivel elevado de protección medio ambiental son los principales objetivos de la política medio ambiental europea $^{1393}$.

En este sentido, Dionisio Fernández de Gatta Sánchez, enseña que: “(...) las disposiciones más importantes relativas a la Política de Medio Ambiente las incluye el Tratado de Funcionamiento de la Unión Europea en su Título XX (arts. 191 ${ }^{1394}$-193),

Este Proceso, para su desarrollo, ha solicitado a los Consejos, en nueve de sus formaciones (Agricultura, Transporte, Energía Mercado Interior, Desarrollo, Industria, Asuntos Generales, Ecofin y Pesca), la elaboración de estrategias de integración para cada una de las áreas sectoriales, prestando especial atención a cuestiones intersectoriales tales como el cambio climático y la dimensión ambiental del empleo. Es éste un proceso que hoy en día sigue avanzando, pese a las dificultades que encierra no sólo la mayor amplitud de sectores implicados, sino también la necesidad de un consenso en el entramado jurídico de los hasta ahora quince miembros de la UE. Si tenemos en cuenta que el desarrollo económico y social ya no depende solamente de la fuerza del trabajo, el capital y la tecnología, sino que también juegan un papel destacado el estado de los recursos, renovables y no renovables, es indudable la importancia creciente del factor ambiental, cada vez mas presente en el desenvolvimiento de la sociedad y que está contribuyendo a modificar muchos conceptos políticos y económicos ya no sólo a nivel nacional o comunitario, sino mundial. En el ámbito de la política ambiental comunitaria ya no se habla únicamente de respetar nuestra fauna, depurar las aguas o tratar los residuos, lo que ahora está en cuestión es todo un modelo de desarrollo insostenible para el conjunto de la humanidad, que está generando el cambio climático, cuyos efectos pueden ser fatales para el planeta si no se toman a tiempo las medidas correctoras necesarias. Para contribuir al logro de una situación más positiva, la política ambiental comunitaria tiene entre sus objetivos la búsqueda de un modelo de desarrollo justo para la humanidad. Disponible en: $<$ http://www.magrama.gob.es/ministerio/pags/Biblioteca/Revistas/pdf_AM\%2FAM_2002_8_43_49.pdf> . Acceso en: 29-09-2015.

${ }^{1393}$ En este sentido, importante señalar que la Carta de los Derechos Fundamentales de la Unión Europea, en su artículo 37 dispone que: "En las políticas de la Unión se integrarán y garantizarán, conforme al principio de desarrollo sostenible, un nivel elevado de protección del medio ambiente y la mejora de su calidad". Vide ARAGÃO, Alexandra. Direito constitucional do ambiente da União Europeia, en Direito Constitucional Ambiental Brasileiro, $5^{a}$ ed., José Joaquim Gomes Canotilho y José Rubens MORATO LEITE (Organizadores), Direito Constitucional Ambiental Brasileiro, Editora Saraiva, São Paulo-Brasil: 2012, p. 45.

1394 Artículo 191(antiguo artículo 174 TCE).

“1. La política de la Unión en el ámbito del medio ambiente contribuirá a alcanzar los siguientes objetivos:

- la conservación, la protección y la mejora de la calidad del medio ambiente,

- la protección de la salud de las personas,

- la utilización prudente y racional de los recursos naturales, 
denominado "Medio Ambiente". Pero, debe tenerse en cuenta que las innovaciones en relación con el antiguo Tratado CE no son muy destacables, reduciéndose a incluir ahora algún objetivo más de la Política Ambiental de la Unión y a perfilar mejor las medidas de ejecución de los Programas Ambientales; lo cual ciertamente no es mucho, aunque debe destacarse, positivamente, la adecuación de la redacción correspondiente de estos preceptos, que proviene originalmente del texto del Acta Única Europea. Con buen criterio sistemático, el art. 191-1-TFUE comienza estableciendo los objetivos de la Política Ambiental de la Unión (...) Objetivos que están definidos con gran amplitud, con lo que la legitimación de la Unión para actuar en cualesquiera ámbito sectorial o geográfico que sea preciso para la protección ambiental es muy amplia, y le permiten adoptar casi todo tipo de acciones y medidas, según las previsiones de los propios Tratados. A continuación, el art. 191-2º-TFUE establece los principios, o ideas matrices de la Política Ambiental de la Unión, teniendo en cuenta al carácter general (y, por tanto, de aplicación a todas las acciones de la Unión) del principio de integración

- el fomento de medidas a escala internacional destinadas a hacer frente a los problemas regionales o mundiales del medio ambiente. y en particular a luchar contra el cambio climático.

2. La política de la Unión en el ámbito del medio ambiente tendrá como objetivo alcanzar un nivel de protección elevado, teniendo presente la diversidad de situaciones existentes en las distintas regiones de la Unión. Se basará en los principios de cautela y de acción preventiva, en el principio de corrección de los atentados al medio ambiente, preferentemente en la fuente misma, y en el principio de quien contamina paga.

En este contexto, las medidas de armonización necesarias para responder a exigencias de la protección del medio ambiente incluirán, en los casos apropiados, una cláusula de salvaguardia que autorice a los Estados miembros a adoptar, por motivos medioambientales no económicos, medidas provisionales sometidas a un procedimiento de control de la Unión.

3. En la elaboración de su política en el área del medio ambiente, la Unión tendrá en cuenta:

- los datos científicos y técnicos disponibles,

- las condiciones del medio ambiente en las diversas regiones de la Unión,

- las ventajas y las cargas que puedan resultar de la acción o de la falta de acción,

- el desarrollo económico y social de la Unión en su conjunto y el desarrollo equilibrado de sus regiones.

4. En el marco de sus respectivas competencias, la Unión y los Estados miembros cooperarán con los terceros países y las organizaciones internacionales competentes. Las modalidades de la cooperación de la Unión podrán ser objeto de acuerdos entre ésta y las terceras partes interesadas.

El párrafo precedente se entenderá sin perjuicio de la competencia de los Estados miembros para negociar en las instituciones internacionales y para concluir acuerdos internacionales". Disponible en: <http://eurlex.europa.eu/legal-content/ES/TXT/?uri=CELEX:12012E/TXT>. Acceso en: 03-10-2015. 
ambiental (art. 11). (...) Seguidamente, con un buen criterio sistemático, el art. 191-3º TFUE establece las cuestiones a tener en cuenta en la elaboración de la Política Ambiental (...). Esta Política Ambiental de la Unión, con los objetivos, principios y condiciones señalados, tiene dos características: es concurrente en relación con la acción de terceros Estados u organismos internacionales (art. 191-4º y mínima en relación con los Estados Miembros y los objetivos señalados (art. 193-TFUE ${ }^{1395}$ ), ya que las medidas de protección de la Unión 'no serán obstáculo para el mantenimiento y la adopción, por parte de cada Estado miembro, de medidas de mayor protección'; las cuales, obviamente, deben ser compatibles con los Tratados, y deben notificarse a la Comisión ${ }^{1396}$.

Respecto a los recursos hídricos, estos están mencionados en el artículo 192 del Tratado de Funcionamiento de la Unión Europea ${ }^{1397}$, referente a los procedimientos,

${ }^{1395}$ Artículo 193 (antiguo artículo 176 TCE).

"Las medidas de protección adoptadas en virtud del artículo 192 no serán obstáculo para el mantenimiento y la adopción, por parte de cada Estado miembro, de medidas de mayor protección. Dichas medidas deberán ser compatibles con los Tratados y se notificarán a la Comisión”. Disponible en: $<$ http://eur-lex.europa.eu/legal-content/ES/TXT/?uri=CELEX:12012E/TXT $>$. Acceso en: 03-10-2015.

${ }^{1396}$ FERNÁNDEZ DE GATTA SÁNCHEZ, Dionisio. Sistema Jurídico-Administrativo de protección del medio cit., pp. 80-83.

${ }^{1397}$ Conforme Dionisio Fernández de Gatta Sánchez, Sistema Jurídico-Administrativo de protección del medio cit., p. 83: "El proceso de adopción de medidas y normas en materia ambiental se establece en el art. 192-TFUE, distinguiendo las medidas generales de esta Política (del art. 191) y las mencionadas antes (en el propio art. 192)”. Artículo 192 (antiguo artículo 175 TCE).

"1. El Parlamento Europeo y el Consejo, con arreglo al procedimiento legislativo ordinario y previa consulta al Comité Económico y Social y al Comité de las Regiones, decidirán las acciones que deba emprender la Unión para la realización de los objetivos fijados en el artículo 191.

2. No obstante el procedimiento de toma de decisiones contemplado en el apartado 1, y sin perjuicio del artículo 114, el Consejo, por unanimidad con arreglo a un procedimiento legislativo especial, a propuesta de la Comisión y previa consulta al Parlamento Europeo, al Comité Económico y Social y al Comité de las Regiones, adoptará:

a) disposiciones esencialmente de carácter fiscal;

b) las medidas que afecten a:

- la ordenación territorial;

- la gestión cuantitativa de los recursos hídricos o que afecten directa o indirectamente a la disponibilidad de dichos recursos;

- la utilización del suelo, con excepción de la gestión de los residuos; 
expresando la misma preocupación del Tratado de Niza, vez que la Unión confirma su atención a los recursos hídricos no solo sobre su calidad, sino también sobre su cantidad, como manera de acceso a ese bien de manera equitativa y en buen estado ${ }^{1398}$.

De este modo, el desarrollo sostenible tiene su concepto y intención reforzados en el Tratado de Lisboa, alcanzando todavía más la interacción de la política ambiental junto a los demás sectores, afirmando así, su responsabilidad y solidaridad con otros países, e indicando su compromiso de cuidar del ambiente como uno y necesario.

Sin embargo, como bien explano Susana Aguilar Fernández: "El problema de la concepción armónica del desarrollo sostenible es doble: por un lado, esta armonía es falsa, ya que relativiza la naturaleza política de las estrategias de sostenibilidad, en el sentido de que las propuestas que éstas incorporan generarán indudablemente ganadores y perdedores - los ganadores serían, hipotéticamente, las generaciones futuras que se beneficiarán de un medio ambiente mejor conservado y de una sociedad menos

c) las medidas que afecten de forma significativa a la elección por un Estado miembro entre diferentes fuentes de energía y a la estructura general de su abastecimiento energético.

El Consejo, por unanimidad, a propuesta de la Comisión y previa consulta al Parlamento Europeo, al Comité Económico y Social y al Comité de las Regiones, podrá disponer que el procedimiento legislativo ordinario sea aplicable a los ámbitos mencionados en el párrafo primero.

3. El Parlamento Europeo y el Consejo adoptarán, con arreglo al procedimiento legislativo ordinario y previa consulta al Comité Económico y Social y al Comité de las Regiones, programas de acción de carácter general que fijen los objetivos prioritarios que hayan de alcanzarse.

Las medidas necesarias para la ejecución de dichos programas se adoptarán de conformidad con las condiciones contempladas en el apartado 1 o en el apartado 2, según proceda.

4. Sin perjuicio de determinadas medidas adoptadas por la Unión, los Estados miembros tendrán a su cargo la financiación y la ejecución de la política en materia de medio ambiente.

5. Sin perjuicio del principio de quien contamina paga, cuando una medida adoptada con arreglo a lo dispuesto en el apartado 1 implique costes que se consideren desproporcionados para las autoridades públicas de un Estado miembro, dicha medida establecerá las disposiciones adecuadas en forma de:

- excepciones de carácter temporal,

- apoyo financiero con cargo al Fondo de Cohesión creado de conformidad con lo dispuesto en el artículo 177, o ambas posibilidades". Disponible en: <http://eur-lex.europa.eu/legalcontent/ES/TXT/?uri=CELEX:12012E/TXT>. Acceso en: 03-10-2015.

${ }^{1398}$ Uniendo este precepto a los demás, se observa la intensión de fortalecer la sostenibilidad de los recursos hídricos, haciendo uso de la mejor tecnología, con una planificación legislativa y de gestión, con principios ambientales visando evitar y combatir la contaminación, a más de esto, dar una mayor énfasis para la eficiencia a los usos sostenibles de esos recursos. 
desigual, mientras que los perdedores serían aquellos grupos productivos que tienen que asumir los costes, en el presente, de las medidas que conducen al desarrollo sostenible. Por otro lado, la compatibilidad que ahora se preconiza se sitúa en el plano retórico, pues no se ha plasmado aún, en la mayor parte de los países, en políticas concretas (con instrumentos, objetivos, plazos y mecanismos de evaluación específicos). La sostenibilidad sólo se puede conseguir revirtiendo, o encauzando, determinadas tendencias políticas, productivas, demográficas y sociales desde una perspectiva de diálogo institucional (entre las distintas administraciones), político (entre los partidos) y social (entre los responsables políticos y los target groups, básicamente), sin olvidar nunca que la responsabilidad del gobierno (sea éste nacional, regional o local) es fundamental a la hora de impulsar y coordinar este proceso" 1399 .

Importante destacar que el principio de integración juntamente con el de corresponsabilidad y de prevención configura la terna básica sobre la que se apoya la gestión ambiental en la Unión Europea ${ }^{1400}$.

En virtud de lo antecedente, la integración ambiental es un proceso dinámico y constante, cuyo éxito consiste en la existencia de mecanismos que aseguren su implementación y permitan evaluar los resultados prácticos obtenidos, sea sectorial o transversalmente, para que continuamente sean realizadas modificaciones políticas necesarias para el buen funcionamiento del sistema ${ }^{1401}$.

Además, es importante resaltar que en este período, la Comunicación de la Comisión, de 3 de marzo de 2010, denominada 'Europa 2020: Una estrategia para un crecimiento inteligente, sostenible e integrador ${ }^{, 1402}$, es una estrategia que debe permitir

\footnotetext{
1399 AGUILAR FERNÁNDEZ, Susana. Evolución y tendencias de la política europea de medio ambiente. Revista Internacional de Sociología (RIS), Tercera Época, n. ${ }^{\circ}$ 35, Mayo-Agosto, 2003, pp. 53-80. Disponible en: $<$ http://revintsociologia.revistas.csic.es/index.php/revintsociologia/article/viewFile/300/306>. Acceso en: 29-09-2015, p.77.

${ }^{1400}$ GÓMEZ OREA, Domingo. Evaluación de Impacto ambiental, $2^{\mathrm{a}}$ ed., Ediciones Mundi Prensa, Madrid-España: 2002, $\quad$ p. $164 . \quad$ Disponible en: $<$ https://books.google.com.co/books?id=f2yWYo21WooC\&printsec=frontcover\&hl=pt$\mathrm{BR} \# \mathrm{v}=$ onepage \&q\&f=false $>$. Acceso en: 29-09-2015.

${ }^{1401}$ LANCHOTTI, Andressa de Oliveira. Evaluación de impacto ambiental y desarrollo sostenible. Arraes Editores, Belo Horizonte-Brasil: 2014, p. 65.

${ }^{1402}$ COM (2010) 2020 final. Blanca Lozano Cutanda, Derecho ambiental cit., p. 229.
} 
a la Unión Europea alcanzar un crecimiento sostenible basado en una economía más verde, más eficaz en la gestión de los recursos y más competitiva ${ }^{1403}$.

En 2011, dado su importancia, destacamos que la Decisión de Ejecución 2011/321/UE de la Comisión, de 27 de mayo (DOUE L143, 31 de mayo de 2011), por la que, en virtud de la Directiva sobre Calidad de las Aguas de Baño, se establecen los símbolos para informar al público de la clasificación de las aguas de baño y de cualquier prohibición o recomendación que afecta al mismo.

Sin embargo, la Comunicación de la Comisión al Parlamento Europeo, al Consejo, al Comité Económico y Social Europeo y al Comité de las Regiones, Balance de la Estrategia Europa 2020 para un crecimiento inteligente, sostenible e integrador ${ }^{1404}$, enuncia que: "A lo largo del siglo XX, la utilización de combustibles fósiles en el mundo se multiplicó por doce y la extracción de recursos materiales por treinta y cuatro. Cada ciudadano de la Unión Europea consume hoy en día quince toneladas de materiales al año, de las cuales cinco se desechan, descargándose la mitad en vertederos. Las empresas se enfrentan al aumento de los costes de las materias primas, la energía y los minerales esenciales y la falta de seguridad del abastecimiento y la volatilidad de los precios tienen efectos perjudiciales sobre la economía. Las fuentes de minerales, metales y energía, así como las reservas pesqueras, la madera, el agua, los suelos fértiles, el aire limpio, la biomasa y la biodiversidad, están sometidos a presión, y lo mismo puede decirse de la estabilidad del sistema climático. Mientras la demanda de alimentos, piensos y fibra podría aumentar en un $70 \%$ de aquí a 2050 , el $60 \%$ de los principales ecosistemas del mundo que contribuyen a la producción de estos recursos ya se ha degradado o se está utilizando de manera insostenible. La calidad del agua y los niveles de contaminación atmosférica sigue siendo causa de preocupación en muchas partes de Europa. El uso insostenible del suelo está acabando con los terrenos fértiles, mientras que continúa la degradación del suelo, y el uso de infraestructuras verdes sigue estando por debajo del nivel óptimo. Del mismo modo, el uso insostenible de los mares amenaza el frágil equilibrio de los ecosistemas marinos y afecta a las actividades económicas relacionadas, como la pesca y el turismo" $" 1405$.

\footnotetext{
${ }^{1403}$ Disponible en: < http://eur-lex.europa.eu/legal-content/ES/TXT/?uri=uriserv:em0028>. Acceso en: 23-09-2015.

${ }^{1404} \mathrm{COM} / 2014 / 0130$ final.

${ }^{1405}$ Disponible en: <http://eur-lex.europa.eu/legal-content/ES/TXT/?uri=celex:52014DC0130>. Acceso
} 
En relación a la evaluación del Sexto Programa, el Comité de las Regiones aprobó, el 5 de octubre de 2010, un Dictamen sobre «El papel de los Entes locales y regionales en la futura política de medio ambiente» (DOUE C 15, 18-01-2011), abogando por una mayor participación de éstos en la política ambiental, reconoce las dificultades de aplicación de la legislación ambiental, y estima necesario mejorar la coordinación y la gobernanza y establecer vínculos más eficaces entre las políticas ${ }^{1406}$.

En este mismo sentido, el Parlamento Europeo adoptó, primero, un Informe de la Comisión de Medio Ambiente, Salud Pública y Seguridad Alimentaria, de 6 de marzo (doc. A7-0048/2012), y después la Resolución de 20 de abril de 2012 sobre «La revisión del Sexto Programa de acción en materia de medio ambiente y establecimiento de prioridades para el Séptimo Programa de Acción en Materia de Medio Ambiente-Un medio ambiente mejor para una vida mejor» [doc. P7_TA-PRoV(2012)0147], en la que, siguiendo a la Comisión, considera «que el VI PMA proporcionado durante una década un marco global para la política medioambiental y que durante este período la legislación en materia de medio ambiente se ha consolidado y completado sustancialmente, así como que su adopción en el marco del procedimiento de codecisión ha reforzado su legitimidad y ha contribuido a crear un sentimiento de identificación; señalando, no obstante, que los Estados miembros y la Comisión no siempre han actuado de acuerdo con este programa y que este tenía algunas carencias, que deben abordarse», aunque asimismo estima que «los avances para alcanzar los objetivos establecidos en el VI PAM han sido variables, puesto que en algunos se han logrado (cambio climático, residuos) y otros no (aire, entorno urbano, recursos naturales), mientras que la consecución de otros tantos depende de los futuros esfuerzos de aplicación (sustancias químicas, pesticidas, aguas), considerando en este sentido que persisten varios problemas y que se requieren esfuerzos adicionales». Además, señala que «el VI PMA se ha visto comprometido por la falta de aplicación del acervo

en: 23-09-2015.

${ }^{1406}$ FERNÁNDEZ DE GATTA SÁNCHEZ, Dionisio. El Séptimo Programa Ambiental de la Unión Europea, 2013-2020. Revista Aragonesa de Administración Pública ISSN 1133-4797, núm. 41-42, Zaragoza, 2013, pp. 71-121. Disponible en: $<$ http://www.aragon.es/estaticos/GobiernoAragon/Organismos/InstitutoAragonesAdministracionPublica/ Areas/03_Revista_Aragonesa_Formacion/02\%20Dionisio\%20Fernández.pdf $>$. Acceso en: 03-10-2015, p. 81 . 
medioambiental» en algunos ámbitos (como contaminación atmosférica, tratamiento del agua y las aguas residuales, residuos y conservación de la naturaleza), y llama la atención sobre el incumplimiento del objetivo de frenar la disminución de la biodiversidad y sobre la necesidad de revisar algunos aspectos de la legislación ambiental, en particular mediante el refuerzo de la independencia de las evaluaciones de impacto ambiental ${ }^{1407}$.

Por su parte, el Comité Económico y Social adoptó el 18 de Enero de 2012 (doc. NAT/528-CESE 152-2012, DOUE C 68, 6.3.2012), un Dictamen sobre la evaluación final del VI PAM, que acoge favorablemente (estimando también que ha sido útil), analiza el mismo, estimando que la introducción de las Estrategias Temáticas aportan un planteamiento más estratégico que permite superar algunas carencias del Programa, y reitera la importancia de la coherencia y la integración de la Política Ambiental en las restantes y en particular en la estrategia Europa 2020, y debiendo mejorarse los instrumentos de esta Política ${ }^{1408}$.

Además, como enuncia Dionisio Fernández de Gatta Sánchez: “El Consejo de Medio Ambiente de 20 de Diciembre de 2010 (doc. 5302/11, Bruselas, 17 de Enero de 2011), en sus Conclusiones sobre «Mejora de los instrumentos de la Política Medioambiental», destacó la necesidad de un Programa de Acción en Materia de Medio Ambiente renovado y amplio que, entre otras cosas, debía aprovechar la Estrategia Europa 2020 y la Estrategia de la UE para un Desarrollo Sostenible de 2006, e invitaba a la Comisión a presentar, a comienzos de 2012, y basándose en la evaluación del Sexto Programa, una Propuesta de nuevo Programa Medioambiental, teniendo en cuenta los

${ }^{1407}$ FERNÁNDEZ DE GATTA SÁNCHEZ, Dionisio. El Séptimo Programa Ambiental de la Unión Europea, 2013-2020. Revista Aragonesa de Administración Pública ISSN 1133-4797, núm. 41-42, Zaragoza, 2013, pp. 71-121. Disponible en: $<$ http://www.aragon.es/estaticos/GobiernoAragon/Organismos/InstitutoAragonesAdministracionPublica/ Areas/03_Revista_Aragonesa_Formacion/02\%20Dionisio\%20Fernández.pdf $>$. Acceso en: 03-10-2015, pp. 81-82.

${ }^{1408}$ FERNÁNDEZ DE GATTA SÁNCHEZ, Dionisio. El Séptimo Programa Ambiental de la Unión Europea, 2013-2020. Revista Aragonesa de Administración Pública ISSN 1133-4797, núm. 41-42, Zaragoza, 2013, pp. 71-121. Disponible en: $<$ http://www.aragon.es/estaticos/GobiernoAragon/Organismos/InstitutoAragonesAdministracionPublica/ Areas/03_Revista_Aragonesa_Formacion/02\%20Dionisio\%20Fernández.pdf $>$. Acceso en: 03-10-2015, p. 82 . 
siguientes desafíos y objetivos: desarrollar una visión ambiciosa de la Política Ambiental de la UE, con el horizonte de 2050, en la que se aborden los problemas medioambientales persistentes en un contexto de desarrollo sostenible a nivel mundial, y que defina claramente las prioridades y metas medioambientales, así como unos objetivos y calendarios realistas y factibles de aquí a 2020; mejorar la coherencia, la complementariedad y las sinergias con otras estrategias pertinentes de la UE, como la Estrategia Europa 2020, y en particular su iniciativa emblemática «Una Europa que utilice eficazmente los recursos», la Estrategia de la UE para un Desarrollo Sostenible, la Estrategia de la UE sobre la Biodiversidad y la Estrategia de Medio Ambiente y Salud; tener en cuenta la repercusión que tiene la UE en el estado del medio ambiente a nivel mundial; mejorar la coherencia mediante una integración mayor y más significativa del medio ambiente, incluido el valor de los recursos naturales, en ámbitos de actuación pertinentes como agricultura, pesca, transporte, energía, industria, comercio, desarrollo e investigación; estimular el desarrollo de una economía ecológica, con unos modelos de producción y consumo más sostenibles y la evolución hacia los mismos, intentando disociar completamente crecimiento económico y deterioro medioambiental; hacer hincapié en el cambio climático, la biodiversidad, la utilización eficiente y sostenible de los recursos, el medio ambiente urbano, la prevención y reducción de la contaminación medioambiental y la mejora de la calidad de vida y la salud humana; potenciar el papel y facilitar la implicación de las Administraciones regionales y locales, así como de todos los demás interesados pertinentes, entre ellos la sociedad civil y el sector privado según proceda; mejorar la utilización, la aplicación y la observancia de los instrumentos de la Política Medioambiental; guiarse por criterios empíricos y científicos, teniendo en cuenta los avances científicos y tecnológicos, y fomentar la innovación ecológica y otras soluciones y tecnologías respetuosas con el medio ambiente, entre otras cosas mediante unas normas dinámicas encaminadas a una aceptación más rápida por parte de los mercados" ${ }^{, 1409}$.

El 4 de junio de 2012, en Bruselas, el Consejo de la Unión Europea con el asunto 'Establecimiento del marco para el Séptimo Programa de Acción de la Unión

${ }^{1409}$ FERNÁNDEZ DE GATTA SÁNCHEZ, Dionisio. Unión Europea: preparando el nuevo Programa Ambiental, en LOPÉZ RAMÓN, Fernando (coord.) y otros, Observatorio de Políticas Ambientales 2012, Ed. Thomson Reuters-Aranzadi, Cizur Menor (Navarra), 2012, pp. 75-99. 
Europea en materia de Medio Ambiente - adopción de conclusiones del Consejo ${ }^{, 1410}$ señala que una mejor aplicación debe constituir una parte fundamental del Séptimo Programa de Acción y, por consiguiente, acoge con satisfacción la Comunicación de la Comisión de 7 de marzo de 2012 sobre la manera de sacar mejor partido de los beneficios de las medidas medioambientales de la UE, y los actuales esfuerzos en esta materia; reitera la necesidad de que se garantice la plena aplicación de las políticas y la legislación medioambientales en el nivel de la UE y, por lo tanto, alienta a la Comisión y en su caso a los Estados miembros, a que siga desarrollando y aplique dentro del respeto del principio de subsidiariedad, los objetivos y las iniciativas que figuran en la Comunicación, tales como:

- mayor desarrollo y una mejor estructuración, difusión y accesibilidad del conocimiento sobre medio ambiente y el fortalecimiento de la interfaz científiconormativa;

- mejora de la aplicación y la ejecución para lograr un mejor seguimiento;

- una mejora de las inspecciones y de los regímenes de vigilancia, evitando cargas administrativas innecesarias;

- mejora de la tramitación de reclamaciones a nivel nacional, en particular de las opciones para la resolución de litigios como la mediación;

- una mejora del acceso a la justicia conforme al Convenio de Aarhus;

- apoyo a las redes a escala de la UE de profesionales del medio ambiente, y también a profesionales de otros sectores pertinentes, y

- la promoción de asociaciones con los Estados miembros que podrían tener la forma de acuerdos de aplicación.

Además, insta a la Comisión a que incluya los objetivos e iniciativas como parte importante del Séptimo Programa.

Por otra parte, insta a la Comisión a que aborde en el Séptimo Programa ámbitos como la biodiversidad, la adaptación al cambio climático, el agua, el medio ambiente urbano y el medio ambiente y la salud, teniendo en cuenta determinadas situaciones, capacidades y necesidades específicas de los Estados miembros. Ello debe realizarse mediante el apoyo a iniciativas en curso y a través del desarrollo de nuevas

1410 Disponible en: $<$ http://register.consilium.europa.eu/doc/srv?l=ES\&t=PDF\&f=ST+10706+2012+INIT $>$. Acceso en: 06$10-2015$. 
iniciativas en su caso, tales como:

* la garantía de la continuidad y mejora de las medidas para proteger la salud humana y el medio ambiente abordando:

- la seguridad y la sostenibilidad de la nanotecnología y materiales avanzados, los interruptores endocrinos, basándose en los logros científicos, para reducir la exposición a éstos, y de proteger la salud humana y el medio ambiente, en particular a los menores,

- determinación y evaluación de la combinación de los efectos de las sustancias químicas en los diferentes sectores, y establecer un plantea- miento global para reducir al máximo la exposición a las sustancias peligrosas y productos químicos,

- la reducción de las emisiones de ruido, la calidad del aire interior, la mejora del conocimiento científico sobre los riesgos emergentes para el medio ambiente y la salud, promoviendo, de ser necesario, la vigilancia biológica de las personas y apoyando la investigación en materia de métodos de evaluación de riesgos y la elaboración de unos métodos adecuados de evaluación de impacto para elaborar nuevas medidas y legislación medioambientales en este ámbito;

*la elaboración y aplicación de una estrategia global de adaptación al cambio climático de la UE, con miras a su integración en las políticas de la UE y para abordar los impactos potenciales y las soluciones en relación con la afectación del cambio climático en el medio ambiente (p. ej., la biodiversidad, los recursos hídricos, los océanos y los suelos, incluidos los posibles riesgos de escasez de agua, las sequías, los fenómenos meteorológicos extremos y la salud humana);

*alcanzar para el año 2020 los fines de la Estrategia de Biodiversidad de la UE y los objetivos de Aichi (Japón) sobre la biodiversidad dentro de la UE, incluidas la integración de dichos objetivos en todas las demás políticas del sector y la movilización de los recursos financieros; y

*el impulso de una estrategia global de la UE que permita determinar el modo más adecuado para que una economía ecológica e incluyente contribuya a mejorar el entorno urbano, centrándose en la integración de la planificación urbana con los objetivos relativos a la eficiencia de los recursos, una economía baja en carbono, el uso sostenible del suelo urbano, la resistencia de los ecosistemas, la gestión del agua, la salud humana, la participación pública en la toma de decisiones y la educación y sensibilización medioambiental. 
Respecto a la 'Transición a una economía ecológica' con la finalidad de mejorar la coherencia de las políticas mediante una integración mejor y más significativa del medio ambiente, entre otras cosas del valor de la biodiversidad y de los recursos naturales, en las restantes políticas, y pasar a una economía ecológica mediante una producción y unas pautas de consumo más sostenibles, así como intentar disociar totalmente el crecimiento económico de la degradación del medio ambiente ${ }^{1411}$; para lo que insta a la Comisión a que proponga indicadores y calendarios que tracen objetivos realistas y alcanzables en relación con la eficacia energética, la disociación de la utilización de los recursos de la actividad económica y las repercusiones ambientales relacionadas con su utilización para recursos naturales clave, como el agua, las materias primas (p. ej., el fósforo y el nitrógeno) y el suelo, así como para los otros sectores clave.

Asimismo, insta a la Comisión a que, respetando la separación de competencias entre la Unión y los Estados miembros, incluya medidas en apoyo del desarrollo del Mercado Único y del crecimiento sostenible, mediante el fomento de productos y servicios sostenibles e impulsando las pautas sostenibles de consumo y de producción, tales como:

- corregir las deficiencias del mercado, p. ej., a través del principio 'quien contamina paga';

- compartir conocimientos y prácticas correctas en cuanto a trasladar la imposición fiscal del trabajo hacia la utilización de los recursos y la energía, así como de las repercusiones negativas en el medio ambiente;

- racionalizar y suprimir gradualmente las subvenciones perjudiciales para el medio ambiente y la economía, incluidos los combustibles fósiles; debiendo tenerse en cuenta su impacto sobre los grupos más vulnerables de la sociedad;

- determinar, y en su caso suprimir, los obstáculos que puedan impedir avanzar hacia el objetivo de la UE de reducción de los gases de efecto invernadero;

\footnotetext{
${ }^{1411}$ FERNÁNDEZ DE GATTA SÁNCHEZ, Dionisio. El Séptimo Programa Ambiental de la Unión cit., p. 91. 
- hacer avanzar la política de producción, ampliando más la utilización de requisitos de eficiencia energética de los productos y apoyando el fomento de un mercado único de productos y servicios seguros y respetuosos con el medio ambiente;

- aumentar la disponibilidad, su carácter más asequible, la funcionalidad y el atractivo de los productos y servicios seguros y respetuosos con el medio ambiente;

- permitir que los consumidores y los clientes tengan acceso a una mejor información sobre los productos;

- fomentar la innovación ecológica y otras soluciones y tecnologías favorables al medio ambiente;

- dar prioridad a iniciativas de fomento de mercados de productos y servicios más ecológicos, p. ej., desarrollando iniciativas, normas y objetivos indicativos para la contratación pública ecológica y compartiendo información sobre nuevos modelos empresariales, $\mathrm{y}$

- tener en cuenta las repercusiones en el medio ambiente y la huella ecológica de los bienes importados.

En esta misma línea, el Consejo, acoge favorablemente la Comunicación de la Comisión de 15 de diciembre de 2011 [COM (2011) 899 final, Bruselas] relativa al Plan de Acción sobre Ecoinnovación, y anima a la Comisión a que junto con los Estados miembros, aplique las acciones y desarrolle en mayor medida el planteamiento que recoge el Plan. Para ello, pide a la Comisión que:

- determine la posible contribución de la innovación tecnológica y no tecnológica a la realización de los objetivos y metas de la hoja de ruta «hacia una Europa eficiente en el uso de los recursos» y demás estrategias y planes de acción;

- proponga aumentar la innovación e introducir cambios sistémicos, con el fin de acelerar los procesos de innovación hacia el crecimiento ecológico;

- determine los medios con que la Comisión y los Estados miembros pueden ayudar a lograr la ecoinnovación;

- haga uso de las herramientas para la gobernanza de Europa 2020, incluidas las orientaciones integradas;

- utilice en su caso los mecanismos financieros actuales, y

- desarrolle el Plan de Acción sobre ecoinnovación hasta hacer de él una cooperación estratégica con los Estados miembros y todas las partes interesadas pertinentes. 
Además alienta la aplicación y el desarrollo ulterior de las asociaciones europeas para la innovación, y apoya la puesta en marcha de estas últimas respecto del agua y las materias primas, con objeto de suprimir los obstáculos a la innovación y facilitar el desarrollo de soluciones innovadoras en los ámbitos de la gestión del agua y del suministro, utilización, reciclado y sustitución sostenibles de las materias primas, teniendo en cuenta sus conclusiones de los días 30 y 31 de mayo de 2012 relativas a las cooperaciones de innovación europea.

Por otra parte, el Consejo también insta a la Comisión a que incluya en su propuesta para el Séptimo Programa medidas en apoyo de las condiciones necesarias para una economía circular y ecológica, como las siguientes:

- aplicar una perspectiva basada en el ciclo de vida;

- estimular la utilización eficiente de los recursos, los ciclos de materiales libres de toxicidad y la reducción de los residuos;

- estimular el mercado de materiales secundarios y la demanda de materiales reciclados;

- estimular el paso a una economía basada en la reducción, la reutilización y el reciclado de residuos, sin poner en peligro la seguridad, el medio ambiente y la salud, y

- reducir al máximo, con vistas a su desaparición gradual, los vertidos de residuos reciclables y biodegradables.

El Consejo también insta a la Comisión a que proponga y ponga a punto, en el marco del Séptimo PAM, medidas que integren los objetivos medioambientales en todas las políticas pertinentes de la Unión Europea, incluidas medidas en apoyo de la integración e incorporación de las acciones relativas al medio ambiente y al clima en el Marco Financiero Plurianual (MFP) 2014-2020, sin perjuicio de las negociaciones en curso en torno al MFP, así como a que mejore la coherencia de las políticas medioambientales con las políticas sectoriales y los instrumentos financieros de la UE, incluida, por ejemplo, la coherencia entre los instrumentos financieros objeto del marco estratégico común y los proyectos integrados del instrumento LIFE.

Finalmente, el Consejo insta a la Comisión a que apoye los esfuerzos realizados con arreglo al plan "Más allá del PIB" para ponderar más ampliamente los progresos sociales, medioambientales y económicos hacia el desarrollo sostenible, recurriendo a las medidas ya existentes y elaborando otras adicionales, también apoyando los esfuerzos internacionales por establecer normas y orientaciones sobre la 
incorporación del capital natural en los sistemas de contabilidad a escala nacional y de la Unión Europea, y anima a la Comisión, a los Estados miembros y a todos los demás interesados a participar eficaz y coordinadamente y a avanzar en este ámbito.

Así, en julio de 2012 se finalizó el Sexto programa de acción Comunitario en materia de Medio Ambiente (VI PMA), sin embargo, siguen aplicándose muchas de las medidas y acciones iniciadas en el marco de ese Programa. En su evaluación final se llegó a la conclusión de que el Programa había sido positivo para el medio ambiente y de que había proporcionado una dirección estratégica general para la política medioambiental. A pesar de esos logros, siguen observándose algunas tendencias no sostenibles en los cuatro ámbitos prioritarios establecidos en el VI PMA: cambio climático, naturaleza y biodiversidad, medio ambiente y salud y calidad de vida, y recursos naturales y residuos.

No obstante, algunas deficiencias se destacaron, de modo que la consecución de los objetivos enunciados en el Séptimo Programa de Acción en materia de Medio Ambiente (VII PMA) exige, por tanto, el pleno compromiso de los Estados miembros y de las instituciones de la Unión competentes y la voluntad de responsabilizarse de que el Programa obtenga los beneficios previstos.

Las tendencias y los desafíos sistémicos mundiales relacionados con las dinámicas demográficas, la urbanización, las enfermedades y pandemias, la evolución acelerada de la tecnología y un crecimiento económico no sostenible dificultan aún más la resolución de los problemas medioambientales y la consecución de un desarrollo sostenible a largo plazo. La prosperidad de la Unión en el futuro depende de la adopción de nuevas medidas para resolver esos problemas.

Así, tras guerras que costaron la vida de millones de personas, la creación de la Unión Europea supuso el inicio de una nueva era en la que los países europeos habrían de solucionar sus problemas mediante el diálogo y no por las armas. Años después, la Unión Europea se compromete a promover sus valores en el mundo contribuyendo a: la paz y la seguridad; el desarrollo sostenible de la Tierra; la solidaridad y el respeto mutuo entre los pueblos; el comercio libre y justo; la erradicación de la pobreza; la defensa de los derechos humanos; el respeto del Derecho internacional y la mejora del mismo tal como se define, en especial, en la Carta de las Naciones Unidas.

En la actualidad, los miembros de la Unión Europea disfrutan de abundantes beneficios. Sin embargo, las normas actuales se concibieron para una Unión Europea 
mucho más pequeña, que no tenía ante sí desafíos a escala planetaria como el cambio climático $^{1412}$, una recesión mundial, la inmigración ilegal o la delincuencia transfronteriza internacional.

Sin embargo, la Unión tiene como objetivo convertirse, de aquí a 2020, en una economía inteligente, sostenible e integradora, por medio de una serie de políticas y actuaciones dirigidas a avanzar hacia una economía hipocarbónica y eficiente en el uso de $\operatorname{los}$ recursos ${ }^{1413}$.

Además, importante destacar que los sucesivos Programas de Acción en materia de Medio Ambiente han proporcionado el marco para la actuación

${ }^{1412}$ Según, María Ángeles González Bustos, El Debate del Cambio Climático en España, Revista Actualidad Administrativa, ISSN 1130-9946, n. ${ }^{\circ}$ 6, España: 2010, p. 1: "La preocupación por el cambio climático ha ido en aumento en los últimos años por lo que los poderes públicos tienen que poner mecanismos para mitigar los efectos del mismo y para adaptar las políticas públicas a los impactos ya producidos. España está realizando actuaciones concretas como son las medidas verticales que inciden en diferentes sectores específicos tales como el energético, el transporte, el agrícola, el forestal, en materia de generación de residuos, y las medias horizontales a través de planes y estrategias concretas". Además, la autora sigue en esa misma línea, en su artículo La política de cambio climático en España, Revista Noticias de la Unión Europea, ISSN 1133-8660, n. ${ }^{\circ}$ 295, España: 2009 (Ejemplar dedicado a: Plan Nacional de Asignación de emisiones 2008-2012), pp. 55-66.

${ }^{1413}$ COM (2010) 2020 y conclusiones del Consejo Europeo de 17 de junio de 2010 (EUCO 13/10). Importante destacar aquí, que muchos de los problemas medioambientales tienen una dimensión mundial y solo pueden resolverse totalmente con un planteamiento completo y global, mientras que otros tienen un carácter fuertemente regional. Esto exige la cooperación con países socios, incluidos los países vecinos y los países y territorios de ultramar. Así, el VII PMA debe apoyarse el cumplimiento, dentro de la Unión y a nivel internacional, de las conclusiones y los compromisos asumidos en la Conferencia de las Naciones Unidas sobre Desarrollo Sostenible de 2012 (Río + 20), cuya finalidad es transformar la economía mundial en una economía verde e integradora en el contexto del desarrollo sostenible y la reducción de la pobreza. De este modo, los objetivos prioritarios de la Decisión n. ${ }^{\circ}$ 1386/2013/UE del Parlamento Europeo y del Consejo de 20 de noviembre de 2013, relativa al Programa General de Acción de la Unión en materia de Medio Ambiente hasta 2020 'Vivir bien, respetando los límites de nuestro planeta', no puede ser alcanzado de manera suficiente por los Estados miembros, sino que, debido a las dimensiones y los efectos de ese programa de acción, puede lograrse mejor a escala de la Unión, esta puede adoptar medidas, de acuerdo con el principio de subsidiariedad consagrado en el artículo 5 del Tratado de la unión Europea. De conformidad con el principio de proporcionalidad enunciado en dicho artículo, la presente Decisión no excede de lo necesario para alcanzar ese objetivo. Disponible en: $<$ http://eur-lex.europa.eu/LexUriServ/LexUriServ.do?uri=OJ:L:2013:354:0171:0200:ES:PDF>. Acceso en: 06-10-2015. 
medioambiental de la Unión desde $1973^{1414}$.

6.12. Especial referencia al Séptimo Programa Ambiental: el Programa General de Medio Ambiente de la Unión hasta 2020 - 'Vivir bien, respetando los límites de nuestro planeta'

Este Séptimo Programa sustituye al Sexto que finalizó en julio de 2012 y, aunque siguen aplicándose muchas de las medidas y acciones iniciadas en el marco del Programa, la evaluación final del Sexto Programa y el informe de la Agencia Europea del Medio Ambiente (AEMA) del año $2010^{1415}$ mostraron la necesidad de plantear nuevos retos que conviertan la Unión Europea en una economía inteligente, sostenible e integradora que avance hacia una economía baja en carbono y eficiente en el uso de los recursos.

${ }^{1414}$ En este sentido, Blanca Lozano Cutanda, Derecho ambiental cit., p. 278 afirma que: "La política para la protección del medioambiente se ha basado en los principios y objetivos fijados, desde 1973, en sucesivos Programas de Acción en materia de medioambiente. Al igual que ocurre en otros campos de actuación comunitaria, el proceso de elaboración de la política y el derecho del medioambiente se inicia con la planificación, que en este ámbito ha revestido especial importancia ante la ausencia, hasta el Acta Única, de previsiones normativas específicas en los Tratados constitutivos”. También, Dionisio Fernández de Gatta Sánchez, El Séptimo Programa Ambiental de la Unión Europea, 2013-2020. Revista Aragonesa de Administración Pública ISSN 1133-4797, núm. 41-42, Zaragoza, 2013, pp. 71-121, afirma que: "Los Programas Ambientales, como sabemos, vienen orientando la política medioambiental de la Unión Europea desde principios de la década de los setenta. Actualmente, en virtud del Tratado de Funcionamiento de la Unión Europea, los Programas se adoptan con arreglo al procedimiento legislativo ordinario (art. 192). El Sexto Programa de Medio Ambiente expiró en Julio de 2012 (aunque naturalmente siguen aplicándose muchas de las medidas y acciones iniciadas en su marco) y, de acuerdo con el marco preparativo que ya hemos analizado, la Comisión Europea propuso e hizo público el 29 de noviembre de 2012 el Séptimo Programa destinado a sucederlo, y la propuesta de Decisión relativa al Programa General de Medio Ambiente de la Unión hasta 2020: «Vivir bien, respetando los límites de nuestro planeta» [COM (2012) 710 final, Bruselas, 29.11.2012]”. Disponible en: $<$ http://www.aragon.es/estaticos/GobiernoAragon/Organismos/InstitutoAragonesAdministracionPublica/ Areas/03_Revista_Aragonesa_Formacion/02\%20Dionisio\%20Fernández.pdf>. Acceso en: 03-10-2015, p. 98 .

${ }^{1415}$ El medio ambiente europeo - Situación y perspectiva 2010 (SOER 2010). 
El 20 de noviembre de 2013 fue aprobada por el Parlamento y Consejo Europeo la Decisión relativa al Programa General de Acción de la Unión en materia de Medio Ambiente ${ }^{1416}$ 'Vivir bien, respetando los límites de nuestro planeta', y entró en vigor e; 17 de enero de 2014 y establecerá el marco para a actuación medioambiental de la Unión Europea durante los próximos años hasta el 31 de diciembre de 2020 (de acuerdo a una perspectiva clara a largo plazo para 2050) ${ }^{1417}$.

Desde mediados de los años setenta, la política medioambiental de la Unión Europea se ha articulado en torno a programas de acción que establecen objetivos prioritarios para un periodo de varios años. El programa actual ${ }^{1418}$, que es el séptimo de

${ }^{1416}$ Según Dionisio Fernández de Gatta Sánchez, El Séptimo Programa Ambiental de la Unión Europea,
2013-2020. Revista Aragonesa de Administración Pública ISSN 1133-4797, núm. 41-42, Zaragoza, 2013,
pp. 71-121, "El nombre de «Programa General» hubiera sido mucho más adecuado desde sus inicios al
realzarse la trascendencia de los mismos en la propia Política Ambiental, y en relación con las restantes.
Actualmente, rompiendo el sistema numérico tradicional, quizás se haya querido resaltar su importancia
en relación con los textos estratégicos que hemos mencionado, y que enmarcan algunas de las propuestas
y medidas del propio en: Programa". $<$ http://www.aragon.es/estaticos/GobiernoAragon/Organismos/InstitutoAragonesAdministracionPublica/ Areas/03_Revista_Aragonesa_Formacion/02\%20Dionisio\%20Fernández.pdf>. Acceso en: 03-10-2015, nota de pie de página 15, p. 100.

${ }^{1417}$ Decisión n. ${ }^{\circ} 1386 / 2013 /$ UE.

${ }^{1418}$ El programa se basa en una visión a largo plazo: “En 2050 vivimos bien, respetando los límites ecológicos del planeta. Nuestra prosperidad y nuestro medio ambiente saludable son la consecuencia de una economía circular innovadora, donde nada se desperdicia y en la que los recursos naturales se gestionan de forma sostenible, y la biodiversidad se protege, valora y restaura de tal manera que la resiliencia de nuestra sociedad resulta fortalecida. Nuestro crecimiento hipocarbónico lleva tiempo disociado del uso de los recursos, marcando así el paso hacia una economía segura y sostenible a nivel mundial". Disponible en: <http://ec.europa.eu/environment/pubs/pdf/factsheets/7eap/es.pdf >. Acceso en: 06-10-2015. Respecto a eso, Dionisio Fernández de Gatta Sánchez, El Séptimo Programa Ambiental de la Unión Europea, 2013-2020. Revista Aragonesa de Administración Pública ISSN 1133-4797, núm. 41-42, Zaragoza, 2013, pp. 71-121, comenta que: “Añadiendo que, para que pueda producirse esta transformación, será preciso integrar plenamente las consideraciones medioambientales en otras políticas, en particular en las de energía, transporte, agricultura, pesca, economía e industria, investigación e innovación y empleo, así como en la política social, de manera que se cree un planteamiento coherente y concertado, y estas medidas de la UE deberán completarse con una acción y una cooperación reforzadas y globales con países vecinos para resolver problemas comunes. Además, la Unión tiene en cuenta los múltiples compromisos internacionales suscritos, en particular los contraídos en la Conferencia de Naciones Unidas sobre Desarrollo Sostenible, celebrada en Río de Janeiro (Brasil) en 2012”. Disponible 
este tipo, fue aprobado por el Parlamento Europeo y el Consejo de la Unión Europea en noviembre de 2013 y abarca el periodo comprendido hasta 2020.

Con este Programa de Acción en materia de Medio Ambiente (PMA), la Unión Europea se compromete a intensificar sus esfuerzos para proteger nuestro capital natural, estimular la innovación y el crecimiento hipocarbónico y eficiente en el uso de los recursos, y proteger la salud y el bienestar de la población, respetando en todo momento los límites naturales de la Tierra.

Se trata de una estrategia común que debe guiar las acciones futuras tanto de las instituciones de la Unión como de los Estados miembros, ya que ambas instancias son responsables de su puesta en práctica y de la consecución de sus objetivos prioritarios.

El programa describe nueve objetivos prioritarios a alcanzar de aquí a 2020. Estos objetivos están previstos en el artículo 2 de la Decisión n. ${ }^{\circ}$ 1386/2013/UE y son los siguientes: proteger, conservar y mejorar el capital natural de la Unión; convertir a la Unión en una economía hipocarbónica, eficiente en el uso de los recursos, ecológica y competitiva; proteger a los ciudadanos de la Unión de las presiones y riesgos medioambientales para la salud y el bienestar; Maximizar los beneficios de la legislación de medio ambiente de la Unión mejorando su aplicación; mejorar la base de conocimientos e información de la política de la Unión de medio ambiente; asegurar inversiones para la política en materia de clima y medio ambiente y abordar las externalidades medioambientales; intensificar la integración medioambiental y la coherencia entre políticas; aumentar la sostenibilidad de las ciudades de la Unión; reforzar la eficacia de la Unión a la hora de afrontar los desafíos medioambientales y climáticos a nivel internacional.

Importante destacar, que se van a aplicar instrumentos de mercado y otras medidas que privilegien la prevención, el reciclado y la reutilización, incluida la extensión de la responsabilidad del productor. Se debe avanzar hacia una economía "circular" regida por el ciclo de vida y en la que los recursos se utilicen en cascada y se

en:

$<$ http://www.aragon.es/estaticos/GobiernoAragon/Organismos/InstitutoAragonesAdministracionPublica/ Areas/03_Revista_Aragonesa_Formacion/02\%20Dionisio\%20Fernández.pdf $>$. Acceso en: 03-10-2015, nota de pie de página 15, p. 102. 
eliminen casi por completo los residuos remanentes ${ }^{1419}$.

Otro campo prioritario es la eficiencia en el uso del agua. Aun cuando la sequía y la escasez de agua afectan cada vez a más zonas de Europa, se estima que sigue derrochándose entre un 20\% y un 40\% del agua disponible en Europa. Por lo tanto hay un amplio margen para mejorar la eficiencia hídrica de la Unión. Se estimulará a los mayores sectores consumidores, como la energía y la agricultura, para que den prioridad a la utilización más eficiente del agua ${ }^{1420}$.

Además, el programa identifica tres ámbitos prioritarios - segunda parte del Séptimo Programa, dedicada a las $<<$ Prioridades temáticas $>>$ (puntos 16 a 52) - que requieren más acciones dirigidas a proteger la naturaleza y fortalecer la resiliencia ecológica (puntos 16 a 26), promover un crecimiento hipocarbónico que utilice los recursos de forma eficiente (puntos 27 a 41) y reducir las amenazas para la salud y el bienestar humanos asociadas a la contaminación, las sustancias químicas y el impacto del cambio climático (puntos 42 a 52).

El primer ámbito de acción tiene que ver con el «capital natural»—suelo fértil, tierra y mares productivos, agua dulce de buena calidad y aire limpio- y con la biodiversidad que lo hace posible. El capital natural presta servicios vitales, desde la polinización de las plantas a la protección natural contra las inundaciones, pasando por la regulación del clima. La Unión se ha comprometido a detener la pérdida de biodiversidad y a conseguir un buen estado para las aguas y el medio ambiente marino de Europa. Además, ha puesto sobre la mesa los medios para conseguirlo, con compromisos legalmente vinculantes como la Directiva marco del Agua, la Directiva sobre la Calidad del Aire y las Directivas de Aves y Hábitats, junto con apoyo técnico y financiero. A pesar de ello, el medio ambiente sigue sometido a presiones considerables. La UE sigue perdiendo biodiversidad y muchos de sus ecosistemas están seriamente degradados. Es preciso hacer mayores esfuerzos ${ }^{1421}$.

1419 Disponible en: < http://abaleo.es/desarrollo-sostenible/vivir-bien-respetando-limites-delplaneta.html>. Acceso en: 06-10-2015.

1420 Disponible en: $\quad<$ http://abaleo.es/desarrollo-sostenible/vivir-bien-respetando-limites-delplaneta.html>. Acceso en: 06-10-2015.

${ }^{1421}$ Como bien comenta Dionisio Fernández de Gatta Sánchez, El Séptimo Programa Ambiental de la Unión Europea, 2013-2020. Revista Aragonesa de Administración Pública ISSN 1133-4797, núm. 41-42, Zaragoza, 2013, pp. 71-121, "No obstante los éxitos logrados y los esfuerzos realizados, el Programa constata que se sigue perdiendo biodiversidad y que hay ecosistemas gravemente dañados (por lo que se 
Para proteger, conservar y mejorar el capital natural de la UE, el Programa garantizará que para 2020 se alcancen estos objetivos: detención de la pérdida de biodiversidad y la degradación de los servicios ecosistémicos, y que los ecosistemas y los servicios que prestan se mantengan y mejoren; reducción considerable de los impactos de las presiones sobre las aguas dulces, costeras y de transición, y sobre las marinas para alcanzar, mantener o mejorar el buen estado de las mismas, de acuerdo con las normas correspondientes; disminución mayor de los impactos de la contaminación atmosférica sobre los ecosistemas y la biodiversidad; que la tierra se

adoptó la Estrategia sobre la Biodiversidad en 2011 con las medidas adecuadas, incluyendo las correspondientes a mejorar la aplicación de las Directivas sobre Aves y sobre hábitats) y que el objetivo de la Directiva Marco del Agua de conseguir en 2015 un buen estado ecológico de las aguas sólo se conseguirá en un $53 \%$, siendo posible que no se alcance algún otro objetivo posterior, a pesar de los éxitos logrados en relación con ciertos contaminantes (pero no así respecto a las deposiciones de nitrógeno y ozono). Para mejorar la situación, se estima necesario atajar en su origen los problemas mediante una mayor integración de los objetivos ambientales relativos al capital natural en otras Políticas (principalmente en las de agricultura, pesca y cohesión, sin olvidar las cuestiones financieras plurianuales), y velar por que las mismas sean coherentes y produzcan beneficios recíprocos. Además, se deben aplicar los planteamientos basados en los ecosistemas a la mitigación del cambio climático y a la adaptación al mismo, al ser también positivos para la biodiversidad. Por otra parte, el Programa también confirma que la degradación, la fragmentación y el uso insostenible de la tierra en la Unión están haciendo peligrar una serie de servicios ecosistémicos fundamentales, suponen una amenaza para la biodiversidad y aumentan la vulnerabilidad de Europa al cambio climático y a las catástrofes naturales, siendo asimismo responsables de la degradación del suelo, pues más del $25 \%$ del territorio europeo está afectado por la erosión del suelo provocada por el agua, comprometiendo así las funciones edáficas y reduciendo la calidad de las aguas dulces. Además, otros problemas persistentes son la contaminación y el sellado del suelo. Para afrontar estos problemas, sin perjuicio de que su solución sea difícil y costosa, las decisiones de ordenación del territorio que se adopten al nivel administrativo pertinente deberán tener en cuenta el impacto ambiental, además del social y el económico; por otra parte, ha de reflexionarse sobre la necesidad de contar con un instrumento jurídicamente vinculante apropiado (dado que el texto propuesto es de 2006), y deberá hacerse frente al problema causado por la incidencia del exceso de nutrientes, mediante la aplicación estricta de la legislación en la materia y abordar el ciclo de los mismos en un planteamiento que interrelacione e integre las acciones relacionadas con tal problema”. Disponible en:

$<$ http://www.aragon.es/estaticos/GobiernoAragon/Organismos/InstitutoAragonesAdministracionPublica/ Areas/03_Revista_Aragonesa_Formacion/02\%20Dionisio\%20Fernández.pdf $>$. Acceso en: 03-10-2015, pp. 103-104. 
gestione de una forma sostenible, el suelo se proteja adecuadamente y sigan saneándose los lugares contaminados; que el ciclo de los nutrientes (nitrógeno y fósforo) se gestione de manera más sostenible y eficiente en cuanto al uso de los recursos; y que se protejan los bosques y los servicios que prestan y se refuerce su capacidad de resistencia frente al cambio climático y los incendios.

Para conseguir estas metas, el Programa Ambiental estima necesario: aplicar plenamente la Estrategia sobre la Biodiversidad y el Programa de Salvaguardia de las Aguas de Europa; asegurar la existencia en 2020 de unas poblaciones de peces saludables, empezando en 2015 por no exceder en ninguna pesquería los niveles correspondientes a un rendimiento máximo sostenible y estableciendo a nivel europeo una meta cuantitativa de reducción de los desechos marinos; cumplir íntegramente la legislación sobre calidad del aire y establecer medidas y metas estratégicas para los años posteriores a 2020; reducir la erosión e incrementar la materia orgánica del suelo, sanear lugares contaminados y reforzar la integración de las consideraciones sobre el uso de la tierra en un proceso decisorio coordinado entre todas las esferas gubernamentales pertinentes, con el apoyo de la adopción de metas relativas al suelo y la tierra como recurso y de objetivos de ordenación territorial; reducir asimismo las emisiones de nitrógeno y fósforo, en particular las procedentes de las aguas residuales urbanas e industriales y del uso de fertilizantes; y desarrollar y aplicar una nueva Estrategia Forestal de la Unión que responda a las demandas que se ejercen sobre los bosques, aborde los beneficios que estos aportan y contribuya a un planteamiento más estratégico de su protección y mejora.

Por eso, el PMA materializa el compromiso de la UE, las autoridades nacionales y las partes interesadas de acelerar los avances en los objetivos de la Estrategia sobre la Biodiversidad hasta 2020 y el Plan para salvaguardar los recursos hídricos de Europa. Existen otros campos que también requieren más acciones tanto a escala europea como nacional. Por ejemplo, la protección del suelo y el uso sostenible de la tierra, o la protección de los recursos forestales. El programa subraya la necesidad de poner en práctica acciones más efectivas para proteger los océanos y los mares, salvaguardar las poblaciones de peces y reducir los desechos marinos.

El segundo ámbito de acción se refiere en las condiciones que ayudarán a transformar la UE en una economía hipocarbónica y eficiente en el uso de los recursos. En concreto: la plena aplicación del paquete de medidas sobre clima y energía para 
alcanzar las metas «20-20-20» y un acuerdo sobre los siguientes pasos que debe dar la política climática más allá de 2020; la mejora significativa del comportamiento medioambiental de los productos a lo largo de su ciclo de vida; la disminución del impacto medioambiental del consumo, lo que incluye cuestiones tales como la reducción del desperdicio de alimentos y el uso de la biomasa de forma sostenible ${ }^{1422}$.

Hay una especial preocupación por transformar los residuos ${ }^{1423}$ en recursos, con más prevención, reutilización y reciclaje, y se insiste en abandonar prácticas

${ }^{1422}$ En este sentido, Dionisio Fernández de Gatta Sánchez, El Séptimo Programa Ambiental de la Unión Europea, 2013-2020. Revista Aragonesa de Administración Pública ISSN 1133-4797, núm. 41-42, Zaragoza, 2013, pp. 71-121, afirma que: "Para avanzar en esta línea, el Programa estima imprescindible la aplicación completa del «paquete» de medidas en materia de clima y energía, debiendo acelerarse el cumplimiento del objetivo en materia de eficiencia energética (20\% para 2020), siendo para ello esencial la nueva Directiva en la materia. Por otra parte, en materia de emisiones de gases de efecto invernadero, la Unión está bien encaminada en el cumplimiento del objetivo acordado (también un 20\% en 2020), si bien el Programa considera que en esta reducción de emisiones deben participar todos los sectores de la economía y que han de prepararse las medidas para después de 2020, en el marco de las negociaciones internacionales y sobre la base de las hojas de Ruta en materia de economía hipocarbónica y energía limpia y del Libro Blanco sobre el transporte, y considerando además la Directiva de Comercio de Emisiones como el pilar fundamental de esta política para el período posterior a 2020. En materia de uso eficaz de recursos y reducción de emisiones, el Programa resalta, además, la importancia de la adopción por la industria de las mejores tecnologías disponibles en el marco de la Directiva de Emisiones Industriales de 2010, al aplicarse a más de 50.000 instalaciones industriales. Igualmente, en esta misma línea de actuación, se adoptarán medidas para mejorar el comportamiento ecológico de bienes y servicios a lo largo de su ciclo de vida, por medio de iniciativas apropiadas (aumentar la oferta de productos sostenibles el incentivar a los consumidores sobre su uso, revisión de la normativa en materia de diseño y etiquetado de productos y sobre la etiqueta ecológica); resaltando la importancia para este objetivo de la normativa sobre ecodiseño. Asimismo, se fijarán metas para reducir el impacto ambiental global del consumo, en particular en los sectores de la alimentación, la vivienda y la movilidad. En relación con el uso eficaz de recurso, resulta esencial utilizar la contratación pública con criterios ambientales, con el objetivo de intentar alcanzar el objetivo de que el 50\% del total de las licitaciones incluya criterios ecológicos, siendo posible la elaboración de nuevas normas por sectores, y ello sin perjuicio de la adopción por la mayoría de Estados Miembros de planes de acción voluntarios y de metas concretas en relación a productos determinados”. Disponible en: $<$ http://www.aragon.es/estaticos/GobiernoAragon/Organismos/InstitutoAragonesAdministracionPublica/ Areas/03_Revista_Aragonesa_Formacion/02\%20Dionisio\%20Fernández.pdf $>$. Acceso en: 03-10-2015, p.106.

${ }^{1423}$ En cuanto al importante problema de los residuos, Dionisio Fernández de Gatta Sánchez, El Séptimo 
perjudiciales y antieconómicas, como los vertederos. Cada vez son más las zonas de Europa que se ven afectadas por la escasez de agua -entre otras causas, por el cambio climático-; por tanto cobra importancia la necesidad de más acciones dirigidas a un uso más eficiente del agua.

En este sentido, Dionisio Fernández de Gatta Sánchez afirma que: “(...) el Programa considera necesario abordar con carácter prioritario la eficiencia en el uso del agua, al considerarse que sigue derrochándose entre un $20 \%$ y un $40 \%$ del agua disponible en Europa (principalmente por fugas en los sistemas de distribución), aunque también inciden la sequía y la escasez en cada vez más zonas, y para contribuir a mantener su buen estado, existiendo todavía un amplio margen para mejorar la eficiencia hídrica, si bien asimismo se prevé un aumento de la demanda de agua y otros problemas derivados de la incidencia del cambio climático. En este contexto, el Programa estima necesario que la Unión y los Estados Miembros adopten medidas, desde ahora hasta el año 2020, para que las extracciones de agua respeten los límites de los recursos hidráulicos renovables, particularmente mejorando la eficiencia hídrica, mediante instrumentos de mercado tales como la tarifación del agua reflejando su valor

Programa Ambiental de la Unión Europea, 2013-2020. Revista Aragonesa de Administración Pública ISSN 1133-4797, núm. 41-42, Zaragoza, 2013, pp. 71-121, enseña que: “(ya que la Unión genera anualmente 2.700 millones de toneladas, de los que 98 corresponden a residuos peligrosos; reciclándose o reutilizándose una media del 40\% de los residuos sólidos, aunque algunos Estados Miembros llegan hasta el 70\%, pero otros aún depositan en vertederos el 75\% de los mismos), para que los mismos puedan utilizarse como recurso, siguiendo la hoja de Ruta sobre uso eficaz de éstos, el Programa considera esencial que la legislación europea en materia de residuos se aplique completamente en la Unión, y con esfuerzos adicionales para reducir su generación, limitar la generación de energía a los materiales no reciclables, eliminar progresivamente el depósito en vertederos, garantizar un reciclado de alta calidad, desarrollar mercados para materias primas secundarias y tratar de gestionar los residuos peligrosos reduciendo al mínimo los efectos negativos para la salud humana y el medio ambiente; debiendo utilizarse asimismo instrumentos de mercado que primen la prevención, el reciclado y la reutilización de los residuos, suprimir obstáculos a las actividades de reciclado en el mercado interior y avanzar hacia una «economía circular», en la que los residuos se utilicen en cascada y se eliminen por completo los residuos remanentes".

Disponible

en: $<$ http://www.aragon.es/estaticos/GobiernoAragon/Organismos/InstitutoAragonesAdministracionPublica/ Areas/03_Revista_Aragonesa_Formacion/02\%20Dionisio\%20Fernández.pdf $>$. Acceso en: 03-10-2015, p.107. 
real, y con técnicas y sistemas innovadores. En relación con todos los ámbitos anteriores, el Programa señala que un marco de políticas a largo plazo y previsible en ellos contribuirá a conseguir un nivel de inversiones y actuaciones que permitirá desarrollar plenamente mercados de tecnologías más ecológicas y promover soluciones empresariales sostenibles, debiendo establecerse para ello indicadores y objetivos en materia de eficiencia en el uso de los recursos que orienten a quienes tienen que tomar decisiones en el ámbito público y privado en el proceso de transformación de la economía, los cuales formarán parte integrante del propio Programa una vez acordados" $" 1424$.

Además de las previsiones señaladas, para que la Unión pueda convertirse en una economía hipocarbónica, ecológica, competitiva y eficiente en el uso de los recursos, el Programa considera que en 2020: deben haberse cumplido los objetivos establecidos en materia de clima y energía, y se esté trabajando para reducir en 2050 las emisiones de gases de efecto invernadero entre un $80 \%$ y un $95 \%$ en comparación con 1990; deben reducirse considerablemente el impacto ambiental global de las empresas y de los principales sectores industriales, y debe aumentarse su eficiencia en el uso de los recursos; deben reducirse el impacto ambiental global de la producción y el consumo, en particular en los sectores de la alimentación, la vivienda y la movilidad; los residuos se gestionen de forma segura como recurso, se registre un descenso absoluto de su proporción per cápita, la recuperación de energía se limite a los materiales no reciclables y hayan dejado de depositarse en vertederos los materiales que puedan hacerse compost y los reciclables; y se haya prevenido o reducido considerablemente la escasez de agua.

Para alcanzar estos objetivos, será necesario: aplicar íntegramente el paquete de medidas sobre clima y energía, y acordar el marco para después de 2020; generalizar la aplicación de las «mejores técnicas disponibles» y promover la adopción de tecnologías, procesos y servicios innovadores; impulsar la investigación y los trabajos

${ }^{1424}$ FERNÁNDEZ DE GATTA SÁNCHEZ, Dionisio. El Séptimo Programa Ambiental de la Unión Europea, 2013-2020. Revista Aragonesa de Administración Pública ISSN 1133-4797, núm. 41-42, Zaragoza, 2013, pp. 71-121. Disponible en: $<$ http://www.aragon.es/estaticos/GobiernoAragon/Organismos/InstitutoAragonesAdministracionPublica/ Areas/03_Revista_Aragonesa_Formacion/02\%20Dionisio\%20Fernández.pdf $>$. Acceso en: 03-10-2015, p. 107. 
de innovación, públicos y privados, necesarios para generalizar tecnologías, sistemas y modelos empresariales innovadores que aceleren la transición hacia una economía hipocarbónica y eficiente en el uso de los recursos, y reduzcan sus costes; establecer un marco más coherente para una producción y un consumo sostenibles, revisar la legislación en materia de productos para mejorar su comportamiento medioambiental y la eficiencia de los productos en el uso de los recursos a lo largo de su ciclo de vida, y fijar metas de reducción del impacto global del consumo; ejecutar íntegramente la legislación de residuos (con sus principios, objetivos e instrumentos); y mejorar la eficiencia hídrica mediante el establecimiento de objetivos a nivel de cuencas hidrográficas y la utilización de mecanismos de mercado, tales como la tarificación del agua.

Así, en un contexto marcado por el alza de los precios de los recursos naturales, escasez y dependencia de las importaciones, en el futuro la competitividad y la capacidad de crecimiento sostenible de Europa dependerán de las mejoras en el uso eficiente de los recursos por parte de todo el tejido económico. El PMA pide que se definan indicadores y objetivos de eficiencia en el uso de recursos, que sirvan de guía para la toma de decisiones en el sector público y en el privado.

Los beneficios de una economía que utiliza los recursos de forma más eficiente empiezan a ser visibles en muchos sectores. El sector de tecnologías y servicios medioambientales está conociendo un éxito de primera magnitud, con un aumento del empleo anual del 3\%. El mercado mundial de las ecoindustrias, cuyo volumen se estima actualmente en un billón de euros, duplicará su tamaño en los próximos 10 años. Esto son muy buenas noticias para las empresas europeas, que ya gozan de un liderazgo mundial en reciclado y eficiencia energética ${ }^{1425}$.

El tercer ámbito de acción cubre los desafíos para el bienestar y la salud de los seres humanos, con aspectos tales como la contaminación del aire y el agua, la contaminación acústica y los productos químicos tóxicos.

Según la Organización Mundial de la Salud, los factores medioambientales podrían estar detrás de hasta un $20 \%$ de las muertes que se producen en Europa. En Europa hay normas estrictas de calidad del aire, pero en muchas ciudades la contaminación sigue estando por encima de los niveles aceptables. El PMA establece

1425 Información disponible en el sitio de la Comisión Europea: $<$ http://ec.europa.eu/environment/pubs/pdf/factsheets/7eap/es.pdf $>$. Acceso en: 06-10-2015. 
compromisos para mejorar la aplicación de la legislación existente y para reducir en mayor medida la contaminación atmosférica y acústica. Por otra parte, también presenta una visión a largo plazo de un entorno no tóxico y propone controlar los riesgos asociados al uso de sustancias químicas en productos y en preparados químicos, especialmente los que afectan al sistema endocrino. En paralelo, se creará un marco de trabajo predecible combinado con más inversiones en conocimiento, para promover la innovación y el desarrollo de soluciones más sostenibles ${ }^{1426}$.

Sin embargo, como bien afirma Dionisio Fernández de Gatta Sánchez: “Aunque el cambio climático, señala el Programa (con ciertas notas catastrofistas), agravará algunos de estos problemas ambientales (olas de calor, inundaciones, tormentas o incendios forestales, así como formas nuevas de enfermedades humanas y que afecten a animales y vegetales), es preciso adoptar medidas para preparar

${ }^{1426}$ El nuevo programa incluye un $<<$ marco instrumental $>>$ con los siguientes cuatro objetivos prioritarios para facilitar avances en Europa: mejorar la aplicación de la legislación; mejorar la información mediante la ampliación de la base de conocimientos; más inversiones -y mejor dirigidas- en el medio ambiente, e integración completa de requisitos y consideraciones medioambientales en otras políticas. Información disponible en el sitio de la Comisión Europea: $<\mathrm{http}$ ://ec.europa.eu/environment/pubs/pdf/factsheets/7eap/es.pdf >. Acceso en: 06-10-2015. Además, Dionisio Fernández de Gatta Sánchez, El Séptimo Programa Ambiental de la Unión Europea, 2013-2020. Revista Aragonesa de Administración Pública ISSN 1133-4797, núm. 41-42, Zaragoza, 2013, pp. 71-121, hace importante observación respecto al tema: "En relación con la contaminación atmosférica, se plantea actuar en los espacios en los que las personas, especialmente los grupos sociales sensibles, y los ecosistemas están más expuestas, como las ciudades y el interior de los edificios. Por otra parte, el Programa constata tanto la positiva incidencia de las aguas de baño de buena calidad para la salud humana y para el turismo, como los problemas de acceso a agua de calidad satisfactoria en algunas zonas rurales y los provocados por las inundaciones, en parte por los cambios en el ciclo hidrológico y en el uso de la tierra. Una parte de los problemas anteriores provienen del hecho de que la legislación de ambas materias no se aplica plenamente en la Unión, por lo que se actualizarán las mismas y en particular sus objetivos de acuerdo con los datos científicos más recientes y se procurará crear sinergias con las relativas al cambio climático, biodiversidad, medio marino y territorio. La prioridad en relación con ambos tipos continúa siendo controlar la contaminación en su origen, a lo que la Directiva de Emisiones Industriales de 2010 contribuirá apreciablemente, así como la hoja de Ruta en materia del mercado único de los transportes, que también incidirá sobre el ruido”. Disponible en: $<$ http://www.aragon.es/estaticos/GobiernoAragon/Organismos/InstitutoAragonesAdministracionPublica/ Areas/03_Revista_Aragonesa_Formacion/02\%20Dionisio\%20Fernández.pdf $>$. Acceso en: 03-10-2015, p. 109. 
adecuadamente a la Unión Europea en relación con el mismo, en especial en materia de adaptación, y fortalecer su resiliencia ambiental, económica y social. Medidas éstas que pueden tener repercusiones socioeconómicas muy positivas, p. ej., en la sanidad pública" $\$ 1427$.

Para alcanzar estos objetivos, el Programa propone que en 2020: la calidad del aire haya mejorado y la contaminación acústica haya disminuido considerablemente; los ciudadanos disfruten de normas elevadas de calidad del agua potable y de baño; se controlen los efectos combinados de los productos químicos y los problemas de seguridad que plantean los alteradores endocrinos, y se evalúen y minimicen los riegos para el medio ambiente y la salud asociados al uso de sustancias peligrosas, incluidas las sustancias químicas presentes en productos; se controlen adecuadamente los problemas de seguridad relacionados con los nanomateriales, aplicando un planteamiento coherente entre distintos ámbitos legislativos; y se hayan realizado avances decisivos en materia de adaptación a los impactos del cambio climático.

Para ello, será necesario: aplicar una política actualizada sobre calidad del aire y ruido, acorde con los conocimientos científicos más recientes, así como medidas contra la contaminación atmosférica y acústica en su origen; impulsar la labor de aplicación de las Directivas de Agua Potable y de Aguas de Baño; desarrollar una estrategia europea para un entorno no tóxico, respaldada por una base exhaustiva de conocimientos sobre toxicidad y exposición a los productos químicos, que propicie la innovación en sustitutivos sostenibles; acordar y aplicar una estrategia de adaptación al cambio climático a nivel de la Unión, incluida la integración de las consideraciones en materia de adaptación y gestión del riesgo de catástrofes en sectores e iniciativas políticas clave.

De este modo, una mejor aplicación de la legislación ya existente aportará numerosas ventajas. En un estudio realizado por la Comisión en 2012 se estimaba que

${ }^{1427}$ FERNÁNDEZ DE GATTA SÁNCHEZ, Dionisio. El Séptimo Programa Ambiental de la Unión Europea, 2013-2020. Revista Aragonesa de Administración Pública ISSN 1133-4797, núm. 41-42, Zaragoza, 2013, pp. 71-121. Disponible en: $<$ http://www.aragon.es/estaticos/GobiernoAragon/Organismos/InstitutoAragonesAdministracionPublica/ Areas/03_Revista_Aragonesa_Formacion/02\%20Dionisio\%20Fernández.pdf $>$. Acceso en: 03-10-2015, p. 110 . 
la aplicación efectiva de la legislación de la UE en materia de residuos supondría un ahorro de 72000 millones de euros al año, un aumento de 42000 millones de euros en la facturación anual del sector europeo de gestión de residuos y reciclaje, y la creación de más de 400000 nuevos empleos hasta 2020. Si la legislación medioambiental de la UE se aplicara correctamente, se crearían unas condiciones equitativas en el mercado único y se generarían oportunidades de inversión sostenible, aparte de los beneficios medioambientales $^{1428}$.

El PMA reconoce la importancia de dar al público un acceso mucho mayor a la información. De este modo, el público entendería mejor la problemática medioambiental y sería más fácil que los individuos aportaran mejoras a su propio entorno.

De acuerdo con las precisiones anteriores, el Programa garantizará en 2020 que: los ciudadanos tengan acceso a información clara sobre cómo se está aplicando la legislación europea de medio ambiente; haya mejorado la aplicación de las normas ambientales; se haya reforzado el cumplimiento de la legislación ambiental en todas las esferas administrativas y se garanticen unas condiciones equitativas en el mercado interior; la legislación ambiental de la Unión inspire más confianza a los ciudadanos; y que se facilite la aplicación del principio de tutela judicial efectiva de los ciudadanos y las organizaciones de la sociedad civil.

Para ello, se prevé necesario: establecer a nivel nacional sistemas de información sobre cómo se está aplicando la legislación ambiental de la Unión, acompañados de cuadros con los resultados de cada Estado Miembro; celebrar acuerdos de asociación para la aplicación de la legislación entre la Comisión y los Estados Miembros; ampliar a toda la legislación medioambiental los criterios que obligan a los Estados Miembros a realizar inspecciones y vigilancias eficaces, y desarrollar una capacidad complementaria a nivel de la UE para actuar ante situaciones en las que haya motivos de preocupación justificados, con el respaldo de redes de profesionales; establecer mecanismos coherentes y eficaces a nivel nacional para la tramitación de denuncias relacionadas con la aplicación de la legislación ambiental de la Unión; y garantizar que las disposiciones nacionales sobre acceso a la justicia reflejen la jurisprudencia del Tribunal de Justicia de la Unión Europea, y promover los 1428 Información disponible en el sitio de la Comisión Europea: $<$ http://ec.europa.eu/environment/pubs/pdf/factsheets/7eap/es.pdf $>$. Acceso en: 06-10-2015. 
procedimientos no judiciales de resolución de conflictos como medio para encontrar soluciones amistosas en conflictos sobre cuestiones de medio ambiente.

Por otra parte, también reconoce la necesidad de mejorar los sistemas de inspección y vigilancia, y de un mejor acceso a la justicia en cuestiones medioambientales.

Para mejorar la base de información de la política de medio ambiente, el Programa garantizará que en 2020: los responsables políticos y las empresas dispongan de una base más adecuada para desarrollar y aplicar las políticas de medio ambiente y clima, en particular para calcular costes y beneficios; hayan mejorado considerablemente nuestros conocimientos y nuestra capacidad de evaluar y gestionar los nuevos riesgos climáticos y medio- ambientales; y se haya consolidado la interfaz ciencia-política en cuestiones ambientales.

A tal fin, se estima necesario: coordinar y concentrar los esfuerzos de investigación de la Unión y los Estados Miembros para colmar las principales lagunas en los conocimientos ambientales, en particular respecto a los riesgos de puntos de inflexión ambientales; aplicar un planteamiento sistemático a la gestión del riesgo; y simplificar, racionalizar y modernizar la recogida, la gestión y la puesta en común de datos e información sobre cambio climático y medio ambiente.

La investigación científica, el seguimiento y la información sobre los cambios medioambientales sirven para que cada vez comprendamos mejor nuestro entorno. Debe facilitarse el acceso de los ciudadanos y responsables políticos a esta base de conocimientos, para que las políticas se fundamenten en una comprensión adecuada del estado del medio ambiente. Al mismo tiempo, la elaboración de políticas de la Unión Europea seguirá rigiéndose por el principio de precaución ${ }^{1429}$.

Según nuestro grado de conocimiento actual, debemos emprender acciones inmediatas en áreas tales como el cambio climático, la desaparición de especies, los umbrales ambientales y los puntos de inflexión ecológicos; con todo, estos conceptos son complejos y, para desarrollar planteamientos de una efectividad máxima, es preciso

${ }^{1429}$ De acuerdo con el Tratado de Funcionamiento de la Unión Europea (TFUE), el principio de precaución busca garantizar un alto nivel de protección del medio ambiente mediante la toma de decisiones preventivas en caso de riesgo. Disponible en: $<$ http://europa.eu/legislation_summaries/consumers/consumer_safety/132042_es.htm>. Acceso en: 06-102015. 
conocerlos más a fondo. El PMA quiere responder a estos desafíos mejorando la forma en que se recopilan, gestionan y utilizan los datos y otra información en toda la UE, invirtiendo en investigación para llenar lagunas de conocimiento y desarrollando un enfoque más sistemático de los nuevos riesgos emergentes.

Para alcanzar los objetivos definidos en el programa se necesitarán inversiones adecuadas e innovación en productos, servicios y políticas públicas, tanto por parte de fuentes públicas como privadas. Esto solo será posible si se cuantifican de forma apropiada los impactos en el medio ambiente y si las señales del mercado reflejan también los verdaderos costes medioambientales ${ }^{1430}$. Eso implica aplicar más sistemáticamente el principio de 'quien contamina paga', hacer desaparecer subsidios que resulten perjudiciales para el medio ambiente, hacer que la carga fiscal no recaiga en el trabajo sino en la contaminación y ampliar los mercados de los productos y servicios medioambientales. Como ejemplo concreto, el PMA reclama que se dedique al menos un 20\% del presupuesto de la UE para el periodo 2014-2020 a la reducción y adaptación al cambio climático ${ }^{1431}$. Las empresas perciben cada vez más las ventajas de

${ }^{1430}$ En este sentido Miren Sarasíbar Iriarte, Las oportunidades de la crisis económica en el derecho ambiental. en concreto, el fondo de carbón. Revista Aragonesa de Administración Pública, n. ${ }^{\circ}$ 41-42, Zaragoza, 2013, pp. 287-306 afirma que: "La parte esencial del medio ambiente se sitúa fuera de la esfera de los intercambios mercantiles ya que el mercado puede provocar efectos desastrosos sobre el ambiente. Para que éste pueda ser incluido en la racionalidad de la economía, es necesario atribuirle un precio o coste externo. Sin embargo, además de que esto no es suficiente, no es el camino deseable ya que atribuir un coste a un elemento ambiental cuando éste ha sido lesionado para que se proceda a su reparación, pueda conllevar a que esos daños sean difícilmente reparables. Por ello, en el Derecho ambiental el concepto de la prevención adquiere tanta importancia y hay que idear las formas para evitar que el ambiente natural se lesione por la actuación humana" (p. 293). Disponible en: $<$ http://www.aragon.es/estaticos/GobiernoAragon/Organismos/InstitutoAragonesAdministracionPublica/ Documentos/docs2/07\%20Miren\%20Saras\%C3\%ADbar.pdf $>$. Acceso en: 17-11-2015.

${ }^{1431}$ En este sentido, Dionisio Fernández de Gatta Sánchez, El Séptimo Programa Ambiental de la Unión Europea, 2013-2020. Revista Aragonesa de Administración Pública ISSN 1133-4797, núm. 41-42, Zaragoza, 2013, pp. 71-121, comenta que: "Por lo que se refiere a la propia Unión, el Marco financiero 2014-2020 propuesto ya integra los objetivos ambientales y climáticos en todos los instrumentos financieros (como el Programa LIFE o los fondos del Banco Europeo de Inversiones), se aumentan un $20 \%$ los gastos relacionados con el clima y se prevén fondos en esta materia en otras Políticas para conseguir esos objetivos. Por lo que se refiere a la utilización por los Estados Miembros de estos fondos europeos, con consideraciones ambientales, su utilización ha sido muy desigual en el período 2007-2013, por lo que deben hacerse más esfuerzos en la integración ambiental en sus estrategias y programas de 
invertir en ecoinnovación y de adoptar nuevas tecnologías, de medir el impacto ecológico de sus actividades y de transmitir a sus inversores y clientes información medioambiental en sus informes anuales. El PMA presenta algunas propuestas para avanzar en esta tendencia.

Con la finalidad de asegurar inversiones para la política ambiental y sobre clima, y fijar correctamente los precios, el Programa prevé que en 2020 se hayan realizado de una forma rentable los objetivos de la política de medio ambiente y clima, que tales objetivos estén respaldados por una financiación adecuada, y que haya aumentado la financiación del sector privado para los dos ámbitos.

Para ello, se considera necesario, en particular: suprimir progresivamente las subvenciones perjudiciales para el medio ambiente, intensificar la aplicación de instrumentos de mercado (en particular impuestos, tarifas y tasas), y ampliar los mercados de bienes y servicios ambientales, teniendo debidamente en cuenta cualquier impacto social negativo; facilitar el acceso de la ecoinnovación a fondos e instrumentos financieros; reflejar adecuadamente las prioridades ambientales y climáticas en las políticas de apoyo a la cohesión económica, social y territorial; adoptar medidas específicas para garantizar el uso integral y eficiente de los fondos disponibles de la Unión para la actuación a favor del medio ambiente (en particular, incrementando significativamente la utilización temprana de los fondos del Marco financiero plurianual de la Unión para 2014-2020 y asignando el $20 \%$ del presupuesto a medidas de adaptación y mitigación del cambio climático), y, junto con unos criterios de referencia claros, el establecimiento de metas y la realización de actividades de seguimiento y notificación; desarrollar y aplicar, antes de 2014, un sistema de notificación y

financiación relativos a la cohesión, el desarrollo rural o la política marítima. Asimismo, se constata que el seguimiento de los gastos en materia de biodiversidad y clima ha resulta dos difícil, por lo que se avanzará en la utilización de sistemas de seguimiento, notificación y evaluación (p. ej., con la metodología de la OCDE). Asimismo, más en general, deben continuar desarrollándose los indicadores de seguimiento del progreso económico más allá del PIB, y lo complementen (mediante una valoración adecuada de los bienes ambientales y ecosistemas, y de los costes del progresivo agotamiento de algunos recursos naturales, una evaluación de los incentivos necesarios para fundamentar decisiones públicas y de inversión y avanzar en el establecimiento de un sistema de contabilidad medioambiental)”. Disponible en: $<$ http://www.aragon.es/estaticos/GobiernoAragon/Organismos/InstitutoAragonesAdministracionPublica/ Areas/03_Revista_Aragonesa_Formacion/02\%20Dionisio\%20Fernández.pdf $>$. Acceso en: 03-10-2015, pp. 114-115. 
seguimiento de los gastos relacionados con el medio ambiente en el Presupuesto de la UE, especialmente en relación con el cambio climático y la biodiversidad; integrar las consideraciones ambientales y climáticas en el proceso del Semestre Europeo, a efectos de las perspectivas de crecimiento sostenible de los Estados Miembros y sea con respecto a las recomendaciones específicas por países; y desarrollar y aplicar indicadores alternativos que vayan más allá del PIB, lo complementen y que permitan controlar si nuestro progreso es sostenible, así como proseguir la integración entre los indicadores económicos y los ambientales y sociales, incluida la contabilidad medioambiental.

La cuarta condición instrumental del programa es una mayor integración de las cuestiones medioambientales en otras áreas políticas, como la política regional o las políticas agrícolas, pesqueras, de energía y de transporte. La evaluación sistemática de los impactos medioambientales, sociales y económicos de las iniciativas políticas y la plena aplicación de la legislación sobre evaluación del impacto ambiental ayudarán a tomar decisiones políticas mejores y más coherentes, lo cual reportará múltiples beneficios.

Buscando responder a los desafíos locales, regionales y mundiales (puntos 87 a 100), el programa se completa con otros dos objetivos prioritarios: el primero es ayudar a las ciudades a ser más sostenibles (puntos 87 a 91). Europa tiene una alta densidad de población y es probable que, para el año 2020, el $80 \%$ de sus habitantes vivan en zonas urbanas y periurbanas. Las ciudades suelen tener en común una serie de problemas, como mala calidad del aire, altos niveles de ruido, emisiones de gases de efecto invernadero, escasez de agua y gestión de los residuos. Para solucionar esto problemas es preciso colaborar ${ }^{1432}$.

\footnotetext{
${ }^{1432}$ Según, Dionisio Fernández de Gatta Sánchez, El Séptimo Programa Ambiental de la Unión Europea, 2013-2020. Revista Aragonesa de Administración Pública ISSN 1133-4797, núm. 41-42, Zaragoza, 2013, pp. 71-121, "Sobre la idea de que las iniciativas de la UE a favor del desarrollo urbano sostenible benefician tanto a quienes viven en zonas urbanas como en el medio rural, el programa considera necesaria una coordinación efectiva entre las distintas Administraciones, y la participación efectiva de las Autoridades regionales y locales en la planificación y el desarrollo de las políticas que inciden en la calidad del medio urbano, resaltando en esta línea los instrumentos previstos en el próximo Marco financiero, y en concreto la Plataforma de Desarrollo Urbano, las nuevas herramientas que permitan simplificar la recogida y gestión de datos ambientales y facilitar el intercambio de información y buenas prácticas, y la mejora en la aplicación de la legislación ambiental a todos los niveles, así como promover
} 
Por ello, el Programa Ambiental quiere que se promuevan y extiendan iniciativas que ayuden a las ciudades a compartir innovaciones y buenas prácticas. El objetivo es garantizar que, para 2020, la mayoría de las ciudades de la UE hayan puesto en práctica políticas de diseño y planificación urbana sostenible, y que utilicen la financiación disponible en la UE para este propósito.

Por fin, la última prioridad se ocupa de los desafíos a escala mundial (puntos 92 a 100). Muchos de los objetivos prioritarios del Séptimo Programa solo podrán alcanzarse cooperando con otros países socios o en el marco de iniciativas globales. La Unión Europea y sus Estados miembros se comprometen a realizar esfuerzos más efectivos para colaborar con sus socios internacionales en la adopción de objetivos de desarrollo sostenible como continuación de la Conferencia Río+20 de 2012. El Programa también propone explorar nuevas vías para reducir los impactos medioambientales fuera de las fronteras de la Unión Europea. 'Vivir bien, respetando los límites de nuestro planeta' es un objetivo global ${ }^{1433}$.

un enfoque integrado de la planificación, construcción y gestión de las ciudades y otros asentamientos urbanos sostenibles, teniendo en cuenta los desafíos económicos y sociales. Además, se considera necesario que la UE continúe promoviendo y, cuando proceda, ampliando las iniciativas de apoyo a la innovación y mejores prácticas en ciudades, y las redes de intercambio entre ellas, utilizando cuando sea pertinente los fondos europeos disponibles. Para aumentar la sostenibilidad de las ciudades de la UE, el Programa considera que en 2020 la mayoría de las ciudades de la Unión ya estén aplicando políticas de ordenación y diseño sostenibles del espacio urbano, para lo que será necesario determinar y acordar un conjunto de criterios para evaluar el comportamiento ambiental de las ciudades, teniendo en cuenta los impactos económicos y sociales, y garantizar que las mismas dispongan de información sobre la financiación de medidas para mejorar su sostenibilidad urbana, y que tengan acceso a tales fondos". Disponible

$<$ http://www.aragon.es/estaticos/GobiernoAragon/Organismos/InstitutoAragonesAdministracionPublica/ Areas/03_Revista_Aragonesa_Formacion/02\%20Dionisio\%20Fernández.pdf $>$. Acceso en: 03-10-2015, pp. 117-118.

${ }^{1433}$ Respecto al papel del Parlamento Europeo, Tina Ohliger, La política de medio ambiente: principios generales y marco básico, enuncia que: "El Parlamento Europeo desempeña un importante papel en la definición de la legislación de la UE en materia de medio ambiente. A lo largo de su séptima legislatura (2009-2014), el Parlamento, colegislador junto con el Consejo, ha adoptado, entre otras cosas, legislación sobre emisiones de vehículos e industriales, residuos electrónicos y bolsas de plástico, traslado ilegal de residuos y desguace de viejos buques. Además, el Parlamento ha reconocido en reiteradas ocasiones la necesidad de mejorar la aplicación como prioridad clave. En una Resolución de 2013 sobre «sacar el mejor partido de las medidas ambientales de la UE: instaurar la confianza mediante la mejora de los 
Para reforzar la eficacia de la Unión Europea para afrontar los desafíos ambientales a nivel regional y mundial, el Programa garantiza que, en 2020: se hayan integrado plenamente las conclusiones de la Cumbre Río+20 en las políticas exteriores de la Unión, y la misma contribuya efectivamente a los esfuerzos mundiales por aplicar compromisos acordados, incluidos los Convenios de Río; la Unión esté apoyando efectivamente los esfuerzos nacionales, regionales e internacionales para resolver los problemas ambientales y climáticos, y garantizar un desarrollo sostenible; y se haya reducido el impacto del consumo de la UE en el medio ambiente de fuera de sus fronteras.

A tal fin, se considera necesario: trabajar por la adopción de Metas de Desarrollo Sostenible que:

— se refieran a ámbitos prioritarios de los objetivos relativos a una economía

conocimientos y la capacidad de respuesta», criticó el nivel insatisfactorio de aplicación de la legislación medioambiental en los Estados miembros y formuló varias recomendaciones para lograr una aplicación más eficaz, como la difusión de mejores prácticas entre Estados miembros y entre autoridades regionales y locales. En su posición sobre el actual Programa de Acción en Materia de Medio Ambiente (que se prolongará hasta 2020), el Parlamento subrayó también la necesidad de hacer cumplir con mayor rigor la legislación de la UE en materia de medio ambiente. Insistió en que el Séptimo Programa de Acción en Materia de Medio Ambiente «contribuirá a un nivel elevado de protección del medio ambiente y a la mejora de la calidad de vida y el bienestar de los ciudadanos». También pidió una mayor seguridad de la inversión que respalda la política medioambiental y esfuerzos para combatir el cambio climático, así como que se preste una atención mayor y mejor a las consideraciones medioambientales en otras políticas. En una Resolución de 2010, el Parlamento consideró que los aspectos medioambientales de la Estrategia UE 2020 son en términos generales demasiado débiles y se han de reforzar y pidió que se fijen metas medioambientales claras y mensurables «dentro de los principales objetivos de la estrategia, esforzándose por detener la pérdida de biodiversidad». Recientemente, el Parlamento ha aprobado una actualización de la Directiva sobre las evaluaciones de impacto ambiental para clarificar el texto, incluir la biodiversidad y el cambio climático y garantizar que las autorizaciones de proyectos no estén sujetas a conflictos de intereses. En el marco de las negociaciones con el Consejo, el Parlamento logró elevar los niveles de calidad para proteger la salud humana y el medio ambiente. Aunque tuvo que ceder por lo que se refiere a las evaluaciones de impacto ambiental obligatorias para la extracción y exploración de gas de esquisto, los riesgos para la salud humana o el medio ambiente deberán tenerse en cuenta en relación con los nuevos proyectos en el ámbito del gas”. Información disponible en el sitio del Parlamento Europeo, Fichas Técnicas la Unión Europea: $<$ http://www.europarl.europa.eu/atyourservice/es/displayFtu.html?ftuId=FTU_5.4.1.html>. Acceso en: 19-10-2015. 
verde e integradora y al desarrollo sostenible en general, en particular la energía, el agua, la seguridad alimentaria, los océanos y una producción y un consumo sostenibles, así como a cuestiones transversales como la equidad, la inclusión social, empleos dignos, el principio de legalidad y la buena gobernanza;

- sean de aplicación universal y cubran los tres ámbitos del desarrollo sostenible (es decir, el económico, el social y el ambiental);

- - - se sometan a evaluación y vayan acompañados de metas e indicadores, $\mathrm{y}$

- sean coherentes con el marco de desarrollo posterior a 2015 y estén integrados en él, y sirvan de apoyo para medidas en el campo del clima;

*trabajar para conseguir una estructura más efectiva de las Naciones Unidas en relación con el desarrollo sostenible mediante la consolidación del PNUMA, en sintonía con las conclusiones de la Cumbre Río+20, prosiguiendo, al mismo tiempo, los esfuerzos para que el mismo ascienda a la categoría de Agencia de las Naciones Unidas, y apoyando los trabajos en curso para intensificar las sinergias entre los acuerdos multilaterales sobre medio ambiente;

* potenciar el impacto de diferentes fuentes de financiación, en particular los impuestos y la movilización de los recursos internos, la inversión privada y otras fuentes nuevas e innovadoras, así como crear opciones respecto a la utilización de la ayuda al desarrollo para hacer uso de esas otras fuentes de financiación como parte de la estrategia de financiación del desarrollo sostenible establecida en Río, así como en las propias polí- ticas de la UE, incluidos los compromisos internacionales a favor de la financiación para la protección de la biodiversidad y la lucha contra el cambio climático;

* establecer relaciones con países socios de una forma más estratégica (por lo que conviene centrar la cooperación con socios estratégicos, con países integrados en la Política Europea de Vecindad y con países en desarrollo, según los casos;

*participar en procesos multilaterales sobre cuestiones ambientales, con vistas a garantizar el cumplimiento a nivel mundial y de la UE de los compromisos para 2020, y acordar la actuación internacional para después de ese año;

* ratificar mucho antes de 2020 todos los principales acuerdos multilaterales sobre medio ambiente, $\mathrm{y}$

* evaluar el impacto ambiental en el mundo del consumo que hace la UE de 
alimentos y productos no alimentarios, y las posibles respuestas a los mismos.

Ya la parte final del programa, o sea, la quinta parte, hace referencia al $<<$ Seguimiento de los avances $>>$. Dicho seguimiento fue encomendado a la Comisión para que esta pueda velar por que se efectúe un seguimiento de la aplicación del programa en el contexto del proceso de seguimiento periódico de la Estrategia Europa 2020, y previendo una evaluación del PMA antes de 2020, en particular sobre la base del informe del estado del medio ambiente de la Agencia Europea de Medio Ambiente (AEMA).

Buscando seguir los avances hacia la consecución de los objetivos prioritarios, el Séptimo Programa señala algunos indicadores que serán utilizados, destacando: los que aplica la AEMA en el seguimiento del estado del medio ambiente y del cumplimiento de las metas y la legislación ambiental, relativos al clima, la energía, la biodiversidad y la eficiencia en el uso de los recursos. Además, establece todavía que, se desarrollarán indicadores suplementarios, en coordinación con las partes interesadas, visando evaluar el progreso en general hacia una economía y una sociedad eficientes en el uso de los recursos en Europa y su contribución a la prosperidad y el bienestar, en el contexto de la Hoja de ruta hacia una Europa eficiente en el uso de los recursos.

Delante de todo eso, se puede afirmar que el Séptimo Programa Ambiental ${ }^{1434}$, de verdad, marca una nueva etapa en la política ambiental de la Unión Europea, vez que su estructura está muy bien elaborada con prioridades temáticas y sus nueve objetivos prioritarios hasta 2020, clasificando así, este programa como instrumento hábil para hacer frente a los retos de la Unión Europea para los años 2013-2020 en materia ambiental $^{1435}$.

${ }^{1434} \mathrm{El}$ texto completo referente al Séptimo Programa, también denominado como 'Programa General de Medio Ambiente de la Unión' está disponible en: < http://eur-lex.europa.eu/legalcontent/ES/TXT/?uri=CELEX:32013D1386>.

${ }^{1435}$ Respecto al Séptimo Programa, Dionisio Fernández de Gatta Sánchez, El Séptimo Programa Ambiental de la Unión Europea, 2013-2020. Revista Aragonesa de Administración Pública ISSN 11334797, núm. 41-42, Zaragoza, 2013, pp. 71-121, resume que: "Este nuevo Programa Ambiental de la Unión Europea, el séptimo, fue presentado el mismo 29 de noviembre de 2012 al Grupo «Medio Ambiente». La Presidencia redactó dos preguntas para orientar el debate político en el Consejo (relativas a si los Estados Miembros consideraban que el mismo estaba a la altura de sus expectativas, al tiempo que cubre los retos ambientales actuales, y si las nueve prioridades establecidas en el mismo son suficientes y pragmáticas en términos de visión, alcance y ambición para el Programa y que las acciones propuestas 
Capítulo 7 - Instrumentos de protección del agua: énfasis en el Derecho Administrativo Sancionador y Derecho Penal

\subsection{Medio ambiente como bien jurídico: contribuciones para la legitimación de la intervención penal}

La ciencia jurídica como un todo se dedica a establecer varios mecanismos de protección al medio ambiente, a empezar por la Constitución, recorriendo un largo camino, verificándose que el Derecho Administrativo, el Derecho Tributario, el Derecho Mercantil, el Derecho Civil, entre otros establecen tratamiento particular al tema. En este contexto, también el Derecho Penal en el curso de su desarrollo, y de manera más segura en las últimas décadas, ha tomado también la misión de protegerlo. En el escenario global no son pocos los casos de profunda lesión del ambiente ocurridos por contaminaciones y degradaciones en las áreas de protección ambiental.

Dado el carácter determinante que tiene el Derecho penal, instrumento más grave que posee el Estado para imponer el cumplimiento de normas, en especial al establecer la privación de la libertad, obligaciones de hacer y condenación en dinero, se torna necesario presentar algunas consideraciones sobre el Derecho Penal y la tutela que promueve sobre el bien jurídico medio ambiente. Crece el análisis de importancia, a la medida que al lado del Derecho Administrativo, el Derecho Penal es manifestación de poder advenida del Estado.

son adecuadas para lograr los objetivos propuestos para 2020). La Comisión presentó su propuesta a la Comisión de Medio Ambiente del Parlamento Europeo el 18 de diciembre, y el COREPER inició su estudio para presentar sus propuestas al Consejo (29). Posteriormente, en efecto, el Programa ha sido objeto de un primer análisis por el Consejo de Medio Ambiente celebrado el 17 de diciembre de 2012 (sesión no 3211, doc. 17582/12, versión provisional); continuando su proceso de aprobación, que incluye, por ahora el dictamen del Comité Económico y Social de 20 de marzo de 2013 (DOUE C 161, 6.6.2013), y el dictamen del Comité de las Regiones de 30 de mayo de 2013". Disponible en: $<$ http://www.aragon.es/estaticos/GobiernoAragon/Organismos/InstitutoAragonesAdministracionPublica/ Areas/03_Revista_Aragonesa_Formacion/02\%20Dionisio\%20Fernández.pdf $>$. Acceso en: 03-10-2015, p. 121. 
Para que se delimite el campo de actuación del Derecho Penal del Ambiente, inicialmente, es de gran importancia definir qué o cuáles elementos componen el bien jurídico que se propugna tutelar.

La preocupación se hace evidente, porque, no obstante el medio ambiente tenga, además del carácter individual de promoción de la sana calidad de vida, también posee un aspecto difuso, como bien indispensable para las presentes y futuras generaciones.

En ese sentido, la discusión sobre la viabilidad o no de la tutela de bienes jurídicos por el Derecho Penal se hace importante para la comprensión de la intervención penal en la protección del medio ambiente, sea como bien jurídico, sea como valor o interés de carácter transindividual, ya que este tipo de actuación fue recomendado por la Constitución Española desde 1978 y por la Constitución Federal Brasileña desde 1988.

A pesar de la determinación constitucional, el tema no es tan simple como parece. La presente materia envuelve aspectos de Dogmática y Política Criminal, en que se investiga más allá de las técnicas adecuadas de tutela, las propias funciones del Derecho Penal en la actualidad.

Como ya bastante señalado, a partir de la segunda mitad del siglo XX, nuevos problemas vinieron a accionar la atención del ordenamiento jurídico delante de una intensa destrucción y empeoramiento en las condiciones del medio ambiente, aparte las previsiones de carácter catastrófico de la naturaleza poniendo en riesgo la propia sobrevivencia de la especie humana.

El Derecho Penal, como rama integrante del ordenamiento jurídico, en la visión de Ferreira "no puede así dejar de ofrecer su contribución para esa salvadora misión, justificándose su intervención no sólo por la gravedad de ese problema y por su universalidad" ${ }^{1436}$ sino porque, modernamente, se insiere dentro de los derechos fundamentales que deben ser tutelados por esta esfera, como ultima ratio.

Caben también importantes reservas en el tema acerca de la tutela penal del medio ambiente, conforme bien destacado por Silveira, "dejando de lado las pasiones, esquivándose del radicalismo de determinados ambientalistas, su presencia solamente

\footnotetext{
${ }^{1436}$ FERREIRA, Ivete Senise. (coord.). Direito Penal Contemporâneo. Estudos em homenagem ao Professor José Cerezo Mir. São Paulo: Editora Revista dos Tribunais, 2007, p. 68.
} 
podrá ser acepta si respetado el principio de la subsidiaridad, porque, del contrario, alterada estaría la configuración del Derecho Penal liberal”"1437.

Miguel Reale Júnior también ve de forma negativa la tendencia tanto en Brasil como en otros países, de considerarse el Derecho Penal "la curación para todos los males". Según él, la creciente actuación del Estado, bajo el argumento de que se intenta tutelar nuevos derechos - difusos y colectivos - lleva a un aumento considerable de leyes incriminadoras, que según, Reale Jr., en ningún momento merecen abrigo en el campo penal $^{1438}$. Además, el autor afirma que se trata de mera "ilusión penal", porque el hecho de utilizarse del miedo y de la intimidación penal para controlar conductas, acaba generando más inseguridad y descreencia de la sociedad en torno a las autoridades, porque se pasa a creer que sólo con mucha intimidación es que va a haber seguridad $^{1439}$.

Delante de esas premisas, entre "misión" e "ilusión" del Derecho Penal en la protección del medio ambiente, no se puede dejar de reconstruir algunos conceptos dogmáticos indispensables para la tomada de posición acerca de la legitimidad (o no) de la actuación del ius puniendi estatal.

\subsubsection{Sobre el objeto o contenido material del bien jurídico}

Como bien esclarecen Bustos Ramírez y Hormazábal Malarée, es necesario definir materialmente que es "bien jurídico" de modo que tal definición pueda servir para diferenciar si lo que la norma protege es o no uno de estos, pues caso no se proceda así, el concepto que aquí se prima no sería más que una "etiqueta" sin contenido e inválida $^{1440}$.

Uno de los primeros autores que se preocupó con la diferenciación entre objeto de la acción y contenido del bien jurídico fue Von Liszt, para quien el primer pertenece

\footnotetext{
${ }^{1437}$ SILVEIRA, Renato de Mello Jorge Silveira. Direito Penal Supra-Individual. Interesses difusos. São Paulo: RT, 2003, p. 137.

${ }^{1438}$ REALE JÚNIOR, Miguel. A Lei de Crimes Ambientais. São Paulo: Revista Forense 345,1999, p.121.

${ }^{1439}$ REALE, JÚNIOR, Miguel. A Lei de Crimes cit., 1999, p.121

${ }^{1440}$ BUSTOS RAMÍREZ, Juan J.; HORMAZÁBAL MALARÉE, Hernán. Nuevo sistema de derecho penal. Madrid: Editorial Trotta, 2004, p. 31.
} 
al mundo biofísico y el segundo al mundo normativo. Además, esclarece el autor que, para alcanzarse el objeto material de un delito hay que verificar su referencia a la acción típica, mientras que, para alcanzarse el contenido del bien jurídico, hay que hacer una interpretación $^{1441}$.

Para Bustos Ramírez y Hormazábal Malarée, en un Estado Social y Democrático de Derecho, la protección penal de determinados objetos relevantes para la sociedad sólo puede ser hecha mediante el condicionamiento de reglas y principios que definen tal estructura social, tales como los principios de igualdad, justicia y dignidad de la persona humana; una vez que tales normas, por si solas, ya descartan del contenido de bienes jurídicos, valores meramente morales, religiosos etc. Para tales autores, lo más importante es concebir cuales son las relaciones sociales concretas que se pretende proteger, para proteger a las personas que en ella estén comprendidas ${ }^{1442}$.

Interesante destacar que para los referidos autores, el bien jurídico es un principio que da fundamento y que al mismo tiempo limita la intervención estatal, ya que al evaluarse la teoría del delito se vislumbra que en la averiguación de lo injusto es necesario que haya lesividad de los bienes jurídicos protegidos por la norma penal.

Roxin adopta una teoría constitucionalista de bien jurídico, afirmando que su objeto debe tener sustrato e importe fático en la Constitución (de un Estado Democrático de Derecho). Sin embargo, tanto Roxin como Ramírez y otros autores ${ }^{1443}$, sostienen que son inadmisibles normas jurídico-penales únicamente motivadas ideológicamente o que atenten contra derechos fundamentales y humanos, porque estos surgen de la relación de la persona con la entidad estatal ${ }^{1444}$. El reconocimiento de estos derechos representa, sin duda, una conquista frente al Estado.

${ }^{1441}$ LISZT, Franz von apud ANGIONI, Francesco. Contenuto e funzioni del concetto di bene giuridico. Milano : Editore Giuffrè, 1983, pp. 99 y ss.

1442 BUSTOS RAMÍREZ, Juan J.; HORMAZÁBAL MALARÉE, Hernán. Nuevo sistema de derecho cit., pp. 32-33.

${ }^{1443}$ Para Hassemer, por ejemplo, la conexión entre dogmática penal y Constitución no es sólo plausible como obvia en lo que se refiere a la teoría del bien jurídico. Esto porque, para él, el Derecho Penal es un derecho que establece límites a la lucha contra el delito, para ello, debe respetar los límites impuestos por la Constitución. HASSEMER, Winfried. ¿Puede haber delitos que no afecten a un bien jurídico penal?. In: HEFENDEHL, Roland (ed.). La teoría del bien jurídico. Madrid: Marcial Pons, 2007, p. 97.

${ }^{1444}$ ROXIN, Claus. A proteção de bens jurídicos como função do Direito cit., p. 20; BUSTOS RAMÍREZ, Juan J.; HORMAZÁBAL MALARÉE, Hernán. Nuevo sistema de derecho cit., p. 33. 
La explicación de Roxin es porque, afirmarse, pura y simplemente que bienes jurídicos deben ser protegidos porque son derechos fundamentales implica en reconocer que, inevitablemente, en una misma relación fática, pueden estar en conflicto dos o más derechos fundamentales proclamados en la Constitución, que también determinan el legislador $^{1445}$.

Por eso la ponderación de Bustos y Malarée de que algunas posturas carecen de fundamentación cuando creen ver en la Constitución la fuente de los bienes jurídicos. Afirman que el bien jurídico no surge de una relación entre la persona y el Estado, sino de la necesidad entre los diversos sujetos, en la más simple relación entre dos personas. Sin embargo, eso no implica desconocer que los derechos fundamentales estén sí, integrados en esta relación $\mathrm{y}$, de que, de cierta forma el Estado también, cuando reconoce los bienes jurídicos, reconoce también los derechos de la persona ${ }^{1446}$.

Otras ponderaciones hechas por Roxin en relación a los límites del legislador en lo que se refiere al contenido y objeto del bien jurídico-penal pueden ser señaladas. Por ejemplo, el autor afirma que el hecho de haber simple transcripción del objeto en ley no significa que eso fundamenta un bien jurídico. En realidad, sobre este aspecto, es necesario, de hecho, verificar si hay una reducción de la coexistencia libre y pacífica de los hombres ${ }^{1447}$.

Otro ponto bastante destacado por varios autores es de que meros atentados a la moral también no son suficientes para sostener la lesión a bienes jurídicos, lógicamente, bien observa Roxin, desde que tales ofensas no disminuyan la libertad y la seguridad de las personas ${ }^{1448}$.

Seher rechaza la protección de contenidos moralistas por las normas penales no por no creer que haya protección de la Moral por el Derecho. En realidad, lo que el autor discrepa es de los valores morales en sí mismos, sin hacer referencia a una relación autor-víctima. Él difiere la protección de un moralismo puro, o sea, la

\footnotetext{
${ }^{1445}$ ROXIN, Claus. A proteção de bens jurídicos como função do Direito cit., pp. 20-21.

${ }^{1446}$ BUSTOS RAMÍREZ, Juan J.; HORMAZÁBAL MALARÉE, Hernán. Nuevo sistema de derecho cit., p. 33.

${ }^{1447}$ ROXIN, Claus. A proteção de bens jurídicos como função do Direito cit., p. 21.

${ }^{1448}$ ROXIN, Claus. A proteção de bens jurídicos como função do Direito cit., p. 21. En este sentido: SEHER, Gerhard. La legitimación de normas penales basada en princípios y el concepto de bien jurídico. In: HEFENDEHL, Roland (ed.). La teoría del bien jurídico. Madrid: Marcial Pons, 2007, p. 87.
} 
protección del orden moral, religiosa o ética en sí mismas y, de un otro lado, la protección penal de un moralismo mixto, en que valores morales deben ser respetados para evitarse daños u nocividad a la vida o salud de las personas ${ }^{1449}$.

\subsection{Responsabilidad Administrativa - aspectos represivos y preventivos}

La responsabilidad administrativa en materia ambiental tendrá lugar cuando haya infracción a normas administrativas ambientales, sujetando el infractor a penalidades (también administrativas) ${ }^{1450}$. Sobre la responsabilidad administrativa en términos ambientales, también algunas nociones esenciales deben ser traídas para la comprensión del presente estudio.

Para Osório Medina, la sanción administrativa tendría cuatro elementos fundamentales: a) autoridad administrativa (elemento subjetivo); b) efecto aflictivo de la medida en que se exterioriza (elemento objetivo), que se subdivide en: b1. privación de derechos existentes, y b2. imposición de nuevos deberes; c) finalidad represora, reprimiéndose una conducta y no restablecimiento de un orden jurídico (elemento teleológico); naturaleza administrativa del procedimiento (elemento formal) ${ }^{1451}$.

De acuerdo con la Ley 9.605/98 (Ley de Crímenes Ambientales), en su art. 70, hay la definición de que infracciones administrativas ambientales son "toda acción u omisión que viole las reglas jurídicas de uso, gozo, promoción, protección y reparación del medio ambiente".

Primeramente, cabe citar el concepto de las sanciones administrativas como siendo las penalidades impuestas por los órganos vinculados de forma directa o indirecta a la Unión, Estados, Municipios y Distrito Federal, obedecidas as competencias previamente fijadas en ley, en razón del llamado "poder de policía"1452 de

${ }^{1449}$ SEHER, Gerhard. La legitimación de normas penales basada en princípios y el concepto de bien jurídico. In: HEFENDEHL, Roland (ed.). La teoría del bien cit., pp. 88-89.

${ }^{1450}$ SILVA, José Afonso da. Direito Ambiental Constitucional. 7. ed. São Paulo: Malheiros, 2009, p. 304. 1451 OSÓRIO, Fábio Medina. Direito Administrativo Sancionador. 4. ed. São Paulo: Revista dos Tribunais : 2011, p. 162.

${ }^{1452}$ Importante recordar que el poder de policía administrativo corresponde a la actividad estatal, en el ámbito de los poderes públicos, de limitar o restringir actividades que lesionen el interés público, principalmente relativos a la seguridad, orden, higiene e incluso actividades económicas que deben ser 
la Administración Pública en relación a aquellos que están a ella vinculados de alguna forma ${ }^{1453}$.

Las sanciones administrativas más comunes en las Leyes Ambientales (conforme art. 72 de la Ley 9.605/98) son: advertencia; multa simple; multa diaria; aprehensión de cosas y objetos; destrucción o inutilización de productos; suspensión de venta o fabricación de producto; embargo de obra o actividad; demolición de obras; suspensión de actividades (parcial o total) e, incluso, determinadas penalidades administrativas restrictivas de derechos (tal como la prohibición de contratar con el Poder Público o la casación de la función o actividad técnica).

Así como en relación a las demás sanciones, la sanción administrativa depende, para su aplicación, de un debido proceso administrativo disciplinar o sancionador, en el Hely Lopes Meirelles afirma ser necesaria la efectuación de las garantías constitucionales del proceso, tales como: contradictorio, oportunidad de defensa, so pena de anulación del proceso ${ }^{1454}$.

La instauración del proceso administrativo sancionador ambiental pode darse por medio de Auto de Infracción o cualquier pieza de información equivalente, en los que la autoridad competente por la actuación deberá describir todos los elementos necesarios para la elucidación de la infracción (día, hora, local, etc.) y para la responsabilización del agente causador (identificación y conducta realizada). A continuación, habrá la instrucción, en que serán apreciadas las pruebas producidas así como será posibilitada la defensa del imputado, en todos los medios admitidos por el

ejercidas mediante control de la administración. Además, se concibe a partir del texto constitucional, una nueva dimensión del poder de policía: frente a la demanda ambiental, que tiene carácter difuso; el interés no es meramente público, porque, con esta nueva concepción, el medio ambiente es un bien de uso común general, perteneciente tanto a las presentes como futuras generaciones, lo que lo hace compartido por un grupo de individuos indeterminados, unidos por relaciones fáticas y de carácter notablemente indivisible. A pesar del poder de policía ser, en la mayoría de los casos, un poder administrativo que es ejercido de oficio, sin provocación del particular - ya que a la Administración conviene también la tomada de actitudes que objetiven proteger el medio ambiente de forma preventiva - , no se dispensa, en ningún momento, las garantías del debido proceso legal.

${ }^{1453}$ FIORILLO, Celso Antônio Pacheco. Curso de Direito Ambiental Brasileiro. $12^{\mathrm{a}}$ ed. rev. atual. e ampl. São Paulo: Saraiva, 2011, pp. 133-137.

${ }^{1454}$ MEIRELLES, Hely Lopes. Direito Administrativo Brasileiro. 26. ed. São Paulo: Malheiros, 2001, p. 661. 
derecho. Al final, la autoridad competente para Juzgar mediante el Informe, juzgará el caso con la propuesta de aplicación de la sanción o absolución del imputado.

La gran discusión sobre la responsabilidad sancionatoria administrativa ambiental está en el complejo cuadro de competencias de diversos órganos - Conselho Nacional do Meio Ambiente (CONAMA), Instituto Brasileiro de Meio Ambiente (IBAMA), Instituto Estadual de Florestas (IEF), Policía Ambiental, etc. -, que actúan (muchas veces) simultáneamente, acerca de la misma infracción o daño al medio ambiente.

Para insertar los moldes de actuación administrativa, que actualmente está principalmente volcada para la prevención de los daños ambientales, la Política Nacional del Medio Ambiente establecida en 1981 mediante la edición de la Ley 6.938/81, creando el SISAMA (Sistema Nacional del Medio Ambiente), se objetivó el establecimiento de estándares que sea posible el desarrollo sostenible, por medio de mecanismos e instrumentos capaces de conferir al medio ambiente mayor protección.

Las directrices de esta política son elaboradas a través de normas y planes destinados a orientar los entes públicos de la federación, en conformidad con los principios listados en el art. $2^{\circ}$ de la Ley 6.938/81 (ej.: principio del planeamiento y fiscalización del uso de los recursos ambientales y del controle y zonificación de las actividades potencial o efectivamente contaminantes).

Ya los instrumentos de la Política Nacional del Medio Ambiente, distintos de los instrumentos materiales noticiados por la Constitución, de los instrumentos procesales, legislativos y administrativos son presentados por el art. $9^{\circ}$ de la Ley 6.938/81, entre otros: "I - el establecimiento de estándares de calidad ambiental; II - la zonificación ambiental; III - la evaluación de impactos ambientales; y, en lo que se refiere al tema de este trabajo, IV - el licenciamiento y la revisión de actividades efectiva o potencialmente contaminantes".

Para SILVA ${ }^{1455}$ las normas de Derecho Administrativo Ambiental imprimen enorme condicionamiento a las actividades humanas, buscando resguardar la calidad del medio ambiente. Sin embargo, se sabe que la adhesión o cumplimiento no siempre son espontáneos, por eso, la legislación prevé controles previos, concomitantes y sucesivos, por parte de las actividades controladas.

${ }^{1455}$ SILVA, José Afonso da. Direito Ambiental cit., p. 280. 


\subsection{Responsabilidades civil y administrativa sobre el agua}

Admitiendo que el medio ambiente sea un bien jurídico, debe ser tutelado por el Estado en la esfera civil, penal y administrativa. Hay varias normas que sirven para proteger el bien de la vida, medio ambiente, en especial el agua, como, por ejemplo, el Código de Aguas, que es el Decreto n. ${ }^{\circ}$ 24.643/1934.

El agua, siendo un bien protegido, debe ser protegida de daños y sus causadores deben ser responsabilizados, en ámbito civil, administrativo y penal. La responsabilidad civil consiste en la obligación de reparar un daño en razón de imprudencia, negligencia etc. Ya en la responsabilidad penal la violación irá alcanzar un bien tutelado por el ordenamiento, una vez que es de extrema importancia, que en el caso es el medio ambiente, diferenciando con la responsabilidad administrativa, no por la función jurisdiccional, sino en el ejercicio de un poder administrativo. Importante resaltar que el agua no siempre fue tutelada como lo es hoy, el Código Civil de 1916, por ejemplo, no cuidaba el medio ambiente. Ya el Código Penal permitía una protección indirecta del medio ambiente.

La responsabilidad civil tiene cuatro objetivos básicos: a) compensación de las víctimas; b) prevención de accidentes; c) minimización de los costes administrativos del sistema; y d) retribución. En la perspectiva clásica revisitada, tanto en el civil law y common law, la responsabilidad civil serviría para la reparación de los daños sufridos por cuenta de una conducta de terceros. Se observa en esta vertiente uso residual de la responsabilización. La teoría de la responsabilidad civil además de basarse en el hecho pretérito incluye hechos que puedan suceder en el futuro, una vez que ellos pueden generar altos costes sociales. La responsabilización civil busca la reparación de los daños. La técnica de reparación ambiental, clásica, es, como se nota, bien ortodoxa; y su lema es el que contamina paga (basado en el principio 'quien contamina paga'). La responsabilidad civil moderna cambia ese lema, que pasa a ser no contamine.

El modelo clásico defendía la idea de una cuestión conflictiva intersubjetiva, o sea, que estaba en el plan individual. Cuestiones supra individuales no eran tratadas en el Derecho Privado. Con el intuito de reforzar ese modelo, que se fue mostrando fallo, una vez que no conseguía influenciar los potenciales degradadores, por eso fue necesario reforzar los presupuestos de eficacia de la responsabilidad civil, usando de: 
ampliación de sujetos responsables, adoptando solidaridad entre ellos y abriendo espacio para desconsideración jurídica, vaciamiento de hipótesis de exclusión, etc.

La responsabilidad civil puede ser definida como una técnica jurídica de asignación de pérdidas y daños oriundos de las actividades humanas ${ }^{1456}$. Que se basa en la conversión del daño en reparación o división del daño entre víctima y autor o en el total coste para la víctima. El Derecho moderno sigue, entre esas tres citadas, la primera técnica, o sea, convierte el daño en reparación.

La responsabilización civil es dispuesta en varios locales, como el mencionado anteriormente, Decreto 24.643/1934, Código de Aguas, reguló los límites de dominios públicos y privado, dividió el agua en de uso común, público y particular, además de fijar reglas de uso sostenible. La lay n ${ }^{\circ}$ 6.938/1981, que es la Ley de Política Nacional del Medio Ambiente, que orienta el poder público en lo que se refiere a la preservación de la calidad ambiental y a la manutención del equilibrio ecológico. Esta Ley siguió el camino de otra implementada en Estados Unidos de América en 1970 (NEPA- National Environmental Policy Act), pero, al contrario de esta, amplió el campo de aplicación. La Ley de los Crímenes Ambientales, Ley no 9.605/1998, establece sanciones penales y administrativas decurrentes de conductas lesivas al medio ambiente.

Ocurrirá responsabilidad, cuando tratarse de contaminación ambiental, de reparar por daños. La responsabilidad en el campo civil es efectuada en cumplimiento de la obligación de no hacer, hacer y en el pago de condenación en pecunia.

La Constitución Española en su art. 45 y la Constitución Brasileña, en su artículo 225, definen la titularidad, en relación al derecho ambiental, de manera difusa. Imponen al Poder Público y a la colectividad el deber de preservar y defender el ecosistema para las presentes y futuras generaciones. El párrafo $3^{\circ}$ del art. 225 de la CF/88 preceptúa: "Las conductas o actividades lesivas al medio ambiente sujetarán los infractores, personas físicas o jurídicas, a sanciones penales y administrativas, independientemente de la obligación de reparar los daños causados", o sea, la obligación de reparar los daños causados al medio ambiente, aunque no haya elemento subjetivo. En el artículo 21, inciso XIX de la Constitución Federal especifica que la competencia de instituir un sistema nacional de gerenciamiento de recursos hídricos y definición de criterios de otorga de derechos de su uso es de la Unión. Vale resaltar que

${ }^{1456}$ MILARÉ, Édis. Tutela jurídica do meio ambiente. Responsabilidade em matéria ambiental. São Paulo: Editora Revista dos Tribunais. 2011, p 90. 
ley complementar autoriza los Estados a también legislar sobre cuestiones del agua. Es de competencia de los tres entes de la federación proteger el medio ambiente y combatir la contaminación en cualquier de sus formas y registrar, acompañar y fiscalizar las concesiones de derechos de investigación y explotación de recursos hídricos y minerales en sus territorios. La Unión, en lo que se refiere a competencia concurrente, se limita a normas generales.

Hay Constituciones Estaduales que traen normas explícitas de responsabilidad civil, por ejemplo, en el Estado de São Paulo, en que está previsto en su respectiva constitución, en el artículo 195, conductas lesivas al medio ambiente sujetan los infractores a sanciones penales y administrativas ${ }^{1457}$.

Brasil, al garantir constitucionalmente y legalmente la defensa del medio ambiente, entra en la vanguardia mundial, estando adelante de países que no tienen normas específicas, como Argentina, así como países con normas específicas, pero insuficientes, como Chile, etc.

La aplicación de la penalidad independe de culpa, como dispone el artículo 14 de la Ley 6.938/81, que es la Ley de la Política Nacional del Medio Ambiente. Basta prueba de acción u omisión del reo del daño y de la relación de causalidad. Por lo tanto, es necesario existir el nexo causal para indemnizar.

La Ley citada 6.938/81-impone al que contamina y al predador de la obligación de recuperar y/o indemnizar los daños causados, en el art. $4^{\circ}$, VII. Como ya mencionado, posibilita que repare los daños independientemente de culpa. Basta probar, entonces, el hecho y la autoría para que el individuo deba indemnizar (Ley 6.938, de 1981, art. 14). El último artículo citado demuestra que sucedió una objetivación de la responsabilidad civil y que ocurrió una legitimación para cobrar del Ministerio Público. Como recuerda Maria Helena Diniz - la responsabilidad civil objetiva se fundamenta

\footnotetext{
${ }^{1457}$ Artículo 195 - "Las conductas y actividades lesivas al medio ambiente sujetarán los infractores, personas físicas o jurídicas, a sanciones penales y administrativas, con aplicación de multas diarias y progresivas en el caso de continuidad de la infracción o reincidencia, incluidas la reducción del nivel de actividad y la interdicción, independientemente de la obligación de los infractores de reparación por los daños causados.

Párrafo único - El sistema de protección y desarrollo del medio ambiente será integrado por la Policía Militar mediante sus unidades de vigilancia forestal y de manantiales, incumbidas de la prevención y represión de las infracciones cometidas contra el medio ambiente, sin perjuicio de los cuerpos de fiscalización de los demás órganos especializados".
} 
en un principio de equidad existente desde el Derecho romano: aquel que lucra con una actividad debe responder por el riesgo o por las desventajas de ella resultantes ${ }^{1458}$.

Las aplicaciones de puniciones administrativas están dispuestas en los incisos I, II, III y IV del artículo 14. Paulo Affonso Leme Machado es claro al afirmar que -la aplicación de la penalidad administrativa, prevista en los incisos I, II, y IV del art. 14 no elide la indemnización o reparación que el Poder Judicial pueda conminar, como se ve sin cualquier duda en el $\S 1^{\circ}$ del aludido art. $14^{1459}$.

La Ley 9.433/97, de la Política Nacional de Recursos Hídricos creó el Sistema Nacional de Gestión de Recursos Hídricos y estableció los fundamentos, directrices, objetivos. Los fundamentos fueron dispuestos en el artículo $1^{\circ}$.

Los objetivos son el de asegurar la disponibilidad de agua, en niveles aceptables. Ya las directrices generales de acción son hacer una gestión de los recursos sin distinción de región para región, o sea, busca integrar la gestión ambiental.

La responsabilidad civil, vale dejar claro, es solidaria, además de objetiva, conforme el artículo 942, caput, segunda parte, del Código Civil. La solidaridad no se presume, artículo 265. Si el contaminador esté, de alguna manera, con una posible contaminación, podrá ser obligado a reparar el daño total, cabiendo, como es el caso en la solidaridad, derecho de retroceso.

\subsection{Tutela administrativa del agua}

La responsabilidad administrativa tiene como causa el poder de policía y puede imponer sanciones administrativas. Las referencias para infracciones administrativas son la Ley 9.605 de 1998, el Decreto 6.514 de 2008, la Ley 9.433 de 1997 y la Ley 6.938 de 1981. La infracción ambiental es caracterizada como conducta ilícita, independientemente de haber daño. El ilícito administrativo es admitido cuando se puede ser concebido objetivamente. La responsabilidad administrativa es aplicada independiente de haber culpa, y el contaminador es obligado a indemnizar o reparar los daños causados al medio ambiente por la realización da su actividad ${ }^{1460}$.

\footnotetext{
${ }^{1458}$ DINIZ, Maria Helena. Curso de direito civil brasileiro. São Paulo: Editora Saraiva. 2004, v. 7, p. 48. ${ }^{1459}$ MACHADO, Paulo Affonso Leme. Direito ambiental cit., p. 250.

${ }^{1460}$ Artigo. 14, $§ 1^{\circ}$ da Lei 6.938-1981.
} 
Manuela Mora Ruiz afirma que el derecho administrativo presenta criterios económicos. Ella explica el principio "Contaminador Pagador"1461, alegando que quien es responsable por realizar un daño al medio ambiente tiene que ser responsable por sanarlo. Ella aún apunta la necesidad de haber un Pacto Ambiental, que es un acuerdo entre el gobierno y las empresas que objetiva la compatibilización de medidas preventivas y correctoras con la viabilidad de la empresa a través de innovaciones tecnológicas en el proceso de producción y en la eliminación de los agentes contaminadores de modo que el pacto sólo puede incorporar el sometimiento de las empresas a auditorías ambientales ${ }^{1462}$.

Para Jésus Jordano Fraga ${ }^{1463}$ el Derecho Administrativo es una realidad histórica a servicio de la comunidad humana y es reflejo de las aspiraciones colectivas y conquistas político-étnicas con la unión de las tendencias externas que son: integración, globalización e individualización. Las transformaciones y las tendencias externas están interconectadas, pero es necesario tener cuidado porque además de subjetivas las tendencias son complejas, entonces no se puede sólo tener en cuenta las tendencias estructurales e ideológicas, sino también por el mundo entorno, o sea, es necesaria una mirada crítica alrededor.

De acuerdo con Vladimir Passos de Freitas, la responsabilidad administrativa sucederá por cuenta de una relación existente entre el ciudadano y el poder público, siendo entonces un vínculo por medio del que se permite al Estado la imposición de una sanción administrativa. Así, determinada acción u omisión pueden constituir un ilícito administrativo, independientemente de ser o no un ilícito penal o civil ${ }^{1464}$. Define el concepto de Zamboni que la responsabilidad administrativa tiene por objeto la aplicación de las penas, que, todavía no hacen parte del Derecho Penal, porque no son

${ }^{1461}$ MORA RUIZ, Manuela. Tendencias del derecho administrativo. El derecho administrativo ambiental: Transformaciones en el derecho administrativo general. Derecho y conocimiento, vol. 1, pp. 523-532. Facultad de Derecho. Universidad de Huelva.

${ }^{1462}$ MORA RUIZ. Tendencias del derecho cit., p. 526.

1463 JORDANO FRAGA, Jésus. El Derecho administrativo en el umbral del siglo XXI, Homenaje al Professor Dr. D. Ramón Martín Mateo: Tendencias de evolución en el derecho administrativo y alguma propuesta iconoclasta. Coodinador: Francisco Sosa Wagner. Tirant lo Blanch : Valencia, 2000, pp. 173174.

${ }^{1464}$ FREITAS, Vladimir Passos de. Direito administrativo e meio ambiente. Curitiba: Juruá, 1995, p. 20. 
aplicadas por el Estado en su función jurisdiccional, pero en el ejercicio de un poder administrativo.

Existiendo diferencia con la responsabilidad civil, que es de obligación de reparar un daño, pudiendo ser por acción, negligencia imprudencia u otra cuestión. Esa cuestión surgirá cuando viola el derecho o genera perjuicio a otra persona, como dispuesto en el art. 186 del Código Civil Brasileño. Ya la responsabilidad penal consiste en la violación de normas que prevé tutela de bienes jurídicos de cierta importancia para la sociedad. Puede generar pena restrictiva de derechos, privativa de libertad o aplicación de penalidad pecuniaria. Ofensa a los bienes jurídicos que son tutelados por el derecho penal podrá generar responsabilidad penal, el daño patrimonial obligará la reparación de responsabilidad civil. El art. 70, de la Ley 9.605, de 12 de febrero de 1998, conceptúa la infracción administrativa: Se considera infracción administrativa ambiental toda acción u omisión que viole las reglas jurídicas de uso, gozo, promoción, protección y recuperación del medio ambiente.

Otra norma importante que se refiere a la infracción administrativa es el Decreto 3.179 de 1999, que dispone sobre sanciones aplicable a las conductas y actividades lesivas, en lo que se refiere al medio ambiente. Es considerada infracción administrativa ambiental toda acción u omisión que viole normas. La sanción administrativa puede ser advertencia, multa diaria, multa simple, aprehensión de productos, animales, etc.; sanciones restrictivas de derecho. Esa última sanción puede ser contra persona jurídica o física, pudiendo generar cancelación de registro; pérdida o restricción de incentivos y beneficios fiscales; pérdida o suspensión de la participación en líneas de financiamiento en establecimientos oficiales de crédito, etc. Así como en el ámbito civil, el infractor debe reparar los daños al medio ambiente independientemente de culpa. La conminación de sanción administrativa el legislador confiere campo de discrecionalidad, no excluyendo el acto de la apreciación del control judicial de la legalidad. En lo que se refiere al elemento subjetivo, el posicionamiento español es otro. La construcción jurisprudencial de España exige la presencia de elemento subjetivo, o sea, existencia de dolo o culpa, que es un presupuesto para aplicar la punición administrativa.

El artículo 70 de la Ley 9.605 de 1998 es suficiente para satisfacer la tipicidad, por tratarse de ley penal en blanco. Este artículo es visto por algunos autores como ley penal en blanco por no especificar las infracciones. El texto del $\S 1^{\circ}$ del art. 70 de la Ley 
9.605/98 determina que: $\S 1^{\circ}$ Son autoridades competentes para redactar auto de infracción ambiental e instaurar proceso administrativo los funcionarios de órganos ambientales integrantes del Sistema Nacional del Medio Ambiente - Sisnama, designados para las actividades de fiscalización, así como los agentes de las Capitanías de Puertos, del Ministerio de Marina. Todo acto emanado de agente incompetente es inválido, por faltar elemento básico de su perfección. La ley que regula el proceso administrativo Federal, Ley 9.784, de 29 de enero de 1999, dispone en su art. $9^{\circ}$, en los incisos III y IV, los legitimados del proceso administrativo - las organizaciones y asociaciones representativas, con respeto a los derechos e intereses colectivos (inciso III) y - las personas o asociaciones legalmente constituidas en lo que se refiere a derechos o intereses difusos (inciso IV). Aun disponen los arts. $5^{\circ}, 6^{\circ}$ y $7^{\circ}$ acerca del inicio del proceso administrativo. El art. $5^{\circ}$ prescribe que el proceso administrativo puede iniciarse de oficio, o a pedido de interesado. Esto vale en lo que se refiere al campo ambiental, en que las organizaciones y asociaciones pueden requerir instauración de proceso administrativo para apurar infracciones administrativas, arts. 70.

El derecho español también prevé el uso de las leyes penales en blanco, sin embargo de forma subsidiaria. Para la punición de ataques más graves o intolerables al bien jurídico es utilizado el derecho penal ambiental. Las leyes penales en blanco corresponden una sanción administrativa. La utilización de las leyes penales en blanco va más allá de la necesidad, ellas son importante medio para articular la complementariedad de las otras ramas del derecho ${ }^{1465}$.

El artículo 70, de la Ley 9.605 de 1998 dispone en el párrafo segundo que cualquier persona, constatando infracción ambiental, podrá presentar representación a las autoridades relacionadas en el párrafo anterior, para efecto del ejercicio do su poder de policía.

Sobre la cuestión constitucional, lesión en materia ambiental, en relación a la cuestión administrativa, es de actuación de la Unión. En lo que se refiere a los municipios, la competencia de este ente es meramente suplementar a la Unión y a los Estados. Visto esta cuestión, se debe analizar, aun, la cuestión del proceso

\footnotetext{
${ }^{1465}$ HERRERA GUERRERO, Mercedes. Derecho penal medioambiental y accesoriedad administrativa en la configuración de algunos delitos en el Código Penal español. Inconvenientes y propuestas de solución. La ley penal, $N^{\circ} 76$, Editorial La Ley. Sección Informe de Jurisprudencia, Noviembre 2010, p. 1-18.
} 
administrativo por medio del que se puede apurar la infracción y la aplicación de la sanción. Para eso es necesario analizar la disposición del $\S 4^{\circ}$ del artículo $70^{\circ}$ y del artículo $71^{\circ}$ de la Ley 9.605 de 1998: $\S 4^{\circ}$ las infracciones ambientales son apuradas en proceso administrativo propio, asegurado el derecho a la amplia defensa y el contradictorio, observadas las disposiciones de esta Ley. Art. 71. El proceso administrativo para apuración de infracción ambiental debe observar los siguientes plazos máximos: I - veinte días para el infractor ofrecer defensa o impugnación contra el auto de infracción, contados de la fecha de ciencia de la actuación; II - treinta días para la autoridad competente juzgar el auto de infracción, contados de la data da su redacción, presentada o no la defensa o impugnación; III - veinte días para el infractor recorrer de la decisión condenatoria a la instancia superior del Sistema Nacional del Medio Ambiente - Sisnama, o a la Dirección de Puertos y Costas, del Ministerio de Marina, de acuerdo con el tipo de actuación; IV - cinco días para el pagamento de multa, contados de la fecha de recibimiento de la notificación.

El debido proceso es garantizado por la constitución conforme el artículo $5^{\circ}$, inciso LIV, además de la garantía de la amplia defensa a los litigantes, garantía del contradictorio. Se resalta que en la actuación administrativa, el auto goza de presunción de veracidad; o sea, se acaba invirtiendo la carga de la prueba.

De acuerdo con la Súmula 467 del STJ: Prescribe en cinco años, contados del término del proceso administrativo, la pretensión de la Administración Pública de promover la ejecución de la multa por infracción ambiental". A lo que se refiere a la imposición de pena, se debe observar el principio de la proporcionalidad. De acuerdo con el art. $6^{\circ}$ de la Ley 9.605 de 1998, la imposición y gradación de la penalidad debe observarse la gravedad del hecho, antecedentes del infractor y situación económica del infractor.

Las sanciones administrativas están dispuestas en el artículo 72 de la Ley 9.605 de 1998 y Decreto 6.514 de 2008, en su artículo tercero. Son ejemplos de sanciones administrativas: advertencia, multa simple, multa diaria, aprehensión, restrictivas de derechos, entre otras.

La primera, advertencia, cabe cuando existe inobservancia de la legislación ambiental. Esa sanción puede ser cumulativa o aislada; teniendo función preventiva y pedagógica. 
Ya la modalidad de sanción formada por la multa simple será aplicada cuando hay dolo o negligencia. La ley dos Crímenes Ambientales permite que la multa simple sea convertida en servicios de preservación, mejora y recuperación de la calidad del medio ambiente. Los valores recaudados son revertidos al Fondo Nacional del Medio Ambiente.

Cuanto a la multa diaria, es aplicada a la infracción continuada. Siendo caracterizada por la acción u omisión, perdurando hasta el momento que se cese. En la aprehensión son aprehendidos productos e instrumentos, además de animales, subproductos y productos de la fauna y flora, etc.

Son ejemplos de restrictivas de derechos: suspensión del registro, licencia, permisión o autorización; cancelación de registro, licencia, permisión o autorización; pérdida o restricción de incentivos fiscales y beneficios fiscales; pérdida o suspensión de la participación en líneas de financiamiento en establecimientos oficiales de crédito; prohibición de contratar con la administración pública, por el período de hasta tres $\operatorname{años}^{1466}$

La ley 6.938 de 1981, que dispone sobre la Política Nacional del Medio Ambiente, sus fines y mecanismos de formulación y aplicación, prevé en su artículo 14 medidas punitivas para casos de no cumplimiento de las medidas necesarias a la preservación o corrección de los casos atípicos, como los daños ambientales. La primera forma de punición es la multa simple o diaria, en los valores mínimos de 10 (diez) y máximo de 1.000 (mil). La segunda sería la pérdida o restricción de los incentivos fiscales concedidos por el Poder Público y, como tercera forma de sanción, sería la pérdida o suspensión de participación en líneas de financiamiento en establecimiento oficiales de crédito. El inciso IV prevé, también, la suspensión de la actividad.

${ }^{1466}$ Artigo $72 \S 8^{\circ}$ da Lei 9.605. 


\subsection{Derecho Administrativo y su carácter sancionador}

El Derecho Administrativo puede ser definido como una rama de la Ciencia jurídica, de Derecho Público interno, que estudia las relaciones de verticalidad establecidas entre la Administración Pública y los administrados ${ }^{1467}$.

Consta del sistema de normas de Derecho a que la Administración y las personas jurídicas públicas se someten, junto a los derechos y deberes conferidos a los ciudadanos, sometidos al poder estatal (aquí comprendido como Administración Pública).

Administración Pública es un término que puede ser entendido ${ }^{1468}$ de dos formas, siendo ambas complementares entre sí: por el sentido orgánico o subjetivo, la Administración Pública se configura por la unión de personas jurídicas de derecho público, sus órganos y servicios, en el ejercicio de una función administrativa; o por el campo material u objetivo, en el que la Administración Pública es reconocida por el ejercicio de la actividad administrativa.

El Derecho Administrativo es visto como el conjunto jurídico concerniente a las estructuras internas del Estado, abarcando aun las normas técnicas de infraestructura. También puede ser apuntado como el reglamento interior de los órganos y servicios públicos; sería la persona jurídica pública apuntando a las personas físicas, que externan su voluntad, como deben proceder para manifestarla correctamente: el Estado mandando en sí propio. Además, es una de las formas que el ente estatal encuentra para estipular como el poder Ejecutivo irá relacionarse con los ciudadanos que viven bajo su égida.

Los principios constitucionales, listados en el art. 37, caput, de la Constitución Federal, a los cuales debe la Administración Pública obedecer, so pena de sus miembros sufrieren sanción administrativa, serán analizados enseguida. Siendo este ente el principal objeto de estudio del Derecho Administrativo, tal análisis se hace de veras relevante.

\footnotetext{
${ }^{1467}$ CRETELLA JÚNIOR, José. Manual de direito administrativo: curso moderno de graduação. Rio de Janeiro: Forense, 2005, p. 4.

${ }^{1468}$ Nesse sentido, consultar: TAVARES, José F. F. Administração pública e direito administrativo. $3^{\mathrm{a}}$ ed. Coimbra: Almedina, 2000, pp. 32 e 33.
} 
Según el principio de la legalidad (stricto sensu), se entiende que la Administración sólo puede realizar los actos que le son expresamente permitidos por ley, o sea, hacer sólo lo que la ley consiente ${ }^{1469}$. Así, cuando la ley nada decir sobre determinado acto, deberá se subentender que es vetado a la máquina pública. No puede ella actuar contra legem ni extra legem, sólo secundum legem ${ }^{1470}$.

Por el principio de la moralidad, el administrador público debe actuar de modo ético, honesto, conforme los valores de buena fe y lealtad, según la disciplina interna y la buena gestión en la Administración Pública. Este también es el entendimiento de Fernanda Marinella ${ }^{1471}$.

Afirma el principio de la impersonalidad que todos los administrados deben ser tratados de la misma manera, por parte de los funcionarios públicos: nadie puede ser privilegiado o desfavorecido en función de relaciones personales ${ }^{1472}$.

Según el principio de la publicidad, todo acto administrativo debe objetivar la transparencia y hacerse público, pasando a ser conocido por parte de toda la población. A los particulares, es garantizado que las conductas del Estado serán "plenamente conocibles y controlables" ${ }^{1473}$, sin acciones obscuras y secretas por parte de los funcionarios.

Por último, por el principio de la eficiencia, la “Administración Pública debe lograr el efecto que el ciudadano desea o espera en la exacta medida de su necesidad con agilidad, mediante adecuada organización interna y óptimo aprovechamiento de los

\footnotetext{
${ }^{1469}$ ALESSI, Rento. Sistema istituzionale del diritto amministrativo Italiano, $3^{\mathrm{a}}$ ed., Milano : Giuffrè Editore, 1960, p. 9.

${ }^{1470}$ STASSINOPOULOS Michel. Traité des Actes Administratifs, Atenas, Recueil Sirey, 1954, pp. 18-19. ${ }^{1471}$ MARINELA, Fernanda. Direito Administrativo. Salvador: Juspodivm, 2005, p. 37.

${ }^{1472}$ En conformidad al principio, como afirma Odete Medauar: "impersonalidad significa la exigencia de ponderación equilibrada de todos los intereses comprometidos, para que no se editen decisiones movidas por prejuicios o radicalismos de cualquier tipo." (MEDAUAR, Odete. Direito administrativo moderno. $6^{\mathrm{a}}$ ed. São Paulo: RT, 2002, p. 252.)

${ }^{1473}$ BINEMBOJM, Gustavo. O princípio da publicidade administrativa e a eficácia da divulgação de atos do poder público pela internet. Revista Eletrônica de Direito do Estado (REDE), Salvador, Instituto Brasileiro de Direito Público, $\mathrm{n}^{\mathrm{o}}$ 19, julho/agosto/setembro, 2009. http://www.direitodoestado.com.br/rede.asp. Acceso en: 08/06/2015.
} 
recursos disponibles" ${ }^{\prime 474}$. De este modo, el Estado, al desempeñar sus tareas, debe obtener el resultado máximo, con el uso mínimo de tempo y bienes materiales y financieros.

Cualquier incumplimiento de estos principios por parte de los servidores y funcionarios públicos configura desvío de poder, constituyendo una infracción administrativa - a la que es imputada sanción de misma naturaleza $-\mathrm{y}$, dependiendo de la gravedad del desvío, también un delito penal. No respetar estas exigencias implica en el ejercicio de un poder arbitrario, que no atiende al poder discrecional conferido a la Administración, aquí entendido como "la margen de libertad otorgada por la ley al administrador" ${ }^{\natural 745}$, según Celso Antônio Bandeira de Mello.

El Derecho Administrativo figura como el sector que disciplina el régimen de funcionarios públicos, bienes públicos, procesos administrativos, poder de policía e ilícitos administrativos, adjuntos a sus sanciones. Al ejercer su función administrativa, el Estado busca atender a los intereses públicos elegidos por el legislador (función pasible de ser controlada por el poder Judicial).

\subsection{Intersecciones entre Derecho Administrativo y Derecho Penal}

Con relación a la capacidad punitiva conferida a la Administración Pública, la doctrina la denomina potestad administrativa sancionadora. Ella compone el ius puniendi superior del Estado, estando conectada a la Administración, para gestionar los intereses públicos ${ }^{1476}$.

Cabe resaltar que el poder punitivo estatal se puede manifestar por medio de la sanción penal y de la sanción administrativa, la primera impuesta en el ejercicio de la función jurisdiccional, y la segunda, en el ejercicio de la función administrativa ${ }^{1477}$. A

${ }^{1474}$ COSTODIO FILHO, Ubirajara. A Emenda Constitucional 19/98 e o Princípio da Eficiência na Administração Pública. In : Cadernos de Direito Constitucional e Ciência Política, São Paulo: Revista dos Tribunais, n. 27, p. 210-217, abr./jul. 1999, p. 214.

${ }^{1475}$ MELLO, Celso Antônio Bandeira. Grandes temas de Direito administrativo. São Paulo: Malheiros, 2009. p. 38 .

${ }^{1476}$ NIETO, Alejandro. Derecho administrativo sancionador. $4^{\mathrm{a}}$ ed. Madrid: Tecnos, 2005, p. 27.

${ }^{1477}$ MELLO, Rafael Munhoz de. Principios Constitucionais de Direito Administrativo Sancionador: as sanções administrativas à luz da Constituição Federal de 1988. São Paulo: Malheiros, 2007, p. 45. 
pesar de algunas diferencias, bajo principios similares al Derecho Penal se asientan las bases del Derecho administrativo sancionador, siendo este incluso considerado más amplio $^{1478}$; sobre ello, una conceptuación y una análisis serán realizadas, en lo que se refiere a sus convergencias y puntos de conflicto con el Derecho Penal. Es el Derecho Administrativo sancionatorio uno de los objetivos principales del presente trabajo, bajo el presupuesto de que entre este y el Derecho Penal existe un número considerable de puntos en común, que superan la cantidad de aspectos divergentes.

De esta área del Derecho, notable es el sistema de doble jurisdicción de Francia. En él hay el orden judicial, competente para juzgar litigios de naturaleza penal y civil y existe también el orden administrativo, competente para apreciar ilícitos dentro del área administrativa. Ligado al poder ejecutivo ${ }^{1479}$.

En Francia se admite el contencioso administrativo (contentieux administratif), en el cual son resueltos los litigios entre servidores públicos y empresas u órganos gestionados por el Gobierno estatal. Además, caso haya discordancias entre el orden administrativo y judicial, caso ambos se declaren competentes o sin competencia para dirimir determinado problema, entra en acción el Tribunal de Conflictos, un órgano neutro ${ }^{1480}$ para decidir y dar la palabra final.

Diferentemente, Brasil adopta el sistema uno de jurisdicción, de modo que sólo el Poder Judicial tienen el poder de juzgar litigios, sean ellos pertenecientes a la esfera civil, penal o administrativa. El principio la acción jurisdiccional está previsto en el art. $5^{\circ}, \mathrm{XXXV}$, de la Constitución Federal. El proceso administrativo figura como un procedimiento extrajudicial.

Al concebir el Derecho como una ciencia cuyo contenido es dinámico y con objetos que realizan conexiones entre sí, es posible afirmar que el elemento punitivo de

${ }^{1478}$ OSÓRIO, Fábio Medina. Direito administrativo sancionador. São Paulo: Revista dos Tribunais, 2000, p. 17.

${ }^{1479}$ MORAIS, Germana de Oliveira; MARQUES, Willian Paiva Júnior. A modernização do modelo brasileiro ante os sistemas de jurisdição administrativa no direito comparado, p. 03. In: XIX Encontro nacional do CONPEDI. Fortaleza: Conselho Nacional de Pesquisa e Pós-graduação em Direito, 2010. p.15. Disponible en: <http://www.conpedi.org.br/manaus/arquivos/anais/fortaleza/3249.pdf >. Acceso en: 29 jun. 2015.

${ }^{1480}$ CRETELLA JÚNIOR, José. Manual de direito administrativo: curso moderno de graduação. Rio de Janeiro: Editora Forense, 2005, p. 395. 
la Administración Pública constituye la intersección entre las materias Derecho Penal y Derecho Administrativo.

Aunque sea posible entender esa disciplina jurídica como englobando componentes de Derecho Económico, Ambiental, Tributario y Financiero, conforme el entendimiento de Cristina Krussewski ${ }^{1481}$, y sin negar la veracidad de esta afirmación, uno de los únicos puntos de confluencia que deben ser considerados aquí será el del aspecto penalista con el administrativista.

Concerniente a la sociedad de riesgos, ya citada anteriormente, cabe resaltar la responsabilidad civil de la cual es proveída el Estado. La teoría del riesgo administrativo $^{1482}$ es pautado este deber del Estado de responder por todo acto lesivo (comisivo u omisivo) practicado por agentes administrativos en el ejercicio de sus funciones.

Uno de los medios por el que puede la Administración Pública valerse de poderes coercitivos, para ejercer sobre las actividades de los administrados, es el Poder de policía. Él consiste en una facultad discrecional perteneciente a la Administración para regular y delimitar el goce de derechos subjetivos o libertades individuales, en provecho del interés público, sea él primario o secundario.

Cabe observar, sin embargo, que no es este el único medio de potestad administrativa sancionadora que el Estado posee, una vez que "está consagrada la idea de que Jueces pueden imponer sanciones administrativas, aunque en el desempeño de actividades jurisdiccionales, desde que habilitados por el legislador" ${ }^{\prime 1483}$.

\footnotetext{
${ }^{1481}$ KRUSSEWSKI, Cristina. Direito administrativo sancionador: apontamentos gerais sobre as infrações administrativas e alguns aspectos de sua relação com o direito penal. Dissertação (Mestrado) Universidade Federal do Paraná, Faculdade de Direito. Curitiba, 2010, p. 101: “[El Derecho Administrativo Sancionador] Se trata, por lo tanto, de un área de penumbra en el sistema jurídico en la que hay una interrelación entre Derecho Administrativo, Derecho Económico, Derecho Ambiental, Derecho Tributario, Derecho Financiero y Derecho Penal, todas ramas del llamado Derecho Público, en que ocurre la imputación de sanciones por el Poder Público".

1482 MEIRELLES, Hely Lopes. Direito Administrativo Brasileiro. 28 a ed. São Paulo: Malheiros, 2003, p. 623: "La teoría del riesgo administrativo hace surgir la obligación de indemnizar el daño del simple acto lesivo e injusto causado a la víctima por la Administración. No se exige cualquier falta de servicio público, ni culpa de sus agentes. Basta la lesión, sin el concurso del lesionado”.

1483 OSÓRIO, Fábio Medina. Direito administrativo sancionador. São Paulo: Editora Revista dos Tribunais, 2000, p. 62.
} 
Además, también los poderes legislativo y judicial, en sus funciones atípicas, son dotados de un quantum de poderes administrativos, en los casos de formulación del reglamento interno de la casa legislativa o del tribunal: a ellos compite disciplinar parlamentares y jueces, respectivamente.

Hechas estas consideraciones, es posible tener en cuenta las tendencias de expansión del Derecho Penal. Con la sociedad postindustrial, abordado por el sociólogo italiano Domenico De Masi ${ }^{1484}$, surgen debates acerca de esa dilatación del sistema punitivo, siendo que algunos autores consideran este fenómeno no como una expansión del campo jurídico-penal, sino como una actualización.

A partir de esa perspectiva, se infiere que el sistema punitivo sufre un proceso de administrativización ${ }^{1485}$, en el que el Derecho Penal se convierte en un sistema de gestión de riesgos generales, conforme entiende Jesús-María Silva Sánchez. Así, no todos los ilícitos prescritos en ley recibirían sanciones penales, cabiendo al Derecho administrativo imputar una pena a los delitos de menor grado de nocividad.

El consentimiento de gran parte de la doctrina es que, siendo el Derecho Penal una herramienta para ser utilizada como ultima ratio, para ser empleada solamente en los casos de alta nocividad a bienes jurídicos, cabe al Derecho Administrativo Sancionador punir las conductas tipificadas como de pequeña magnitud nociva a bienes jurídicos. También aquellas atinentes a la violación de normas técnicas y no observación de reglamentos internos de la Administración Pública.

Desde el establecimiento de las contribuciones de la Sociología a partir de la segunda mitad del siglo XX, en particular en temas como globalización, sociedad del riesgo, expansión de los límites del Derecho Penal, habiendo aquí la absorción o

${ }^{1484}$ MASI, Domenico de. A sociedade pós-industrial; 4. ed. São Paulo: Editora Senac São Paulo, 2003, p. 35: "Los cinco aspectos que la definen son: 1) la transferencia de la producción de bienes para la economía de servicios; 2) la preeminencia de la clase de los profesionales y de los técnicos; 3 ) el carácter central del saber teórico, generador de la innovación y de las ideas directivas en las que la colectividad se inspira; 4) la gestión del desarrollo técnico y el controle normativo de la tecnología; 5) la creación de una nueva tecnología intelectual”.

${ }^{1485}$ SILVA SÁNCHEZ, Jesús-María. La expansión del derecho penal: Aspectos de la política criminal en las sociedades postindustriales. $2^{\mathrm{a}}$ ed. Madrid: Editora Civittas, 2001, p. 123: "El Derecho Penal, que reaccionaba a posteriori contra un hecho lesivo individualmente delimitado (en relación al sujeto activo y al pasivo), se convirtió en un Derecho de gestión (punitiva) de riesgos generales y, en esa medida, se «convirtió en administrativo»". 
interiorización de algunos fundamentos del Derecho Administrativo, pasó a ser común que la doctrina penal emplease el término "administrativización del Derecho Penal”.

Sobre el tema, es innegable el hecho de que toda actividad económica que consiste en la explotación del medio ambiente se relaciona directamente con el ordenamiento jurídico administrativo del Estado, ya que esta actividad debe realizarse en los parámetros de autorización, permiso y licencia de las autoridades administrativa con competencia ambiental constitucionalmente establecida para la concesión de la liberación de dicha actividad. Por tal asertiva se concluye que las consideraciones y restricciones del Derecho Administrativo para el tema medio ambiente son esenciales para la actuación del Derecho Penal del medio ambiente ${ }^{1486}$.

Actualmente, se puede ver el intento doctrinal en mejor distinguir las dos categorías a través de los criterios teleológico entre el Derecho Penal y el Derecho Administrativo-sancionador. Entre varios se destaca la posición de vanguardia construida por Jesús-Maria Silva Sánchez, para distinguir el ámbito del Derecho Penal y del Derecho Administrativo. Para el Derecho Penal, afirma que "persigue la protección de bienes concretos en casos concretos y sigue criterios de lesividad o peligrosidad concreta y imputación de un injusto. El segundo busca la ordenación, en general, de un modelo específico de gestión sectorial ${ }^{1487}$.

Pero no hay ningún acuerdo aún en la doctrina penal acerca de la legitimidad del Derecho Penal para establecer la protección de los llamados bienes difusos. Así, por un lado está la defensa de la teoría del bien jurídico estrictamente individualista, por la cual el Derecho Penal debe dedicarse sólo a la protección subsidiaria y represiva de los bienes jurídicos esenciales para el desarrollo del individuo, a través de los instrumentos tradicionales de imputación de responsabilidad y de conformidad con los principios y reglas clásicas de garantía, puesto que el Derecho Penal no puede tutelar bienes

${ }^{1486}$ Breves reflexiones sobre la administrativización del direito penal, delitos por acumulación y anticipación de la tutela penal en la protección del bien jurídico ecológico. In http://www.diritto.it/docs/28544-breves-reflex-es-sobre-a-administrativiza-o-do-direito-penal-delitos-poracumula-o-e-antecipa-o-da-tutela-penal-na-prote-o-do-bem-jur-dico-ecol-gico. Acceso en: 02-12-2015.

${ }^{1487}$ Breves reflexiones sobre la administrativización del direito penal, delitos por acumulación y anticipación de la tutela penal en la protección del bien jurídico ecológico. In http://www.diritto.it/docs/28544-breves-reflex-es-sobre-a-administrativiza-o-do-direito-penal-delitos-poracumula-o-e-antecipa-o-da-tutela-penal-na-prote-o-do-bem-jur-dico-ecol-gico. Acceso en: 02-12-2015. 
jurídicos configurados libremente. Se trata de una posición clásica, también llamada por algunos de conservadora.

Por otro lado, en una posición diametralmente opuesta está la propuesta de flexibilización de los instrumentos dogmáticos y de las reglas de atribuciones de responsabilidades, con el objetivo de que el Derecho Penal adquiera condiciones para actuar en la protección de bienes jurídicos supra-individuales y en el control de los nuevos fenómenos de riesgo, puesto que en este diseño él es la condición de estabilidad de la sociedad del riesgo, posición esta desarrollada en este trabajo ${ }^{1488}$.

\subsection{Derecho Administrativo Sancionador}

Por ser un sector relativamente reciente del Derecho, y aún poco estudiado, siéndole dedicada menos atención que la merecida, puede ser problematizada la cuestión sobre cuáles serían las bases legales que se fundamenta el Derecho administrativo sancionador. Hay dos concepciones diferentes que presentan una respuesta a la indagación de que cual es la matriz de la potestad administrativa sancionadora.

La primera concepción es la de Alejandro Nieto, que defiende, bajo un abordaje de aspecto administrativista, que la base de ese Derecho sería el Derecho público estatal $^{1489}$, que, sin menospreciar las garantías individuales, da prevalencia para la concretización de los intereses generales y públicos.

La segunda, atinente a la visión de Fábio Medina Osório, entiende que el Derecho Administrativo Sancionador encuentra su matriz no dentro del Derecho estatal público, sino en el ámbito del Derecho Penal, de modo que comparten ambos los campos de los principios de legalidad, culpabilidad y non bis in idem, por ejemplo.

\footnotetext{
${ }^{1488}$ Nuevas tesis dogmáticas jurídico-penales para la protección del bien jurídico ecológico en la sociedad del riesgo, disponible en: <http://www.diritto.it/archivio/1/28208.pdf>. Acceso en: 03-12-2015.

${ }^{1489}$ Alejandro Nieto. Derecho administrativo sancionador. $4^{\mathrm{a}}$ ed. Madrid: Tecnos, 2005, p. 27: "En definitivo, contra todas las posibilidades, hay que afirmarse que el Derecho Administrativo Sancionador es, como su propio nombre indica, Derecho Administrativo ligado directamente al Derecho público estatal y no en un Derecho Penal vergonzoso; de la misma manera que la potestad administrativa sancionadora es una potestad vinculada a toda potestad atribuida a la Administración para la gestión de los intereses públicos."
} 
Incluso Nieto reconoce la gran influencia penalista dentro del Derecho Administrativo Sancionador, al decir que él toma prestado los instrumentos del Derecho Penal, los cuales son útiles debido a la maturación más avanzada y a la superioridad teórica ${ }^{1490}$.

Será adoptada la posición de Fábio Medina Osório como la más adecuada; entre los motivos, se destaca que Derecho Penal y Administrativo Sancionador componen el conjunto unitario del ius puniendi estatal, constituyen potestades de imputar sanciones a ilícitos tipificados. Además, caso fuese considerado en el presente trabajo, el Derecho Administrativo Sancionador como fundado en el Derecho público estatal, estaría implícito un alejamiento expresivo de aquel con el Derecho Penal, lo que no se pretende.

El Derecho Administrativo Sancionador puede ser conceptuado como la disciplina que tiene por objeto de estudio el poder punitivo (potestad sancionadora), de que es dotada la Administración Pública, de imputar una pena a ilícitos que alcanzan el interés público. Eso se hace a través de sanciones administrativas, aplicadas por el poder Executivo o por el poder Judicial.

Del mismo modo, también se incluye entre la competencia punitiva de los agentes estatales el Poder de Policía, que puede inspeccionar, emitir advertencias, o aplicar multas a todo administrado que cometer una infracción de orden administrativo o a normas técnicas. Las mismas están ligadas, conforme la doctrina funcionalista del penalista alemán Claus Roxin, a los peligros abstractos y a la creación de riesgos jurídicamente no permitidos ${ }^{1491}$ por el ordenamiento jurídico-penal.

Estas sanciones, ora son dirigidas a agentes $\mathrm{u}$ órganos públicos que cometen desvíos de poder, ora direccionadas a los administrados, correspondiendo estos como ciudadanos comunes, o personas jurídicas de derecho privado, como asociaciones, fundaciones y empresas de pequeño o gran porte.

Pode ser comprendido el Derecho Administrativo Sancionador como un complejo de puniciones poco conocido, tomado por obscuro e incierto a los ojos del ciudadano medio $^{1492}$, que no conoce, de hecho, siquiera la centésima parte del contenido

\footnotetext{
${ }^{1490}$ NIETO, Alejandro. Derecho administrativo cit., p. 86.

${ }^{1491}$ ROXIN, Claus. A proteção de bens jurídicos como função do Direito Penal. Org. e trad. André Luís Callegari e Nereu José Giacomolli. 2 $2^{\text {a }}$ ed. Porto Alegre: Livraria do Advogado Editora, 2009, pp. 39-44. ${ }^{1492}$ NIETO, Alejandro. Derecho administrativo cit., p. 31.
} 
del ordenamiento normativo. Las infracciones administrativas engloban casi todas las esferas de la vida, incluso actos más banales y habituales.

Por ser un derecho que tiene por objetivo castigar las pequeñas acciones equivocadas, como cruzar el semáforo en rojo, tirar papeles al suelo y no mantener las condiciones básicas de higiene en un establecimiento, la gente vive bajo la incertidumbre de estar practicando o no una infracción administrativa, contando con la suerte para no ser sorprendido por un agente inspector. Este escenario puede causar inseguridad social, en razón de la inevitabilidad de esas infracciones ser cometidas y debido a la arbitrariedad de su persecución.

En Brasil, los ilícitos y las sanciones administrativas se encuentran asistemáticamente difusos en medio a diversos diplomas legales y leyes ordinarias, dificultando, de este modo, la comprensión dogmática de los estudios sobre el elemento sancionatorio de la Administración Pública e, incluso, el conocimiento de estos ilícitos, por el ciudadano lego. Para este, es necesaria la mayor publicidad de esas normas, a través de amplia divulgación. Como ejemplo de diploma regulando el asunto, tenemos la Ley 9.605/1998, que dispone sobre infracciones penales y administrativas contra daños al medio ambiente ${ }^{1493}$.

Además, uno de los puntos más considerables del Derecho Administrativo Sancionador es su dinamismo, una vez que consigue acompañar las transformaciones de la postmodernidad en la misma velocidad que ocurren. Tienden, de esta manera, a proteger bienes jurídicos difusos (colectivos y meta individuales), como el medio ambiente. Pretende punir delitos cumulativos y crímenes de peligro abstracto ${ }^{1494}$, que, al considerarse aisladamente, no causan daño aparente, pero, en razón de sus repeticiones en escala global lesionarían sobremanera los bienes jurídicos difusos.

Otra aplicación potencial del Derecho administrativo sancionador se da en la gestión del desarrollo técnico y en control normativo de la tecnología; estas actividades, en el ámbito jurídico, pueden ser gestionadas por reglas de este sector del Derecho.

\footnotetext{
${ }^{1493}$ MELlo, Rafael Munhoz de. Principios Constitucionais de Direito Administrativo Sancionador: as sanções administrativas à luz da Constituição Federal de 1988, pp. 15-16.

${ }^{1494}$ SILVA SÁNCHEZ, Jesús-María. La expansión del derecho cit., pp. 127-128, “muchas veces sólo adquiere dicho aspecto material si las infracciones se contemplan en conjunto. Pero, contempladas una a una resultan, ciertamente, formales, esto es, muchas veces siquiera de peligro abstracto, sino de mero peligro global, estadístico, presumido, etc".
} 
Se suma a eso que el Estado se dispone a financiar institutos de investigación y desarrollo, considerando algunos sectores técnico-científico-informacional como estratégicos para la seguridad nacional, a saber las áreas nuclear, aeroespacial y de telecomunicaciones.

La Administración Pública tiene, pues, alta importancia en la regulación de estos sectores primordiales a la evolución científica y a la estabilidad sociopolítica, sancionando aquel que presenta obstáculo a su buen funcionamiento.

\subsubsection{Principios esenciales}

Algunos de los principios más importantes a que se somete la potestad sancionadora de la Administración Pública son los principios de la legalidad, de la culpabilidad y del non bis in idem. Con las debidas adaptaciones, sirven de fundamento, no sólo para la rama jurídico-penal, sino también para el Derecho administrativo sancionador.

Por legalidad, no se trata, de su concepción amplia, prevista en el art. $5^{\circ}$ de la Constitución de 1988, sino del sentido estricto del término, en el que el Estado no puede realizar los actos administrativos no previstos en ley, sólo pudiendo actuar cuando la ley expresamente permitir ${ }^{1495}$. Esta legalidad, consonante la tipificación de ilícitos y sanciones conminadas, es compuesta por conceptos jurídicos con alto grado de indeterminación y cláusulas generales ${ }^{1496}$. Los tipos de ese campo del Derecho son más flexibles.

En lo que respecta a la tipicidad de infracciones administrativas, se constata que los tipos de esta rama jurídica deben presentar una clareza suficiente, de modo a poseer una previsibilidad mínima sobre su contenido. Las normas sancionatorias no pueden ser excesivamente vagas, ya que deben ser redactadas con precisión, para dar la exacta noticia a respeto de su contenido prohibitivo ${ }^{1497}$. El lenguaje normativo de las

\footnotetext{
${ }^{1495}$ MELLO, Rafael Munhoz de. Princípios constitucionais de direito administrativo sancionador: cit., p. 112.

${ }^{1496}$ OSÓRIO, Fábio Medina. Direito administrativo cit., p. 205.

${ }^{1497}$ CARBONELL, Eloísa; e MUGA, José Luis. Agencias y procedimiento administrativo en Estados Unidos de América. Madrid: Marcial Pons, 1996, pp. 117-118.
} 
leyes en blanco, aun así, no hiere el principio de la tipicidad, conforme entiende gran parte de la doctrina.

Con respeto a la proporcionalidad, se sabe que debe haber una razón de equilibrio entre la gravedad de la conducta y la gravedad de la sanción imputada. Así, una conducta leve no podría ser punida por una pena grave, mucho menos el contrario.

Este principio se refleja, en el Derecho Administrativo Sancionador, tanto en la tipificación de actos ilícitos, como en la punición correspondiente ${ }^{1498}$. De esta manera, los contornos de los deberes de los administrados son delimitados, y al Estado es definido el alcance de los tipos represores e su concreta aplicación ${ }^{1499}$.

Por non bis in idem, se entiende la no acumulación de penas aplicadas para un mismo hecho típico previsto en ley. Esta garantía de que el ciudadano será juzgado e imputado apenas una vez por un ilícito encuentra reflejos en el Derecho Administrativo Sancionador, para más allá del Derecho Penal. Se traduce, en las palabras de Susana Lorenzo, en la "obligación para la Administración de inhibirse de volver a ventilar un contradictorio de infracción que ya hubiese sido resuelto" ${ }^{\prime 1500}$. Nadie podrá recibir sanciones administrativas dos veces, por el mismo hecho, cometido en única ocasión.

Según el Tribunal Europeo de Derechos Humanos (TEDH), la imputación a una persona (física o jurídica) de una sanción penal más una sanción administrativa consagra la violación de ese principio. Ese fue el posicionamiento adoptado en decisión del TEDH contra Italia ${ }^{1501}$. A pesar de esto, recibir una sanción penal y otra administrativa derivadas del mismo hecho típico no constituye bis in idem ${ }^{1502}$ dentro del ordenamiento brasileño, por ser consideradas sanciones de naturalezas distintas.

\footnotetext{
${ }^{1498}$ MELLO, Rafael Munhoz de. Principios constitucionais de direito administrativo sancionador: cit., pp. 200-201.

${ }^{1499}$ MELLO, Rafael Munhoz de. Principios constitucionais de direito administrativo sancionador: cit., p. 202.

${ }^{1500}$ LORENZO, Susana. Sanciones administrativas. Montevideo, Julio Cesar Faira, 1996, p. 113. En el mismo sentido, v. VITTA, Heraldo Garcia. A sanção no direito administrativo. São Paulo: Malheiros Editores, 2003, pp.118-119.

${ }^{1501}$ SILVEIRA, Paulo Burnier da. O direito administrativo sancionador e o princípio non bis in idem na União Europeia: uma releitura a partir do caso "Grande Stevens" e os impactos na defesa da concorrência. RDC, Vol. 2, nº 2, Novembro de 2014, p. 10.

1502 MELLO, Rafael Munhoz de. Princípios constitucionais de direito administrativo sancionador: cit., p. 213.
} 
La irretroactividad también consta en el Derecho Administrativo Sancionador e implica que un hecho sólo puede recibir una sanción administrativa bajo la luz de disposiciones vigentes en el momento en que sucedió, de modo que no se puede recibir una sanción por norma anterior a la conducta (y no más vigente) ni ser punido por ley posterior $^{1503}$. Conviene resaltar que tanto la ley más grave no es retroactiva en favor del infractor, como la ley más benigna y blanda no produce efectos en el pasado para beneficiar el reo ${ }^{1504}$. La irretroactividad, en Derecho Administrativo Sancionador, es dotada de un carácter más amplio.

Por fin, con relación al debido proceso legal, que se encuentra implícito en el orden constitucional ${ }^{1505}$, se garante que una serie de procedimientos y rituales, de carácter formal y material será realizada mediante una acción judicial envolviendo infracciones administrativas. Tal garantía es resultado de que todo procedimiento judicial o administrativo debe notificar o citar el imputado, darle la oportunidad de defenderse plenamente, motivar previa resolución por parte de autoridad competente y permitir ser imparcial el órgano decisorio ${ }^{1506}$.

No pode haber falta de proporcionalidad ${ }^{1507}$, debiendo la razonabilidad controlar el poder discrecional, siendo que esta facultad es que irá garantizar un debido proceso legal substancial. También son aseguradas la presunción de inocencia y el derecho a la amplia defensa, que serán posteriormente tratados.

\subsubsection{Ilícito administrativo}

Es conditio sine qua non para estatuirse sanciones administrativas, la existencia de ilícitos administrativos. Estos deben ser elaborados por el legislador competente y

${ }^{1503}$ GONZÁLEZ PÉREZ, Jésus. El principio general de la buena-fe en el derecho administrativo. $3^{\mathrm{a}}$ ed. Madrid: Civitas, 1999, p. 428.

${ }^{1504}$ OSÓRIO, Fábio Medina. Direito administrativo cit., p. 277.

${ }^{1505}$ PERRINI, Raquel Fernandes. Os princípios constitucionais implícitos. Cadernos de Ciência, Direito Constitucional e Ciência Política. São Paulo: Revista dos Tribunais, n. ${ }^{\circ}$ 17, 1996.

${ }^{1506}$ CARBONELL, Eloísa e MUGA, José Luis. Agencias y procedimiento administrativo en Estados Unidos cit., pp. 98 e 101.

${ }^{1507}$ DI PIETRO, Maria Sylvia Zanella. Discricionariedade administrativa na Constituição de 1988. São Paulo: Atlas, 1991, p. 147. 
observados por la Administración Pública, en el ejercicio de su poder discrecional ${ }^{1508}$, siendo vinculados al principio de la estricta legalidad.

Cualquier aplicación que no atienda a las normas de Derecho Administrativo configura desvío de poder, si cometido por agentes públicos en sus cargos, o ilícitos administrativos, si cometidos por los administrados. Es conveniente aquí, establecer distinciones entre las categorías ilícito administrativo e ilícito penal, e indicar cuál será la concepción acatada.

Según la corriente cualitativa, existe una diferencia en la esencia de cada especie de ilícito. Los ilícitos penales (crímenes) son los que afectan intereses importantes a los individuos que componen el cuerpo social ${ }^{1509}$ y que buscan garantizar los valores esenciales que fundamentan la sociedad; mientras que por ilícitos (infracciones) administrativas, se encuentran comportamientos perjudiciales a intereses menores ${ }^{1510}$, causadores de lesiones menos graves al orden social, pudiendo, incluso, los daños causados referirse sólo a los intereses exclusivos del Estado.

Por la corriente cuantitativa, se defiende que ontológicamente los dos tipos de ilícitos son equivalentes: entre ambos, sólo consta diferencia en el grado de intensidad de los bienes jurídicos protegidos. Así, un ilícito penal sería aquel referente a conductas típicas de magnitud muy grave (ejemplo: homicidio calificado); con relación a los ilícitos administrativos, ellos serían atinentes a comportamientos típicos no tan graves (ejemplo: inobservancia de procedimientos de higiene en comedores).

Además de esas dos corrientes, surge la del "criterio formal"1511, que diverge de ambas al afirmar que tanto una como otra, son inadecuadas, porque pretenden diferenciar ilícito administrativo de ilícito penal con base en criterio meta-jurídico, que no está fundado en el derecho objetivo, siendo usada como criterio la conducta del infractor $^{1512}$. De este modo, ilícito administrativo es la conducta típica a la que una

${ }^{1508}$ CRETELLA JÚNIOR, José. Manual de direito administrativo: curso moderno de graduação. Rio de Janeiro: Editora Forense, 200, pp. 148-151.

${ }^{1509}$ MODERNE, Frank. Sanctions administratives et justice constitutionnelle. Paris: Economica, 1993, p. 127.

${ }^{1510}$ MODERNE, Frank. Sanctions administratives et justice cit., p. 127.

${ }^{1511}$ MELLO, Rafael Munhoz de. Princípios constitucionais de direito administrativo sancionador: cit., p. 60.

1512 DE PALMA DEL TESO, Ángeles. El princípio de culpabilidad en el derecho administrativo sancionador. Madrid: Tecnos, 1996, p. 31. 
sanción administrativa es atribuida e ilícito penal es la conducta típica a la que una sanción penal es imputada. Entiende Fábio Medina Osório que es criterio del legislador decidir cuál naturaleza será un ilícito, pudiendo incluso un ilícito penal tornarse administrativo y viceversa.

No es la posición del "criterio formal" más acertada, porque la posibilidad de permutar ilícitos en ramas distintas del Derecho afectaría el principio de la seguridad jurídica, dificultando la dosimetría de una sentencia judicial y una eficaz comprensión por la doctrina, en el momento de formular conceptos coherentes sobre los atributos de los diferentes ilícitos. Además, es posible notar que tanto la corriente cualitativa como la cuantitativa tienen sentido y no se excluyen mutuamente, por el contrario, se complementan.

\subsubsection{Sanción administrativa}

Sanción administrativa constituye, en sentido estricto, una medida represiva, de carácter aflictivo, que puede o no tener naturaleza disciplinar. Ella es impuesta por órganos y mecanismos de la Administración activa y comporta gran variedad de especies, relativas a los sectores de la economía, salud, circulación, transporte, desarrollo ${ }^{1513}$, etc. Es competente la Administración Pública para imputarla, además del poder judicial o corporaciones de derecho público, en los casos que la ley le permite.

Así, en sentido amplio, consiste la sanción administrativa en un mal o castigo, con alcance general y ex nunc, impuesto por la Administración Pública o por los entes ya citados (en los casos en que la ley permitir) a un administrado, agente público o persona jurídica, como consecuencia de una conducta tipificada como ilegal. Ella tiene una finalidad represora o disciplinar, en la esfera de aplicación material y formal del Derecho Administrativo ${ }^{1514}$.

A hacer una investigación teleológica de esa sanción, es posible concluir que ella posee carácter retributivo, o sea, consiste en la aplicación de una medida aflictiva direccionada al infractor de la norma administrativa, sin la pretensión de que los daños

${ }^{1513}$ DELLIS, Georges. Droit penal et droit administratif: L'influence des principes du droit penal sur le droit administrative répressif. Paris: LGDJ, 1997, p. 10 e ss.

${ }^{1514}$ OSÓRIO, Fábio Medina. Direito administrativo cit., p. 80. 
causados sean reparados. Este es el entendimiento de autores como Fábio Medina Osório ${ }^{1515}$ y Manuel Rebollo Puig, que no admiten la presencia del fin resarcitorio en ellas, siendo que este autor incluso afirma que la sanción administrativa "no sirve para restablecer la realidad física o los bienes jurídicos lesionados tampoco para compensar el daño causado"1516. De la misma forma, Guido Zanobini declara que la sanción "materialmente no restaura la ofensa conducida por el delincuente a la víctima y, a través de esta, a la sociedad" $" 1517$.

Contrariamente, considera Rafael Munhoz de Mello que suena como un exagero clasificar las penas resarcitorias como no pertenecientes a la categoría de sanciones administrativas.

La posición adoptada por la mayor parte de la dogmática es la de que esas sanciones poseen contenido retributivo, pero no se figura como imposible que la Administración Pública impute penas resarcitorias a cualquier persona física o jurídica. A pesar de eso, la visión más coherente es la de que al aplicar una pena resarcitoria, el Estado adentra en los dominios del derecho privado ${ }^{1518}$, como ocurre cuando el gobierno celebra un contrato con particulares, tal cual sucede en el caso de licitaciones o concesiones de servicio público.

En contrapartida al sistema punitivo penal, que visa asegurar los valores de la sociedad y su paz ${ }^{1519}$, el objetivo del administrativo es la garantía del buen desempeño endógeno de los servicios públicos y de orden administrativo ${ }^{1520}$.

Integran, así, como contenido de las sanciones de esa naturaleza, las penas restrictivas de derechos, la interdicción temporaria de derechos y las penas pecuniarias

\footnotetext{
${ }^{1515}$ MODERNE, Frank. Sanctions administratives et justice cit., p. 94-95: "las medidas de carácter resarcitorio no se integran en el concepto de sanción administrativa, porque no asumen efecto aflictivo o disciplinar, sino restitutorio, de reparación".

${ }^{1516}$ REBOLLO PUIG, Manuel. El derecho administrativo sancionador. In MOREIRA NIETO, Diogo de Figueiredo (coord.). Uma avaliação das tendências contemporâneas do direito administrativo: obra em homenagem a Eduardo García de Enterría. Rio de Janeiro: Renovar, 2003, pp. 267-68.

${ }^{1517}$ ZANOBINI, Guido. L'attività amministrativa e la legge. In Scritti vari di diritto pubblico. Milano: Dott. A. Giuffrè Editore, 1955, pp. 203-218.

${ }^{1518}$ ZANOBINI, Guido. Le sanzioni amministrative. Torino: Fratelli Bocca, 1924, pp. 4-5.

${ }^{1519}$ MEIRELLES, Hely Lopes. Direito administrativo brasileiro. 22 ${ }^{\mathrm{a}}$ ed., atualizada por Eurico de Andrade Azevedo e outros. São Paulo: Malheiros, 1997, p. 109.

${ }^{1520}$ OSÓRIO, Fábio Medina. Direito administrativo cit., p. 126.
} 
(por ejemplo, multa) - pero no la pena privativa de libertad. Además, para tipificar normas que atribuyan sanciones administrativas tienen competencia discrecional los legisladores de la Unión, de los estados-miembros y de los municipios.

\subsubsection{Proceso}

El proceso administrativo tiene como presupuesto una serie de actos anteriores, siendo estos de fundamental importancia para construir la voluntad de la Administración Pública. Por esta vía, el agente público se encuentra vinculado a los principios jurídicos que rigen el Derecho Administrativo Sancionador, y es a través de estos principios que el acto editado por el agente será disciplinado ${ }^{1521}$. Además, este proceso presenta similitudes con las demás ramas del Derecho Procesal.

Por la presunción de la inocencia, que es una garantía vigente en el procedimiento sancionador en su plenitud ${ }^{1522}$, nadie será considerado culpado hasta que se compruebe la relación de esta persona con el hecho ilícito y, con respeto al ilícito administrativo, la sanción solamente podrá ser impuesta después del término del proceso, cuando no sea más posible ningún recurso administrativo ${ }^{1523}$. Ya en relación a la amplia defensa, esta tiene como objetivo la garantía de la protección de los acusados en general, de modo que, en el Derecho Administrativo Sancionador, es condición básica de validad del proceso la ciencia del acusado sobre las imputaciones a él enderezadas, de modo que el acusado conozca los actos procedimentales y pueda manifestarse ${ }^{1524}$, o incluso abstenerse del pronunciamiento.

Aun, por el principio de la motivación de las decisiones sancionadoras, se puede aducir que todo acto sancionatorio de la Administración debe poseer un motivo racionalmente fundamentado y justificado, basado en el interés público. Debe todo acto

\footnotetext{
${ }^{1521}$ MELLO, Rafael Munhoz de. Principios constitucionais de direito administrativo sancionador: cit., p. 223.

1522 ESCUSOL BARRA, Eladio; RODRÍGUEZ-ZAPATA PÉREZ, Jorge. Derecho procesal administrativo. Madrid: Tecnos, 1995, pp. 185-186.

${ }^{1523}$ MELLO, Rafael Munhoz de. Princípios constitucionais de direito administrativo sancionador: cit., p. 245.

${ }^{1524}$ OSÓRIO, Fábio Medina. Direito administrativo cit., p. 400.
} 
ser motivado para garantirse la discreción y evitarse desvíos arbitrarios de poder. La motivación, en las palabras de Zanella di Pietro, es "inherente al principio de la legalidad, al debido proceso legal, siendo imprescindible para que los ciudadanos puedan ejercer el derecho de obtener informaciones de la Administración Pública" ${ }^{\$ 25}$. Además, debe la autoridad administrativa decidir de forma clara, directa y sin ambigüedad.

Además, al instituto de la prescripción, también es subordinado el poder punitivo de la Administración Pública, constando esa garantía en la Constitución ${ }^{1526}$. Ese instituto se fundamenta en la seguridad jurídica, de manera que la potestad administrativa sancionadora no puede ser ejercida frente a determinado hecho, cuando caducado el período de tiempo establecido por el ordenamiento jurídico.

Entienden algunos autores que, en los casos do no estabelecimiento del plazo para la imposición de sanción, analogías deben ser hechas, de modo que se adopten plazos de caducidad que regulen situaciones semejantes ${ }^{1527}$. Sin embargo, se admite lo que afirma la Ley 9.873/1999, cuando establece en su art. $1^{\circ}$ que, delante del silencio de la Ley, se prescribe en 5 (cinco) años a acción punitiva de la Administración Pública Federal.

\subsubsection{Accesoriedad Administrativa en materia ambiental}

Por accesoriedad administrativa, se entiende, la interdependencia del Derecho Penal con el Administrativo, en la que un tipo penal recibe la complementación de normas pertenecientes a este campo del Derecho o de actos administrativos ${ }^{1528}$. A la accesoriedad administrativa, cabe dar el complemento de leyes penales en blanco ${ }^{1529}$, y

${ }^{1525}$ DI PIETRO, Maria Sylvia Zanella. Discricionariedade administrativa na Constituição cit., pp. 151152.

${ }^{1526}$ BACELLAR FILHO, Romeu Felipe. Processo administrativo disciplinar. $2^{\mathrm{a}}$ ed. São Paulo, Max Limonad, 2003, p. 379.

${ }^{1527}$ FERREIRA, Daniel. Sanções administrativas. São Paulo, Malheiros Editores, 2001, p. 176.

${ }^{1528}$ SOUZA, Pablo Moitinho de. O direito penal e a proteção do patrimônio ambiental cultural. Dissertação (mestrado), Universidade de São Paulo, Faculdade de Direito, São Paulo, 2010, nota no 334, p. 96.

${ }^{1529}$ En estudio realizado en el marco del Proyecto de Investigación SEJ 2004-01046/JURI, «Régimen 
que contengan conceptos jurídicos indeterminados; en esas leyes, aun así, debe estar indicado cual es el bien jurídico protegido y el núcleo esencial del tipo penal debe ser presentado de forma precisa y objetiva ${ }^{1530}$, de modo a no contrariar el principio de taxatividad.

De acuerdo con Helena Regina Lobo da Costa, la reglamentación de conductas que objetivan proteger el medio ambiente, deben partir del presupuesto que casi todas las actividades humanas pueden generar algún perjuicio ambiental. En este sentido, la tarea de diferenciar que es prohibido de lo que es permitido, irá depender de una serie de variables (cuantitativas, temporales o locales) ${ }^{1531}$.

De esta forma, es posible inferir que hoy, ejemplificativamente, un determinado nivel de emisión de sustancias en la atmosfera sea soportable, pero puede a

jurídico de los recursos naturales», del Ministerio de Educación y Ciencia, Jesús Jordano Fraga. La Administración en el Estado Ambiental de Derecho. Revista de Administración Pública, n. ${ }^{\circ}$ 173, Madrid, mayo-agosto (2007), pp. 101-141 enseña que: "Por eso, es necesario el reforzamiento máximo del núcleo subjetivo del Derecho ambiental y configurar, con las especialidades que sean precisas, un derecho fundamental, un Derecho público subjetivo en el núcleo del Estado de derechos fundamentales (HÄBERLE). Probablemente, la estructura del derecho a disfrutar de un medio ambiente adecuado reclama la inmediación normativa a imagen y semejanza de los tipos en blanco del Derecho penal. Es precisa una determinación que requiere la labor del legislador. Aunque esto sea en parte cierto, ello sucede en el ámbito de otros derechos fundamentales clásicos (como el derecho de huelga, la libertad sindical, el derecho a la educación). Es muy posible que la inercia histórica que colocó desde 1789 la propiedad y la libertad como elementos polarizadores del sistema haya marginado otros derechos del núcleo duro. Hoy esto no tiene sentido cuando amenazas como la pérdida de biodiversidad, el efecto invernadero o los peligros bioquímicos de las nuevas sustancias son mucho más poderosas que las limitaciones o peligros potenciales que acechan a los derechos clásicos. En cualquier caso, una diferente estructura no es razón bastante para una marginación del núcleo duro. Por ejemplo, en términos de garantías procesales. Probablemente, en medio ambiente sea mucho más necesaria una protección jurisdiccional ágil que en otras materias. Este objeto procesal no resiste demoras. Creo que los ordenamientos deben superar dogmas (derecho objetivo ambiental, como el artículo 20 de la Ley Fundamental) y situar al derecho a disfrutar de un medio ambiente adecuado en el núcleo duro de derechos fundamentales" (pp.134-135).

${ }^{1530}$ GUERRERO, Mercedes Herrera. Derecho penal medioambiental y accesoriedad administrativa en la configuración de algunos delitos en el Código Penal español. Inconvenientes y propuestas de solución. $L a$ Ley Penal, N 76, Sección Informe de Jurisprudencia, Noviembre 2010, Editorial LA LEY, p. 05.

${ }^{1531}$ COSTA, Helena Regina Lobo da. Proteção Penal Ambiental. Viabilidade. Efetividade. Tutela por outros ramos do direito. São Paulo: Saraiva, 2010, pp. 189 y ss. 
depender de los cambios climáticos, dentro de algunos meses, esto sea prohibido. Como bien señalado por esta autora, "sería absurdo prohibir la emisión de cualquier sustancia, prohibir la pesca en todos los locales y épocas y prohibir cualquier tala de vegetación en todo el territorio brasileño" 1532 . Así también comenta Renato de Mello Jorge Silveira: “clamar por una protección ambiental radical, además de utópico, es impensable en el mundo de hoy" $" 1533$.

Esta riqueza de detalles de los asuntos ambientales hace surgir la necesidad de conocimientos técnicos específicos en cada local y época del año, materia esta que está vinculada a las funciones del derecho administrativo, sea por medio de reglamentos, decretos, portarías y resoluciones, tanto en ámbito municipal, estadual o federal $^{1534}$.

A partir de estas consideraciones, surge otro punto característico de las normas que se refieren a la protección penal del medio ambiente: la fuerte relación entre el Derecho Penal y el Derecho Administrativo, intitulada como 'accesoriedad administrativa $^{1535}$.

${ }^{1532}$ COSTA, Helena Regina Lobo da. Proteção Penal cit., pp. 189 y ss.

${ }^{1533}$ SILVEIRA, Renato de Mello Jorge. Direito Penal Supra-Individual. Interesses difusos. São Paulo: RT, 2003, p. 139.

${ }^{1534}$ Conforme COSTA, Helena Regina Lobo da. Proteção Penal cit., pp. 189 y ss.

${ }^{1535}$ Este término fue utilizado por la mayoría de la doctrina alemana (cf. HEINE, G.) y española (Cf. MATA BARRANCO, N. J.), siendo actualmente también adoptado por Renato de Mello Jorge Silveira en su obra "Direito Penal Econômico como Direito Penal de Perigo" (São Paulo: Editora Revista dos Tribunais, 2006). Sin embargo, el referido autor, en obras anteriores, utilizaba la grafía "assessoriedade" (Cf. SILVEIRA, Renato de Melo Jorge. Direito Penal Supra-Individual. Interesses difusos. São Paulo: RT, 2003, p. 139) sin mayores problemas. Helena Regina Lobo da Costa (Proteção Penal cit., p. 68) prefirió utilizar el término "assessoriedade administrativa" con la siguiente explicación: "Grafía que entiendo describir más correctamente el fenómeno, una vez que el derecho penal ambiental es auxiliado, socorrido o asesorado por el derecho administrativo, sin que eso lo haga, necesariamente, dependiente de él o accesorio. En muchos casos, la configuración del tipo penal dependerá, efectivamente, de una decisión de la esfera administrativa. No obstante, pueden existir tipos penales cuya redacción remeta a un simple concepto del derecho administrativo, lo que no significa, en esta hipótesis específica, que será necesaria una decisión en la esfera administrativa sobre eventual ilícito para la configuración del delito. Así, la grafía "assessoriedade" abarca no sólo las situaciones de efectiva dependencia, sino también aquellas de mera complementación conceptual o normativa". 
Sobre este asunto, es importantísimo citar los estudios realizados por Günther Heine, para quien, investigándose los moldes de relacionamiento entre el Derecho Penal y el Derecho Administrativo, es posible verificarse tres tipos de interacciones, que varían conforme el grado de dependencia de una esfera de la otra: protección penal absolutamente independiente; absolutamente dependiente $\mathrm{y}$, relativamente dependiente ${ }^{1536}$. Además, para el referido autor, hay un modelo de legitimación específico para cada modelo de tipo penal así relacionado.

Renato de Mello Jorge Silveira verifica que lo ideal de adoptarse es una conciliación entre derecho penal y derecho administrativo, o sea, un concepto mixto. Él llega a esta conclusión porque, al observar países que pretenden atender únicamente al modelo penal ambiental, tales como Portugal, Holanda etc.; hacen uso de exagerado número de normas penales en blanco, poniendo en cuestión el principio de la legalidad. De otro lado, también no es del todo correcto un modelo puramente administrativo, tal como el canadiense, americano o inglés, ya que atribuyen únicamente al Derecho Penal Ambiental la tarea de reforzar el cumplimiento de las normas administrativas, lo que quita el carácter autónomo de la ciencia penal ${ }^{1537}$.

Según Helena da Costa, "no hay como fijar parámetros técnicos de cada actividad en la norma penal" porque eso puede llevar a un casuismo exagerado que, al contrario, no conduce a una clareza y certeza de los tipos penales ${ }^{1538}$.

La remisión legislativa en materia ambiental impone la exigencia de violación de las disposiciones extrapenales juntamente con el requisito de actuarse sin o contra la autorización administrativa, que, en la visión de Basocco, tiene fundamento directo en un "delicado equilibrio de intereses": se quiere conciliar la protección ambiental al desarrollo de actividades económicas que son útiles a la vida social.

De este modo, se relega, muchas veces a órganos administrativos ambientales casi que la decisión acerca de la lesión o exposición de peligro soportable por el bien jurídico tutelado por las normas penales. Además, esta constante remisión

\footnotetext{
${ }^{1536}$ HEINE, Günther. Accesoriedad administrativa en el derecho penal del medio ambiente. Anuario de Derecho Penal y Ciencias Penales, Tomo 46, Fasc/Mes 1, 1993, pp. 289-316. Disponível na Internet em: http://dialnet.unirioja.es/servlet/articulo?codigo=46426. Acceso en: junho de 2012.

${ }^{1537}$ SILVEIRA, Renato de Mello Jorge. Direito Penal Supra-Individual. cit., p. 140.

${ }^{1538}$ COSTA, Helena Regina Lobo da. Proteção Penal cit., p. 69.
} 
posibilita, de cierta forma, la entrada en el sistema penal, de principios y consideraciones que muchas veces le son ajenos ${ }^{1539}$.

Sobre este aspecto, Blanca Mendoza Buergo afirma que existen dos cuestiones diferentes relacionadas entre sí: la primera tiene que ver con la creciente adopción de reglas de tipificación que más tiene que ver con el Derecho Administrativo que con el Penal, y que esta rama acaba acogiéndolas. Después, estaría la llamada “accesoriedad administrativa”, de la cual varios problemas surgen ${ }^{1540}$.

Según Mendonza Buergo, el primer de los problemas de la complementariedad administrativa bajo el aspecto de la dependencia absoluta del Derecho Penal Ambiental, se consustancia en el hecho de que la necesaria existencia de un sector administrativo de amplitud y transcendencia hace prácticamente inevitable la continua referencia, remisión y dependencia de la protección penal a las normas $\operatorname{administrativas}^{1541}$.

Además de los problemas levantados por la controversia relacionada con la naturaleza incidental de la reglamentación criminal en relación a la administrativa, claro que eso tiene implicaciones para la dimensión técnico-jurídica en la formulación de sus propios tipos, no sólo para el uso de infracciones penales en blanco, pero en otras ocasiones, dependiendo de la existencia de una violación criminal previa administrativa o falta de - o de la infracción - un acto ilícito ${ }^{1542}$.

De esta forma, como para la realización del tipo penal básico de la protección penal ambiental, depende de la infracción de las normas administrativas relacionadas, hay una limitación del contenido de la acción típica, como forma de imponer una exigencia adicional, para delimitar el ámbito de las acciones penalmente relevantes. Esta es una consideración que adopta una perspectiva de dependencia absoluta del Derecho Penal en relación a las regulaciones administrativas, otorgándose a estas la competencia para establecer que determinados peligros no son relevantes

\footnotetext{
${ }^{1539}$ TERRADILlOS BASOCCO, Juan. Derecho Penal del Medio Ambiente. Madrid: Trotta, 1997, p. 47. ${ }^{1540}$ MENDOZA BUERGO, Blanca. El delito ecológico y sus técnicas de tipificación. Disponible en: http://www.ecoiurislapagina.com/biblio/articulos/art125.htm. Acceso en: 25-03-2015.

${ }^{1541}$ MENDOZA BUERGO, Blanca. El delito ecológico y sus técnicas de tipificación. Disponible en: http://www.ecoiurislapagina.com/biblio/articulos/art125.htm. Acceso en: 29-06-2015

1542 MENDOZA BUERGO, Blanca. El delito ecológico y sus técnicas cit. Disponible en: http://www.ecoiurislapagina.com/biblio/articulos/art125.htm. Acceso en: 29-06-2015
} 
penalmente y la que determina, en definitivo, los límites del riesgo permitido en materia penal ambiental.

Basándose en estas críticas que Mendonza Buergo afirma que, no es necesario rechazar la accesorieddad administrativa del derecho penal ambiental, sin embargo, es necesario que las infracciones penales sean construidas conforme criterios propios de relevancia penal, para que no se haga un desvalor de la conducta por mera violación de deber o inobservancia administrativa ${ }^{1543}$.

En suma, las críticas aquí presentadas reconocen como relativa la complementariedad administrativa necesaria para la tutela del medio ambiente, pero, se refuerza la necesidad de criminalizarse conductas que puedan, definitivamente, afectar tal bien jurídico de forma grave, evitándose así "el mero refuerzo sancionatorio de la infracción a reglas de comportamiento que tutelan el funcionamiento de un subsistema, o sea, una infracción que no esté referida a una situación de peligro subyacente"1544.

Puede ser vista la accesoriedad administrativa como una derivación de las normas penales en blanco, consistiendo esta como una técnica legislativa en la que es traída una definición general de lo que se pretende punir ${ }^{1545}$, dotada de propósito de lagunas, que deben ser colmatadas por otras disposiciones legales. En el caso de la accesoriedad administrativa, es por medio de normas de Derecho Administrativo que el complemento al "blanco" de la norma penal será realizado; en vista de la indeterminación estratégicamente pensada de algún concepto jurídico.

El gran campo de actuación de la accesoriedad administrativa es el Derecho Penal Ambiental, en el que normas penales que objetivan tutelar el medio ambiente bien jurídico difuso - son redactadas con una margen de indeterminación, aunque el núcleo esencial del tipo prohibido esté explícito: Es el Derecho Penal Ambiental que formula las conductas pasibles de punición, a que se presenta de manera auxiliar o

1543 MENDOZA BUERGO, Blanca. El delito ecológico y sus técnicas cit.. Disponible en: http://www.ecoiurislapagina.com/biblio/articulos/art125.htm. Acceso en: 29-06-2015

${ }^{1544}$ MENDOZA BUERGO, Blanca. El delito ecológico y sus técnicas cit. Disponible en: http://www.ecoiurislapagina.com/biblio/articulos/art125.htm. Acceso en: 29-06-2015

1545 SOUZA, Sarah Rosignoli. A assessoriedade administrativa nos crimes de poluição cit., p. 11 Disponible en: http://www.terrabrasilis.org.br/ecotecadigital/images/A acessoriedade.pdf. Acceso en: 2906-2015. 
accesoria del Derecho ambiental administrativa ${ }^{1546}$. Por ejemplo, la norma administrativa que irá asesorar la ley penal podrá establecer la definición de algún concepto técnico del área biológico-ambiental, o ejemplificar el lenguaje previsto en el tipo.

Dentro del sistema jurídico brasileño, esta situación se ejemplifica por la Ley 9.605/1998 (Ley de crímenes ambientales), prevista en medio a la legislación penal extravagante. Su primera oración trae el delito de "Causar contaminación de cualquier naturaleza en niveles que resulten o puedan resultar en daños a la salud humana, o que provoquen la mortandad de animales o la destrucción significativa de la flora", teniendo como pena la reclusión, de un a cuatro años, y multa.

Es posible percibir la necesidad de la técnica de la accesoriedad en el $\S 2^{\circ}, \mathrm{V}$, al afirmar que "caso el crimen ocurra por lanzamiento de residuos sólidos, líquidos o gaseosos, o detritos, aceites o sustancias oleaginosas, en desacuerdo con las exigencias establecidas en leyes o reglamentos", la pena será aumentada ${ }^{1547}$. Por esta vía, habrá otras normas accesorias de Derecho Administrativo, que irán determinar cuáles son estos residuos no tolerados para lanzamiento al medio ambiente.

Así, es perceptible que las normas penales en blanco, sin perjuicio del principio de la reserva legal, remeten a otros dispositivos su complemento, que se pauta, preferencialmente, en conceptos técnicos de carácter tecnológico-científicos ${ }^{1548}$; los cuales sólo especialistas de los sectores ambientales, económicos y físico-químicos dominan con excelencia, no teniendo el legislador la obligación de conocerlos.

Por fin, cabe resaltar que las lesiones no tan graves, caben al Derecho Administrativo Sancionador punir. Pues, Derecho Penal y Derecho Administrativo

${ }^{1546}$ MENDO ESTRELlA, Álvaro. El delito «ecológico» del art. 325.1 del Código Penal. Valencia: Tirant Editorial, 2009, p. 86.

${ }^{1547}$ SOUZA, Sarah Rosignoli. A assessoriedade administrativa nos crimes de poluição cit., p. 8. Disponible en: http://www.terrabrasilis.org.br/ecotecadigital/images/A acessoriedade.pdf. Acceso en: 2906-2015.

${ }^{1548}$ GUARAGNI, Fábio André. Critérios de compatibilização da norma penal em branco com o Princípio da Reserva Legal, no aspecto formal da competência legislativa exclusiva para edição de normas incriminadoras. In: CONAMP / AMPERN. (Org.). Teses do XX Congresso Nacional do Ministério Público - 25 anos do novo Ministério Público: a construção de uma identidade. Brasília: Gomes e Oliveira Livraria e Editora, 2013, v. 1, p. 4. 
Sancionatorio deben coordinarse con el propósito de fornecer la mejor tutela posible a los bienes jurídicos y a los Derechos Humanos.

\subsection{Análisis comparativo entre el Derecho Penal y el Derecho} Administrativo Sancionador: Aspectos semejantes. Observancia del principio de la razonabilidad y de la proporcionalidad

Realizando un resumen histórico, se observa que fue la Revolución Francesa que permitió el fortalecimiento de un Derecho Penal legalizado y positivado. Sin embargo, a pesar de estos cambios de paradigmas en esta rama, muchas administraciones mantuvieron sus propios poderes sancionadores.

Este hecho descrito se perpetuó en el tiempo, de manera que es posible su demonstración actual por la a existencia de poderes sancionadores en las manos de las Administraciones Públicas, sea con el objetivo de desahogar el Poder Judicial, que en el escenario brasileño se encuentra sobrecargado, sea porque las funciones sancionatorias realmente son necesarias en la dinámica administrativa ${ }^{1549}$.

Basado en lo ya explanado sobre el Derecho Penal - como su función de punir conductas lesivas o peligrosas a bienes jurídicos - así como sobre el Derecho Administrativo Sancionador - que posee el "intuito de disciplinar y promover el interés general" 1550 -, primordial a la continuación del raciocinio, es interesante esbozar un paralelo entre ambos, delimitando posibles puntos convergentes y divergentes.

El punto de partida se encuentra en la existencia del poder de punir del Estado (ius puniendi). Se entiende que Derecho Penal y Derecho Administrativo beben de la misma fuente, o sea, ambos proveen de uno sólo tronco: el Derecho Constitucional.

Además, se muestra de suma importancia para la comprensión del tema propuesto en ese artículo el análisis de otras similitudes existentes entre ambas ramas del Derecho.

${ }^{1549}$ SANTOS NETO, João Antunes dos. O impacto dos direitos humanos fundamentais no direito administrativo. Belo Horizonte: Fórum, 2008, p. 117.

${ }^{1550}$ PRADO, Luis Regis. Curso de direito penal cit., p. 69. 
El principio de la proporcionalidad, juntamente con el principio del debido proceso legal, es esencial dentro del área del Derecho Administrativo. En normas de Derecho Administrativo que tipifiquen y sancionen categorías de actos ilícitos, es de primordial importancia la manifestación de ese principio "sea en la adecuación típica de las conductas a las descripciones de las normas, sea en la atenuación de los rigores sancionatorios abstractos"1551.

Además, consonante al punto de vista de Fábio Medina Osório ${ }^{1552}$, Brasil es un Estado de Derecho, lo que presupone la necesidad de defensa de los derechos del hombre. Justamente en ese punto es que el autor destaca la importancia del principio aquí discutido, de forma que el mismo es inseparable a la vigencia formal y material de un Estado de Derecho.

El principio de la proporcionalidad también está presente, de manera no menos importante, en el Derecho Penal, que, conforme ya explanado anteriormente, se divide en tres líneas: adecuación, necesidad y proporcionalidad en sentido estricto. Es establecida, así, la relación entre los delitos y las penas con el objetivo de buscar el equilibrio entre el injusto penal y la pena conminada. Según Luiz Regis Prado, este principio impone el análisis de los medios empleados y de los fines que se pretende $\operatorname{alcanzar}^{1553}$.

Con relación a la razonabilidad, se entiende que ella está presente en toda actividad sancionadora estatal, poseyendo un nexo irrenunciable con el debido proceso legal. Según el pensamiento de Fábio Medina Osório, razonabilidad y proceso legal "son principios complementares e indisociables"1554.

Una parte de la doctrina considera que sólo cuando la Administración Pública (u otro órgano estatal) pretende privar el hombre de sus bienes o de su libertad hay que exigirse la observancia al principio de la razonabilidad. En contrapartida, para Fábio Medina Osório ${ }^{1555}$ no se restringe a esas situaciones la aplicación de la razonabilidad, sin embargo, ella también debe hacerse presente en los procesos o procedimientos cuya finalidad no sea directamente la privación de libertad o de usufructo de bienes. Por

\footnotetext{
${ }^{1551}$ OSÓRIO, Fábio Medina. Direito Administrativo cit., p. 171.

${ }^{1552}$ OSÓRIO, Fábio Medina. Direito Administrativo cit., p. 174.

${ }^{1553}$ PRADO, Luiz Regis. Curso de direito penal cit., p. 149.

${ }^{1554}$ OSÓRIO, Fábio Medina. Direito Administrativo cit., p. 165.

${ }^{1555}$ OSÓRIO, Fábio Medina. Direito Administrativo cit., p. 165.
} 
ejemplo, los procesos que poseen el objetivo de suspensión de los derechos políticos u otras restricciones.

La razonabilidad también está íntimamente relacionada al Estado Democrático de Derecho. Humberto Ávila ${ }^{1556}$ destaca tres concepciones, a saber: equidad (relación de las normas generales al caso concreto), congruencia (vinculación de la medida adoptada a la finalidad deseada) y equivalencia (relación de equivalencia entre las dos grandezas)

7.8.1. Carácter punitivo en la búsqueda por la protección de los intereses tutelados. Observancia del principio de la intervención mínima. Tipicidad del ilícito disciplinar. Aspectos discrepantes

La finalidad punitiva de la sanción administrativa no es, según el paradigma de Fábio Medina Osório ${ }^{1557}$, incompatible con finalidad disciplinar, que aunque posea objetivo pedagógico, no deja de ser punitiva.

Además, Osório reconoce la existencia de corrientes según las que na cabe conceptuar la sanción administrativa como poseyente de finalidad puramente represiva. Sin embargo, el hecho de la misma poseer carácter puramente represivo, no es incompatible con la realización de las pretensiones pedagógicas.

Se tiene por tanto, que no solamente el Derecho Penal posee como objetivo la protección de los intereses tutelados. Mientras este cuida de bienes jurídicos, en primer plan, el Derecho Administrativo observa los intereses públicos; ambos sancionando al sujeto infractor.

Por el principio de la intervención mínima el Derecho Penal debe, en regla, abstenerse siempre que posible. Su actuación será legitimada frente a la grave ofensa a un bien jurídico, siempre que él no encontrar garantía eficaz en ninguna otra rama del Derecho.

Debido a su gravedad, es atribuido al Derecho Penal la característica de ultima ratio. Según el pensamiento de Luiz Regis Prado, “el Derecho Penal sólo debe actuar en

${ }^{1556}$ ÁVILA, Humberto. Teoria dos princípios da definição à aplicação dos princípios jurídicos. $4^{\mathrm{a}}$ ed. São Paulo: Malheiros, 2005, p. 103.

${ }^{1557}$ OSÓRIO, Fábio Medina. Direito Administrativo cit., p. 78. 
la defensa de los bienes jurídicos imprescindibles a la coexistencia pacífica de los hombres y que no puede ser eficazmente protegido de forma menos gravosa" ${ }^{\text {1558 }}$.

Del mismo modo, el principio de la intervención mínima incide, de manera igualmente relevante, sobre el Derecho Administrativo Sancionador, aunque con una menor concentración. Esta actuación busca evitar que la autoridad sancionadora administrativa incurra en arbitrariedades y en abuso de poder.

Partiendo del entendimiento de que tipo es la formalización de una conducta prohibida, se tiene que la tipicidad en las administraciones públicas deriva genéricamente del principio de la legalidad ${ }^{1559}$, de la misma manera que sucede en el ámbito del Derecho Penal.

Es esencial, en el ámbito del sistema penal, que la conducta prohibida sea tipificada. Eso corresponde a una garantía del ciudadano frente al arbitrio del Estado, una vez que, en un Estado Democrático de Derecho, se estima por la protección de los derechos fundamentales. Así, el ius puniendi estatal solamente puede infringir la esfera de libertad del ser humano cuando él incurra en la conducta tipificada.

Además, es importante observar que la Constitución expresamente declara que "nadie será obligado a hacer o dejar de hacer alguna cosa a no ser en virtud de ley" " Luego, de la misma manera la Administración Pública se somete a la exigencia de la legalidad, lo que implica en una tipicidad permisiva para elaborar modelos de conductas prohibidos, pasibles de sanción. No basta que ocurra el acto que está en desacuerdo con la autorización administrativa, pero es necesario que la conducta prohibida corresponda a aquella tipificada con sanción.

Así sucede que la mera violación de la norma habilitante por el agente público da lugar, sin duda, a inúmeras sanciones, comenzando por la del acto, reparación del daño y responsabilidad del Estado ante terceros. Sin embargo, el mero incumplimiento no autoriza la inmediata incidencia del Derecho Administrativo Sancionador (imposición de multas, restricciones a derechos e imposición de deberes), lo que debe respetar la importancia de la tipificación.

\footnotetext{
${ }^{1558}$ PRADO, Luiz Regis. Curso de direito penal cit., p. 148.

${ }^{1559}$ OSÓRIO, Fábio Medina. Direito Administrativo cit., p. 207.

${ }^{1560}$ BRASIL. Constituição da República Federativa do Brasil. Marcos Antônio Oliveira Fernandes (org.).

$20^{\mathrm{a}}$ Ed. São Paulo: Ed. Rideel, 2014, art. 5º, II.
} 
Se tiene como primordial elemento que distingue las sanciones administrativas de las penales su naturaleza, además del hecho de que aquellas recorren a la Administración Pública. También, las primeras consistirían en castigo, con alcance para el futuro, realizadas por el Judicial o por corporaciones de Derecho Público frente a un administrado (agente público, individuo o persona jurídica) ${ }^{1561}$; y las segundas, tendrían en sí el objetivo de prevención y de protección de la sociedad.

Otras distinciones aún se muestran importantes y serán analizadas, más detenidamente, a continuación.

\subsubsection{Forma procesal para aplicación de sanción. Autoridad competente}

La base fundamental del Derecho Administrativo Sancionador brasileño se encuentra en la cláusula del due process of law, que apunta la necesidad de seguirse un procedimiento justo cuando la acción pública tenga por objetivo la protección de un bien de la vida. Se busca el "equilibrio entre los elevados intereses públicos y protegidos por el Estado y los intereses privado, individuales y particulares de los agentes sujetos a la actividad estatal sancionadora" ${ }^{, 1562}$.

Sin embargo, con relación a las sanciones administrativas, el proceso (elemento formal) no posee una única naturaleza, pudiendo ser de origen judicial o administrativa. La administración Pública no posee la exclusividad de aplicación de las referidas sanciones, ya que jueces de primer grado y miembros de los Tribunales Judiciales también las pueden aplicar ${ }^{1563}$.

Diferentemente, en el área penal, las penas son impuestas, únicamente, por miembros del judicial - jueces -, a través del debido proceso legal. Son respetados, incluso, los principios del contradictorio y de la amplia defensa, caracterizando el formalismo de esta área.

\footnotetext{
${ }^{1561}$ OSÓRIO, Fábio Medina. Direito Administrativo cit., p. 80.

${ }^{1562}$ OSÓRIO, Fábio Medina. Direito Administrativo cit., p. 164.

${ }^{1563}$ OSÓRIO, Fábio Medina. Direito Administrativo cit., p. 119.
} 
Eso no significa que haya una jerarquía entre ambas: la sanción penal por encima de la sanción administrativa ${ }^{1564}$. El comienzo de separación entre ambas es puramente dogmático. Hay situaciones, por ejemplo, en las cuales las sanciones administrativas causan mayor "dolor" y "sufrimiento" al infractor que una sanción penal.

Aun, existen doctrinadores que sostienen la idea de que las sanciones administrativas discrepan cualitativamente de las penales, porque tienen contenido diverso.

El poder sancionador de la Administración Pública sería una función administrativa. Esa tesis no resiste a la idea de que las sanciones administrativas pueden cumplir funciones idénticas a las funciones penales, restaurando la paz en el ordenamiento jurídico y puniendo el transgresor. Del mismo modo, acciones administrativas pueden ser realizadas por jueces de derecho.

En el escenario del derecho brasileño tanto las autoridades administrativas como el propio Judicial pueden imponer sanción administrativa. Este actúa incluso en el desempeño de sus actividades jurisdiccionales, con la exceptuación de que debe ser accionado por el legislador. Por lo tanto, se ve que la figura de la autoridad administrativa no configura como elemento indisociable de la sanción administrativa, visto que pueden las autoridades judiciales, de igual modo, aplicarla.

En contrapartida, cuando el análisis se vuelve al Derecho Penal y para aquel que posee legitimidad para aplicar la sanción característica de esa rama, esa situación no se repite. Las sanciones penales solamente pueden ser aplicadas por jueces revestidos de jurisdicción penal.

7.8.3. Gravedad. Manera de positivación: ¿en código o no?. Legitimidad para legislar

En regla, el Derecho Penal es más grave, una vez que posee la capacidad de privar el ser humano de su libertad, hecho que lo califica como instrumento subsidiario del Estado. Consecuentemente, sufre mayor intervención del principio de la

${ }^{1564}$ OSÓRIO, Fábio Medina. Direito Administrativo cit., p. 136. 
insignificancia, a partir de que solamente interesa al Derecho Penal conductas lesivas o efectivamente peligrosas a bienes jurídicos.

Del contrario, el Derecho Administrativo Sancionador revela menor gravedad cuando de su actuación. Él ordena, de modo general, sectores de actividad y se utiliza de la sanción para reiterar un modelo específico. Además, su esfera de actuación se somete a una gran interferencia del interés público, mayor que aquella que se sucede en el Derecho Penal.

Cuando se estudian las leyes penales se percibe que ellas están reunidas y sistematizadas en el Código Penal (Decreto Ley n 2.848 de 1940), con excepción de la legislación penal complementar. Eso facilita la búsqueda y la determinación de lo que es clasificado como dispositivo penal.

Sin embargo, se verifica que lo mismo no ocurre en relación al Derecho Administrativo, porque la aplicación de sanción administrativa, aunque positivada y ya clasificada por el legislador dentro del ilícito administrativo, no está sistematizada y codificada en un único lugar.

Se tiene, por lo tanto, que el jurista que desear verificar si determinado comportamiento es un ilícito administrativo y, confirmada su sospecha, tener ciencia de cuál es la sanción administrativa pertinente, tendrá el trabajo de "pincelar" en todo el ordenamiento jurídico (código de defensa del consumidor, derecho constitucional, derecho ambiental, etc.) las conductas descritas como ilícitos administrativos.

Otro punto distintivo entre Derecho Administrativo Sancionador y Derecho Penal reside en la diferencia de entes de la Federación que poseen legitimidad para la creación de leyes. El primer es más amplio, una vez que, de acuerdo con la doctrina dominante, la Unión, los Estados y los Municipios pueden legislar en materia administrativa.

Sin embargo, a lo que se refiere al Derecho Penal, se verifica que la legitimidad para legislar en esta área pertenece exclusivamente a la Unión, no pudiendo los Estados y tampoco los Municipios legislar en materia penal. 


\subsection{Ilícito penal y administrativo. ¿Derecho de Intervención como} alternativa viable?. Posicionamiento crítico

Observándose la unidad del ordenamiento jurídico, se tiene como corolario de ese hecho que una misma conducta no puede ser considerada ilícita por una rama del Derecho y aprobable/deseable por otra. Sería la contradicción madre de la seguridad jurídica $^{1565}$.

Para la finalidad de ese estudio, se dividirá el ilícito en dos categorías ${ }^{1566}$, siendo que la primera es la ilicitud formal. El tipo es aquel que formaliza una conducta prohibitiva: la ilicitud es formalmente afirmada por el tipo que prevé el modelo de conducta prohibida. La segunda es la ilicitud material, que es resultado del análisis de si el acto efectivamente ofende o no el bien jurídico protegido por la norma. Se parte del punto de que todo ilícito es una contravención a la ley, independiente de su naturaleza.

Luego, se tiene que todo ilícito se caracteriza por la no observancia a un dispositivo legal, caracterizando una ofensa o amenaza a un bien o interés jurídico. La importancia atribuida a ese bien es que determina la naturaleza de la sanción, por ejemplo, administrativa o penal. Así, la diferencia entre ambas las ilicitudes es cuantitativa, se pauta por el grado de gravedad: el Derecho Administrativo es minus frente al Derecho Penal.

A partir del análisis comparativo entre ambas ramas del Derecho - Derecho Penal y Derecho Administrativo Sancionador -, se nota la importancia del breve análisis de una tercera vía: el Derecho de Intervención. Hassemer se pauta por el hecho del Derecho Penal Moderno caracterizarse por la ininterrumpida creación de nuevos tipos penales, destinados a la protección de bienes jurídicos, que, todavía, son definidos de forma altamente imprecisa. Él ha concluido por la necesidad de superación de esa situación y del control de la expansión desmedida del Derecho Penal, proponiendo su reducción a un Derecho Penal Nuclear.

Como corolario de las discusiones acerca de cuál medio sería el más indicado para tutelar las situaciones características da nueva realidad, este autor propone el "derecho de intervención" - mitad del camino entre el Derecho Penal y el Derecho Administrativo Sancionador.

\footnotetext{
${ }^{1565}$ OSÓRIO, Fábio Medina. Direito Administrativo cit., p. 270.

${ }^{1566}$ OSÓRIO, Fábio Medina. Direito Administrativo cit., p. 271.
} 
Según Silva Sánchez ${ }^{1567}$, el Derecho de Intervención tutelaría cuestiones referentes a ilícitos que envuelven drogas y economía, por ejemplo. Sería un Derecho más pretencioso en lo que se refiere a las garantías, pero con sanciones más suaves que las penales tradicionales. Él autor también cree que podría existir dentro del Derecho Penal una parte menos intensa, que cuidase de situaciones que no generasen la pena de prisión.

Innegable es el hecho de que se vive no Brasil, en un Estado que se distancia de los preceptos de la modernidad, del Estado de bienestar social e del Estado paternalista. El fin del siglo XX y el inicio del siglo XXI revelaron una elevada alteración de la sociedad con el surgimiento de la globalización y del neoliberalismo, de manera que el Estado-nación perdió su carácter interventor y pasó a actuar solamente como regulador de las conductas sociales. El poder económico, por ejemplo, superó sus límites nacionales, lo que posibilitó la no extrañeza de la situación en la que una gran empresa tiene rendimientos anuales superiores al PIB de un país.

Atinente a estos cambios en las configuraciones externas, se admite la necesidad de actualización del Derecho a la nueva realidad que se identifica, una vez que el mismo debe servir a la sociedad y acompañar a los fenómenos a su alrededor.

Consecuentemente, se ve la imposibilidad del Derecho Penal esquivarse de esa situación, una vez que su misión clásica es la protección de bienes jurídicos circunstancias reales dadas.

La naturaleza histórica de esa rama del Derecho es personal y concreta, o sea, sólo la lesión o la efectiva colocación en peligro de un bien de la vida del individuo como la vida, libertad, integridad y honor - era pasible de tutela penal. Sin embargo, el Derecho Penal actual no puede confundirse a aquel pensado en el siglo XIX. Pues, la actual sociedad se caracteriza por la existencia de bienes jurídicos colectivos - como el orden económico, medio ambiente y orden tributaria. Los riesgos inherentes a ella ya no son más individuales, sino colectivos, y amenazan de la misma manera el bienestar del ser humano.

Así, la actuación de esa rama del Derecho frente a los bienes jurídicos difusos se tiene como legítima. El hecho de ser caracterizados por la colectividad y por la

${ }^{1567}$ SILVA SÁNCHEZ, Jésus Maria. A Expansão do direito penal. Aspectos da política criminal nas sociedades pós industriais. Tradução Luís Otávio de Oliveira Rocha. $2^{\mathrm{a}}$ ed. São Paulo: Editora Revista dos Tribunais, 2011, p. 183. 
abstracción no configura obstáculo a esa constatación, porque la sociedad de riesgos es caracterizada por la masificación y por la valoración de la sociabilidad; y la abstracción es comprendida como esencial para que se prevengan delitos efectivamente lesivos a la existencia físico psíquico del hombre.

Eso no significa, sin embargo, que su aparición sea desmedida. Se deben respetar los principios de intervención mínima, subsidiariedad, proporcionalidad y legalidad, por ejemplo, so pena de autoritarismo. El aumento extremado del ius puniendi estatal, en ámbito penal, puede ser problemático, porque podría herir en alto grado la libertad en el momento de la aplicación desnecesaria de la pena privativa de libertad.

En esta línea de raciocinio, se admite, también, la legitimidad de la actuación del Derecho Administrativo Sancionador para que la actuación del Derecho Penal no sea excesiva. El Estado y sus instituciones deben ser protegidos por el área del Derecho responsable por la administración pública, desde que observados los derechos fundamentales y respetados los principios de amplia defensa, contradictorio y legalidad.

De ese modo, no se concluye por el Derecho Penal Mínimo ni por el Máximo y menos por el abolicionismo. Ambas las ramas del Derecho, aquí presentados, son legitimados para la regulación de bienes jurídicos difusos, pero un (Derecho Penal) volcado a la protección del ser humano y el otro (Derecho Administrativo Sancionador), en la manutención de los intereses del Estado. La pregunta que se hace es, ¿a partir de cuál momento una conducta es suficientemente gravosa a punto de superar el ámbito del mero interés estatal de seguridad y orden, y alcanzar el efectivo interés humano?

\subsection{Responsabilidad penal ambiental: evolución legislativa y dogmática}

Para la comprensión de la responsabilidad penal por conductas lesivas al medio ambiente, tal como predicado en el texto constitucional patrio de 1988 (art. 225), como hace parte de los objetivos centrales de este estudio, se hace extremamente importante, ex ante, proceder al levantamiento de la evolución histórico-legislativa y dogmática de la actuación del Derecho Penal del ambiente.

Antes de 1988, ninguna Carta Magna Brasileña había traído la determinación de tutela penal para la protección del medio ambiente. Lo que habían eran leyes 
dispersas y con poca eficacia, que preveían, de forma aleatoria, crímenes y contraventores ambientales relativas a la prohibición de la tala de árboles, de caza y pesca y perturbación de la propiedad ajena sin la debida autorización.

Uno de los primeros tipos penales que se tiene conocimiento consistía en la prohibición del corte ilegal de árboles, que desde 1446, en las Ordenaciones del Reino determinadas por D. Afonso IV, era considerado "crimen de injuria al rey"1568. Especialmente, el carácter penal de esta intervención se debía a la gran preocupación de la Corona en punir más severamente aquellos que atentasen contra las riquezas de los bosques, ya que la madeira era importante a los proyectos de navegación de los portugueses $^{1569}$.

Después, en 1521, en el período de las Ordenaciones Manuelinas, que entraron en vigor en 1521 en Brasil-Colonia, fueron prohibidas la caza de determinados animales y la extracción de determinados árboles fructíferas, para garantir el suministro de los alimentos que pudiesen restar escasos en la Corona Portuguesa ${ }^{1570}$.

Las ordenaciones filipinas también preveían "delitos ecológicos" de esta categoría, restringiéndose la caza y pesca de animales, muerte de abejas y de ganado y la contaminación acuática.

En general, la legislación durante todo el período del Brasil-Colonia era de poca sistematicidad y bastante dispersa, no habiendo una unicidad en las reglas y aplicación de las penas relacionando tales "delitos" al medio ambiente. Además, las grandes distancias dificultaban bastante a profusión de estas leyes por el territorio.

El Código Penal de 1830, influenciado por la venida de la familia real portuguesa a Brasil en 1806, disponía sobre crímenes contra el corte ilegal de árboles y contra el patrimonio histórico-artístico. En 1850, la Ley de Tierras trajo disposiciones penales sobre talas de bosques y quemas ${ }^{1571}$.

Sin embargo, solamente a partir de una nueva Constitución Democrática, como fue la de 1934 es que se fue posible editar la primera legislación brasileira que trajo

\footnotetext{
${ }^{1568}$ ACETI JÚNIOR, Luiz Carlos e outros. Crimes Ambientais. Responsabilidade das Pessoas Jurídicas. São Paulo: Imperium Editora, 2007, pp. 49-50.

${ }^{1569}$ FERREIRA, Ivete Senise. Tutela penal do patrimônio cultural. Biblioteca de Direito Ambiental. São Paulo: Editora Revista dos Tribunais, 1995, p. 77.

${ }^{1570}$ FERREIRA, Ivete Senise. Tutela penal do patrimônio cit., p. 78.

${ }^{1571}$ FERREIRA, Ivete Senise. Tutela penal do patrimônio cit., p. 81.
} 
aspectos específicos de tutela penal ambiental - el Código Forestal -, instituido por el Decreto 23.793/1934 y, en el mismo año, se editó también el Código de Caza (Decreto 24.645/34). En estas legislaciones eran traídos crímenes y contravenciones penales contra abusos en la utilización de bosques y de especímenes animales.

Con la edición de los actuales: Código Penal (Decreto-Ley 2.848/1940) y Ley de Contravenciones Penales (Decreto 3.688/1941), pocas fueron las innovaciones en materia de protección penal ambiental.

Solamente más adelante, es que se promovió una renovación en las tipificaciones penales ambientales, promovidas, especialmente, con la inserción del Código Forestal instituido por la Ley $4.471 / 1965^{1572}$ y por una serie de otras leyes ambientales específicas (tales como la Ley 3.924/61 ${ }^{1573}$; Ley 5.197/67 ${ }^{1574}$; Dec-Ley 221/67 ${ }^{1575}$; Dec-Ley 303/67 ${ }^{1576}$; que entre otras normas ${ }^{1577}$, previeron crímenes y penas para la contaminación del suelo, agua y aire y la destrucción de monumentos del patrimonio histórico-artística) ${ }^{1578}$.

Notoriamente, fue a partir de la promulgación de la Carta Magna de 1988, que se puso fin a la controversia de que el "medio ambiente ecológicamente equilibrado"

${ }^{1572}$ Fue actualmente revocado por la Ley no 12.651 , de 25 de mayo de 2012. Para los ambientalistas, estas alteraciones son fruto de un intento de los ruralistas, por más de diez años, de alterar la "Ley Forestal" para beneficiar la explotación económica en desfavor de la preservación de los ecosistemas, tal como los determinados por las áreas de preservación permanente y de reserva legal, obligatorias a los dueños o poseyentes de inmuebles rurales. Aunque con el veto parcial de la actual Presidente, Dilma Rousseff, y, con la Medida Provisoria n. 571, de 25de mayo de 2012, los defensores de una protección integral y sostenible del medio ambiente aun claman por cambios. Sobre tales protestos, ver discusiones en la web de la campaña favorable a la reforma da reciente ley, disponible en: http://www.florestafazadiferenca.com.br/home/. Acceso en: julio de 2012.

${ }^{1573}$ Ley que traía la protección de los monumentos arqueológicos y prehistóricos.

${ }^{1574}$ Ley de protección a la fauna que sólo traía contravenciones penales, que depués, en 1988, fueron convertidas en crimenes de contravenciones por la Ley 7.653/88.

${ }^{1575}$ Decreto que trata de protección de la pesca, notadamente a acuática.

${ }^{1576}$ Decreto que trató de protección contra contaminación de las aguas, suelo, aire.

${ }^{1577}$ Una ley curiosa fue la Ley 7.643/87 que incriminaba la pesca de cetáceos (ballenas) en las aguas brasileñas, cuya pena privativa de libertad prevista era mínima de 2 y máxima de 5 años, sumada a la pena de multa.

${ }^{1578}$ FERREIRA, Ivete Senise. Tutela penal do patrimônio cultural. Biblioteca de Direito Ambiental. São Paulo: Editora Revista dos Tribunais, 1995, pp. 82-85. 
debería, en carácter de derecho fundamental, ser protegido penalmente, teniendo como sujetos pasivos no sólo la presente sino también las futuras generaciones.

La Ley Mayor, en las lecciones de Luiz Régis Prado, estableció "un mandato expreso de criminalización de las conductas lesivas al medio ambiente"1579, así, se entiende como una determinación constitucional de la necesaria protección de este bien por el Derecho Penal, de forma que la Carta Magna, con eso, ha solucionado cualesquier dudas acerca de la indispensabilidad de una tutela penal ambiental. "Se reconoce la existencia y la relevancia del ambiente para o hombre y su autonomía como bien jurídico, debiendo, para tanto, el ordenamiento jurídico echar mano incluso de la pena, aunque en ultima ratio, para garantirlo" ${ }^{\prime 1580}$.

En lo que se refiere a la interferencia del Derecho Penal, tampoco hay discusiones sobre la determinación constitucional de intervención penal en el ambiente, incluso porque la Constitución, en su art. 225, fue clara al afirmar la tutela penal. Lo que aun importante se hace destacar la función de los mecanismos de control instituidos posteriormente, por determinación constitucional, a saber la Ley 9.605/98 (Ley de Crímenes Ambientales), así como la Ley 11.105/2005 (Ley de Bioseguridad), entre otras, por representaren medios represivos y, especialmente, preventivos a los nuevos riesgos surgidos con la globalización.

Una vez valiéndose de las lecciones traídas por Luiz Régis Prado, con relación a la protección penal del medio ambiente, la referencia al sistema punitivo, que establece la distinción entre las sanciones, además de ser factor importante de su eficacia, sólo puede ser comprendida a la luz de los principios inherentes a la propia

${ }^{1579}$ PRADO, Luiz Régis. Direito Penal cit., p. 80.

${ }^{1580}$ PRADO, Luiz Régis. Direito Penal cit., p. 80. En este sentido, Vladmir y Gilberto Freitas hablan de la importancia de la protección penal ambiental y la expresa orden constitucional de criminalización de las conductas ofensivas al medio ambiente: "a importância da tutela penal do meio ambiente de há muito vem sendo destacada. Basta lembrar que no XII Congresso Internacional de Direito Penal, realizado em Varsóvia em 1975, foi aprovada a resolução de tratar como delitos contra a humanidade e submeter a grave repressão as agressões ao meio ambiente. No Brasil, abre espaço a essa resolução e expressamente a impõe a Constituição Federal de 1988, no art. $225 \S 3^{\circ}$, quando estabelece que "as condutas e atividades lesivas ao meio ambiente sujeitarão os infratores, pessoas físicas ou jurídicas, a sanções penais". FREITAS, Vladimir Passos de; FREITAS, Gilberto Passos de. Crimes contra a natureza. Editora Revista dos Tribunais, 2006, p. 31. 
Constitución - en una visión lógico-sistemática y teleológica - y en el sentido tradicional de las categorías jurídico-penales ligadas a ellos.

Para el referido autor, a partir de esta determinación constitucional, se obliga el legislador ordinario a "construir un verdadero sistema normativo penal que defina, de modo determinado y limitado, las conductas punibles y respectivas penas, en armonía con los principios constitucionales penales, como estructura jurídica mínima para dar cumplimiento a lo estatuido en la Constitución Federal" $" 1581$.

Cumpliendo la mencionada determinación constitucional, la Ley 9.605/98, de 12 de febrero de 1998, impuso medidas administrativas y penales a las conductas lesivas al medio ambiente.

Hasta el surgimiento de la Ley 9.605/98, como dicho, las leyes penales ambientales sufrían graves problemas de sistematización. En este punto, la actual Ley Penal Ambiental en cuestión tuvo el mérito, por lo tanto, de sistematizar y unificar las infracciones penales contra el medio ambiente en un único diploma legal, aunque aún haya infracciones ambientales tipificadas en otros textos normativos.

Respecto a los tipos penales, el Capítulo V, a partir del art. 29 de la Ley 9.605/98, trae la lista de los crímenes contra el medio ambiente, divididos en: Crímenes contra la Fauna, Crímenes contra la Flora, Crímenes Ambientales ligados a la Contaminación, Crímenes contra el Ordenamiento Urbano y el Patrimonio Cultural y de los Crímenes contra la Administración Ambiental. En lo que se refiere a las especies y los límites de las penas aplicadas, hay en su mayor parte penas privativas de libertad, de reclusión (hasta 5 años) y detención (hasta 1 año), con causas especiales de aumento de pena, aparte las penas restrictivas de derechos, prestación de servicios a la comunidad y multa.

Al iniciar el abordaje de la estructura dogmática de la tutela penal ambiental, se hace extremamente importante resaltar el debate sobre la responsabilización penal de las personas jurídicas, en tesis traído en el art. $225, \S 3^{\circ}$ de la Constitución, verbis: "las conductas y actividades consideradas lesivas al medio ambiente sujetarán los infractores, personas físicas o jurídicas, a sanciones penales y administrativas, independientemente de la obligación de reparar los daños causados".

${ }^{1581}$ PRADO, Luiz Régis. Direito Penal cit., p. 76. 
La Ley 9.605/98 no pareció haber solucionado todas las dudas sobre tal conflicto, porque prevé, explícitamente, la responsabilización criminal de persona jurídica, haciéndolo en el artículo $3^{\circ}$, pero de forma vaga, confusa e incompatible con las reglas de imputación penal previstas en el Código Penal y demás legislaciones penales.

Otro punto traído en la Ley 9.605/98 se refiere a la integralidad del medio ambiente que debe ser protegido. Por lo que se verifica, el acto normativo contempló el medio ambiente en su acepción amplia, comprendiendo tanto el medio ambiente natural, como el artificial y el cultural, englobando infracciones sobre el ordenamiento urbano y el patrimonio histórico-artístico.

Hay que destacarse que, en razón de los principios de la precaución y de la prevención, en materia de tipos ambientales, pocos son los crímenes de daño, que exigen la lesión efectiva. La mayoría de los crímenes ambientales son crímenes de peligro, muchos de peligro concreto, $y$, en la mayor parte de los casos de peligro abstracto. En aquellos, el peligro integra el tipo como elemento normativo, de modo que el delito sólo se consuma con su real ocurrencia para el bien jurídico, esto es, el peligro debe ser efectivamente comprobado. En los de peligro abstracto, el peligro constituye únicamente la ratio legis, inherente a la acción, no necesitando de comprobación ${ }^{1582}$.

En estos tipos penales, la legislación penal busca evitar el acontecimiento del daño, por su efecto preventivo. Basta, por lo tanto, la mera conducta, independientemente de la producción del resultado. De ese modo, el carácter sancionador está en un momento anterior al efectivo y eventual daño causado al ambiente, lo que trae un carácter intimidante e, incluso, educativo.

Otra característica notable en los crímenes ambientales es la presencia exorbitante de normas penales en blanco, que son aquellas en que la descripción de la conducta es incompleta o presenta lagunas, necesitando de complementación por otro dispositivo. Hay que resaltarse también que, la mayoría de los tipos penales volcados a la protección del medio ambiente posee elementos normativos que remiten el intérprete al Derecho Administrativo. Tales elementos, como enseña Miguel Reale Júnior, poseen “contenido variable, considerados a partir de otras normas jurídicas, o extrajurídicas, en el momento de la aplicación del tipo al hecho concreto" $" 1583$.

\footnotetext{
${ }^{1582}$ PRADO, Luiz Régis. Direito Penal cit., p. 152.

${ }^{1583}$ REALE JÚNIOR, Miguel. Instituições de Direito Penal, vol. 1. Rio de Janeiro: Forense, 2002, p. 38.
} 
Evidente, pues, que el Derecho Penal encuentra, en los términos de esta ley, problemas para abarcar tantas minucias en la estructura típica, y el auxilio por el Derecho Administrativo se impone. Además, hasta para rellenar un principio fundamental del sistema jurídico, el de la unidad del Derecho, es edificante que el tipo penal quede ligado a la decisión administrativa, evitando los conocidos problemas resultantes de adoptarse una línea de "independencia entre las instancias", como ampliamente sucedía en el ámbito de los crímenes tributarios.

Renato de Mello Jorge Silveira, sin embargo, advierte, sobre la proliferación de la actuación en el área penal. Según el autor, el tema es saber los límites de actuación del Estado en este campo legal, porque es innegable que la preocupación penal ambiental ganó espacio en todo el mundo a punto de que, más recientemente, se han notado diversas incoherencias. Silveira señala que la Ley ambiental brasileña, en este aspecto, fue profundamente criticada, ya que, en su visión, varios puntos necesitan de atención más detallada ${ }^{1584}$.

En cuanto a la protección penal del medio ambiente, con mucho más intensidad es necesario la imputación a la persona jurídica. En este sentido, Fábio Guedes de Paula Machado, establece fundamentos basados en reglas de política criminal y de orden dogmática ${ }^{1585}$. Respecto a la primera, afirma que "la propia empresa se constituye como una de las principales fuentes de riesgos para los bienes jurídicos fundamentales del hombre, como la vida, la salud y el medio ambiente" ${ }^{\Perp 1586}$. Concluye la afirmación diciendo que en obediencia a los principios de intervención mínima que orientan el Derecho Penal, este no puede guardar silencio o negar protección a valores o bienes y que son $\tan$ caros a la humanidad ${ }^{1587}$.

En cuanto a su aplicación práctica, afirma el autor que los conceptos tradicionales de la teoría del delito no sirven para imputar un delito a una persona

\footnotetext{
${ }^{1584}$ SILVEIRA, Renato de Melo Jorge. Direito Penal Supra-Individual. cit., p. 136.

${ }^{1585}$ MACHADO, Fábio Guedes de Paula. Culpabilidade no direito cit., p. 264.

${ }^{1586}$ MACHADO, Fábio Guedes de Paula. Culpabilidade no direito cit., p. 265. Del mismo autor: Dos bens jurídicos supra-individuais de conteúdo difuso como o meio ambiente. Rivista Diritto \& Diritti, 2009. Disponible en:
} $<$ https://docs.google.com/viewerng/viewer?url=http://www.diritto.it/pdf/28542.pdf?download\%3Dtrue>. Acceso en: 02-12-2015.

${ }^{1587}$ MACHADO, Fábio Guedes de Paula. Culpabilidade no direito cit., p. 265. 
jurídica, eso porque ellos y sus elementos y requisitos se han construido en obediencia a los rasgos antropológicos y por supuesto son distintas de las inherentes a la persona jurídica $^{1588}$. Por lo tanto, la necesidad de reconstruir las diversas categorías sistemáticas del delito en obediencia a los atributos normativos de la personalidad jurídica ${ }^{1589}$.

Hechas las consideraciones generales sobre la responsabilización penal ambiental, tal como se encuentra legislada en Brasil, cabrá ahora, como objetivo del presente estudio, promover la profundización de la tutela penal del agua.

\subsection{Tutela penal del agua}

Para afirmar que el agua es un bien que deba ser tutelado por el Derecho Penal, es necesario saber cuáles bienes de la vida que esa rama protege. El Derecho Penal ampara el bien de la vida nombrado de bien jurídico (a veces referido como bien jurídico-penal cuando esta nomenclatura también es utilizada para el Derecho Civil, a pesar de no ser tan común es bastante criticado por parte de la doctrina). Sin embargo, existen varias teorías de bien jurídico, en este trabajo se irá destacar sólo cuatro.

Para Franz Von Liszt, uno de los participantes da teoría del positivismo, el bien jurídico es el derecho que debe ser protegido, el derecho que es de interés sea para el individuo sea para la colectividad. Liszt también afirma que quien dicta lo que debe ser protegido es la vida humana, y no el derecho en sí, debe ser considerado bien jurídico lo que fuere esencial para los hombres ${ }^{1590}$.

Combatiendo la teoría positivista, el neokantismo delimitó el tema de bien jurídico describiendo este como una ligación entre los planes del ser y del deber ser. Vale resaltar que esta teoría se atentó en volver a la enseñanza kantiana (de Immanuel Kant) y que para ella el ser es - los juicios de existencia y el deber ser es - los juicios

${ }^{1588}$ MACHADO, Fábio Guedes de Paula. Culpabilidade no direito cit., p. 274.

${ }^{1589}$ MACHADO, Fábio Guedes de Paula. Culpabilidade no direito cit., p. 274. Sobre los modelos de imputación de Derecho Penal a la persona jurídica, vide Reminiscências da Responsabilidade Penal da Pessoa Jurídica. In Revista Brasileira de Ciências Criminais - RBCCRIM n. 79. São Paulo: Revista dos Tribunais, 2009, pp. 74-79.

${ }^{1590}$ LISZT, Franz Von. Tratado de Direito Penal Alemão. Trad. José Hygino Duarte Pereira. Tomo I. Rio de Janeiro: F. Briguiet \& C. Editores. 1899, pp. 93 e 94. 
de valores ${ }^{1591}$. De este modo es posible inferir que el bien jurídico sería entonces lo que conecta los dos mundos, que existe y que tiene una valoración, y es en función de esa valoración que debe ser protegido.

Según el principal integrante de la teoría finalista, Hans Welzel, ${ }^{1592}$ la función del Derecho Penal es proteger los bienes jurídicos, tales como la existencia del Estado, la vida, la salud, la libertad, la propiedad, etc. Esa tutela prohíbe acciones que pueden lesionar o amenazar lesionar eses bienes de la vida, evitando así la desvalorización de las acciones. Sin embargo, para él, la misión principal del Derecho no es proteger tales bienes, sino, hacer las personas respetar las leyes que orientan el Estado, vivir según el derecho.

En la teoría funcionalista, se destaca el autor Claus Roxin, que retrata el Derecho Penal como siendo el guardián de la sociedad, que garantiza a los ciudadanos una convivencia armónica, de modo que las restricciones hechas sean exactamente para afirmar la libertad de todos. Y para ellos, los bienes que aseguran esa armonía y la libertad son los llamados bienes jurídicos, tales como la vida, la integridad corporal, la propiedad, etc.

Es importante destacar que Roxin también propone los derechos fundamentales como bienes jurídicos ${ }^{1593}$.

Adecuando el bien jurídico a los días actuales se explica que es posible notar que el bien jurídico en un Estado democrático es centrado en el hombre, en lo que es esencial para su sobrevivencia y para su convivencia en sociedad. No es considerado objeto de tutela del Derecho Penal objetos o —valores político-sociales.

Explicado lo que es bien jurídico, es posible notar que el agua se encuadra en ese concepto. Porque, según la corriente positivista se encaja cuando esta retrata los intereses sociales e individuales, el agua siendo uno de los elementos más importantes para la sobrevivencia humana es realmente un interés. Para el neokantismo, el agua se adecua como algo valorado que debe ser protegido. Para Welzel, se puede colocar el

\footnotetext{
${ }^{1591}$ PRADO, Luis Regis. Curso de Direito Penal Brasileiro. $11^{\mathrm{a}}$ ed. São Paulo: Revista dos Tribunais. 2012, p. 115.

1592 WELZEL, Hans. Derecho penal: parte general. Trad. Carlos Fontán Balestra. Buenos Aires: Roque Depalma. 1956, p. 2.

${ }^{1593}$ ROXIN, Claus. A proteção de bens jurídicos como função do direito penal. Organizadores: André Luís Callegari e Nereu José Giacomolli. 2. ed. Porto Alegre: Livraria do Advogado, 2009, pp. 6-18.
} 
agua como bien jurídico por ser algo demasiadamente importante para la vida humana y para la salud humana, y esta debe ser tutelada por el Derecho Penal para garantizar que los ciudadanos no la abusen ni la contaminen exageradamente. En el concepto de Roxin, el agua se condice tanto en la protección de los derechos fundamentales como en la protección de bienes que sirven a la vida humana. Finalizando, en el concepto de bien jurídico en el Estado Democrático de Derecho, como anteriormente dicho, el agua es importante para sobrevivencia humana.

Guilherme Guimarães Feliciano ${ }^{1594}$ afirma, también, que el medio ambiente, extendido al agua, es un bien jurídico y debe ser tutelado por el Derecho Penal, en virtud del art. 225 de la $\mathrm{CF} / 88$, porque es una de las funciones del Estado asegurar un medio ambiente ecológicamente equilibrado.

Como Brasil es un país que adopta el Derecho Penal como la ultima ratio, o sea, como el último recurso a ser utilizado, es necesario esclarecer que las sanciones civiles y administrativas deben ser aplicadas primero, la sanción penal solamente si aquellas no resolvieren. Todavía, para Luís Paulo Sirvinskas, las esferas civiles y administrativas no están obteniendo mucho éxito en relación a la protección del medio ambiente. El autor da el ejemplo de que — de las multas aplicadas por el IBAMA, en 1997 , solamente un seis por ciento fueron recogidas a los cofres públicos $[\ldots]^{1595}$ y en la parte civil no está siendo diferente, pero en el caso serían las acciones civiles públicas que se caracterizan por el retraso del proceso, lo que perjudica el resultado, porque muchas de las veces puede resultar en la prescripción del delito.

En razón de las áreas civiles y administrativas no consiguieren el éxito deseado para la protección del medio ambiente, principalmente en la cuestión de las aguas, es necesario que el Derecho Penal sea más rigoroso en este punto. Porque así, tal acción de punir con penas penales no será más útil en el futuro, porque aparte punir, el Derecho Penal también tiene la función de socio educador ${ }^{1596}$. Además, sobre las teorías que versan sobre el futuro del Derecho Penal, especialmente sobre su abolición, una que relata exactamente eso, es la que defiende que el Estado debería ser más intenso en su

\footnotetext{
${ }^{1594}$ FELICIANO, Guilherme Guimarães. Teoria da imputação objetiva no direito penal ambiental brasileiro. São Paulo: LTR Editora, 2005, p. 270.

${ }^{1595}$ SIRVINSKAS, Luís Paulo. Tutela penal do meio ambiente. $3^{\text {a }}$ ed. São Paulo: Editora Saraiva. 2004, p. 15.

${ }^{1596}$ SIRVINSKAS. Tutela penal cit., p. 15.
} 
fiscalización, porque de este modo evitaría algunos crímenes previniéndolos. Roxin ${ }^{1597}$ compara esa fiscalización del Estado con la de un Estado totalitario, pero se debe atentar que las penas no serán tan intensificadas como de este. Para el autor tal opción, de la vigilancia avivada, es una buena opción, en virtud de poder disminuir la criminalización, sin embargo tal prevención sólo sería admisible en algunos casos, y no en todos los crímenes. No obstante, en estos pocos casos en que es aceptable, sería un medio eficaz de combatir el crimen. Para complementar la idea de la fiscalización, se usa de la entrevista del Ministro del Superior Tribunal de Justicia, Herman Benjamin $^{1598}$, en ella el Ministro afirma que en relación a las leyes que protegen las aguas, Brasil está bien, en virtud de estar entre los pocos países que poseen legislación para los recursos hídricos, sin embargo Brasil está malo en la cuestión de poner en práctica tales legislaciones, y en este caso porque falta una fiscalización rigurosa y necesaria.

En relación a la punición del Derecho Penal, es esencial explanar que hay una diferencia significativa de riesgo y daño, una vez que la legislación penal actualmente condena sólo cuando se causa un daño, se tiene los ejemplos del artículo $270^{1599}$ del CP; y art. $54^{1600}$ de la ley $9.605 / 1998$. Significándolos, riesgo es —una posibilidad de suceso futuro, mientras que, en la hipótesis de daño, el perjuicio es un hecho cierto, aunque se pueda verificar en el presente o, incluso, en el futuro ${ }^{1601}$. Así, es posible deducir que los crímenes contra el agua, son crímenes de daño, y no de peligro, principalmente el del art. 54 de la ley, por tratarse de una legislación especial y revocar parte del art. 270 del

${ }^{1597}$ ROXIN, Claus. Estudos de Direito Penal. Tradução: Luís Greco. Organizadores: Luís Greco e Fernando Gama de Miranda Netto. 2. ed. Rio de Janeiro: Renovar. 2008, pp. 5-9.

${ }^{1598}$ BULLA, Beatriz; FERNANDES, Talita. Será difícil exigir entrega de água que não existe, diz ministro do STJ. Entrevista feita para o jornal Estadão. Disponible en: http://saopaulo.estadao.com.br/noticias/geral,sera-dificil-exigir-entrega-de-agua-que-nao-existe-diz-ministro-dostj,1630831. Acceso en: 10-06-2015.

${ }^{1599}$ Art. 270 - "Envenenar água potável, de uso comum ou particular, ou substância alimentícia ou medicinal destinada a consumo: Pena - reclusão, de dez a quinze anos”.

${ }^{1600}$ Art. 54. "Causar poluição de qualquer natureza em níveis tais que resultem ou possam resultar em danos à saúde humana, ou que provoquem a mortandade de animais ou a destruição significativa da flora: $\S 2^{\circ}$ Se o crime: III - causar poluição hídrica que torne necessária a interrupção do abastecimento público de água de uma comunidade".

${ }^{1601}$ ARRUDA, Domingos Sávio de Barros. A categoria acautelatória da responsabilidade ambiental. Responsabilidade em matéria ambiental. São Paulo: Editora Revista dos Tribunais. 2011, p. 758. 
CP. Como enseña Guilherme de Souza Nucci, crimen de daño es el que se agota con el daño al bien protegido, mientras que crimen de peligro es aquel que a pesar de no ser consumado, es condenado en virtud de la alta probabilidad del suceso del daño, evitándose así que se consuma la lesión ${ }^{1602}$. El art. 54 de la ley 9.605/1998 tipifica un delito de daño, en virtud de que para ser considerado delito es necesaria su consumación, o sea, es necesaria la comprobación que el agua fue contaminada. A pesar de que para Sirvinskas, la segunda parte del tipo penal es considerada un crimen de peligro concreto (utilizando de Nucci nuevamente, crimen de peligro concreto es el que necesita de la comprobación de la probabilidad del daño realizarse concretamente, que se diferencia del crimen de peligro abstracto porque en este la probabilidad viene en virtud de ley ${ }^{1603}$. Por el artículo, utilizar de la colocación - 'que puedan resultar' [...], no constituyendo necesidad de perjudicar la salud humana, basta colocarla en riesgo, y tal riesgo ser debidamente comprobado, que ya es considerado un delito ${ }^{1604}$. Importante relatar que tal delito admite su forma intentada, según la doctrina.

No obstante, la tutela penal no protege el agua ya contaminada, como destaca Édis Milaré ${ }^{1605}$. El autor afirma que el Código es inadecuado en ese punto, en virtud de no punir aquellos que contaminan agua ya contaminada, eso genera una serie de problemas, ya que el proceso de descontaminación de aquel local se convertirá más dificultoso y más demorado. Él muestra el ejemplo ${ }^{1606}$ del caso ocurrido en $1977^{1607}$, en la ciudad de Americana en São Paulo, en que una empresa tiró residuos industriales en el río Jaguari, que se queda en las cercanías, antes mismo de tener una licencia del Poder Público de funcionamiento, en octubre del mismo año, el estado del río se quedó tan malo que la mayoría de los peces que allí vivían murieron, y hubo un momento que en virtud de la contaminación del rio, la población de la ciudad se quedó sin agua por 33 horas. La empresa no fue condenada ni en primera ni en segunda instancia judicial, en primera porque el juez entendió que no existía tipicidad por el hecho del agua ya estar

\footnotetext{
${ }^{1602}$ NUCCI, Guilherme de Souza. Código penal comentado. 14 a ed. Rio de Janeiro: Editora Forense. 2014 , p. 641 .

${ }^{1603}$ NUCCI. Código penal cit., p. 642.

${ }^{1604}$ SIRVINSKAS. Tutela penal cit., p. 196.

${ }^{1605}$ MILARÉ, Édis. Tutela jurídica cit., p. 783.

${ }^{1606}$ MILARÉ, Édis. Tutela jurídica cit., p. 783.

${ }^{1607}$ O Estado de São Paulo, ed. 27-02-83, p. 54.
} 
contaminada y el Código Penal prohibir solamente la contaminación de aguas potables; y en segunda instancia porque, a pesar de la reforma de la decisión por los jueces, el caso ya se había prescripto, por haber transcurrido el plazo legal.

Se Defiende aquí que carece de ser protegido penalmente tanto el riesgo, el daño de contaminación del agua, como también la contaminación del agua ya contaminada. Domingos Arruda, describe que el riesgo ambiental, puede sí, ser considerado un acto ilícito, según los principios, ya que estos son elementos centrales de una norma jurídica y para la mayoría de la doctrina, aquellos prevalecen sobre estas. Pero, para caracterizarse acción ilícita, los riesgos derivados da ella deben ser —considerados intolerables (prohibidos), sean ellos conocidos o no $[\ldots]^{1608}$.

Cumple resaltar que los tipos penales existentes sobre la protección del agua son de pequeño número, y no abordan las posibles causas de destrucción de este bien tan precioso. Las acciones tipificadas son encontradas en los artículos $161 / \mathrm{CP},{ }^{1609}$ que trata de la usurpación del agua ajena, en su inciso I; $270 / \mathrm{CP}^{1610}$, que discurre sobre envenenamiento de agua potable; $271 / \mathrm{CP}^{1611}$, cuyo texto es sobre la contaminación o corrupción del agua potable; y el art. $54^{1612}$ de la Ley 9.605 de 1998 , que también trata de la polución del agua, pero se diferencia de los artículos del Código Penal porque además de proteger la salud humana, abarca también la flora y la fauna. Aunque aquellos que defienden que el agua está muy protegida legalmente, como el ministro Benjamin $^{1613}$, consiguen visualizar que hay fallos en esa legislación de protección, necesitando, así, de ser, al mínimo, reformadas.

${ }^{1608}$ ARRUDA. Domingos Sávio de Barros. A categoria acautelatória da responsabilidade ambiental. Responsabilidade em matéria ambiental. São Paulo: Editora Revista dos Tribunais, 2011, p. 768.

${ }^{1609}$ Art. 161 - Suprimir ou deslocar tapume, marco, ou qualquer outro sinal indicativo de linha divisória, para apropriar-se, no todo ou em parte, de coisa imóvel alheia: $\S 1^{\circ}$ - Na mesma pena incorre quem: I desvia ou represa, em proveito próprio ou de outrem, águas alheias;

${ }^{1610}$ Art. 270 - Envenenar água potável, de uso comum ou particular, ou substância alimentícia ou medicinal destinada a consumo. Pena - reclusão, de dez a quinze anos.

${ }^{1611}$ Art. 271 - Corromper ou poluir água potável, de uso comum ou particular, tornando-a imprópria para consumo ou nociva à saúde: Pena - reclusão, de dois a cinco anos.

${ }^{1612}$ Art. 54. "Causar poluição de qualquer natureza em níveis tais que resultem ou possam resultar em danos à saúde humana, ou que provoquem a mortandade de animais ou a destruição significativa da flora: Pena - reclusão, de um a quatro anos, e multa".

${ }^{1613}$ BULLA; FERNANDES. Será difícil exigir entrega de água que não existe, diz ministro do STJ. 
Sobre las imaginables causas de estrago del agua, afirma Marcelo Malucelli, que no es sólo la contaminación que la degrada, caracteriza también peligro a ella -el desperdicio en proporciones gigantescas, el aterramiento de lagos y mangues, la compra y venta de agua sin licencia, la alteración de su composición química [...], el monocultivo, especialmente de eucalipto, a las márgenes de los ríos, etc. ${ }^{1614}$. Además la ley penal no abarca todas las causas de deterioración del agua, la tipificación penal de crímenes contra el medio ambiente son en su mayoría leyes penales en blanco. Eso sucede, en virtud de la problemática existente en la doctrina sobre la protección penal de los derechos difusos, como ocurre con el medio ambiente ${ }^{1615}$. Conforme Juarez Cirino dos Santos ${ }^{1616}$, leyes penales en blanco son las que precisan de suplemento por una acción diferente, sea ella legislativa o administrativa, o sea, necesita de una legislación o un acto administrativo para finiquitarla. Para Andrea Bulgakov Klock el hecho de ser normas penales en blanco, esto es, que necesitan de complemento - quita su carácter de especificidad y efectividad ${ }^{1617}$ convirtiéndolas (las leyes de protección ambiental) sólo una ley más en el ordenamiento jurídico, sin características especiales.

De ese modo, se enfatiza aquí, que es necesario la creación de una legislación (o la reforma de la actual) que pueda abarcar todos estos tipos de degradación del agua. Especialmente en relación al desperdicio, porque es esta acción que más ayudó la crisis hídrica que el país actualmente está viviendo, y la escasez mundial. De acuerdo con Maude Barlow, el desperdicio está aumentando en los últimos tiempos, porque la sociedad perdió el reconocimiento del agua como algo sagrado, como algo vital para la vida, especialmente en razón del —crecimiento ilimitado y la expansión del comercio

${ }^{1614}$ MALUCELLI, Marcelo. Tutela Penal das Águas. Águas - aspectos jurídicos e ambientais. $3^{\text {a }}$ ed. Curitiba: Juruá Editora, 2007, p. 192.

${ }^{1615}$ La problemática aquí referida es que parte de la doctrina cree que es necesario a la protección penal de tales bienes difusos, y la otra parte cree no ser necesario en virtud de la dificultad que sería en la tutela de estos bienes, porque se tratan de bienes colectivos, y no individuales como la mayoría de los bienes jurídicos.

${ }^{1616}$ SANTOS, Juarez Cirino dos. Direito penal - parte geral. $5^{\mathrm{a}}$ ed, Florianópolis: Editora Modelo, 2012, p. 50 .

${ }^{1617}$ KLOCK, Andrea Bulgakov. Sociedade de risco e sistema penal ambiental. Revista do programa de mestrado em ciência jurídica, da Fundinopi- UENP. Jacarezinho, n. 11.p.141-152, julho-dezembro de 2009. 
mundial $^{1618}$. El Ministro Benjamin defiende, también, el perfeccionamiento de tipo penal en relación al desperdicio del agua, ya que es imprescindible — perfeccionar la legislación existente en los fallos que presenta al proteger los recursos naturales [...], por ejemplo, previendo formas más rápidas de responsabilización del mal administrador público en el campo de los recursos hídricos ${ }^{1619}$. Además de punir en el uso doméstico y agrícola. Rogelio Barba Álvarez ${ }^{1620}$ defiende que el legislador debe tomar una iniciativa de punir penalmente aquellos que utilizan el agua sin discreción, sea en la vida cotidiana (en los ambientes domésticos) o en las empresas que echan contaminantes en los ríos, lagos, azudes, etc.

En relación a la punición penal de la empresa, es importante destacar que el ordenamiento jurídico brasileño pune la persona jurídica, como dicta el $\S 3^{\circ}$ del art. 225 , $\mathrm{CF} / 88,{ }^{1621}$ a pesar de la discordia en parte de la doctrina. Sirvinskas ${ }^{1622}$ piensa que tal punición es de buen grado, porque son las industrias y las empresas las que más degradan el medio ambiente, consecuentemente el agua. Él afirma que con la responsabilidad penal de la persona jurídica es posible punir incluso empresas que el núcleo de decisión esté en el extranjero. El autor destaca el XIII Congreso de la Asociación Internacional de Derecho Penal que sugiere tal posibilidad de punibilidad. Como el Código Penal es volcado para la punición de la persona física, al trabajar con la persona jurídica el juez queda a la deriva, pero la doctrina entiende que como la pena de la persona física es calculada basada en su culpabilidad en el delito, y como persona jurídica no posee el subjetivismo del hombre, su pena debe ser calculada con base en las - consecuencias y la extensión de los daños causados al medio ambiente ${ }^{1623}$. Se aprovecha para atentar al hecho que la persona física que toma las decisiones de la

${ }^{1618}$ BARLOW, Maude. La protección del agua: diez principios. El oro azul. 2001. Disponible en: < http://www.blueplanetproject.net/documents/espanol/El_oro_azul.pdf>. Acceso en: 10-06-2015.

${ }^{1619}$ BULLA, Beatriz; FERNANDES, Talita. Será difícil exigir entrega de água que não existe, diz ministro do STJ. Entrevista feita para o jornal Estadão.

${ }^{1620}$ ÁLVAREZ, Rogelio Barba. El agua como derecho fundamental y su protección jurídico-penal. Revista prolegómenos - Derechos e valores. Bogotá, v.14, n. 27, p. 213-229, julho - dezembro de 2011.

${ }^{1621} \S 3^{\circ}$ Las conductas y actividades consideradas lesivas al medio ambiente sujetarán los infractores, personas físicas o jurídicas, a sanciones penales y administrativas, independentemente de la obrigación de reparar los daños causados.

${ }^{1622}$ SIRVINSKAS. Tutela penal cit., p. 53-67.

${ }^{1623}$ SIRVINSKAS. Tutela penal cit., p. 61. 
persona jurídica, sea su director, gerente, órgano colegiado, presidencia, etc.; puede ser considerada coautora del crimen como también partícipe. Para concretizar tal responsabilidad es importante que la persona jurídica tenga o haya tenido interés o beneficio con la práctica delictuosa, sea directa o indirectamente. Las puniciones para la persona jurídica, para acción tipificada en el medio ambiente, están previstas en la ley de crímenes ambientales, Ley n ${ }^{\circ} 9.605$ de 1998, en los artículos: 21 a 24. Las penas son de multa, restrictivas de derechos, prestación de servicio a la comunidad $^{1624}$, desconsideración de la persona jurídica y liquidación forzosa de la persona jurídica. Siendo que las penas de multa serán computadas de la misma forma que dicta el Código Penal en su artículo $49^{1625}$, pero el artículo 18 de la ley $9.605 / 1998^{1626}$ afirma que si tal valor calculado sea ineficaz por el porte de la empresa, su valor máximo podrá ser multiplicado hasta tres veces; las penas restrictivas de derechos son las que constan en los incisos del artículo $22^{1627}$ de la Ley 9.605/98; la prestación de servicios a la comunidad está presente en el art. $23^{1628}$ de la misma ley, equivaliendo que su objetivo es programas para la protección del medio ambiente y su descontaminación, en el caso del agua; a pesar de la desconsideración de la persona jurídica no estar presente en la lista del art. 21 de la ley aquí comentada, el art. $4^{\circ}$ la aborda cuando retrata que tal acción será posible si la personalidad fuere barrera para la indemnización de los perjuicios; y la liquidación forzada de la persona jurídica, la pena considerada más grave, está presente en el artículo 24, de la ley discutida, que relata que tal pena será impuesta a la persona jurídica que tiene el fin de permitir, facilitar u ocultar la práctica de crimen definido en la ley, y su patrimonio irá para el Fundo Penitenciario Nacional,

\footnotetext{
${ }^{1624}$ Artigo 21 de la Ley 9.605/1998.

${ }^{1625}$ La pena de multa consiste en el pago al fondo penitenciario del importe fijado en la sentencia y calculada en días-multa. Será, al mínimo, de diez y, al máximo, de trescientos y sesenta días-multa.

${ }^{1626}$ La multa será calculada según los criterios del Código Penal; si mostrarse ineficaz aunque aplicada en el valor máximo, podrá ser aumentada hasta tres veces, teniendo en cuenta el valor de la ventaja económica obtenida.

${ }^{1627}$ Las penas restrictivas de derechos de la persona jurídica son: I- suspensión parcial o total de las actividades; II- interdicción temporaria de establecimiento, obra o actividad; III- prohibición de contratar con el Poder Público, bien como de ello obtener subsidios, subvenciones o donaciones.

${ }^{1628}$ La prestación de servicios a la comunidad por la persona jurídica consistirá en: I- financiamiento de programas y de proyectos ambientales; II- ejecución de obras de recuperación de áreas degradadas; IIImanutención de espacios públicos; IV- contribuciones a entidades ambientales o culturales públicas.
} 
que es discordado en parte de la doctrina que cree que carecería ser revertido para la manutención del medio ambiente ${ }^{1629}$.

Así como es la pena de la persona física, la de la persona jurídica sirve, además de punición para el dañó al medio ambiente y para la población en algunos casos, como una medida socioeducativa, que pretende proteger el bien jurídico, y claro, la prevención de crímenes.

Hay, sin embargo, en controversia, corrientes doctrinarias que defienden el Derecho Penal mínimo que es la relativización del derecho penal, o sea, una intervención estatal menor posible pretendiendo mayor libertad. Podemos destacar la Escuela Garantista que propone un sistema de garantías y la Escuela de Frankfurt que presenta un Derecho Penal clásico ${ }^{1630}$.

El mayor representante de la Escuela Garantista es Luigi Ferrajoli y su doctrina puede ser utilizada en cualquier rama del derecho ${ }^{1631}$. El Derecho Penal en el sistema garantista es mínimo y presentan las garantías de presunción de inocencia, o in dubio pro reo y analogía in bona partem ${ }^{1632}$.

Esta Escuela propone la protección y la seguridad de bienes y derechos individuales, delante de posibles agresiones provenientes de otros individuos, o incluso del Estado. Ellos defienden la existencia de un Estado mínimo, o sea, la disminución del poder punitivo del Estado pretendiendo la mayor libertad humana. Esa necesidad era volcada para el autoritarismo del estado, pero en el contexto del Estado Democrático de Derecho esa teoría está ultrapasada.

Además el agua es un bien difuso, o sea, colectivo, no debe ser tutelado por el derecho penal si utilizamos esta doctrina, una vez que ella afirma que sólo tiene que haber la protección de derechos individuales.

En contrapartida surge la Escuela de Frankfurt que también defendía el Derecho Penal Mínimo, pero con una ideología diferente, su principal representante es Winfried Hassemer. Él llega a la conclusión que el derecho penal para tutelar el medio ambiente en largo plazo sería más dañoso que útil, tanto para el medio ambiente como

\footnotetext{
${ }^{1629}$ SIRVINSKAS. Tutela penal cit., p. 67.

${ }^{1630}$ COSTA, Carlos Fernando da Cunha. A tutela penal do meio ambiente. Conciliação entre dois sistemas de proteção. Curitiba: Editora Juruá, 2013, p. 93.

${ }^{1631}$ PRADO. Curso de Direito Penal cit., p. 129.

${ }^{1632}$ PRADO. Curso de Direito Penal cit., p. 131.
} 
para el Derecho Penal ${ }^{1633}$, porque quien utiliza el derecho como prima ratio hace las cosas muy fáciles y desiste de buscar medios para la protección de la naturaleza ${ }^{1634}$.

Cada vez más se ha utilizado el Derecho Penal para afirmar su eficacia frente a las demandas de la sociedad moderna, con esto ocurre la relativización del derecho penal nuclear que objetiva la víctima y el bien jurídico protegido ${ }^{1635}$. Aun, el Derecho Penal ambiental se destaca por su accesoriedad con el Derecho Administrativo, porque los límites de la punibilidad entre ellos se confunden ${ }^{1636}$, esa es la primera razón destacada por él para asegurar que el derecho penal no deba tutelar el medio ambiente.

La segunda razón es la imputación de la responsabilidad criminal porque el derecho penal debe tener conceptos claros y sólidos además de prever una responsabilidad individual para la práctica de un delito, o sea, el hecho ilícito tiene que ser atribuido a alguien. En los crímenes ambientales en la mayoría de las veces la responsabilidad es colectiva, en cuanto el derecho penal seguir teniendo como sanción la privación de la libertad, no podrá dejar de lado las imputaciones individuales.

La tercera razón es que no hay necesidad de la resocialización de quien practica crímenes ambientales además de que la multa no trae efecto perceptible, o sea, estas medidas no cumplen con los fines de la pena.

Las teorías absolutas, el retribucionismo clasifica la pena como retribución al mal generado, siendo que la pena sería un mal justo como forma de restablecer el derecho ${ }^{1637}$. Con el surgimiento de las teorías relativas, la función de la pena ganó un nuevo significado. La prevención general negativa trae la idea de prevención de la criminalidad, o sea, disminuir la ocurrencia de nuevos ilícitos, probando en las personas una coerción psicológica que las impida de practicar el delito ${ }^{1638}$. En contrapartida se tiene la prevención general positiva que busca una afirmación del ordenamiento jurídico, pero de forma colectiva y no intimidadora.

\footnotetext{
${ }^{1633}$ HASSEMER, Winfried. Direito penal libertário. Trad. Regina Greve. Belo Horizonte: Del Rey, 2007, p. 226.

${ }^{1634}$ HASSEMER, Winfried. Direito penal cit., p. 227.

${ }^{1635}$ HASSEMER, Winfried. Direito penal cit., p. 227.

${ }^{1636}$ HASSEMER, Winfried. Direito penal cit., p. 159.

${ }^{1637}$ BUSATO, Paulo César. Direito Penal Parte Geral. São Paulo, Editora Atlas 2013, p. 750.

${ }^{1638}$ BUSATO, Paulo César. Direito Penal cit., p. 759.
} 
También tenemos que destacar que la prevención especial tiene función de rehabilitar el criminoso, porque implican que si alguien comete un crimen la posibilidad de haber reincidencia es grande. La prevención especial negativa es la pena en sí, o sea, su alejamiento de la convivencia social, porque imposibilita la práctica de nuevos delitos en ese período ${ }^{1639}$. La prevención especial positiva objetiva la resocialización en sí, por eso es que en las prisiones debe haber equipos de: sociólogos, psicólogos, psiquiatras y otros funcionarios, para preparar los detenidos para cuando ya hayan cumplido sus penas volvieren a la sociedad y no vuelvan a delinquir.

La última razón es llamada de simbólica, transformando el derecho penal en discusión política, desobligando los poderes públicos de buscar una protección concreta para el medio ambiente. De esa manera se crea una falsa esperanza de solución del problema con la utilización de un derecho penal severo ${ }^{1640}$. Con eso Hassemer al analizar estas cuatro razones se posiciona contrario a la tutela penal del medio ambiente, en consecuencia también contrario a la tutela del agua.

\footnotetext{
${ }^{1639}$ BUSATO, Paulo César. Direito Penal cit., p. 764.

${ }^{1640}$ HASSEMER, Winfried. Direito penal cit., p. 233.
} 


\section{CONCLUSIONES}

Estamos delante de Constituciones no eximes de contradicciones, a veces excesivamente minuciosas, pero Constituciones que se abren para el futuro, con promesas de realización de un Estado Social y Democrático de Derecho, como es España y, Estado Democrático de Derecho, como es el caso de Brasil, ambas con un mismo ideal, la construcción de una sociedad libre, justa y solidaria, que garanta el desarrollo nacional, erradique la pobreza y la marginalización, que reduzca las desigualdades regionales y sociales, promueva, finalmente, el bienestar de todos sin discriminación de cualquier naturaleza; un Estado por tanto, que asegure el ejercicio de los derechos sociales e individuales, la libertad, la seguridad, el bienestar, el desarrollo, la igualdad y la justicia como valores supremos de una sociedad fraterna, pluralista y sin prejuicio, fundada en el armonía y comprometida con soluciones pacíficas de controversia. Es lo que la población quiere y espera. Los tres contenidos típicos del Estado social: el derecho a la protección de la salud, al medio ambiente y a la vivienda digna y adecuada. Todos ellos son elementos esenciales de la calidad de vida y los tres dependen del agua. Además, esas dos Constituciones surgieron buscando adoptar una idea de derecho que informa una nueva concepción de Estado y de Sociedad.

Los bienes ambientales se configuran como objeto precipuo del Derecho del Ambiente y de la Gestión Ambiental, áreas que operan con concreciones y cosas reales. El bienestar, las influencias benéficas resultantes, son valores de otros ordenes, que derivan, como efectos, de las acciones jurídicas y gerenciales, o sea, de la protección conferida por el Derecho, así como de la correcta destinación proporcionada por la administración ambiental. En realidad, esos resultados positivos y deseados constituyen el objetivo y el núcleo de tales acciones -o sea, del Derecho y de la Gestión-, hasta mismo porque el beneficio buscado es de naturaleza social -el bienestar de la colectividad- como quieran las Constituciones, y vital, como el acceso y uso del agua.

El agua siempre ha sido elemento fundamental en todas las sociedades y civilizaciones en el pasar de la historia. Esencial para el mantenimiento de la vida, fue condición predominante para el establecimiento de las sociedades humanas, constituyéndose, por esto, desde la más remota civilización, en fuente de poder y factor clave para su respectivo desarrollo debido a su necesidad vital. 
Desde la antigüedad, el ser humano sabe que la existencia y la viabilidad de la vida en el planeta están íntimamente relacionadas al agua. El dominio y la evolución del conocimiento lo llevaron a la creación de técnicas, que lo auxiliaron en la comprensión y ampliación de su idea de mundo. A la medida que aumentaba este conocimiento, el ser humano idealizaba el sentido común de que el agua dulce era elemento abundante e inagotable, dotado de infinita capacidad de regeneración.

De este modo, el agua era vista como un elemento que servía tanto para las más variadas finalidades biológicas, y para los más variados procesos de producción, cuanto como deposito de desechos de esas dos áreas. La creencia sobre la infinita fuente de agua en la Tierra sólo comenzó a ser cuestionada a partir de estudios científicos que demostraron la existencia de un proceso cíclico y cerrado que tenía el agua como elemento circulante, el ciclo hidrológico. Su comprobación rompió los dogmas que afirmaban ser el agua infinita y pasa a ser vista como componente de un proceso natural de causa y efecto en todas sus fases.

En este sentido, pasó a constatarse la influencia de la actividad humana en la disponibilidad de agua dulce, así como en su calidad, principalmente a partir de la revolución industrial y de la verificación de sus consecuencias para el medio ambiente y para la salud humana. Importante destacar que a partir de la revolución industrial el ciclo hidrológico fue más afectado que en las sociedades pre-industriales, vez que sus actividades pasaron a imponer un ritmo de consumo y de contaminación muy superiores al que la naturaleza podría soportar, además de generar contaminantes letales al medio ambiente y a la salud humana y animal. Este hecho tiene como consecuencia la disminución de la cantidad de agua dulce disponible para el consumo poblacional del planeta.

La intervención del hombre por medio de la contaminación urbana e industrial, de la contaminación de los manantiales por productos inorgánicos y microorganismos nocivos a la salud, la impermeabilización de los suelos en razón de la creciente urbanización en casi todas las regiones del planeta, contribuyen a afectar la disponibilidad y distribución de lluvias en las más variadas regiones, así como el caudal de los ríos y el volumen de los lagos y de las aguas subterráneas.

Conjuntamente a eso, la demanda por agua dulce viene creciendo de manera aterrorizante, su utilización para la agricultura en larga escala, para la industria y para el consumo humano, hace con que el estrés hídrico aumente, afectando directamente el 
equilibrio del ciclo hidrológico. Además, el desperdicio de agua dulce en los medios poblacionales rurales y urbanos, sobretodo en estos, aun sea factor preocupante, tanto en función de las ineficientes estructuras de saneamiento o su mal estado de conservación, cuanto en función de la persistencia de la idea de que el agua es un recurso inagotable, son los sectores productivos los principales culpados por el alto consumo y por el elevado grado de contaminación de las reservas de agua dulce. Lo que nos lleva a concluir que la creciente indisponibilidad hídrica en la Tierra, así como la base de los alertas y de las previsiones en relación a su inminente escasez es consecuencia de los modelos productivos sin frenos de la sociedad industrial y del creciente consumo dictado por el capitalismo y la globalización.

También, claro, existen factores climáticos y geográficos que contribuyen para el agravamiento de la crisis hídrica, muchos de ellos ocasionados por la consecuencias de la producción industrial humana en el medio ambiente.

Estos hechos, así como la preocupación en relación a la crisis hídrica mundial, tiene atraído, en las últimas cuatro décadas, la atención de la sociedad internacional para el problema de la disciplina jurídica internacional de protección, conservación y gestión del agua dulce, principalmente en función de su escasez generalizada.

El régimen jurídico, construido gradualmente a lo largo de las últimas décadas, y que en mucho acompañó la formación del sistema convencional internacional de protección de la persona humana y del medio ambiente, mantuvo fidelidad con los principios, normas y reglas del régimen jurídico dentro del cual fue originado y del cual es componente, el de las Naciones Unidas.

Y así, incluso por obligación sistémica, no podría dejar de ser. Dentro de un régimen jurídico de orientación inminentemente humanista el elemento natural, esencial al mantenimiento de la vida humana, en todas sus dimensiones, no podría recibir régimen jurídico diferente de aquello orientado a su protección y preservación y al reconocimiento de su esencialidad. Dentro de esta lógica sistémica, el régimen jurídico internacional del agua dulce tiene abarcado cuestiones importantes, entre ellas el reconocimiento de la interconectividad del agua dulce con las más diversas áreas de actividad humana, tales como la diversidad biológica, la salud, el saneamiento y la vivienda, como también la necesidad de reconocimiento expreso en normas jurídicas de orden pública, de la existencia de derecho humano fundamental de acceso y uso del agua dulce. 
A pesar de los cambios el derecho internacional aun peca por la ausencia de expreso reconocimiento, en su ordenamiento positivo, del derecho de acceso al agua como derecho fundamental, una vez que condicionante directo del mantenimiento de la vida humana, requisito primordial para la realización de las infinitas actividades y de los derechos a ellas correlatos.

A ejemplo de lo que ocurrió con la evolución del reconocimiento de derechos esenciales al mantenimiento y protección de las condiciones de ejercicio de los padrones mínimos de dignidad para la persona humana, y de la consciencia de la necesidad de protección del medio ambiente, el derecho de acceso y uso del agua, en cantidades y calidades suficientes para el mantenimiento de un nivel digno de vida, parece todavía no haber despertado la conciencia de los sujetos de derecho internacional público para la necesidad de su expreso reconocimiento.

No obstante esta consciencia ya ha sido, por diversas veces, manifestada en las más diferentes declaraciones y resoluciones, apuntando para la urgente necesidad de reconocimiento expreso de tal derecho fundamental, la verdad es que la sociedad internacional aún no se movió en el sentido no sólo de reconocer, sino principalmente de garantir, el acceso al agua potable a todos.

Es verdad que algunos tratados y convenciones, de forma aislada, garantizan acceso al agua a diversos grupos de personas, sin embargo, sin que se los sea reconocido este acceso como derecho fundamental. No hay, en el derecho internacional público convencional multilateral, disposición expresa acerca del reconocimiento erga omnes del acceso al agua dulce, en cantidades y calidad suficientes para el mantenimiento y satisfacción de las primeras necesidades vitales, como derecho fundamental. Cuando mucho, en las normas internacionales que lo mencionan, el acceso al agua es tenido o como forma de viabilizar la concreción del derecho a la salud o como forma de prevenir prácticas discriminatorias a determinados grupos humanos. Es aquella que indirectamente lo hacen, sólo lo hacen mediante condicionantes ligadas a situaciones extremas o catastróficas.

Además, la actual política pública sobre gestión hidrológica, tanto en España, como en Brasil, adoptó los instrumentos económicos y las estrategias administrativas dictadas por las principales organizaciones que rigen el derecho internacional económico, lo que demuestra filiación mucho más a sus respectivos intereses que a los principios y normas del régimen jurídico internacional del agua dulce que prioriza la 
importancia humana y ambiental del agua dulce. También, sus reglas y principios no priorizan el consumo humano elementar de agua dulce, ni tampoco la garantía de su acceso para las necesidades humanas básicas a todo y cualquier individuo, sobretodo aquellos que no poseen condiciones económicas o sociales para costear tal acceso, lo que se ausencia peligrosa cuando se compara preceptos legales que declaran el valor económico del agua, o el pago por cualesquier de sus múltiples usos.

De esta manera, España y Brasil demuestran ser mucho más influenciados por la perspectiva económica del tratamiento jurídico del agua dulce, repercutiendo sus ideas, principios e instrumentos sin la debida adecuación a la realidad social local y mundial, y sin el discrimine necesario para la separación entre lo que puede ser utilizado positivamente de lo que no debería ser adoptado. De este modo, también formatea la mentalidad general de la sociedad, convenciéndola - al menos en su mayoría - de que la solución para los problemas enfrentados en relación al agua dulce van a ser todos integralmente solucionados por instrumentos económicos y por la mentalidad del mercado.

Y lo hace en sentido contrario de las Constituciones Española y Brasileña, que establecen la dignidad de la persona humana y la ciudadanía como uno de sus fundamentos, además de establecer la prevalencia de los derechos humanos como uno de los principios directores de sus relaciones internacionales. Además de esto, la prevalencia de los derechos humanos, de la ciudadanía y de la dignidad de la persona humana son características profundamente marcadas por todo el texto constitucional, no pudiendo una política pública de agua dulce, que bajo su manto yace, eximirse de confrontar tales principios.

Quizá por el derecho al agua estar implícito en el derecho a la vida, siendo además, un elemento esencial de la calidad de vida, la legislación administrativa da por supuesto el derecho al agua y no lo regula. Sin embargo, claro está que es de fundamental importancia precisar el derecho al agua, y su alcance para marcar claramente la diferencia entre el derecho al agua como derecho a una prestación vital exigible de los poderes públicos y los derechos de aprovechamiento del recurso hídrico que se pueden adquirir en virtud de los títulos jurídicos previstos por el ordenamiento para la realización de actividades que no satisfacen, no de forma inmediata, las necesidades vitales. 
Sin duda, urge además, una reformulación del comportamiento de la sociedad humana, a través de un cambio cultural que refrene la civilización del consumo y del desperdicio e inyecte en la sociedad una preocupación mayor con la equidad intergeneracional.

No basta, en una palabra, que el Capítulo del medio ambiente en la Constitución de los Estados sea el más avanzado del mundo, es indispensable que la legislación infraconstitucional tenga a su frente un instrumento normativo $\mathrm{y}$, cuanto posible, operacional, apto a inserir las atribuciones del Poder Público y el ejercicio de la ciudadanía en un contexto moderno y dinámico, a que nos tiene conducido la historia universal y la historia del Derecho.

Como se puede observar, no hay tiempo a perder en el enfrentamiento de las emergencias que ya están ahí. Y es necesario que todas las instancias estén empeñadas en cambios de paradigmas que nos lleven a verdaderas soluciones. Puede parecer obvio, pero esta es la tarea inescapable de las actuales generaciones.

Ocurrida la exposición o daño al medio ambiente, el Derecho Penal y el Derecho Administrativo Sancionador son importantes instrumentos públicos para garantir la recuperación ambiental.

Aunque tienen diferentes propósitos, el Derecho Penal precipuamente, actuando en ultima ratio para la promoción del bien jurídico; mientras en Derecho Administrativo Sancionador impone la sanción en carácter retributivo, ambos son formas de actuación de la potestad del Estado, y por esto no pueden ser aplicados conjuntamente bajo pena de incidir en bin in idem. Así, la actuación del Derecho Penal en la protección del agua debe darse siempre en carácter residual, o sea, se dará únicamente la tutela penal cuando ocurrir un hecho típico, antijurídico y culpable. Infracciones administrativas de cuño ambiental son objeto exclusivo de apreciación del Derecho Administrativo Sancionador.

Respecto a la contaminación de aguas, se impone la aplicación del Derecho Penal por fuerza de los artículos $325^{1641}, 326^{1642}$ y 326 bis ${ }^{1643}$, del Código Penal Español y en Brasil del artículo $54^{1644}$ de la Ley $9605 / 98$, de 12 de febrero.

\footnotetext{
${ }^{1641}$ Artículo 325.

“1. Será castigado con las penas de prisión de seis meses a dos años, multa de diez a catorce meses e inhabilitación especial para profesión u oficio por tiempo de uno a dos años el que, contraviniendo las leyes u otras disposiciones de carácter general protectoras del medio ambiente, provoque o realice directa
} 
o indirectamente emisiones, vertidos, radiaciones, extracciones o excavaciones, aterramientos, ruidos, vibraciones, inyecciones o depósitos, en la atmósfera, el suelo, el subsuelo o las aguas terrestres, subterráneas o marítimas, incluido el alta mar, con incidencia incluso en los espacios transfronterizos, así como las captaciones de aguas que, por sí mismos o conjuntamente con otros, cause o pueda causar daños sustanciales a la calidad del aire, del suelo o de las aguas, o a animales o plantas.

2. Si las anteriores conductas, por sí mismas o conjuntamente con otras, pudieran perjudicar gravemente el equilibrio de los sistemas naturales, se impondrá una pena de prisión de dos a cinco años, multa de ocho a veinticuatro meses e inhabilitación especial para profesión u oficio por tiempo de uno a tres años. Si se hubiera creado un riesgo de grave perjuicio para la salud de las personas, se impondrá la pena de prisión en su mitad superior, pudiéndose llegar hasta la superior en grado”.

1642 Artículo 326.

“1. Serán castigados con las penas previstas en el artículo anterior, en sus respectivos supuestos, quienes, contraviniendo las leyes u otras disposiciones de carácter general, recojan, transporten, valoricen, transformen, eliminen o aprovechen residuos, o no controlen o vigilen adecuadamente tales actividades, de modo que causen o puedan causar daños sustanciales a la calidad del aire, del suelo o de las aguas, o a animales o plantas, muerte o lesiones graves a personas, o puedan perjudicar gravemente el equilibrio de los sistemas naturales.

2. Quien, fuera del supuesto a que se refiere el apartado anterior, traslade una cantidad no desdeñable de residuos, tanto en el caso de uno como en el de varios traslados que aparezcan vinculados, en alguno de los supuestos a que se refiere el Derecho de la Unión Europea relativo a los traslados de residuos, será castigado con una pena de tres meses a un año de prisión, o multa de seis a dieciocho meses e inhabilitación especial para profesión u oficio por tiempo de tres meses a un año".

${ }^{1643}$ Artículo 326 bis.

"Serán castigados con las penas previstas en el artículo 325, en sus respectivos supuestos, quienes, contraviniendo las leyes u otras disposiciones de carácter general, lleven a cabo la explotación de instalaciones en las que se realice una actividad peligrosa o en las que se almacenen o utilicen sustancias o preparados peligrosos de modo que causen o puedan causar daños sustanciales a la calidad del aire, del suelo o de las aguas, a animales o plantas, muerte o lesiones graves a las personas, o puedan perjudicar gravemente el equilibrio de los sistemas naturales".

${ }^{1644}$ Artigo 54.

“Causar poluição de qualquer natureza em níveis tais que resultem ou possam resultar em danos à saúde humana, ou que provoquem a mortandade de animais ou a destruição significativa da flora:

Pena - reclusão, de um a quatro anos, e multa.

$\S 1^{\circ}$ Se o crime é culposo:

Pena - detenção, de seis meses a um ano, e multa.

$\S 2^{\circ}$ Se o crime:

I - tornar uma área, urbana ou rural, imprópria para a ocupação humana;

II - causar poluição atmosférica que provoque a retirada, ainda que momentânea, dos habitantes das áreas afetadas, ou que cause danos diretos à saúde da população; 
III - causar poluição hídrica que torne necessária a interrupção do abastecimento público de água de uma comunidade;

IV - dificultar ou impedir o uso público das praias;

V - ocorrer por lançamento de resíduos sólidos, líquidos ou gasosos, ou detritos, óleos ou substâncias oleosas, em desacordo com as exigências estabelecidas em leis ou regulamentos:

Pena - reclusão, de um a cinco anos.

$\S 3^{\circ}$ Incorre nas mesmas penas previstas no parágrafo anterior quem deixar de adotar, quando assim o exigir a autoridade competente, medidas de precaução em caso de risco de dano ambiental grave ou irreversível". 


\section{BIBLIOGRAFÍA}

1. ${ }^{\circ}$ FÓRUM MUNDIAL DA ÁGUA. Disponible en:

$<$ http://www2.ana.gov.br/Paginas/imprensa/noticia.aspx?id_noticia=12417\%20>,

Último acceso en: 31-05-2015.

$6^{\circ}$ FÓRUM MUNDIAL DA ÁGUA. Disponible en: http://www.worldwaterforum6.org/commissions/thematic/. Acceso en: 31-05 2015.

ABALEO FACTORIA DE SOLUCIONES AMBIENTALES. Vivir bien, respetando los límites de nuestro planeta. Disponible en: < http://abaleo.es/desarrollosostenible/vivir-bien-respetando-limites-del-planeta.html>. Acceso en: 06-10-2015.

ACCIOLY, Hildebrando. Manual de direito internacional público. 12. ed. Rio de Janeiro: Ed. Saraiva, 1996.

ACETI JÚNIOR, Luiz Carlos e outros. Crimes Ambientais. Responsabilidade das Pessoas Jurídicas. São Paulo: Imperium Editora, 2007.

ACTA ÚNICA EUROPEA (AUE). Revisa los Tratados de Roma para reactivar la integración europea y llevar a cabo la realización del mercado interior. Modifica las normas de funcionamiento de las instituciones europeas y amplía las competencias comunitarias, en particular, en el ámbito de la investigación y el desarrollo, el medio ambiente y la política exterior común. Disponible en: < http://eur-lex.europa.eu/legalcontent/ES/TXT/?uri=URISERV\%3Axy0027>. Acceso en: 14-09-2015.

ACTA ÚNICA EUROPEA, DO, L n. ${ }^{\circ}$ 169/1 de 29-06-1987.

ACUERDO ADMINISTRATIVO ENTRE ESPAÑA Y FRANCIA SOBRE GESTIÓN DEL AGUA. Disponible en: < http://www.boe.es/buscar/doc.php?id=BOE-A-200614633>. Acceso en: 02-11-2015.

ACUERDO COMERCIAL DE LUCHA CONTRA LA FALSIFICACIÓN (ACTA). Disponible en: $<$ http://www.europarl.europa.eu/aboutparliament/es/20150201PVL00008/El-Tratadode-Lisboa>. Acceso en: 26-09-2015.

AGÊNCIA NACIONAL DE ÁGUAS (ANA). $<$ http://www2.ana.gov.br/Paginas/default.aspx> . Acceso en: 29-04-2015. 
AGUILAR CALAHORRO, Augusto. El sistema constitucional de España. Disponible en: <http://www.ugr.es/ redce/REDCE15/articulos/01AAguilar.htm>. Acceso en: 1008-2015.

AGUILAR FERNÁNDEZ, Susana. Evolución y tendencias de la política europea de medio ambiente. Revista Internacional de Sociología (RIS), Tercera Época, n. ${ }^{\circ} 35$, Mayo-Agosto, 2003. Disponible en: $<\mathrm{http}: / /$ revintsociologia.revistas.csic.es/index.php/revintsociologia/article/viewFile/300/ 306>. Acceso en: 29-09-2015.

ALASTUEY DOBÓN, Maria Carmem. Consideraciones sobre el objeto de protección en el derecho penal del medio ambiente. In: PRADO, Luiz Régis (coord.). Direito Penal Contemporâneo. Estudos em homenagem ao Professor José Cerezo Mir. São Paulo: Editora Revista dos Tribunais, 2007.

ALESSI, Rento. Sistema istituzionale del diritto amministrativo Italiano. 3. ed. Milano : Giuffrè Editore, 1960.

ALEXY, Robert. El concepto y la validez del derecho. 2. ed. Barcelona : Gedisa Editorial, 1997.

Teoría de los derechos fundamentales. Trad. de Ernesto Garzón Valdés. Centro de Estudios Políticos y Constitucionales, Madrid, 2002. . Tres escritos sobre los derechos fundamentales y la teoría de los princípios. Trad. y presentación de Carlos Bernal Pulido. Bogotá : Universidad Externado de Colombia 2003.

ALLAN, John Anthony. Avoiding war over natural resources. In: FLEMING, S. (Ed.) war and water. Ginebra: ICRC Publication Division. ALLAN, John Anthony. Water resources in semi-arid regions: real deficits and economically invisible and politically silent solutions. In: TURTON, A. R.; HENWOOD, R. (Ed.). Hydropolitics in the developing world: a Southern African perspective. Pretoria: African Water Issues $\begin{array}{llll}\text { Research Unit (AWIRU). Disponible } & \text { en }\end{array}$ $<$ http://www.internationalwaterlaw.org/bibliography/articles/hydropolitics_book.pdf $>$. Acceso en 04-05-2015.

ALLAN, John Anthony. Virtual water: a long term solution for water short middle Eastern economies. British association festival of science. Universidad de Leeds, 1997. ALLAN, John Anthony. Virtual water: a strategic resource. Global solutions to regional deficits. In: Groundwater, n. ${ }^{\circ}$ 36, v.4. 
ALLAN, John Anthony. Virtual water: an essential element in stabilizing the political economies of the middle east. Yale University Forestry \& Environmental Studies Bulletin, n. ${ }^{\circ} 103$.

ALONSO GARCÍA, Enrique. El Derecho Ambiental de la Comunidad Europea. El Marco Constitucional de la Política Comunitaria de Medio Ambiente. Aplicación de la Legislación Ambiental Comunitaria, Volumen 1, Editorial Civitas, S.A., 1a edición, Madrid-España: 1993.

ALONSO GARCIA, Ricardo. Sistema Jurídico de la Unión Europea. 2. ed. Madrid: Thomson-Civitas, 2010.

ÁLVAREZ, Rogelio Barba. El agua como derecho fundamental y su protección jurídico-penal. Revista prolegómenos - Derechos e valores. Bogotá, v.14, n. 27, p. 213229, julho - dezembro de 2011.

ALVES, Wagner Antônio. Princípios da precaução e da prevenção no direito ambiental brasileiro. São Paulo: Editora Juarez de Oliveira, 2005.

AMARAL, Diogo Freitas do. Direito do urbanismo. Lisboa: Almedina, 1993.

AMORIM, João Alberto Alves. Direito das Águas: O Regime Jurídico da Água Doce no Direito Internacional e no Direito Brasileiro. 2. ed. São Paulo: Editora Atlas, 2015.

ANDRADE, José Carlos Vieira de. Os direitos fundamentais na Constituição Portuguesa de 1976. 3. ed., reimpressão da edição de 2004. Coimbra : Editora Almedina, 2006.

ANGIONI, Francesco. Contenuto e funzioni del concetto di bene giuridico. Milano : Editore Giuffrè, 1983.

ANTUNES, Paulo de Bessa. Direito ambiental. 7. ed. Rio de Janeiro: Lumen Juris, 2005.

ARAGÃO, Alexandra. Direito constitucional do ambiente da União Europeia. Direito Constitucional Ambiental Brasileiro. 5. ed. CANOTILHO, José Joaquim Gomes; LEITE, José Rubens Morato. (Organizadores). Direito Constitucional Ambiental Brasileiro. São Paulo: Saraiva, 2012.

ARDUINI, Juvenal. Antropologia: ousar para reinventar a humanidade. São Paulo: Paulus, 2002.

ARRAZOLA, L. Voz “Agua”, en Enciclopedia Española de Derecho y Administración, (1849), 
ARRUDA, Domingos Sávio de Barros. A categoria acautelatória da responsabilidade ambiental. Revista de Direito Ambiental, São Paulo, n.42, ano 11, abr./jun.2006. ARTÍCULO 106.2 DE LA CONSTITUCIÓN ESPAÑOLA Y ARTÍCULOS 139 Y SIGUIENTES DE LA LEY, 30/1992, de 26 de noviembre, de Régimen Jurídico de las Administraciones Públicas y del Procedimiento Administrativo Común (LRJAP-PAC). Disponible en: $\quad<\quad$ https://www.boe.es/buscar/pdf/1992/BOE-A-1992-26318consolidado.pdf $>$. Acceso en: 28-10-2015.

ASSIS, Wilson Rocha. A Normatividade dos princípios e a pós modernidade. Disponible en: <http://jus2.uol.com.br/doutrina/texto.asp?id=8212> acceso: 20-052015.

ÁVILA, Humberto. Teoria dos princípios da definição à aplicação dos princípios jurídicos. 5 ed. São Paulo: Malheiros Editores, 2006.

BACELLAR FILHO, Romeu Felipe. Processo administrativo disciplinar. 2. ed. São Paulo, Max Limonad, 2003.

BANDEIRA DE MELLO, Celso Antônio. Curso de direito administrativo. São Paulo: Malheiros, 2002.

BANDERA AZUL. Disponible en: http://www.adeac.es/bandera_azul. Acceso en: 1609-2015.

BARCELLOS, Ana Paula de. A eficácia jurídica dos princípios constitucionais: o princípio da dignidade da pessoa humana. Rio de Janeiro: Editora Renovar, 2002.

BARLOW, Maude. La protección del agua: diez principios. El oro azul. 2001. Disponible en:

http://www.blueplanetproject.net/documents/espanol/El_oro_azul.pdf>. Último Acceso en: 10 de junho de 2015.

. Agua: pacto azul. São Paulo: Editora M. Books, 2009.

BARRERO RODRÍGUEZ, Concepción. Lecciones De Derecho Administrativo. Volumen III. Tecnos, Madrid, 2015.

BARROSO, Luís Roberto (organizador). A nova interpretação constitucional: ponderação, direitos fundamentais e relações privadas. 2. ed. Rio de Janeiro: Editora Renovar, 2006.

BARROSO, Luís Roberto. A dignidade da pessoa humana no direito constitucional contemporâneo. Tradutor: Humberto Laport de Mello. Belo Horizonte: Editora Fórum, 2013. 
BASTOS, Celso Ribeiro. Curso de Teoria do Estado e Ciência Política. 4. ed. São Paulo: Saraiva, 1999.

BECK, Ulrich. A reinvenção da política: rumo a uma teoria da modernização reflexiva. ; GIDDENS, Anthony; LASH, Scott. Modernização Reflexiva: política, tradição e estética na ordem social moderna. Tradução de Magda Lopes. São Paulo: UNESP, 1997.

. La sociedad del riesgo: Hacia una nueva modernidad. Traducción de Daniel Jiménez, Jorge Navarro e Mª Rosa Borras. Barcelona: Paidós, 1998.

. O que é globalização? Equívocos do globalismo: respostas à globalização. Tradução de André Carone. São Paulo: Paz e Terra, 1999.

. Liberdade ou capitalismo: Ulrich Beck conversa com Johannes Willms. Tradução de Luiz Antônio Oliveira de Araújo. São Paulo: UNESP, 2003.

BENJAMIN, Antônio Herman V. Os princípios do Estudo de Impacto Ambiental como limites da discricionariedade administrativa. Revista Forense. Rio de Janeiro, v. 317, 1992.

. Direito Constitucional Ambiental brasileiro. In: CANOTILHO, José Joaquim Gomes; LEITE, José Rubens Morato (Orgs.). Direito Constitucional Ambiental Brasileiro. São Paulo: Saraiva, 2007.

BENTHAM, Jeremy. An introduction to the principles of moral and legislation. Disponible en: <http://socserv.mcmaster.ca/econ/ugcm/3113/bentham/morals.pdf $>$. Acceso en: 29-07-2015.

BETANCOR RODRÍGUEZ, Andrés. Derecho Ambiental. Madrid: Editora La Ley, 2014.

BIANCHI, Paula. Rio é o estado que mais consome água, o dobro do recomendado pela ONU. Disponible en: $\quad<$ http://noticias.uol.com.br/cotidiano/ultimasnoticias/2015/02/05/rio-e-o-estado-que-mais-consome-agua-o-dobro-do-recomendadopela-onu.htm $>$ Último acceso en: 04-06-2015.

BINEMBOJM, Gustavo. O princípio da publicidade administrativa e a eficácia da divulgação de atos do poder público pela internet. Revista Eletrônica de Direito do Estado (REDE), Salvador, Instituto Brasileiro de Direito Público, $\mathrm{n}^{\circ}$ 19, julho/agosto/setembro, 2009. http://www.direitodoestado.com.br/rede.asp. Acceso en: 08-06-2015.

BOBBIO, Norberto. A Era dos Direitos. Rio de Janeiro: Editora Campus, 1992. 
BOFF, Leonardo. Planeta Terra, Ecologia e Ética. In: ARRUDA, Marcos; BOFF, Leonardo. Globalização: desafios socioeconômicos, éticos e educativos. 2. ed. Petrópolis : Vozes, 2001.

Saber cuidar: ética do humano - compaixão pela terra. 8. ed. Petrópolis:

Vozes, 2002.

. Crise, oportunidade de crescimento. Campinas: Verus, 2002.

. Civilização Planetária: desafios à sociedade e ao cristianismo. Rio de

Janeiro: Sextante, 2003.

BONAVIDES, Paulo. Do Estado Liberal ao Estado Social. São Paulo: Saraiva, São Paulo, 1961.

. Curso de direito constitucional. 18 ed. São Paulo: Editora Malheiros, 2006.

BOROWSKI, Martin. La estructura de los derechos fundamentales. Trad. de Carlos Bernal Pulido. Bogotá: Universidad Externado de Colombia, Serie de Teoría Jurídica y Filosofía del derecho $\mathrm{n}^{\circ}$. 25, 2003.

BOURG, Dominique; SCHLEGEL, Jean-Louis. Anteciparse a los riesgos: el principio de precaución. Barcelona: Ariel, 2004.

BRAGA, Antônio Sérgio; MIRANDA, Luiz Camargo de. (Org.) Comércio e Meio Ambiente: uma agenda positiva para o desenvolvimento sustentável apud ALVES, Wagner Antônio. Princípios da precaução e da prevenção no direito ambiental brasileiro. São Paulo: Editora Juarez de Oliveira, 2005.

BRANCHÁT, V. Tratado de los Derechos y Regalías que corresponden al real patrimonio en el reyno de Valencia y en la jurisdicción del intendente. T. I. Valencia : Imprenta de Joseph y Tomas de Orga, 1784.

BRASIL. Constituição da República Federativa do Brasil. Marcos Antônio Oliveira Fernandes (org.). 20. Ed. São Paulo: Ed. Rideel, 2014, art. $5^{\circ}$, II.

BULLA, Beatriz; FERNANDES, Talita. Será difícil exigir entrega de água que não existe, diz ministro do STJ. Entrevista feita para o jornal Estadão. Disponible en: $<$ http://sao-paulo.estadao.com.br/noticias/geral,sera-dificil-exigir-entrega-de-agua-quenao-existe-diz-ministro-do-stj,1630831>. Último acceso en: 10-06-2015.

BUSATO, Paulo César. Direito Penal Parte Geral. São Paulo, Editora Atlas 2013.

BUSTOS RAMÍREZ, Juan José ; HORMAZÁBAL MALARÉE, Hernán. Nuevo sistema de derecho penal. Madrid: Editorial Trotta, 2004. 
CALDAS, Cadu. O Brasil conta gotas: entenda as causas e desafios da falta de água que se pelo país. Disponible en: http://zh.clicrbs.com.br/rs/noticias/noticia/2015/01/o-brasil-conta-gotas-entenda-ascausas-e-desafios-da-falta-de-agua-que-se-espalha-pelo-pais-4691649.html Acceso en 17-05-2015.

CAMPILONGO, Celso Fernandes. O direito na sociedade complexa: com apresentação e ensaio de Raffaele De Giorgi. São Paulo: Max Limonad, 2000.

CANÇADO TRINDADE, Antônio Augusto. Direitos Humanos e Meio-Ambiente: Paralelo dos Sistemas de Proteção Internacional. Porto Alegre: Sérgio Antonio Fabris Editor, 1993.

CANOSA USERA, Raúl. Aspectos constitucionales del Derecho Ambiental. Revista de Estudios políticos (Nueva Época), n. ${ }^{\circ}$ 94, Octubre-Diciembre: 1996. . Constitución y medio ambiente. Madrid: Editorial S.L.- Dykinson, 2000. . El derecho a la integridad personal. Valladolid : Editorial Lex Nova, 2006. CANOTILHO, José Joaquim Gomes. Direito Constitucional e Teoria da Constituição. 7 ed. Coimbra: Almedina, 2003.

; LEITE, José Rubens Morato (Organiz). Direito Constitucional Ambiental Brasileiro, Editora Saraiva, São Paulo-Brasil: 2007.

; Vital MOREIRA. Constituição da República Portuguesa anotada. São Paulo: Editora Revista dos Tribunais 2007, v. I.

CAPRA, Fritjof. A teia da vida: uma nova compreensão científica dos sistemas vivos. Tradução de Newton Roberval Eichemberg. São Paulo: Cultrix, 1996.

CARBONELL, Eloísa; e MUGA, José Luis. Agencias y procedimiento administrativo en Estados Unidos de América. Madrid: Marcial Pons, 1996.

CARO-PATÓN CARMONA, I.; MACERA, B. F. El reparto de competencias entre el Estado y las Comunidades Autónomas en materia de protección ambiental y aguas. Secretariado de Publicaciones e Intercambio Editorial. Valladolid : Universidad de Valladolid, 2002.

CARRILlO DONAIRE, Juan Antonio; GALÁN VIOQUE, Roberto. ¿Hacia un Derecho Fundamental a un medio ambiente adecuado? En Eduardo García Enterría (Director), Civitas Revista española de Derecho Administrativo, n. ${ }^{\circ} 86$ abril/junio, 1995. 
CARTA DE LOS DERECHOS FUNDAMENTALES DE LA UNIÓN EUROPEA (2000/c 364/01). Disponible en el sitio del Parlamento Europeo: < http://www.europarl.europa.eu/charter/pdf/text_es.pdf $>$. Acceso en: 31-10-2015.

CARTA EUROPEIA DA ÁGUA. Disponible en: $<$ http://www.apdconsumo.pt/CARTA_EUROPEIA_AGUA.pdf > Acceso en 30-052015.

CARVALHO, Delton Winter de. Dano ambiental futuro: a responsabilização civil pelo risco ambiental. Revista de Direito Ambiental. São Paulo, ano 12, n.45, jan./mar. 2007. CARVALHO, Érika Mendes de. O bem jurídico protegido nos delitos florestais. Revista dos Tribunais v. 89, n. 776, São Paulo: Revista dos Tribunais, jun. 2000.

CASADO CASADO, Lucía. Los Vertidos de Aguas Continentales. Las Técnicas de Intervención Administrativa, Colección Estudios de Derecho Administrativo, Editorial Comares, Granada-España: 2004.

- Principales repercusiones de la Directiva Marco de Aguas en el ordenamiento jurídico español. In Santiago González-Varas Ibáñez (Coordinador), Nuevo Derecho de Aguas, Navarra: Aranzadi, 2007.

CASSÉ, Michel. O cosmos: concepções e hipóteses. In: MORIN, Edgar (Coord.). A religação dos saberes: o desafio do século XXI. $2^{\mathrm{a}}$ ed. Tradução de Flávia Nascimento. Rio de Janeiro: Bertrand Brasil, 2002.

CASTILLO DAUDÍ, Mireya. El derecho humano al agua en el Derecho internacional: aspectos generales. In Antonio Embid Irujo (Director). El Derecho al Agua. Editorial Aranzadi, Navarra-España: 2006.

CAVAliERI FILHO, S. Programa de Responsabilidade Civil. 6. ed. São Paulo: Malheiros, 2005.

CELI MALDONADO, Alejandra. Mínimo vital. Diccionario Iberoamericano de Derechos Humanos y Fundamentales. Disponible en: $<$ http://diccionario.pradpi.org/inicio/index.php/terminos_pub/view/9>. Acceso en: 3110-2015.

CERQUEIRA, Wagner de. Água. Disponible em: $<$ http://www.brasilescola.com/geografia/agua.htm> Acceso en 22-06-2015.

CHANG, Elvira Méndez. El Principio Precautorio y su Aplicación a los Ensayos Nucleares Subterráneos Franceses en el Pacífico Sur. Lima: Fondo Editorial del Pontificia Universidad Católica del Perú, 1996. 
Código de Aguas Normativa Autonómica. Disponible en: < http://boe.es/legislacion/codigos/codigo.php?id=139_Codigo_de_Aguas_Normativa_Au tonomica\&modo=1>. Acceso en: 02-12-2015.

Código de Aguas Normativa Estatal:

$<$ https://www.boe.es/legislacion/codigos/codigo.php?id=032 Codigo de Aguas Norm ativa_Estatal\&modo=1>. Acceso en: 02-12-2015.

COMISIÓN DE LAS COMUNIDADES EUROPEAS. Bruselas, 11.02.2004. $\operatorname{COM}(2004) 60$ final. Comunicación de la comisión al consejo, al parlamento europeo, al comité económico y social europeo y al comité de las regiones. Hacia una estrategia temática sobre el medio ambiente urbano . Disponible en: http://www.upv.es/contenidos/CAMUNISO/info/U0512367.pdf>. Acceso en: 20-092015.

COMISIÓN DE LAS COMUNIDADES EUROPEAS. Bruselas, 9.2.2005 Com(2005) 37 final. Comunicación de la comisión al consejo y al parlamento Europeo. Revisión en 2005 de la estrategia de la unión europea para un desarrollo sostenible: Primer balance y orientaciones futuras $\{\sec (2005) \quad 225\}$. Disponible en: < http://www.europarl.europa.eu/meetdocs/2004_2009/documents/com/com_com(2005)0 037_/com_com(2005)0037_es.pdf>,pp.16-17. Acceso en: 23-09-2015.

COMISIÓN DE LAS COMUNIDADES EUROPEAS. Bruselas, 22.10.2007. Com(2007) 642 final. Comunicación de la comisión al consejo y al parlamento europeo. Informe provisional sobre la estrategia de desarrollo sostenible $2007\{\sec (2007) 1416\}$. Disponible en: $\quad<\quad$ http://eur-lex.europa.eu/legalcontent/ES/TXT/?uri=celex:52007DC0642>. Acceso en: 23-09-2015.

COMISIÓN DE LAS COMUNIDADES EUROPEAS. Bruselas, 24.7.2009 Com(2009) 400 final. Comunicación de la Comisión al Parlamento Europeo, al Consejo, al Comité Económico y social europeo y al comité de Las regiones Incorporación del desarrollo sostenible en las políticas de la UE: Informe de 2009 sobre la estrategia de la unión europea para el desarrollo sostenible. Disponible en: $<$ http://eurlex.europa.eu/LexUriServ/LexUriServ.do?uri=COM:2009:0400:FIN:ES:PDF>. Acceso en: 23-09-2015.

COMMISSION OF THE EUROPEAN COMMUNITIES. Brussels, 15.5.2001. COM(2001)264 final. Communication from the Commission. A Sustainable Europe for a Better World: A European Union Strategy for Sustainable Development. Disponible 
en:

$<$ http://eur-

lex.europa.eu/LexUriServ/LexUriServ.do?uri=COM:2001:0264:FIN:EN:PDF>. Acceso en: 23-09-2015.

COMPARATO, Fábio Konder. A afirmação histórica dos direitos humanos. 2. ed. Revista e ampliada. São Paulo: Editora Saraiva, 2001.

COMUNICACIÓN DE LA COMISIÓN AL CONSEJO Y AL PARLAMENTO EUROPEO - COMUNICACIÓN SOBRE EL FUTURO DESARROLLO DE LA INICIATIVA DE LA UE PARA EL AGUA Y LAS MODALIDADES DE CREACIÓN DE UN FONDO PARA EL AGUA PARA LOS PAÍSES ACP /* COM/2004/0043 final */ Disponible en: < http://eur-lex.europa.eu/legalcontent/ES/TXT/?uri=celex:52004DC0043>. Acceso en: 24-09-2015.

COMUNICACIÓN DE LA COMISIÓN AL CONSEJO Y AL PARLAMENTO EUROPEO INFORME ANUAL 2006 SOBRE LA POLÍTICA DE DESARROLLO DE LA COMUNIDAD EUROPEA Y LA EJECUCIÓN DE LA AYUDA EXTERIOR EN 2005. Comunicación de la comisión al consejo y al parlamento Europeo. Informe anual 2006 sobre la política de desarrollo de la comunidad europea y la Ejecución de la ayuda exterior en 2005. Disponible en: < https://ec.europa.eu/europeaid/sites/devco/files/annual-report-2006-highlights-ecdevelopment-policy-external-assistance-com2006326_es_5.pdf $>$. Acceso en: 24-092015 .

COMUNICACIÓN DE LA COMISIÓN AL PARLAMENTO EUROPEO, AL CONSEJO, AL COMITÉ ECONÓMICO Y

Comunicación de la Comisión al Parlamento Europeo, al Consejo, al Comité Económico y Social Europeo y al Comité de la Regiones sobre la aplicación de la legislación ambiental comunitaria $\{$ SEC(2008) 2851\} \{SEC(2008) 2852\} \{SEC(2008) 2876\}. COM (2008) 773 final, de 18 de noviembre. Disponible en: $<$ http://www.bizkaia.net/ogasuna/europa/pdf/documentos/08-com773.pdf $>$. Acceso en: 17-11-2015.

COMUNICACIÓN DE LA COMISIÓN DE 15 DE MAYO DE 2001. «Desarrollo sostenible en Europa para un mundo mejor: estrategia de la Unión Europea para un desarrollo sostenible (Propuesta de la Comisión ante el Consejo Europeo de Gotemburgo)» [COM (2001) 264 final - no publicada en el Diario Oficial]. COMUNICACIÓN DE LA COMISIÓN DE 13 DE DICIEMBRE DE 2005 relativa a la 
revisión de la Estrategia para un desarrollo sostenible - Plataforma de acción [COM (2005) 658 final - no publicada en el Diario Oficial]. Disponible en: <http://eurlex.europa.eu/legal-content/ES/TXT/?uri=URISERV:128117>. Acceso en: 23-09-2015. CONDITIONS FOR SUCCESS. Disponible en:< http://www.worldwaterforum6.org/index.php?id=17\#get-involve>, Acceso en: 31-052015.

CONFERENCIA DE NACIONES UNIDAS SOBRE DESARROLLO SOSTENIBLE, celebrada en Río de Janeiro (Brasil) en 2012". Disponible en: $<$ http://www.aragon.es/estaticos/GobiernoAragon/Organismos/InstitutoAragonesAdmin istracionPublica/Areas/03_Revista_Aragonesa_Formacion/02\%20Dionisio\%20Fernánd ez.pdf $>$. Acceso en: 03-10-2015.

CONFERENCIA DE LAS NACIONES UNIDAS SOBRE DESARROLLO SOSTENIBLE DE 2012 (RÍO + 20). Decisión n. ${ }^{\circ}$ 1386/2013/UE del Parlamento Europeo y del Consejo de 20 de noviembre de 2013, relativa al Programa General de Acción de la Unión en materia de Medio Ambiente hasta 2020. Disponible en: $<$ http://eur-

lex.europa.eu/LexUriServ/LexUriServ.do?uri=OJ:L:2013:354:0171:0200:ES:PDF>. Acceso en: 06-10-2015.

CONFERÊNCIA INTERNACIONAL SOBRE A ÁGUA E O MEIO AMBIENTE, Disponible em: http://institutoaimara.blogspot.com.br/2012/06/as-conferenciasinternacionais-sobre.html

CONNOR, Richard. The united nations world water development report 2015: water for a sustainable world. Disponible $<$ http://unesdoc.unesco.org/images/0023/002318/231823E.pdf> Acceso en: 02-05-2015. CONSEJO DE MEDIO AMBIENTE CELEBRADO EL 17 DE DICIEMBRE DE 2012 (sesión no 3211, doc. 17582/12, versión provisional); continuando su proceso de aprobación, que incluye, por ahora el dictamen del Comité Económico y Social de 20 de marzo de 2013 (DOUE C 161, 6.6.2013), y el dictamen del Comité de las Regiones de 30 de mayo de 2013”. Disponible en: $<$ http://www.aragon.es/estaticos/GobiernoAragon/Organismos/InstitutoAragonesAdmin istracionPublica/Areas/03_Revista_Aragonesa_Formacion/02\%20Dionisio\%20Fernánd ez.pdf $>$. Acceso en: 03-10-2015. 
CONSEJO EUROPEO CELEBRADO EN GOTEMBURGO EN 2001. Disponible en: < http://eur-

lex.europa.eu/LexUriServ/LexUriServ.do?uri=COM:2005:0658:FIN:ES:PDF>. Acceso en: 23-09-2015.

CONSENSO EUROPEO SOBRE DESARROLLO. SÍNTESIS DE LA LEGISLACIÓN

DE LA UE. Disponible en: < http://eur-lex.europa.eu/legalcontent/ES/TXT/?uri=uriserv:r12544> . Acceso en: 24-09-2015.

CONSTITUCIÓN ESPAÑOLA. Disponible en: http://www.boe.es/diario_boe/txt.php?id=BOE-A-1978-31229>. Acceso en: 30-102015.

CONVENIO DE AARHUS SOBRE EL ACCESO A LA INFORMACIÓN, LA PARTICIPACIÓN DEL PÚBLICO EN LA TOMA DE DECISIONES Y EL ACCESO A LA JUSTICIA EN ASUNTOS AMBIENTES, de 1998, Disponible en: < https://www.boe.es/buscar/doc.php?id=BOE-A-2005-2528>. Acceso en: 27-10-2015.

CONVENIO DE COOPERACIÓN PARA LA PROTECCIÓN Y EL APROVECHAMIENTO SOSTENIBLE DE LAS AGUAS DE LAS CUENCAS HIDROGRÁFICAS HISPANO-PORTUGUESAS", más conocido como el Convenio de la Albufeira. Es aplicable a las cuencas de los ríos Miño, Limia, Duero, Tajo y Guadiana, que representan el $41 \%$ de la superficie total de España y el $62 \%$ de la de Portugal. Disponible en:

http://www.magrama.gob.es/es/agua/legislacion/conveniodealbufeira_tcm728658.pdf>. Acceso en: 02-11-2015.

COSTA NETO, Nicolao Dino de Castro e. Proteção jurídica do meio ambiente - I Florestas. Belo Horizonte: Del Rey, 2003.

COSTA, Carlos Fernando da Cunha. A tutela penal do meio ambiente. Conciliação entre dois sistemas de proteção. Curitiba: Editora Juruá, 2013.

COSTA, Elaine Romero. O princípio da proibição de retrocesso social no atual marco jurídico-constitucional brasileiro. Revista de Direito Constitucional, ano 18, $\mathrm{n}^{\circ} 73$, out$\operatorname{dez} 2010$.

COSTA, Helena Regina Lobo da. Proteção Penal Ambiental. Viabilidade. Efetividade. Tutela por outros ramos do direito. São Paulo: Saraiva, 2010. 
COSTODIO FILHO, Ubirajara. A Emenda Constitucional 19/98 e o Princípio da Eficiência na Administração Pública. In : Cadernos de Direito Constitucional e Ciência Política, São Paulo: Revista dos Tribunais, n. 27, abr./jul. 1999.

CRETELLA JÚNIOR, José. Manual de direito administrativo: curso moderno de graduação. Rio de Janeiro: Forense, 2005.

CROSA, Emilio. Lo Stato Democratico. Turín : Ed. UTET, 1946.

CRUZ, Ana Paula Fernandes Nogueira da. Crimes de perigo e riscos ao ambiente. Revista de Direito Ambiental, n. 42. São Paulo: Editora Revista dos Tribunais, 2006.

CUNHA, L. H.; COELHO, M. C. N. Política e Gestão Ambiental. In: CUNHA, S. B.; GUERRA, A. J. T. (org.). A questão ambiental: diferentes abordagens. Rio de Janeiro: Bertrand Brasil, 2003.

CUNHA, L. Veiga da; GONÇALVES, A. Santos; FIGUEIRA, V. Alves; LINO, Mário. A gestão da água, princípios fundamentais e sua aplicação em Portugal. Lisboa : Fundação Calouste Gulbenkian, 1980.

DALLARI, Pedro Bohomoletz de Abreu. Constituição e tratados internacionais. São Paulo: Ed. Saraiva, 2003.

DALLA-ROSA, Luiz Virgílio. O direito como garantia: pressupostos de uma teoria constitucional. Rio de Janeiro: Editora América, 2003.

DE LA CUESTA ARZAMENDI, José Luis. La Tutela Penal de las Aguas Continentales (Especial consideración de delito contra el ambiente: artículo 347 bis CP). In EMBID IRUJO, Antonio. La calidad de las aguas. Madrid: Civitas, 1994.

DECISIÓN No 1600/2002/CE DEL PARLAMENTO EUROPEO Y DEL CONSEJO DE 22 DE JULIO DE 2002. Por la que se establece el sexto programa de acción comunitario en materia de medio ambiente. Disponible en: < http://eurlex.europa.eu/legal-content/ES/TXT/PDF/?uri=CELEX:32002D1600\&from=ES>. Acceso en: 05-10-2015.

DECLARAÇÃO DA ÁGUA, TRIBUNAL LATINO AMERICANO DA ÁGUA. Disponible en: < http://tragua.com/quienes-somos/declaracion-del-agua/>, Acceso en: 22-05-2015.

DECLARAÇÃO No 23 DO FÓRUM MUNDIAL DA ÁGUA DE KYOTO. Disponible en: $<$ http://www.projetoagua.dape.net/kiotobiologia $>$ Acceso en: 31-05-2015. DECLARAÇÃO No 28 DO FÓRUM MUNDIAL DA ÁGUA DE KYOTO, Disponible en: $<$ http://www.projetoagua.dape.net/kiotobiologia $>$ Acceso en: 31-05-2015. 
DECLARAÇÃO UNIVERSAL DOS DIREITOS DA ÁGUA. Disponible en $<$ http://www.direitoshumanos.usp.br/index.php/Meio-Ambiente/declaracao-universaldos-direitos-da-agua.html> Acceso en: 22-05-2015.

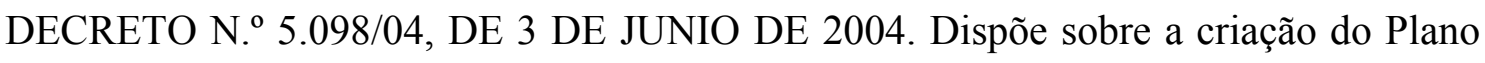
Nacional de Prevenção, Preparação e Resposta Rápida a Emergências Ambientais com PRODUTOS QUÍMICOS PERIGOSOS - P2R2, E DÁ OUTRAS PROVIDÊNCIAS. Disponible en: $\quad<\quad$ http://www.planalto.gov.br/ccivil_03/_ato20042006/2004/decreto/d5098.htm>. Acceso en: 16-11-2015.

DEL CASTILLO MORA, Daniel. El medio ambiente: derecho y competencia en el ordenamiento jurídico español y autonómico. Análisis particular del caso andaluz tras la Ley Orgánica 2/2007, de 19 de marzo, de reforma del Estatuto de Autonomía para Andalucía. Disponible en: $<$ http://www.juntadeandalucia.es/institutodeadministracionpublica/aplicaciones/boletin/ publico/Boletin26/Articulos_26/RAAP_MEDIO_AMBIENTE.pdf $>$. Acceso en: 21-102015, p. 138.

DEL SAZ, S. Aguas subterráneas, aguas públicas (El nuevo Derecho de aguas). Madrid : Marcial Pons, 1990.

DELGADO PIQUERAS, Francisco. La Protección Ambiental de las Aguas Continentales, in ORTEGA ÁLVAREZ, Luis (Director), Lecciones de Derecho del Medio Ambiente. 4. Ed. Valladolid : Editorial Lex Nova S.A., 2005.

DELLIS, Georges. Droit penal et droit administratif: L'influence des principes du droit penal sur le droit administrative répressif. Paris : LGDJ, 1997.

DERANI, Cristiane. Direito ambiental econômico. 2 ed. São Paulo: Max Limonad, 2001.

DERBLI, Felipe. O princípio da proibição de retrocesso social na Constituição de 1998. Rio de Janeiro: Renovar, 2007.

DE TENA, Ortiz. Lecciones De Derecho Administrativo. Volumen III. Tecnos, Madrid, 2015 .

DI PIETRO, Maria Sylvia Zanella. Direito administrativo. São Paulo: Atlas, 1990.

DI PIETRO, Maria Sylvia Zanella. Discricionariedade administrativa na Constituição de 1988. São Paulo: Atlas, 1991. 
DIA MUNDIAL DA ÁGUA: SANEAMENTO BÁSICO AINDA É PRECÁRIO. Disponible en: $<$ http://www.inesc.org.br/noticias/noticias-gerais/2008/marco/diamundial-da-agua-saneamento-basico-ainda-e-precario> Acceso en: 17-06-2015.

DIAS, E. C. Convenção do Clima. Disponible en: < http://www1.jus.com.br/doutrina/texto.asp?id=5600>. Aceso en: 08-08-2005.

DIAS, Jorge de Figueiredo. Direito Penal. Parte Geral. Tomo I. 1. ed. brasileira. São Paulo: Editora Revista dos Tribunais / Coimbra: Coimbra Editora, 2007.

DÍAZ, Elías. Estado de Derecho y Sociedad Democrática. Madrid: Editorial Cuadernos para el Diálogo, 1973.

DICTAMEN DEL COMITÉ DE LAS REGIONES - HACIA UNA POLÍTICA URBANA INTEGRADA PARA LA UNIÓN EUROPEA, consultado en el sitio de la Unión Europea, Parlamento Europeo, disponible en: < http://www.europarl.europa.eu/meetdocs/2014_2019/documents/regi/dv/cor-201306902_/cor-2013-06902_es.pdf>. Acceso en: 20-09-2015.

DÍEZ-PICAZO, Luis María. Sistema de derechos fundamentales. 2. ed. NavarraEspaña: Editorial Aranzadi, 2005.

DIMOULIS, Dimitri; MARTINS, Leonardo. Teoria geral dos direitos fundamentais. São Paulo: Editora Revista dos Tribunais, 2007.

DINIZ, Maria Helena. Curso de direito civil brasileiro. São Paulo: Editora Saraiva. 2004, v. 7.

DIRECTIVA - 2000/60/CE DEL PARLAMENTO EUROPEO Y DEL CONSEJO de 23 de octubre de 2000, por la que se establece un marco comunitario de actuación en el ámbito de la política de aguas. Diario Oficial n. ${ }^{\circ}$ L 327 de 22-12-2000, pp. 1-73. Disponible $\quad$ en: $\quad<\quad$ http://eur-lex.europa.eu/legalcontent/ES/TXT/?uri=CELEX:32000L0060>. Acceso en: 23-09-2015.

DIRECTIVA 2004/35/CE DEL PARLAMENTO EUROPEO Y DEL CONSEJO de 21 de abril de 2004 sobre responsabilidad medioambiental en relación con la prevención y reparación de daños medioambientales. Disponible en: <http://eurlex.europa.eu/LexUriServ/LexUriServ.do?uri=OJ:L:2004:143:0056:0075:es:PDF>. Acceso en: 28-10-2015.

DIRECTIVA 2006/123/CE, relativa a los servicios en el mercado interior, considerado 70 . 
DIRECTIVA 2006/21/CE DEL PARLAMENTO EUROPEO Y DEL CONSEJO, de 15 de marzo de 2006, sobre la gestión de los residuos de industrias extractivas y por la que se modifica la DIRECTIVA 2004/35/CE. Disponible en: <http://eurlex.europa.eu/legal-content/ES/TXT/?uri=celex:32006L0021>. Acceso en: 28-10-2015. Posteriormente alterada por la Directiva 2009/31/CE del Parlamento Europeo y del Consejo, de 23 de abril de 2009, relativa al almacenamiento geológico de dióxido de carbono y por la que se modifican la Directiva 85/337/CEE del Consejo.

DIRECTIVA 2013/30/UE DEL PARLAMENTO EUROPEO Y DEL CONSEJO, de 12 de junio de 2013, sobre la seguridad de las operaciones relativas al petróleo y al gas mar adentro, y que modifica la Directiva 2004/35/CE. Disponible en: <http://eurlex.europa.eu/legal-content/ES/TXT/?uri=celex:32013L0030>. Acceso en: 28-10-2015. DIRECTIVA MARCO EUROPEA DEL AGUA (DMA). Disponible en: < http://www.magrama.gob.es/es/agua/temas/planificacion-hidrologica/marco-delagua/default.aspx>. Acceso en: 24-09-2015.

DIRECTIVA, ASÍ COMO UNA TABLA DE CORRESPONDENCIA ENTRE LA PRESENTE DIRECTIVA Y LAS DISPOSICIONES NACIONALES ADOPTADAS”. Disponible en: $<$ http://eurlex.europa.eu/LexUriServ/LexUriServ.do?uri=OJ:L:2004:143:0056:0075:es:PDF>. Acceso en: 28-10-2015.

DIRECTIVAS 2000/60/CE, 2001/80/CE, 2004/35/CE, 2006/12/CE, 2008/1/CE Y EL REGLAMENTO (CE) NO 1013/2006 DEL PARLAMENTO EUROPEO Y DEL CONSEJO. Disponible en: $\quad<$ http://eur-lex.europa.eu/legalcontent/ES/TXT/?uri=celex:32009L0031>. Acceso en: 28-10-2015.

DOMÍNGUEZ SERRANO, Judith El funcionamiento del sistema de protección ambiental de la Unión Europea: principios, instituciones, instrumentos, in Revista Estudios Demográficos y Urbanos, Vol. 22, n. 3 (66), p. 691, México-DF: 2007. Disponible en: http://codex.colmex.mx:8991/exlibris/aleph/a18_1/apache_media/66CS1DF5IT3VEDR KVQIITMFKFNTTXU.pdf>. Acceso en: 07-09-2015.

DUPAS, Gilberto. Ética e poder na sociedade da informação: de como a autonomia das novas tecnologias obriga a rever o mito do progresso. São Paulo: UNESP, 2000.

DWORKIN, Ronald. Levando os direitos à sério. Trad. Nelson Boeira. São Paulo: Editora Martins Fontes, 2002. 
E/CONF. 70/29. Informe de la Conferencia de las Naciones Unidas sobre el agua, Mar del Plata, 14 al 25 de marzo de 1977, Naciones Unidas, Nueva York, 1977.

EL PAÍS. "El naufragio de Europa: la UE debe asumir que la emigración es su principal problema y actuar ya", publicada el 03-09-2015.

EL PAÍS. "Refugiados: la migración de Europa”, publicada el: 08-09-2015. Disponible en:

$<$ http://internacional.elpais.com/internacional/2015/09/08/actualidad/1441747441_3788 03.html>. Acceso en: 21-09-2015.

EL PAÍS. Editorial "El naufragio de Europa." Disponible en: < http://elpais.com/elpais/2015/09/02/opinion/1441213709_408502.html>. Acceso en: 2109-2015.

EMBID IRUJO, A. (director). Gestión del agua y descentralización política. Aranzadi, Cizur Menor, 2009.

ENOUGH SAFE WATER FOR ALL, INTEGRATED SANITATION FOR ALL, WATER FOR FOOD, WATER AND ENERGY, WATER AND CITIES, MANAGING AND RESTORING ECOSYSTEMS FOR WATER SERVICES AND BIODIVERSITY.

en: http://eng.worldwaterforum7.org/introduce/program/thematic.asp. Acceso en: 31-052015.

ERICE, María Valentina. Tesis doctoral La protección de las aguas subterráneas en el Derecho de Aguas Español, Universidad de Navarra, Pamplona, 2012. Disponible en: $<$ http://dadun.unav.edu/bitstream/10171/23721/1/Tesis\%20Valentina\%20Erice.pdf $>$. Acceso en: 19-10-2015.

ESCRICHE, J. Voz “Agua”, en Diccionario razonado de legislación y jurisprudência, 1858.

ESCUSOL BARRA, Eladio e RODRÍGUEZ-ZAPATA PÉREZ, Jorge. Derecho procesal administrativo. Madrid: Tecnos, 1995.

ESPÍNDOLA, Ruy Samuel. Conceito de Princípios Constitucionais: elementos teóricos para uma formulação dogmática constitucionalmente adequada. São Paulo: Editora Revista dos Tribunais, 1998.

ESTABLECIMIENTO DEL MARCO PARA EL SÉPTIMO PROGRAMA DE ACCIÓN DE LA UNIÓN EUROPEA EN MATERIA DE MEDIO AMBIENTE Adopción de Conclusiones del Consejo. Disponible en: 
$<\mathrm{http}: / /$ register.consilium.europa.eu/doc/srv?l=ES\&t=PDF\&f=ST+10706+2012+INIT $>$. Acceso en: 06-10-2015.

ESTEVE PARDO, José. Derecho del medio ambiente. 2 ed. Madrid: Marcial Pons, 2008.

FARIAS, Talden. Introdução ao Direito Ambiental. Belo Horizonte : Editora Del Rey, 2009.

FELDMANN, Fábio José (Org.). Guia da ecologia. Editora Guias Abril, São PauloBrasil: 1992.

FELICIANO, Guilherme Guimarães. Teoria da imputação objetiva no direito penal ambiental brasileiro. São Paulo: LTR Editora, 2005.

FENSTERSEIFER, Tiago. A dimensão ecológica da dignidade humana: as projeções normativas do direito (e dever) fundamental ao ambiente no Estado Socioambiental de Direito.

Disponible

en:

$<\mathrm{http}$ //www.unisc.br/portal/upload/com_arquivo/dissertacao___a_dimensao_ecologica _da_dignidade_humana_as_projecoes_normativas_do_direito_(e_dever)_fundamenta 1_ao_ambiente_no_estado_socioambiental_de_direito.pdf $>$. Acceso en: 05-08-2015.

FERNÁNDEZ DE GATTA SÁNCHEZ, Dionisio. La incidencia del Acta Única Europea en la política ambiental de la Comunidad Europea, en Actualidad y perspectiva del Derecho Público a finales del siglo XX: homenaje al profesor Garrido Falla, Universidad Complutense de Madrid, Madrid-España: 1992.

. La Política Ambiental Comunitaria en el Tratado de la Unión Europea, Revista de Derecho Ambiental, n. ${ }^{\circ}$ 12, España:1994.

. Evolución y regulación actual de la Política Ambiental Comunitaria, in Revista Noticias de la Unión Europea, n. ${ }^{\circ}$ 153, España: 1997.

. El régimen jurídico del control integrado de la contaminación. In Revista de Derecho Ambiental, n. ${ }^{\circ}$ 22. Asociación de Derecho Ambiental Español. ADAME, España: 1999.

Auditorías y Sistemas de Gestión Ambientales en la Unión Europea: Evolución, régimen vigente y perspectivas futuras, in Revista Noticias de la Unión Europea, n. ${ }^{\circ}$ 228, España: 2004.

Derecho ambiental: aspectos generales sobre la protección jurídica del medio ambiente. Este trabajo constituye el texto de la conferencia actualizada impartida en el Seminario sobre "El Derecho y la Cooperación Ibérica”, organizado por el Centro 
de Estudios Ibéricos en la ciudad de Guarda (Portugal) el 16 de Abril de 2004. Disponible en: <https://www.boe.es/buscar/doc.php?id=BOE-T-1995-18444>. Acceso en: 26-10-2015.

. Unión Europea y cambio climático: el régimen europeo del comercio de derechos de emisión de gases de efecto invernadero, in Revista Noticias de la Unión Europea, n. ${ }^{\circ}$ 258, España: 2006.

Articulación y perspectiva del desarrollo sostenible en la Unión Europea, Revista Noticias de la Unión Europea, n. ${ }^{\circ}$ 264, España: 2007.

. Política ambiental de la Unión Europea: las insuficiencias estatales para garantizar el cumplimiento de las exigencias comunitárias. En LOPÉZ RAMÓN, Fernando (coord.) y otros, Observatorio de Políticas Ambientales. Navarra : Thomson Reuters-Aranzadi, Cizur Menor, 2009.

- Unión Europea: Liderazgo en cambio climático, mirando al futuro. Observatorio de Políticas Ambientales. LOPÉZ RAMÓN, Fernando (coord.) y otros. Cizur Menor (Navarra) : Ed. Thomson Reuters-Aranzadi, 2011.

. El régimen de la sostenibilidad Medioambiental, Revista jurídica de Castilla y León. n. ${ }^{\circ}$ 25. Septiembre, 2011.

. Unión Europea: preparando el nuevo Programa Ambiental. In LOPÉZ RAMÓN, Fernando (coord.) y otros. Observatorio de Políticas Ambientales 2012. Cizur Menor. Navarra : Ed. Thomson Reuters-Aranzadi, 2012.

. El Séptimo Programa Ambiental de la Unión Europea, 2013-2020. Revista Aragonesa de Administración Pública, núm. 41-42, Zaragoza, 2013. Disponible en:

$<$ http://www.aragon.es/estaticos/GobiernoAragon/Organismos/InstitutoAragonesAdmin istracionPublica/Areas/03_Revista_Aragonesa_Formacion/02\%20Dionisio\%20Fernánd ez.pdf $>$. Acceso en: 03-10-2015.

. Sistema Jurídico-Administrativo de protección del medio ambiente, Ratio Legis Ediciones, Salamanca-España: 2014.

FERNANDO PABLO, Marcos Matías. El derecho ambiental tras la Ley 42/2007 de Patrimonio Natural y de la Biodiversidad. Revista Aranzadi de Derecho Ambiental, n. ${ }^{\circ}$ 15, Thomson Reuters, 2009, 
; GONZÁLES BUSTOS, Maria Ángeles. Tema 3: El control jurisdiccional de las administraciones públicas. Cuadernos de Derecho Administrativo II. Garantías jurídico-administrativas. 2. ed. Salamanca : Ratio Legis, 2013.

FERRAJOLI, Luigi. Diritto e ragione: Teoria del garantismo penale. 3. ed. Bari: Laterza, 1996.

FERREIRA FILHO, Manoel Gonçalves. Estado de Direito e Constituição. São Paulo: Editora Saraiva, 1988.

. Direitos humanos fundamentais. São Paulo: Saraiva, 1996.

FERREIRA, Daniel. Sanções administrativas. São Paulo, Malheiros Editores, 2001.

FERREIRA, Ivete Senise. Tutela penal do patrimônio cultural. Biblioteca de Direito Ambiental. São Paulo: Editora Revista dos Tribunais, 1995.

FERRY, Luc. A nova ordem ecológica: a árvore, o animal e o homem. Rio de Janeiro: Difel, 2009.

FIGUEIREDO, Amazonas de. A lei das XII tábuas e o código de hamurabi apud ALVES, Wagner Antônio. Princípios da precaução e da prevenção no direito ambiental brasileiro. São Paulo: Editora Juarez de Oliveira, 2005.

FIGUEIREDO, Guilherme José Purvin de. A propriedade no direito ambiental. 3 ed. rev., atual. e ampl. São Paulo: RT, 2008.

FIGUEROA, Alfonso García. Principios y positivismo jurídico. El no positivismo principialista en las teorías de Ronald Dworkin y Robert Alexy. Centro de Estudios Políticos y Constitucionales. Madrid, 1998.

FIORILLO, Celso Antônio Pacheco. Curso de Direito Ambiental Brasileiro. 12. ed. rev. atual. e ampl. São Paulo: Saraiva, 2011.

FOROS MUNDIALES DEL AGUA E INFORMACIONES SOBRE EL DESARROLLO DE LOS RECURSOS HÍDRICOS EN EL MUNDO. Disponible en: < http://www.unesco.org/new/es/natural-sciences/environment/water/wwap/>. Acceso en: 31-10-2015.

FORSTHOFF, Ernst. Stato di Diritto in Trasformazione. Milano : Giuffrè, 1973.

FRANCO SALA, Luis. La política medioambiental comunitaria: planteamientos, instrumentos $\mathrm{y}$ resultados. Afers Internacionals, n. ${ }^{\mathbf{0}}$ 34-35. file://C:/Users/usuario/Downloads/28010-27934-1-PB.pdf . Acceso en: 31-10-2015.

FREESTONE, D. Implementando Cautelosamente o Princípio da Precaução - A Abordagem Precautória no Acordo das Nações Unidas sobre a Conservação e o 
Ordenamento de Populações de Peixes Tranzonais e de Populações de Peixes Altamente Migratórios. In: VARELLA, M. D.; PLATIAU, A. F. B. (org. e co-autores). Princípio da Precaução. Belo Horizonte: Del Rey, 2004.

; HEY, E. Implementando o Princípio da Precaução: Desafios e Oportunidades. In: VARELlA, M. D.; PlATIAU, A. F. B. (org. e co-autores). Princípio da Precaução. Belo Horizonte: Del Rey, 2004.

FREITAS MARTINS, Ana Gouveia e. O Princípio da Precaução no Direito do Ambiente. Lisboa: Associação Académica da Faculdade Direito Lisboa, 2002.

FREITAS, Juarez. Sustentabilidade - Direito ao Futuro. Belo Horizonte: Editora Fórum, 2011.

FREITAS, Vladimir Passos de. Direito administrativo e meio ambiente. Curitiba: Juruá, 1995.

. A Constituição Federal e a efetividade das normas ambientais. São Paulo:

RT, 2000.

; FREITAS, Gilberto Passos de. Crimes contra a natureza: Editora Revista dos Tribunais, 2006.

FRIEDE, Reis. Curso resumido de Ciência Política e Teoria Geral do Estado. Rio de Janeiro: Forense Universitária, 2002.

G1 DO SUL DE MINAS. Hidrelétrica de Furnas deixa de produzir energia durante a madrugada. Disponible en: $\quad<\quad$ http://g1.globo.com/mg/sul-deminas/noticia/2014/05/hidreletrica-de-furnas-deixa-de-produzir-energia-durantemadrugada.html> Acceso en: 17-06-2015.

G1 DO TRIÂNGULO MINEIRO. Uberlândia é a única cidade brasileira a expor no $7^{\circ}$ Fórum Mundial da Água. Disponible em: <http://g1.globo.com/minas-gerais/triangulomineiro/noticia/2015/04/uberlandia-e-unica-cidade-brasileira-expor-no-7-forummundial-da-agua.html> Acceso en: 31-05-2015.

GALÁN VIOQUE, Roberto. Obras Públicas de Interés General, Tirant lo BlanchInstituto Andaluz de Administración Pública, Valencia, 2004.

Lecciones De Derecho Administrativo. Volumen III. Tecnos, Madrid, 2015.

GALLEGO ANABITARTE, A.; MENÉNDEZ REXACH, A. y DÍAZ LEMA, J. M. El Derecho de aguas en España, t. I, Centro de Publicaciones Secretaría General Técnica, Ministerio de Obras Públicas y Urbanismo, Madrid, 1986. 
GALLO, Silvio. Ética e cidadania: caminhos da filosofia. Campinas: Papirus, 1997.

GARCÍA, Aniza. El Derecho Humano al Agua. Madrid: Editorial Trotta, 2008.

GARCÍA-PELAYO, Manuel. Las transformaciones del Estado contemporáneo. 2 ed. Madrid: Alianza Editorial, 1985.

El Estado Social y democrático de Derecho en la Constitución Española. Las transformaciones del Estado contemporáneo, Madrid: Alianza Editorial. Disponible en: < http://www.uned.es/dpto-derecho-politico/IV._Manuel_Garcia_Pelayo.pdf $>$. Acceso en 27-07-2015.

GARCÍA-ALMONACID, Pablo. Disponible en: < http://www.internatura.org/opinion/dumping.html>. Acceso en: 02-09-2015.

GARRIGA DOMÍNGUEZ Ana; ÁLVAREZ GONZÁLEZ, Susana. Notas sobre el derecho a un disfrutar de un medio ambiente adecuado. Sevilla : ArCiBel, 2008.

GASTALDI, J. Petrelli. Elementos de economia política. 17. ed. São Paulo: Saraiva, 2000.

GIANNINI, Massimo Severo. Ambiente: aspectos jurídicos. RTDP, fasc. I, 1973.

GIMÉNEZ CASALDUERO, María; BABIANO AMELIBIA, Luis. El reconocimiento europeo del derecho humano al agua y al saneamiento: garantía ciudadana para el disfrute de los servicios públicos. Disponible en: $<$ http://revistas.lis.ulusiada.pt/index.php/8cigpa/article/viewFile/665/697>. Acceso en: 31-10-2015.

GOLDBLATT, David. Teoria social e ambiente. Lisboa: Piaget, 1996.

GOMES, Abílio Soares. Propriedades físico-químicas da água. Disponible en: $<$ http://www.uff.br/ecosed/PropriedadesH2O.pdf> Aceso en: 27-05-2015.

GOMES, Carla Amado. A prevenção à prova no Direito do Ambiente. Coimbra: Coimbra Editora, 2000.

GÓMEZ LIAÑO, F. La legitimación colectiva y el artículo 7 de la LOPJ. Justicia Revista de Derecho Procesal n. 3. Barcelona : Bosch, 1986.

GÓMEZ OREA, Domingo. Evaluación de Impacto ambiental, 2. ed. Madrid: Ediciones Mundi Prensa, 2002. Disponible en: $<$ https://books.google.com.co/books?id=f2yWYo2lWooC\&printsec=frontcover\&hl=pt$\mathrm{BR} \# \mathrm{v}=$ onepage \&q\&f $\mathrm{f}=$ false $>$. Acceso en: 29-09-2015.

GÓMEZ PUERTO, Ángel B. Aspectos jurídicos y administrativos de la protección del medio ambiente en España

(I). Disponible en: 
$<\mathrm{http}: / /$ www.egov.ufsc.br/portal/conteudo/aspectos-jur\%C3\%ADdicos-yadministrativos-de-la-protección-del-medio-ambiente-en-españa-i>. Acceso en: 21-102015

GONZÁlEZ BUSTOS, María Ángeles. El Debate del Cambio Climático en España, Revista Actualidad Administrativa, n. ${ }^{\circ}$ 6, España: 2010.

. La política de cambio climático en España. Revista Noticias de la Unión Europea. n. ${ }^{\circ}$ 295, España: 2009 (Ejemplar dedicado a: Plan Nacional de Asignación de emisiones 2008-2012.

Tema 1: Los bienes públicos. Cuadernos de Derecho Administrativo IV. Bienes públicos. Salamanca : Ratio Legis, 2014.

GONZÁleZ BUSTOS, M. ${ }^{\mathrm{a}}$ Ángeles; GONZÁLEZ IGLESIAS, Miguel Ángel. Sostenibilidad y responsabilidad en la edificación. Revista de Derecho Urbanístico y medio ambiente. Don Francisco José Alegría Martínez de Pinillos (Director), año XLIX,

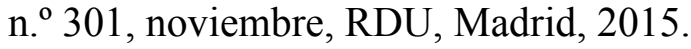

GONZÁLEZ GONZÁLEZ, Jorge. El acceso al agua potable como derecho humano. Alicante: Editorial Club Universitario, 2014.

GONZÁleZ IGLESIAS, Miguel Á. Dominio público hidráulico. Cuadernos de Derecho Administrativo (IV). Bienes públicos. Salamanca : Ratio Legis, 2014.

GONZÁLEZ HERNÁNDEZ, Rut. La responsabilidad civil por daños al medio ambiente. Anuario Jurídico y Económico Escurialense, XLV, 2012.

. El acceso al agua potable como derecho humano. Editorial Club Universitario. Alicante-España: 2014.

GONZÁLEZ PÉREZ, Jesús. La disgnidad de la persona humana. Madrid: Civitas, 1986.

. El principio general de la buena-fe en el derecho administrativo. 3. ed. Madrid: Civitas, 1999.

GRAU, Eros Roberto. Ensaio e discurso sobre a interpretação e aplicação do direito. 2. ed. São Paulo: Ed. Malheiros, 2003.

GRINEVALD, Jacques. Ideas y preocupaciones acerca del papel de la especie humana en la biosfera. In NAREDO, José Manuel; GUTIËRREZ, Luís (Editores). La incidencia de la especie humana sobre la faz de la Tierra. Granada : Editora Universidad de Granada.

Disponible en: 
http://www.fcmanrique.org/recursos/publicacion/4d399d901a\%20incidencia\%20de\%201 a\%20especie\%20humana\%20(parte\%201).pdf>. Acceso en: 25-08-2015.

GUARAGNI, Fábio André. Critérios de compatibilização da norma penal em branco com o Princípio da Reserva Legal, no aspecto formal da competência legislativa exclusiva para edição de normas incriminadoras. In: CONAMP / AMPERN. (Org.). Teses do XX Congresso Nacional do Ministério Público - 25 anos do novo Ministério Público: a construção de uma identidade. Brasília: Gomes e Oliveira Livraria e Editora, 2013, v. 1 .

GUERRA FILHO, Willis Santiago. Processo constitucional e direitos fundamentais. 4. ed. São Paulo: Editora RCS, 2005.

GUERRERO, Mercedes Herrera. Derecho penal medioambiental y accesoriedad administrativa en la configuración de algunos delitos en el Código Penal español. Inconvenientes y propuestas de solución. La Ley Penal, $\mathrm{n}^{0}$ 76. Sección Informe de Jurisprudencia, Noviembre 2010.

GUSMÃO, Paulo Dourado de. Introdução ao Estudo do Direito. 10. ed. Rio de Janeiro: Editora Forense, 1984.

HASSEMER, Winfried. Direito penal libertário. Trad. Regina Greve. Belo Horizonte: Del Rey, 2007.

. Puede haber delitos que no afecten a un bien jurídico penal? In: HEFENDEHL, Roland (ed.). La teoría del bien jurídico. Madrid: Marcial Pons, 2007. HAVA GARCÍA, Esther. Protección jurídica de la fauna y flora en España. Prólogo de Juan Terradillos Basocco. Madrid: Editorial Trotta, 2000.

HEFENDEHL, Roland. De largo aliento: El concepto de bien jurídico. O qué ha sucedido desde la aparición del volumen colectivo sobre la teoria del bien jurídico.La teoría del bien jurídico. Madrid: Marcial Pons, 2007.

HEINE, Günther. Accesoriedad administrativa en el derecho penal del medio ambiente. Anuario de Derecho Penal y Ciencias Penales, Tomo 46, Fasc/Mes 1, 1993. Disponível en http://dialnet.unirioja.es/servlet/articulo?codigo=46426. Acceso en: 10-06-2012.

HERRERA GUERRERO, Mercedes. Derecho penal medioambiental y accesoriedad administrativa en la configuración de algunos delitos en el Código Penal español. Inconvenientes y propuestas de solución. La ley penal, n 76 , Editorial La Ley. Sección Informe de Jurisprudencia, Noviembre 2010.

HESSE, Konrad. Porto Alegre : Editora Sergio Antonio Fabris Editor, 1998. 
HIRSCH, Andrew von. El concepto de bien jurídico y el principio del daño. In: HEFENDEHL, Roland (ed.). La teoría del bien jurídico. Madrid: Marcial Pons, 2007. HISPAGUA SISTEMA ESPAÑOL DE INFORMACIÓN SOBRE EL AGUA: < http://hispagua.cedex.es/instituciones/distribucion\#5>. Acceso en: 27-10-2015.

HISPAGUA SISTEMA ESPAÑOL DE INFORMACIÓN SOBRE EL AGUA: $<\mathrm{http}: / /$ hispagua.cedex.es/instituciones/distribucion\#5>. Acceso en: 27-10-2015. En la tabla: *Texto Refundido de la Ley de Aguas y ** Ley Reguladora de Bases del Régimen Local.

HOESKTRA, Arjen. Y.; HUNG, P. Q. Globalization of water resources: international water flows in relation to crop trade. Global Environmental Change, n. ${ }^{\circ}$ 15, 2005. Disponible en: <http://www.bvsde.paho.org/bvsacd/cd16/hoekstra.pdf>. Acceso en: 0505-2015.

; CHAPAGAIN, A. K. Water footprint of nations: water use by people as a function of their consumption pattern. Water Resource Manage, v. 21, 2007. Disponible en: <http://waterfootprint.org/media/downloads/Hoekstra_and_Chapagain_2007.pdf $>$. Acceso en: 05-05-2015.

; MEKONNEN, M. M. National water footprint accounts: the blue, green and gray water footprint of production and consumption. Value of Water Research Report Series, n. ${ }^{\circ}$ 50, v. 1, Holland: University of Twente, Twente Water Center, mayo 2011. Disponible en: <http://waterfootprint.org/media/downloads/Report50NationalWaterFootprints-Vol1.pdf>. Acceso en: 05-05-2015.

; MEKONNEN, Mesfin. The water footprint of humanity. Proceedings of

National Academy of Science, 109 (9), Febrero de 2012. Disponible en: $<$ http://waterfootprint.org/media/downloads/Hoekstra-Mekonnen-2012-WaterFootprintof-Humanity.pdf>. Acceso en: 04-05-2015.

IBÁÑEZ MÉNDEZ, Inés. Los poderes públicos y la defensa del medio ambiente. Disponible en: <http://ccoo.webs.upv.es/files/Medio-Ambiente/2006/Politica-deMedio-ambiente-en-Europa-en-30-anos.pdf> . Acceso en: 08-09-2015.

INFORME DE LA COMISIÓN AL CONSEJO, AL PARLAMENTO EUROPEO, AL COMITÉ ECONÓMICO Y SOCIAL EUROPEO Y AL COMITÉ DE LAS REGIONES DE CONFORMIDAD CON EL ARTÍCULO 14, APARTADO 2, DE LA DIRECTIVA 2004/35/CE, SOBRE RESPONSABILIDAD MEDIOAMBIENTAL EN RELACIÓN CON LA PREVENCIÓN Y REPARACIÓN DE DAÑOS MEDIOAMBIENTALES /* 
COM/2010/0581 final. Disponible en: <http://eur-lex.europa.eu/legalcontent/ES/TXT/?uri=celex:52010DC0581>. Acceso en: 28-10-2015.

INSTITUTO BRASILEIRO DE GEOGRAFIA E ESTATÍSTICA (IBGE). Disponible en: <http://www.ibge.gov.br/apps/populacao/projecao/>. Acceso en: 30-04-2015.

INSTRUMENTO DE RATIFICACIÓN DEL ACTA UNICA EUROPEA, FIRMADA EN LUXEMBURGO EL 17 DE FEBRERO DE 1986. Publicado en: «BOE» núm. 158, de 3 de julio de 1987, páginas 20172 a 20182 (11 págs.). Disponible en: $<$ https://www.boe.es/diario_boe/txt.php?id=BOE-A-1987-15279>. Acceso en: 14-092015.

IRRIGATION AND SOCIETY IN MEDIEVAL VALENCIA. Disponible en: $<$ http://www.tribunaldelasaguas.org/en/el-tribunal-ing/proyeccion-exterior-ing $>$ Último acceso en: 10-06-2015.

JACQUES, Paulino. Curso de direito constitucional. 8. ed. Rio de Janeiro: Forense, 1977.

JIMÉNEZ DE PARGA, Patricia. Capítulo VII - Reglas y principios estructurales de carácter internacional: canon de civilización ecológica. In Derecho Ambiental de BETANCOR RODRÍGUEZ, Andrés. Madrid-España: Editora La Ley, 2014.

JORDANA DE POZAS, Luis. El Derecho español de aguas y la oportunidad de su revisión. Real Academia de Jurisprudencia y Legislación, Madrid, 1962.

. La evolución del Derecho de las aguas en España y en otros países.

Revista de Administración Pública, núm. 37, 1962.

JORDANO FRAGA, Jesús. La protección del derecho a un medio ambiente adecuado. Barcelona : J.M. Bosch Editor, 1995.

. El derecho a disfrutar de un medio ambiente adecuado: elementos para su articulación expansiva. Medio Ambiente \& Derecho: Revista electrónica de derecho ambiental, $\quad \mathrm{n}^{\circ} . \quad 0, \quad 1998 . \quad$ Disponible en: $<$ https://idus.us.es/xmlui/bitstream/handle/11441/17294/file_1.pdf?sequence=1>. Acceso en: 10-08-2015.

. Responsabilidad civil por daños al medio ambiente en Derecho público: última jurisprudencia y algunas reflexiones de lege data y contra lege ferenda, en Civitas - Revista española de Derecho Administrativo, n. ${ }^{\circ}$ 107, 2000.

El Derecho administrativo en el umbral del siglo XXI, Homenaje al Professor Dr. D. Ramón Martín Mateo: Tendencias de evolución en el derecho 
administrativo y alguma propuesta iconoclasta. Coodinador: Francisco Sosa Wagner. Tirant lo Blanch : Valencia, 2000

El Derecho administrativo em el umbral del siglo XXI, Homenaje al Professor Dr. D. Ramón Martín Mateo: Tendencias de evolución em el derecho administrativo y alguma propuesta iconoclasto. Coodinador: Francisco Sosa Wagner. Valencia: Tirant lo Blanch, 2000.

- Responsabilidad por daños al medio ambiente. Derecho del Medio Ambiente y Administración Local. Fundación Democracia y Gobierno Local. Estudios de derecho judicial. $\mathrm{n}^{\mathrm{o}}$. 56, 2004 (Ejemplar dedicado a: Reparto competencial en materia de medio ambiente. Control medioambiental de la administración pública). Disponible en: $<$ http://repositorio.gobiernolocal.es/xmlui/bitstream/handle/10873/1122/medio_ambient e_26_jordano.pdf?sequence=1>. Acceso en: 18-11-2015.

- La Administración en el Estado Ambiental de Derecho. Revista de Administración Pública, n. ${ }^{\text {o } 173, ~ M a d r i d, ~ m a y o-a g o s t o, ~} 2007$.

- Un desafío para los ordenamientos en el siglo XXI: el desarrollo sostenible. En: Cuadernos de derecho local, n. ${ }^{\circ}$ 16, febrero de 2008. Fundación Democracia y Gobierno Local. Disponible en: < http://repositorio.gobiernolocal.es/xmlui/bitstream/handle/10873/351/qd116_09_est06_j ordano.pdf? sequence=3>. Acceso en: 17-11-2015.

. El futuro del Derecho Ambiental. Medio Ambiente \& Derecho: Revista electrónica de derecho ambiental, n. 24, 2013. Disponible en: $<$ http://huespedes.cica.es/gimadus/24/01_el_futuro_del_derecho_medioambiental.html $>$ . Acceso en: 17-11-2015.

JUNOY, Gonzalo. Sesiones del Parlamento Europeo - primera parte, In: Revistas de Instituciones Europeas, Crónicas de las instituciones comunitarias, v. 1, n. ${ }^{\circ}$ 2, 1974.

JUSTE, José, El derecho al agua en el marco internacional. In Antonio Embid Irujo (Director). El Derecho al Agua. Editorial Aranzadi, Navarra-España: 2006.

KLOCK, Andrea Bulgakov. Sociedade de risco e sistema penal ambiental. Revista do programa de mestrado em ciência jurídica, da Fundinopi- UENP. Jacarezinho, n. 11. julho-dezembro de 2009.

KRUSSEWSKI, Cristina. Direito administrativo sancionador: apontamentos gerais sobre as infrações administrativas e alguns aspectos de sua relação com o direito penal. 
Dissertação (Mestrado) Universidade Federal do Paraná, Faculdade de Direito. Curitiba, 2010

LA CARTA DE LOS DERECHOS FUNDAMENTALES DE LA UNIÓN EUROPEA. Disponible en: < http://www.europarl.europa.eu/ftu/pdf/es/FTU_1.1.6.pdf>. Acceso en: 24-09-2015.

LA CARTA DE LOS DERECHOS FUNDAMENTALES. SÍNTESIS DE LA LEGISLACIÓN DE LA UE. Disponible en: < http://eur-lex.europa.eu/legalcontent/ES/TXT/?uri=uriserv:133501> y también en: < http://europa.eu/pol/pdf/consolidated-treaties_es.pdf $>$. Ambos con acceso en: 26-092015.

LA LEY DE AGUAS DE 1866, ANTECEDENTES Y ELABORACIÓN. Derecho de aguas. Centro de Estudios Hidrográficos, Madrid: Civitas, 1997.

La Unión Europea, 2013-2020. Disponible en: $<$ http://www.aragon.es/estaticos/GobiernoAragon/Organismos/InstitutoAragonesAdmin istracionPublica/Areas/03_Revista_Aragonesa_Formacion/02\%20Dionisio\%20Fernánd ez.pdf>. Acceso en: 03-10-2015.

LAMELA, Antonio. El agua en España: nuevos lagos sustentables. Madrid: Ed. Leo, 2014

; MOLINÍ, Fernando. Geoísmo y Cosmoísmo. Disponible en: $<$ http://www.uam.es/personal_pdi/filoyletras/geoinova/geoismo/definiciones.html >. Acceso en: 02-11-2015.

LANCHOTTI, Andressa de Oliveira. Evaluación de impacto ambiental y desarrollo sostenible. Belo Horizonte : Arraes Editores, 2014.

LATOUR BROTÓNS, J. Antecedentes de la primitiva Ley de aguas. Ilustre Colegio de Abogados de Elche : Madrid, 1955.

LEGISLACIÓN CONSOLIDADA DE LA LEY 29/1998, de 13 de julio, reguladora de la Jurisdicción Contencioso-administrativa. Disponible en: $<$ https://www.boe.es/buscar/act.php?id=BOE-A-1998-16718\&p=20131210\&tn=2>. Acceso en: 28-10-2015.

LEGISLACIÓN CONSOLIDADA DE LA LEY 6/1985, de 1 de julio, del Poder Judicial. Disponible en: < https://www.boe.es/buscar/act.php?id=BOE-A-1985-12666>. Acceso en: 30-10-2015. 
LEINZ, Viktor; AMARAL, Sérgio Estanislau do. Geologia Geral. 14. ed. São Paulo: Editora Nacional, 2003.

LEITE, José Rubens Morato; AYALA, Patryck de Araújo. Direito Ambiental na Sociedade de Risco. Rio de Janeiro: Forense Universitária, 2002.

; AYALA, Patrick de Araújo. Dano Ambiental. Do individual ao coletivo extrapatrimonial. Teoria e prática. 4. ed. São Paulo: Editora Revista dos Tribunais, 2011.

LEY 10/2001, de 5 de julio, del Plan Hidrológico Nacional. Disponible en: < https://www.boe.es/buscar/doc.php?id=BOE-A-2001-13042>. Acceso en: 03-11-2015.

LEY 11/2005, de 22 de junio, por la que se modifica la Ley 10/2001, de 5 de julio, del Plan Hidrológico Nacional. Disponible en: http://www.boe.es/diario_boe/txt.php?id=BOE-A-2005-10622>. Acceso en: 03-112015.

LEY 29/1998, DE 13 DE JULIO, REGULADORA DE LA JURISDICCIÓN CONTENCIOSO-ADMINISTRATIVA. Disponible en: < https:/www.boe.es/buscar/act.php?id=BOE-A-1998-16718>. Acceso en: 28-10-2015. LEY 30/1992, de 26 de noviembre, de Régimen Jurídico de las Administraciones Públicas y del Procedimiento Administrativo Común. Disponible en: < https:/www.boe.es/buscar/doc.php?id=BOE-A-1992-26318>. Acceso en: 28-10-2015. LEY DE 28 DE DICIEMBRE DE 1978, DEL PARQUE NACIONAL DE DOÑANA (artículo 11); Ley de 3 de mayo de 1980, del Parque Nacional de las Tablas de Daimiel (artículo 13); Ley de 25 de mayo de 1981 del Parque Nacional de Garajonay (artículo 17); Ley de 25 de marzo de 1981, del Parque Nacional de la Caldera de Taburiente (artículo 17); y la Ley de 25 de marzo de 1981 del Parque Nacional del Timanfaya (artículo 17).

Ley n. ${ }^{\circ}$ 7.347/1985, de 24 de julio, que Disciplina a ação civil pública de responsabilidade por danos causados ao meio-ambiente, ao consumidor, a bens e direitos de valor artístico, estético, histórico, turístico e paisagístico (VETADO) e dá outras providências. Disponible

en: $<$ http://www.planalto.gov.br/ccivil_03/Leis/L7347orig.htm>. Acceso en: 16-11-2015. LEY ORGÁNICA 2/1979, de 3 de octubre, del Tribunal Constitucional, ha sufrido 6 modificaciones incluyendo la última que se ha dado el 17 de octubre de 2015. Disponible em 
http://www.tribunalconstitucional.es/ES/TRIBUNAL/Paginas/Tribunal.aspx>. Acceso en: 20-10-2015.

LIFANTE VIDAL, I., La interpretación jurídica en la teoría del derecho contemporánea, Centro de Estudios Políticos y Constitucionales. Madrid, 1999.

LINTON, J.; BUDDS, J. The hydrosocial cycle: defining and mobilizing a relationdialectical approach to water. Geoforum (2013). Disponible en: $<\mathrm{http}: / / \mathrm{www}$. sciencedirect.com/science/article/pii/S0016718513002327>. Acceso en: 04-05-2015.

LISZT, Franz Von. Tratado de Direito Penal Alemão. Trad. José Hygino Duarte Pereira. Tomo I. Rio de Janeiro: F. Briguiet \& C. Editores. 1899.

LOPERENA ROTA, Demetrio. El derecho al medio ambiente adecuado. Madrid: Civitas, 1998.

El agua como derecho humano. In: Santiago González-Varas Ibáñez (Coord.). Nuevo derecho de aguas. Editorial Aranzadi, Navarra-España: 2007.

LORENZO, Susana. Sanciones administrativas. Montevideo: Julio Cesar Faira, 1996. VITTA, Heraldo Garcia. A sanção no direito administrativo. São Paulo: Malheiros Editores, 2003.

LOZANO CUTANDA, Blanca; PLAZA MARTÍN Carmen. La Política de Medio Ambiente - Capítulo XX. In LINDE PANIAGUA, Enrique (Coordinador), Políticas de la Unión Europea. 3. ed. Madrid: Colex, 2006.

LOZANO CUTANDA, Blanca. Derecho Ambiental Administrativo. Madrid: La Ley, 2010 .

LUHMANN, Niklas. Globalization or world society: how to conceive of modern society? Disponible en: http://www.libfl.ru/Luhmann/Luhmann2.html. Acceso en: 1409-2007.

- Sociologia do Direito I. Tradução de Gustavo Bayer. Rio de Janeiro: Edições Tempo Brasileiro, 1983.

. Sociologia do Direito II. Tradução de Gustavo Bayer. Rio de Janeiro: Edições Tempo Brasileiro, 1985.

LUSA. ONU reconhece acesso à água potável como um direito humano. Notícia por DN Globo. Disponible en: $<$ http://www.dn.pt/inicio/globo/interior.aspx?content_id=1629749\&page=-1>. Último acceso en: 21-06-2015. 
MACHADO, Fábio Guedes de Paula. Culpabilidade no direito penal. São Paulo: Quartier Latin, 2009.

; GIACOMO, Roberta Catarina. Breves reflexões sobre a administrativização do direito penal, delitos por acumulação e antecipação da tutela penal na proteção do bem jurídico ecológico. In Rivista Diritto \& Diritti, 2009. Disponible en: http://www.diritto.it/docs/28544-breves-reflex-es-sobre-aadministrativiza-o-do-direito-penal-delitos-por-acumula-o-e-antecipa-o-da-tutela-penalna-prote-o-do-bem-jur-dico-ecol-gico. 2009. Consultado en 02.12.2015.

; GIACOMO, Roberta Catarina. Novas teses dogmáticas jurídico-penais para a proteção do bem jurídico ecológico na sociedade do risco. In Rivista Diritto \& Diritti, 2009. Disponible en: http:/www.diritto.it/archivio/1/28208.pdf. Consultado en: 03.12.2015.

; GIACOMO, Roberta Catarina. Dos bens jurídicos supra-individuais de conteúdo difuso como o meio ambiente. Rivista Diritto \& Diritti, 2009. Disponible en: https://docs.google.com/viewerng/viewer?url=http://www.diritto.it/pdf/28542.pdf?down load\%3Dtrue. Consultado en: 02.12.2015.

. Reminiscências da Responsabilidade Penal da Pessoa Jurídica. In Revista Brasileira de Ciências Criminais - RBCCRIM n. 79. São Paulo: Revista dos Tribunais, 2009.

MACHADO, Marta Rodriguez de Assis. Sociedade do risco e Direito Penal: uma avaliação de novas tendências político-criminais. São Paulo: IBCCRIM, 2005.

MACHADO, Paulo Affonso Leme. Direito ambiental brasileiro. 22 ed. São Paulo: Malheiros 2014.

MALUCELli, Marcelo. Tutela Penal das Águas. Águas - aspectos jurídicos e ambientais. 3. ed. Curitiba: Juruá Editora, 2007.

MARIA DÍEZ-PICAZO, Luís. Sistema de derechos fundamentales. Madrid: Thomsom Civitas, 2003.

MARINELA, Fernanda. Direito Administrativo. Salvador: Juspodivm, 2005.

MARTÍN MATEO, Ramón. Tratado de Derecho ambiental, vol. I. Madrid: Trivium, 1992.

. Manual de Derecho Ambiental. 3. ed. Navarra : Thompson Aranzadi, 2003. 
MARTÍN-RETORTILLO, S. (1960), La elaboración de la Ley de aguas de 1866. Revista de Administración Pública, núm. 32, pp. 11-54, (1963).

MARTINS DA SILVA, Américo Luís. Direito do Ambiente e dos Recursos Naturais. Volume 1. São Paulo: RT, 2004.

MARUM, Jorge Alberto de Oliveira. Meio ambiente e direitos humanos. Revista de Direito Ambiental. São Paulo, n. ${ }^{\circ} 28$, ano 7, out./dez.2002.

MASI, Domenico de. A sociedade pós-industrial. 4. ed. São Paulo: Editora Senac São Paulo, 2003.

MAXIMILIANO, Carlos. Hermenêutica e aplicação do direito. 19. ed. Rio de Janeiro: Editora Forense, 2003.

MAZZUOLI, Valério de Oliveira. Direito Internacional Público: parte geral. São Paulo: Editora RT, 2004.

MECANISMOS LEGALES PARA LA DEFENSA DEL MEDIO AMBIENTE. Elaborado por el Instituto Internacional de Derecho y Medio Ambiente. Disponible en: $<$ http://www.iidma.org/privado/Archivos/Guiamecanismosport.pdf $>$. Acceso en: 28-102015.

MEDAUAR, Odete. Direito Administrativo Moderno. 7. ed. rev.e atual. São Paulo: Editora Revista dos Tribunais, 2003.

MEDIO AMBIENTE. Disponible en: $\quad<$ http://eur-lex.europa.eu/legalcontent/ES/TXT/?uri=URISERV:a15000>. Acceso en: 23-09-2015.

MEIRELLES, Hely Lopes. Direito Administrativo Brasileiro. 28. ed. São Paulo: Malheiros, 2003.

MELLO, Celso Antônio Bandeira de. Elementos de Direito Administrativo. 2. ed. rev. ampl. e atual. com a Constituição Federal de 1988. São Paulo: Editora Revista dos Tribunais, 1990.

. Curso de Direito Administrativo. 14. ed. ref. ampl e atual. São Paulo: Malheiros, 2002.

. Grandes temas de Direito administrativo. São Paulo: Malheiros, 2009.

MELLO, Leonal Itaussu Almeida; COSTA, Luís César Amad. História moderna e contemporânea. São Paulo: Scipione, 1999.

MELLO, Rafael Munhoz de. Princípios Constitucionais de Direito Administrativo Sancionador: as sanções administrativas à luz da Constituição Federal de 1988. São Paulo: Malheiros, 2007. 
MELO, Celso Albuquerque. Curso de direito internacional público. 13. ed. Rio de Janeiro: Editora Renovar, 2001, v. I.

MENDO ESTRELLA, Álvaro. El delito «ecológico» del art. 325.1 del Código Penal. Valencia: Tirant Editorial, 2009.

MENDOZA BUERGO, Blanca. El derecho penal en la sociedad del riesgo. Madrid: Civitas, 2001.

El delito ecológico y sus técnicas de tipificación. Disponível na Internet em: http://www.ecoiurislapagina.com/biblio/articulos/art125.htm. Acesso em 25-0320155.

MENÉNDEZ MARIÑO, Fernando. In PICON RISQUEZ, Juan (Coord.), Derecho Medioambiental de la Unión Europea. Monografía Ciencias Jurídicas, Madrid: Editora McGraw-Hill, 1996.

MENÉNDEZ REXACH, Ángel. El derecho al agua en la Legislación española. Anuario da Facultade de Dereito da Universidade da Coruña - AFDUC 15, 2011. Disponible en: http://ruc.udc.es/dspace/bitstream/2183/10385/1/Ad\%2015\%202011\%20art\%203.pdf Acceso em: 25-03-2015.

. El agua como bien jurídico global: el Derecho Humano al agua.

AFDUAM 2012. 16, Disponible en: <
https://www.uam.es/otros/afduam/pdf/16/AngelMenendezRexach.pdf $>$. Acceso en: 2503-2015.

MENEZES, Paulo Roberto Brasil Teles de. O Direito do Ambiente Na Era de Risco: perspectivas de mudanças sob a ótica emancipatória. Revista de Direito Ambiental. São Paulo, ano 8, n.32, set./out.2003.

MERINO NORVERTO, María. Sinopsis artículo 10 de la Constitución española. Disponible en:

http://www.congreso.es/consti/constitucion/indice/sinopsis/sinopsis.jsp?art=10\&tipo=2 >. Acceso en: 27-07-2015.

MIGUEL GARCÍA, Pablo de (1980), "Régimen jurídico para la protección de las aguas subterráneas". Documentación Administrativa, núm. 187, 1980. Disponible en http://revistasonline.inap.es/index.php?journal=DA\&page $=\operatorname{article} \& o p=$ view $\&$ path $\% 5 \mathrm{~B}$ $\% 5 \mathrm{D}=4478 \&$ path $\% 5 \mathrm{~B} \% 5 \mathrm{D}=4532$. Acceso en: 27-07-2015.

MILARÉ, Edis (Coord). Ação civil pública (Lei 7.347/85 - reminiscências e reflexões após dez anos de aplicação). São Paulo: Revista dos Tribunais, 1995. 
Direito do Ambiente. A gestão ambiental em foco. Doutrina. Jurisprudência. Glossário. 7. ed. São Paulo: Revista dos Tribunais, 2011.

- Tutela jurídica do meio ambiente. Responsabilidade em matéria ambiental. São Paulo: Editora Revista dos Tribunais. 2011.

; Flavia Tavares Rocha. Meio ambiente e os direitos da personalidade.

Revista de Direito Ambiental, São Paulo, n. ${ }^{\circ}$ 37, ano 10, jan./mar.2005.

MIR PUIG, Santiago. El derecho penal en el Estado Social y Democrático de Derecho. Barcelona : Ariel Derecho, 1994.

MIRANDA, Jorge. Manual de direito constitucional: Constituição. 3. ed. Revista e actualizada. T. IV. Coimbra : Editora Coimbra, 2000.

MIRANDA, Pontes de. Tratado de direito internacional privado. Rio de Janeiro: Livraria José Olímpio Editora,1935, t. I.

MIRRA, Álvaro Luiz Valery. Princípios fundamentais do Direito Ambiental. Revista de Direito Ambiental. São Paulo: Revista dos Tribunais, n. 2.

. Direito Ambiental: o princípio da precaução e sua aplicação judicial.

Revista de Direito Ambiental. São Paulo, n.21, ano 6, jan./mar. 2001.

MODERNE, Frank. Sanctions administratives et justice constitutionnelle. Paris: Economica, 1993.

MONTOYA MARTÍN, Encarnación. Lecciones De Derecho Administrativo. Volumen III. Tecnos, Madrid, 2015.

MORA RUIZ, Manuela. Tendencias del Derecho Administrativo. "El Derecho Administrativo Ambiental: Transformaciones en el Derecho Administrativo General". Derecho y conocimiento, vol. 1, W. Hoffman-Riem, "La reforma del Derecho administrativo", DA, 234 (abril-junio), 1993. Disponible en: < http://rabida.uhu.es/dspace/bitstream/handle/10272/1568/b1205773.pdf?sequence=1>. Acceso en: 17-11-2015.

MORAIS, Germana de Oliveira; MARQUES, Willian Paiva Júnior. A modernização do modelo brasileiro ante os sistemas de jurisdição administrativa no direito comparado. In: XIX ENCONTRO NACIONAL DO CONPEDI. Fortaleza: Conselho Nacional de Pesquisa e Pós-graduação em Direito, 2010. 15 p. Disponible en: $<$ http://www.conpedi.org.br/manaus/arquivos/anais/fortaleza/3249.pdf $>$. Acceso en: 2906-2015. 
MOREIRA NETO, Diogo de Figueiredo. Introdução ao direito ecológico e ao direito urbanístico. Rio de Janeiro - São Paulo: Forense, 1975.

MOREIRA, Vescijudith Fernandes. La eficacia del sistema de protección y reutilización del agua en España y Brasil. Un análisis jurídico-ambiental derivado de la política de la Unión Europea. Tesis doctoral presentada en la Universidad de Salamanca, 2011.

MORIN, Edgar. As duas globalizações: comunicação e complexidade. In: SILVA, Juremir Machado da; CLOTET, Joaquim. As duas globalizações: complexidade e comunicação, uma pedagogia do presente. Porto Alegre: Sulina, 2002.

MOTA, Myriam Becho; BRAICK, Patrícia Ramos. História: das cavernas ao Terceiro Milênio. São Paulo: Moderna, 1997.

MUÑOZ JIMÉNEZ, José María. Manual del texto refundido de la Ley de Aguas. Manual del domínio público hidráulico. Madrid: J.M. Muñoz, 2002.

NACIONES UNIDAS. DECENIO INTERNACIONAL PARA LA ACCIÓN 'EL AGUA FUENTE DE VIDA' 2005-2015: < http://www.un.org/spanish/waterforlifedecade/human_right_to_water.shtml>. Acceso en: 31-10-2015.

NARDY, A. J. F. Uma leitura transdisciplinar do Princípio da Precaução. In: SAMPAIO, J. A. L.; WOLD, C.; NARDY, A. J. F. Princípios de Direito Ambiental. Belo Horizonte: Del Rey, 2003.

NIETO, Alejandro. Aguas subterráneas: subsuelo árido y subsuelo hídrico. Revista de Administración Pública, núm. 56, 1968.

. Derecho administrativo sancionador. 4 ed. Madrid: Editora Tecnos, 2005.

NORBERTO, Bobbio. Teoria do Ordenamento Jurídico. 10. ed. Trad. Maria Celeste dos Santos. Brasília : Editora Universidade de Brasília, 1999.

NUCCI, Guilherme de Souza. Código penal comentado. 14. ed. Rio de Janeiro: Editora Forense, 2014.

OBJETIVOS DE DESENVOLVIMENTO DO MILÊNIO. Disponible en: $<$ http://www.objetivosdomilenio.org.br/objetivos> Último acceso en: 22-06-2015. OBJETIVOS DO FÓRUM. en: $<$ http://www.worldwaterforum5.org/index.php?id=1875>,

OHLIGER, Tina. La política de medio ambiente: principios generales y marco básico, disponible en el sitio del Parlamento Europeo, Fichas Técnicas sobre la Unión Europea: 
$<$ http://www.europarl.europa.eu/atyourservice/es/displayFtu.html?ftuId=FTU_5.4.1.htm 1>. Acceso en: 19-10-2015.

ONU. ÁGUA POTÁVEL: DIREITO HUMANO FUNDAMENTAL. Disponible en: $<$ http://nacoesunidas.org/agua-potavel-direito-humano-fundamental/ $>$, Último acceso en: 22-05-2015.

ONUBR. DEMANDA POR ÁGUA DISPARARÁ 55\% ENTRE A POPULAÇÃO MUNDIAL EM 2050, ALERTA FAO. Disponible en: $<\mathrm{http}$ //nacoesunidas.org/demanda-por-agua-disparara-55-entre-a-populacao-mundialem-2050-alerta-fao/> Último acceso en: 27-05-2015.

ONUBR. SEMINÁRIO DA ONU EM BRASÍLIA DISCUTE CRISE HÍDRICA. Disponible en: <http://nacoesunidas.org/seminario-da-onu-em-brasilia-discute-crisehidrica/> Último acceso en: 02-06-2015.

ORDENAÇÕES FILIPINAS, 11 de janeiro de 1603, Livro V, Título LXXXVIII, Disponible en: <http://www1.ci.uc.pt/ihti/proj/filipinas/15p1238.htm >, Último acceso en: 21-05-2015.

ORDÓÑEZ SOLÍS, David. Aguas, medio ambiente y Unión Europea - la política comunitaria europea de aguas: armonización y financiación. In: Santiago GonzálezVaras Ibáñez (Coord.). Nuevo derecho de aguas. Editorial Aranzadi, Navarra-España: 2007.

ORTEGA ÁLVAREZ, Luis. El concepto de medio ambiente. Lecciones de Derecho del Medio Ambiente. 4. Ed. Valladolid : Editorial Lex Nova S.A., 2005.

ORTEGA BERNARDO, Julia. “¿Quién ha apostado por la efectiva implantación del derecho de acceso a la justicia a favor de las organizaciones no gubernamentales en defensa del medio ambiente?” . Actualidad Jurídica Ambiental, 03-10-2011.

OSÓRIO, Fábio Medina. Direito administrativo sancionado. São Paulo: Editora Revista dos Tribunais, 2000.

PALMA DEL TESO, Ángeles de. El princípio de culpabilidad en el derecho administrativo sancionador. Madrid: Tecnos, 1996.

PALOMAR OLMEDA, Alberto. La protección del Medio Ambiente en materia de aguas, Revista Administración Pública, n. ${ }^{\circ}$ 110, 1986.

PAREJO ALFONSO, Luciano y otros. Manual de Derecho Administrativo. Barcelona : Ariel. Vol. II, 1998. 
PARLAMENTO EUROPEO: FICHAS TÉCNICAS SOBRE LA UNIÓN EUROPEA. Disponible en: < http://www.europarl.europa.eu/ftu/pdf/es/FTU_3.1.1.pdf>. Acceso en: 12-09-2015.

PARLAMENTO EUROPEO: FICHAS TÉCNICAS SOBRE LA UNIÓN EUROPEA. SUBSIDIARIEDAD. Consultado en el sitio de la Unión Europea: $<\mathrm{http}: / /$ www.europarl.europa.eu/ftu/pdf/es/FTU_1.2.2.pdf $>$. Acceso en: 14-09-2015.

PENA, Rodolfo F. Alves. Consumo de água no mundo. Disponible en: $<$ http://www.mundoeducacao.com/geografia/consumo-agua-no-mundo.htm $>$ Último acceso en: 04-06-2015.

Hidrelétricas no Brasil. Disponible en: < http://www.mundoeducacao.com/geografia/hidreletricas-no-brasil.htm> Último acceso en: 17-06-2015.

PEREIRA, Rodrigo da Cunha. Princípios fundamentais norteadores do Direito de Família. Belo Horizonte : Editora Del Rey, 2006.

PÉREZ LUÑO, Antonio Enrique. Estado de Derecho y Derecho Fundamental. Los Derechos Humanos - Significación, Estatuto Jurídico y Sistema. Coord. por Antonio Enrique Pérez Luño. Sevilla : Publicaciones de la Universidad de Sevilla, 1979.

PEREZ LUÑO, E. Los derechos fundamentales. 3. ed., Madrid: Editorial Tecnos, 1998. PERRINI, Raquel Fernandes. Os princípios constitucionais implícitos. Cadernos de Ciência, Direito Constitucional e Ciência Política. São Paulo: Revista dos Tribunais, n. 17, 1996.

PESCOD. Wastewater treatment and use in agriculture. Disponible en: $<$ http://www.fao.org/docrep/t0551e/t0551e00.htm> Último aceso en: 03-06-2015. PIOVESAN, Flávia. Direitos Humanos e Globalização. In: SUNDFELD, Carlos Ari; VIEIRA, Oscar Vilhena (Orgs.). Direito Global. São Paulo: Max Limonad, 1999. - Direitos Humanos e princípio da dignidade humana. Dos princípios constitucionais: considerações em torno das normas principiológicas da Constituição. In George Salomão LEITE (org.). São Paulo-Brasil: Editora Malheiros, 2003.

PLAUTIAU, Ana Flávia Barros. A legitimidade da governança global ambiental e o principio da precaução. In: VARELLA, Marcelo Dias; PLATIAU, Ana Flávia Barros (Orgs.). Princípio da Precaução. Belo Horizonte: Del Rey, 2004.

PLAZA MARTÍN, Carmen. La política y cit., p. 319. Disponible en: < http://www.boe.es/doue/2010/083/Z00013-00046.pdf>. Acceso en: 29-09-2015. 
PODESTÁ COSTA, L. A. Manual de derecho internacional publico. Buenos Aires: Librería Editora El Ateneo, 1943.

POLAINO NAVARRETE, Miguel. La criminalidad ecológica en la legislación española. Política criminal y reforma penal. Libro Homenaje a la memória del Prof. Dr. Juan del Rosal. Madrid: Edersa, 1993.

POMPEU, Cid Tomanik. Fundamentos para a gestão de recursos hídricos: aspectos jurídicos. In: BARTH, Flavio Terra. Modelos para gerenciamento de recursos hídricos. São Paulo: Editora Nobel/ABRH, 1999.

- O Direito de águas no Brasil. São Paulo: Revista dos Tribunais novembro de 2009 - $98^{\circ}$ ano. São Paulo: RT.

PRADO, Luiz Régis. Direito Penal Contemporâneo. Estudos em homenagem ao Professor José Cerezo Mir. São Paulo: Editora Revista dos Tribunais, 2007.

. Direito Penal do Ambiente. 2. ed. São Paulo: RT, 2009.

. Curso de Direito Penal Brasileiro. 11. ed. São Paulo: Revista dos

Tribunais, 2012.

PREÂMBULO DA CONFERÊNCIA INTERNACIONAL SOBRE ÁGUA E DESENVOLVIMENTO SUSTENTÁVEL, Paris, 1998, Disponible en: $<$ http://www.meioambiente.uerj.br/emrevista/documentos/paris.htm>, Último acceso en: 30-05-2015.

PRIORIDADES DE AÇÃO. Disponible $<$ http://www.worldwaterforum6.org/index.php?id=17\#get-involve $>$, Último acceso en 31-05-2015.

PROCESO DE CARDIFF. Disponible $<$ http://www.magrama.gob.es/ministerio/pags/Biblioteca/Revistas/pdf_AM\%2FAM_20 02_8_43_49.pdf $>$. Acceso en: 29-09-2015.

PROGRAMAS DE ACCIÓN AMBIENTAL Y DEMÁS NORMATIVAS. Disponible en: <https://www.boe.es/diario_boe/txt.php?id=BOE-A-1987-15279>. Acceso en: 1409-2015.

PROTOCOLO DE REVISIÓN DEL CONVENIO SOBRE COOPERACIÓN PARA LA PROTECCIÓN Y EL APROVECHAMIENTO SOSTENIBLE DE LAS AGUAS DE LAS CUENCAS HIDROGRÁFICAS HISPANO-PORTUGUESAS Y EL PROTOCOLO ADICIONAL, suscrito en Albufeira el 30 de noviembre de 1998. 
Disponible en: < http://boe.vlex.es/vid/convenio-hidrograficas-portuguesas-albufeira74617539>. Acceso en: 02-11-2015.

QUEIROZ, Cristina. O princípio da não reversibilidade dos direitos fundamentais sociais. Coimbra : Coimbra Editora, 2006.

REAL ACADEMIA ESPAÑOLA. Disponible $<\mathrm{http}: / /$ dle.rae.es/?w=holismo\&o=h $>$. Acceso en: 02-10-2015.

REAL DECRETO 849/1986, de 11 de abril, por el que se aprueba el Reglamento del Dominio Público Hidráulico, que desarrolla los títulos preliminar I, IV, V, VI y VII de la Ley 29/1985, de 2 de agosto, de Aguas. Disponible en: < https://www.boe.es/buscar/act.php?id=BOE-A-1986-10638>. Acceso en: 03-11-2015. REAL DECRETO 907/2007, de 6 de julio, por el que se aprueba el Reglamento de la Planificación Hidrológica. Disponible en: http://www.boe.es/diario_boe/txt.php?id=BOE-A-2007-13182>. Acceso en: 03-112015.

REALE JÚNIOR, Miguel. A Lei de Crimes Ambientais. São Paulo: Revista Forense 345/121, 1999. Instituições de Direito Penal, vol. 1. Rio de Janeiro: Forense, 2002.

REALE, Miguel. Lições preliminares de direito. 22. ed. São Paulo: Editora Saraiva, 1995.

REBOLLO PUIG, Manuel. El derecho administrativo sancionador. In MOREIRA NIETO, Diogo de Figueiredo. Uma avaliação das tendências contemporâneas do direito administrativo: obra em homenagem a Eduardo García de Enterría. Rio de Janeiro: Renovar, 2003.

REBOUÇAS, Aldo. Proteção dos Recursos Hídricos. In: Revista de Direito Ambiental, n. ${ }^{\circ}$ 32, ano 8, outubro-dezembro de 2003. São Paulo: Editora RT.

RESOLUCIÓN DEL CONSEJO DE LAS COMUNIDADES EUROPEAS Y DE LOS REPRESENTANTES DE LOS GOBIERNOS DE LOS ESTADOS MIEMBROS REUNIDOS EN EL SENO DEL CONSEJO. Disponible en: < http://eurlex.europa.eu/legal-content/ES/TXT/?uri=CELEX:41977X0613>. Acceso en: 08-092015 .

RESOLUCIÓN DEL CONSEJO DE LAS COMUNIDADES EUROPEAS Y DE LOS REPRESENTANTES DE LOS GOBIERNOS DE LOS ESTADOS MIEMBROS REUNIDOS EN EL SENO DEL CONSEJO DE 7 DE FEBRERO DE 1983 
RELATIVA A LA PROSECUCIÓN Y EJECUCIÓN DE UNA POLÍTICA Y DE UN PROGRAMA DE ACCIÓN DE LAS COMUNIDADES EUROPEAS EN MATERIA DE MEDIO AMBIENTE. DOC C 46/1 de 17-02-83. Disponible en: $<$ http://ccoo.webs.upv.es/files/Medio-Ambiente/2006/Politica-de-Medio-ambiente-enEuropa-en-30-anos.pdf>. Acceso en: 08-09-2015.

REZEK, Francisco. Direito internacional público: curso elementar. 8. ed. São Paulo: Ed. Saraiva, 2000.

RIECHENBERG, Kurt. Derecho Comunitario Ambiental - Evolución y análisis de la acción comunitaria en materia de medio ambiente. Su tratamiento en el Tratado de la Comunidad Europea. In: MAR CAMPINS i ERITJA; ISABEL PONT i CASTEJÓN (Coord.), Perspectivas de Derecho Comunitario Ambiental. Edición Instituto Universitario de Estudios Europeos. Barcelona : Bellaterra, 1997.

RIOS, Aurélio Virgílio Veiga; DERANI, Cristiane. Princípios gerais do Direito Internacional Ambiental. In: RIOS, Aurélio Virgílio Veiga; IRIGARAY, Carlos Teodoro Hugueney. O direito e o desenvolvimento sustentável: curso de direito ambiental. São Paulo: Peirópolis/IEB, 2005.

RIVERO ORTEGA, Ricardo. Introducción al Derecho Público Económico. Salamanca : Edit. Ratio Legis, 1999.

RODRIGUES, Geisa de Assis. Da audiência pública como instrumento de participação popular no licenciamento ambiental independente de realização de estudo prévio de Impacto Ambiental. In: Congresso Internacional de Direito Ambiental - 5 anos após a ECO -92, 1997, São Paulo. Congresso Internacional de Direito Ambiental. São Paulo: Imprensa Oficial de São Paulo, 1997.

RODRIGUES, Marcelo Abelha. Instituições de direito ambiental. São Paulo: Editora Max Limonad, 2002.

ROXIN, Claus. A proteção de bens jurídicos como função do Direito Penal. Trad. André Luís Callegari e Nereu José Giacomolli. 2. ed. Porto Alegre: Livraria do Advogado, 2009.

SADELER, Nicolas. Environmental principles, modern and post-modern law. In Richard Macrory et all (eds.), Principles of European Environmental Law. Groningen : Europa Law Publishing, 2004. 
SALINAS ALCEGA, Sergio, El derecho al agua como Derecho humano. Contenido normativo y obligaciones de los Estados. In Antonio Embid Irujo, Navarra: Aranzadi, 2006.

SAMPAIO, José Adércio Leite. Constituição e Meio Ambiente na perspectiva do Direito Constitucional Comparado. In: SAMPAIO, J. A. L.; WOLD, C.; NARDY, A. J. F. Princípios de Direito Ambiental. Belo Horizonte: Del Rey, 2003.

. Direito A Constitucionalização dos princípios de Direito Ambiental. In: SAMPAIO, José Adércio Leite; WOLD, Chris; NARDY, Afrânio. Princípios de direito ambiental. Belo Horizonte: Del Rey, 2003.

- Direito fundamental ao meio ambiente saudável, adequado e ecologicamente equilibrado. In: SAMPAIO, José Adércio Leite; WOLD, Chris; NARDY, Afrânio. Princípios de direito ambiental: na dimensão internacional e comparada. Belo Horizonte: Del Rey, 2003.

Direitos fundamentais: retórica e historicidade. Belo Horizonte : Editora Del Rey, 2004.

SÁNCHEZ MUÑOZ, María Jesús. Treinta años de actuación en materia medio ambiental en la Unión Europea, Disponible en: <http://ccoo.webs.upv.es/files/MedioAmbiente/2006/Politica-de-Medio-ambiente-en-Europa-en-30-anos.pdf>. Acceso en: 08-09-2015.

SÁNCHEZ-MARTÍNEZ， Ma Teresa; RODRÍGUEZ-FERRERO, Noelina; SALASVELASCO, Manuel. La gestión del agua en España. La unidad de Cuenca. Revista de Estudios Regionales n. ${ }^{\circ}$ 92, 2011:199-220.

SANDS, P. O Princípio da Precaução. In: VARELLA, M. D.; PLATIAU, A. F. B. (org. e co-autores). Princípio da Precaução. Belo Horizonte: Del Rey, 2004.

SANJURJO REBOLLO, Beatriz. Medio ambiente y acción popular. Artículo publicado en el Boletín "Urbanismo", el 1 de enero de 2011. Disponible en: < http://www.elderecho.com/tribuna/administrativo/Medio-ambiente-accionpopular_11_233680001.html>. Acceso en: 05-11-2015.

SANTOS NETO, João Antunes dos. O impacto dos direitos humanos fundamentais no direito administrativo. Belo Horizonte: Fórum, 2008.

SANTOS, Juarez Cirino dos. Direito penal - parte geral. 5. ed. Florianópolis: Editora Modelo, 2012. 
SARASÍBAR IRIARTE, Miren. Las oportunidades de la crisis económica en el derecho ambiental. en concreto, el fondo de carbón. Revista Aragonesa de Administración Pública, n. ${ }^{\circ}$ 41-42, Zaragoza, 2013. Disponible en: $<$ http://www.aragon.es/estaticos/GobiernoAragon/Organismos/InstitutoAragonesAdmin istracionPublica/Documentos/docs2/07\%20Miren\%20Saras\%C3\%ADbar.pdf $>$. Acceso en: $17-11-2015$.

SARLET, Ingo Wolfgang. Dos princípios constitucionais: consideração em torno das normas principiológicas da Constituição. George Salomão LEITE (Org.), São Paulo: Editora Malheiros, 2003.

. Direitos fundamentais sociais e proibição de retrocesso: algumas notas sobre o desafio da sobrevivência dos direitos sociais num contezto de crise. Revista da AJURIS, ano XXXI, n 95 , setembro de 2004.

; FENSTERSEIFER, Tiago. Direito constitucional ambiental: Constituição, Direitos fundamentais e proteção do ambiente. 2. ed. Rev. e Atual. São Paulo: Editora Revista dos Tribunais, 2012.

; MARINONI, Luiz Guilherme; MITIDIERO, Daniel. Curso de direito constitucional. São Paulo: Editora Revista dos Tribunais, 2012.

. Curso de direito constitucional. São Paulo: Editora Revista dos Tribunais, 2012.

A eficácia dos direitos fundamentais: uma teoria geral dos direitos fundamentais na perspectiva constitucional, 12. ed. Porto Alegre : Livraria do Advogado, 2014.

SARMENTO, Daniel. Direitos Fundamentais e Relações Privadas. 2. ed. Rio de Janeiro: Lumen Juris, 2006.

SCALZO, Marília. Corpo líquido. Disponible en: $<$ http://planetasustentavel.abril.com.br/noticia/saude/conteudo_240527.shtml> Último acceso en: 04-03-2015.

SCARLET, Ingo Wolfgang. A eficácia dos direitos fundamentais. 7. Ed. Porto AlegreBrasil: Editora Livraria do Advogado, 2007.

SCHMITT, Carl. Legalidad y Legitimidad. Trad. esp. José Díaz García. Madrid: Ed. Aguilar, 1971.

SCHULT, Bernd. Direitos Fundamentais Segurança Social e Proibição de Retrocesso. Revista da AJURIS, ano XXXII, nº 99, setembro de 2005. 
SEHER, Gerhard. La legitimación de normas penales basada en princípios y el concepto de bien jurídico. In: HEFENDEHL, Roland (ed.). La teoría del bien jurídico. Madrid: Marcial Pons, 2007.

SEMINARIO DE ESTUDIOS DE LOS TRIBUNALES CONSTITUCIONALES DE ITALIA, PORTUGAL Y ESPAÑA. LISBOA, OCTUBRE DE 2009. La Propiedad en la Jurisprudencia del Tribunal Constitucional Español. Delegación del Tribunal Constitucional de España, Letrado: Juan Luis REQUEJO PAGÉS. Disponible en: < http://www.tribunalconstitucional.es/fr/actividades/Documents/Ponencia\%20Trilateral \%202009\%20Lisboa.pdf>. Acceso en: 18-11-2015.

SENTENCIA 64/1982, de 4 de noviembre de 1982, del Tribunal Constitucional de España. Disponible en el sitio del Tribunal Constitucional de España: $<$ http://hj.tribunalconstitucional.es/HJ/en-

US/Resolucion/Show/SENTENCIA/1982/64>. Acceso en: 26-10-2015.

SENTENCIA DE TS, SALA 3 $3^{\mathrm{a}}$, DE LO CONTENCIOSO-ADMINISTRATIVO, 7 DE NOVIEMBRE DE 1990, M. 1.887. PONENTE: Excmo. Sr. don Francisco González Navarro. PROCEDIMIENTO: Ordinario. Apelación núm. 522/1989. MATERIA: Apertura de pub; licencia. Sentencia disponible en: $<$ http://supremo.vlex.es/vid/209083475>. Acceso en: 26-10-2015.

SÉPTIMO PROGRAMA DESTINADO A SUCEDERLO, Y LA PROPUESTA DE DECISIÓN RELATIVA AL PROGRAMA GENERAL DE MEDIO AMBIENTE DE LA UNIÓN HASTA 2020. Disponible $<\mathrm{http}: / /$ www.aragon.es/estaticos/GobiernoAragon/Organismos/InstitutoAragonesAdmin istracionPublica/Areas/03_Revista_Aragonesa_Formacion/02\%20Dionisio\%20Fernánd ez.pdf $>$. Acceso en: 03-10-2015.

SÉPTIMO PROGRAMA. PROGRAMA GENERAL DE MEDIO AMBIENTE DE LA UNIÓN. Disponible en: $\quad<\quad$ http://eur-lex.europa.eu/legalcontent/ES/TXT/?uri=CELEX:32013D1386>.

SERRANO DOMÍNGUEZ, Judith. Disponible en: $<$ http://codex.colmex.mx:8991/exlibris/aleph/a18_1/apache_media/66CS1DF5IT3VED RKVQIITMFKFNTTXU.pdf>. Acceso en: 21-09-2015.

SEXTO PROGRAMA. Disponible en:

$<$ http://www.aragon.es/estaticos/GobiernoAragon/Organismos/InstitutoAragonesAdmin 
istracionPublica/Areas/03_Revista_Aragonesa_Formacion/02\%20Dionisio\%20Fernánd ez.pdf>. Acceso en: 03-10-2015.

SILVA FILHO, Derly Barreto e. A processualidade das licenças ambientais como garantia dos Administrados. Revista de Direito Ambiental. São Paulo: RT, n.5, 1997.

SILVA SÁNCHEZ, Jesús-María. La expansión del derecho penal : Aspectos de la política criminal en las sociedades postindustriales. 2. ed. Madrid: Editora Civitas, 2001.

A Expansão do direito penal. Aspectos da política criminal nas sociedades pós-industriais. Tradução Luís Otávio de Oliveira Rocha. 2. ed. São Paulo: Editora Revista dos Tribunais, 2011.

SILVA, Américo Luís Martins da. Direito do meio ambiente e dos recursos naturais. São Paulo: RT, 2005.

SILVA, Geraldo Eulálio do Nascimento e. Direito Ambiental Internacional. 2 ed. Rio de Janeiro: Thex Editora, 2002.

SILVA, José Afonso da. Fundamentos constitucionais da proteção ao meio ambiente. Revista de Direito Ambiental, São Paulo, n. ${ }^{\circ}$ 27, ano 7, jul./set. 2002.

. Curso de direito constitucional positivo. 25. ed. São Paulo: Malheiros Editores, 2005.

. A advocacia pública e o Estado Democrático de Direito. Disponible en: < http://bibliotecadigital.fgv.br/ojs/index.php/rda/article/viewFile/46346/45117

. Direito Ambiental Constitucional. 7. ed. São Paulo: Malheiros, 2009.

SILVA, Juremir Machado da. Pensar a vida, viver o presente. In: CLOTET, Joaquim; SILVA, Juremir Machado da (Org.). As duas globalizações: complexidade e comunicação, uma pedagogia do presente. 2. ed. Porto Alegre: Sulina/EDPUCRS, 2002. SILVA, Virgílio Afonso da. Princípios e regras: mitos e equívocos acerca de uma distinção. Revista Latino-Americana de Estudos Constitucionais. Belo Horizonte, n. 1, jan./jun., 2003.

. Direitos Fundamentais: conteúdo essencial, restrições e eficácia. São Paulo: Editora Malheiros, 2009.

SILVEIRA, Paulo Burnier da. O direito administrativo sancionador e o princípio non bis in idem na União Europeia: uma releitura a partir do caso "Grande Stevens" e os impactos na defesa da concorrência. RDC, Vol. 2, nº 2, Novembro de 2014. 
SILVEIRA, Renato de Mello Jorge Silveira. Direito Penal Supra-Individual. Interesses difusos. São Paulo: RT, 2003.

Direito Penal Econômico como Direito Penal de Perigo. São Paulo:

Editora Revista dos Tribunais, 2006.

SINGER, Peter. Ética Prática. São Paulo: Martins Fontes, 1994.

SÍNTESIS DE LA LEGISLACIÓN DE LA UE. Disponible en: < http://eurlex.europa.eu/legal-content/ES/TXT/?uri=uriserv:128015>. Acceso en: 23-09-2015.

SÍNTESIS DE LA LEGISLACIÓN DE LA UE. Disponible en: <http://eurlex.europa.eu/legal-content/ES/TXT/?uri=URISERV:128117>. Acceso en: 23-09-2015.

SÍNTESIS DE LA LEGISLACIÓN DE LA UNIÓN EUROPEA, consultado en el sitio de la Unión Europea, legislaciones y publicaciones de la UE, disponible en: <http://eurlex.europa.eu/legal-content/ES/TXT/?uri=URISERV:a15000>. Acceso en: 23-09-2015. SIQUIERA, Julio Pinheiro Faro Homem de. Da reserva do possível e da proibição do retrocesso social. Revista do Tribunal de Contas do Estado de Minas Gerais, julho setembro 2012, v. 26 - n. 3 - ano XXVIII.

SIRVINSKAS, Luís Paulo. Tutela penal do meio ambiente. 3. ed. São Paulo: Editora Saraiva. 2004.

SISTEMA COMUNITARIO DE GESTIÓN Y AUDITORÍA MEDIOAMBIENTAL EMAS. Programa 21 local, autoevaluación de las administraciones locales. Disponibles en: $<$ http://eur-lex.europa.eu/legal-content/ES/TXT/?uri=URISERV:128022> y $<$ http://eur-lex.europa.eu/legal-content/ES/TXT/?uri=CELEX:52004DC0060>. Ambos con Acceso en: 20-09-2015.

SISTEMA JURISDICCIONAL DE LA UNIÓN EUROPEA: TRIBUNAL DE JUSTICIA Y TRIBUNAL DE PRIMERA INSTANCIA. Síntesis de la legislación de la UE. Disponible en: $\quad<$ http://eur-lex.europa.eu/legalcontent/ES/TXT/?uri=URISERV:xy0018>. Acceso en: 24-09-2015.

SOARES, Guido Fernando Silva. Curso de direito internacional público. São Paulo: Ed. Atlas, 2002.

SOCIAL EUROPEO Y AL COMITÉ DE LAS REGIONES. RELATIVA A LA REVISIÓN INTERMEDIA DEL SEXTO PROGRAMA DE ACCIÓN COMUNITARIO EN MATERIA DE MEDIO. \{SEC(2007) 546\}. Disponible en: < http://ec.europa.eu/transparency/regdoc/rep/1/2007/ES/1-2007-225-ES-F1-1.Pdf $>$. Acceso en: 24-09-2015. 
SOUZA, Motauri Ciocchetti. Interesses difusos em espécie: temas de direito do consumidor, ambiental e da lei de improbidade administrativa. São Paulo: Saraiva, 2000 .

SOUZA, Pablo Moitinho de. O direito penal e a proteção do patrimônio ambiental cultural. Dissertação (mestrado), Universidade de São Paulo, Faculdade de Direito, São Paulo, 2010.

SOUZA, Sarah Rosignoli. A acessoriedade administrativa nos crimes de poluição no Direito luso-brasileiro. Lisboa: Universidade de Lisboa, 2010. Disponible en: $<$ http://www.terrabrasilis.org.br/ecotecadigital/images/A acessoriedade.pdf $>$. Acceso en: 29 jun. 2015.

STASSINOPOULOS Michel. Traité des Actes Administratifs. Atenas : Recueil Sirey, 1954.

STC 102/1995, de 26 de junio, FJ 8 . Disponible en: $<$ https://www.boe.es/buscar/doc.php?id=BOE-T-1995-18444>. Acceso en: 02-11-2015. TAVARES, André Ramos. Curso de direito constitucional. 5. ed. São Paulo: Editora Saraiva, 2007.

TAVARES, José F. F. Administração pública e direito administrativo. 3. ed. Coimbra: Almedina, 2000.

TEMAS DEBATIDOS NO IV FÓRUM DA ÁGUA. Disponible en: < http://www.folhadomeio.com.br/publix/fma/folha/2006/03/2agua166.html>, Último acceso en: 31-05-2015.

TEMAS DO $7^{\circ}$ FÓRUM MUNDIAL DA ÁGUA. Disponible en: $<$ http://eng.worldwaterforum7.org/introduce/program/thematic.asp $>$, Último acceso en: 31-05-2015.

TERRADILlOS BASOCCO, Juan. Derecho Penal del Medio Ambiente. Madrid: Trotta, 1997.

THE COURT OF WATERS OF THE FERTILE VALLEY OF VALENCIA IS THE OLDEST EXISTING INSTITUTION OF JUSTICE IN EUROPE. Although some legal institution that solved the water problems of the territories of Valencia would already exist from Roman, Disponible en: $<$ http://www.tribunaldelasaguas.org/en/el-tribunaling/historia-ing $>$ Último acceso en: 10-06-2015. 
THE DUBLIN STATEMENT ON WATER AND SUSTAINABLE DEVELOPMENT. $<$ http://www.wmo.int/pages/prog/hwrp/documents/english/icwedece.html $>\quad$ Último acceso en: 31-05-2015.

THOMAS, Keith. O Homem e o mundo natural: mudança de atitudes em relação às plantas e aos animais. São Paulo: Companhia das Letras, 1996.

TRATADO CONSTITUCIONAL AL TRATADO DE LISBOA. Disponible en: http://www.hablamosdeeuropa.es/panorama/historia/constitucion-a-lisboa. Acceso en: 24-09-2015.

TRATADO CONSTITUTIVO DE LA COMUNIDAD EUROPEA. Disponible en: $<$ http://europa.eu/eu-law/decision-

making/treaties/pdf/treaty_on_european_union/treaty_on_european_union_es.pdf >. Acceso en: 21-09-2015.

TRATADO DA UNIÃO EUROPEIA. Disponible en: <http://europa.eu/eulaw/decision-

making/treaties/pdf/treaty_on_european_union/treaty_on_european_union_es.pdf >. Acceso en: 21-09-2015.

TRATADO DE ÁMSTERDAM. Disponible en: <http://eur-lex.europa.eu/legalcontent/ES/TXT/?uri=URISERV:a15000>. Acceso en: 23-09-2015.

TRATADO DE FUNCIONAMIENTO DE LA UNIÓN EUROPEA (TFUE). Disponible en:

$<\mathrm{http}$ //europa.eu/legislation_summaries/consumers/consumer_safety/132042_es.htm>. Acceso en: 06-10-2015.

TRATADO DE LA UNIÓN EUROPEA Y DEL TRATADO DE FUNCIONAMIENTO DE LA UNIÓN EUROPEA. Versión consolidada del Tratado de la Unión Europea Versión consolidada del Tratado de Funcionamiento de la Unión Europea - Protocolos Anexos - Declaraciones anejas al Acta Final de la Conferencia intergubernamental que ha adoptado el Tratado de Lisboa firmado el 13 de diciembre de 2007 - Tablas de correspondências. Diario Oficial n ${ }^{\circ}$ C 326 de 26/10/2012 p. 0001 - 0390. Disponible en: $<$ http://eur-lex.europa.eu/legal-content/ES/TXT/?uri=CELEX:12012E/TXT>. Acceso en: 03-10-2015.

TRATADO DE LA UNIÓN EUROPEA. Disponible en: < http://www.boe.es/doue/2010/083/Z00013-00046.pdf>. Acceso en: 29-09-2015. 
TRATADO DE LA UNIÓN EUROPEA. Disponible en: <http://europa.eu/eulaw/decision-

making/treaties/pdf/treaty_on_european_union/treaty_on_european_union_es.pdf >. Acceso en: 21-09-2015.

TRATADO DE LA UNIÓN. Disponible en: <http://europa.eu/eu-law/decisionmaking/treaties/pdf/treaty_on_european_union/treaty_on_european_union_es.pdf >. Acceso en: 21-09-2015.

TRATADO DE LISBOA. Disponible en: <https://www.euskadi.eus/r48contaeue/es/contenidos/informacion/v2_ue_euskadi/es_lisboa/adjuntos/su_guia_tratado _lisboa_es.pdf $>$. Acceso en: 27-09-2015.

TRATADO DE MAASTRICHT SOBRE LA UNIÓN EUROPEA. Disponible en: $<$ http://europa.eu/legislation_summaries/economic_and_monetary_affairs/institutional_ and_economic_fram ework/treaties_maastricht_es.htm>. Acceso en: 21-09-2015.

TRATADO DE NIZA Y LA CONVENCIÓN SOBRE EL FUTURO DE EUROPA. consultado en el sitio de la Unión Europea, Parlamento Europeo, Disponible en: $<$ http://www.europarl.europa.eu/ftu/pdf/es/FTU_1.1.4.pdf > . Acceso en: 24-09-2015.

TRATADO DE NIZA Y LA CONVENCIÓN SOBRE EL FUTURO DE EUROPA. Disponible en: <http://www.europarl.europa.eu/ftu/pdf/es/FTU_1.1.4.pdf > . Acceso en: 24-09-2015.

TRATADO DE NIZA. Por el que se modifican el tratado de la unión europea, Los tratados constitutivos de las Comunidades europeas y determinados actos conexos (2001/c 80/01). Disponible cn: < http://www.boe.es/legislacion/enlaces/documentos/ue/Trat_niza_es.pdf>. Acceso en: 24-09-2015.

TRIBUNAL CONSTITUCIONAL DE ESPAÑA. Disponible en el sitio del Tribunal Constitucional de España: $<\mathrm{http}$ ://www.tribunalconstitucional.es/es/tribunal/competencias/Paginas/COMPT_02_C I.aspx>. Acceso en: 30-10-2015.

TRIBUNAL DE AGUAS DE LA VEJA DE VALENCIA. Disponible en: < http://www.tribunaldelasaguas.org/en/actividades-ing> Último acceso en: 10-06-2015. TRIBUNALES SUPERIORES DE JUSTICIA DE LAS COMUNIDADES AUTÓNOMAS. Disponible en: $<$ http://guiasjuridicas.wolterskluwer.es/Content/Documento.aspx?params=H4sIAAAA 
AAAEAO29B2AcSZY1Ji9tynt_SvVK1-

B0oQiAYBMk2JBAEOzBiM3mkuwdaUcjKasqgcplVmVdZhZAzO2dvPfee-999577733ujudTif33_8_XGZkAWz2zkrayZ4hgKrIHz9-fB8_IorZ7LPT33sHz-7_v17v_Ayr5uiWn62t7NzsPNg5wAfFOfXT6vpmtV_t15Vjb5_wO4nqckNQAAAA==WKE $>$. Acceso en: 30-10-2015.

TRINDADE, Antônio Augusto Cançado. A proteção internacional dos direitos humanos. São Paulo: Editora Saraiva, 1992.

TRINDADE, Antônio Augusto cançado. Direitos Humanos e Meio-Ambiente: Paralelo dos Sistemas de Proteção Internacional. Porto Alegre: Sérgio Antonio Fabris Editor, 1993.

TS - EXPLICACIÓN DEL FUNCIONAMIENTO DEL TRIBUNAL SUPREMO, SUS SALAS Y SUS FUNCIONES. Disponible en el sitio del Poder Judicial de España: $<$ http://www.poderjudicial.es/cgpj/es/Poder\%2DJudicial/Tribunal\%2DSupremo/Inform acion $\% 2$ Dinstitucional/Como\%2Dfunciona\%2Del\%2DTS\%2D>. Acceso en: 30-102015.

UN AÑO DESPUÉS DE LA CUMBRE MUNDIAL SOBRE EL DESARROLLO SOSTENIBLE. SÍNTESIS DE LA LEGISLACIÓN DE LA UE. Disponible en: < http://eur-lex.europa.eu/legal-content/ES/TXT/?uri=URISERV:128142>. Acceso en: 2409-2015.

UNIÓN EUROPEA - TRATADO DE AMSTERDAM. Disponible en: < http://europa.eu/eu-law/decision-

making/treaties/pdf/treaty_of_amsterdam/treaty_of_amsterdam_es.pdf $>$. Acceso en: 2309-2015.

UNITED NATION. International Decade for Action “WATER FOR LIVE” 2005-2015.

Disponible en: <http://www.un.org/waterforlifedecade/milestones.shtml $>$ Último acceso en: 17-06-2015.

UNITED NATIONS ENVIRONMENT PROGRAMME. Disponible en: < http://www.unep.org>. Comitê Brasileiro do Programa das Nações Unidas para o Meio Ambiente. Disponible en: < http://brasilpnuma.org.br $>$ y también en: < http://web.unep.org/regions/brazil/> . Acceso en: 04-09-2015.

V FÓRUM DA ÁGUA, ISTAMBUL. Disponible en: $<$ http://www.worldwaterforum5.org/index.php?id=1897\&L=onf...blurLink\%2528this\% $2529 \% 2520$ title $\% 253 \mathrm{D} \% 2520 \operatorname{target} \% 253 \mathrm{D} \% 2520 \operatorname{target} \% 253 \mathrm{D} \% 2520 \operatorname{target} \% 253 \mathrm{D} \% 2$ 
520target $\% 253 \mathrm{D} \% 2520 \operatorname{target} \% 253 \mathrm{D} \% 2520 \operatorname{target} \% 253 \mathrm{D} \% 2520 \operatorname{target} \% 253 \mathrm{D} \% 2520 \operatorname{tar}$ get $\% 253 \mathrm{D} \% 2520 \operatorname{target} \% 253 \mathrm{D} \% 2520 \operatorname{target} \% 253 \mathrm{D} \% 2520 \operatorname{target} \% 253 \mathrm{D} \% 2520 \operatorname{target} \% 2$ 53D\%2520target\%253D>, Último acceso en: 31-05-2015.

VARELLA, M. D. Variações sobre um mesmo tema: o exemplo da implementação do Princípio da Precaução pela CIJ, OMC, CJCE e EUA. In: VARELLA, M. D.; PLATIAU, A. F. B. (org. e co-autores). Princípio da Precaução. Belo Horizonte: Del Rey, 2004.

VELÁSQUEZ MUÑOZ, Carlos Javier. La protección del medio ambiente urbano en la Unión Europea. Revista de Derecho, n. ${ }^{\circ}$ 24. Barranquilla : Universidad del Norte, 2005. VERCHER NOGUERA, Antonio. Avanzando Hacia un Derecho Penal Ambiental Comunitario. In VERCHER NOGUERA, Antonio (Director). Derecho Europeo Medioambiental: La Protección del Medio Ambiente en la Unión Europea. Aspectos Críticos, Editorial Consejo General del Poder Judicial, Estudios de Derecho Judicial, n. ${ }^{\circ}$ 134. Madrid: Editora Lerko Print S.A., 2008.

VERDÚ, Pablo Lucas. La Lucha por el Estado de Derecho. Bolonia : Publicaciones del Real Colegio de España, 1975.

VICENTE GIMÉNEZ, Teresa (coord.). Justicia ecológica y protección del medio ambiente. Madrid: Editorial Trotta, 2002.

VICENTE MARTÍNEZ, Rosario de. Derecho Penal del Medio Ambiente. Lecciones de Derecho del Medio Ambiente. In ORTEGA ÁlVAREZ, Luis (Coordinador), 4. ed. Valladolid : Ed. Lex Nova, 2005.

VILLANUEVA RÍO, Ángel; SAINZ SASTRE, Juan Antonio. Agua. La situación del agua en España. Recursos, gestión y tendencias. Colección EOI Medio Ambiente, 2008. WAINER, Ann Helen. Legislação ambiental brasileira: evolução histórica do direito ambiental. Revista forense, v. 88, n. 318, abr./jun. 1992.

. Revista de informação legislativa, v. 30, n. 118, abr./jun. 1993.

WATKINS, Kevin. Human development report 2006. Disponible en: $<$ http://hdr.undp.org/sites/default/files/reports/267/hdr06-complete.pdf $>$ Último acceso en: 04-06-2015.

WATSON, Stephanie. Como funciona a água-viva. Disponible en: $<$ http://ciencia.hsw.uol.com.br/agua-viva.htm> Último acceso en: 04-06-2015.

WELZEL, Hans. Derecho Penal: parte general. Trad. Carlos Fontán Balestra. Buenos Aires: Roque Depalma. 1956. 
WOLD, Chris; NARDY, Afrânio. Princípios de direito ambiental. Belo Horizonte, Del Rey, 2003.

WOLfRUM, R. O Princípio da Precaução. In: VARELlA, M. D.; PLATIAU, A. F. B. (org. e co-autores). Princípio da Precaução. Belo Horizonte: Del Rey, 2004.

WORLD HEALTH ORGANIZATION. UN-WATER GLOBAL ANALYSIS AND ASSESSMENT OF SANITATION AND DRINKING-WATER (GLAAS) 2014 REPORT: INVESTING IN WATER AND SANITATION: INCREASING ACCESS, REDUCING INEQUALITIES. Disponible en: $<$ http://apps.who.int/iris/bitstream/10665/139735/1/9789241508087_eng.pdf?ua=1> Último acceso en: 03-06-2015.

ZAMAN, Syed Zaid. Milagre asiático gera renda mas polui mais. Disponible en: $<$ http://www.pnud.org.br/Noticia.aspx?id=50> Último acceso en: 02-06-2015.

ZANOBINI, Guido. Le sanzioni amministrative. Torino : Fratelli Bocca, 1924. . L’attività amministrativa e la legge. In Scritti vari di diritto pubblico. Milano : Dott. A. Giuffrè Editore, 1955. 